
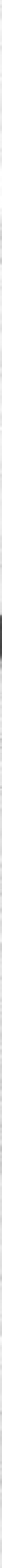


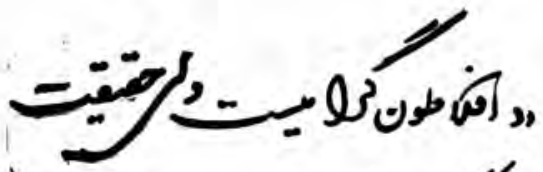

$$
\begin{aligned}
& \text { " a }
\end{aligned}
$$

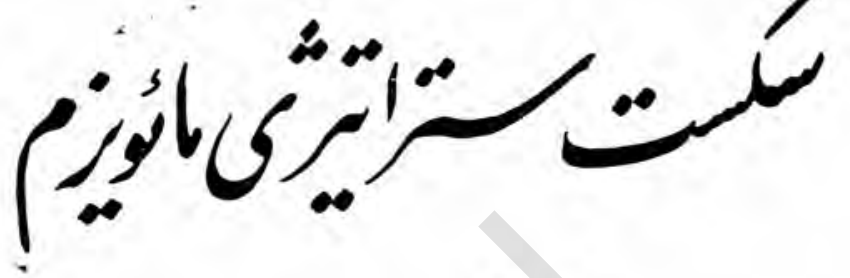

$$
\begin{aligned}
& \text { • }
\end{aligned}
$$

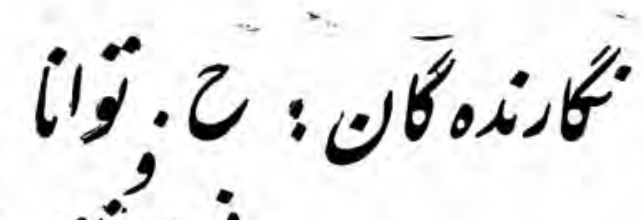

$$
\begin{aligned}
& \text { ت }
\end{aligned}
$$

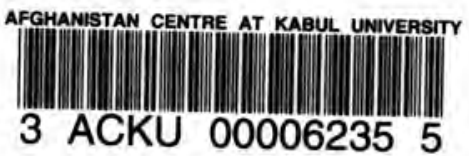


الف

1

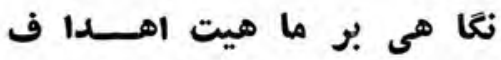

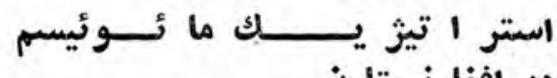
در افغا نستا نز

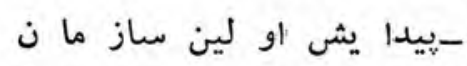

$\varepsilon$ مائوئيستى افغانستا ن :

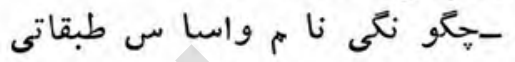

IE او لين كرو ه ما نو نيست

rq

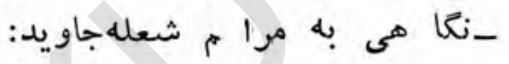
ـما هيت استر اتيزى ما ثو ثيسم

r^ در افغا نستا ن :

\&o - بر نا مؤ سا ما : سدر تسمت اهدا ف سيا ست خار جى : ०ᄉ

$7 \wedge$

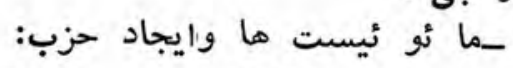

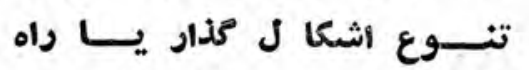
مساكت آميز و مسلحا نه انقلاب

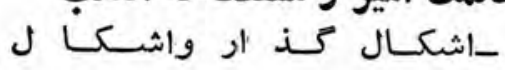

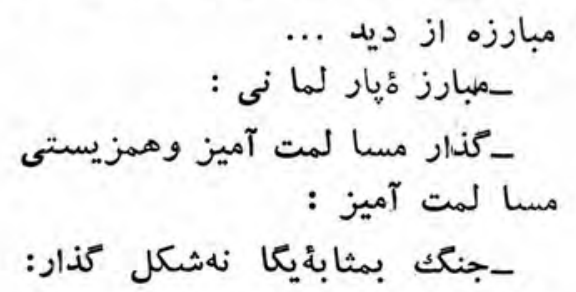
1.0
115

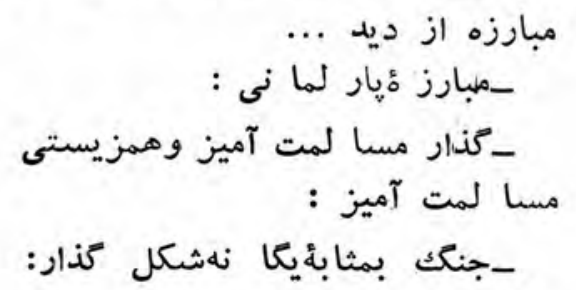


$|r|$

$|\varepsilon|$

IoV

lov

171

IVE

in

198

rrI

एहा

rาA

rVo

rVq

rar

rq०

r.l

r.q
ـكود تا يا انقلاب :

ساسا و جنا يت ايت

توو ويسم "(رسامال،

_تكا مي بير امو ن اسـاسات

مساله:

-جنك بار تيزا نى و جنكسـ

$$
\text { جر يكى : }
$$

-ترور يسم ساما :

$$
\text { _-نمو نه ديكر : }
$$

جبهه متعد ملى است يا مبمع دئ

مر تجعين

"بوها نى "يا وا بستئى

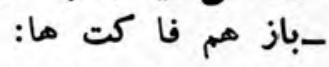

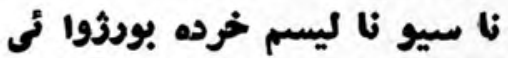

وانتر ناسيوناليسم برولتر ى

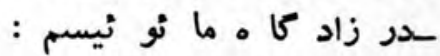

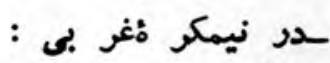

سدر كثور آزادة ما ،اففغا نستان

$$
\begin{aligned}
& \text { مستقل و متر قى : مثرد آنادة }
\end{aligned}
$$

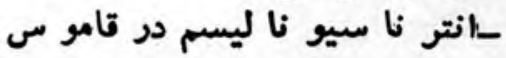

$$
\begin{aligned}
& \text { ما ثو نيسم : }
\end{aligned}
$$

-جين خصم جنبش آزاد يبخش

ملف : 
rro

rar

rav

$\varepsilon .1$

$\varepsilon .7$

$\varepsilon . \wedge$

\&1.

EIr

\&Y.

\&ro

\&Y7

\&rA

(r)

\section{ملح وجنك}

مائوئيسم و مساله مركزى دوران ما

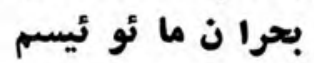

_نمو نهٔ بر كشت از ما نو يسم در هند:

ـ ـ نمونه از شكست مائو نيسم

$$
\text { در ايرا ن : نون : }
$$

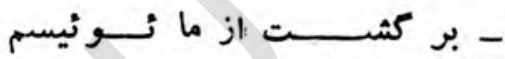

$$
\text { در بنكله ديش : }
$$

ـفلاكت ناشىاز نفوذمائو نيسم:

_نتايج ارزشمند و ثمربخش : -بحرا ن و شكست ما نو نيسم

$$
\text { در افغا نستا ن : }
$$

ـنمو نهمشخص بحران وشكست

ما نو نيسم : ـ ملا قأ ت با اعضا ى بيـــــــ سياسى و كميته مركزى : ملات ـمدو لت سو سيا ل دموكريات اسلامى : ـتبارزكرايش ضد ما نو در كروه ييكار : ـانديشه ماى مائودر برابرسيلم

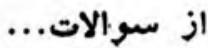




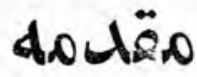

در افغانستا ن ، جدا از "هزبدموكرا تيك خلق افغانستان ه كروه

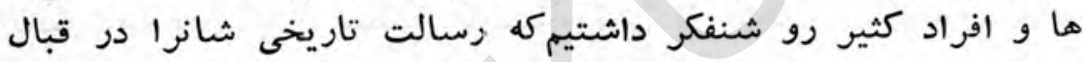

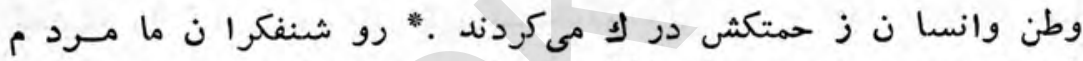

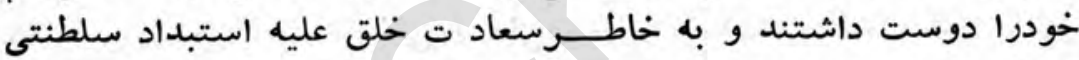

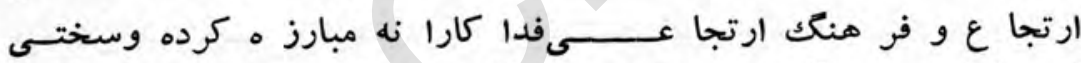

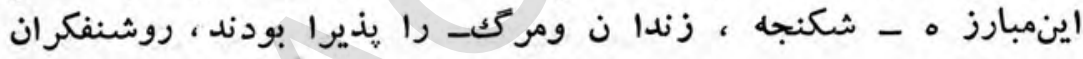

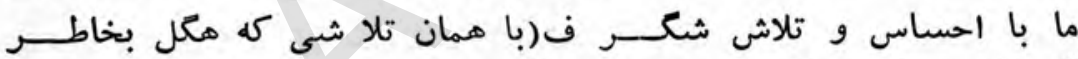

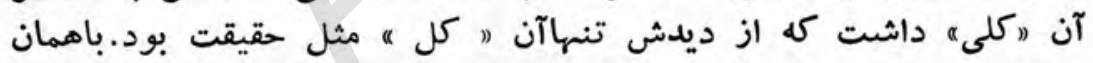

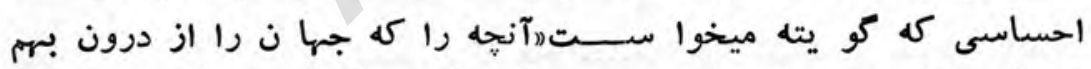

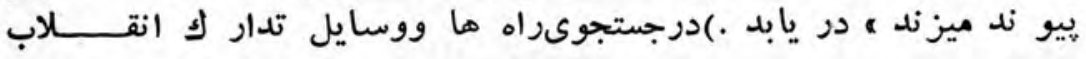

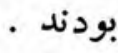

"-_البته واضح است كه مايـرنيرو ماى سياسى و اجتماعى كشور

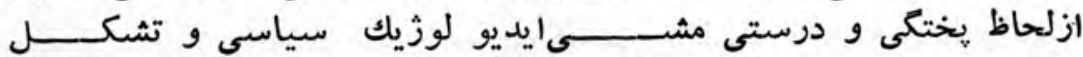

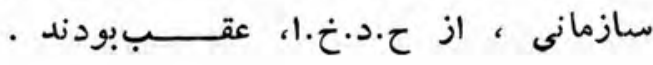


يس از بيروز ى انقلاب ملسى سدموكرا تيك ثور ه بـ به اثر اشتباهات

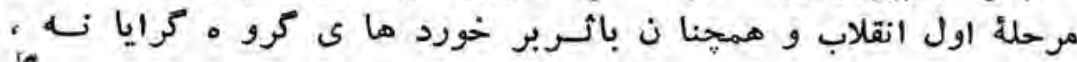

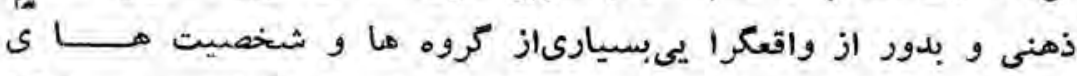

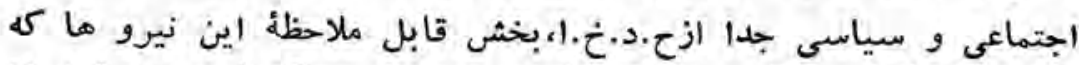

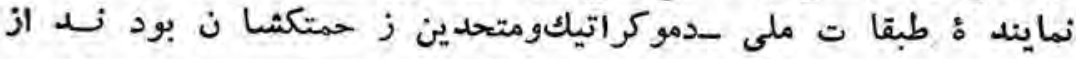

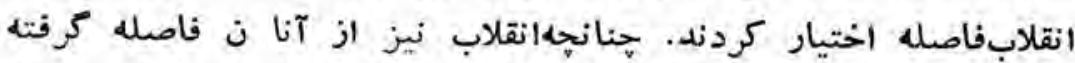

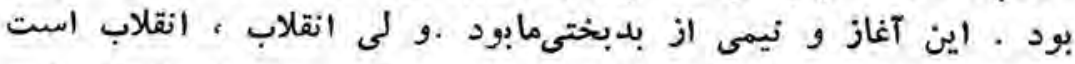

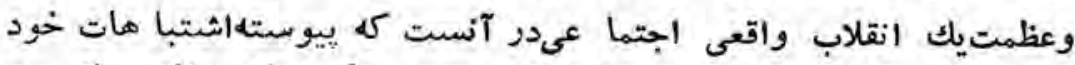

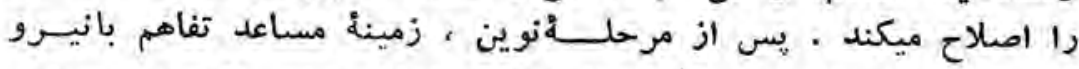

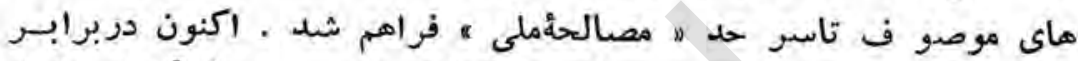

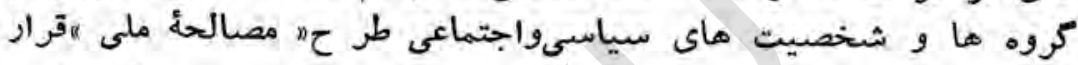

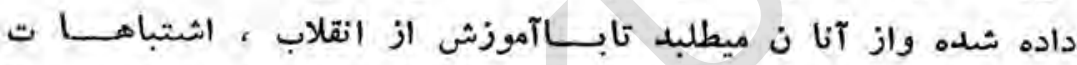

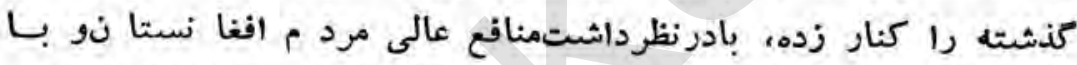

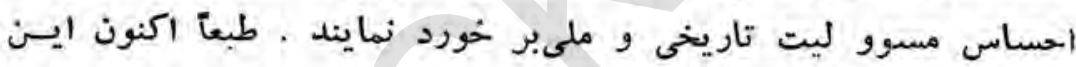

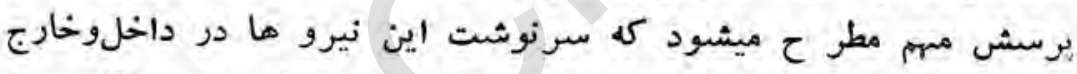

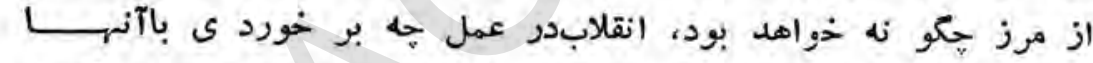

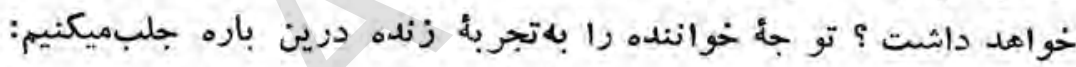

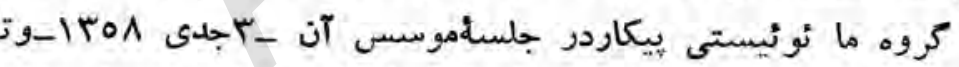

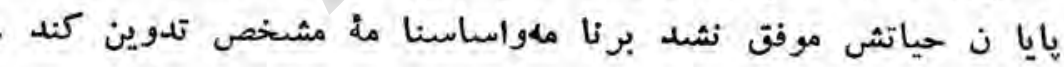

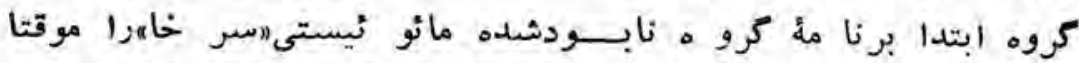

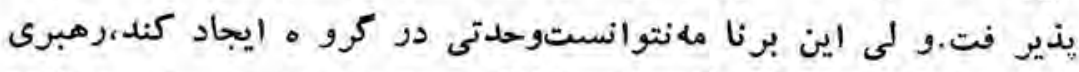

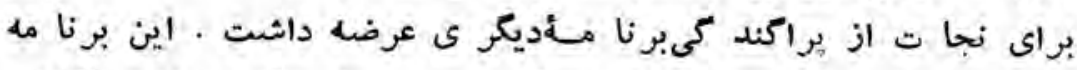

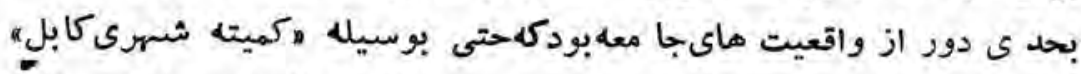

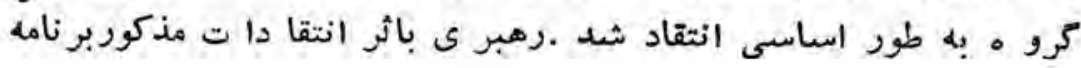




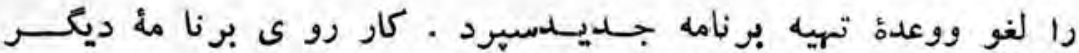

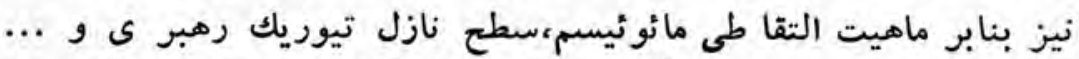

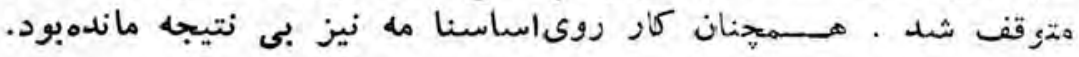

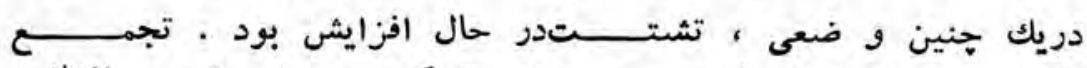

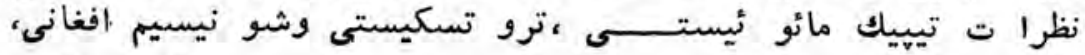

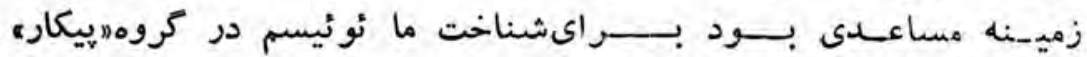

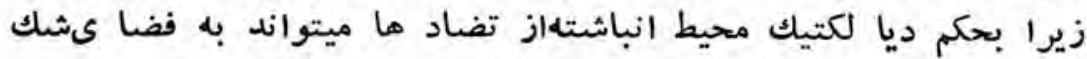

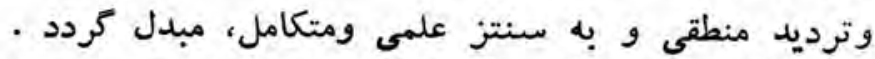

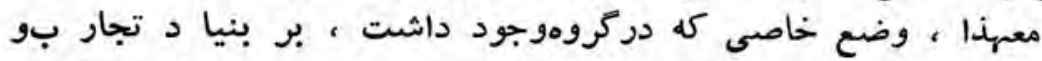

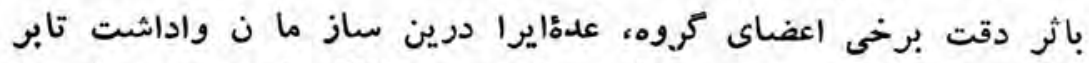

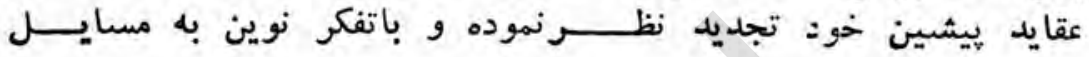

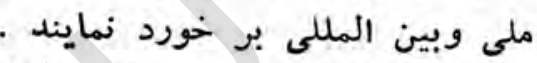

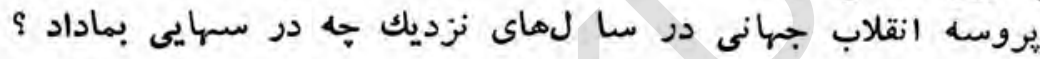

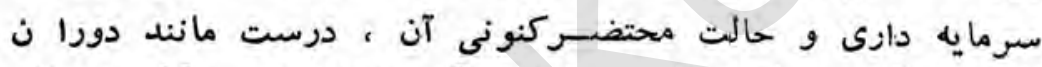

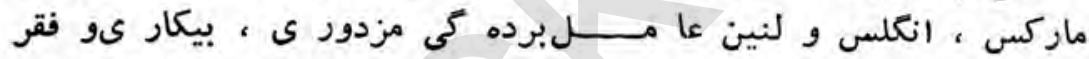
موسو م به " فقرنو" ودركيـر ىجنكها ى منطقه اى و جهانى بودهو

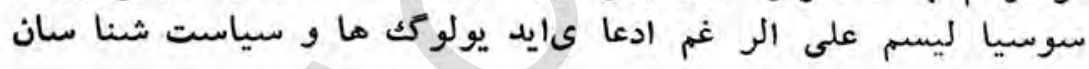

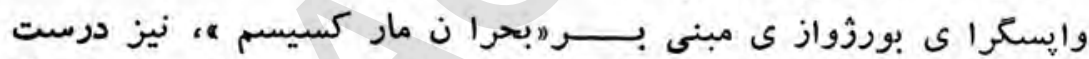

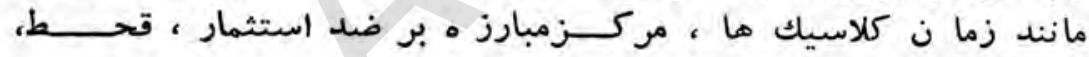

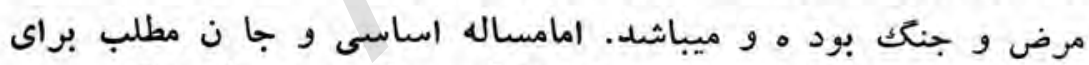

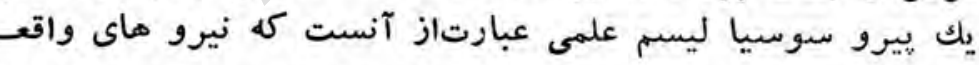
سوسيا ليسم را از مدعيا ن كاذبآن جِكز نه ميتوا ن تفكيك كرد

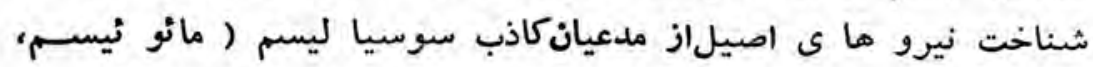

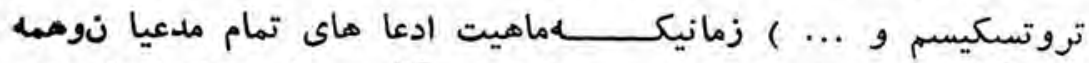

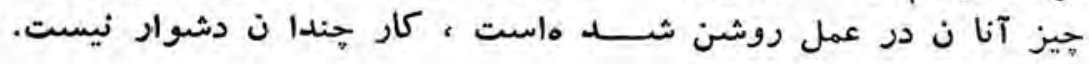




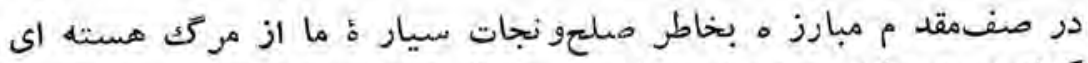

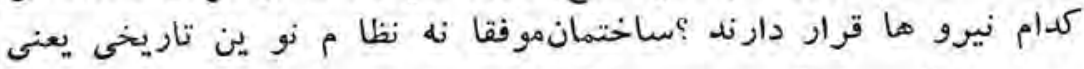

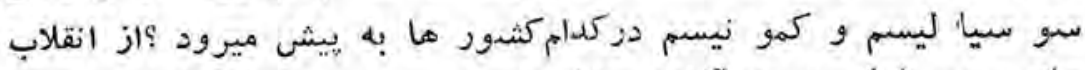

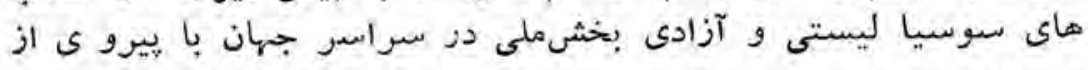

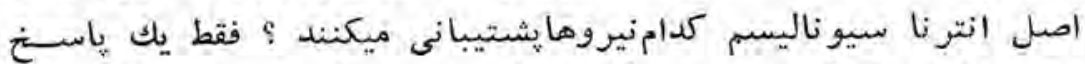

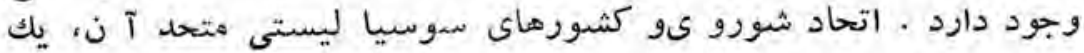

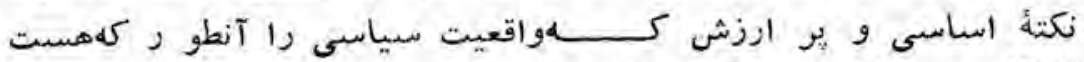

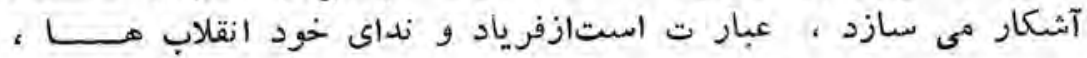

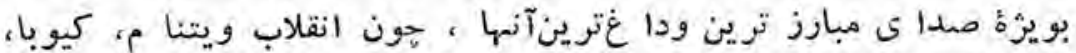

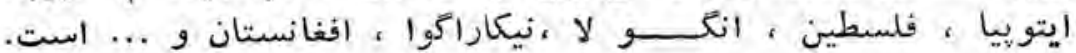

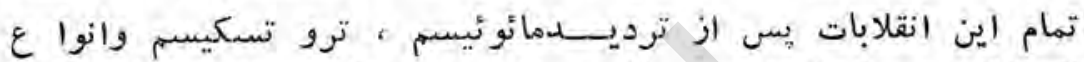

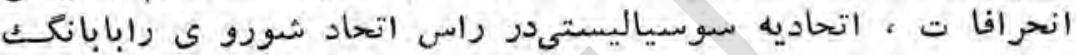

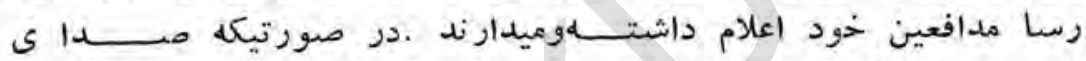

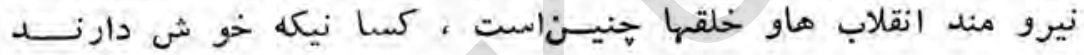

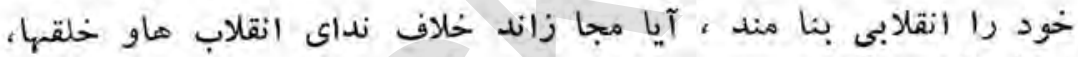

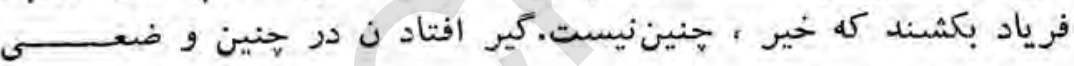

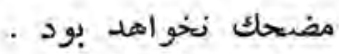

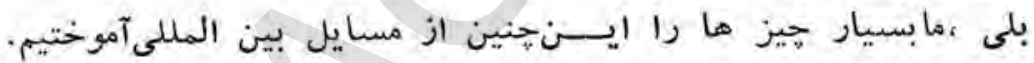

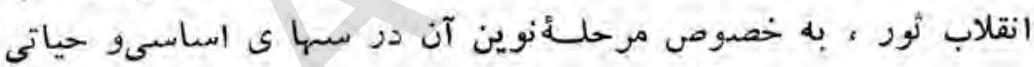

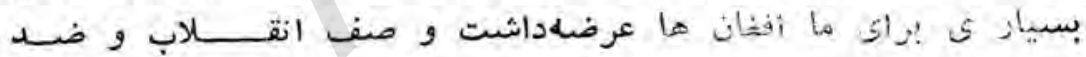

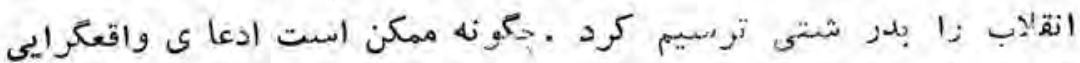

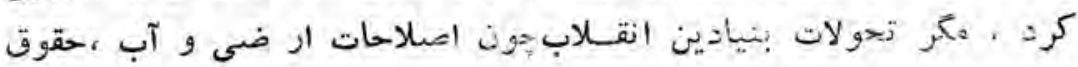

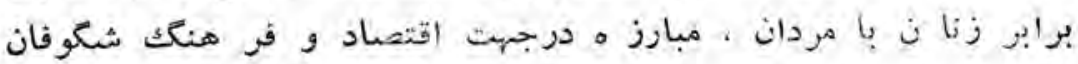

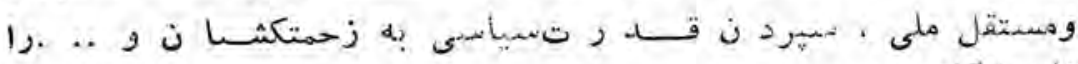

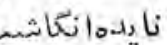




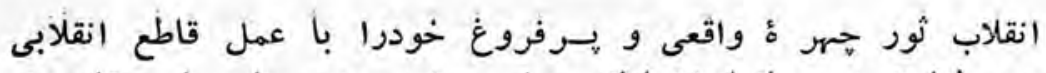

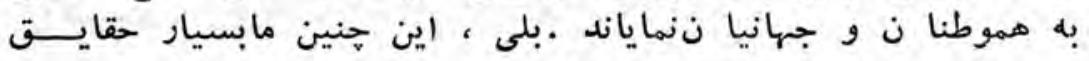

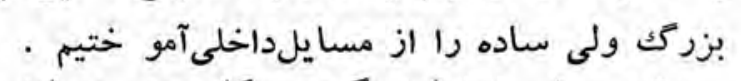

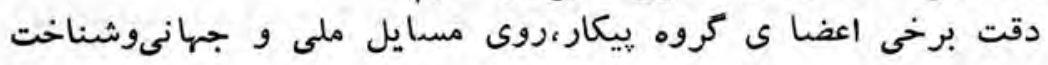

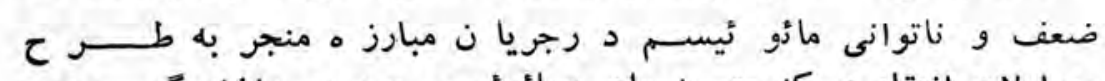

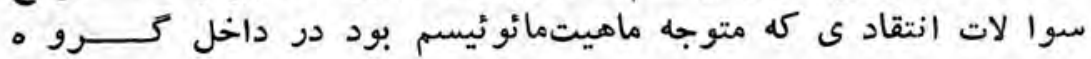
: شر

ـدر صورتيكه مائوئيســــم ،مار كسيسم -لنينيسم دور ا نمابود

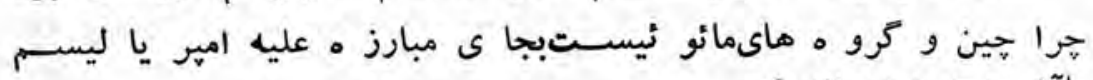
بآن متحد شده و اند ؟

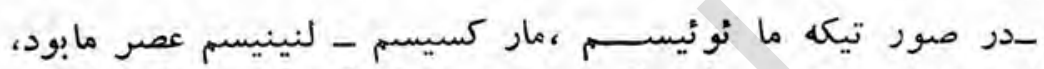

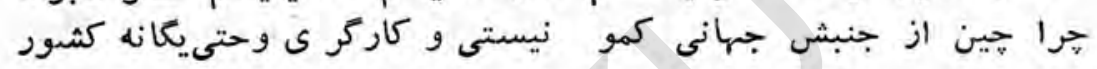

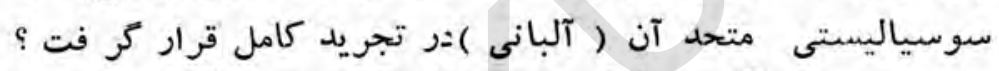

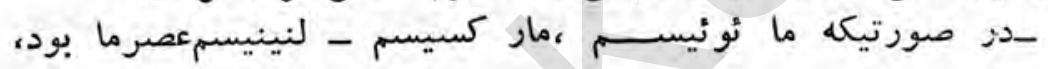

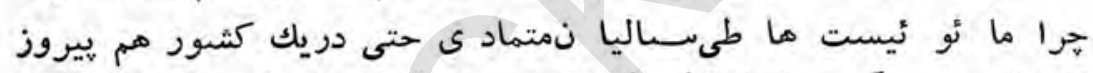

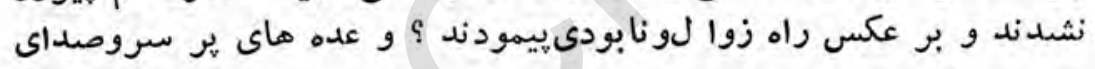

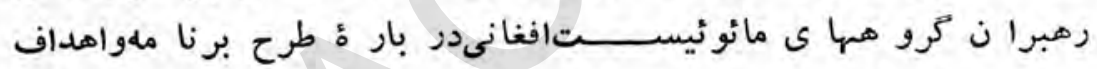

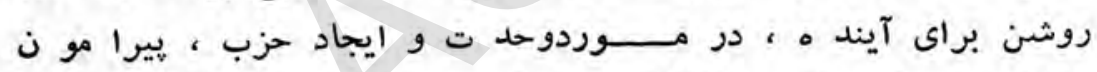

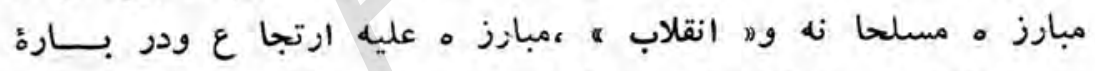

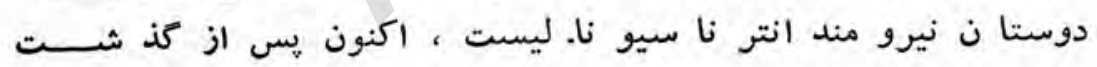

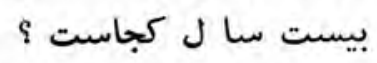

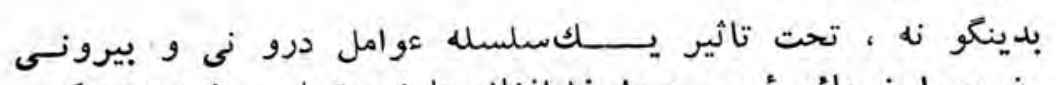

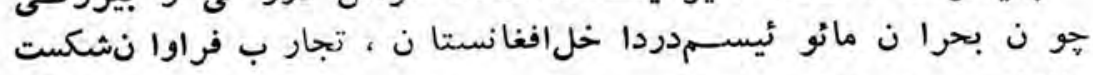

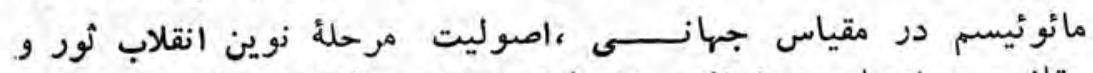

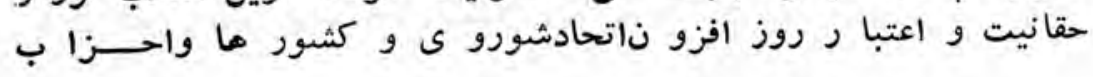


برادر و رويداد ماى مشخص مانتدمواضع ثوين " فدائيا ن خلقايرانه

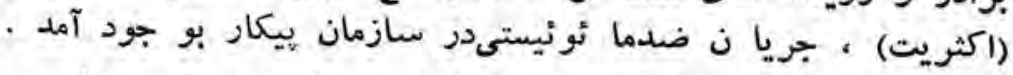

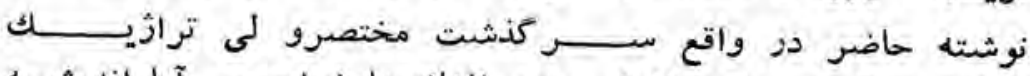

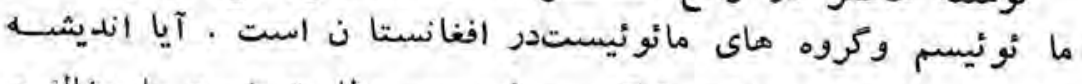

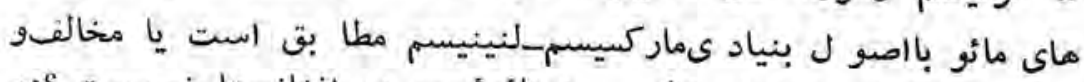

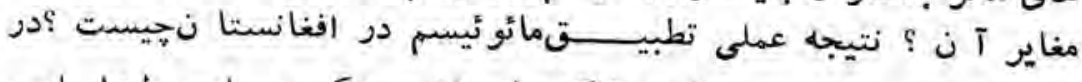

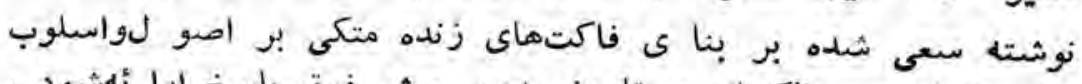

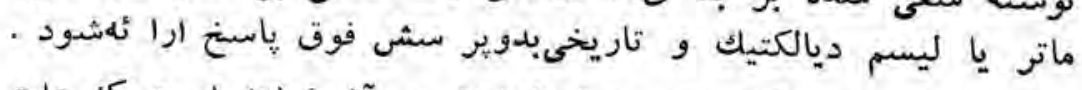

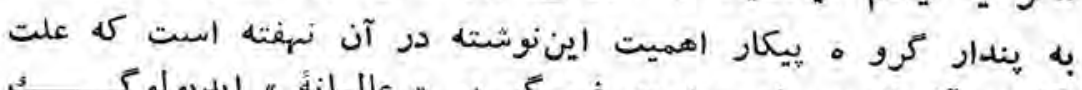

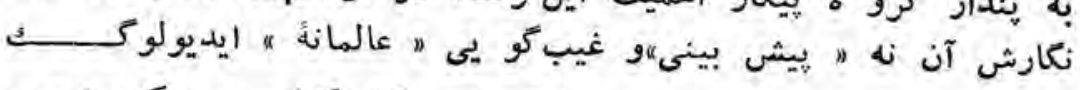

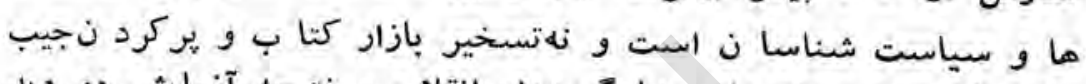

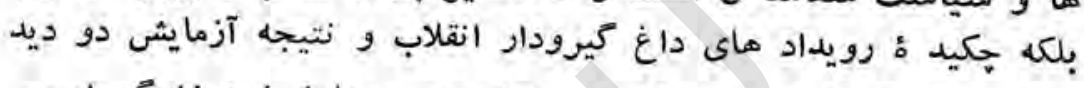

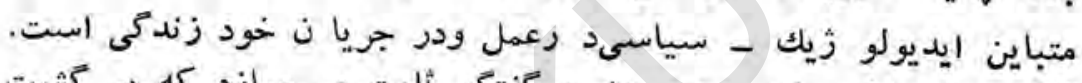

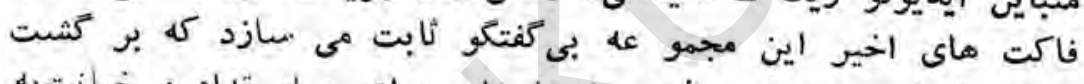

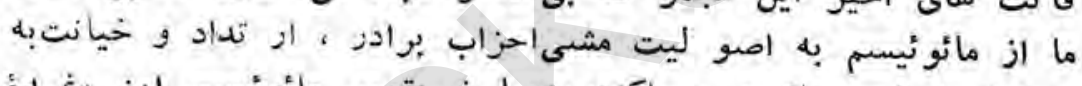

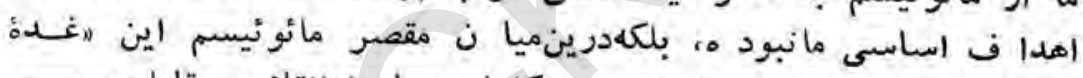

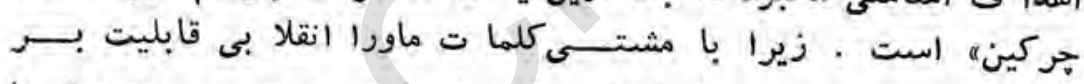

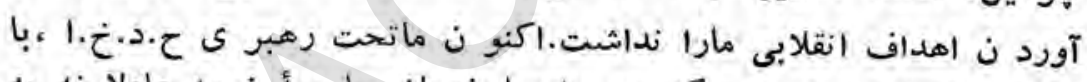

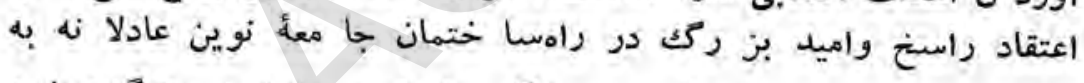

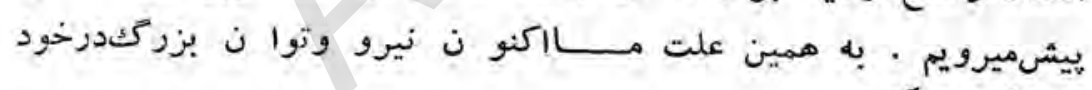
احساس ميكنيم

روشنفكرا ن با احساس ممميهن كه با مائوئيسم سرو كار دا شتب

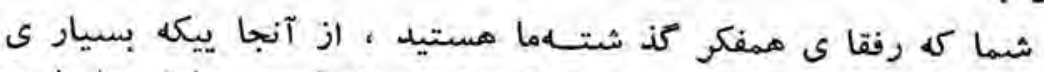

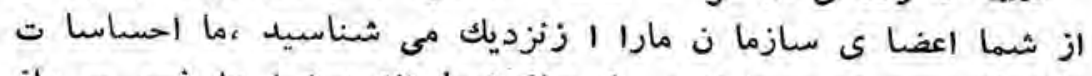

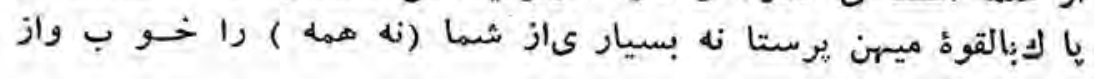


نزديك احساس ميكنيم .ما آن فضاوحالت تعليق سياسى وايديو لوزئ-

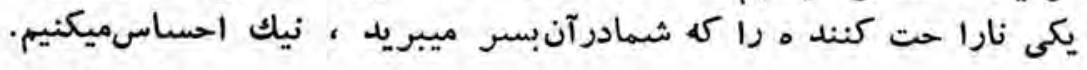

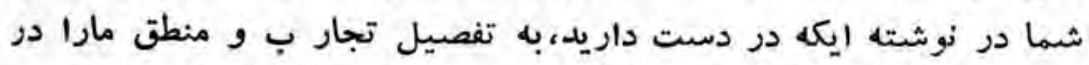

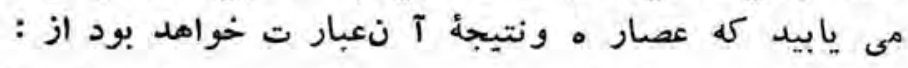

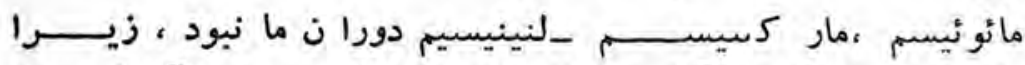

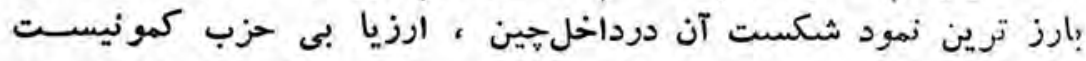

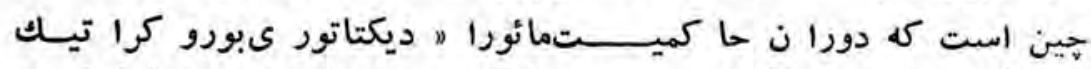

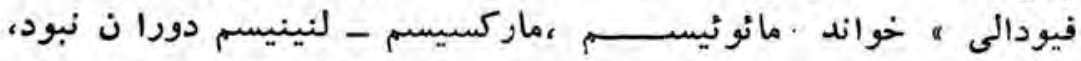

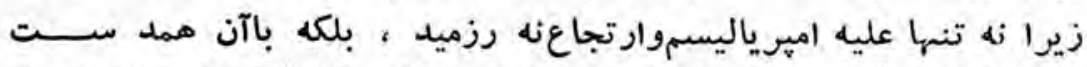

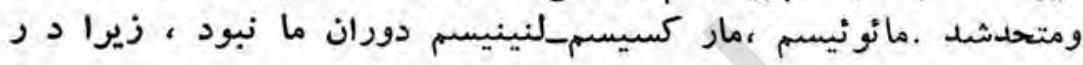

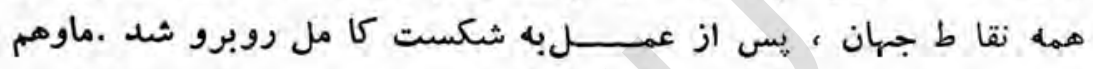

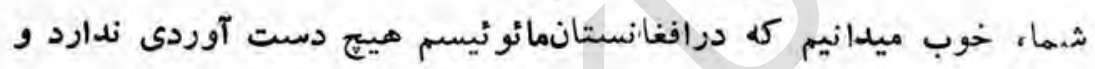

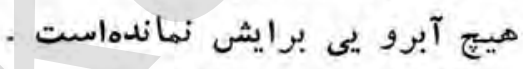

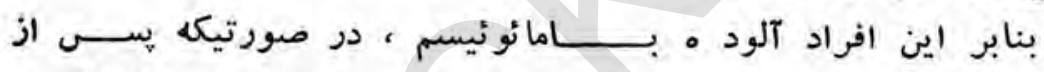

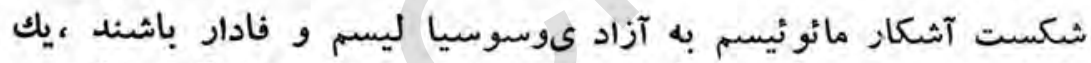

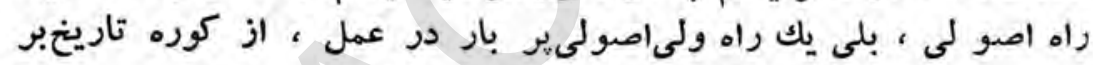

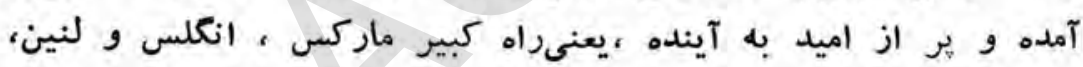

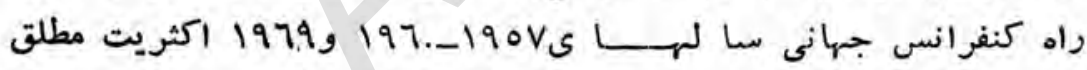

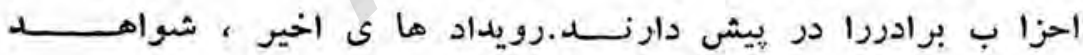

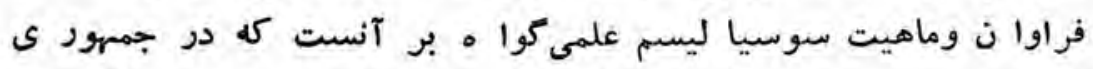

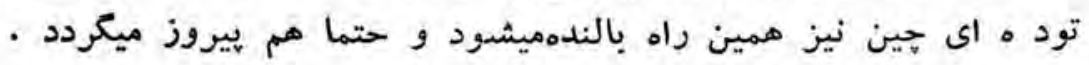

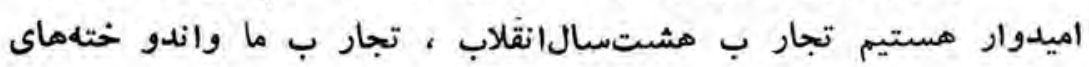

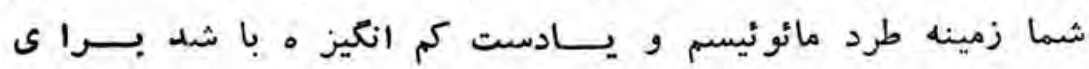

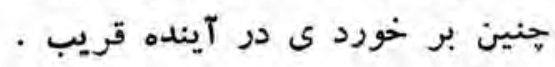


روند اتحاد نيرو هاى انقلا بى ودموكرا تيك ، هِ از انقلاب ثوردر

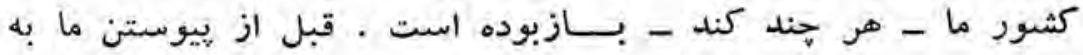

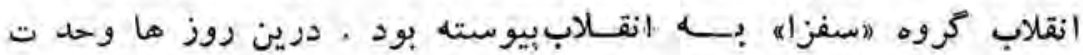

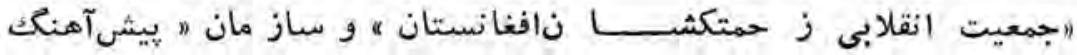

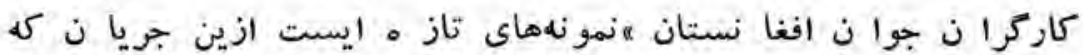

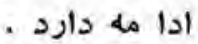

اوضا ع در ميهن ما، در منطقهوجهان ييجيده است .و ظليفه خطيسر

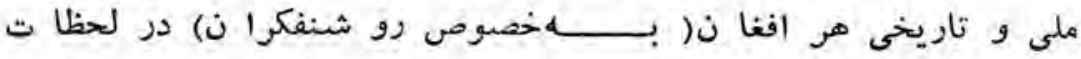

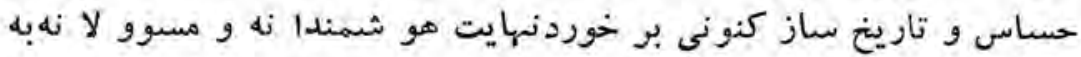

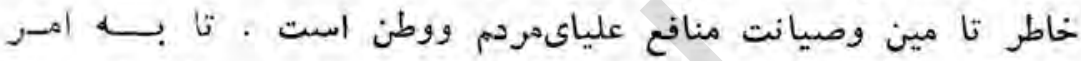

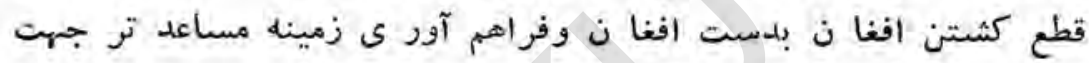

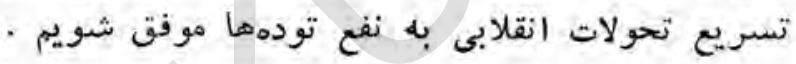

\section{مستحكم باد وحدت جنبث جهانى ممو نيستى وكاركرى !}




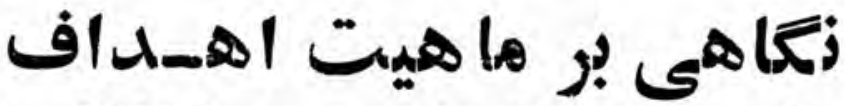

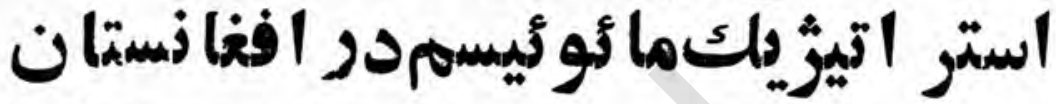

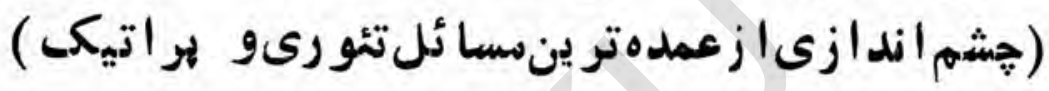

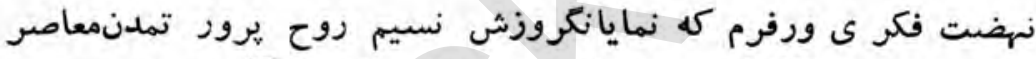

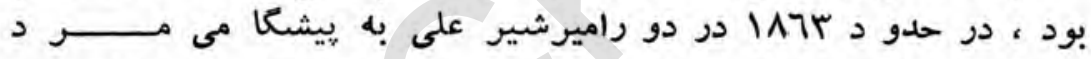

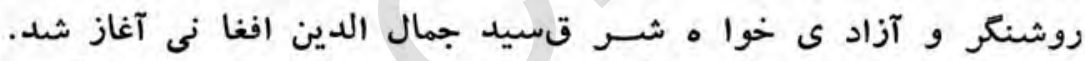

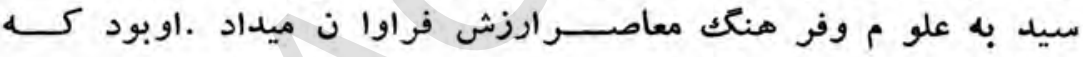
ميكفت :

"جاهل دشمن خود و دشمن عالماست . ، آغاز دو مين تجاوزكستردة

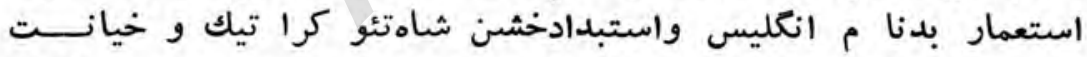

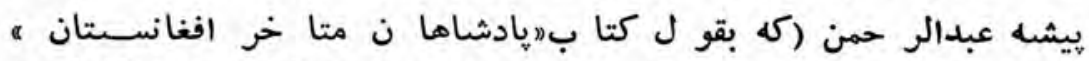

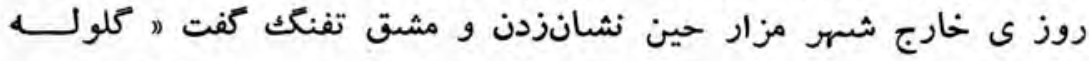

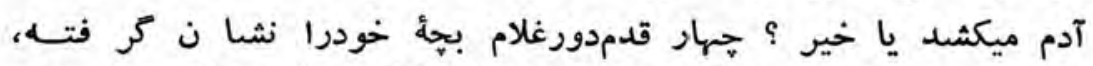

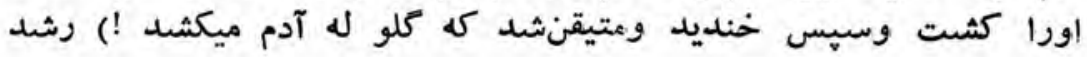

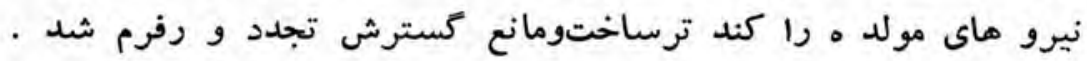




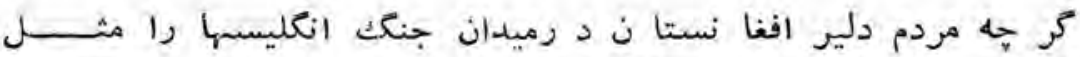

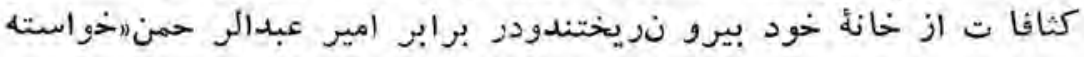

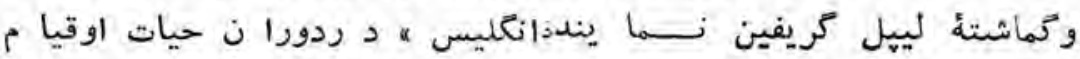

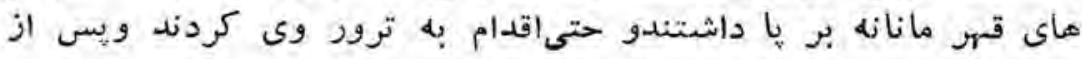

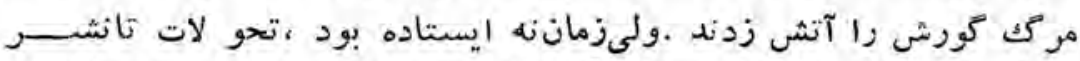

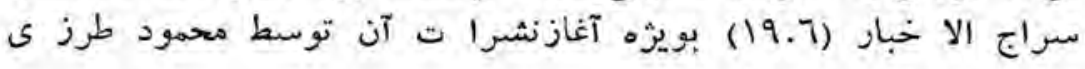

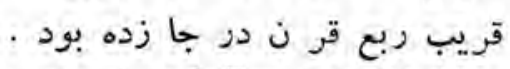

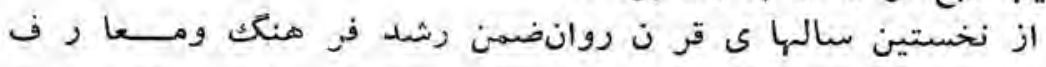

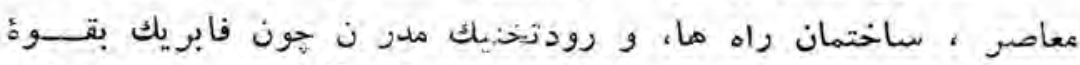

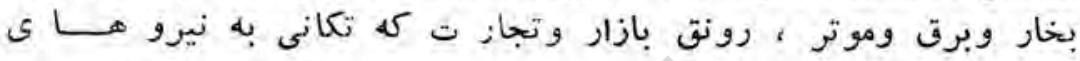

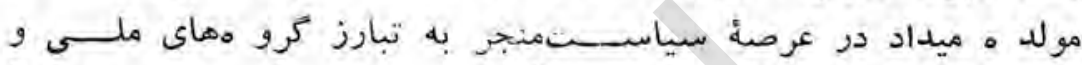

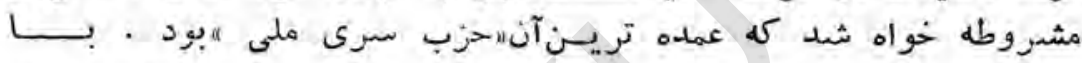

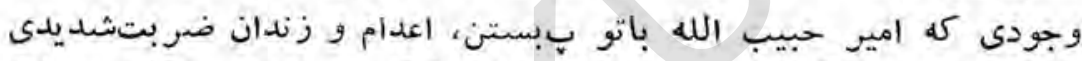

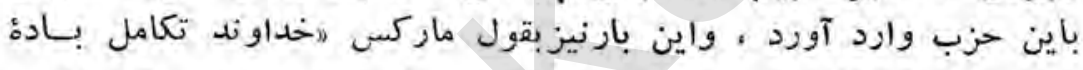

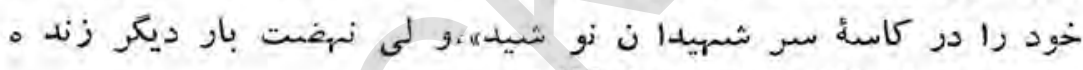

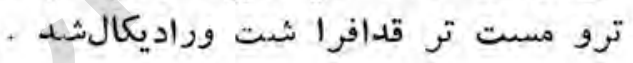

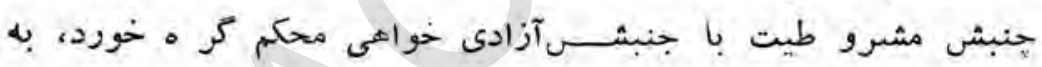

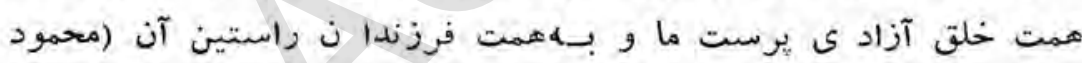

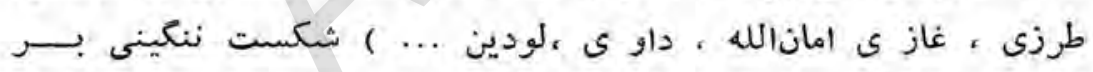

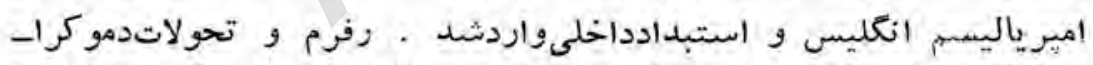

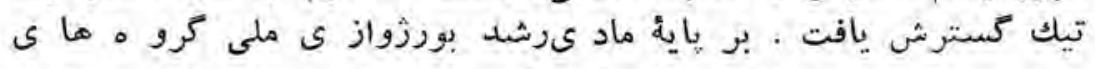

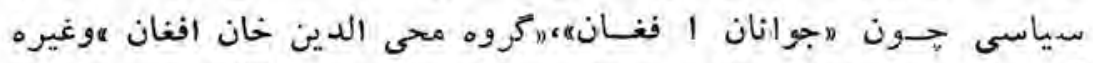

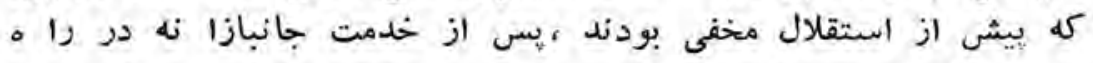

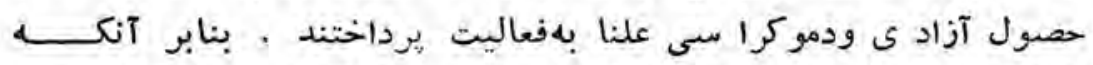

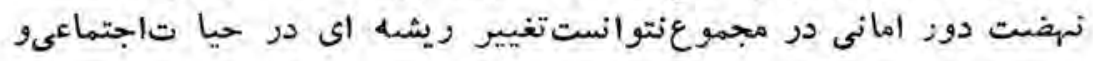

$$
-r
$$


اقتصاد ى كشور وارد كنــــ وازيشتيبا نى توده ماى ز حمتكثـــ

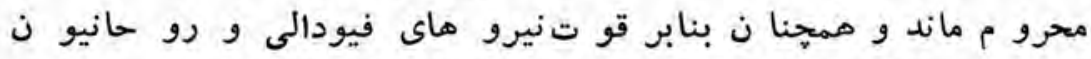

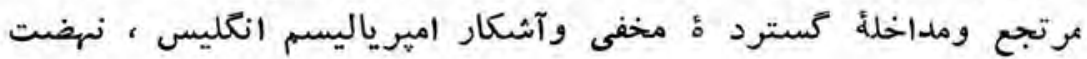

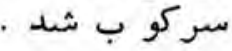

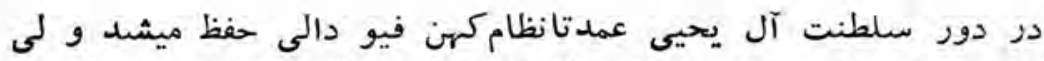

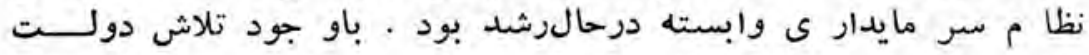

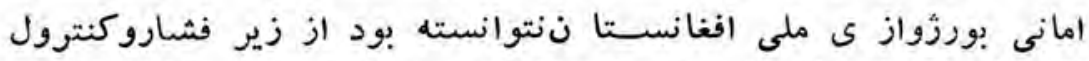

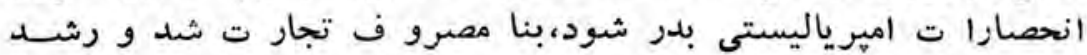

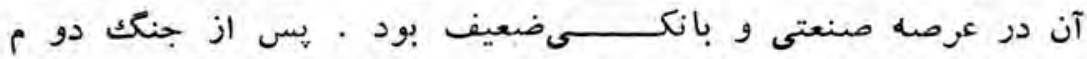

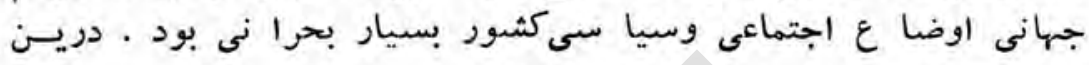

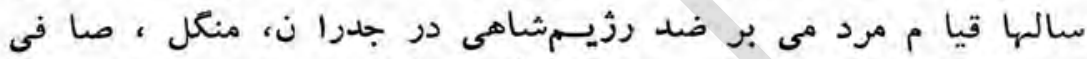

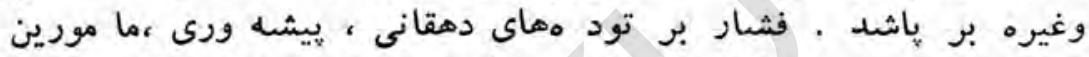

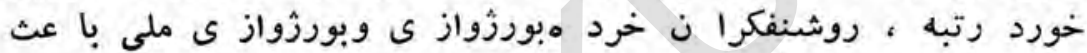

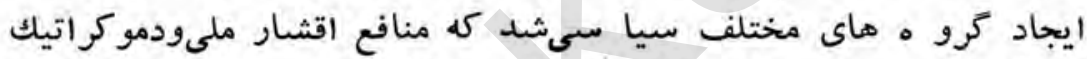

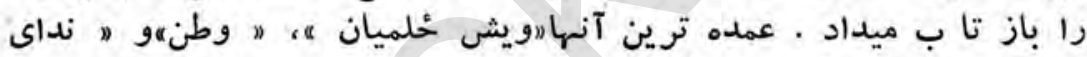

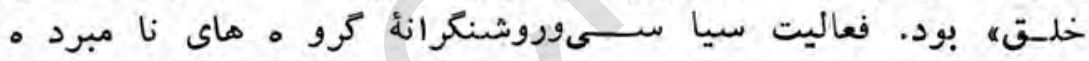

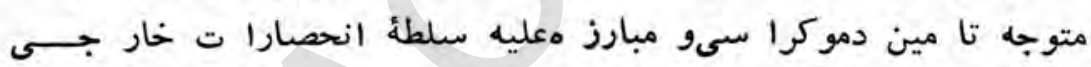
بود بون

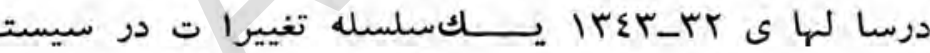

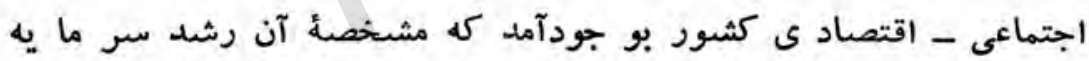

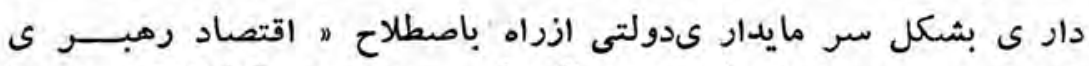

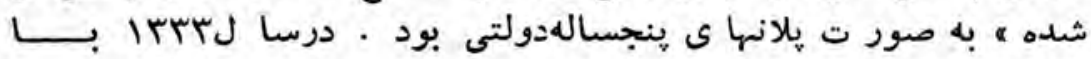

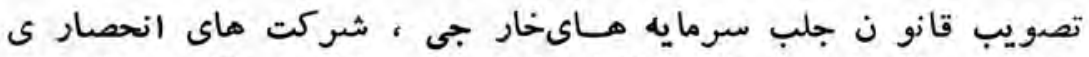

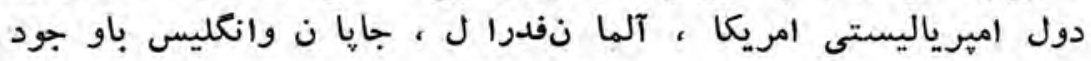

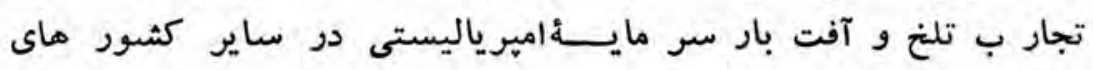


رو به رشد دز افغانستا ن فعالشد.دراين سالها مناسبا ت با اتحساد

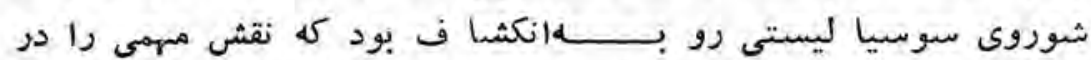

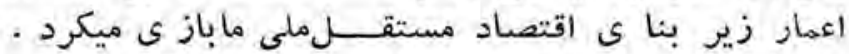

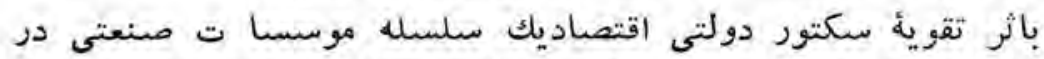

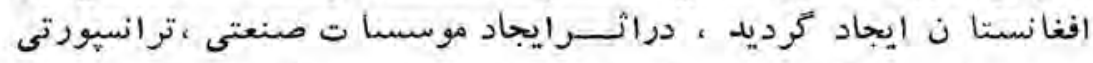

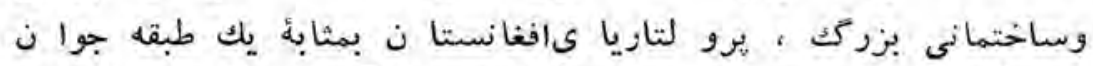

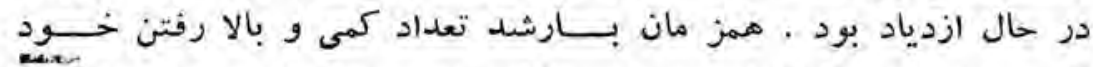

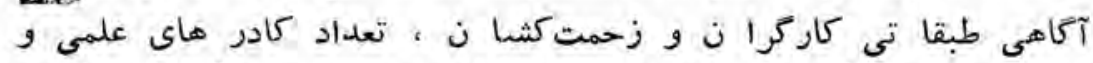

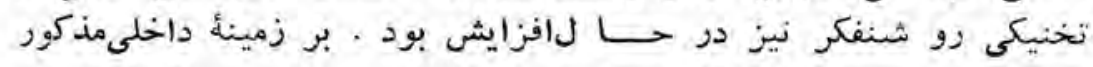

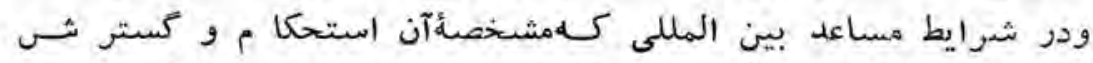

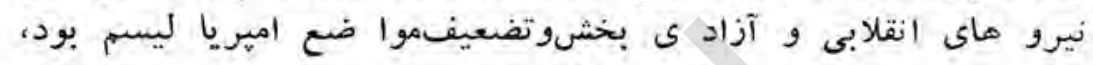

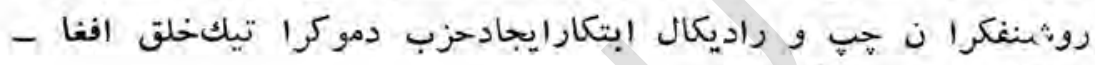

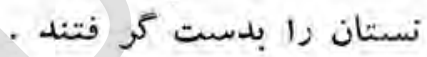

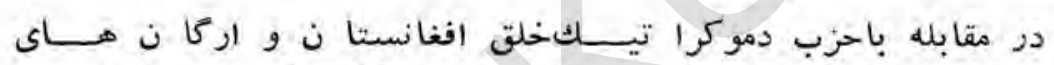

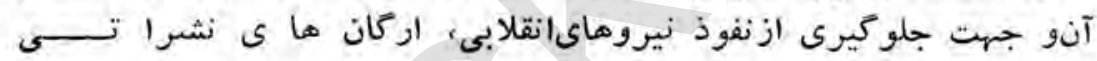

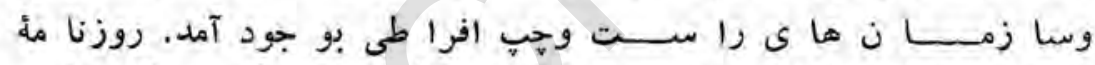

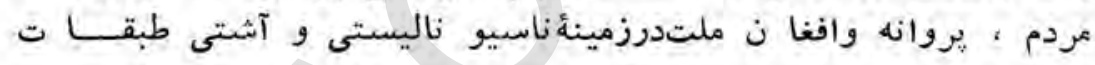

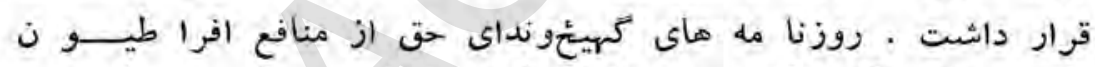

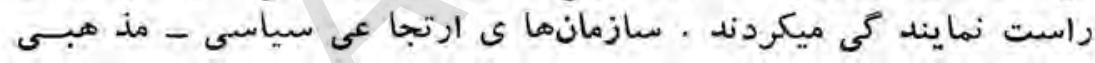

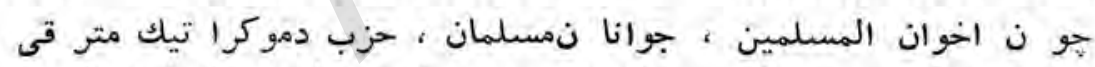

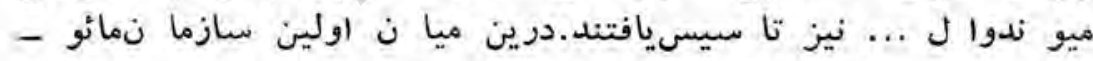

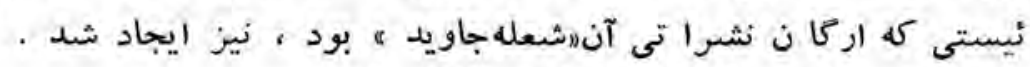

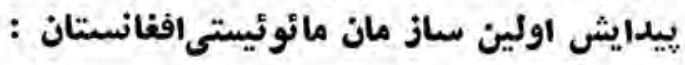

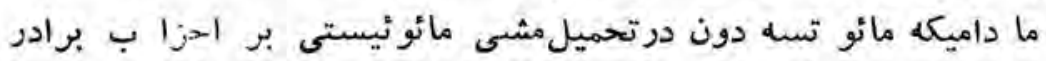

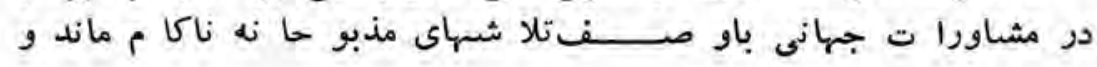




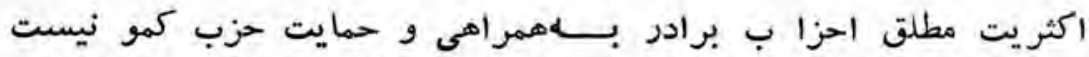

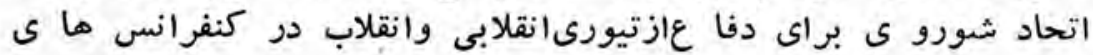

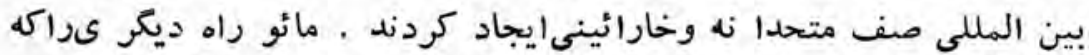

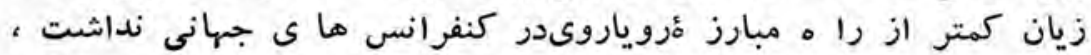

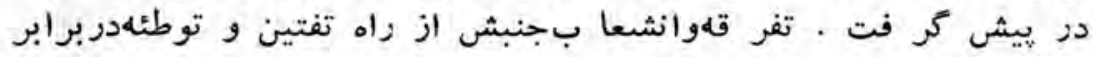

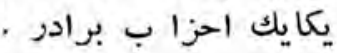

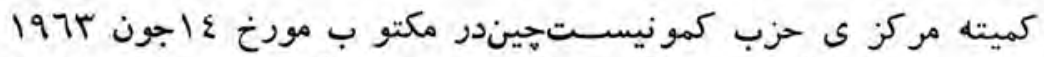

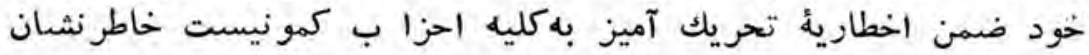

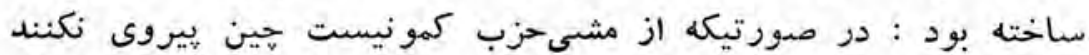

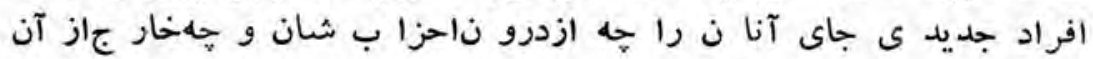

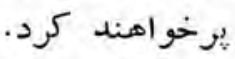

مائوئيستها در نشر يه يه اى تحتعنوا ن ضا رهبرا ن حزب كمونيست

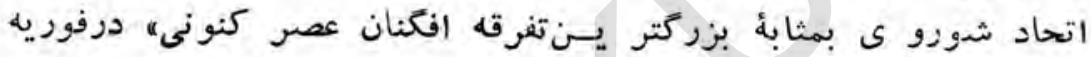

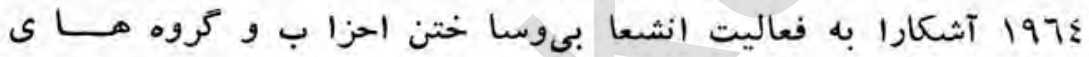

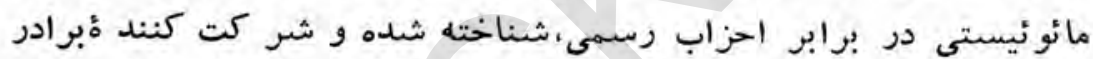

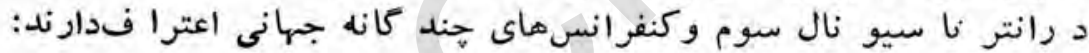

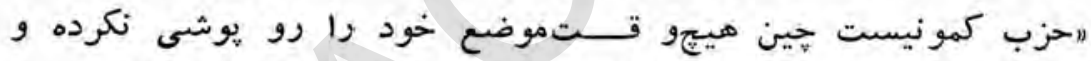

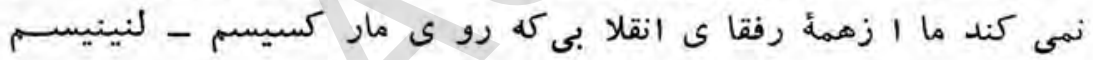

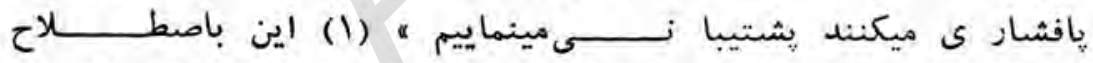

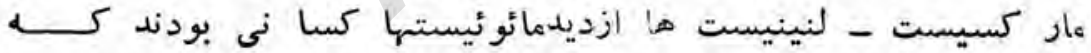

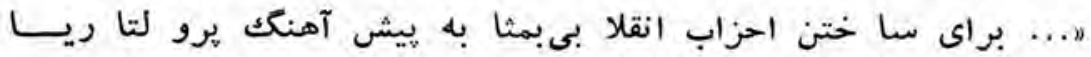

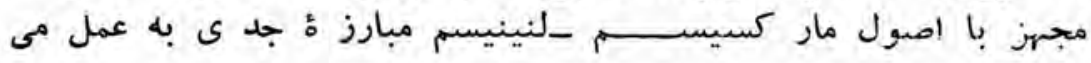

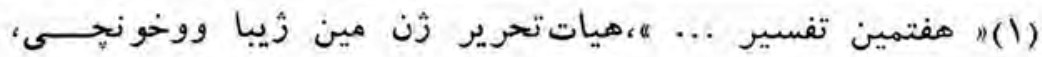
فورية 
(1) آورند ....

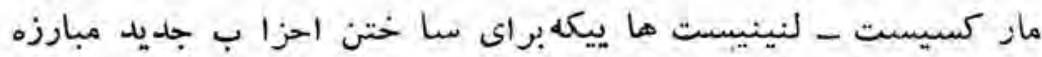

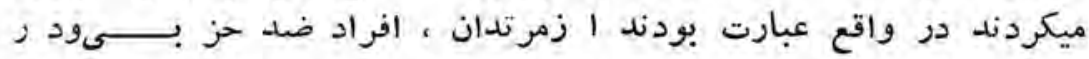

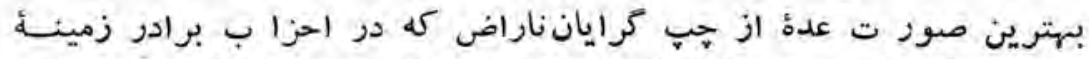

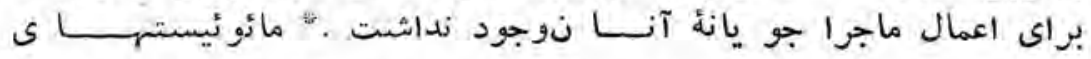

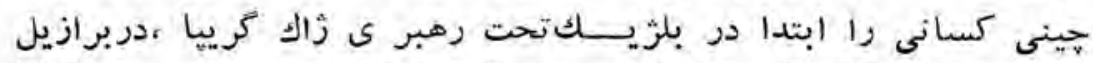

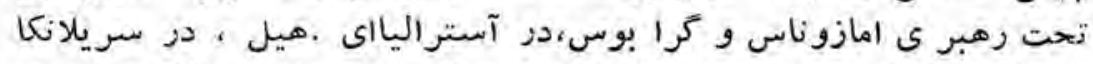

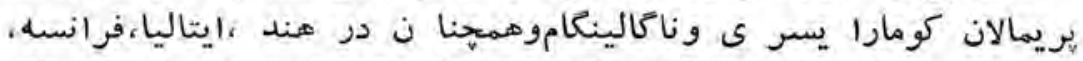

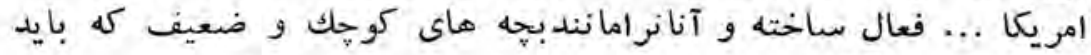

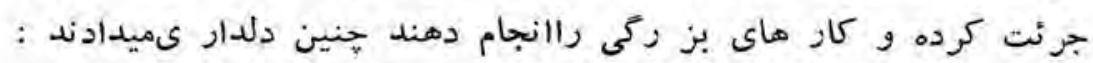

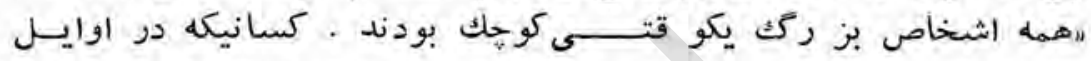

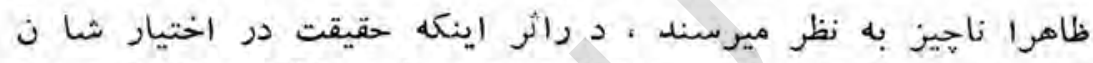

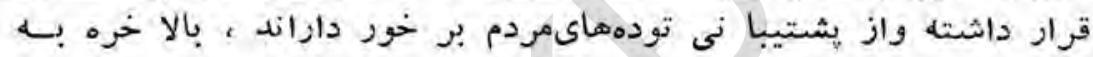

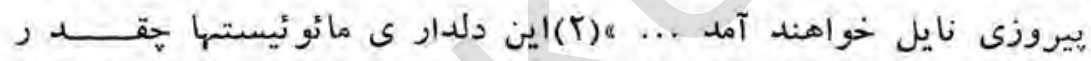

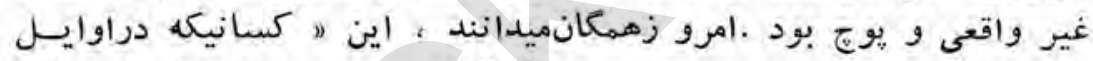

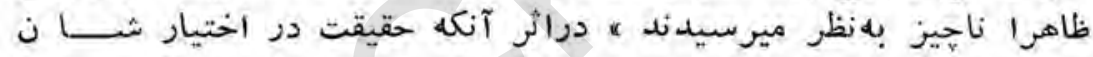

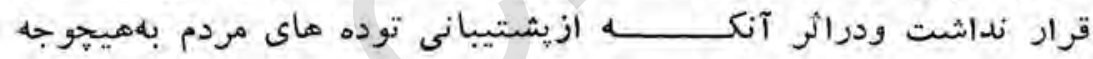

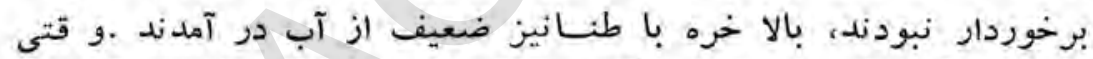

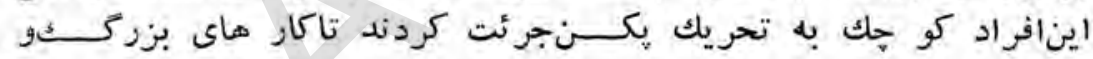

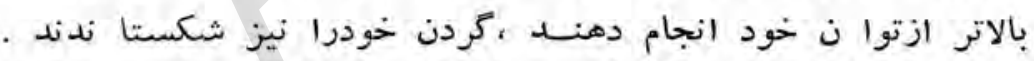

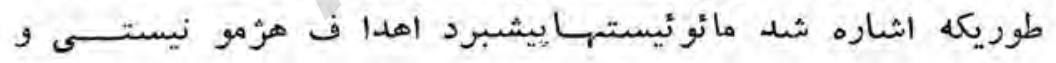

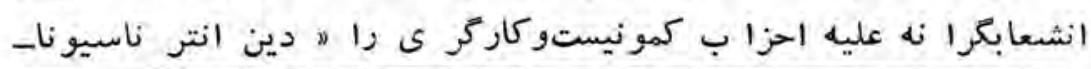

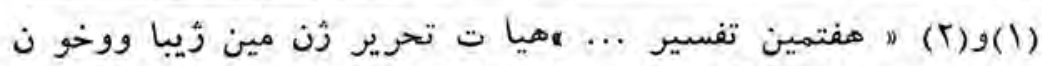

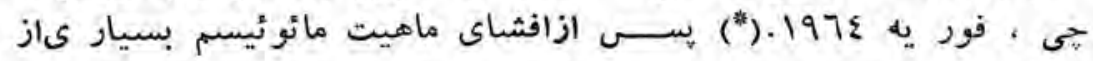

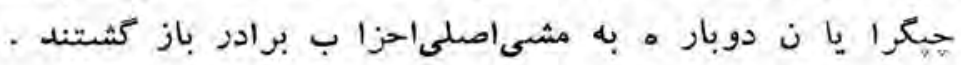


ليستى ه عنوا ن كرده و يشتيبانسى همه جانبه خودرا جهت تاسيس كروه

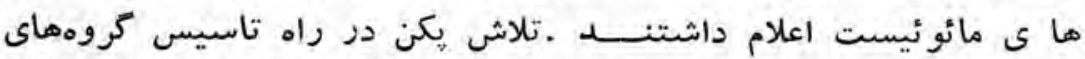

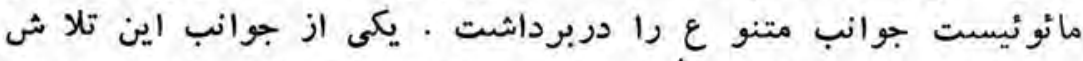

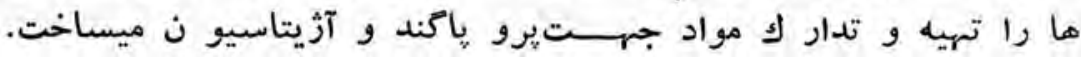

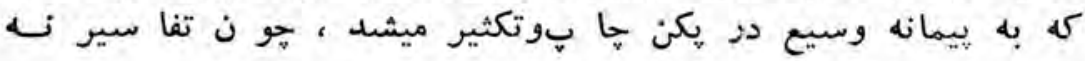

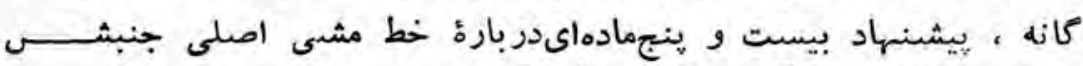

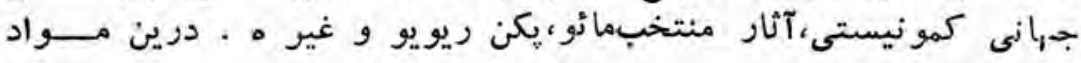

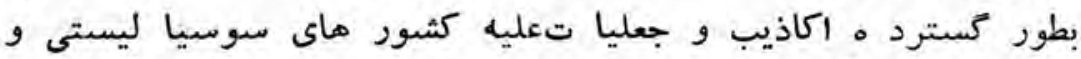

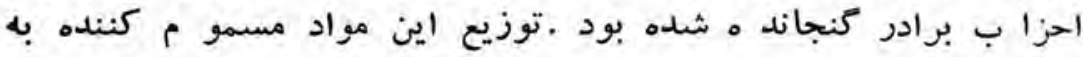

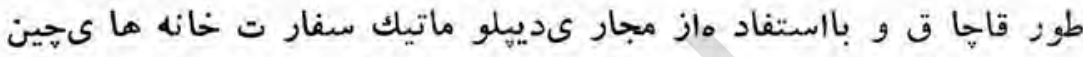

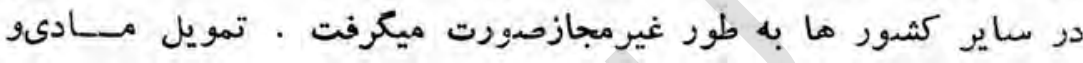

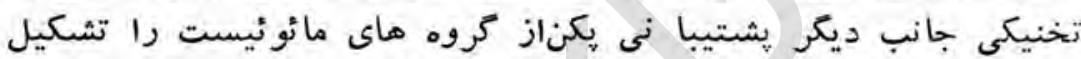
ميداد . به اثر تلا شهاي دا منه دار بركن تاسا لـ

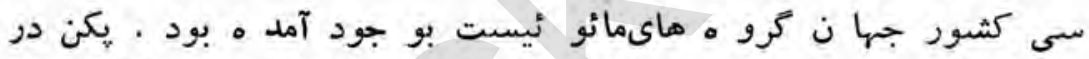

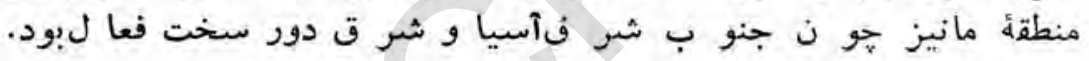

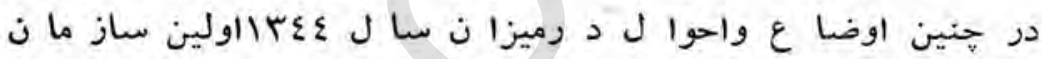

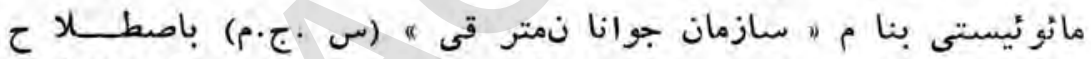

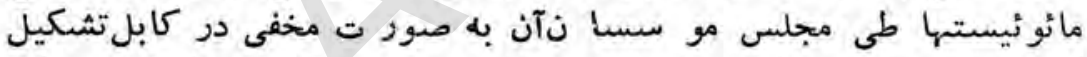

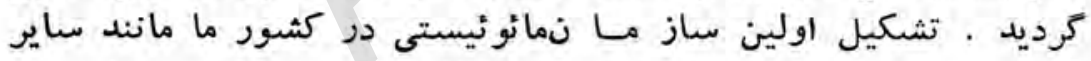

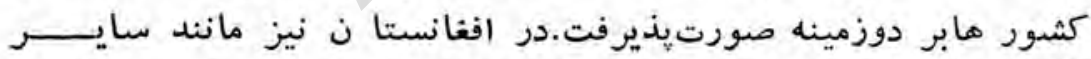

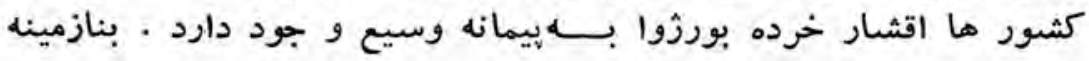

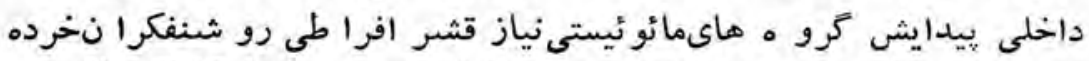

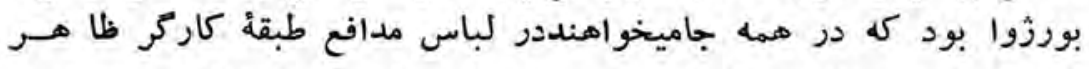

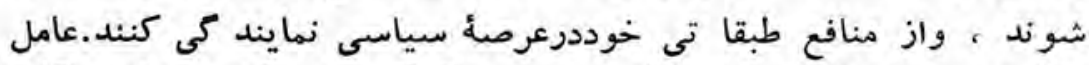

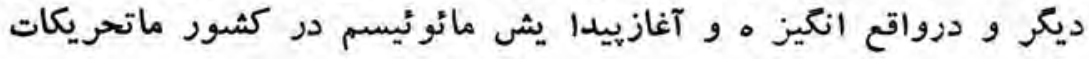




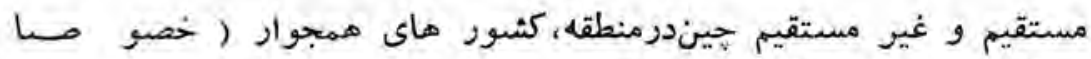

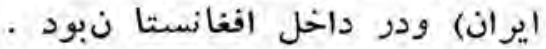

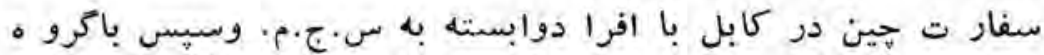

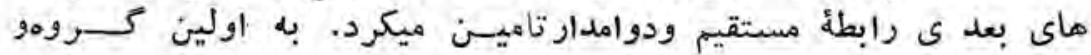

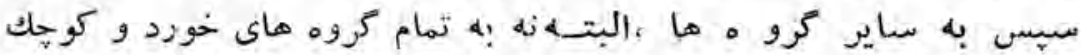

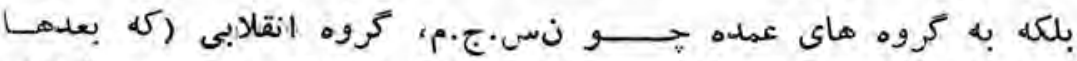

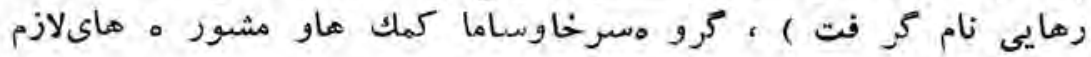

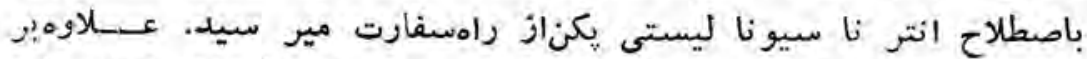

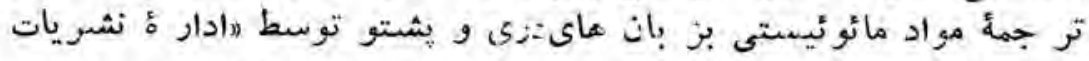

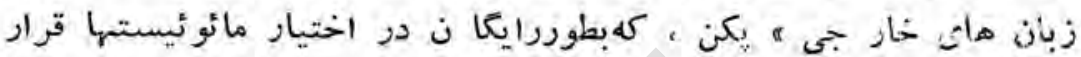

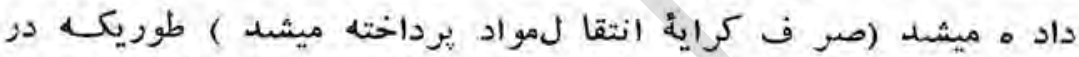

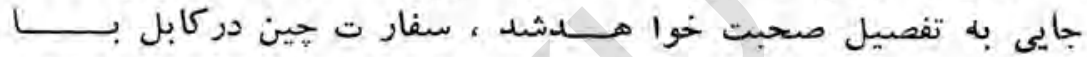
استفاد ه از مصو ونيت دييلوماتيكاز طريق يست ... آثار مائو راوارد

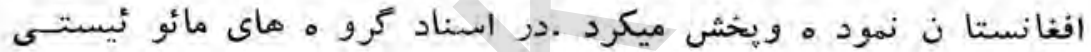

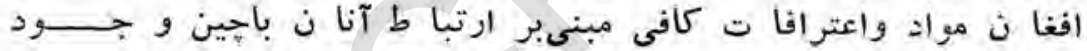
دارد .

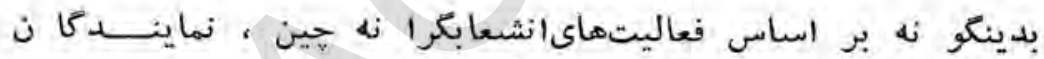

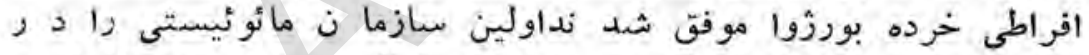

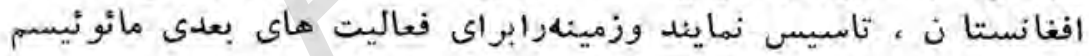

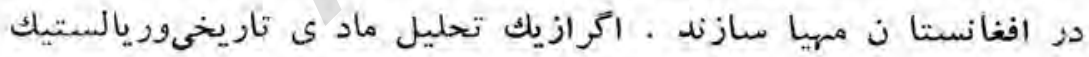
تكريسته شود با دو كتكور ىافراددر تركيب اولين سا زمانما ئو 'يستسى بر ميخوريمي :

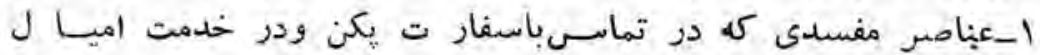

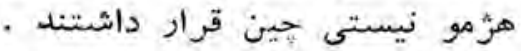

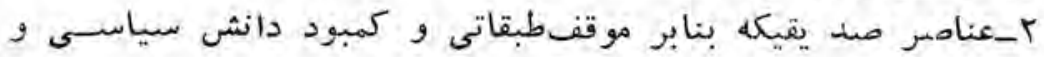


ايديولوز يكى تحت تاثير تيور ىماىمائو قرار كر فتند وساده لو حانئن

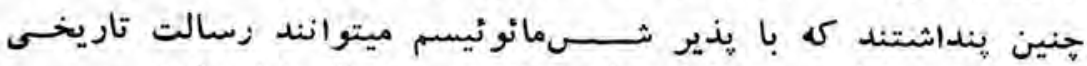

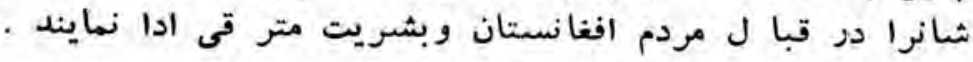

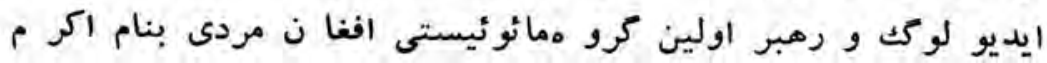

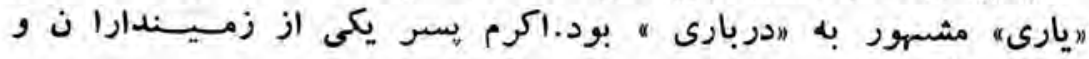

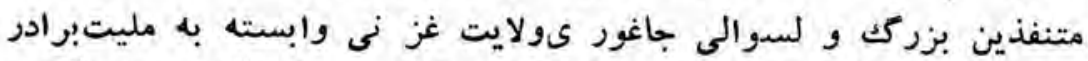

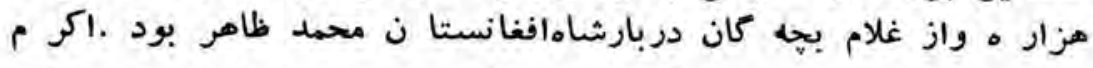

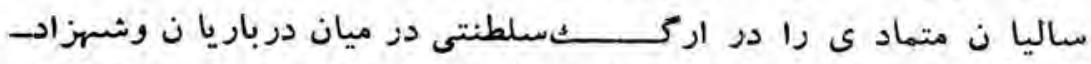

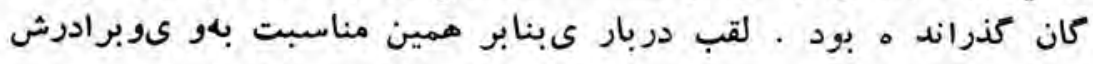

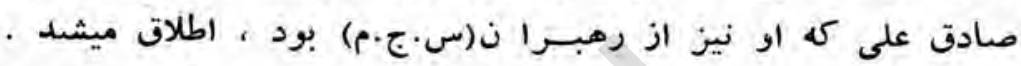

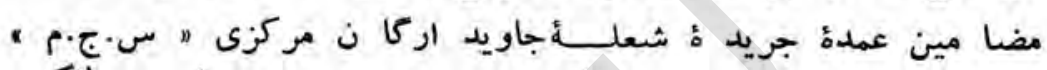

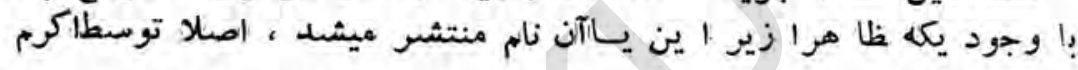

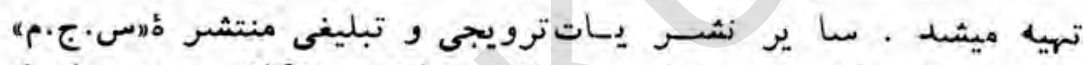

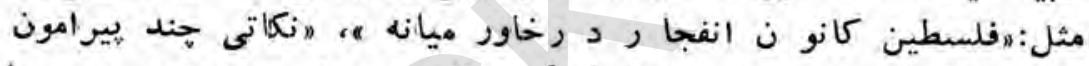

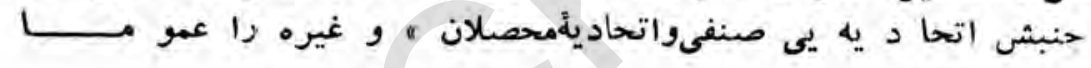

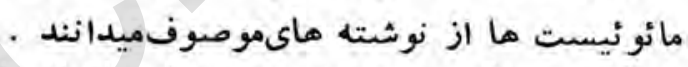

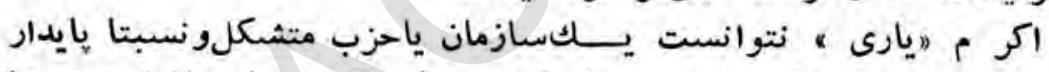

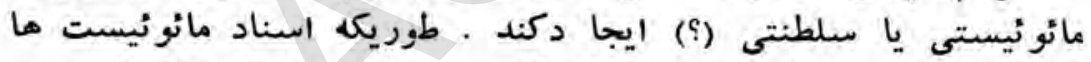

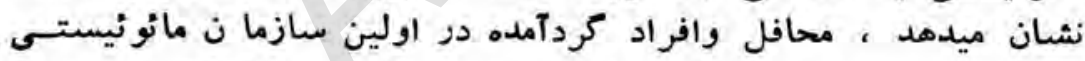

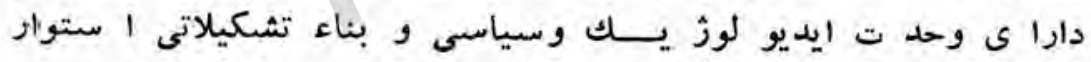

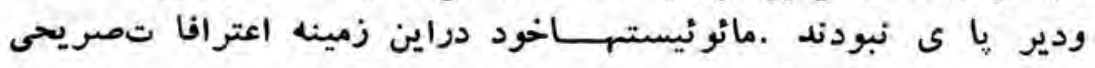

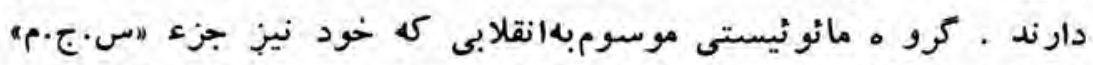

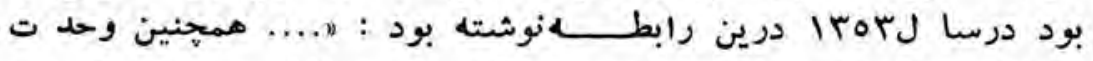

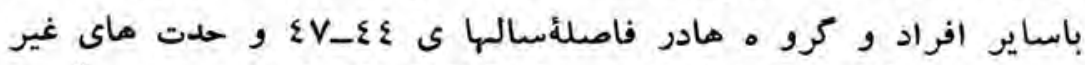

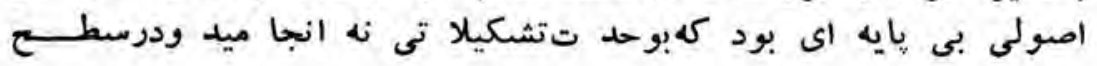




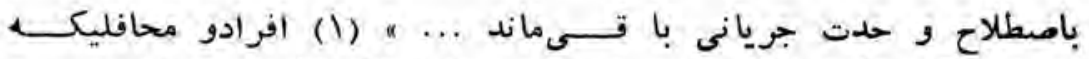

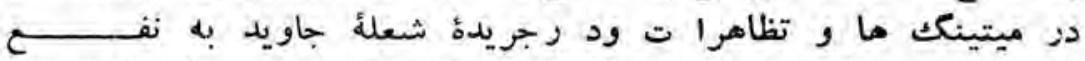

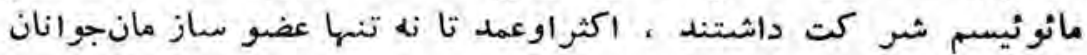

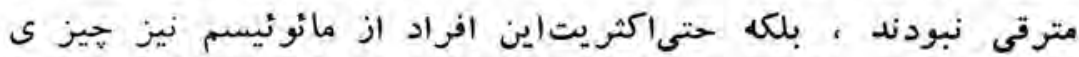

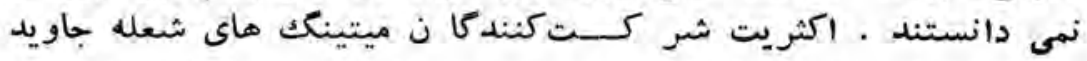

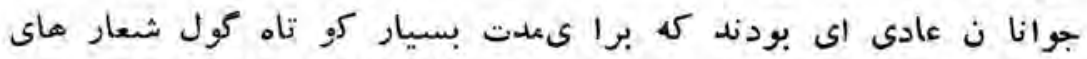

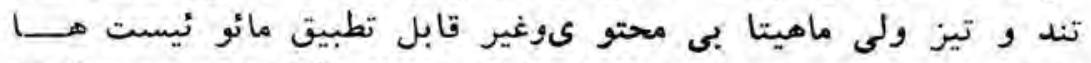

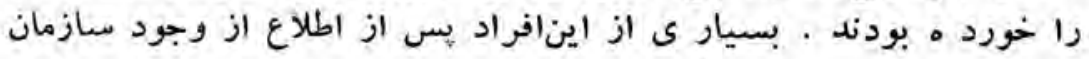

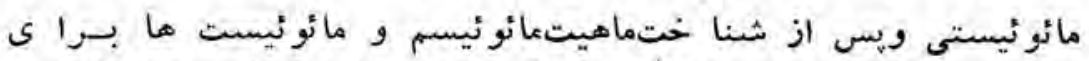

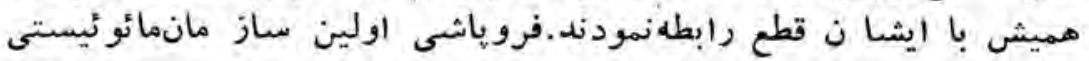

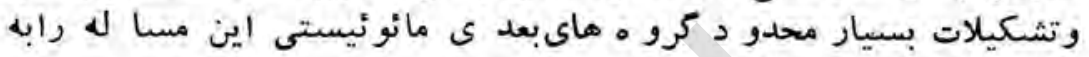
طور قناعت بخش اثبات ميكند . مرون مار

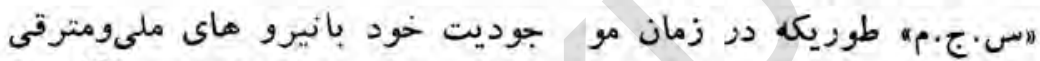

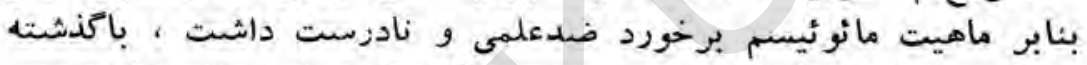

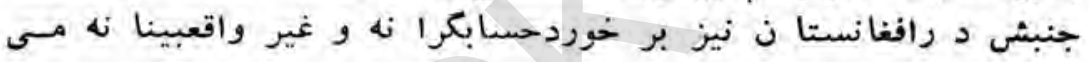

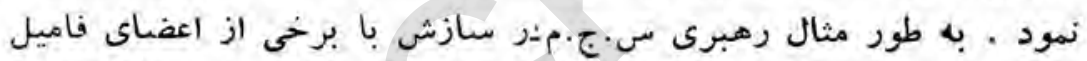

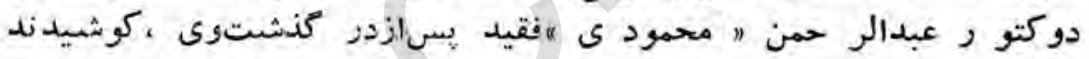

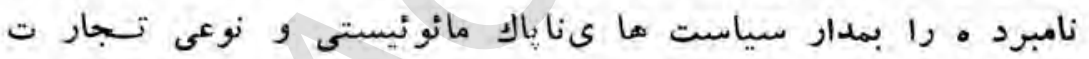

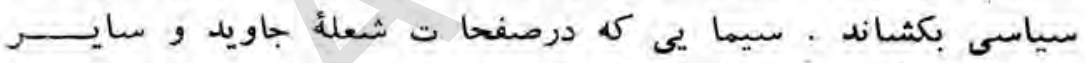

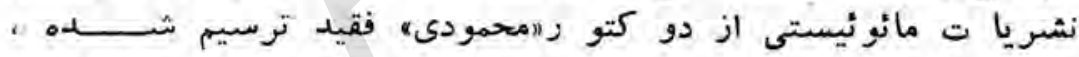

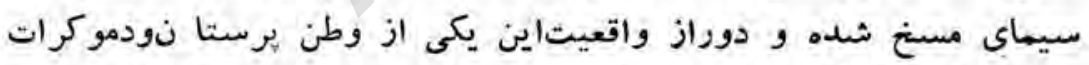

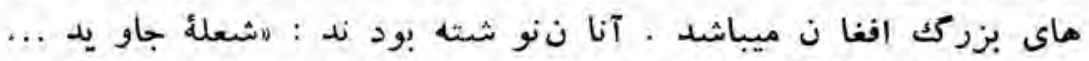

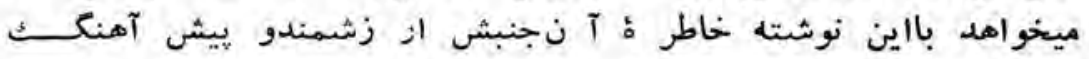

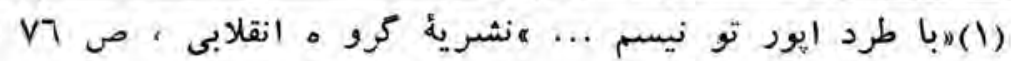

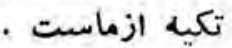




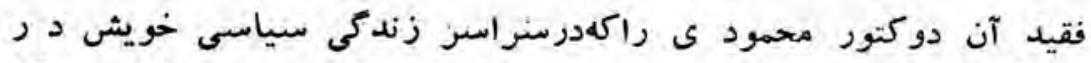

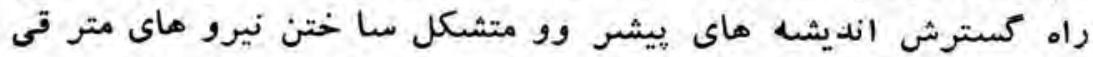

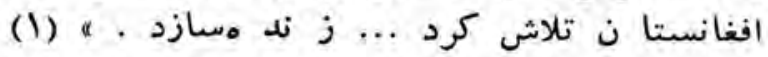

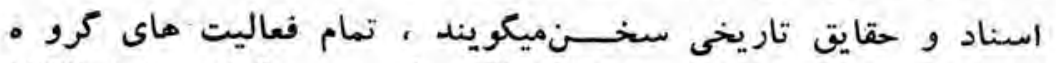

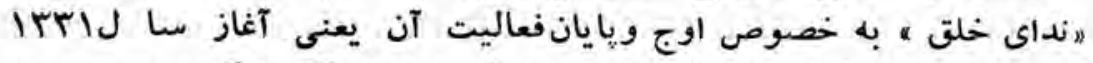

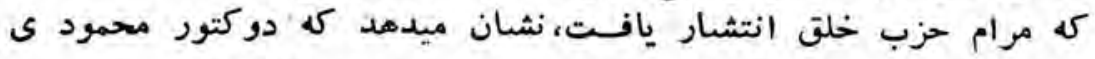

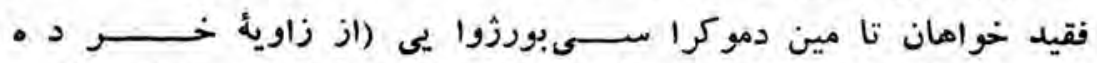

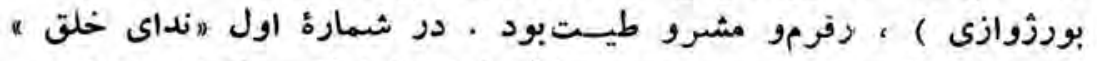

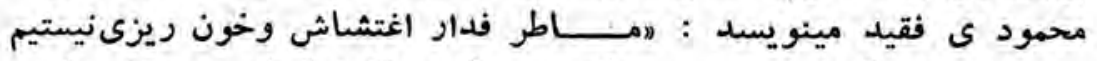

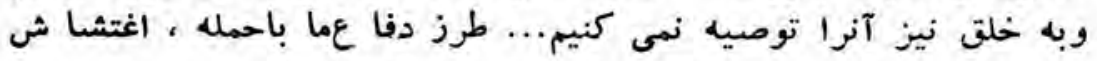

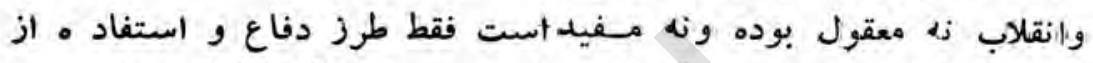

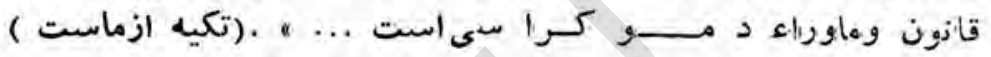

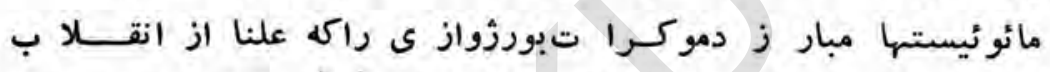

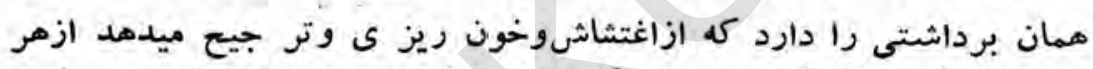

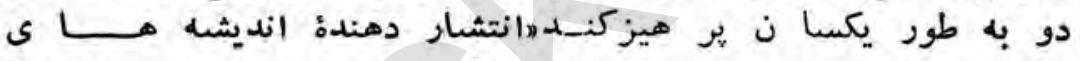

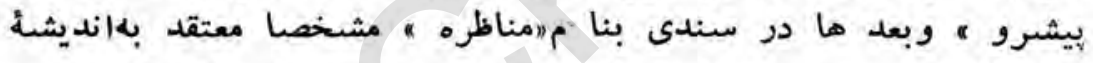

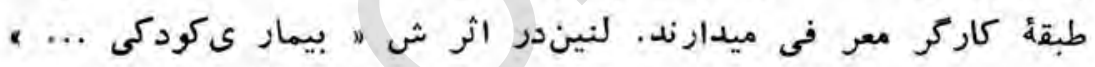

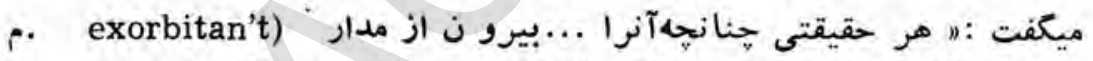

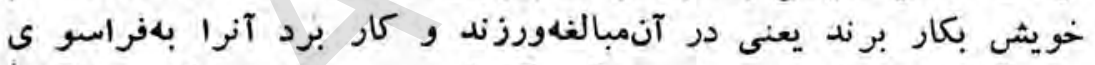

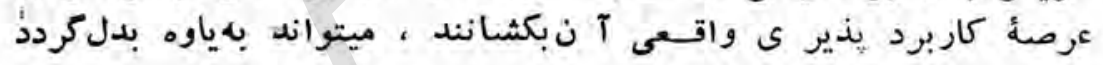

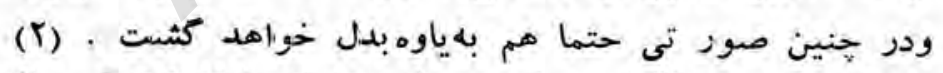

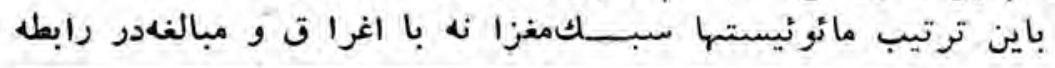

(1) (1) (1)

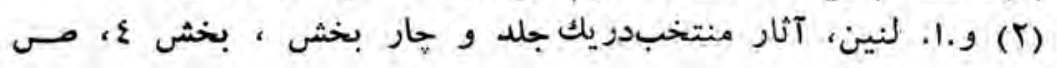

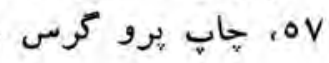


با فعاليتهاى دوكتور محمودىفقيلدحتو ى اصلى فعاليت وطنيرستانه

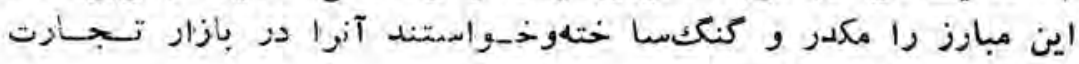
سياسى به ياوه مارد بدل سازند

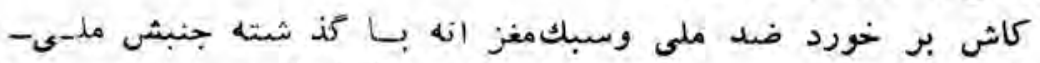

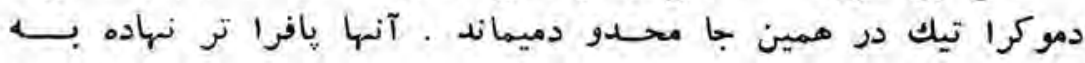

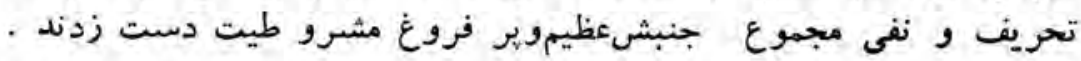

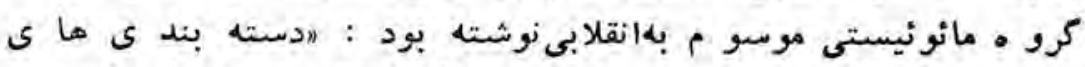

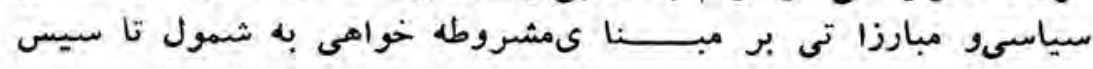

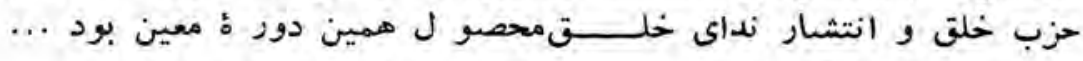

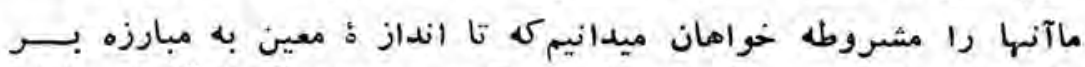

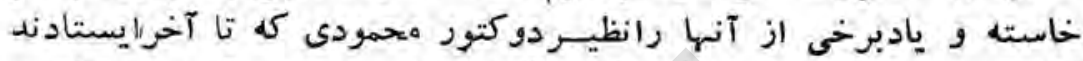

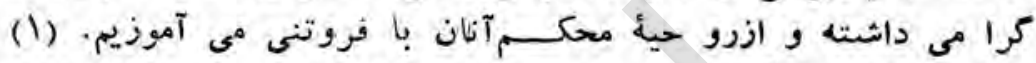

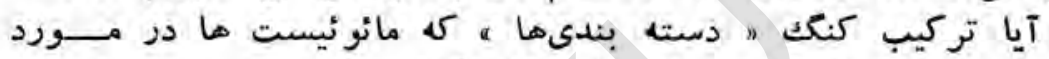

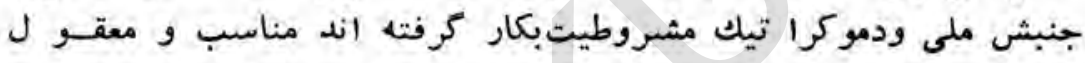

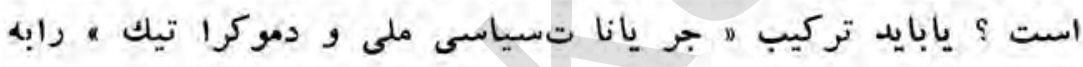

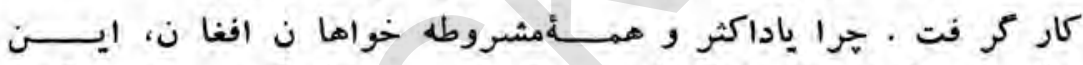

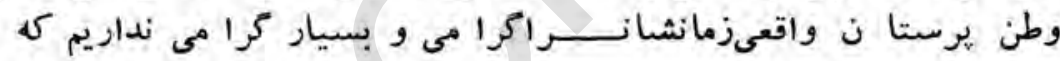

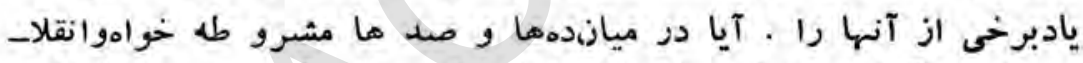

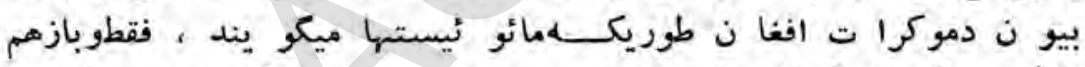

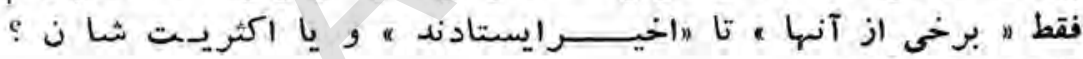
تاريخ ها مه ميكويد :

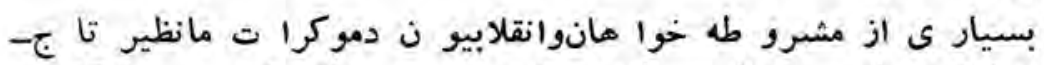

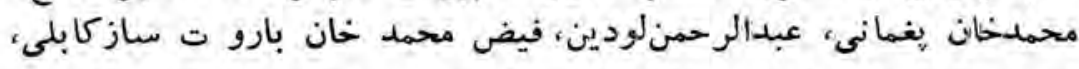

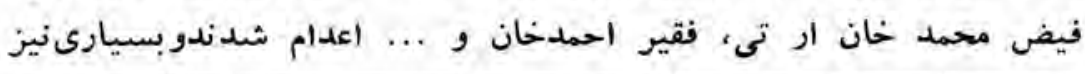

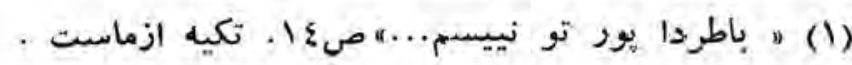




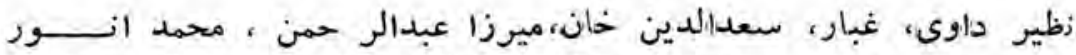

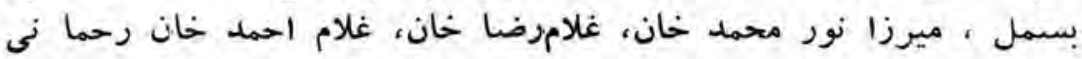

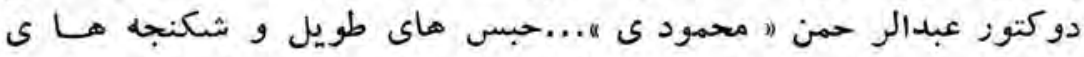

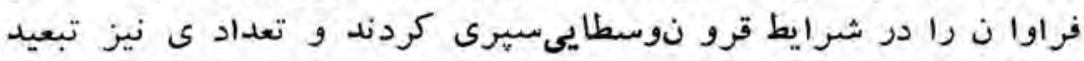

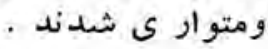

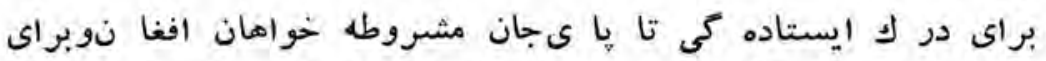

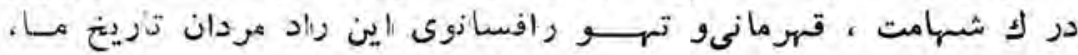

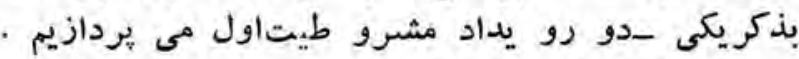

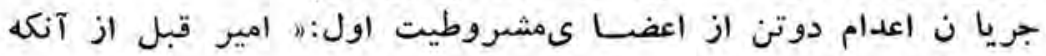

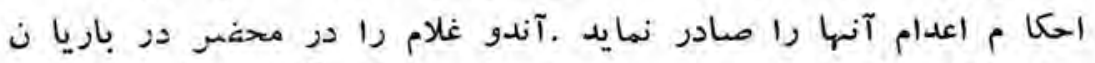

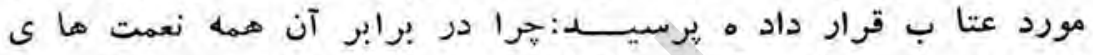

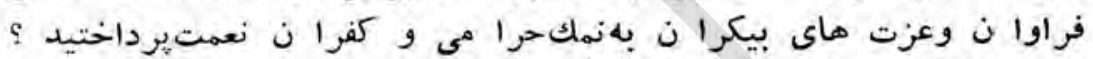

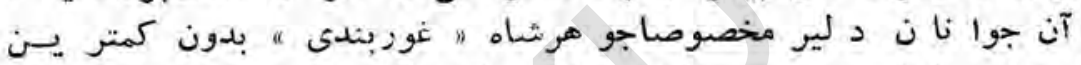

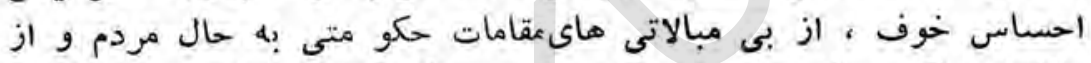

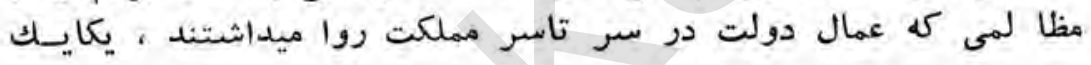

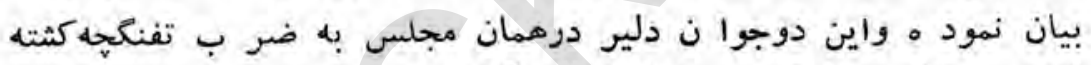

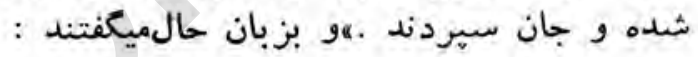

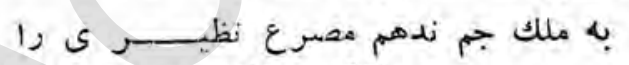

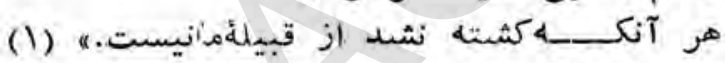

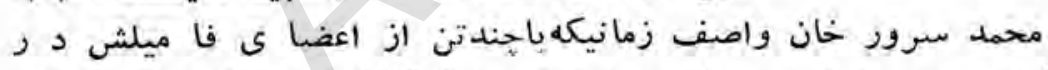

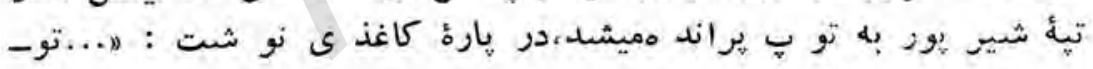

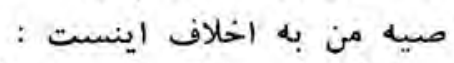

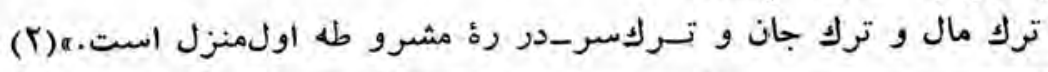

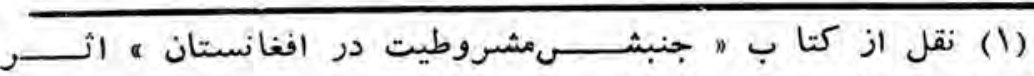

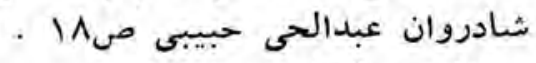
. 


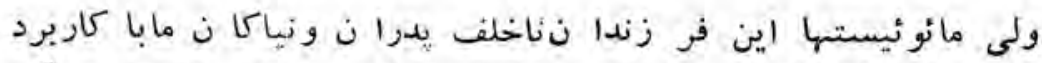

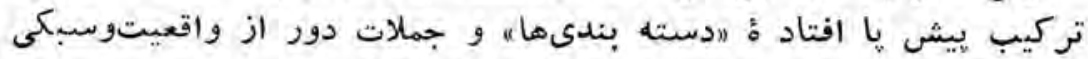

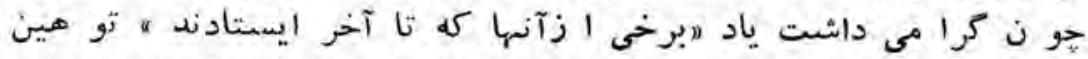

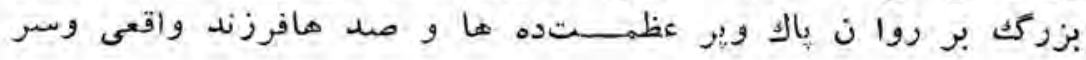

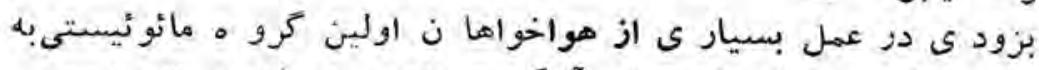

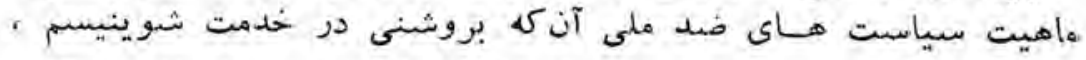

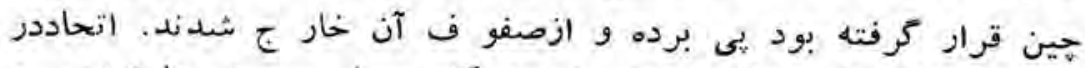

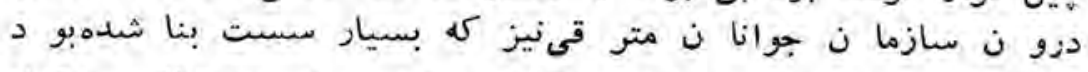

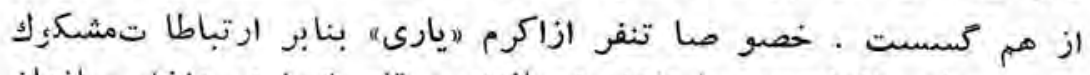

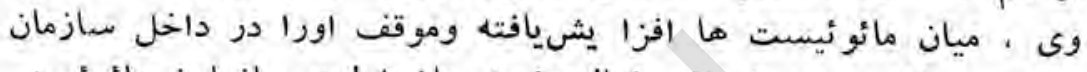

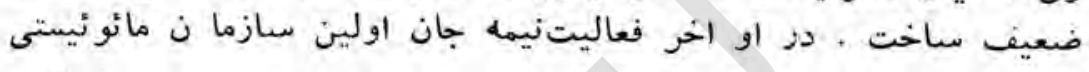

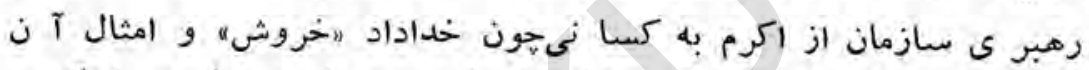

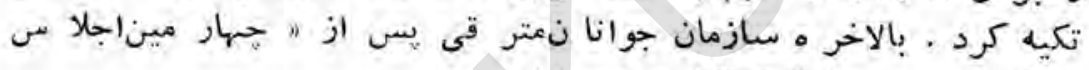

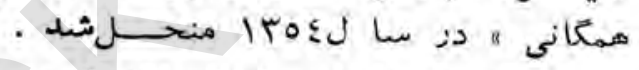

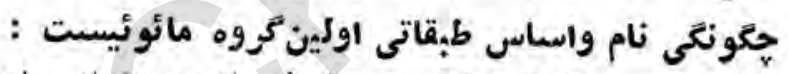

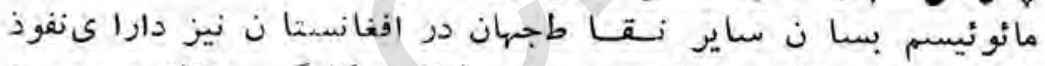

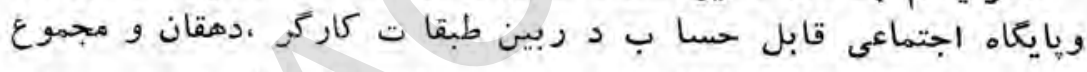

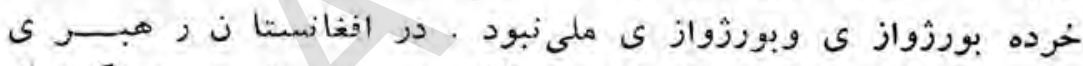

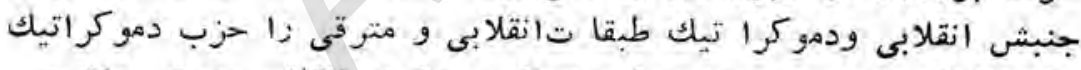

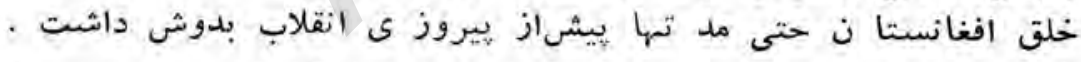

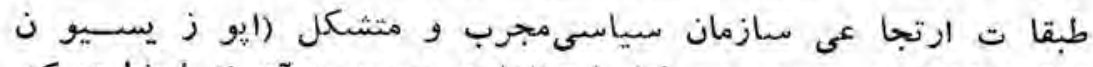

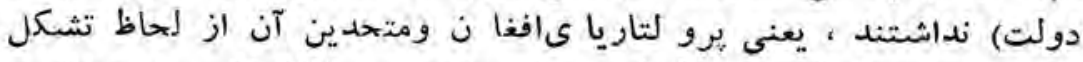

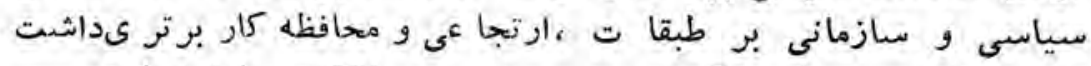

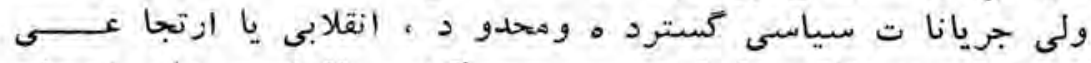

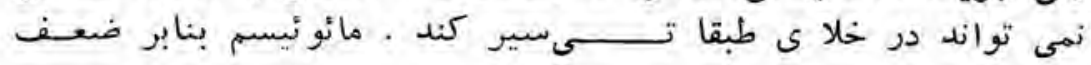


سياسبى وتشتت فكر ى نه نمايثدةيك طبقة بلكه نمايند م طبقا تسى نـ

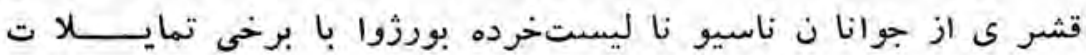

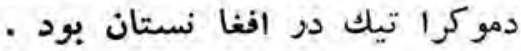

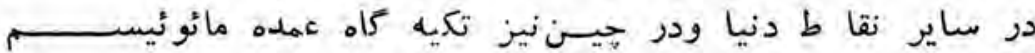

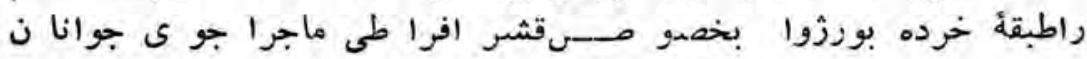

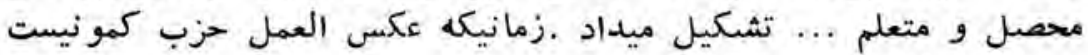

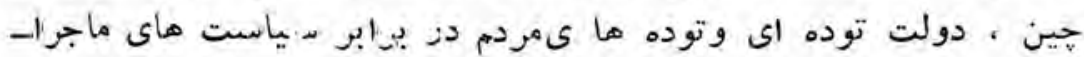

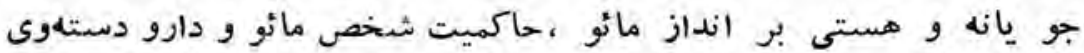

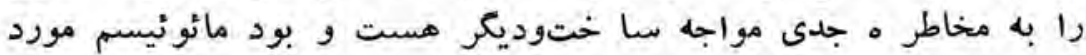

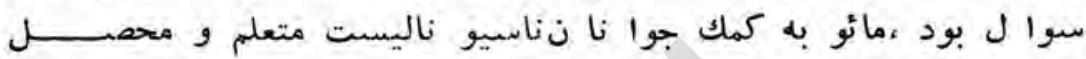

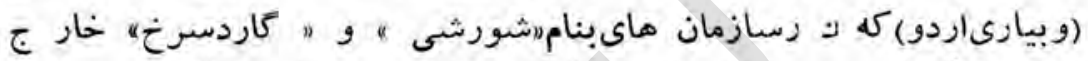

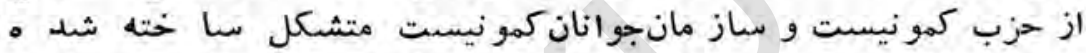

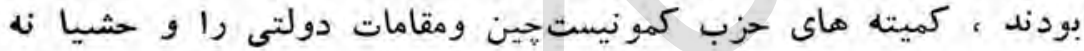

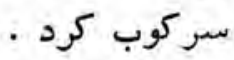

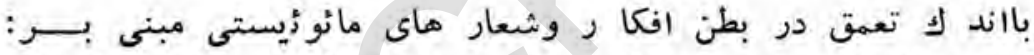

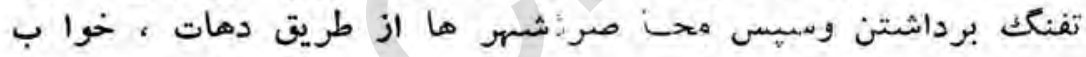

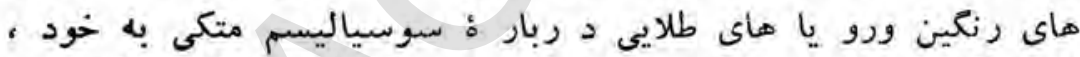

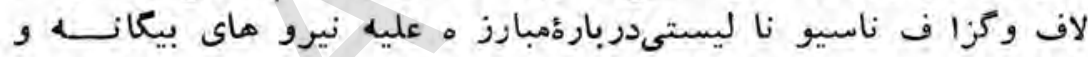

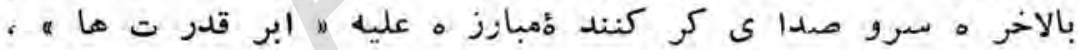

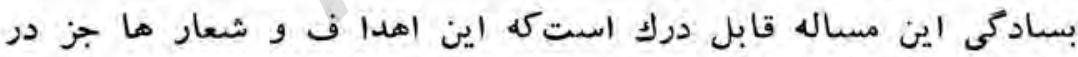
ميا ن بخشى از جوانا ن ناسيونا ليست با سطع ناز لل دانشو تجربئ

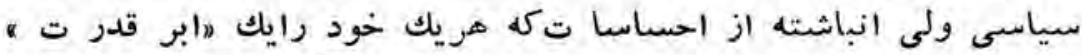

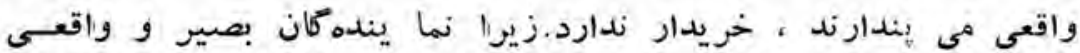

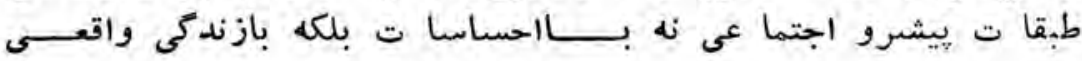

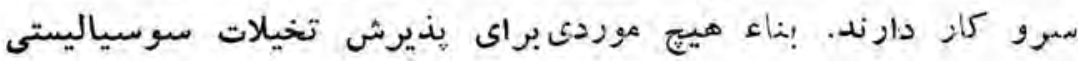


مائو د زميان نمايندها ن واقعى وآكاه طبقا ت انقلابى و متر قـى ،

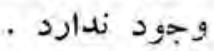

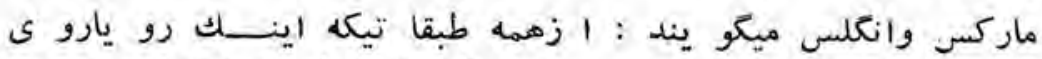

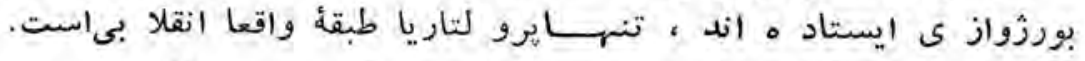

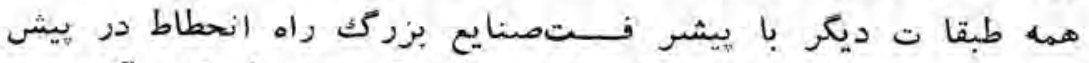

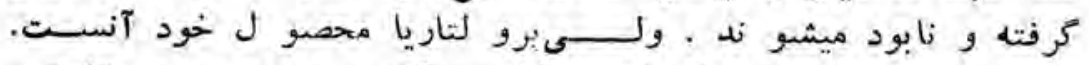

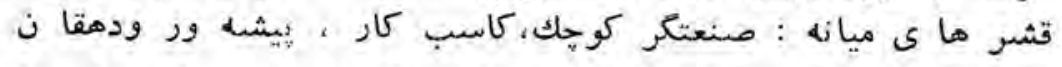

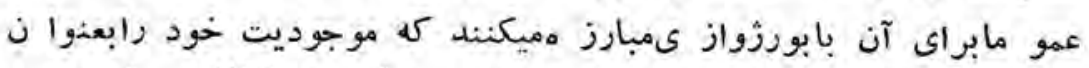

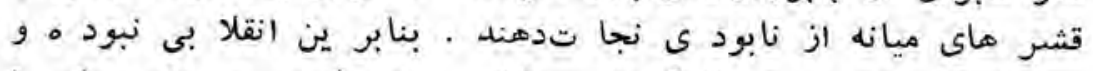

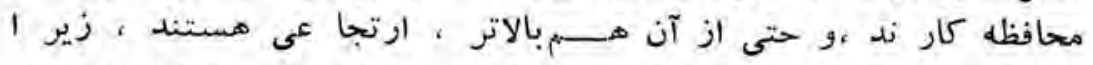

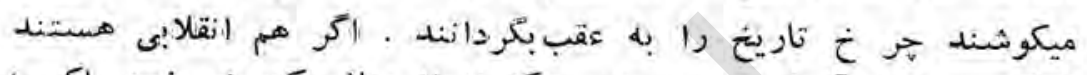

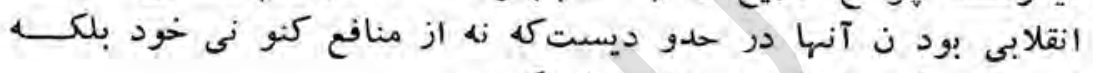

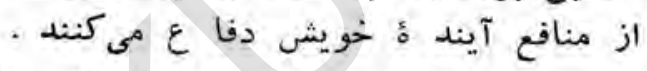

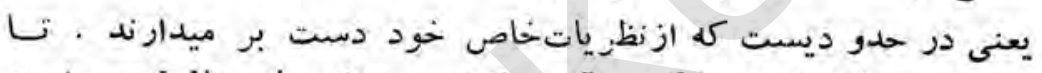

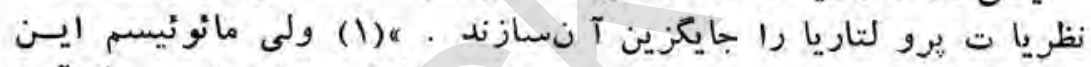

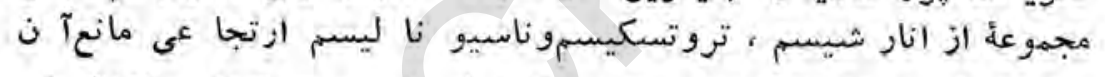

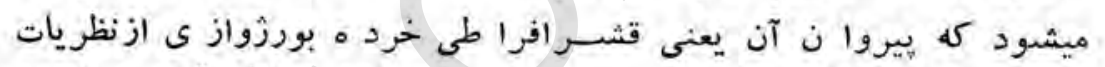

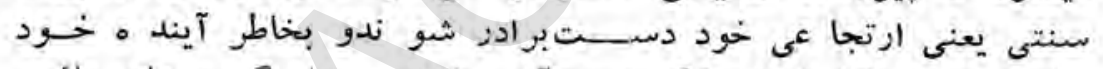

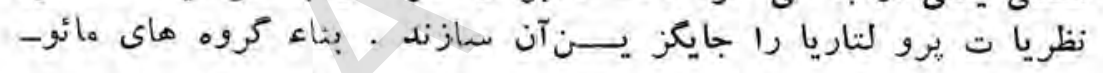

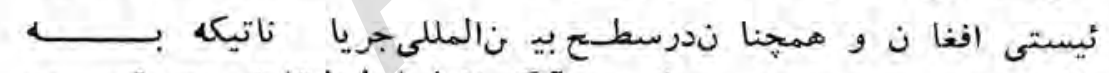

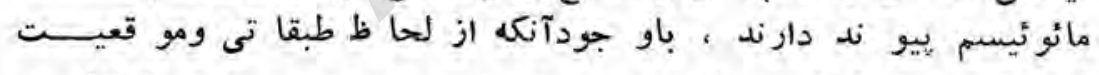

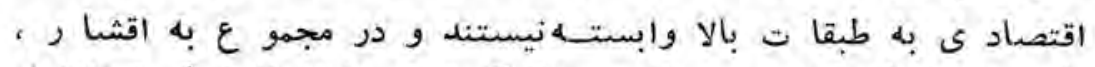

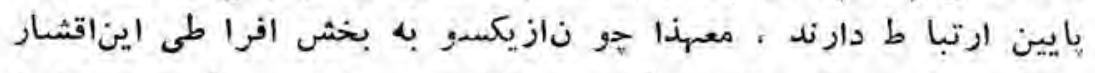

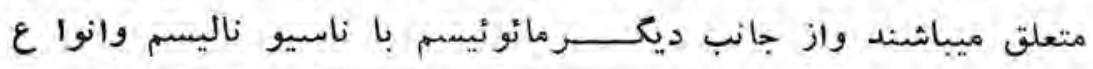

. مانيفست حزب كمونيست (1) 


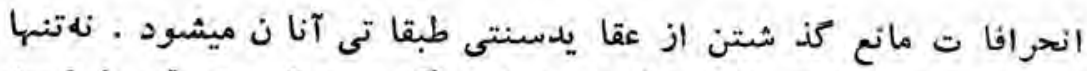

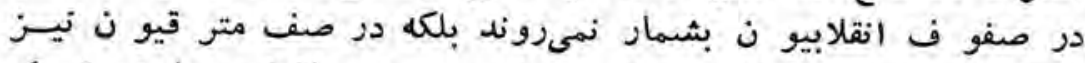

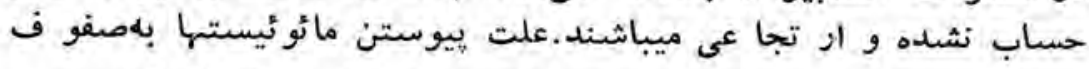

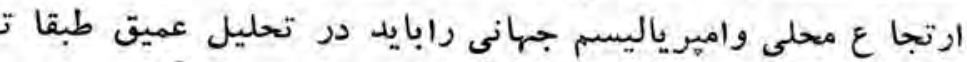

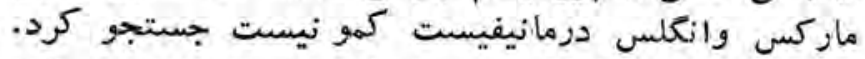

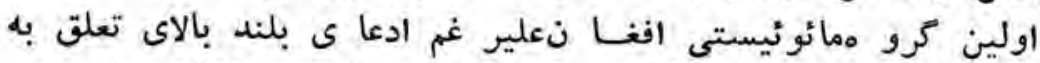

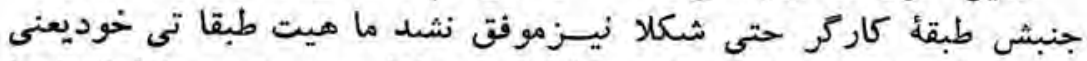

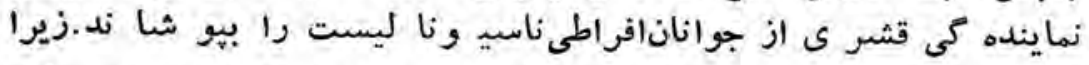

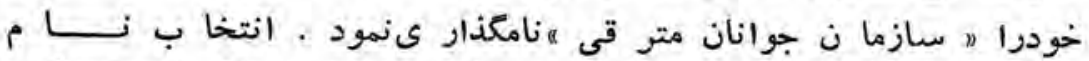

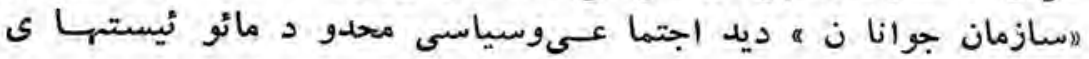

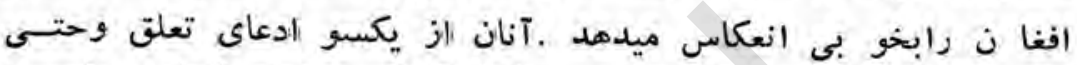

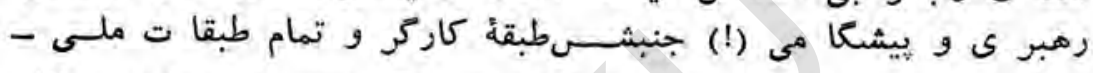

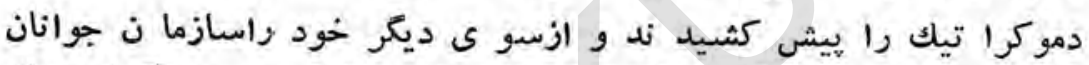

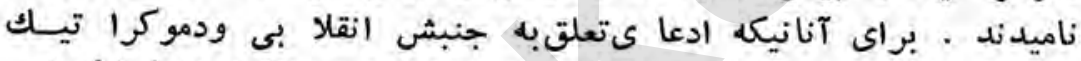

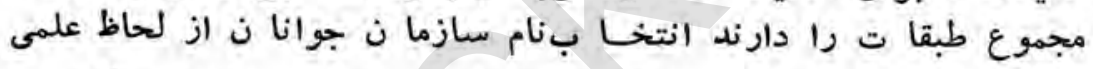

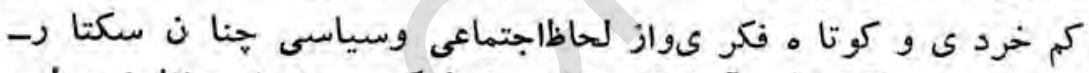

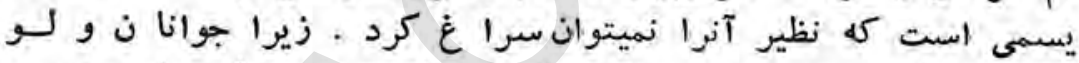

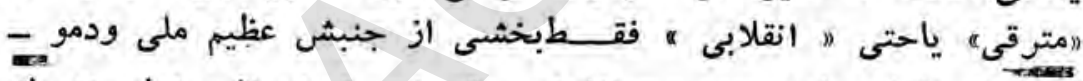

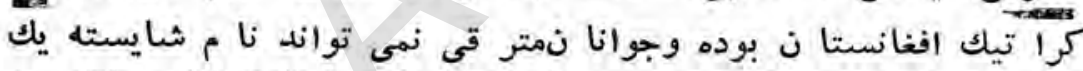

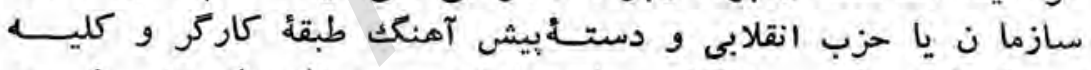

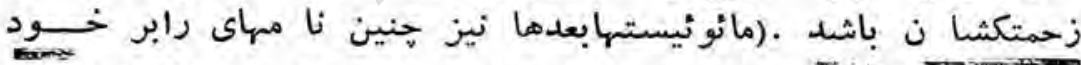

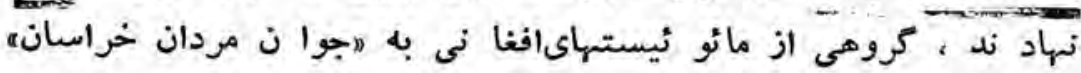

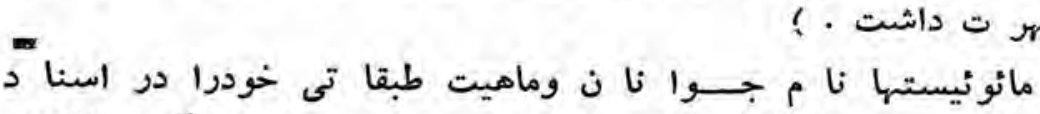

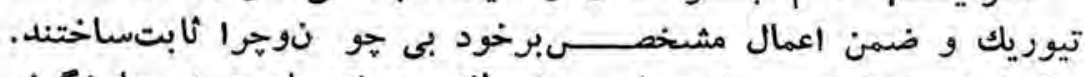

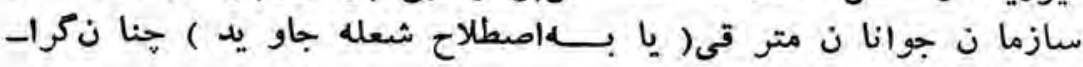


يشى به جوانان داشت كانه إتحاديؤ محصلين را به كعبئ آمال خودبدل

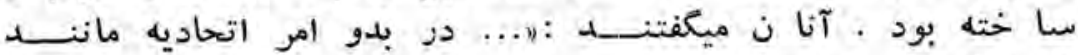

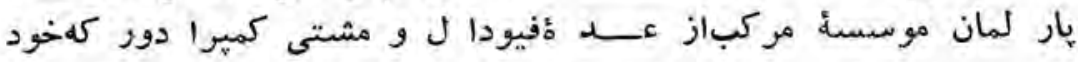

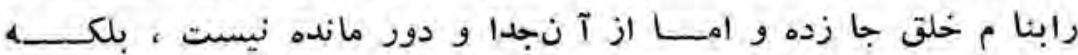

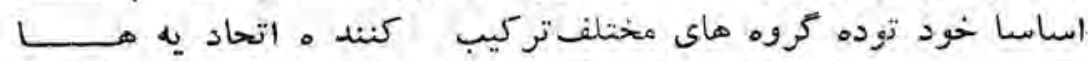

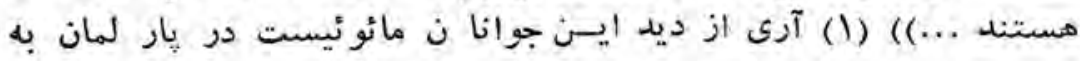

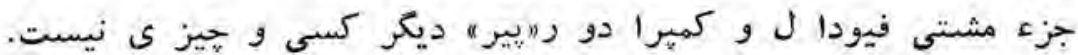

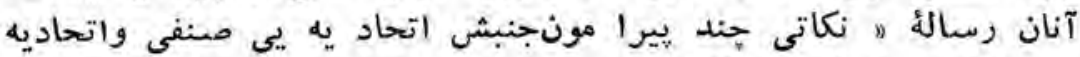

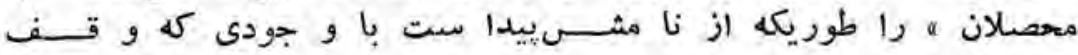

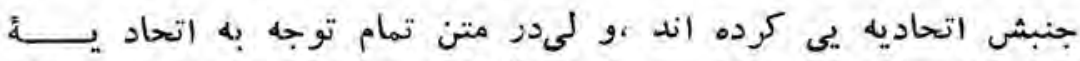

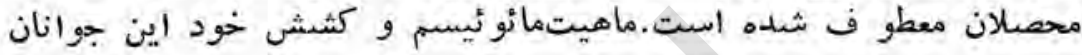

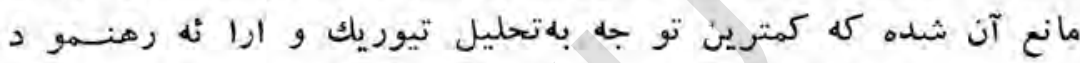

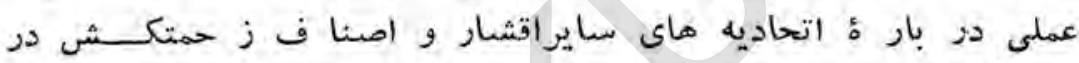

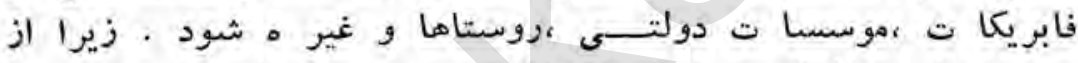

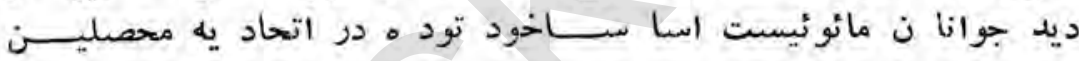

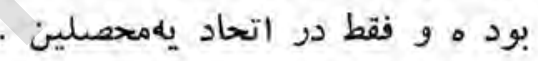

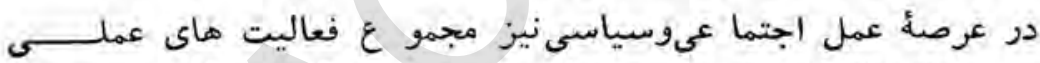

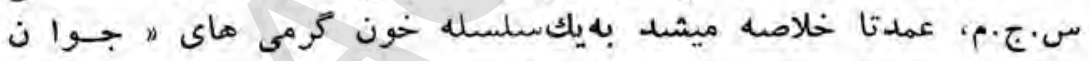

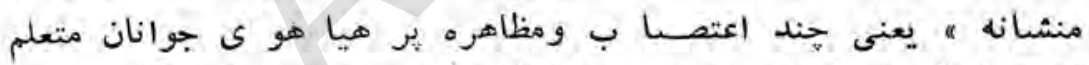

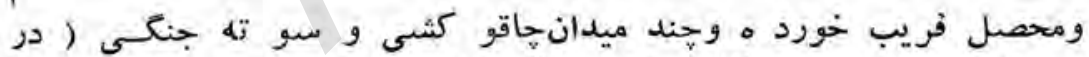

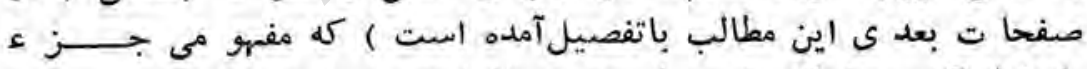

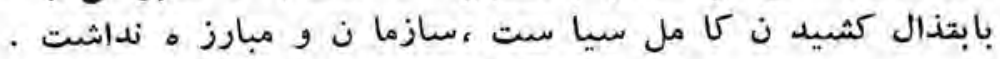

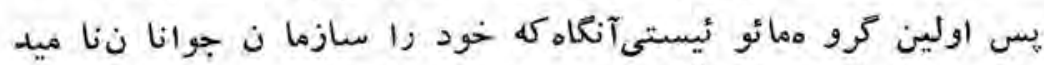

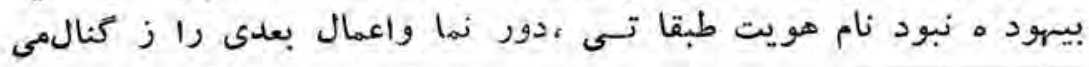




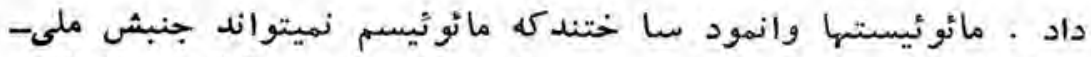

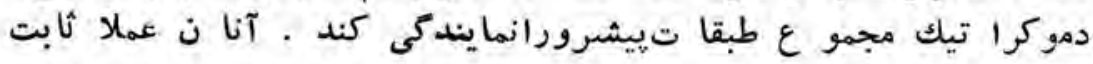

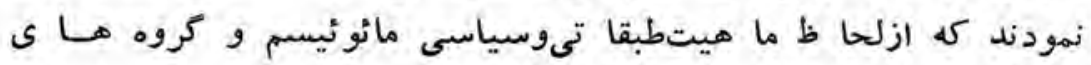

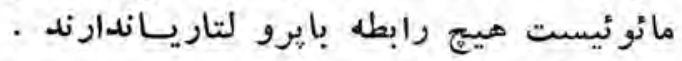

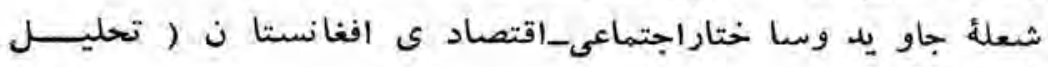

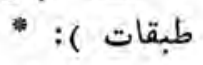

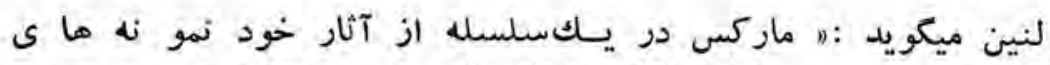

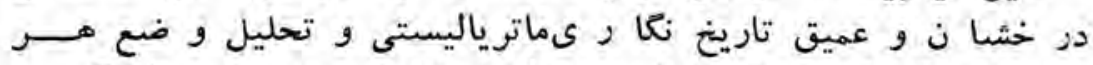

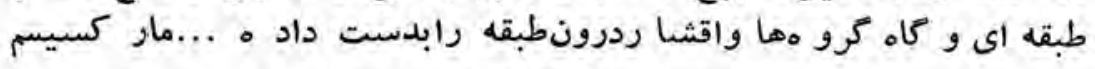

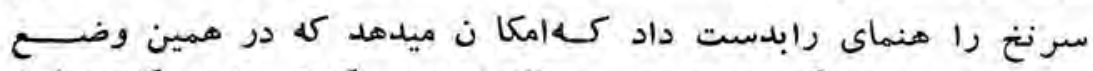

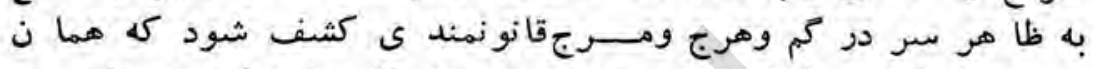

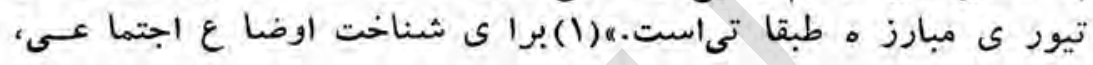

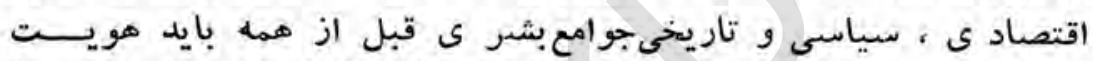

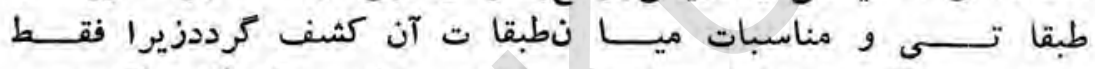

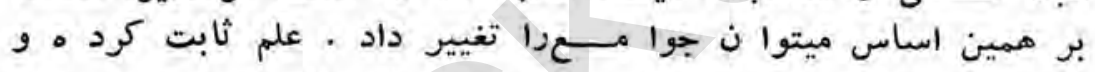

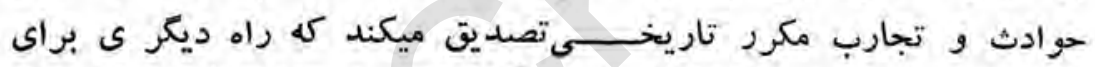

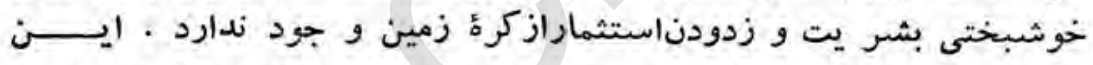

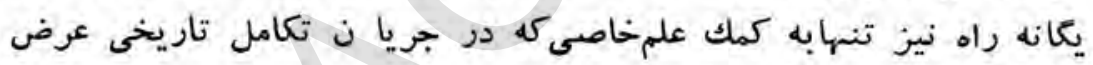

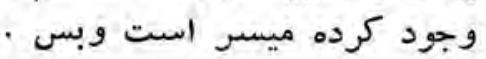

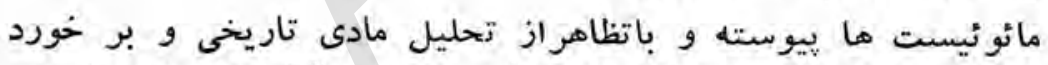

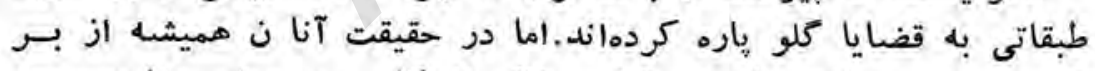

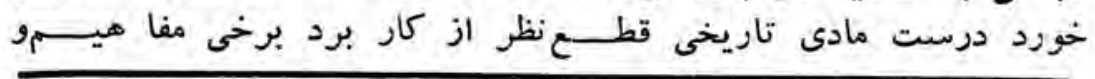

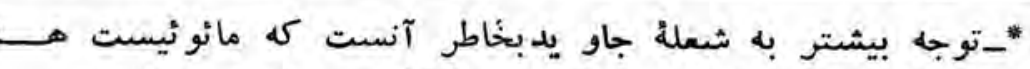

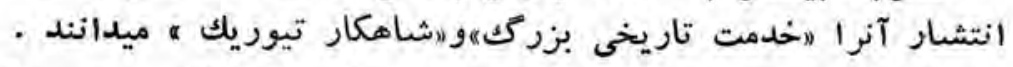

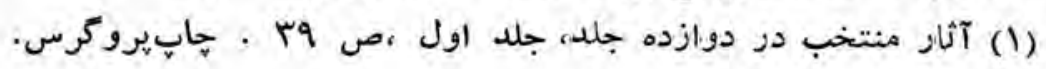




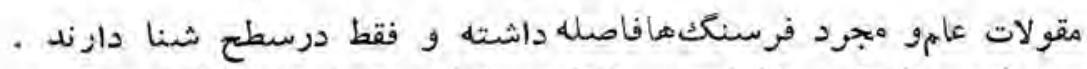

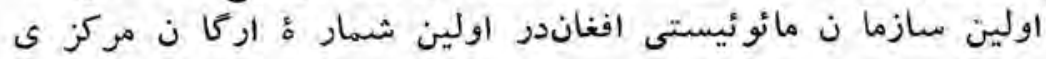

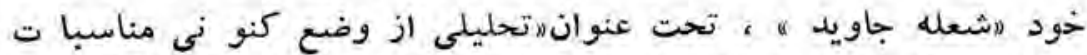

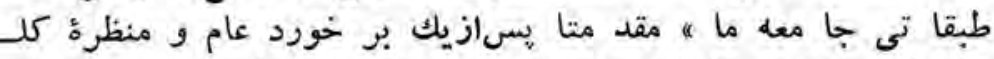

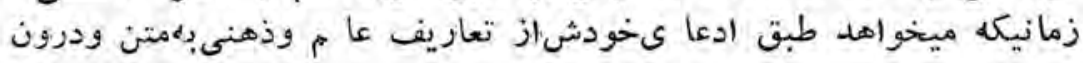

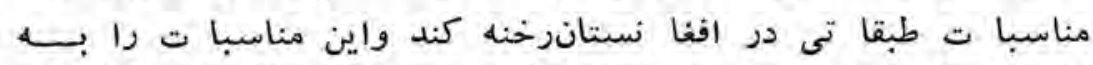

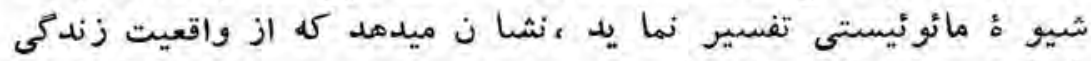

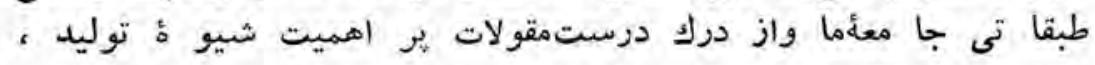

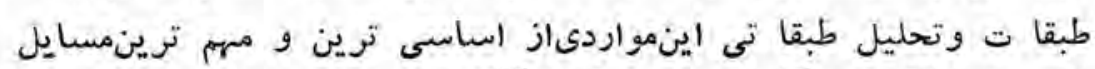

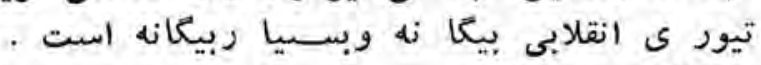

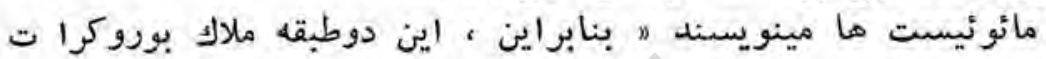

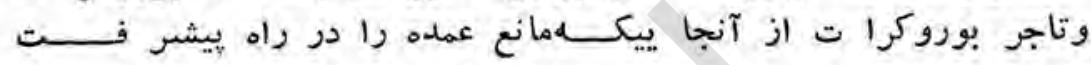

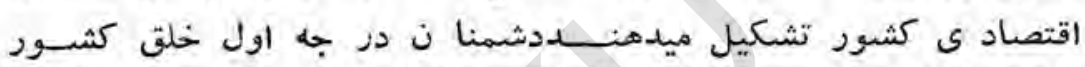

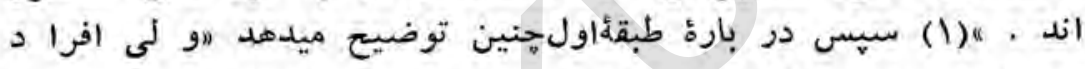

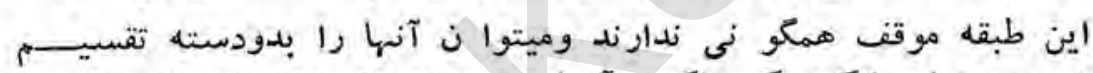

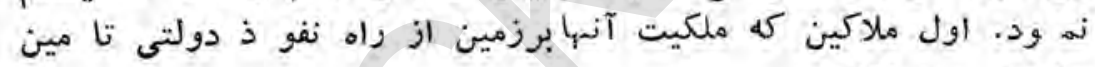

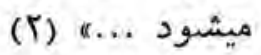

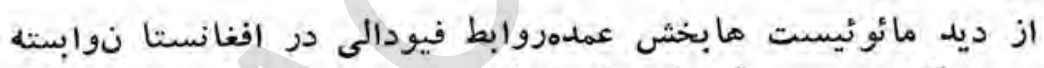

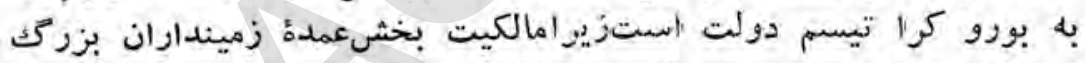

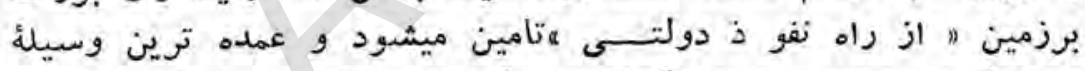

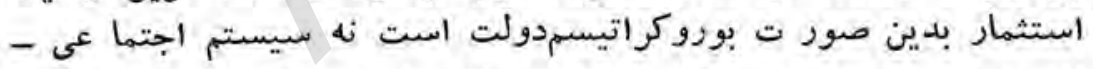

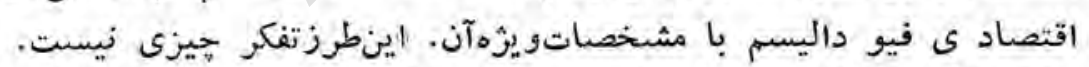

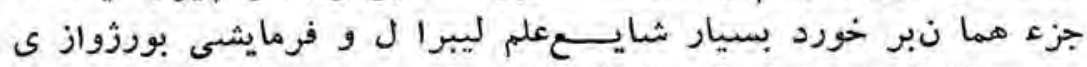

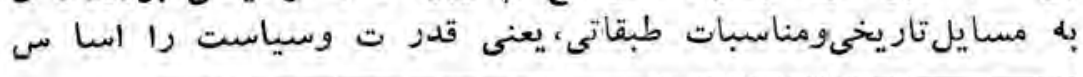

(1)و(r) شعلكُ جاو يد ، شمارهاول ، صدوم ، ثكيه از ماست . 
طبقا ت و مبارز ه طبقا تىودرمجموعتكوين تاريخ و جا معه انسا نسـى

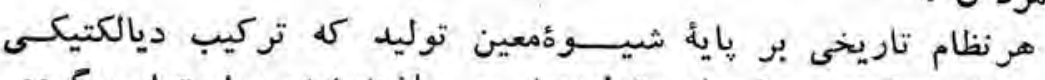

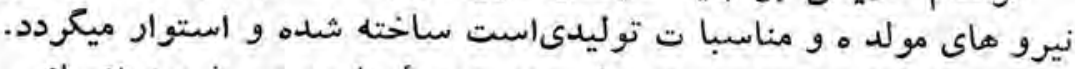

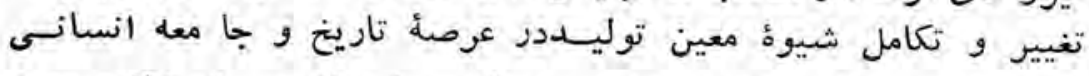

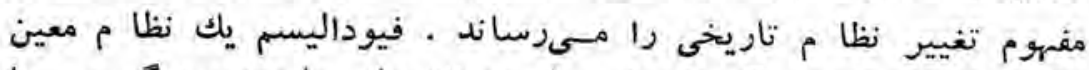

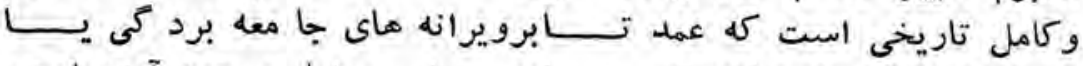

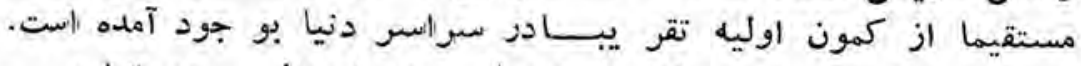

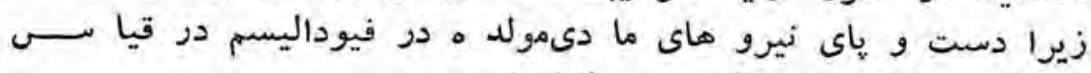

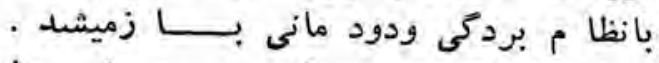

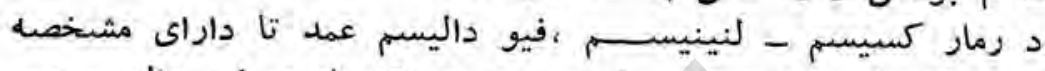

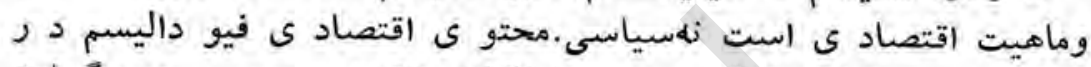

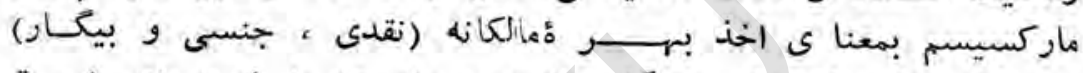

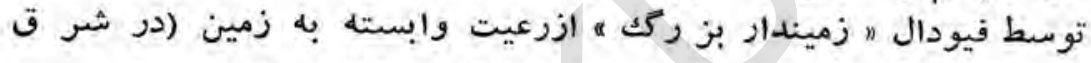

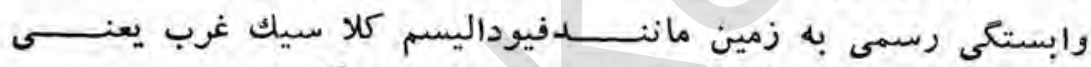

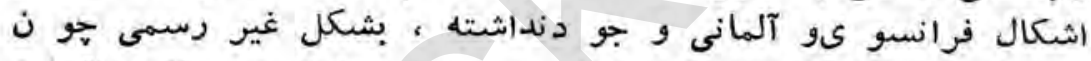

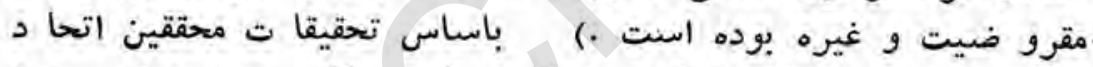

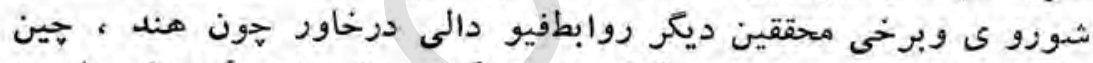

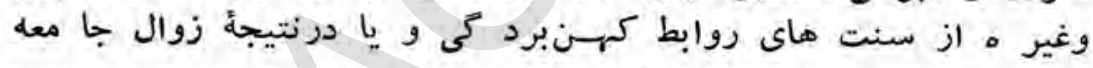

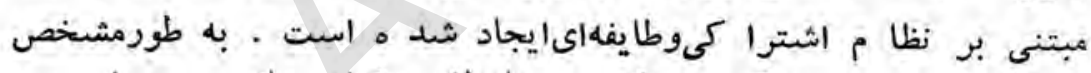

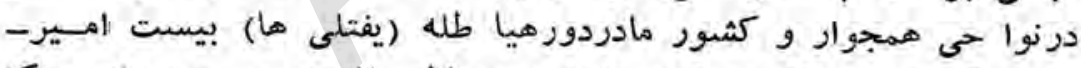

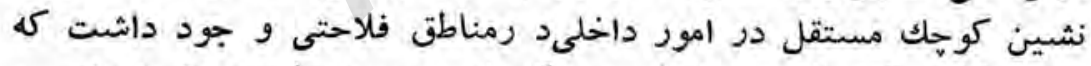

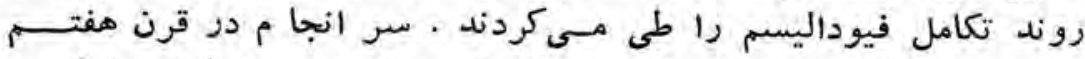

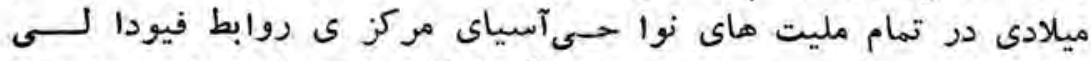

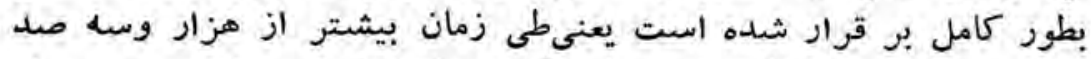

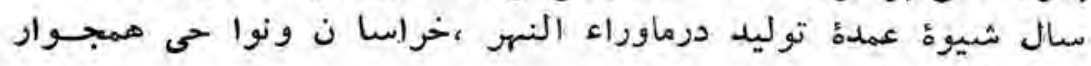
فيودا لى بود . 


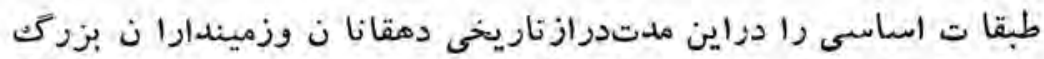

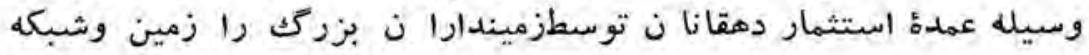
هاى آييار ى كه در دست زميندارانودربرخى موارد دز دست شــا ه. و

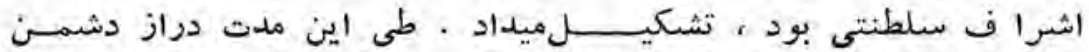

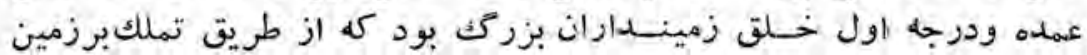

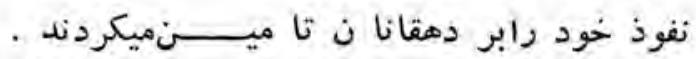

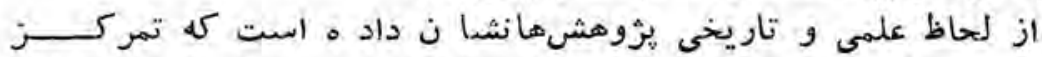

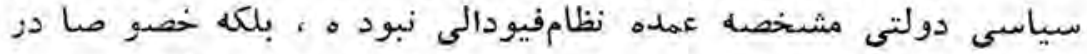

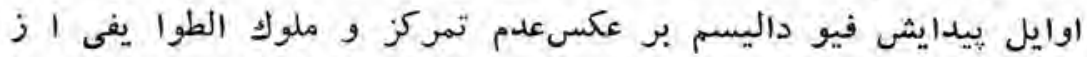

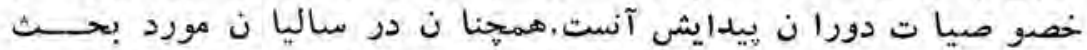

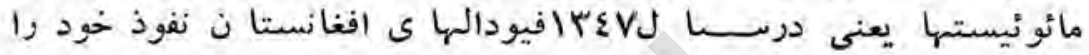

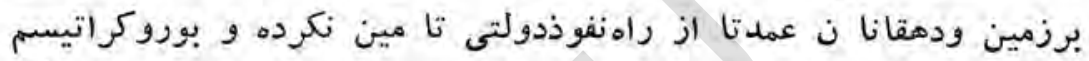

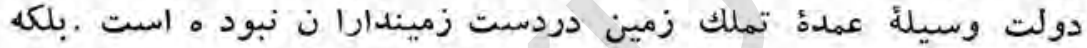

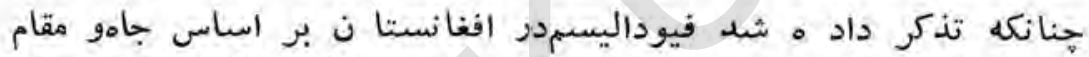

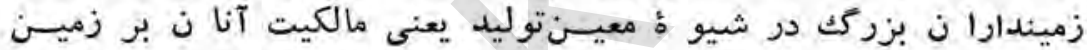

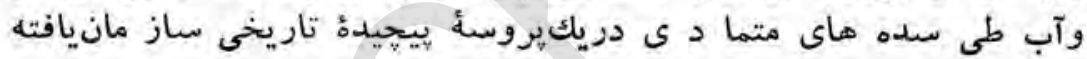
است واب

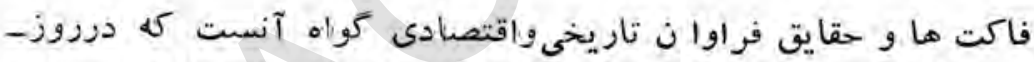

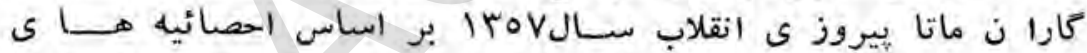

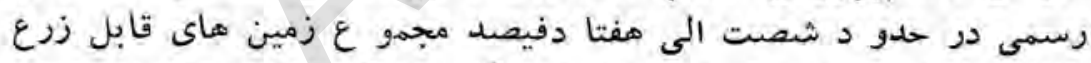

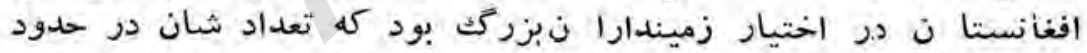

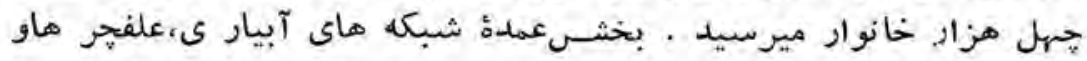

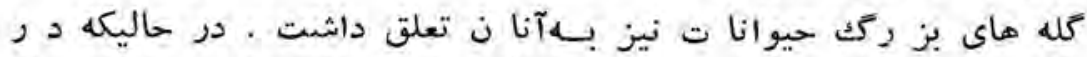

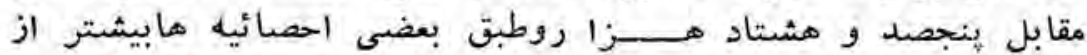

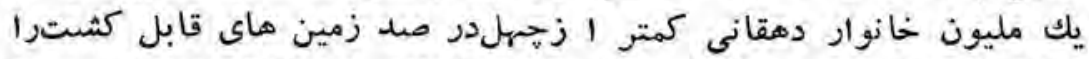

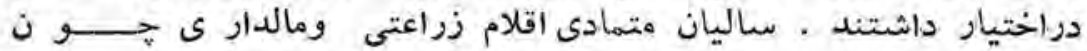




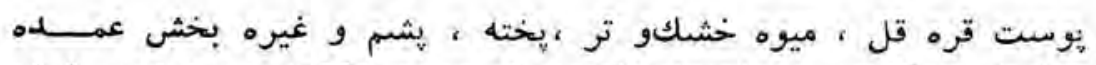

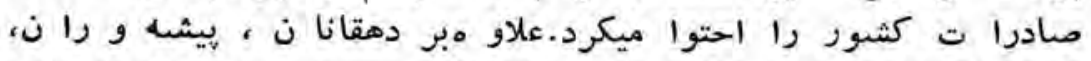

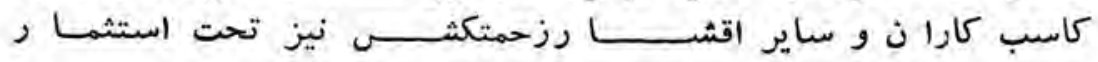

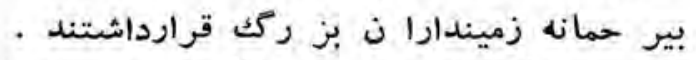

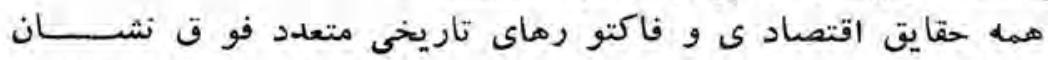

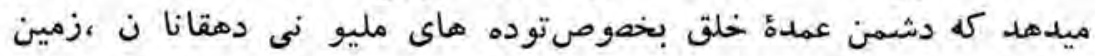

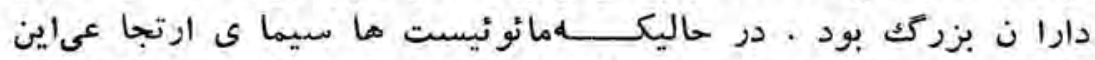

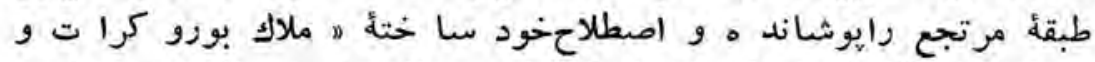

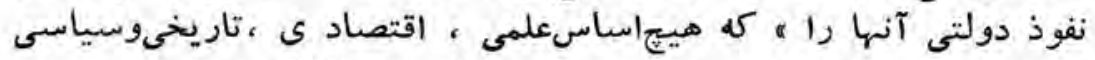

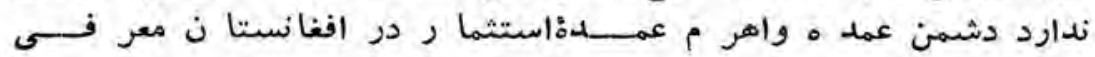

داشتند . دارد دثمن

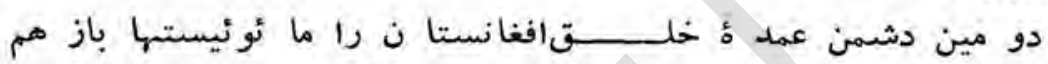

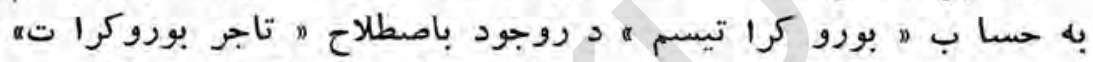

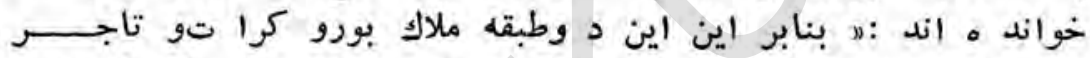

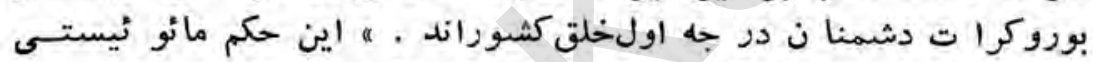

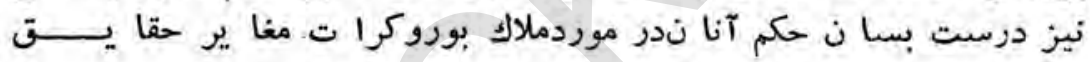

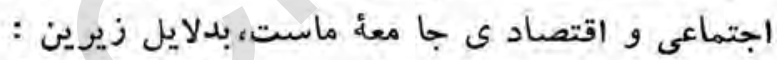

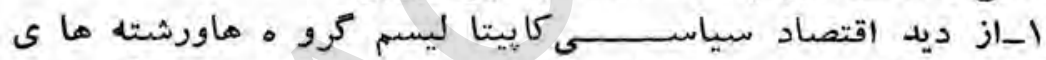

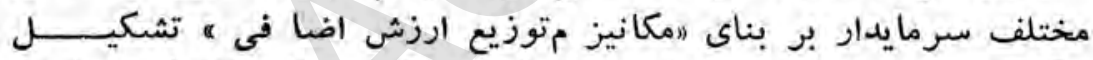

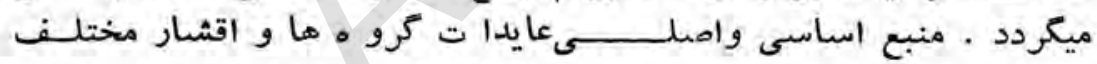

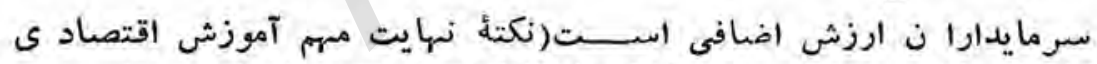

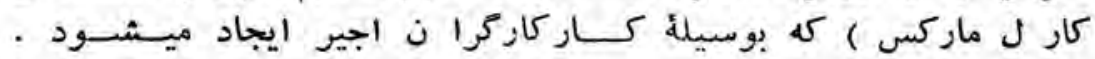

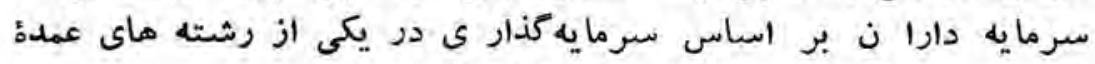

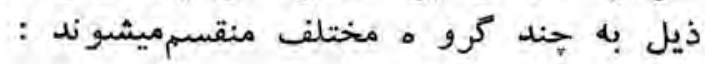

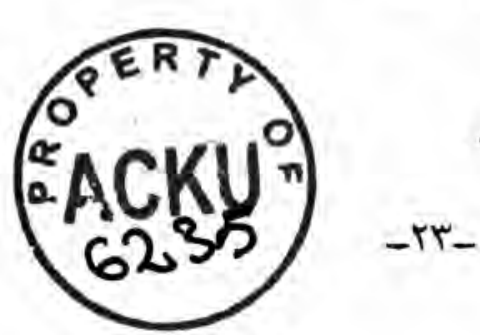

· ا-سر مايئ صنعتى

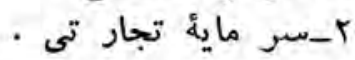

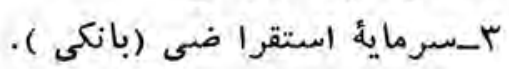


ع-بورزواز ى روستا ( عا يســسرمايدار ى زمين ).

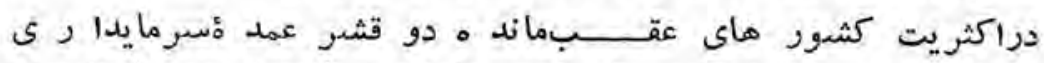

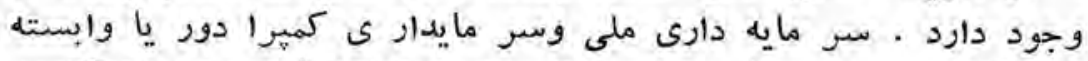

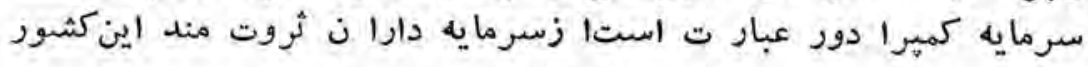

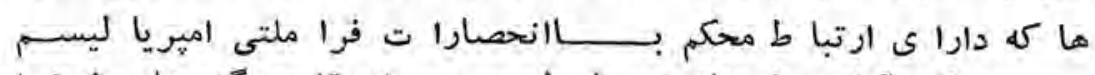

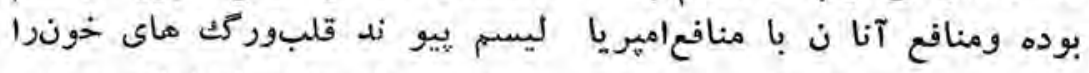

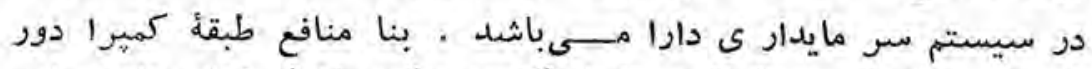

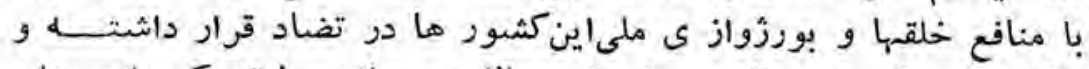

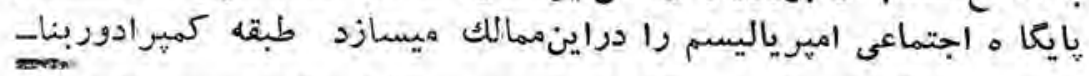

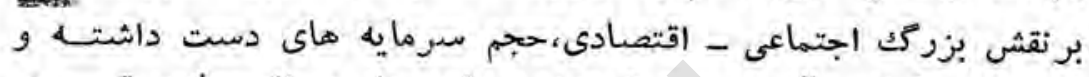

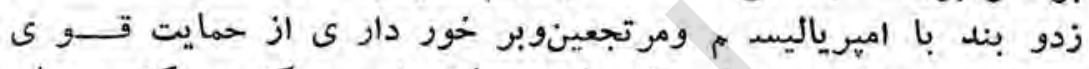

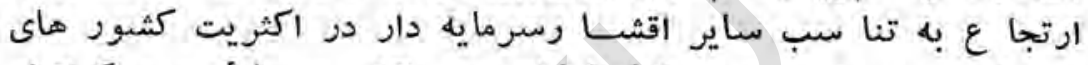

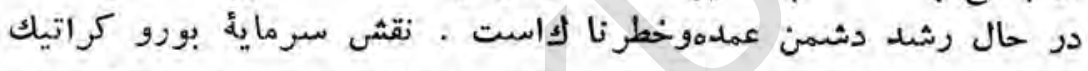

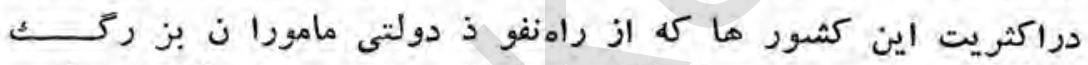

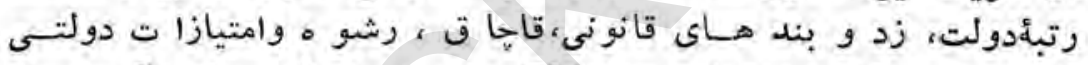

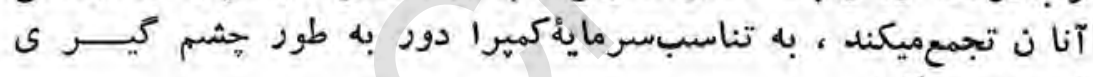
ضعيف ميباشد .

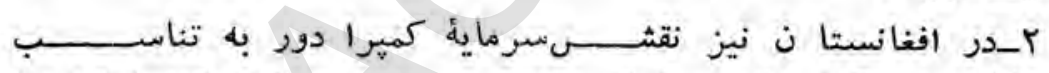

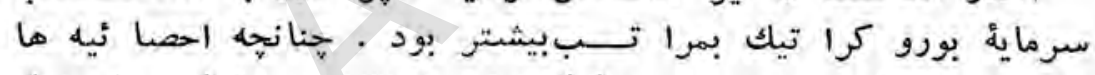

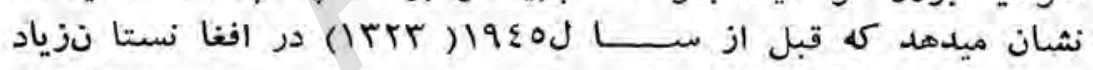

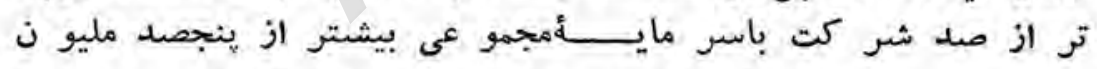

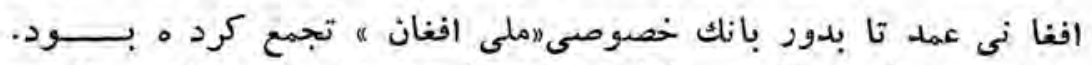

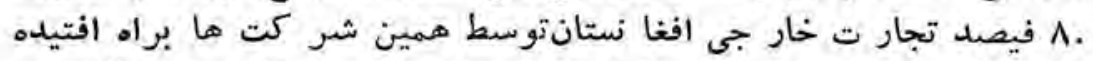

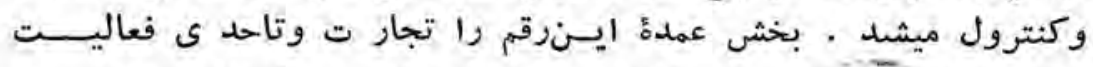

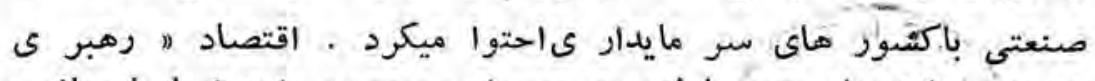

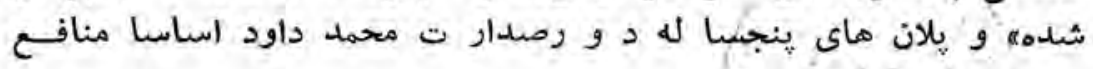

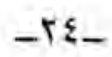




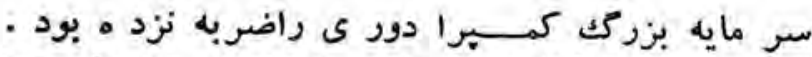

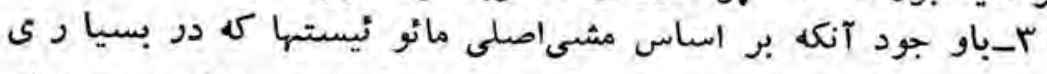

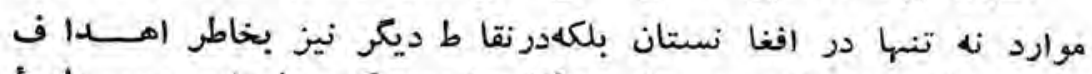

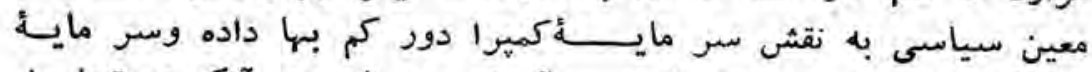

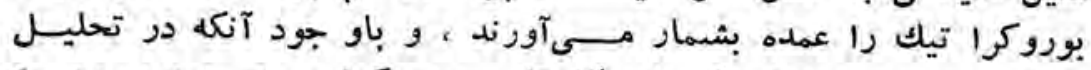

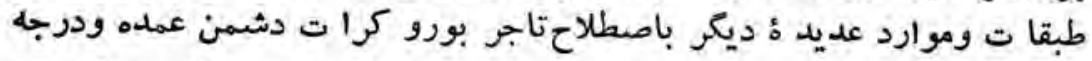

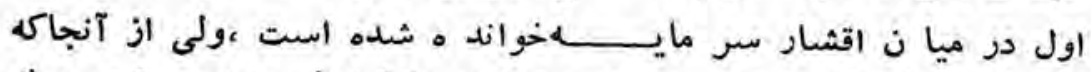

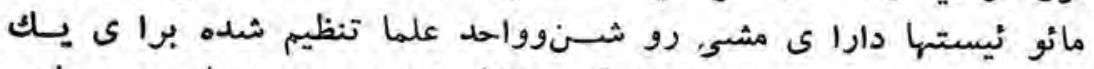

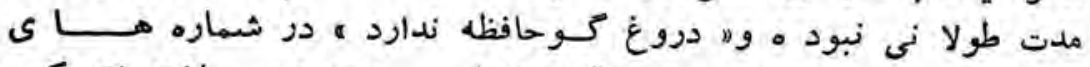

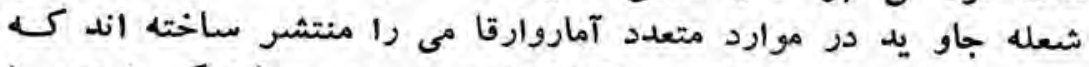

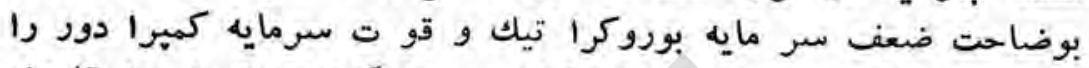

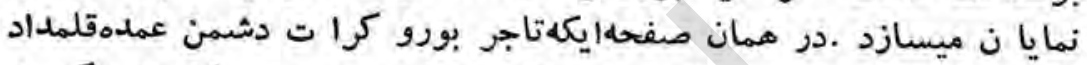

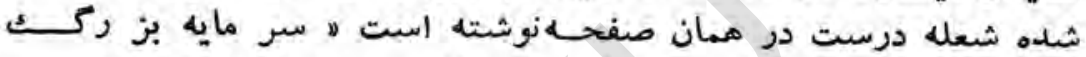

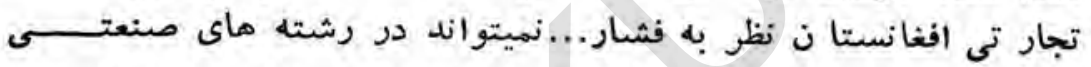

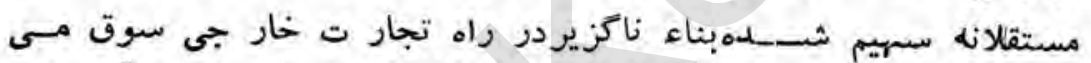

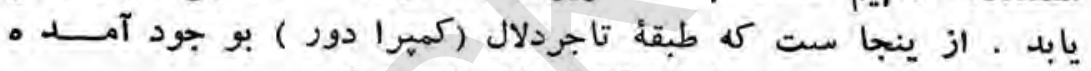

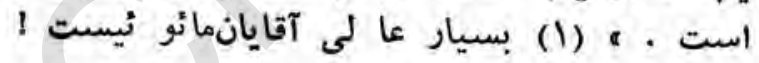

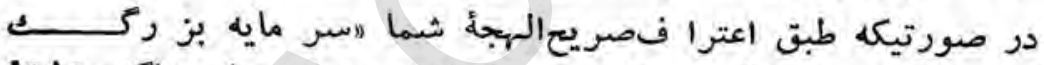

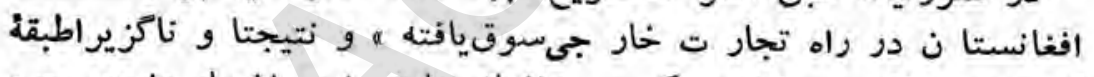

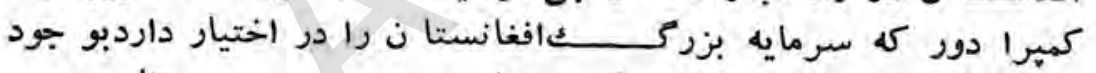

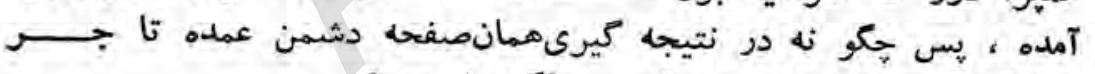

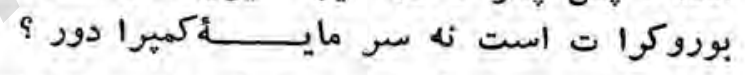

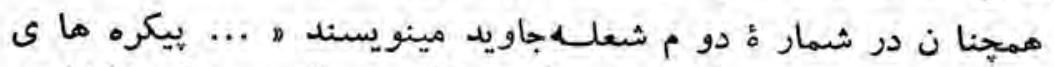

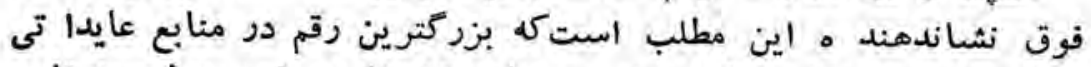

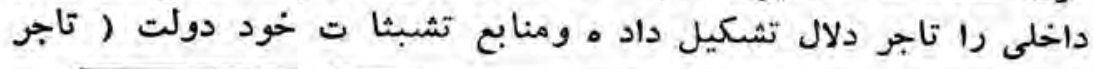

(1) (1) شعله جاويد ه ، شمارماول،صفحه دوم . تكيه از ماست . 


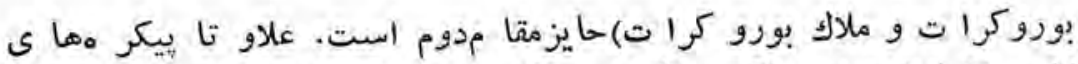

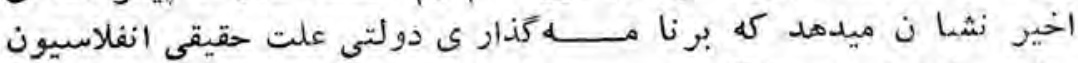

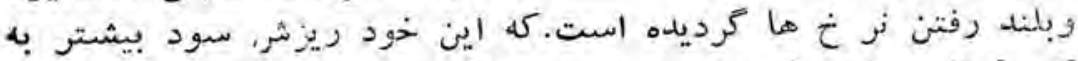

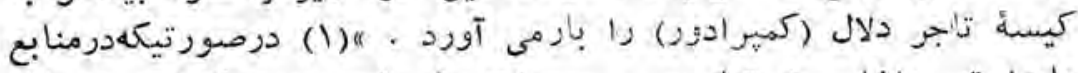

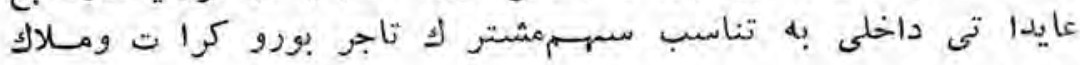

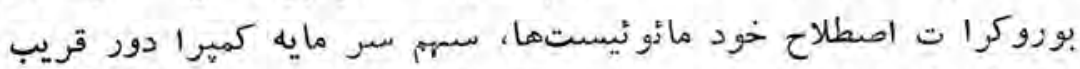

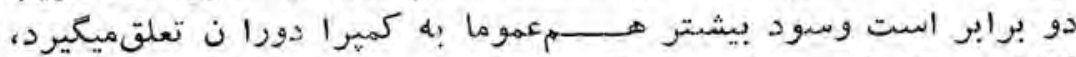

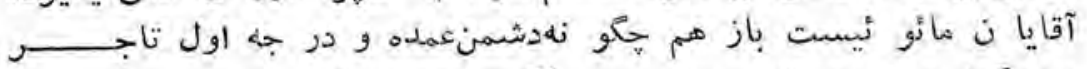

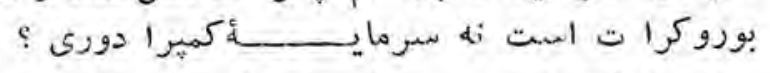

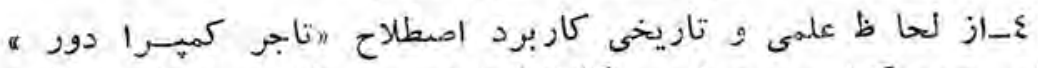

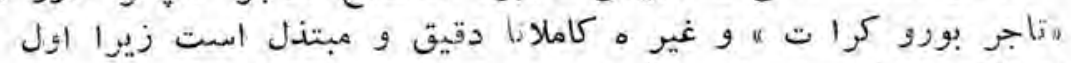

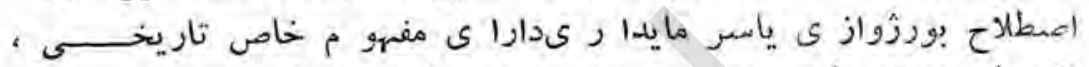

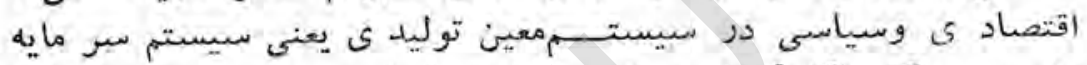

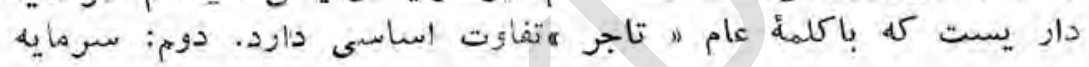

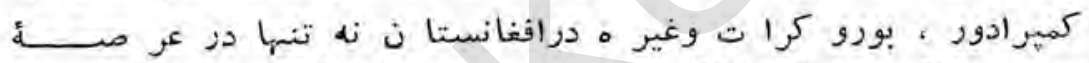

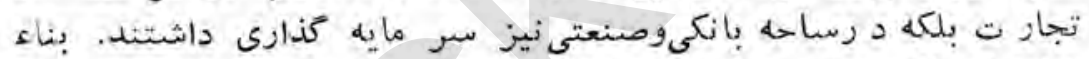

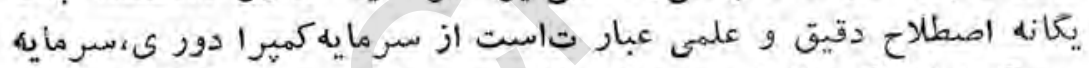

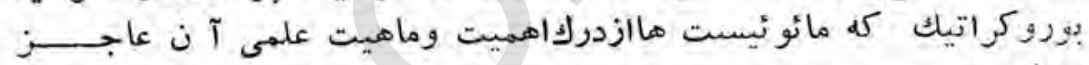

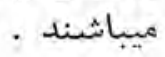

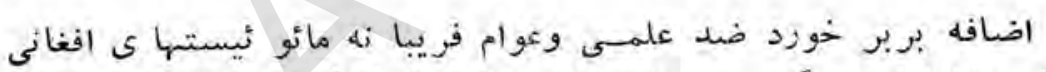

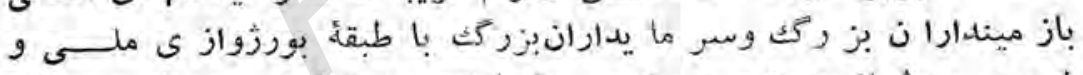

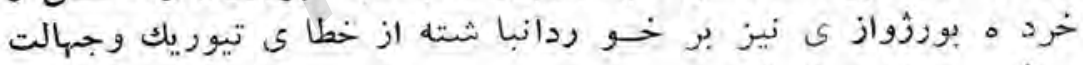

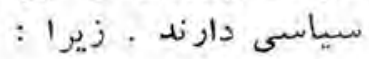

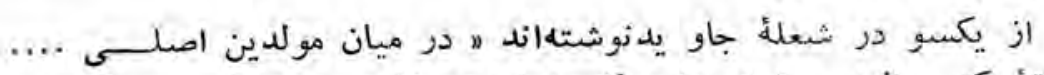

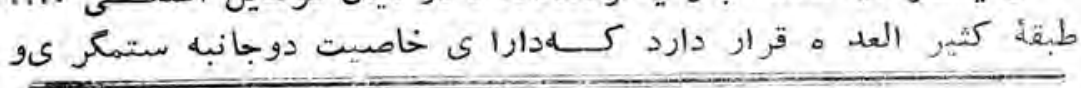
) شعلئ جاويد ه شمار مدوم،صفحه اول 


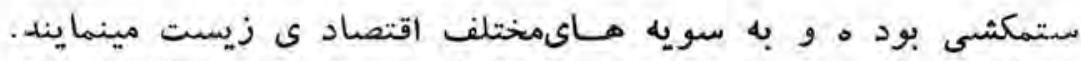

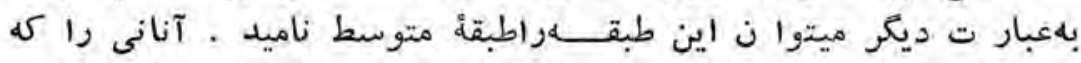

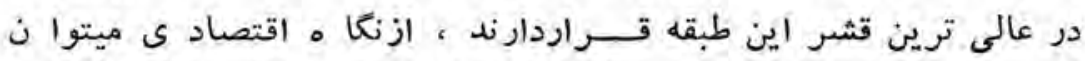

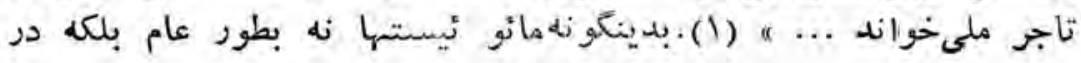

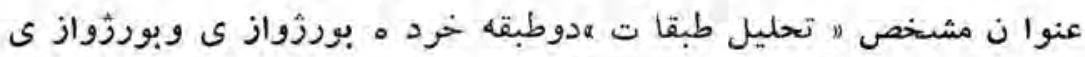

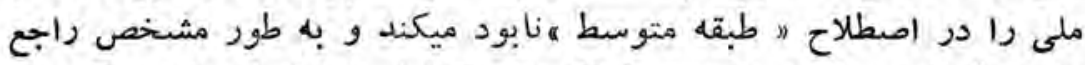

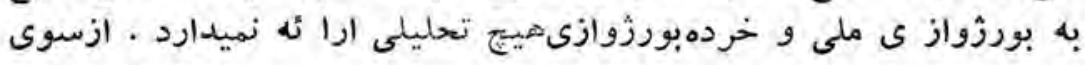

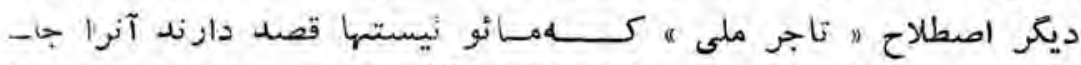

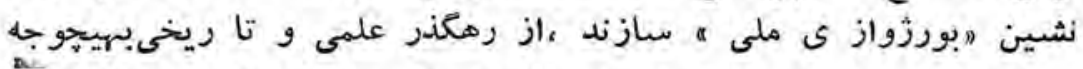

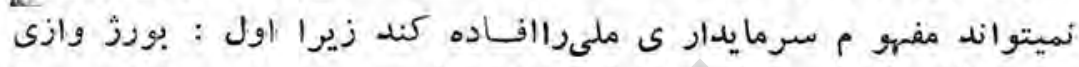

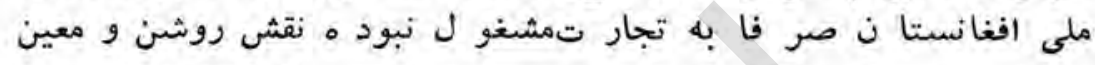

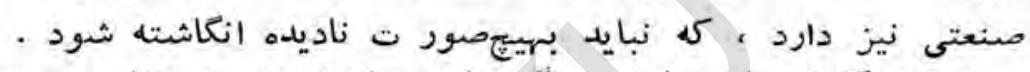

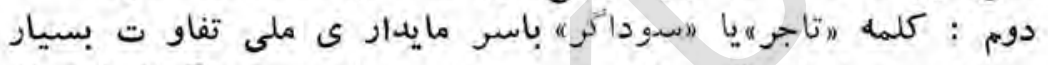

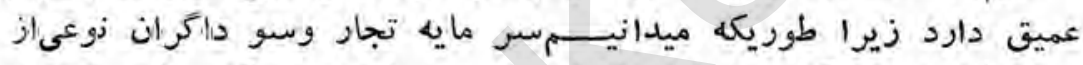

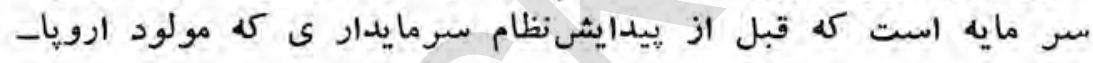

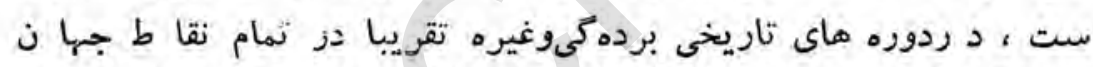

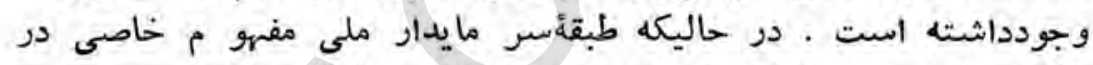

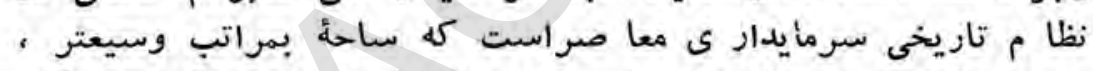

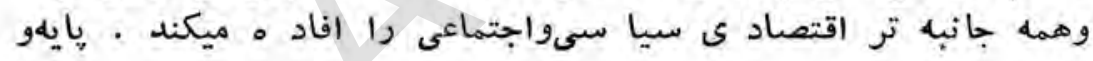

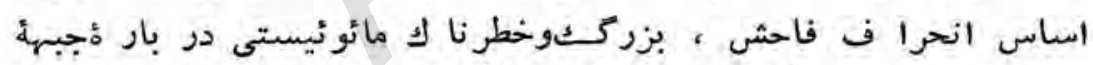

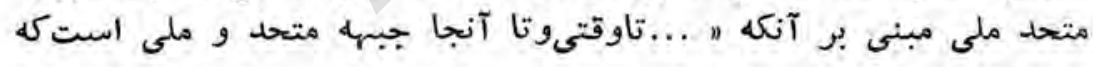

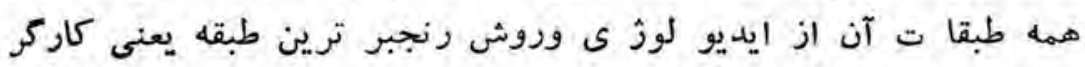

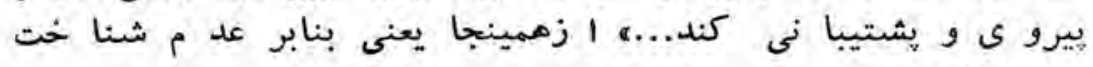

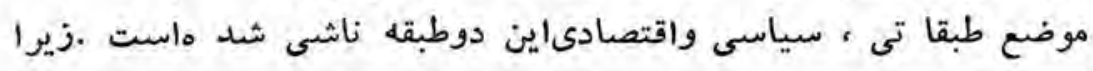
(1) 


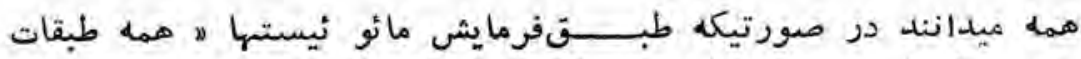

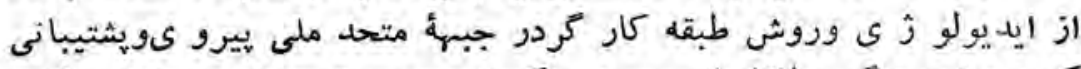

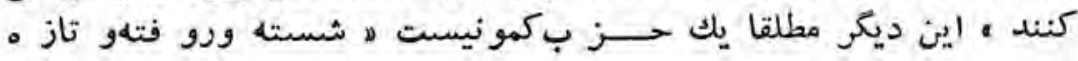

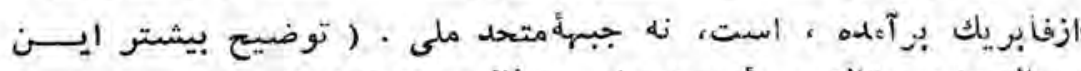

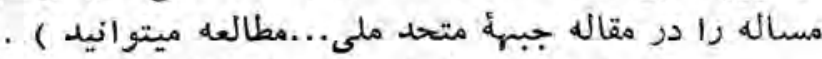

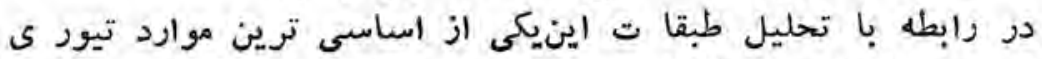

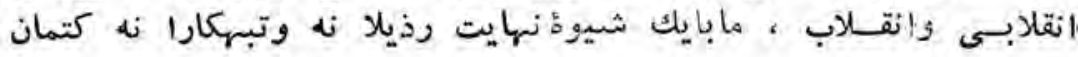

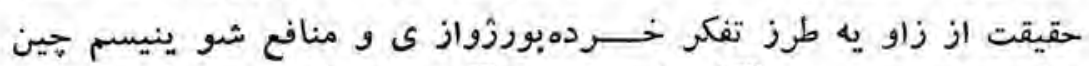

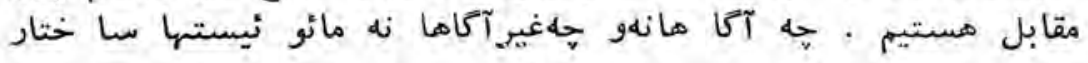

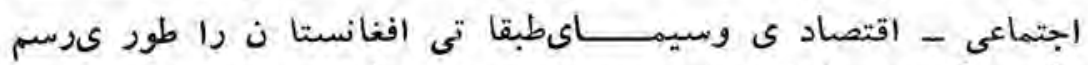

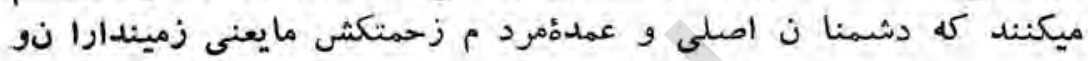

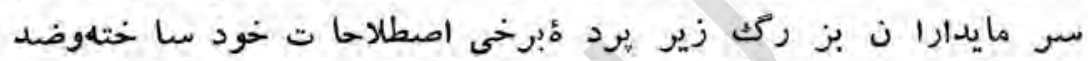

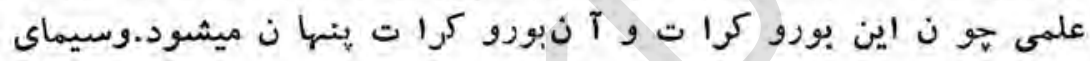

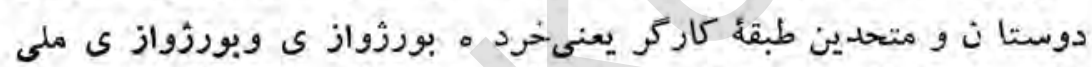

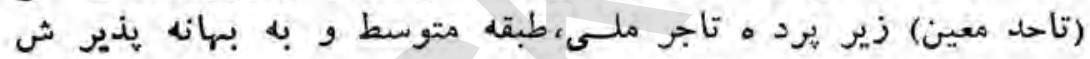

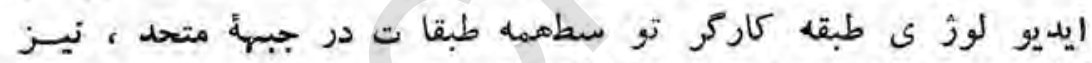

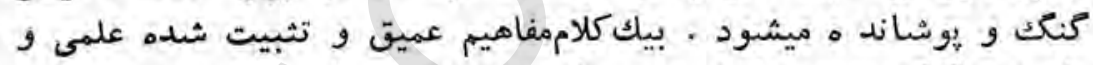

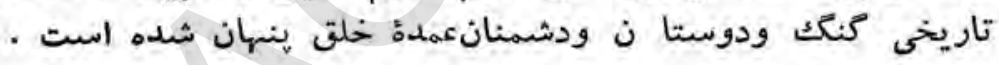

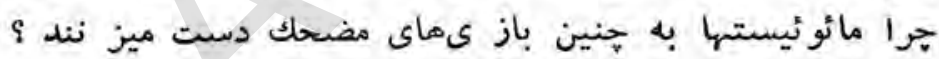

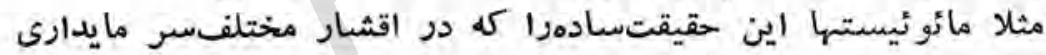

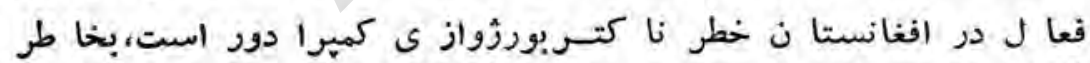

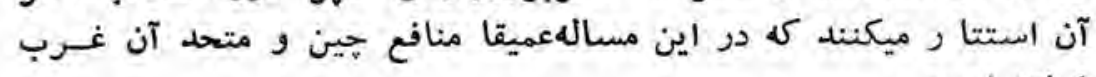

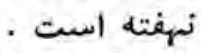

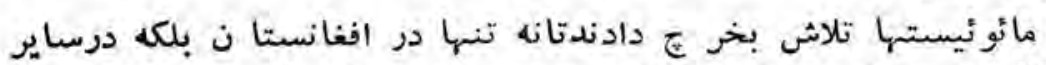

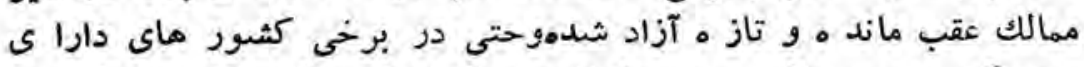

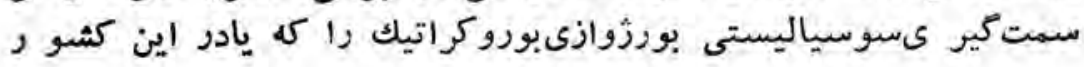




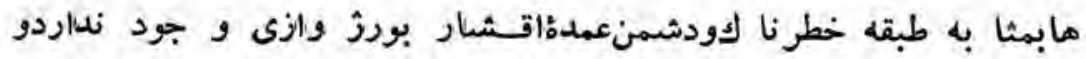

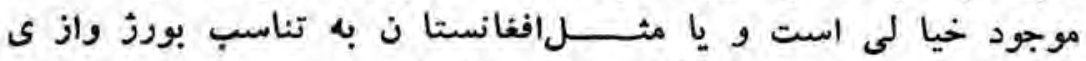

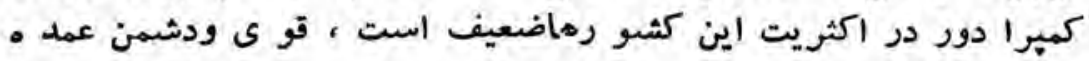

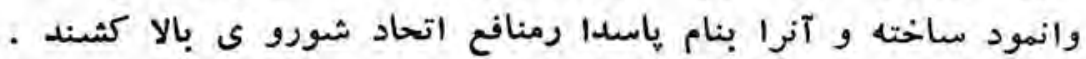

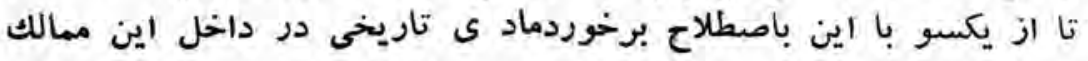

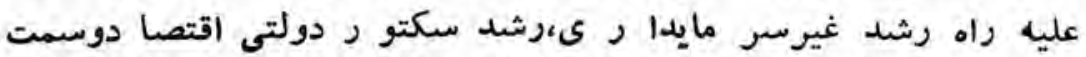

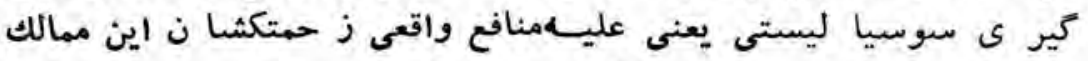

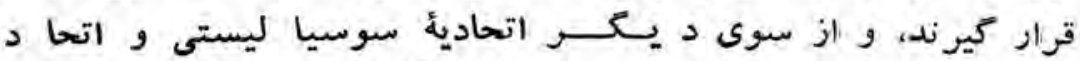

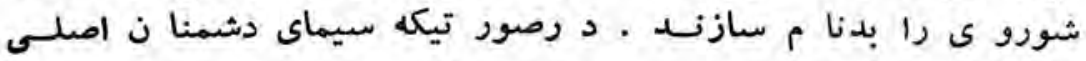

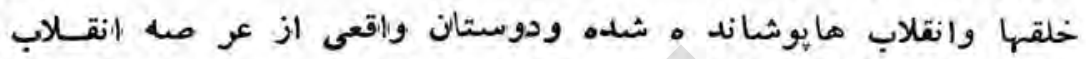

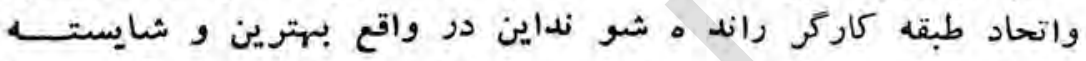

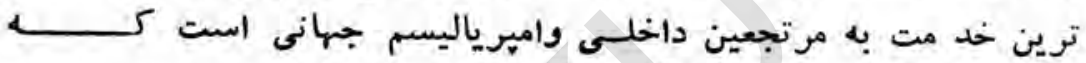

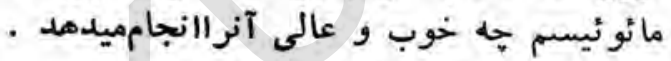

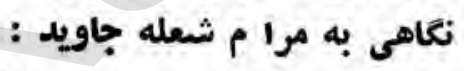

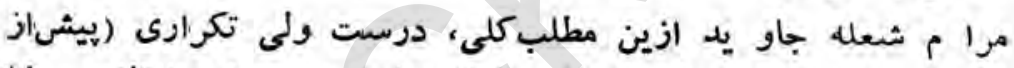

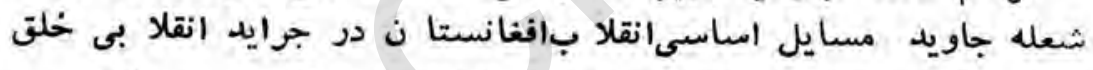

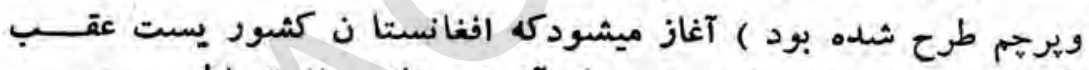

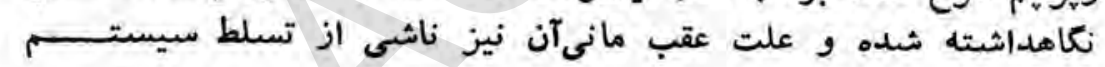

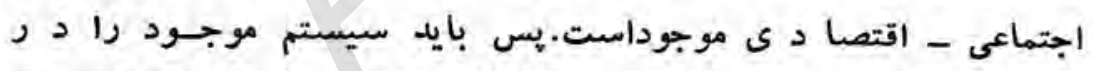

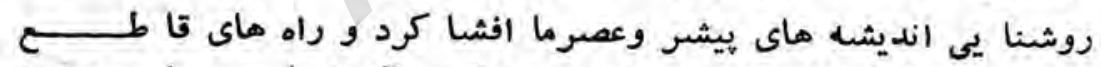

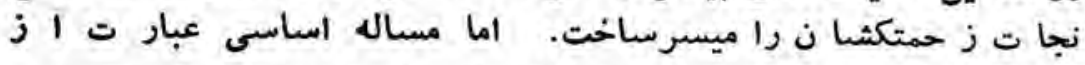

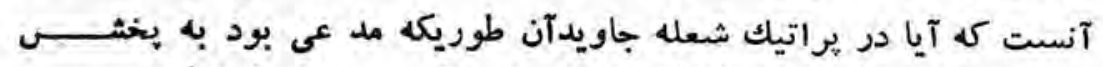

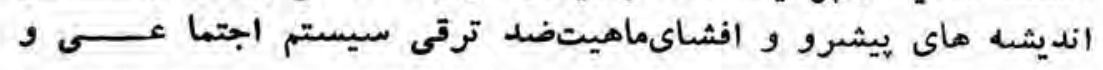

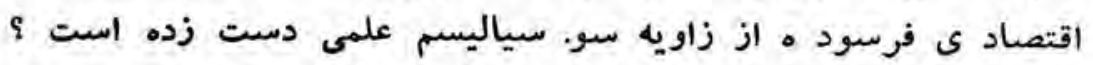

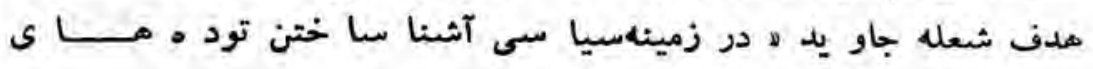




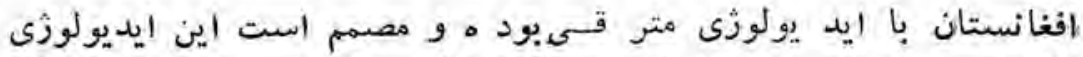

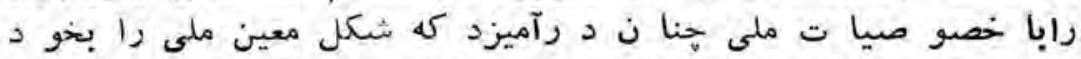

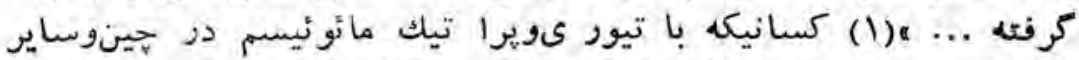

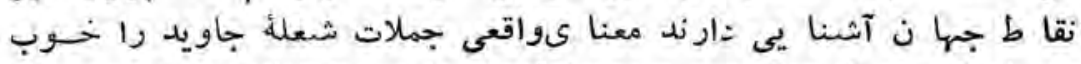

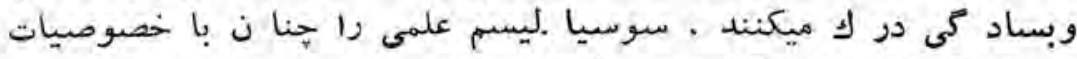

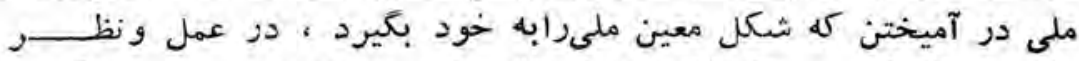

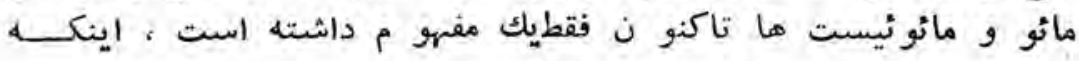

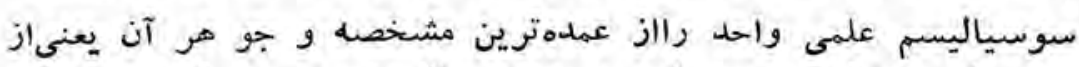

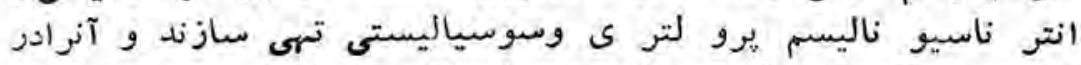

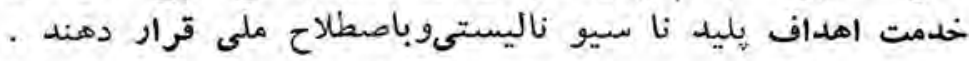

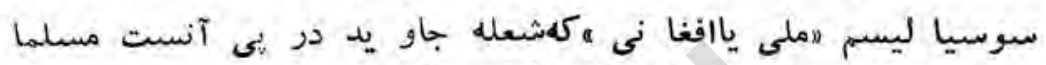

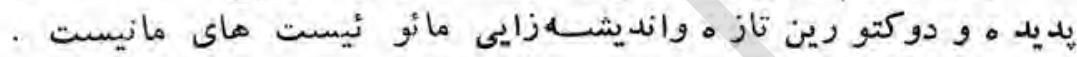

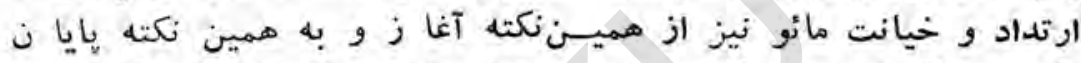

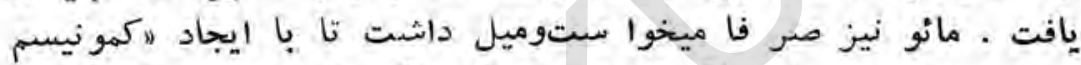

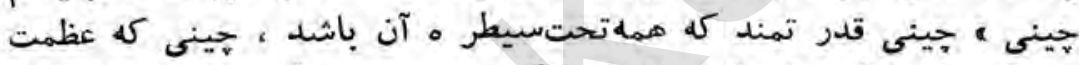

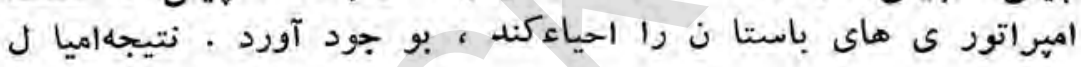

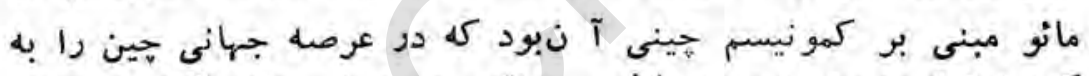

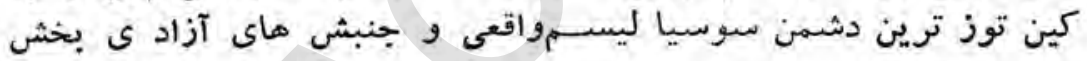

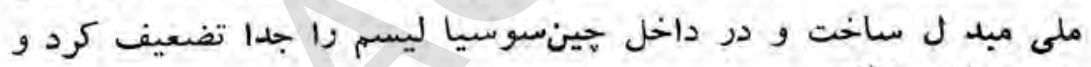
به مخاطر ه افكند

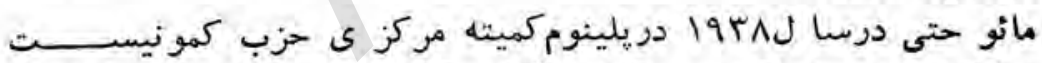

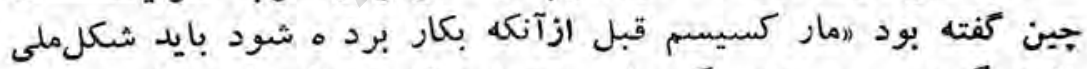

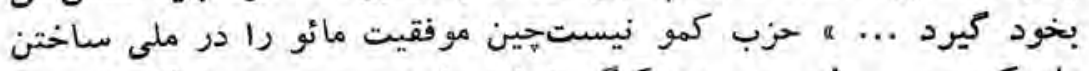

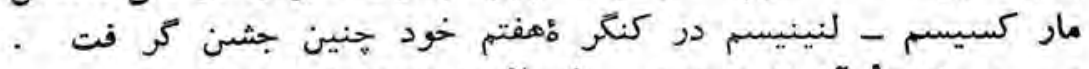

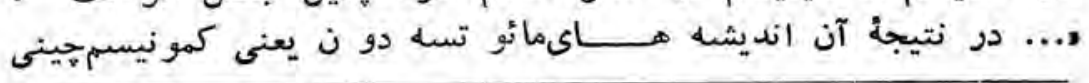

(1) شعله جاويد ه شمار او ل،ص اول . 
يديد آمده است . مائو بر شكـــلــارو يايى مار كسيسم فايق آمد و

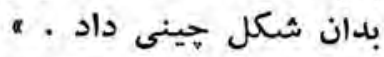

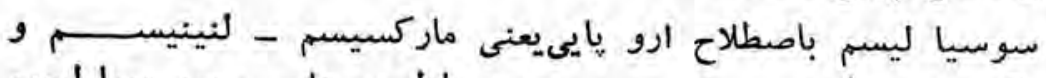

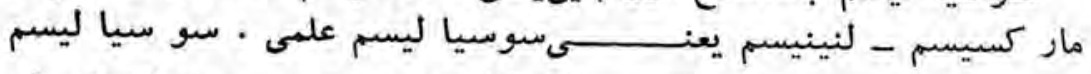

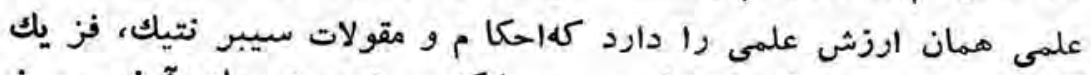

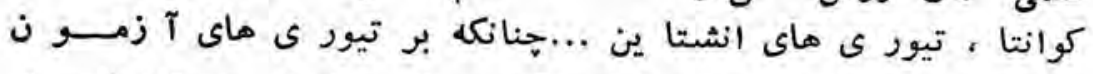

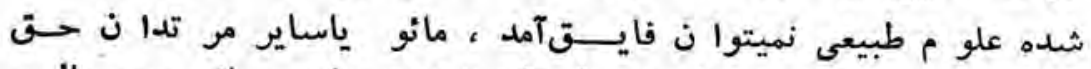

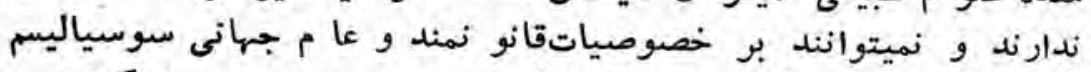

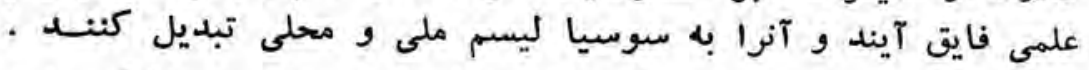

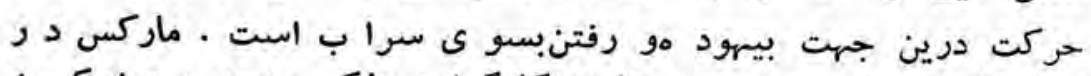

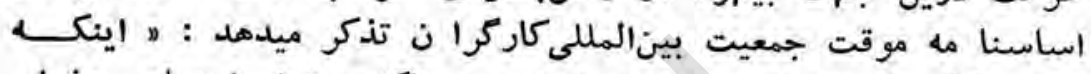

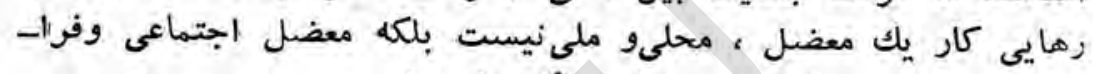

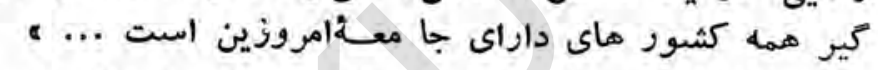

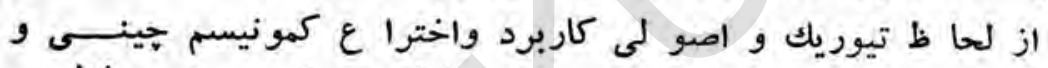

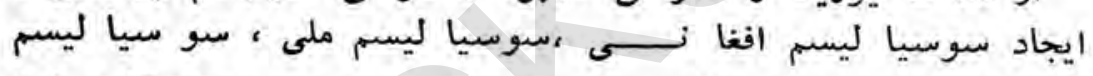

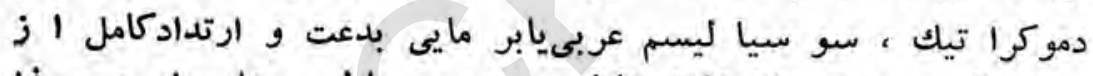

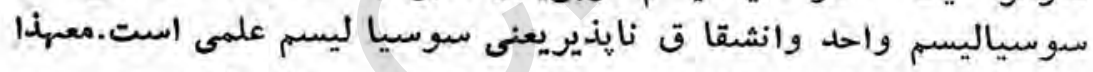

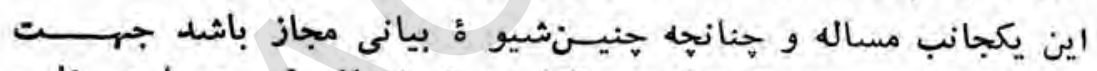

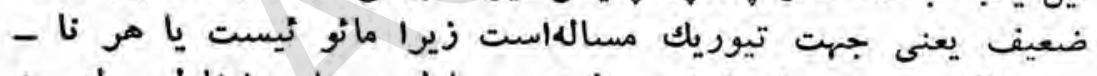

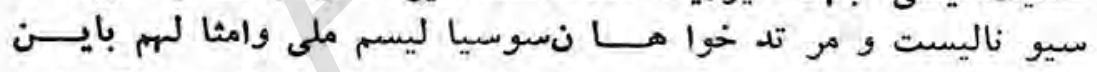

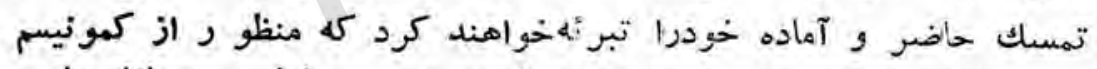

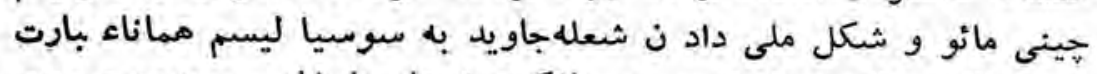

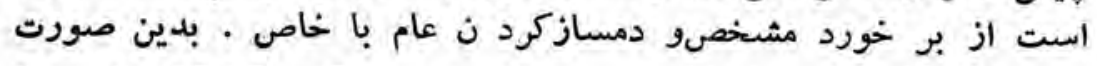

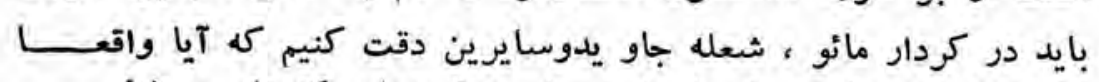

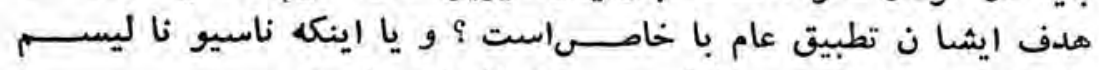

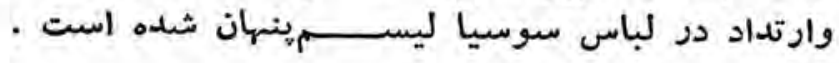


در مرام شعله جاو يد راجع بـهمايل جهانى فقط اين جمله وجود في مارد

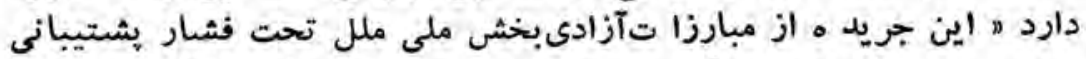

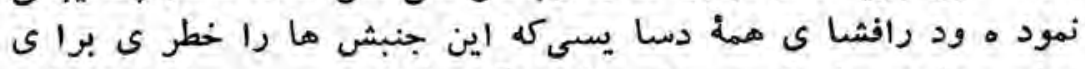

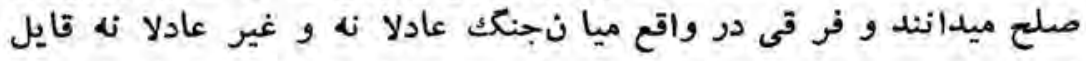

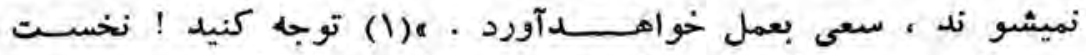

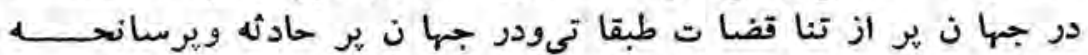

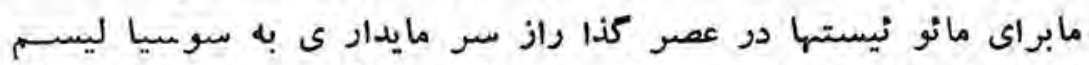

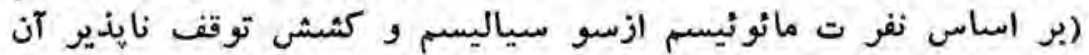

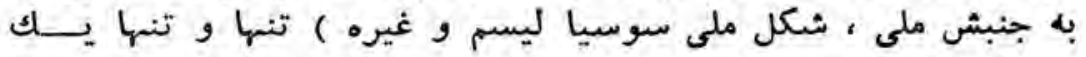

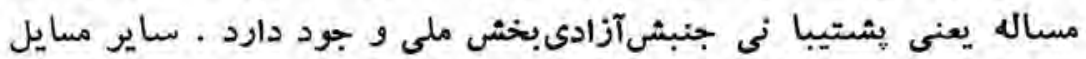

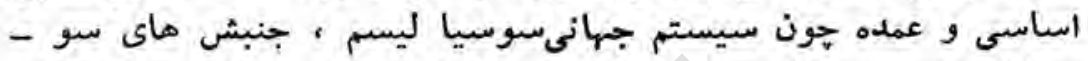

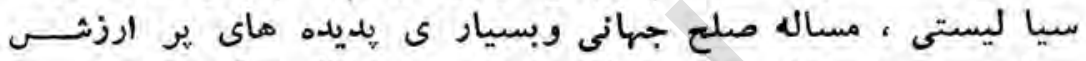

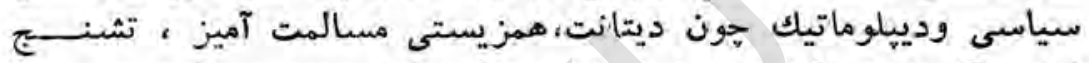

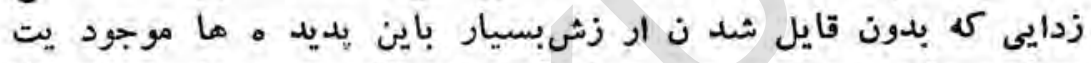

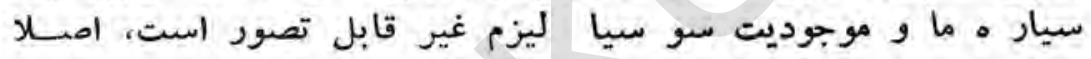

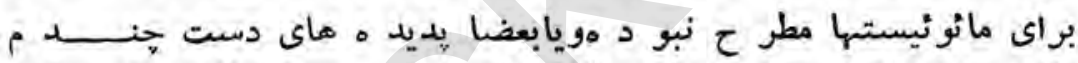

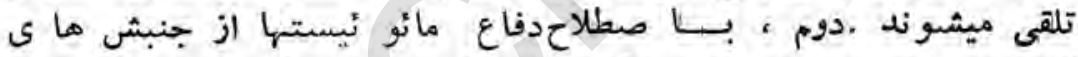

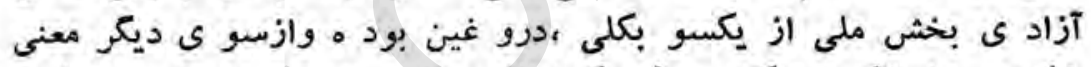

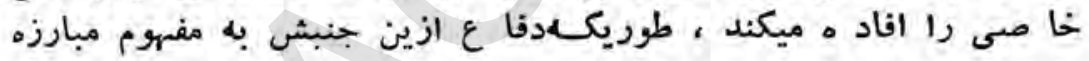

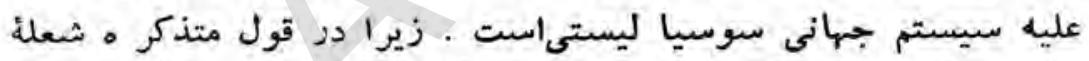

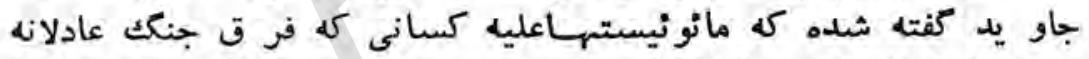

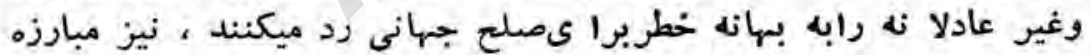

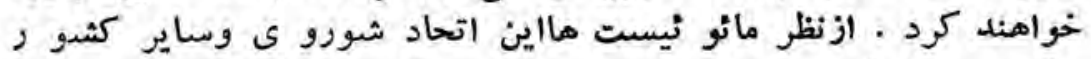

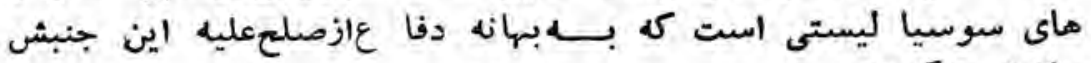

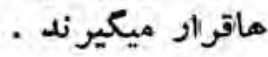

(1) شعله جاويد ، شماره اول ،ص اول . تكيه از ماست . 
علت عمله سا ختن جنبش آزاد ميخش ملى توسط مائو روشين است.

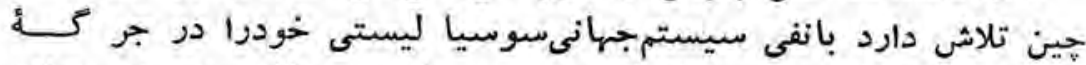

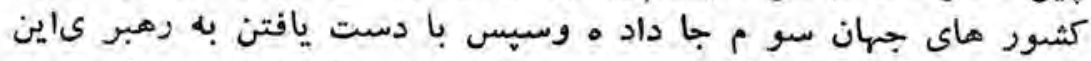

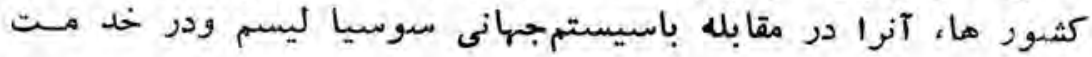

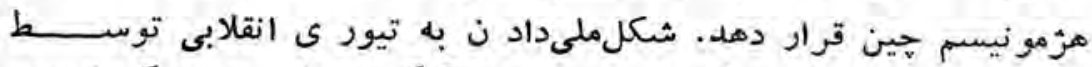

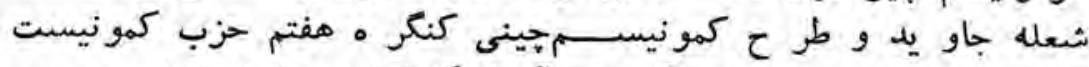

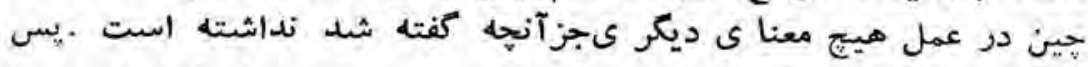

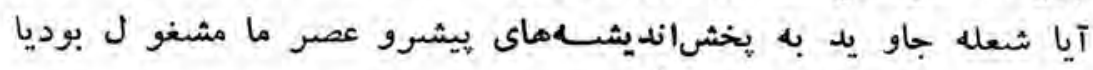

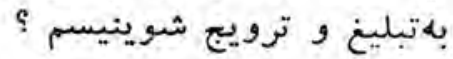

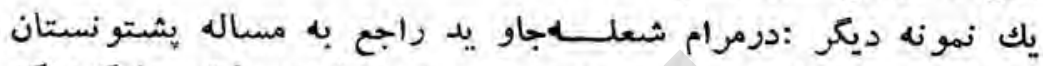

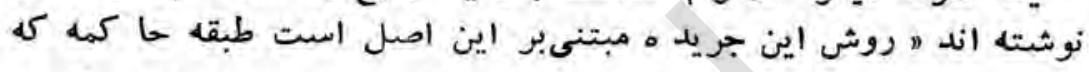

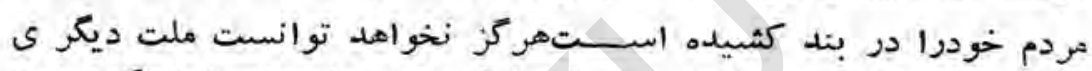

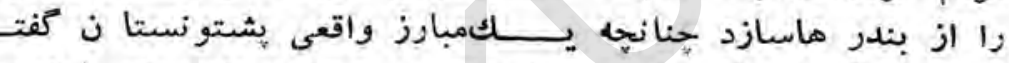

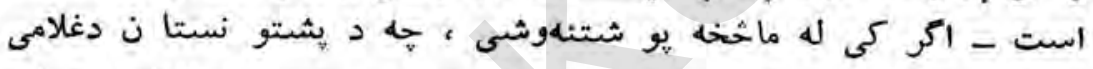

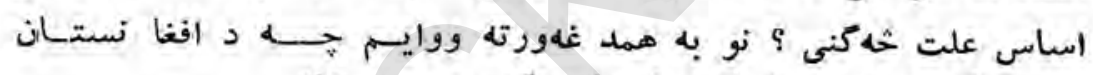

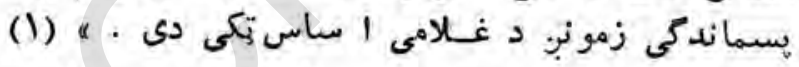

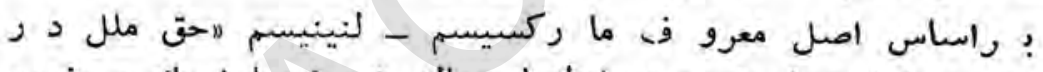

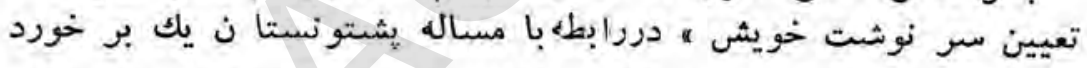

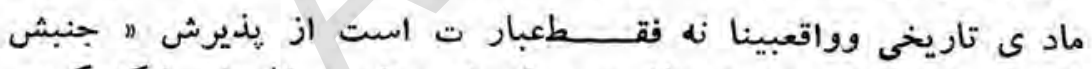

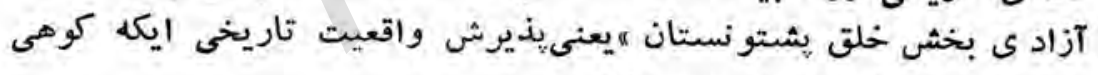

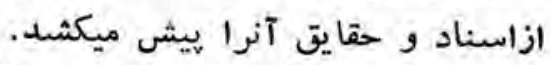

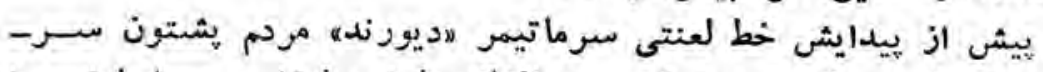

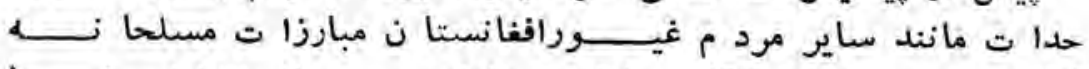

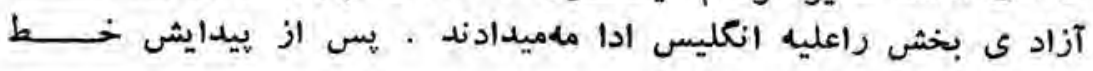

(1) شعله جاويد ، شماره اول ،صفحه اول. تكيه از ماست. $-r{ }_{-}$ 


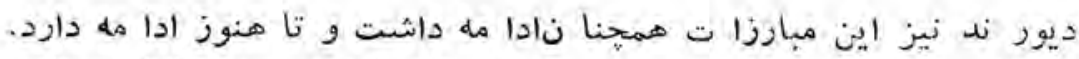

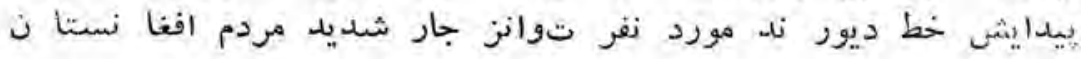

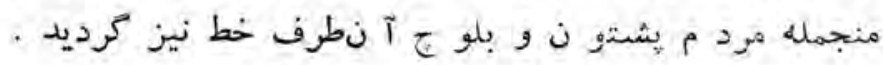

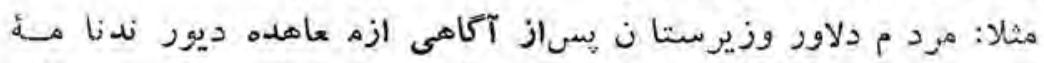

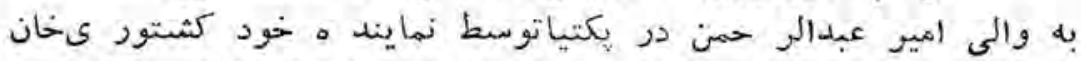

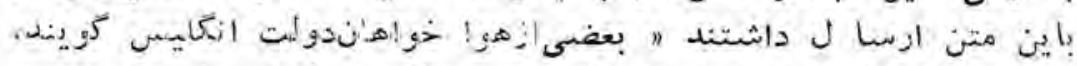

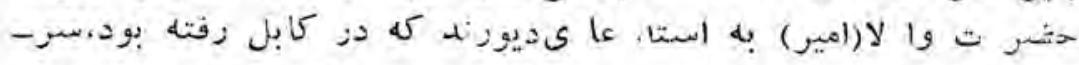

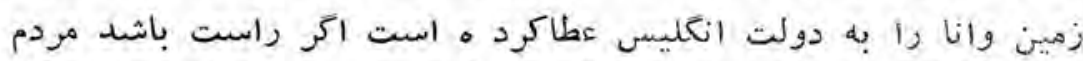

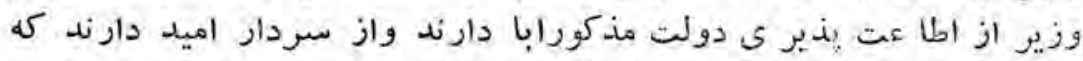

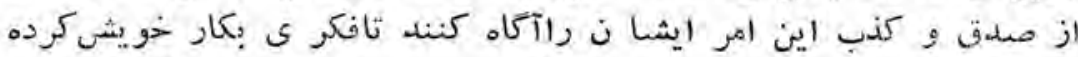

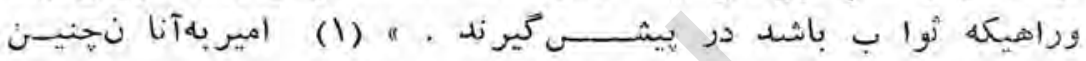

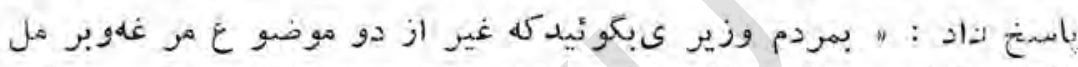

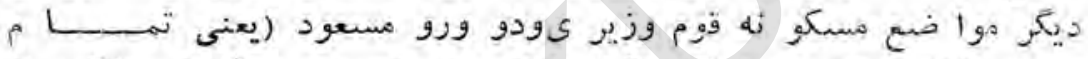

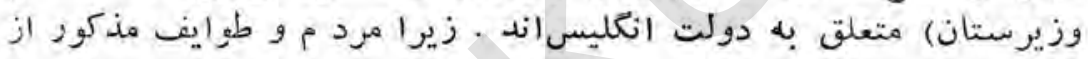

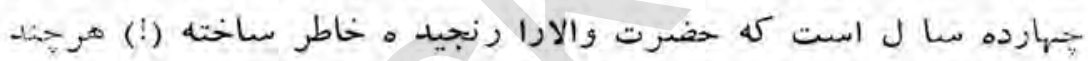

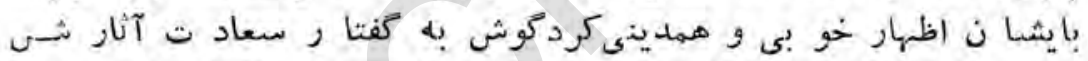

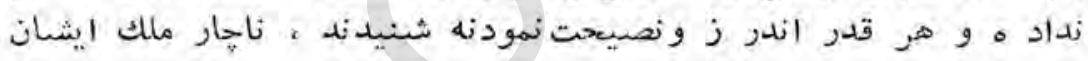

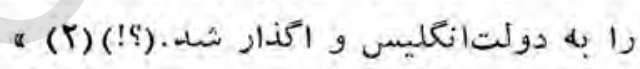

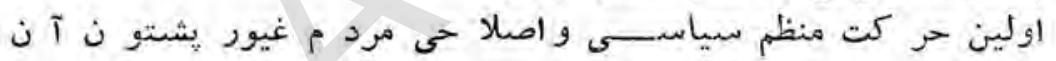

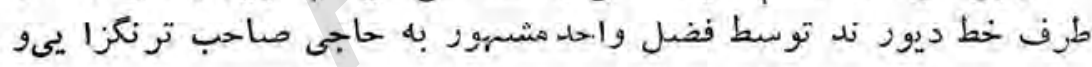

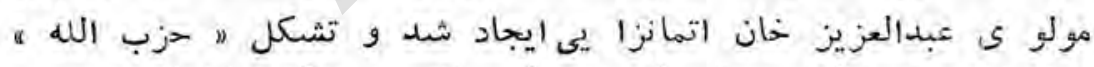

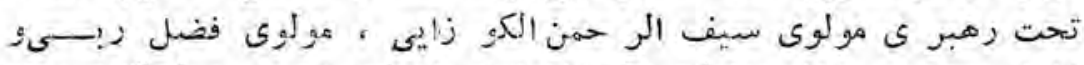

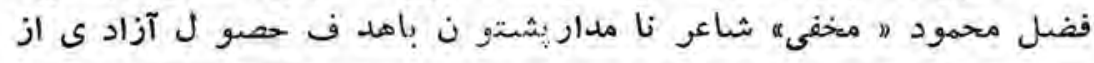

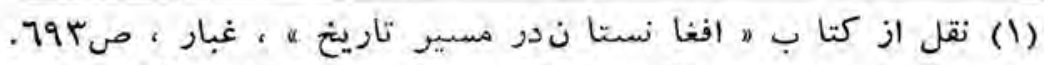

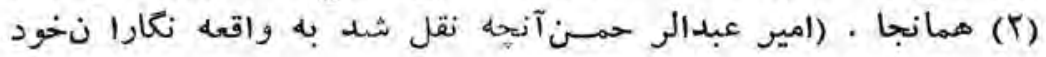
نوشته بود تا به قو م وزير عبكو الريند.) 


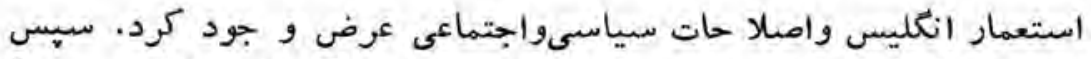

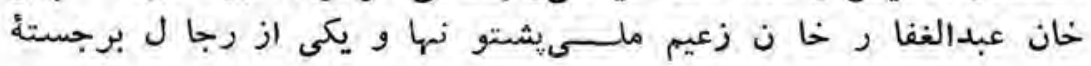

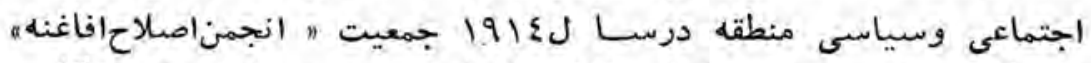

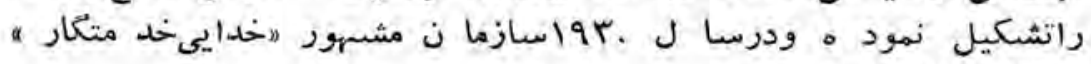
راسازمانداد . رانشيل

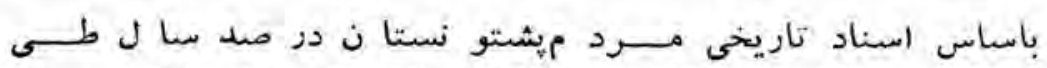

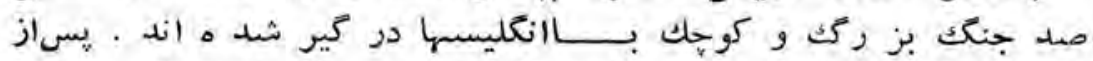

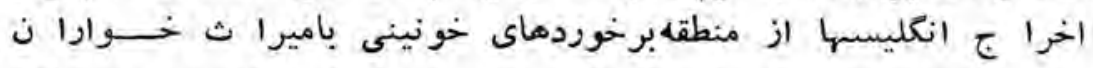

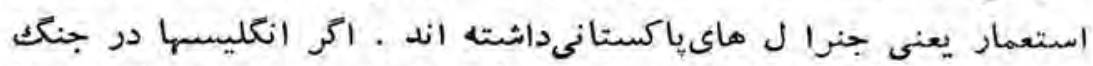

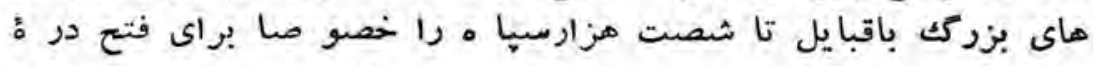

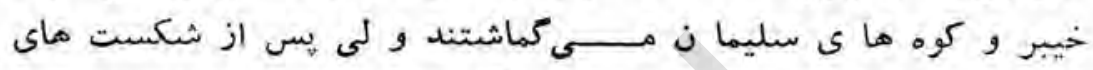

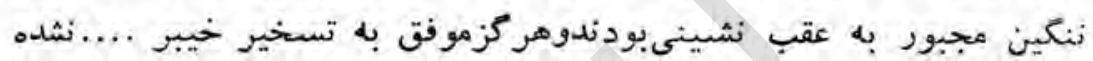

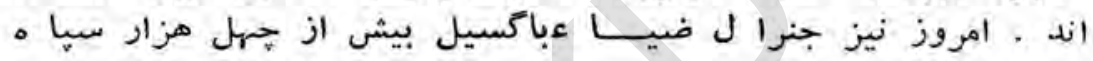

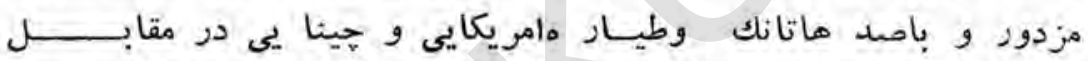

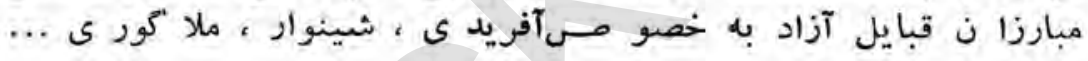

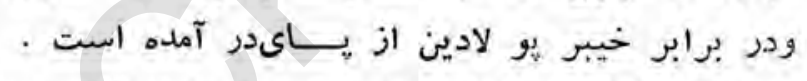

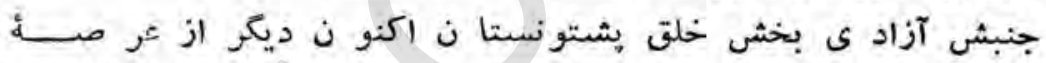

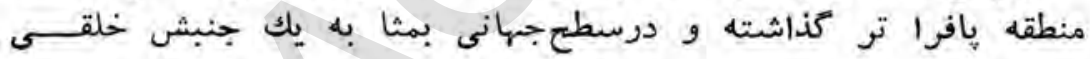

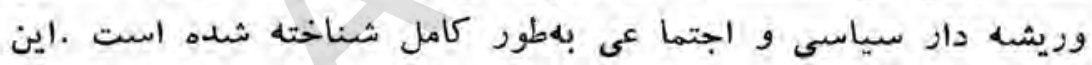

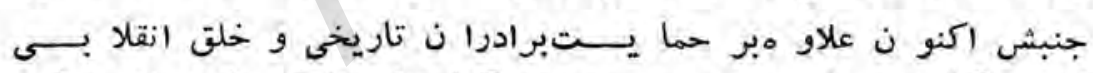

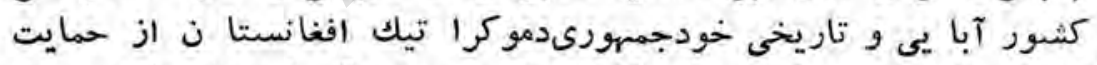

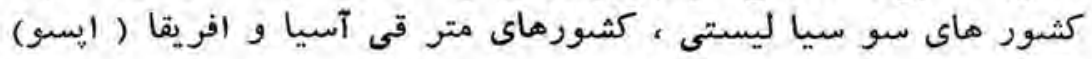

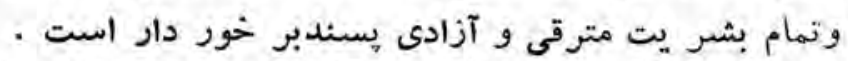

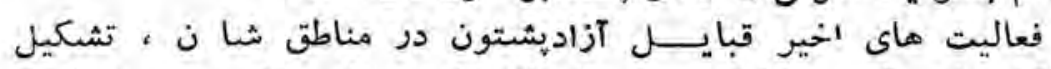

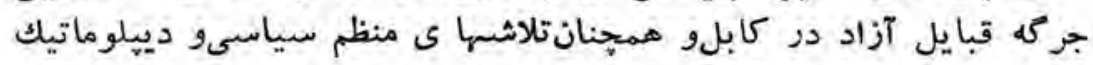

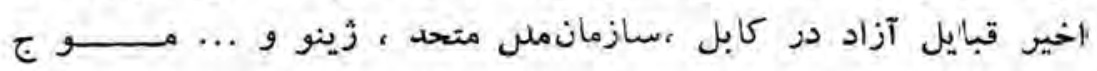


كسترد ه و نوين بيدار ى روزافزونآنا ن بشمار ميرود .

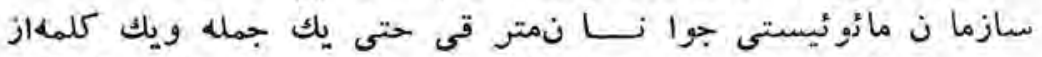

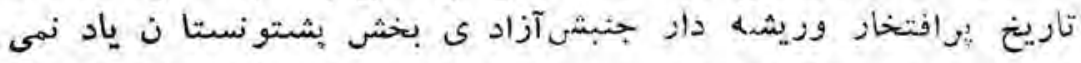

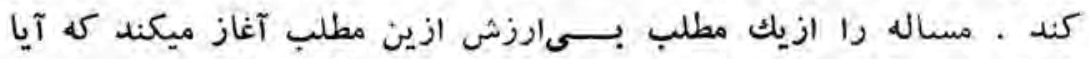

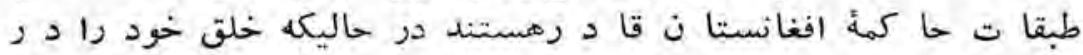

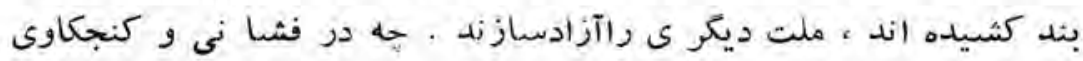

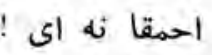

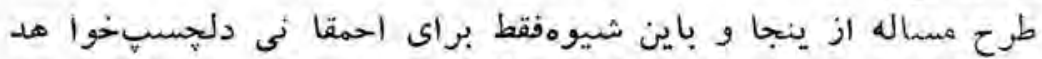

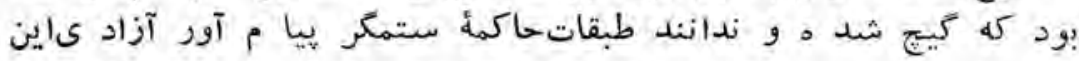

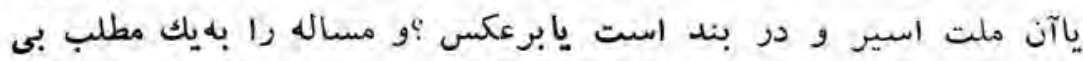

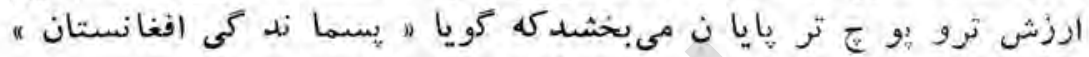

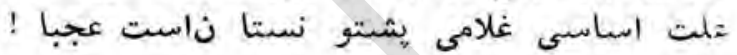

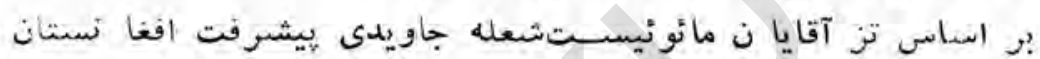

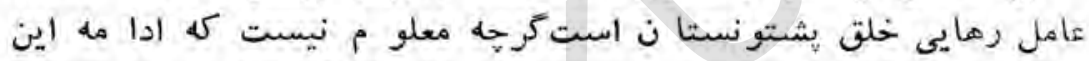

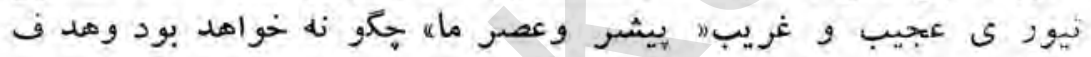

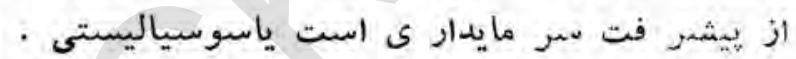

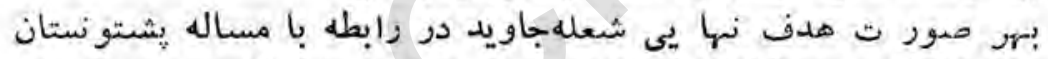

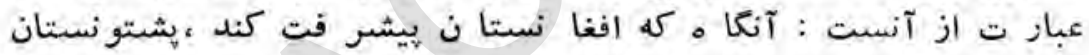

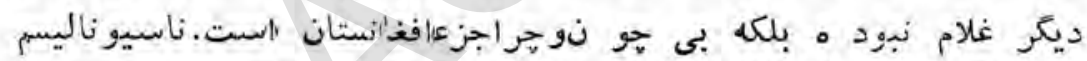

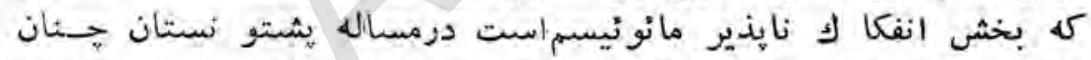

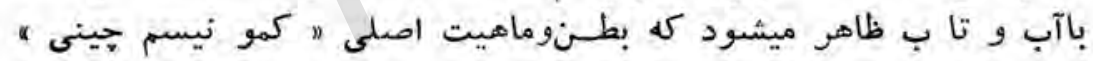

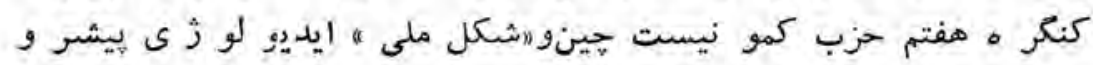

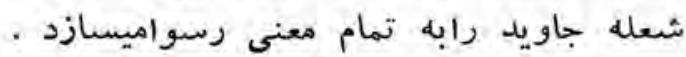

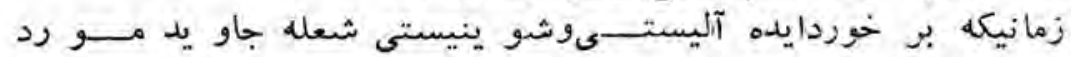

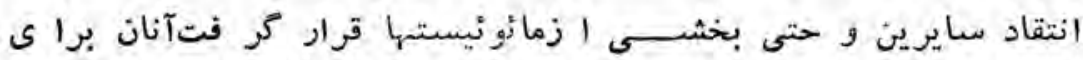

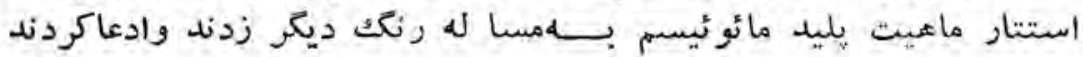




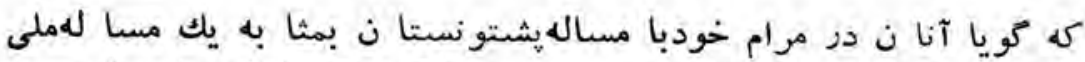

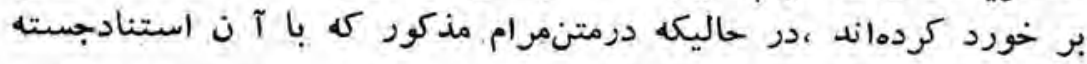

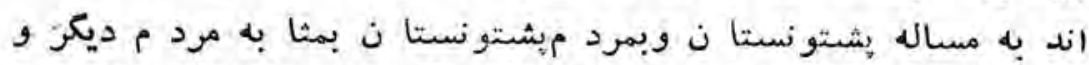

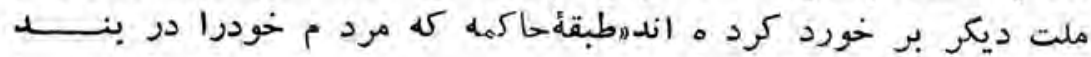

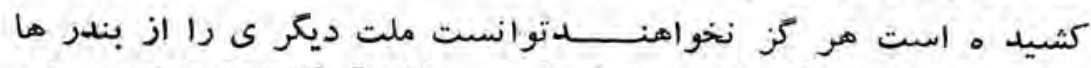

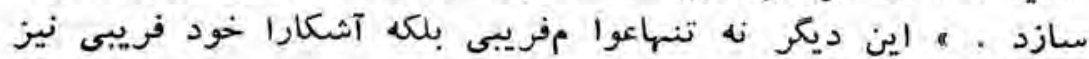

براى تكميل برداشت مااز ماهيتضل خلقى و شوينيستى مائو نيسم

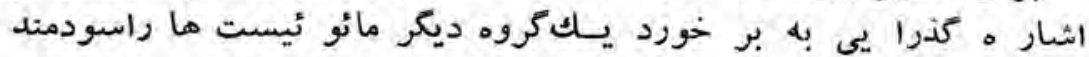

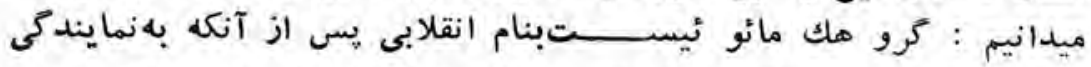

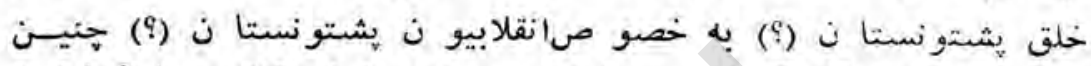

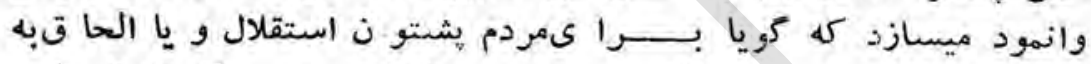

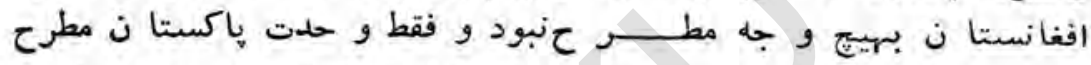

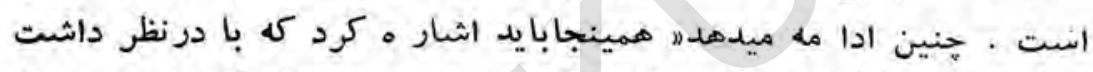

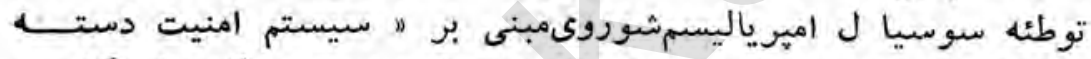

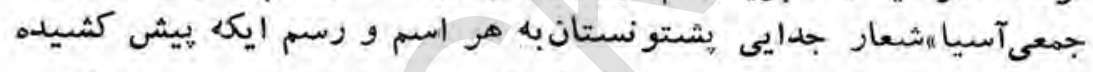

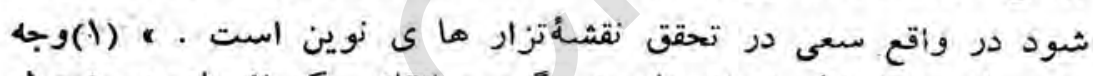

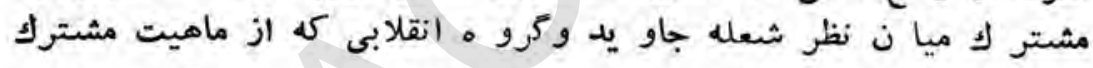

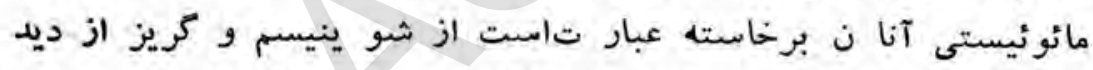

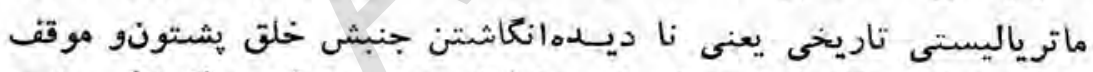

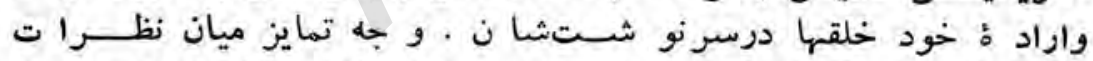

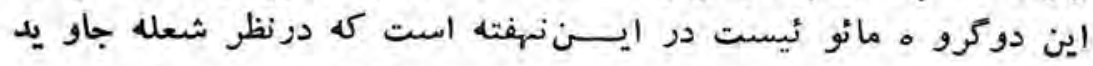

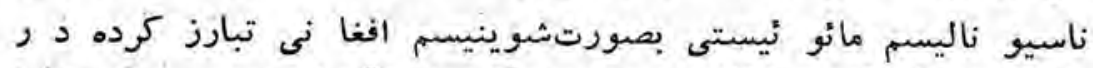
حاليكه درنظر كرو ه انقلا بى بصورت نهايت شرمبر آورشوينيسم هينىمتبارز

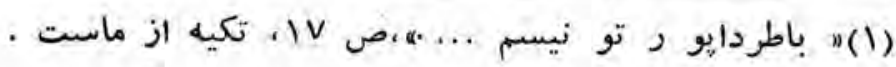




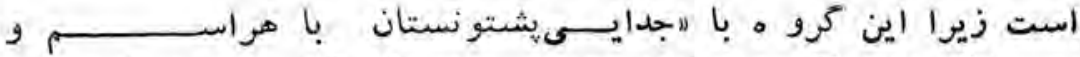

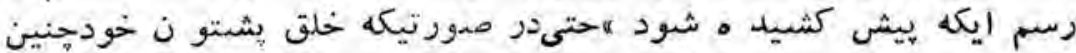

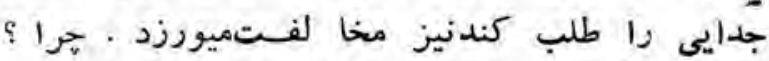

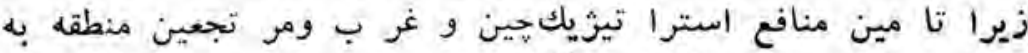

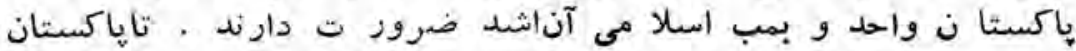

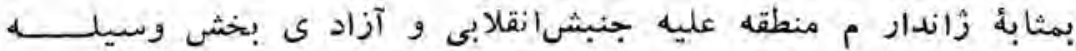

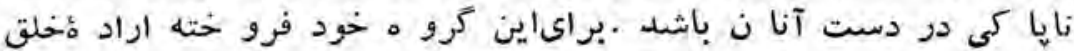

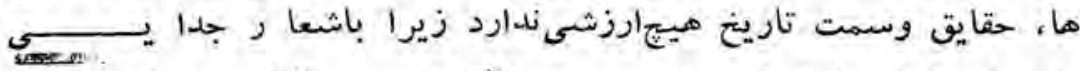

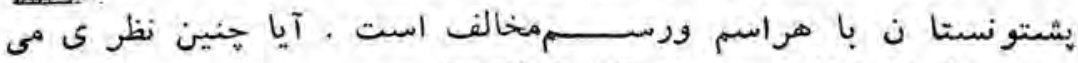

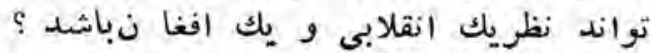

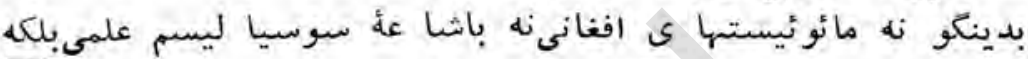

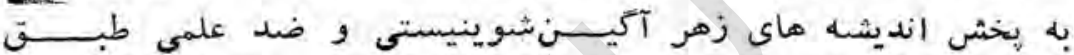

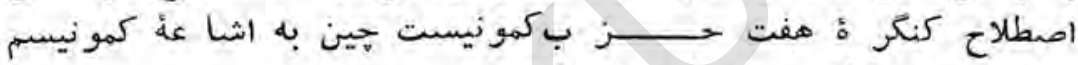

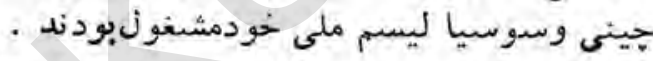

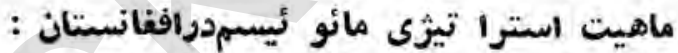

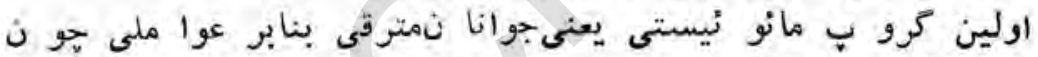

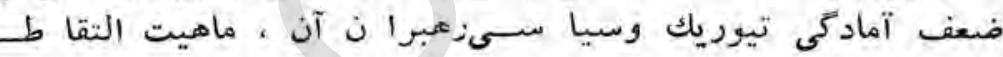

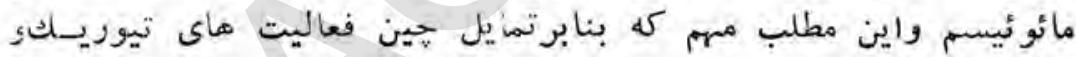

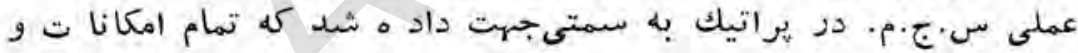

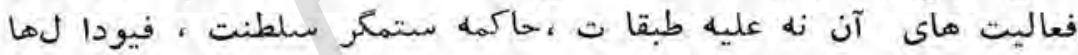

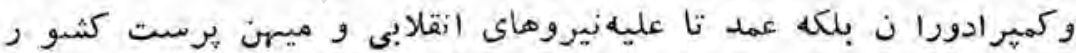

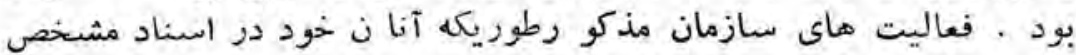

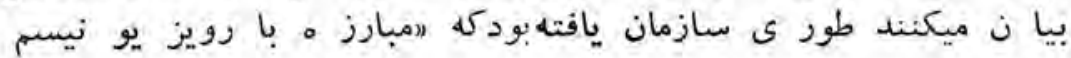

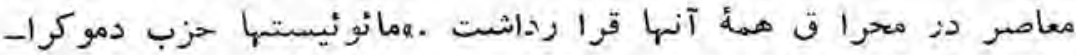

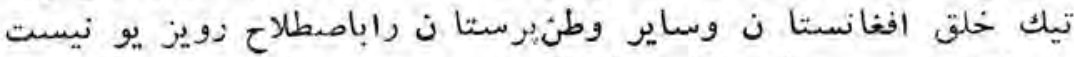

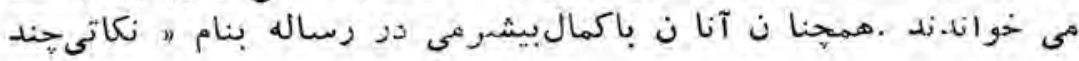




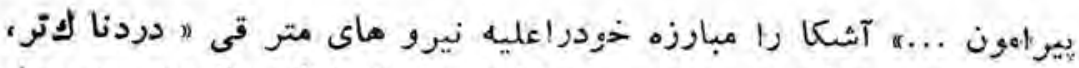

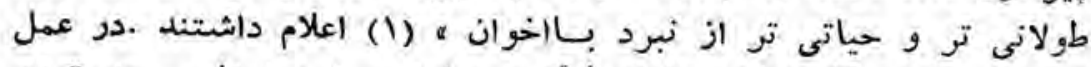

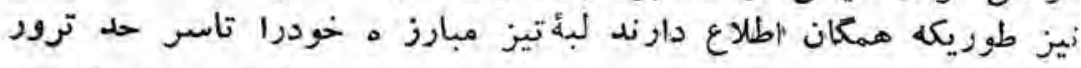

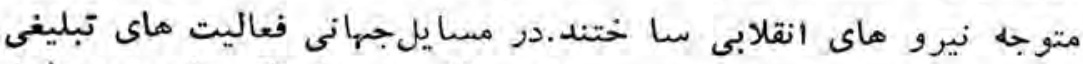

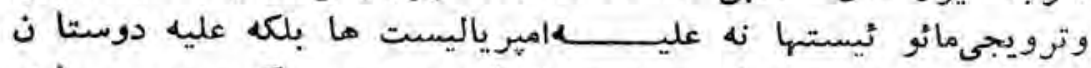

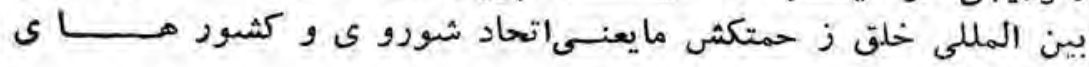
سوسيا ليستى بود .

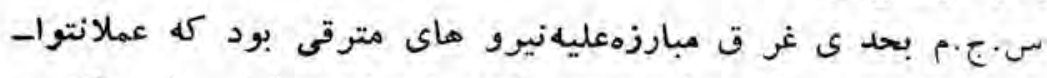

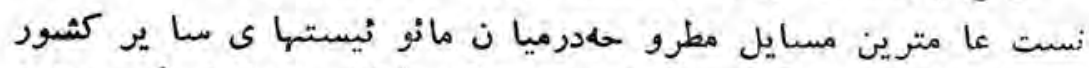

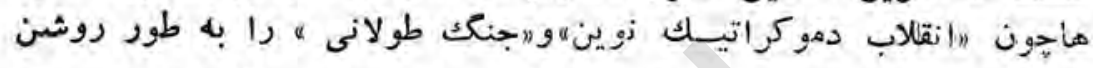

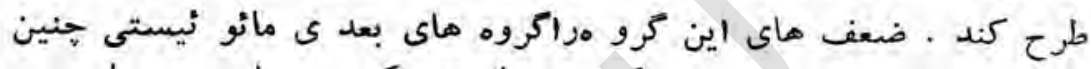

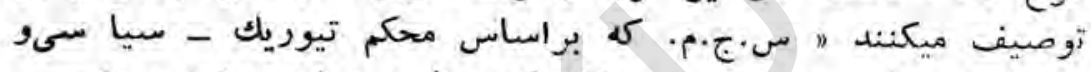

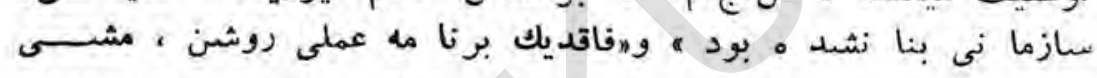

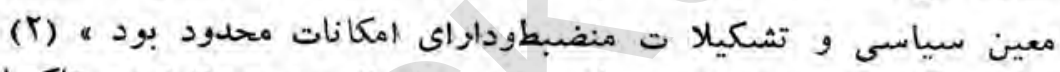

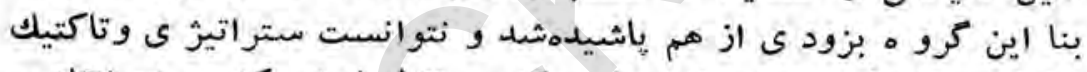

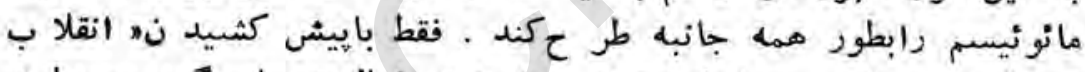

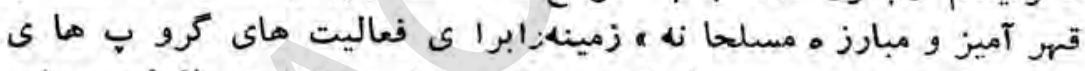

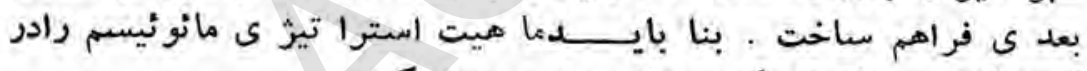

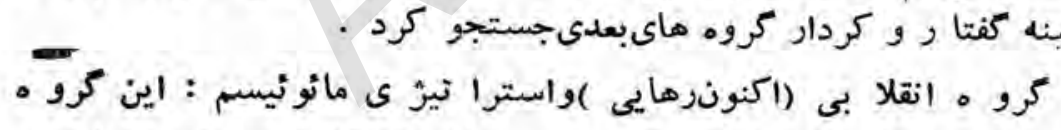

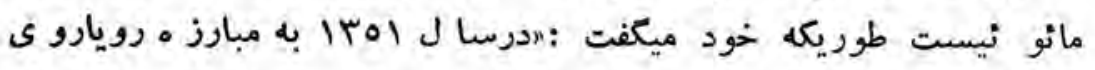

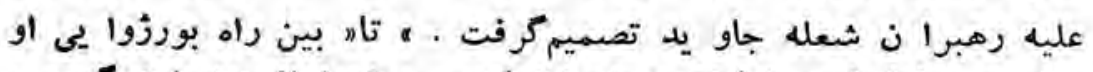

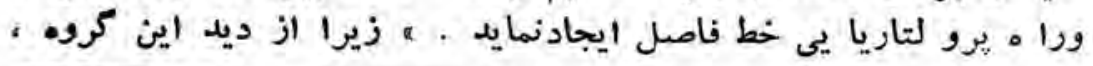

$$
\begin{aligned}
& \text { رساله مذكور . ص ريك. } \\
& \text { " مشعل رهايى " ، ص سله. }
\end{aligned}
$$




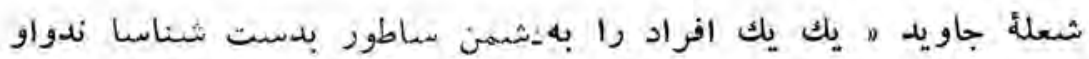

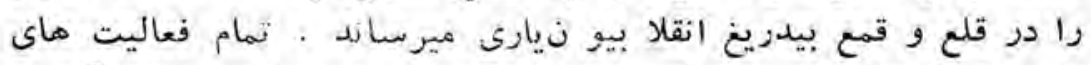

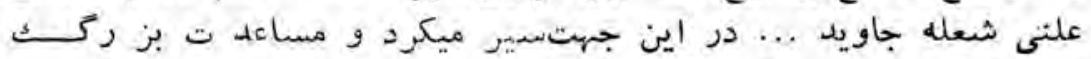

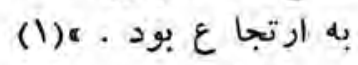

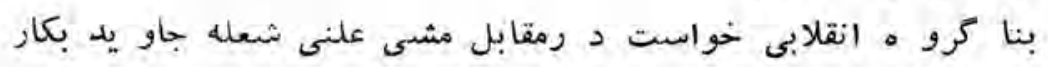

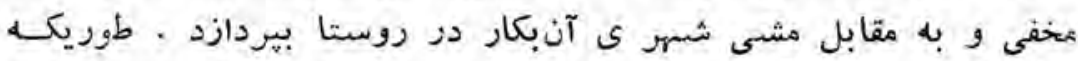

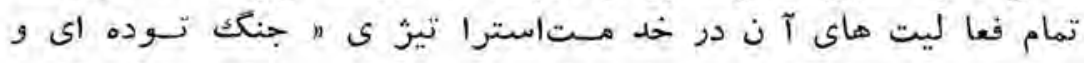

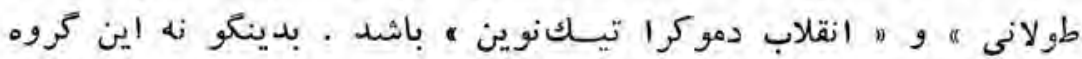

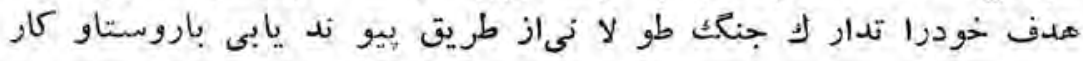

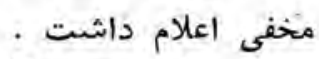

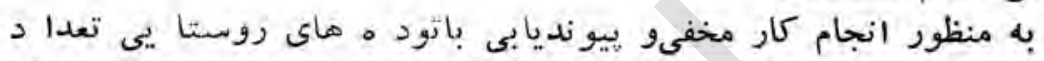

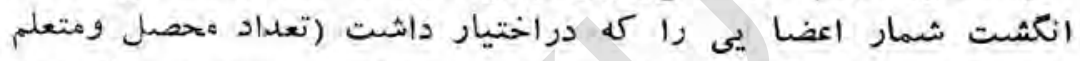

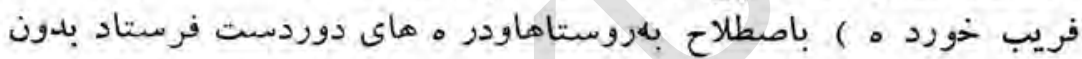

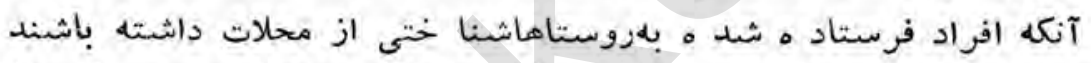

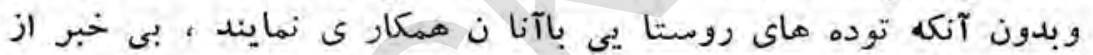

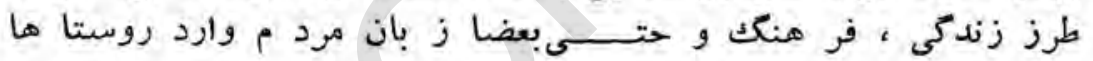

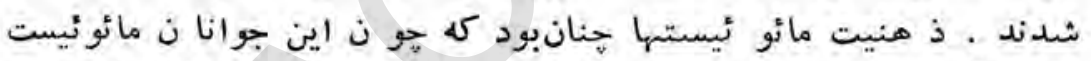

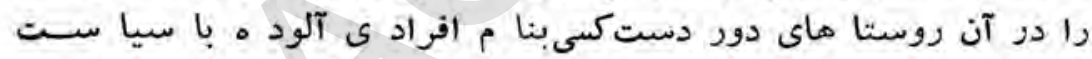

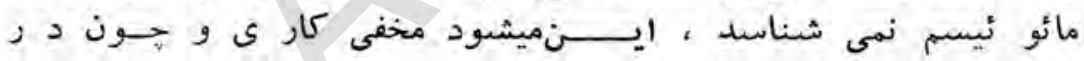

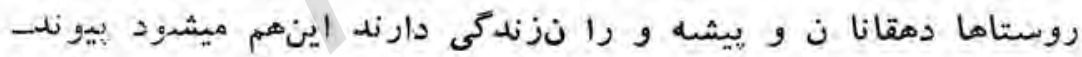

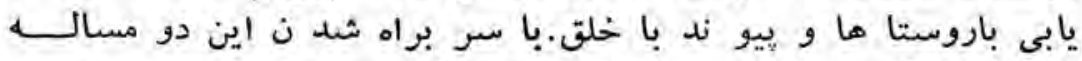

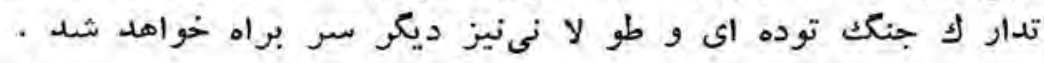

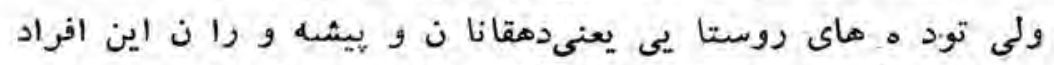

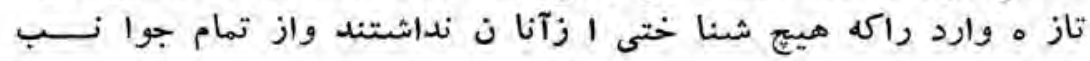

(1) ״با طردا يو ر تونيسم ... باز نشرا ت كرو ه انقلابى · 


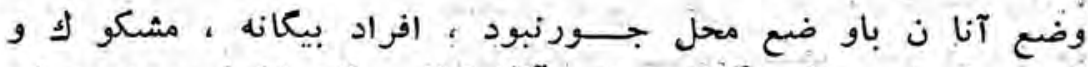

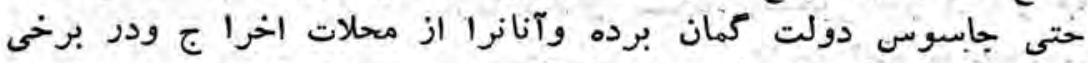

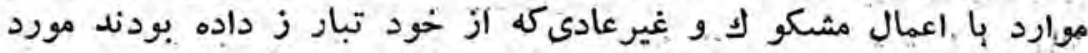

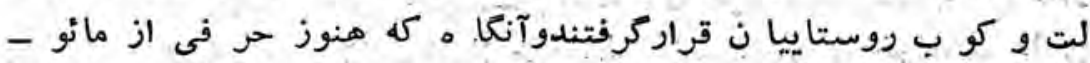

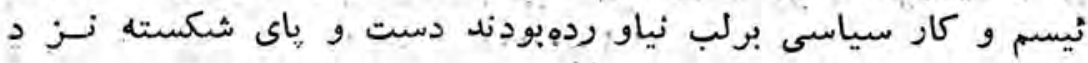

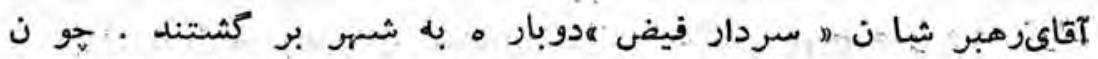

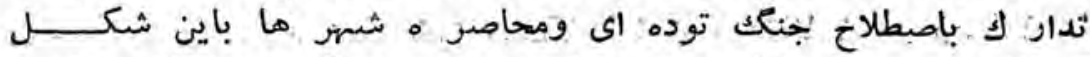

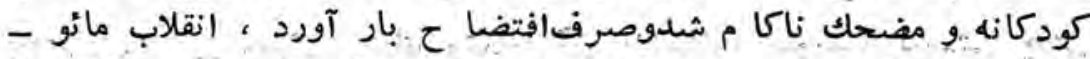

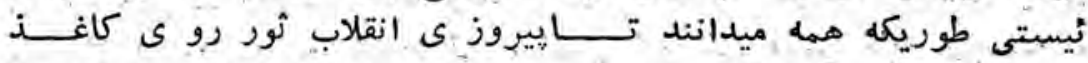

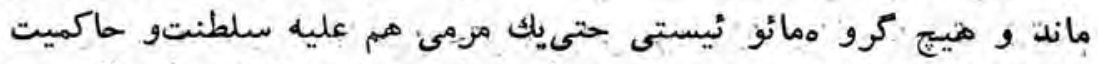

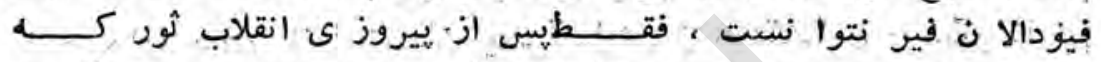

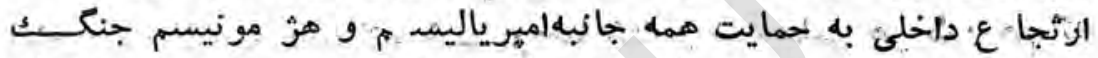

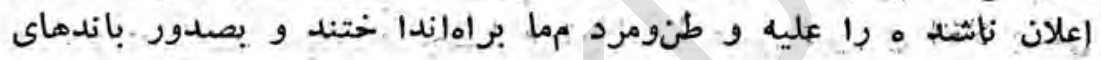

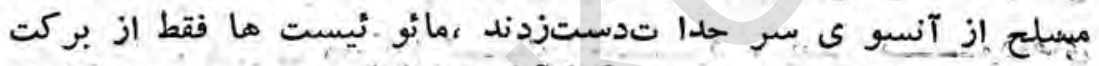

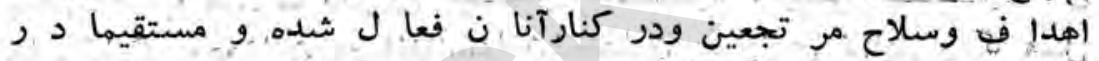

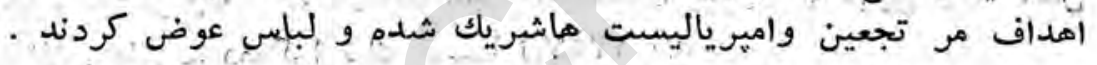

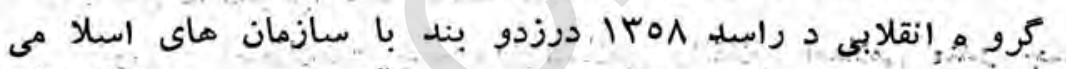

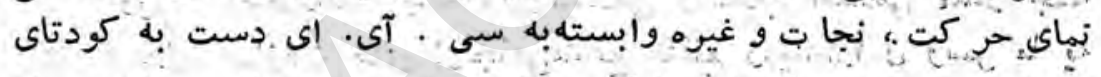

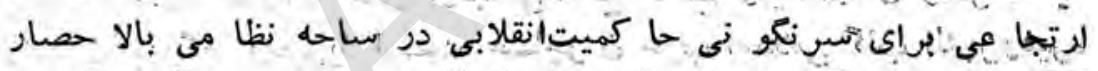

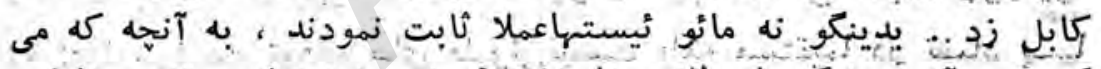

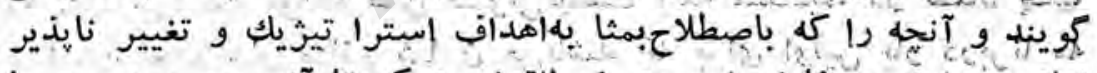

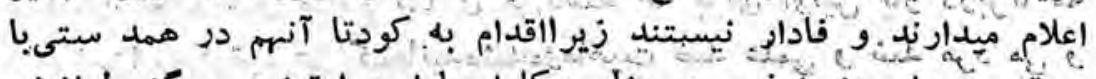

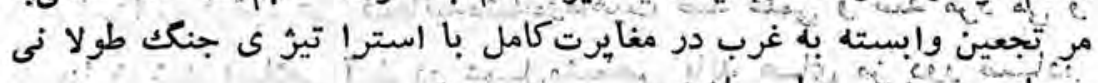

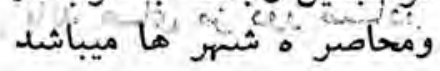

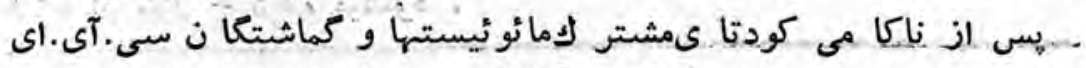

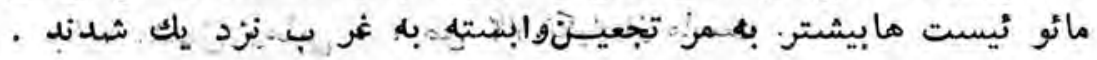




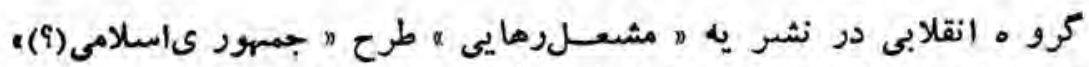

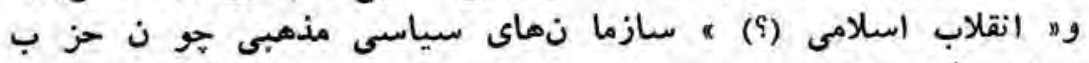

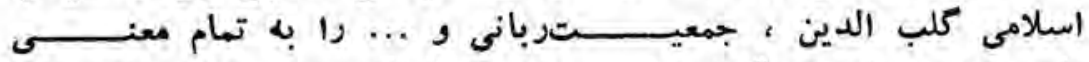

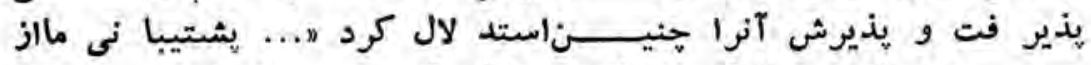

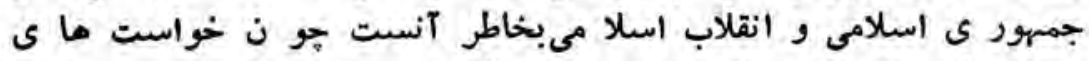

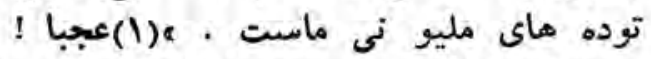

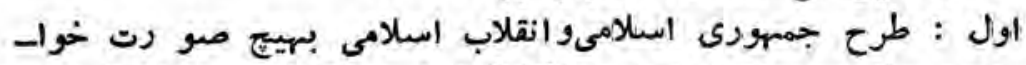

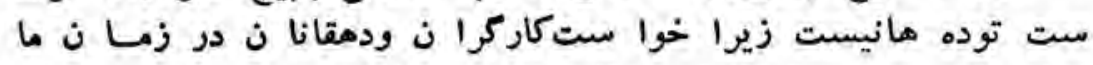

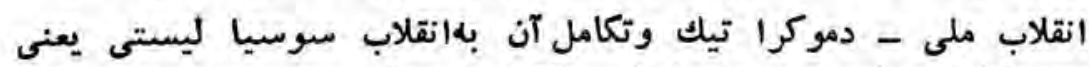

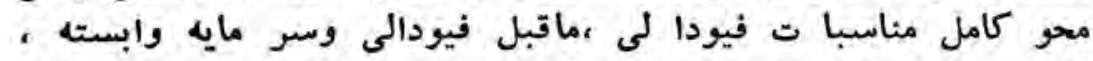

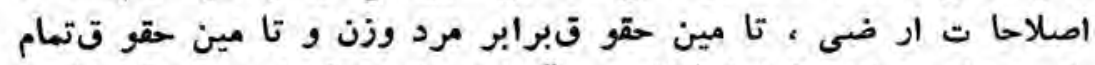

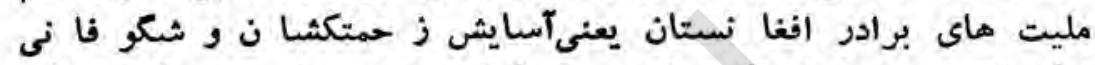

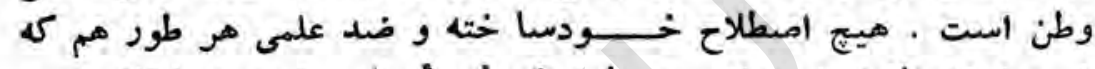

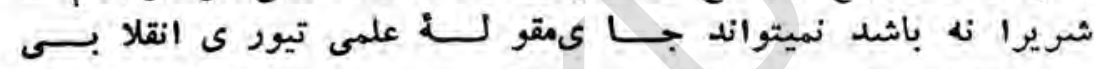

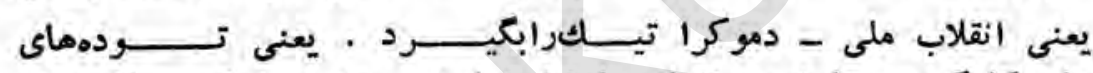

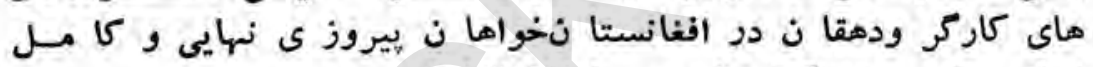

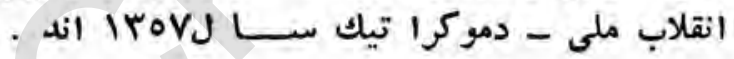

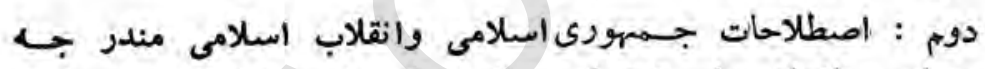

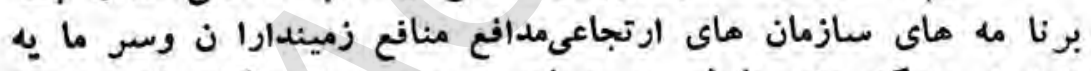

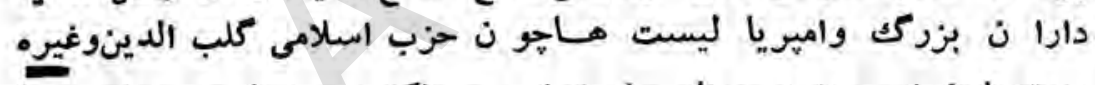

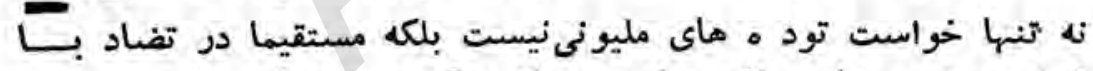

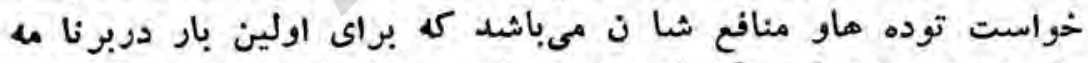

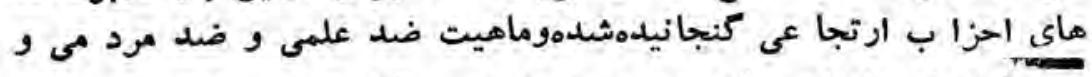

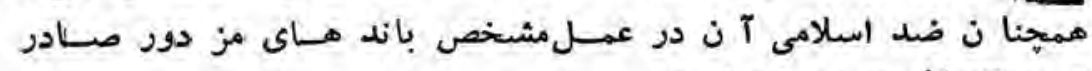
شده از خار ج ديلده ميشود آناهي

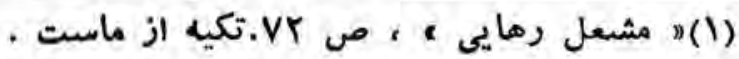




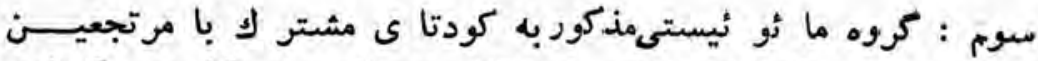

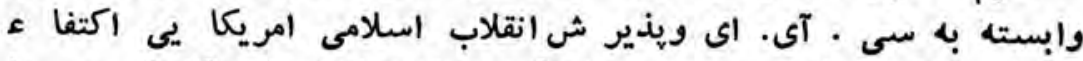

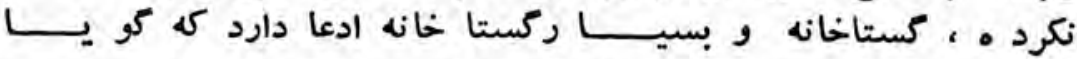

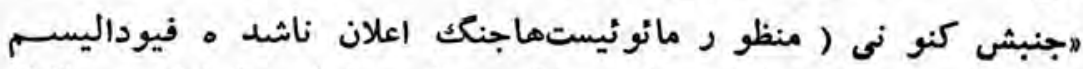

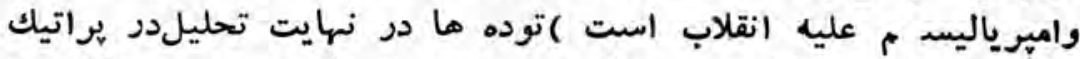

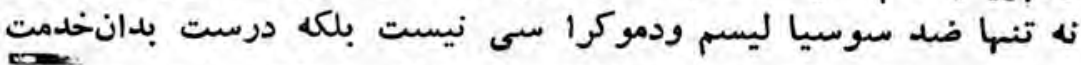

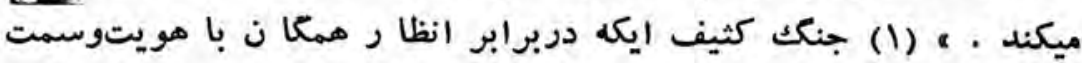

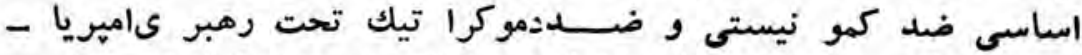

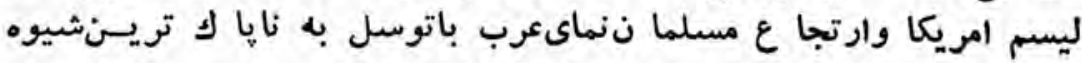

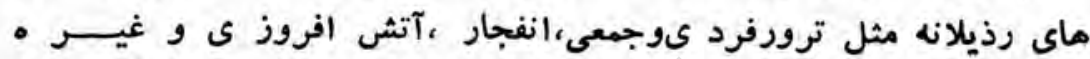

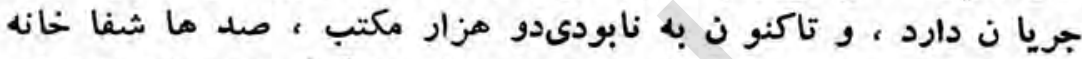

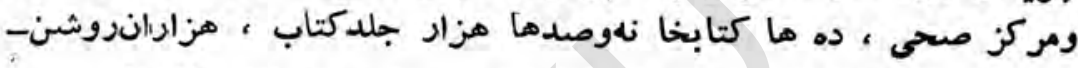

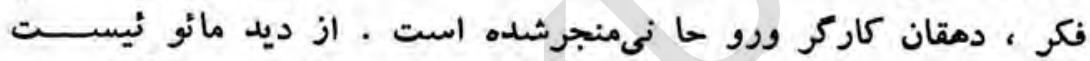

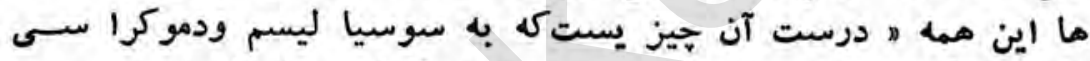

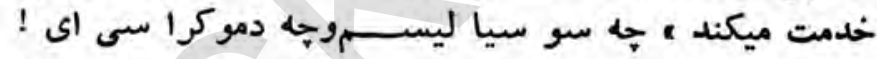

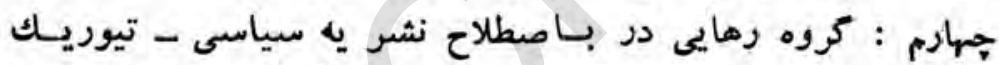

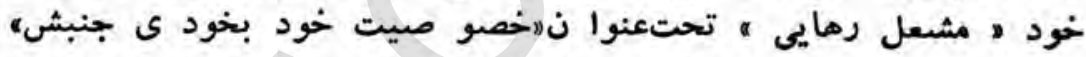

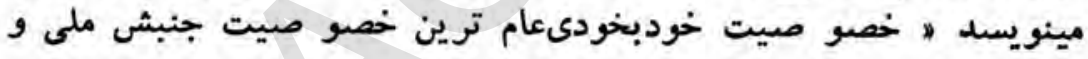

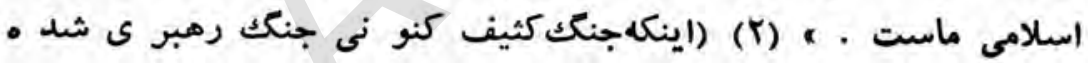

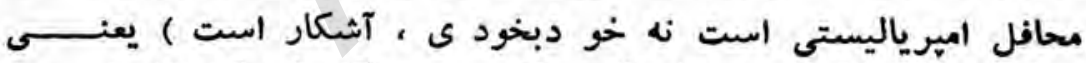

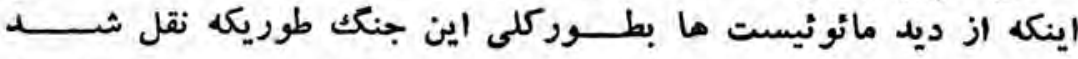

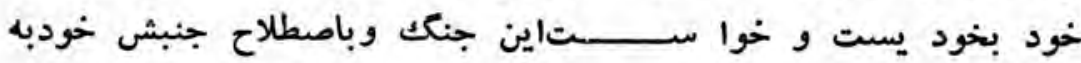
خودى نيز طوريكه تذكر داده شـدجمهور |

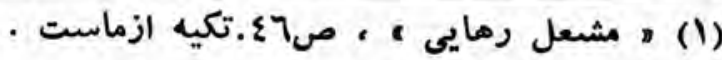

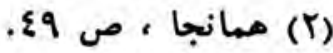




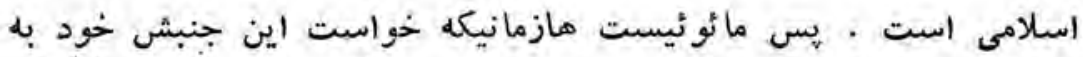

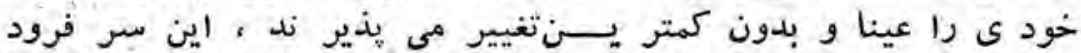

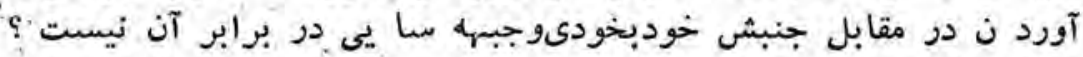

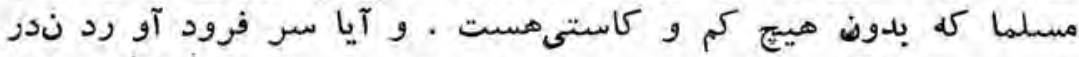

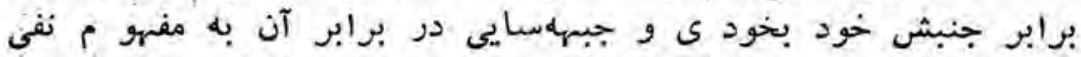

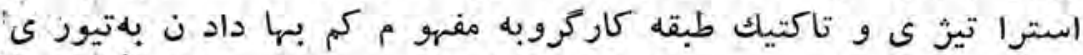

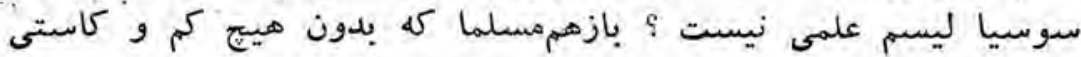

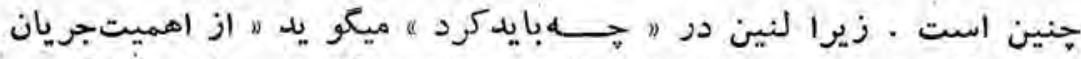

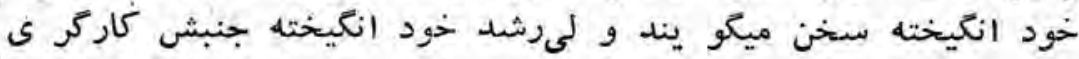

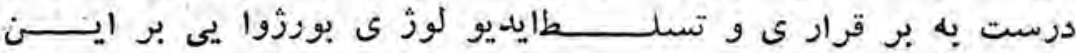

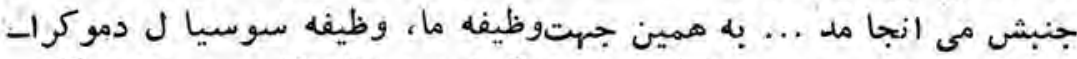

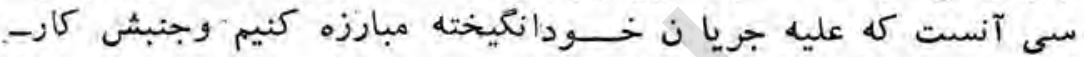

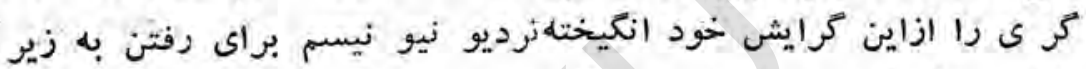

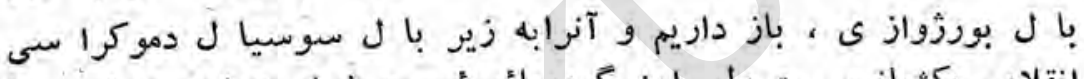

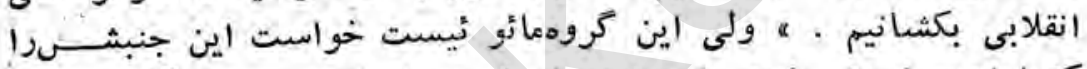

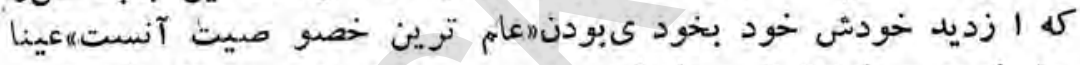

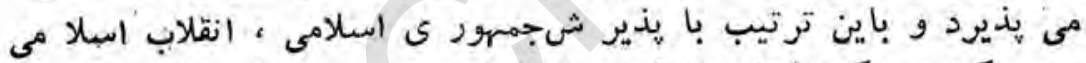

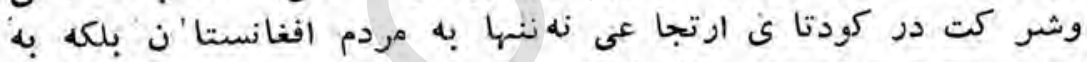

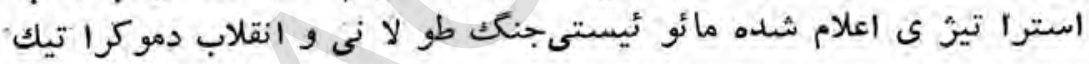

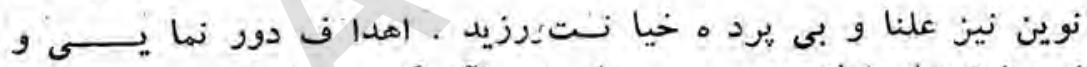

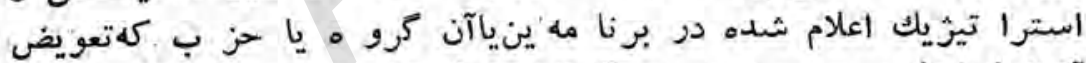

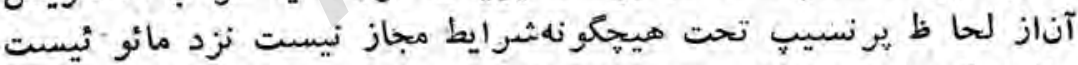

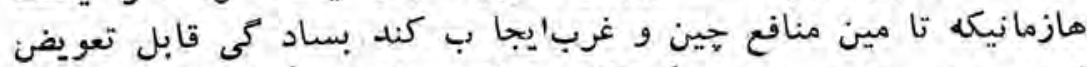

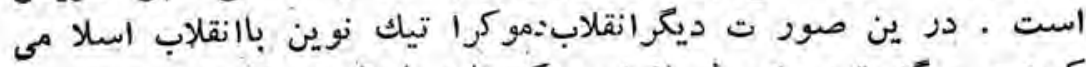

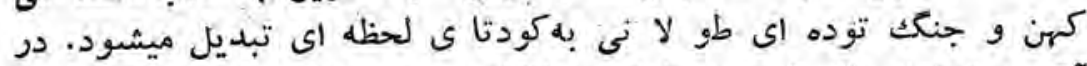

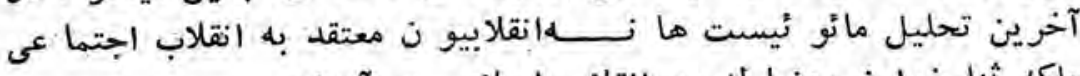

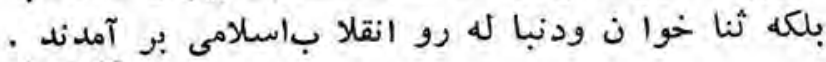




\section{: بونا مه بساما :}

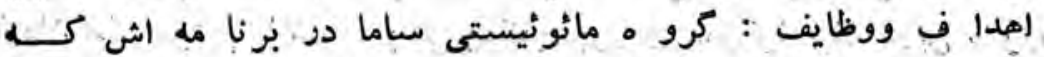

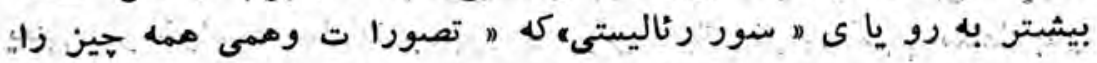

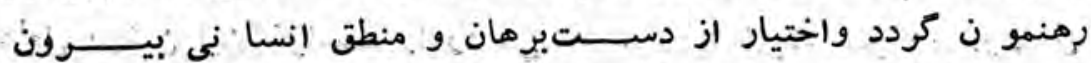

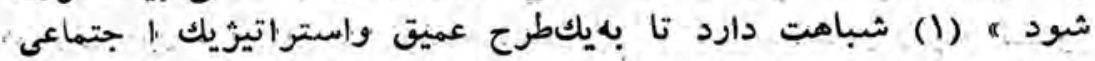

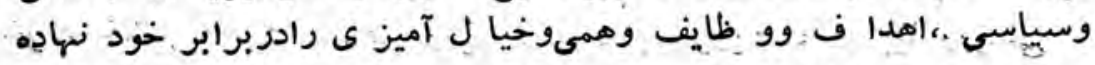

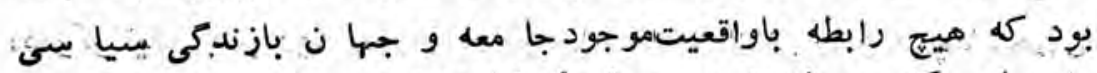

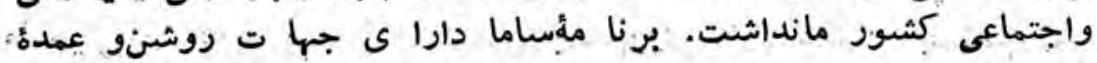

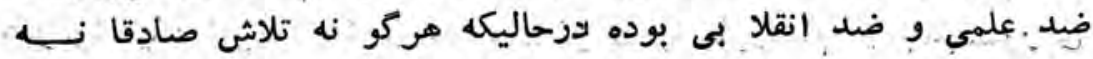

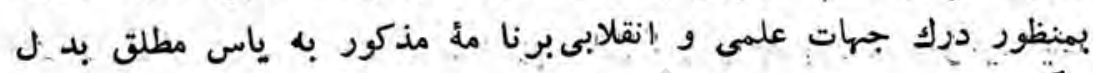

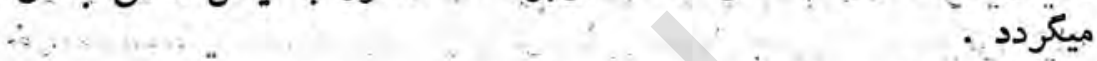

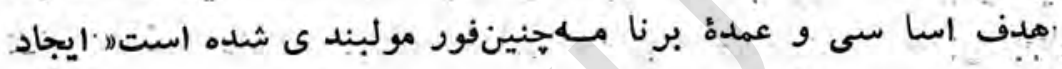

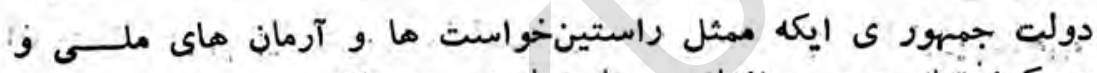

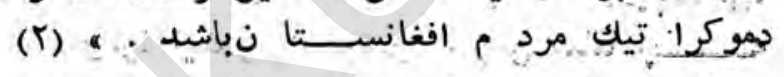

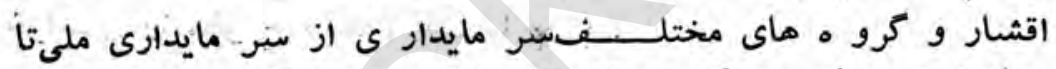

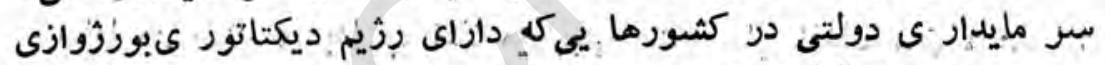

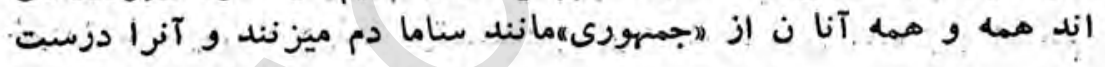

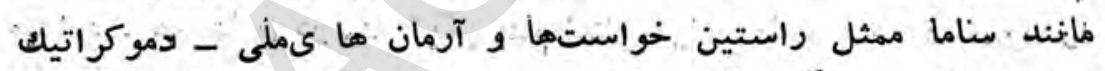

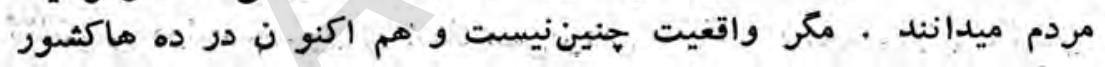

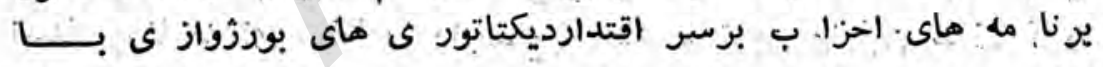

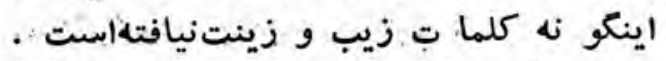

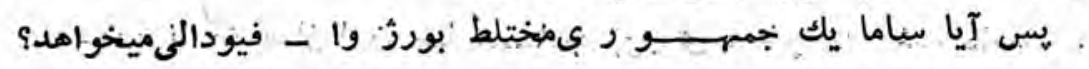

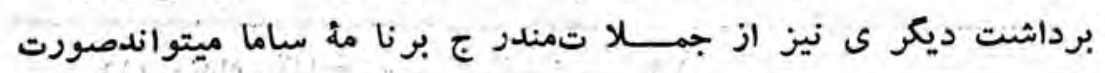

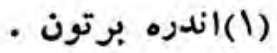

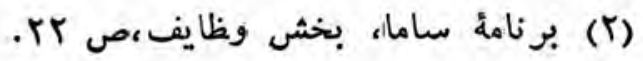




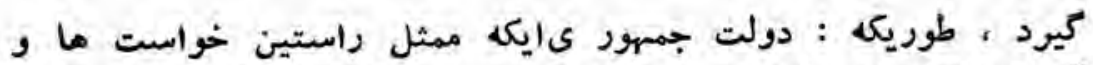

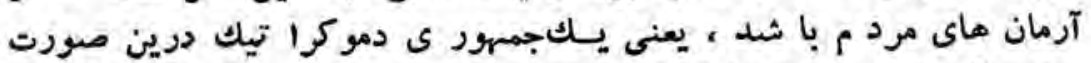

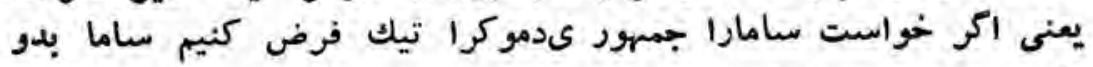

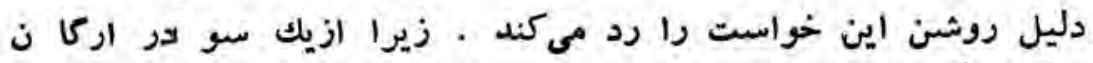

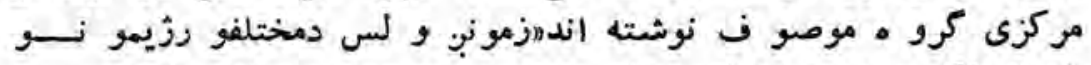

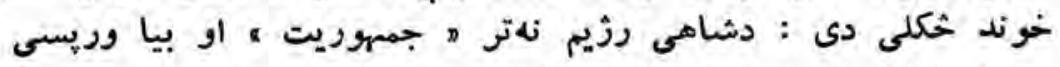

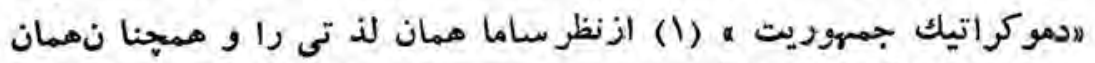

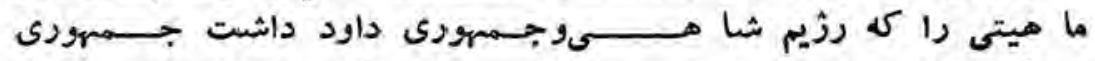

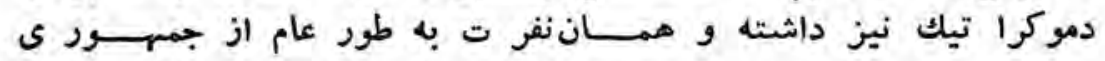

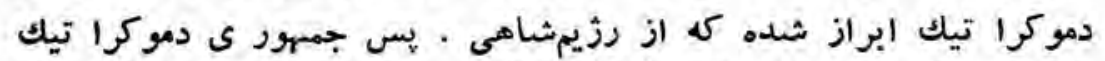

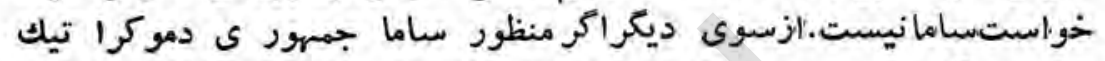

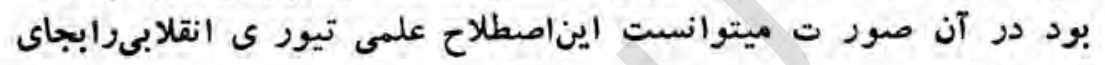

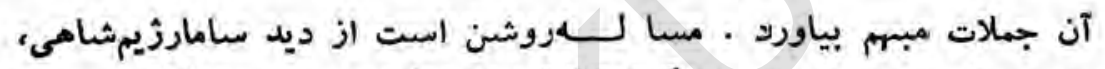

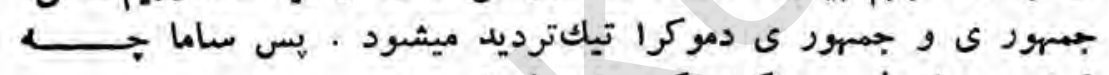

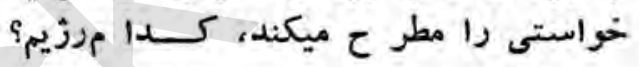

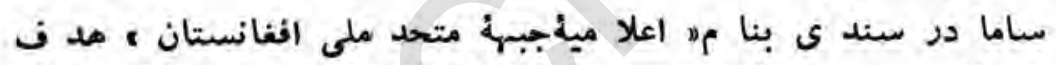

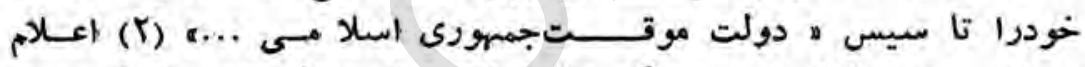

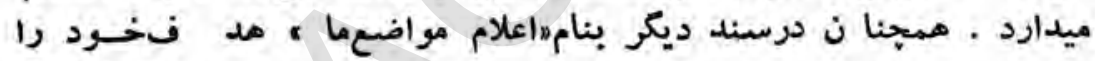

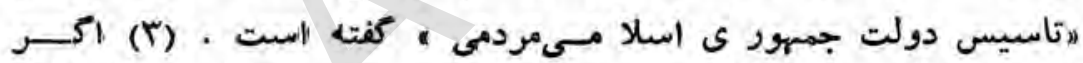

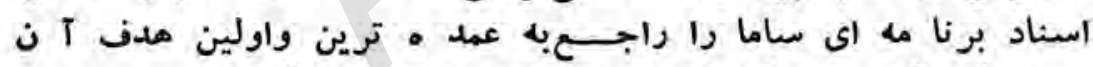

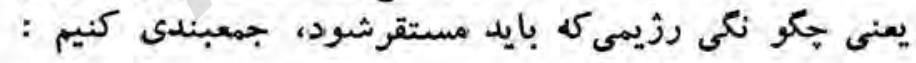

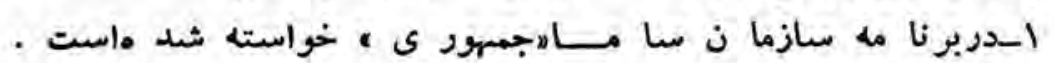

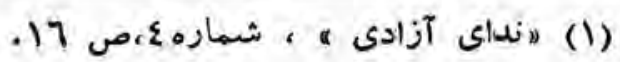

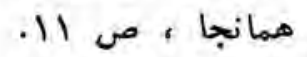

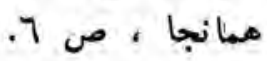


ז-در اعلا ميه جبهه متحد ملسيوتا سيس دولت موقت جمهور ى

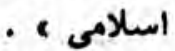

بـدر " اعلا م موا ضع سامسـا، تاسيس دولت جمهور ى اسلا مسى

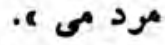

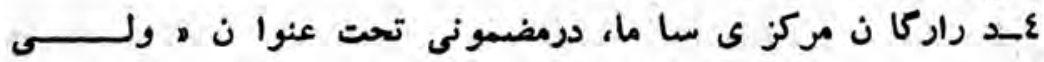

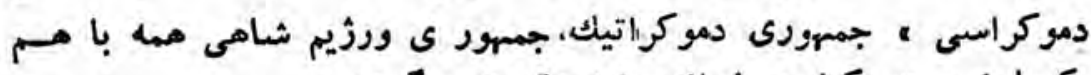

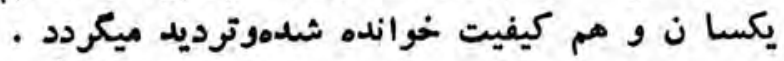

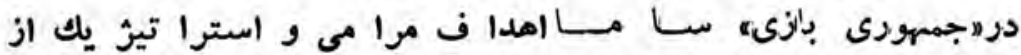

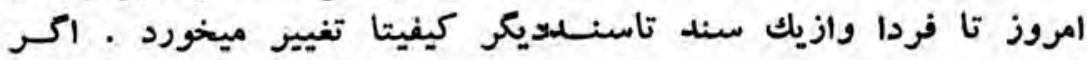

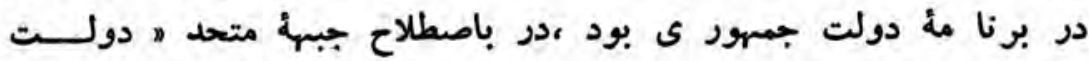

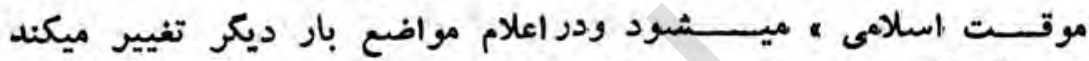

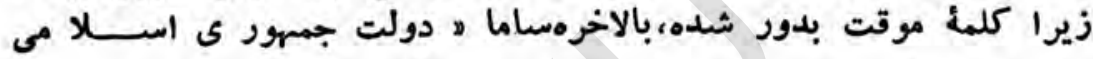

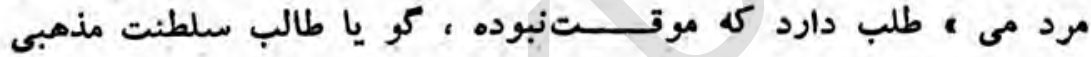

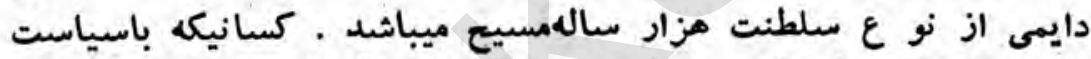

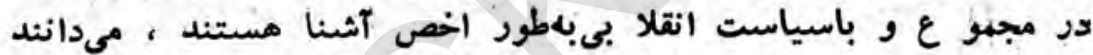

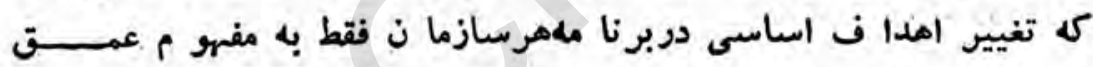

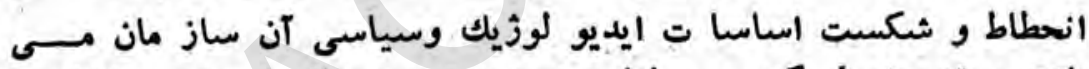

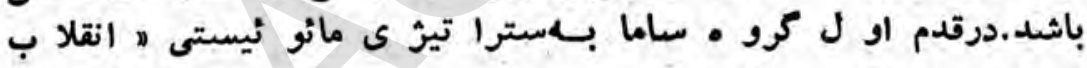

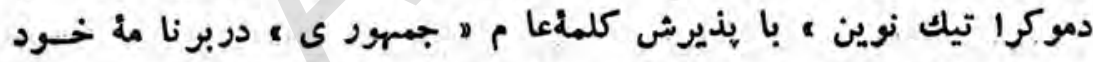

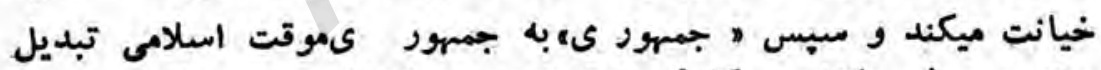

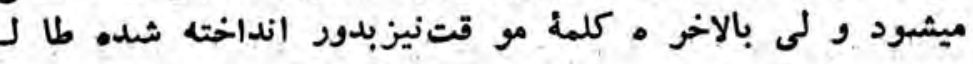

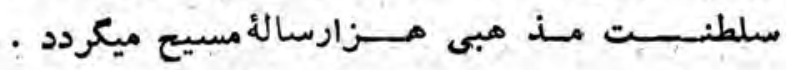

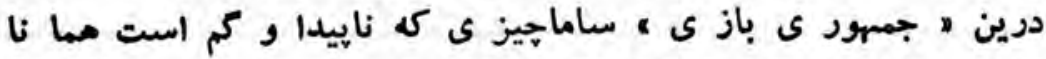

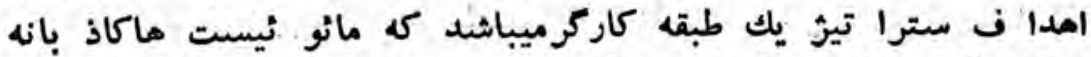

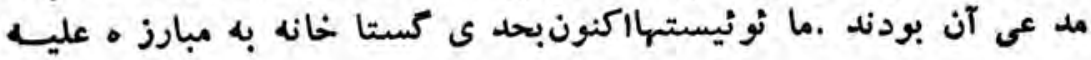




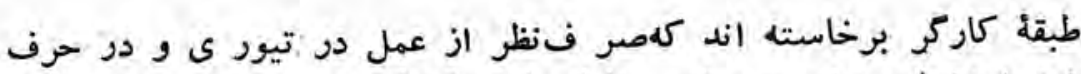

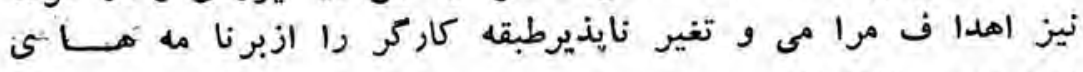

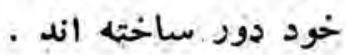

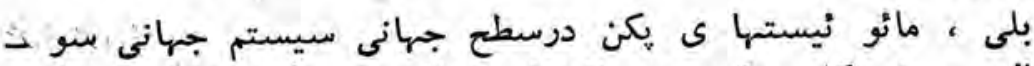

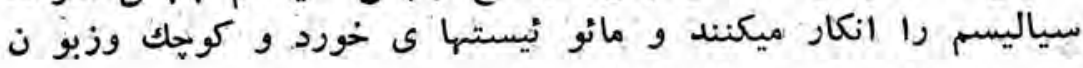

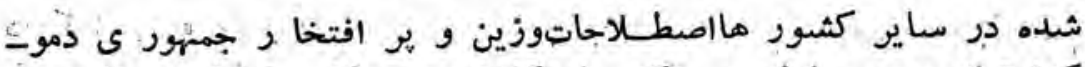

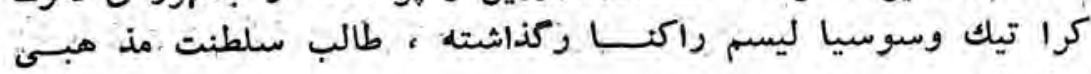
ميشيوند :

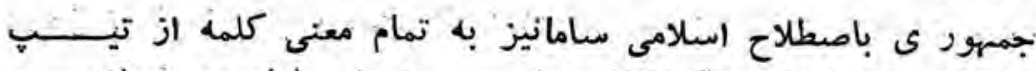

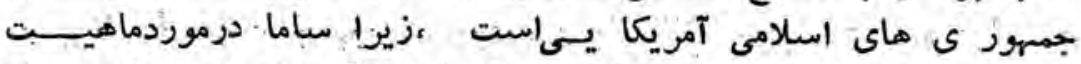

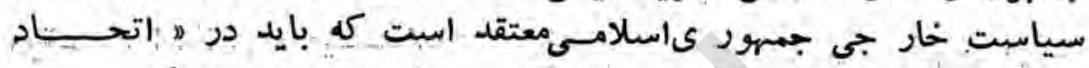

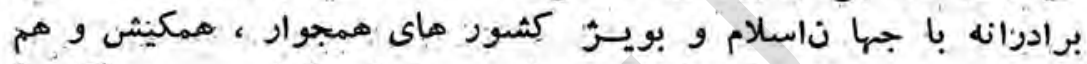

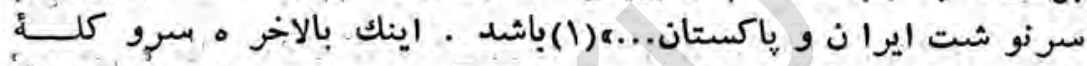

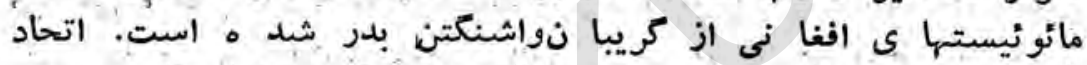

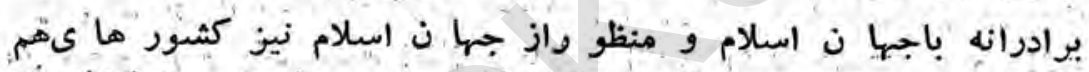

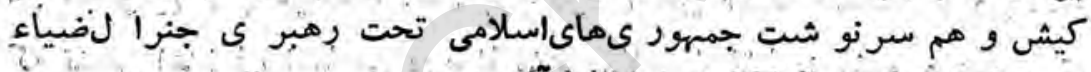

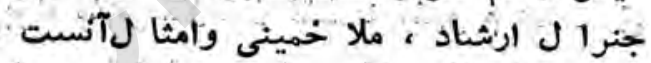

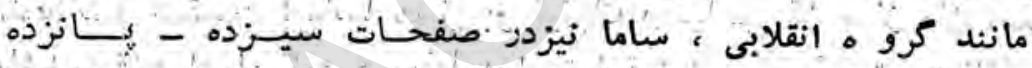

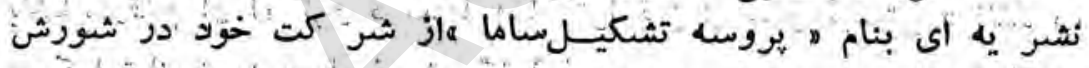

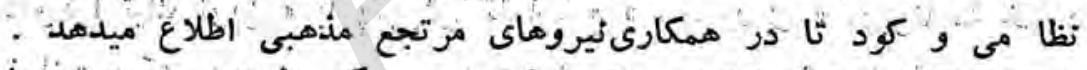

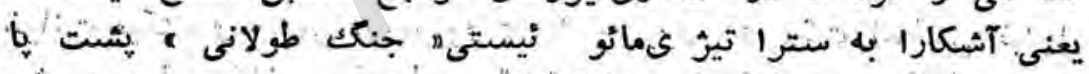

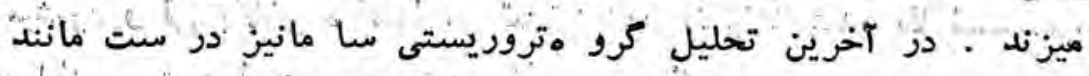

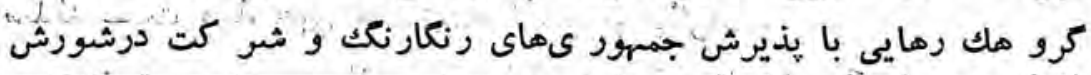

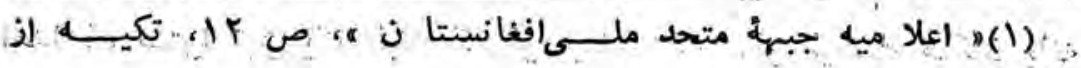




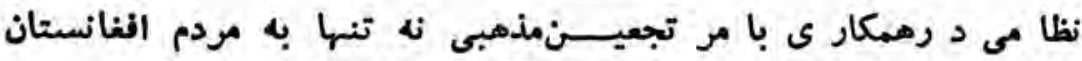

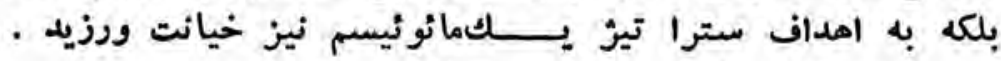

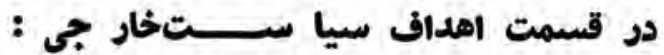

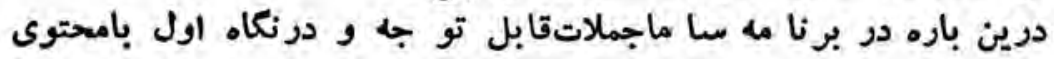

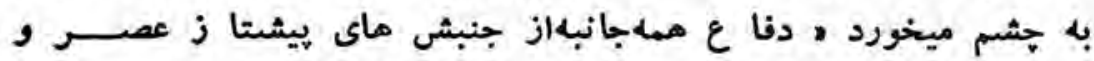

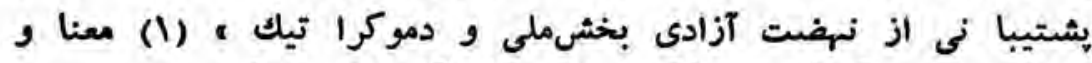

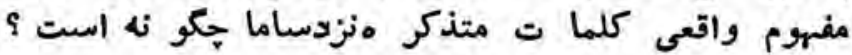

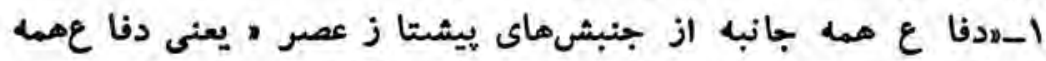

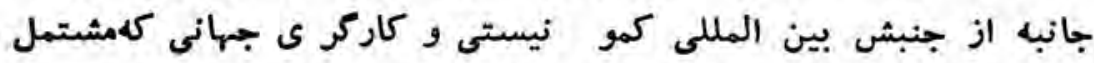

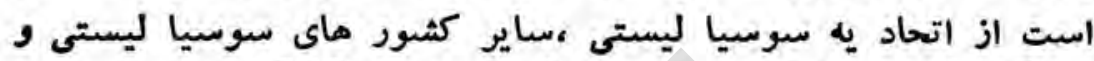

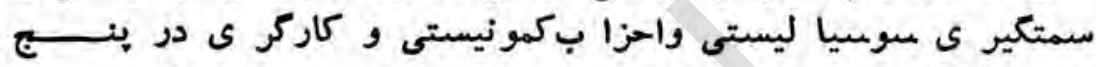

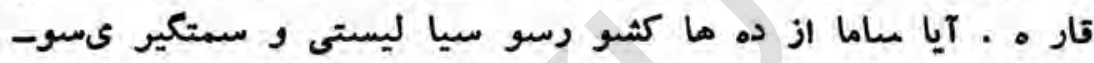

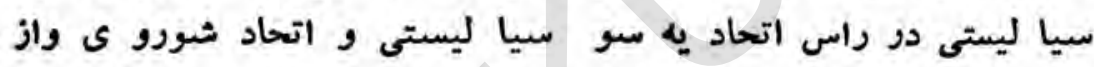

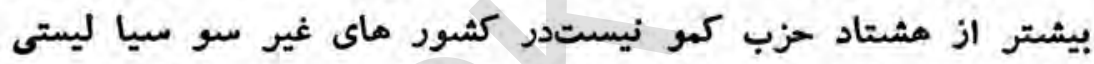

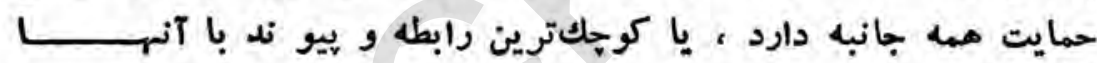
ندارد ؟

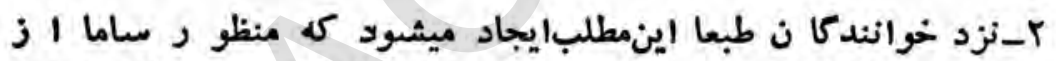

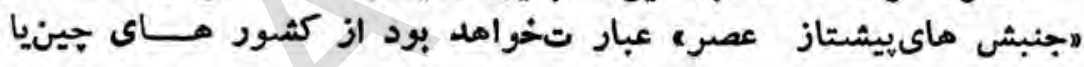

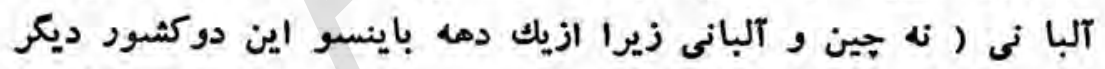

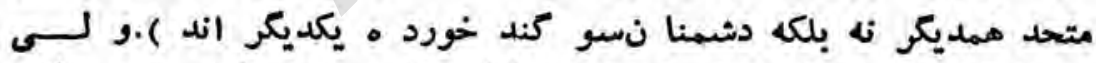

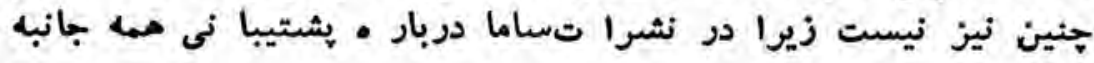

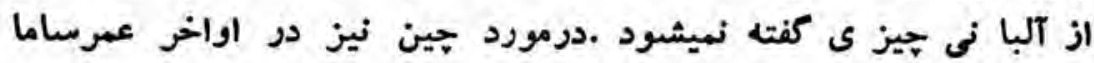
بر خورد روشن و نظر واحد ديلدهنميشود . در كذ شئه محافل متحده 


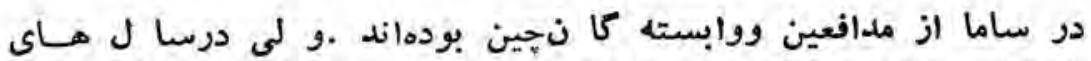

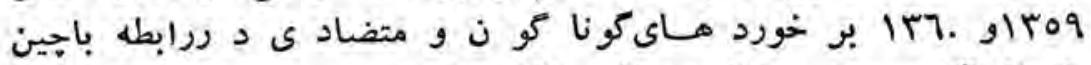

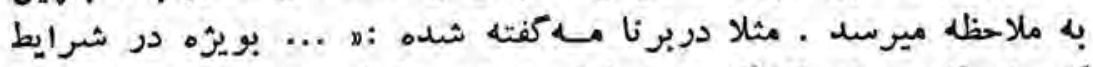

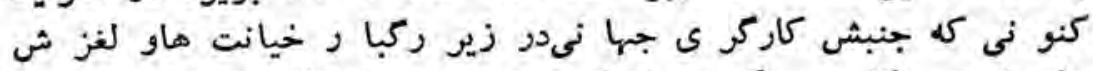

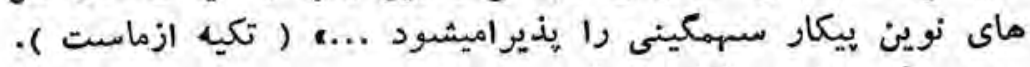

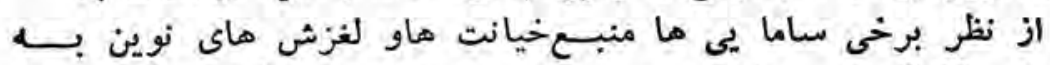

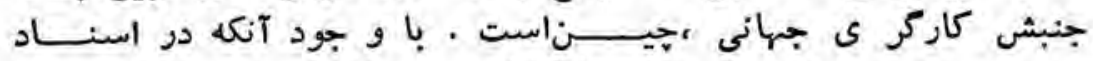

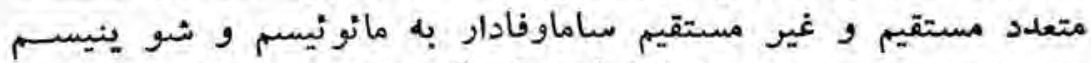

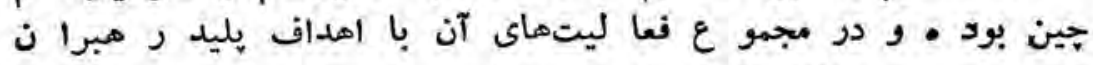

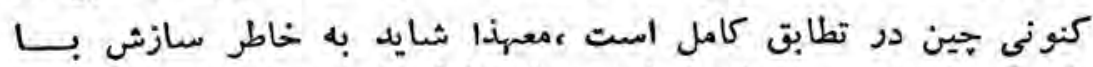

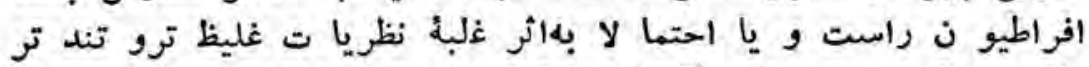

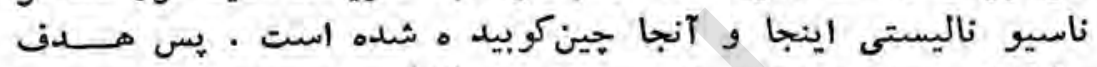

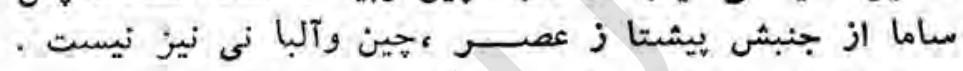

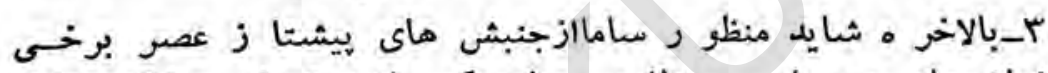

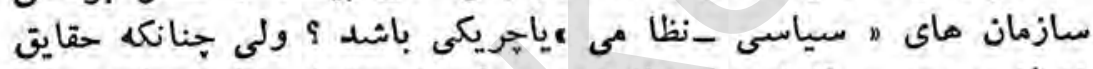

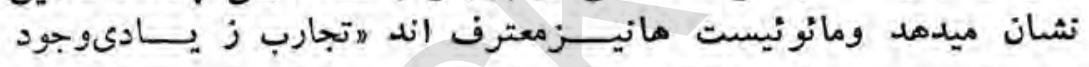

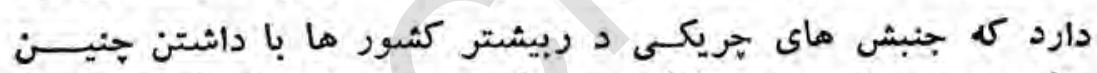

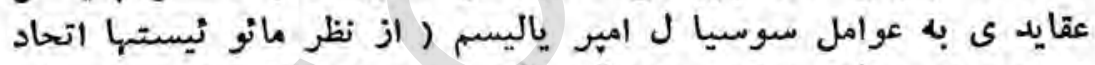

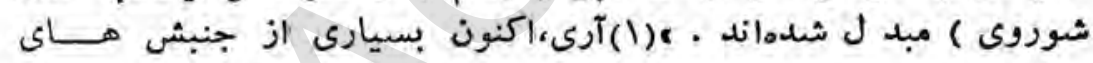

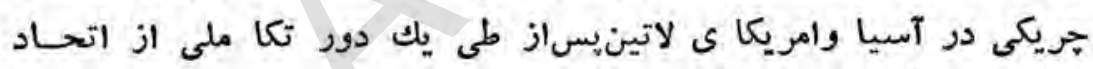

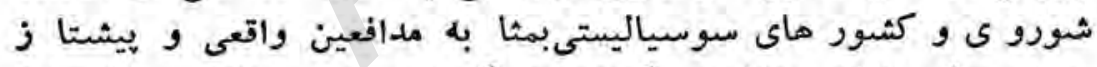

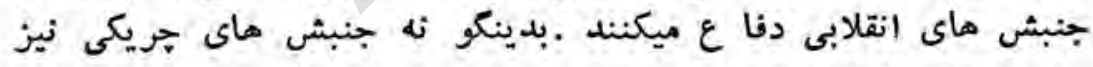
مطمع نظر سانما نيست.

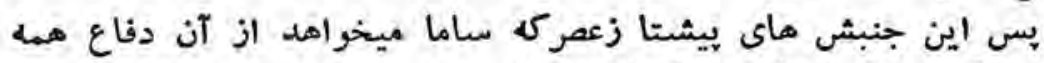

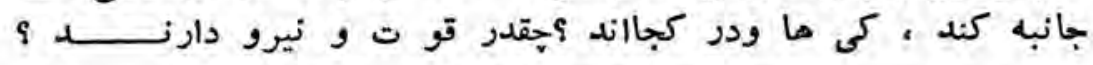

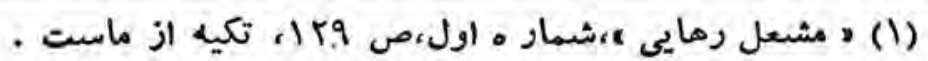




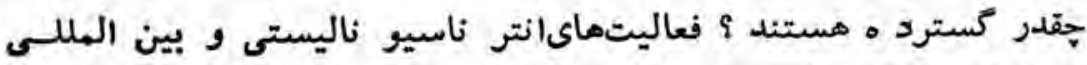

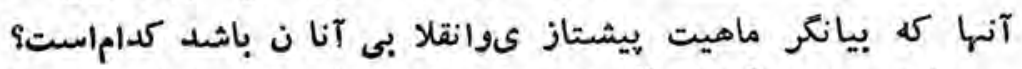

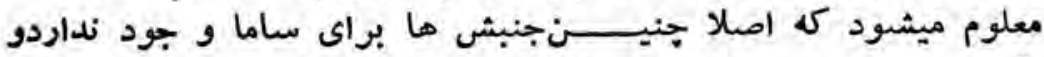

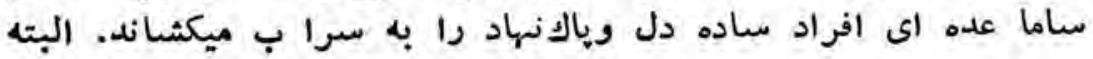

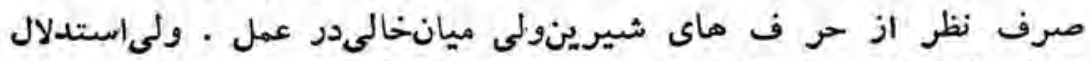

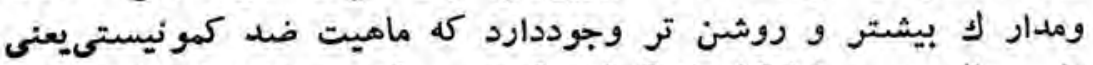

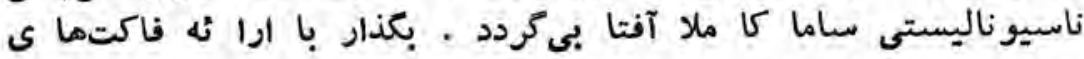

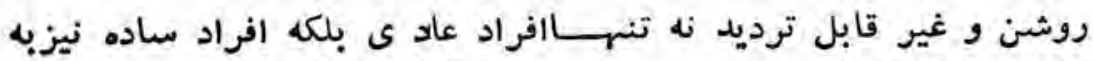

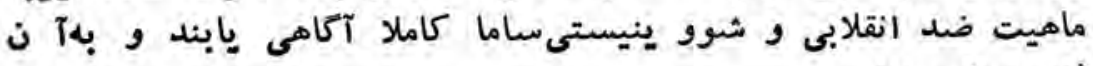

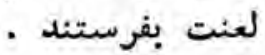

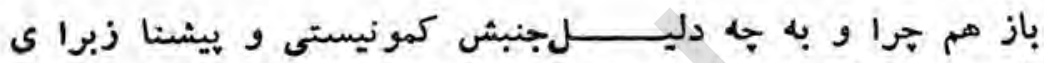

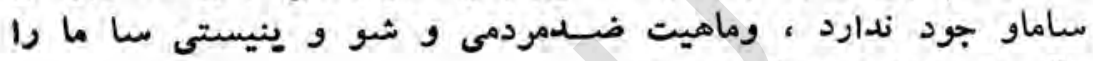
جكو نه ميتوا ن در كـ نهود وماهيت

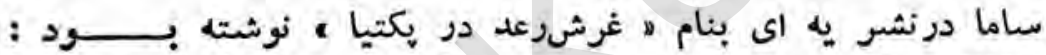

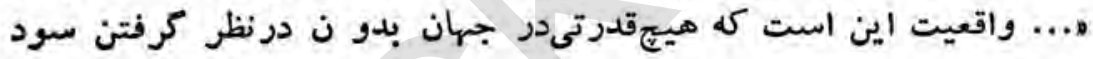

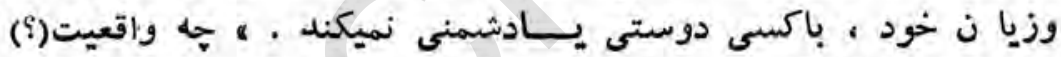

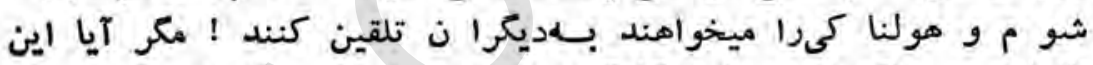

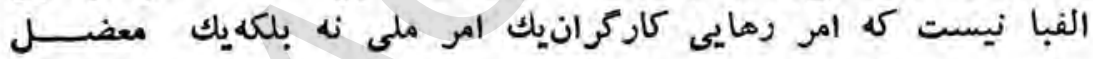

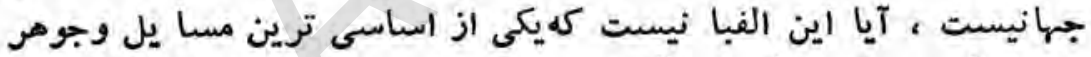

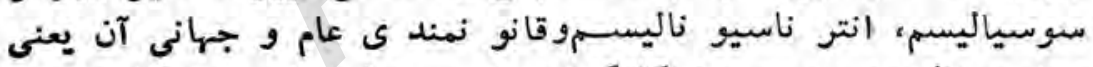

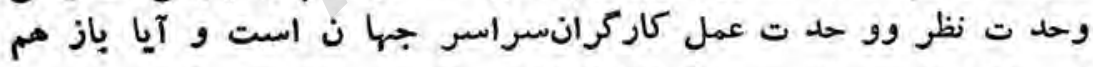

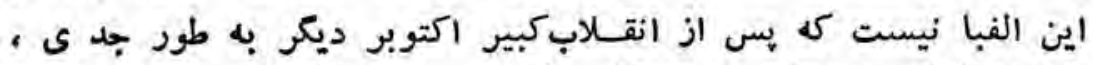

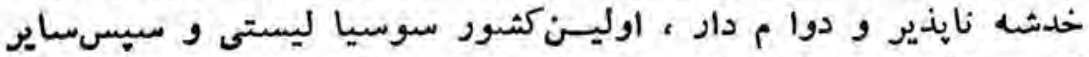

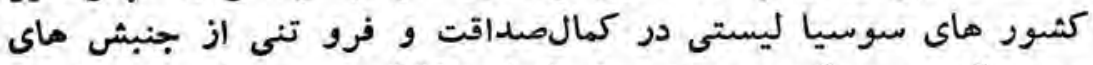

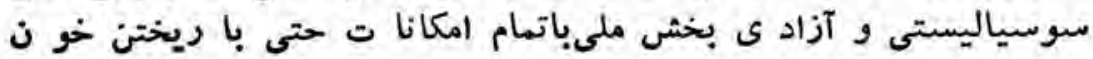
فرزندان خود دفا ع كرده و ميكنئد. 


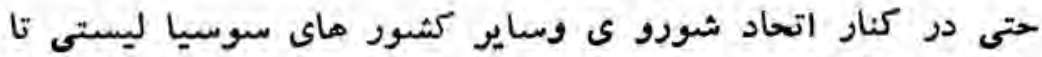

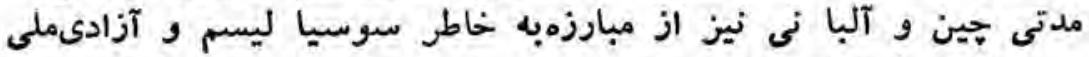

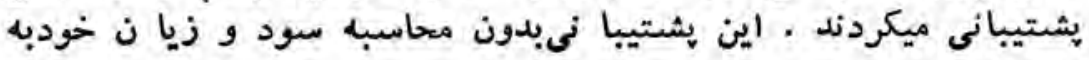

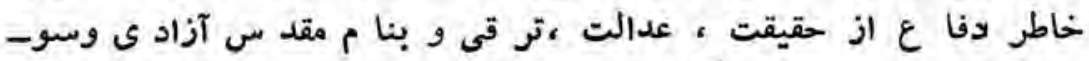

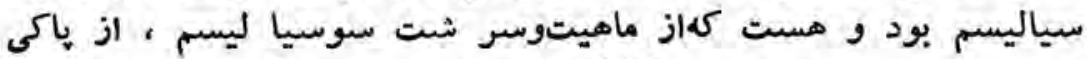

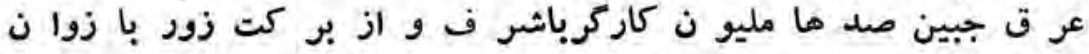

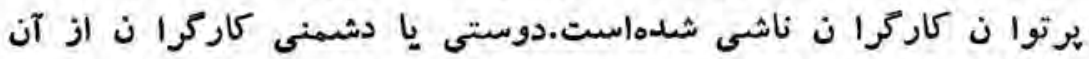

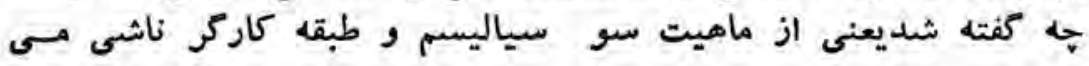

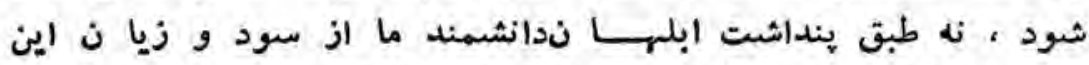

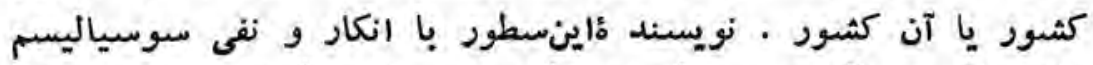

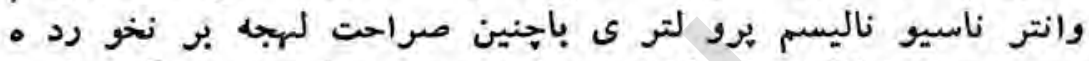

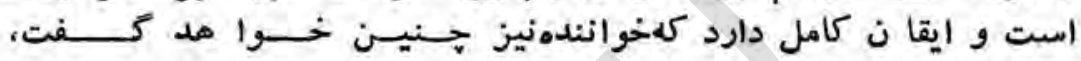

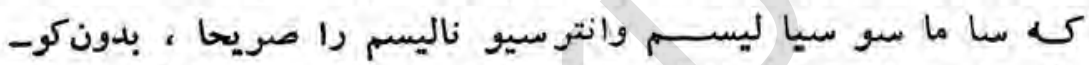

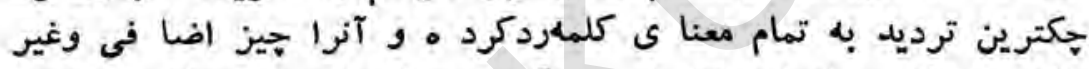

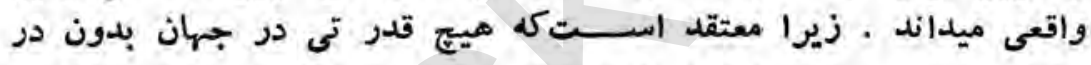

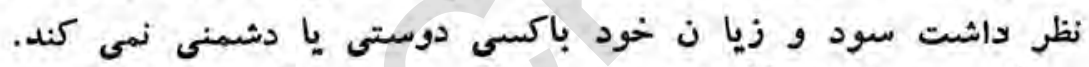

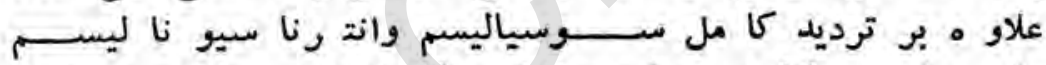

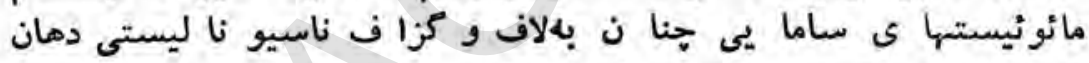

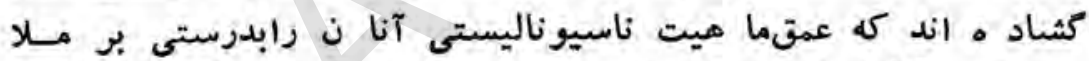

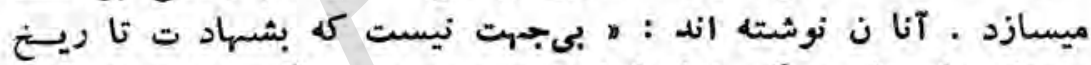

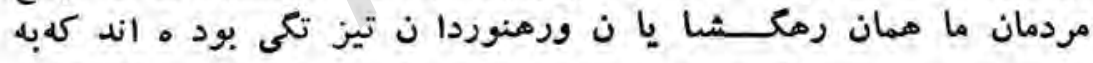

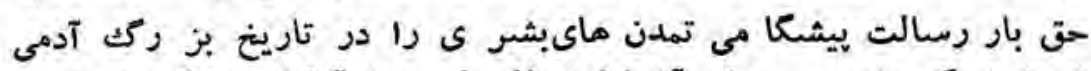

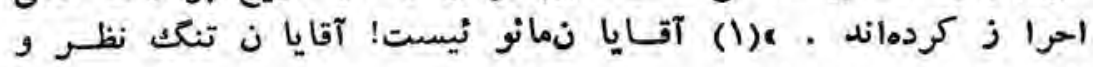

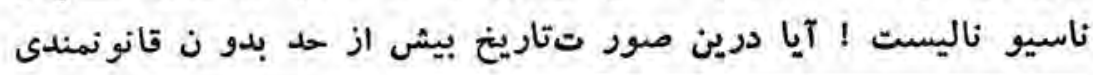

(1). نداى آزادى ، ، شها ر ماول ، ص مفت . تكيه از ماست. 
وبيش از حد سنكك دل نبوده كه بهار رسالت بيشكامى تملن هـاو

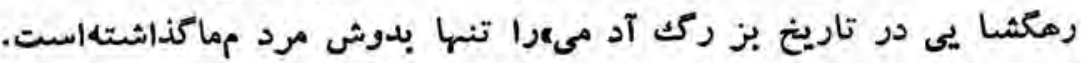

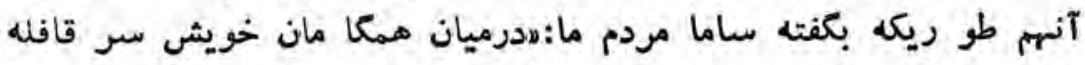

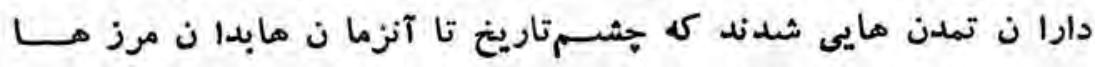

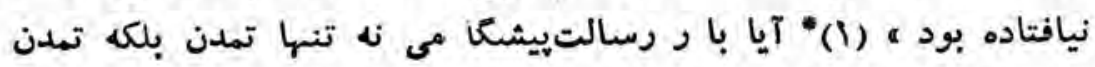

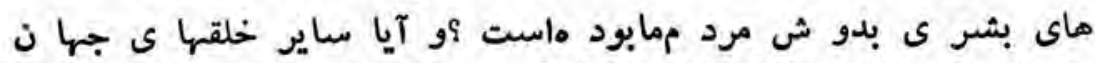

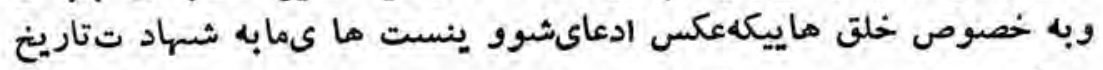

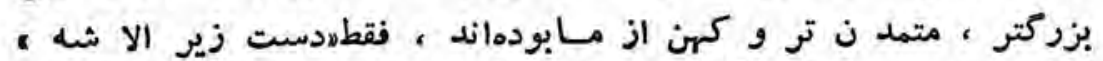

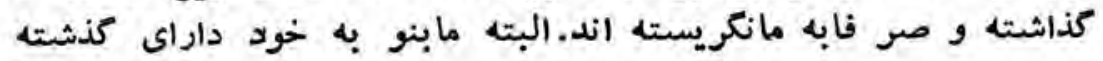

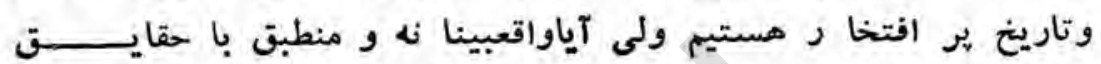

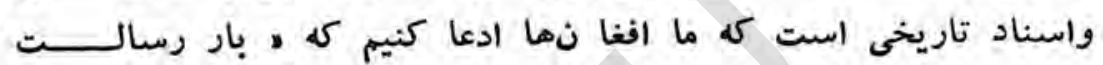

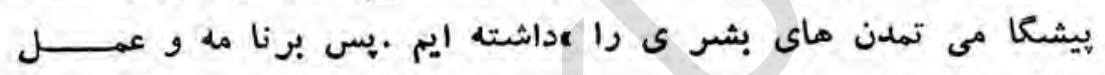

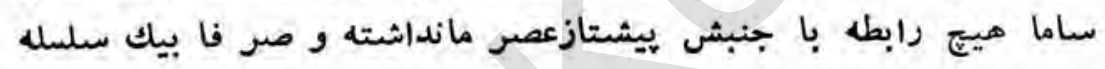

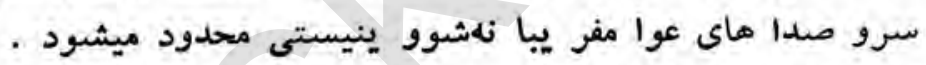

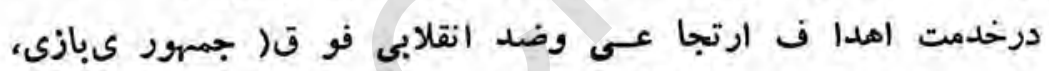

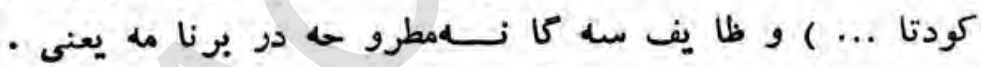

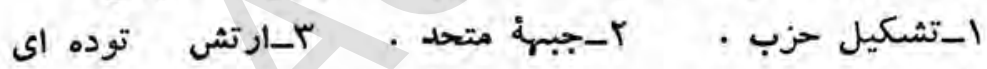

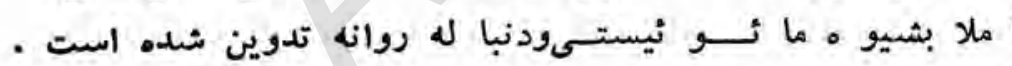

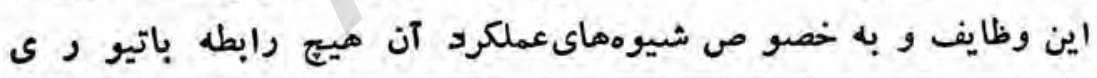

(1) "نداى آزادى"، شماره اولصفحه مفت . تكيه از ماست.

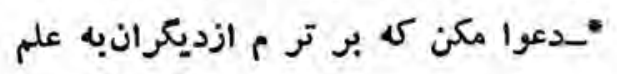

ج ون كبـركرد ى از همه دونا ن فرو تسر ى ازدي (سعدى) 


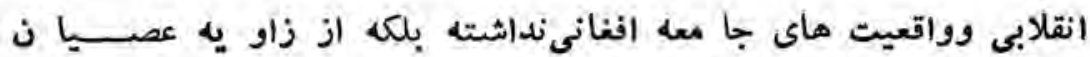

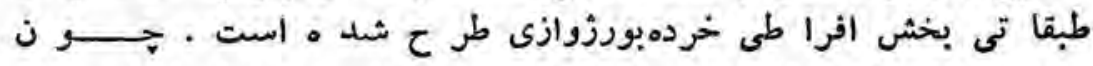

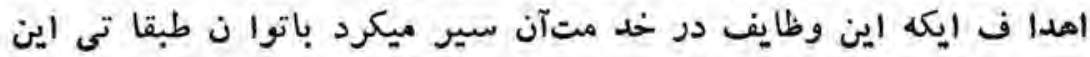

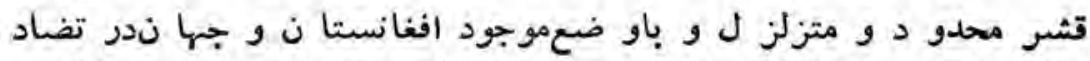

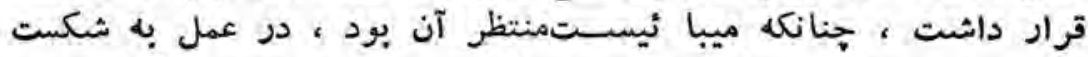

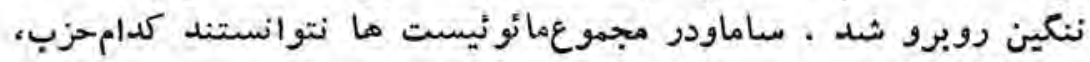

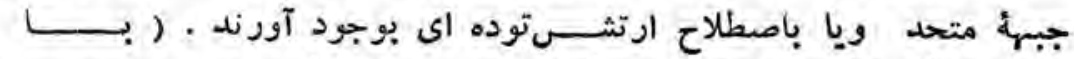

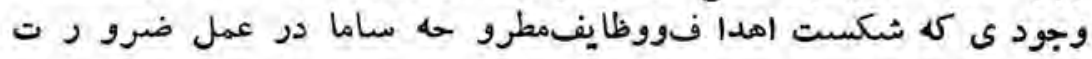

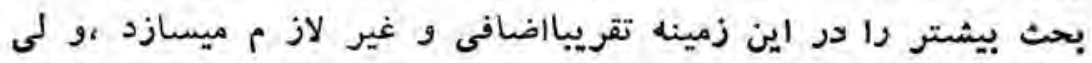

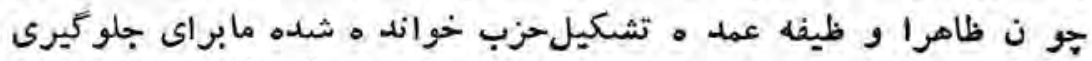

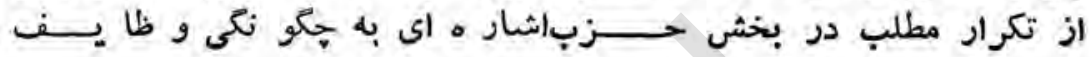
ساما خواهيم داشت ).

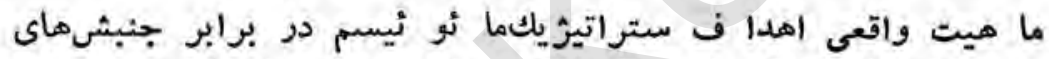

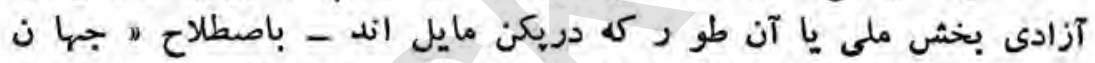

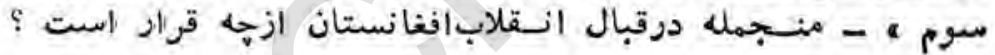

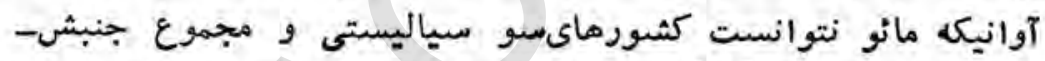

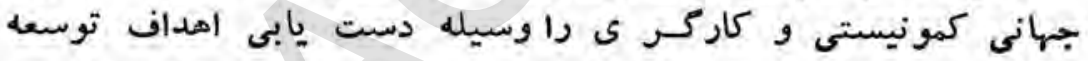

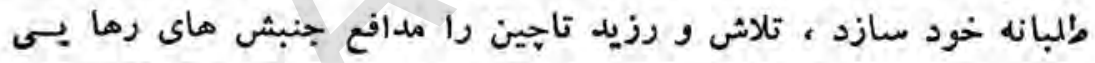

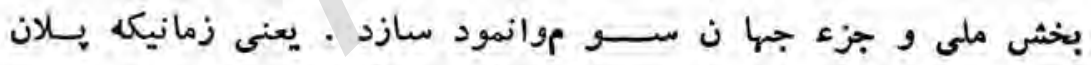

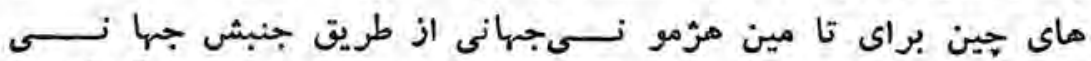

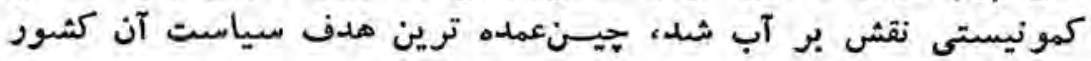

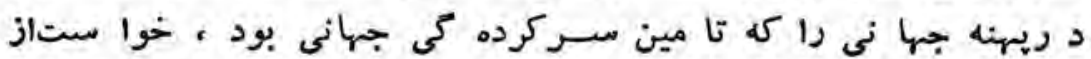

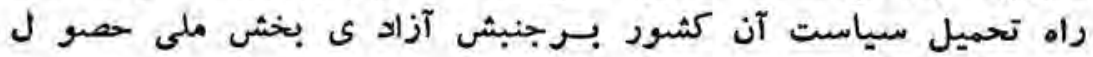


جنبش آزاد ى بخش ملى و كشورهاى "اجهانسوم × عمد تا از دو رواه

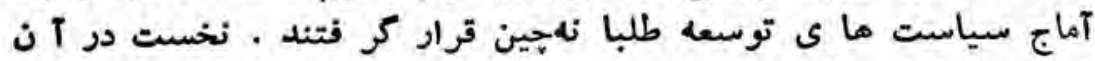

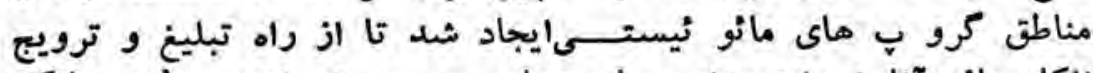

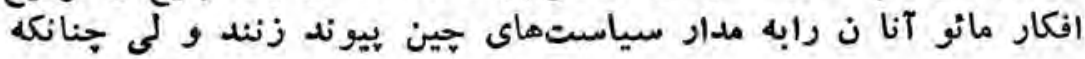

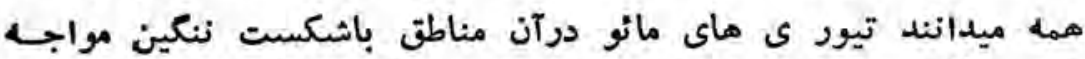

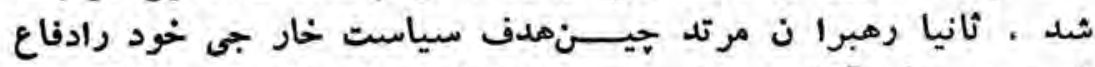

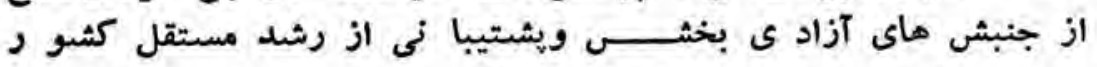

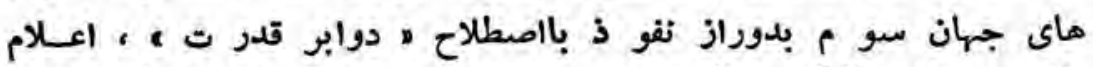

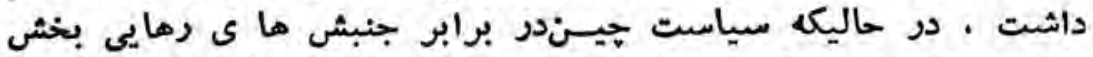

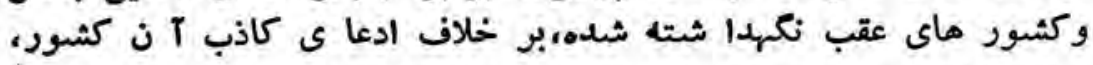

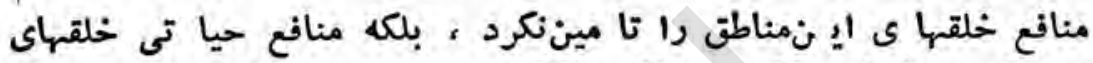

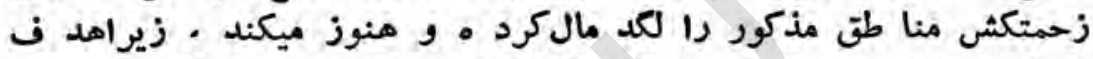

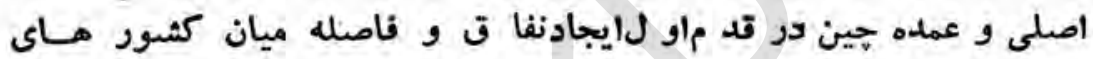

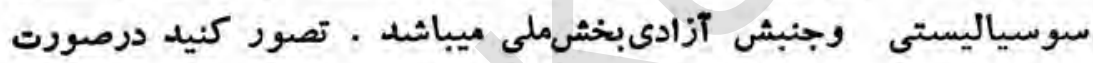

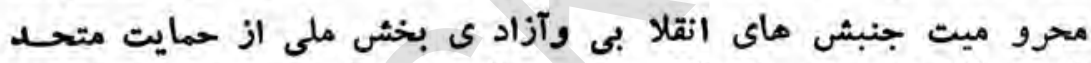

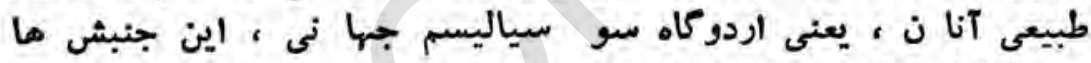

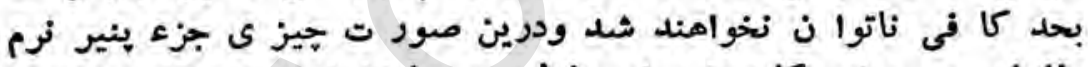

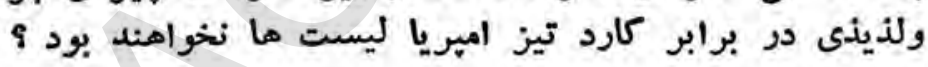

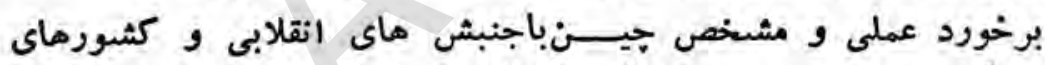

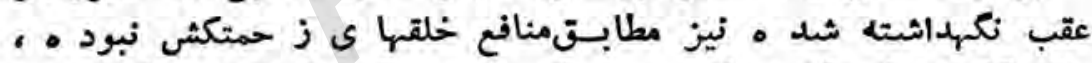

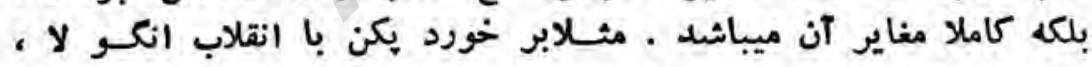

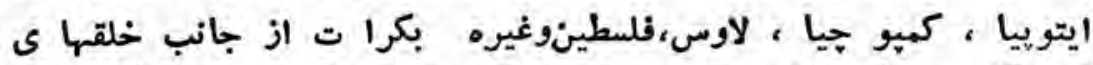

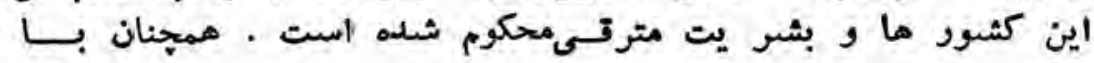

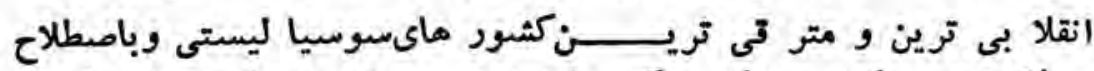

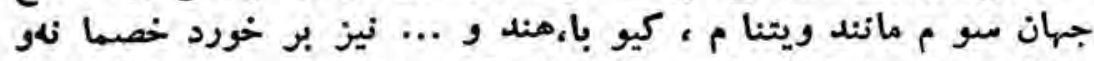

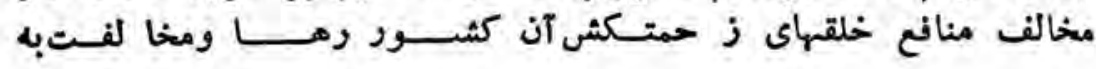




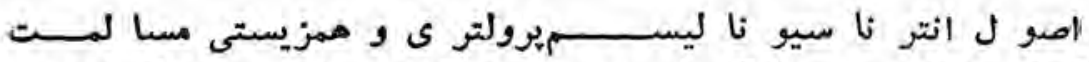

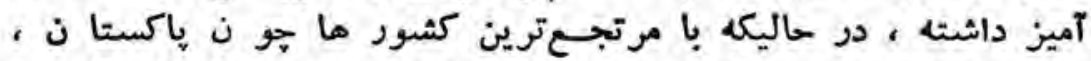

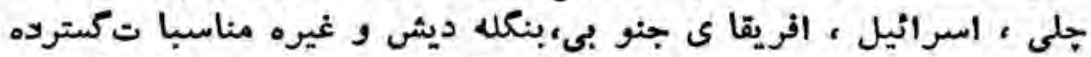

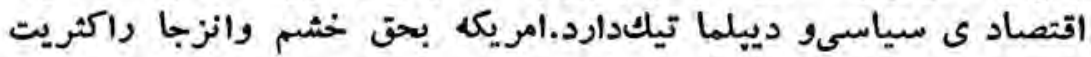

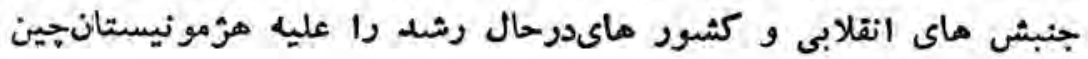
شعله ور ساخته است مائ و كثرو

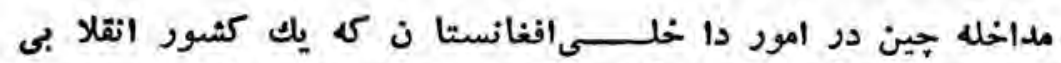

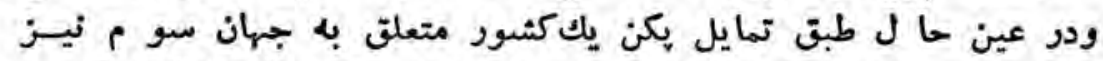

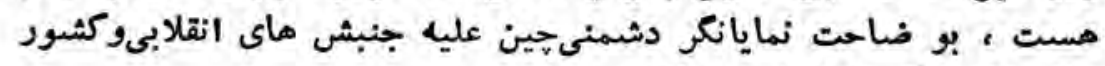

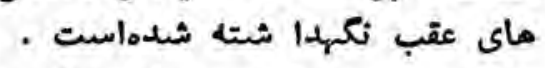

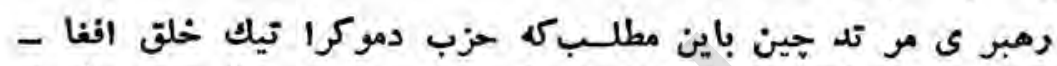

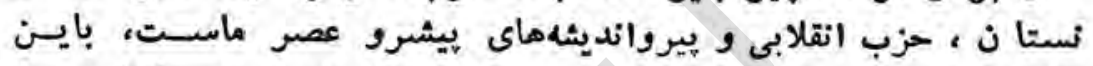

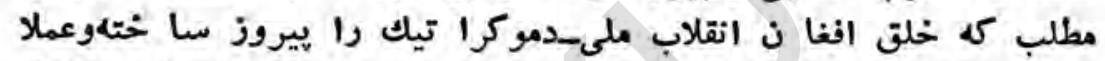

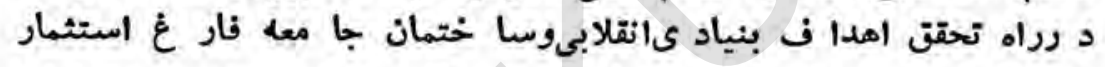

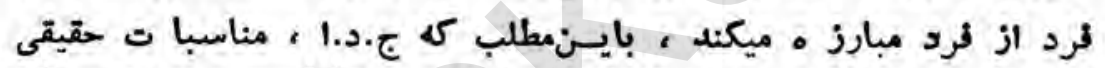

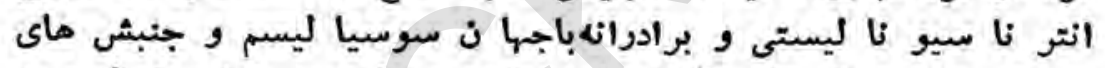

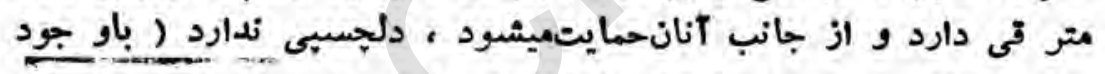

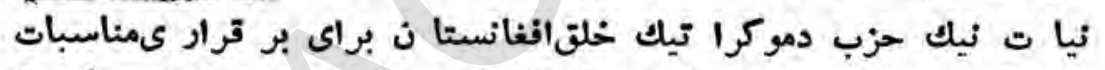

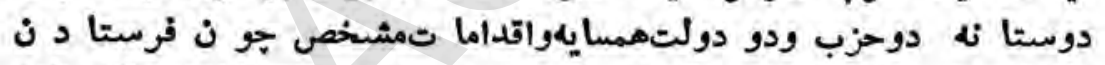

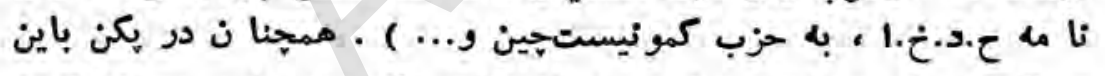

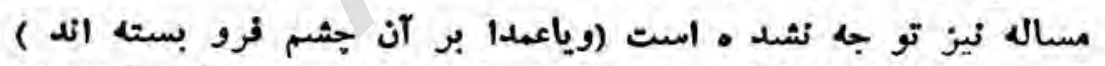

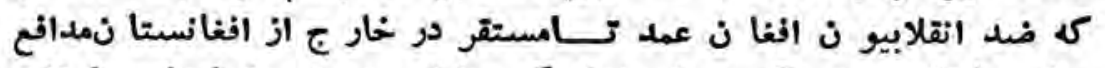

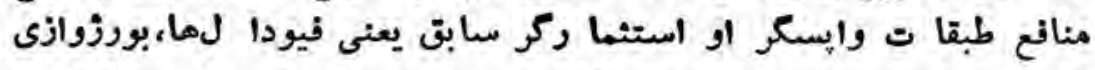

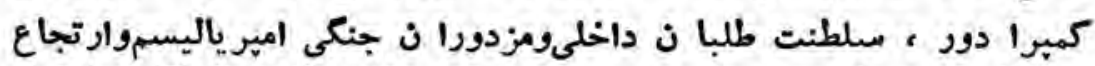

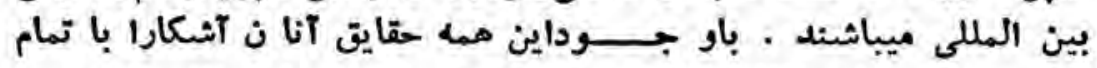

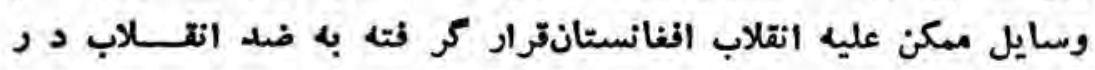


همسويى با امير ياليزم و ار تجاعداخلى همه جانبه مساعد ت ميكنند.

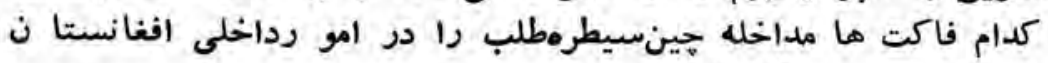

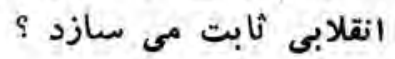

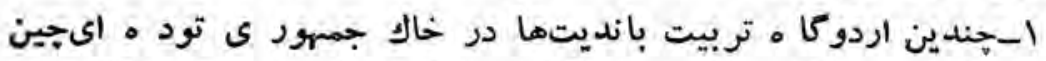

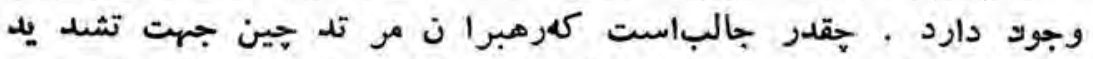

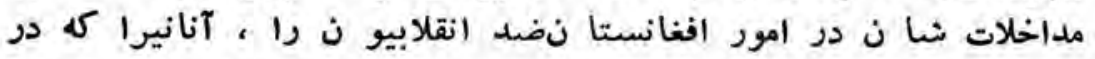

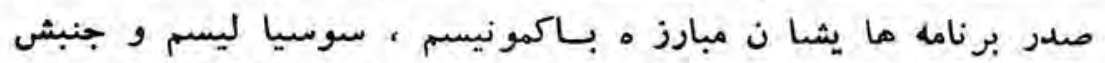

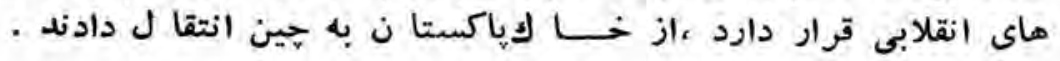

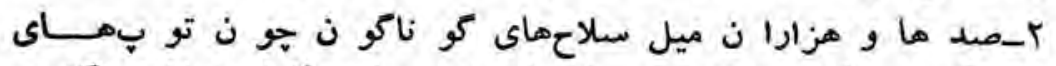

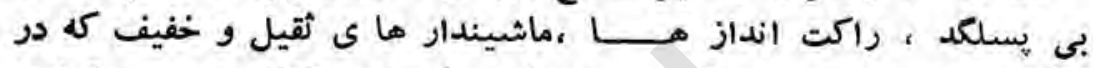

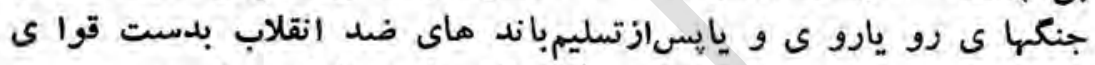

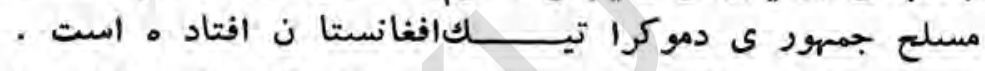

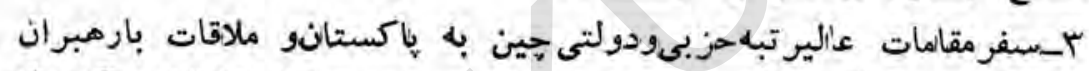

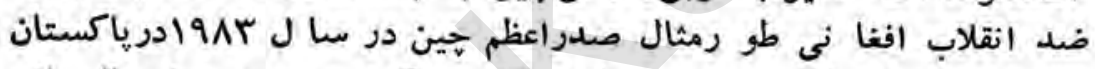

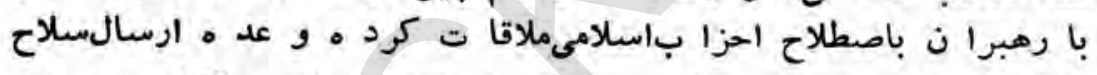

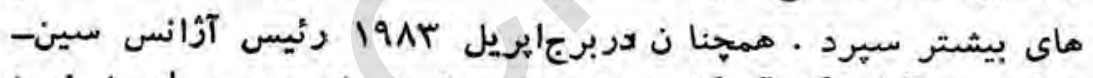

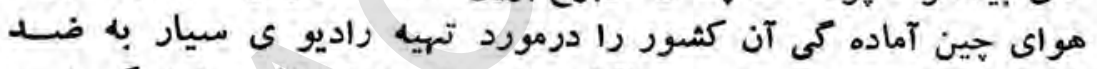

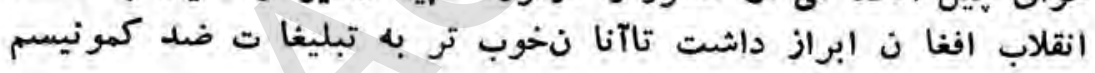

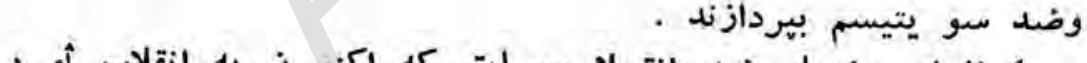

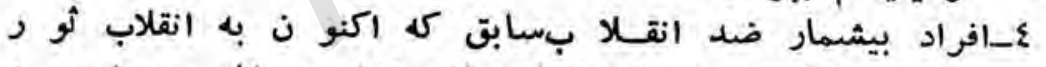

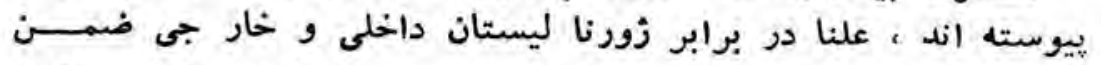

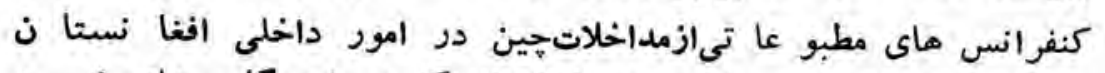

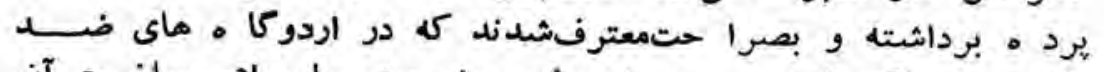

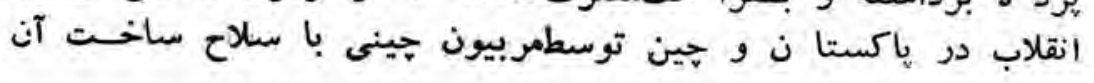

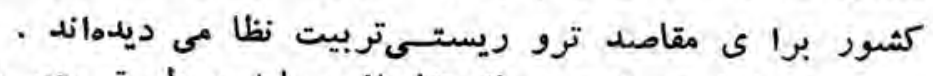

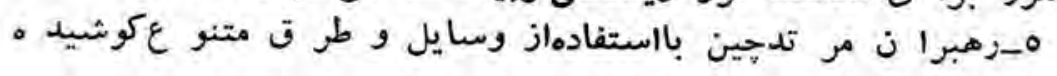




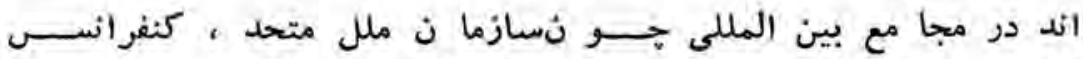

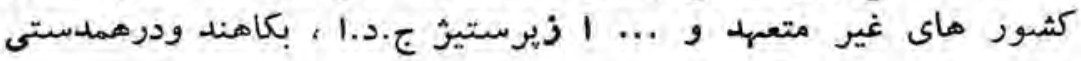

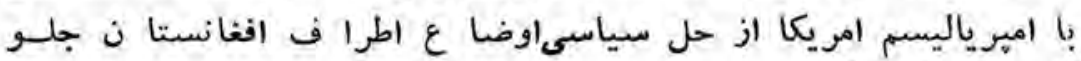
* كير ى نمايند

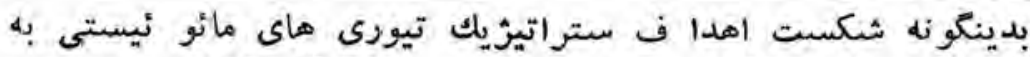

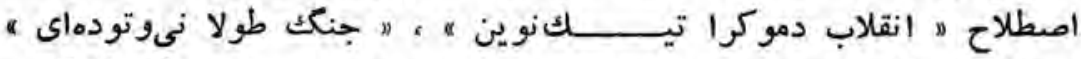

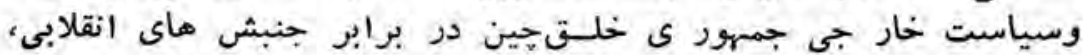

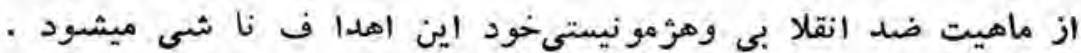

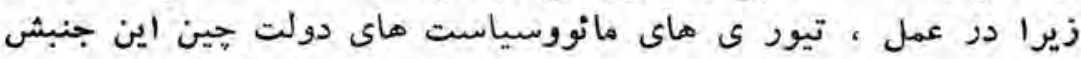

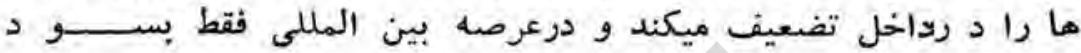

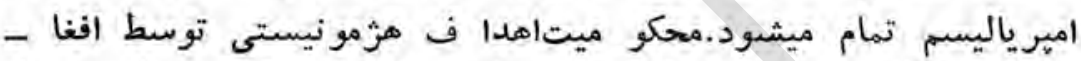

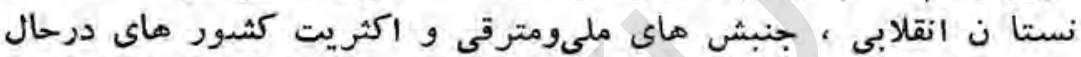

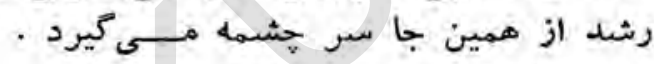
ائ.

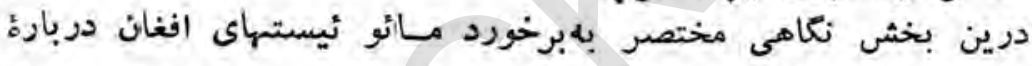

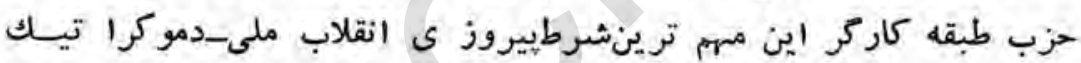

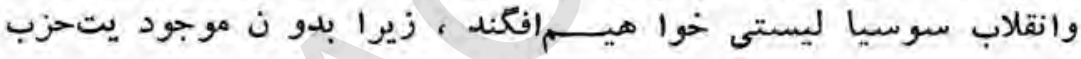

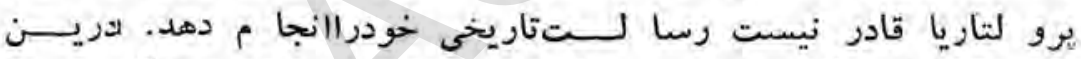

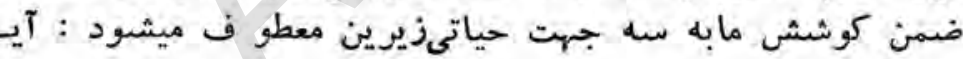

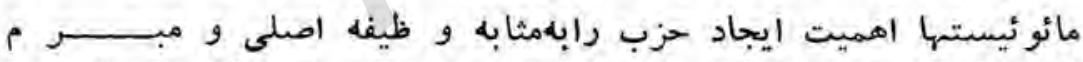

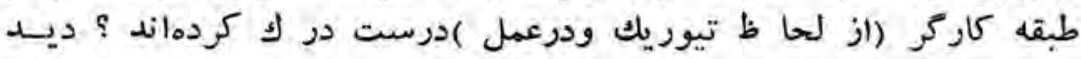

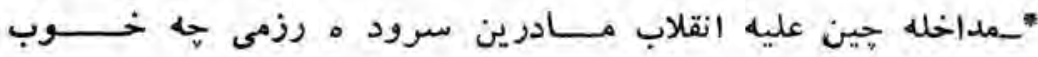
صراحت يافته است :

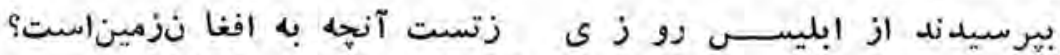

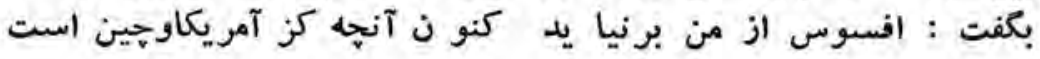




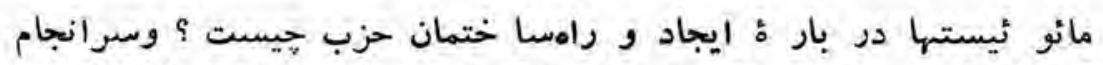

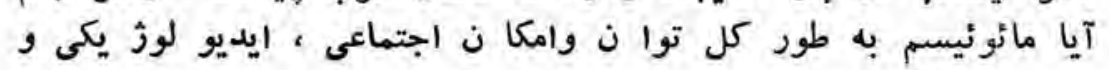

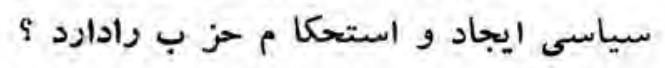

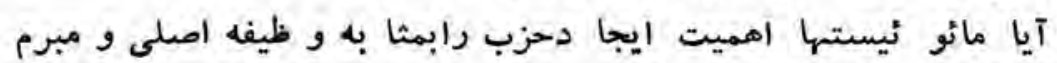

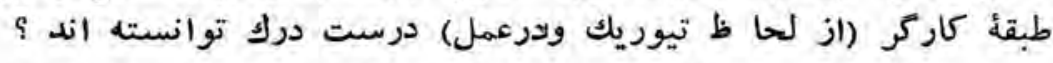

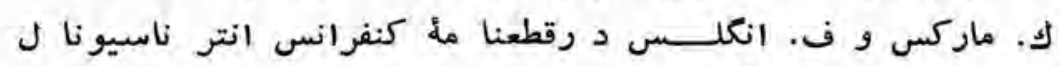

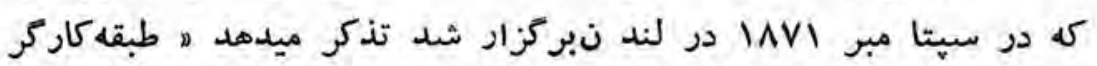

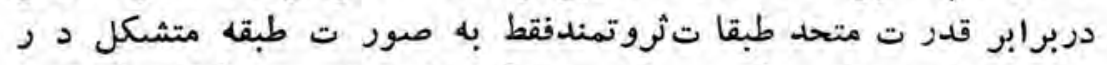

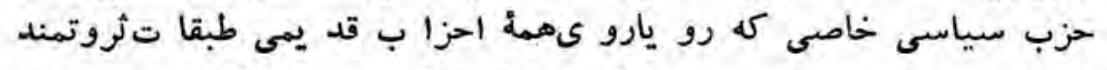

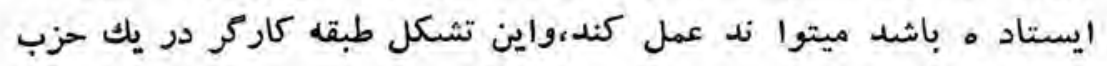

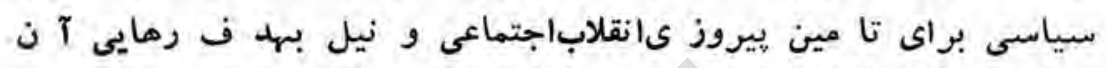

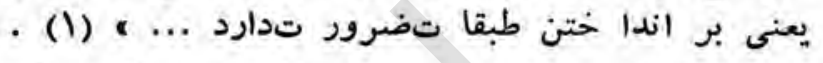

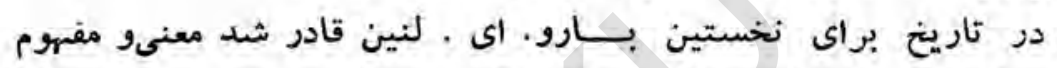

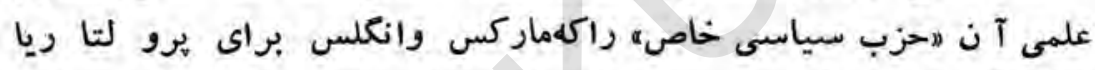

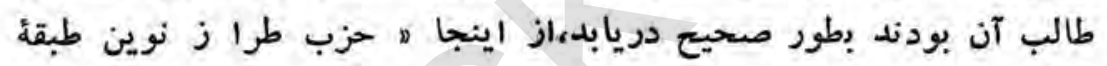

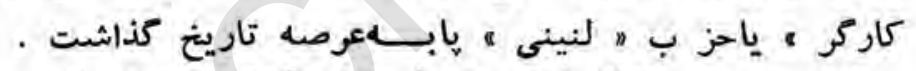

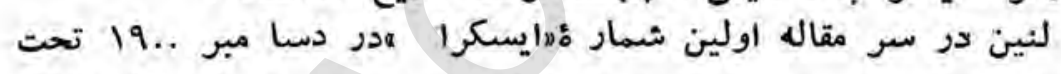

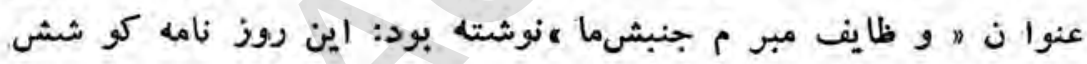

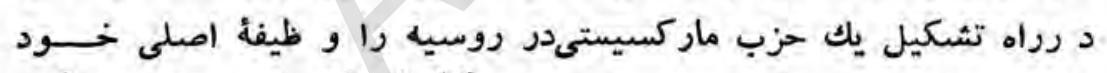

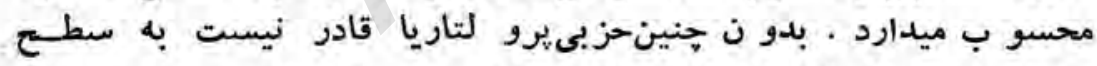

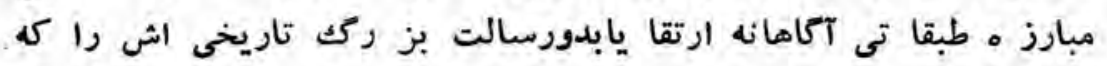

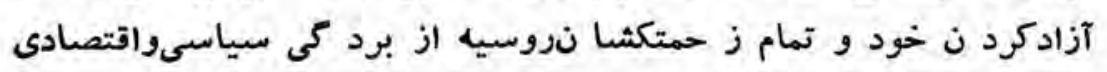

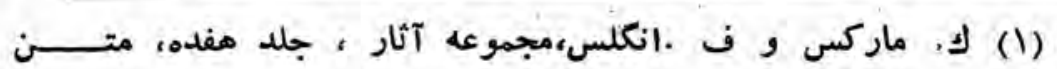

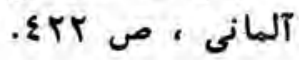




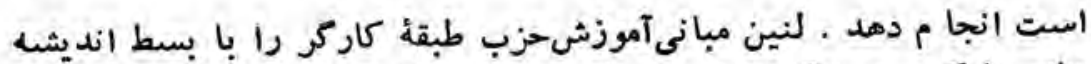

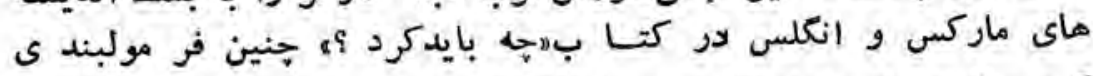

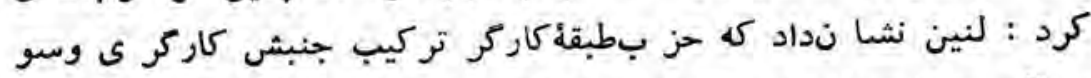

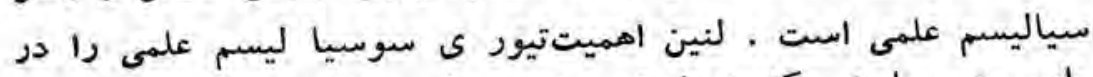

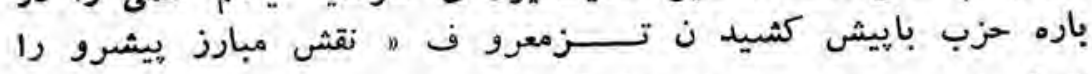

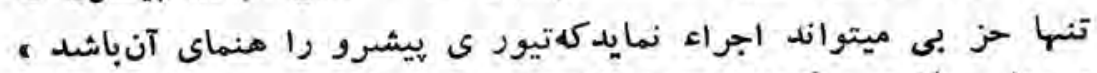

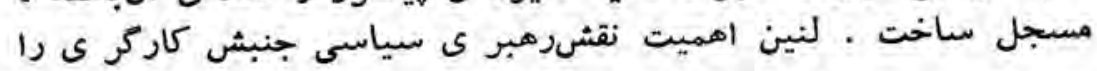

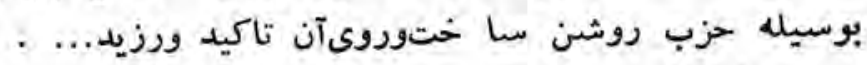

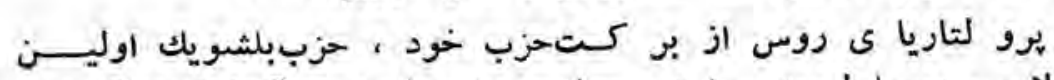

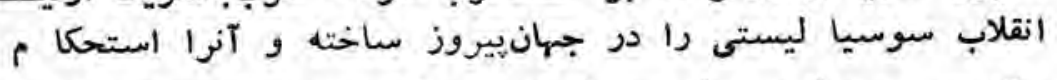

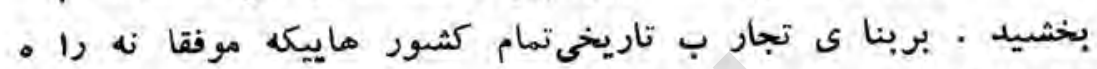

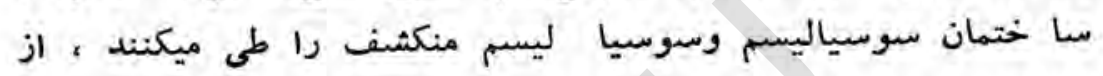

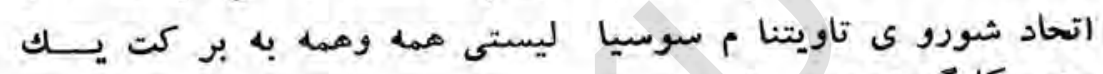

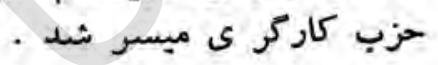

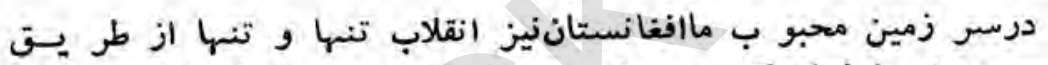

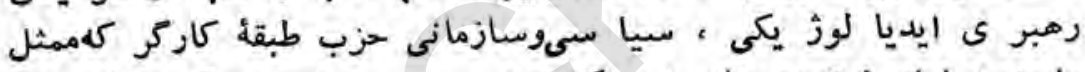

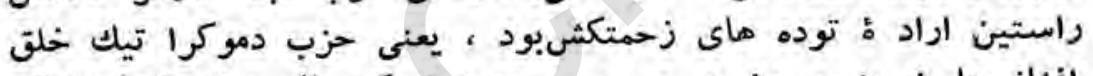

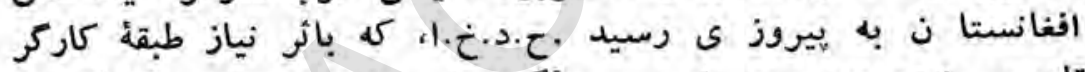

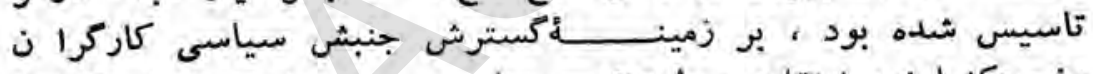

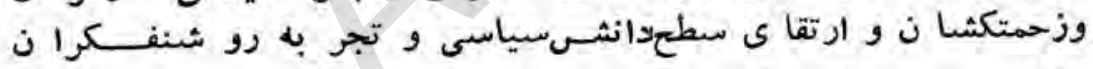

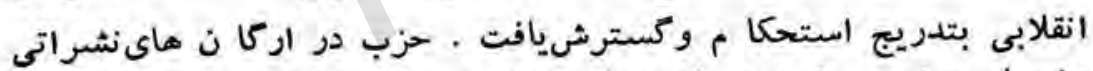

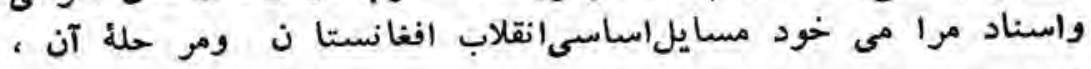

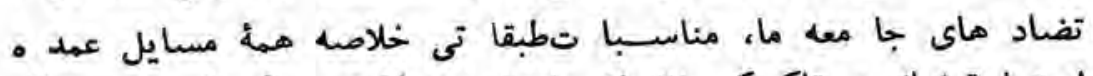

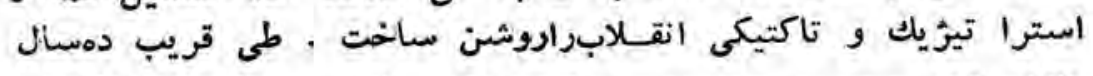

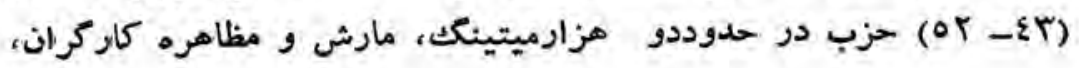




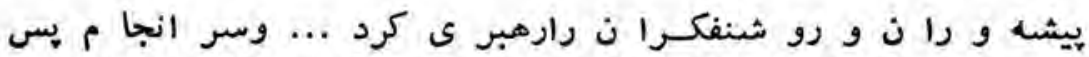

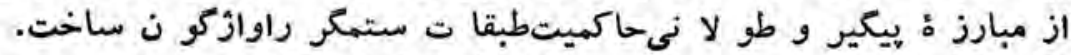

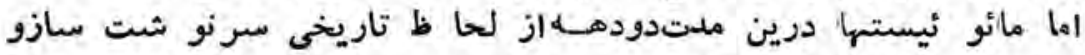

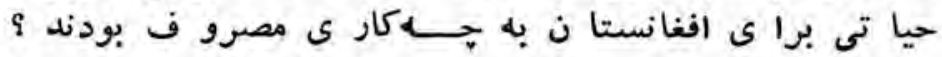

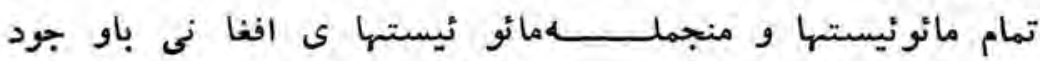

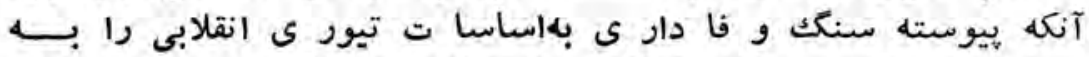

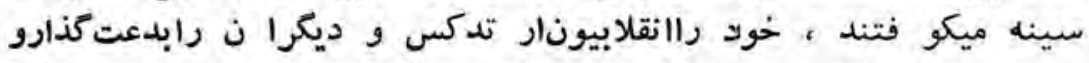

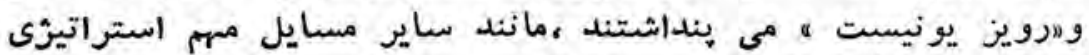

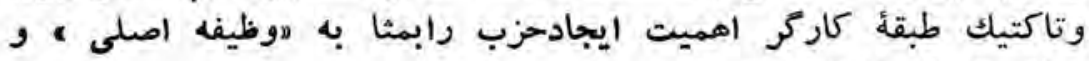

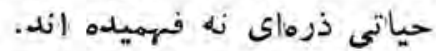

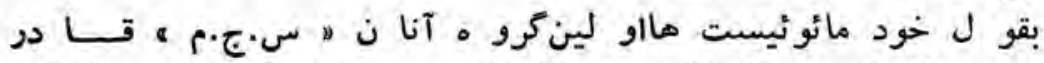

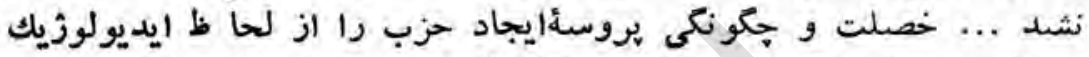

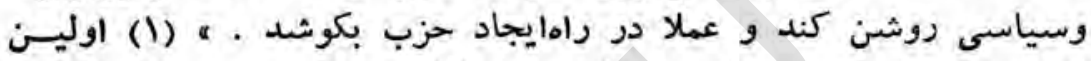

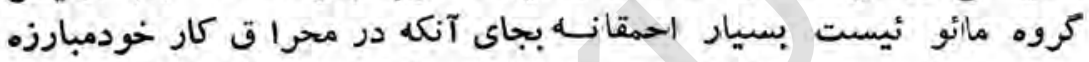

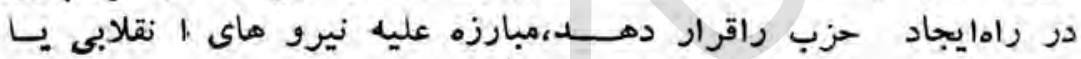

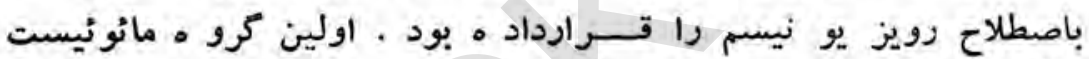

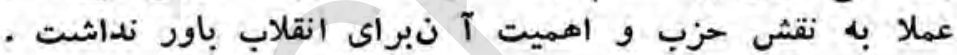

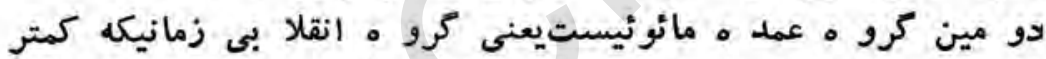

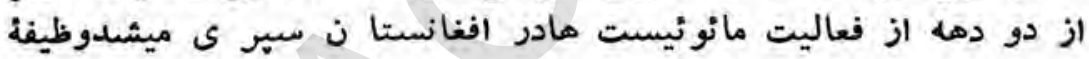

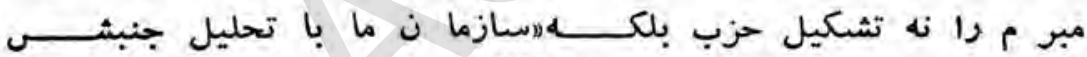

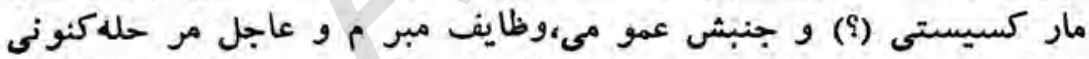

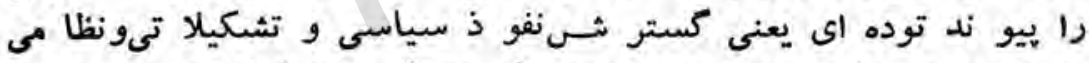

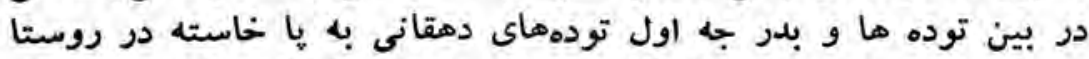

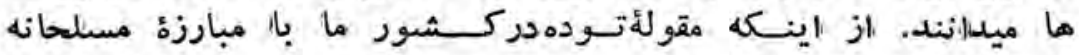

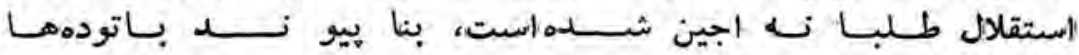

(1) " مشعل رهايى ، شمار ماول،صجار . 


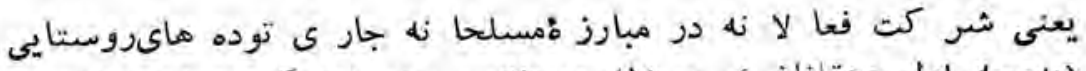

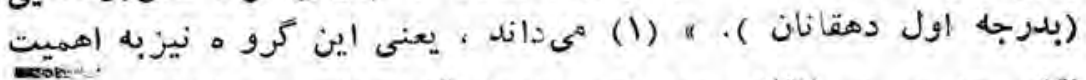

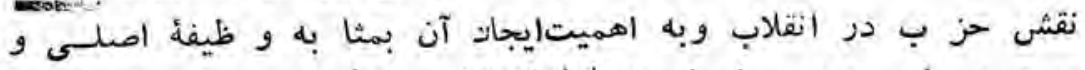

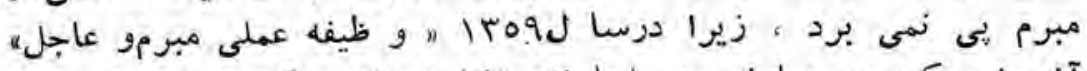

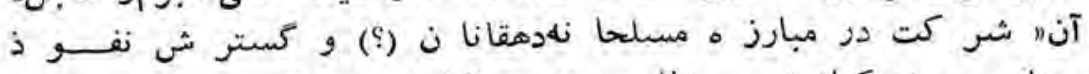

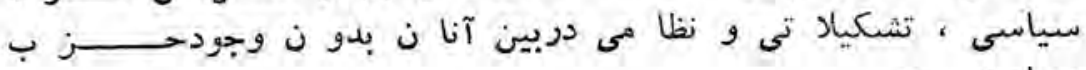

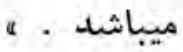

سو مين كرو ه عمد م مائوئيستى يعنى سا ما باو جود م كه دربخش

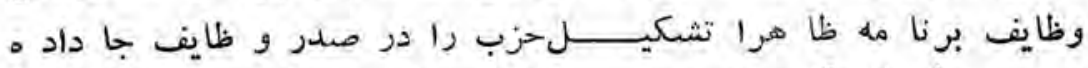

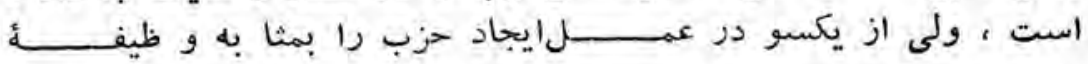

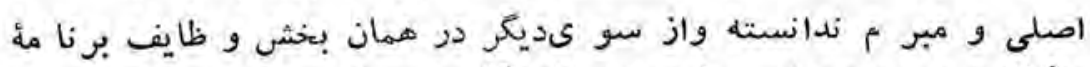

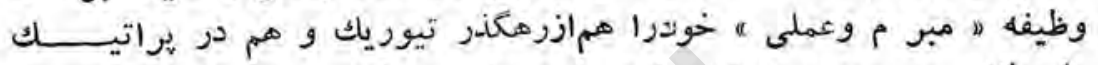

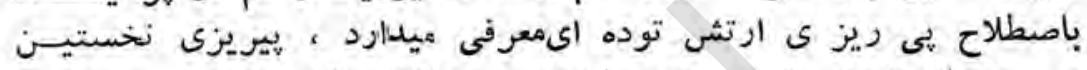

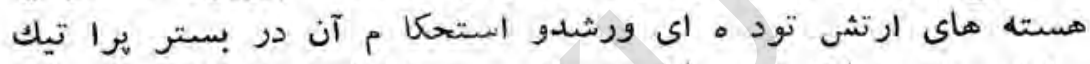

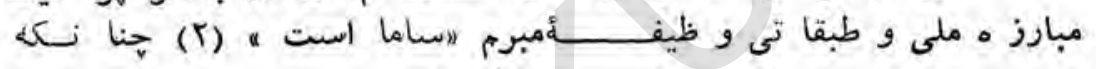

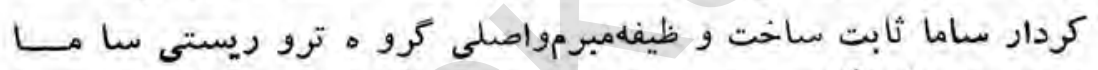

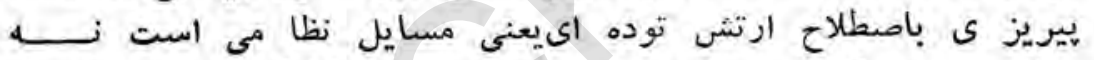

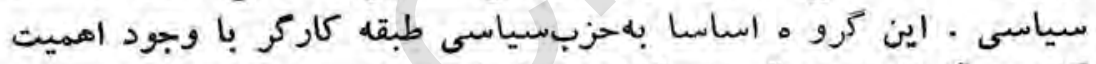

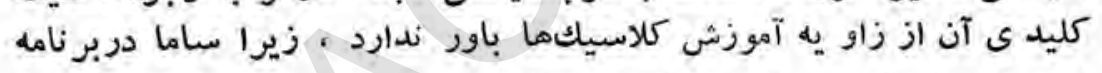

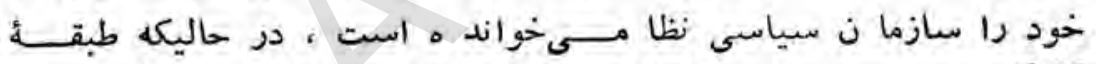

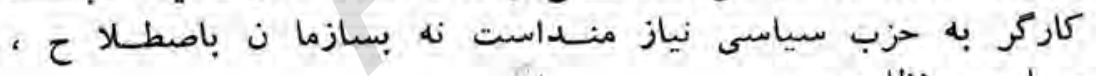

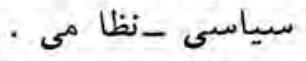

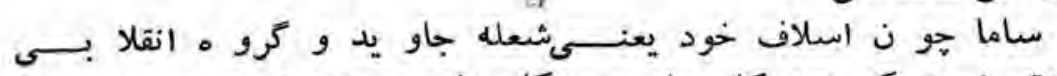

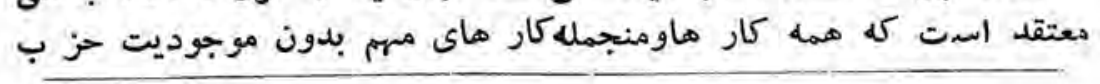

r.

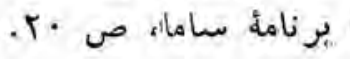


ممكن است ، زيرا عملا در راه بـرآورد ن بسا اهدا ف مهم تلاثـــ

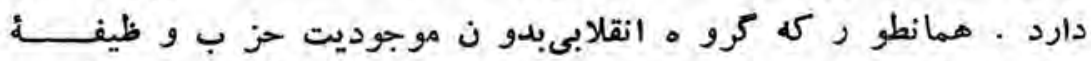

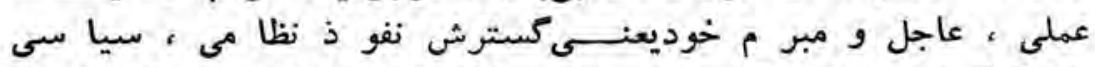

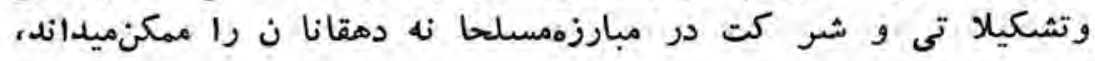

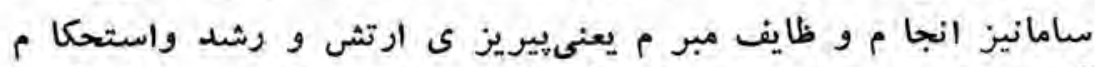

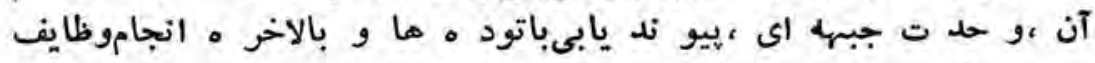

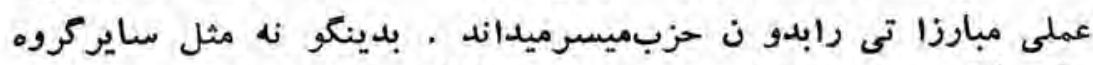

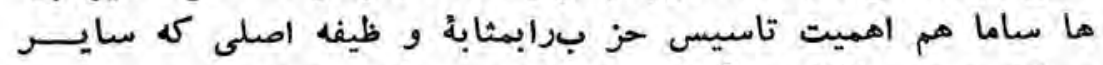

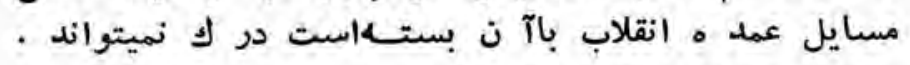

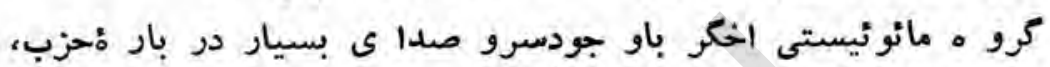

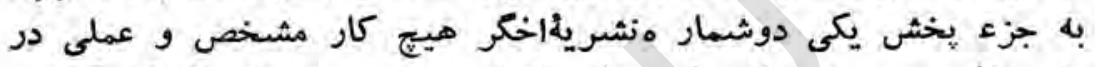

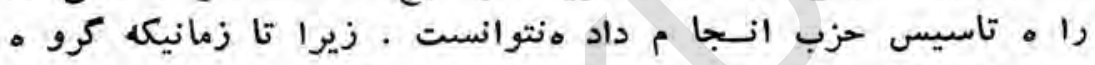

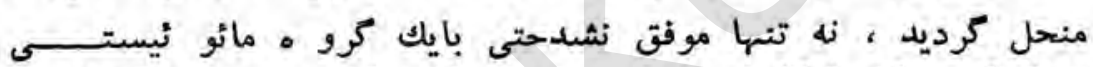

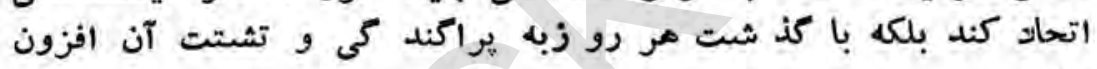

ميشد . مات كنا

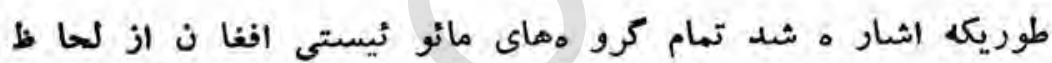

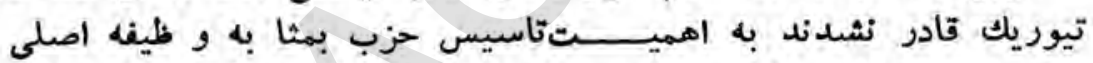

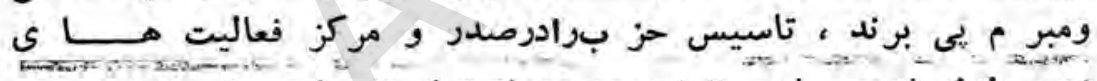

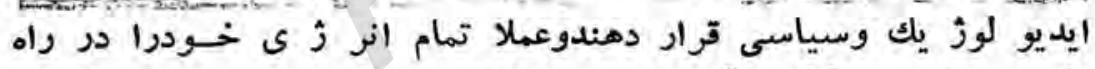

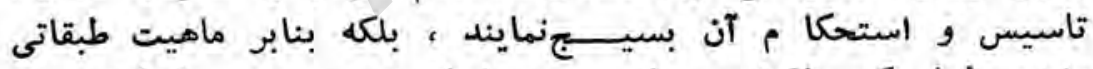

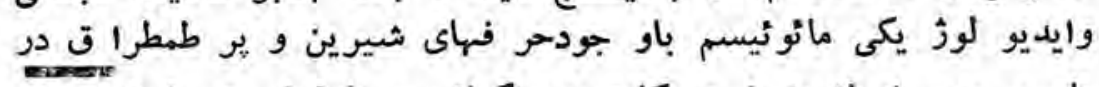

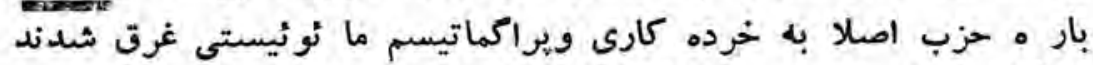

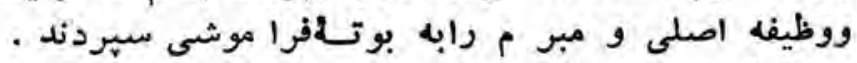

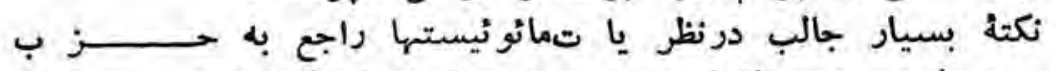

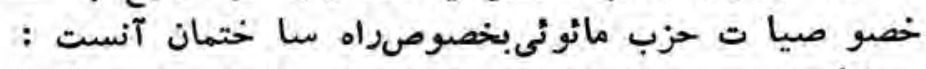

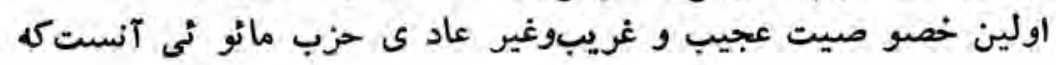




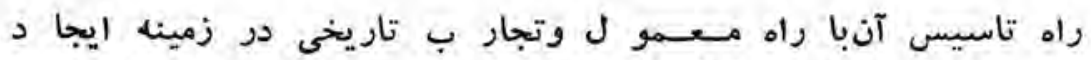

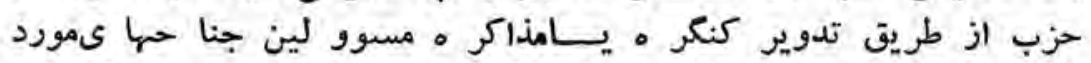

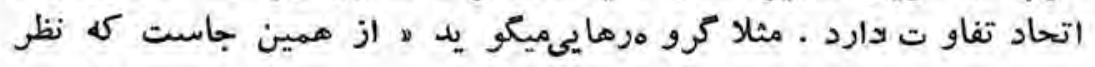

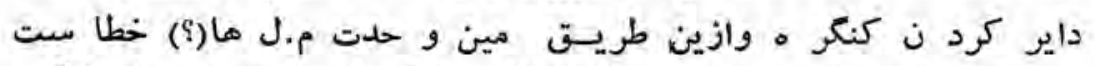

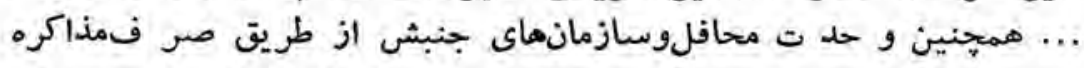

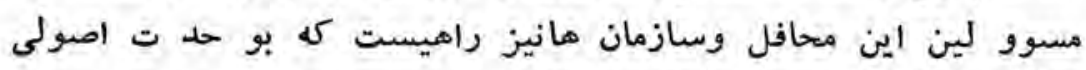

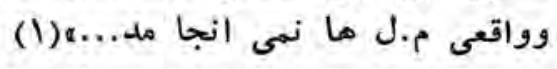

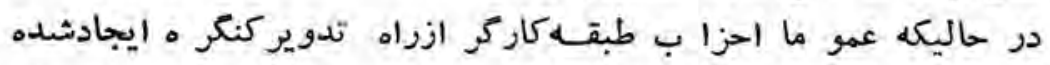

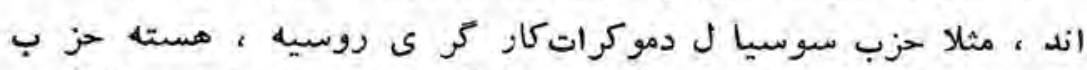

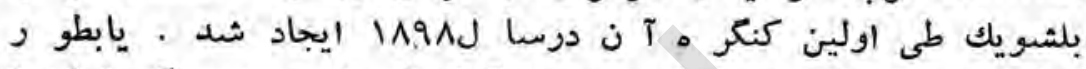

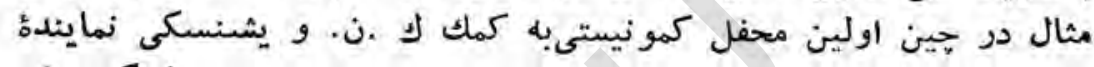

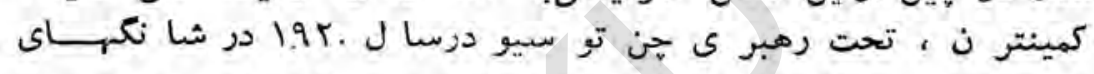

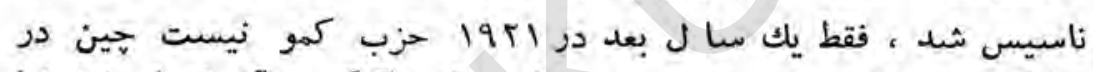

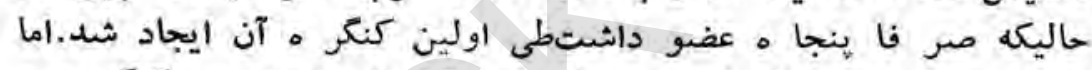

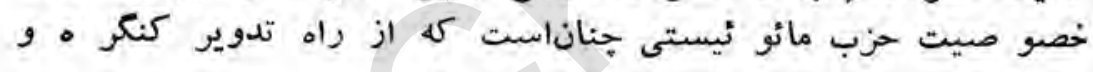

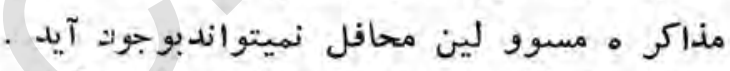

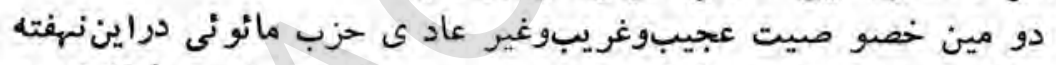

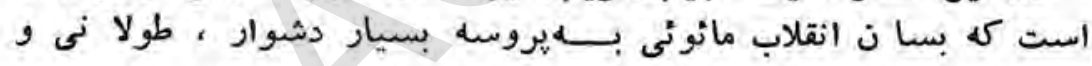

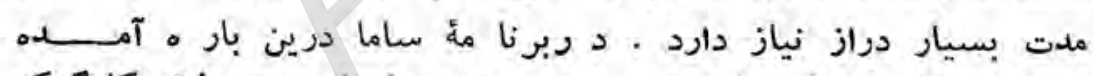

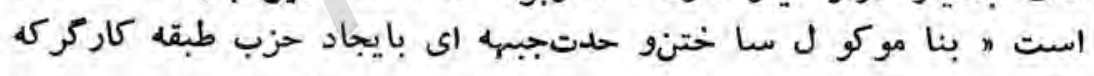

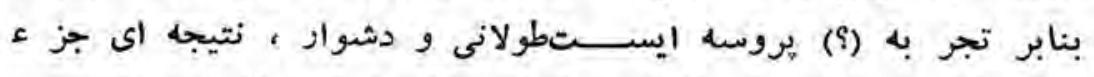

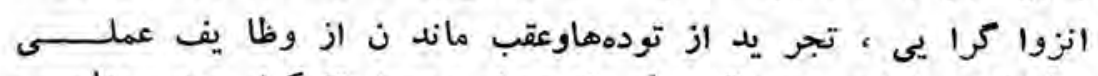

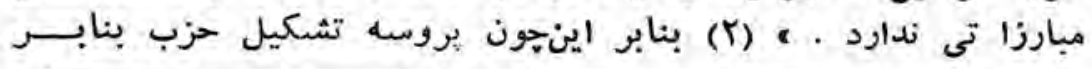

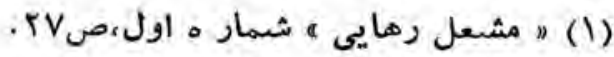

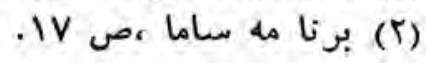




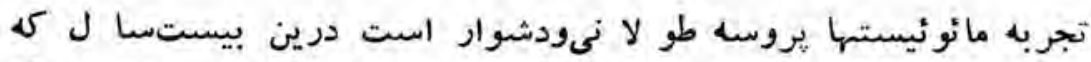

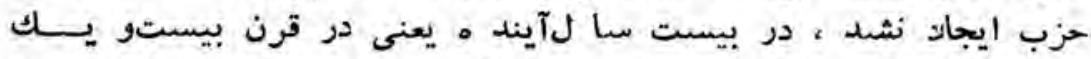

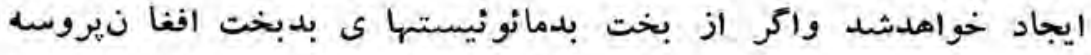

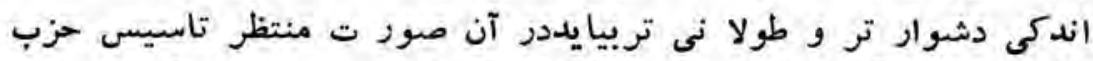

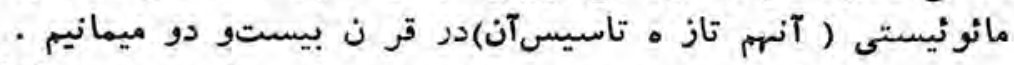

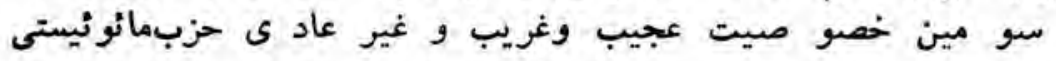

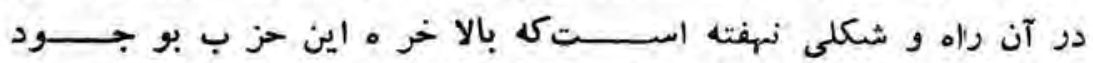

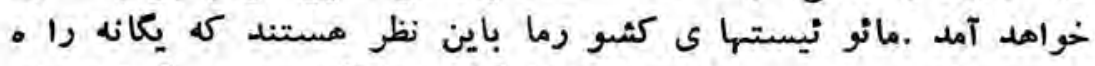

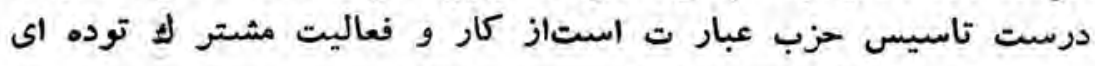

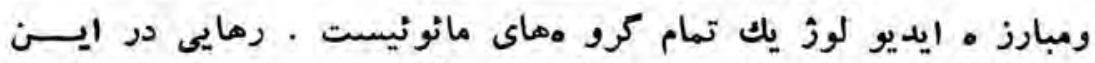

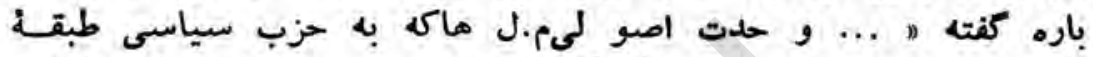

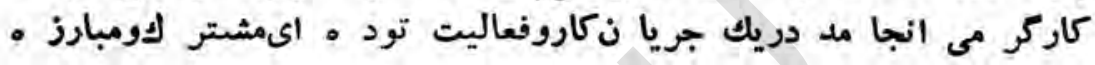

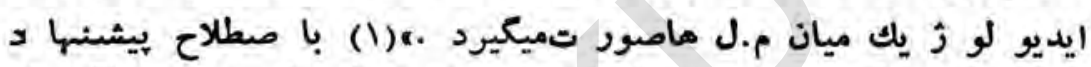

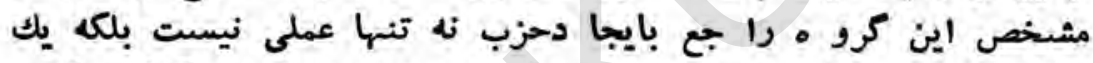

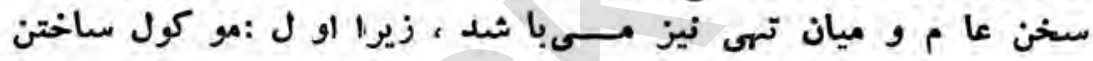

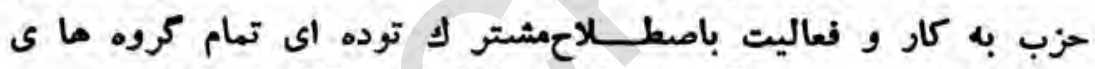

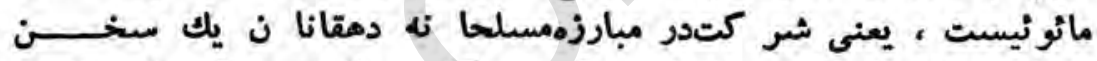

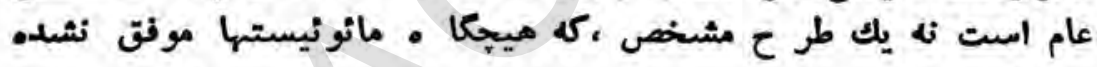

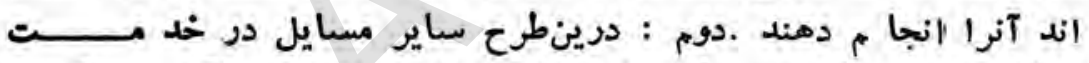

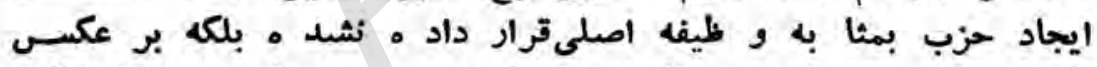

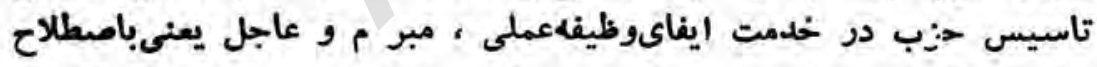

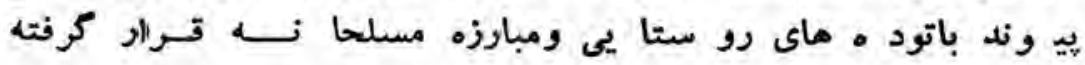
- اسعت

خلامه همان سبك مغز ى و برخورد انحرا فى كه ايو د تو نيستها

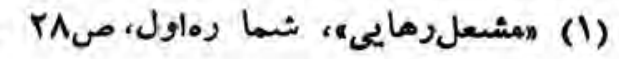




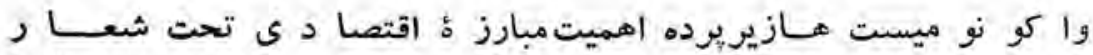

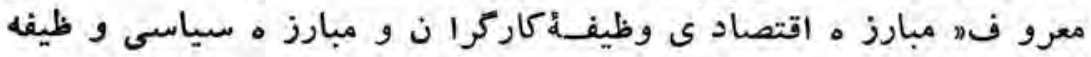

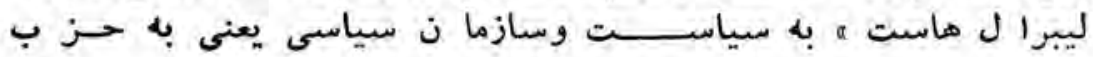

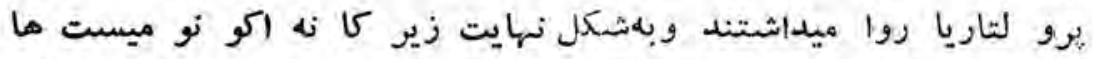

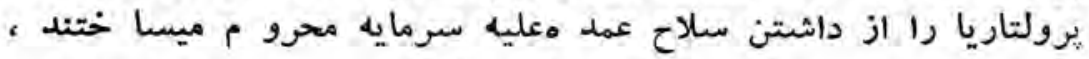

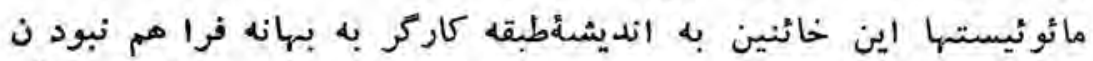

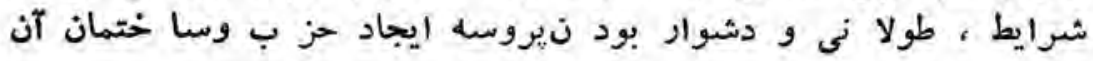

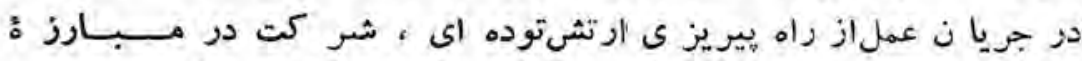

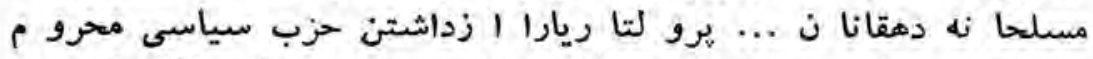

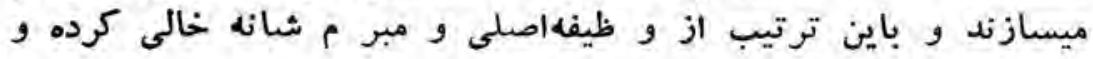

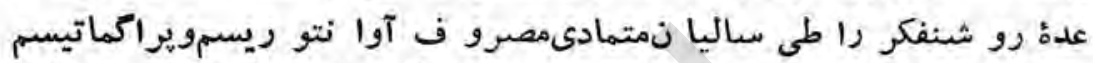

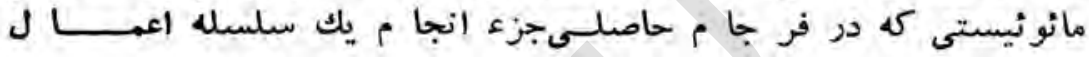

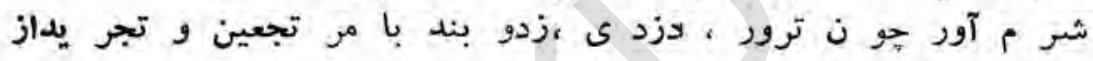

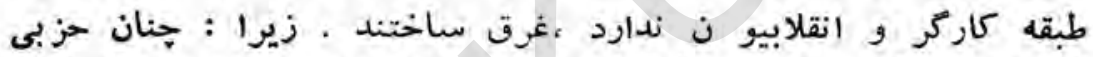

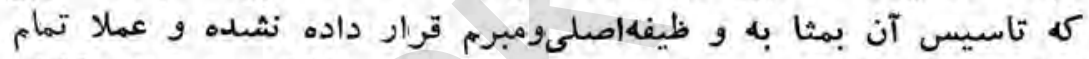

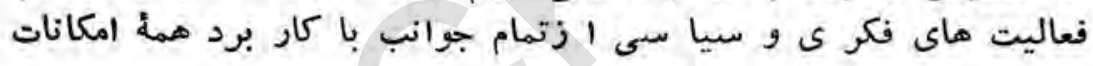

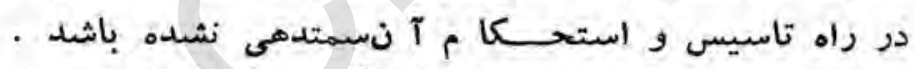

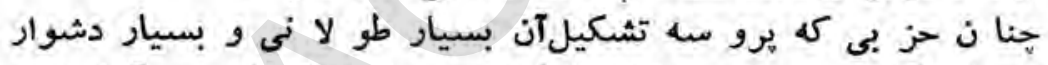

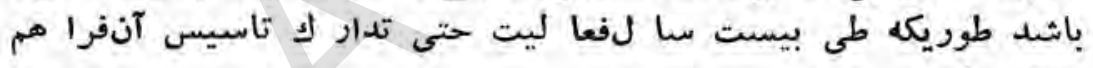
نشده باشد ماند

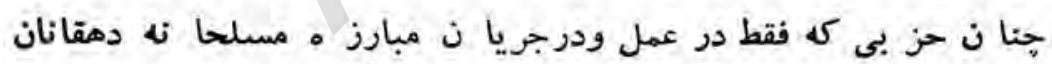

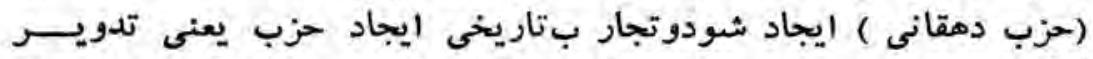

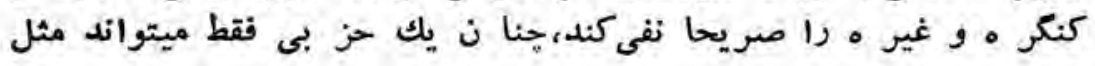

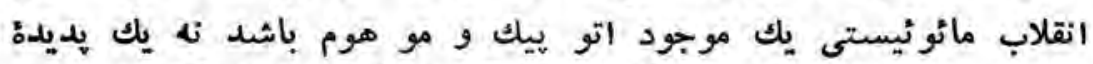

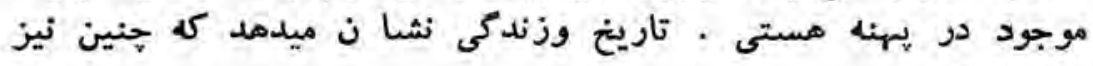
بوده است . نوجن 
علت اساسى و ضع بسيارمضحكوخنده دار مائوئيست ما در مسا لها له

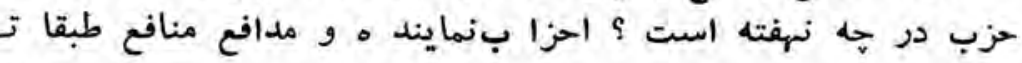

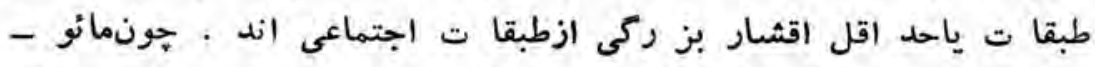

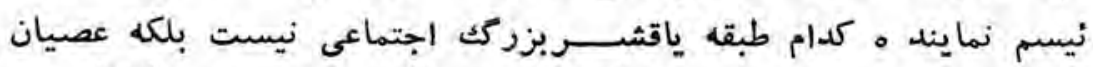

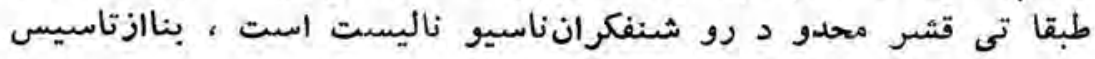

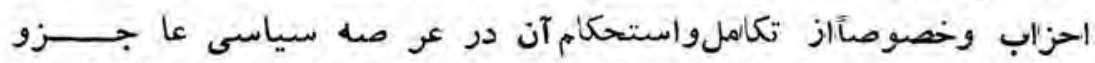

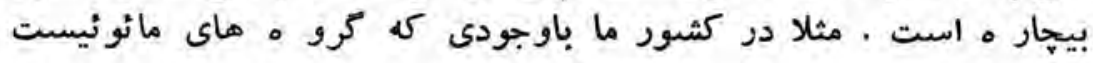

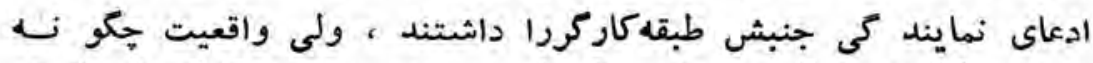

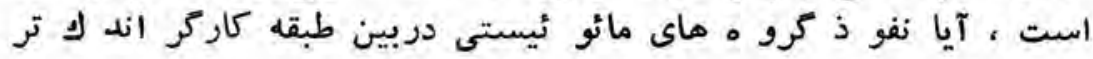

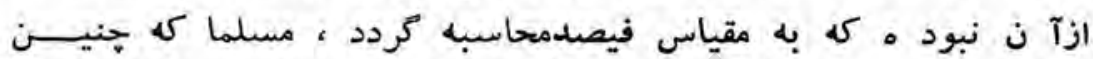

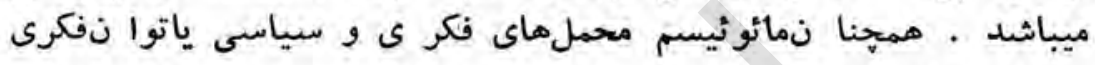

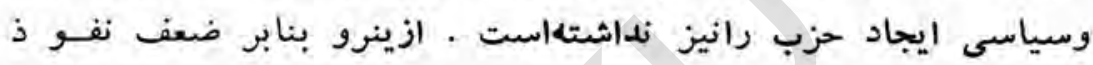

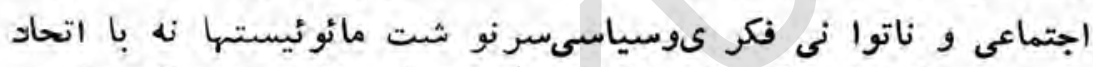

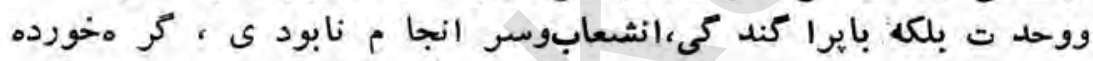
است 


\section{تنوع اشكال كذار}

!ي

رأهمسالمت آميز ومسلحاذة انقلاب

\section{تيور}

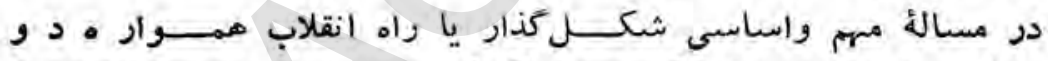

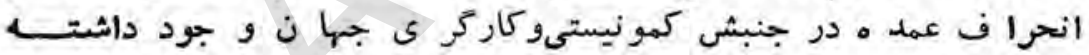

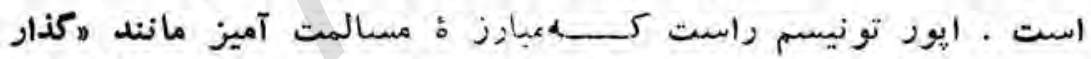

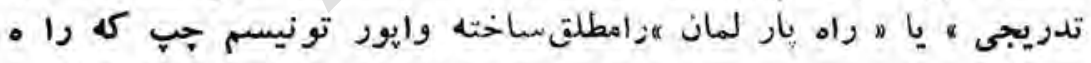

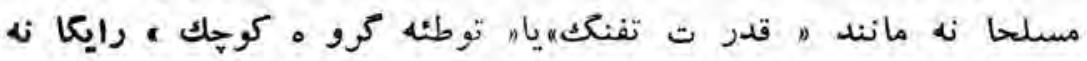

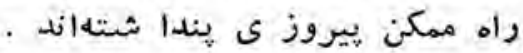

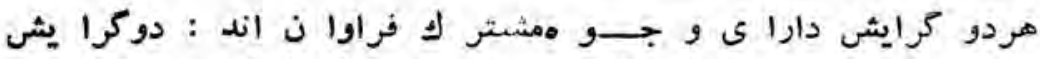

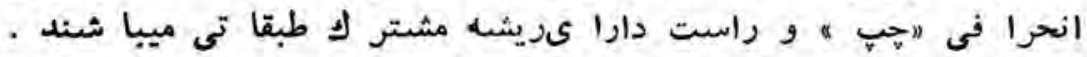

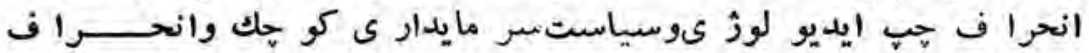




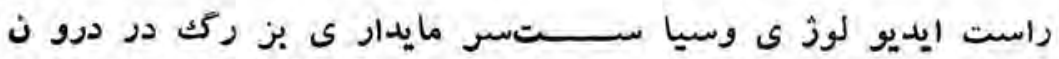

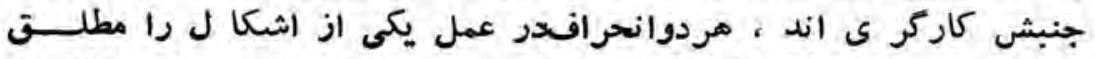

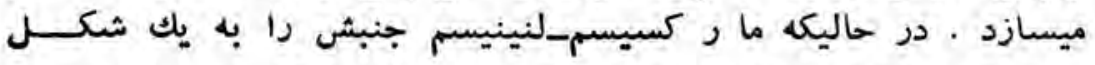

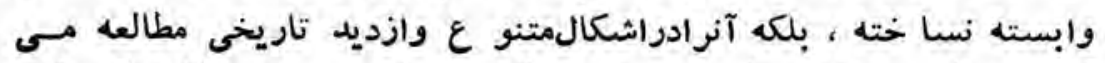

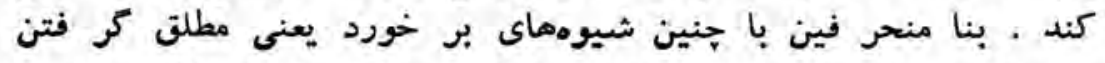

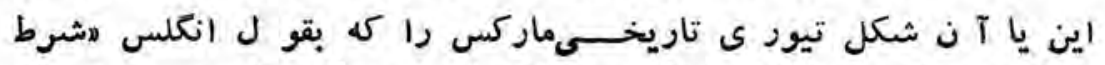

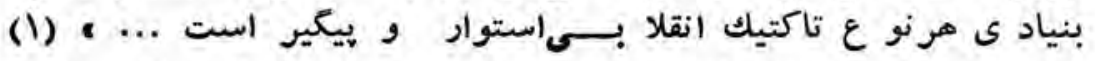

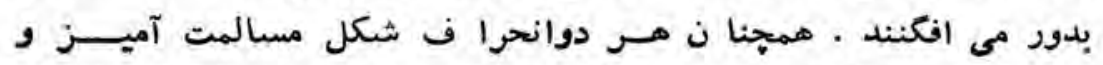

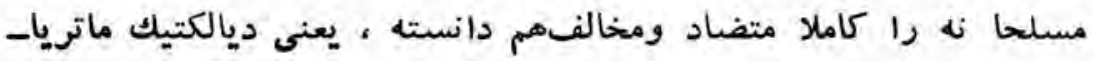

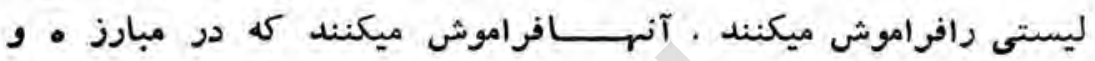

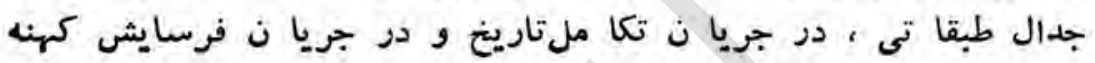

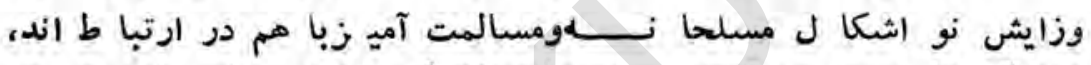

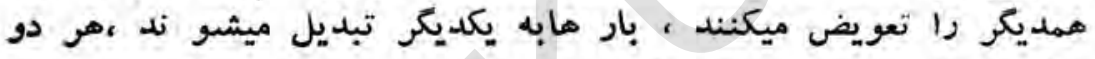

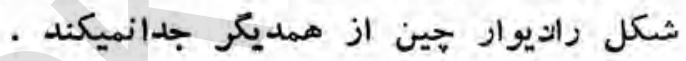

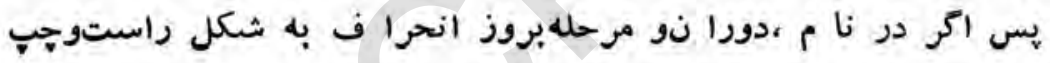

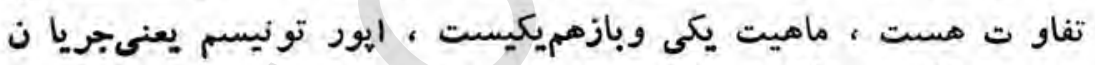

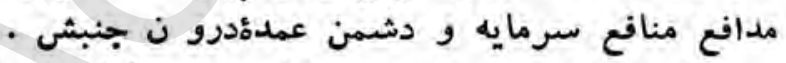

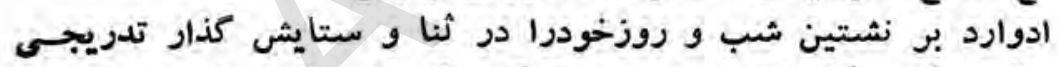

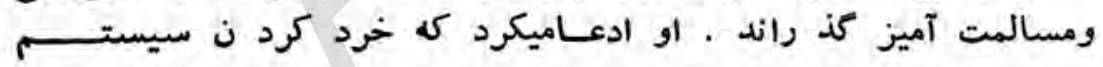

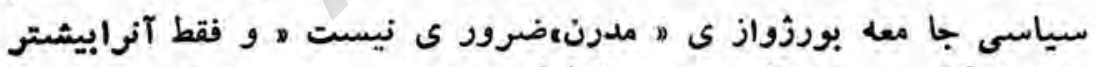

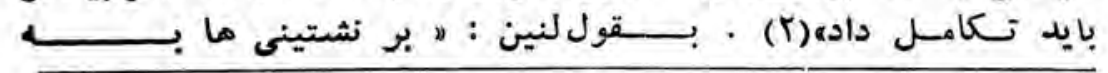

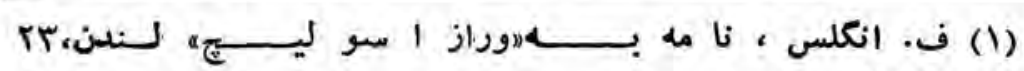
آوريل (1) في انكلـ

(5) بر نشتين ، "وظظايفمقدماتىسو سيا ليسم وو ظايف حز بسور

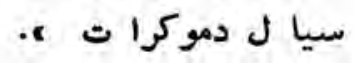


مار كسيسم عار ى از جنبه انقلا بىآن معتقد بود ه و هستئد آنهـــ

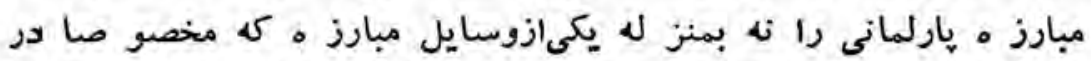

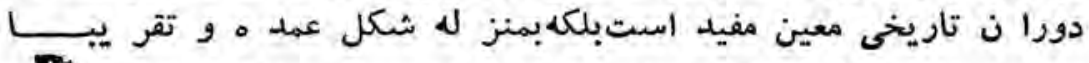

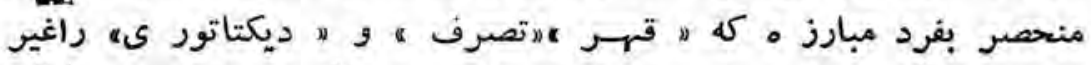

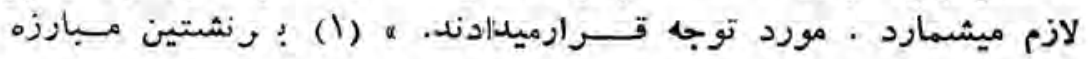

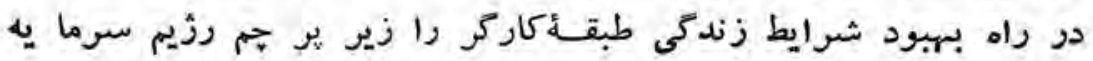

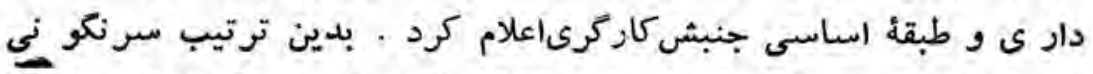

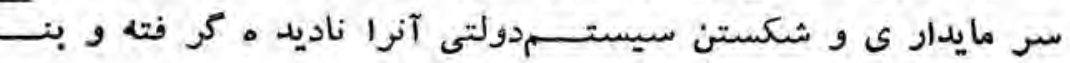

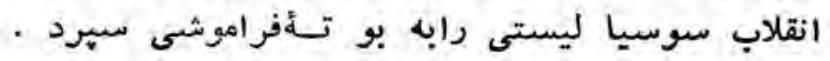

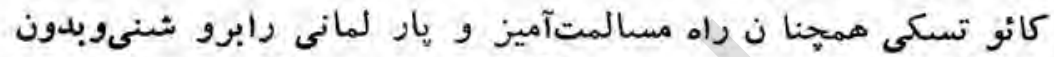

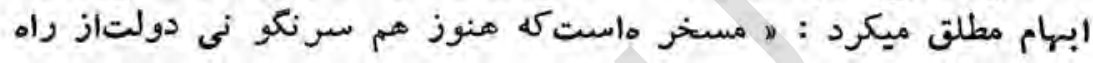

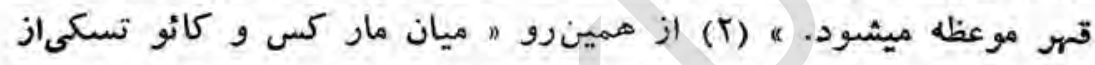

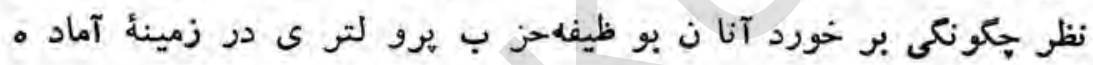

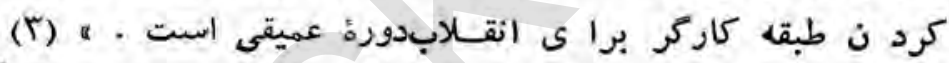

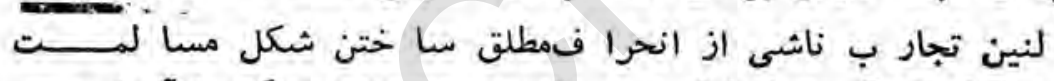

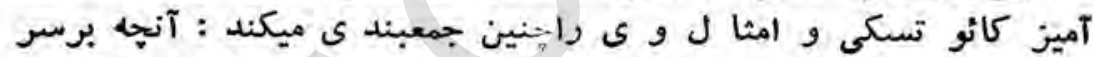

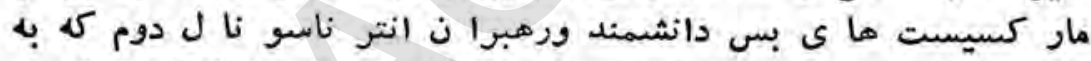

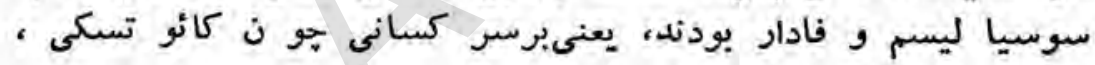

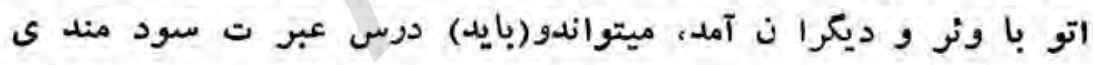

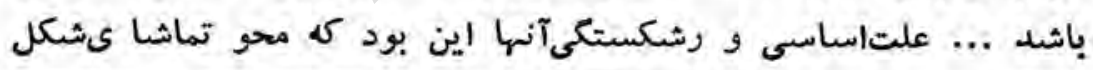

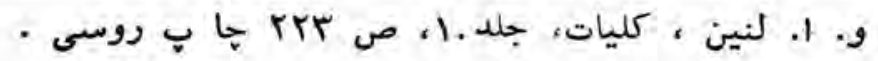

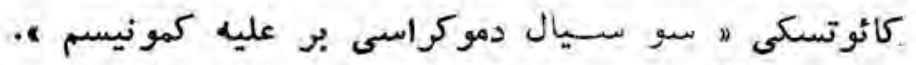

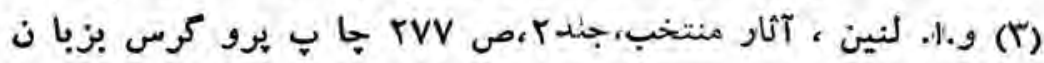




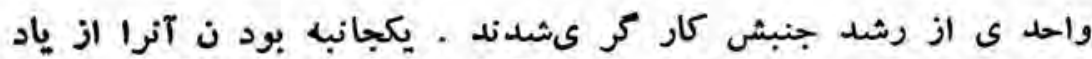

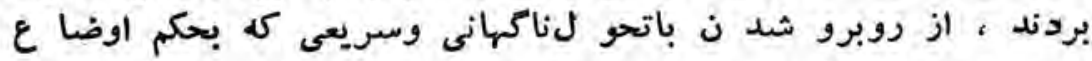

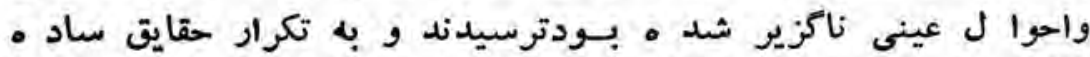

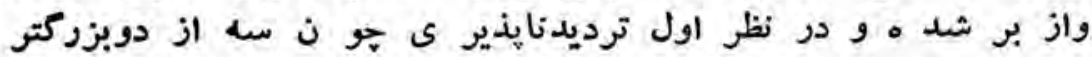

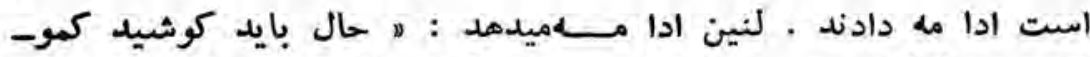

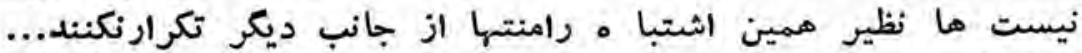

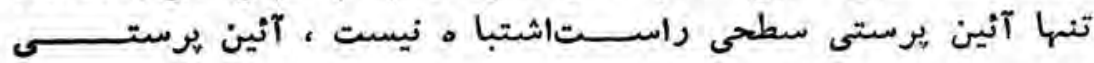

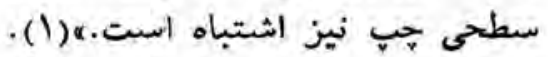

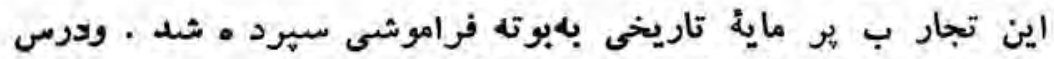

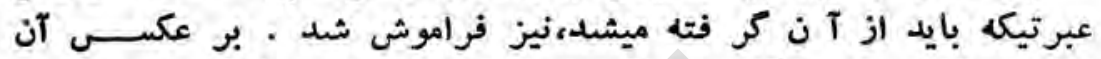

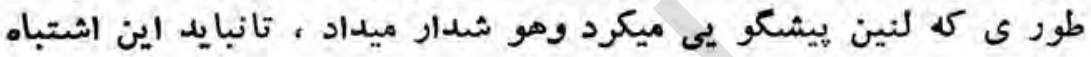

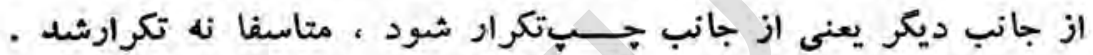

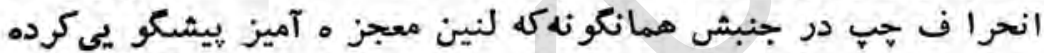

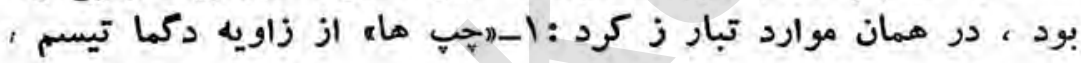

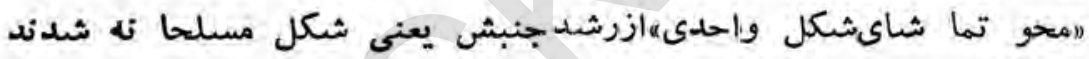

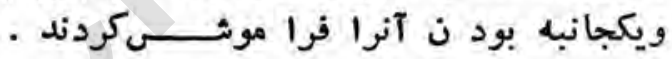

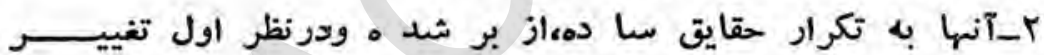

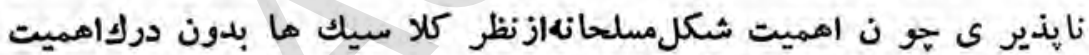

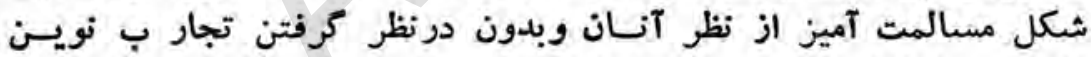

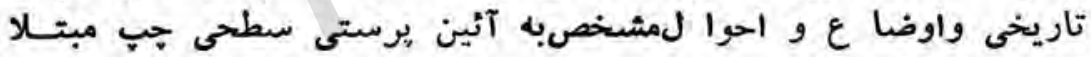

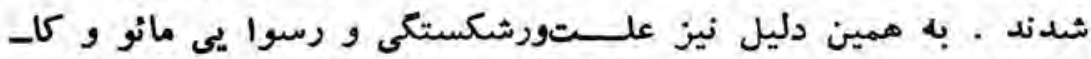

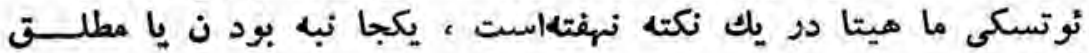
كرايى

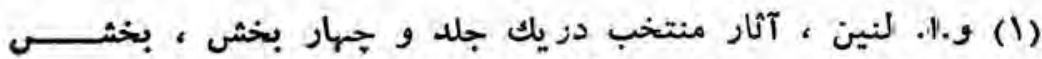

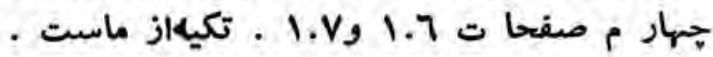




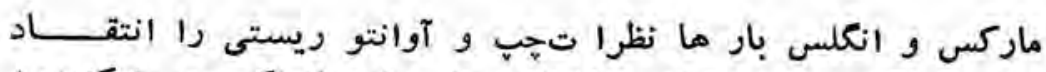

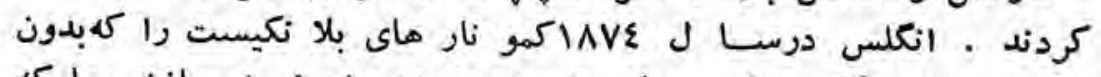

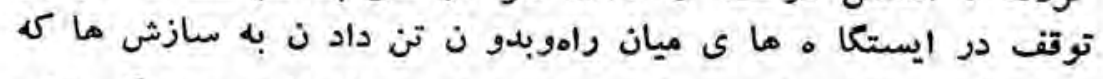

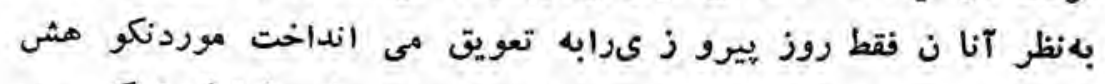

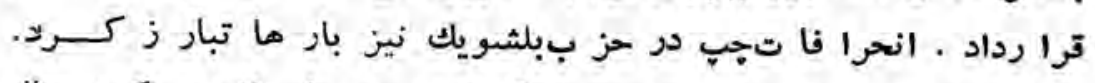

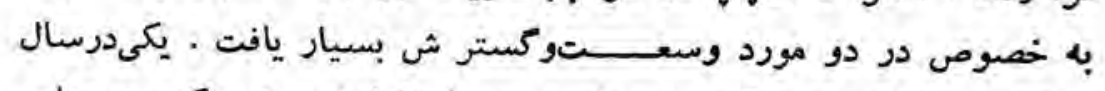

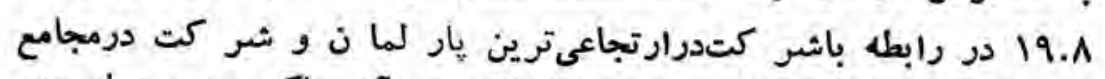

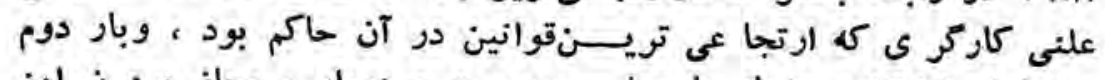

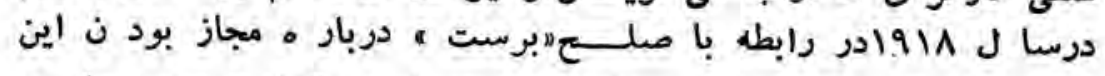

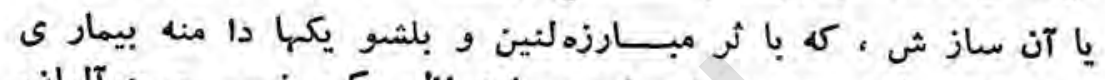

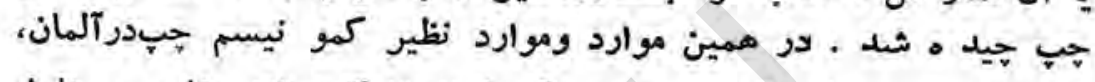

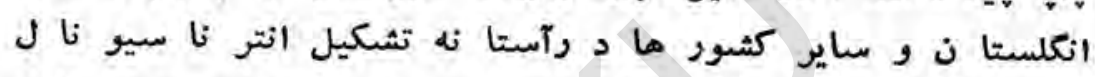

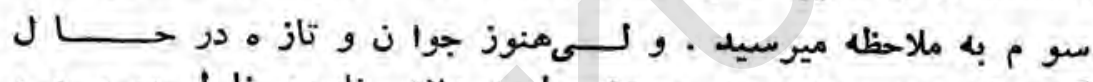

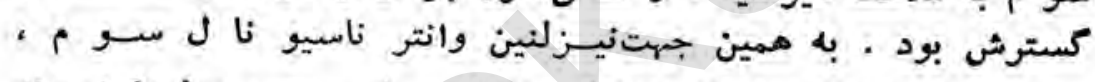

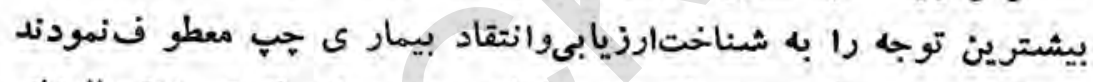

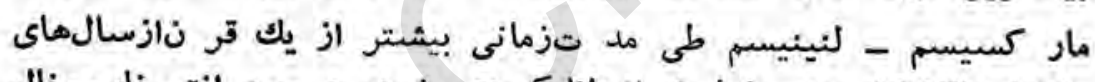

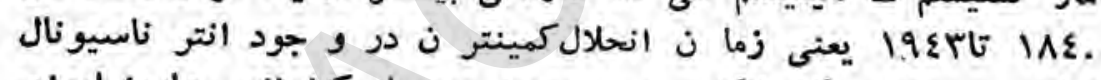

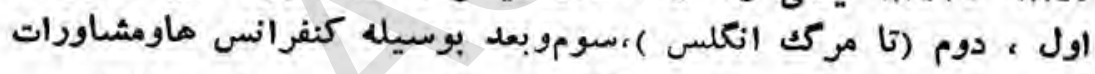

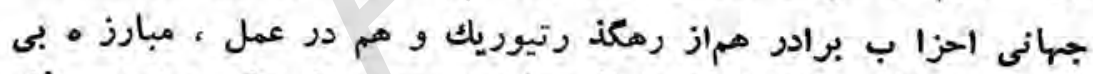

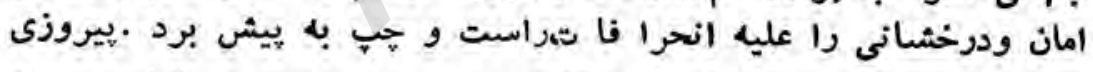

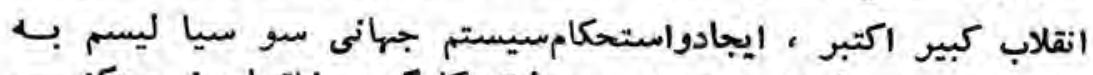

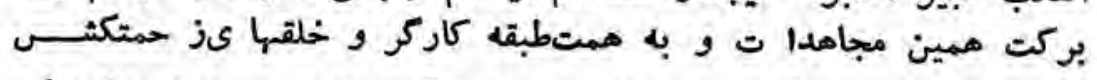

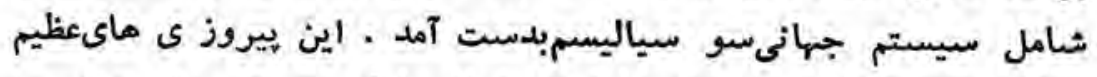

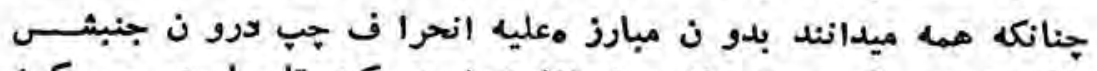

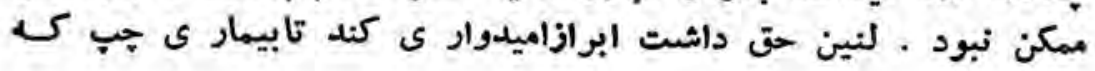




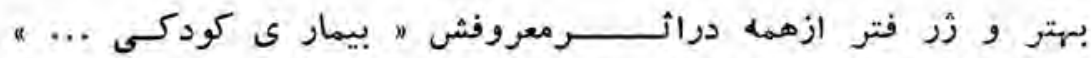

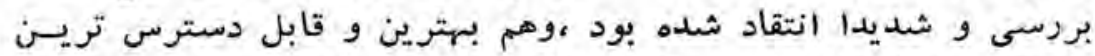

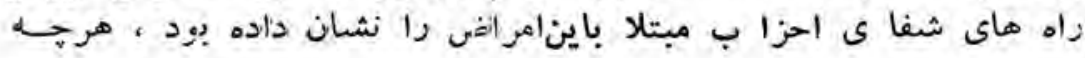

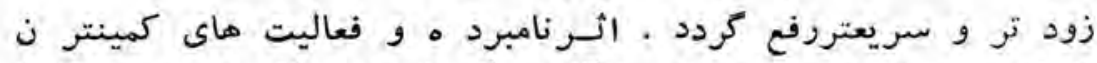

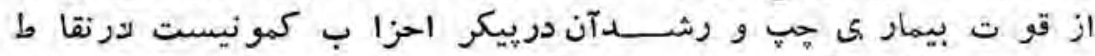

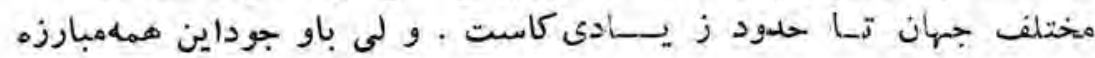

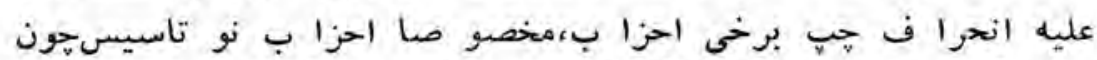

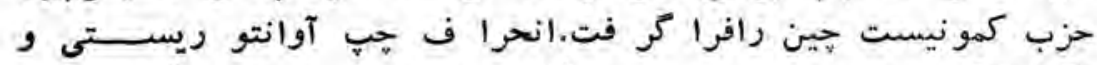

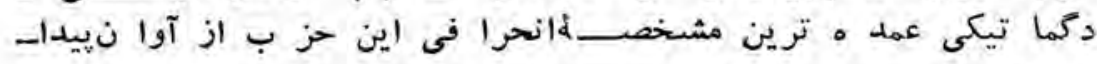

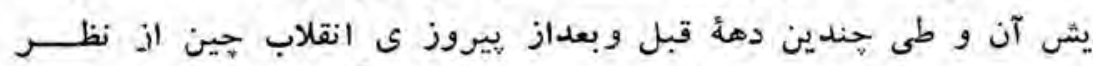

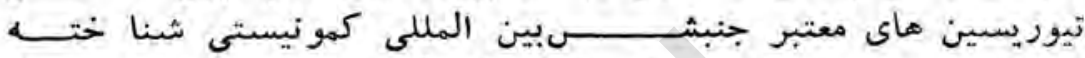

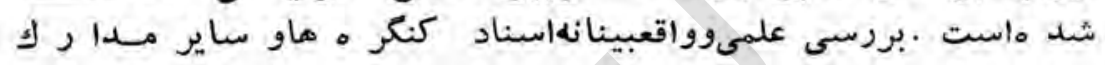

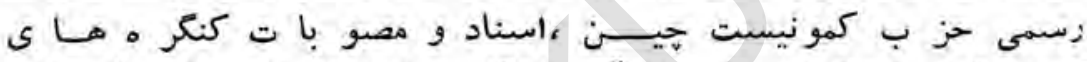

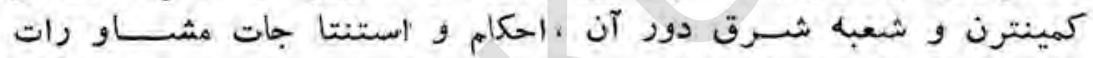

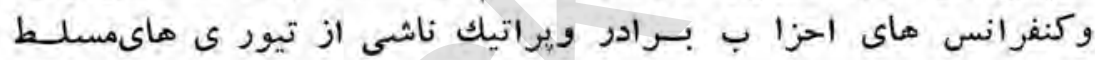

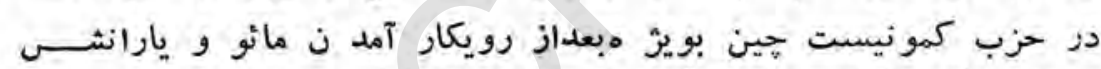

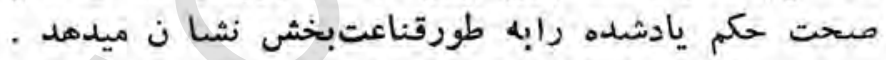

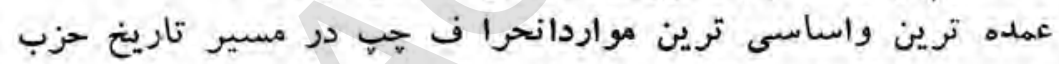

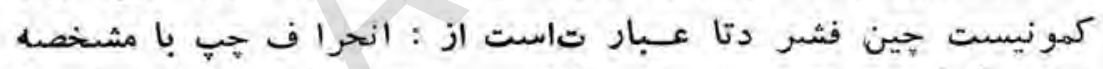

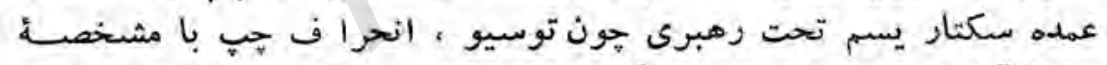

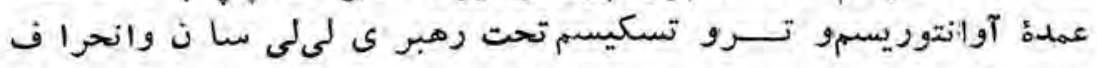

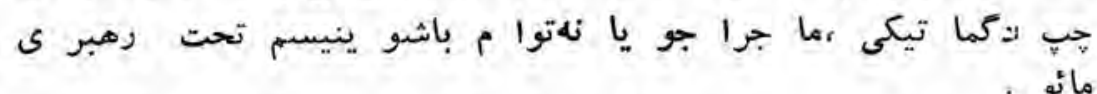

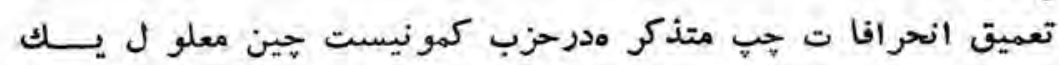

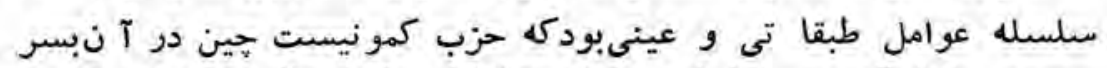

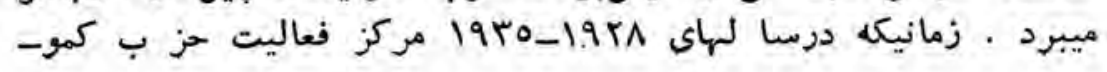




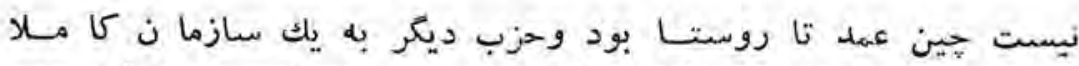

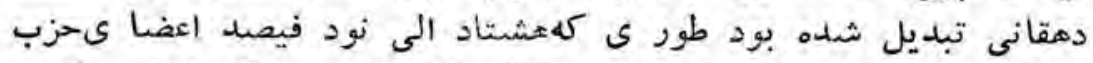

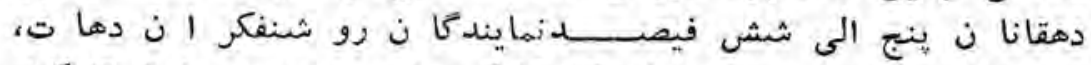

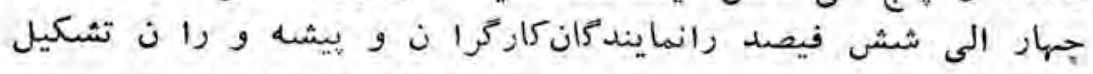

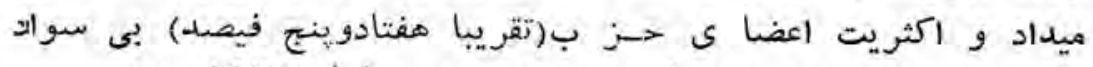

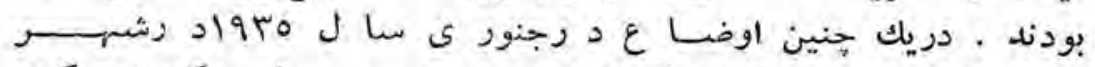

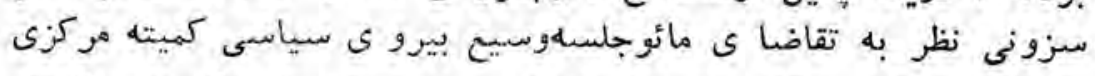

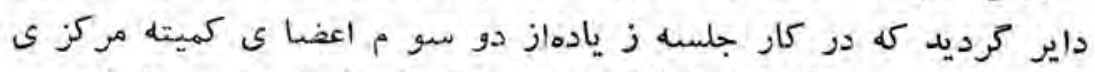

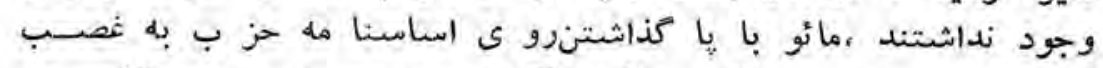

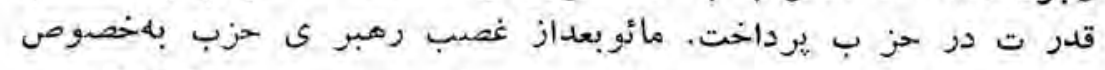

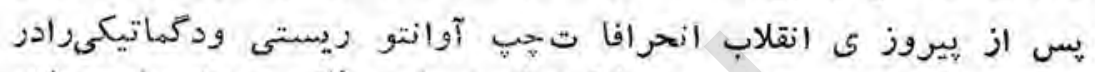

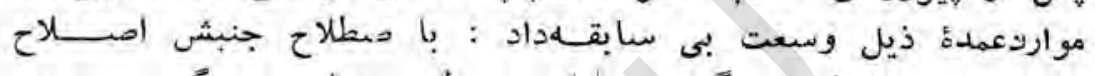

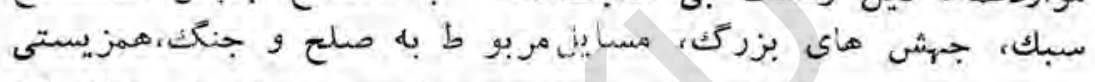

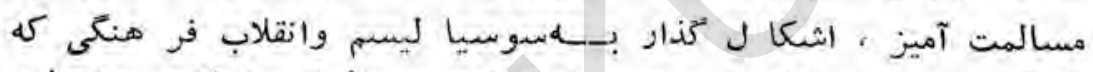

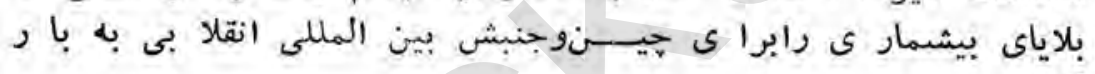
- آورد

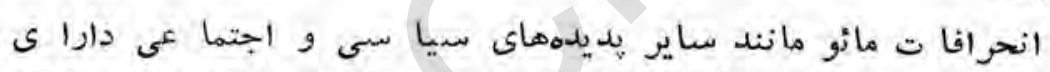

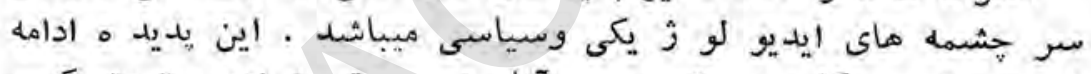

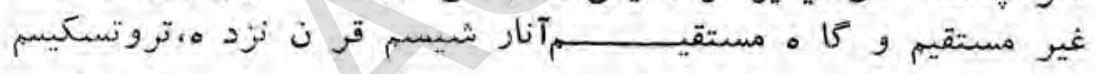

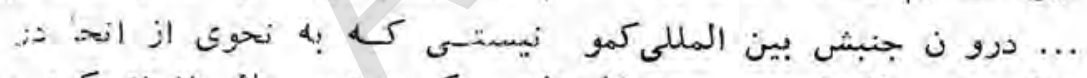

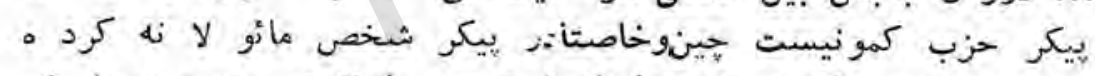

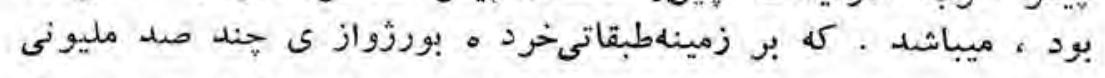

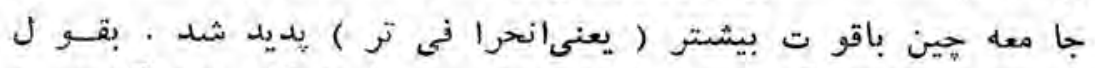

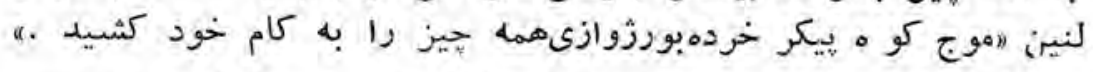

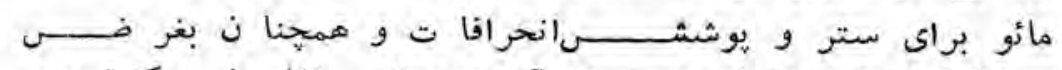

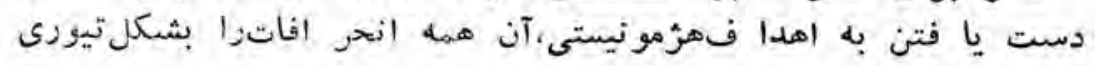




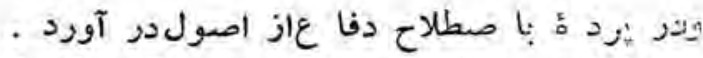

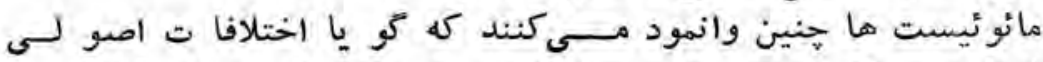

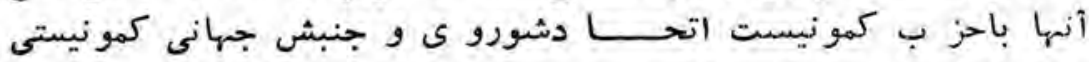

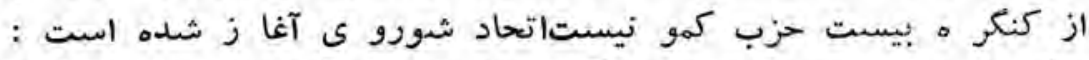

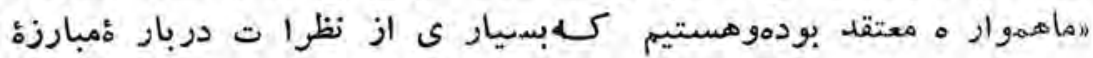

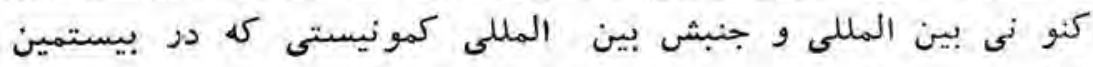

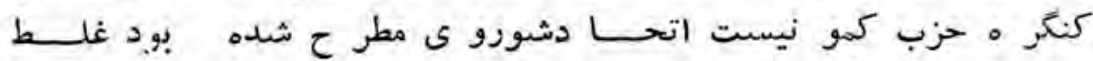

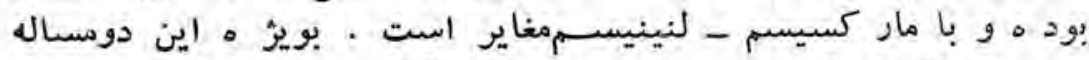

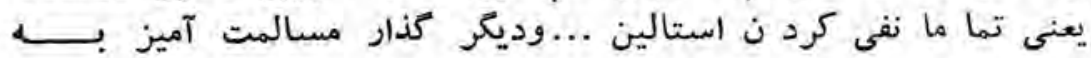

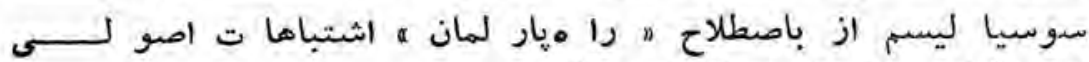

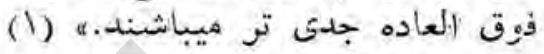

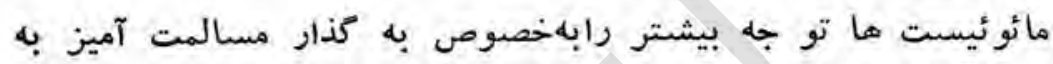

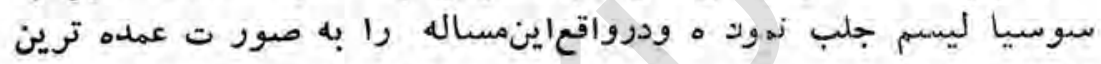

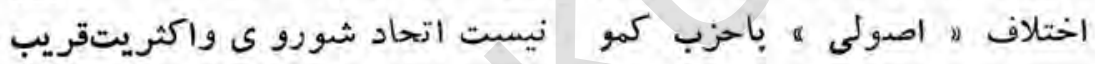

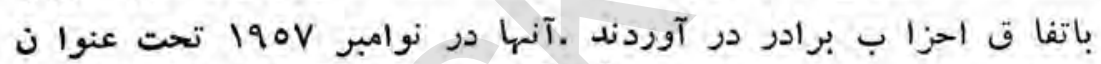

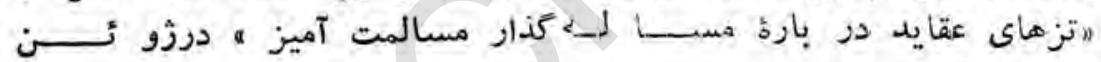

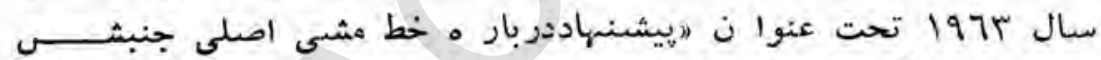

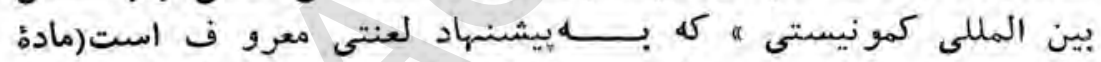

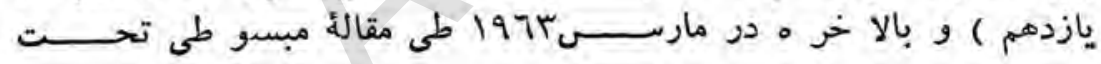

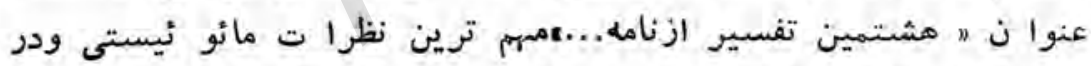

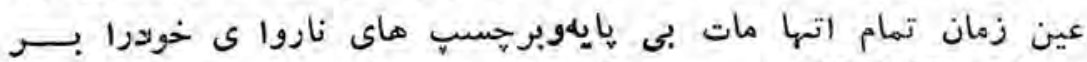

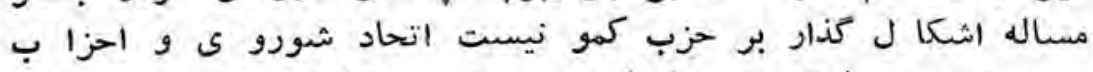

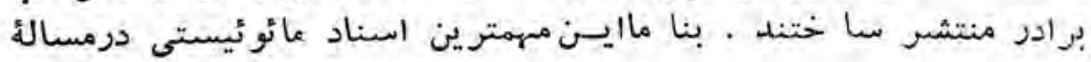

(1) (1) تفسير از نا مه سر كشادهميته مركز ى ح.ك.ا.ش ، اسبيتامبر - . 


$$
\text { كذاد را هورد بروسى قرارميدهيم. }
$$

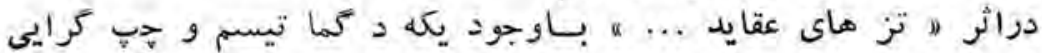

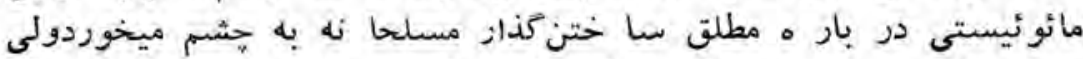

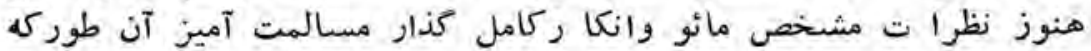

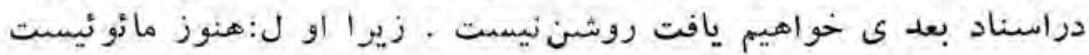

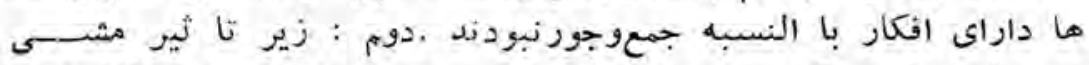

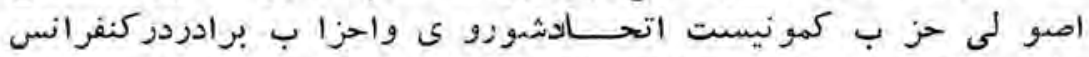

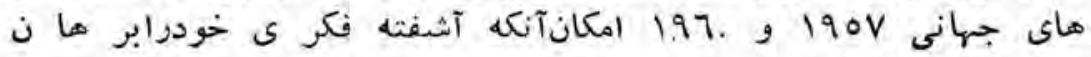

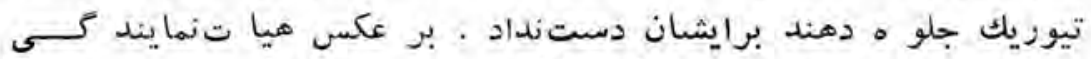

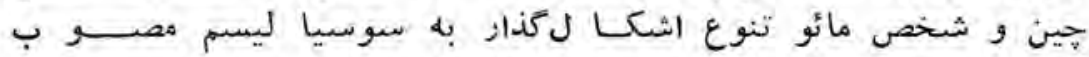

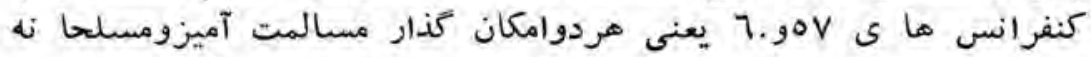

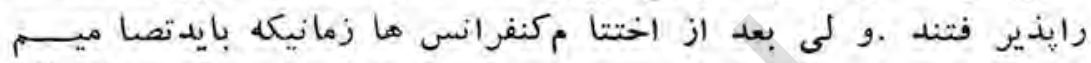

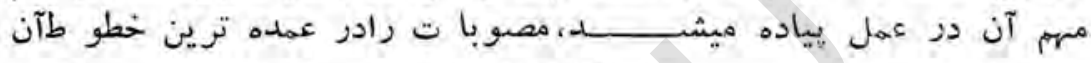

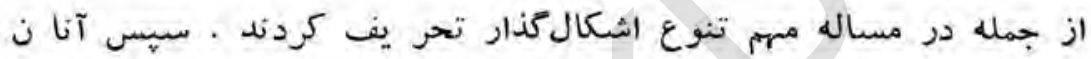

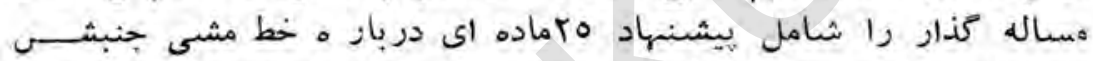

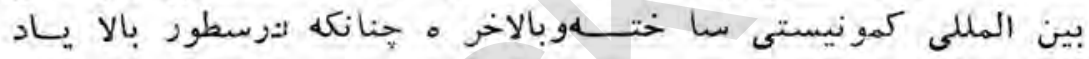

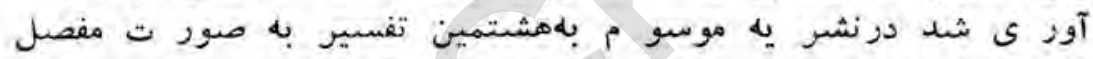

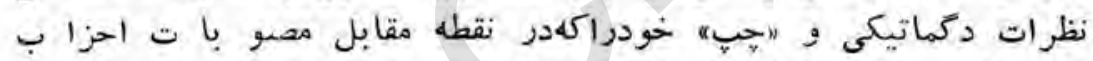

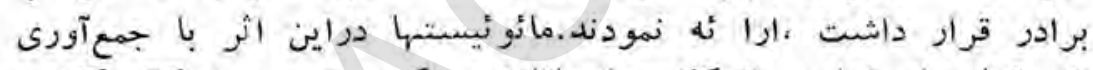

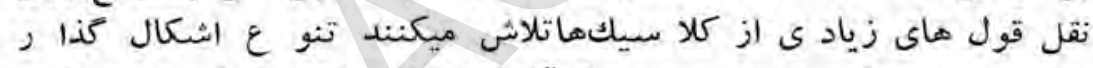

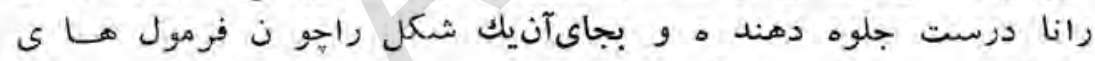

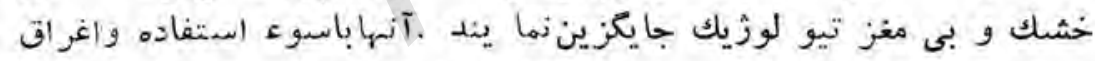

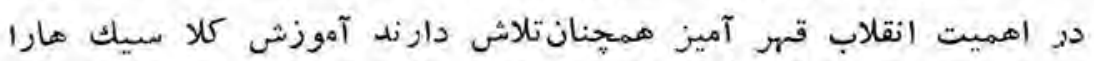

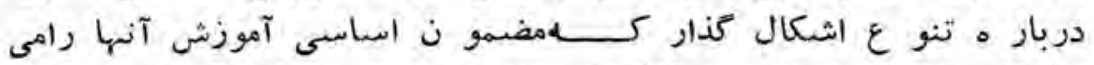

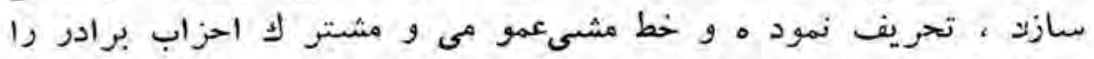

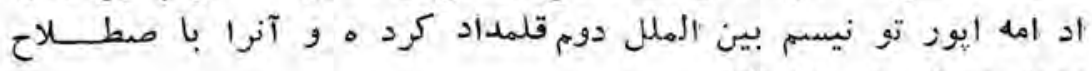

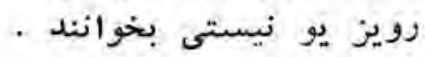




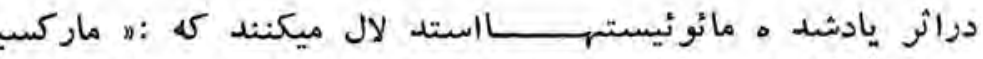

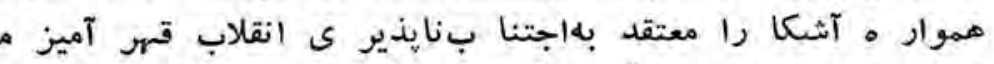

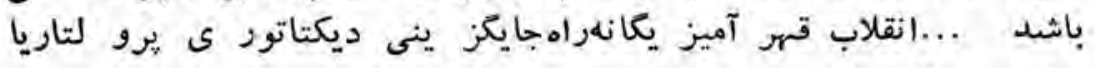

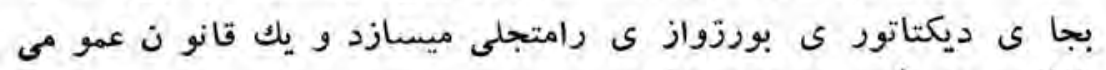

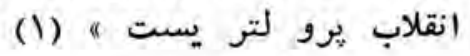

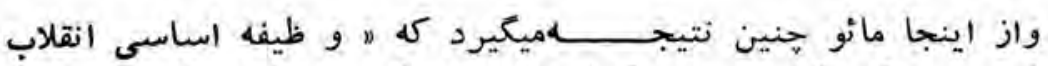

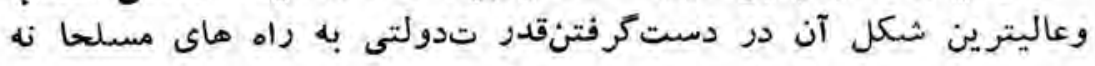

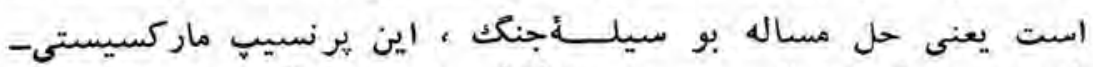

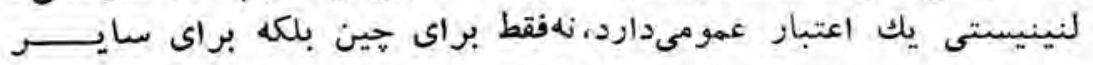

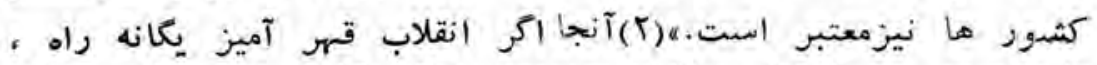

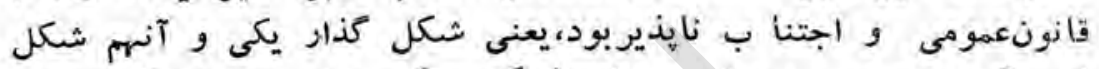

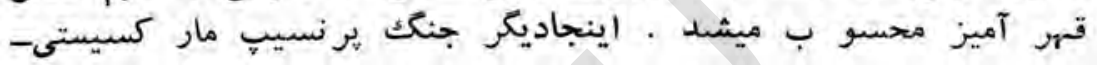

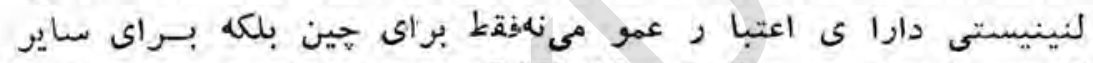

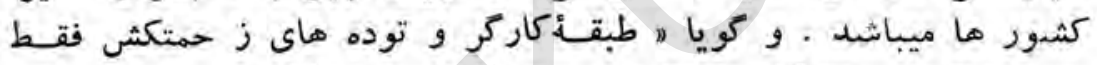

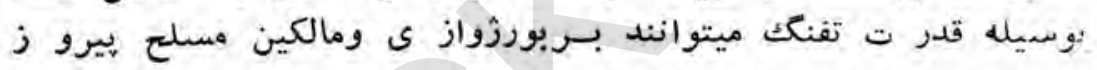

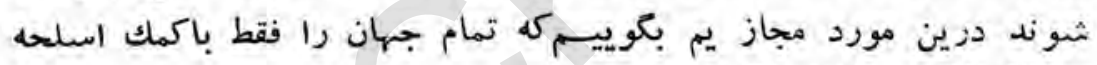
هيتوان تغيير داد.نه

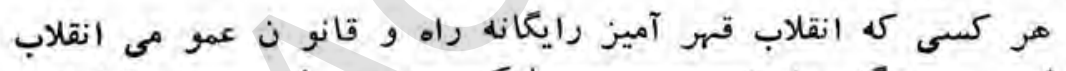

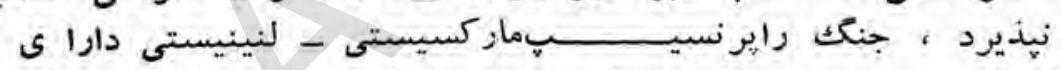

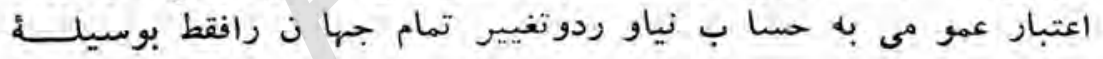

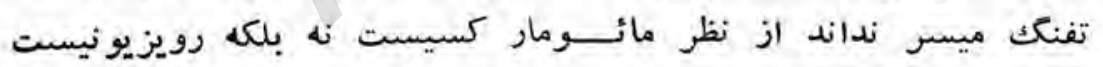

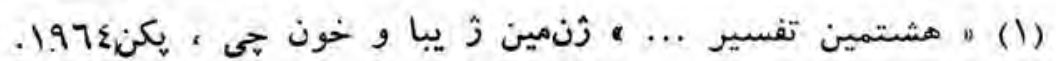
تكيه از ماست . ناست

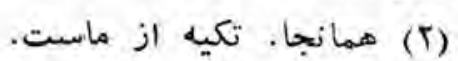
همانجاء تكيه از مانست. 


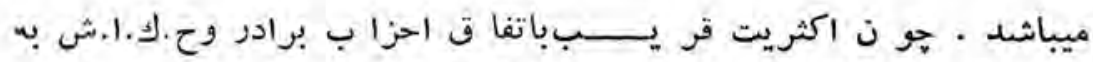

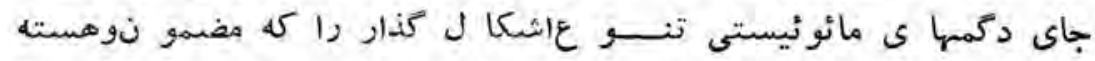

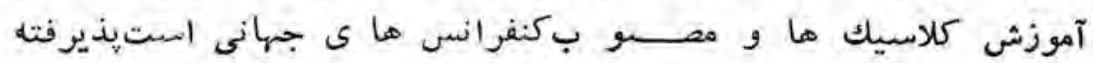

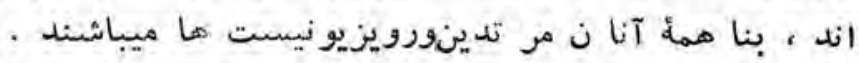

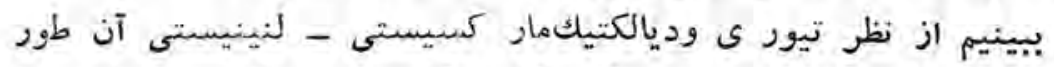

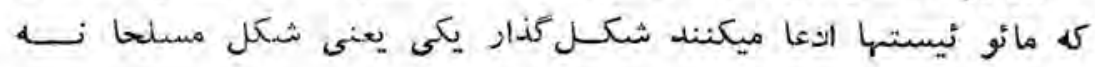
است

كارل ماركس درسا ل JAVIادركنفرانس جمعيت بين المللى كار-

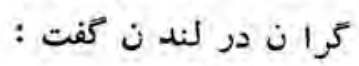

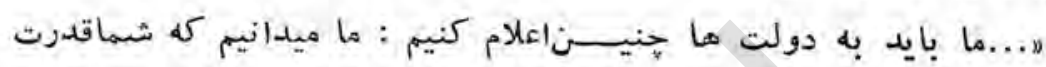

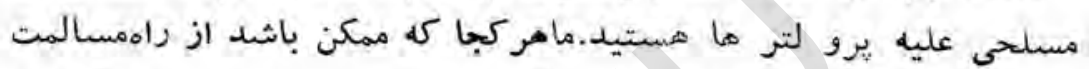

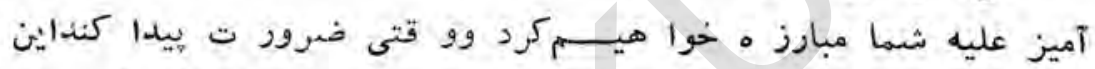

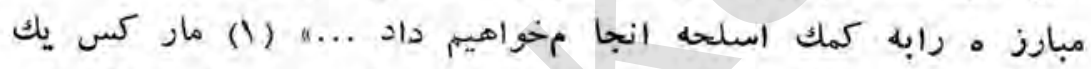

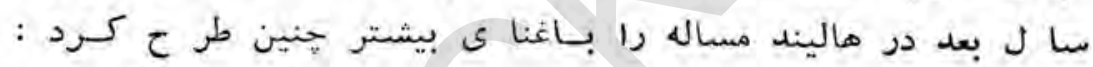

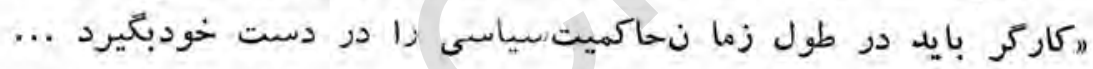

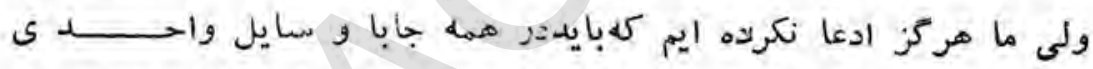

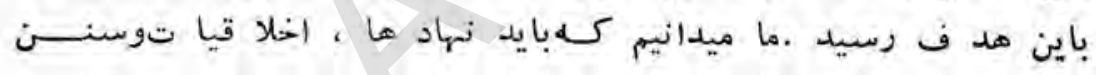

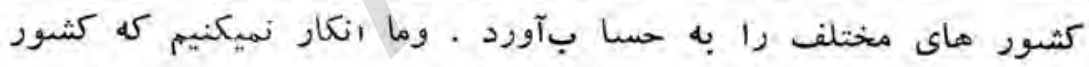

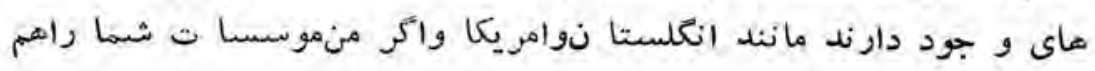

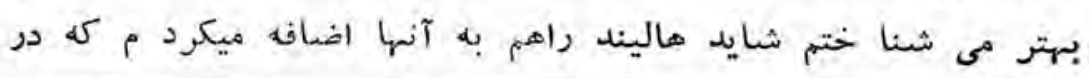

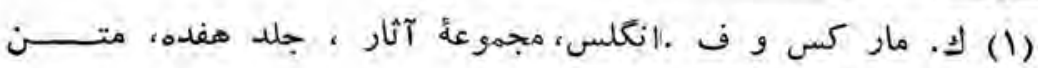

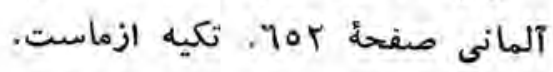


آنها كاركرا ن ميتوانيد با وسايلمسالمت آميز بههد فها ى خــــود

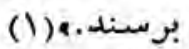

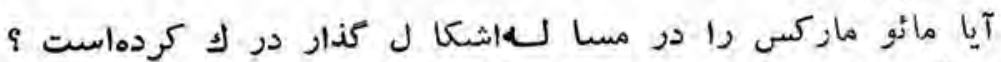

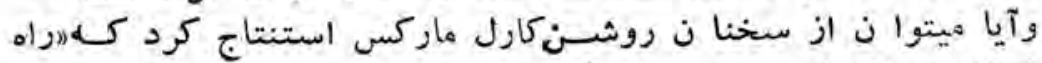

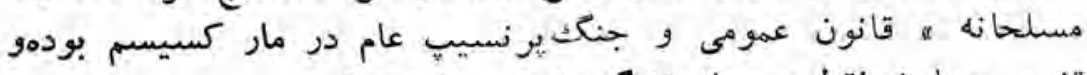

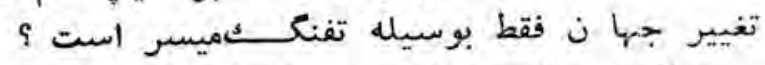

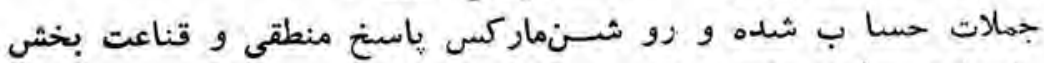

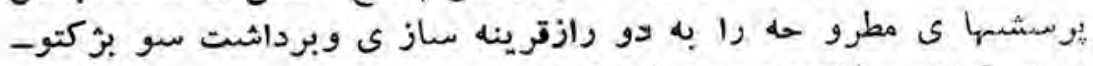

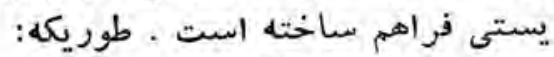

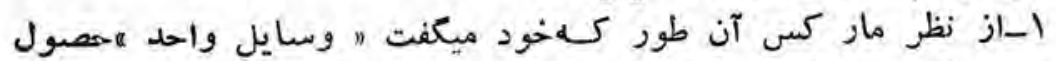

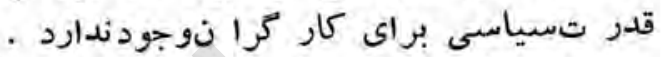

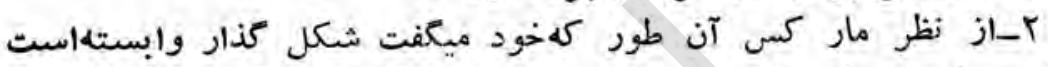

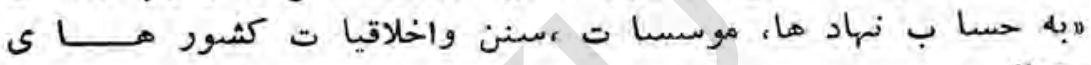

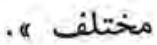

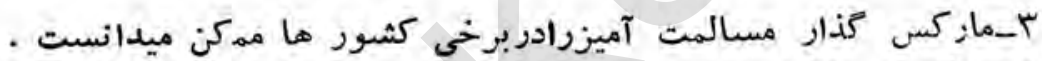

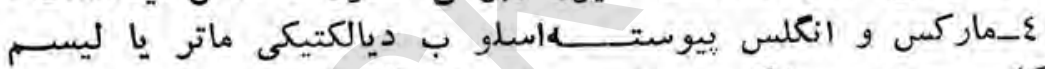

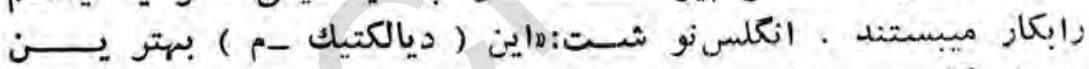

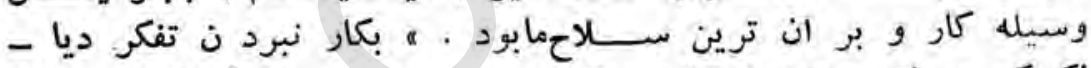

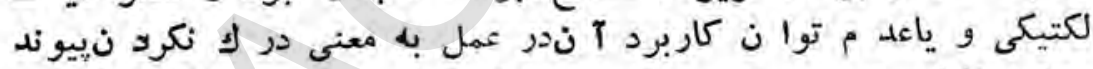

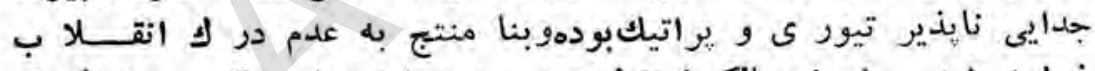

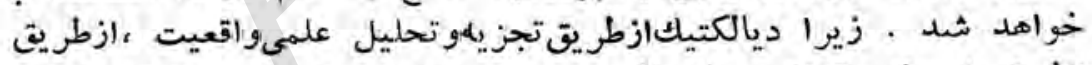

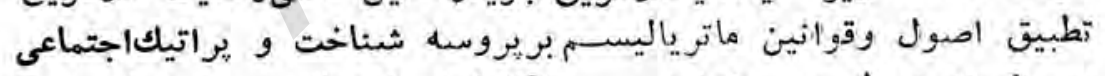

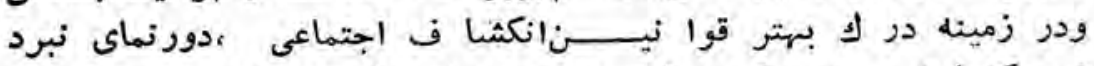

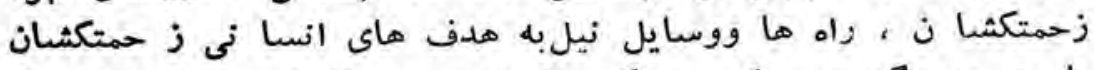

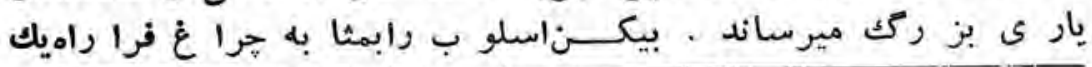

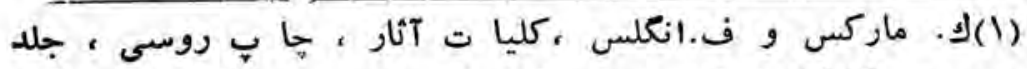

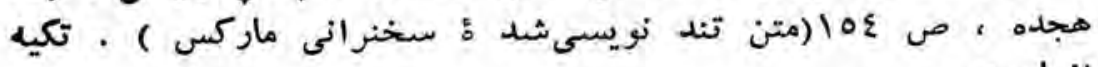
ازماست , - إسده 


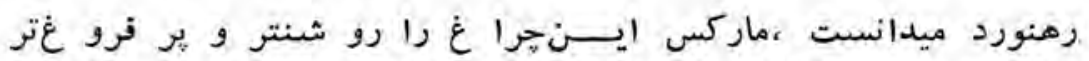

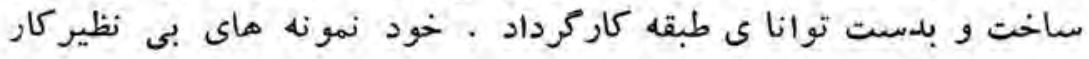

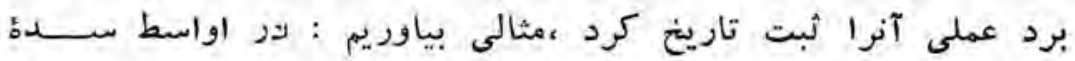

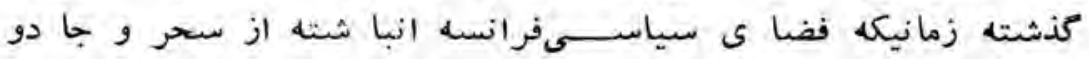

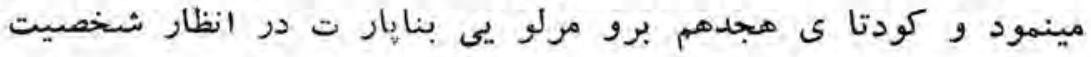

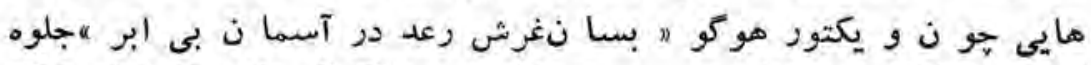

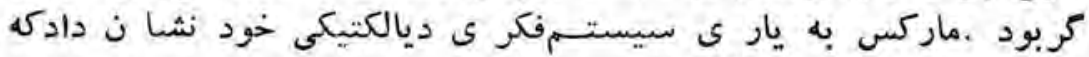

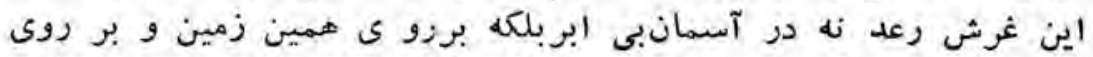

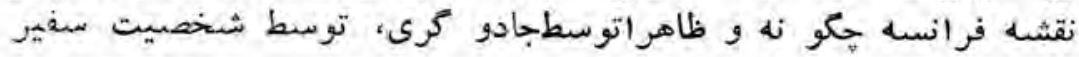

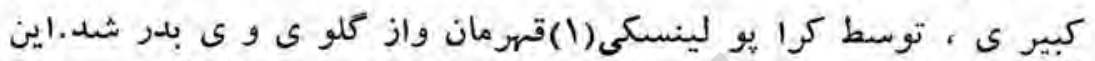

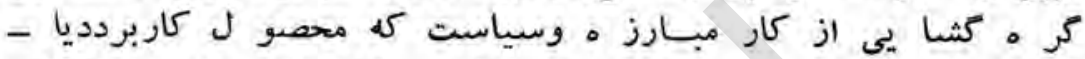

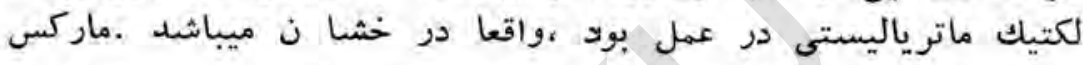

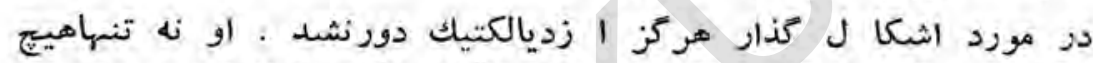

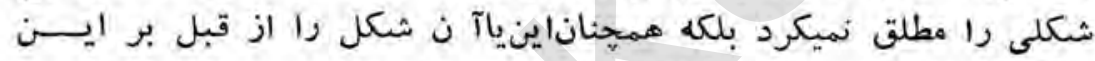

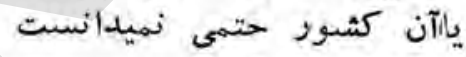

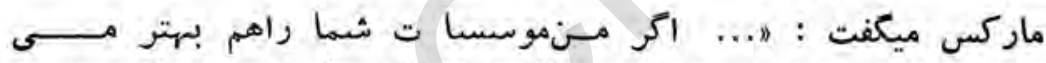

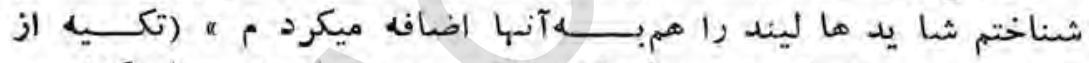

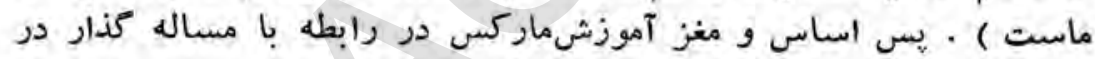

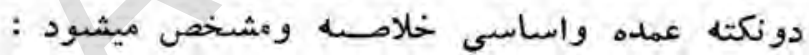

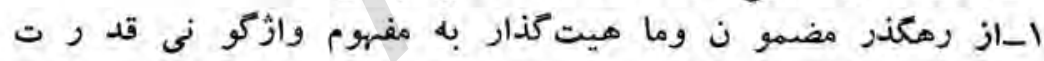

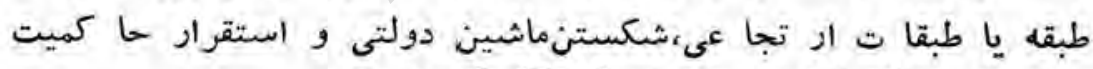
دولتى ز حمتكشا ن بر هبر ى طبقهار كار كر است .

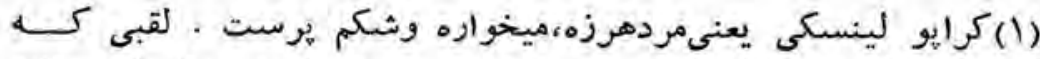

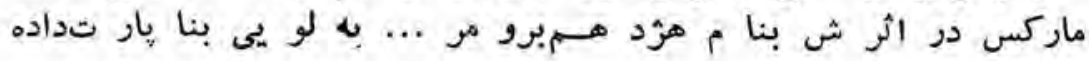


r- از رهكذر شكل، شكل:طلق،قانو ن عمو مى و اجتنا ب نايذيردر

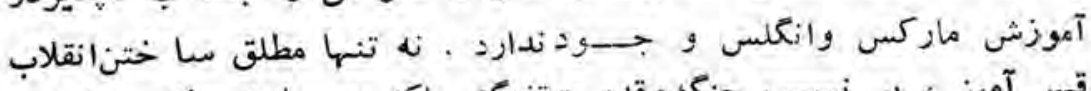

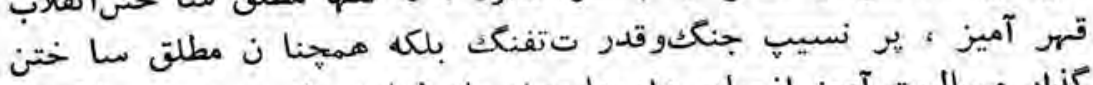

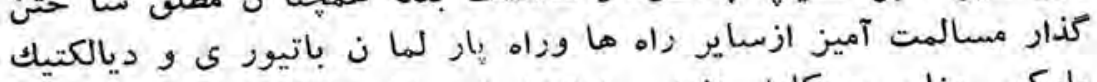

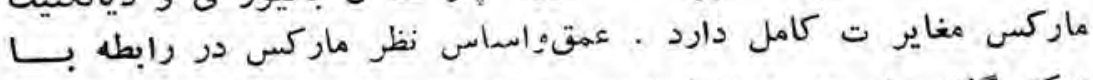

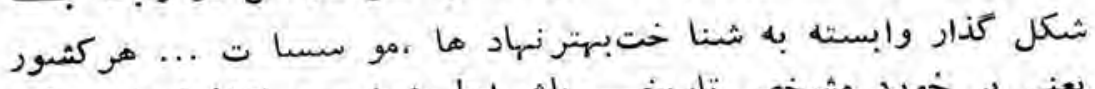

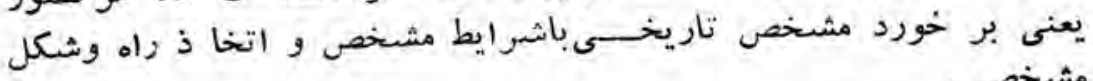

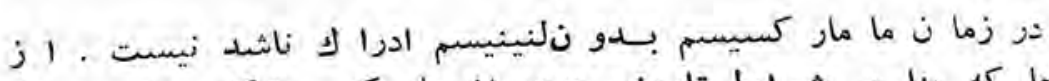

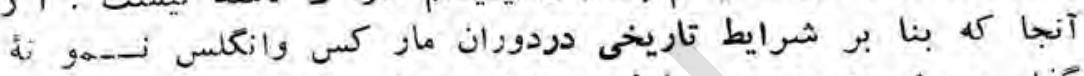

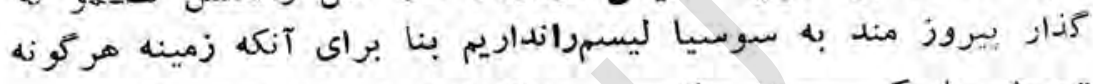

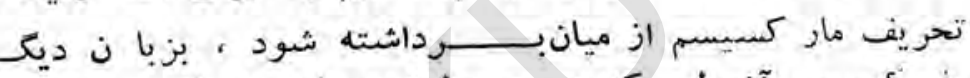

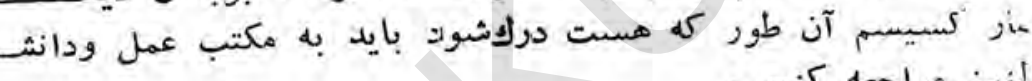

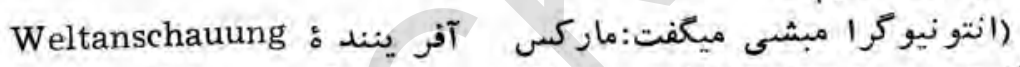
(جهانبينى - نويسنده ) است وامآورد ه ايليتج كدام است ؟ ؟ ...ياسنخ در خود مار كسيسم است:ه دانشىوعمل مانس ... آنا ن نمايانكر دو مرحله

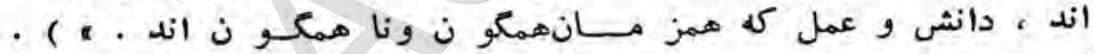

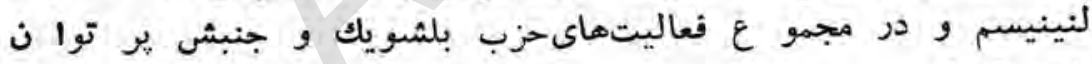

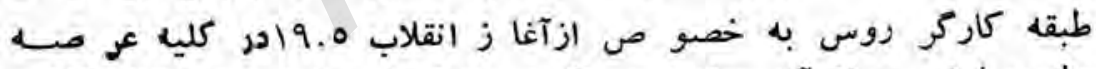

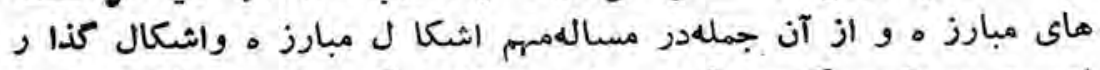

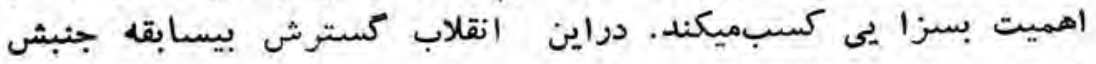
اعتصا بى ، در آهيز ى اعتصا باقتصاد ى وسياسى و تبديل آ نبه

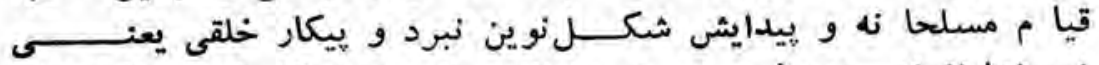

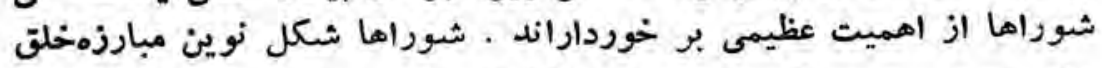

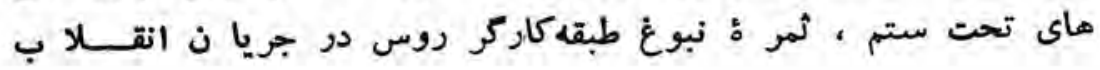


19.V_19.0

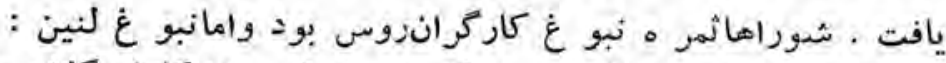

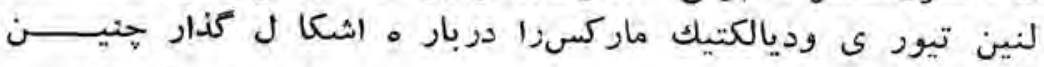

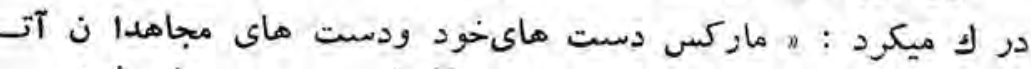

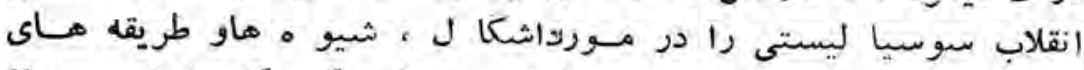

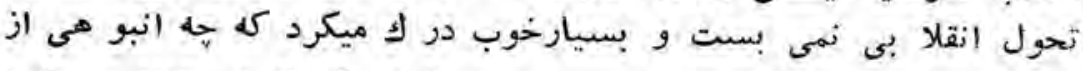

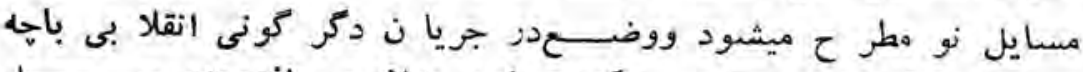

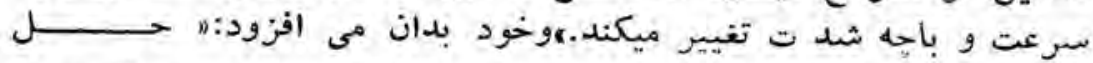

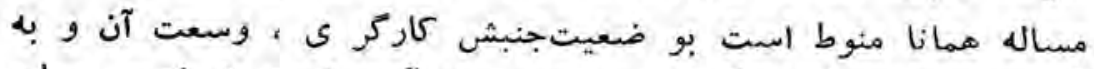

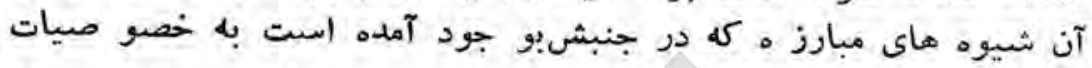

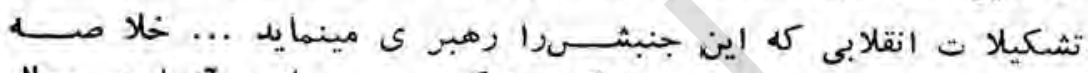

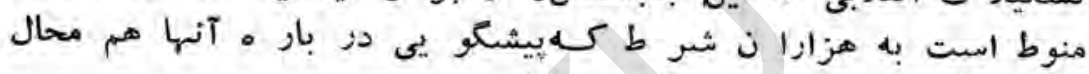

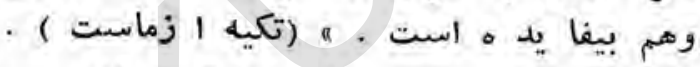

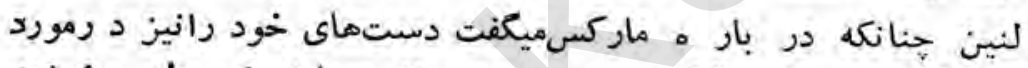

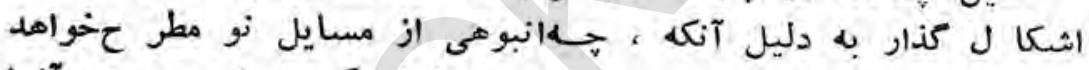

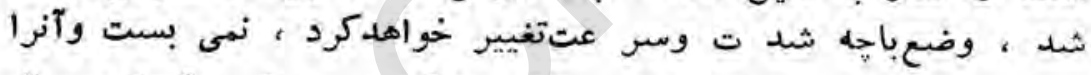

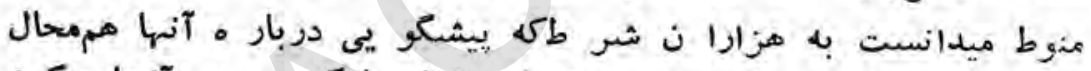

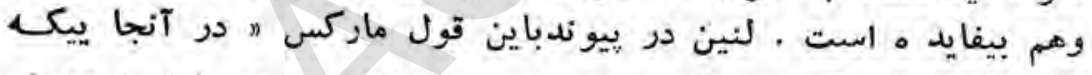

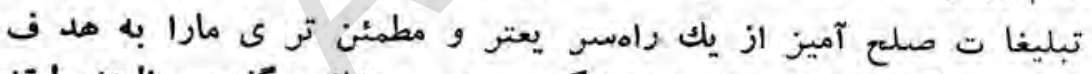

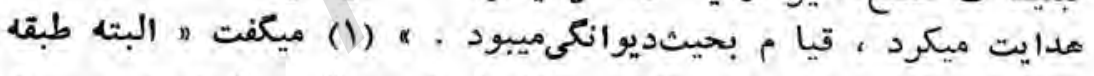

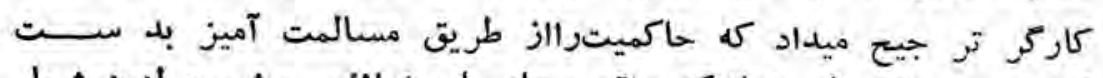

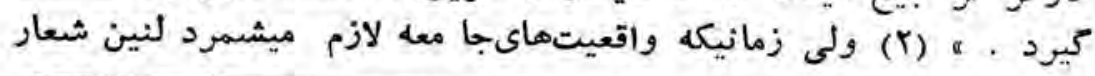

(1) كارل ماركس و فر يدريشانكلس ، مجمو عه آثار ، جلدهفده،

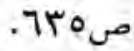

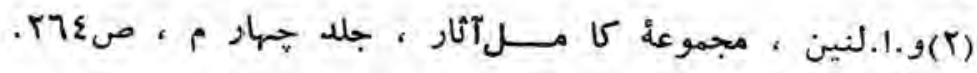




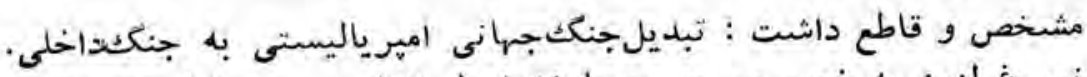

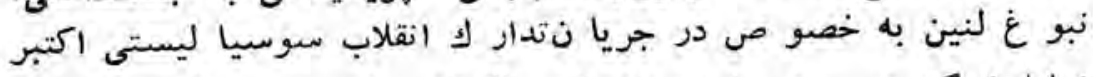

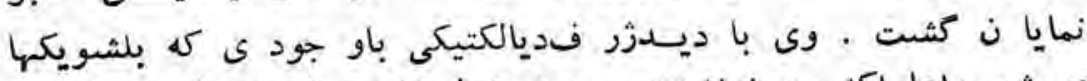

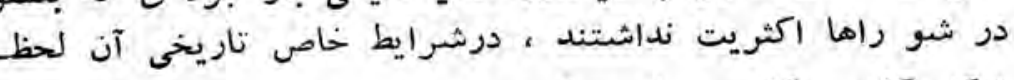

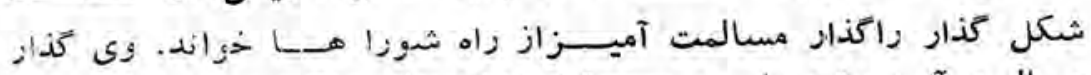

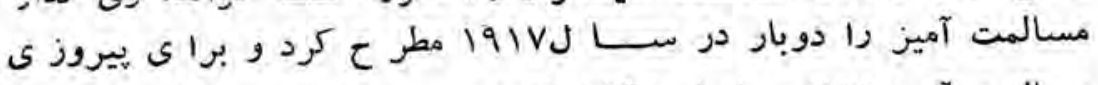

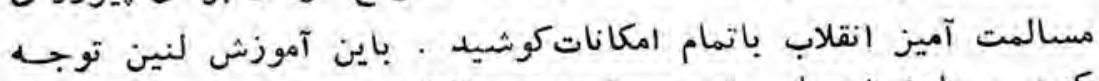

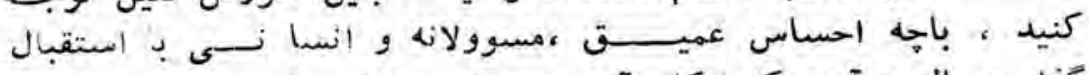

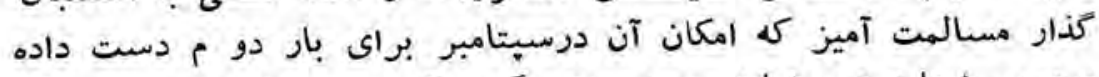

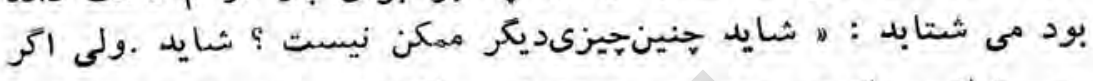

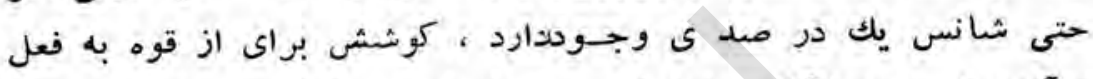

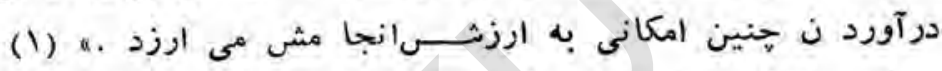

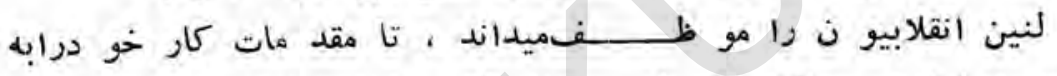

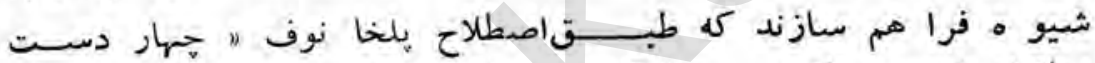

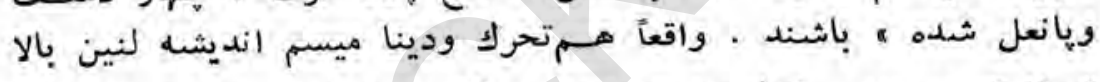

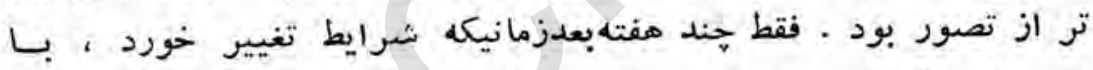

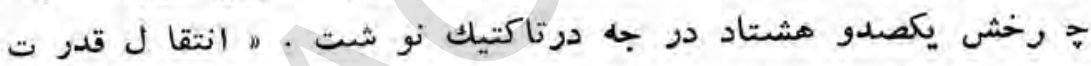

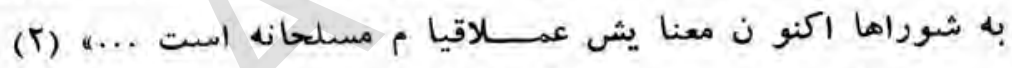

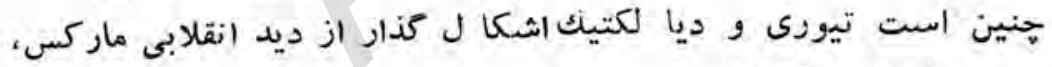

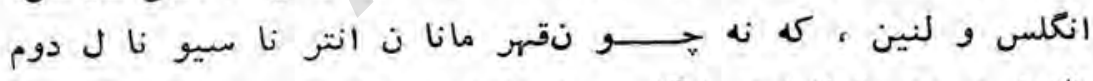

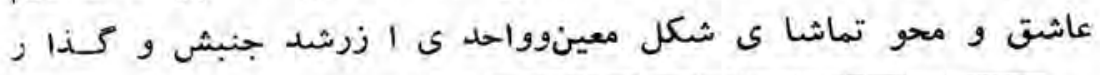

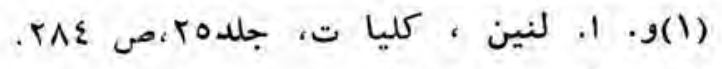

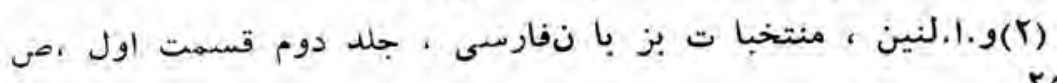




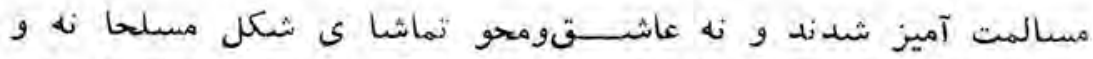

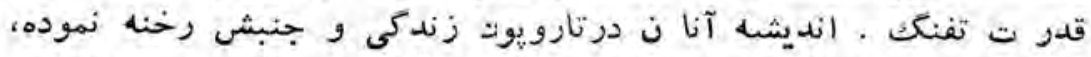

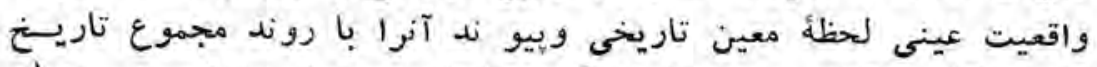

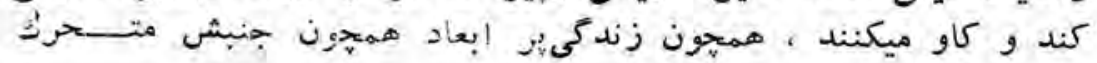

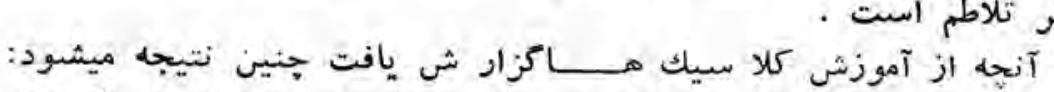

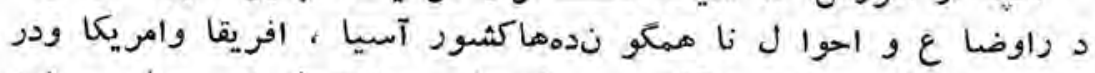

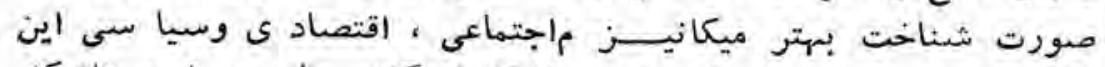

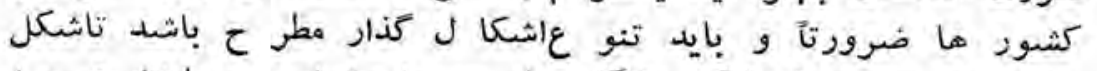

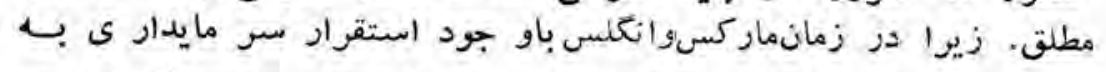

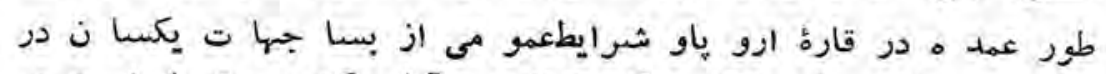

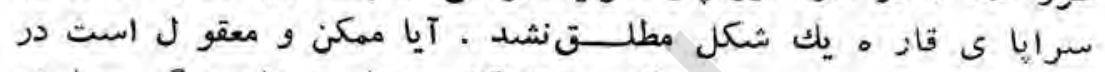

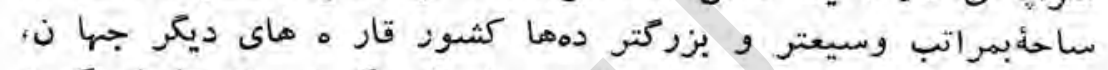

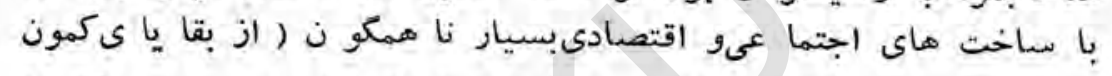

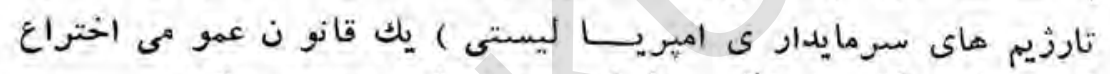

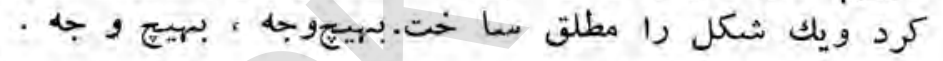

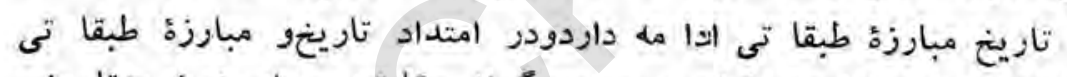

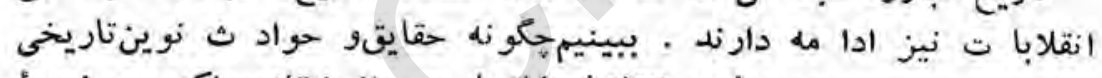

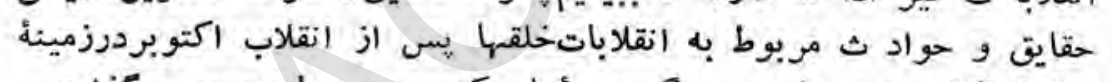

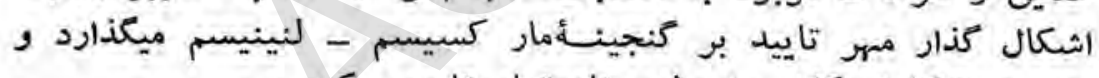

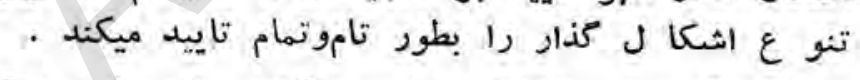

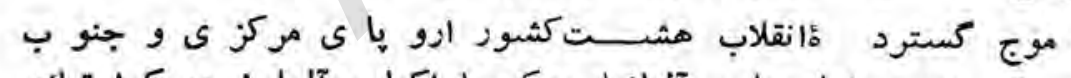

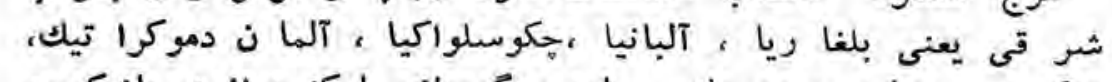

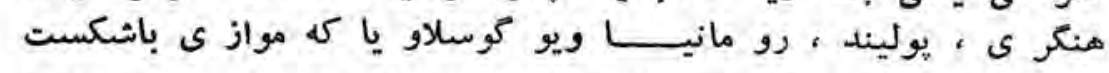
فاشيسم بادر آميز ى عميقمبارز هٔملى و مبارز ؛ اجتماعى به به بيروز

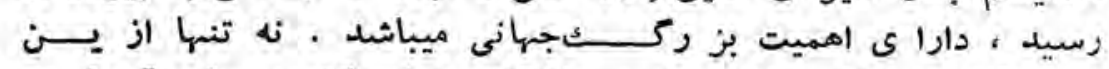

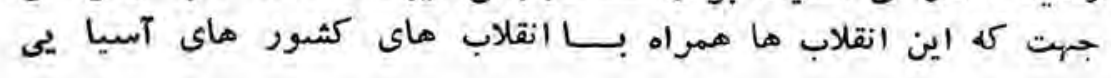


ويتنا م ، جين و كوريا باعث ايجا دسيستم جهانى سوسيا ليستى زشدند،

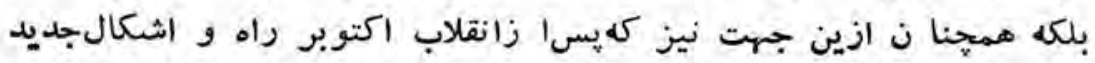

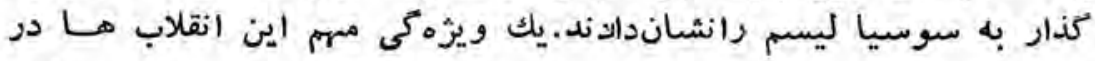

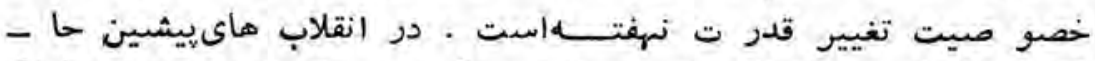

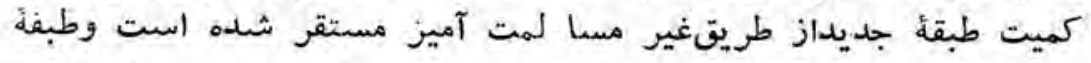

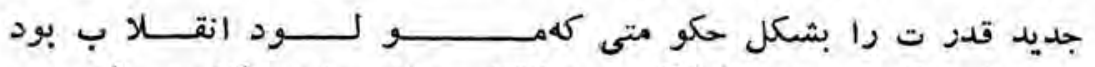

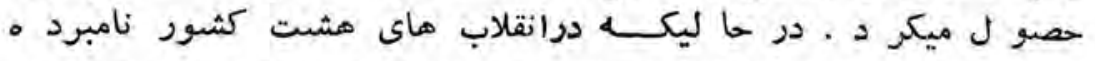

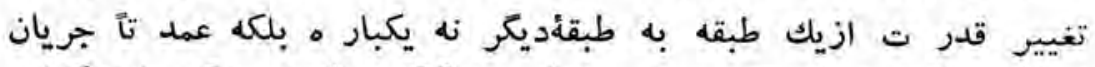

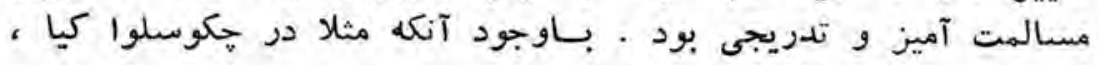

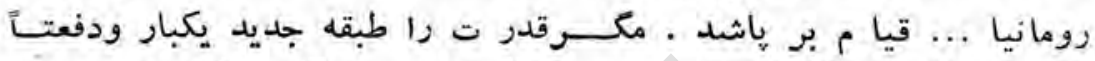

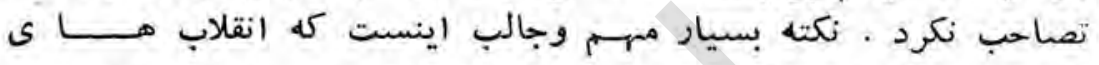

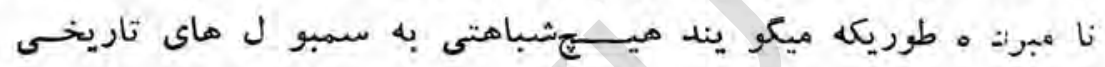

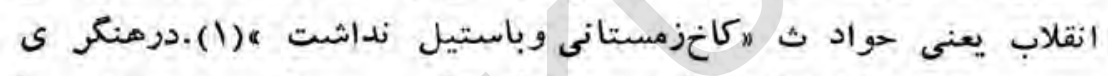

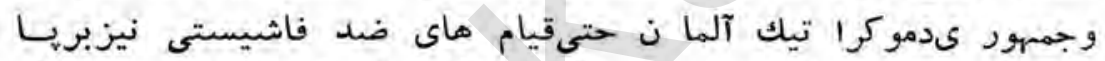

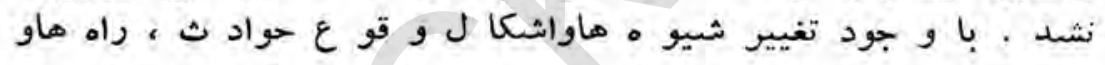

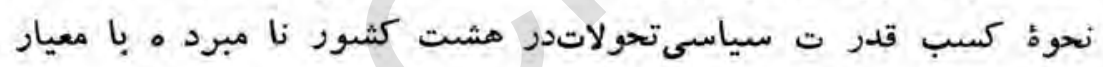

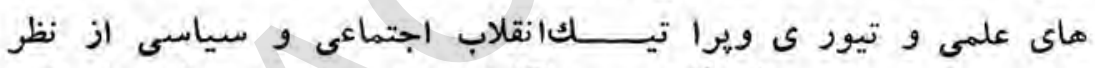

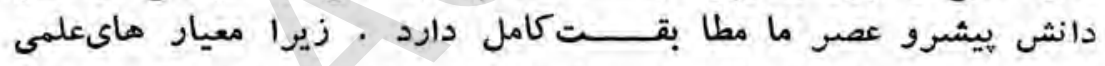

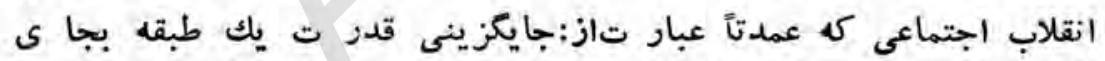

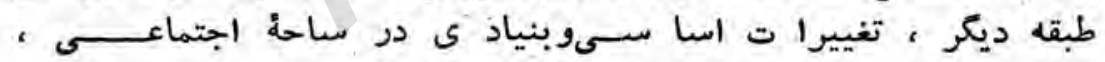

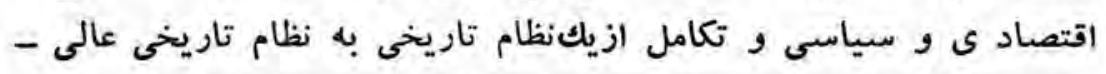

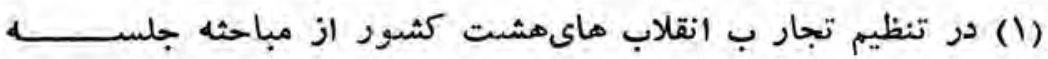

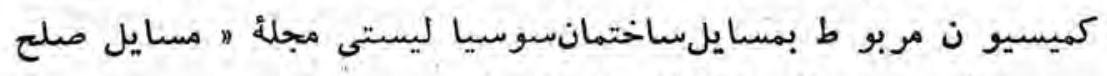

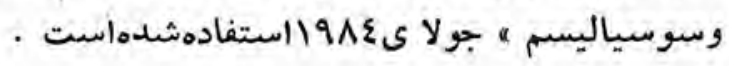


تث ميباشد ، در مورد آن كشورهاكاملا مصداق مى يابد ـ ـ طبقه كاركر

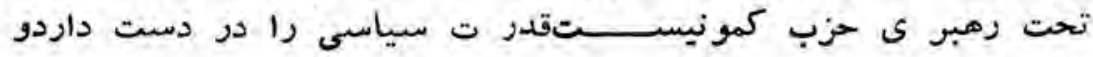

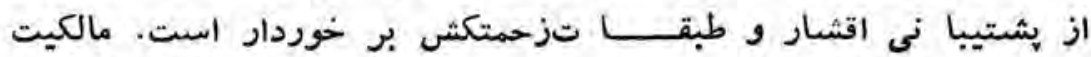

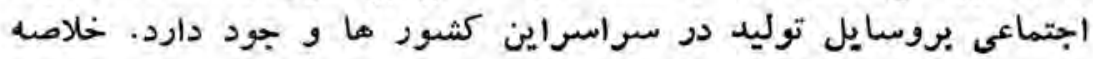

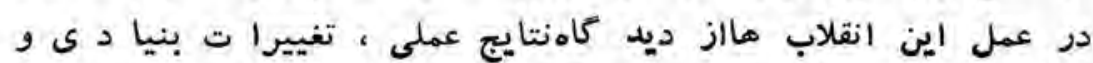

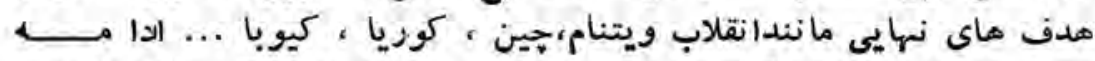

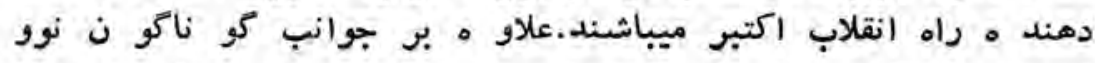

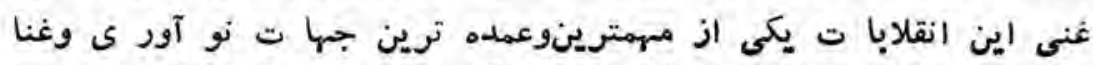

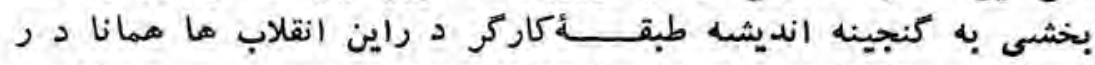

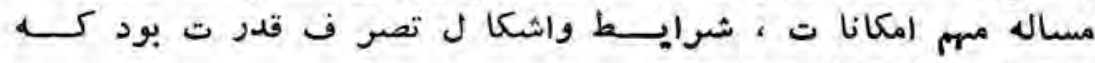

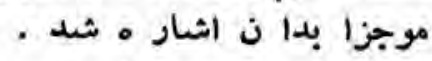

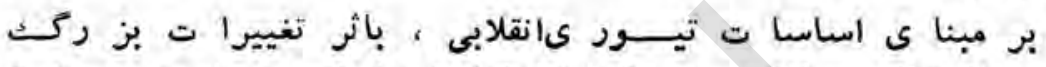

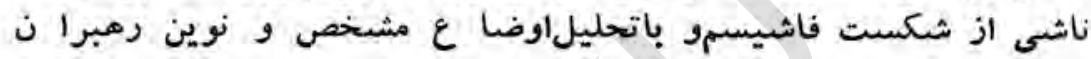

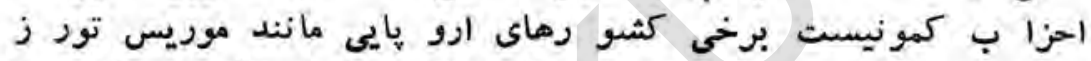

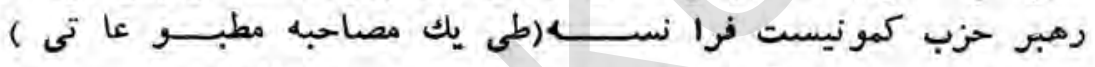

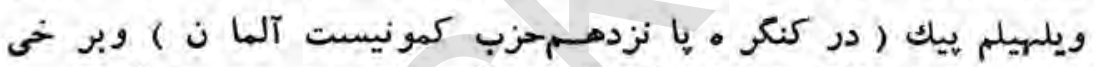

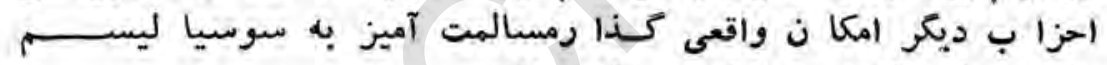

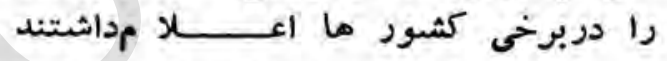

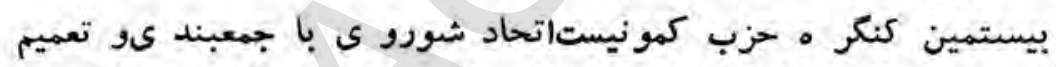

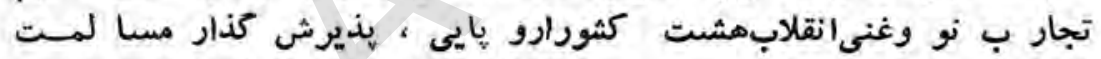

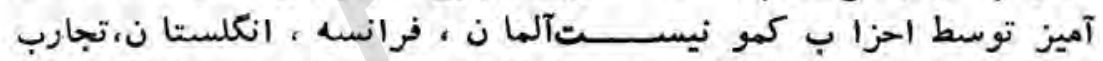

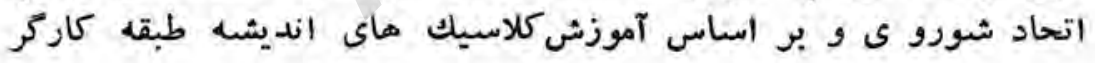

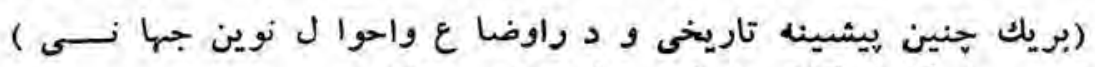

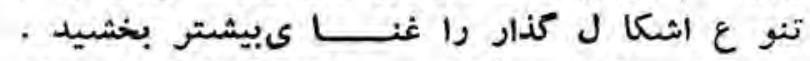

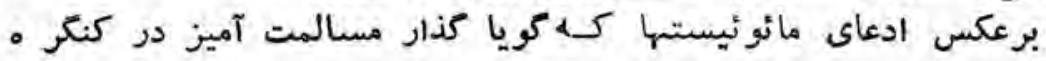

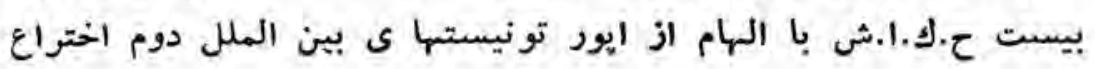




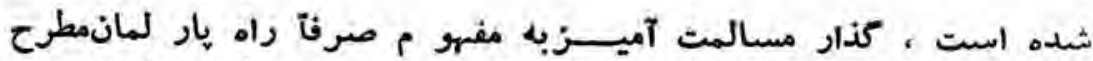

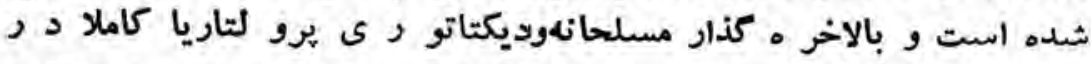

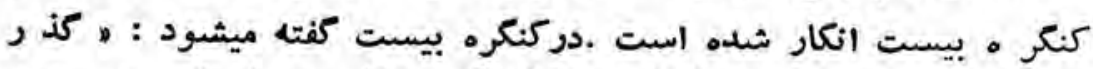

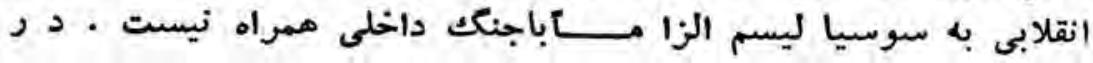

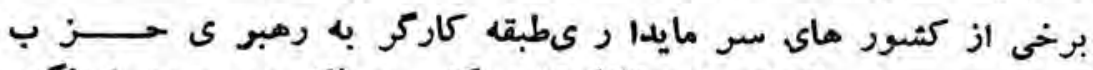

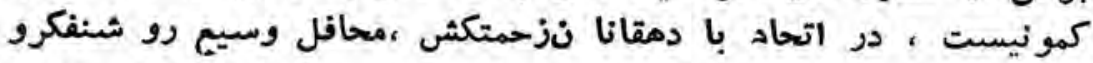

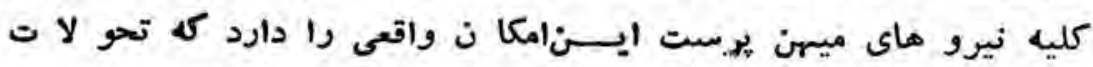

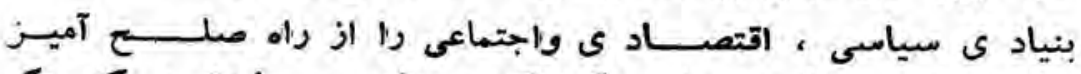

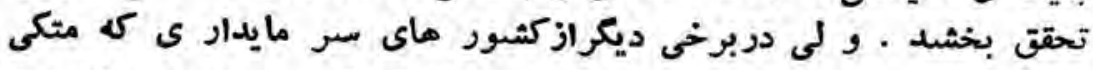

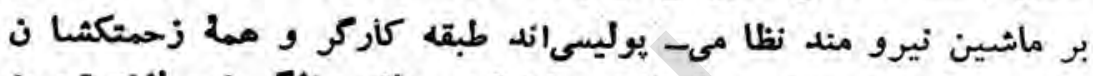

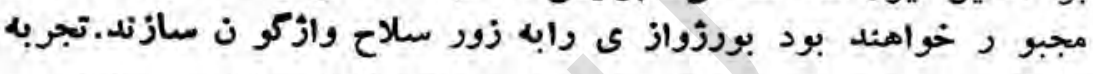

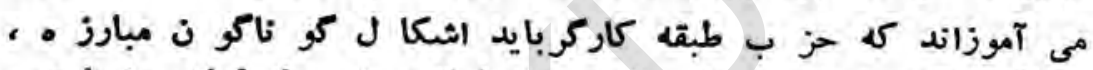

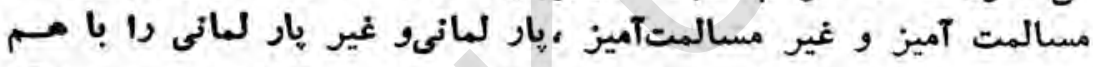

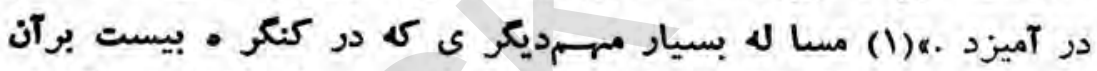

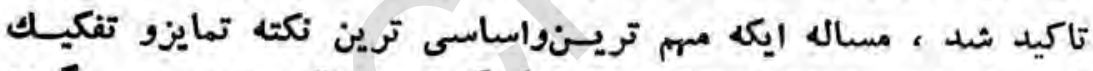

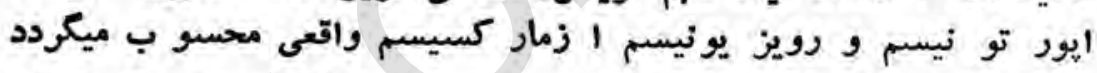

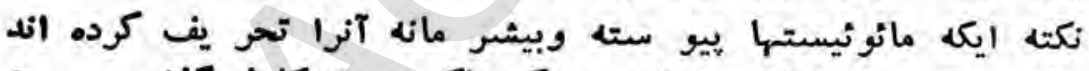

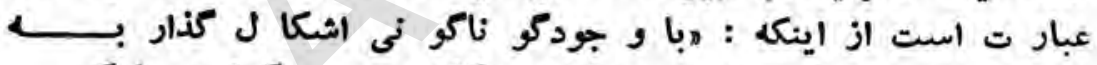

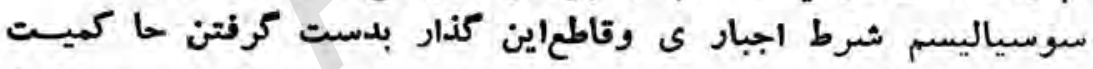

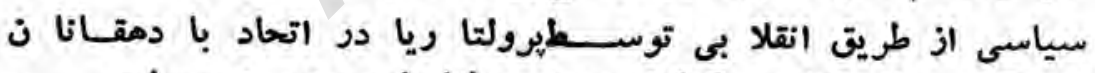

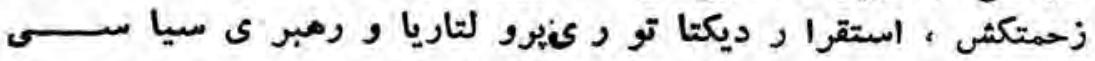

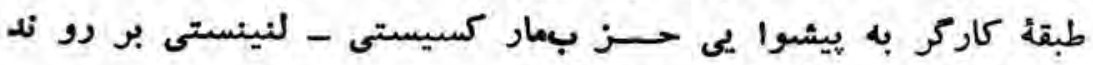

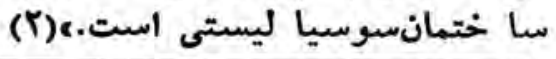

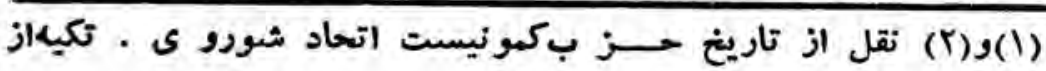
ماست . 


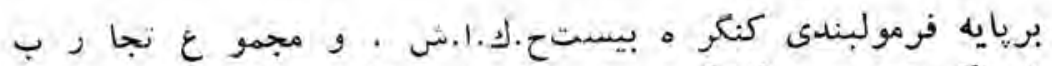

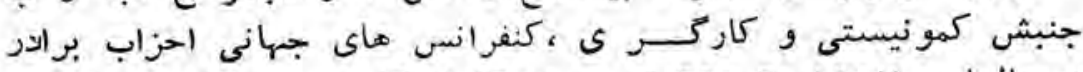
دوسالها ى $190 \mathrm{~V}$

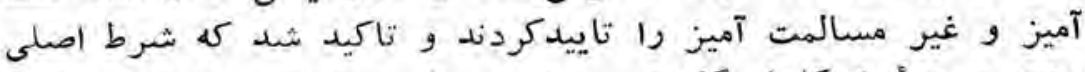

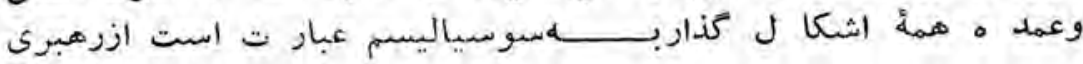

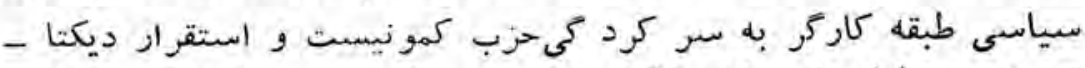

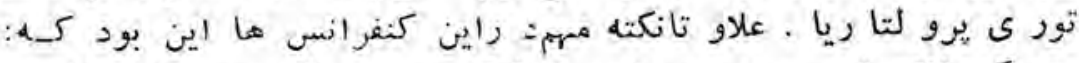

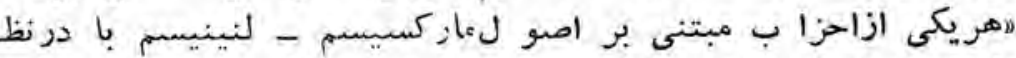

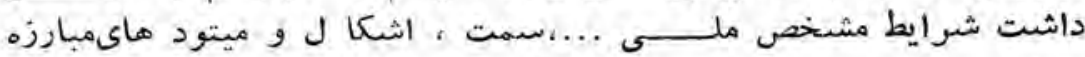

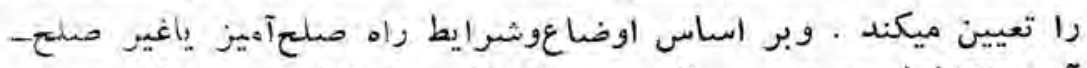

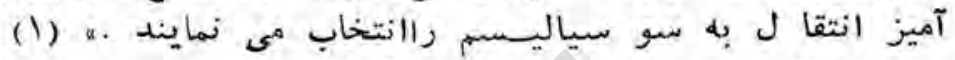

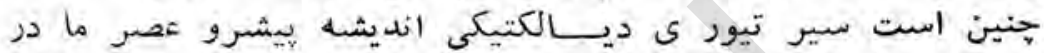

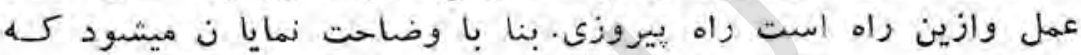

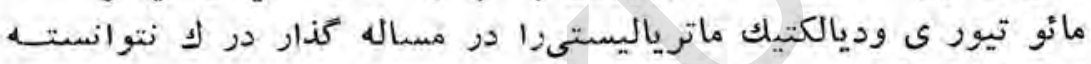

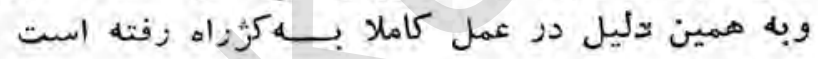

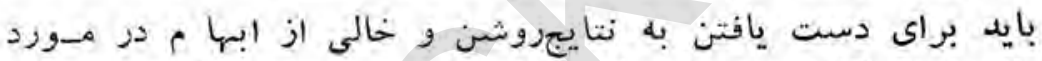

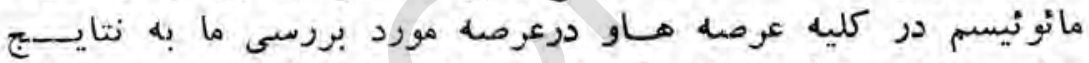

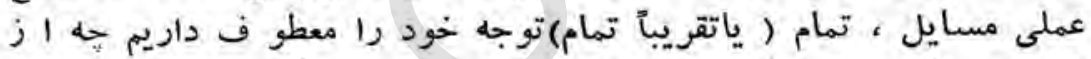

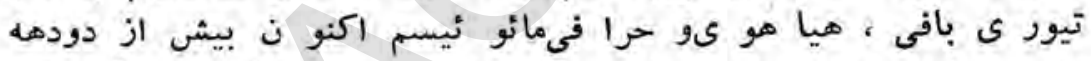

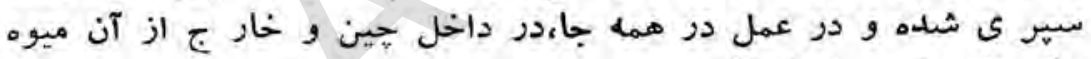

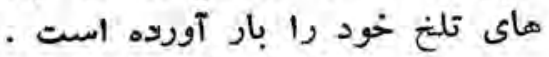

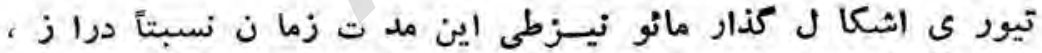

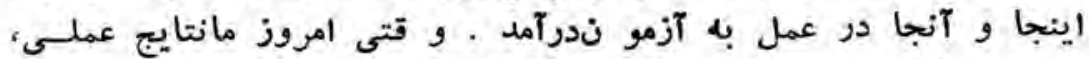

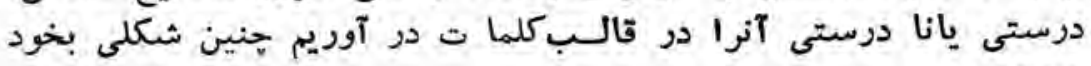

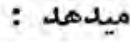

(1) كنفرانس بين المللى احزاب كمونيست و كاركر ى ، مسكو ،

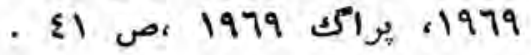




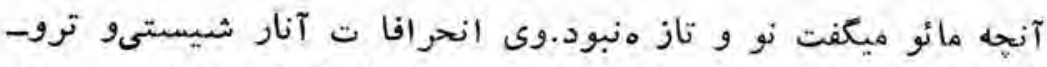

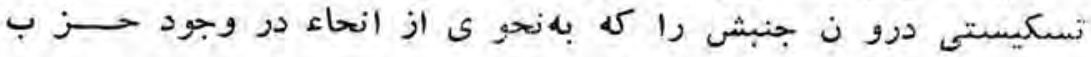

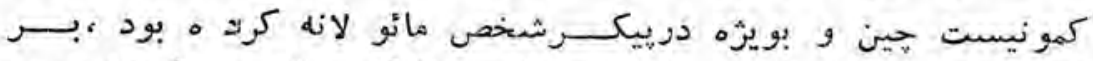

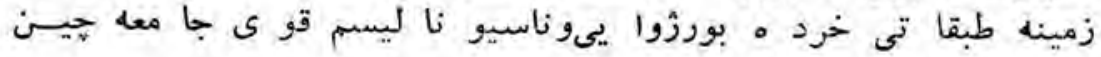

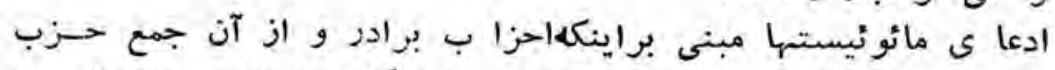

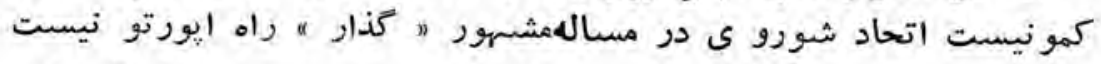

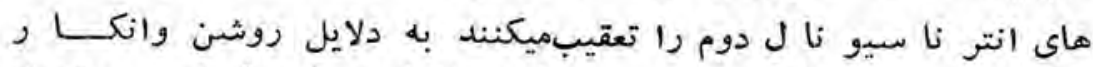

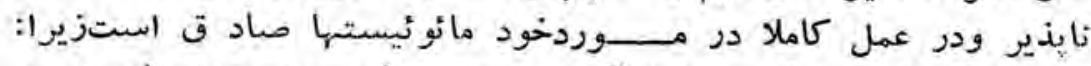

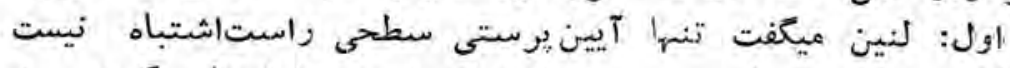

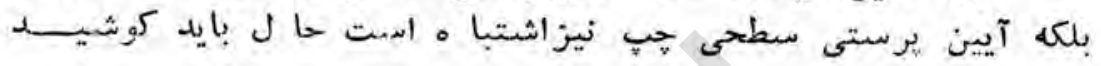

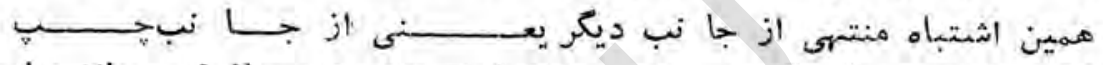

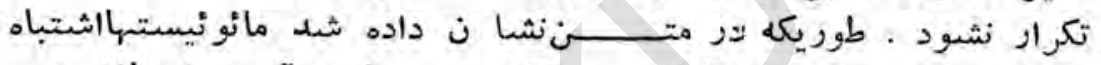

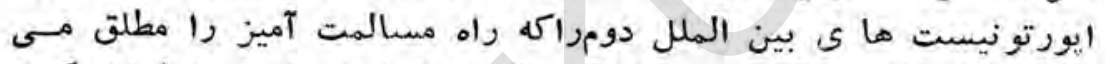

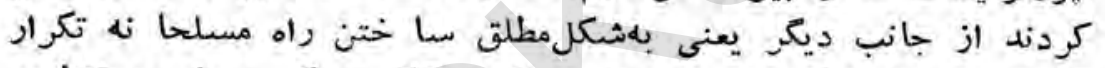

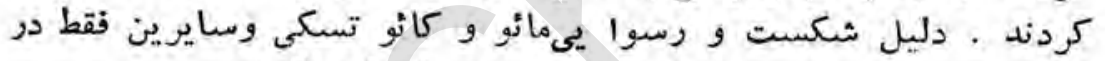

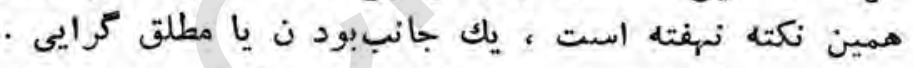

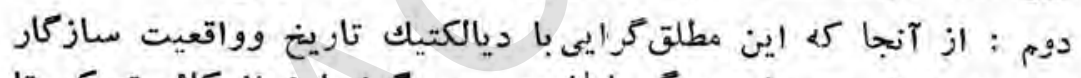

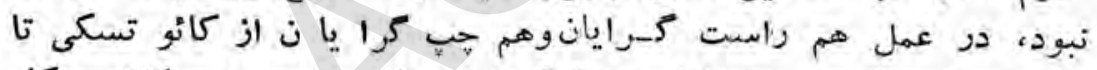

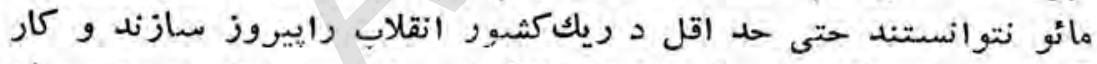

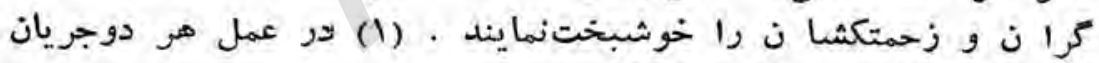

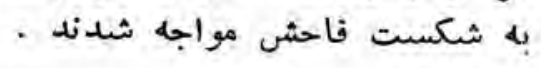

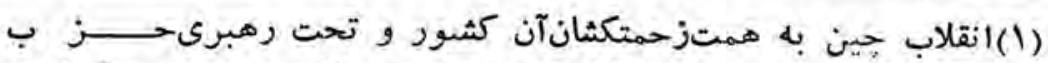

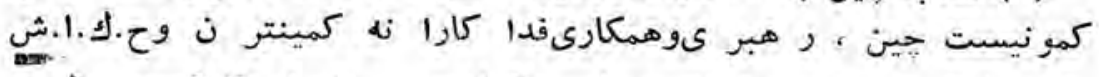

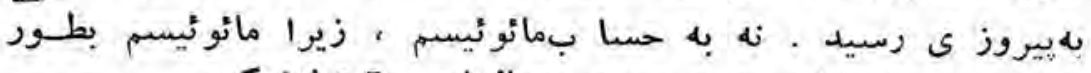

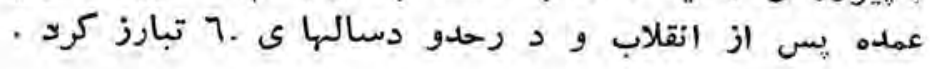




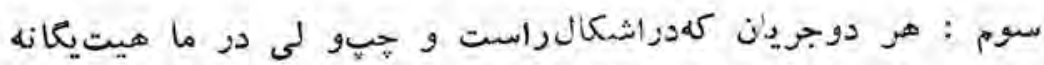

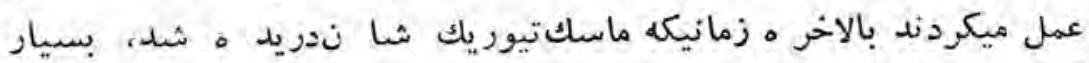

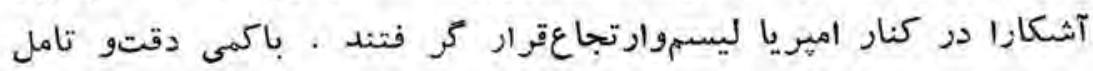

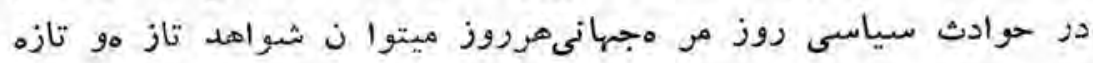

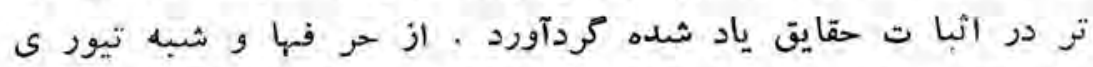

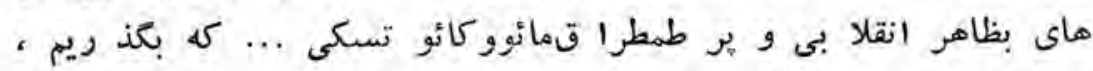

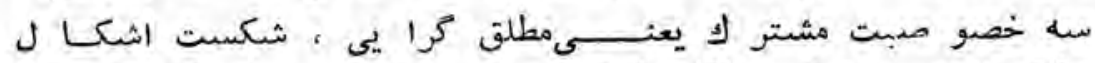

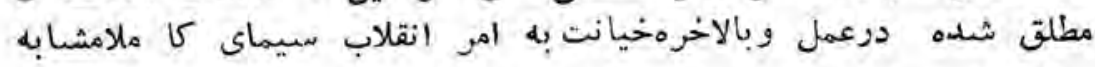

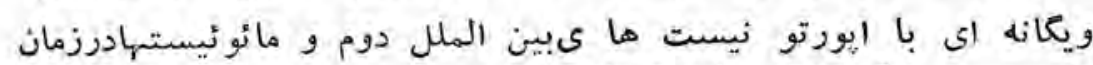

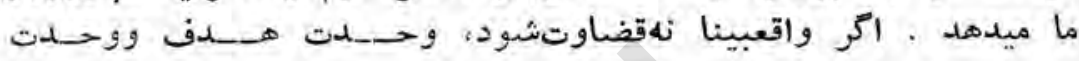

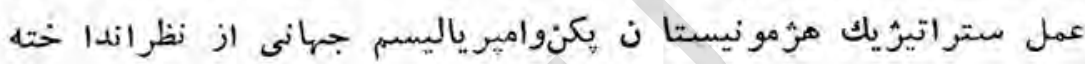

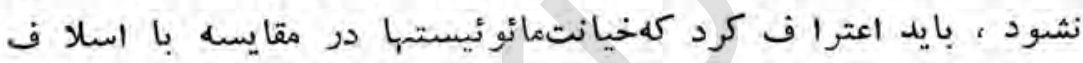

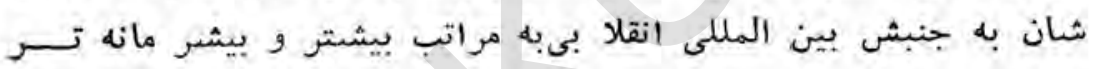

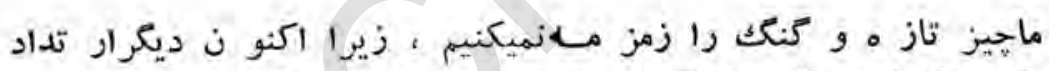

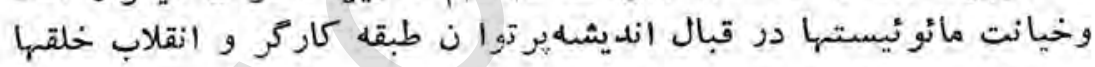

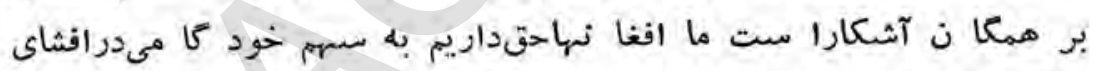

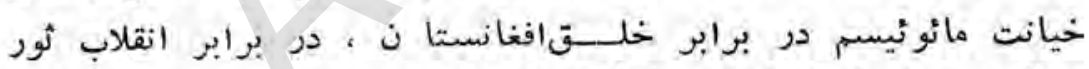

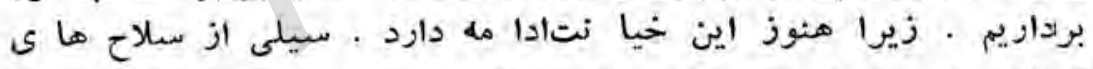

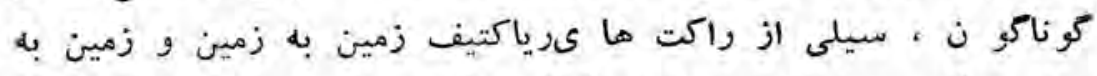

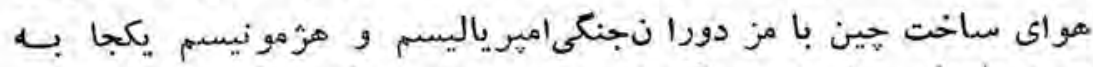

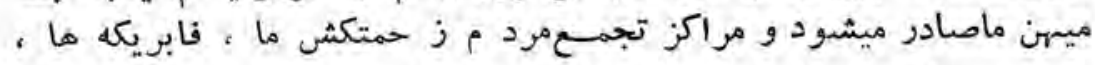

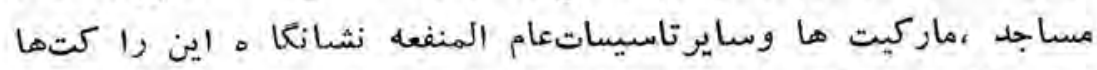

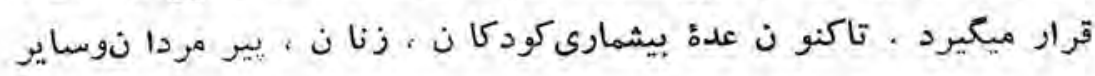


افراد بيدفا ع باثر استعمال راكتهاى مركبا ر هينى به آتش و خون كشبيد ه شدهاند · به ممين مناسبتما دنبا له ائه اين مقاله رابه طورمشخص

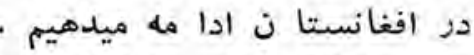

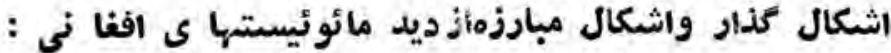

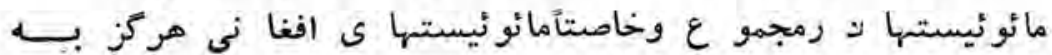

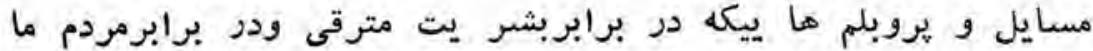

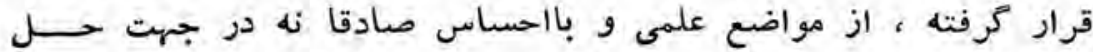

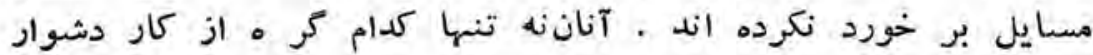

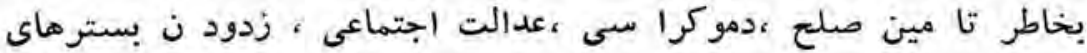

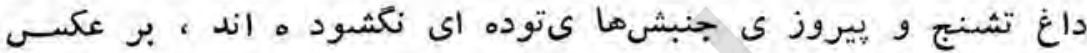

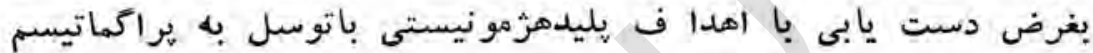

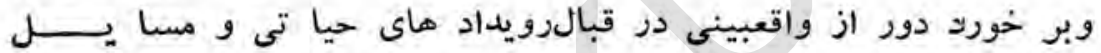

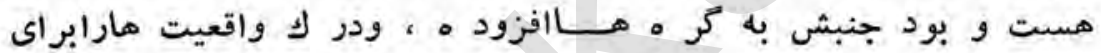

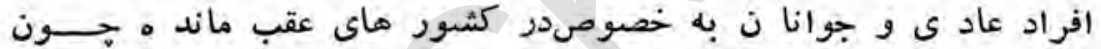
كشور ما دشوار تر سا خته اند مائوئيستها در اكثر مسايل عمديدة ستراتيز ى و تاكتيك مبارزا تــــبقه كاركر برنا مه واهداف روشن

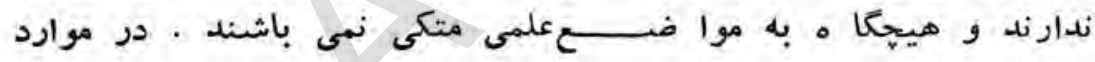

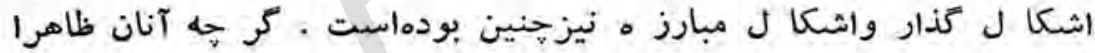

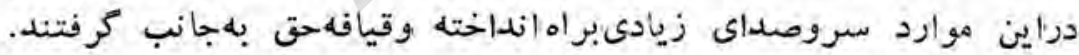

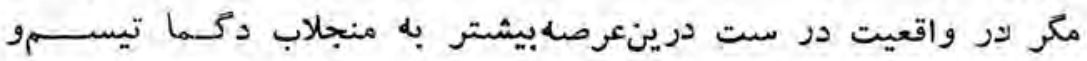

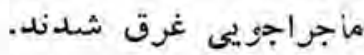

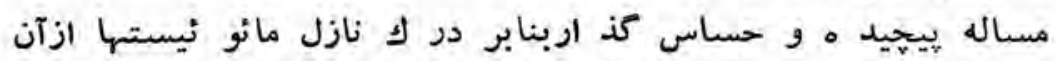

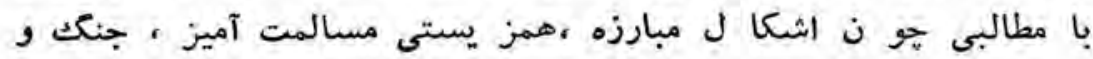


مسلح حز آميخته و بشكل سحرآميزومو هو مى در آمده است ." مائو-

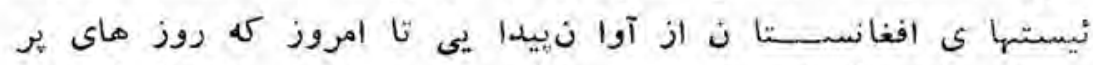

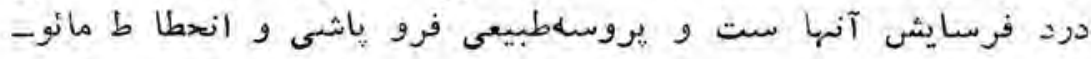

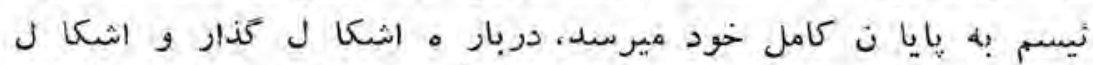

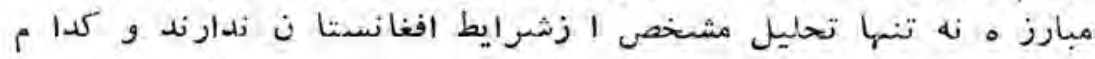

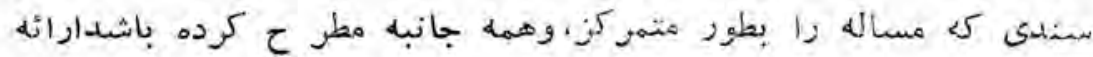

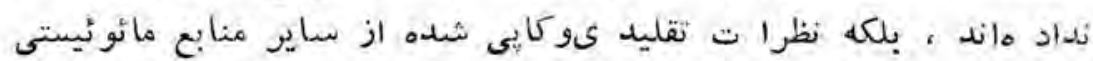

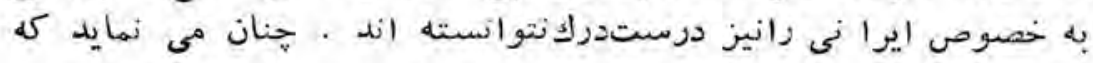

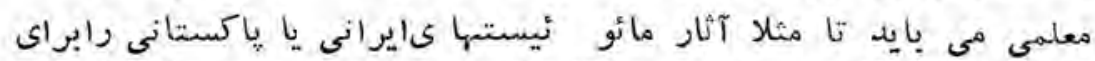

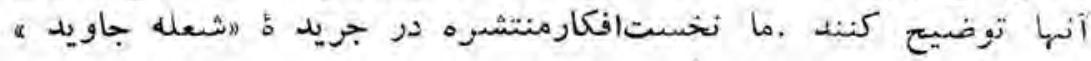

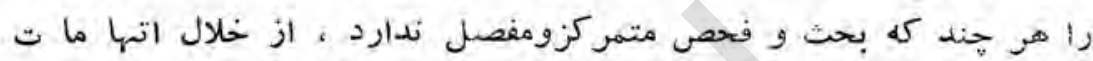

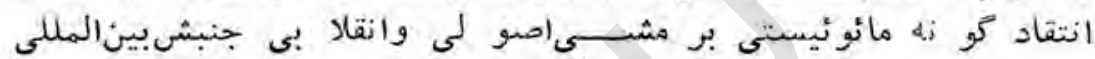

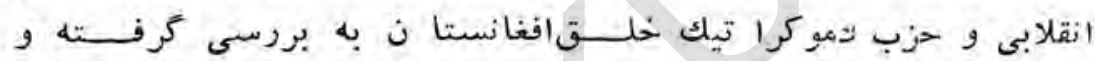

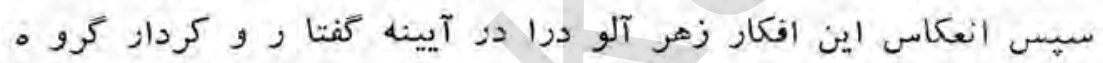

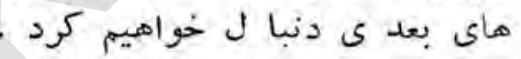

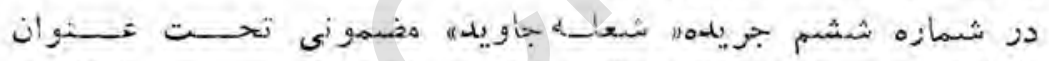

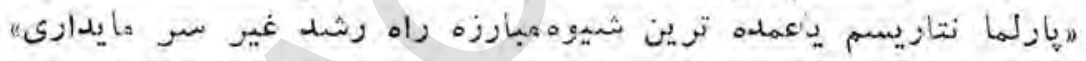

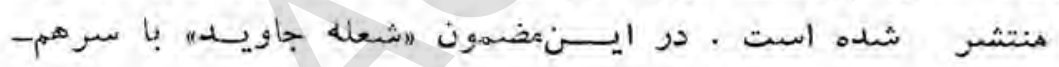

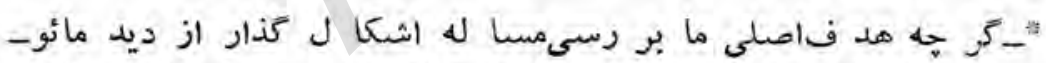

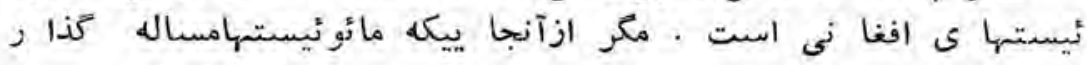

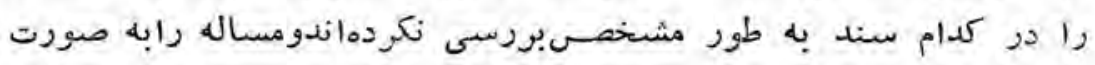

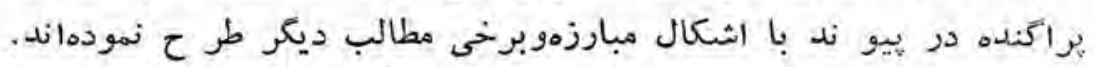

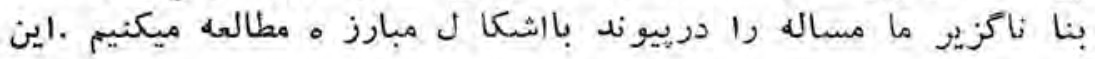

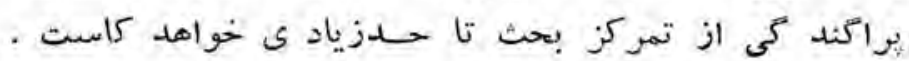




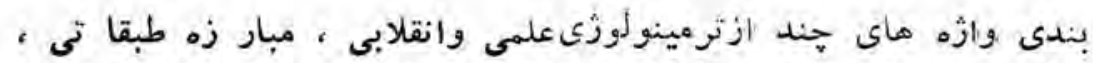

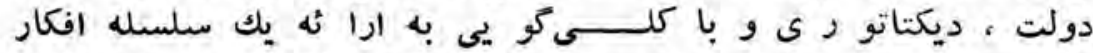

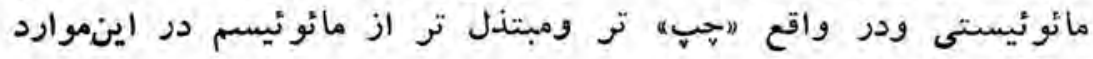

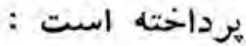

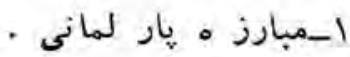

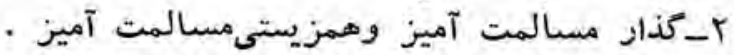

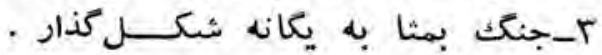

\section{مبارزة يار كمانى :}

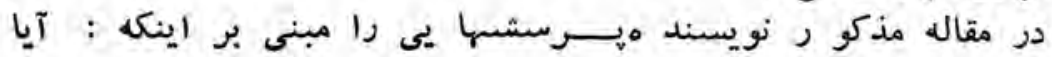

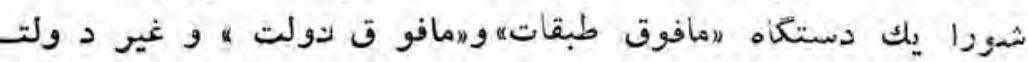

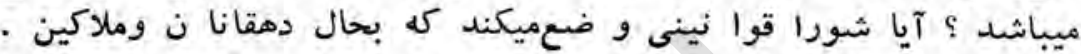

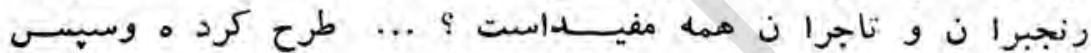

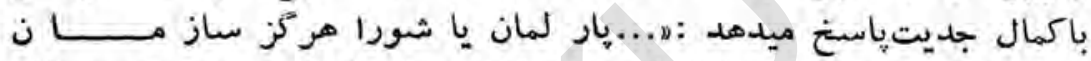

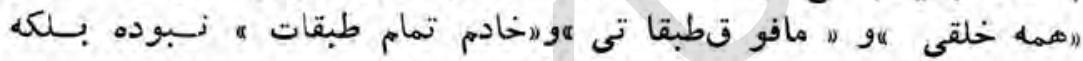

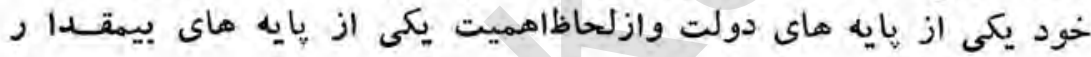

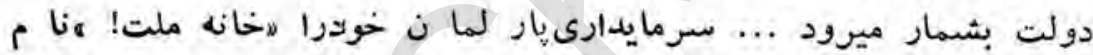

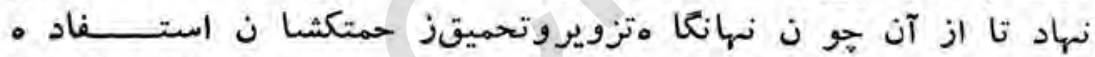

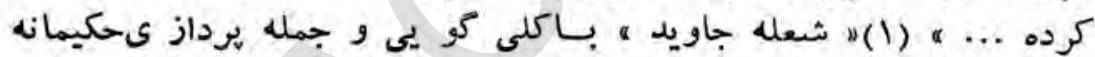

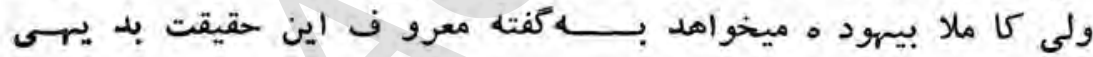

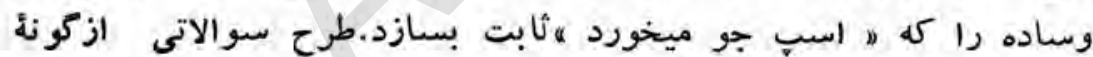

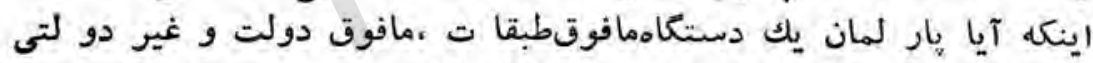

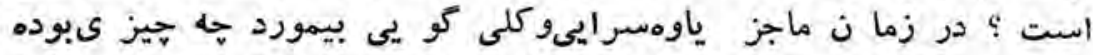

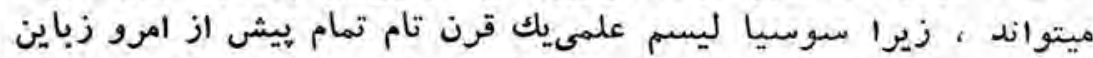

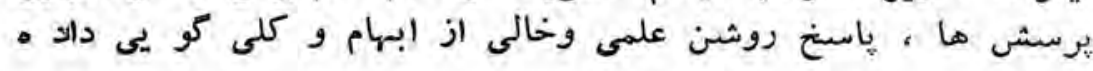

(1)(شعله جاويد ها، شـما ر مششم ،ص دوم - 


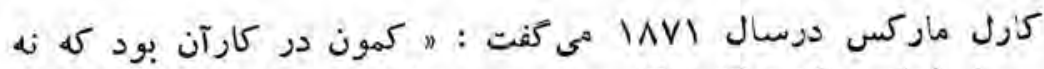

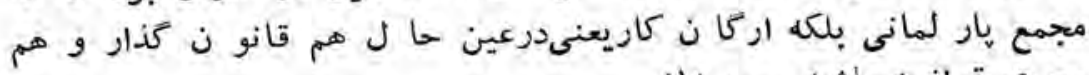

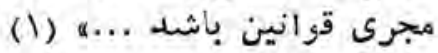

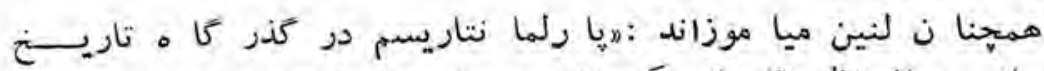

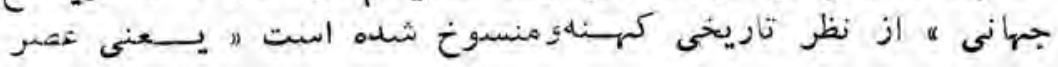

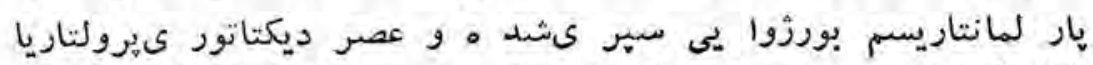

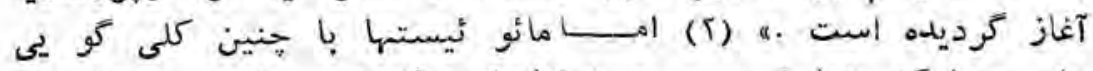

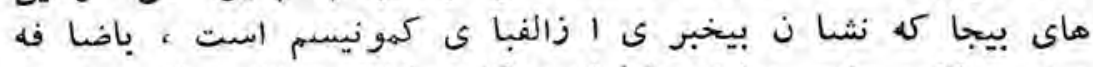

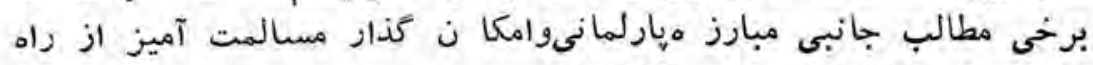

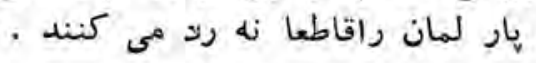

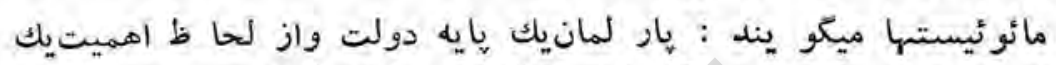

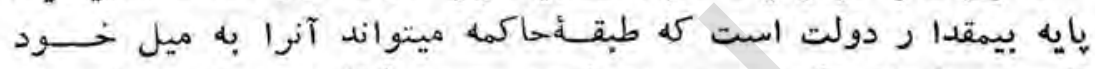

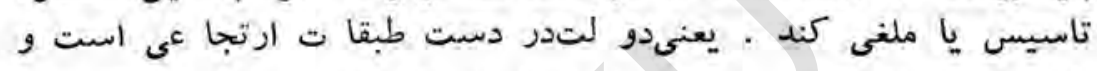

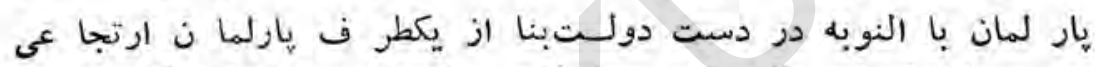

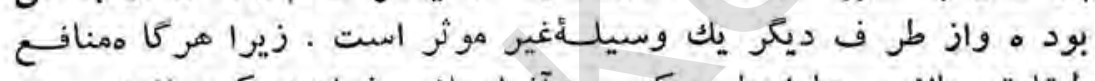

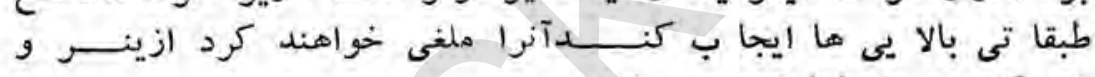

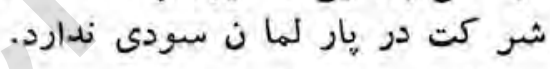

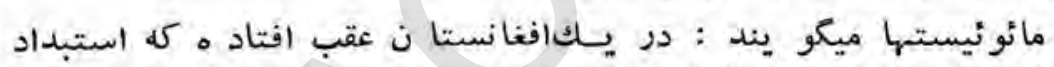

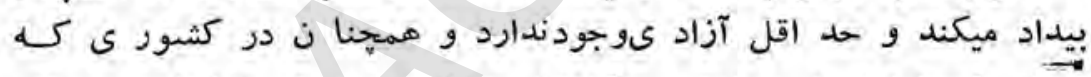

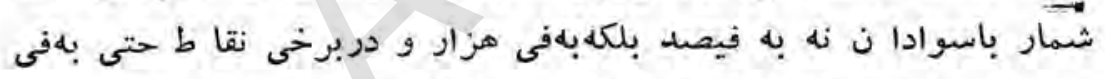

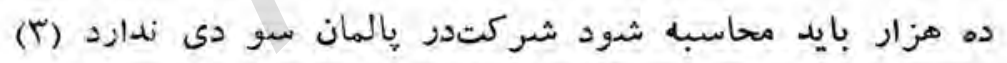

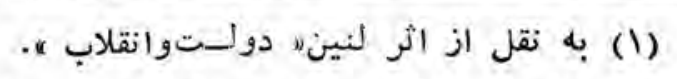

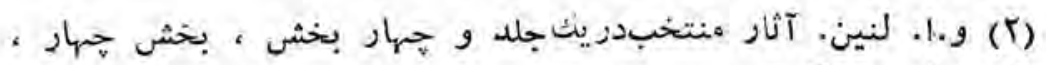

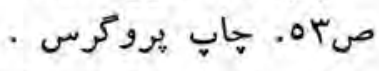

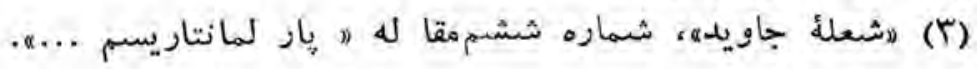


بالاخره مهم ترين بر مان تيور يكنفى مبارز م مار لمانى سه سال بعد

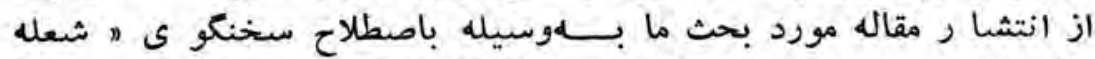

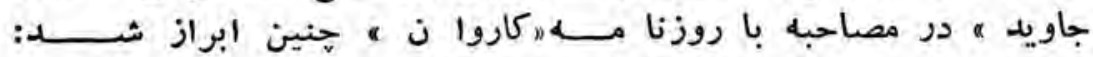

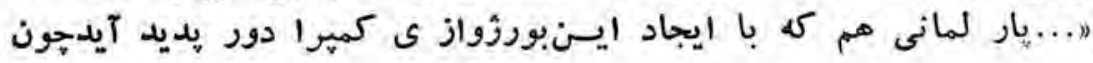

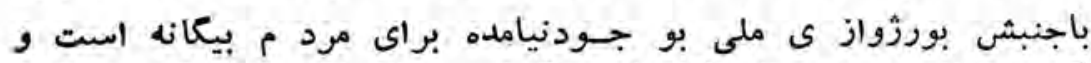

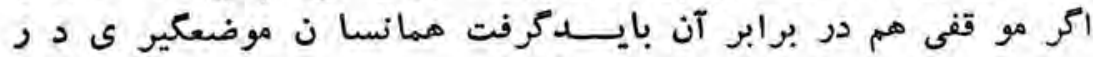

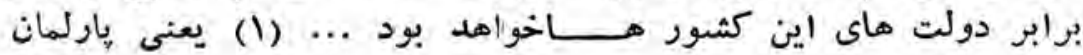

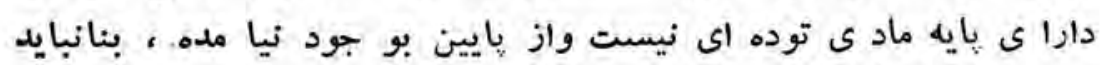

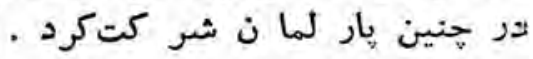

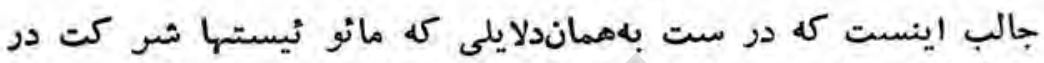

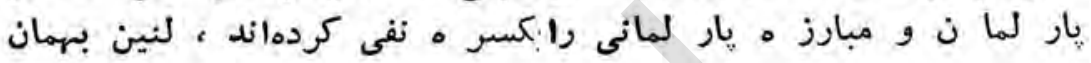

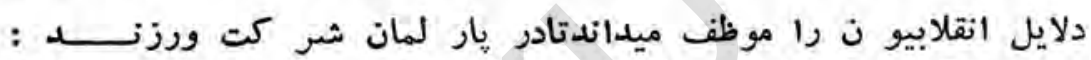

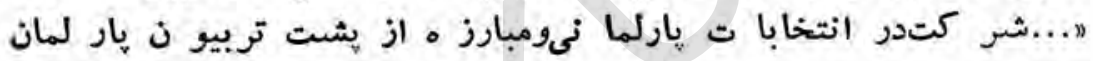

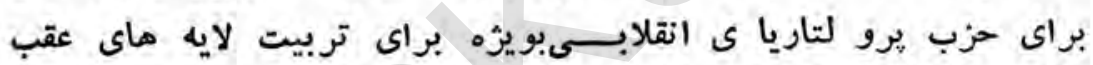

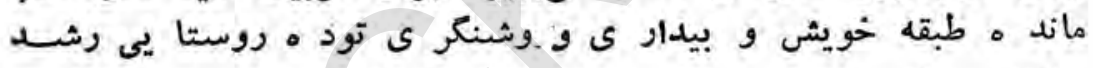

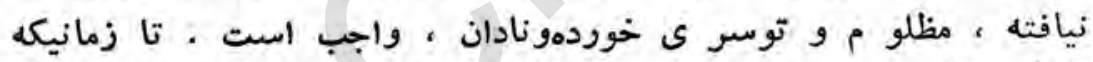

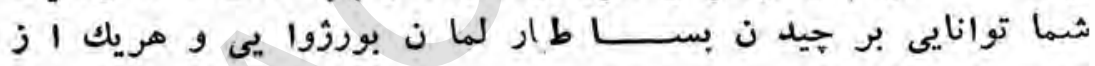

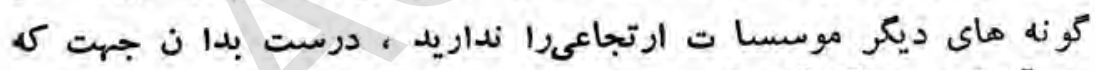

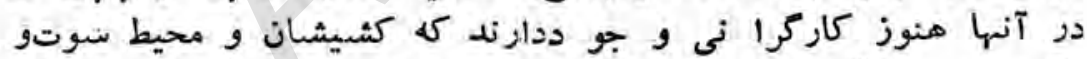

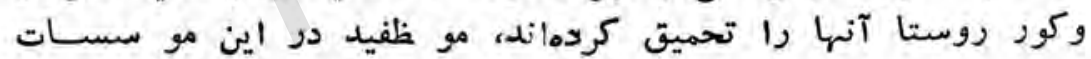

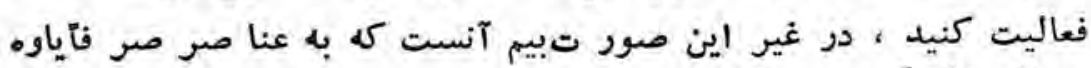

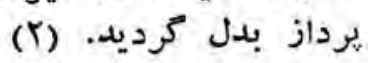

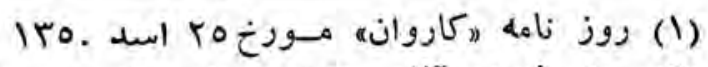

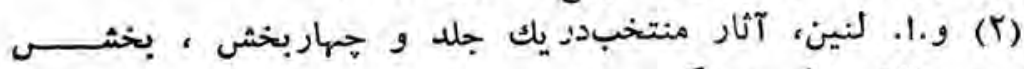

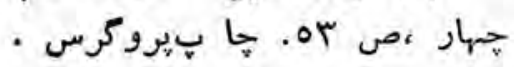




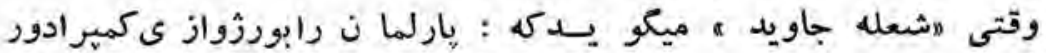

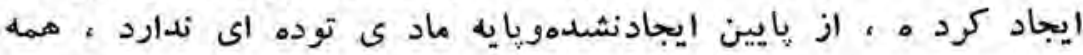

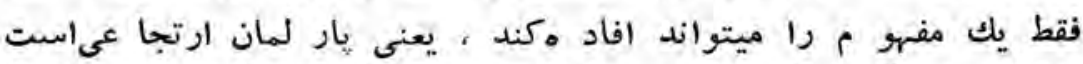

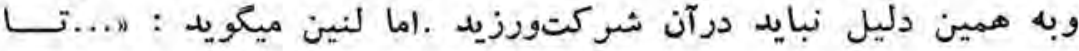

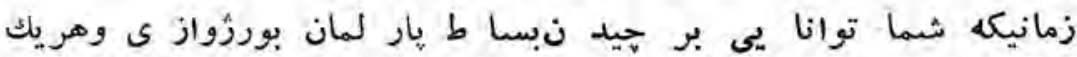

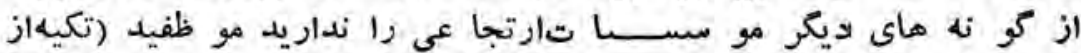

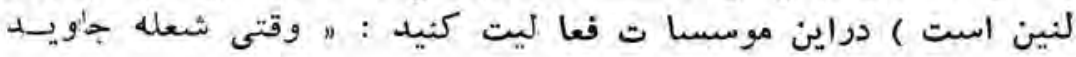

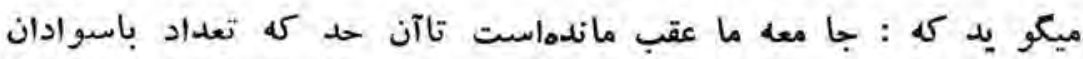

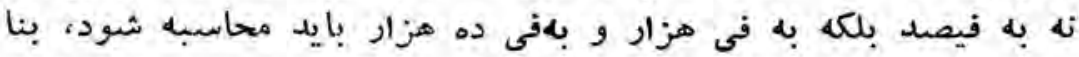

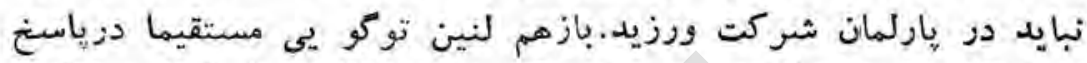

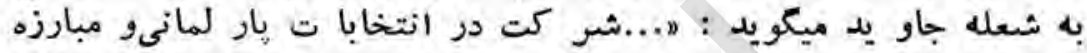

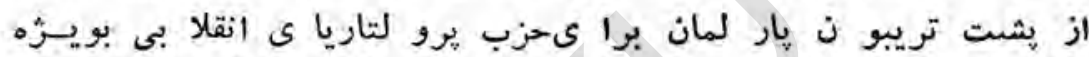

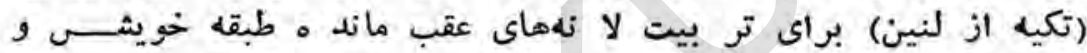

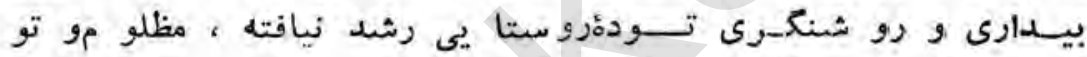

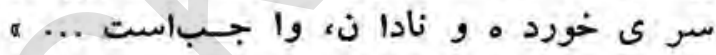

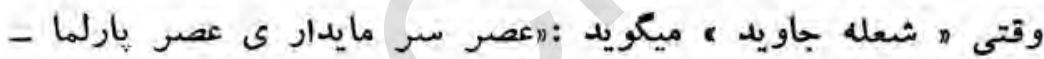

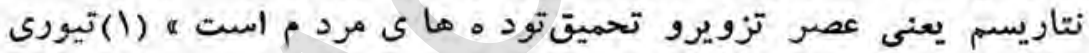

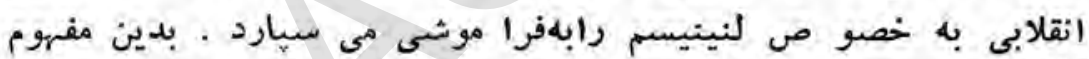

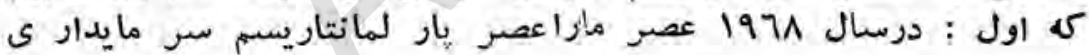

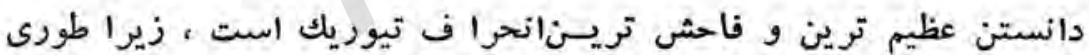

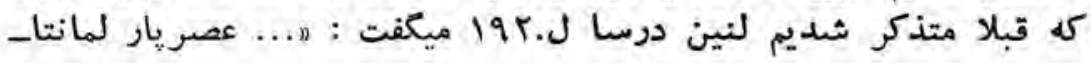

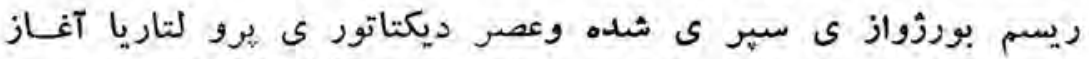

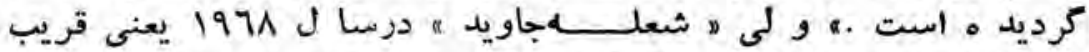

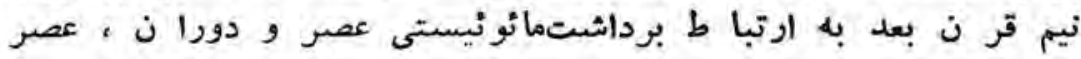

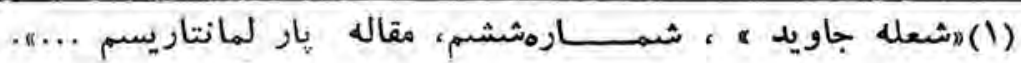




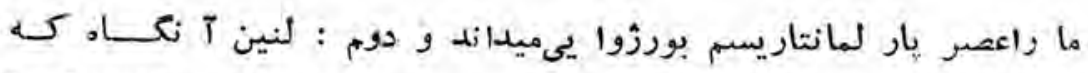

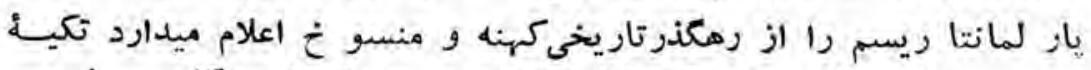

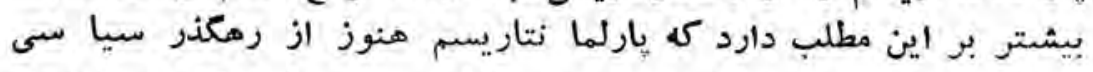

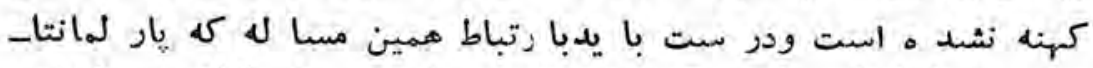

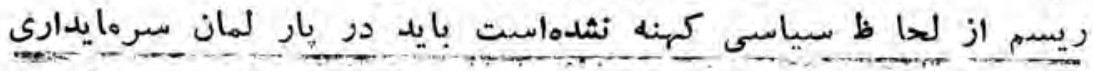

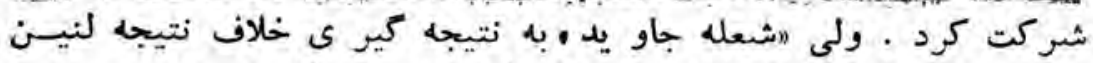

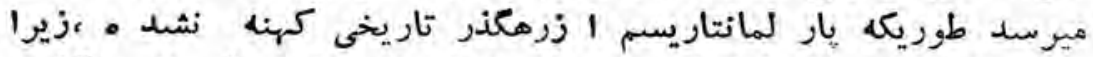

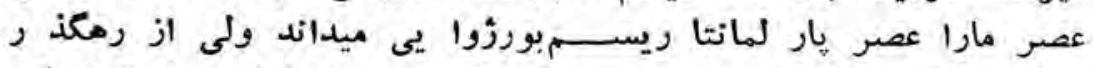

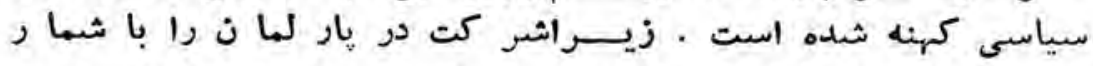

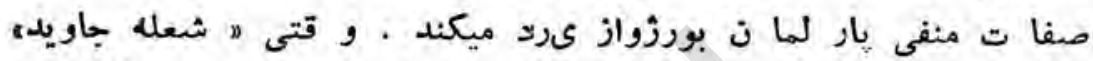

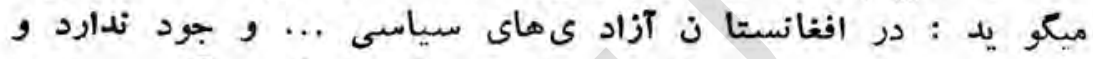

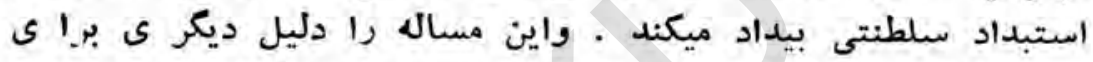

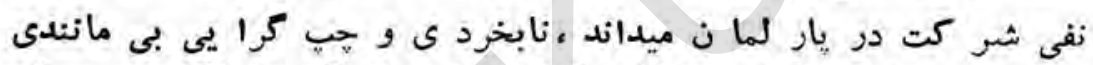

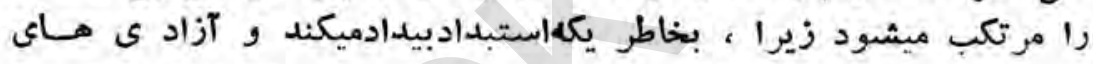

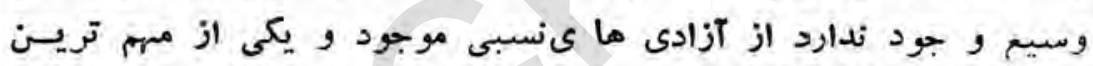

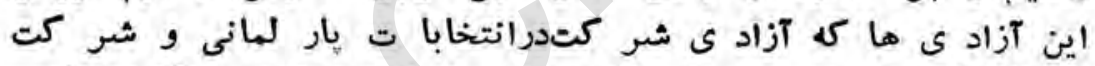

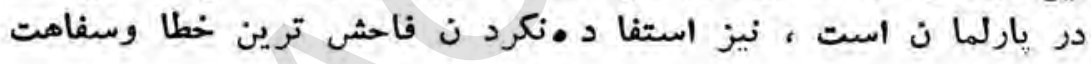

\section{انكلس در بار ه اهميت مبارز •يار لهانى و مبارز ه علنى مينويسد:}

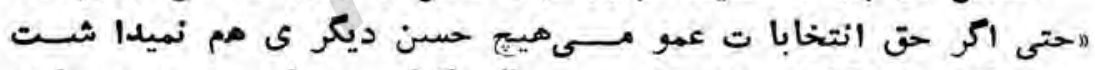

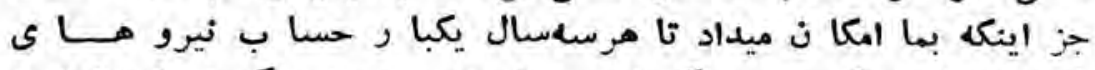

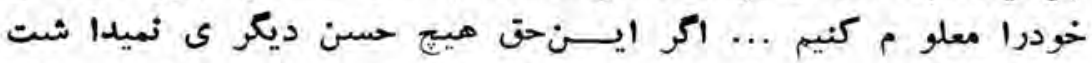

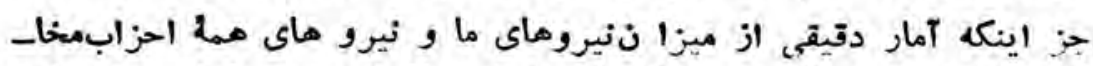

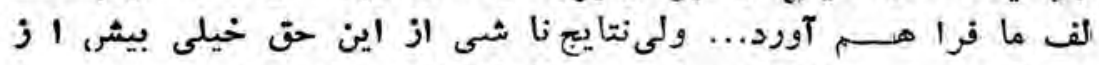

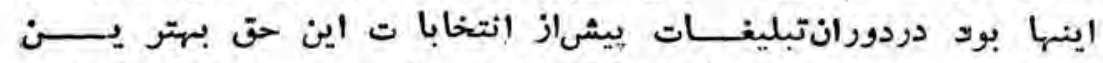

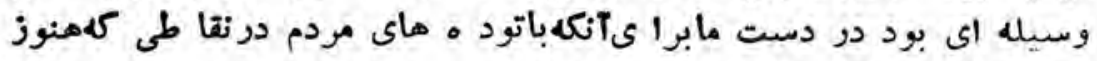




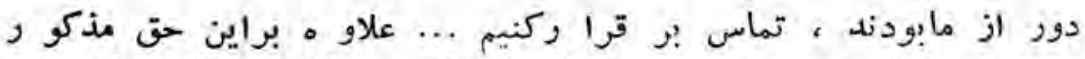

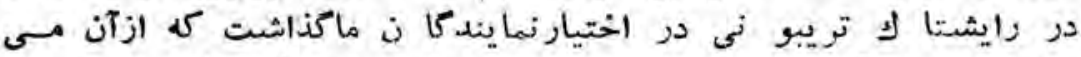

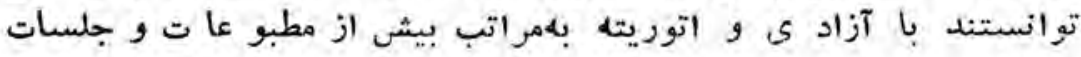

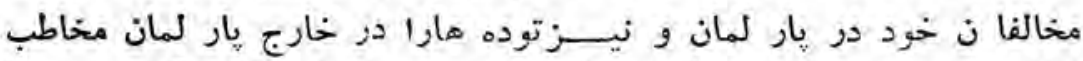

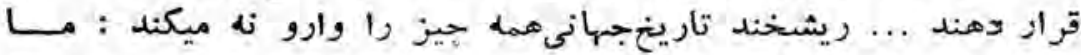

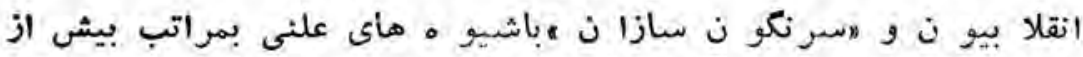

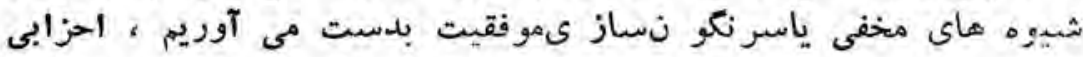

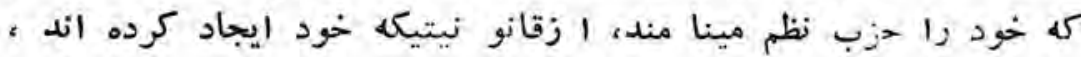

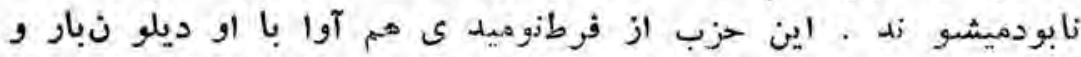

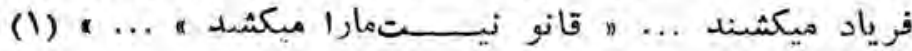

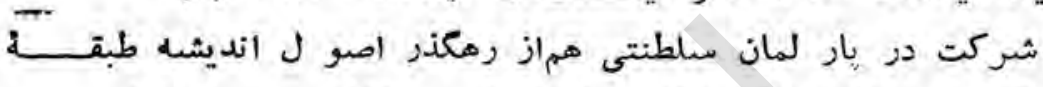

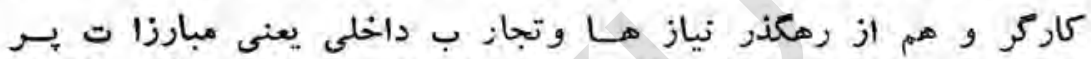

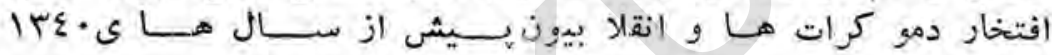

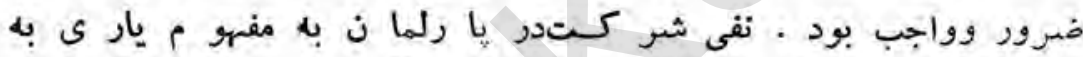

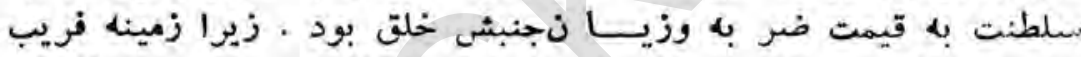

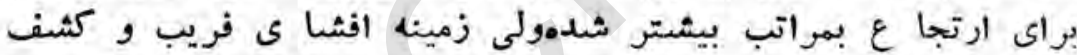

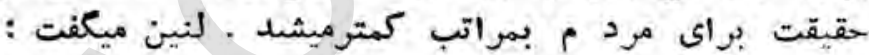

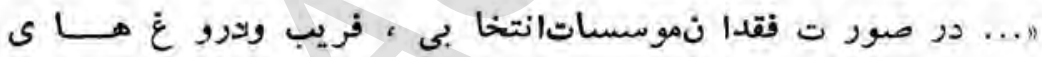

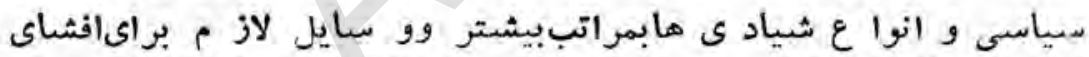

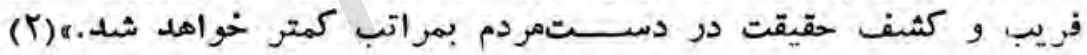

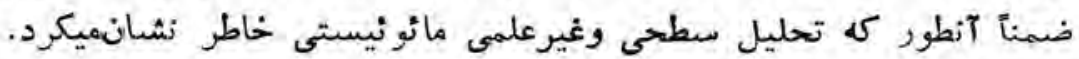

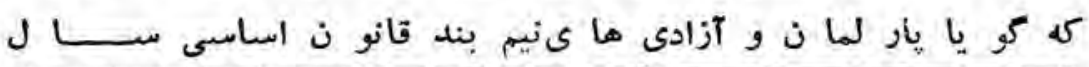

(1)ف. انكلس \# مقد ملهبر كتابماركس " مبارز ه طبقا تي درفرانسهي

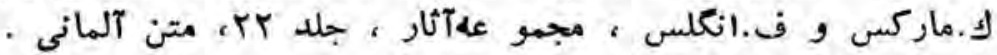

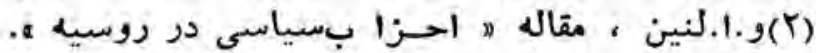




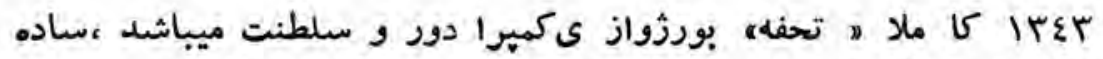

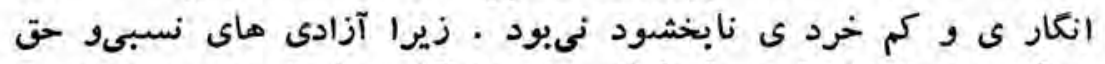

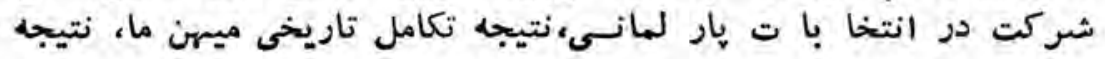

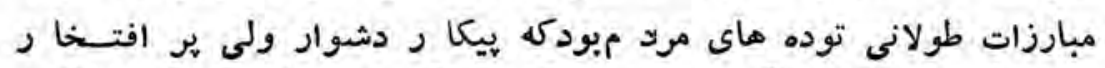

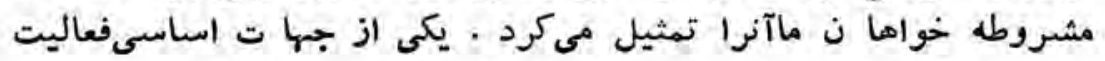

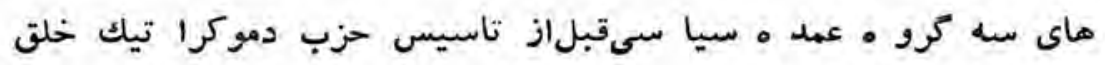

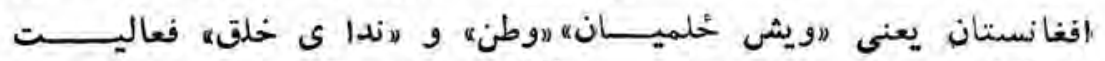

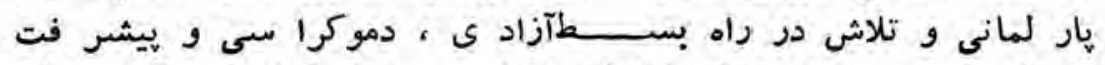

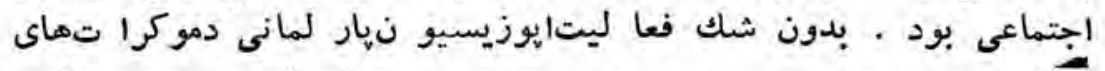

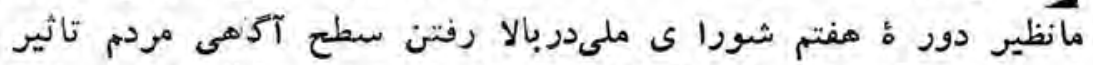

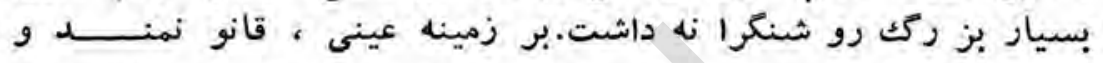

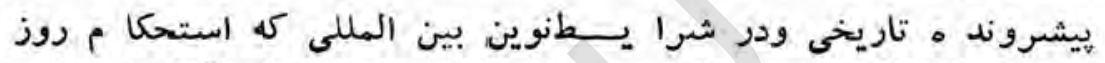

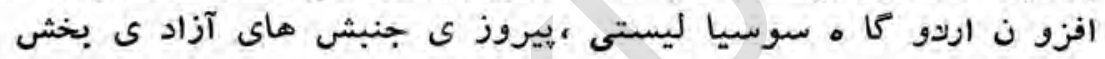

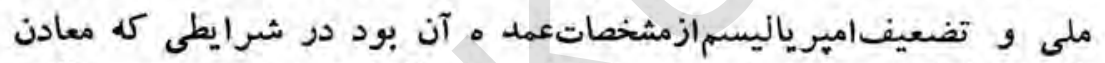

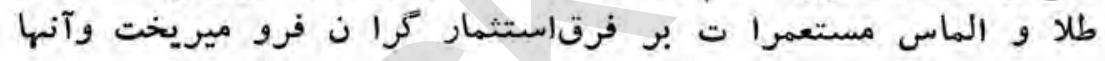

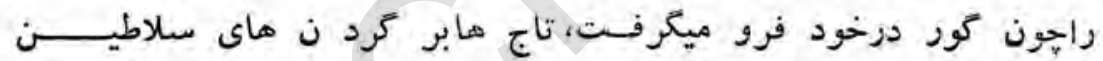

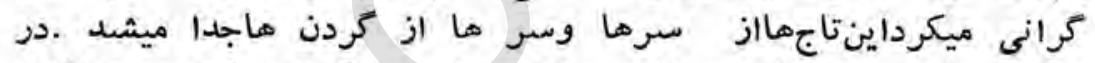

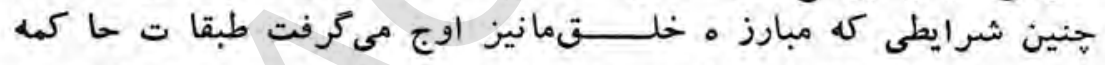

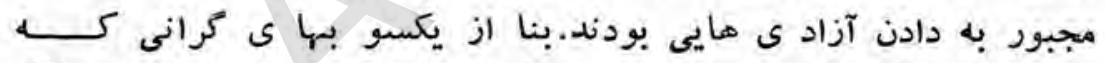

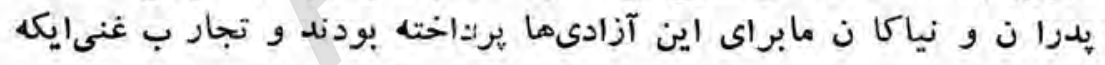

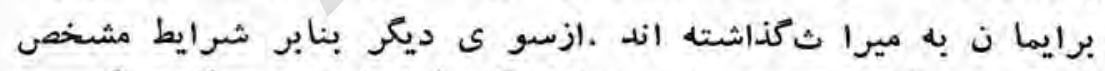

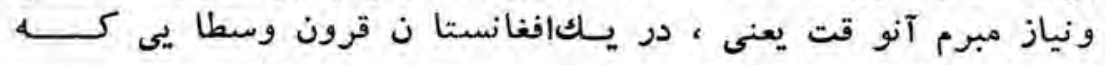

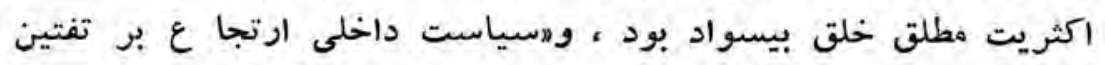

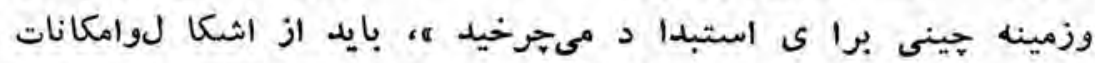

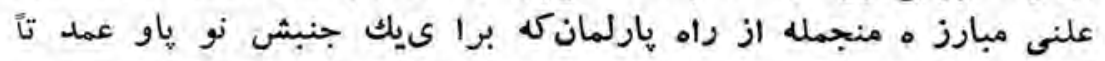




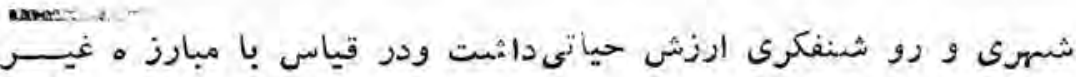

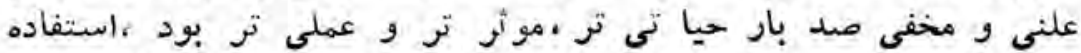

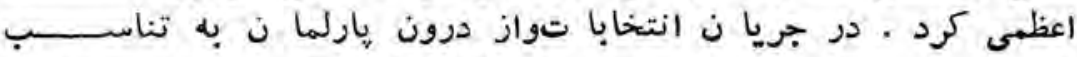

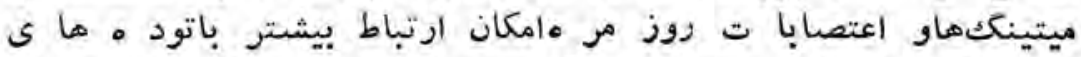

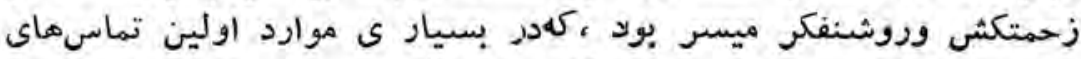

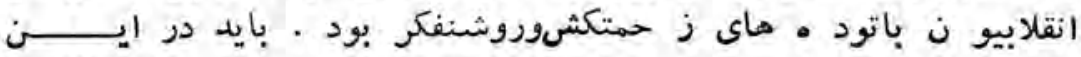

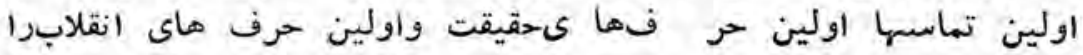
-1 : كفت : با الهام از ثيور ى انقلابى وبراساس تجار ب مبار مبارز ه ميار لمانى

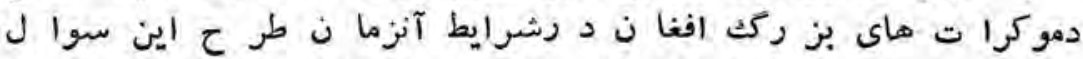

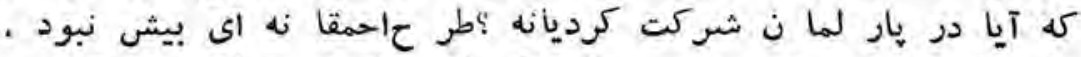

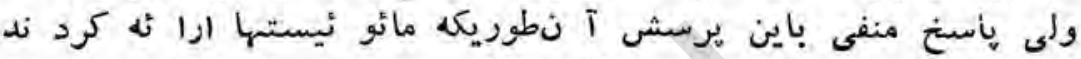

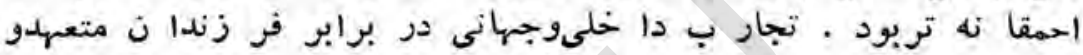

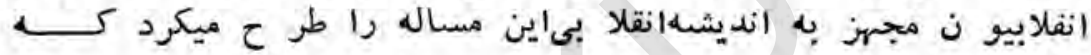

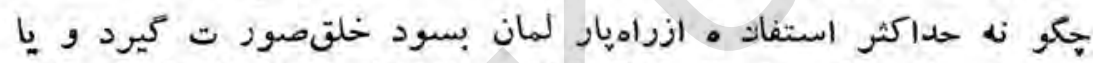

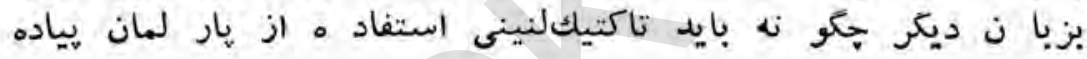

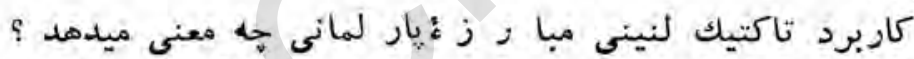

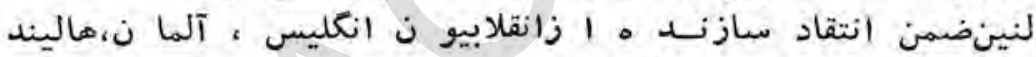

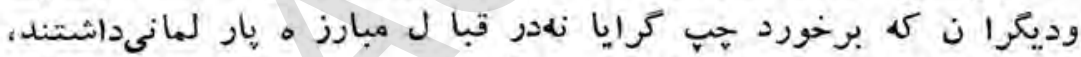

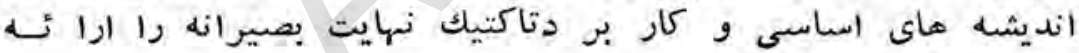

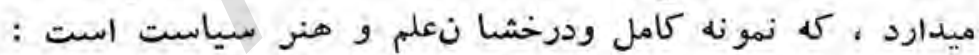

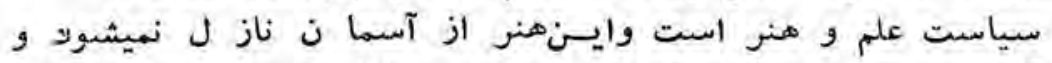

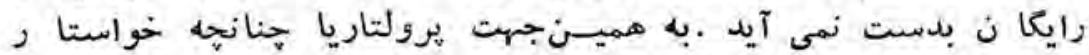

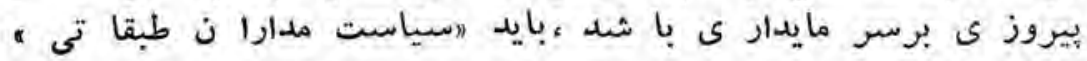

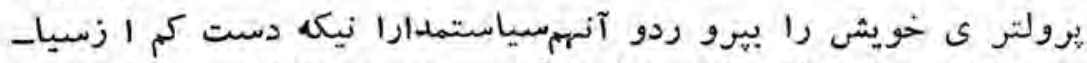

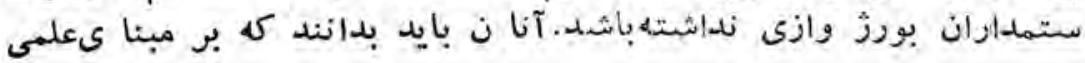


عمل كنند . وعلم خواستا ر آنستك اول تجربه كثبور هأي ديكريب.

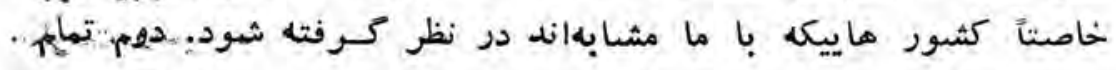

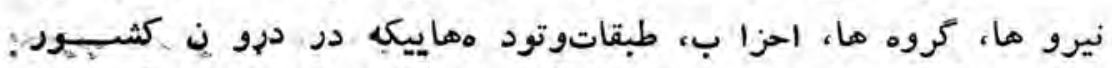

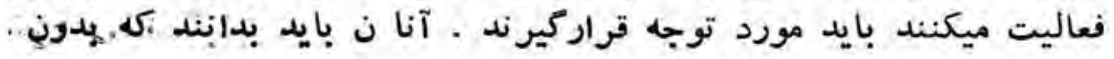

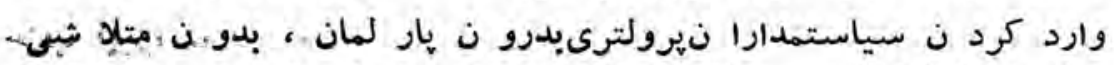

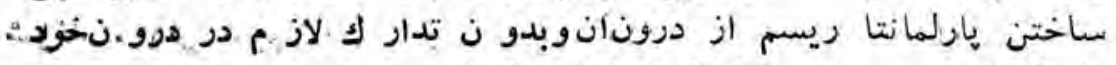

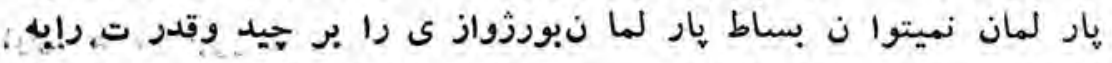

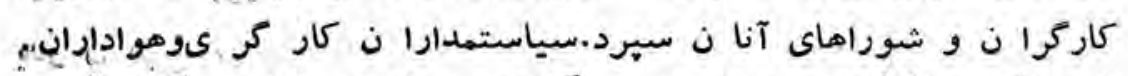

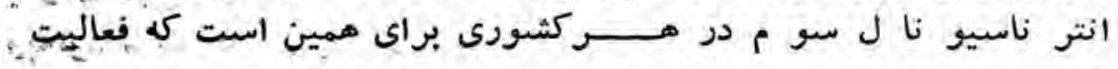

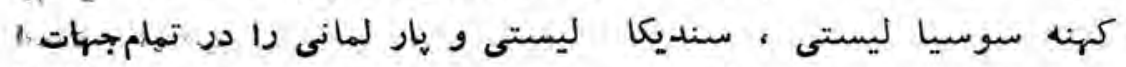

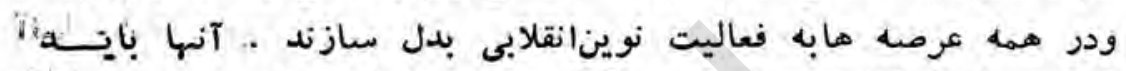

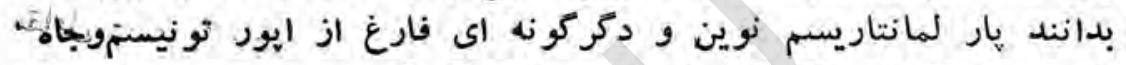

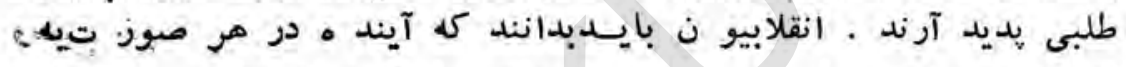

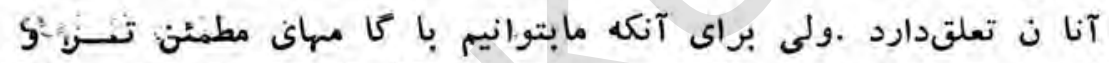

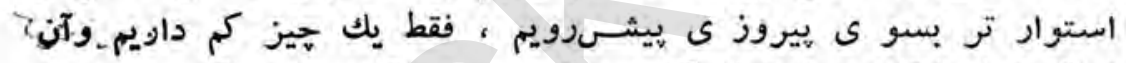

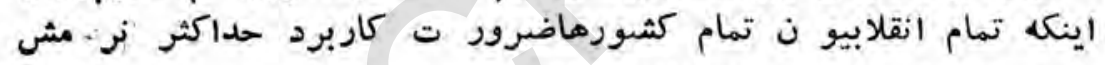

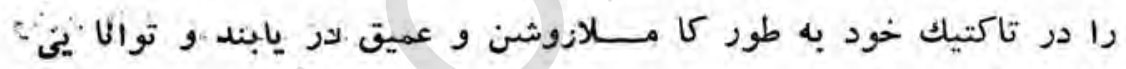

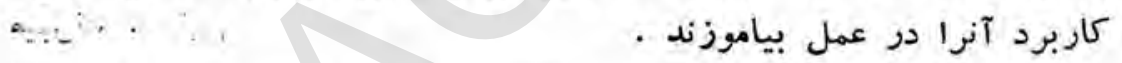

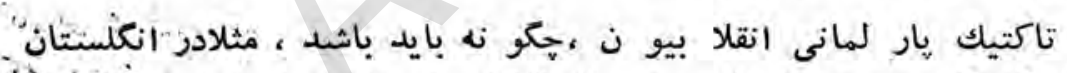

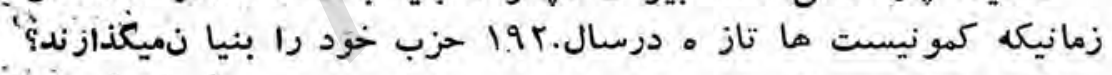

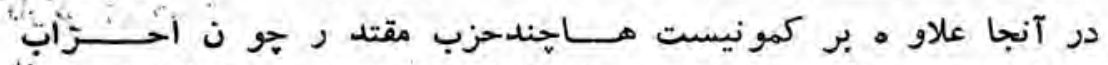

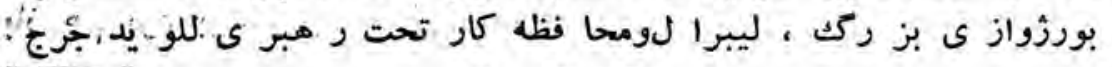

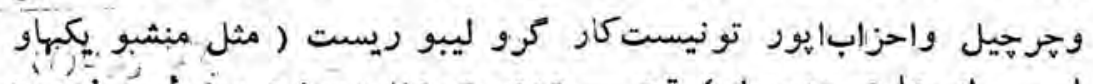

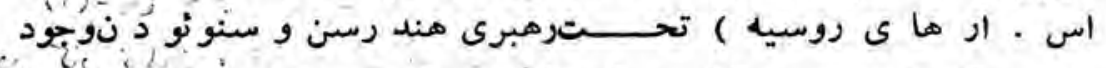

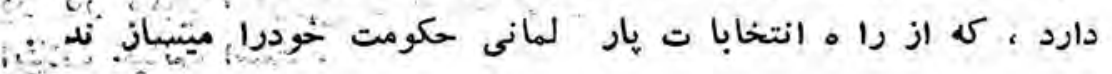


حزب ليبرال و محافظ كار اتحادىراعليه حزب كاركر تشكيل دادهوبه

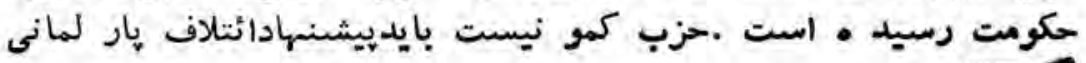

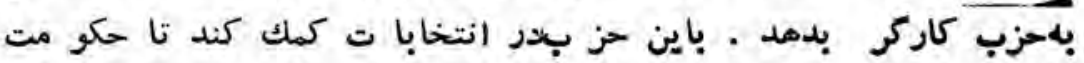

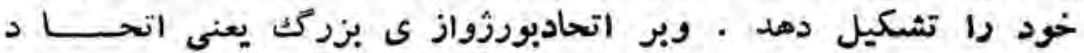

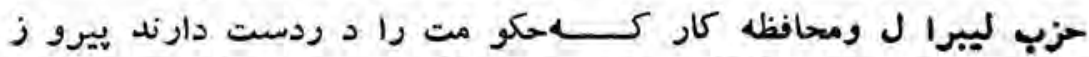

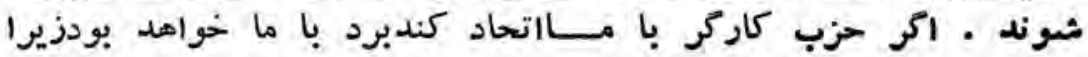

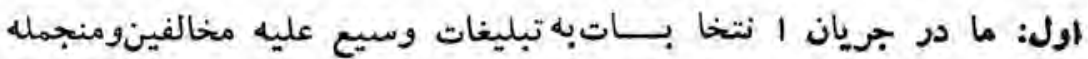

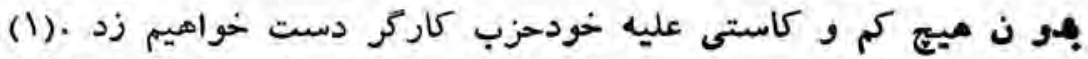

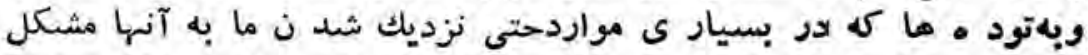

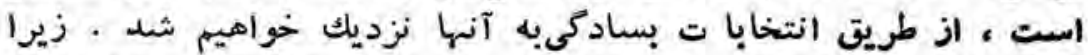

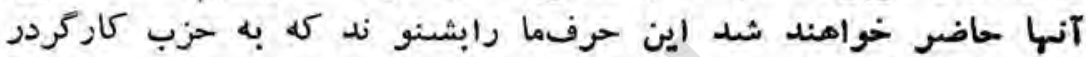

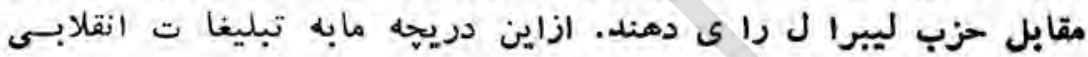

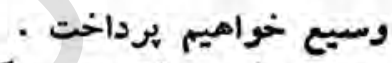

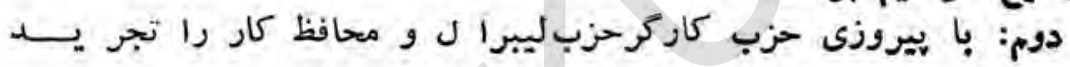

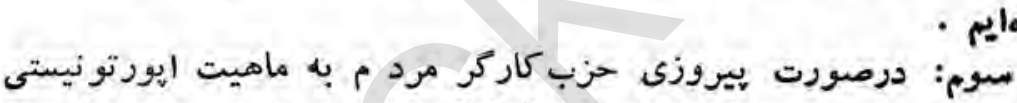

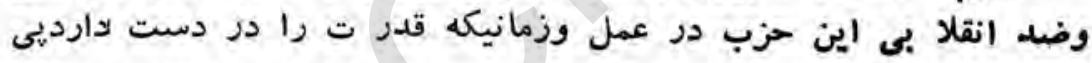

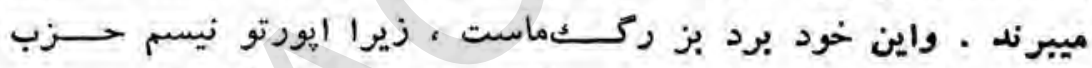

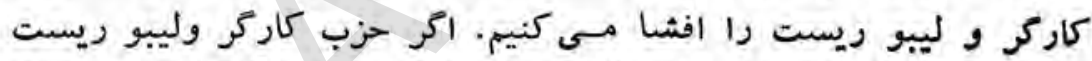

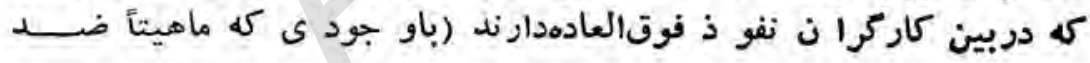

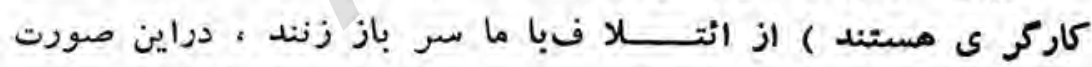

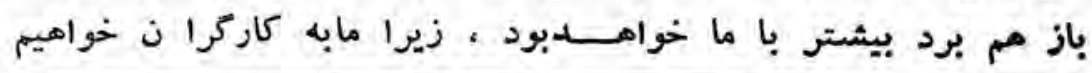

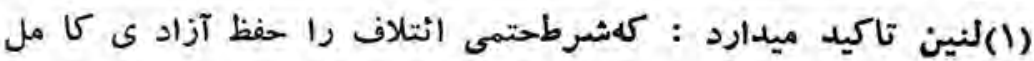

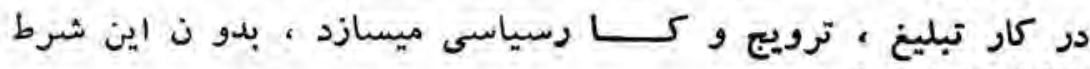

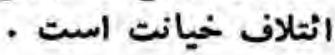




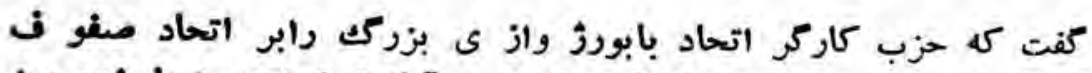

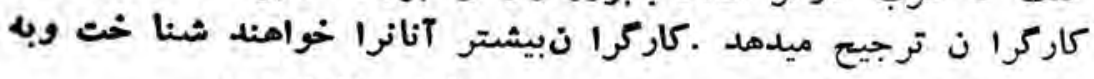

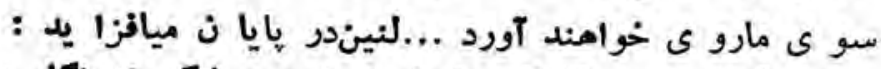

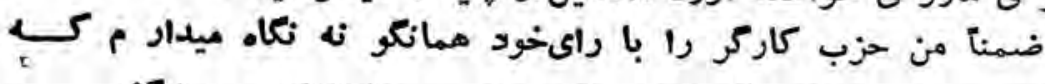

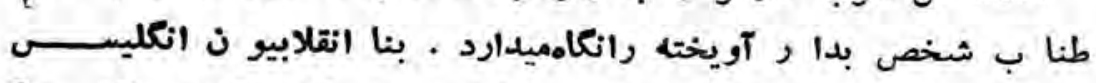

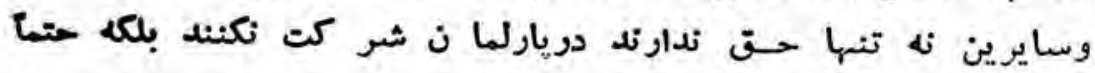

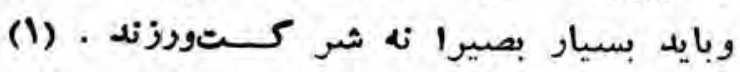

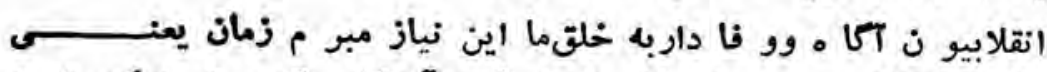

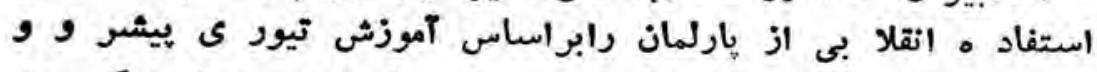

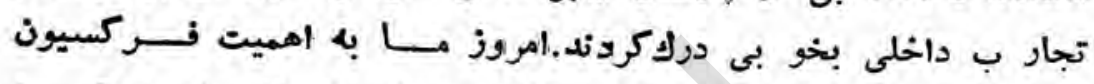

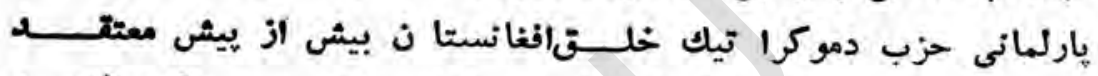

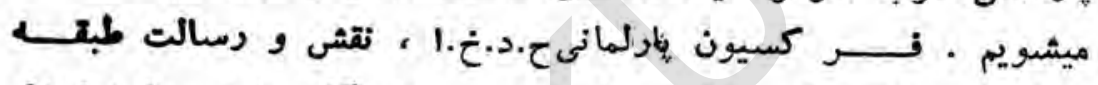

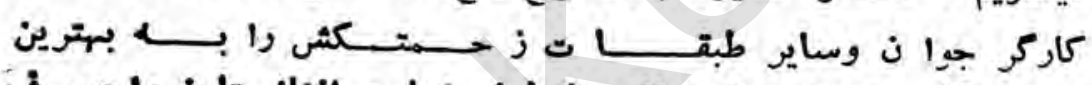

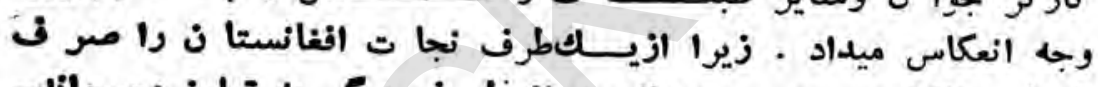

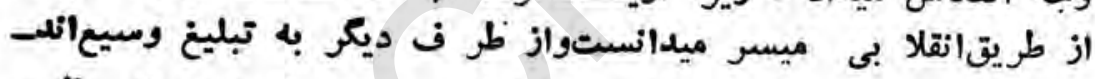

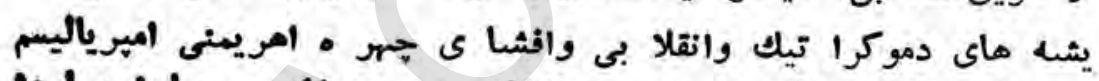

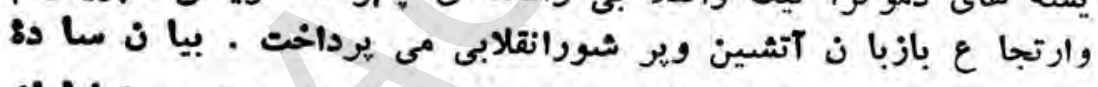

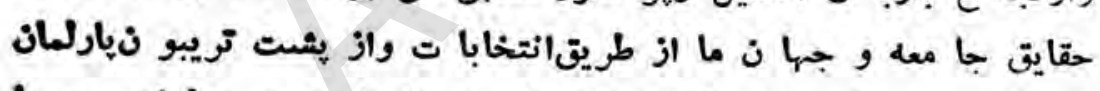

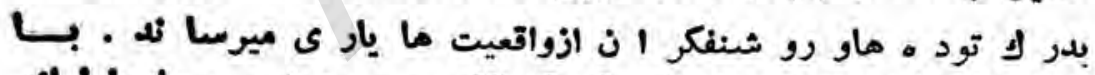

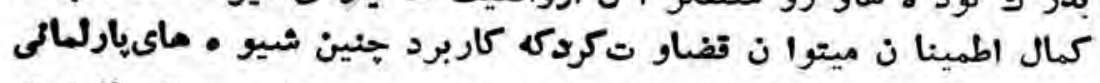

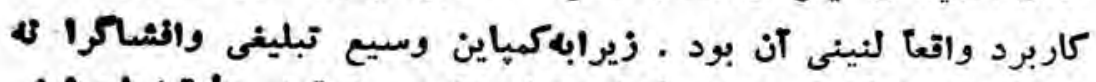

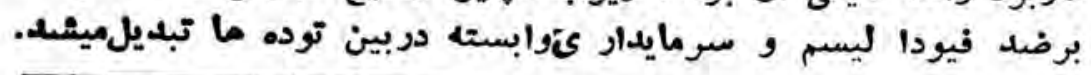

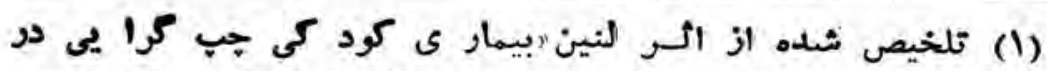

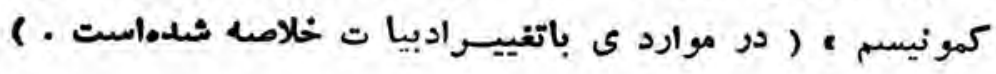




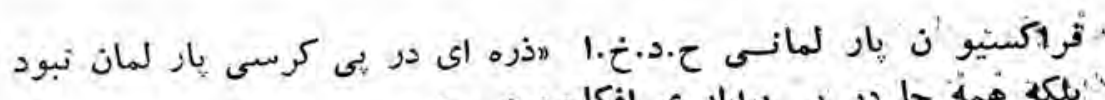

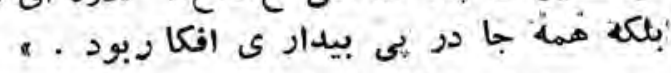

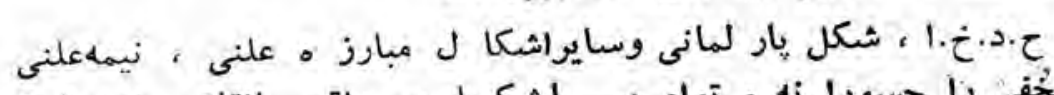

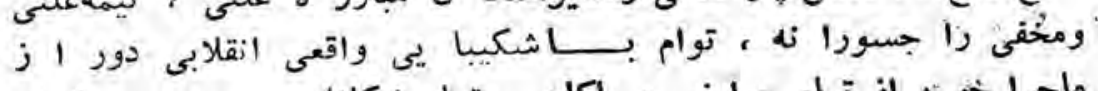

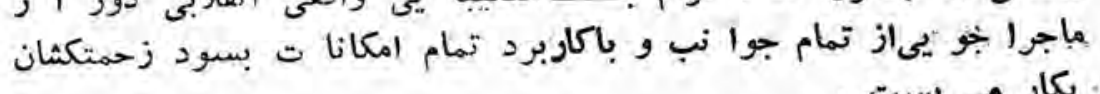

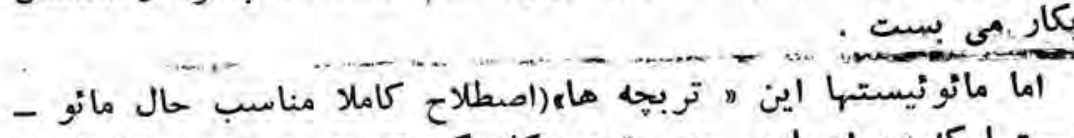

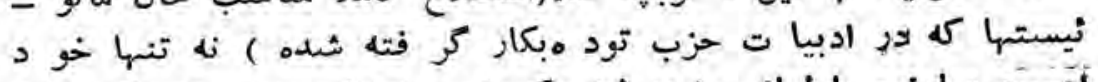

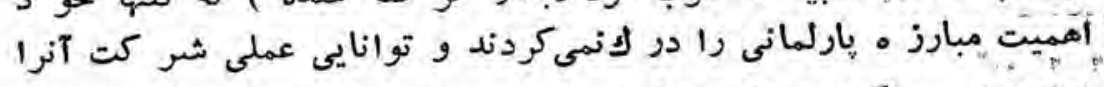

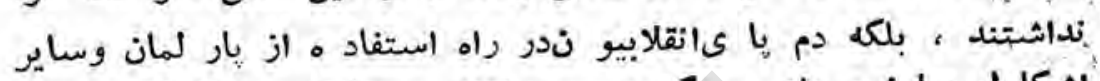

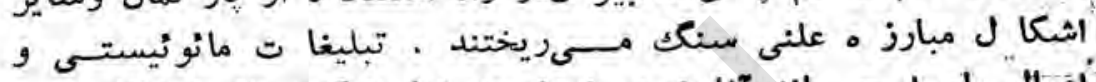

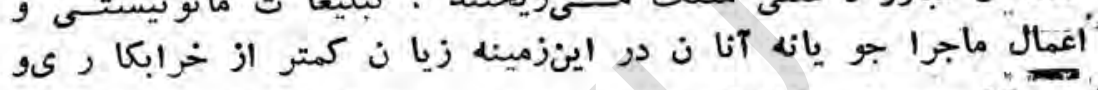

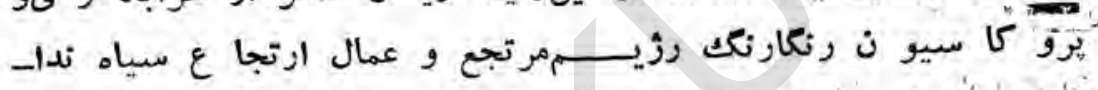

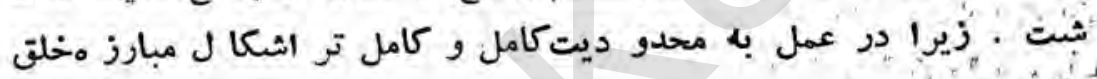

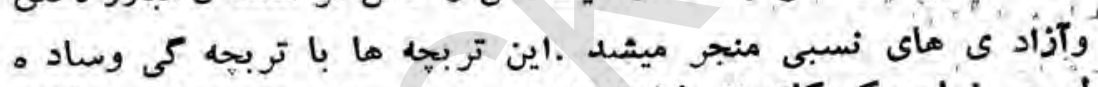

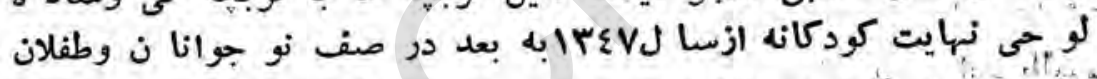

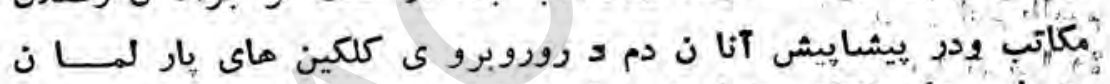

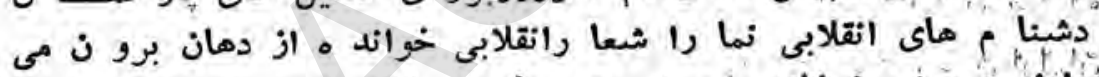

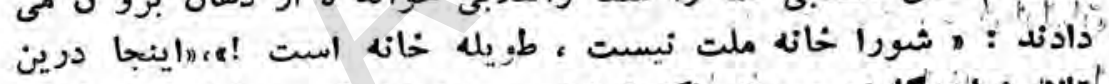

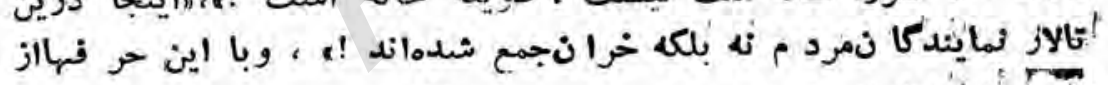

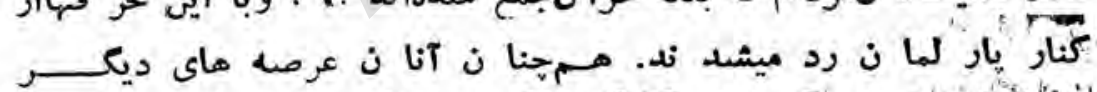

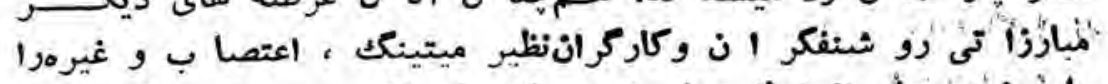

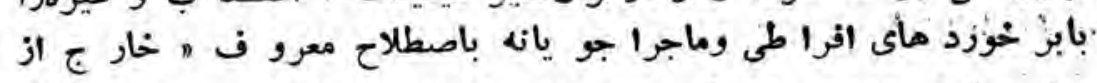

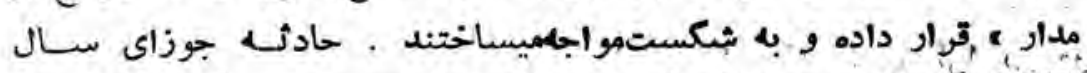
وعV

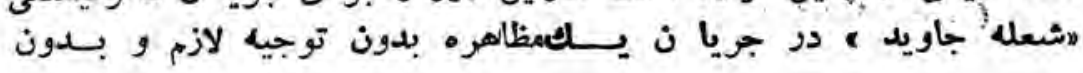

$$
-1 \cdot \varepsilon-
$$




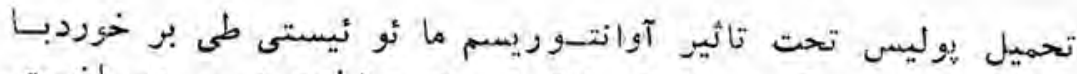

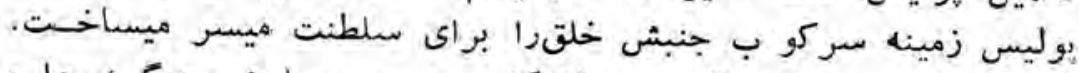

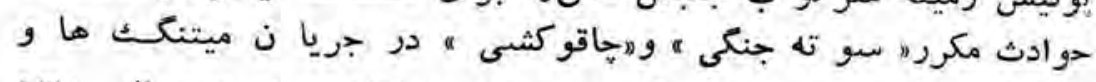

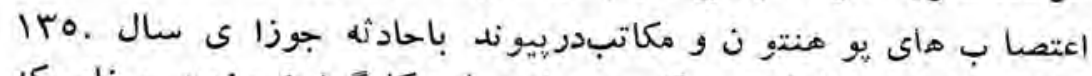

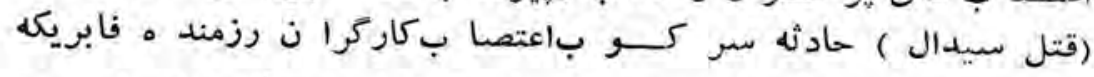

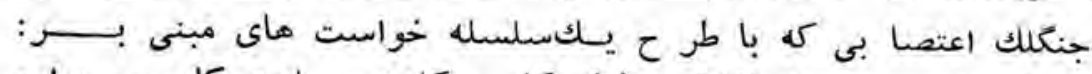

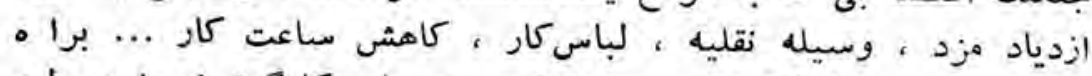

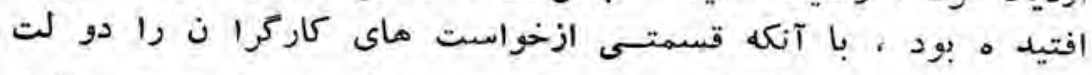

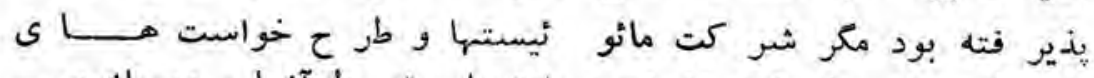

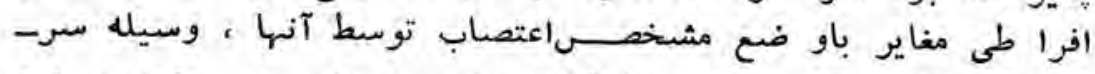

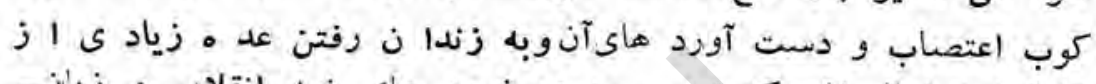

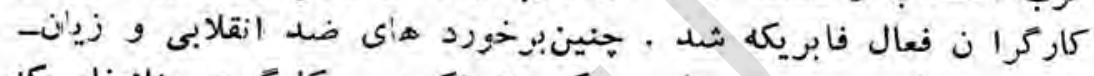

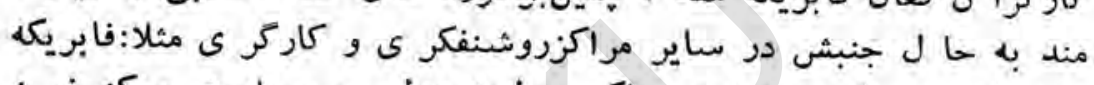

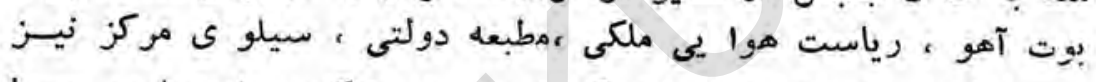

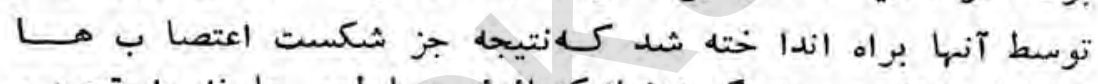

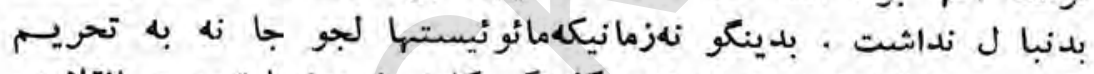

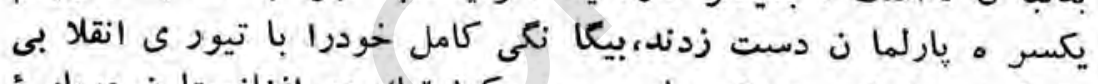

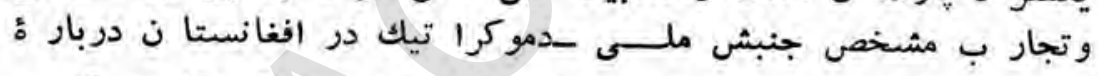

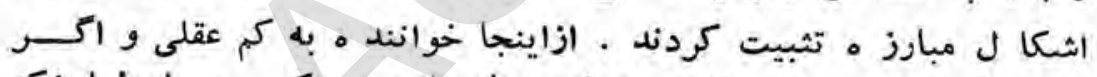

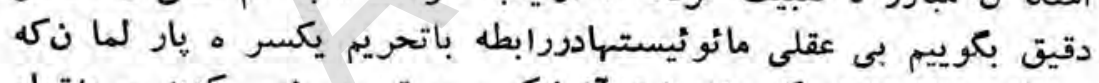

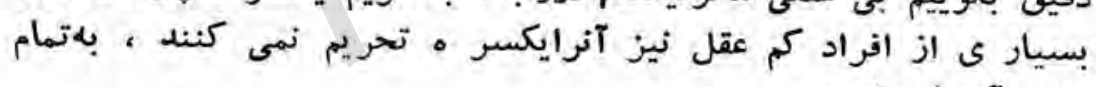

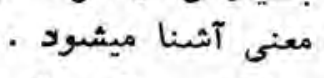

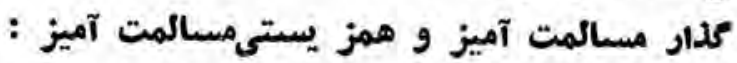

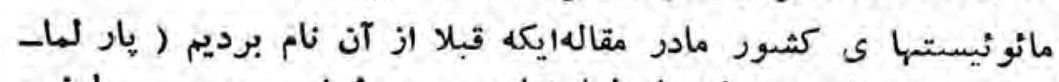

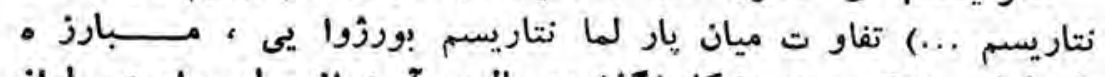

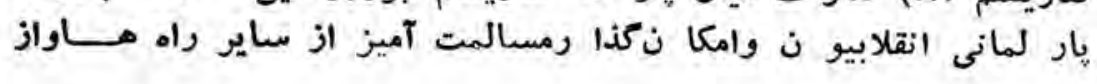

$$
-1 \cdot 0
$$




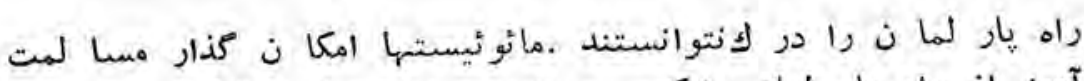

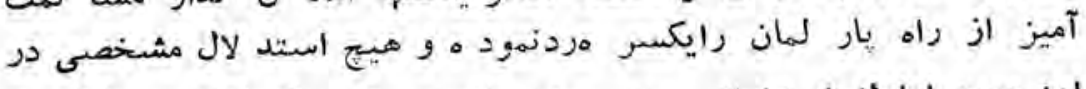

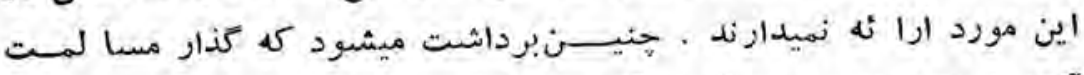

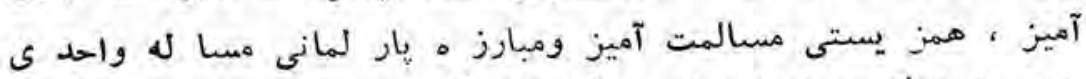

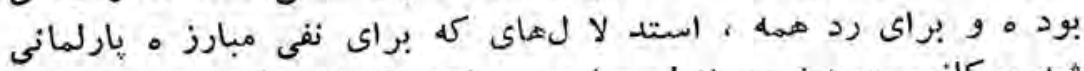

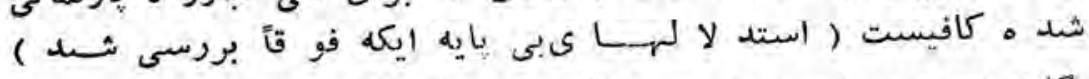

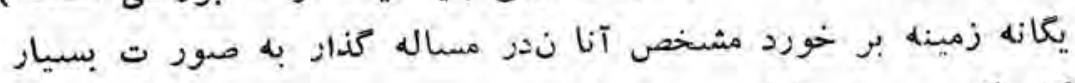

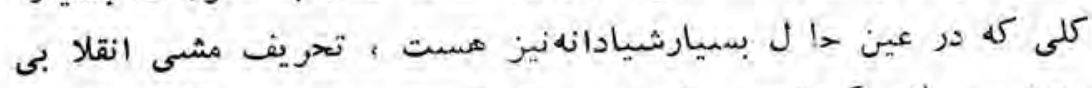

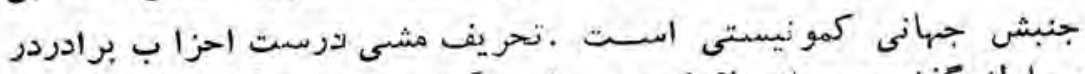

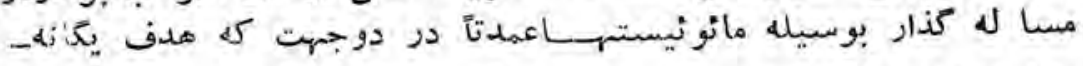

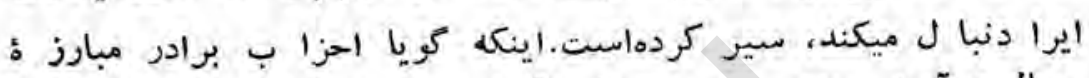

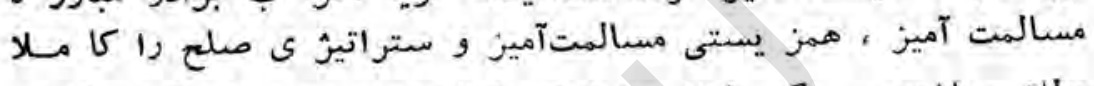

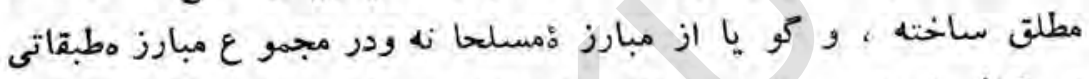

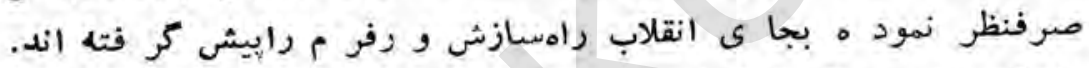

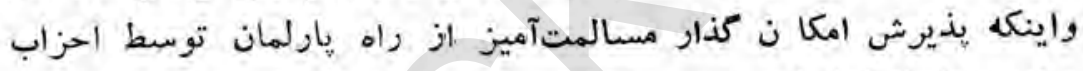

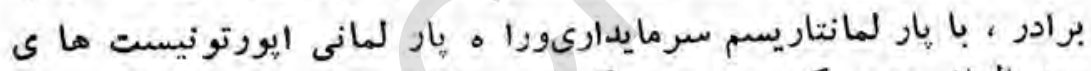

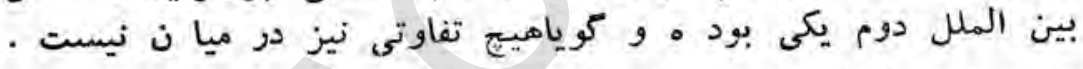

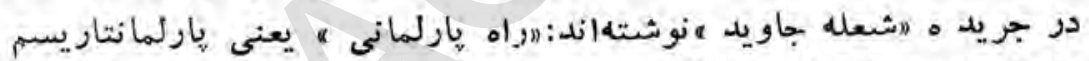

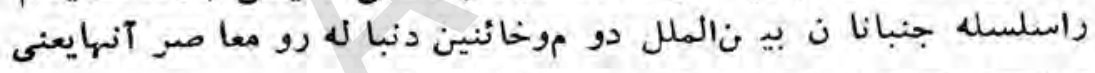

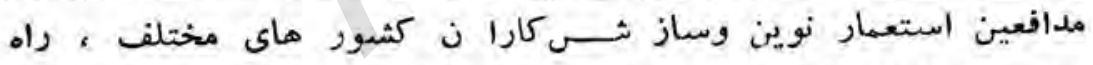

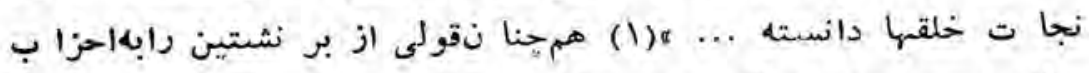

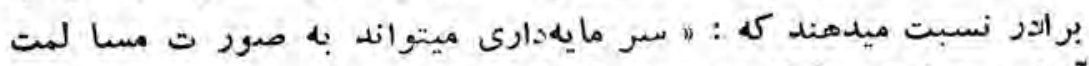

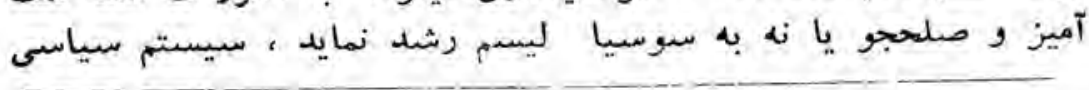

) (1) 
سر مايدار ى نبايد ازبين برده شدهبلكه تنها بيشتر بايد تكا مل داد م

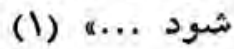

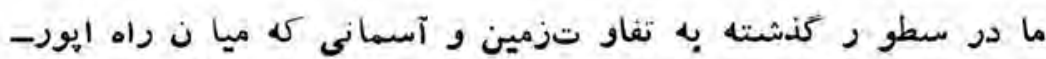

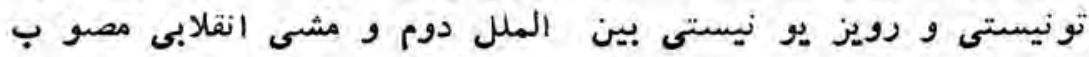

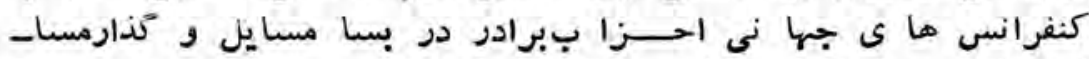

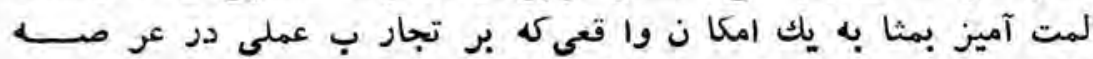

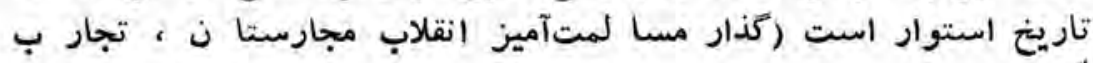

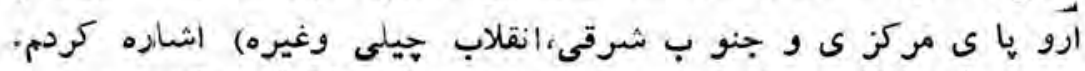

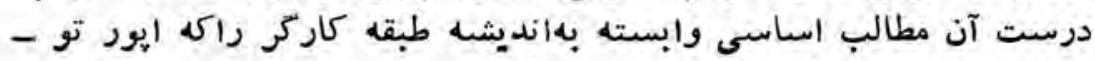

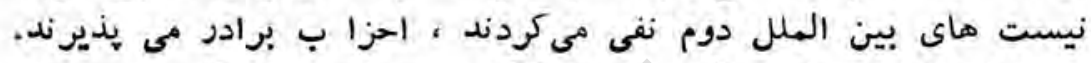

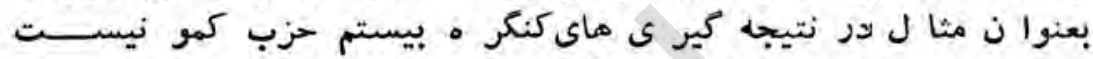

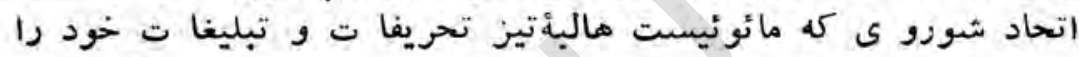

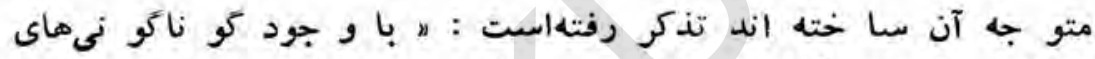

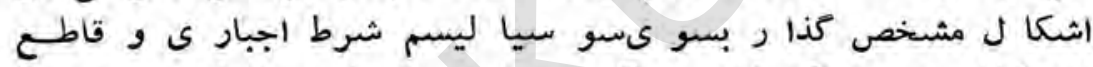

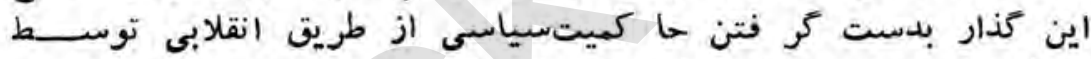

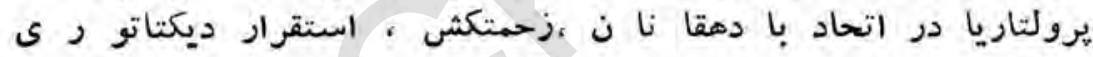

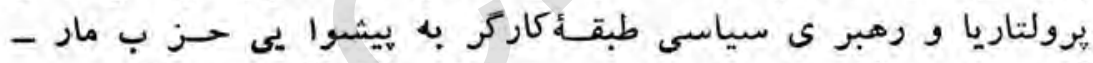

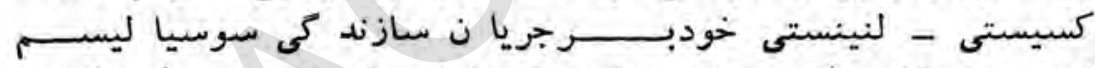

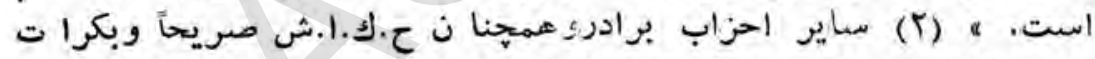

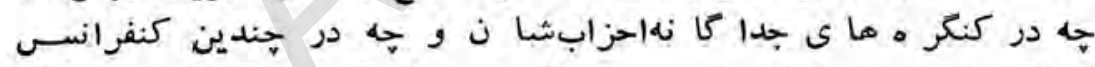

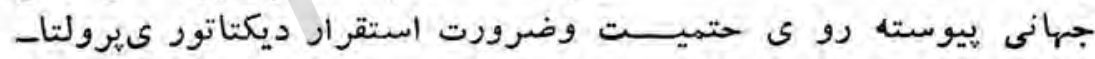

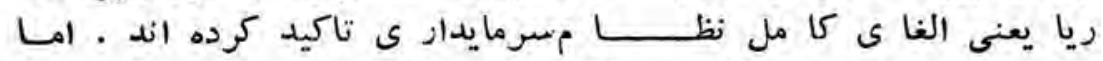

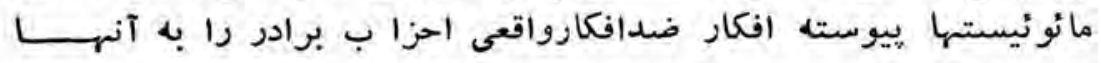

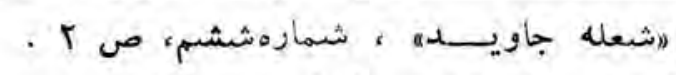

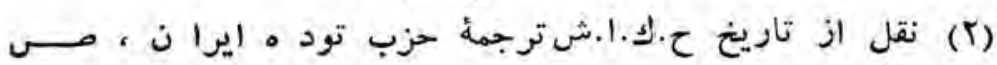

. Irr

$$
-1 \cdot v-
$$




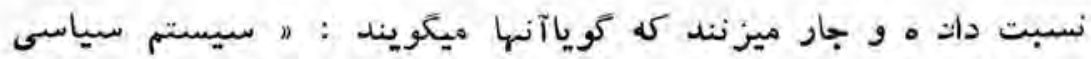

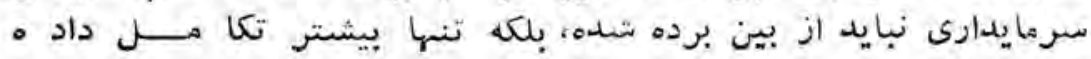

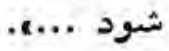

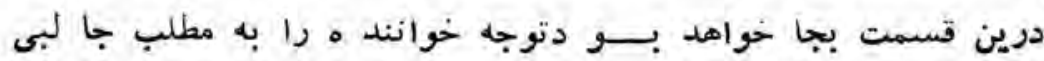

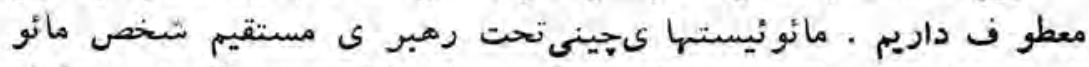

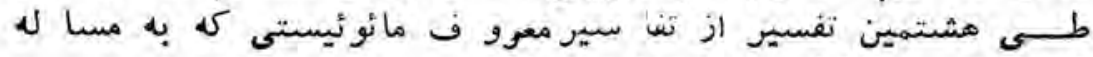

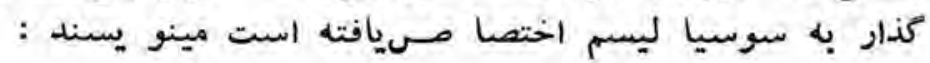

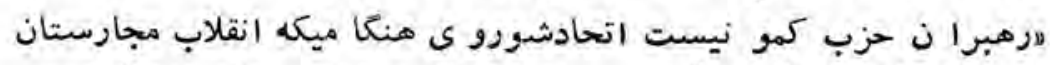

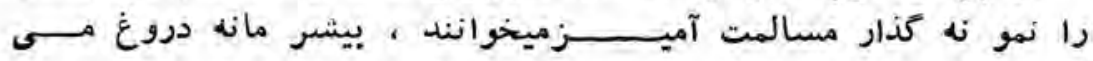

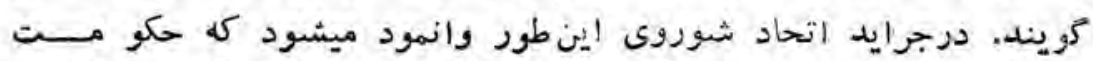

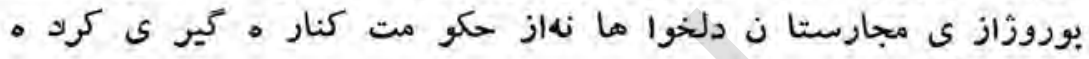
(1) (1) (1)

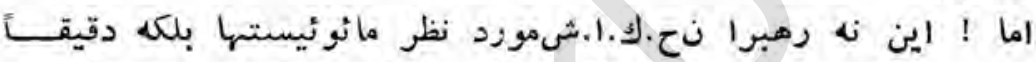

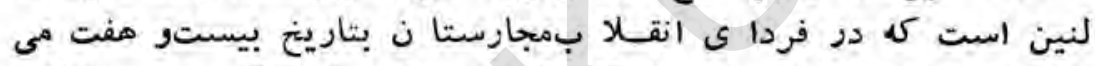

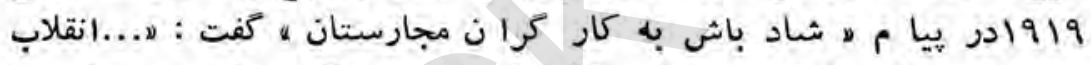

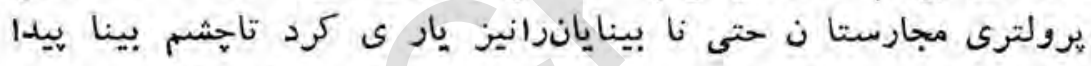

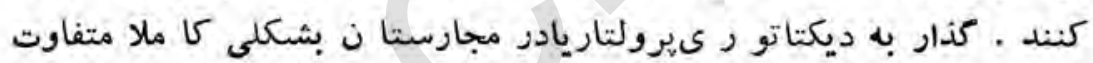

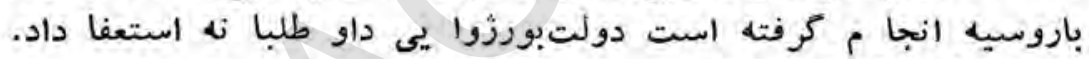

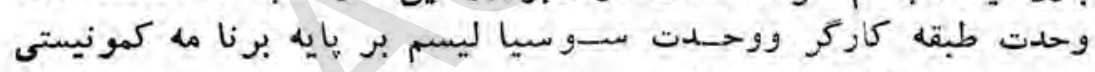

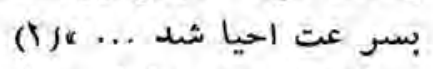

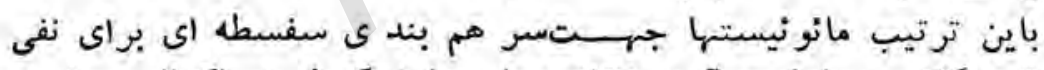

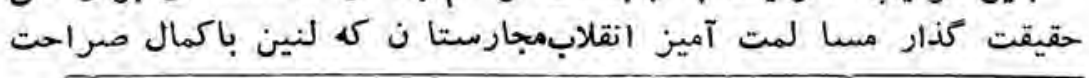

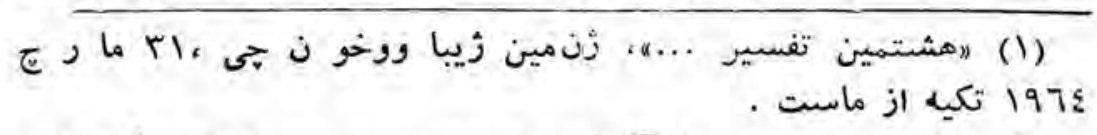

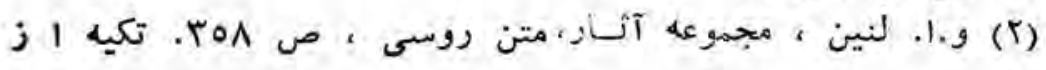




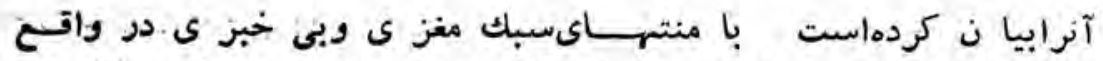

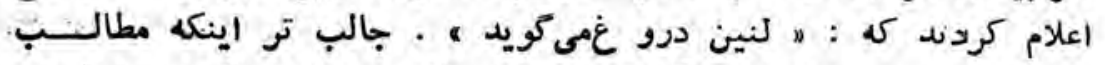

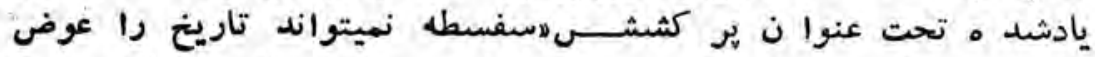

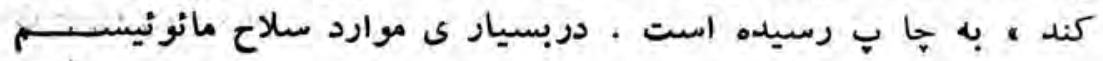

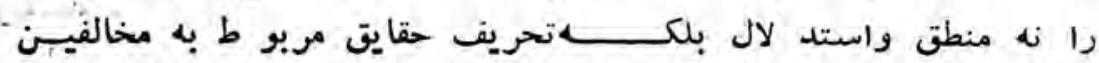

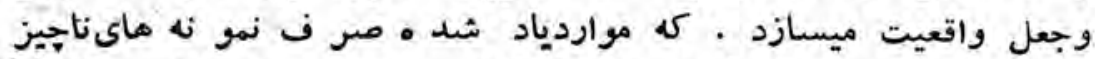

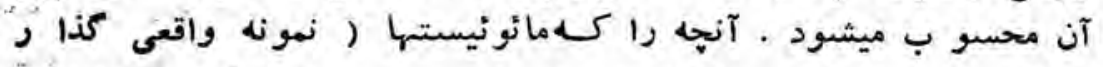

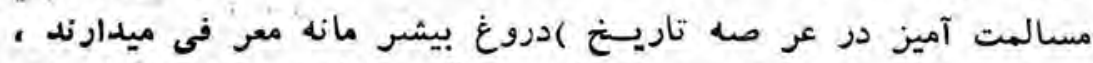

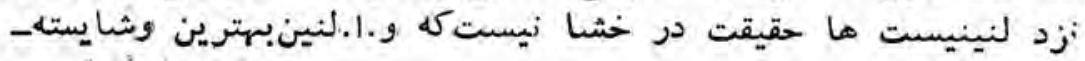

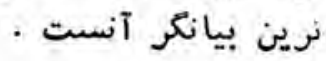

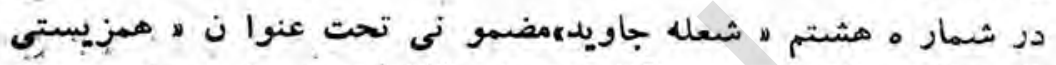

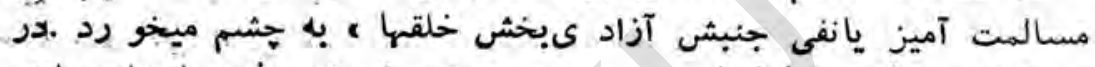

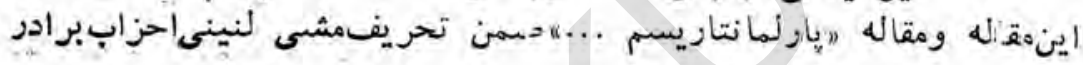

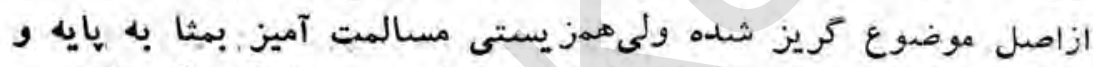

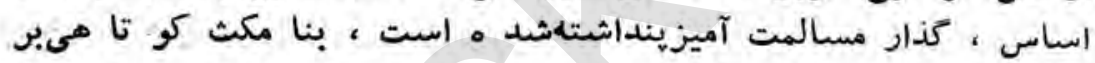

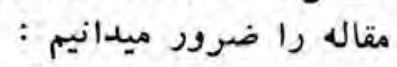

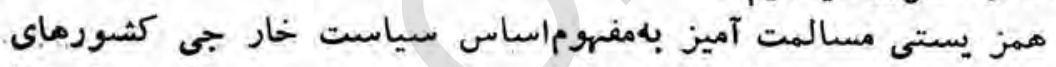

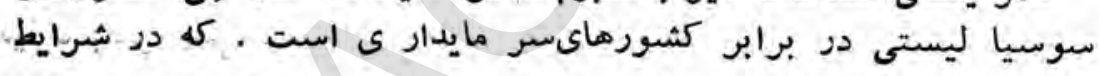

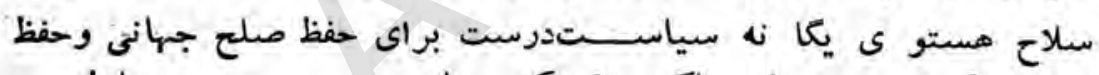

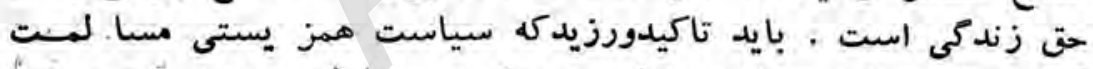

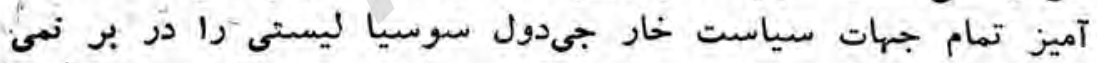

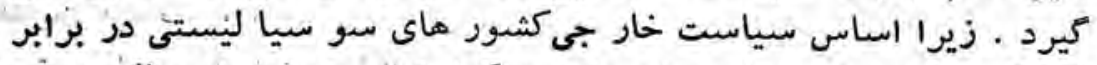

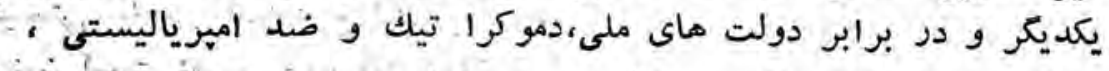

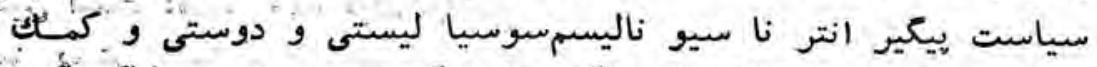

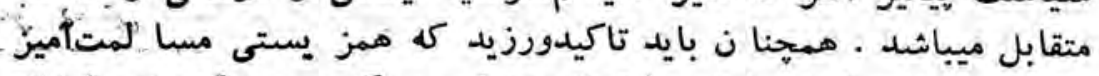

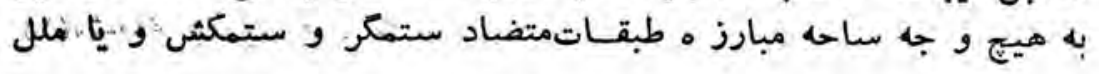


اسير واميريا ليسم را د وبر نمسكيرد بله آنجا مبارز ه آشتىنايذيو

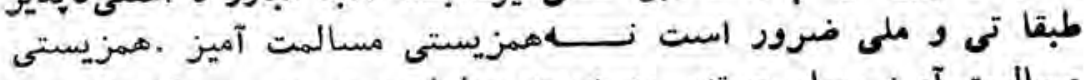

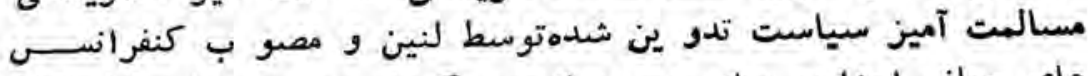

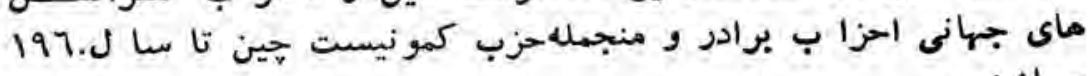

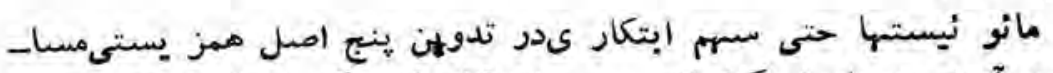

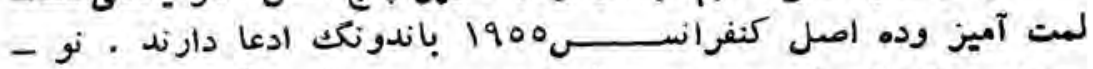

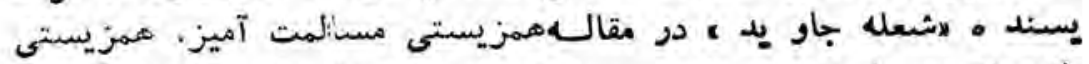

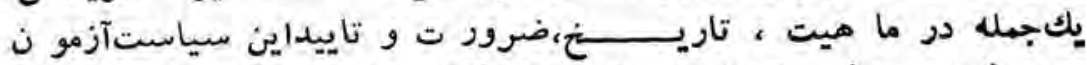

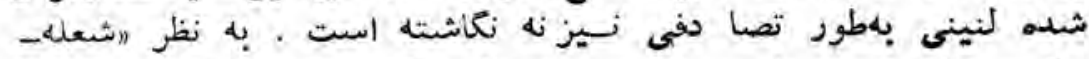

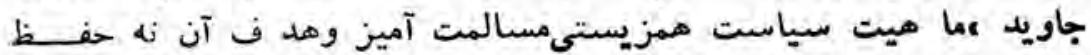

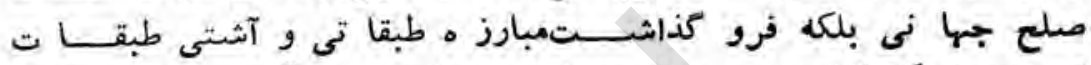

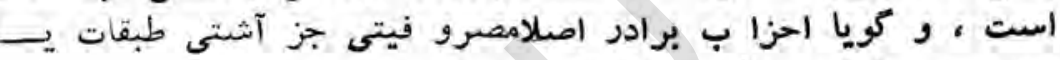

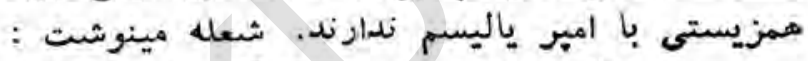

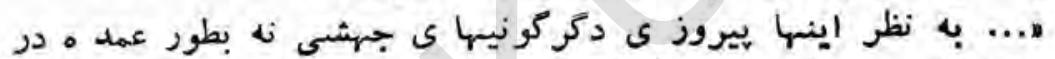

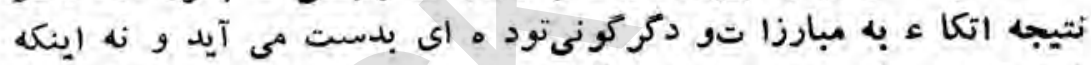

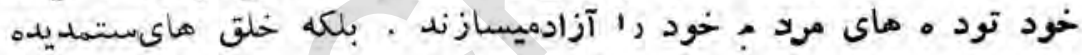

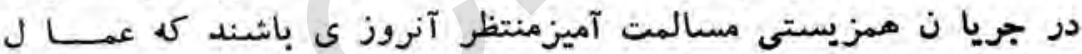

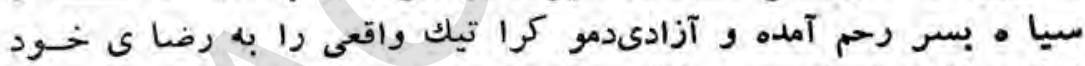

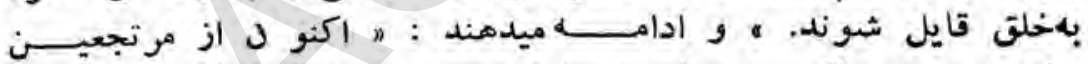

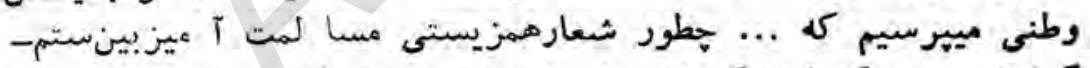

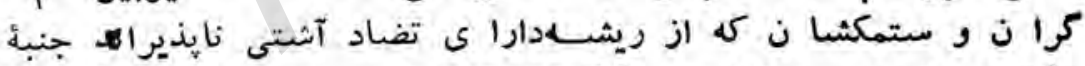

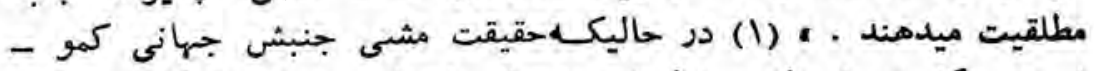

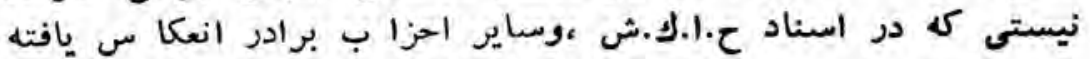

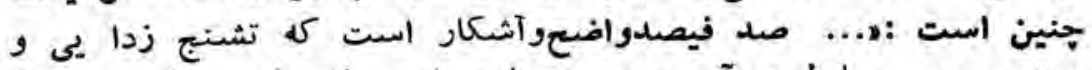

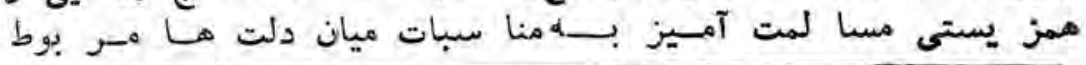

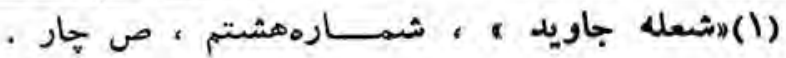




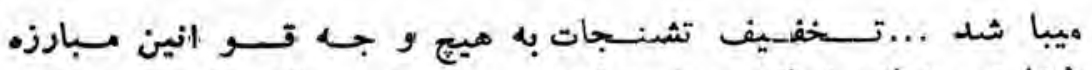

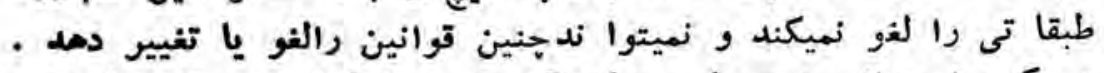

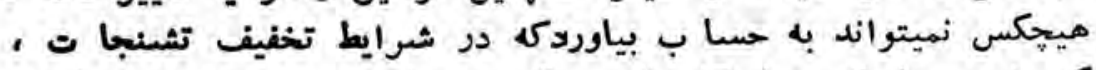

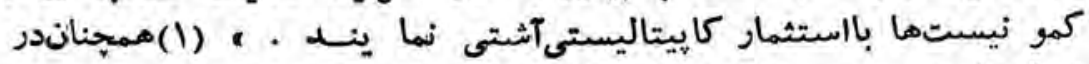

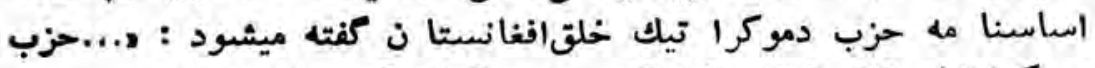

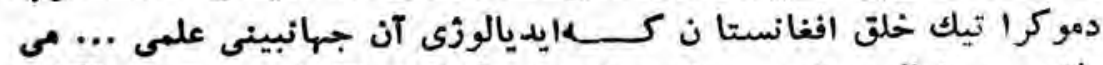

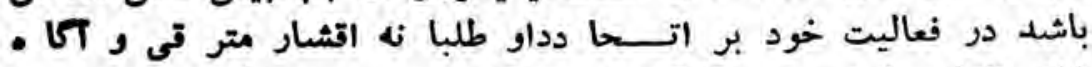

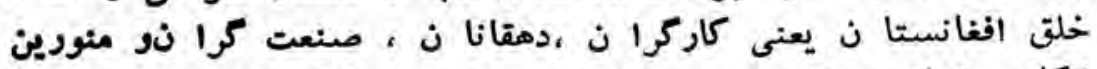

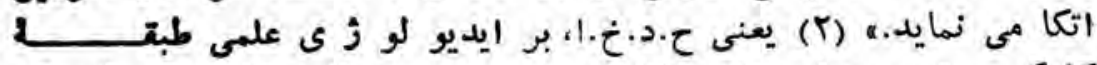

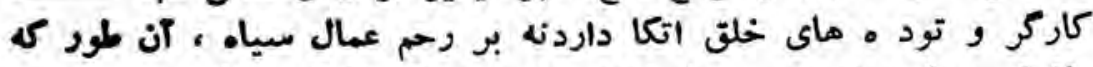

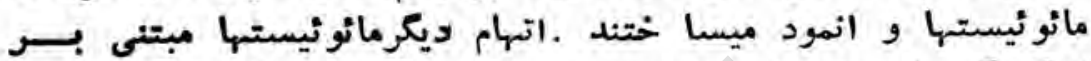

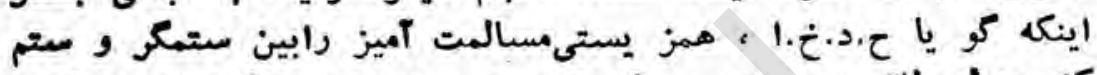

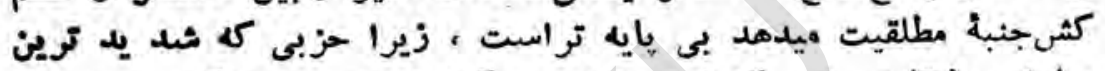

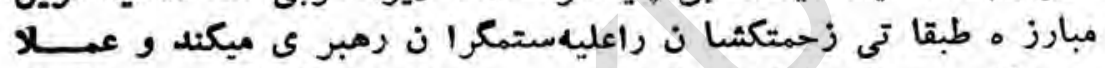

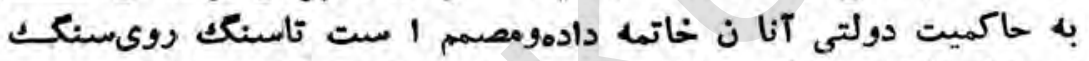

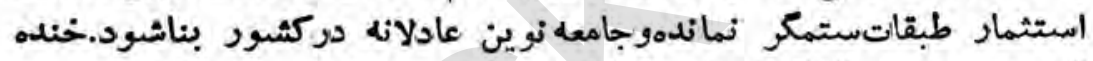

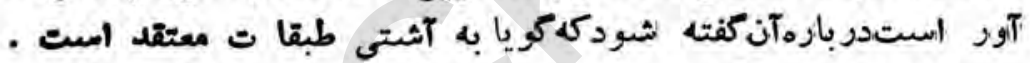

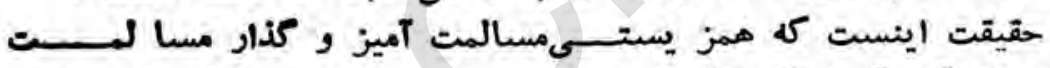

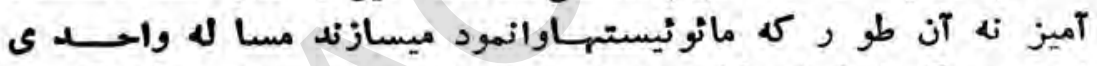

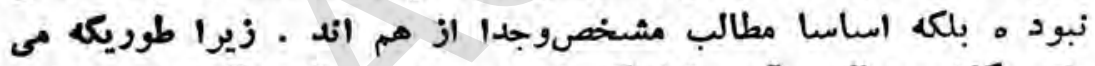

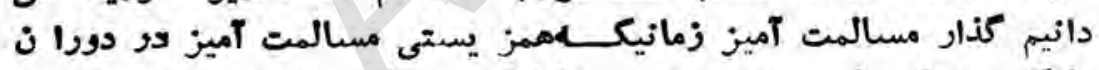

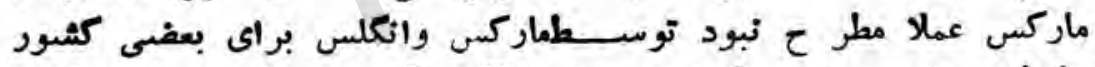

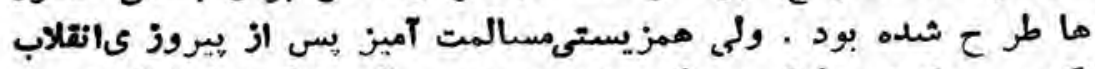

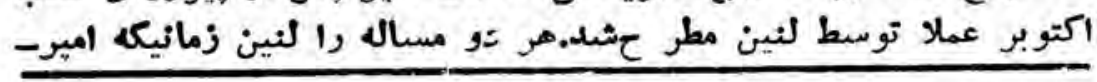

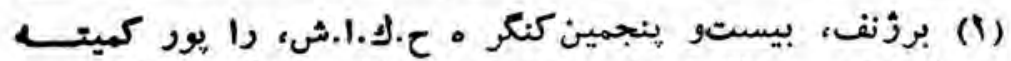

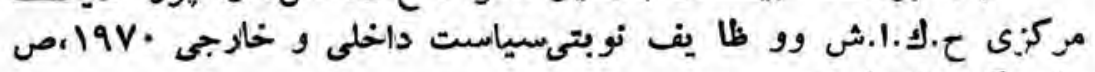

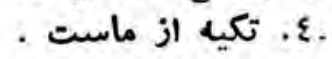

(r)(اساسنا مه حزب دموكرا تيكخلق افغانستا ن ،ماد م اول . -111- 


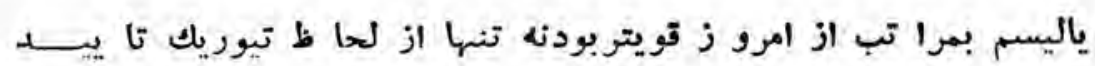

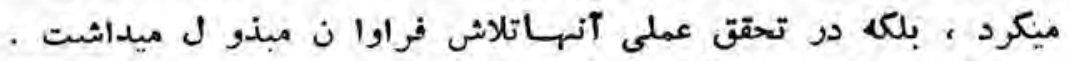

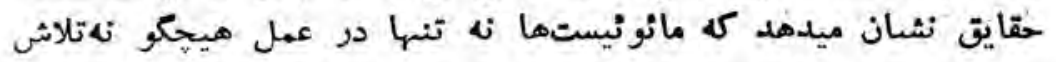

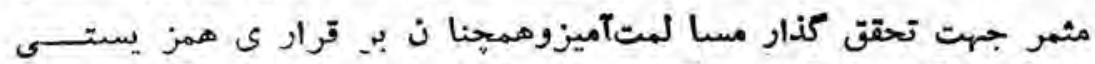

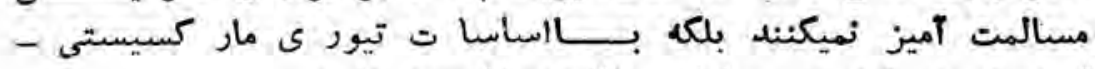

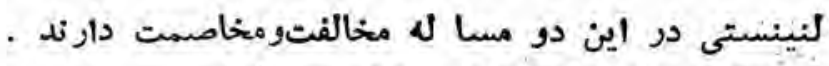
جنك بمثابه يكانه شعل مدرار :

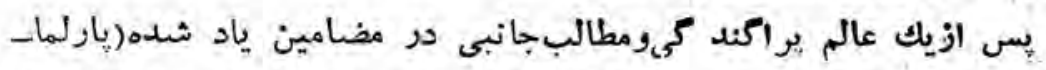

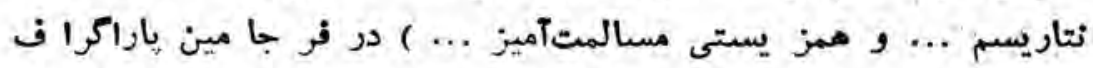

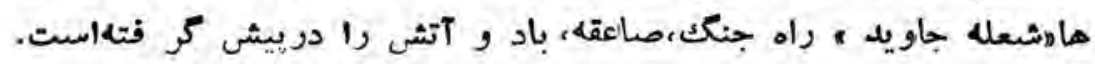

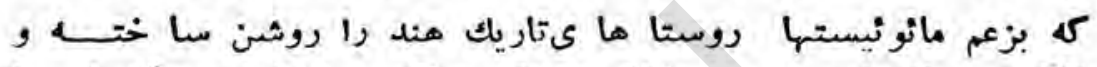

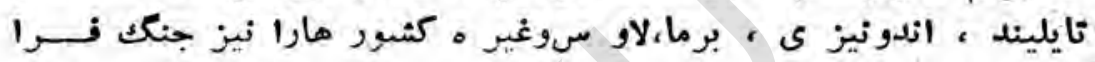

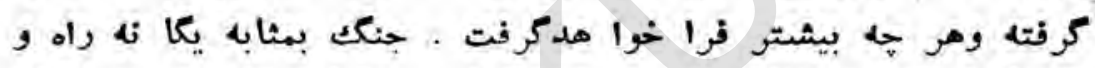

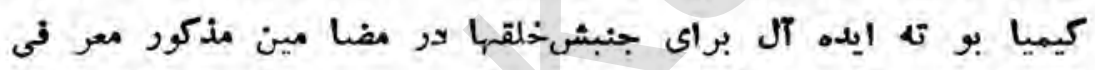

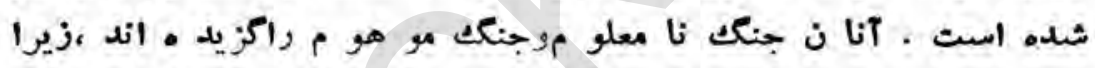

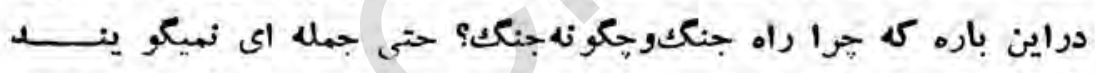

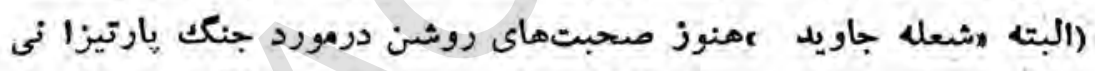

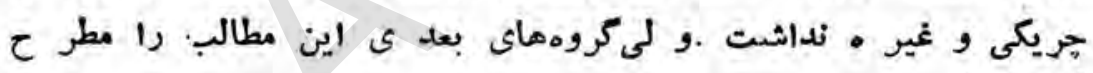

نمودند )

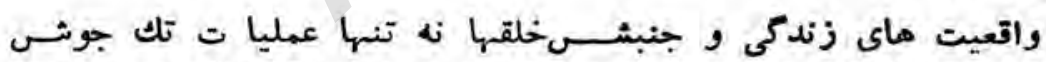

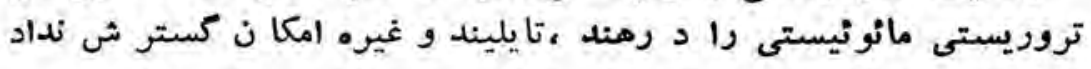

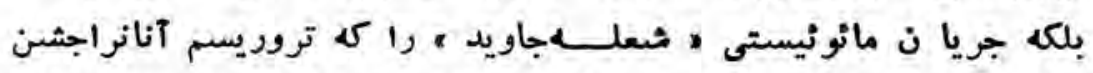

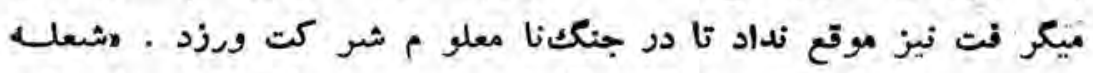

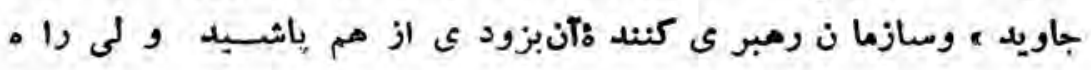

$-114$ 
جنكك و حساءقه و بادو آتش رابراىكروه هاى بعد ى مائوئيستى ميراث كذاشت .

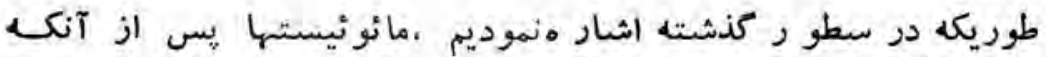

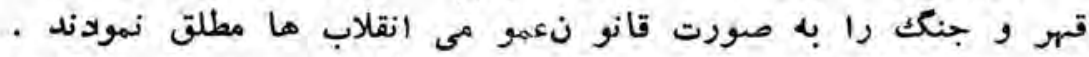

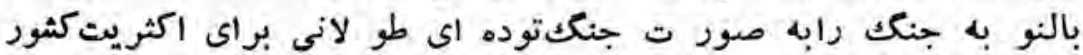

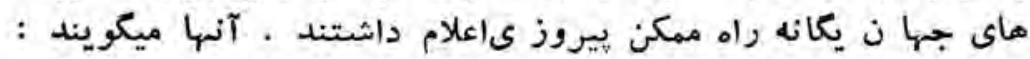

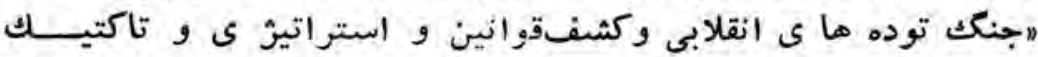

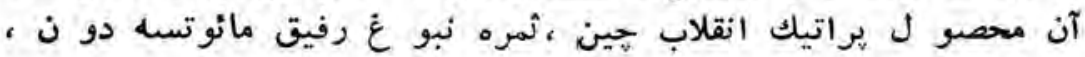

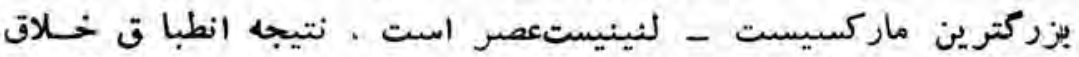

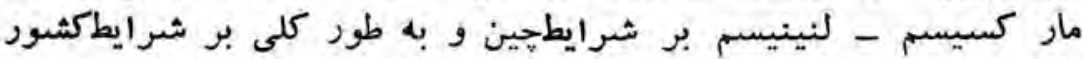

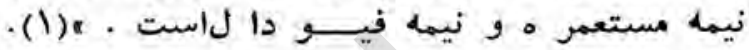

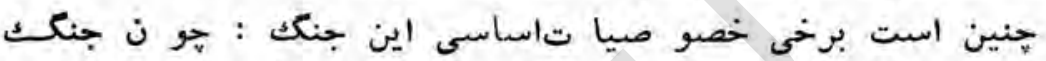

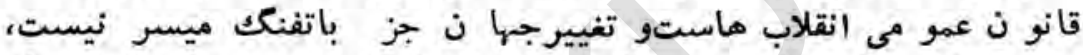

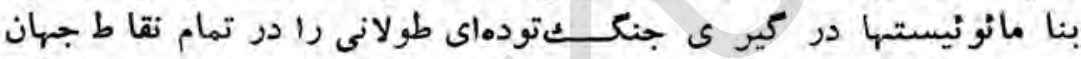

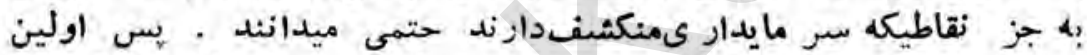
خصوصيت اين جنكك ناكزيو ى وحتميت آنست براى اكثريت اكريت كشور

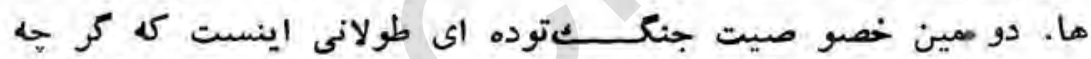

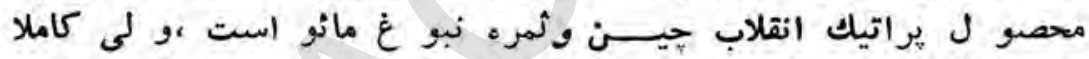

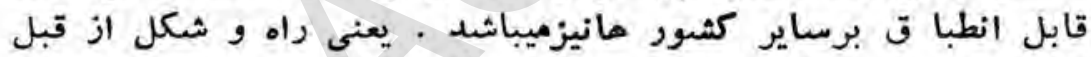

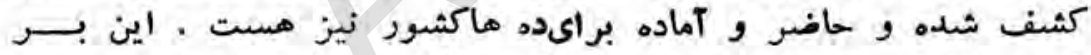

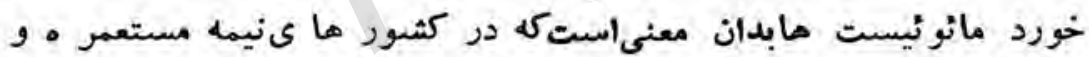

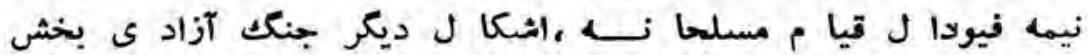

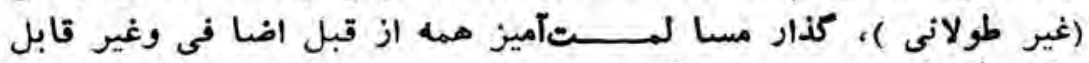

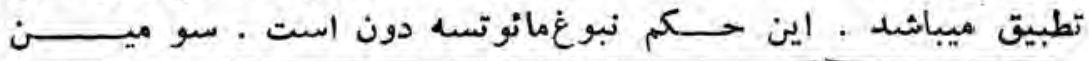

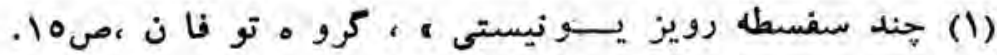
تكيه از ماست آنيد 


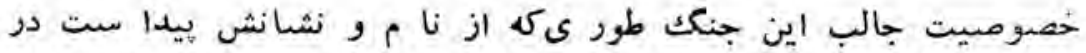

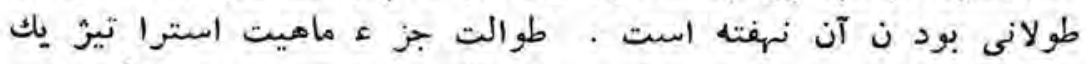

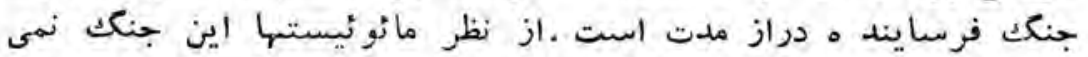

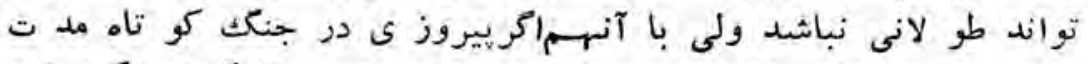

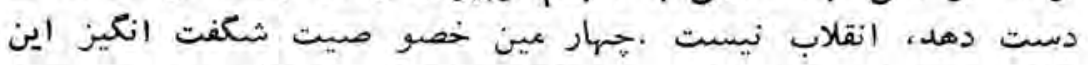

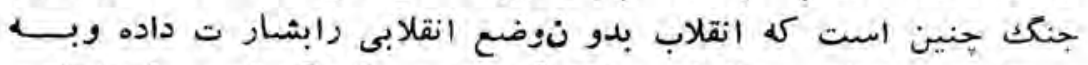

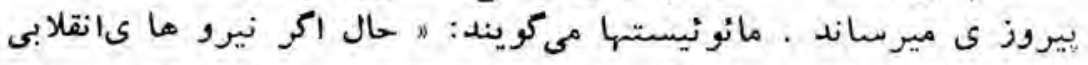

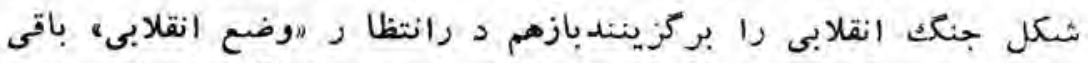

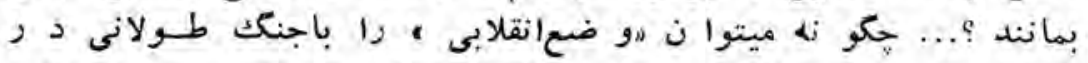

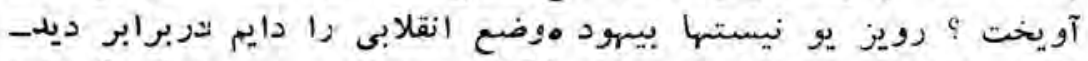

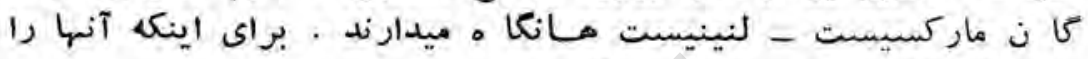

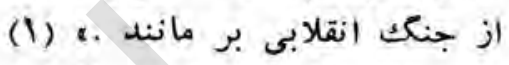

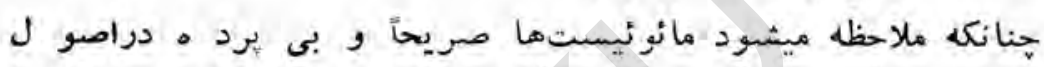

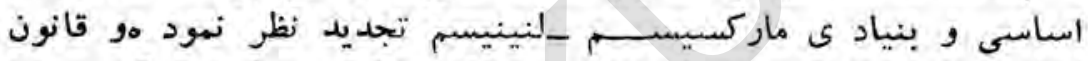

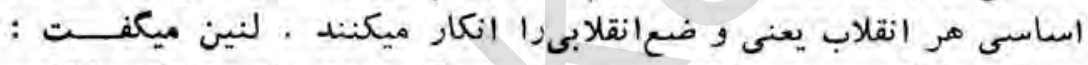

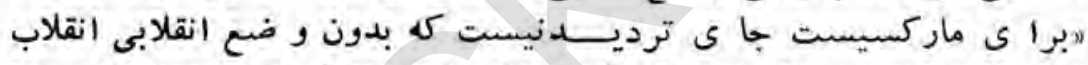

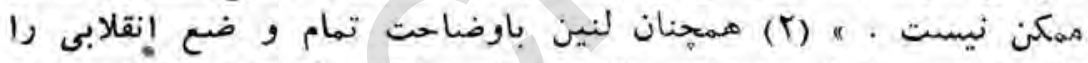

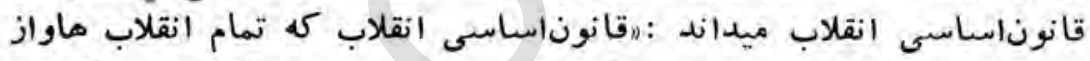

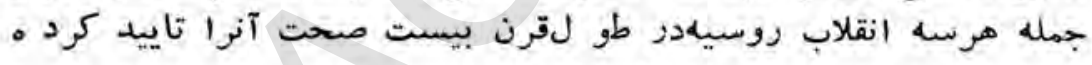

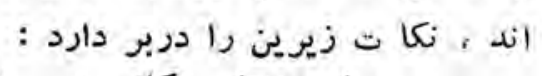

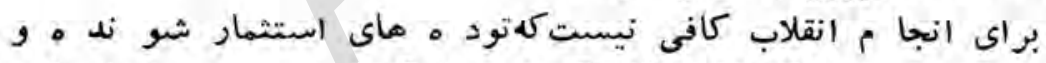

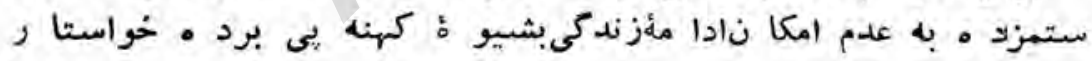

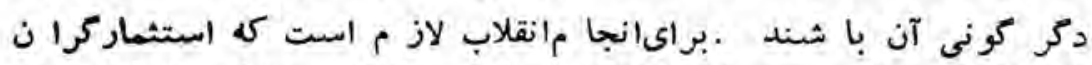

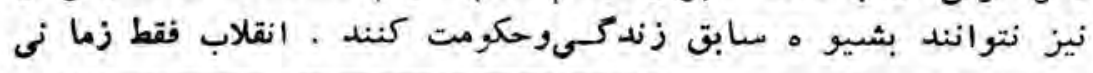

$$
\begin{aligned}
& \text {. }
\end{aligned}
$$

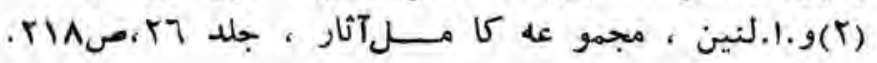




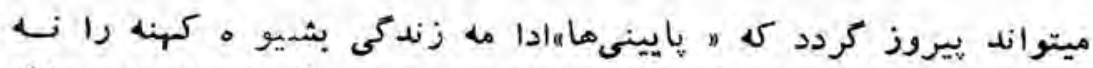

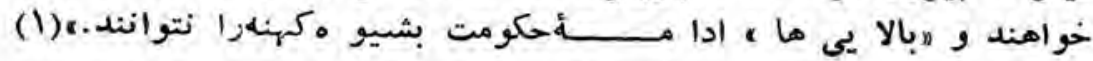

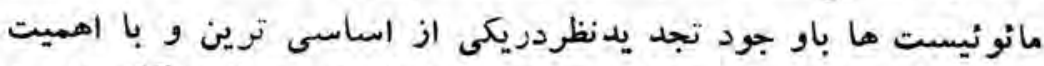

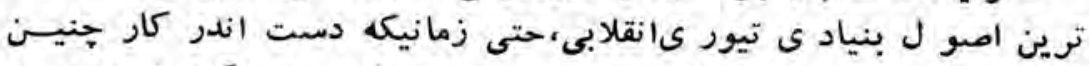

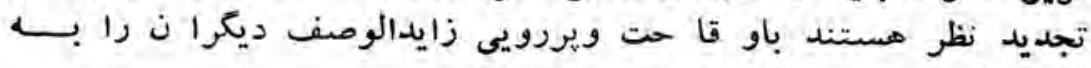

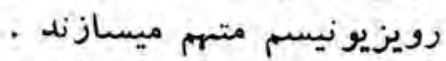

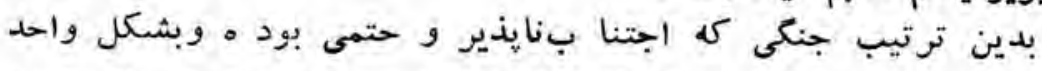

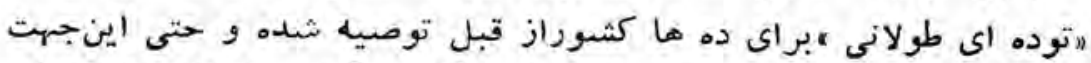

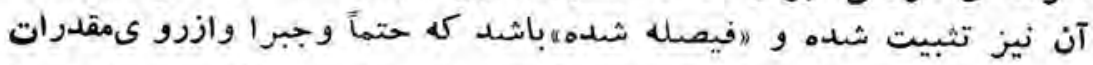

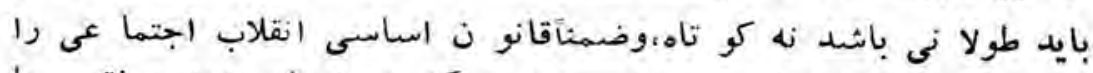

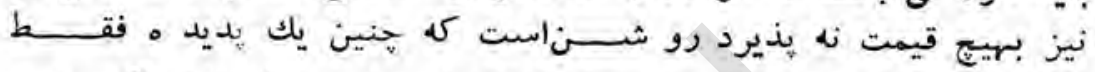

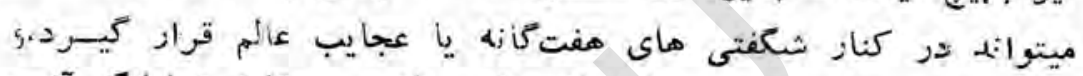

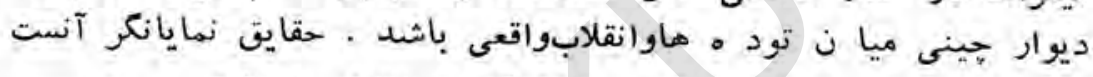

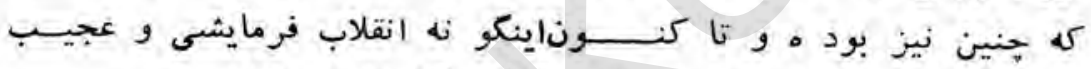

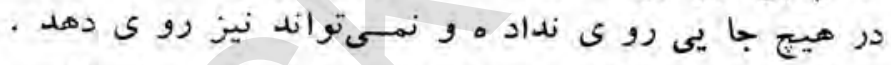

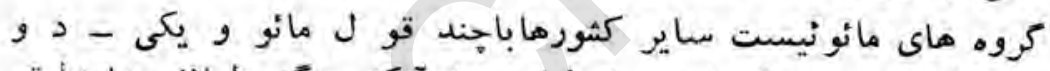

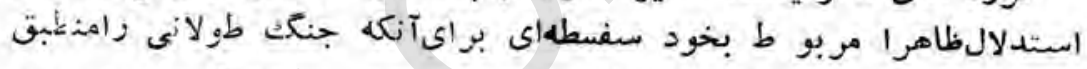

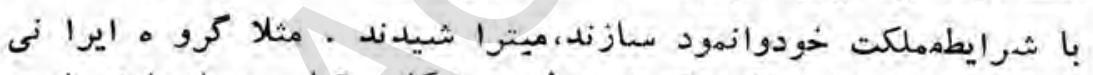

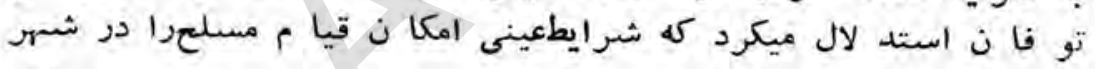

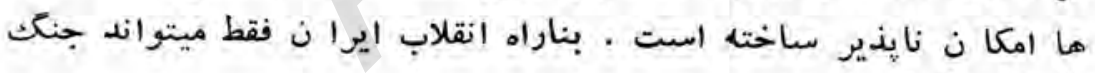

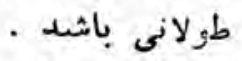

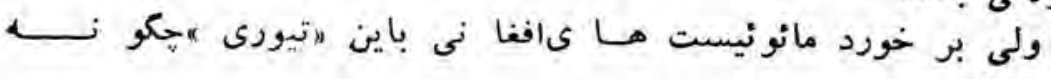
است ؟

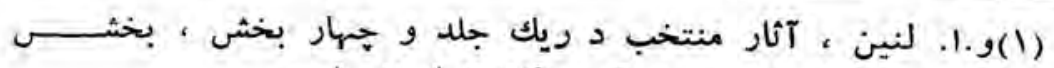

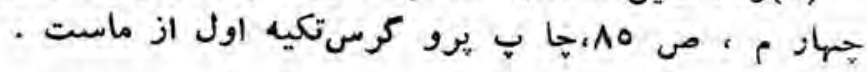




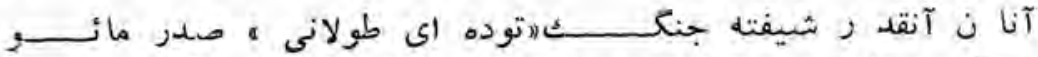

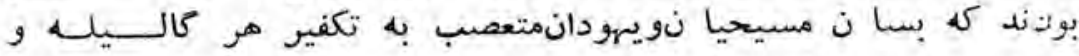

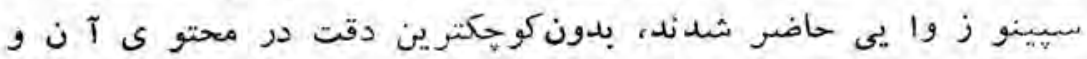

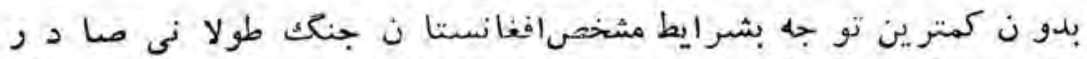

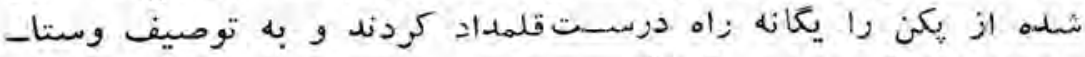

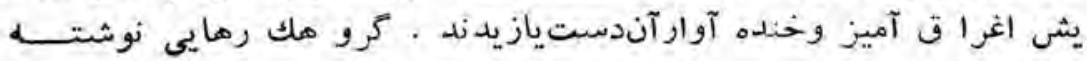

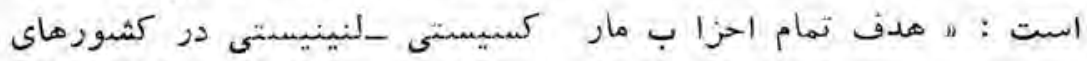

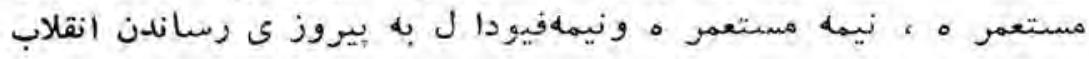

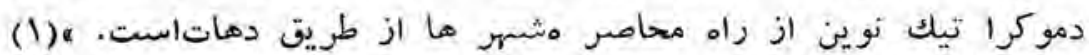

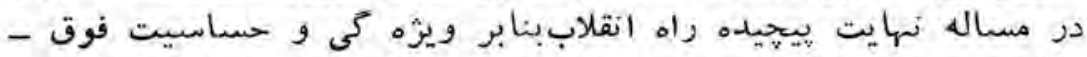

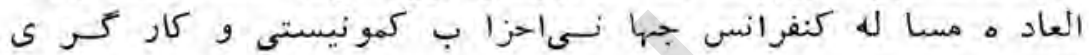

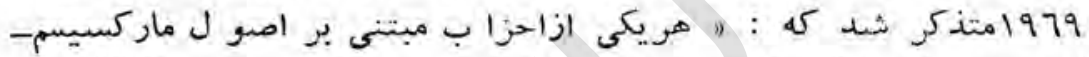

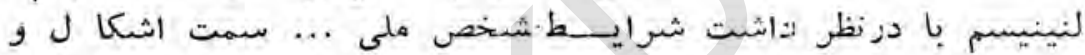

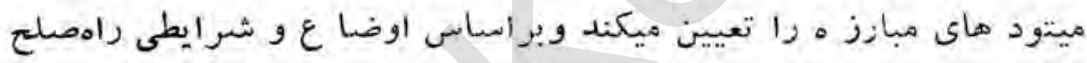

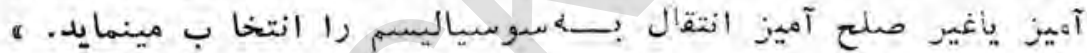

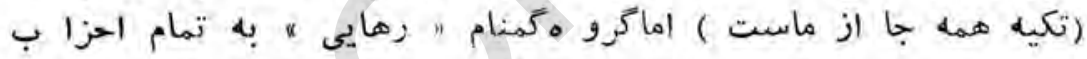

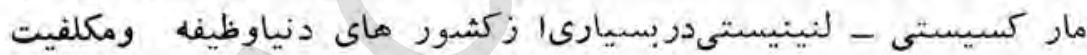

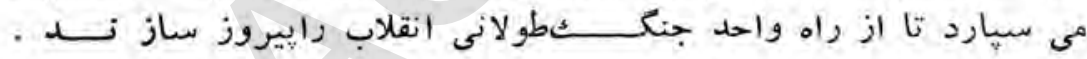

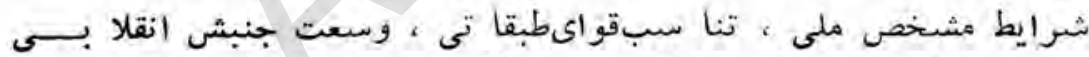

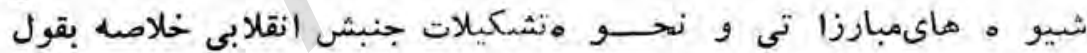

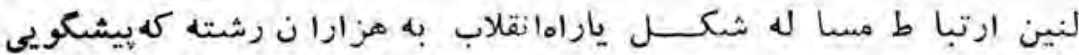

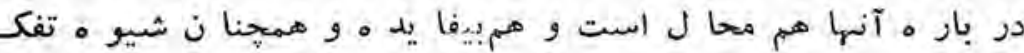

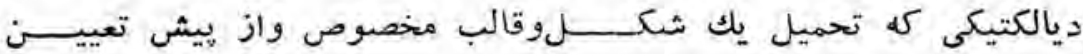

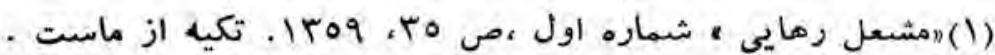




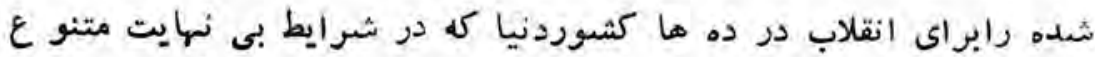

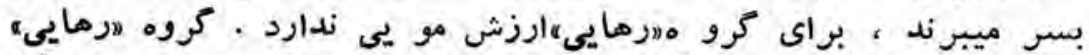

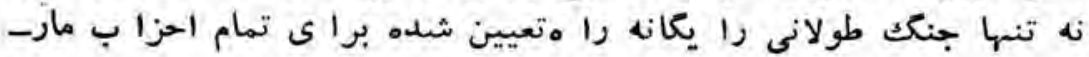

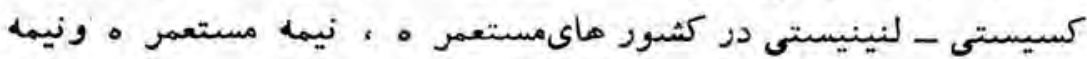

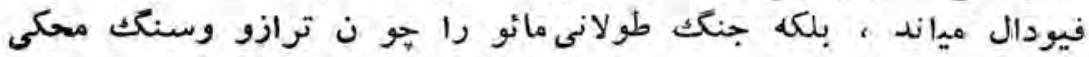

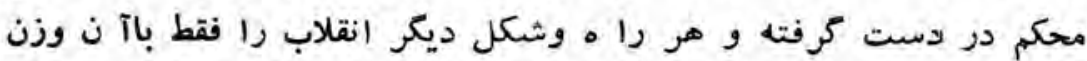

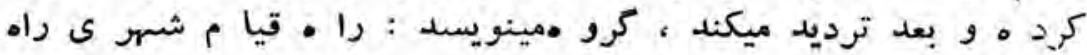

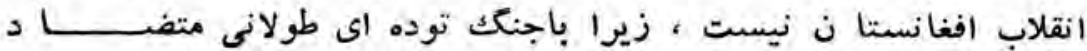

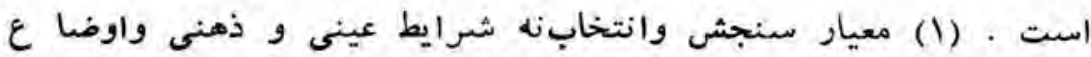

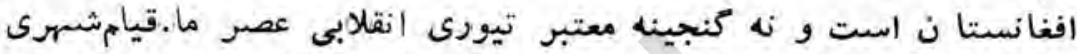

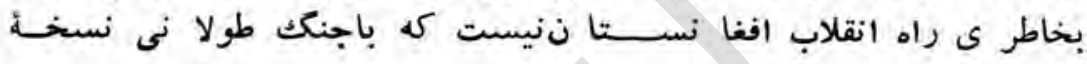

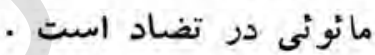

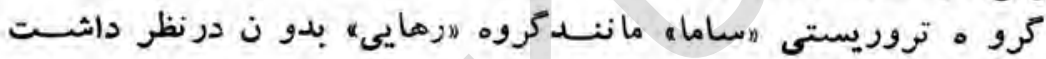

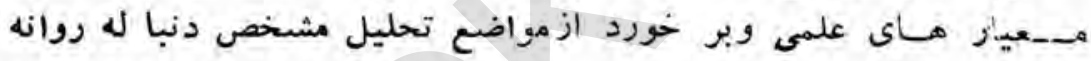

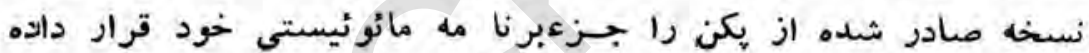

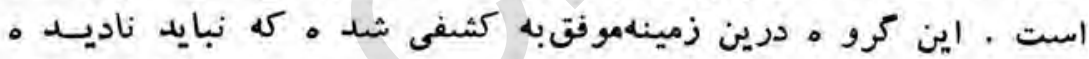

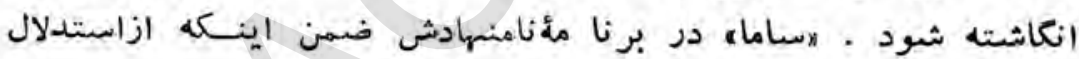

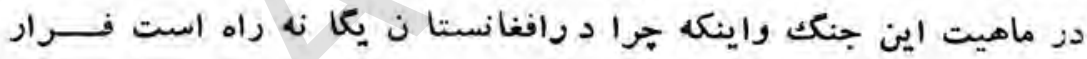

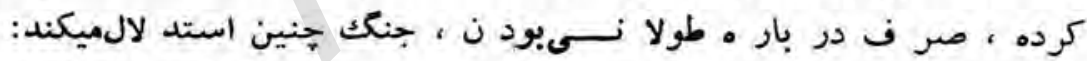

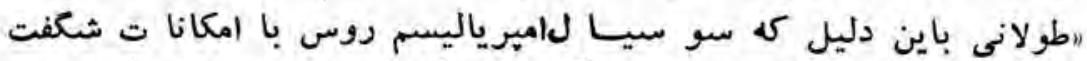

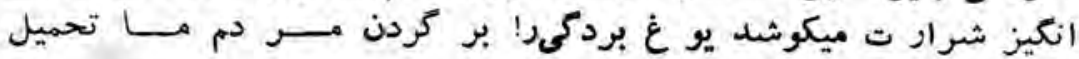

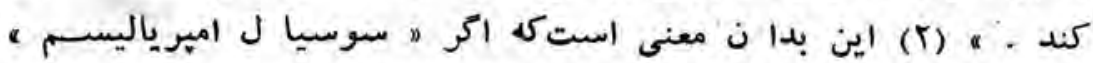

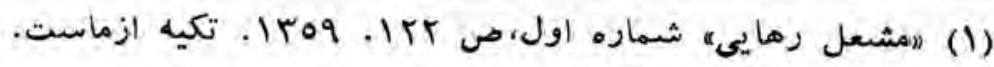

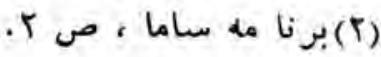




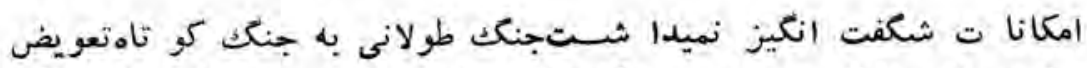

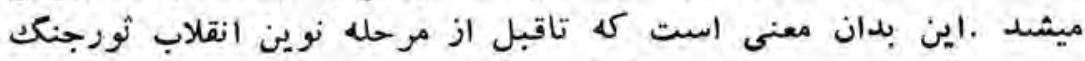

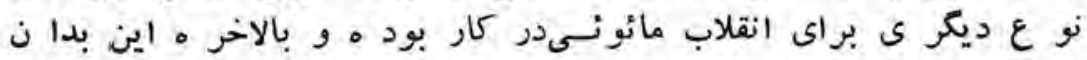

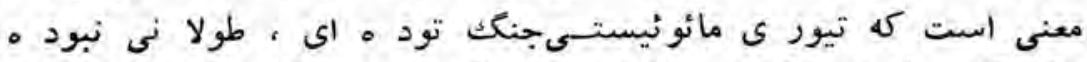

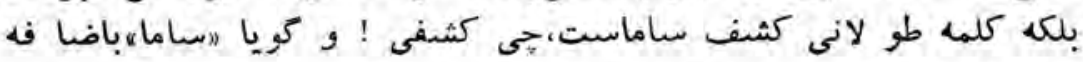

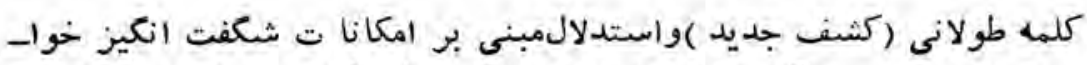

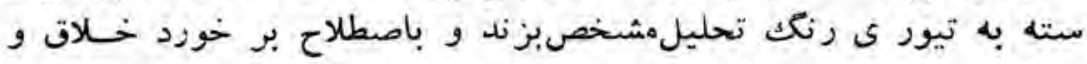

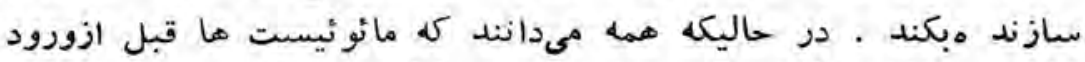

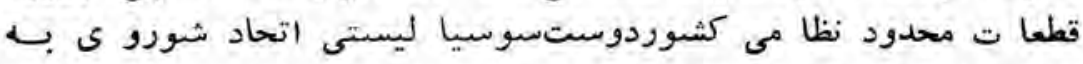

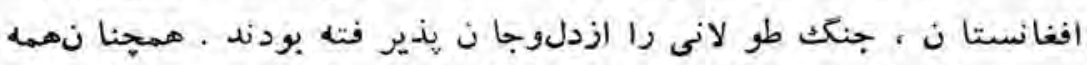

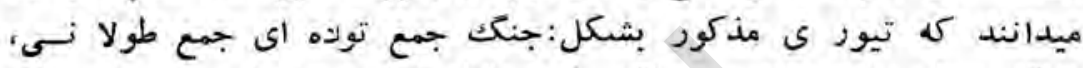

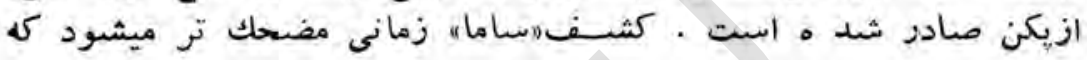

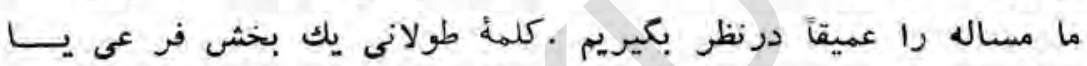

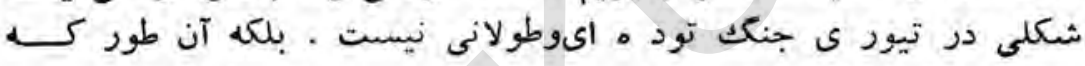

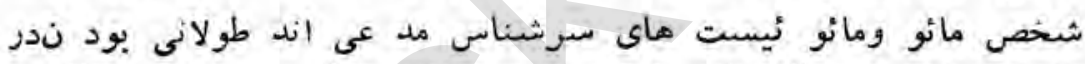

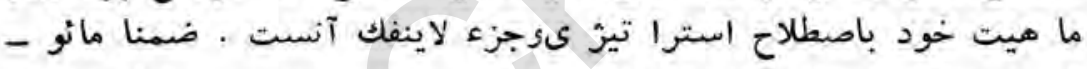

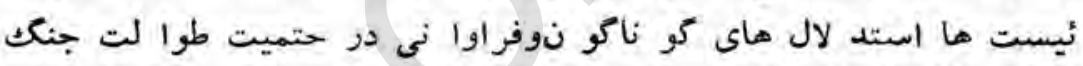

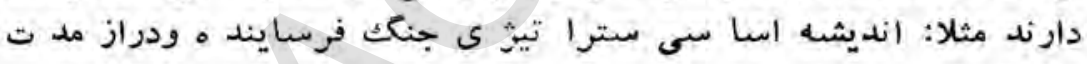

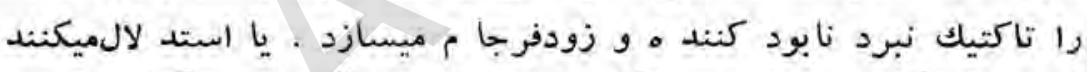

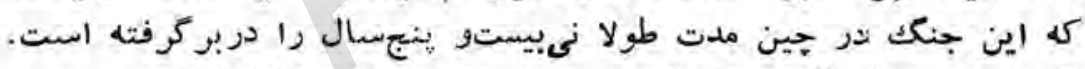

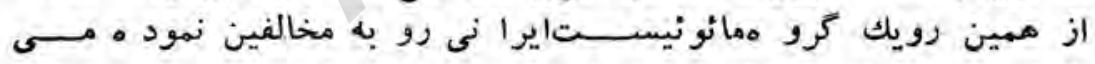

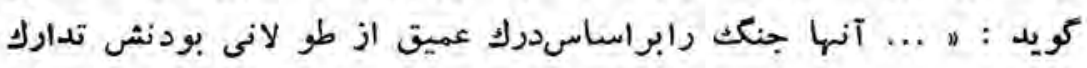

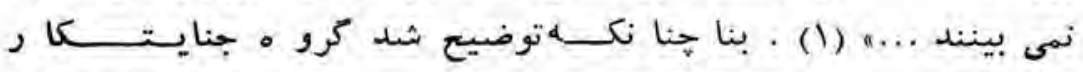

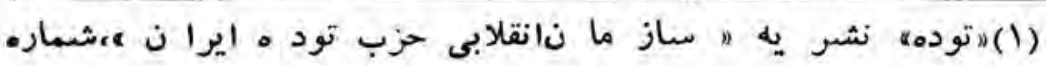

.

$-111-$ 
מساماه حتى قادر بدر ك تيور ىمائو نيستى جنك توده ای طو لانى نيز

نشده است . نشاهت

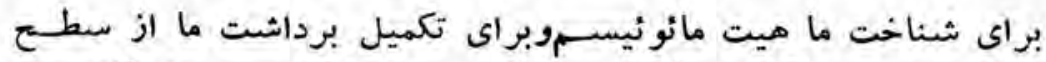

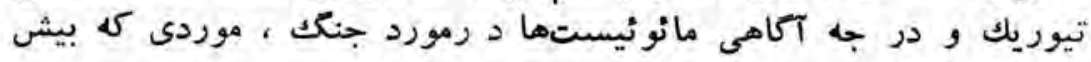

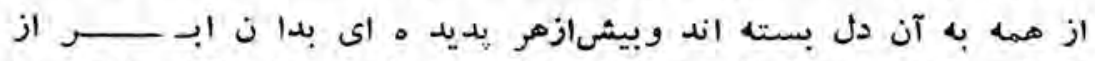

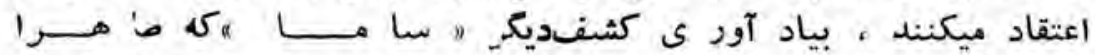

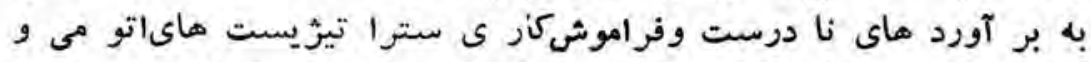

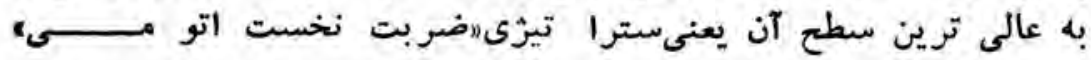

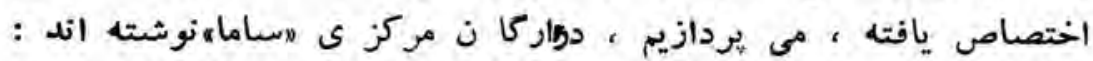

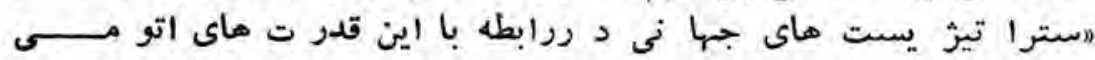

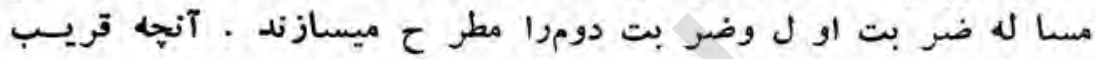

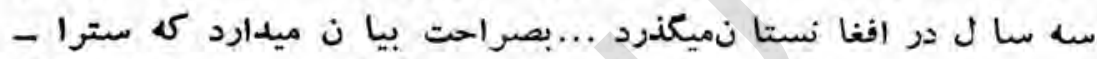

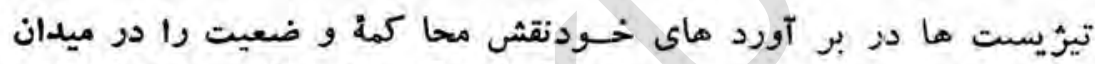

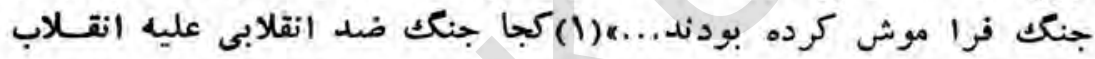

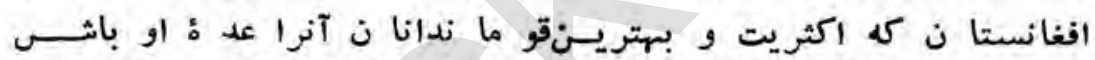

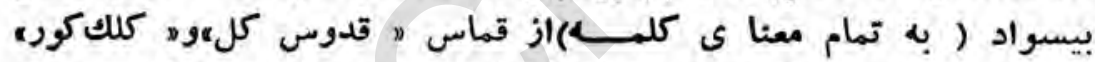

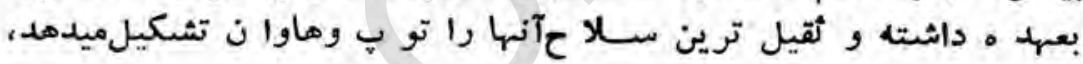

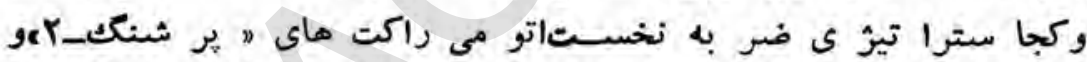

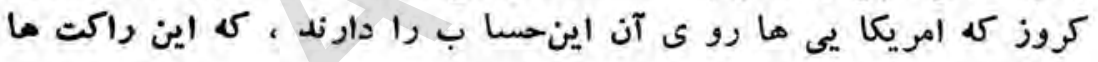

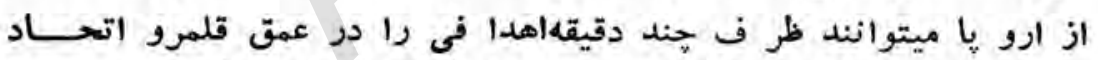

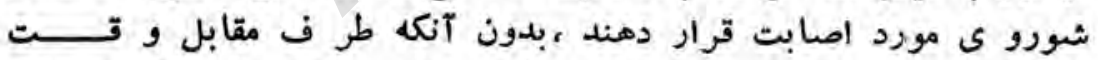

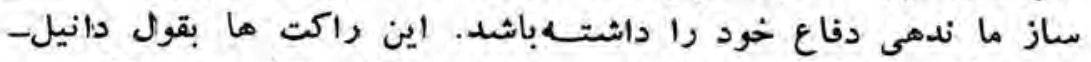

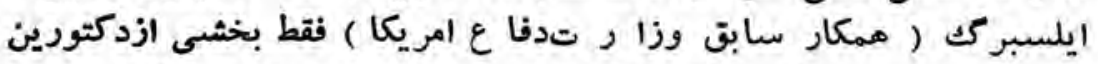

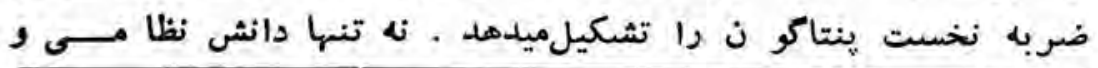

(1) م نداى آزاد ى ه شمار هسومهص هنج · تكيه از ماست .

$-119-$ 
سياسى اكلدميك معاصر بلكه عقـلـوخرد عاد ى انسا ن دمه ماي اخير

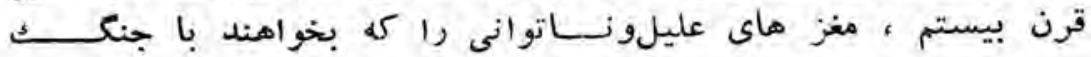

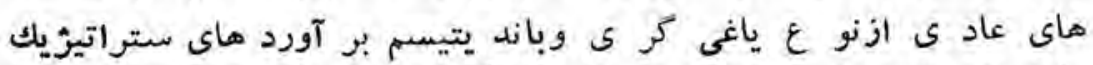

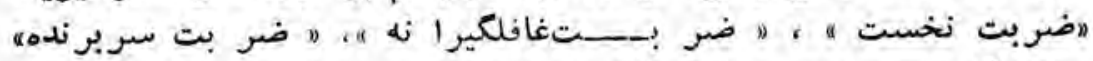

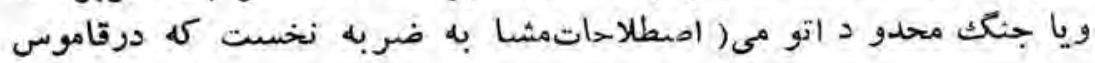

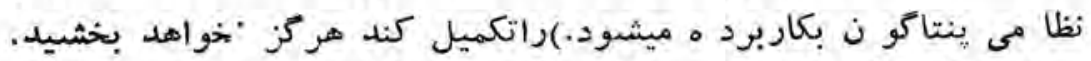

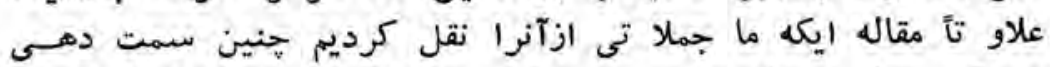

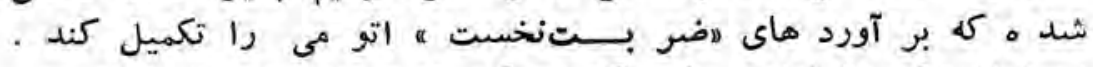

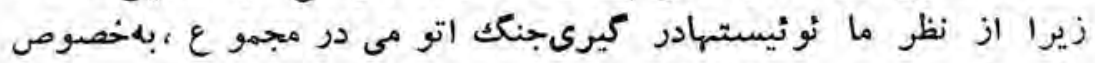

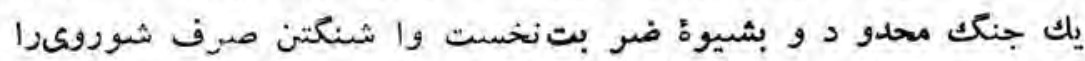

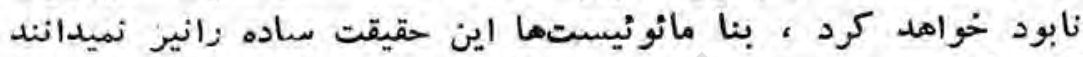

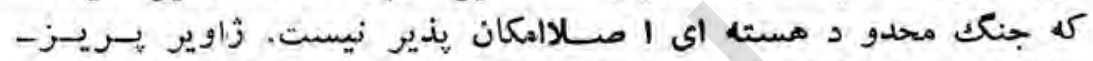

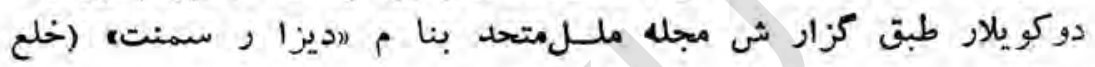

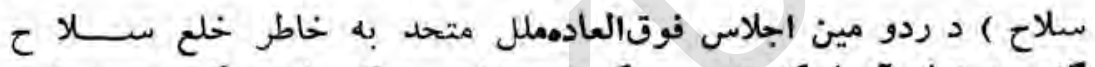

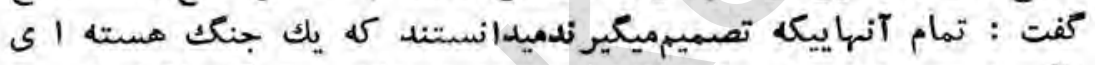

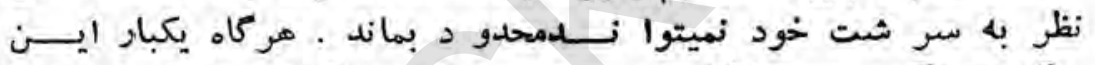

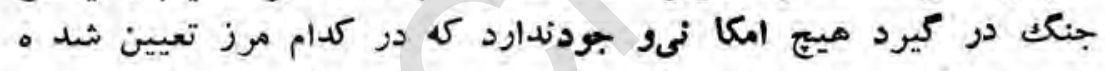

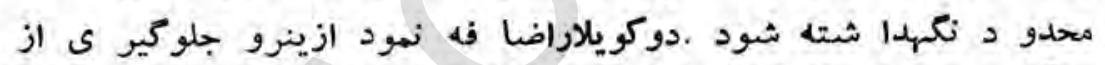

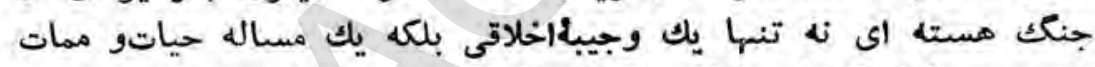

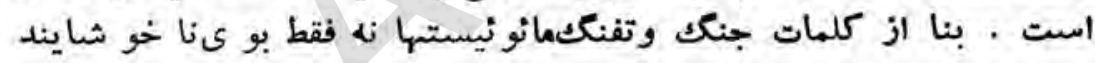
بيخبر ى و كو تاه فكر ى بلكه بوىتند جنايت هسته اي نيز بـ مشام ميزند

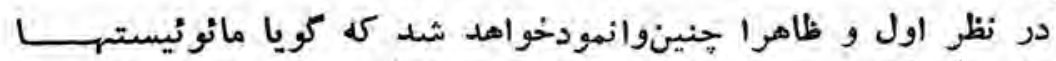

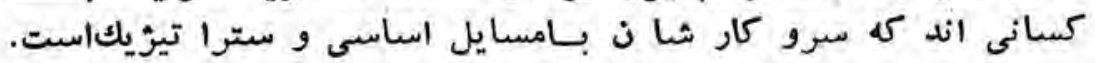
ولى اكر د رماهيت اصطلاحا ت بهظاهر وزين و تيوريك آنها دقــت تهرت

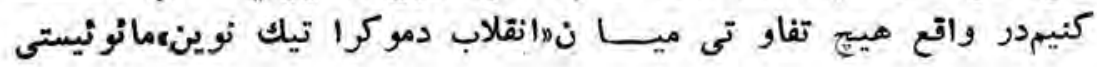




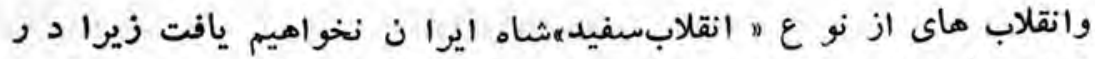

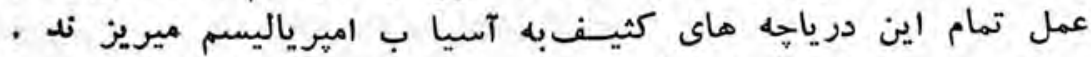

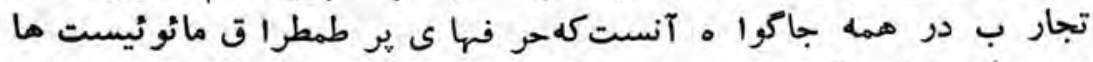

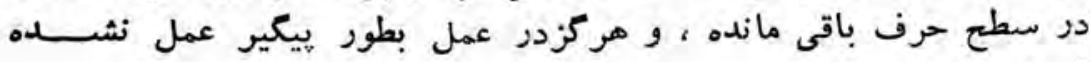

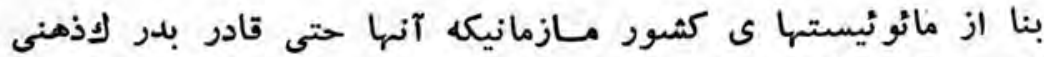

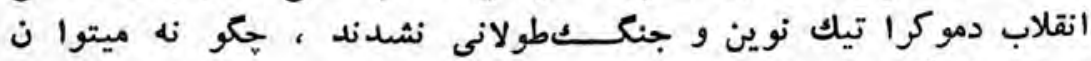

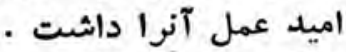

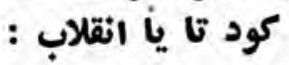

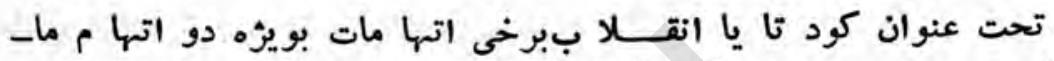

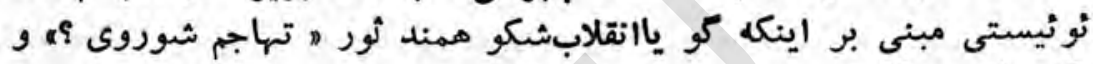

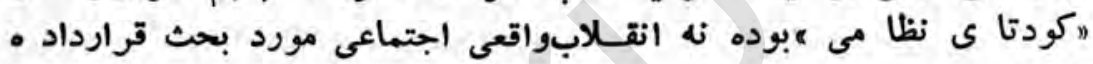

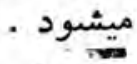

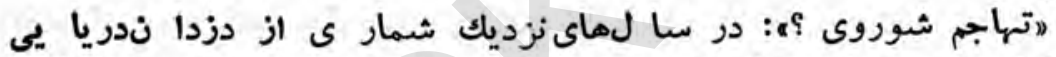

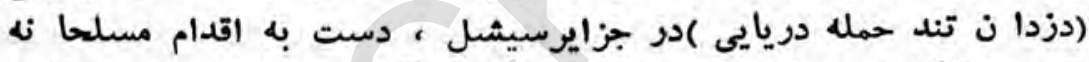

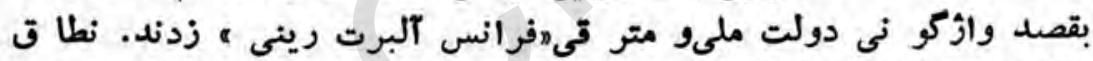

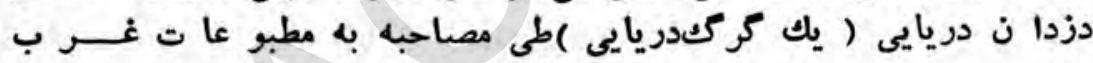

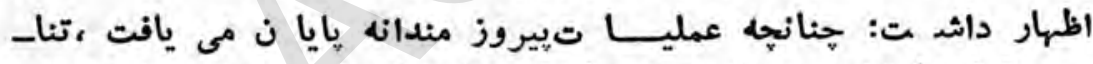

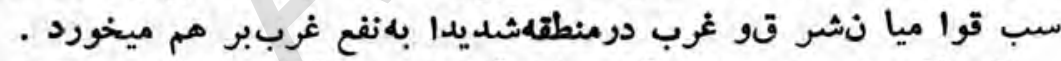

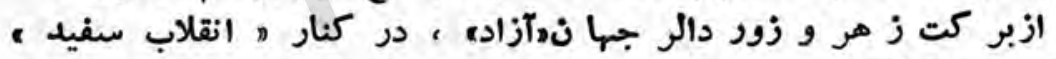

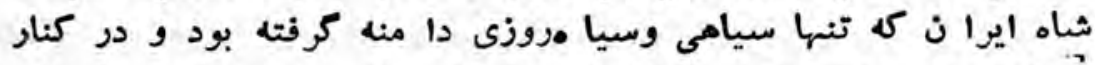

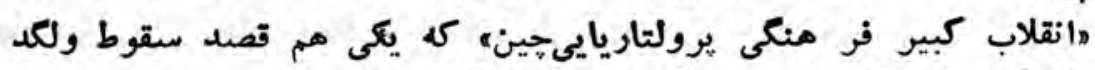

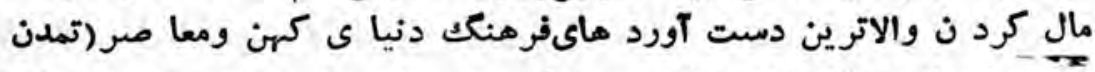

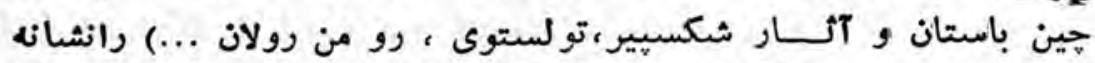

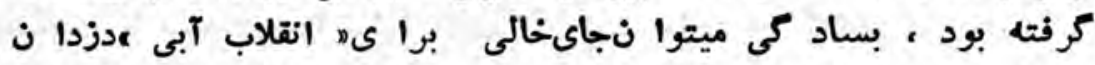

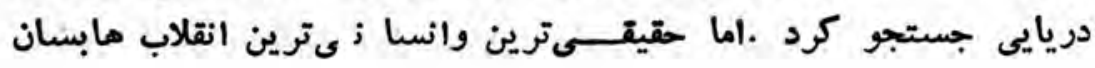


انقلاب ويتنا م · كيوبا ، نيكاراكوا،فلسطين ، افغانستان ... رايارتهاجم

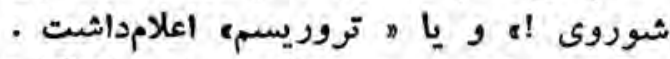

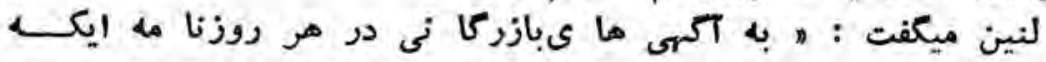

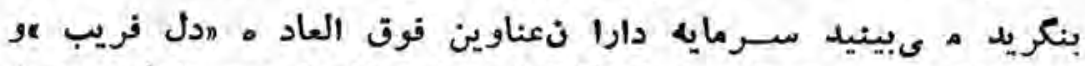

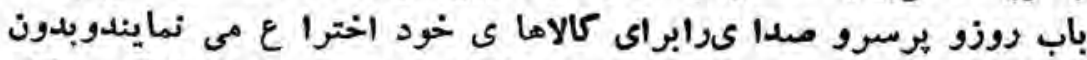

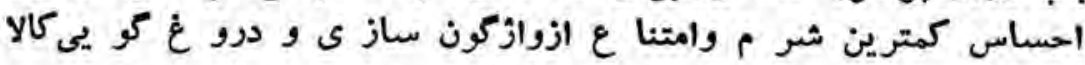

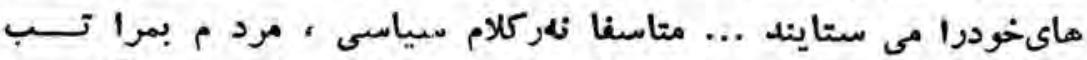

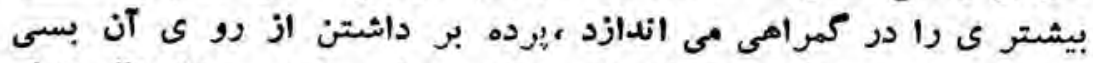

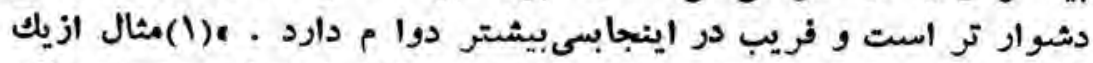

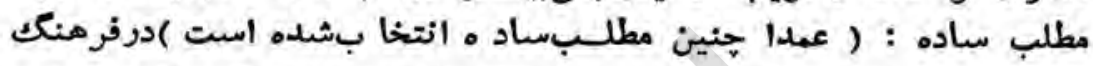

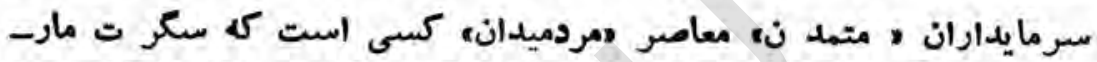

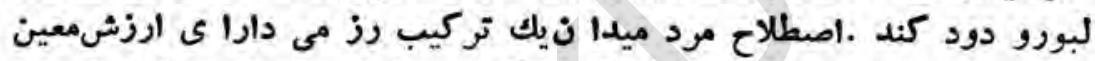

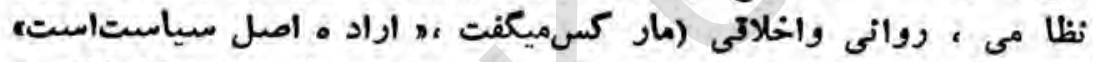

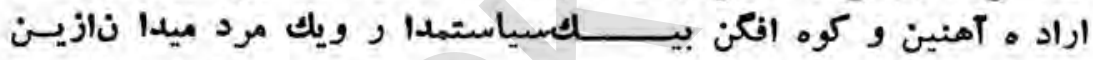

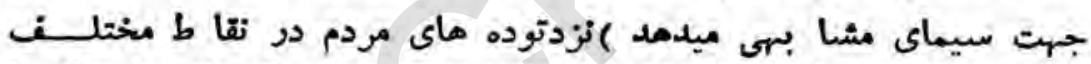

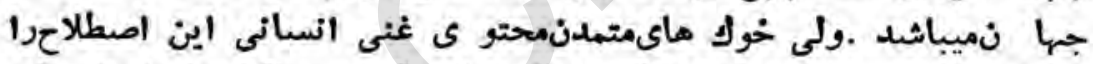

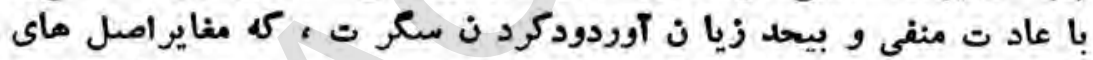

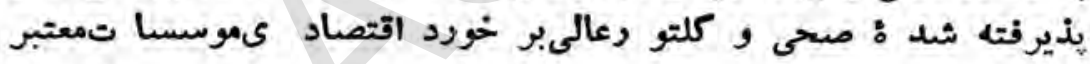

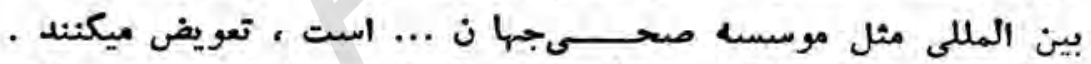

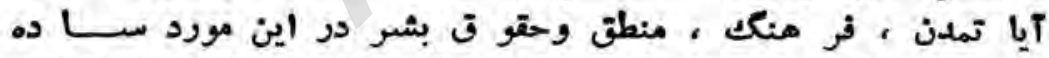

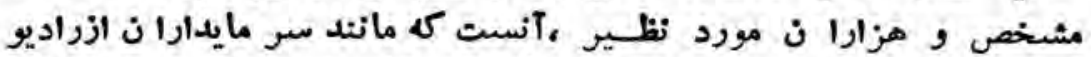

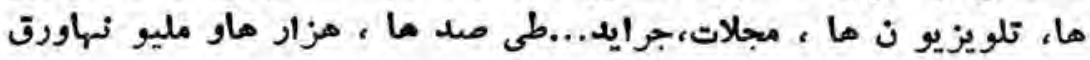

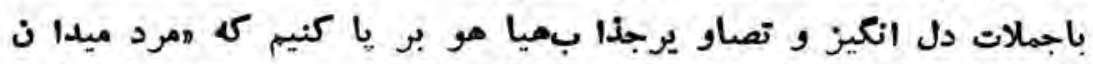

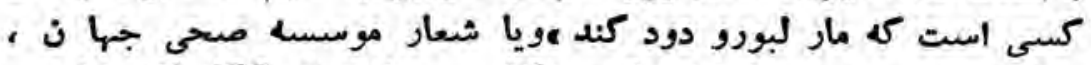

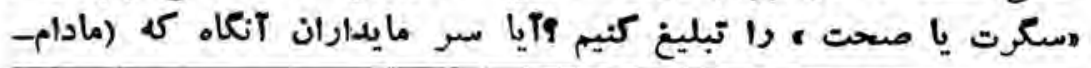

(1)و.ا.لنين ، مقاله , احسـزابسياسى در روسيه ه.

-1 rro 


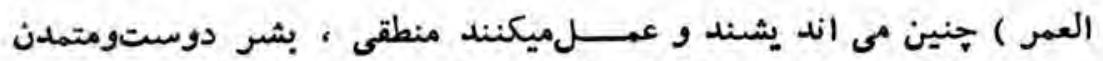

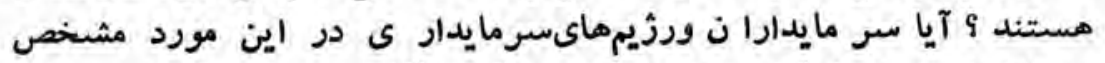

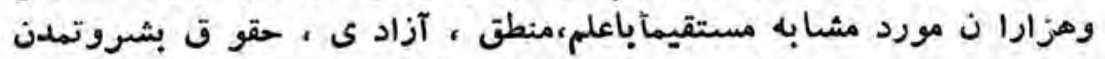
وإقعى در تضاد و مخا صمت قـردارندارند ؟

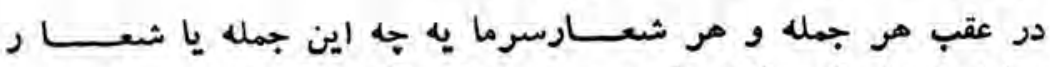

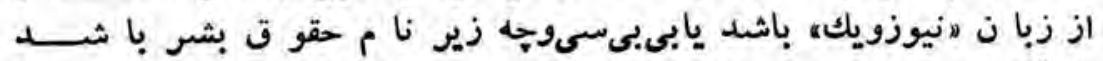

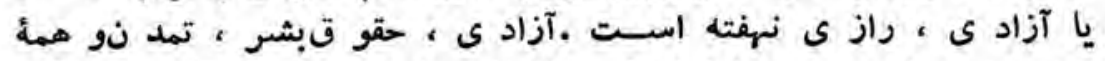

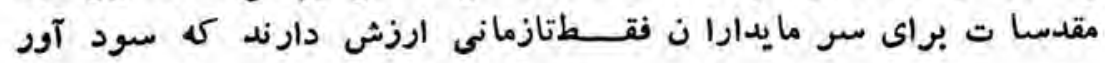

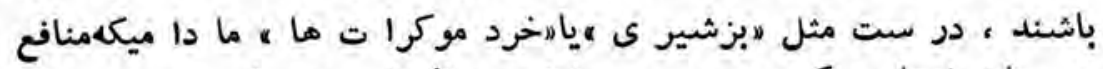

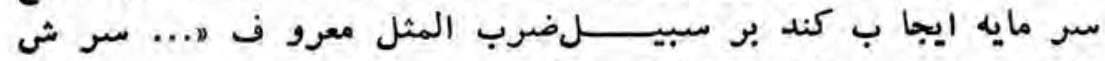

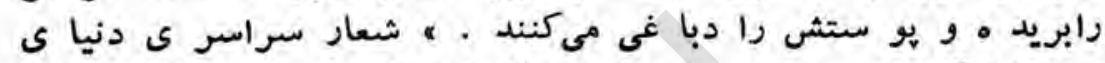

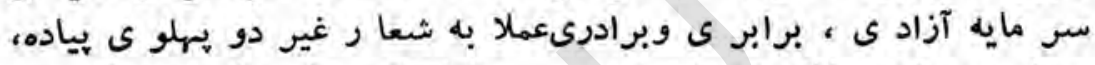

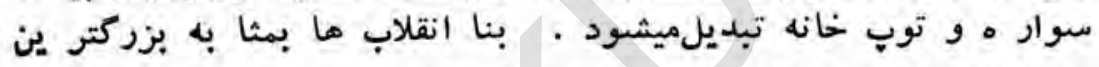

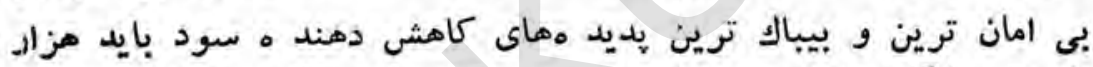

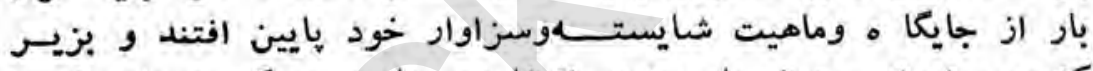

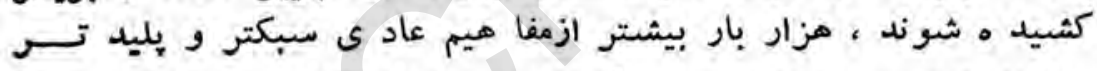

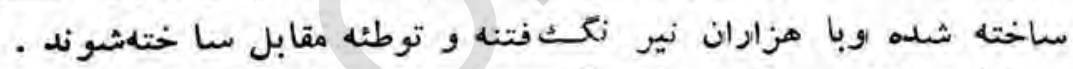

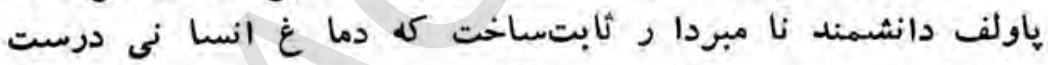

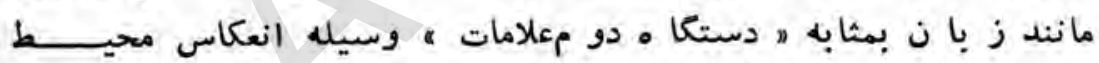

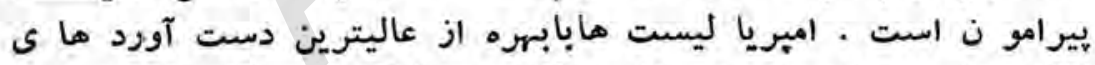

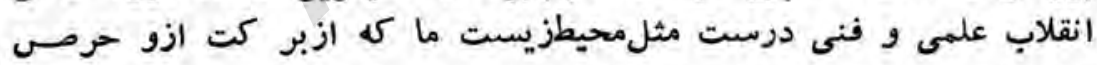

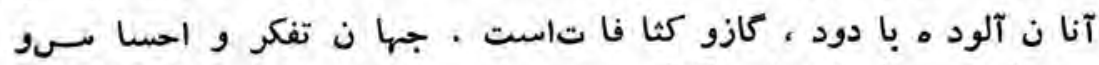

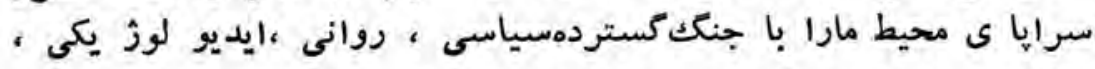

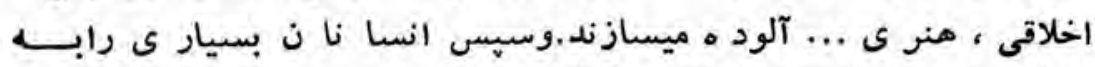

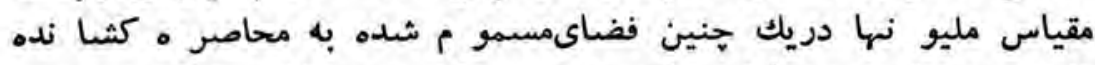

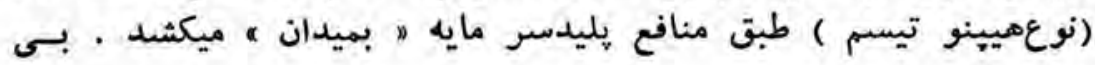




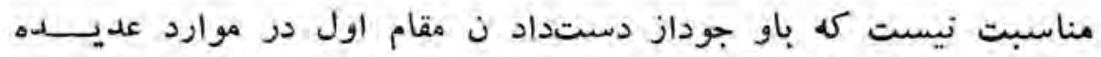

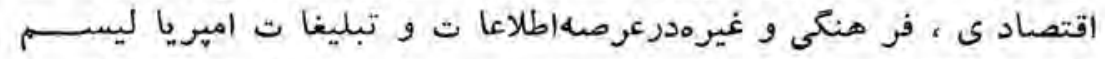

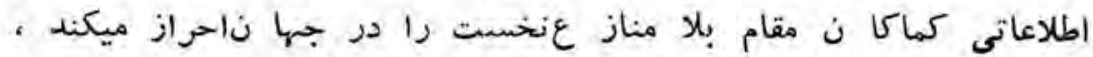

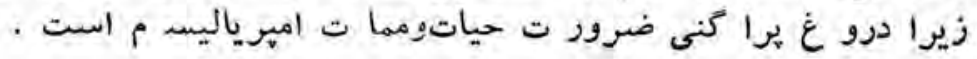

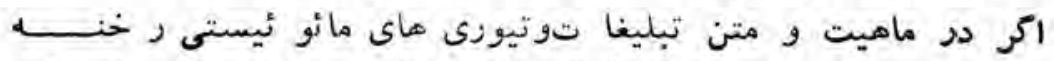

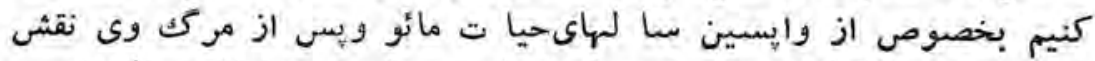

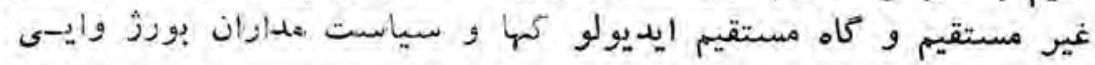

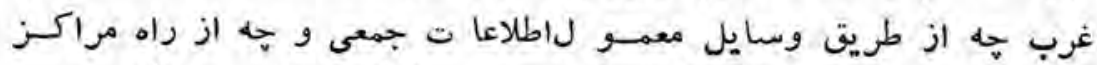

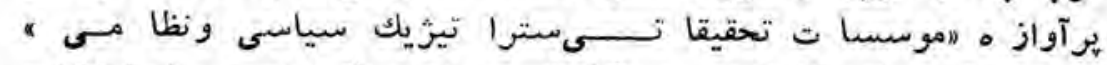

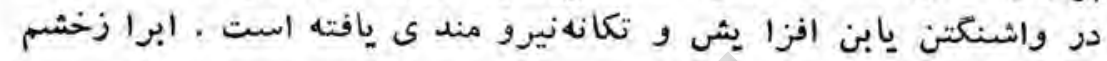

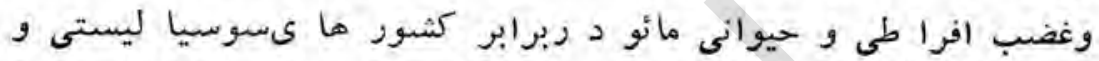

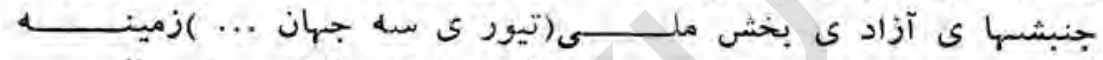

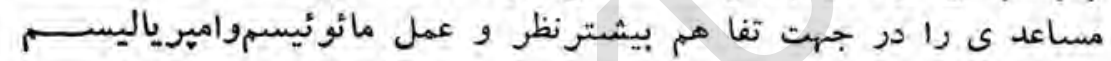

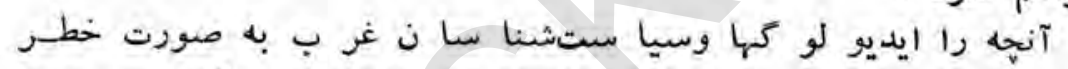

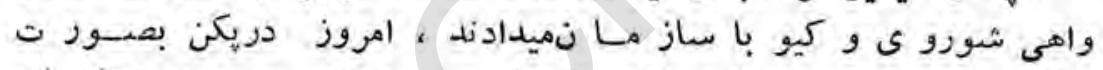

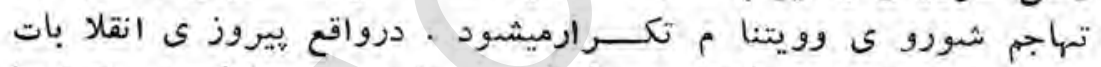

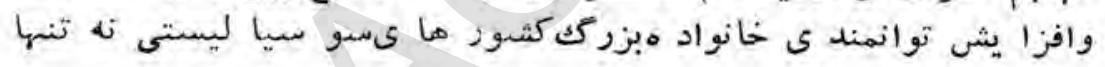

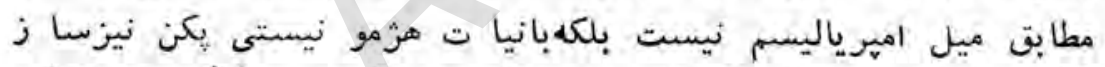

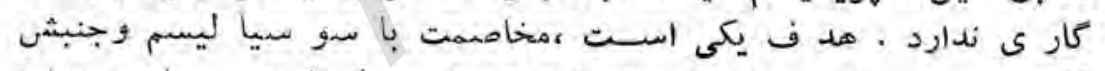

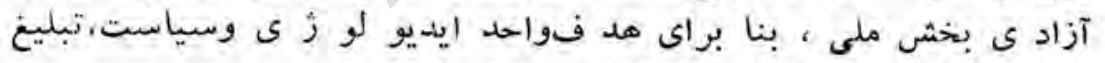

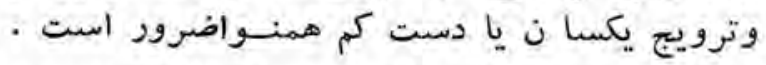

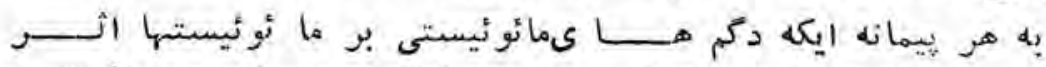

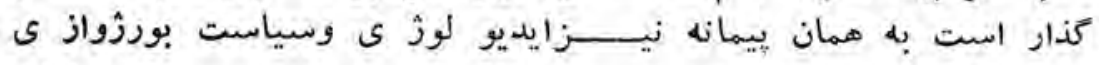

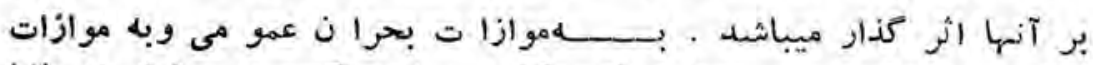

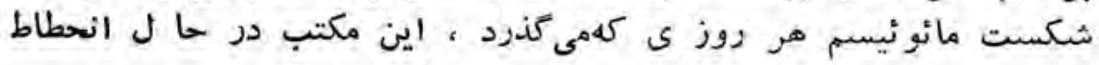




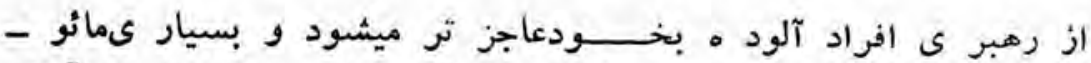

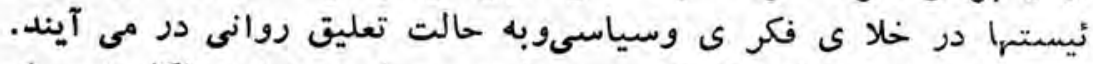

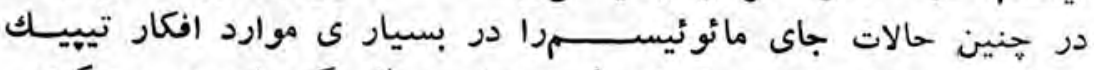

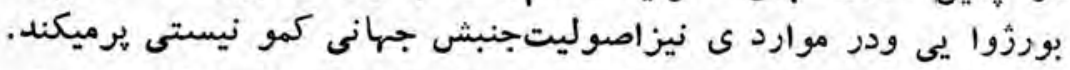

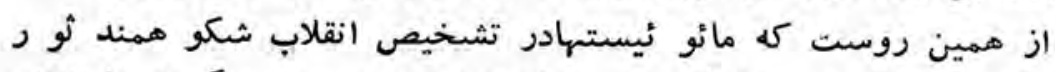

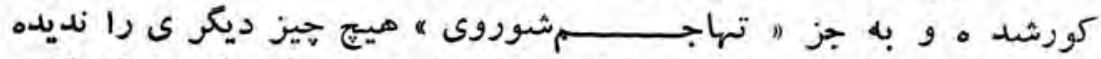

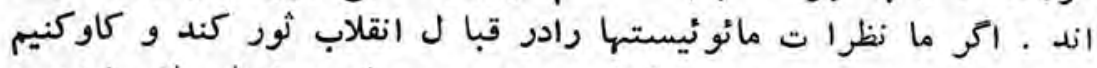

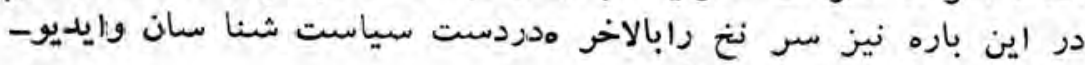

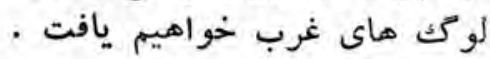

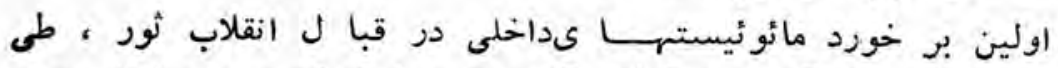

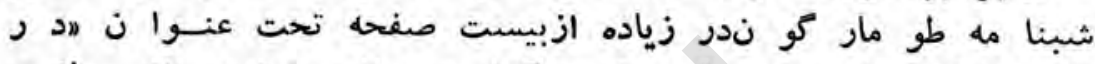

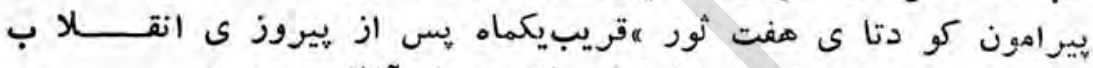

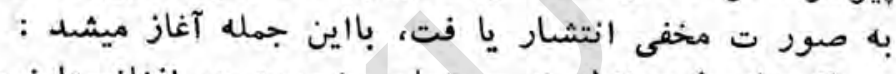

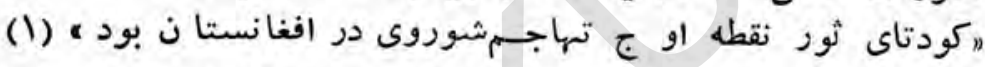

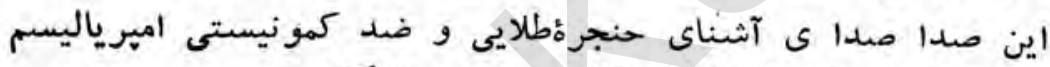

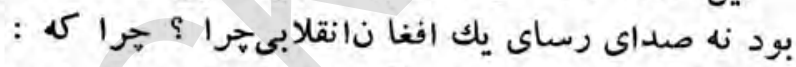

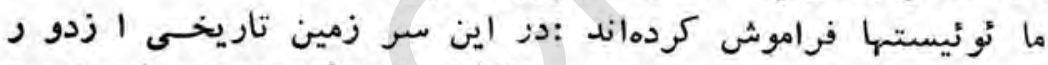

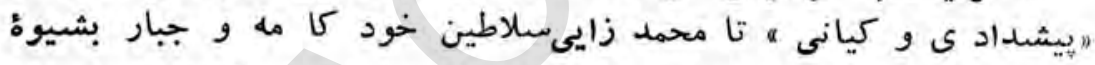

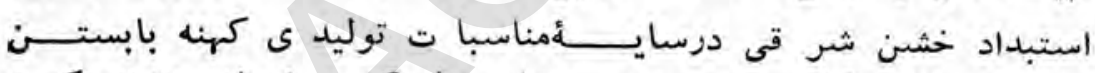

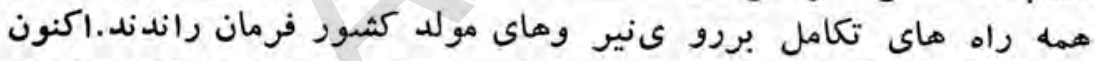

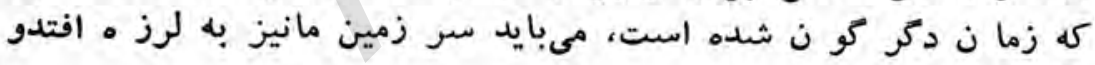

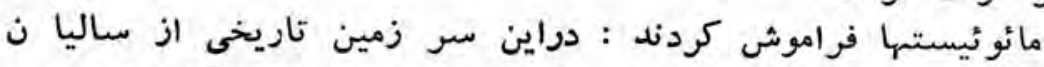

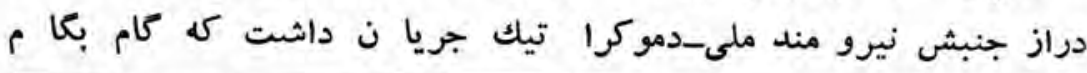

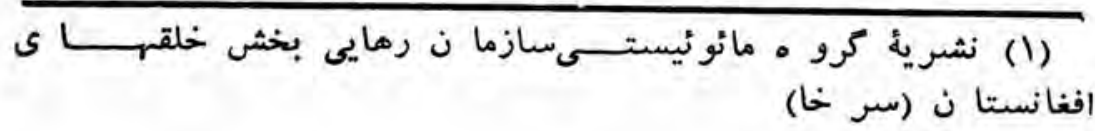




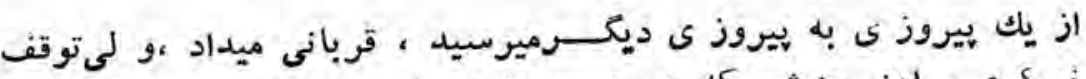

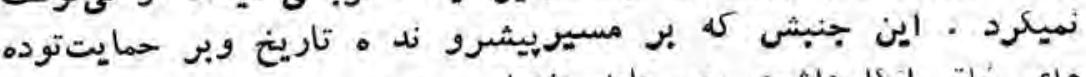

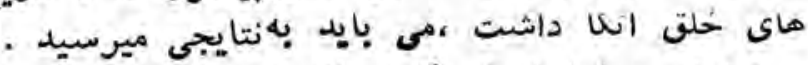

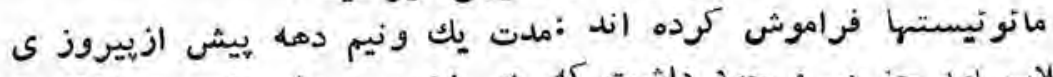

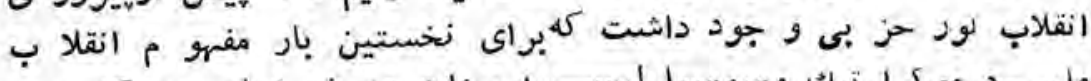

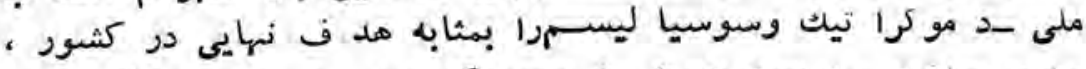

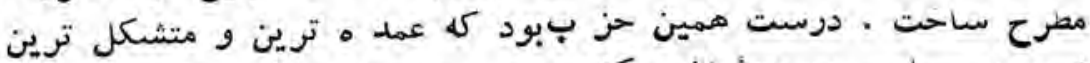

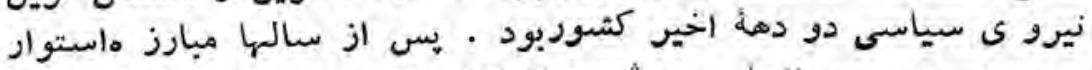

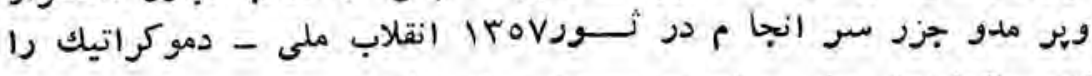

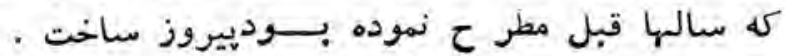

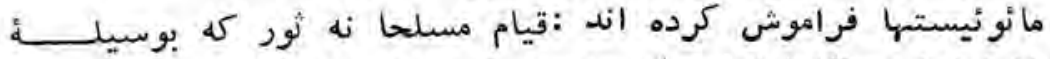

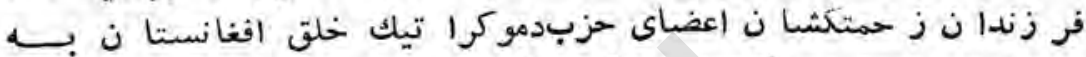

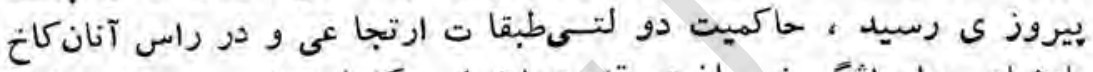

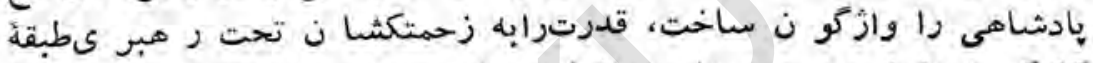

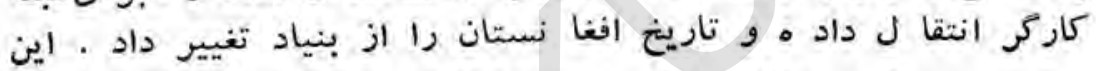

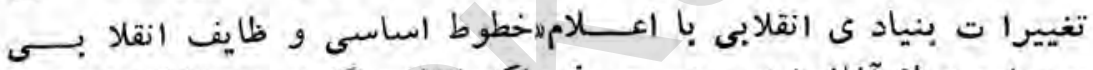

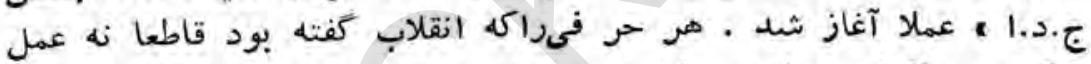

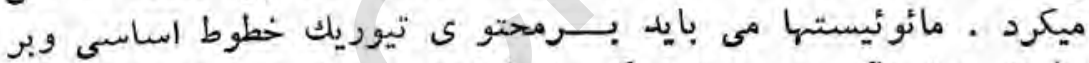

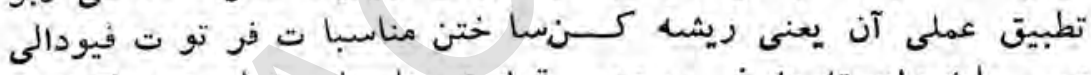

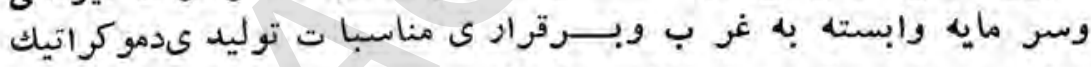

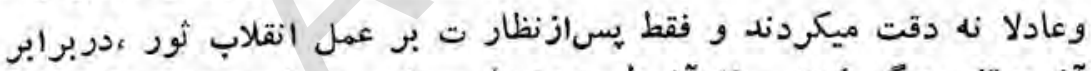

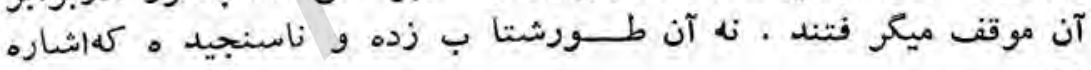
ش ش بدين كو نه علت و قوع انقلا بثور نه تهاجيم شورو ى بلكه ماند مانند

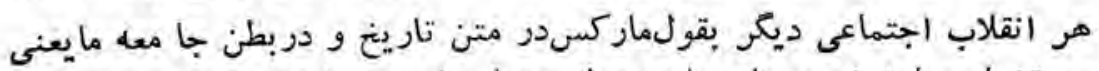

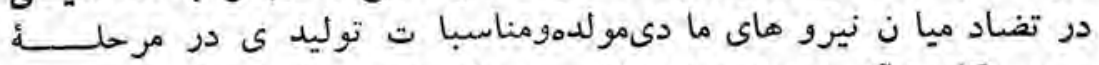

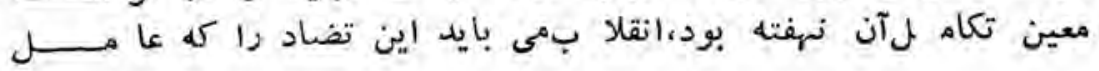




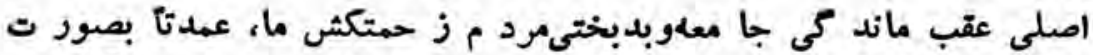

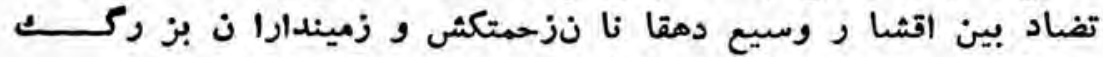

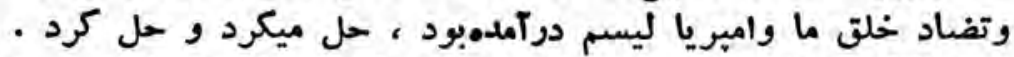

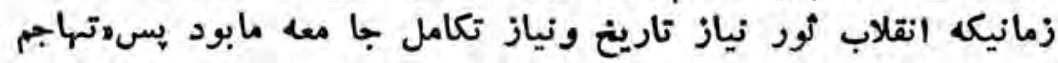

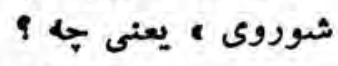

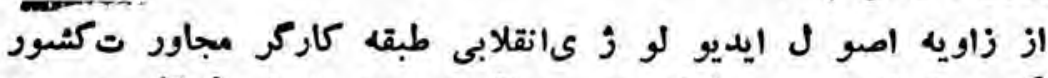

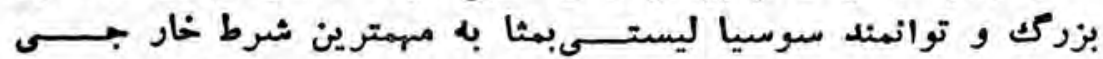

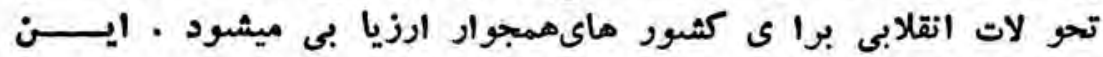

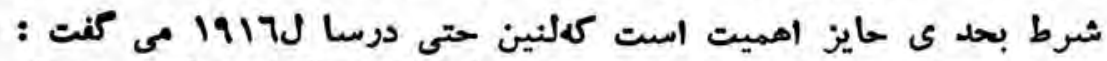
ب....

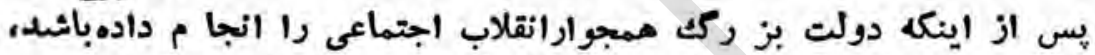

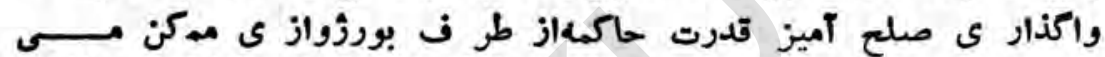

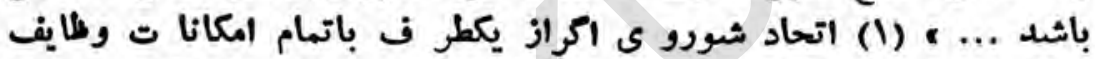

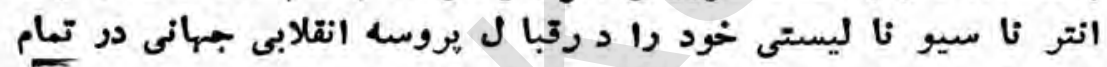

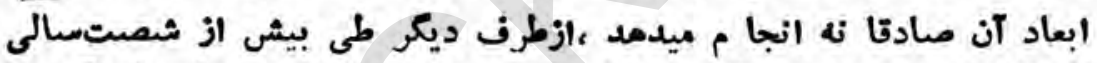

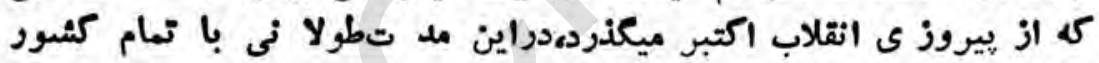

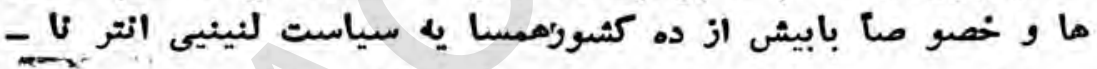

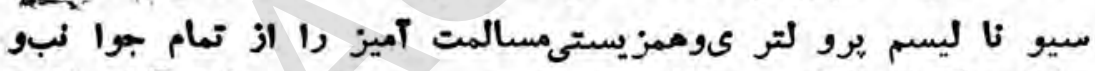

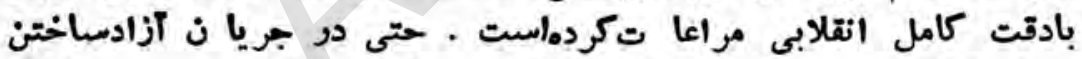

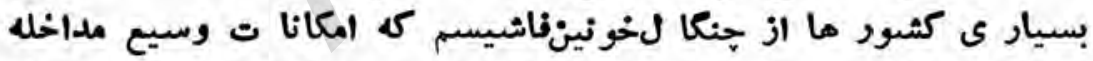

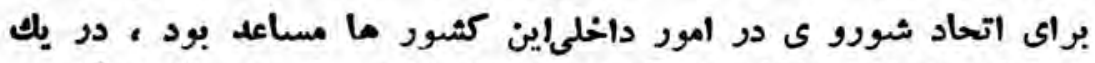

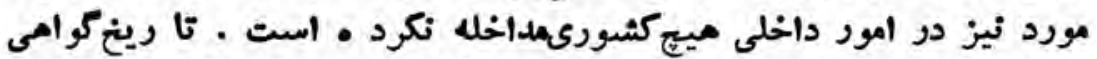

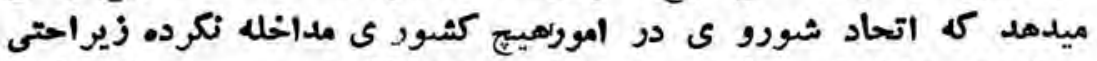

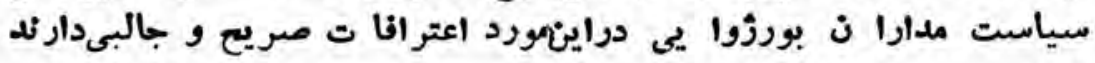

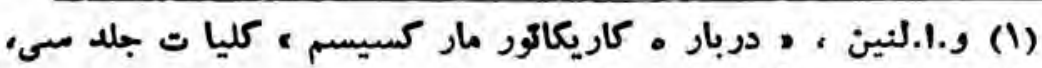
ص זrا. تكيه از ماست . مربار . 


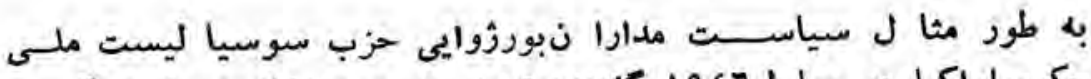

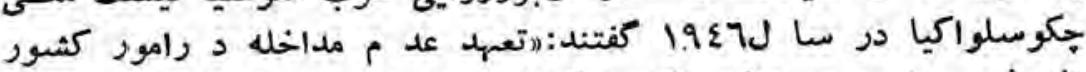

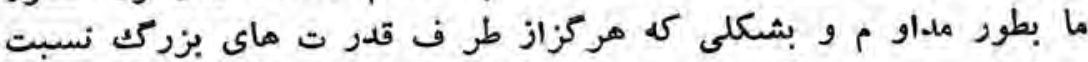

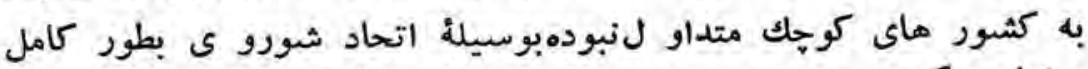

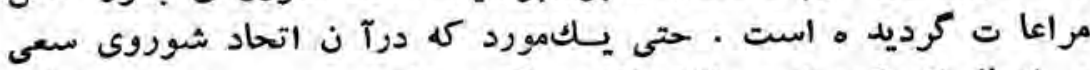

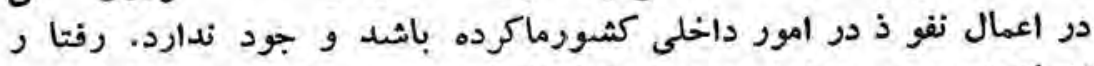

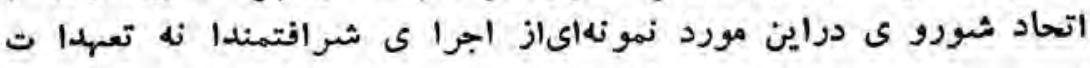

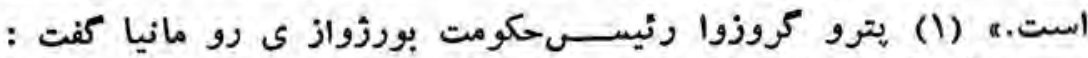

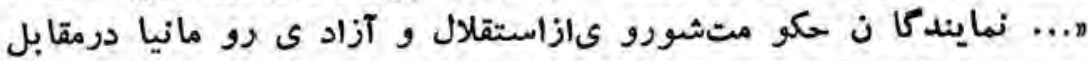

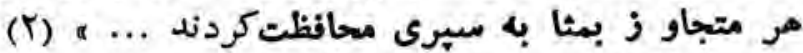

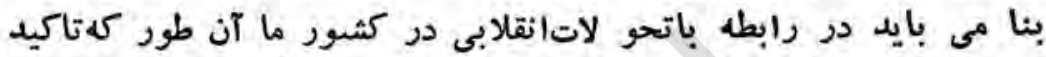

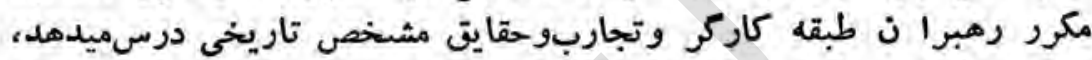

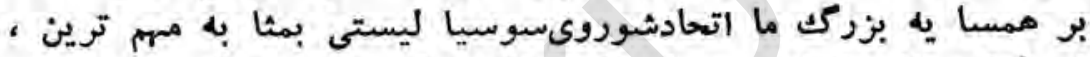

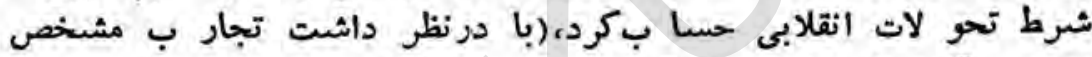

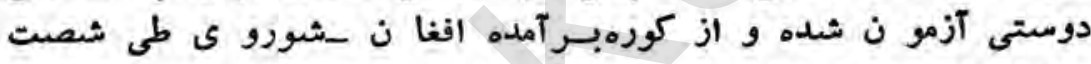

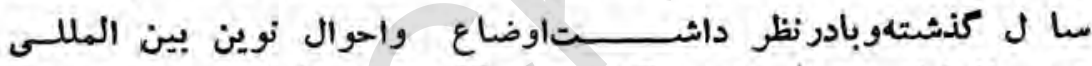

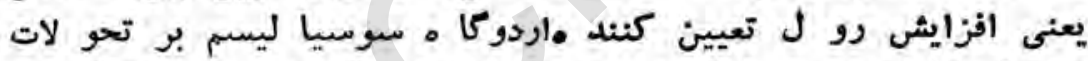

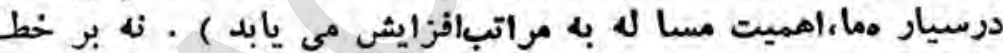

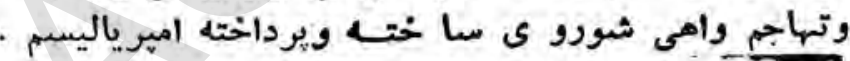

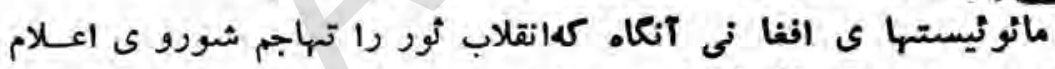

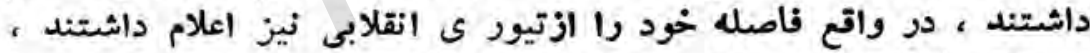

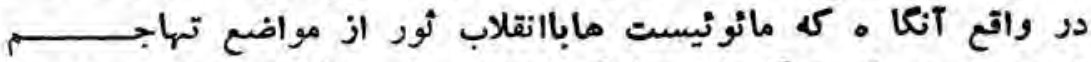

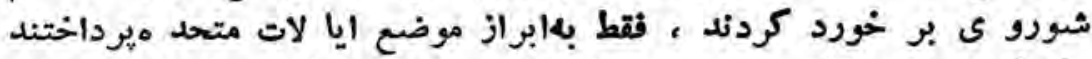

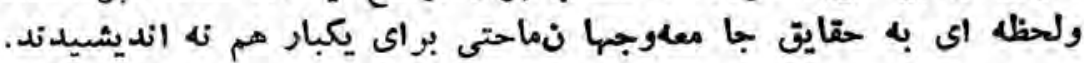

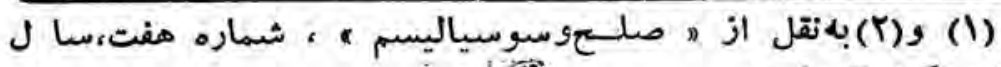

$$
\begin{aligned}
& \text { ति }
\end{aligned}
$$

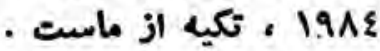




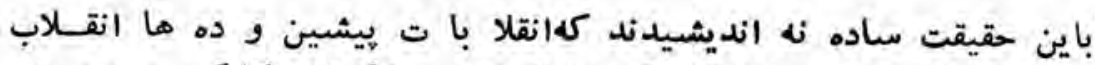

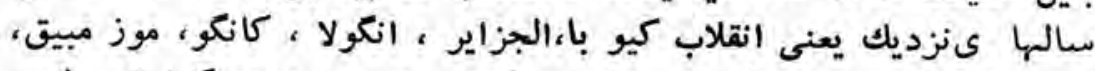

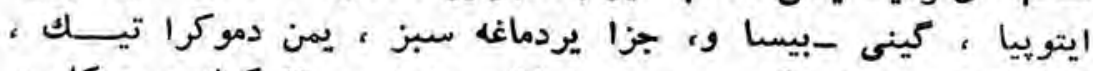

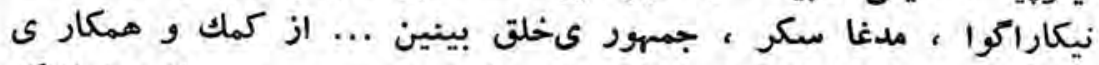

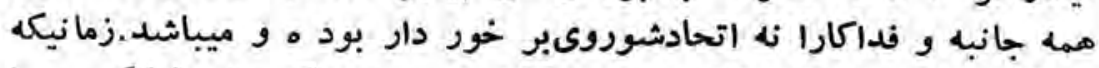

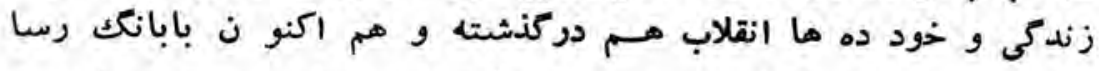

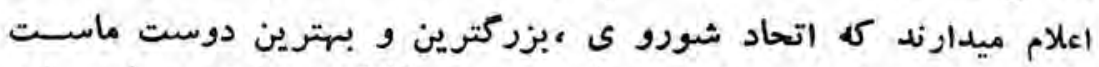

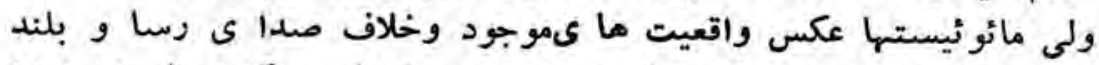

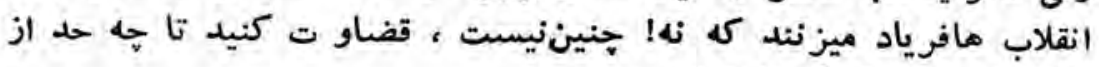

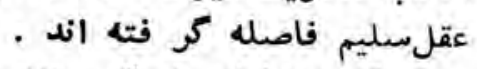

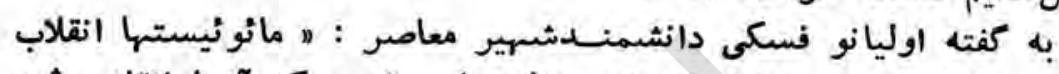

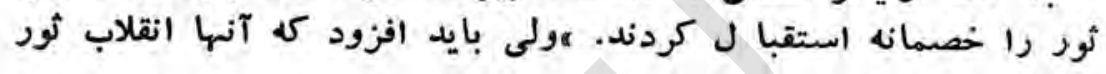

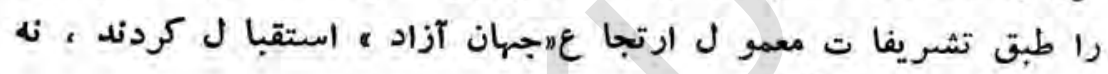

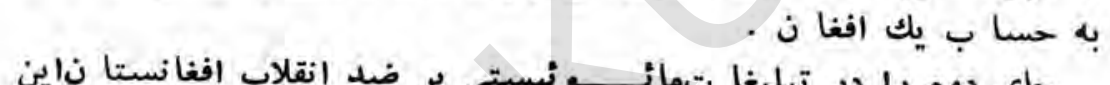

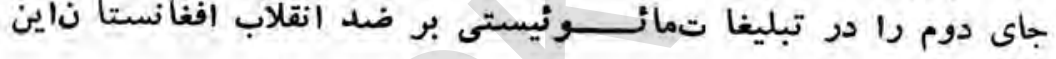

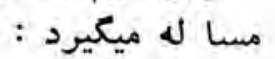

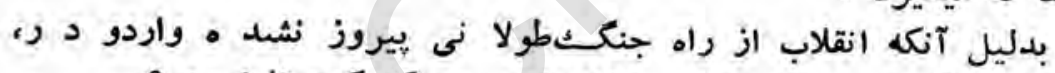

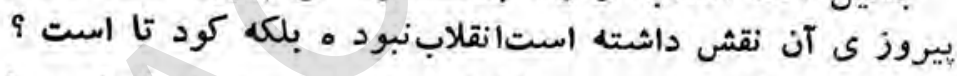

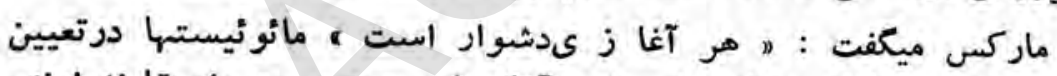

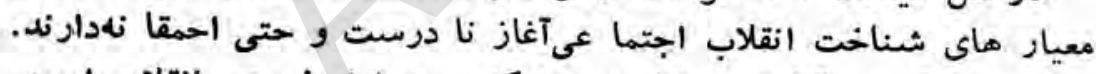

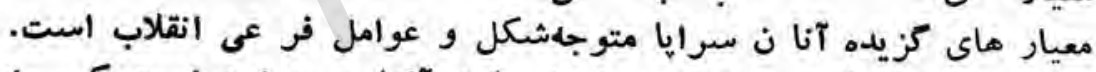

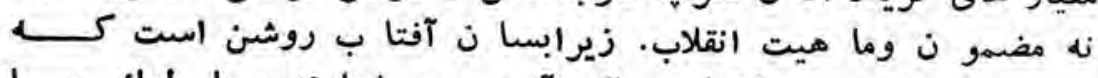

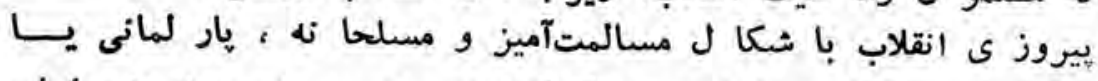

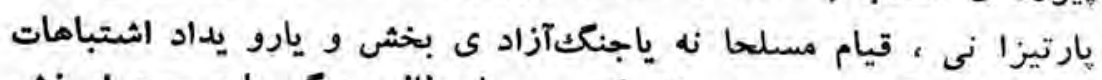

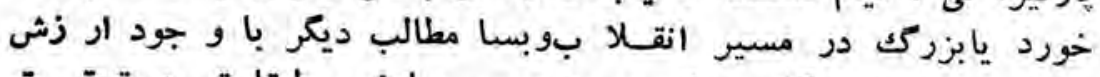

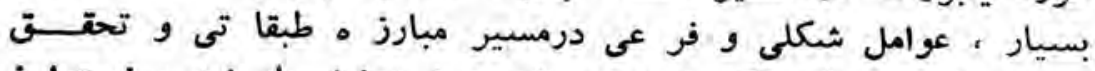

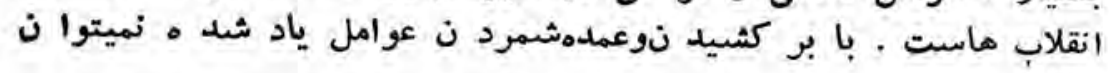




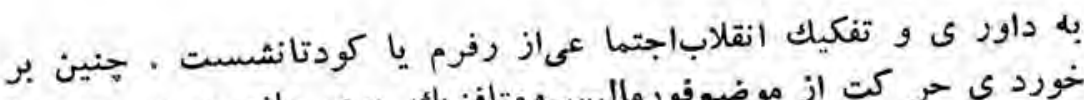

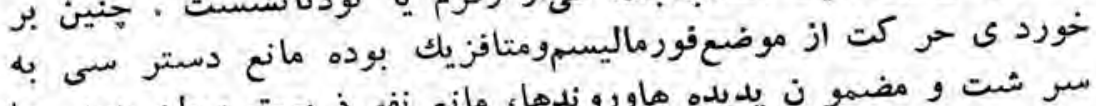

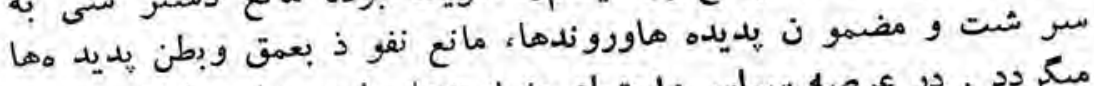

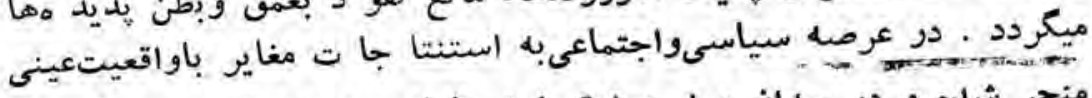

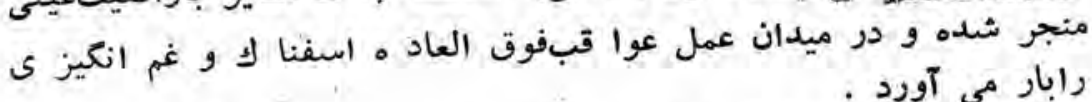

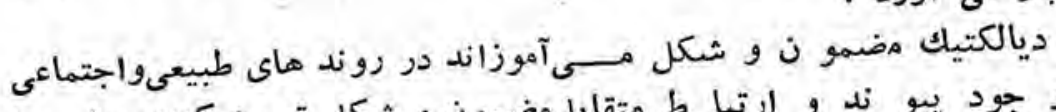

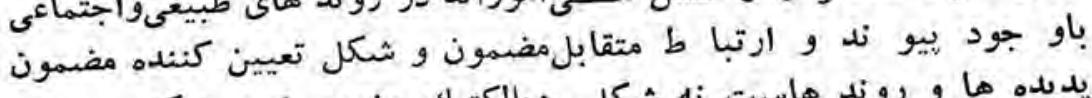

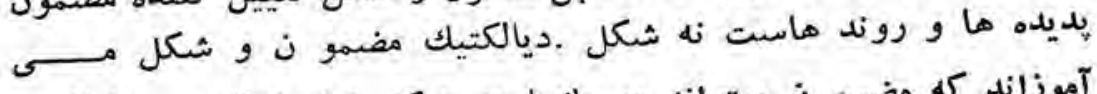

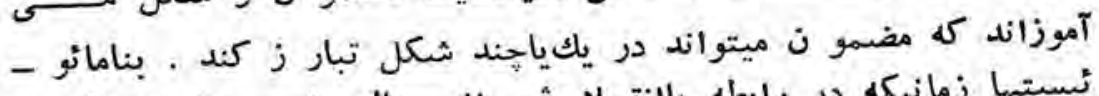

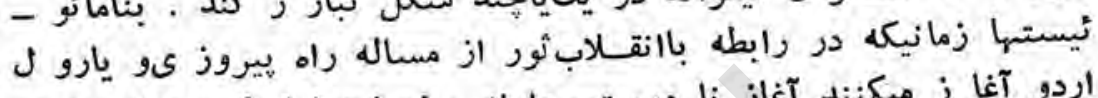

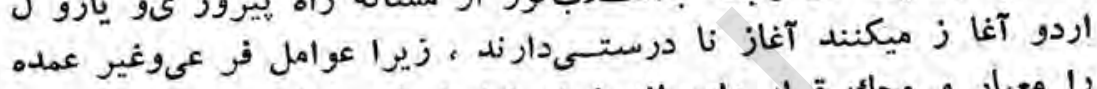

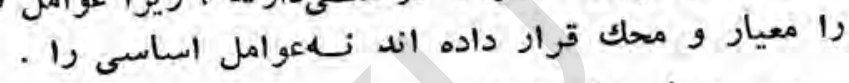

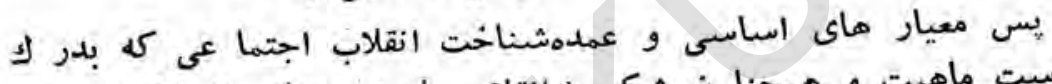

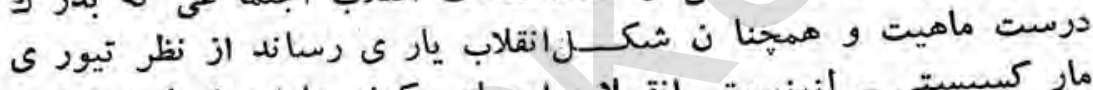

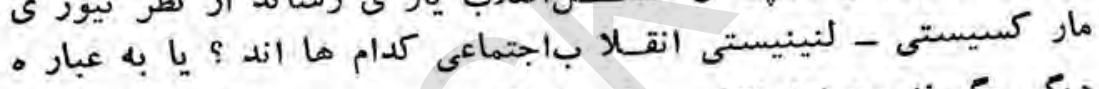

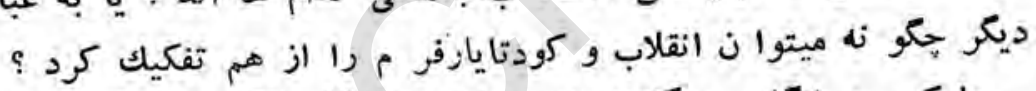

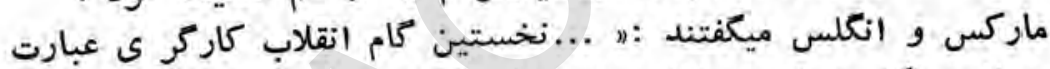

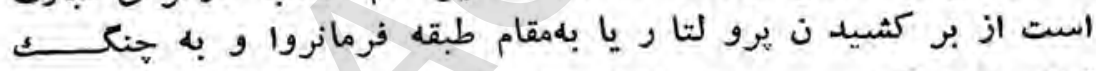

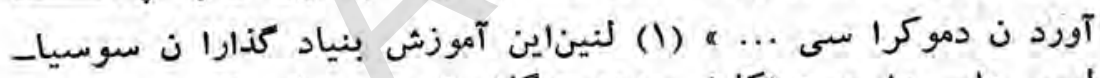

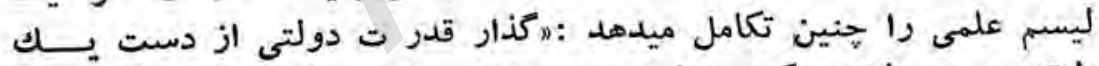

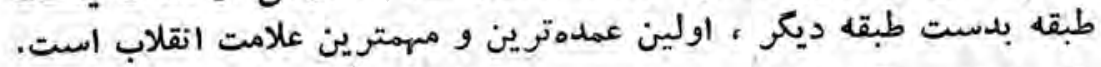

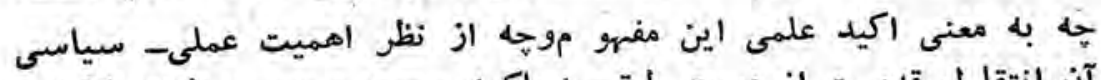

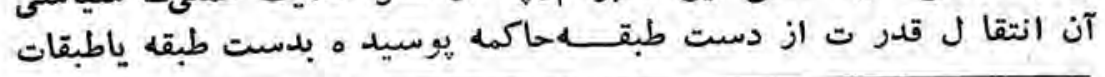
(1) كو .ماركس و ف . انكلس ،مانيفست .... ، تر جمه جديدفارسي حزب توده ايرا نمار ن 


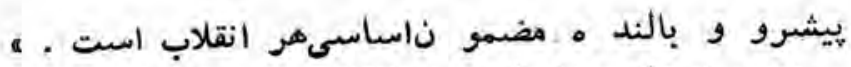

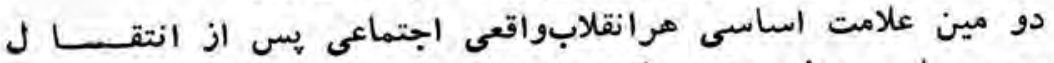

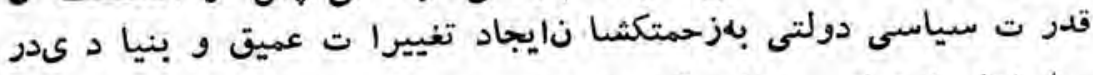

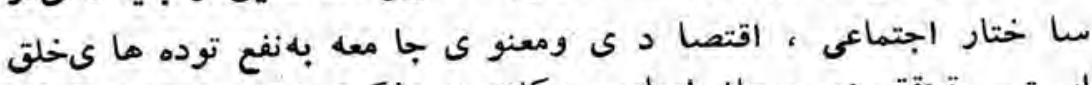

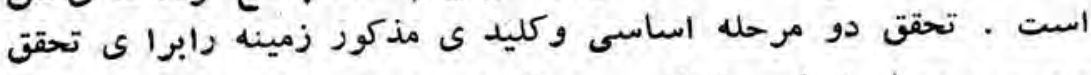

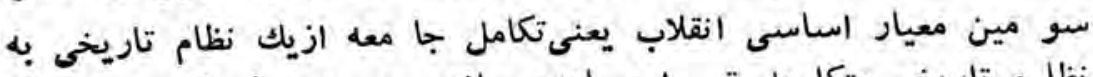

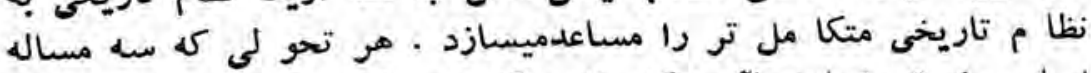

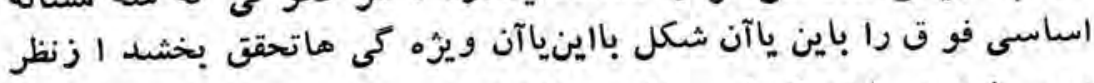

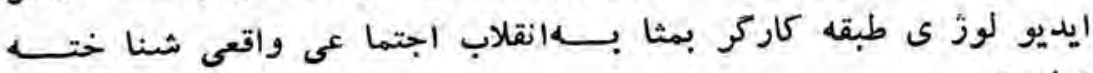
ميشود . ميدر كرو

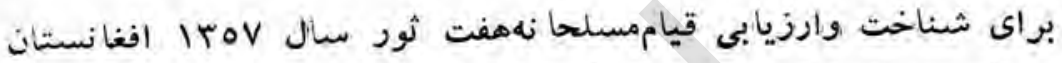

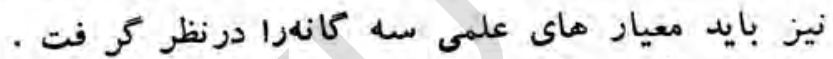

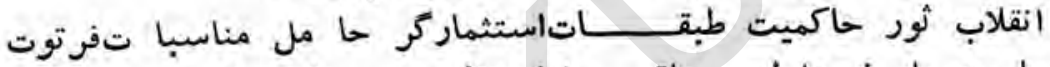

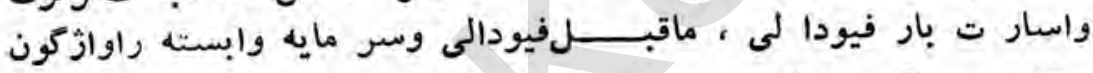

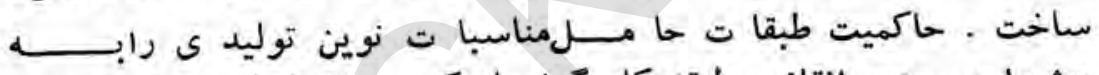

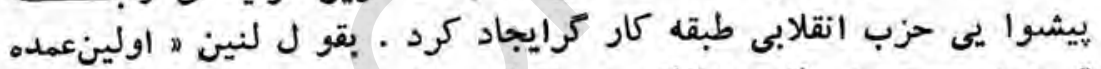

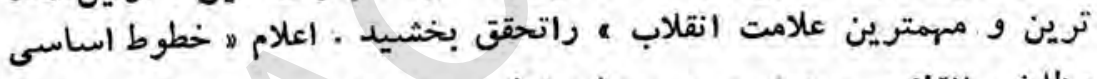

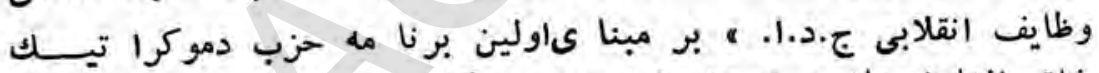

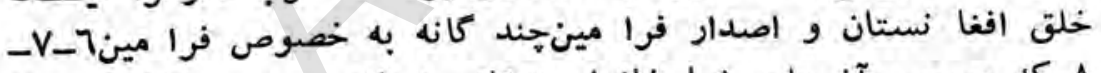

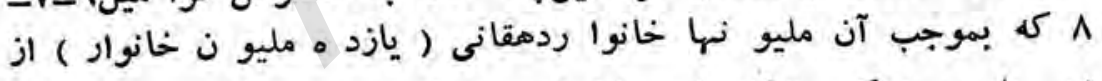

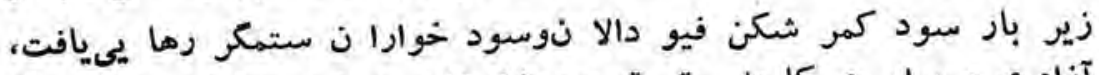

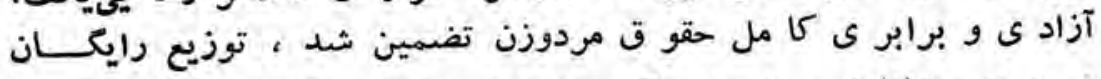

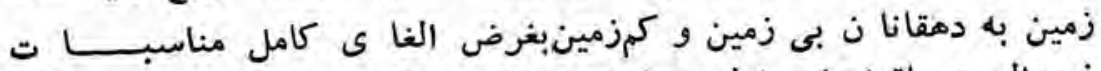

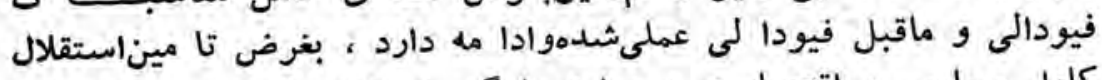

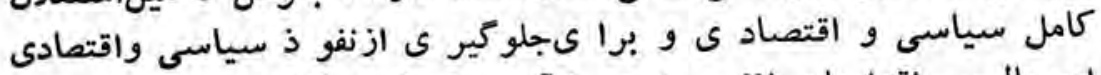

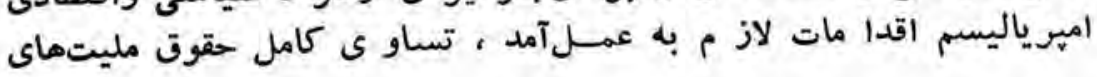




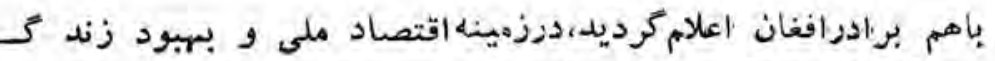

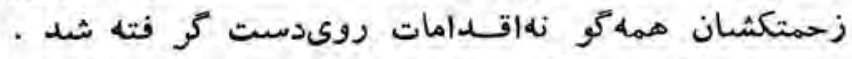

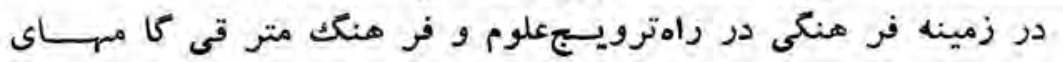

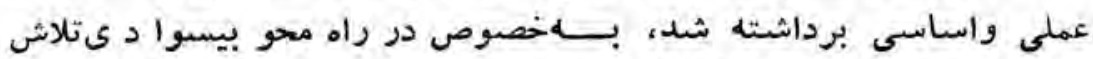

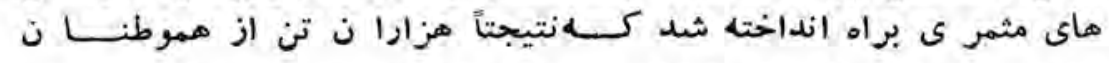

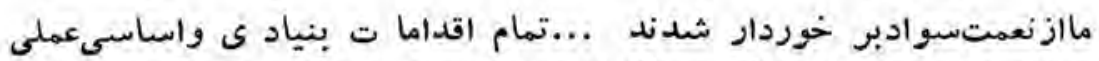

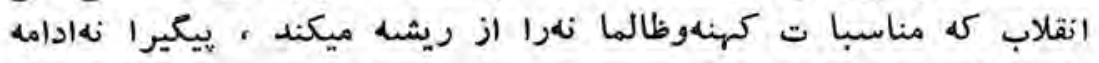

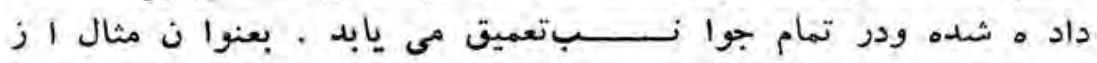

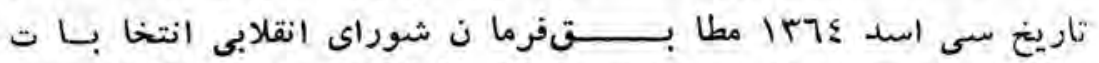

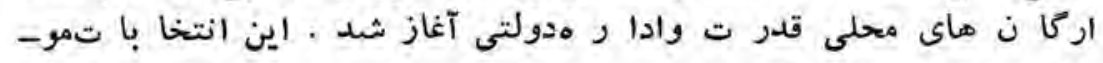

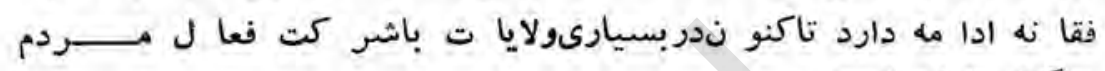

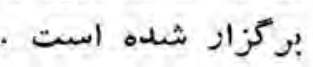

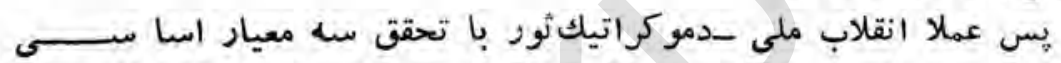

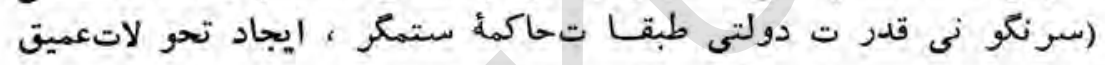

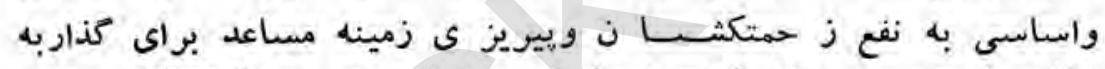

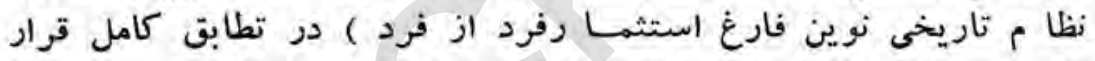

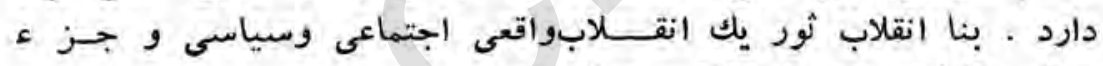

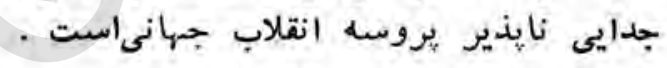

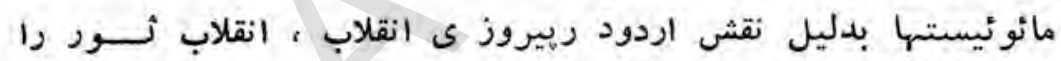

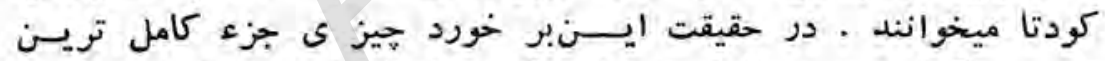

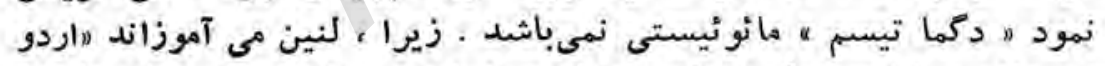

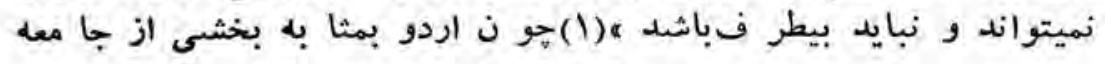

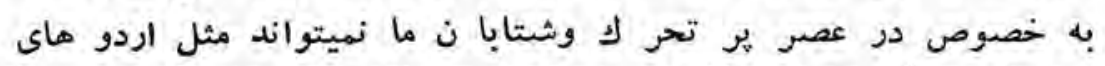

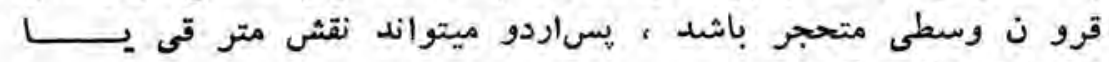
ارتجا عى باز ى كثى متدج .

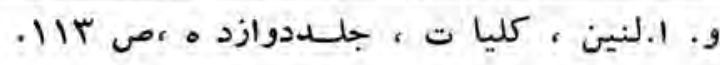




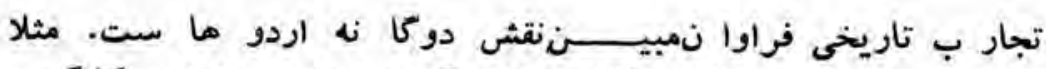

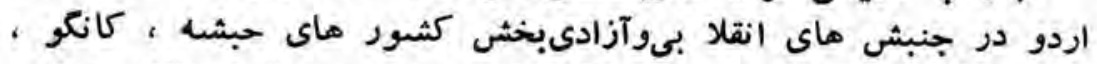

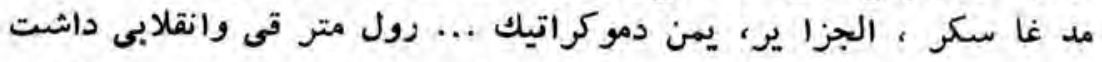

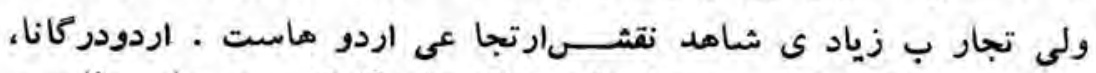

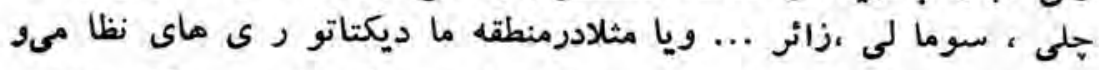

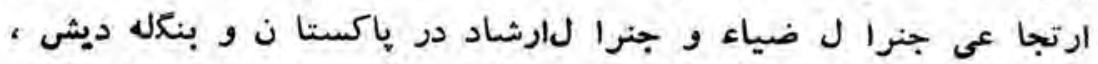

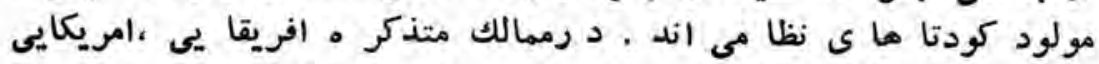

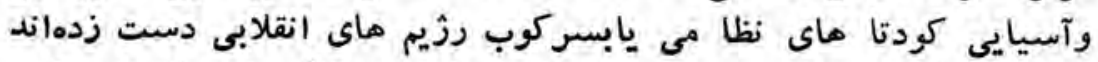

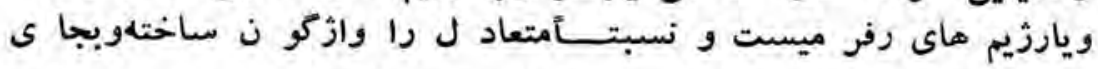

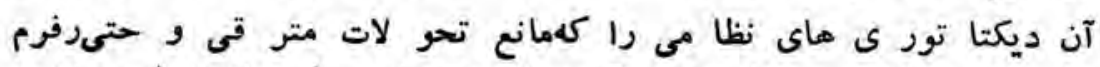

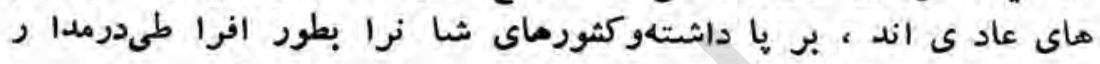

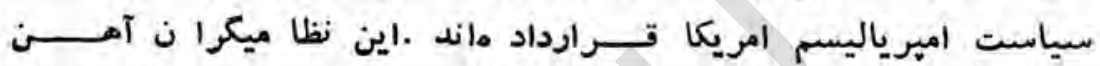

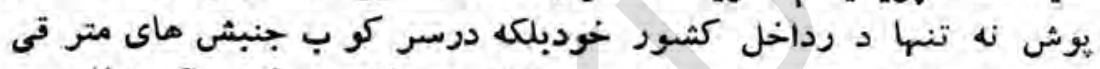

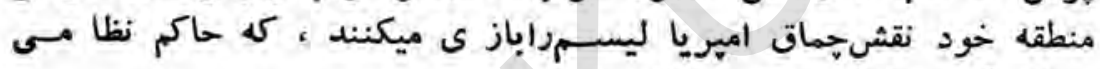

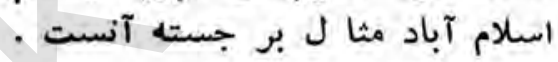

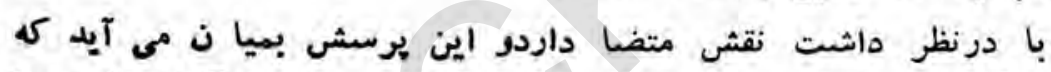

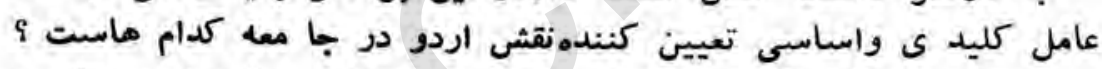

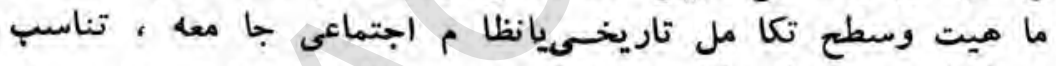

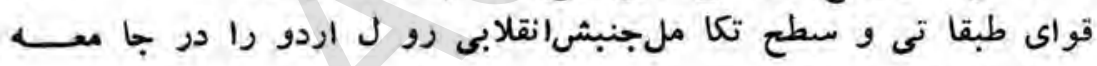

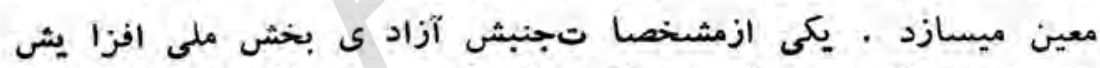

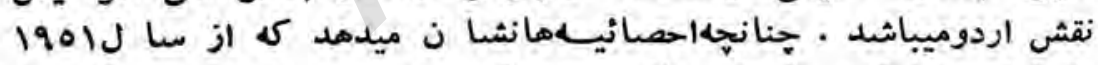

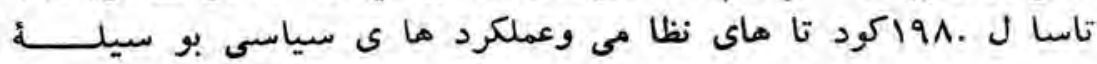

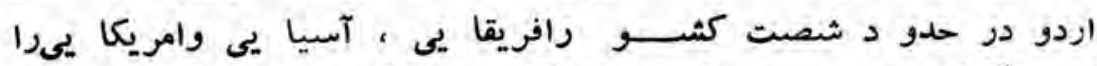

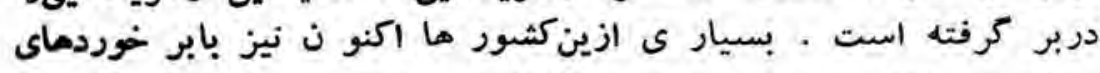

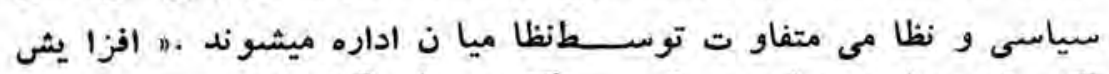

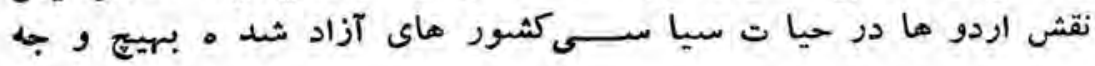

-1 rro 


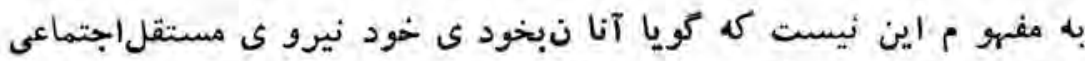

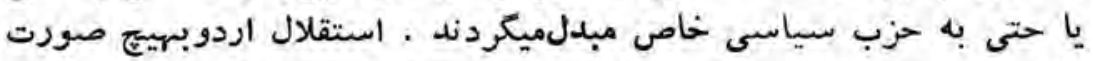

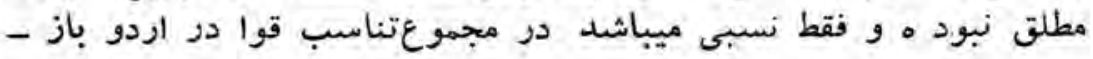

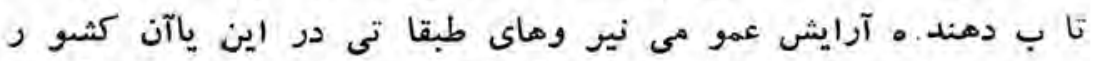

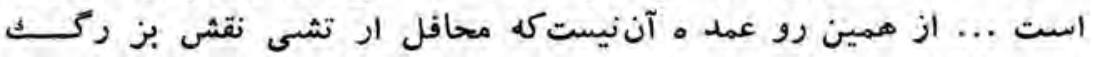

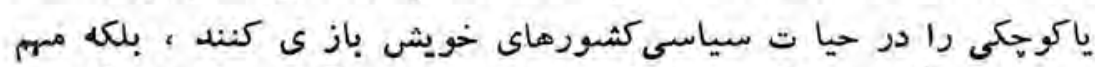

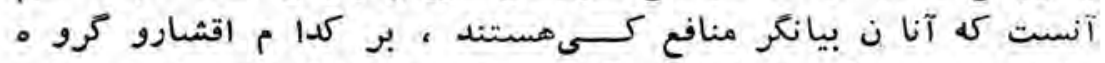

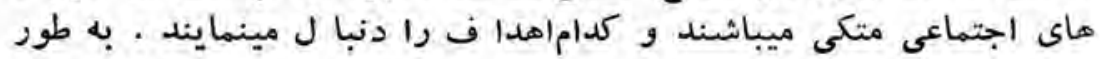

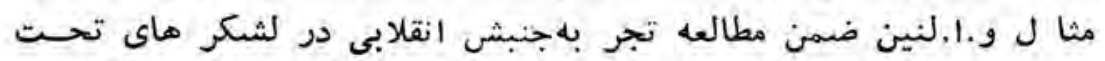

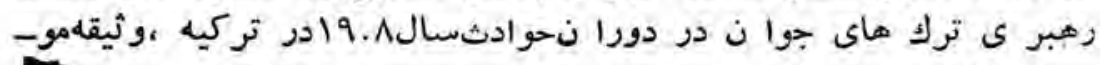

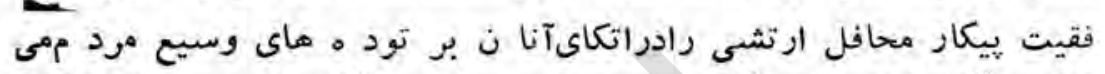

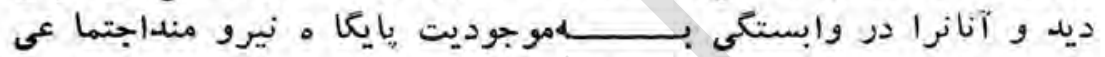

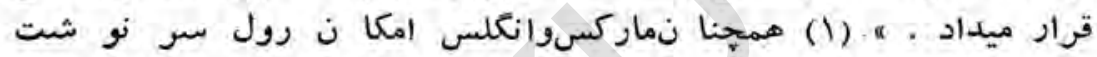

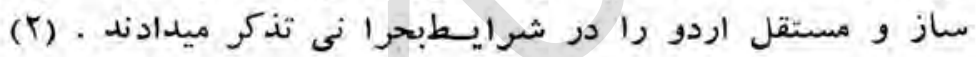

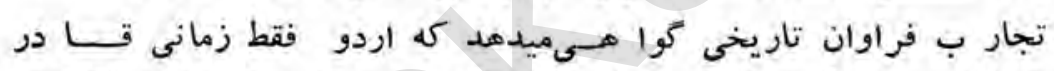

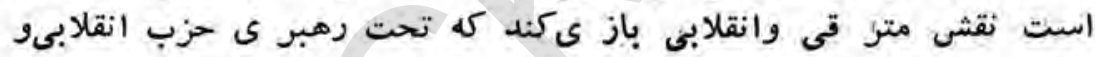

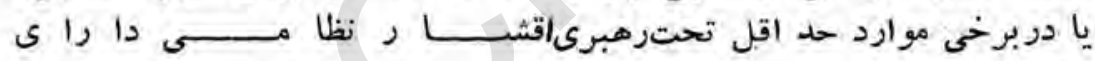

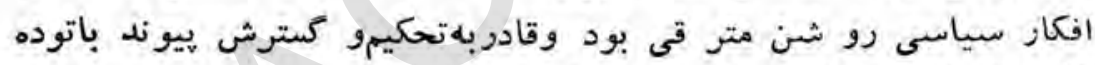

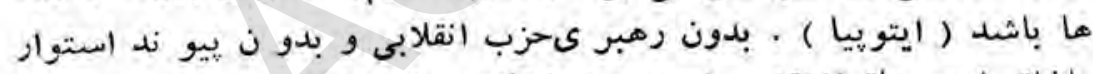

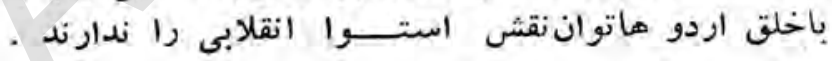

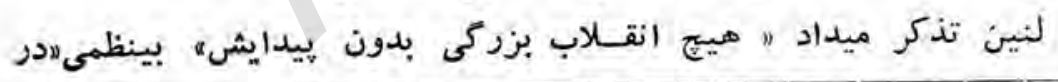

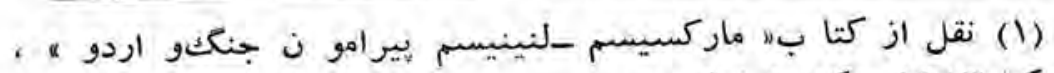

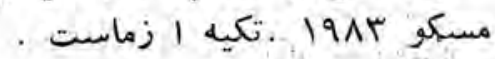

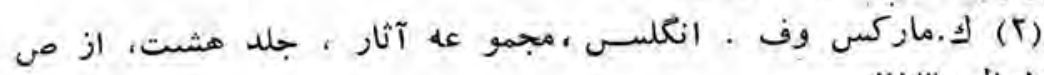
IVV 


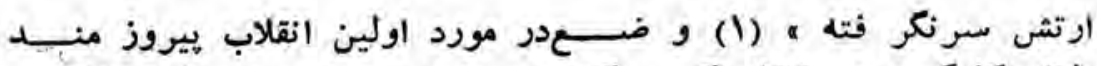

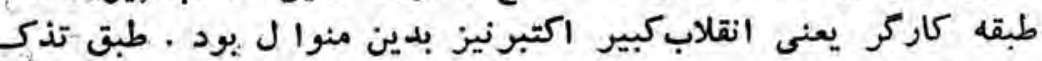

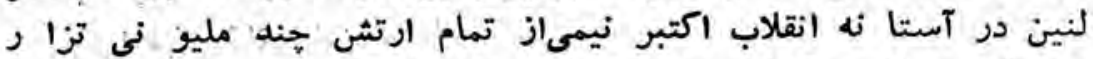

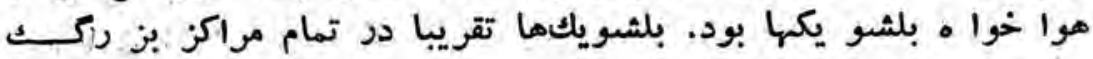

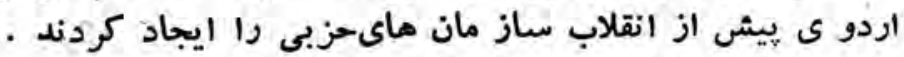

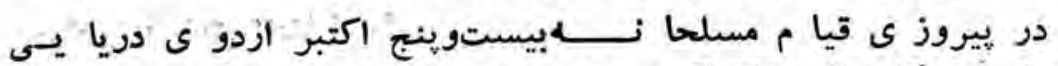

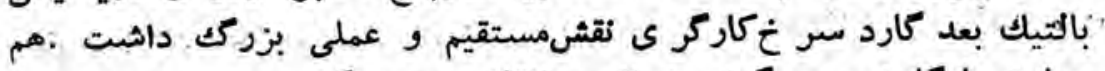

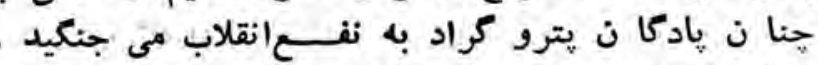

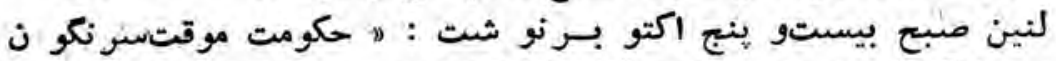

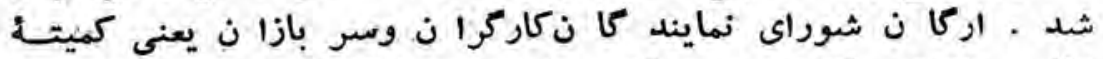

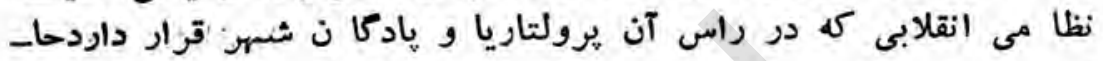

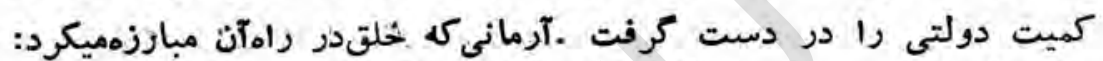

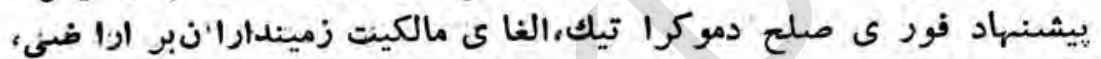

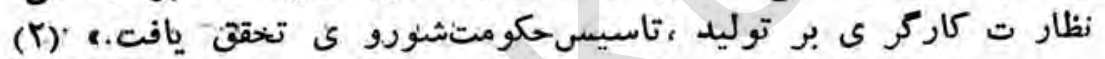

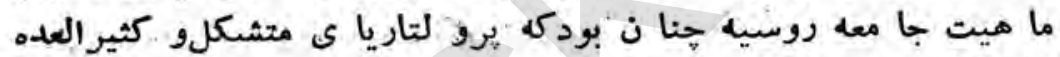

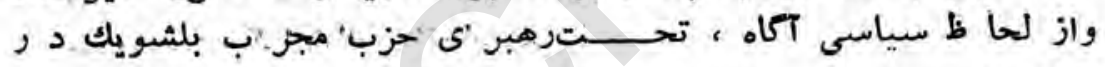

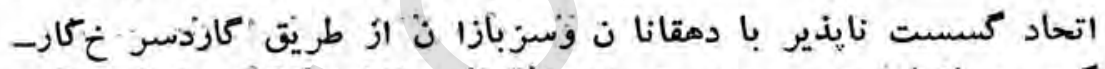

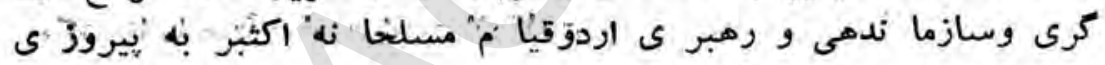

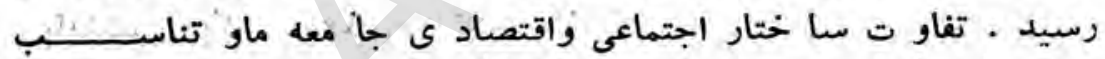

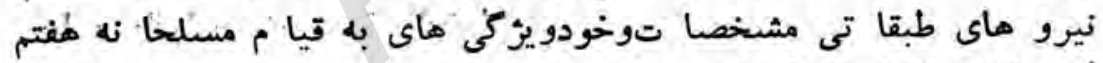

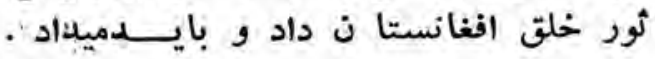

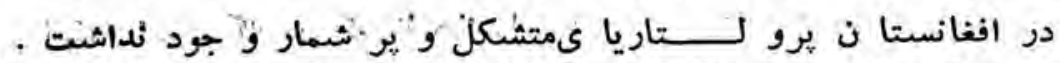

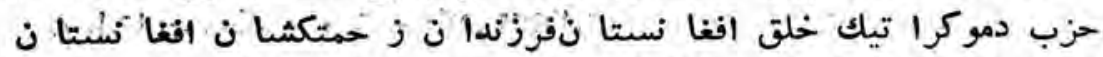

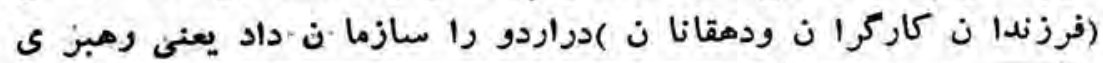

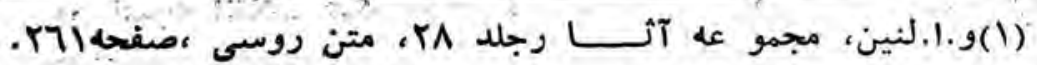

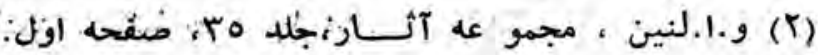




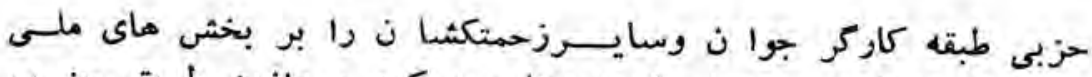

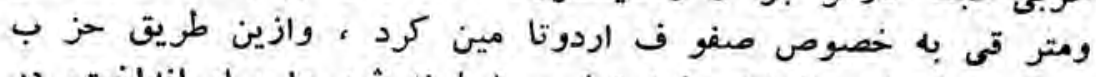

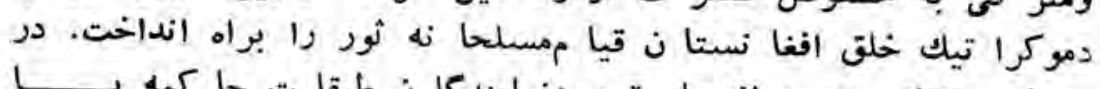

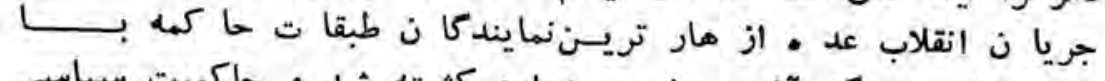

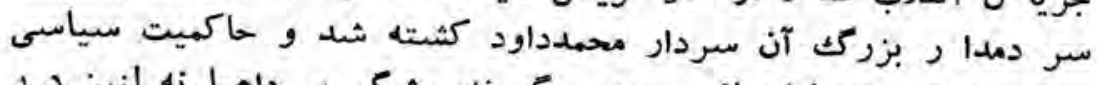

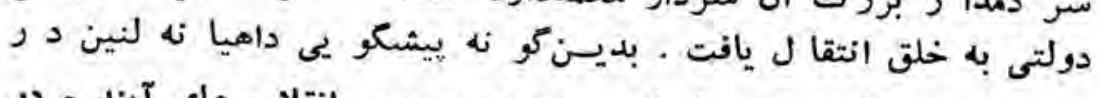

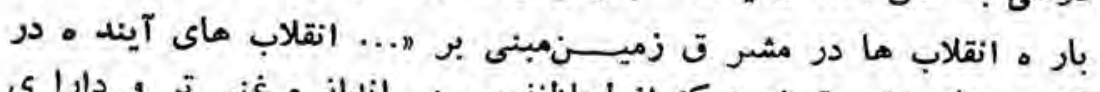

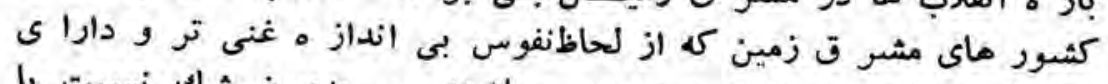

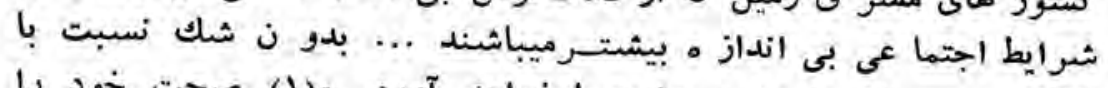

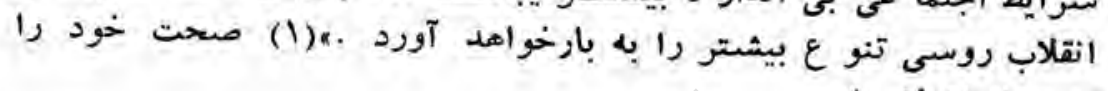

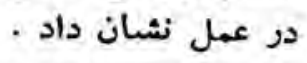

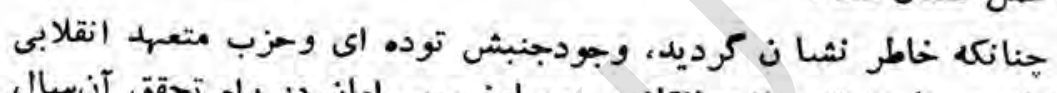

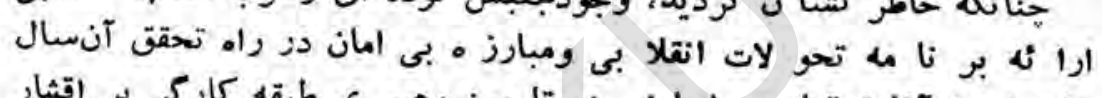

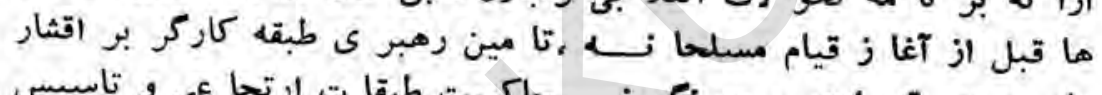

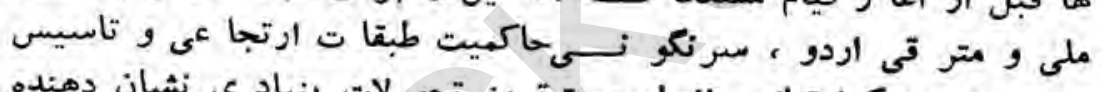

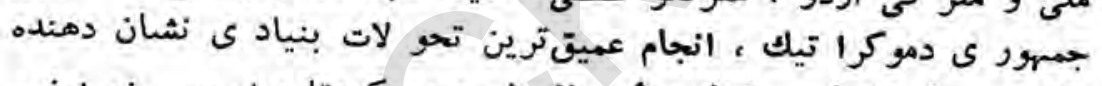

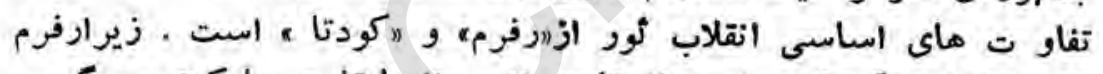

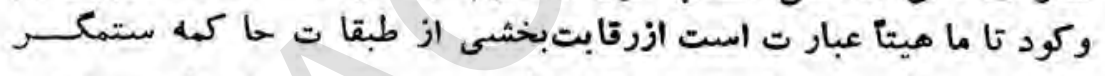

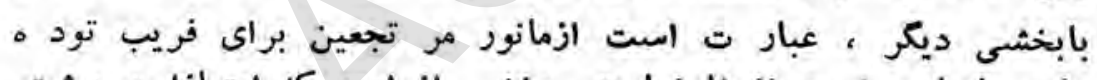

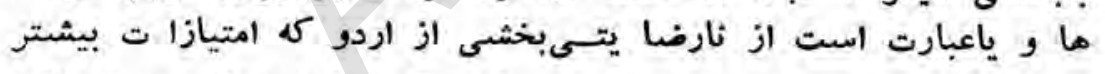

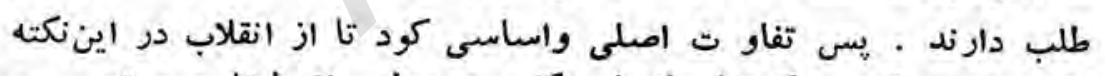

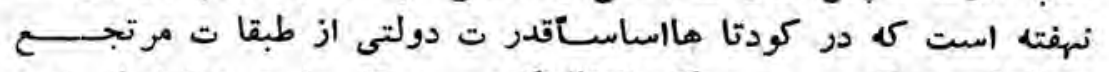

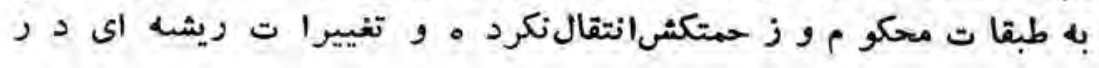

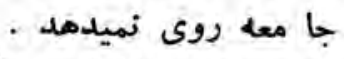
در نتيجه انقلاب شكو همثل ثورفيودالا ن ، اشرا ف · بورو كرا ت

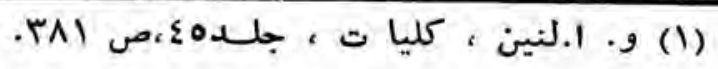




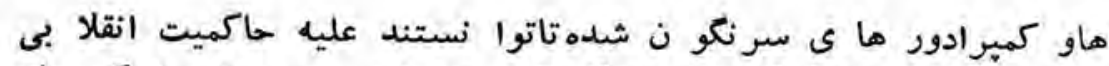

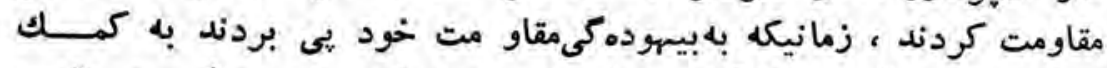

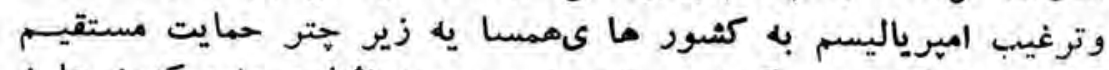

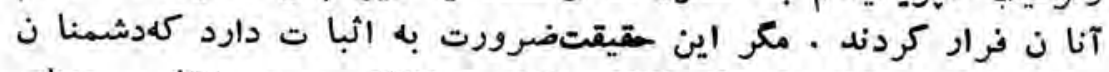

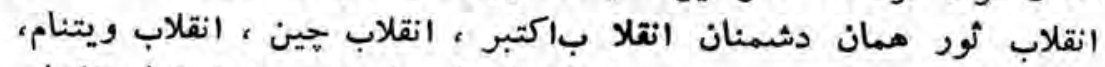

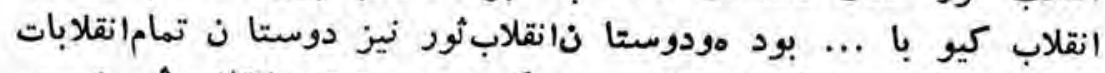

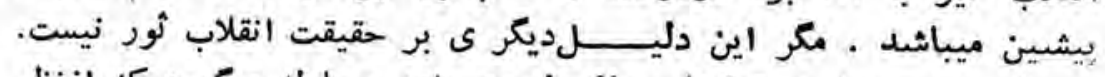

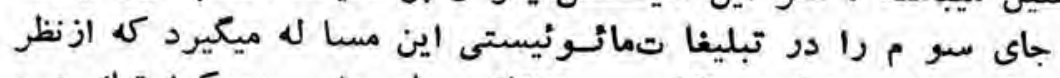

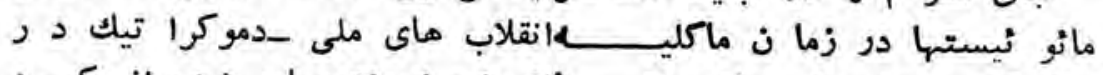

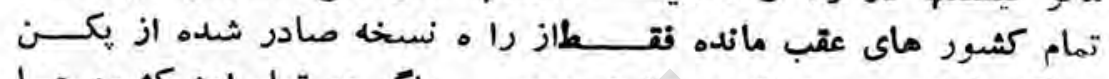

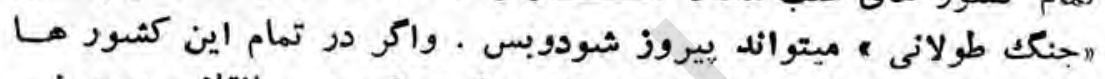

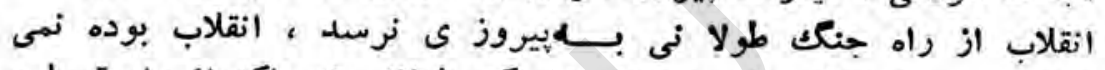

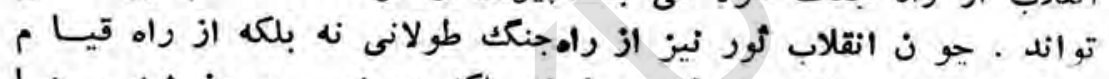

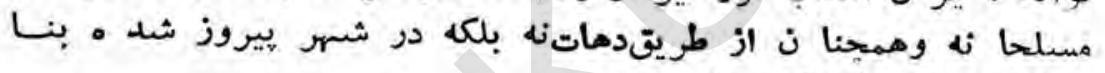

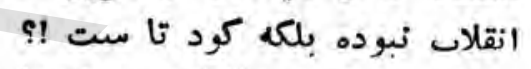

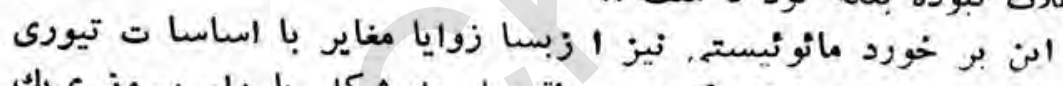

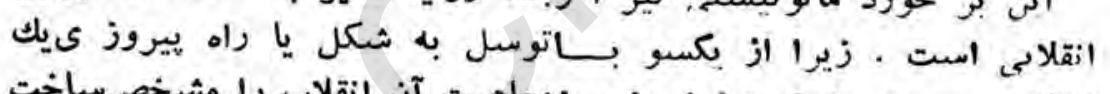

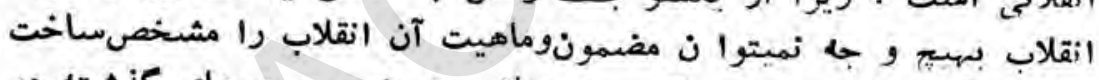

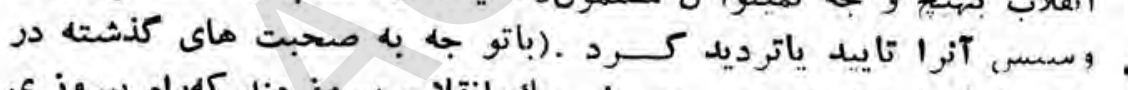

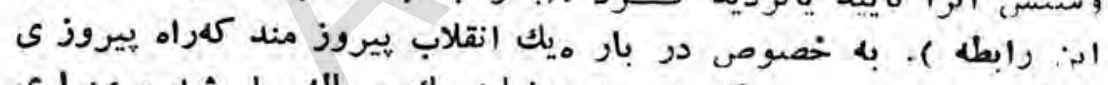

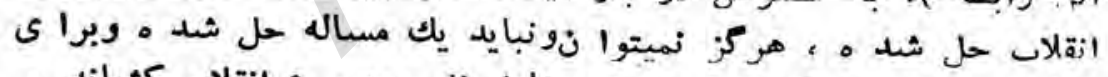

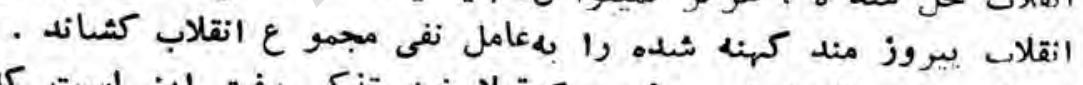

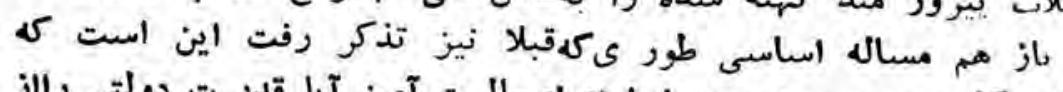

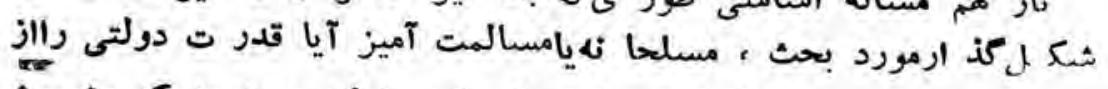

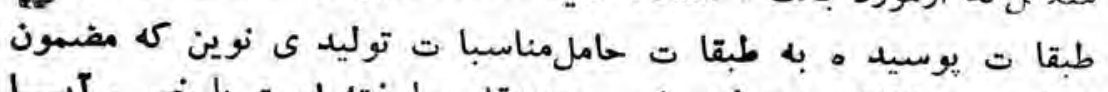

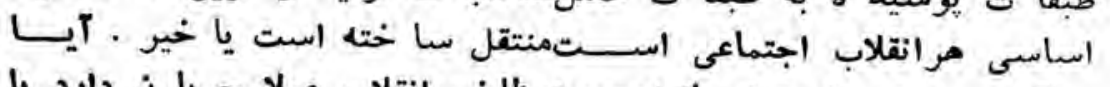

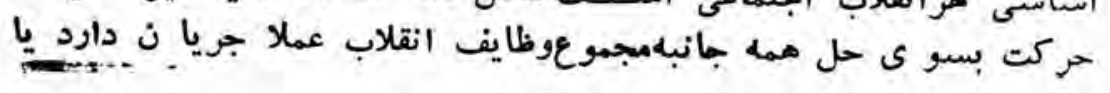




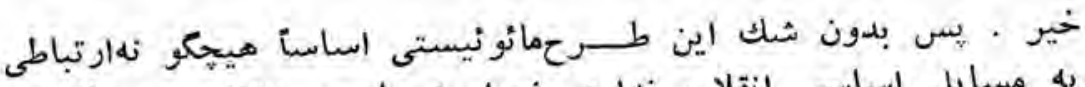

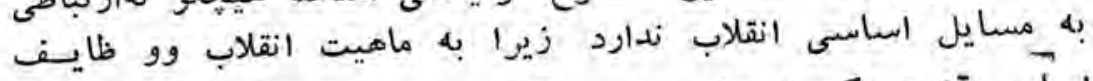

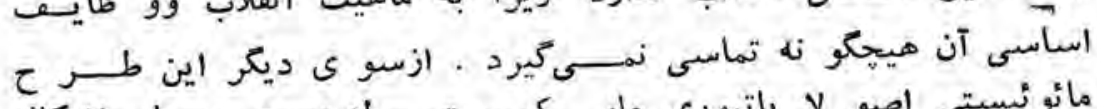

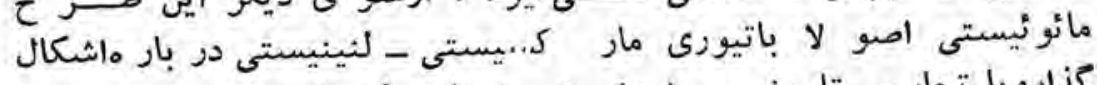

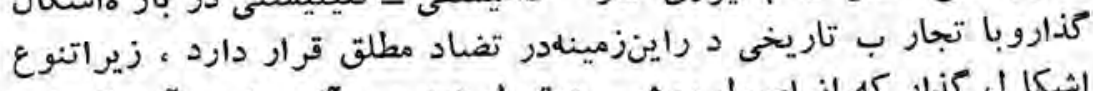

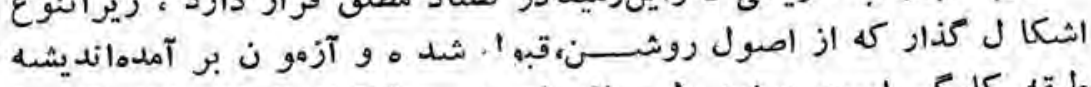

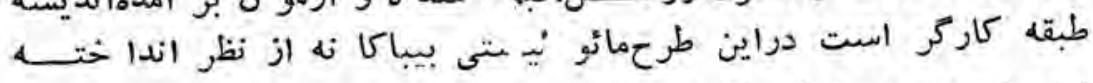

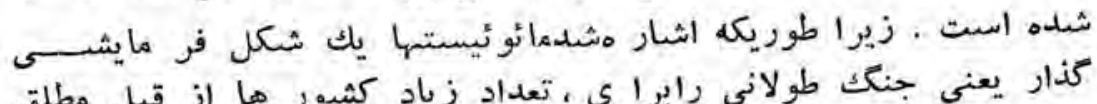

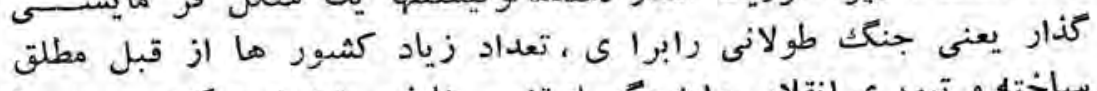

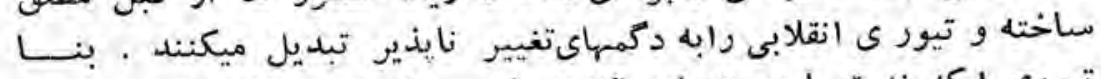

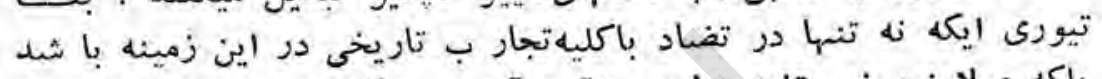

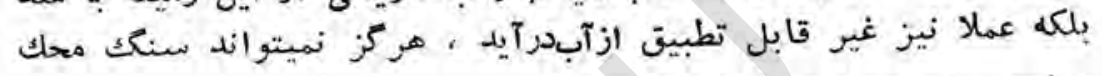

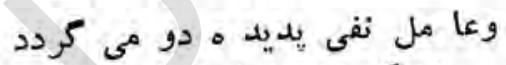

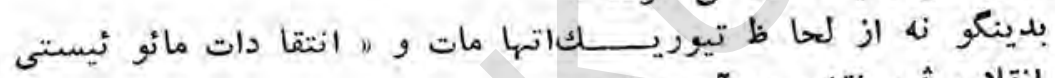

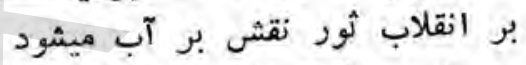

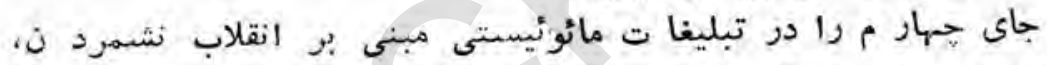

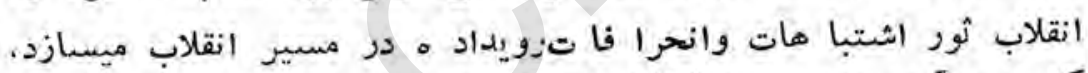

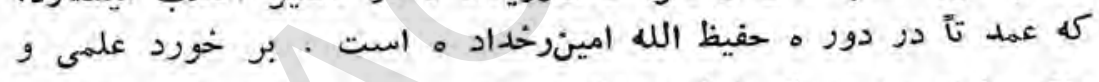

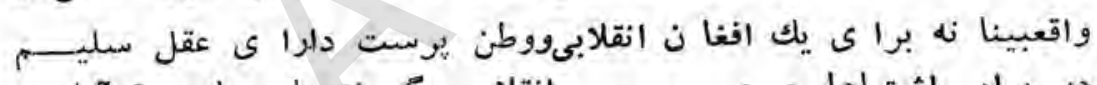

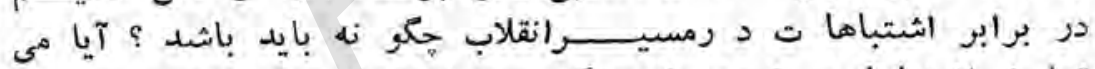

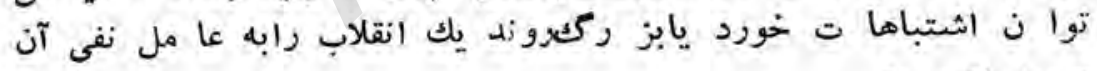

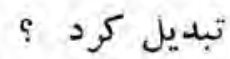

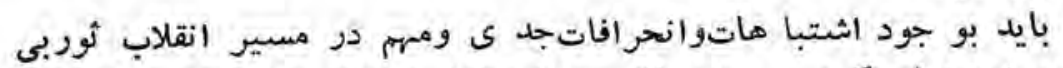

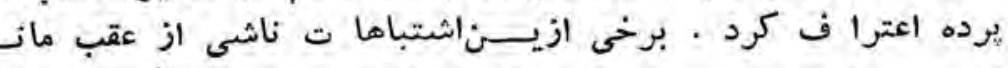

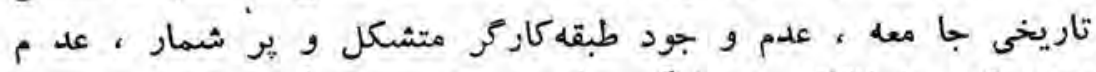

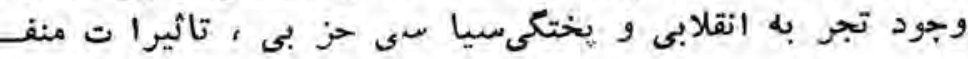




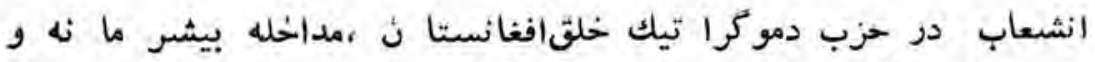

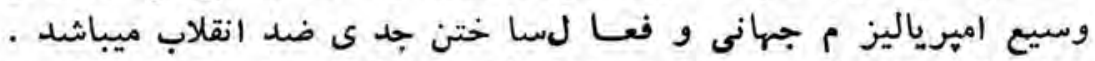

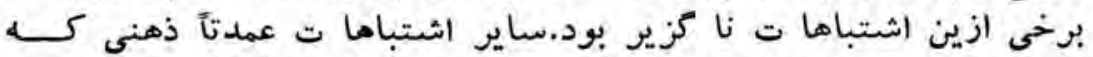

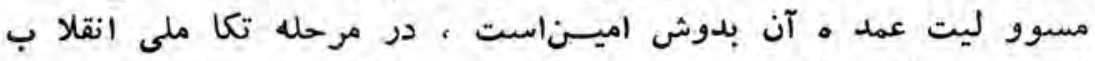

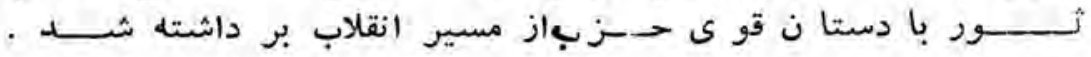

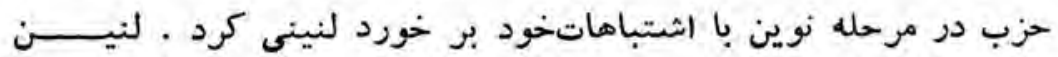

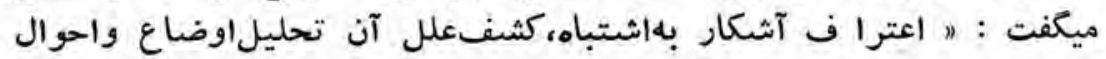

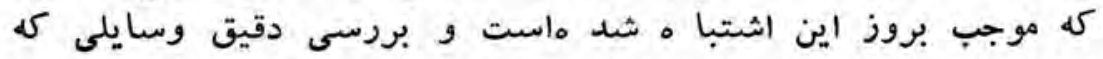

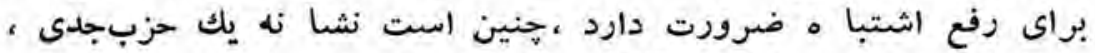

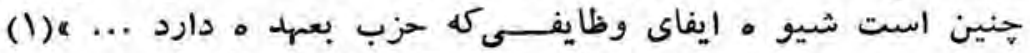

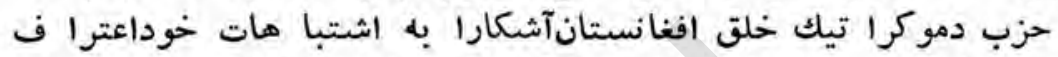

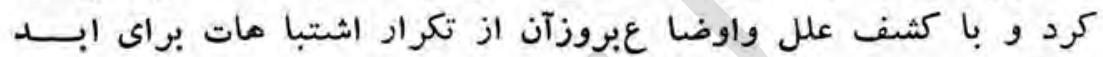

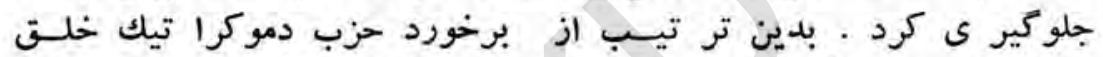

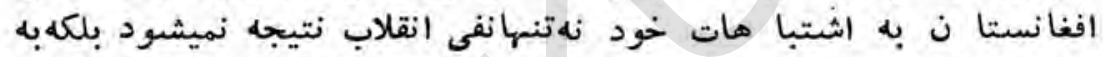

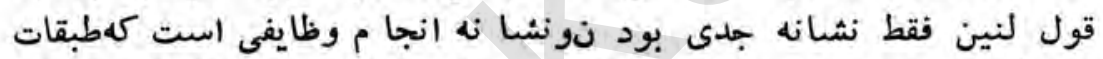

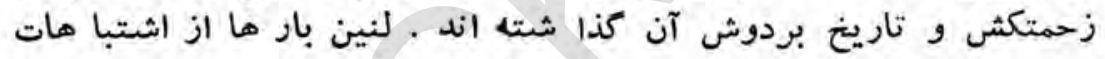

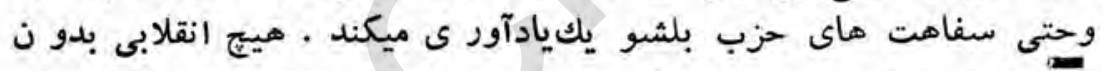

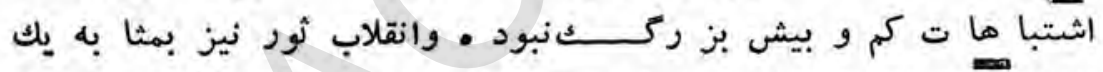

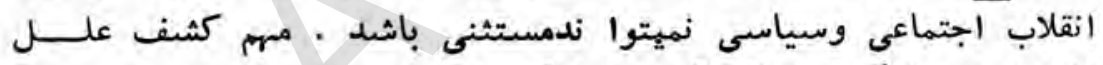

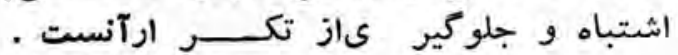

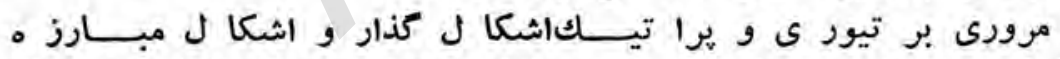

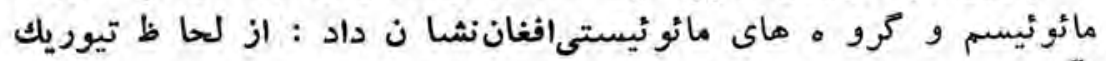
مأ نؤيسيم در اين زمينه نيز تركيبىاز دكما تيسم و آوانتوريسم خردهـ

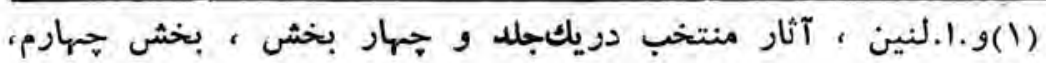

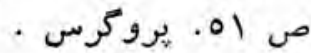




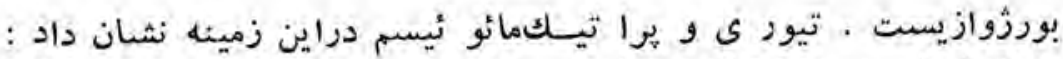

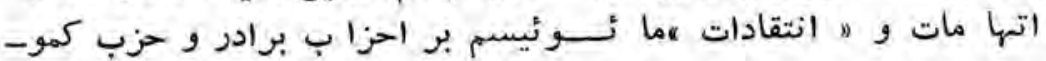

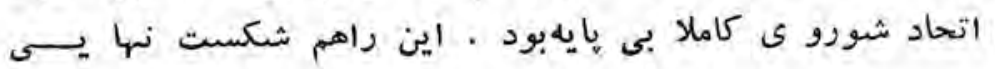

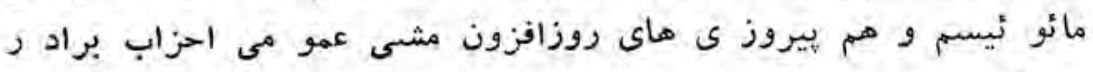

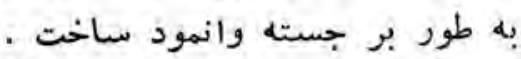

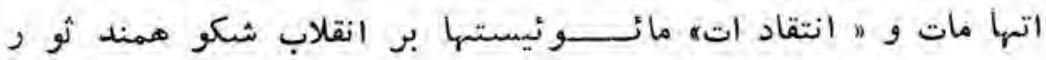

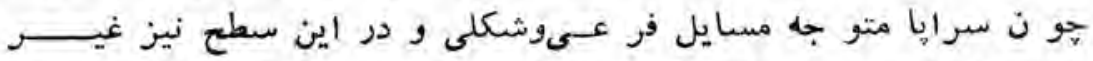

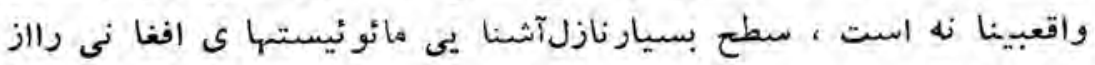

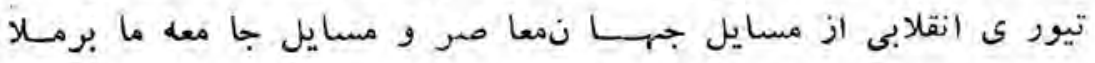

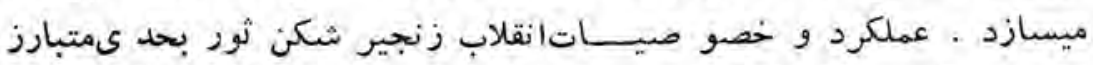

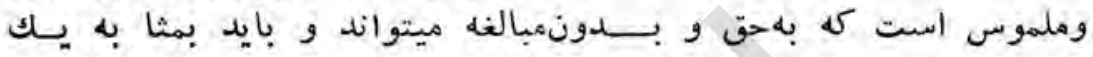

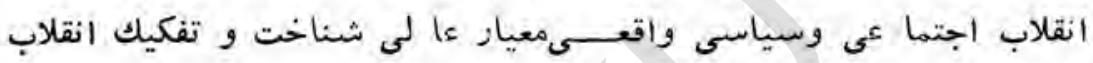

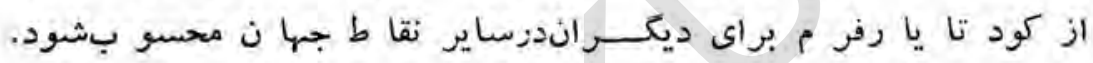

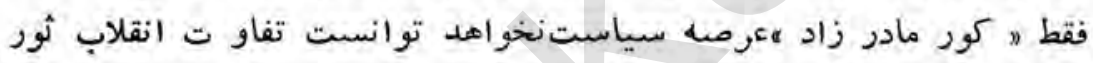

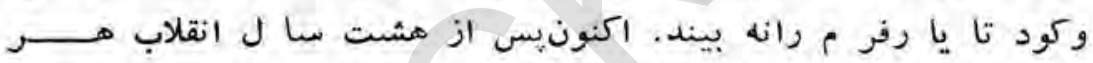

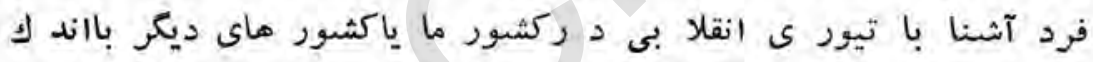

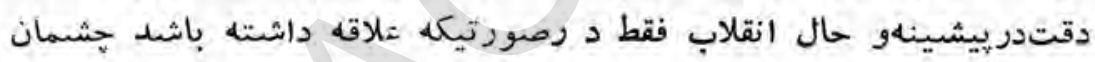

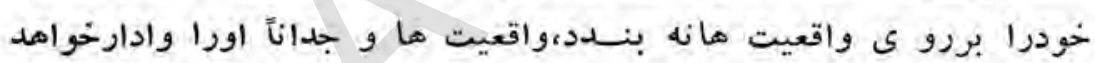

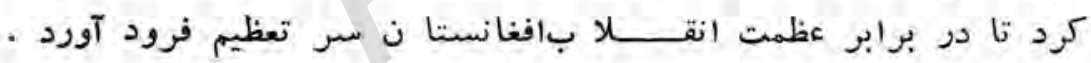

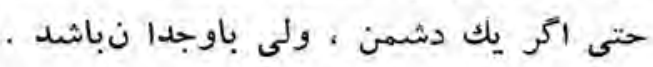

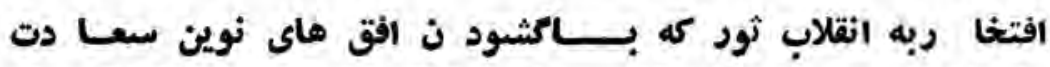

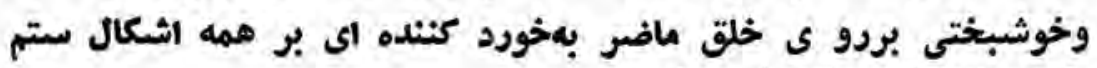
ملى و اجتماعى وارد نمود ؛ 


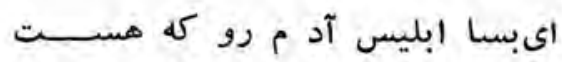

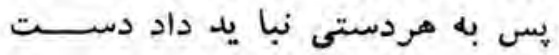

"امولوى بلخى نيا يل داد

ساماوجنايت

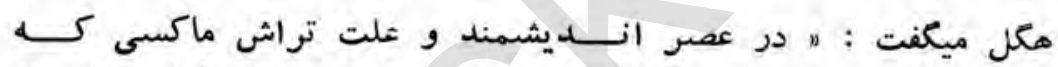

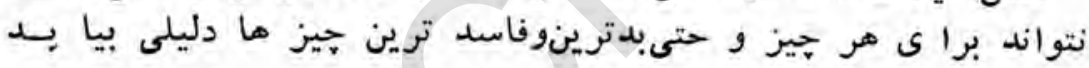

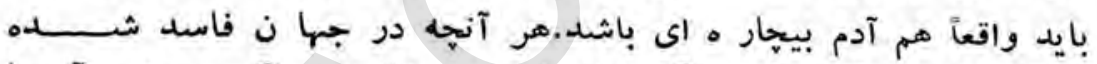

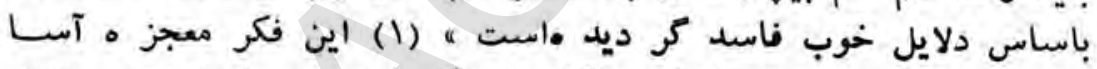

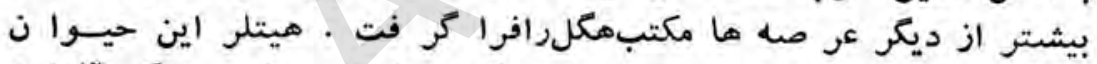

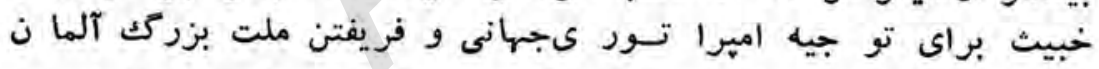

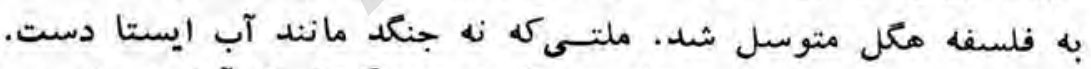

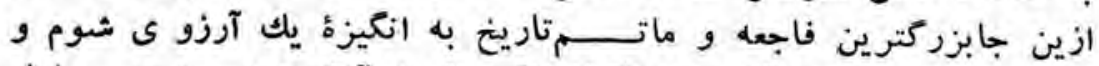

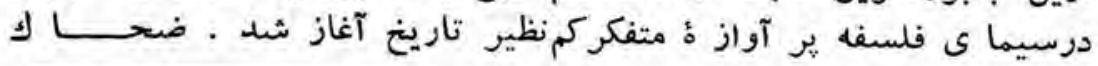

(1) هكل دايرة المعار ف، بخشـسنخست ، منطق ، ص Y؟.

$-|\varepsilon|-$ 


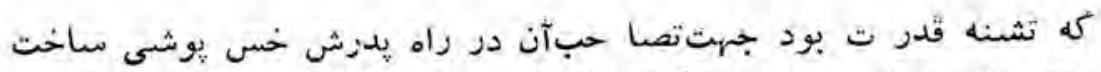

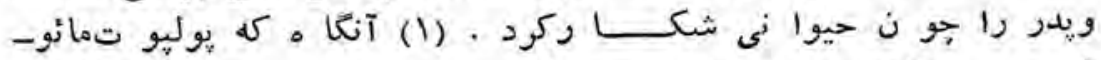

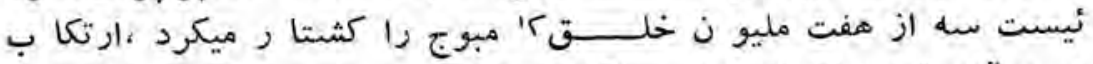

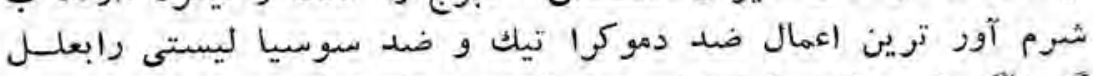

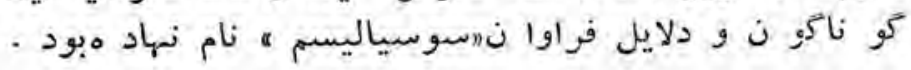

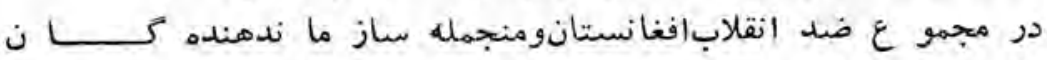

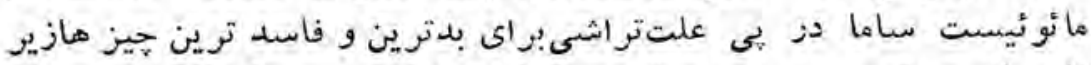

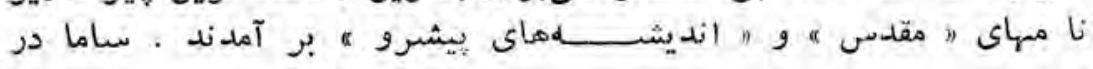

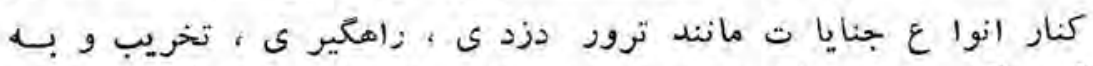

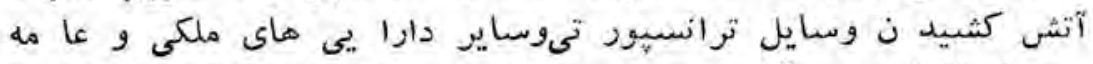

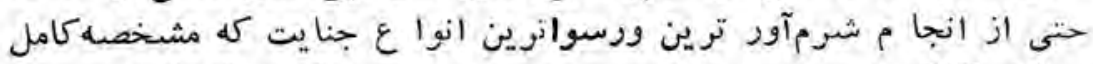

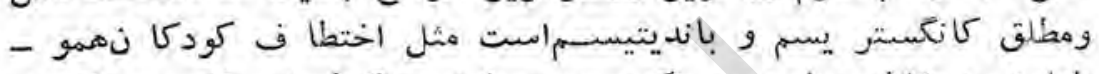

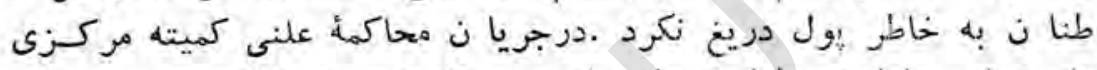

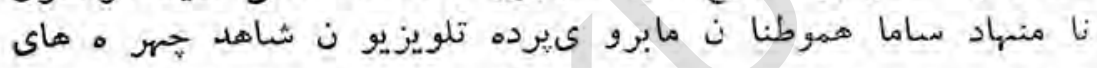

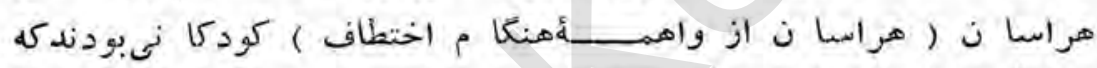

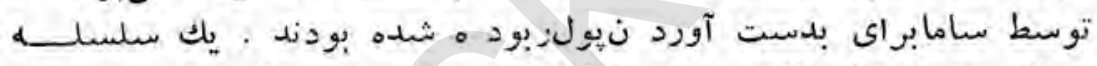

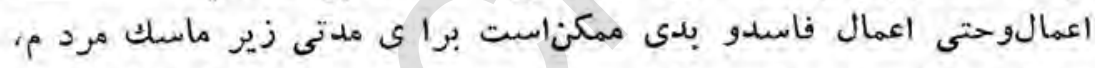

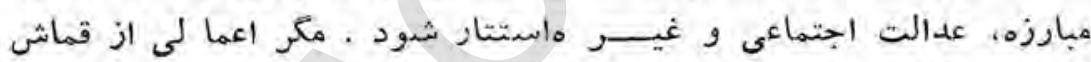

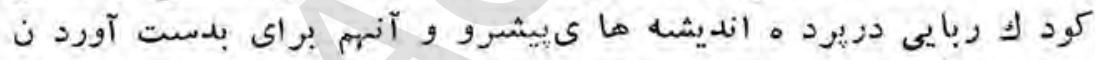

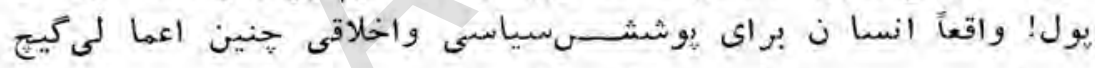

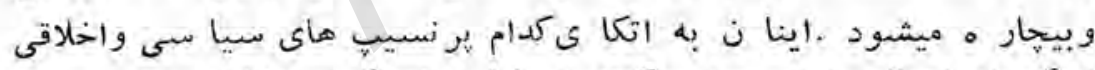

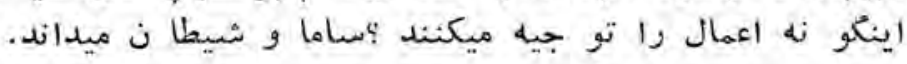

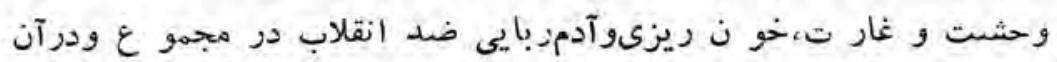

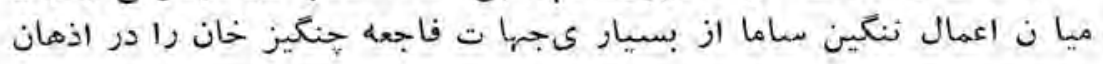

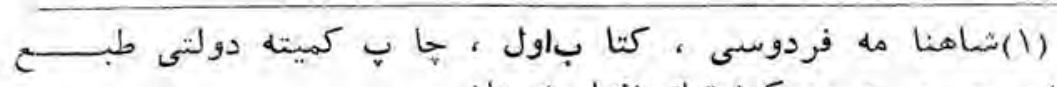
رشسر جمهوز 


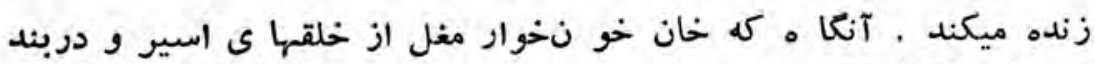

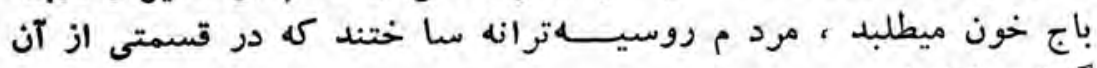
كفته ميشد :

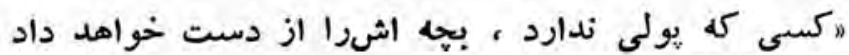

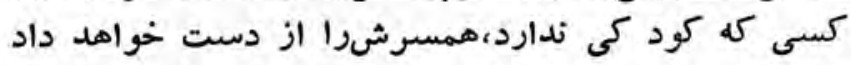

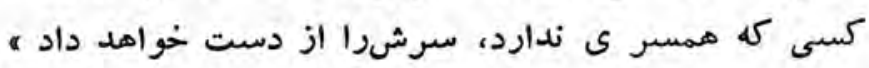

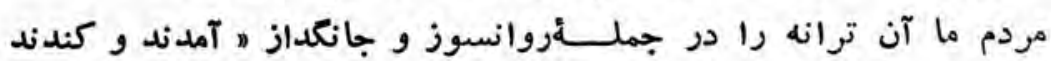

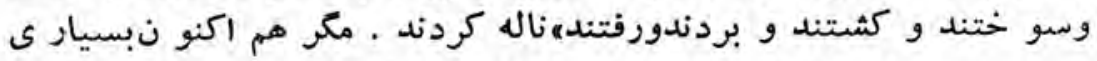

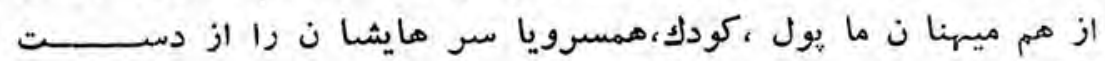
نلداده اندم

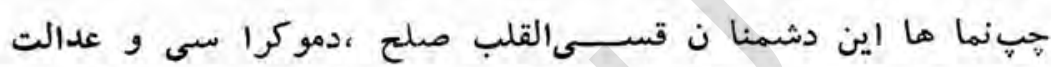

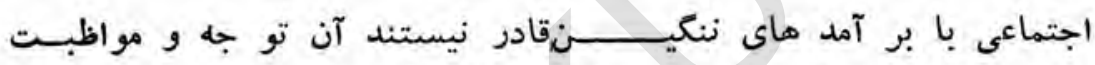

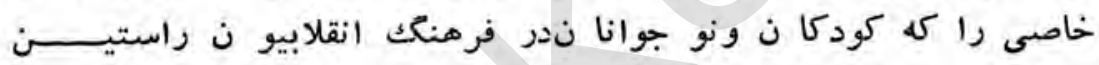

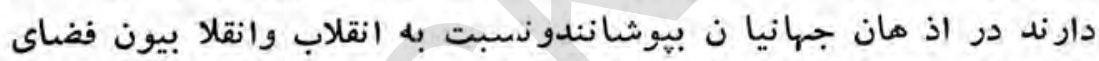

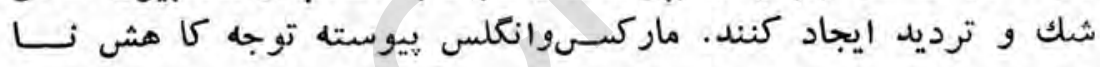

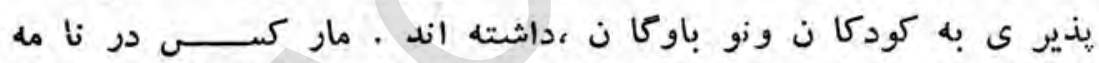

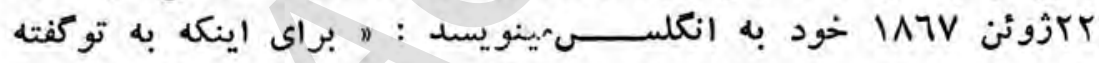

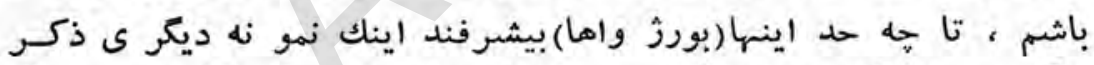

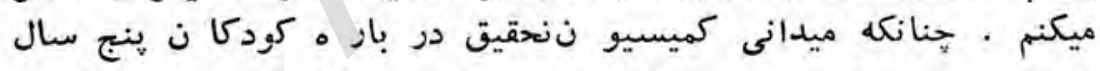

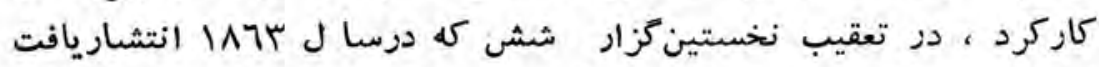

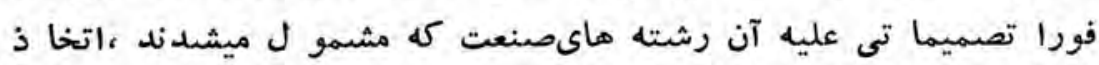

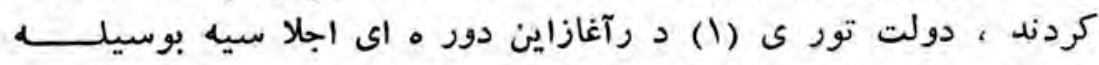

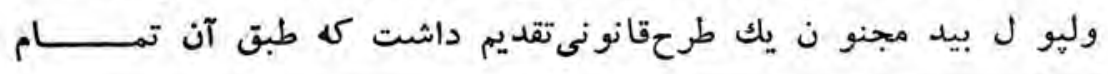

(1) سلف حزب محافظه كـا ركنو نى بريتانيا . 
يبينها دات كميسيو ن و لوبشكلرقيق شده مورد يذيرش قراركرفت.

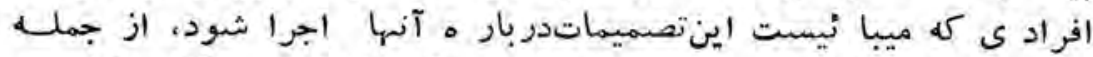

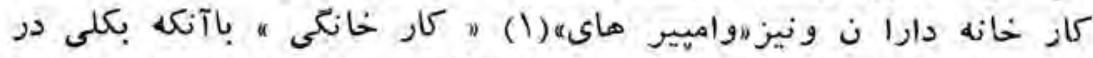

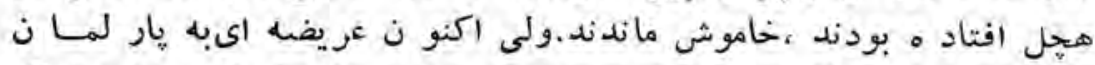

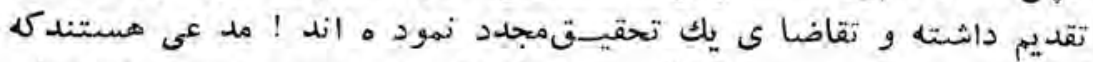

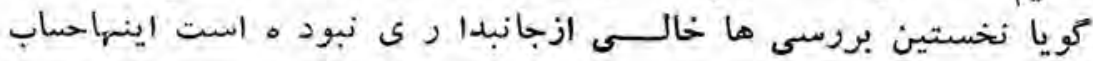

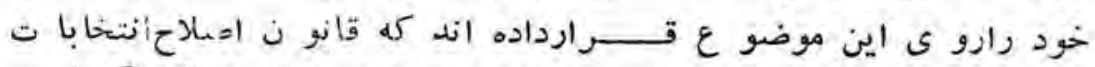

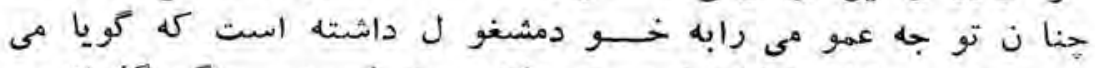

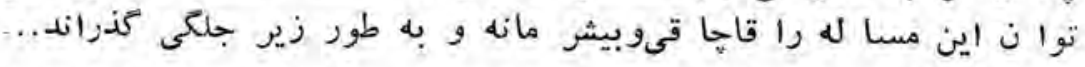

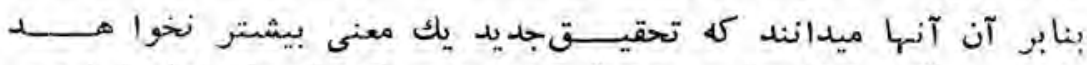

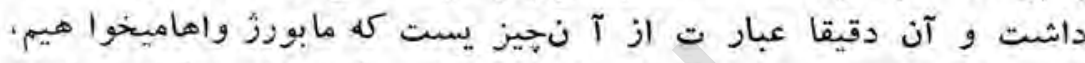

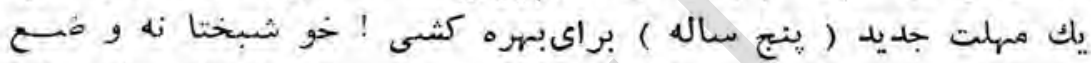

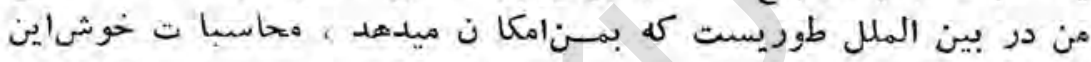

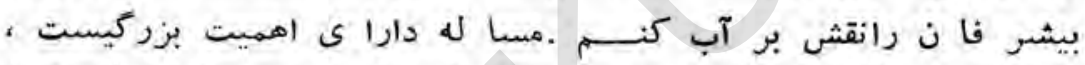

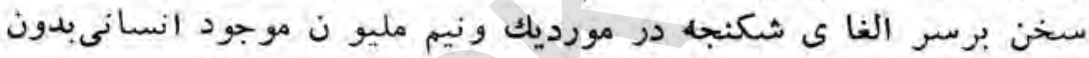

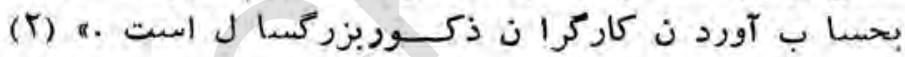

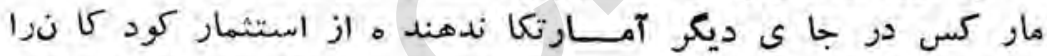

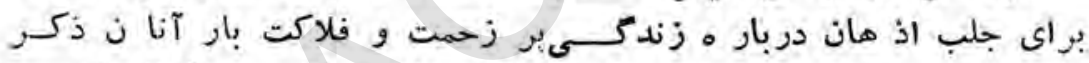

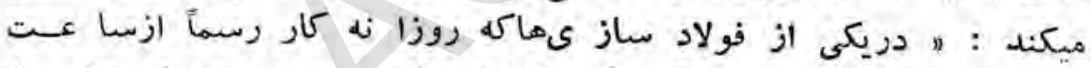

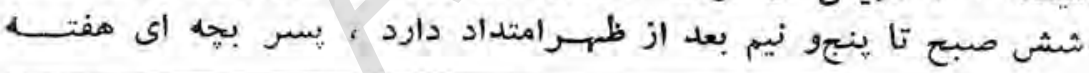

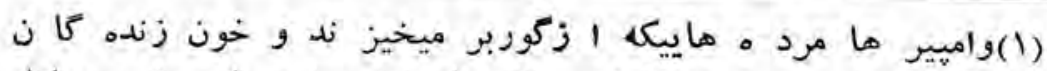

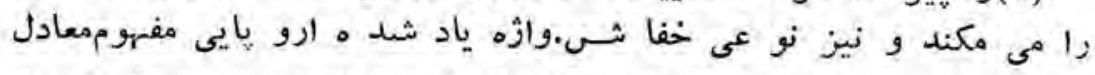

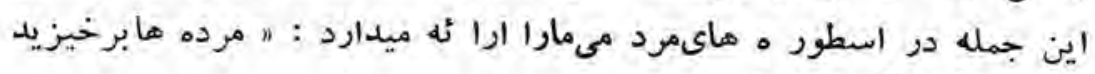

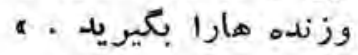

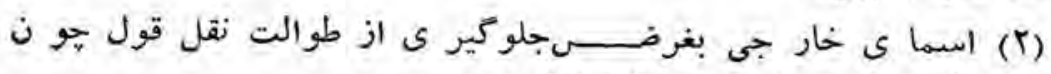

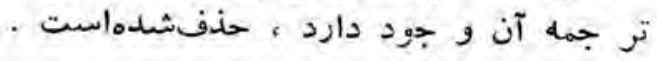


جهار شب را لاقل تاسا عت مشتونيم شب روز بعد كار ميكرد ...اين

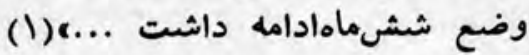

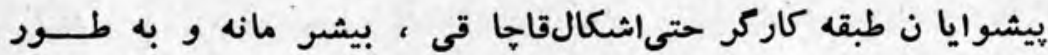

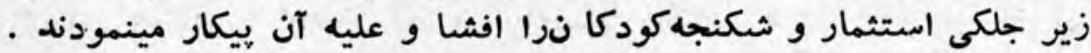

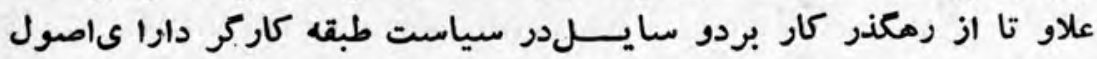

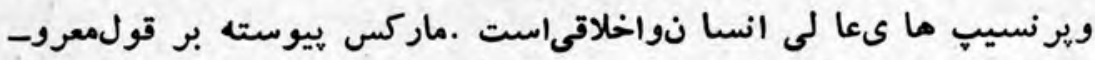

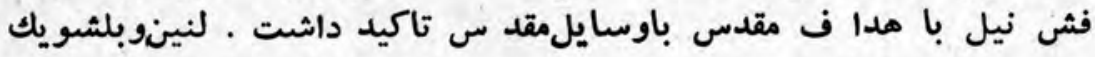

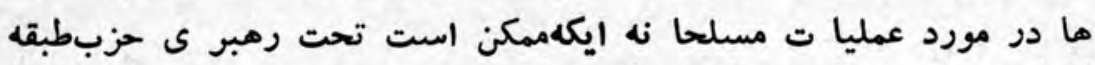
كاركر صور ت كيرد تاكيد ميكردندكه :

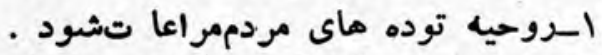

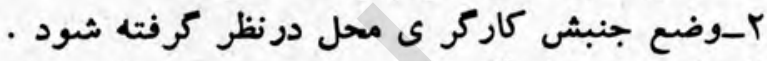

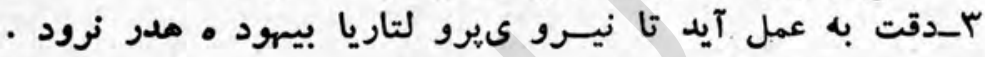

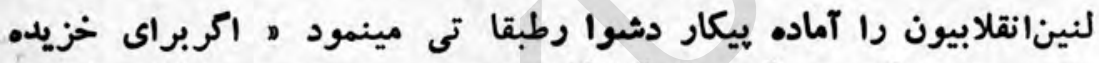

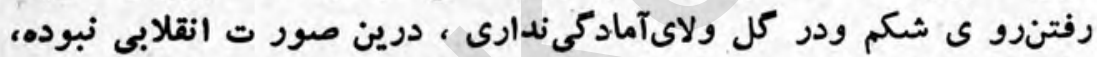

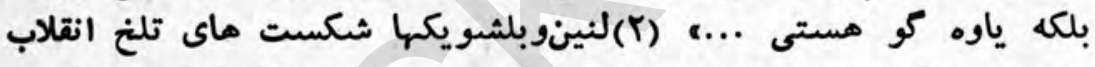

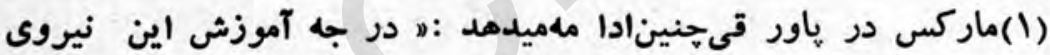

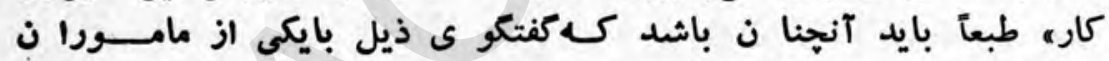

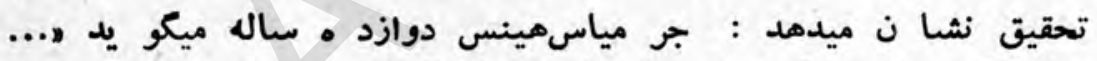

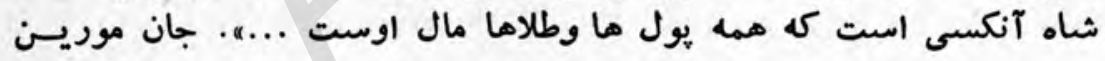

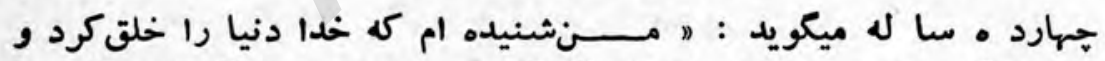

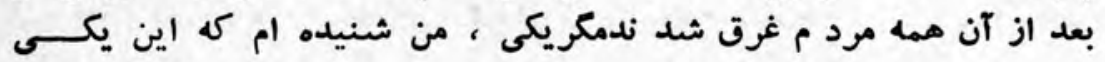

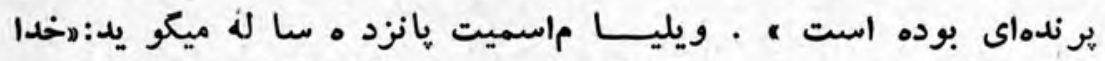

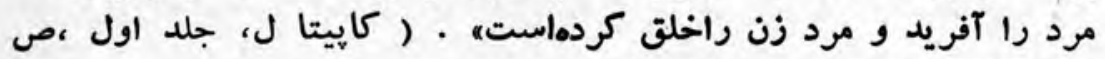
) ror

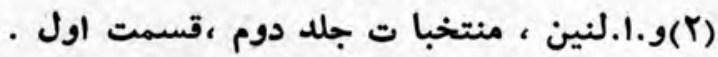


19.V_19.0

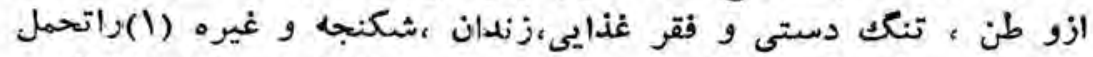

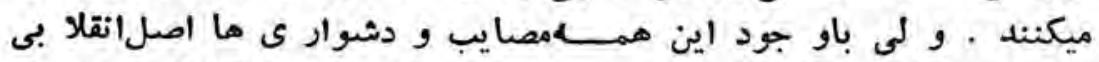

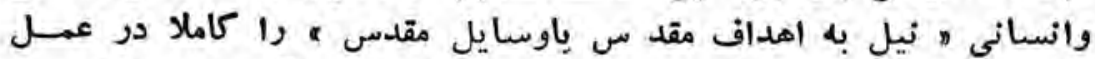

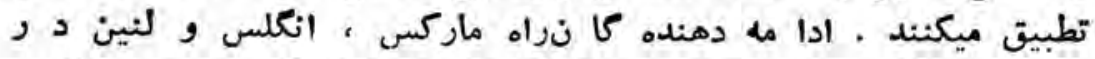

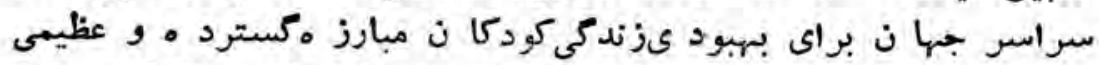

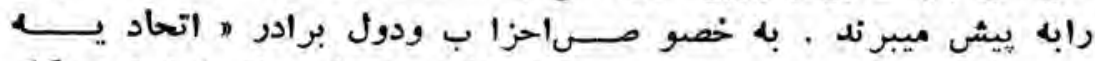

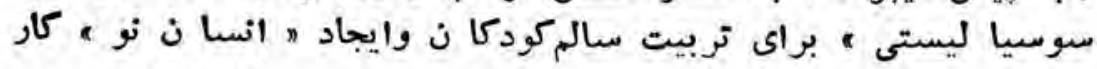

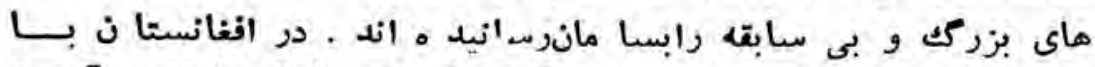

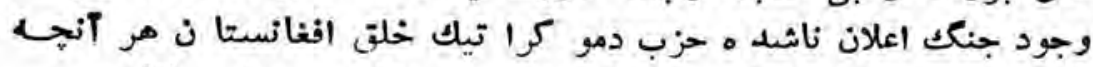

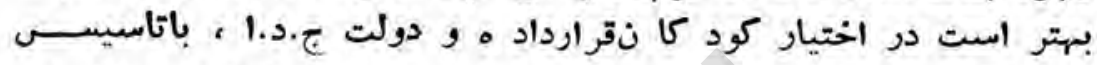

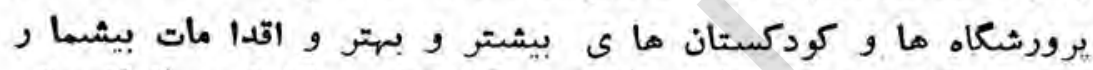

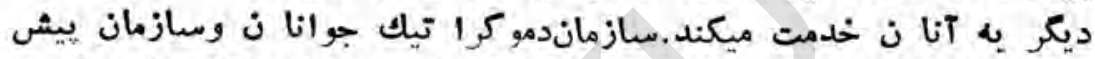

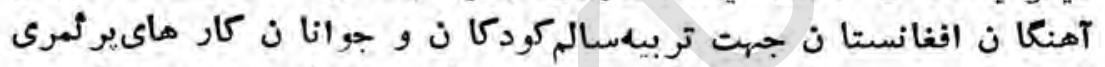

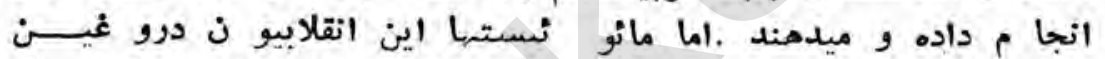

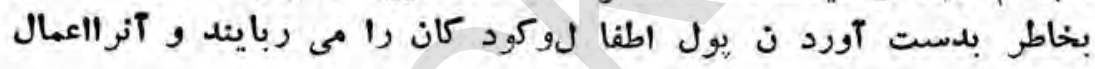

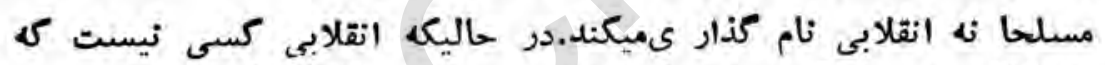

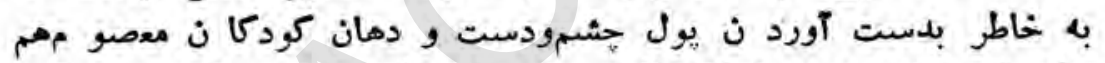

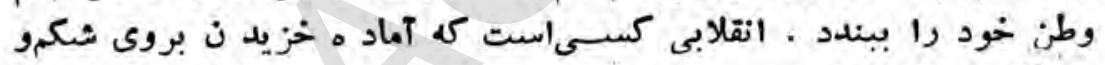

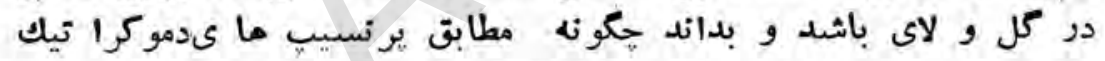

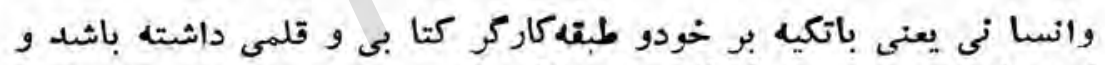

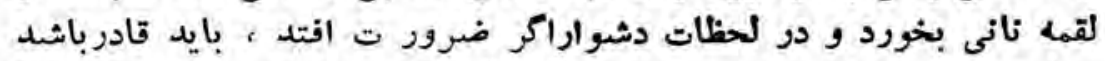

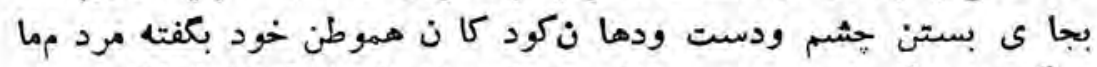

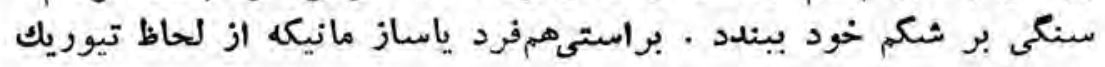

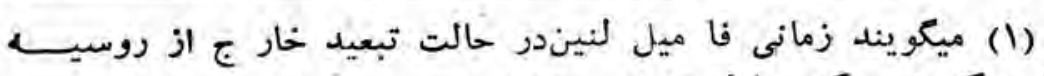

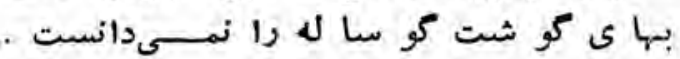




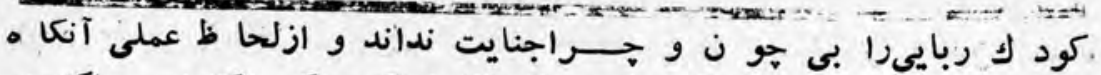

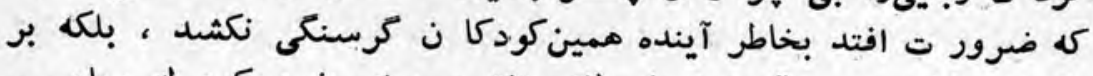

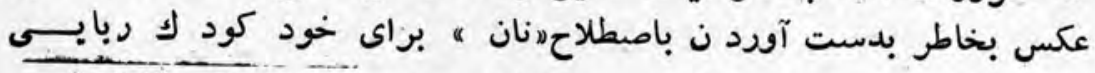

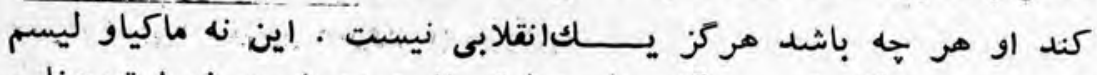

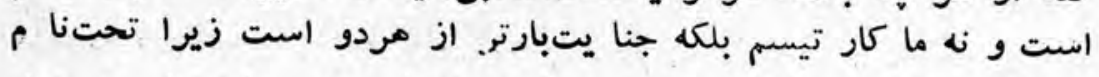

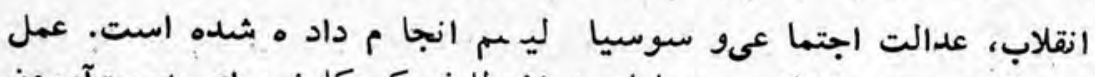

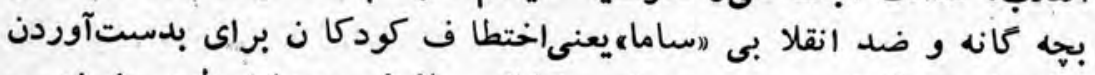

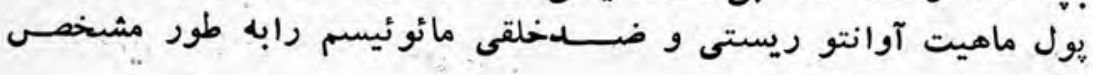

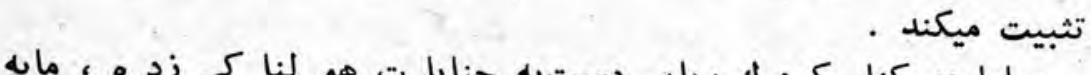

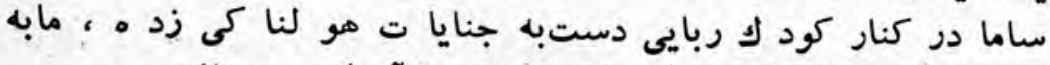

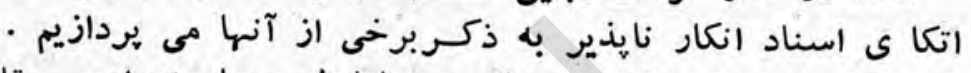

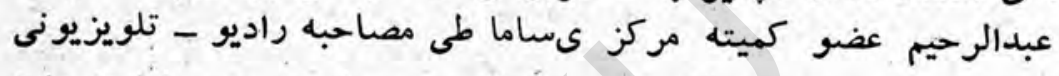

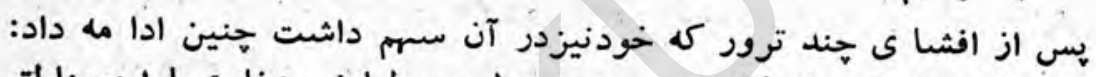

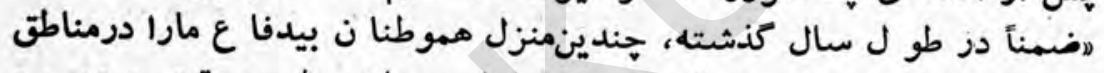

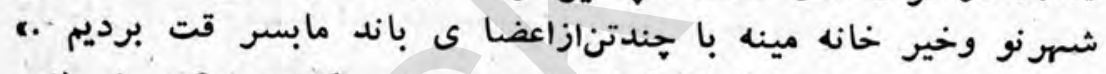

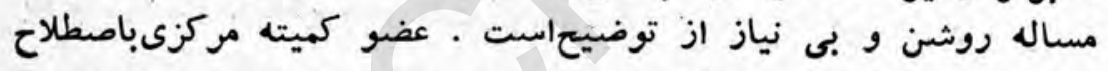

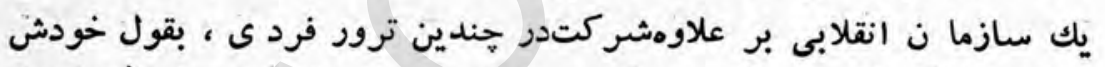

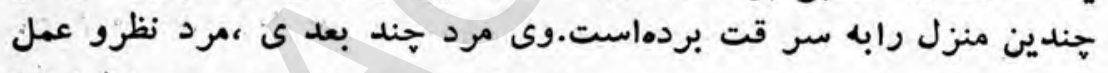

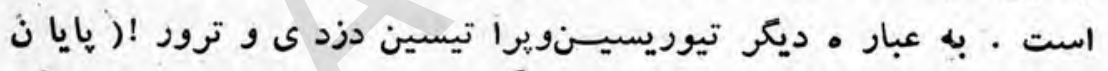

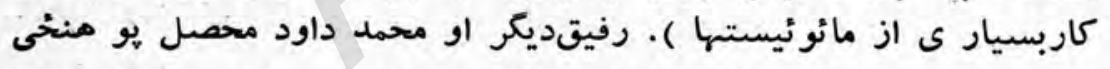

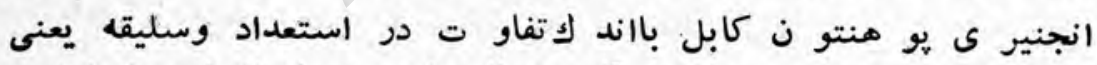

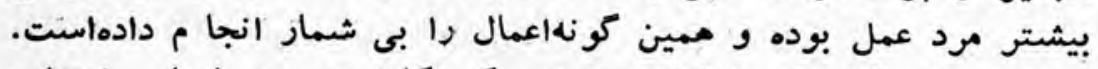

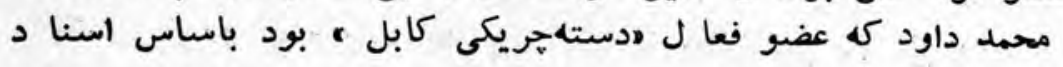

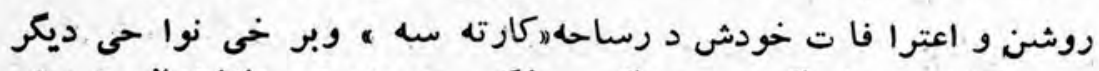

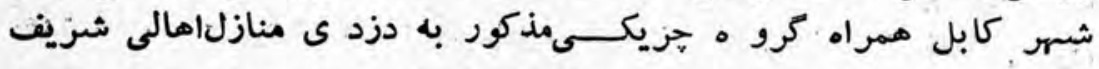

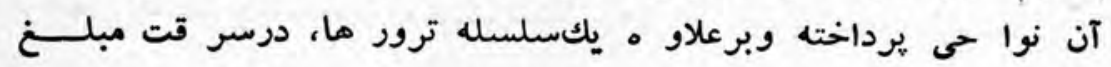




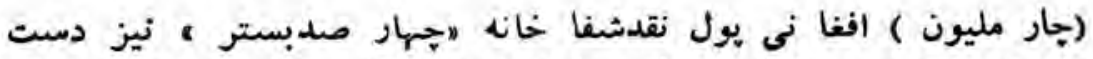

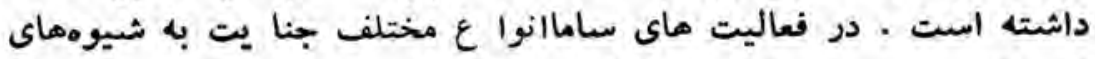

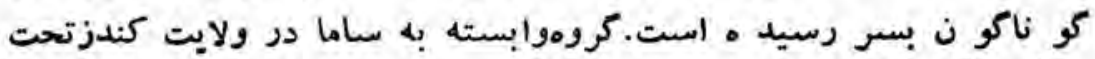

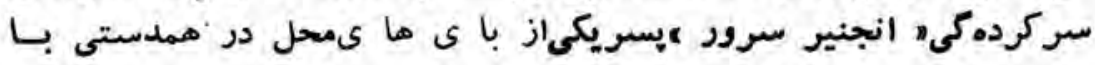

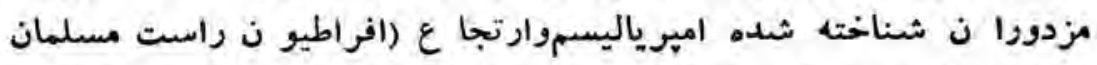

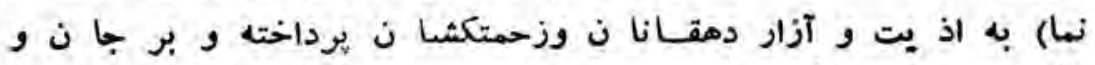

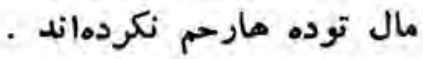

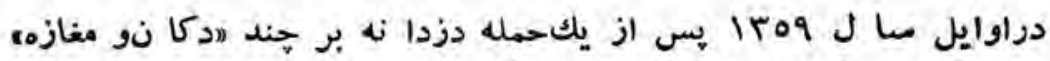

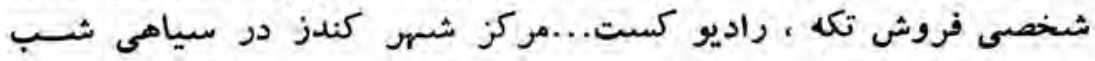

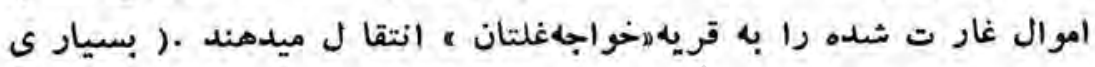

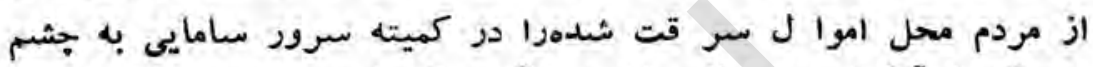

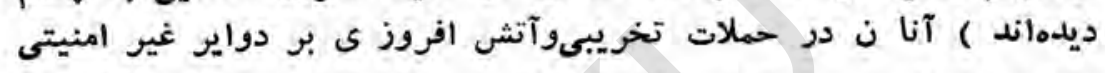

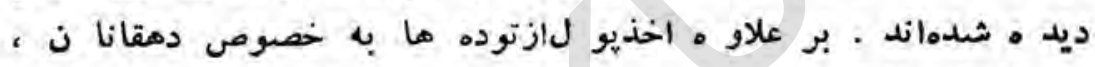

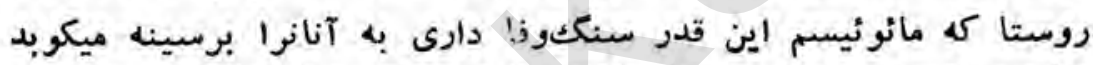

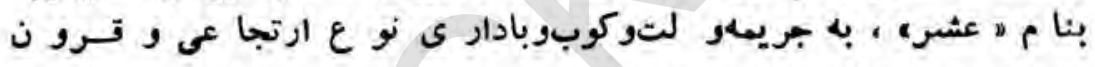

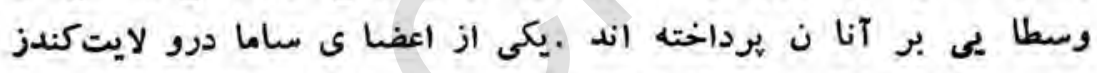

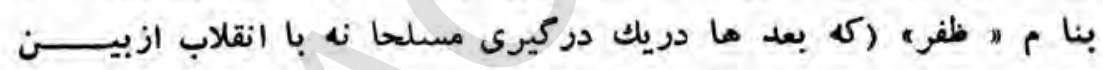

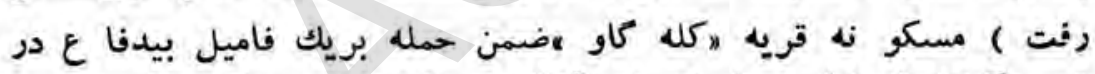

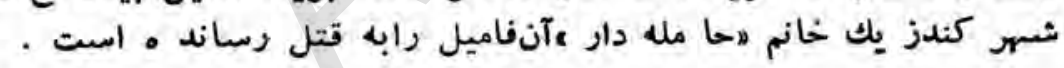

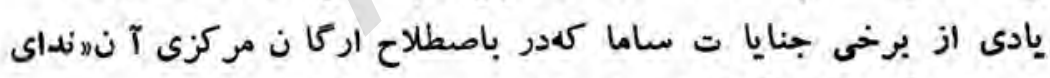

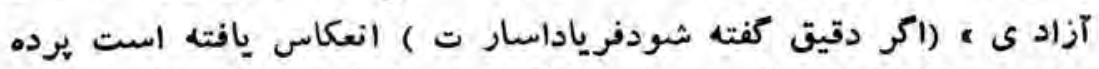

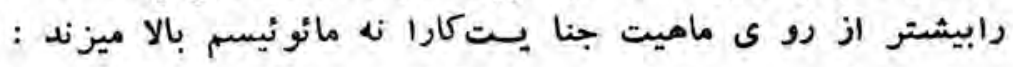

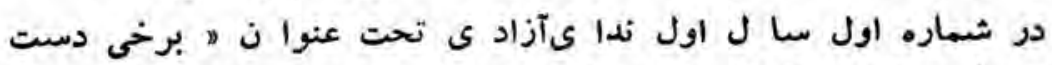

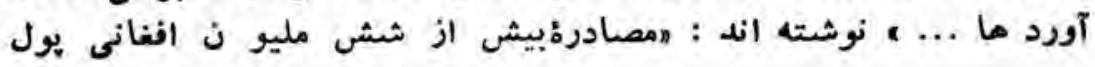




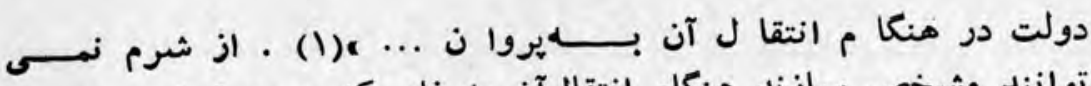

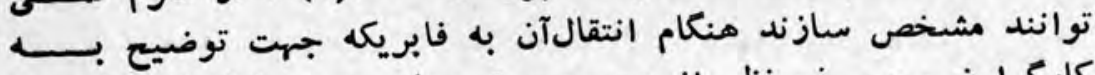

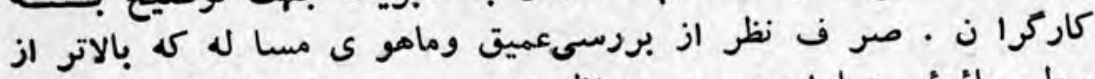

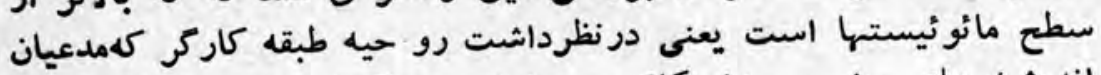

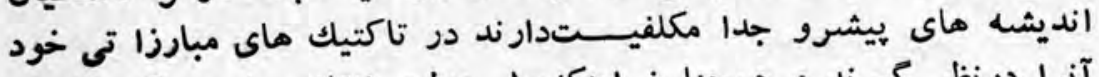

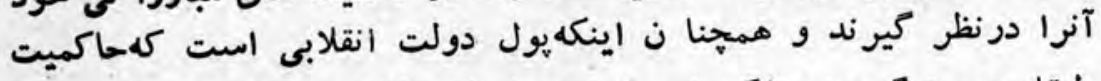

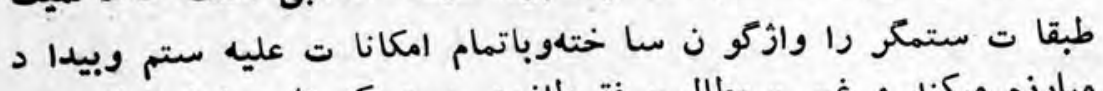

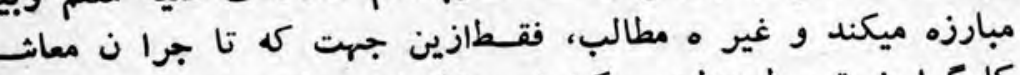

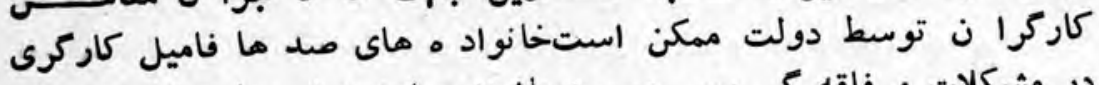

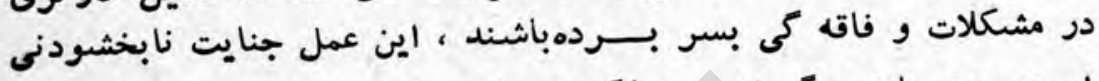

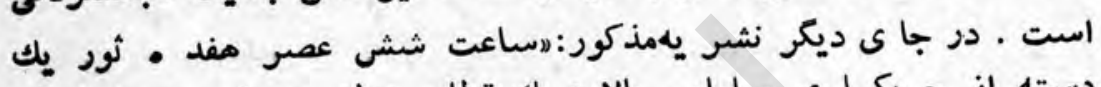

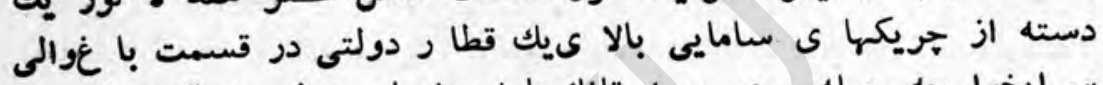

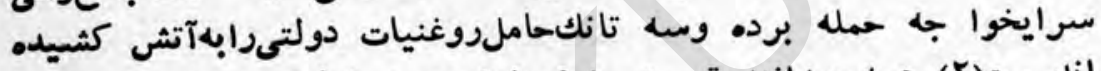

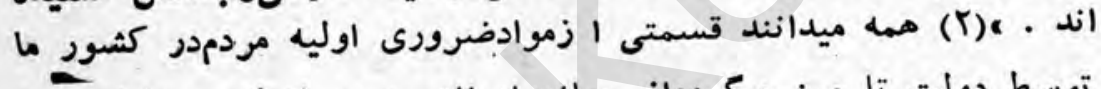

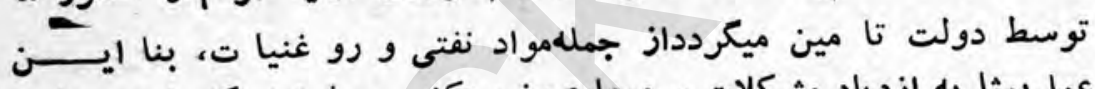

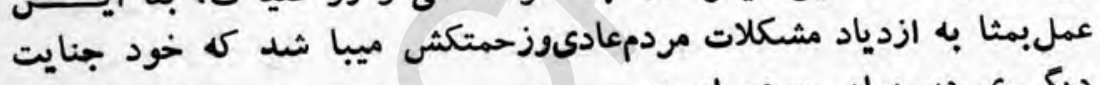

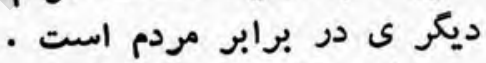

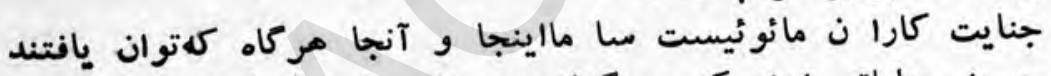

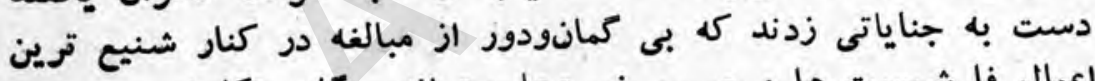

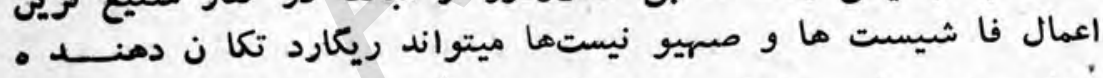

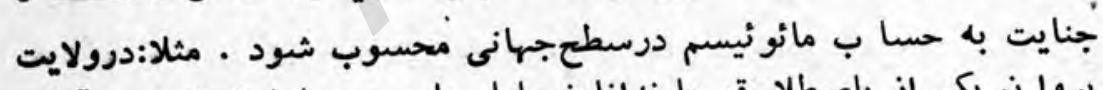

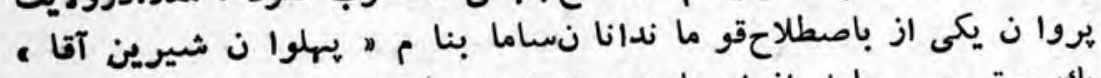

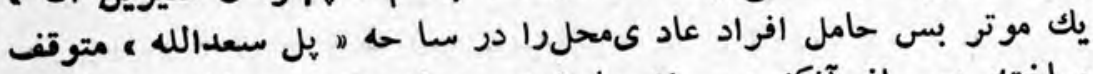

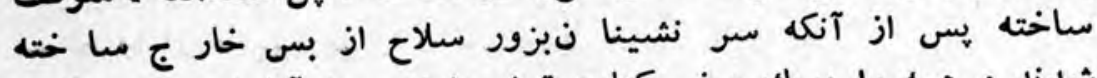

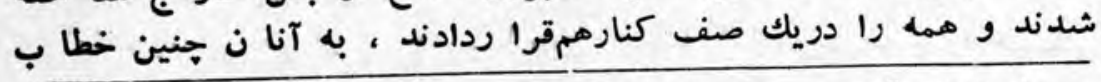

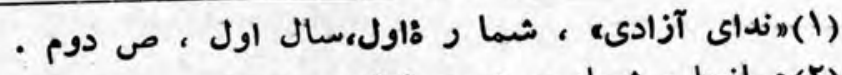

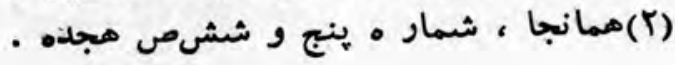




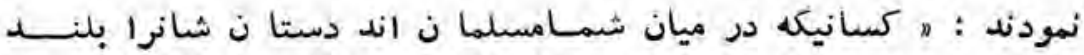

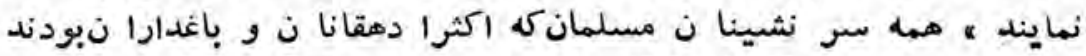

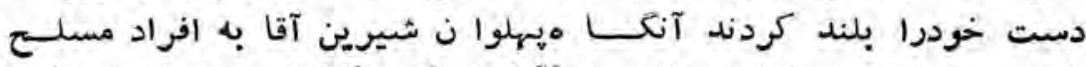

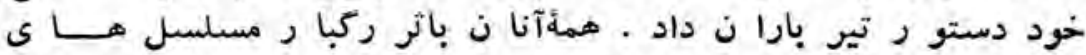

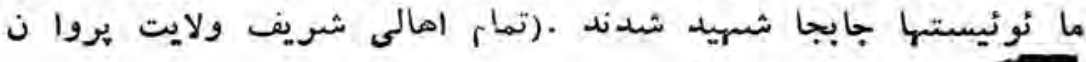

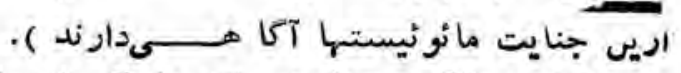

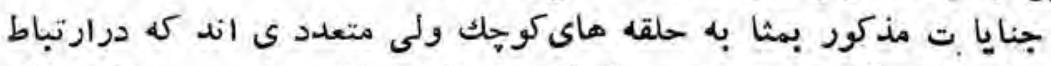

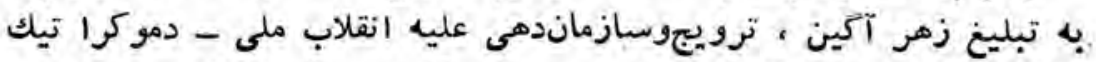

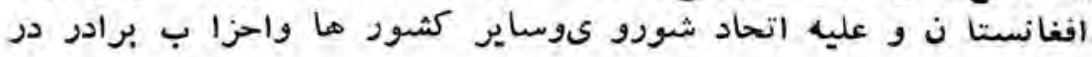

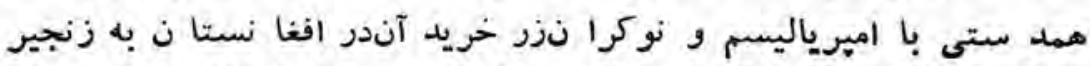

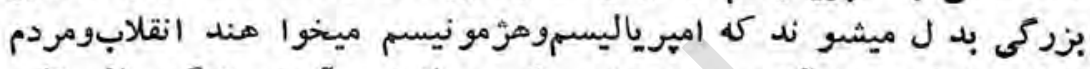

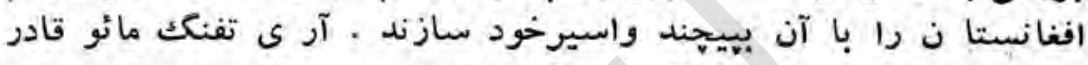

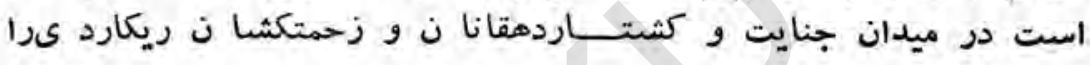

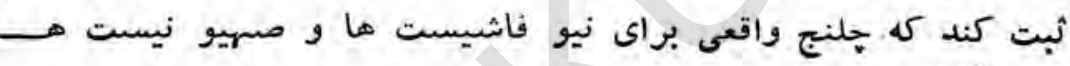

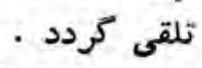

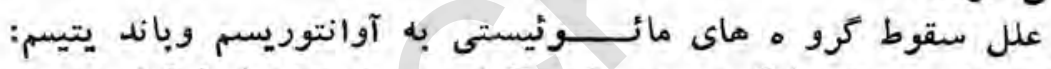

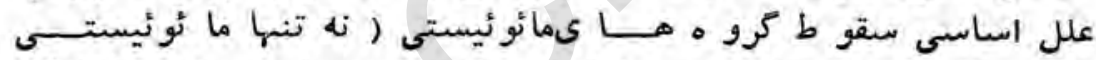

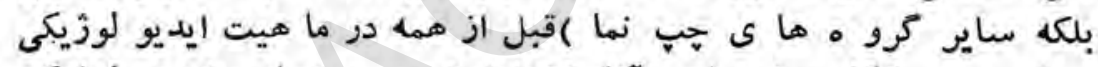

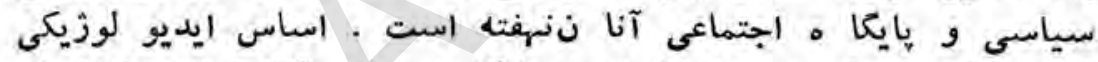

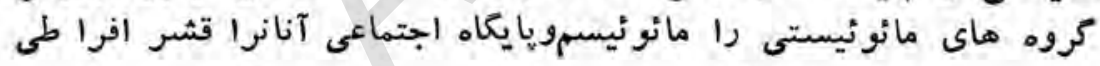

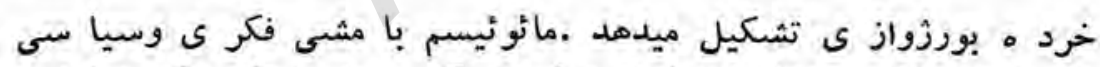

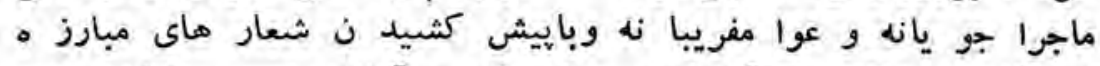

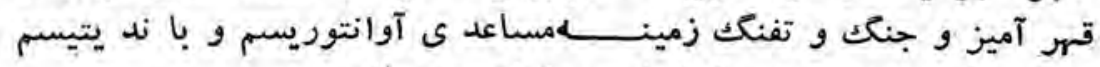

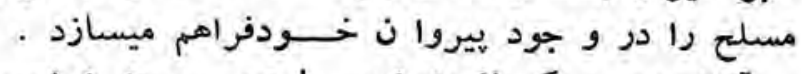

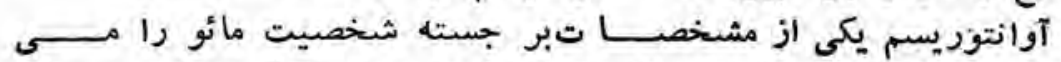

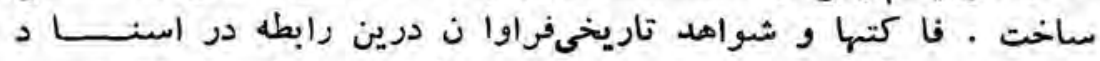

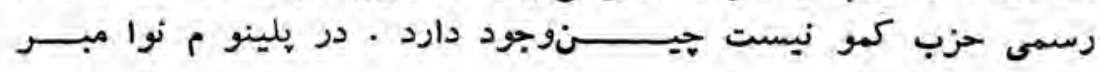


larV

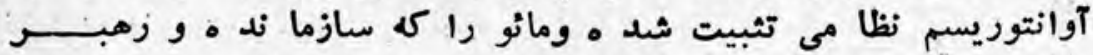

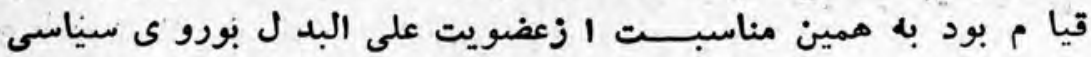

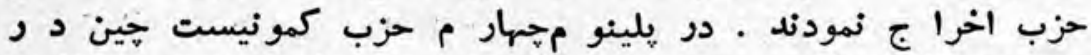

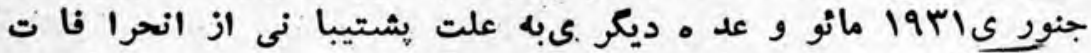

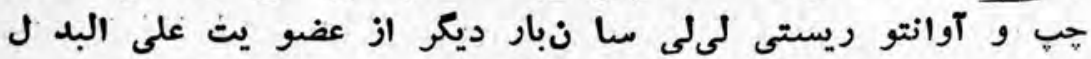

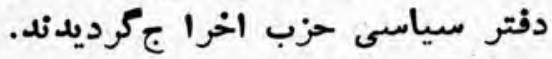

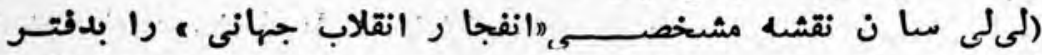

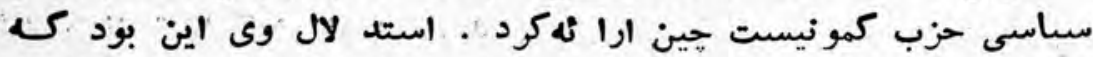

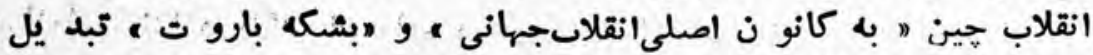

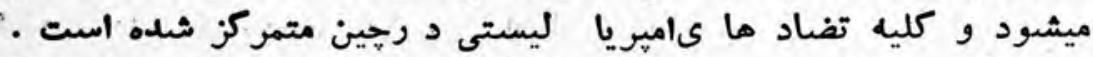

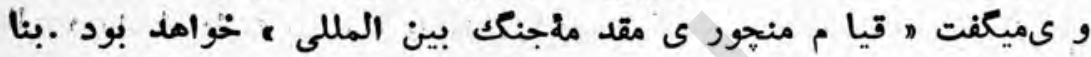

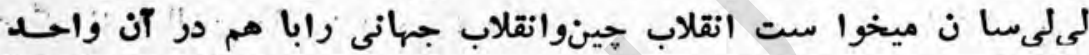

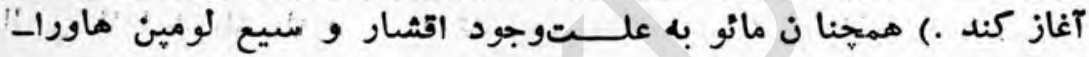

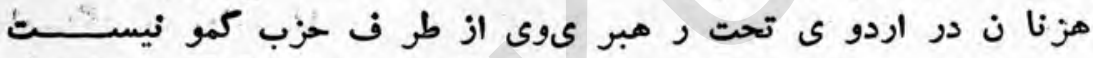

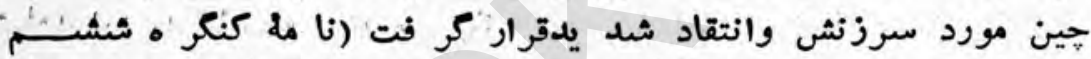

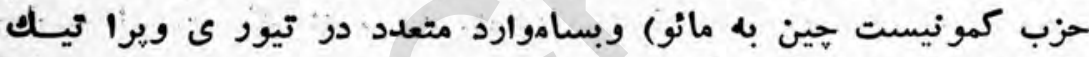

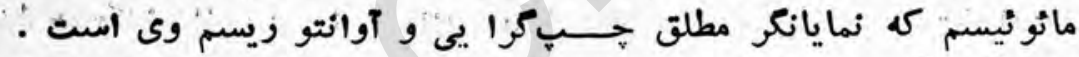

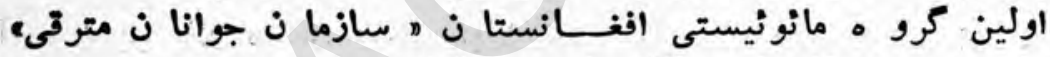

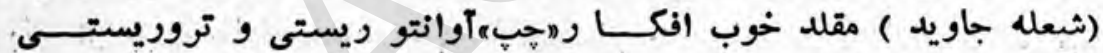

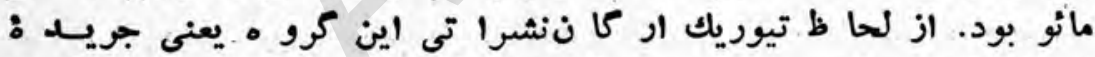

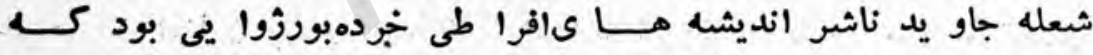

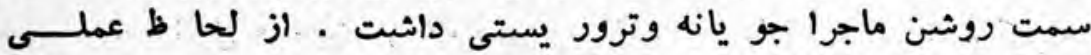

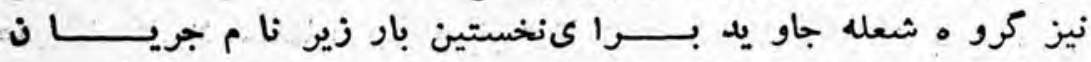

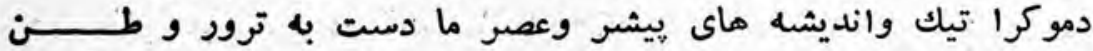

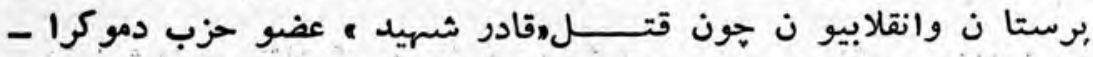

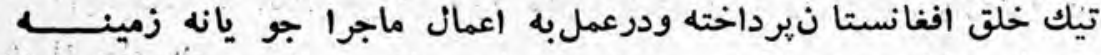

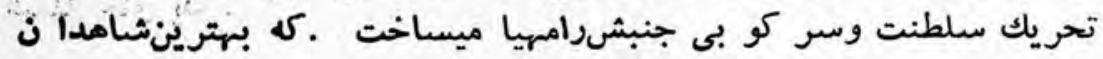




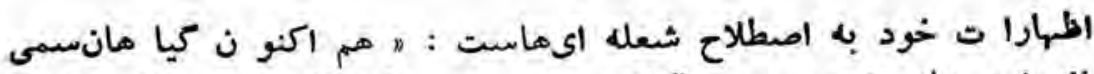

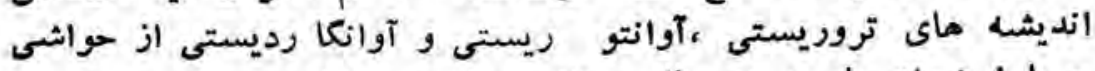

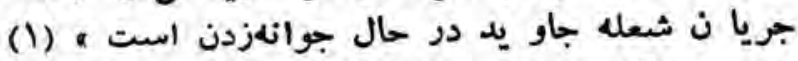

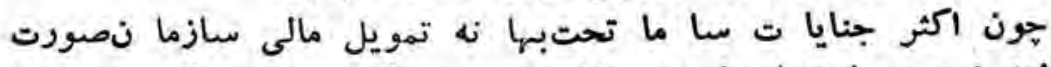

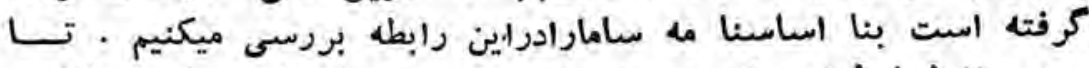

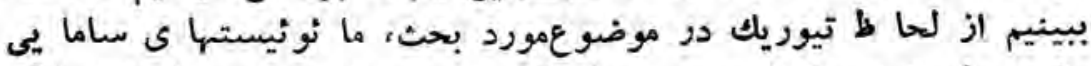

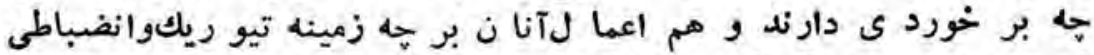

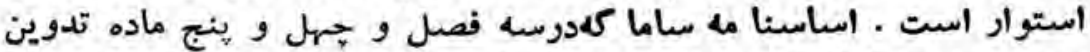

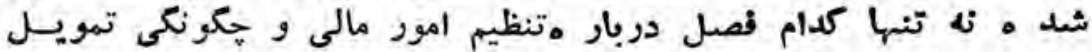

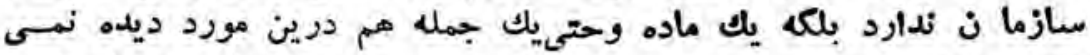

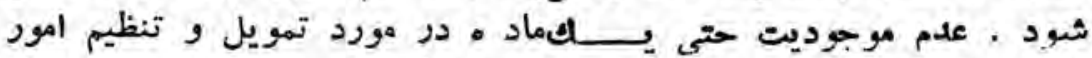

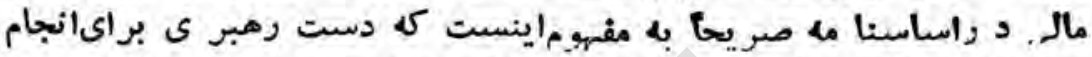

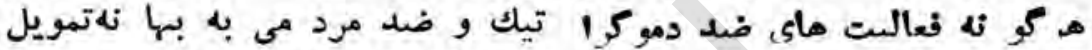

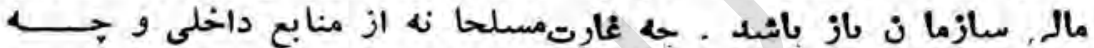

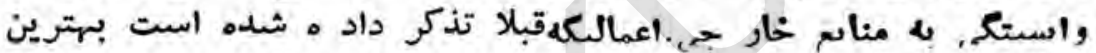

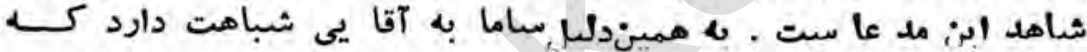

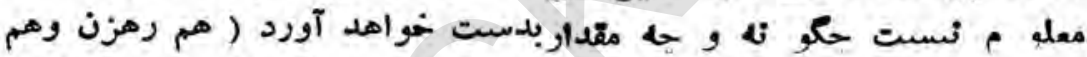

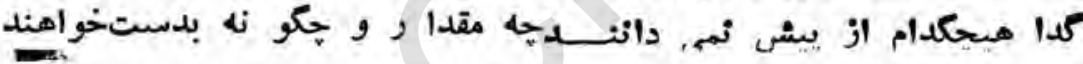

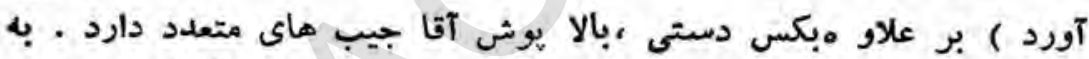

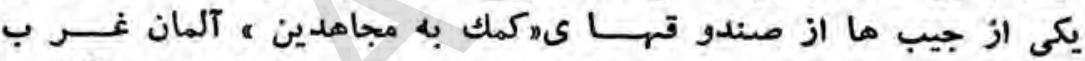

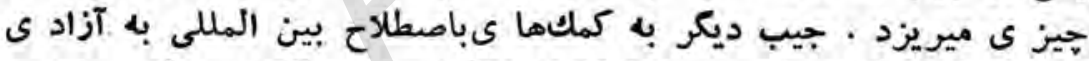

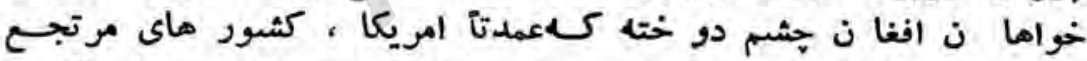

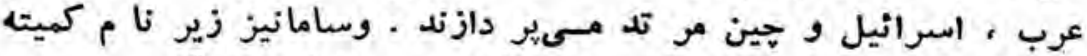

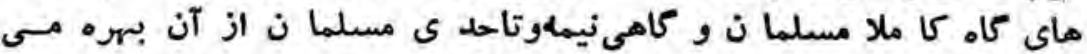

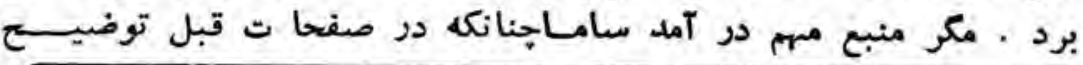

(1)نوشته n انقلابيكر ى خرد مبورزوا يى را بدور افكنيم عازنشرات

شعله جاو يد . ش 
شد ثابت نيست كاه منزل هموطنى

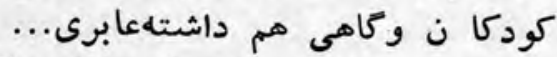

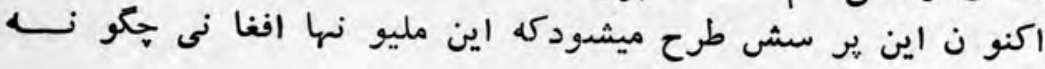

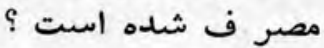

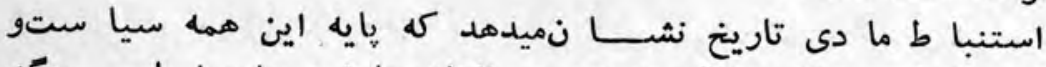

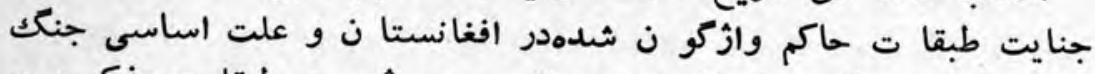

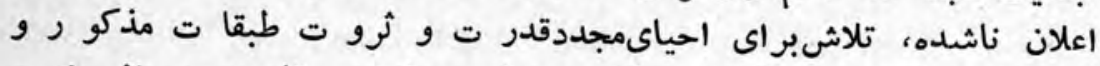

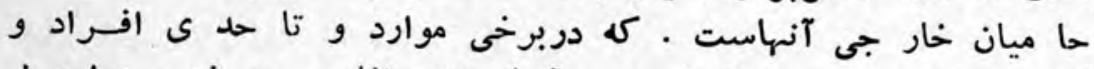

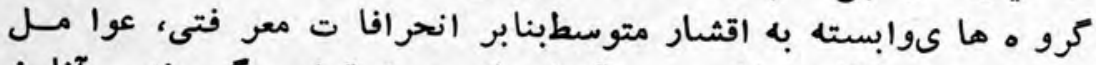

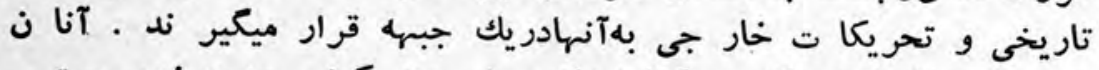

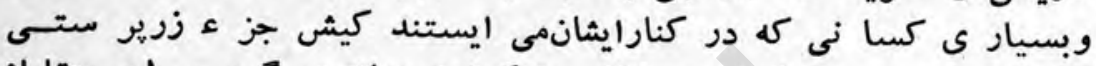

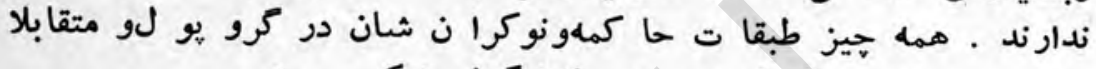

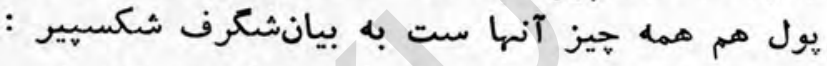

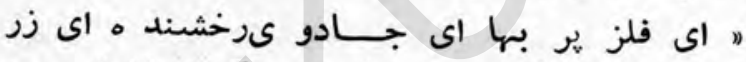

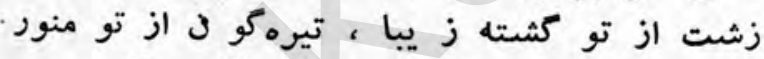

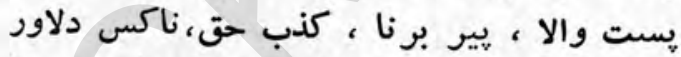

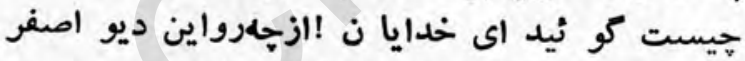

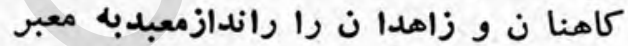

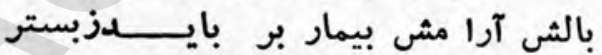

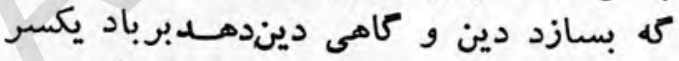

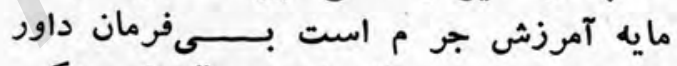

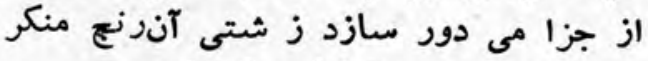

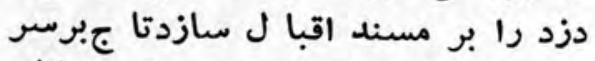

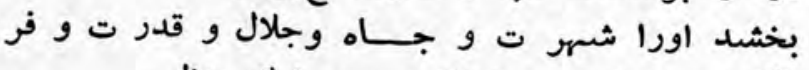

$$
\begin{aligned}
& \text { وآن عجوز شو م رواسازدعرو ستيك ونيك منظر }
\end{aligned}
$$

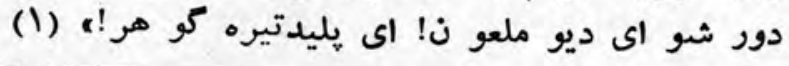

(1) شكسيير : Timon of Athens

$$
\text { -lor_ }
$$


طوريكه قبلا تذكر داد م شدمنابع يولى مجمو ع ضد الد انقلاب افغانستان

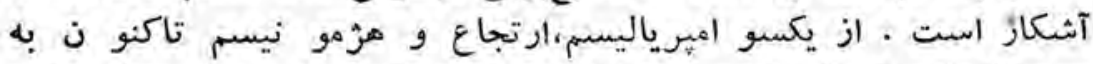

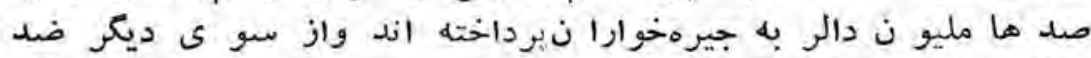

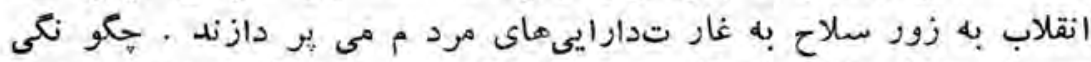

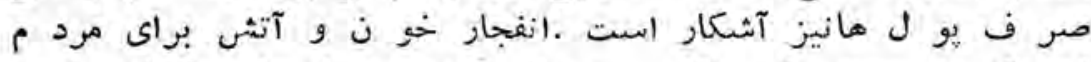

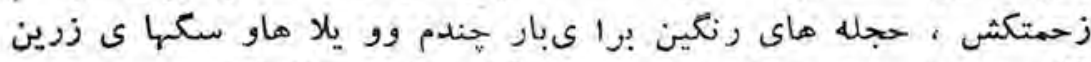

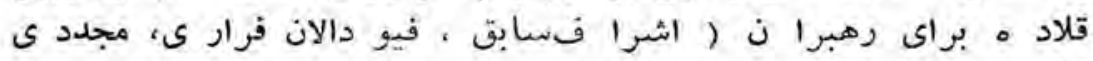

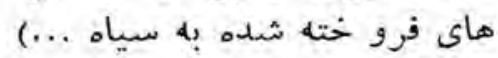

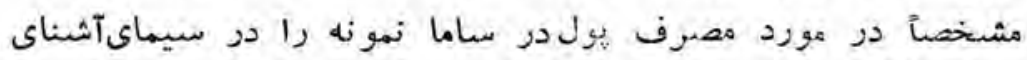

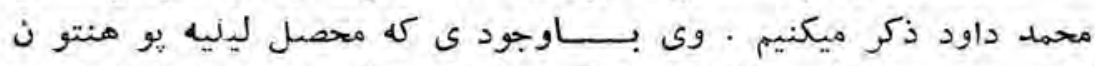

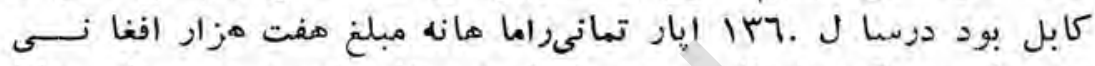

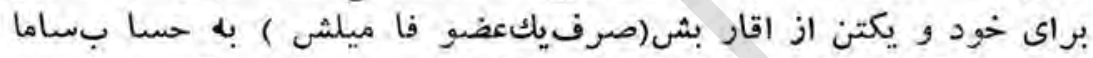

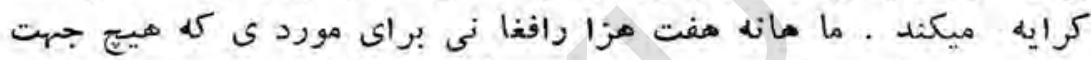

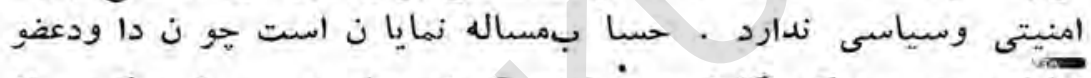

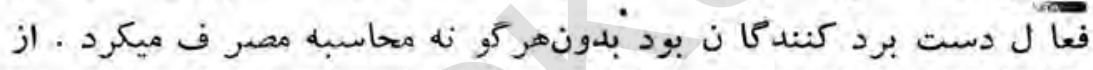

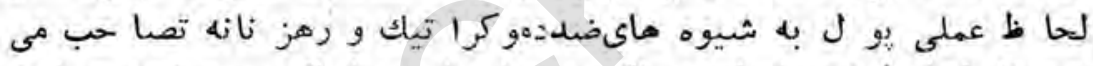

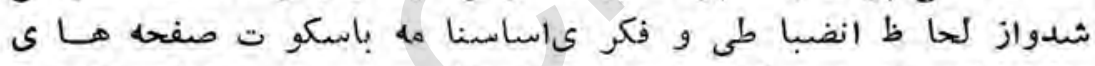

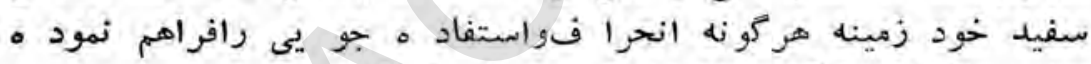

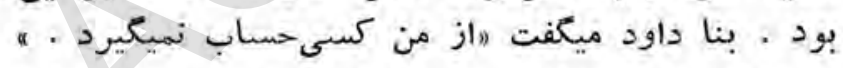

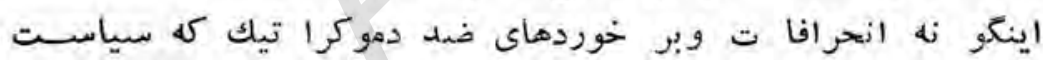

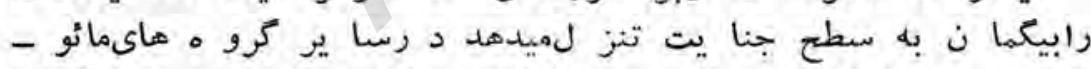

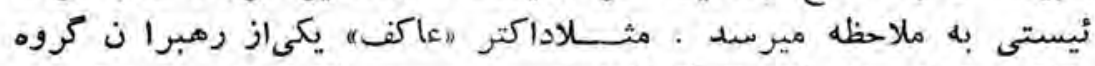

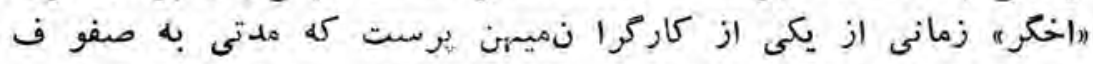

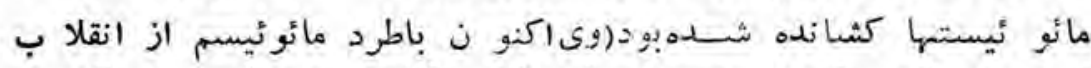

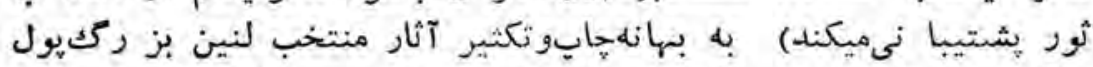

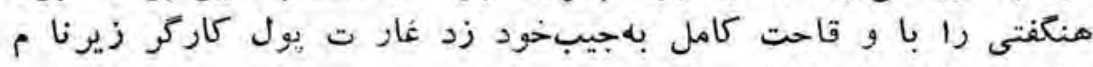

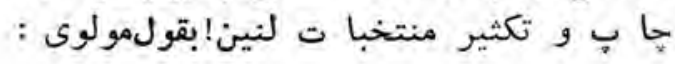


يس به هر دستى نبايد داددست

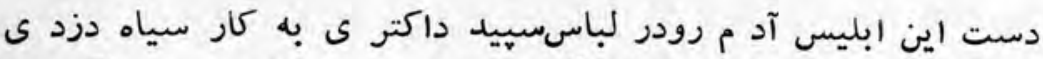

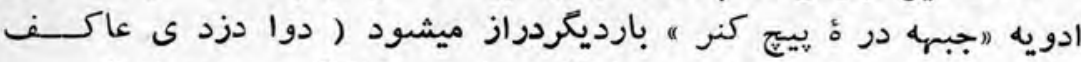

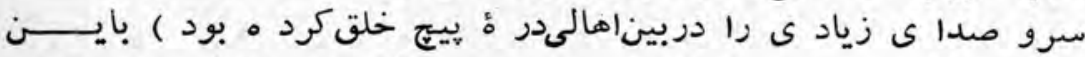

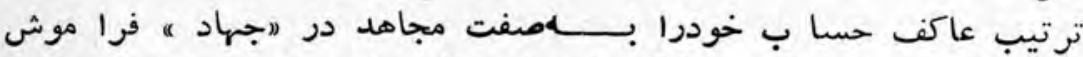

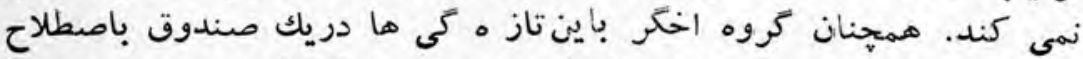

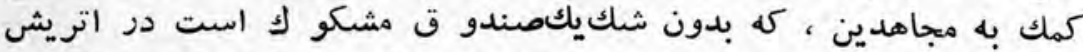

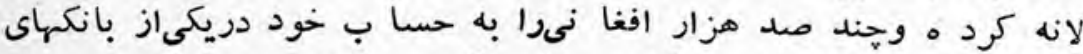

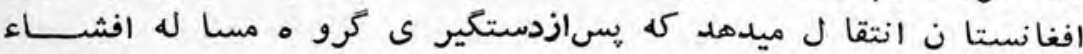

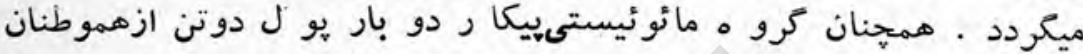

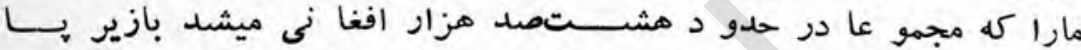

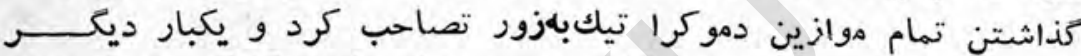

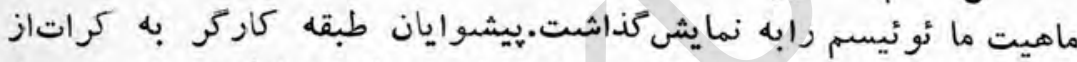

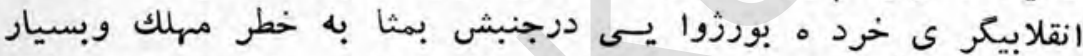

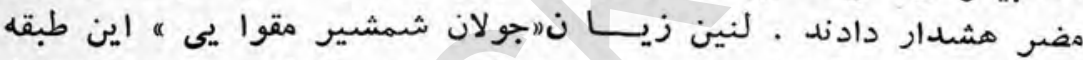

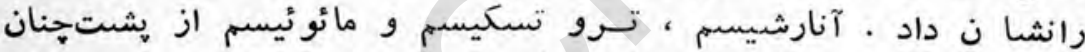

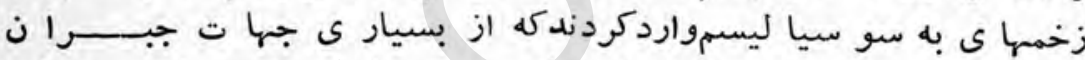

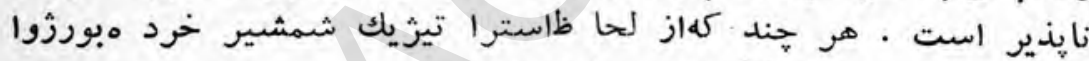

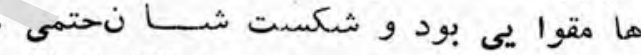

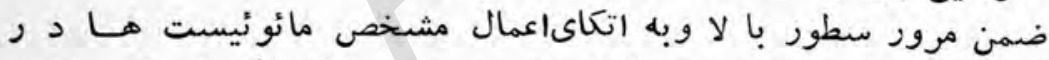

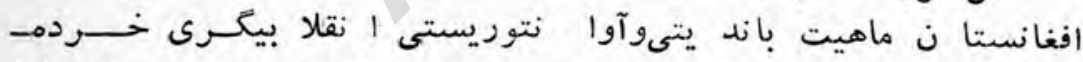

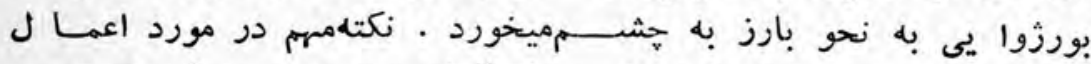

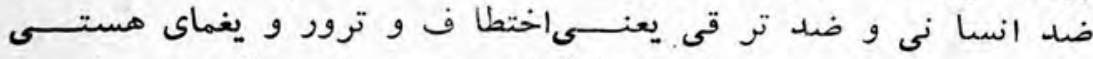

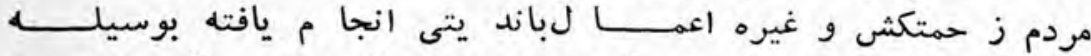

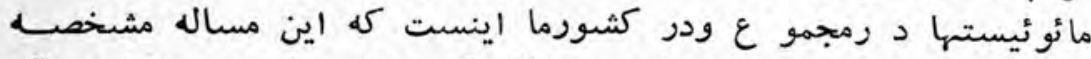

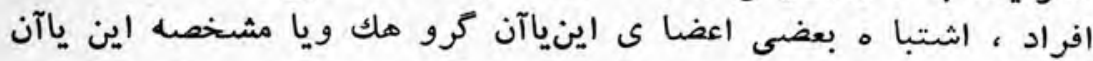




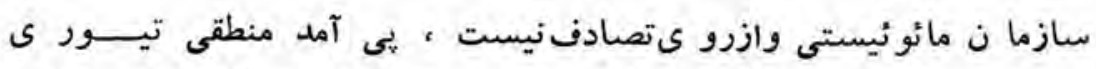

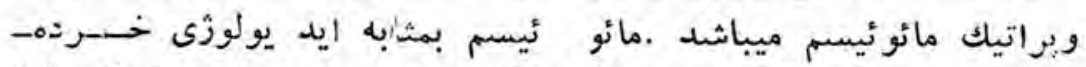

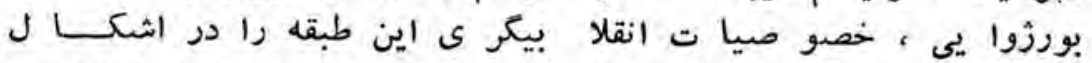

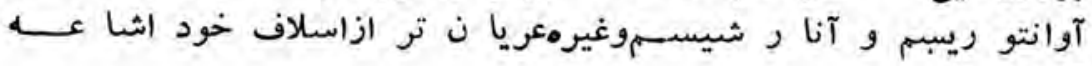

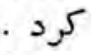

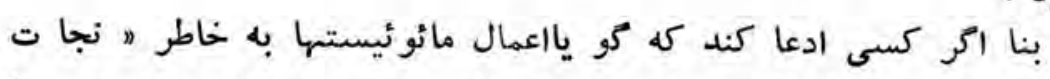

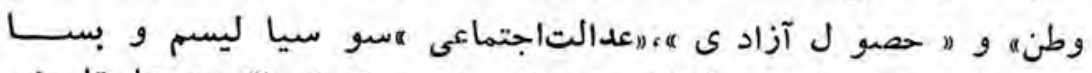

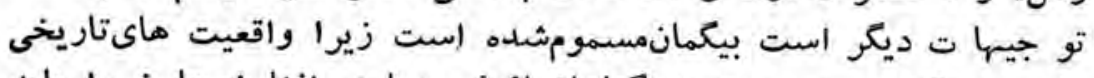

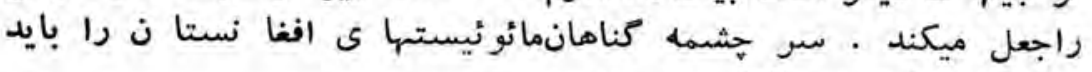

وبايد در ما ميت مائو ئيسم جست . منسان.

$-107$ 


\section{تروريسم》ساماه}

نكاهى vييرامو ن اساسا تمساله:

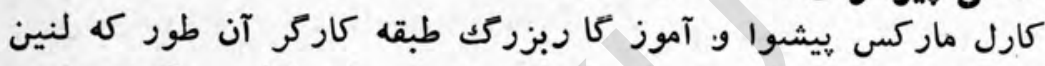

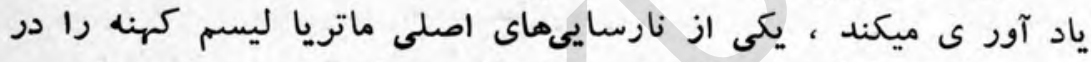

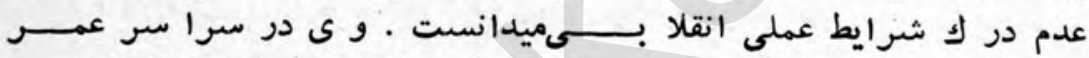

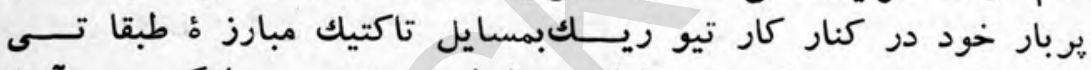

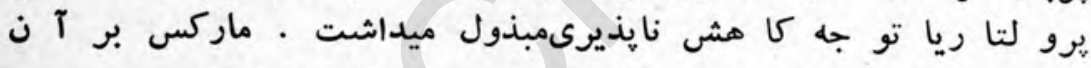

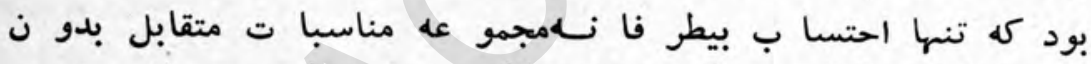

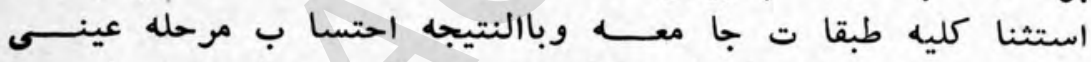

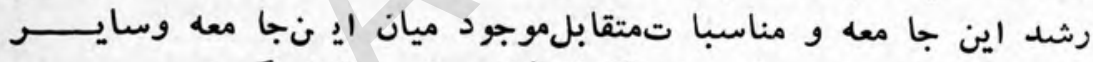

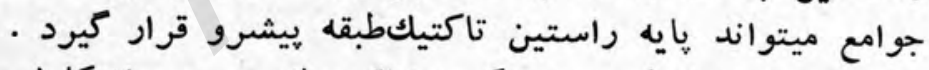

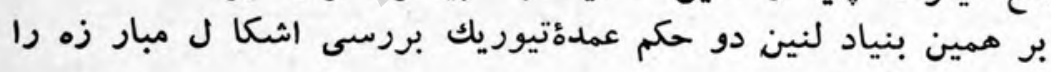

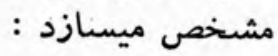

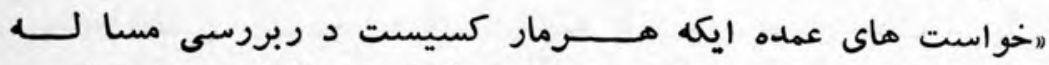

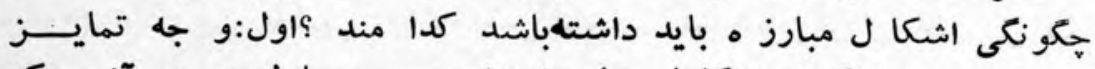

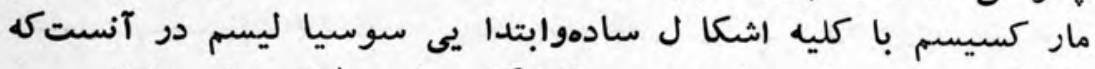

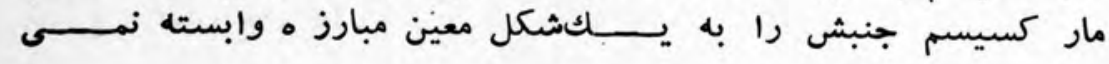

$$
-10 V_{-}
$$




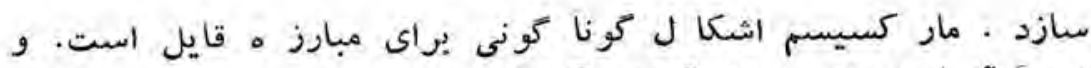

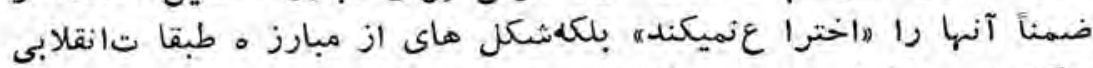

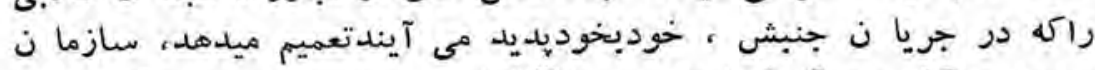

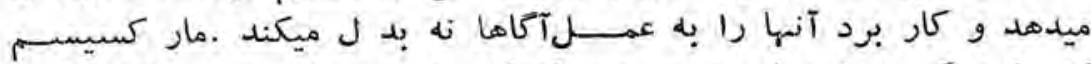

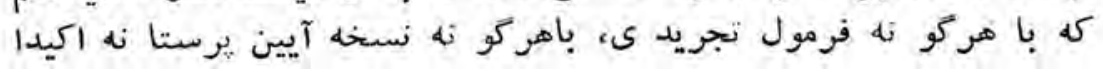

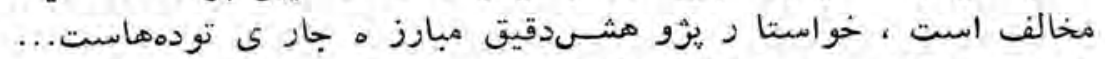

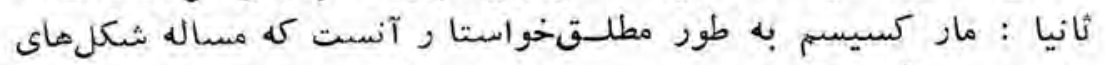

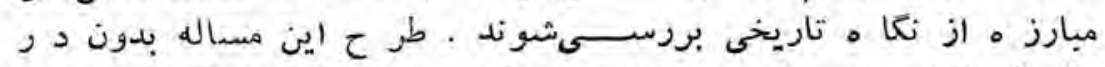

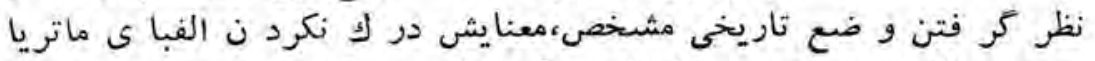

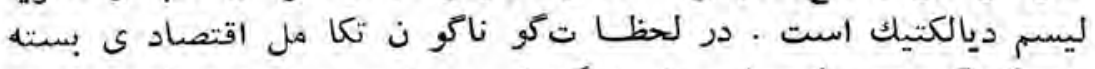

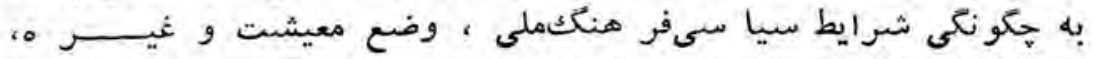

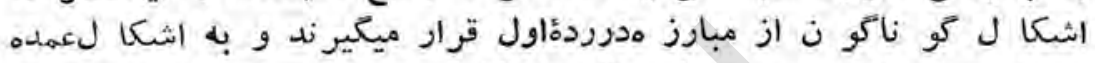

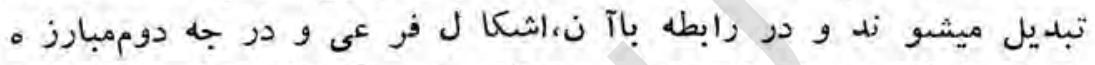

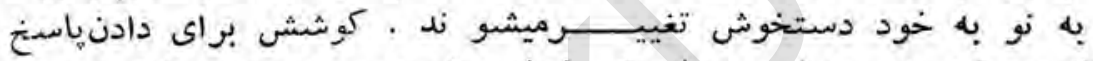

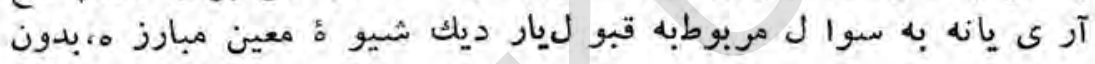

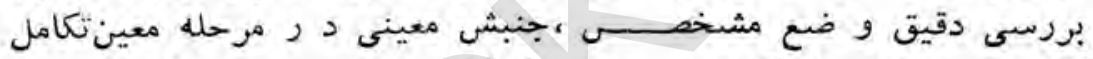

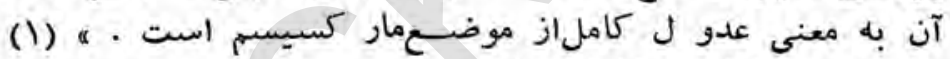

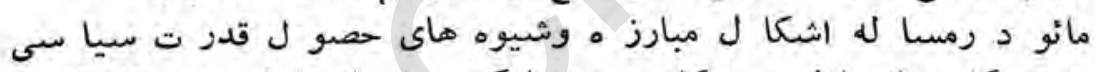

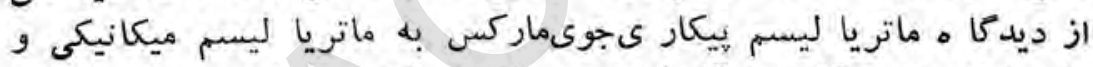

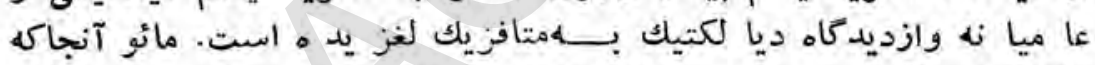

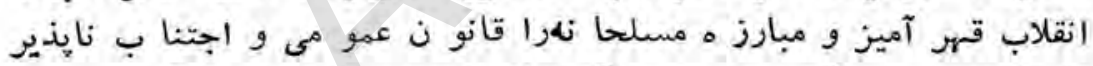

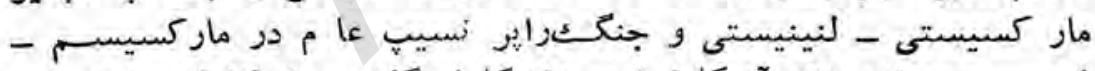

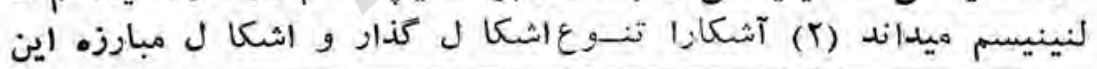

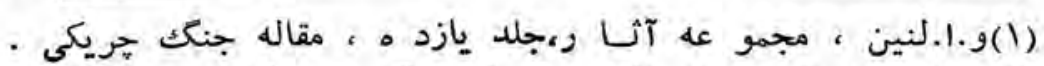

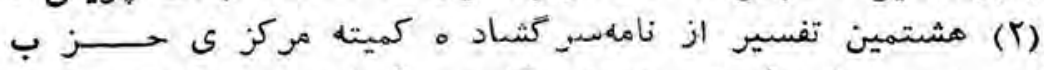

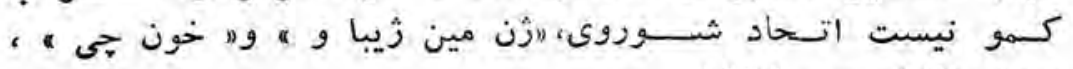

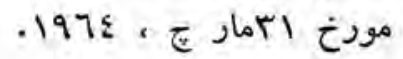


اصل قبو ل شده ، صريح، رو شــنوغير قابل "جنه زنى، تيور ىماركس

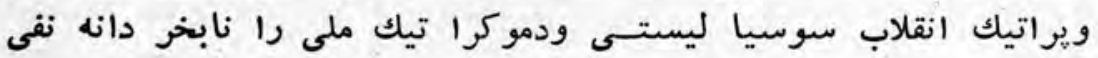
ميكند وريل

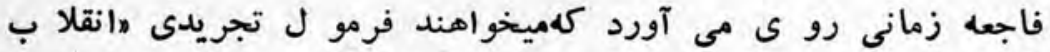

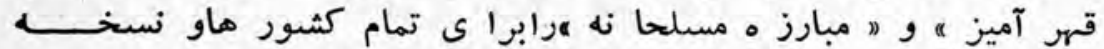

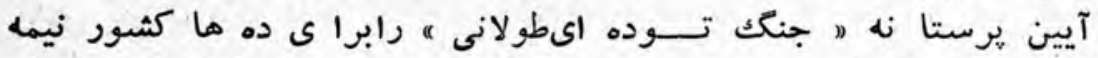

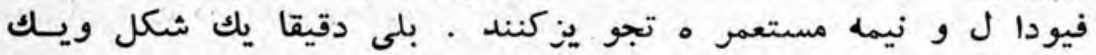

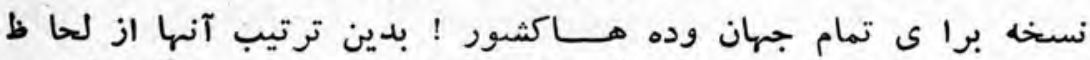

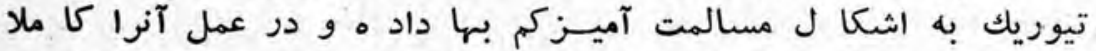

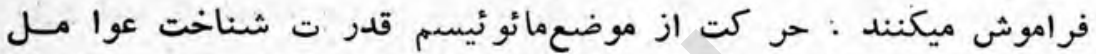

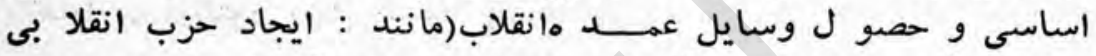

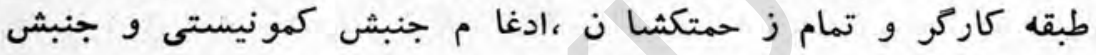

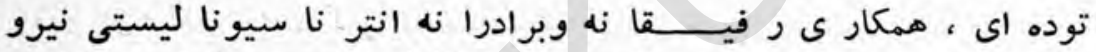

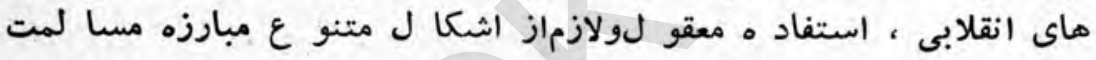

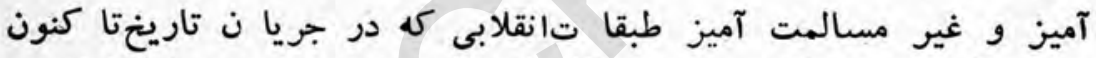

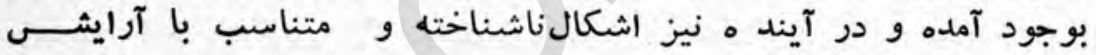

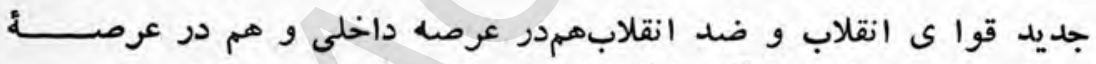

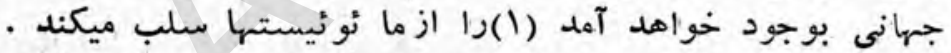

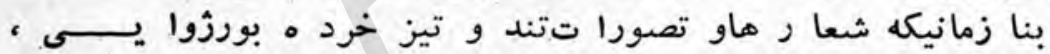

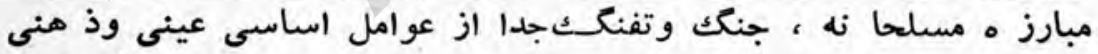

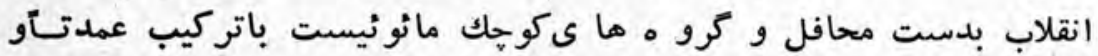

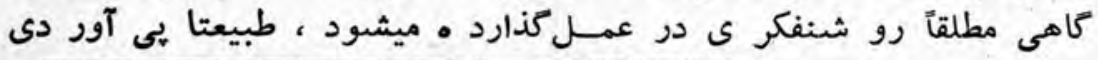

(1) بهضصوص در دوران مابايد تضاد اساسى دورا ن يعنى تضاد

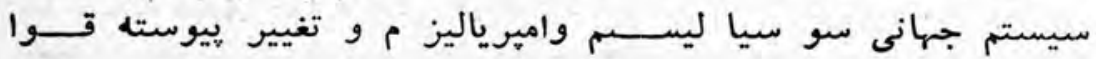

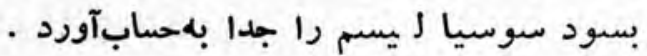




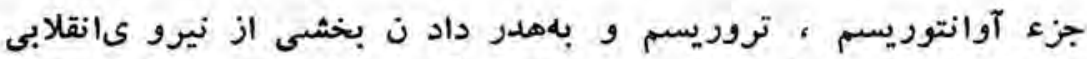

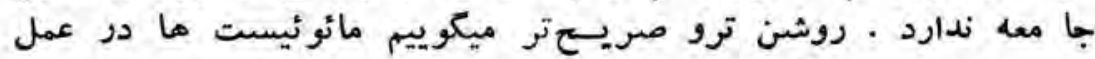
قادر به تحقق انقلاب تهر آميز ومبارز ه مسلحا نهائه ه خوديه نيستئد .

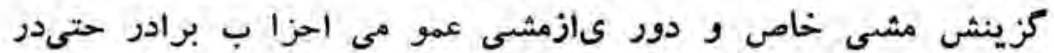

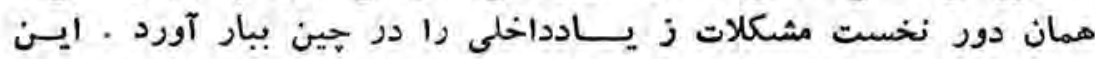

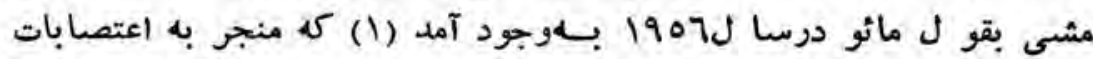

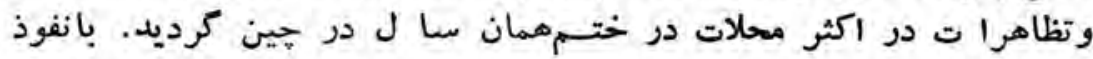

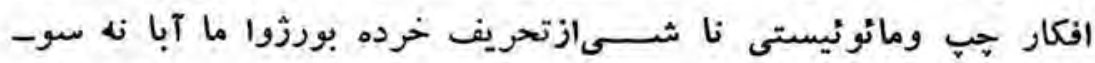

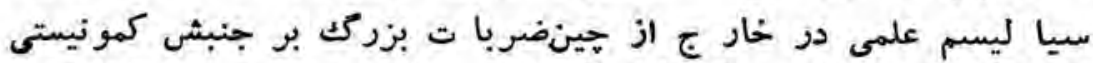

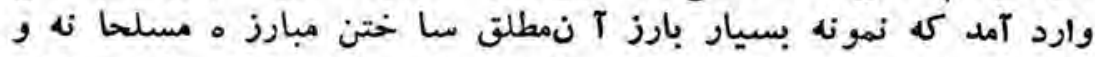

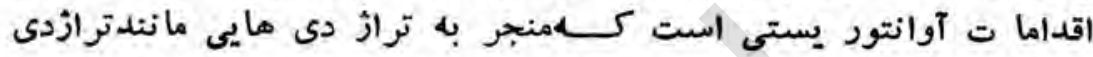

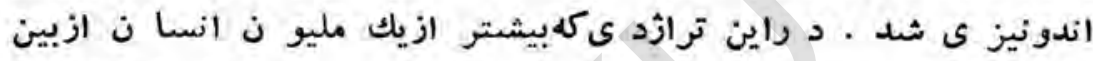

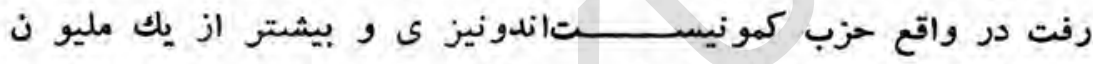

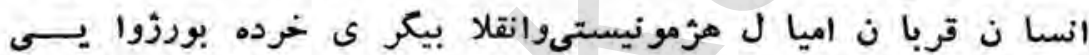

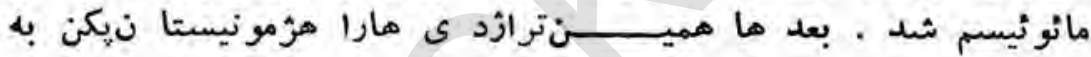

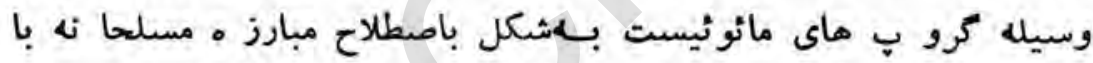

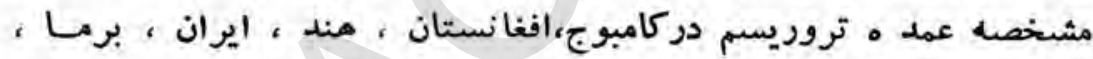

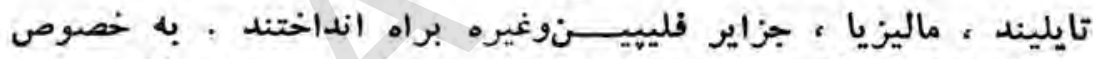

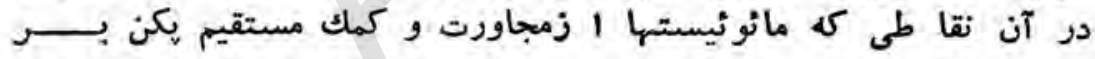

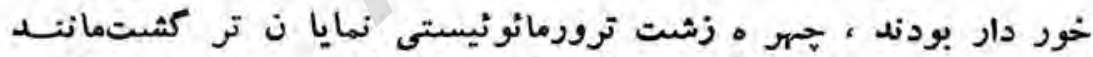

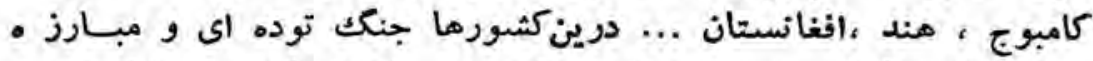

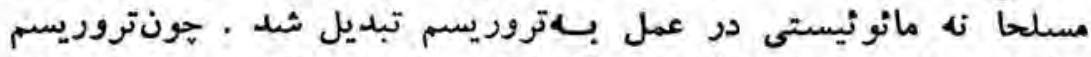

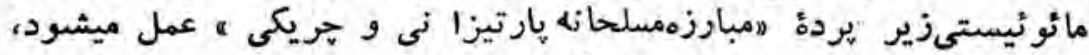

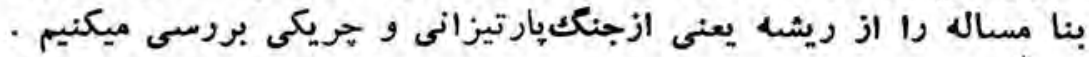




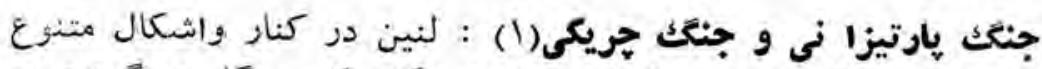

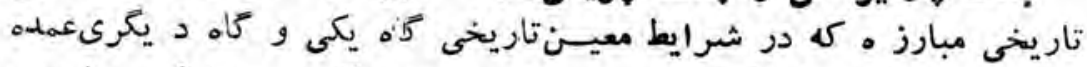

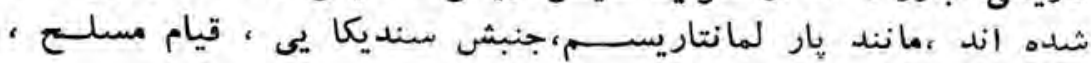

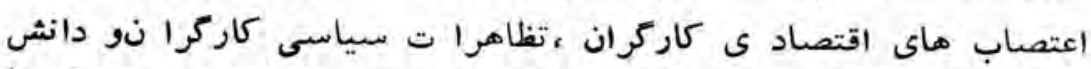

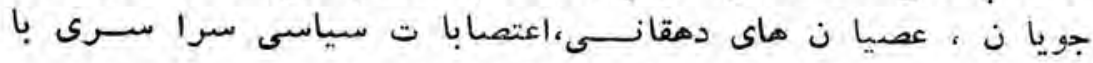

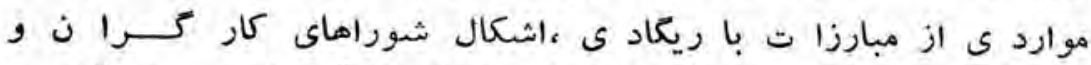

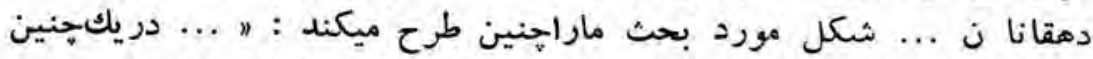

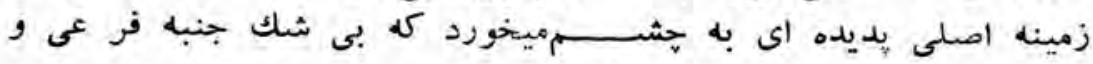

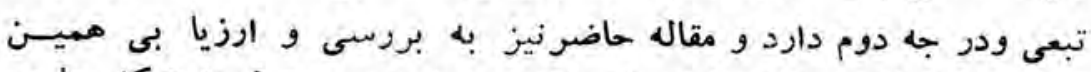

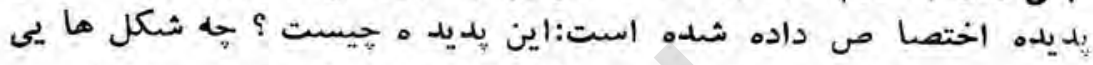

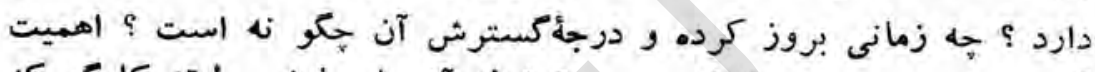

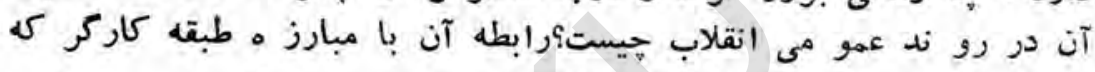

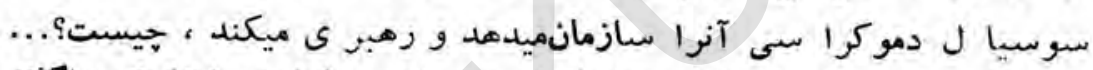

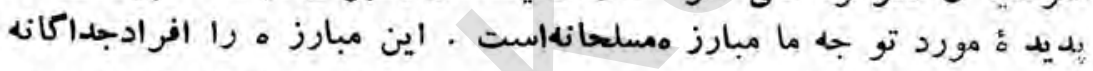

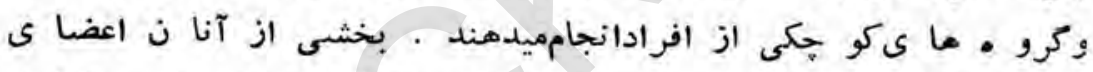

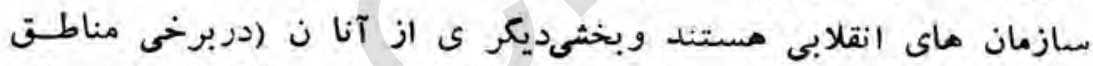

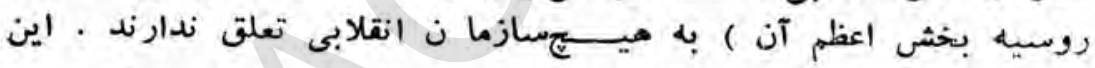

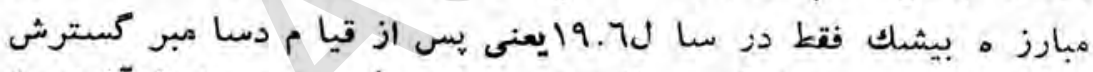

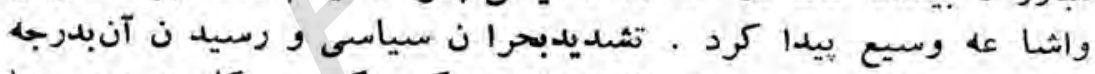

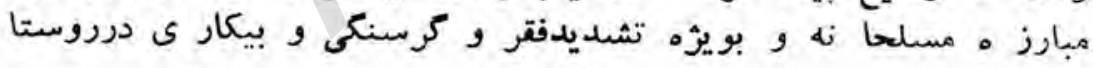

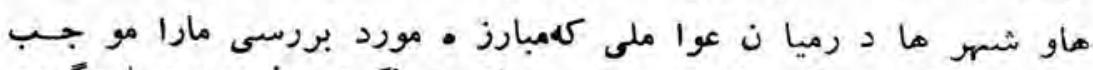

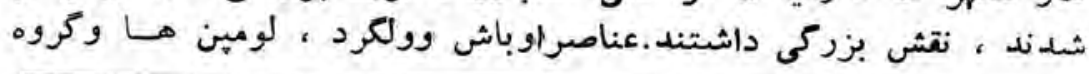

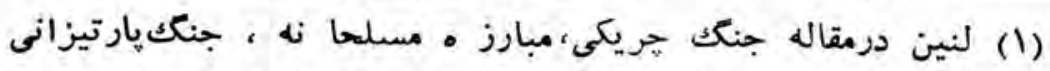

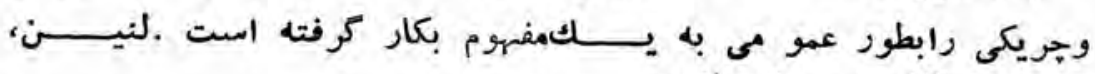
مجهو عه آلار ، . ، جلد يازده . 


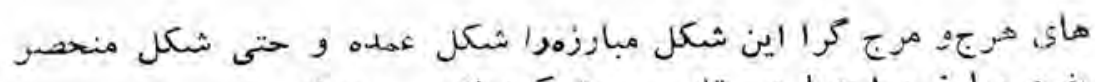

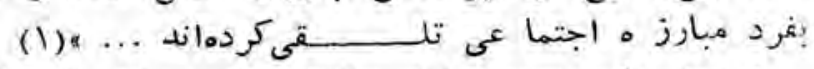

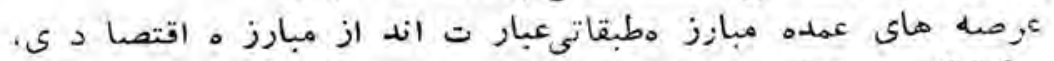

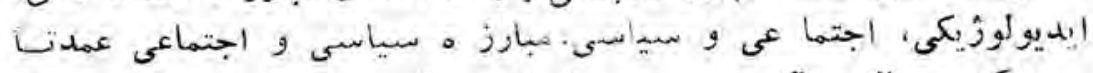

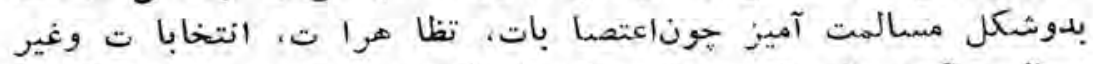

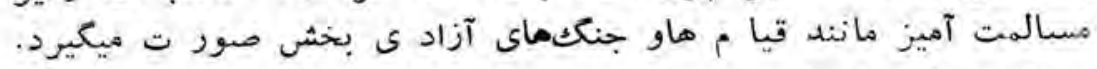

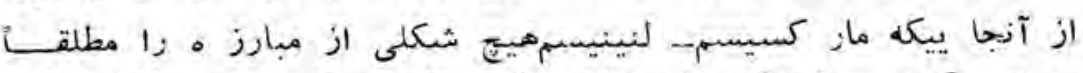

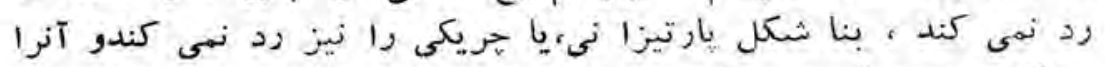

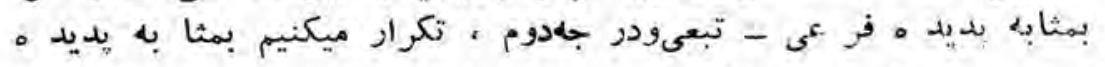

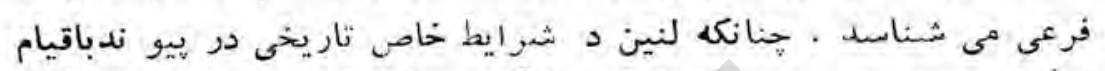

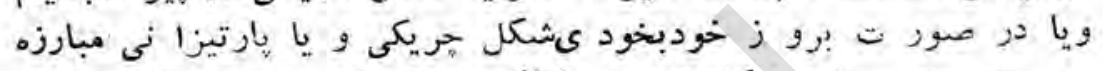

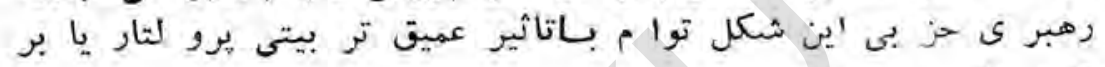

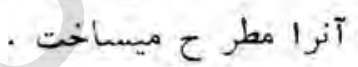

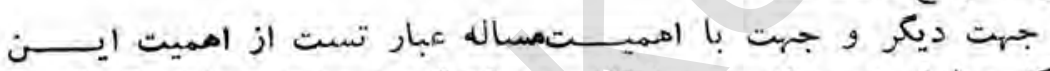

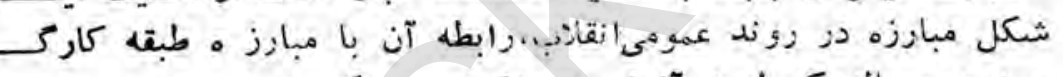

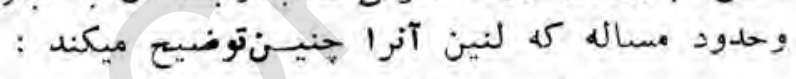

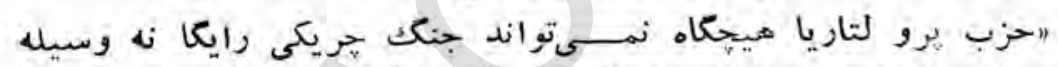

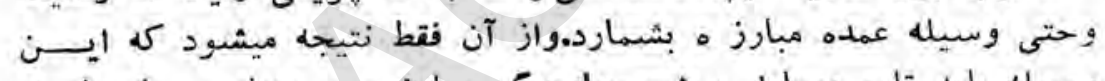

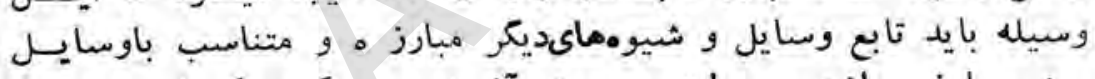

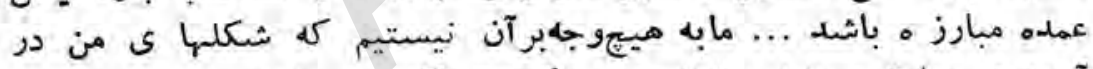

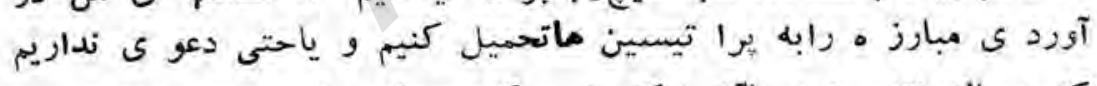

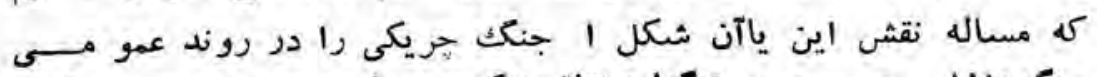

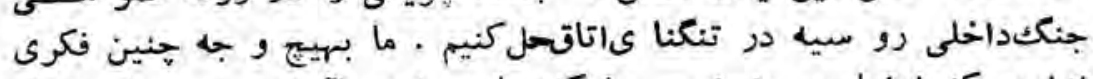

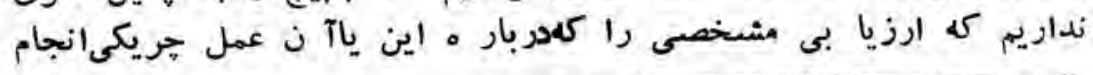

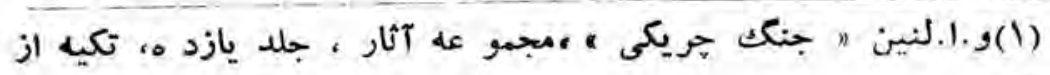




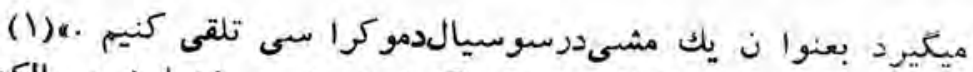

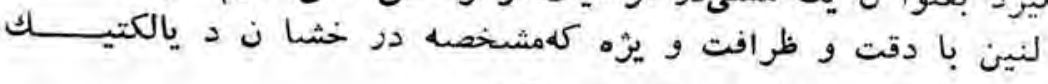

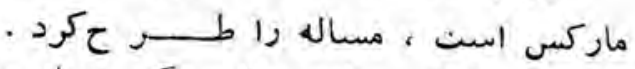

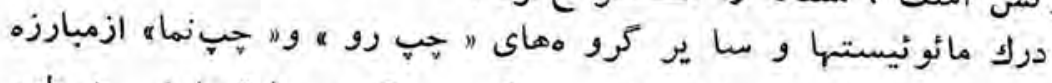

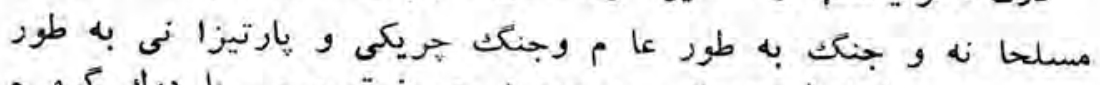

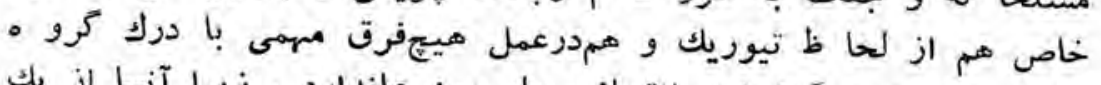

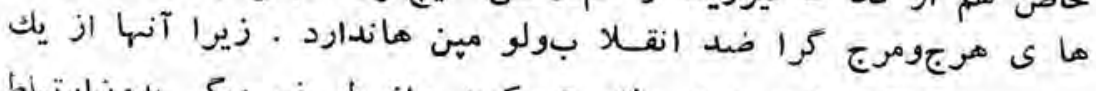

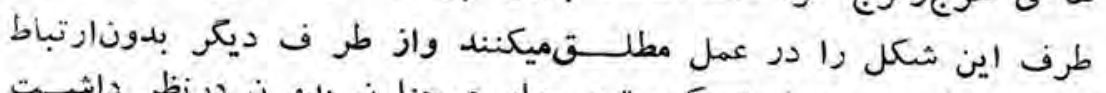

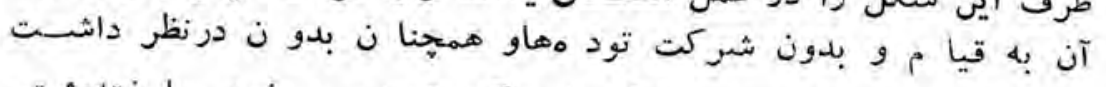

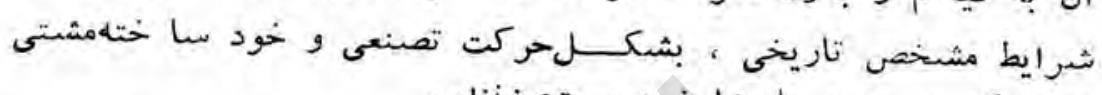

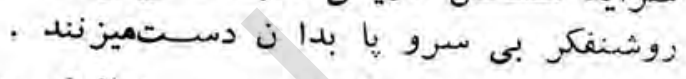

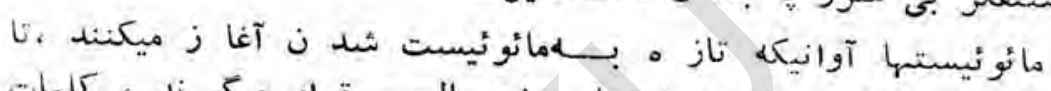

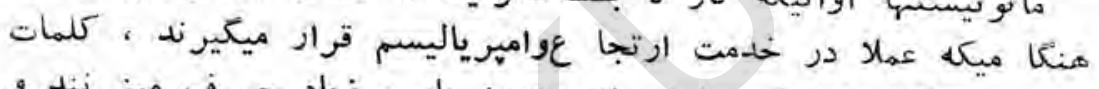

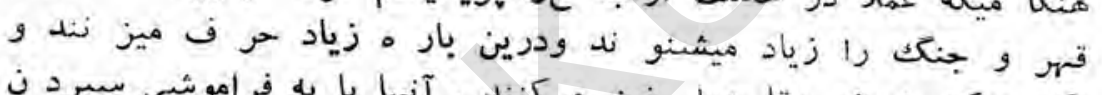

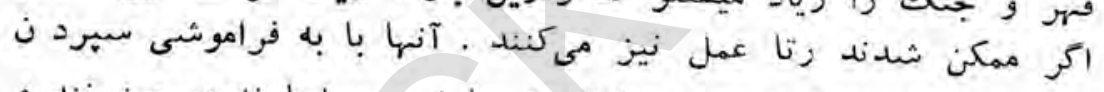

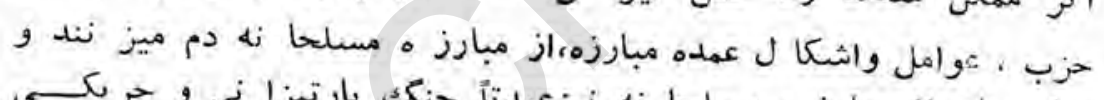

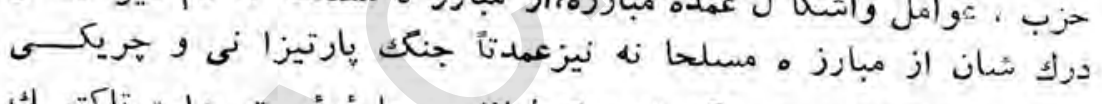

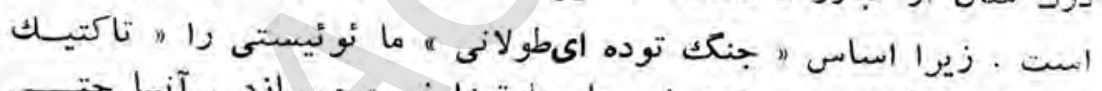

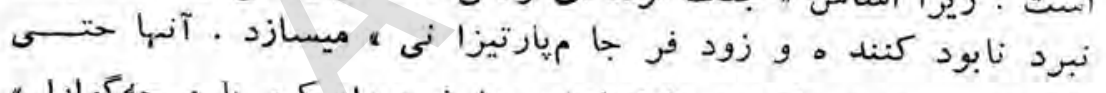

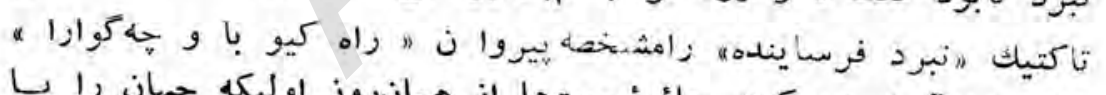

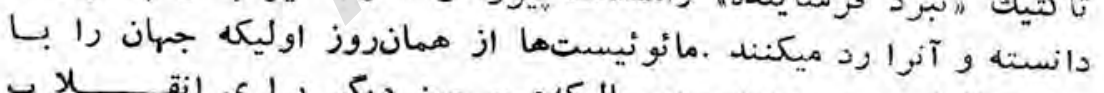

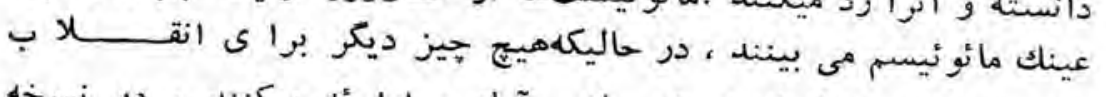

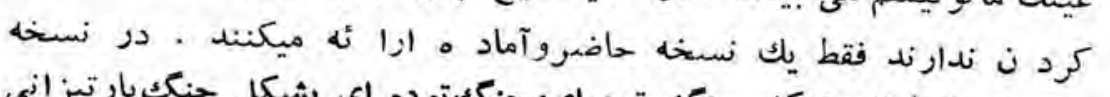

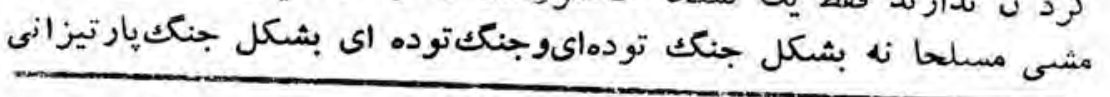

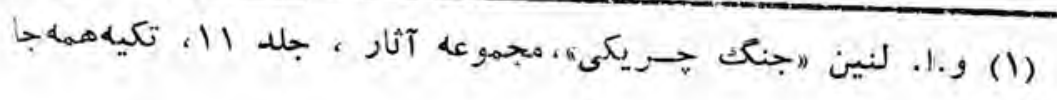




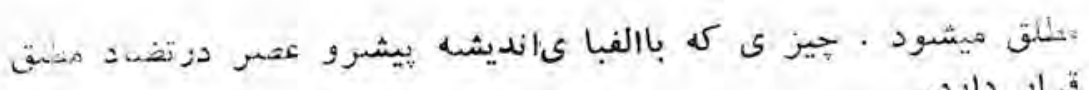
قرار دارد.

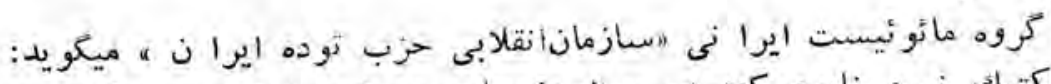

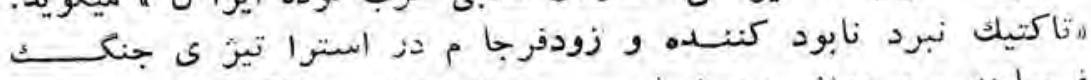

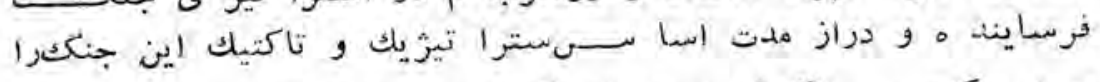

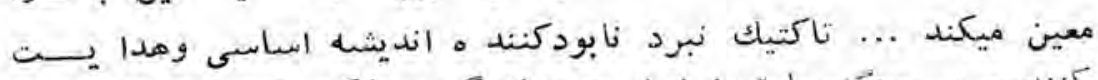

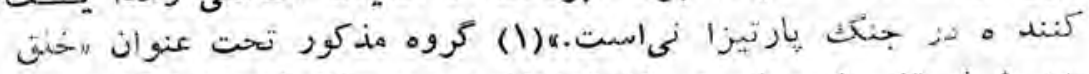

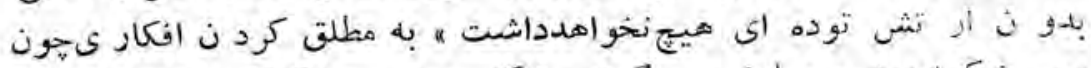

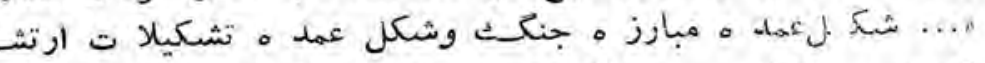

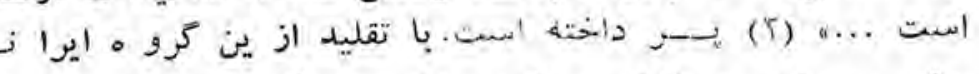

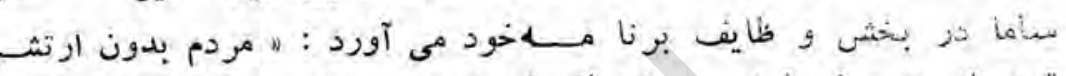

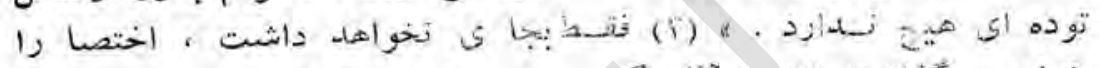

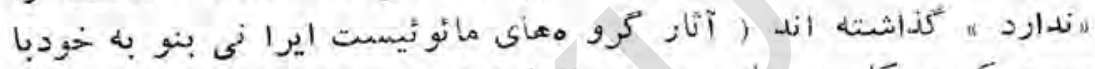

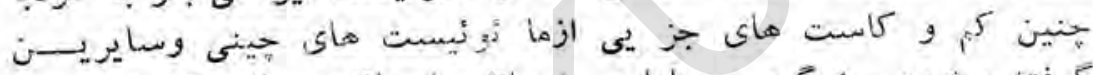

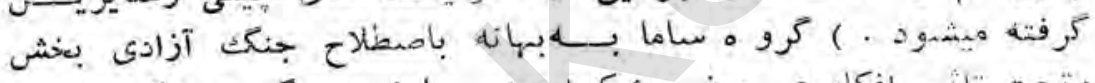

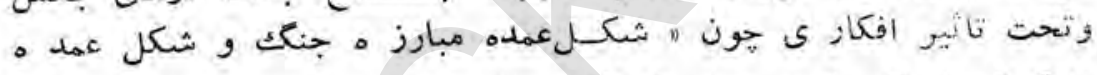

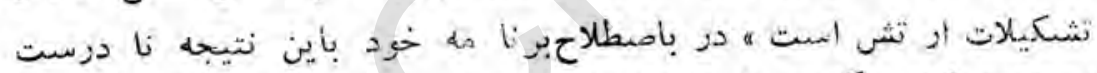

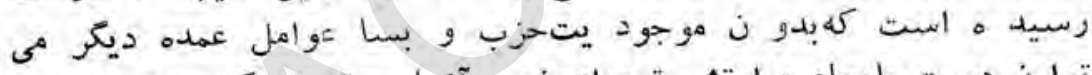

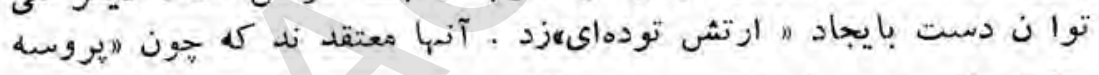

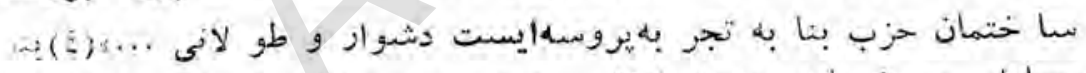

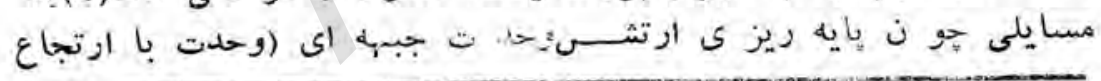

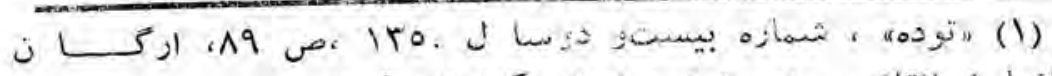

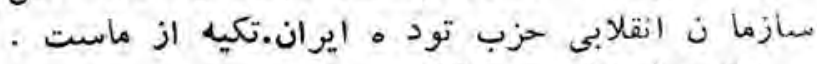

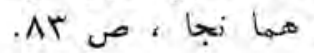

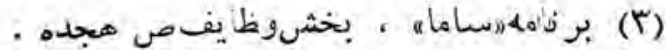

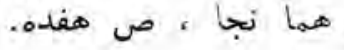




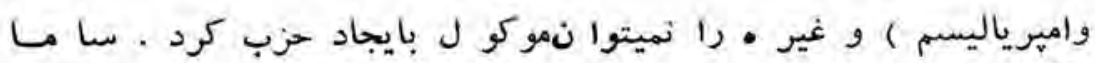

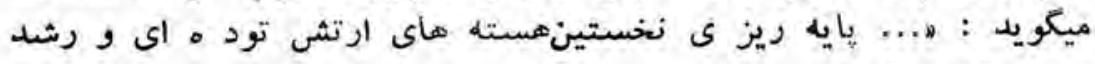

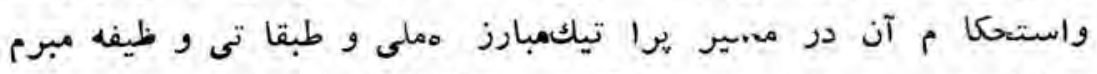

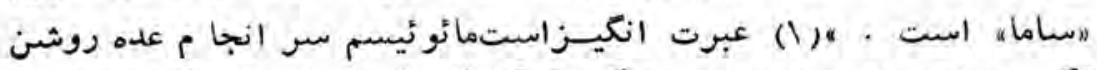

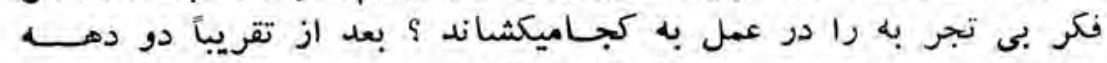

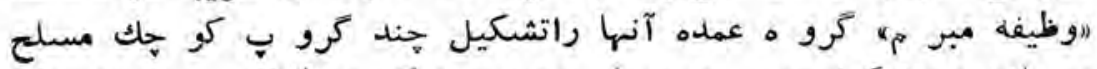

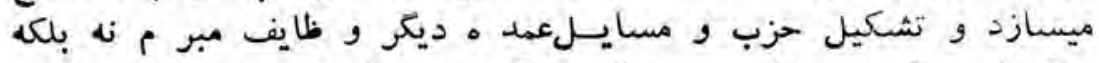

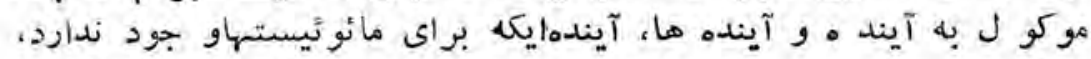

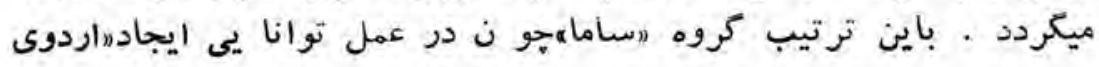

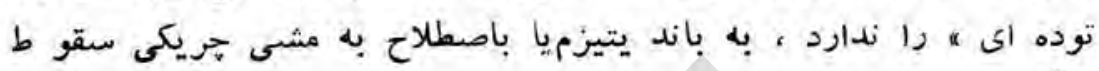
ميكند . مان

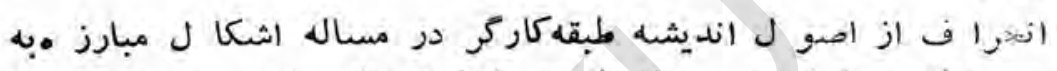

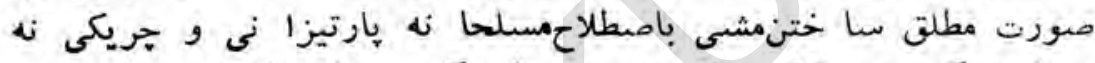

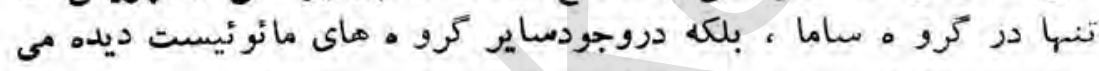

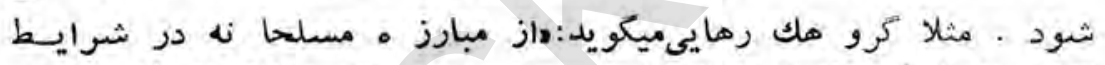

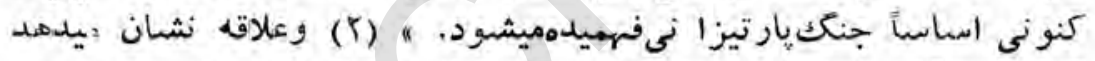

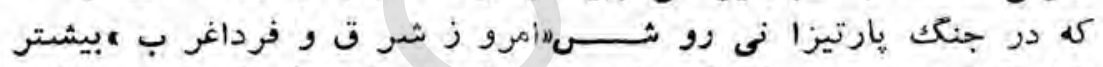

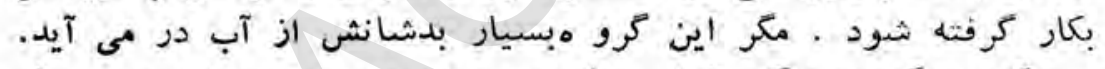

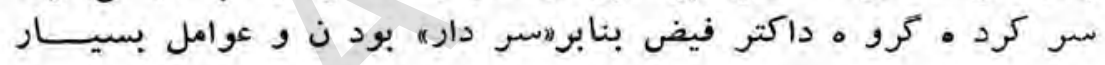

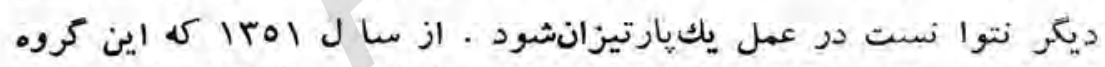

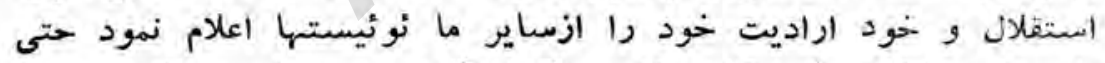

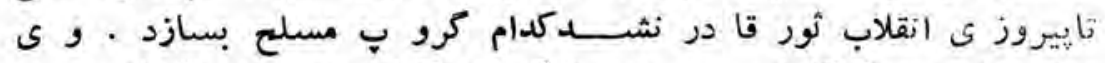

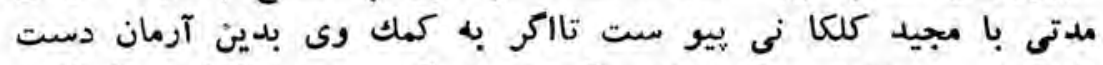

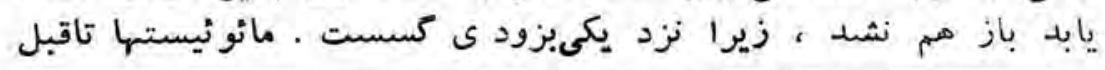

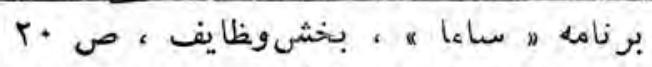

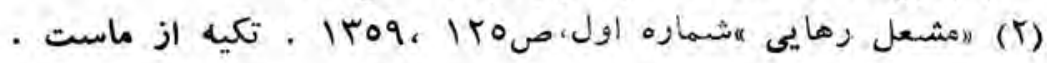




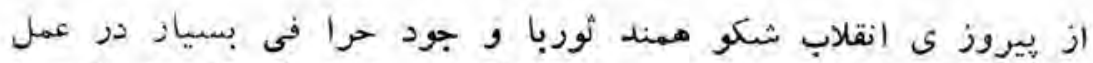

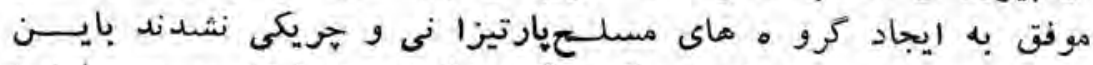

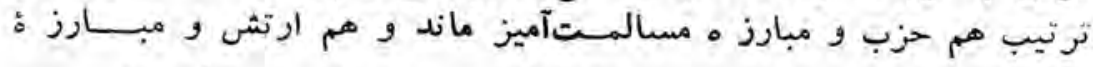

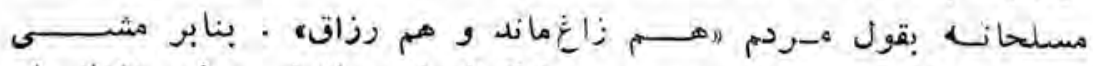

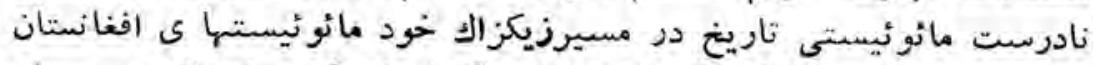

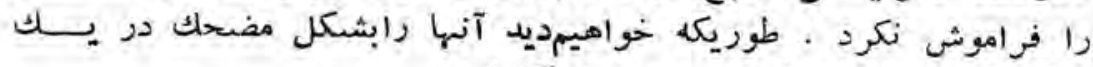

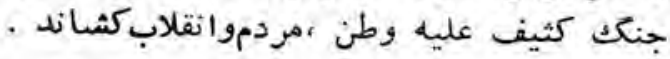

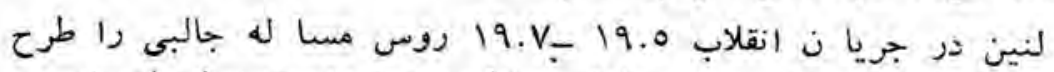

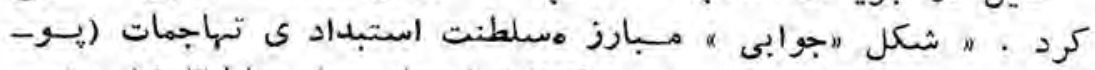

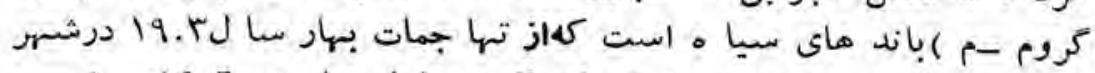

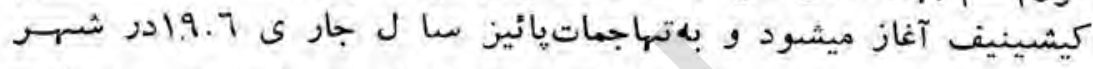

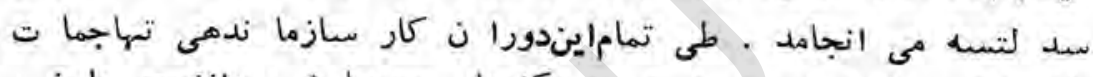

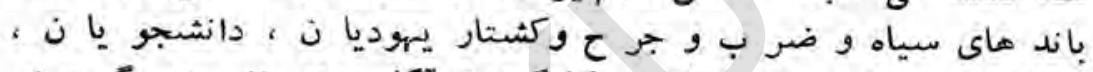

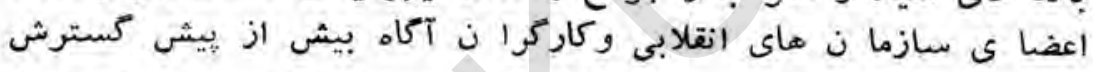

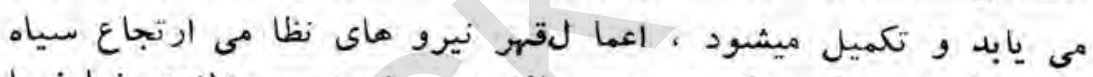

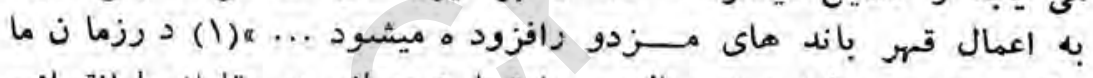

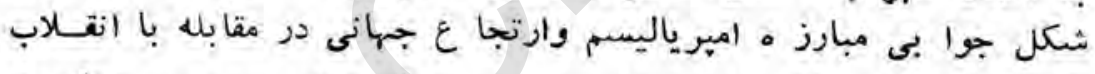

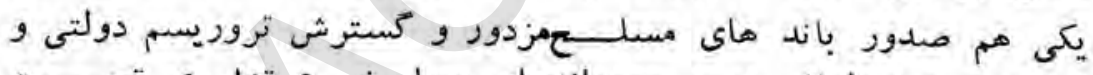

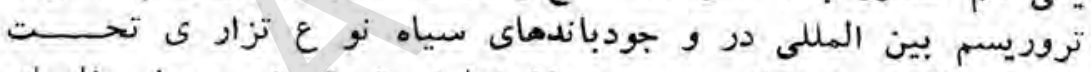

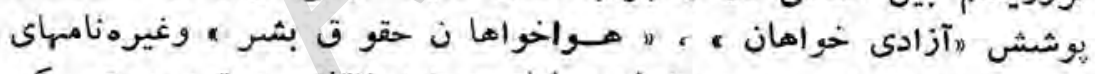

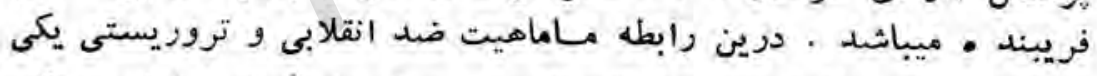

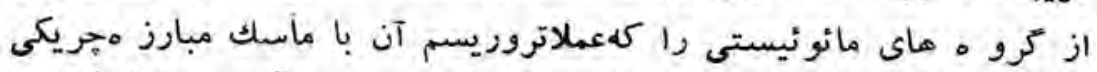

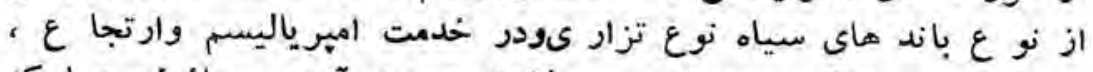

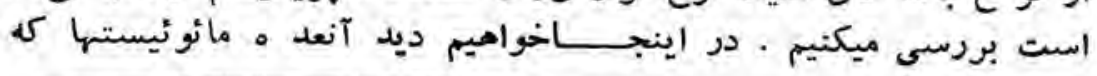

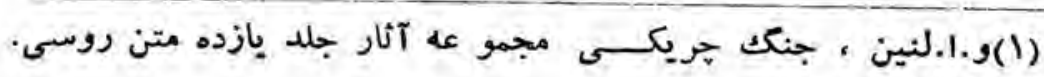
تكيه از ماست . 


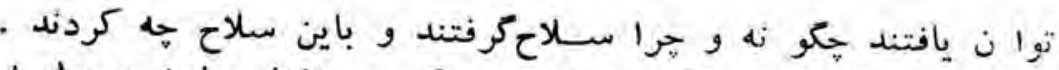

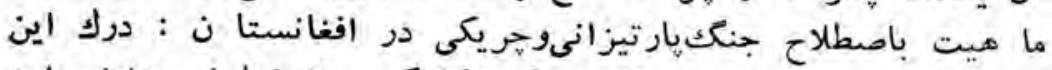

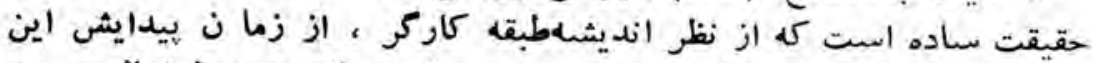

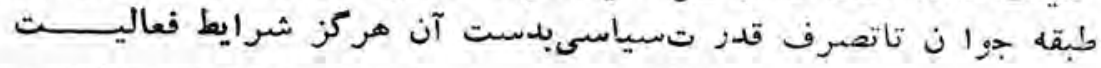

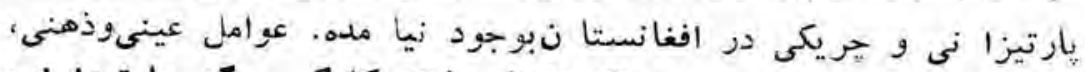

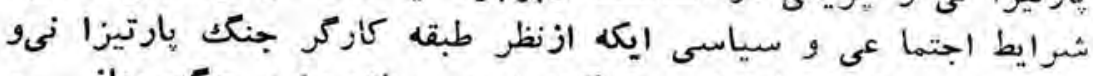

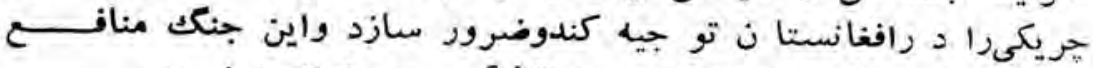

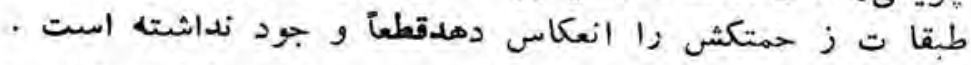

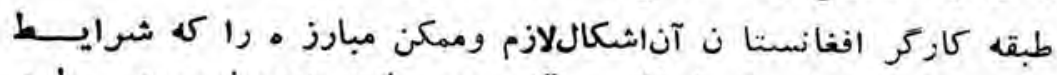

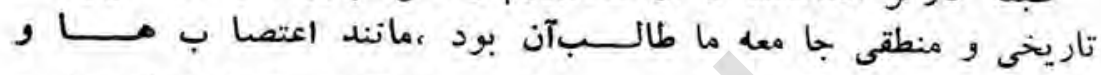

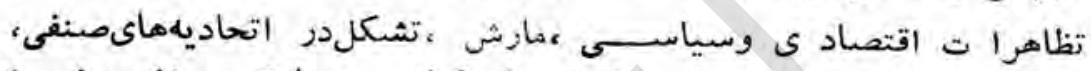

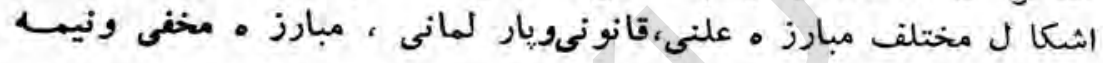

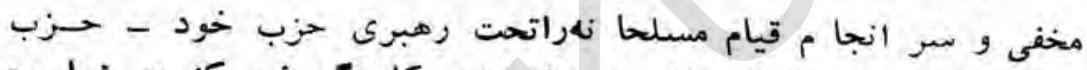

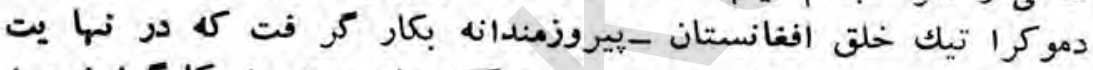

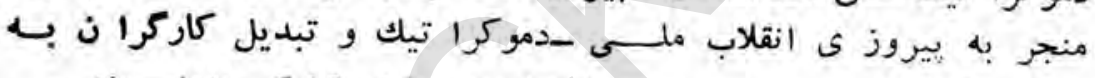

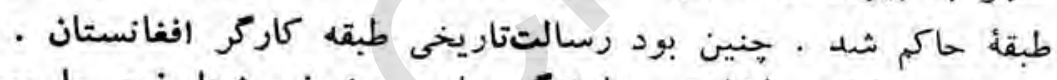

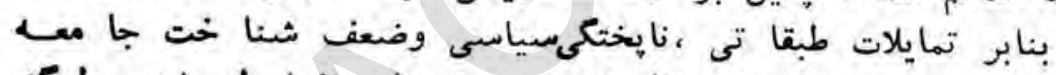

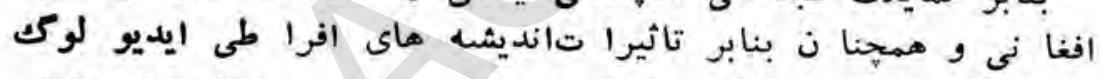

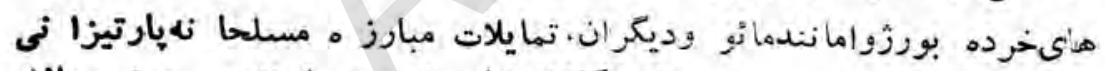

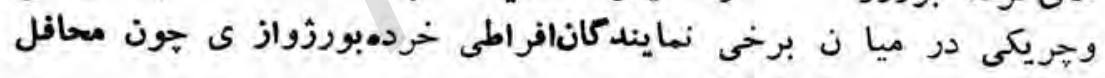

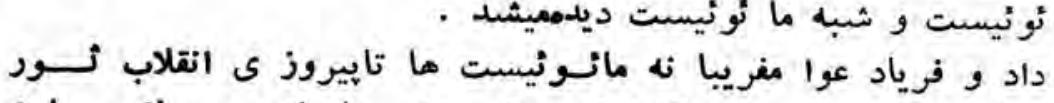

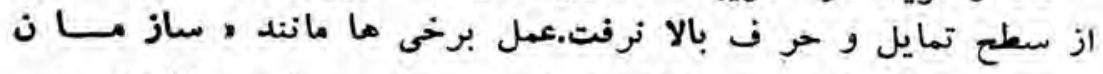

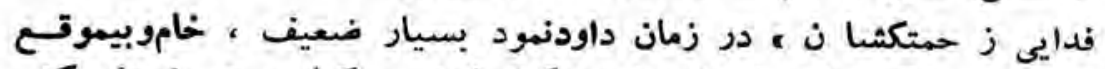

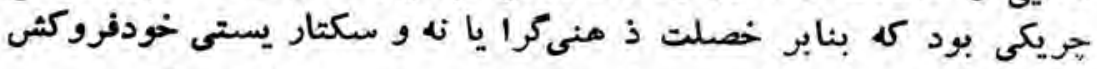

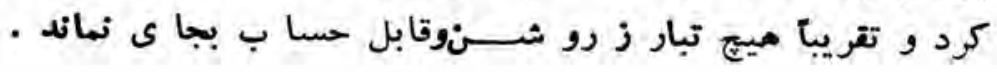




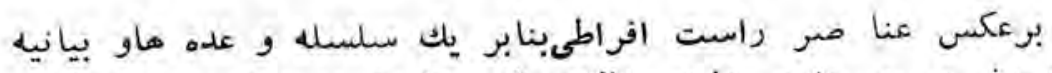

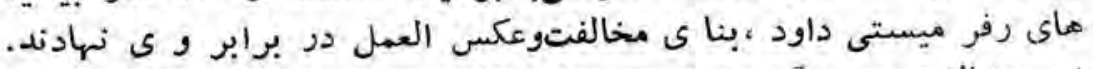

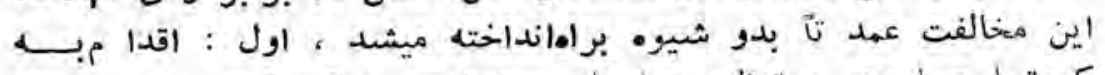

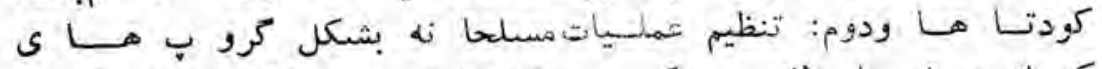

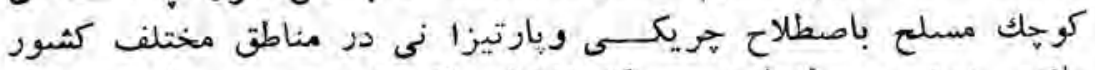

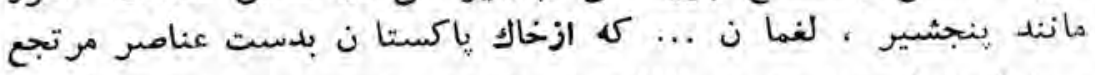

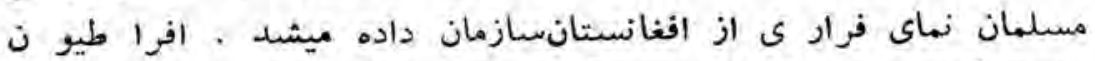

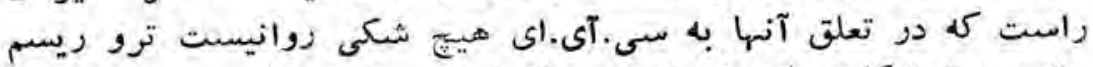

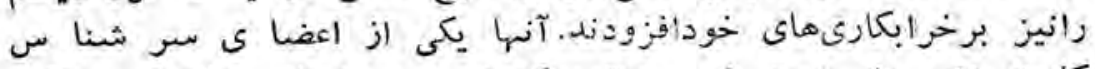

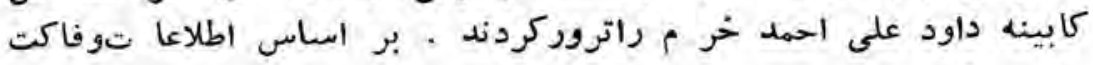

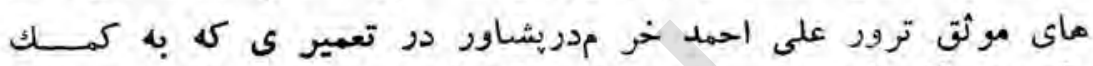

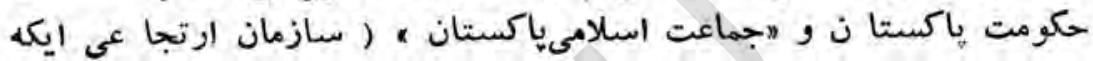

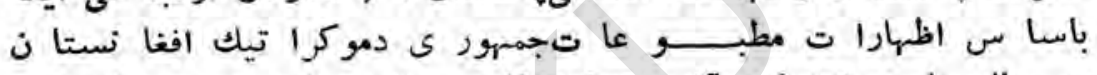

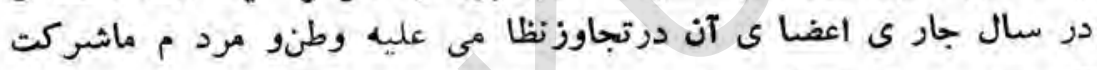

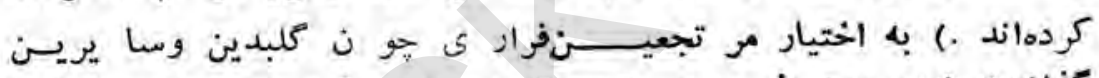

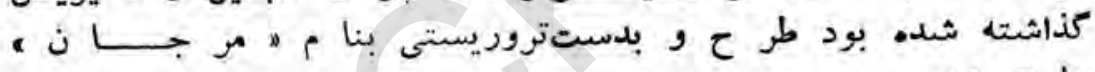
تطبيق شد .

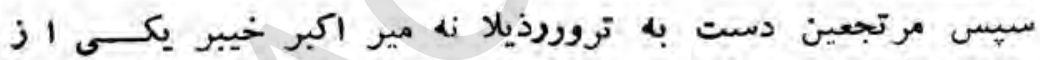

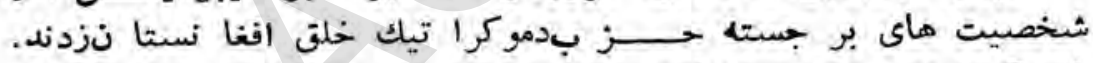

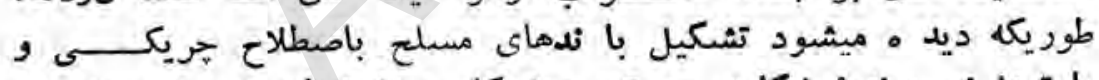

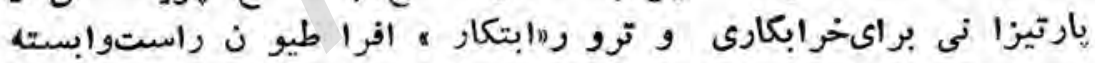

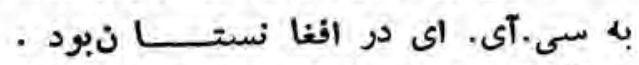

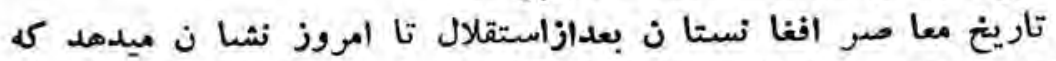

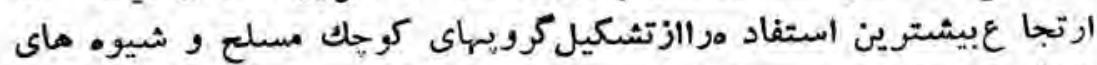

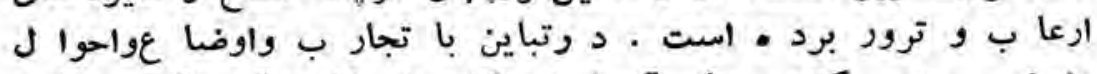

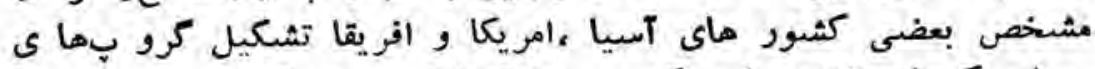

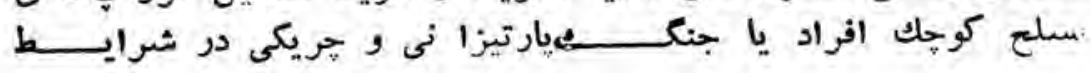


مشتص افغانستا ن مشخصه انقلابنيست ، بلكه مشخصله ضل رابل انقلاب

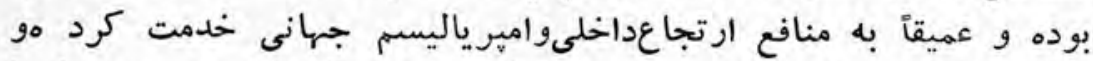

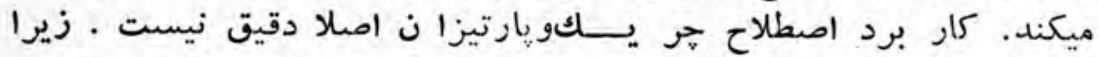

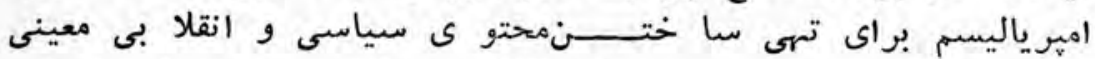

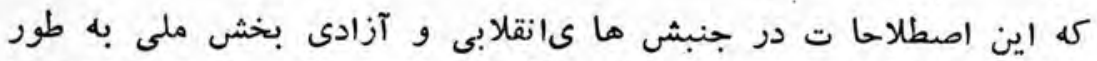

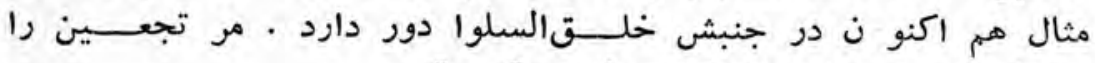

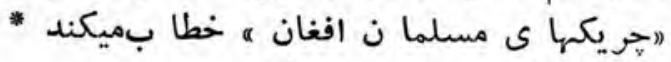

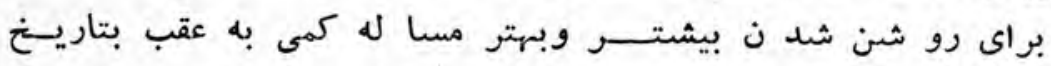
باز ميكرديم

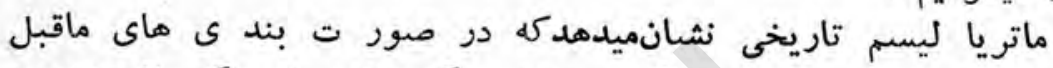

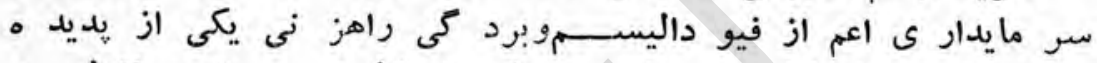

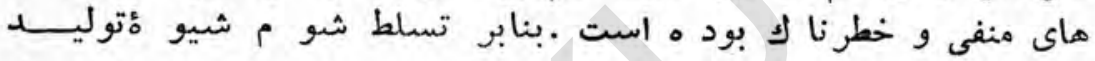

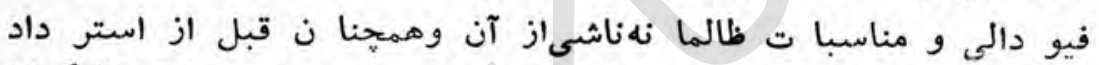

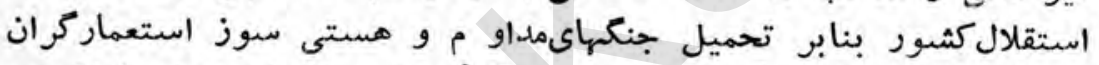

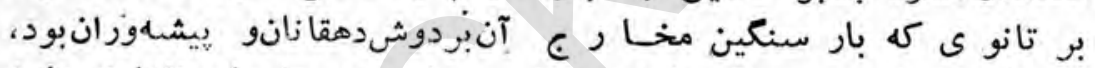

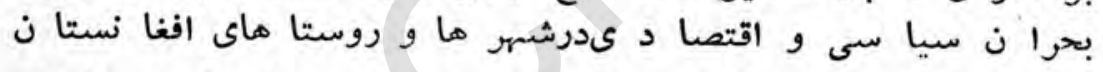

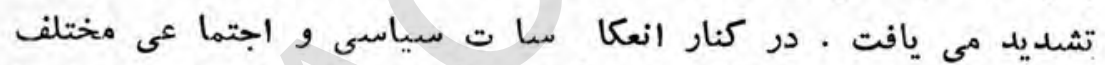

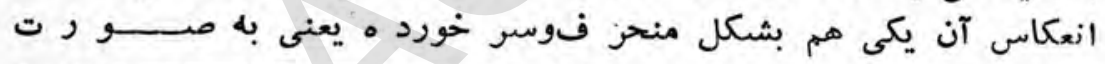

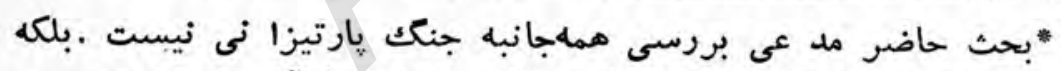

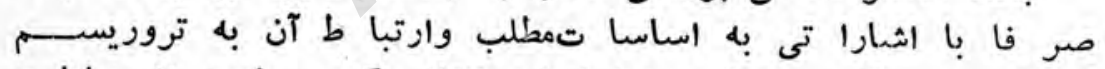

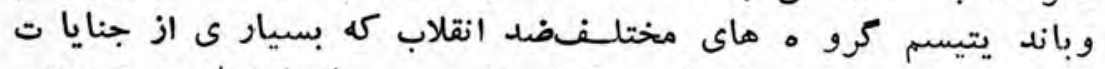

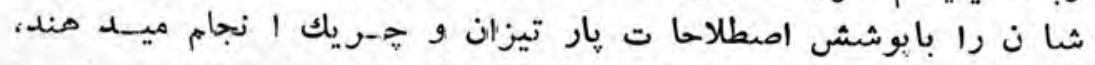

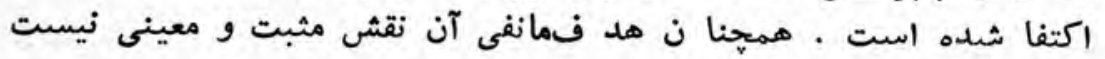

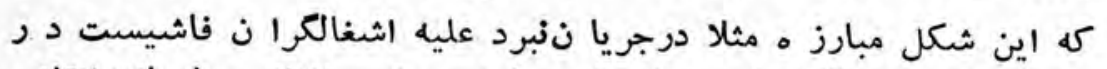

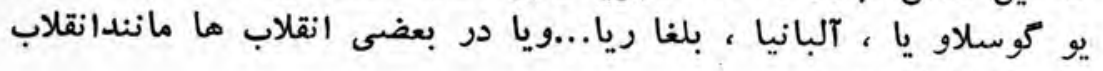

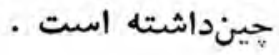


تشكيل كرو ب ماى رامز نى تبارزميكرد .

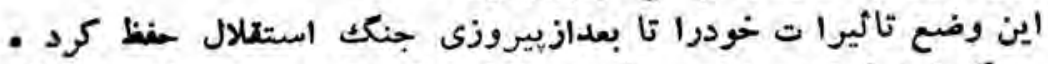

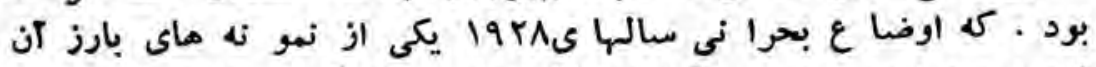

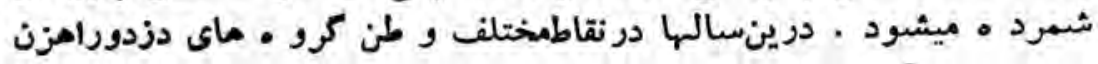

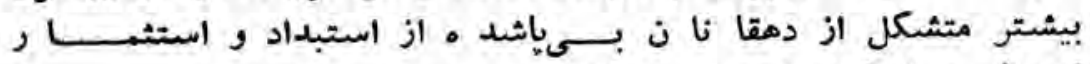

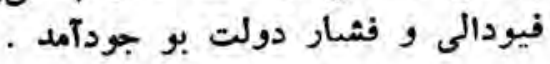

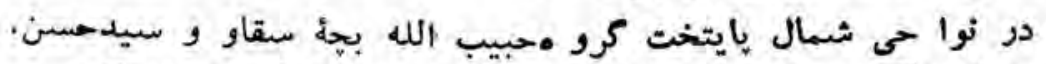

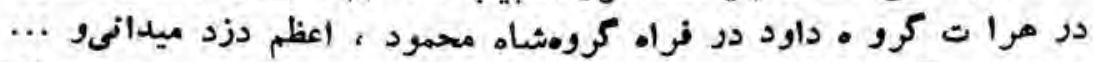

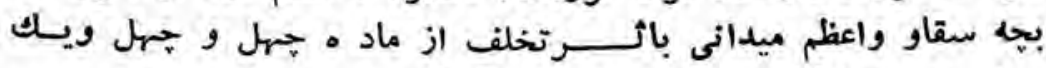

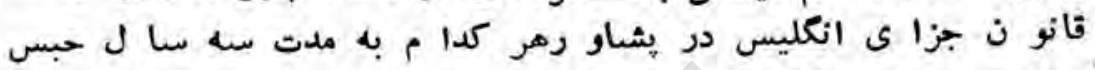

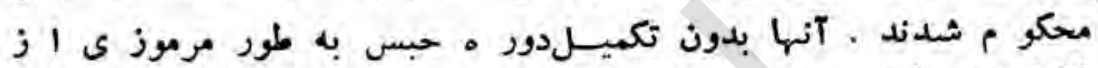

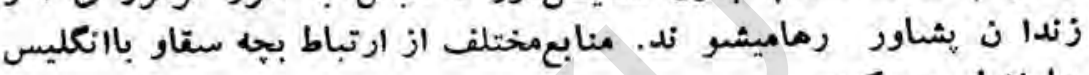

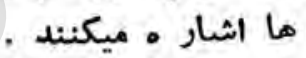

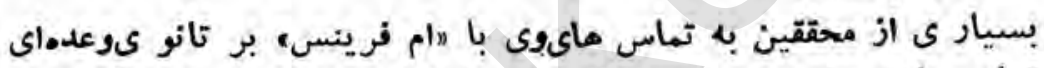

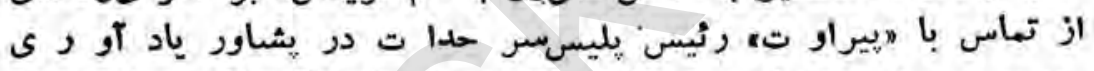

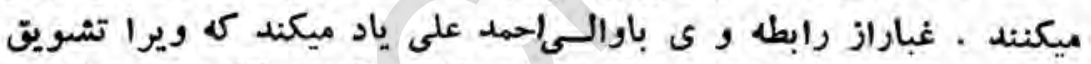

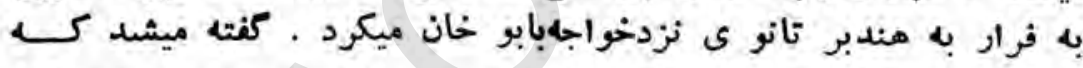

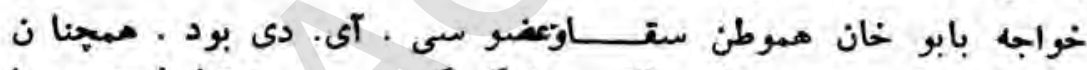

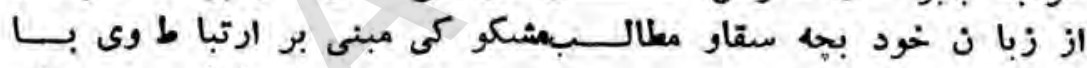

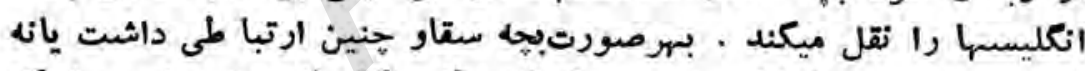

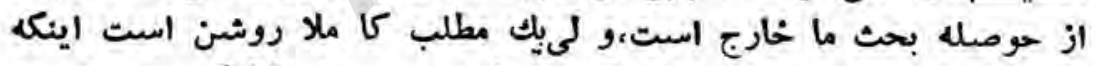

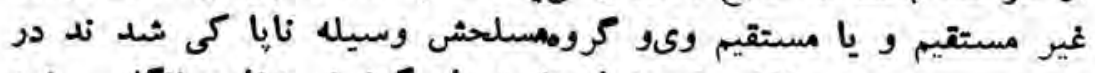

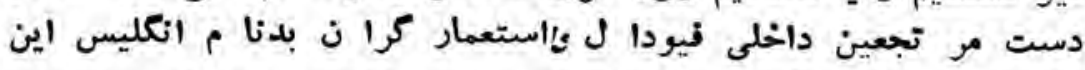

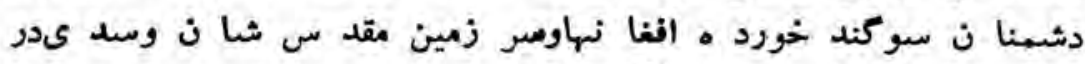

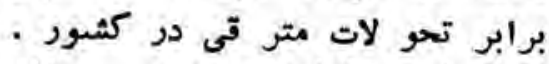

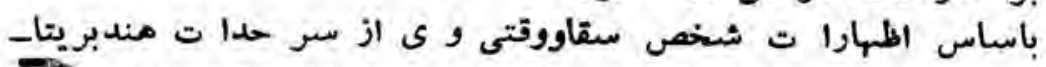

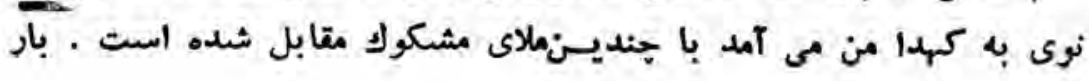

$$
-18 \cdot
$$


اول د ربديكو ت باساس توصيـملايى و وى زير در ختى را مئكافد،

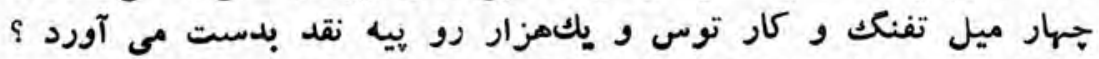

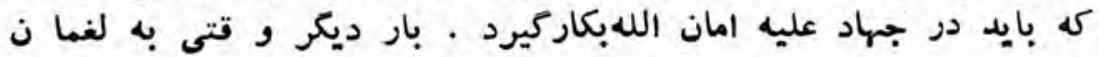

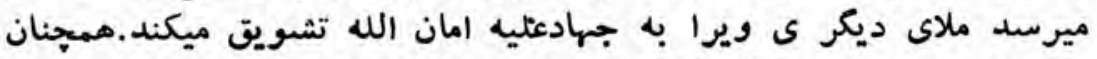

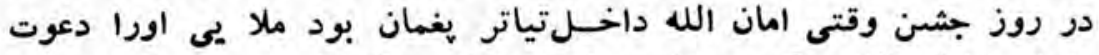

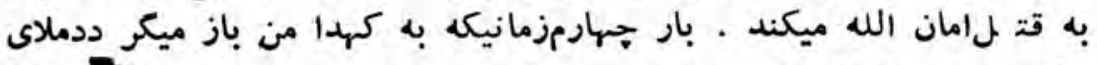

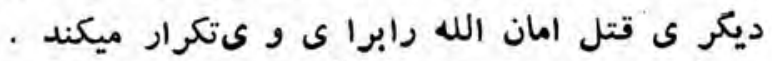

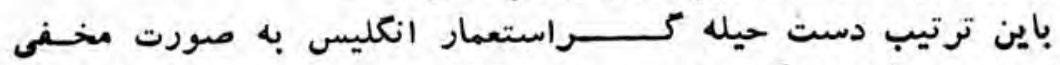

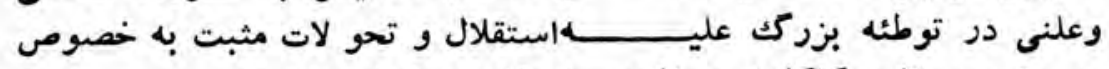

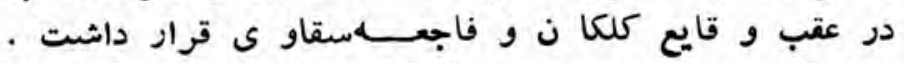

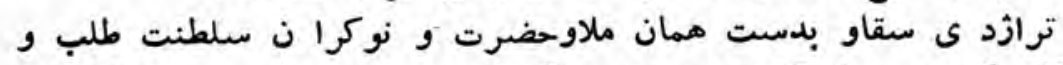

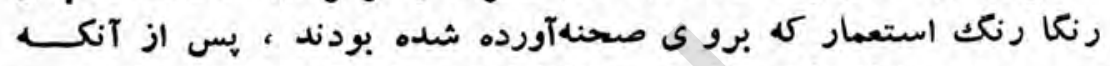

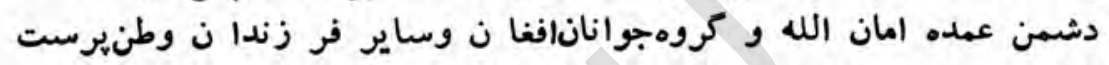

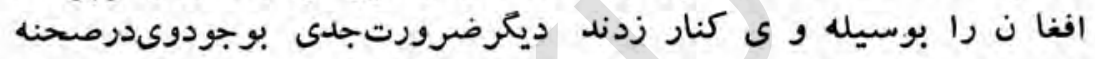

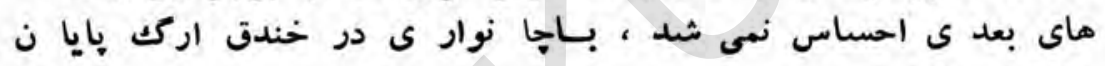

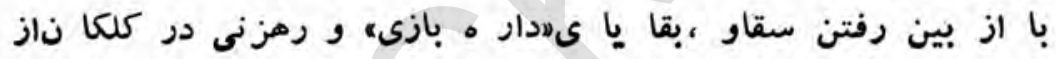

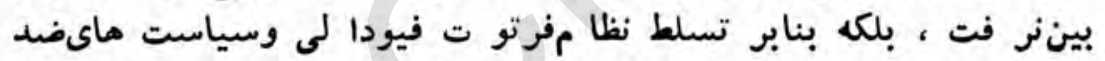

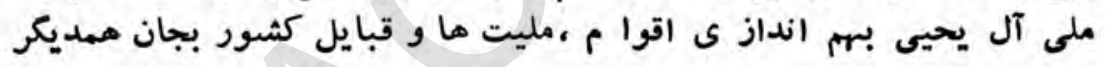

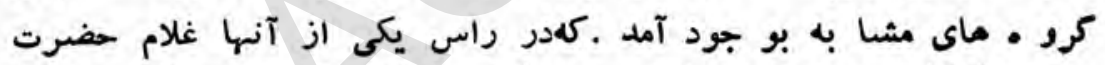

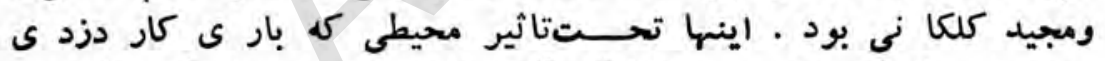

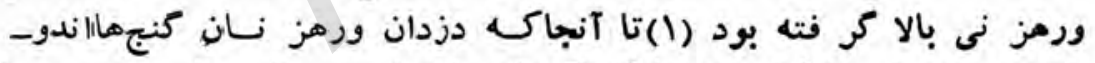

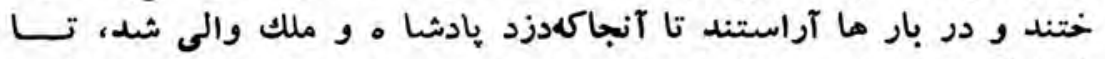

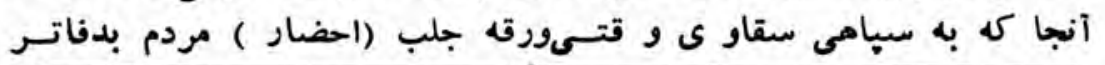

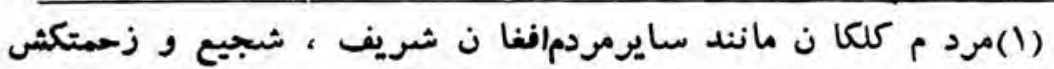

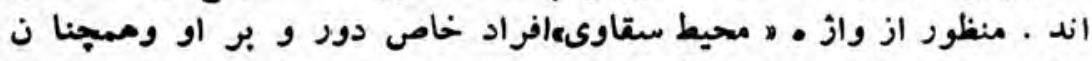

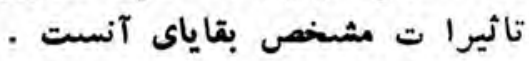




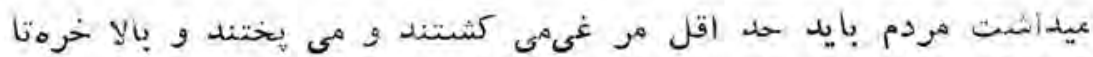

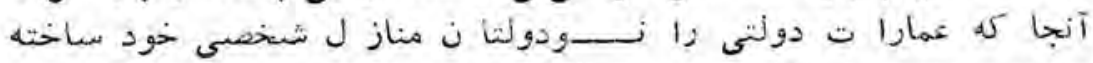

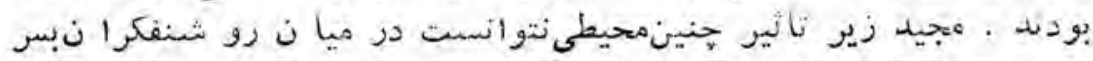

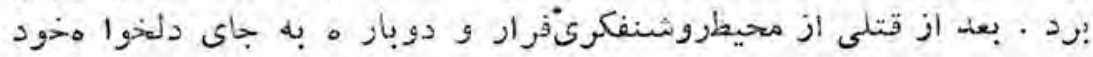

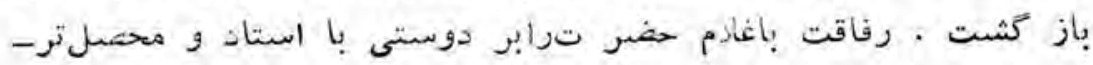

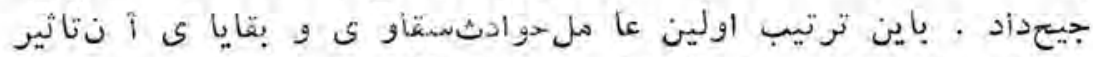

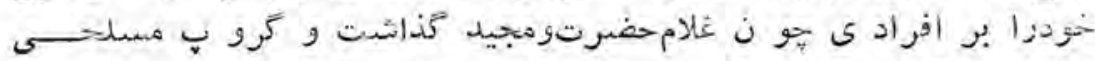

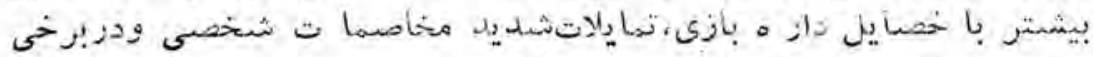

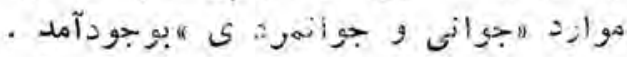

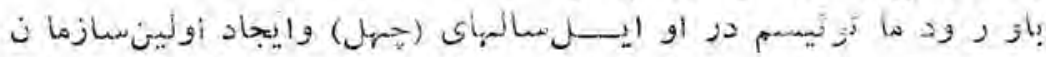

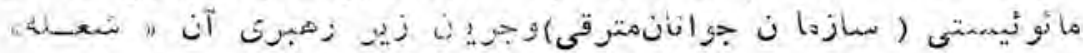

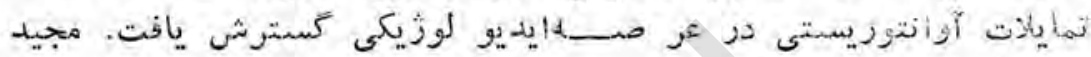

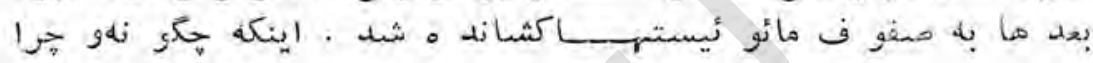

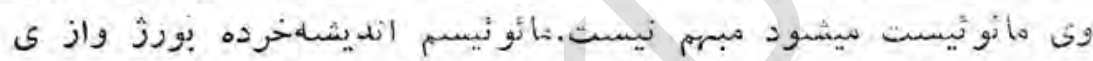

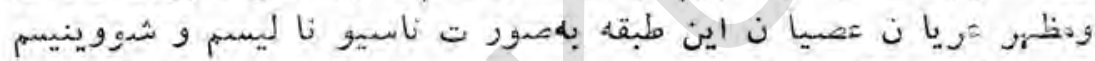

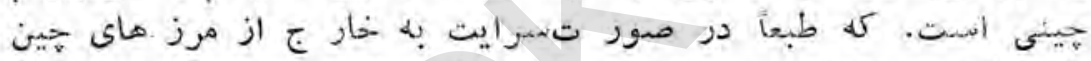

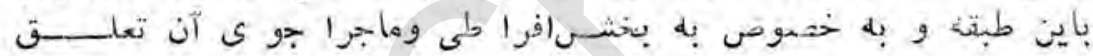

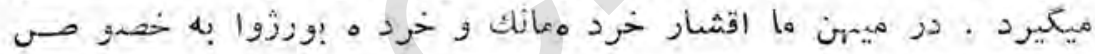

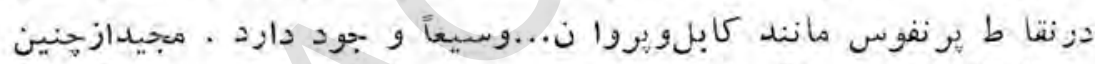

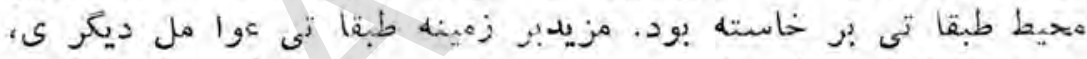

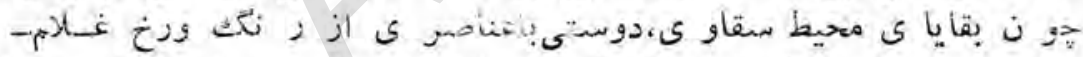

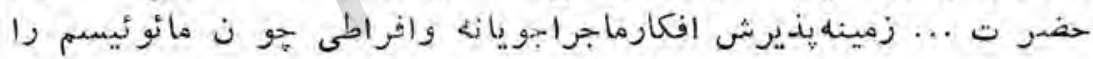

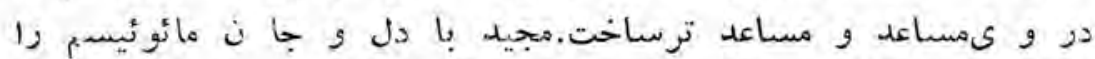

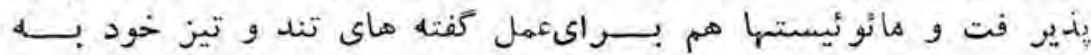

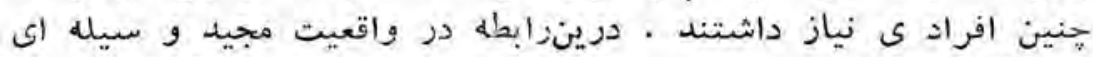

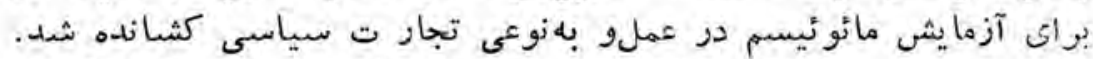

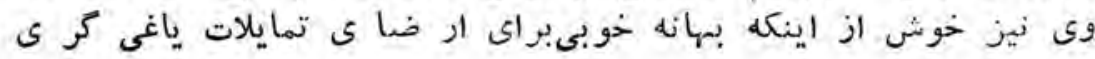




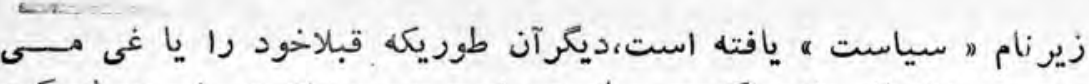

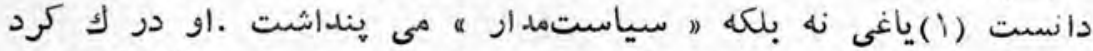

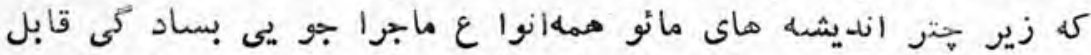

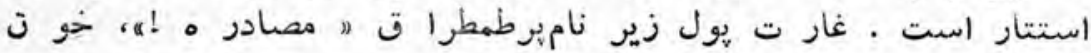

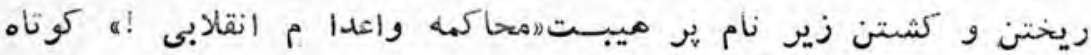

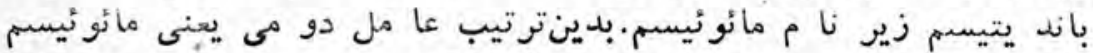

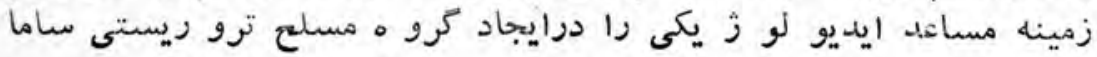

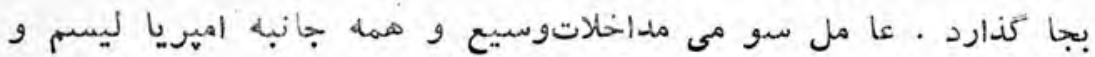

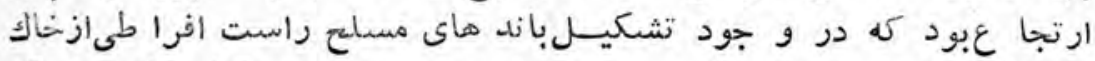

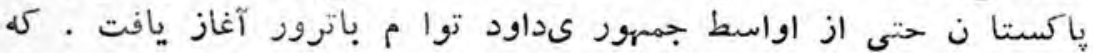

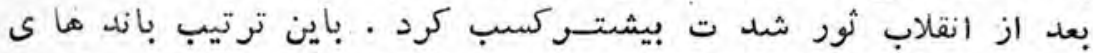

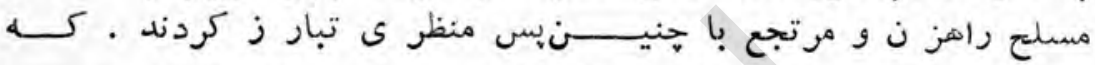

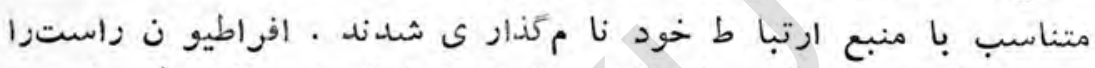

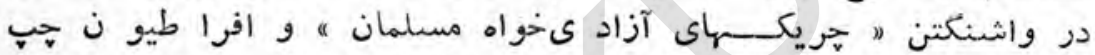

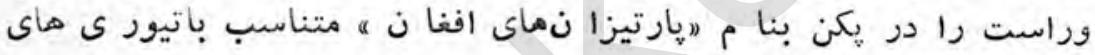
مائوئيستى نا مانذار ى نمودند

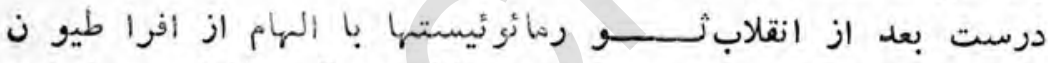

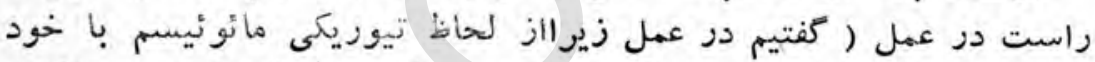

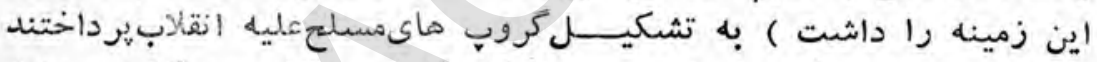

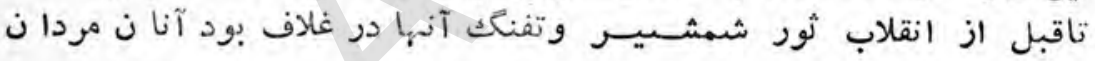

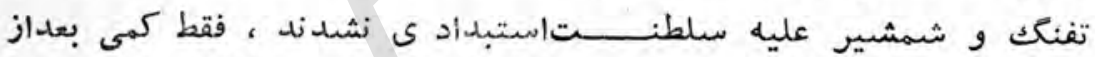

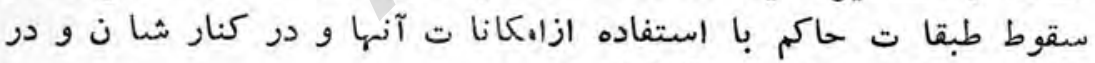

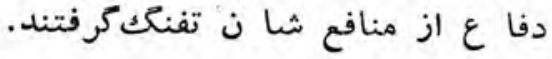

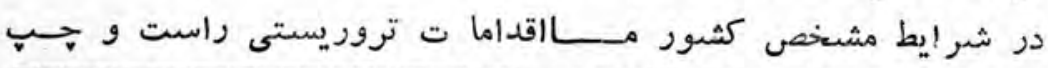

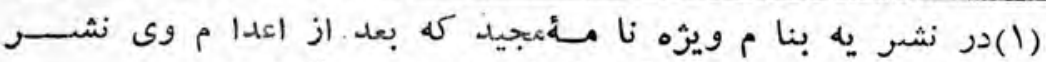

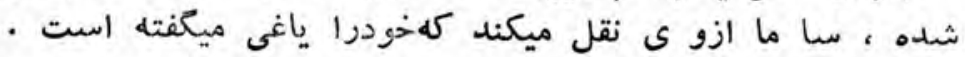




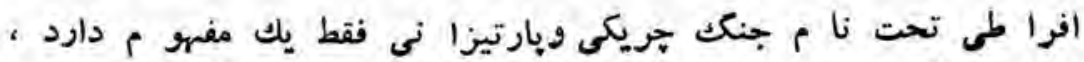

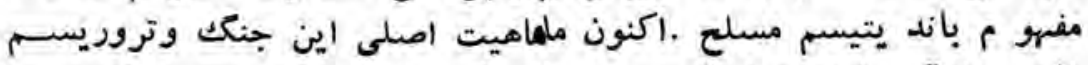

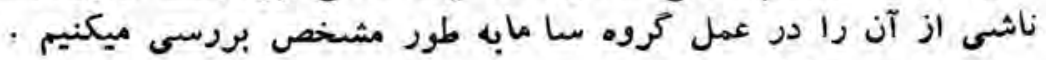

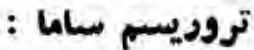

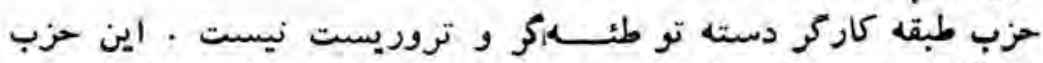

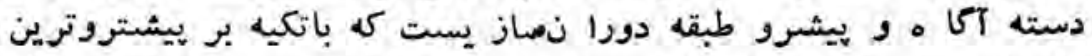

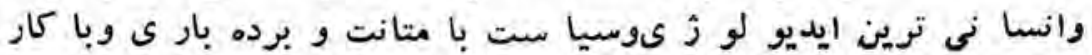

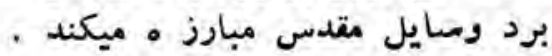

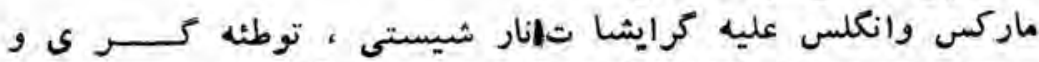

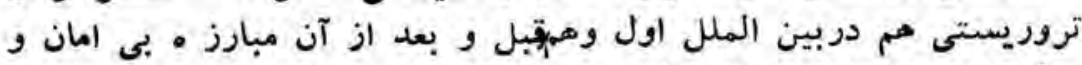

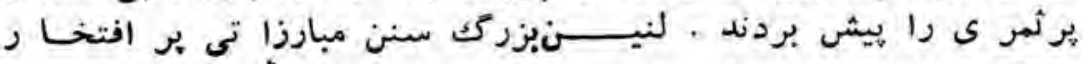

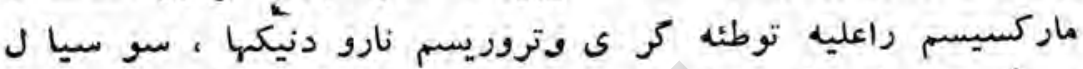

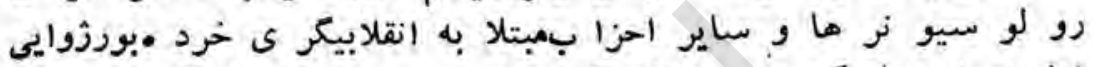

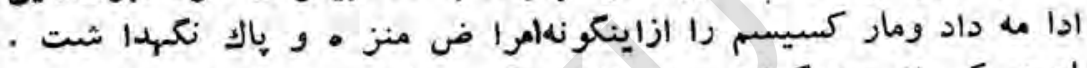

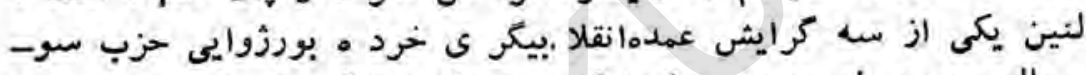

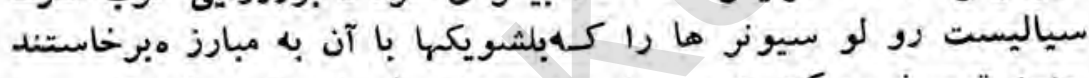

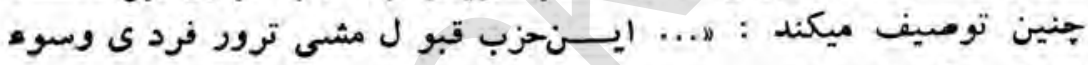

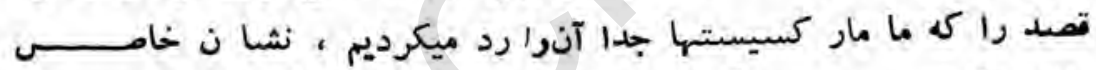

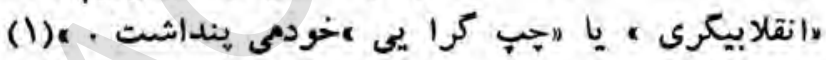

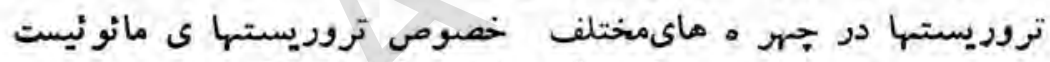

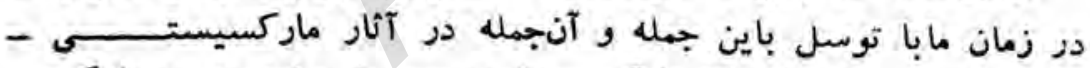

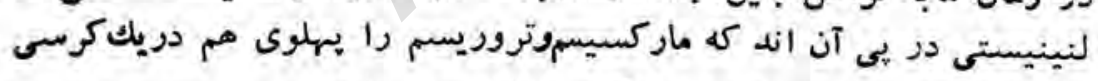

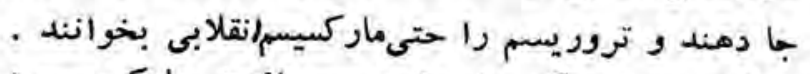

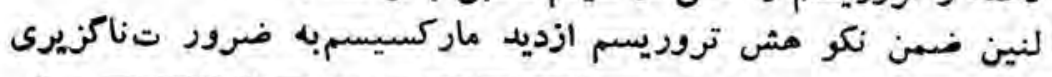

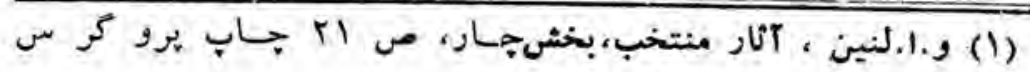

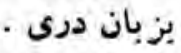




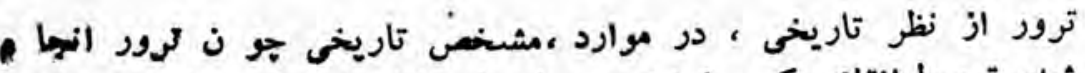

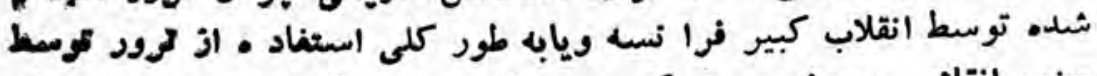

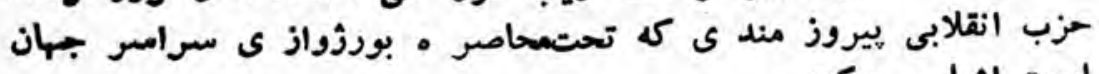
است اشار • ميكند . ميروز مند

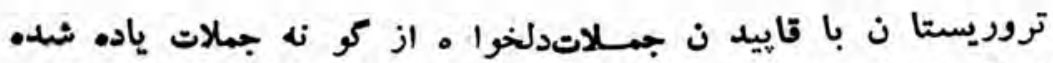

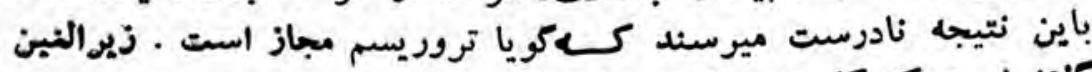

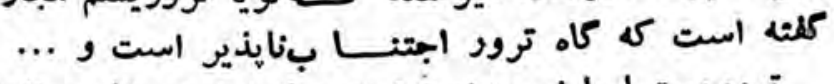

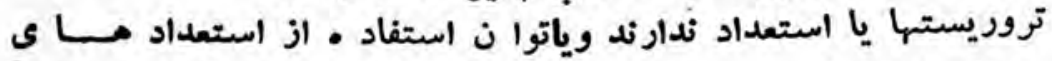

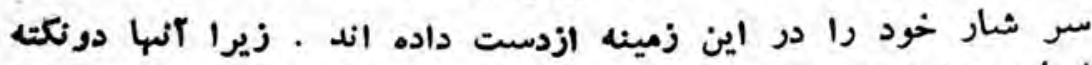

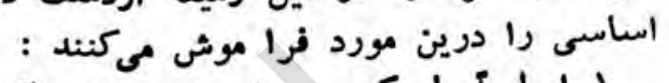

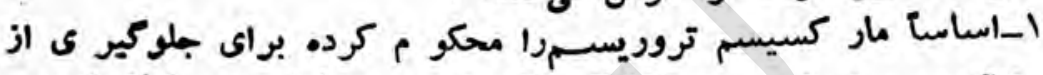

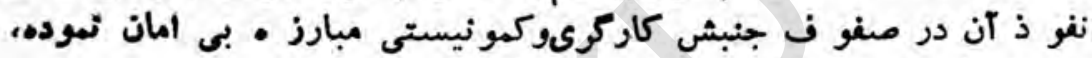

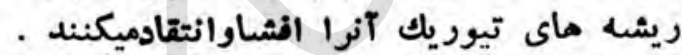

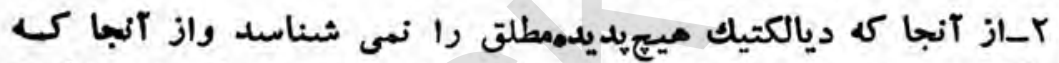

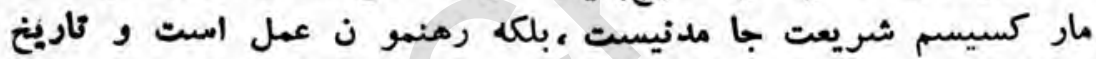

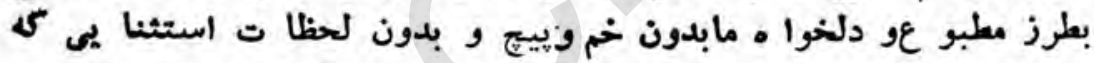

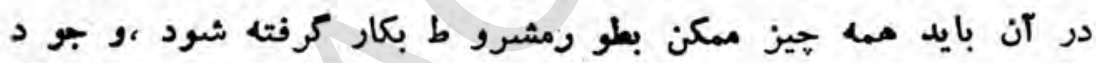

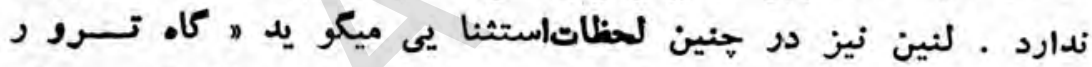

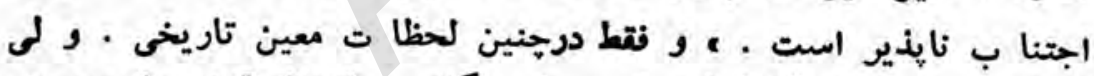

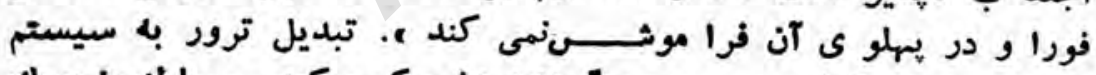

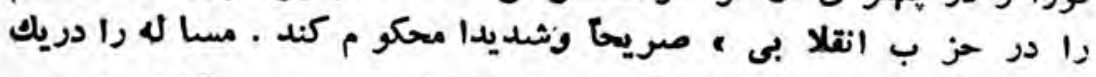

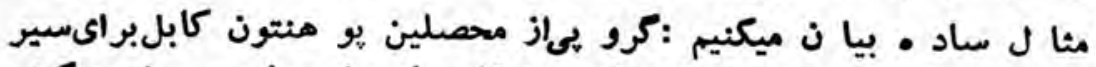

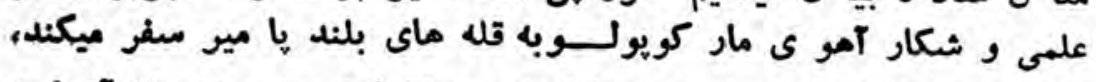

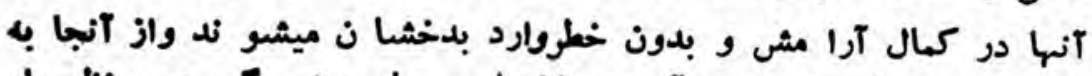

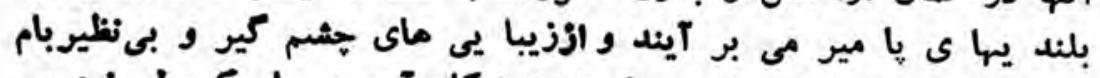

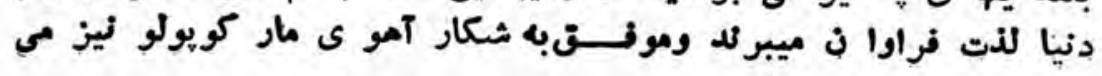




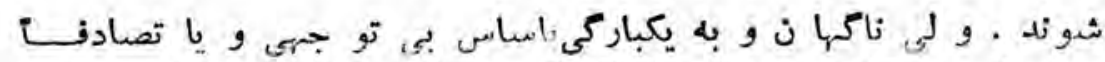

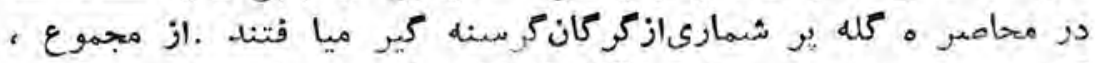

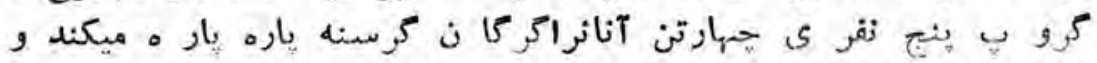

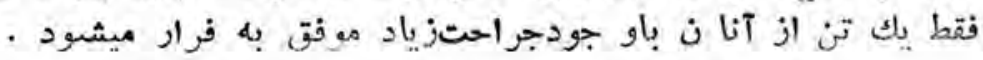

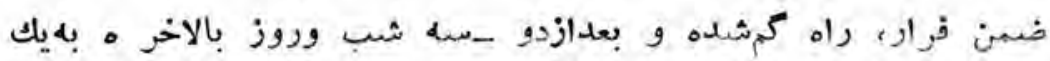

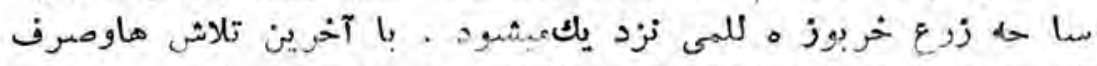

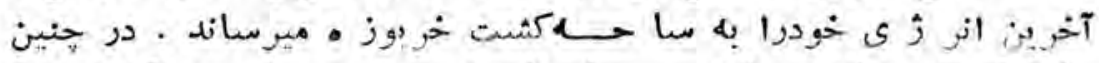

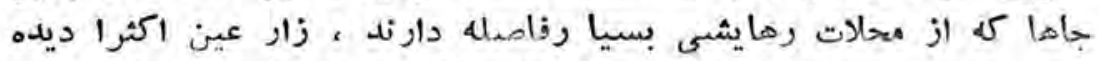

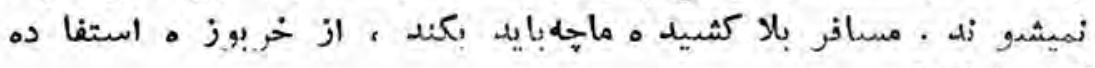

كند يا نه

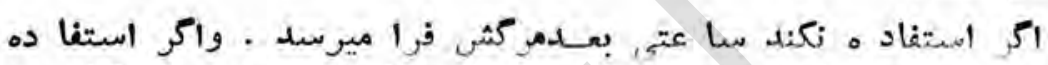

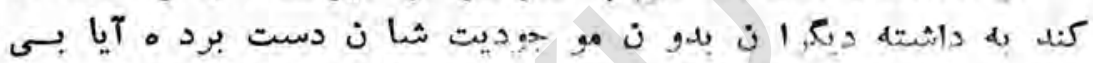

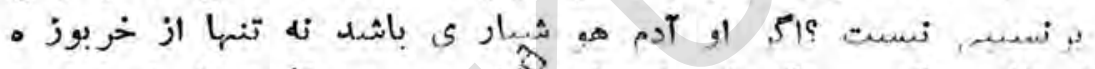

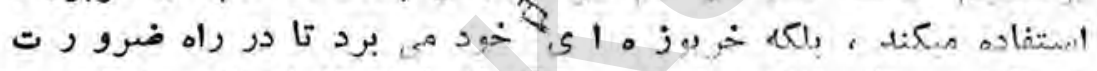

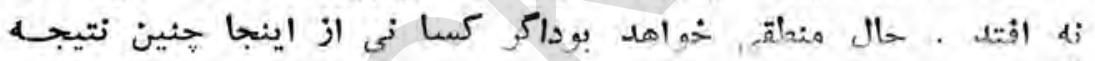

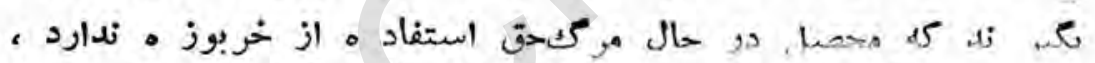

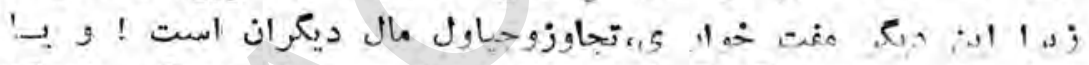

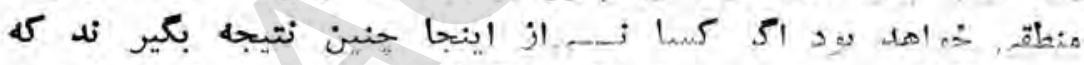

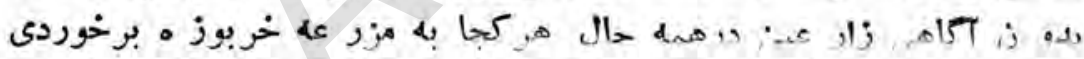

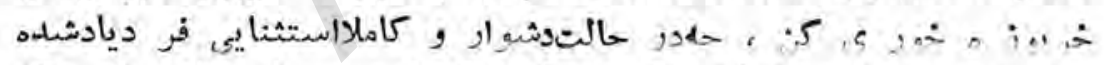

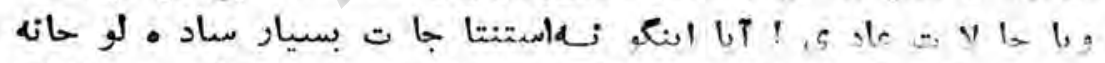

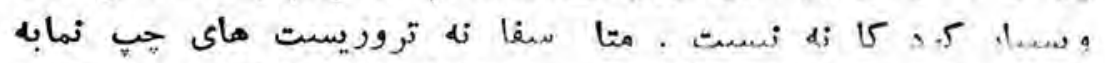

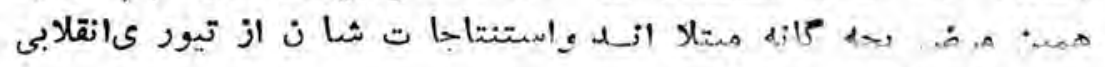

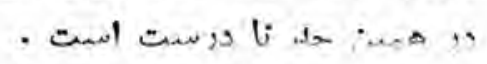

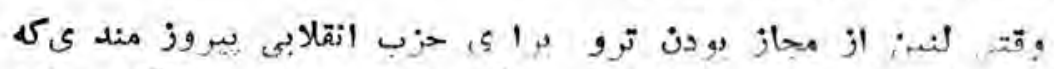

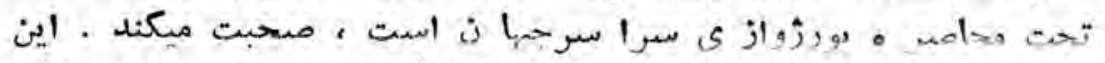
حزب درست حالت مها ن مسافرمارا داردكه دو صور ت عدماستفاده 


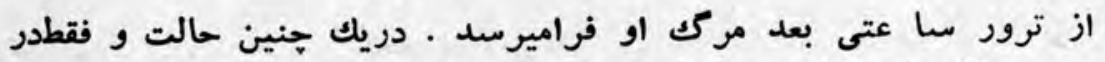

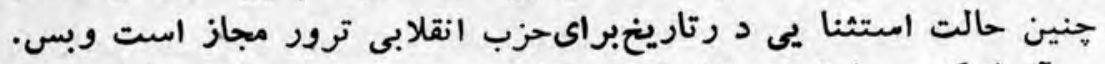

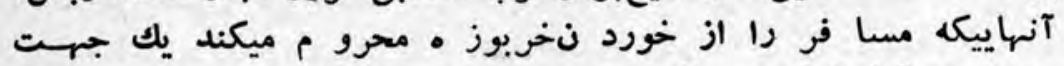

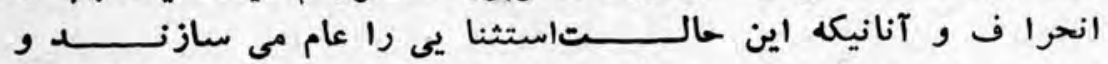

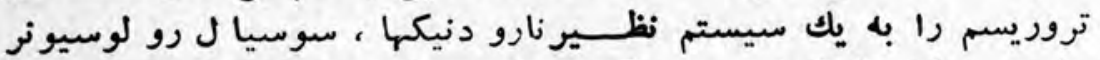

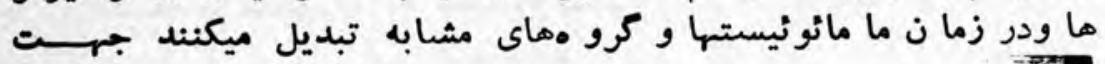

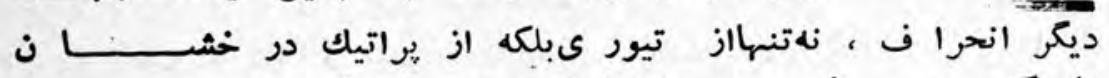

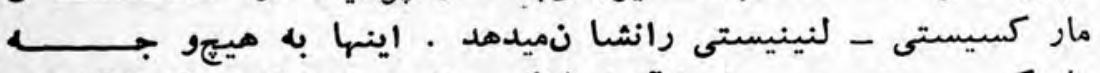

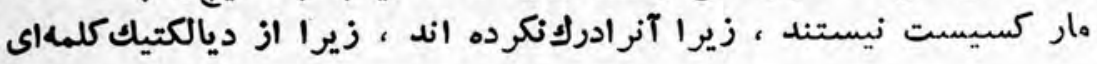

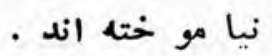

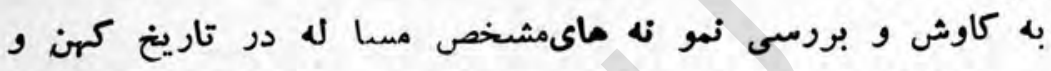

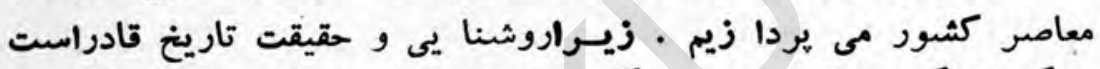

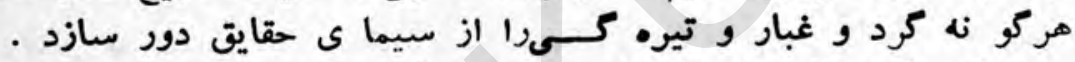

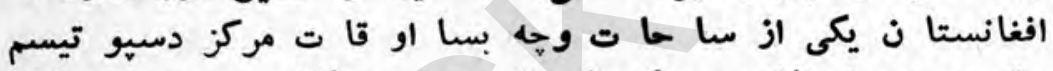

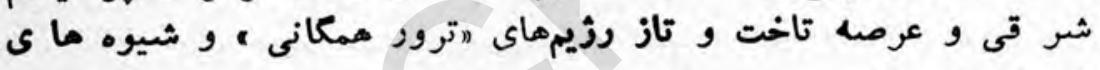

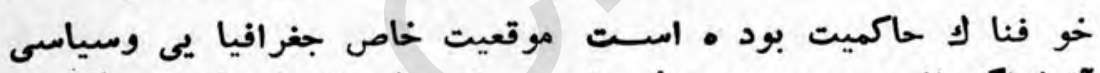

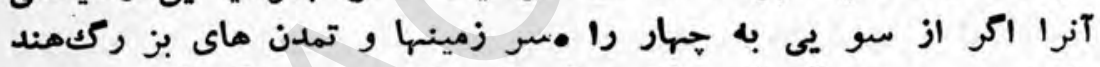

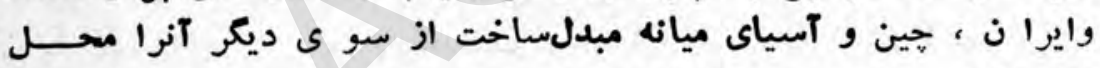

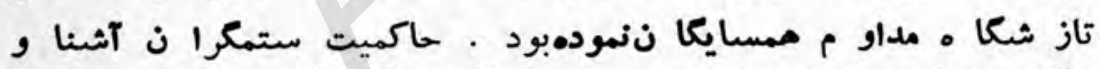

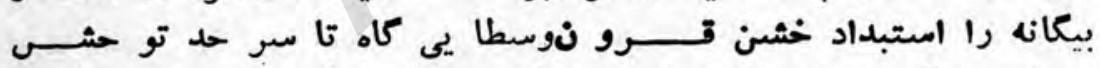

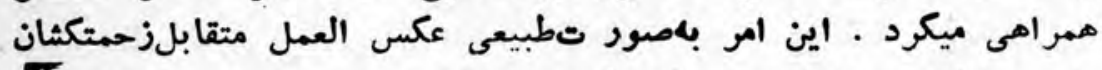

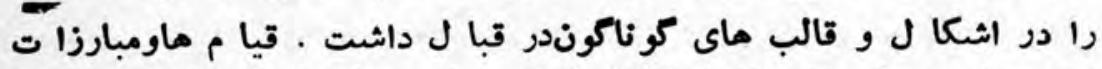

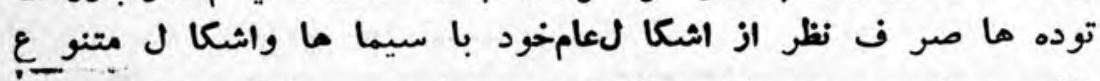

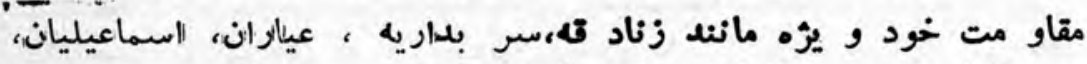

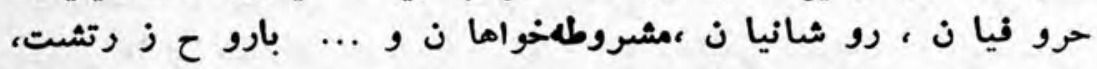

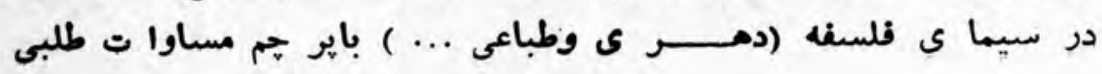

$-I V V$ 


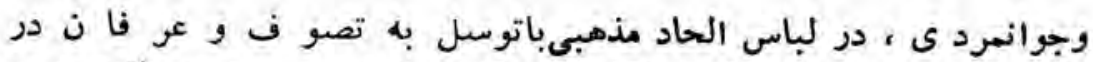

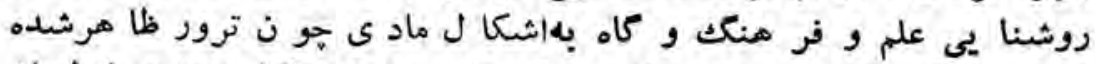

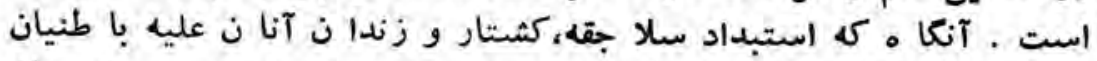

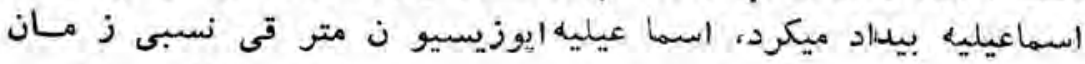

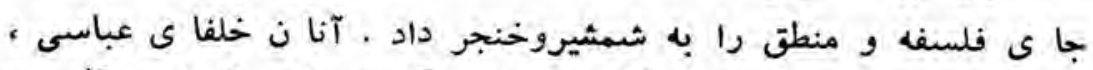

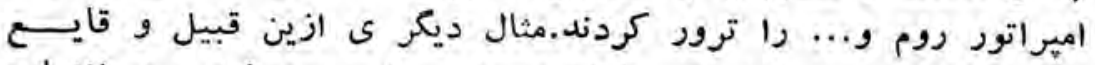

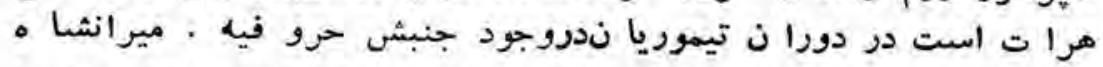

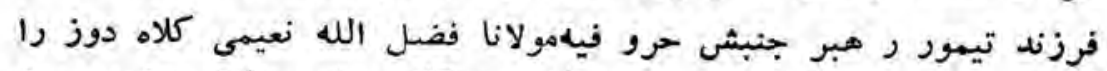

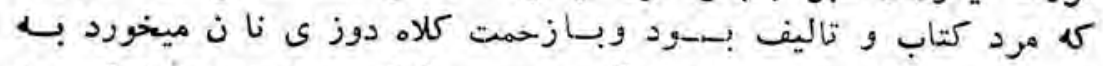

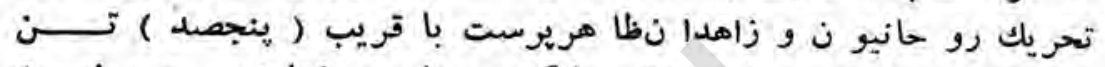

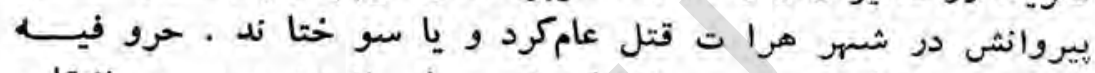

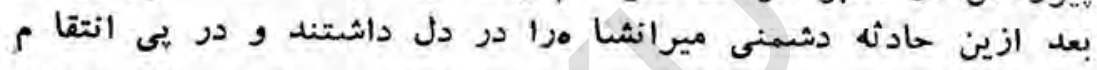

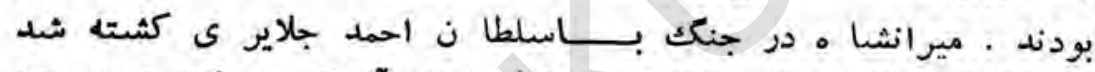

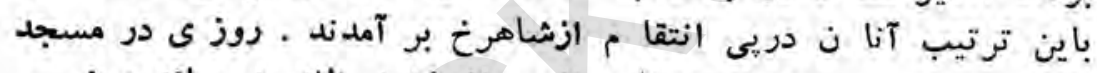

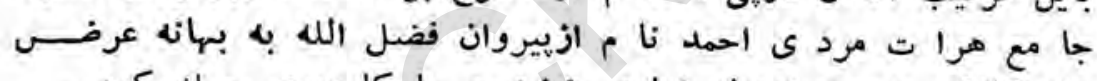

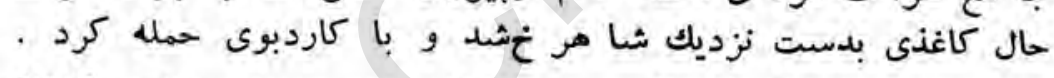

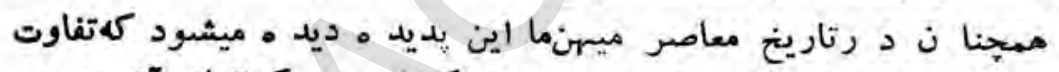

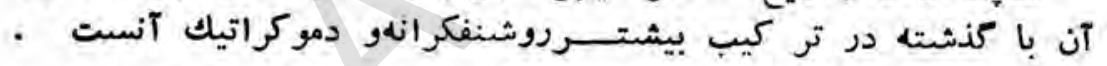

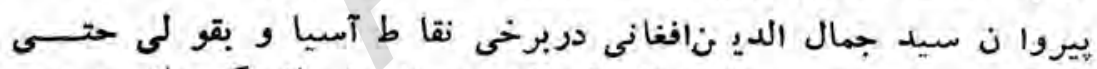

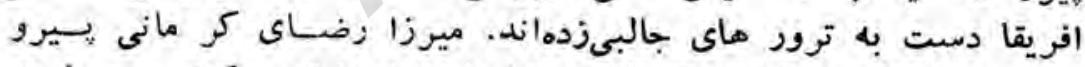

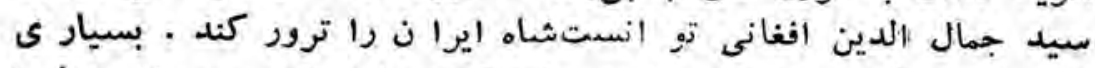

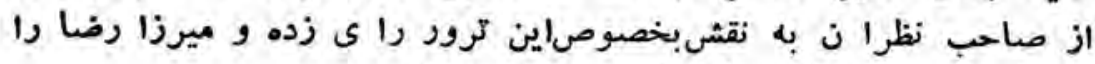

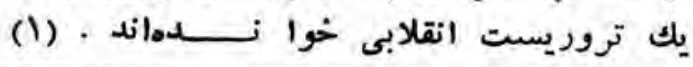

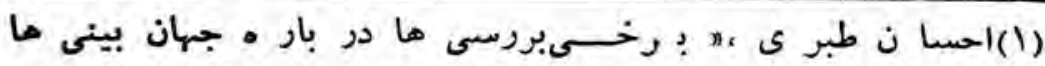

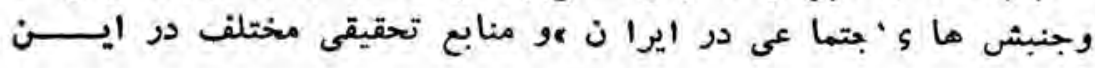
زمينه 
نمونه بسيار بار ز مساللاقداماتمثرو طه خواها ن ماست مبنى بـر فير

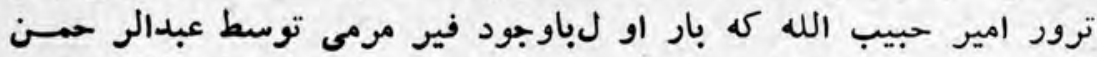

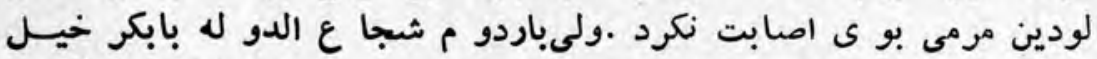

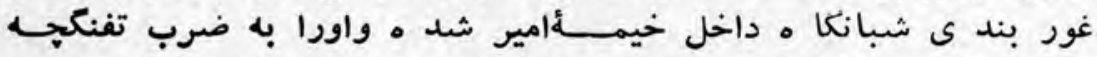

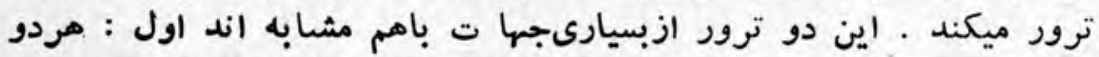

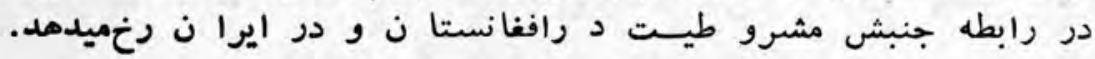

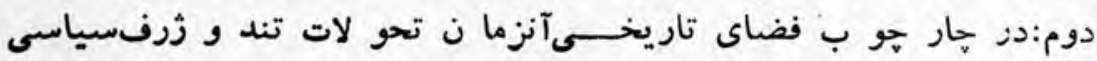

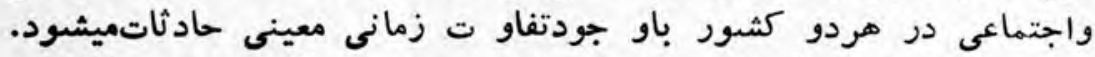

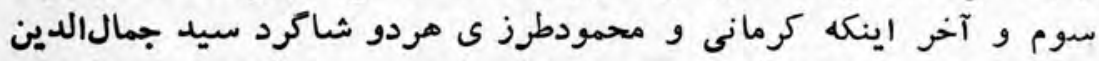

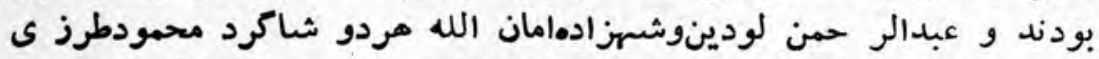

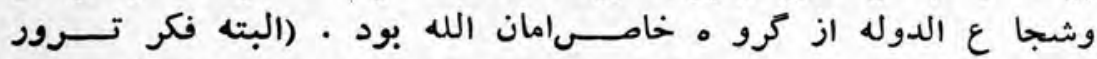

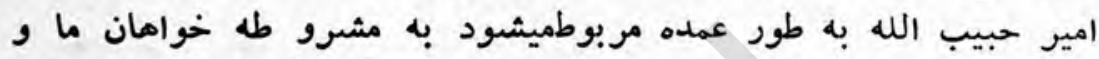

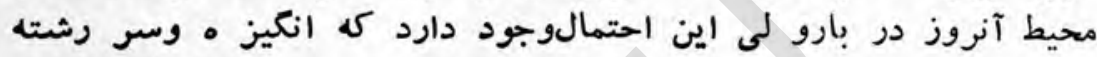

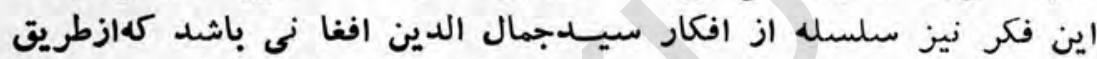

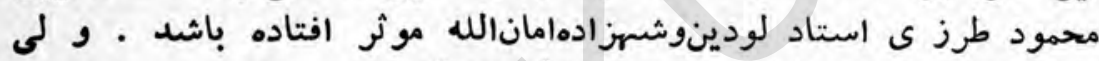

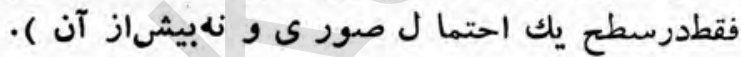

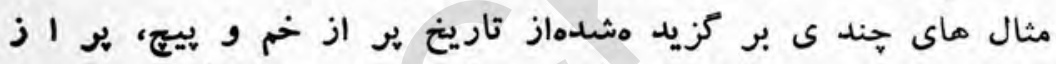

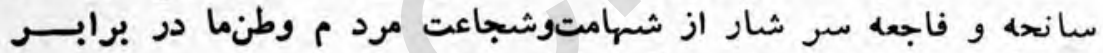

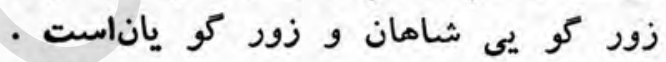

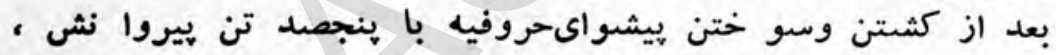

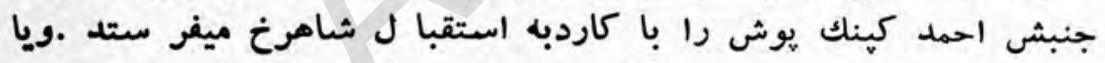

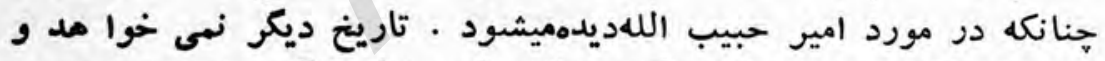

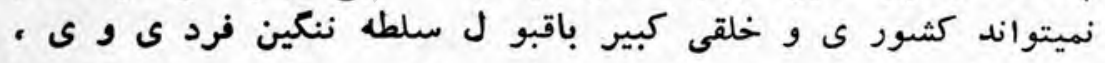

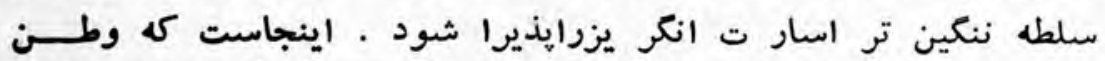

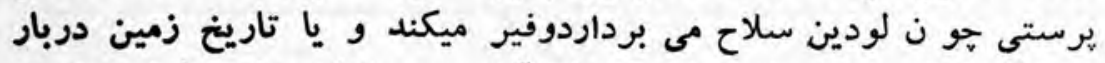

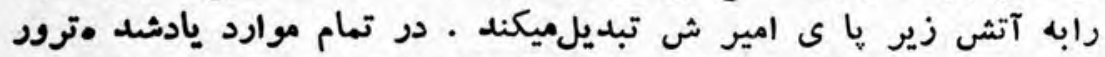

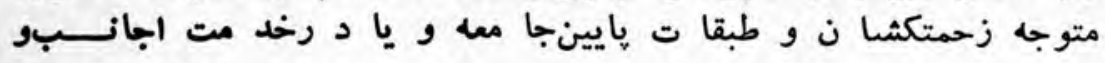




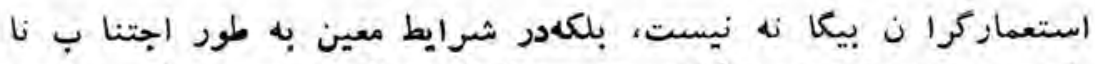

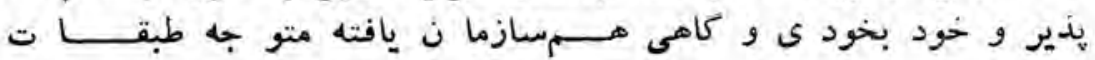

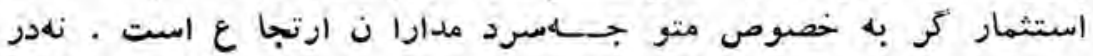

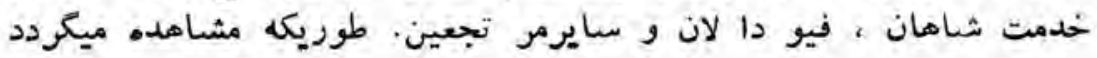

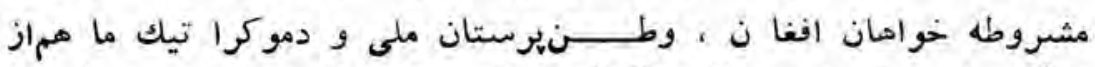

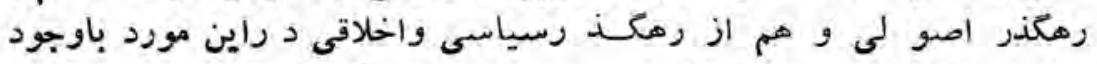

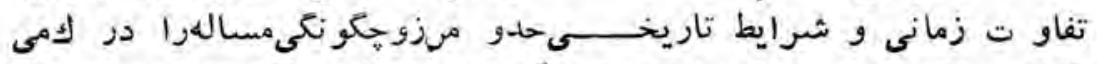

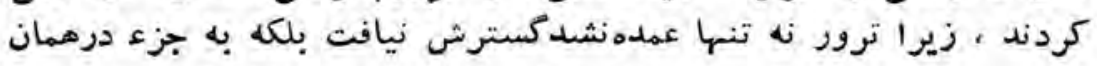

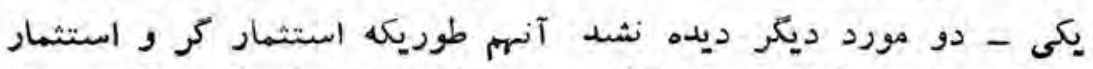

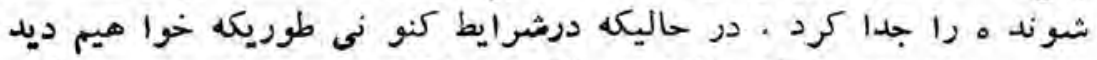

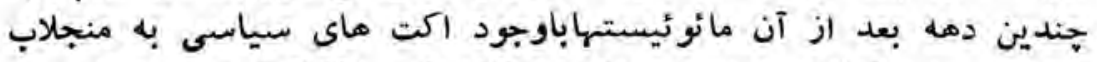

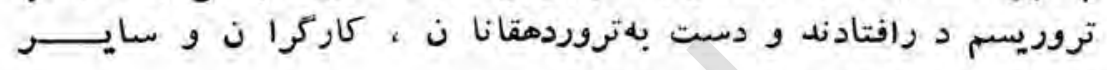

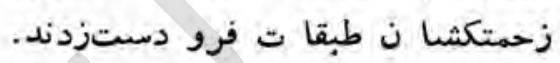

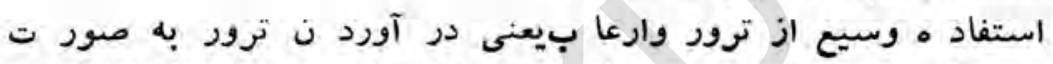

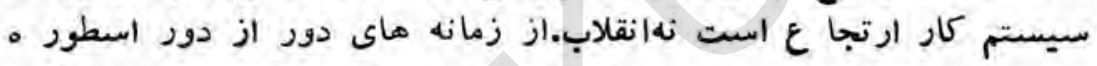

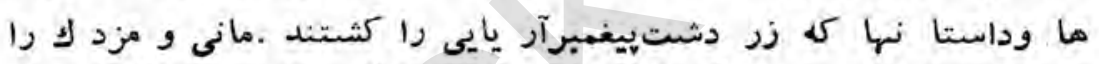

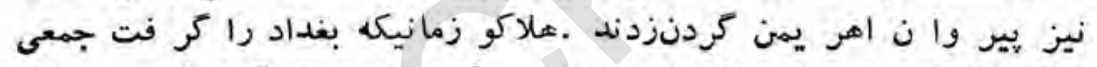

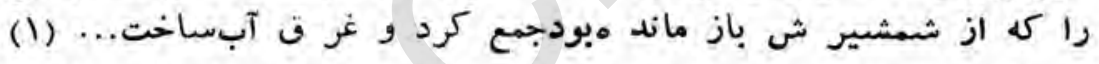

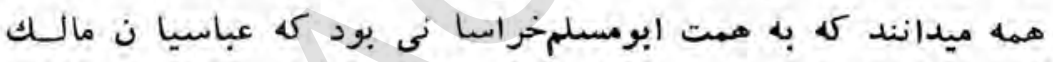

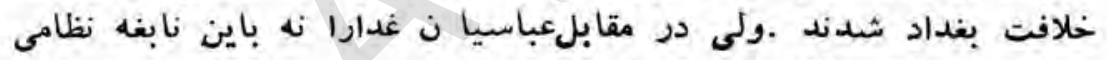

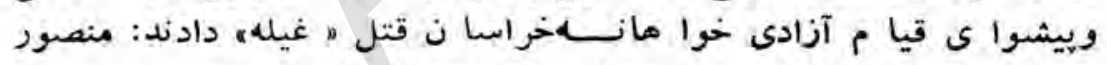

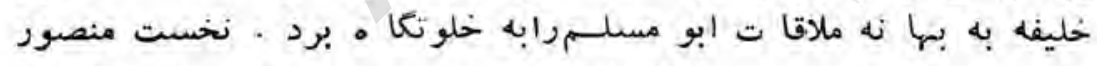

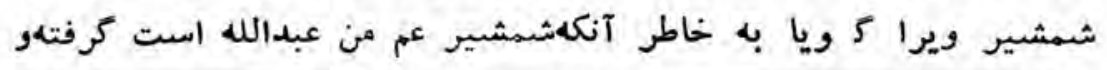

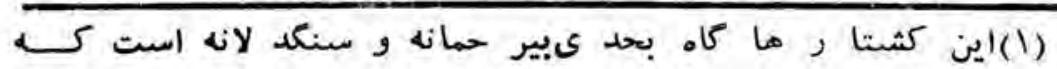

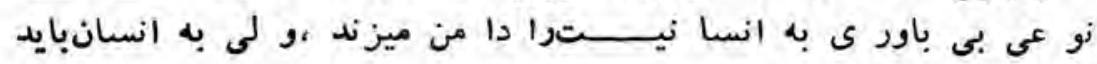

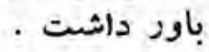


زير تتك ( دوشك) خود كذاشت.در جريا ن صحبت خليفه تند ى مى إنى

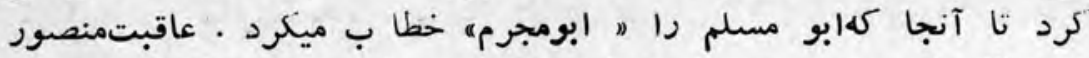

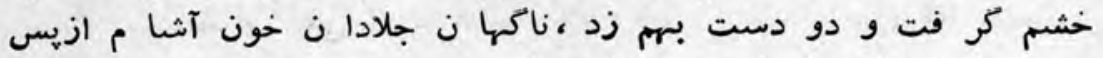

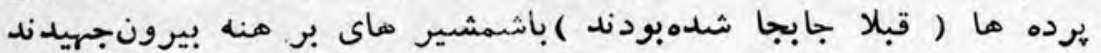

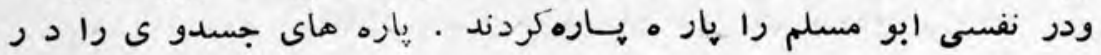

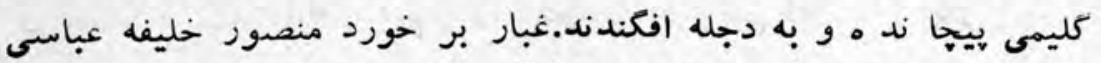

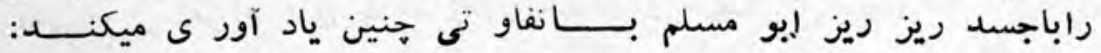

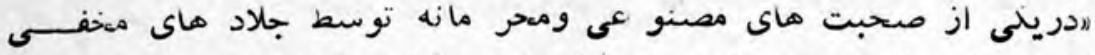

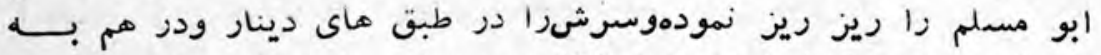

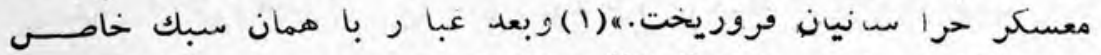

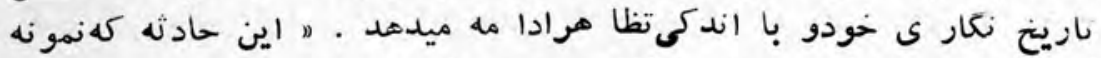

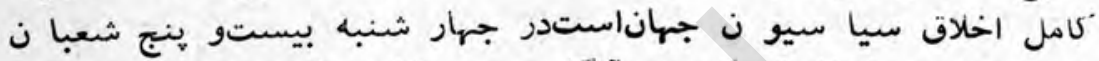

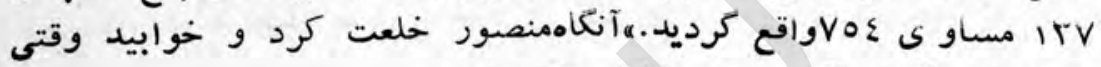

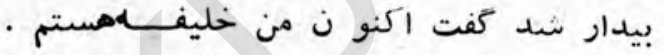

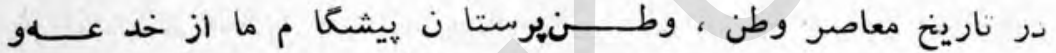

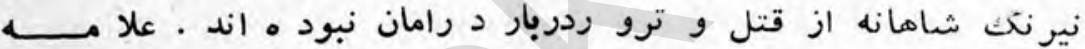

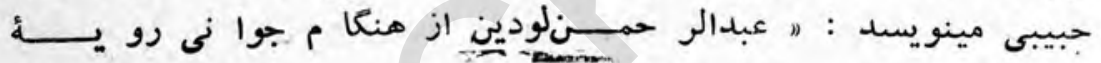

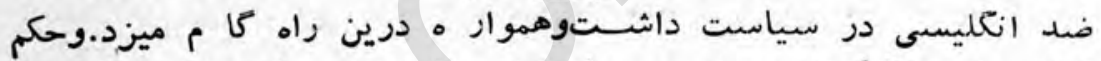

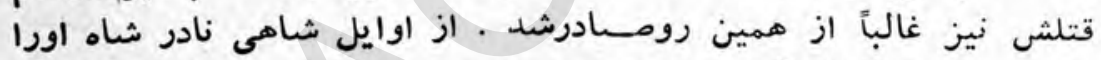

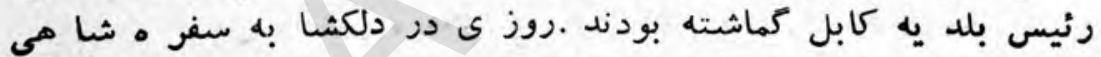

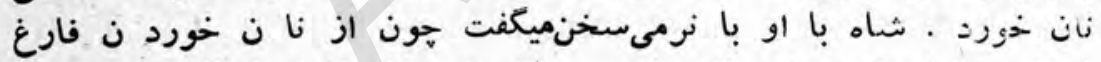

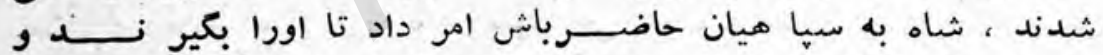

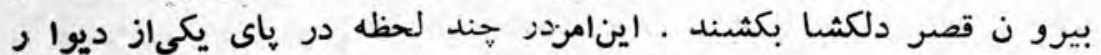

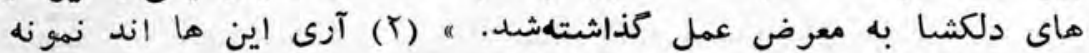

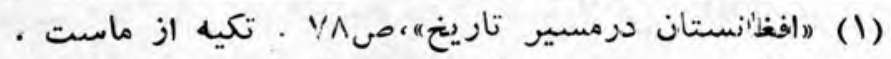

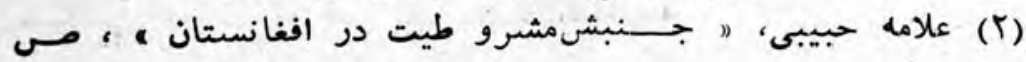


هاى كا ملى از اخلاق سيا سيو نمرتجع جها ن ! (ولى تاريخ كاهزودتر

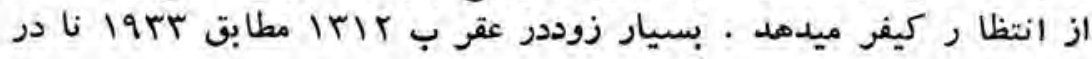

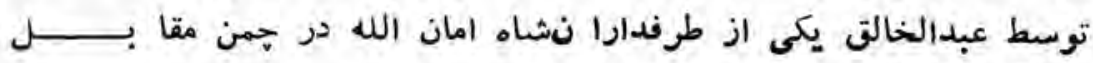

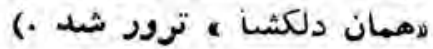

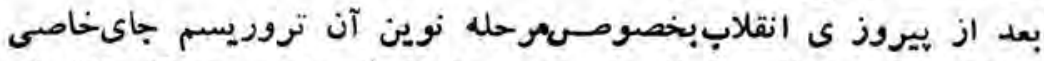

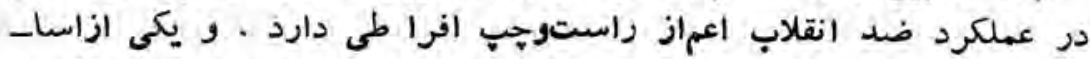

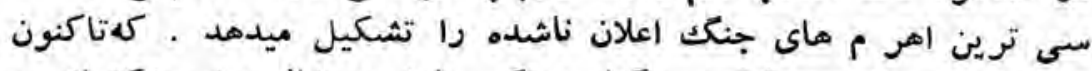

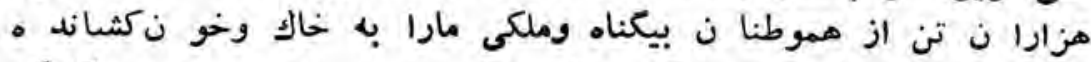

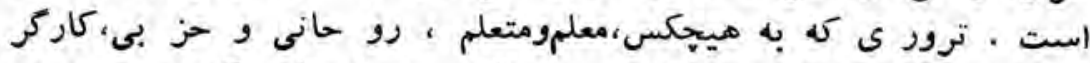

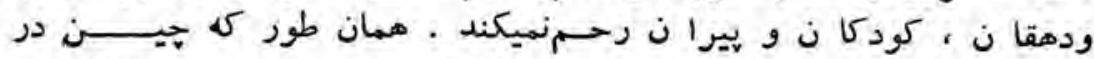

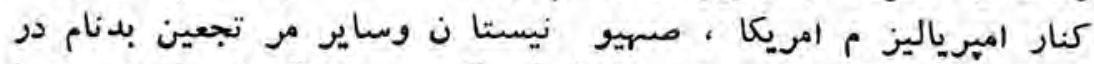

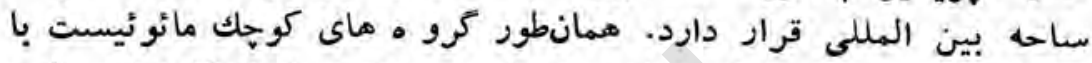

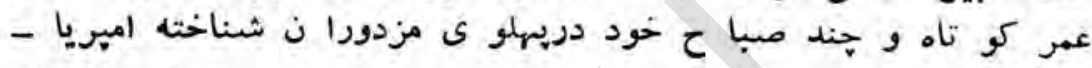

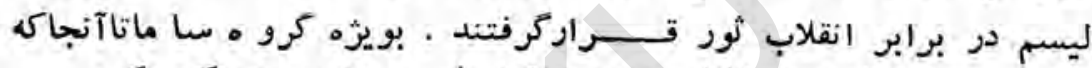

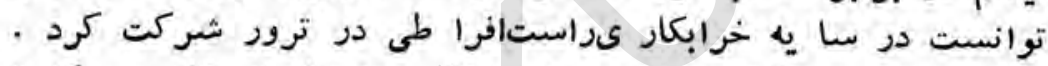

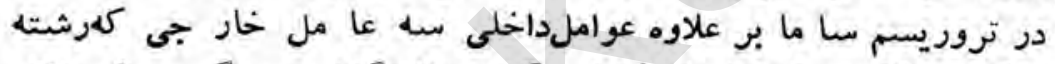

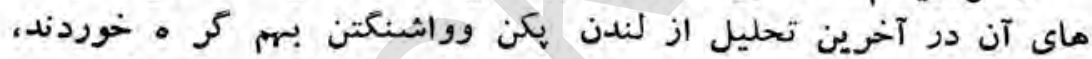

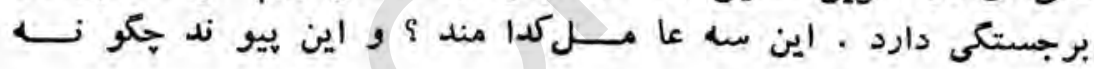
است

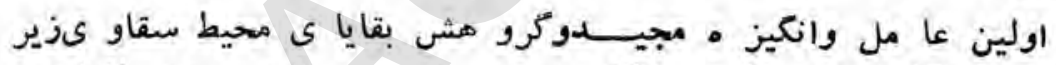

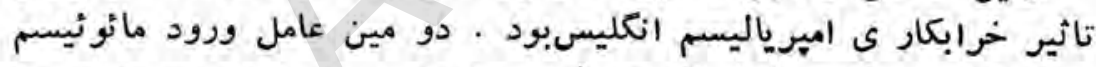

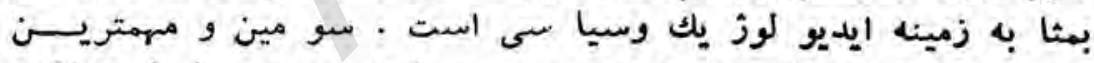

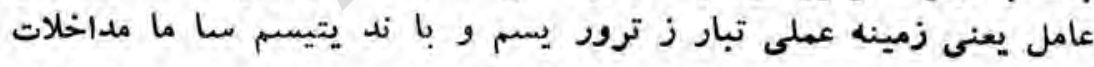

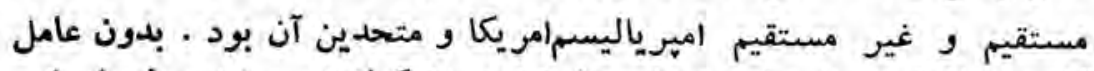

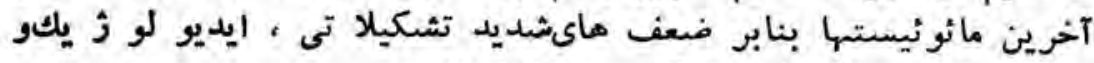

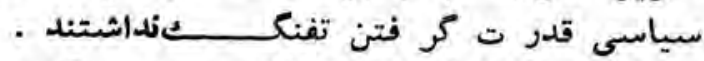

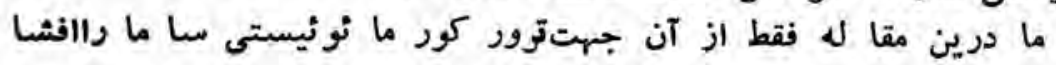




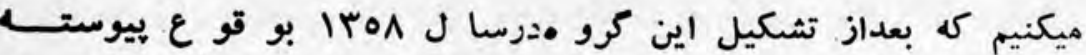

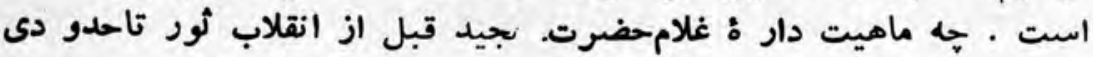

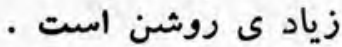

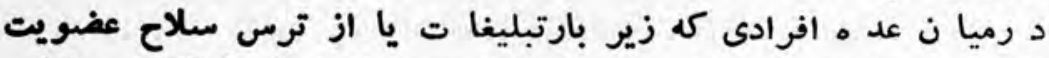

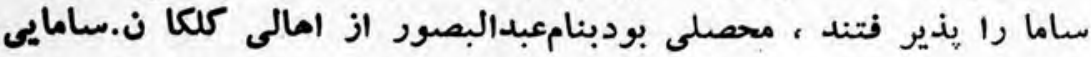

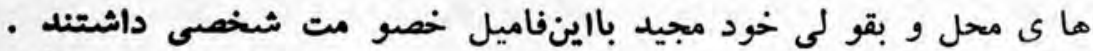

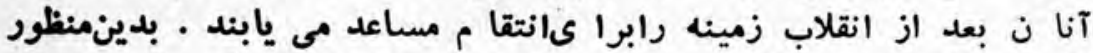

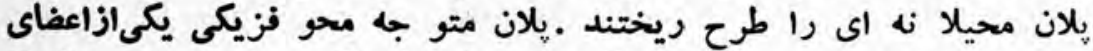

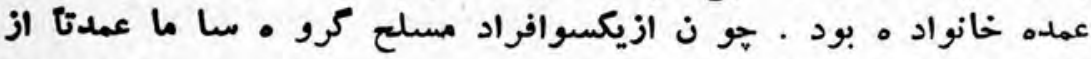

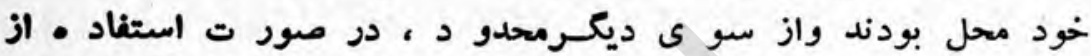

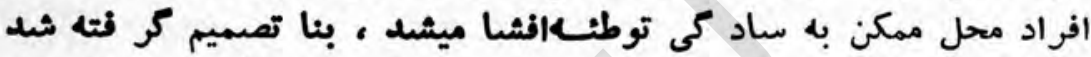

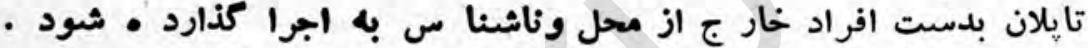

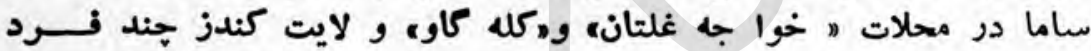

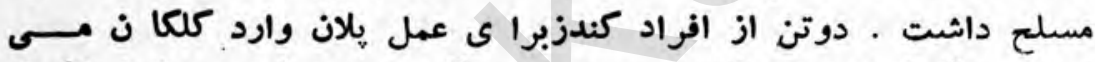

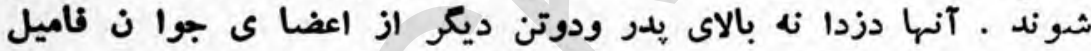

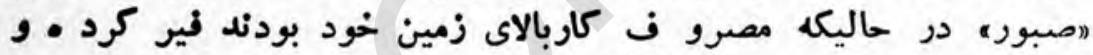

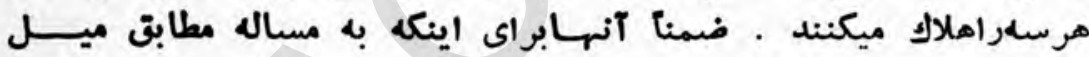

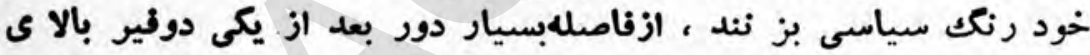

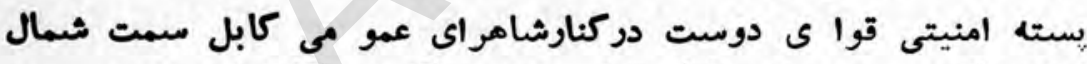

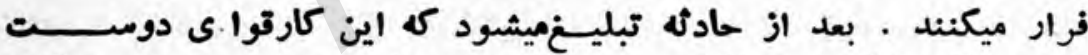

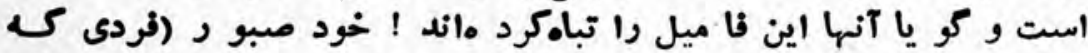

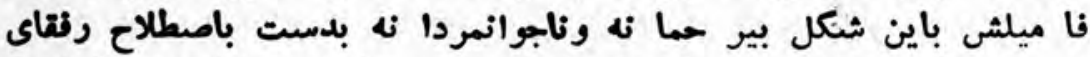

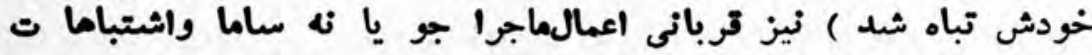

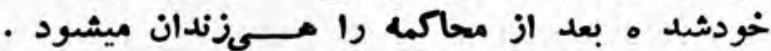

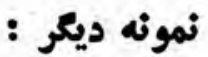

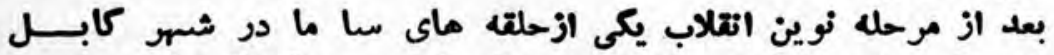

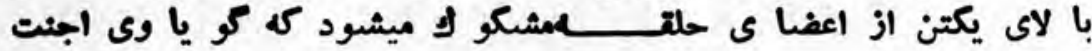


بود ه و بدرو ن حلقهلانه كرد هاست.فرد مشكو كـ بدون بدون آنكه اتها موارده

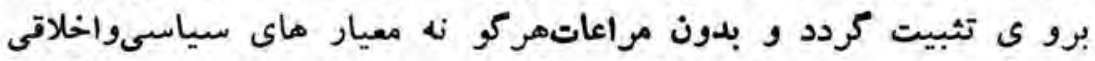

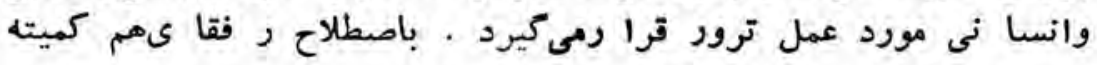

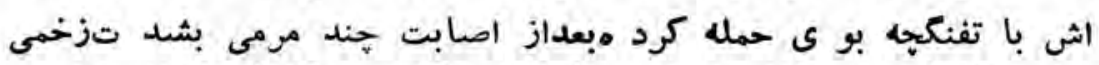

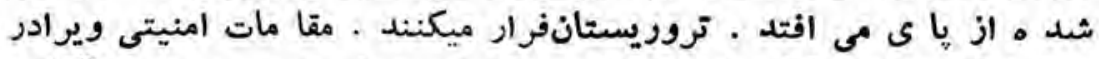

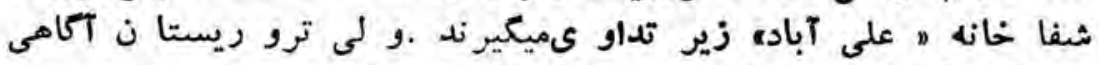

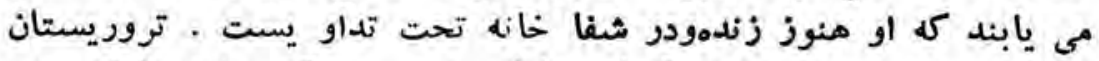

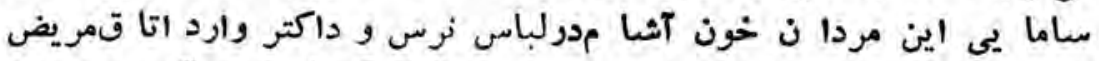

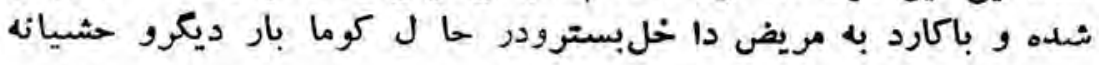

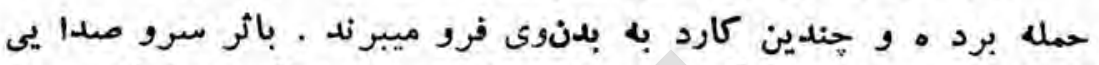

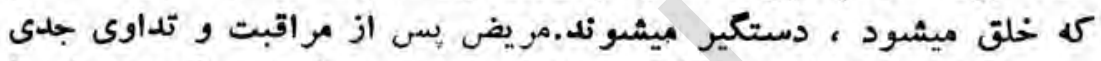

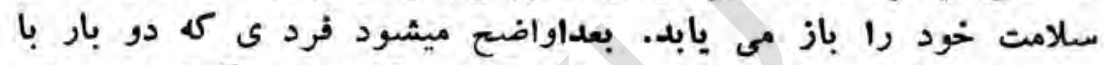

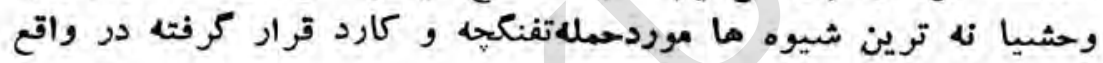

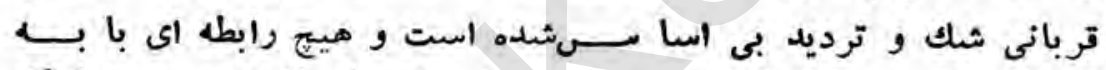

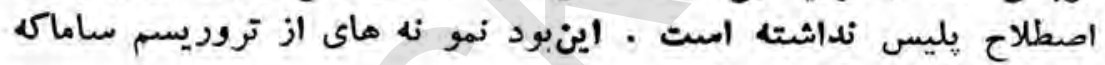
اعضايش آما ج آن بودماند

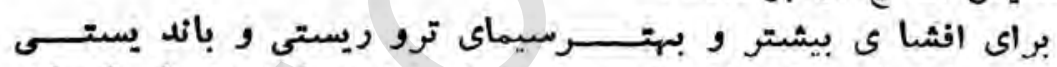

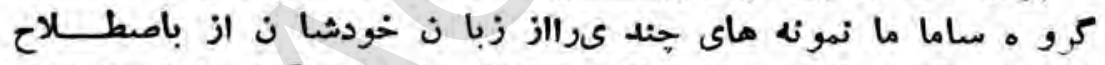

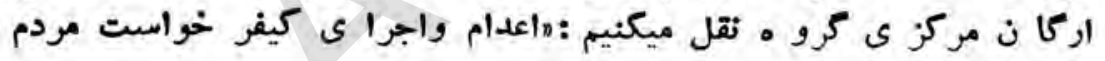

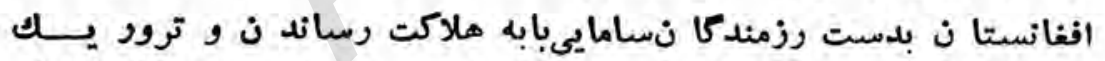

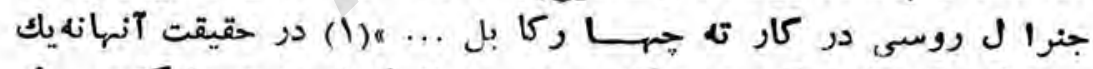

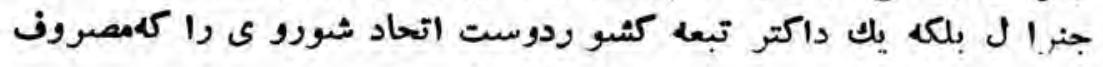

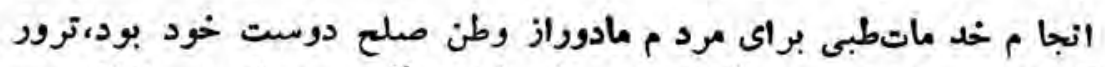

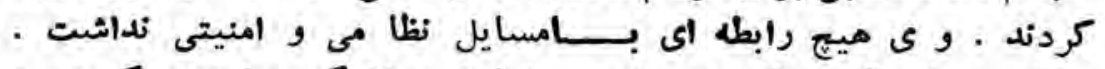

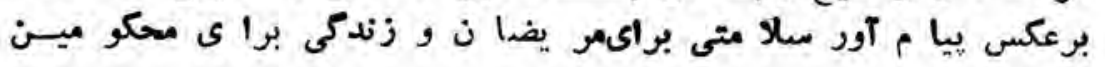

(1) هنداى آزادى • ،شماره اولهسا ل اول ، صفهـ 17. 


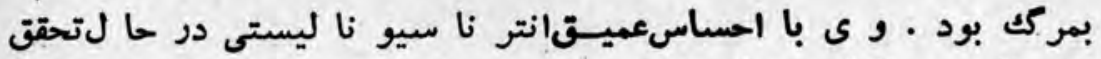

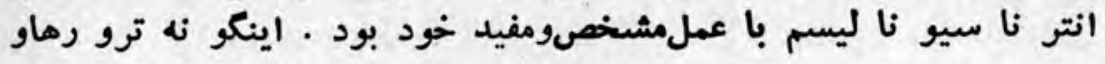

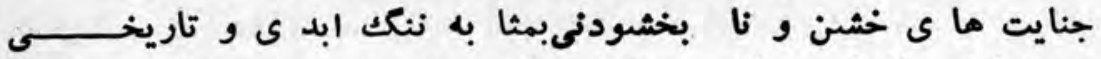

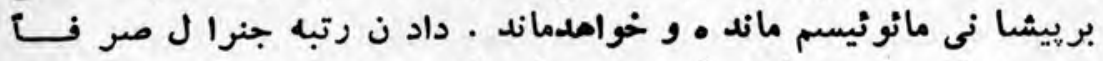

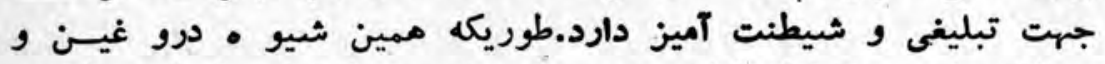

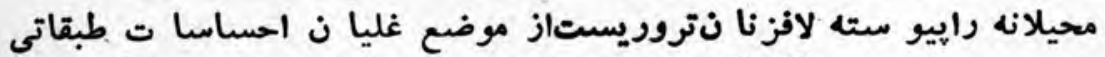

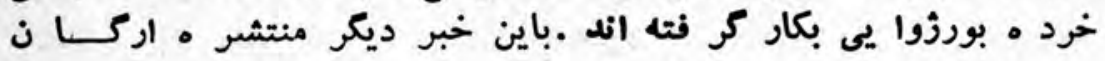

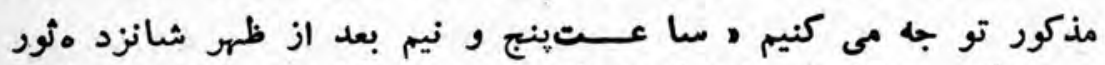

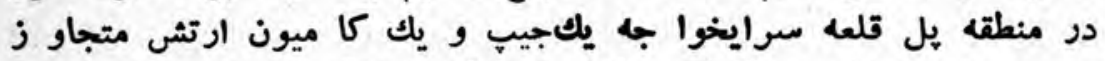

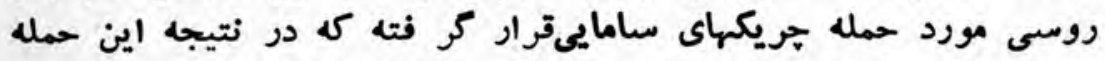

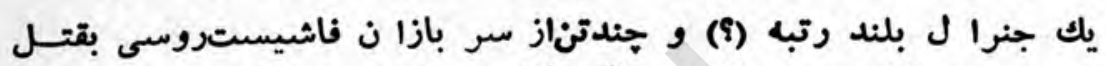

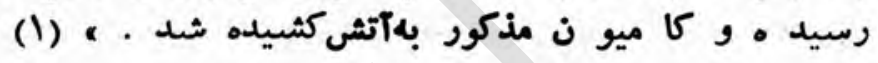

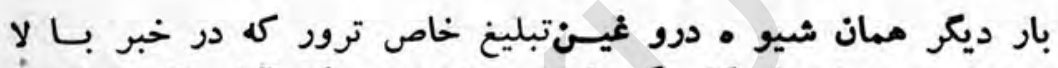

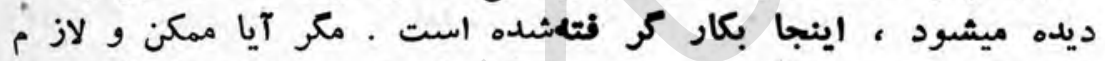

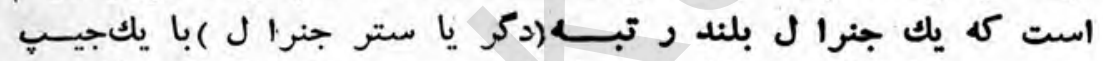

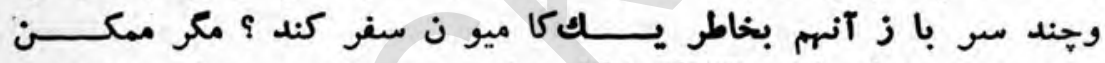

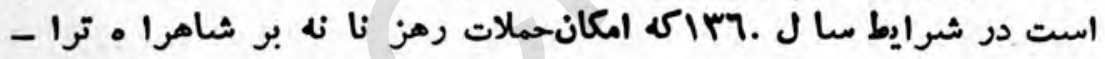

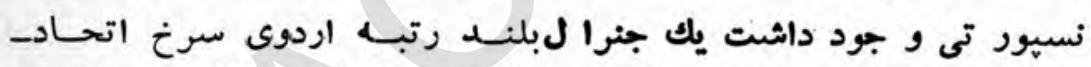

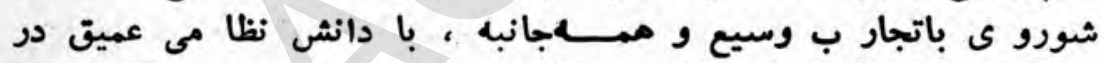

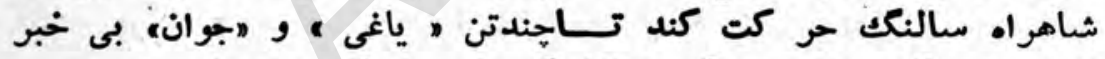

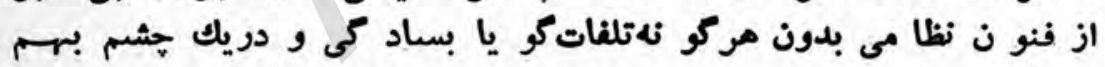

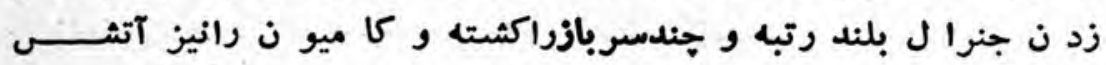
زنثد ؟ ز

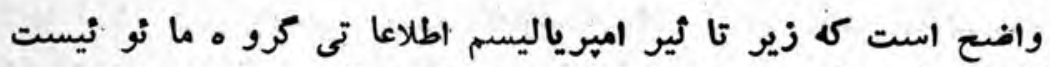

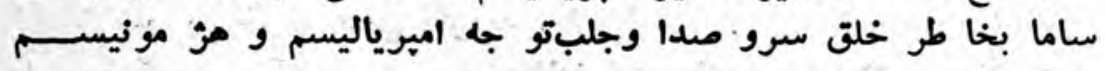

(1) (نداى آزاد ى، ، شماره•و7ففحه مجده . 
وهم به خاطر تو جيه ترور افرادعادىومرد م بيكنا ه بيوسته از ترور و

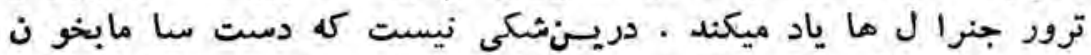

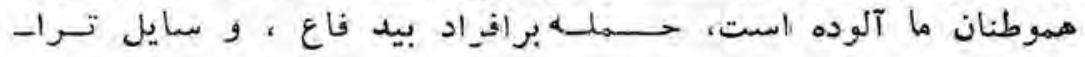

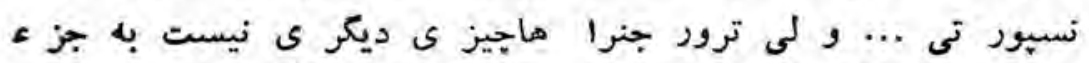

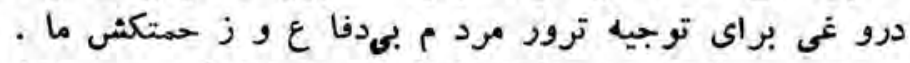

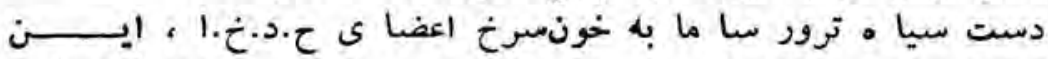

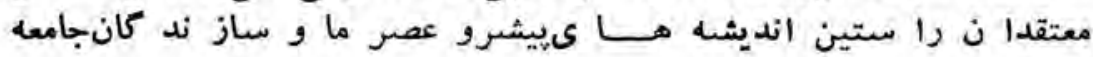
نوين عادلانه در كشور ما آغشتـهاست كهصر ف باذكر نمو نه نه ائاز

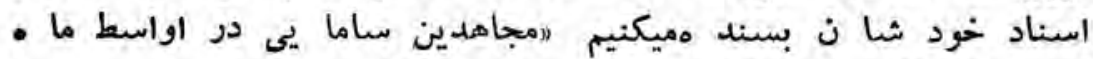

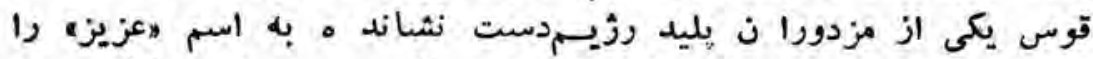

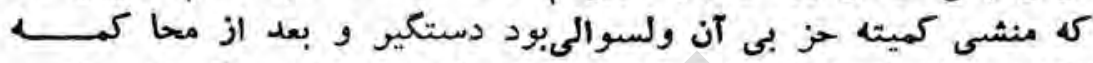

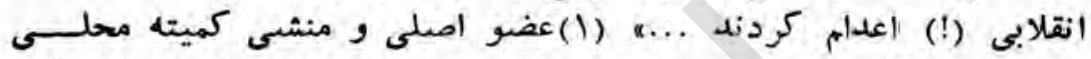

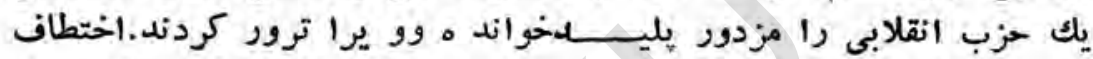

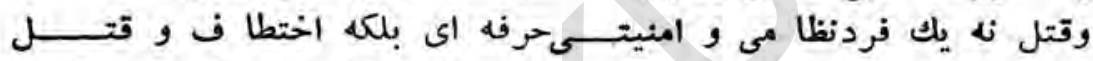

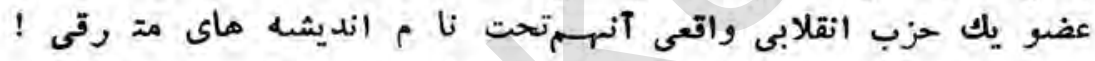

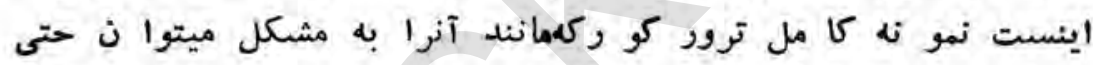

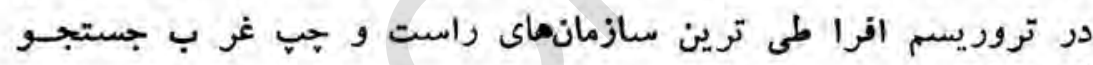

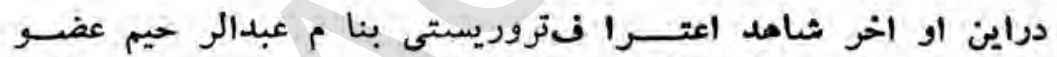

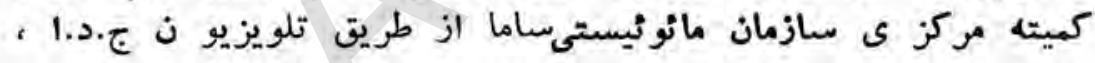

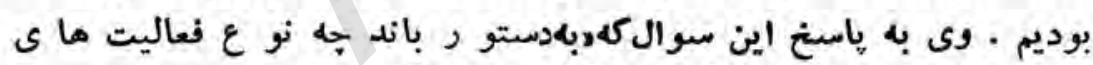

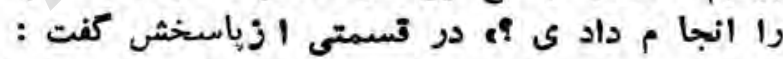

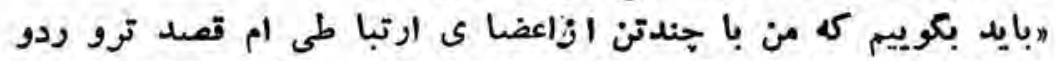

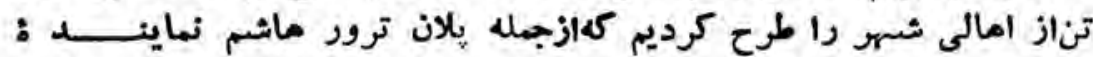

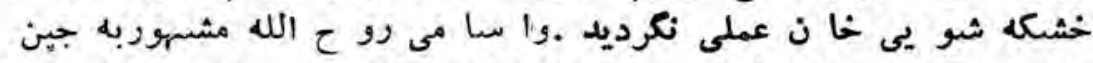

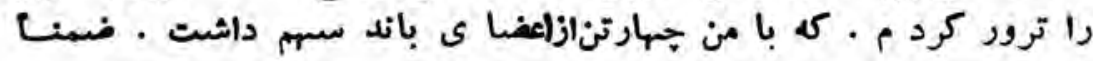

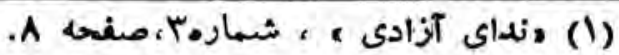
$-117$ 


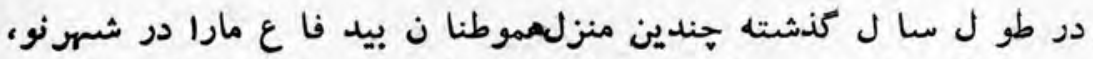

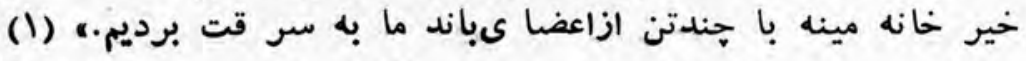

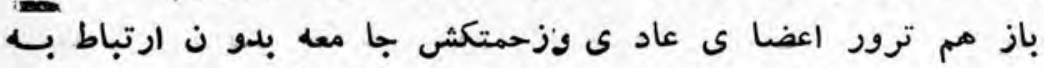

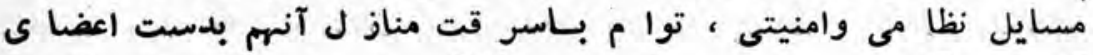

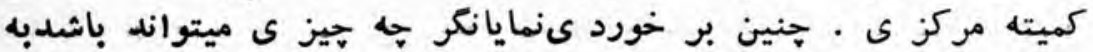

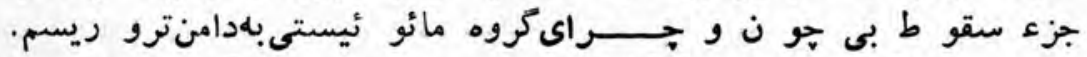

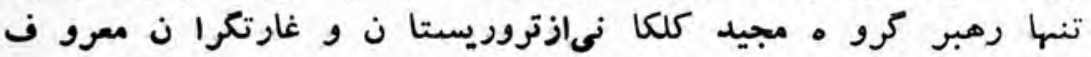

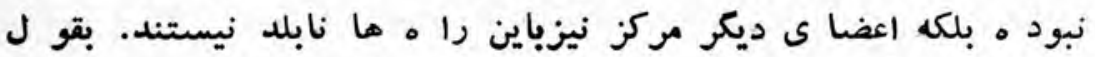

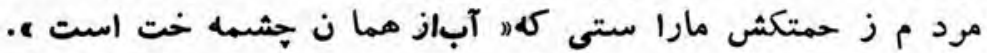

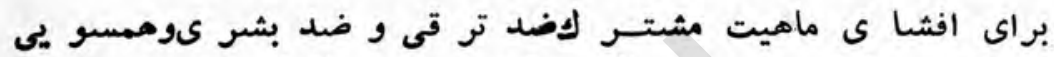

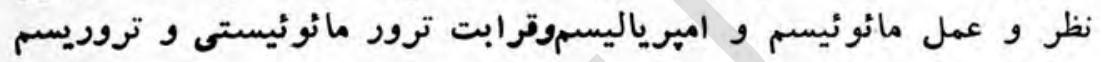

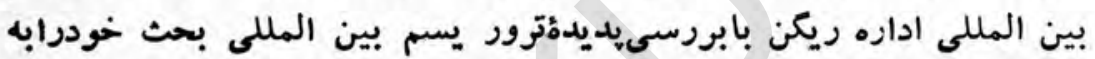

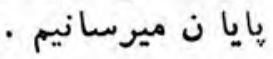

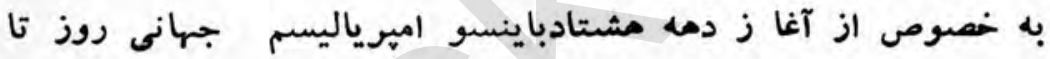

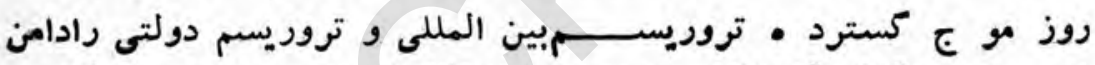

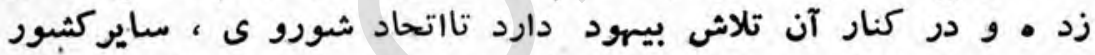

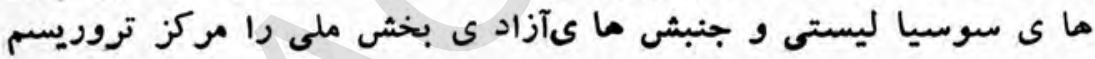

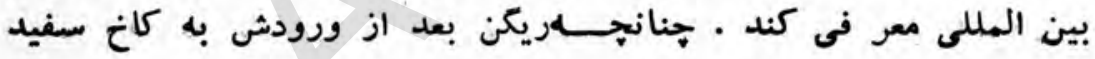

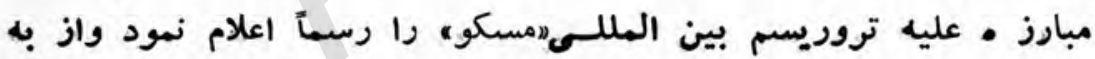
رسميت شنا ختن سازما ن آزاد ىبخش مرد م فلسطين باين بهارئ بهانهانهانه

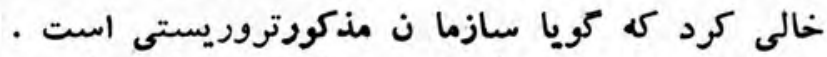

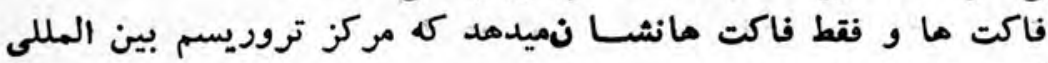
كجاست ؟ فاكت ع

بل (1) مصا حبه راديو تلويزيو نمعبلالرحيم عضو كميته مركزىساما.

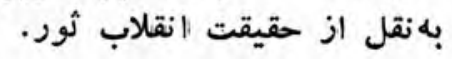




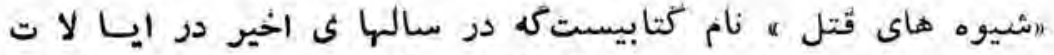

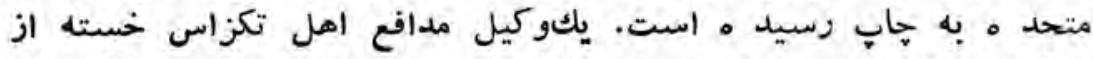

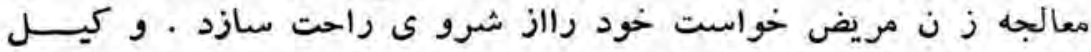

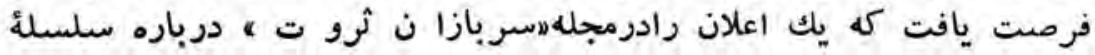

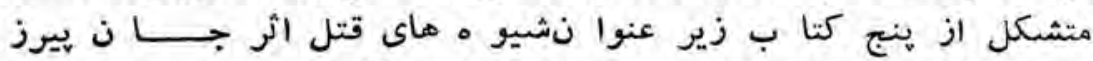

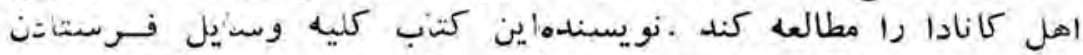

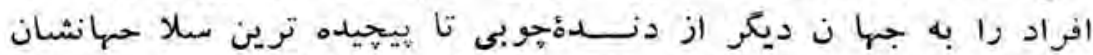

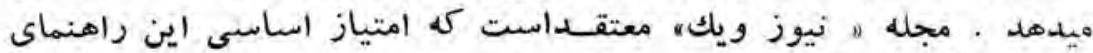

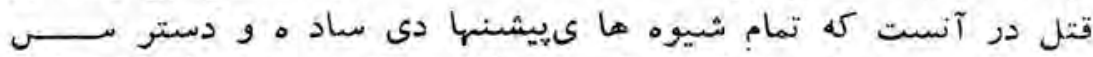

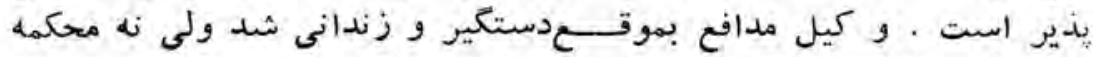

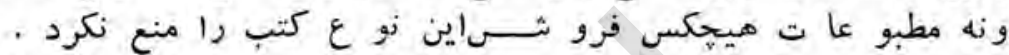

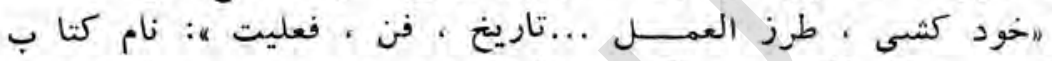

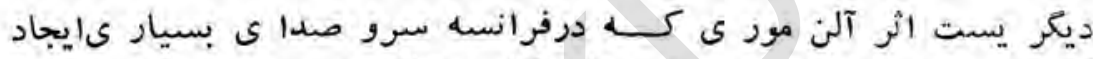

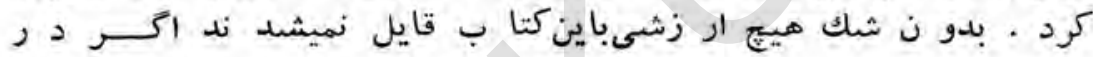

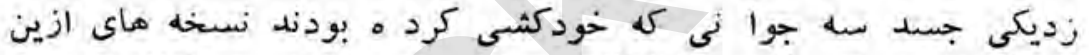

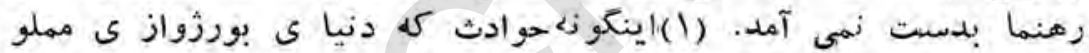

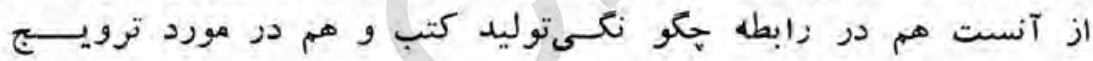

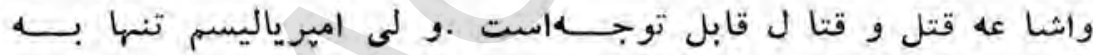

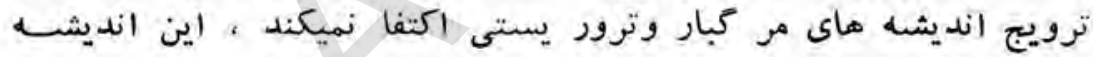

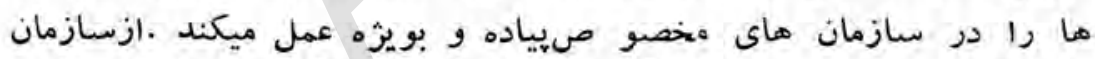

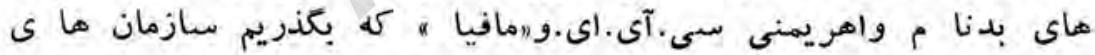

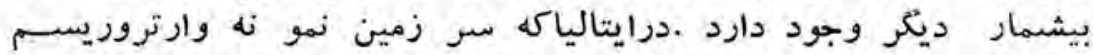

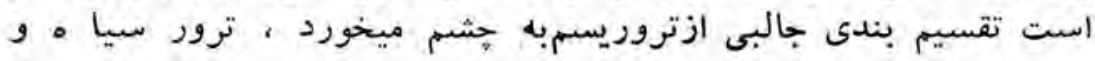

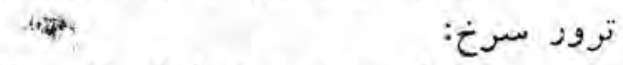

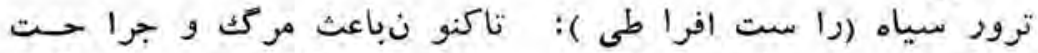

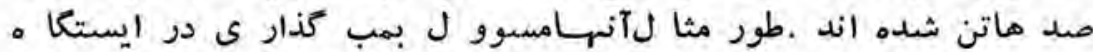

(1) (1) ازل مجله مسايل صلح وسوسيا ليسم ، شماره اول ، سا ل $-\backslash \Lambda \Lambda$ $.19 \wedge r$ 


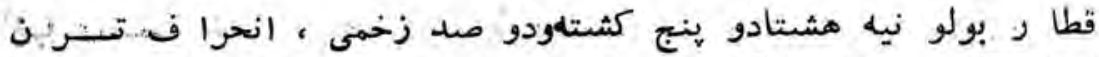

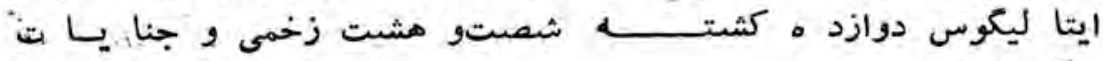

$$
\begin{aligned}
& \text { ديكر ميباشند اليكوسن دوازد } \\
& \text { ترور سرخ (هي افرا طى ) ): }
\end{aligned}
$$

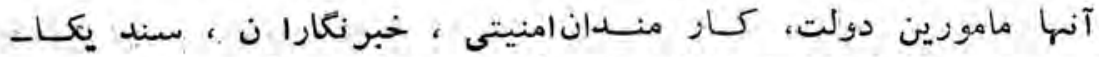

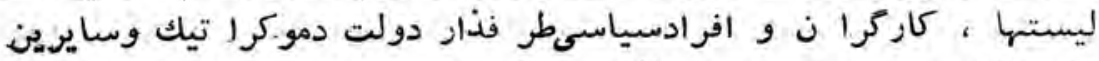

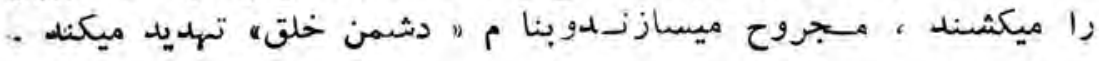

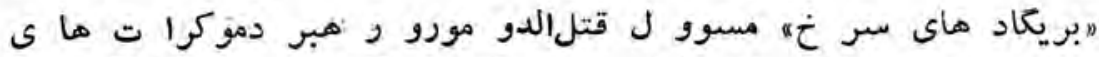

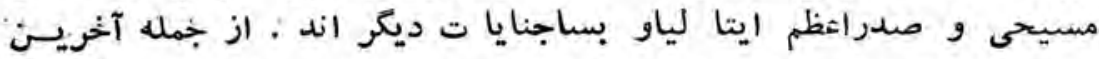

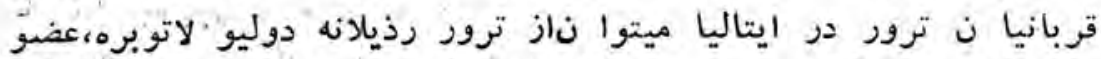

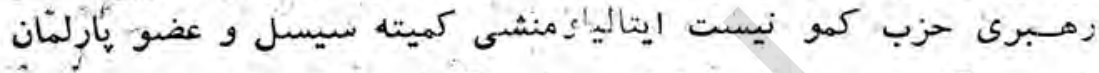

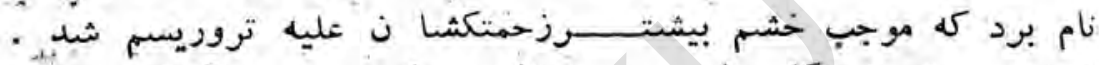

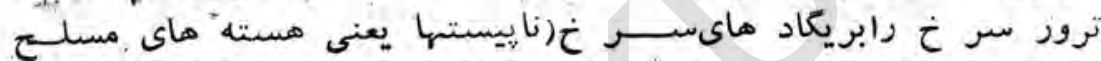

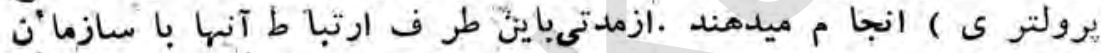

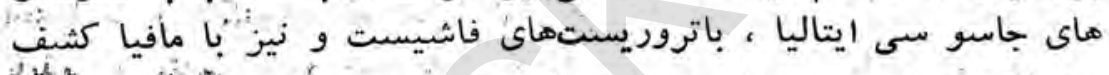

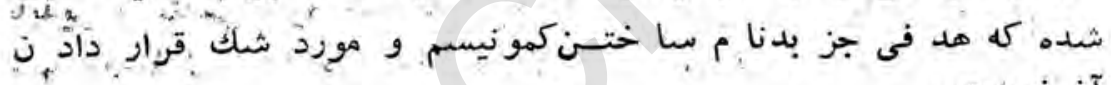

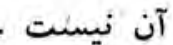

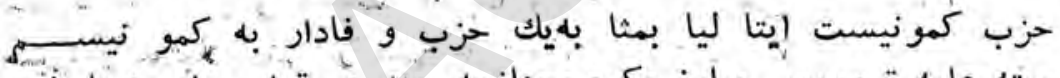

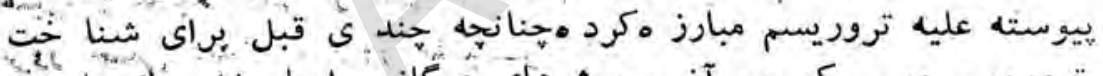

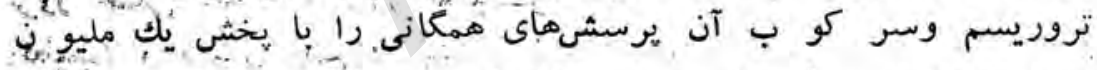

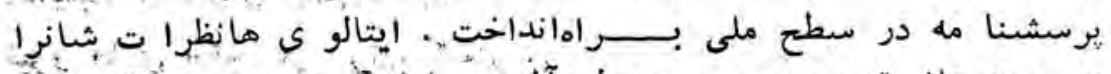

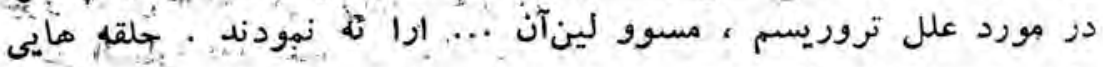

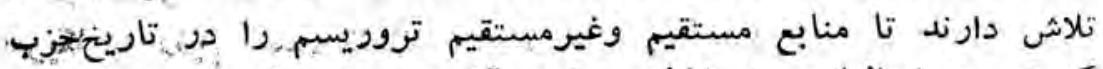

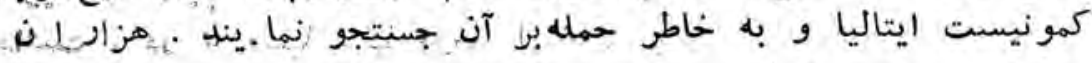

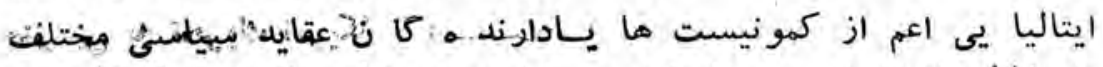

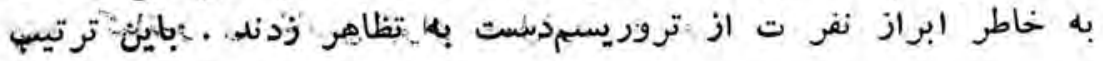




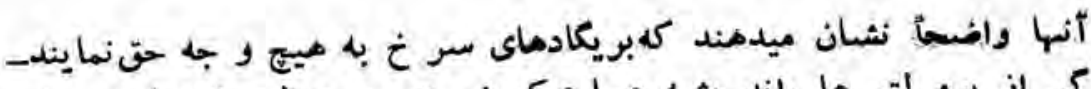

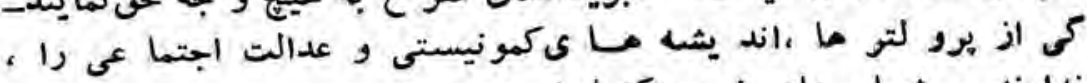

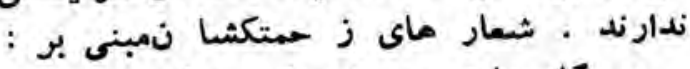

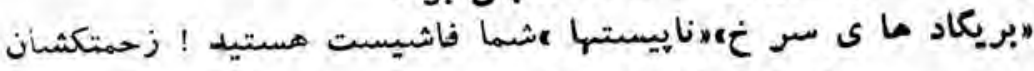

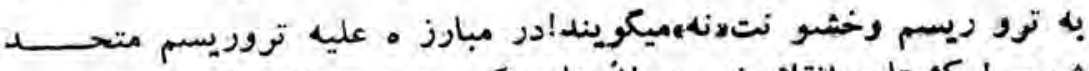

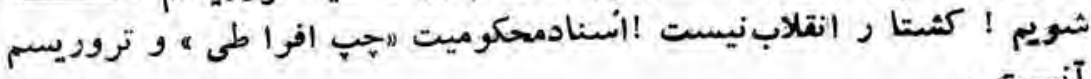
آنست

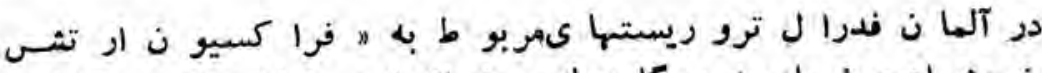

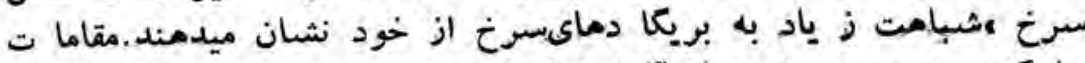

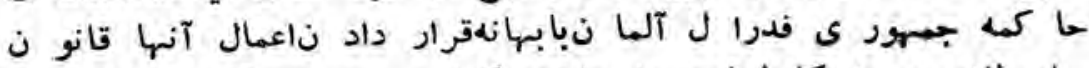

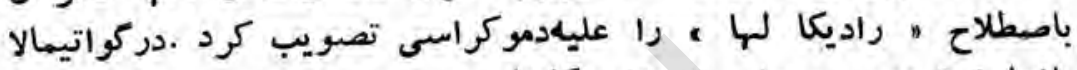

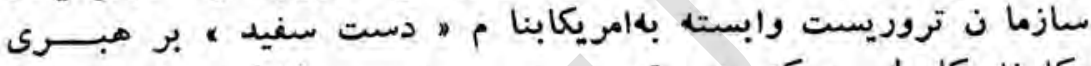

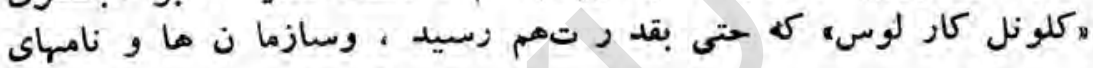

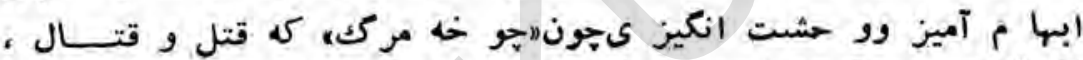

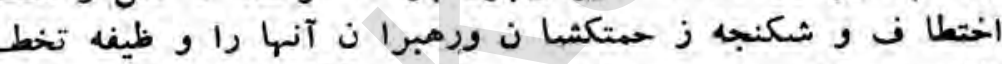

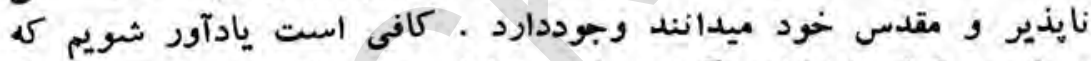

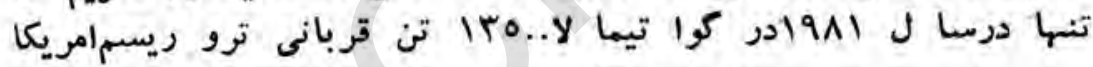

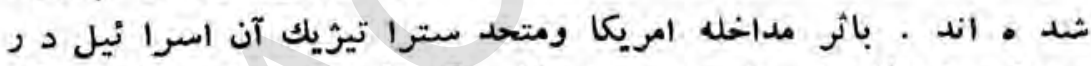

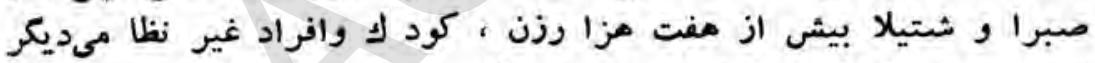

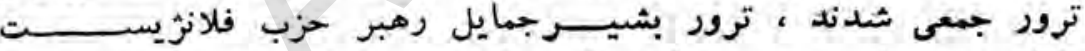

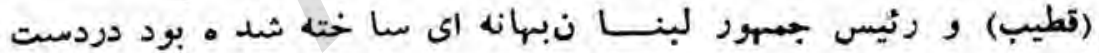

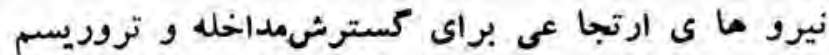

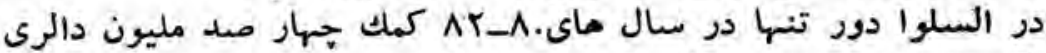

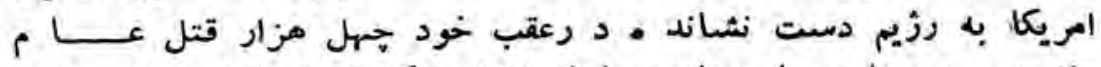

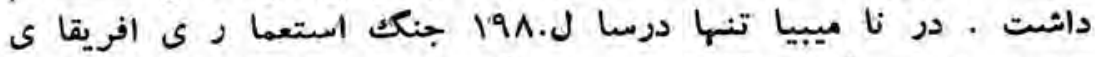

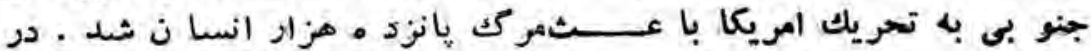

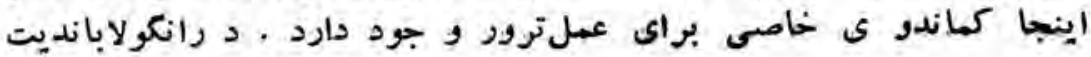




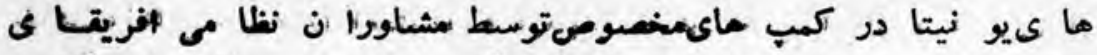

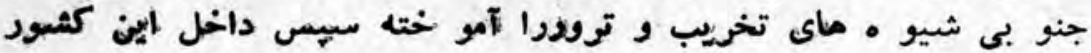

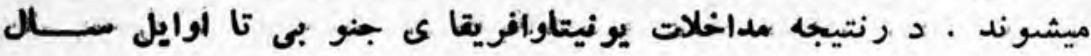

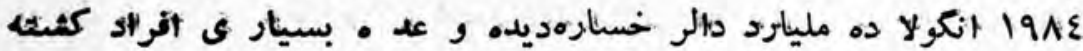

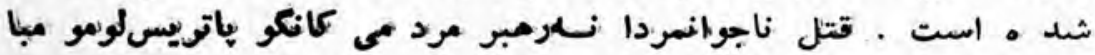

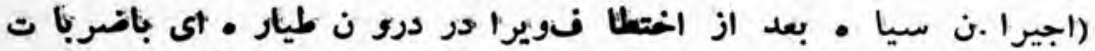

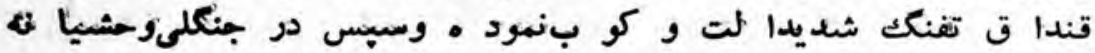

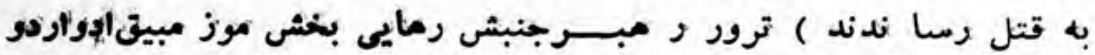

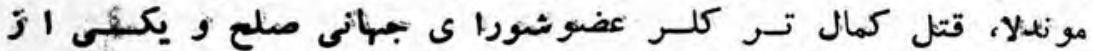

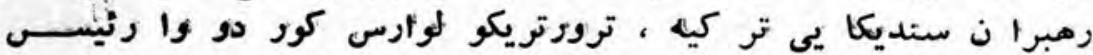

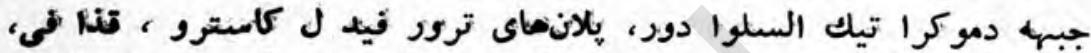

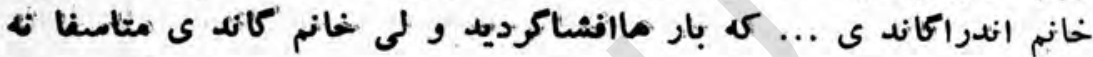

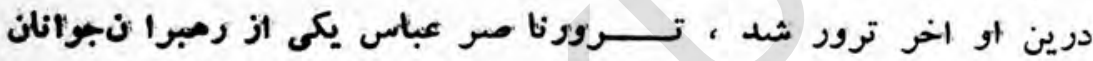

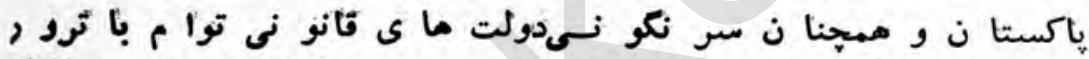

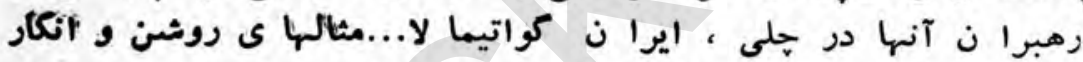

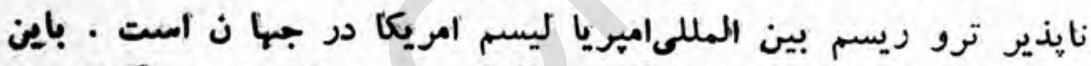

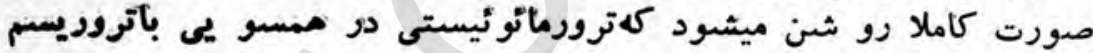

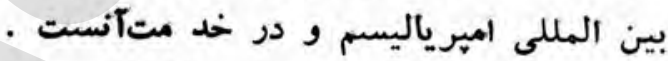

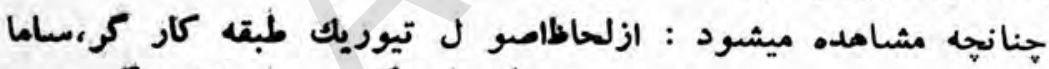

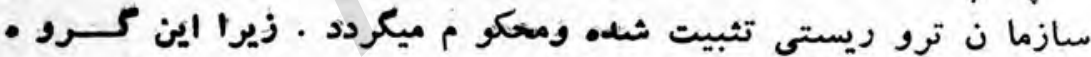

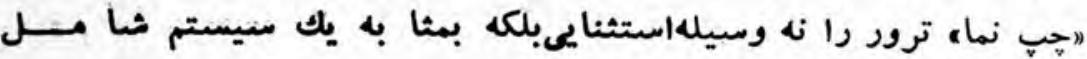

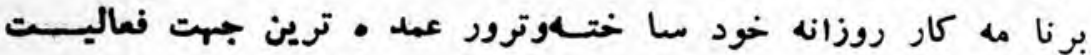

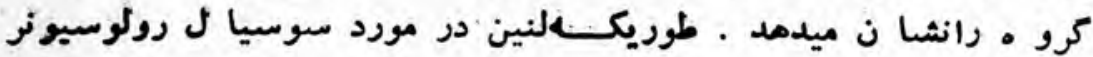

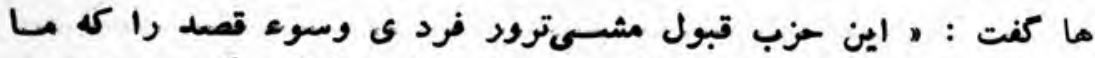

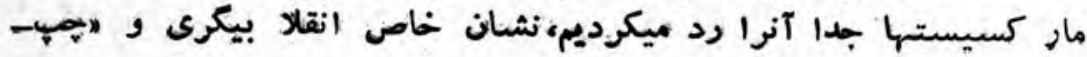




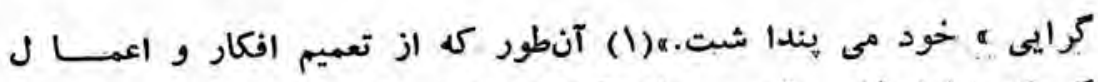

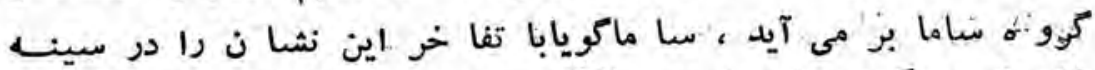

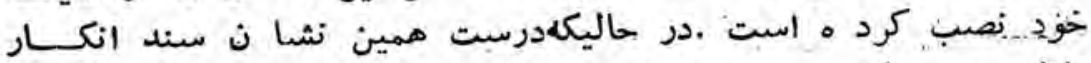

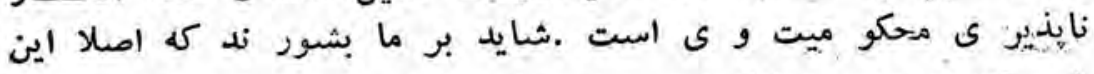

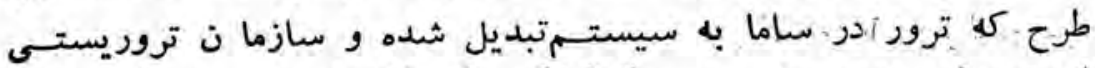

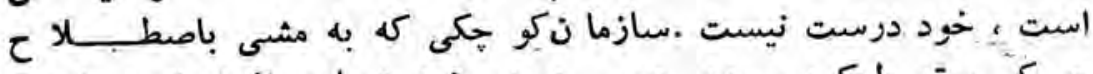

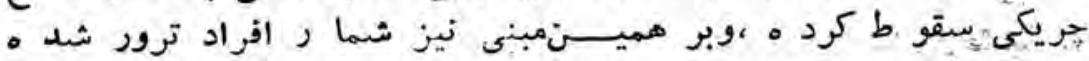

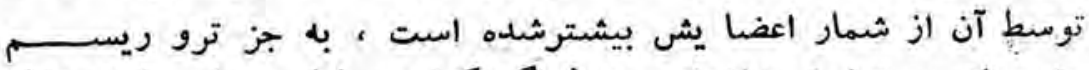

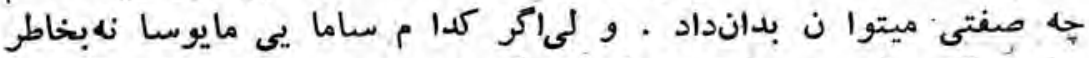

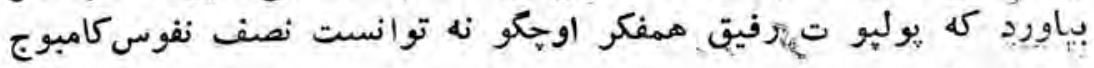

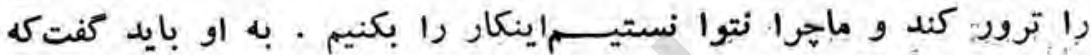

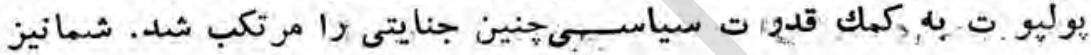

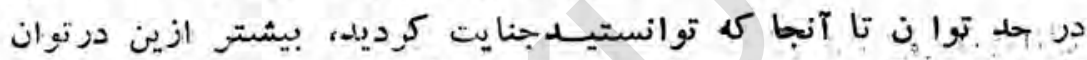

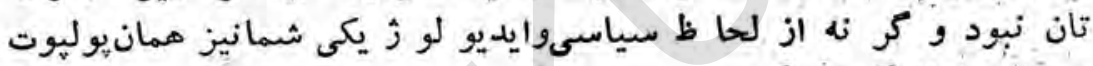

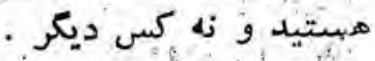

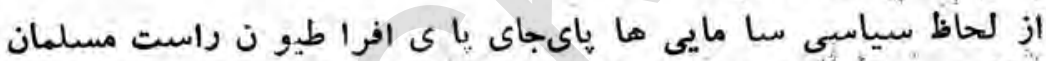

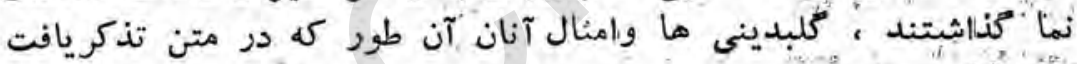

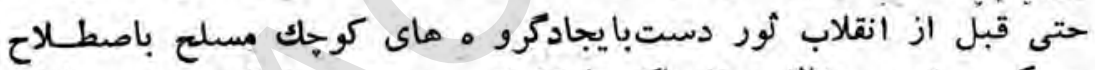

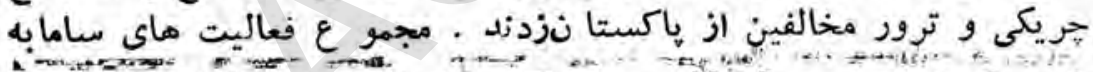

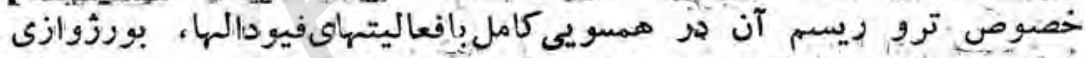

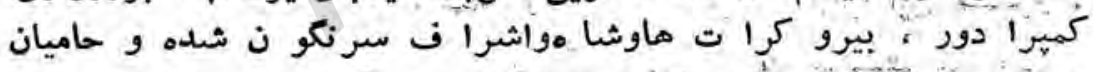

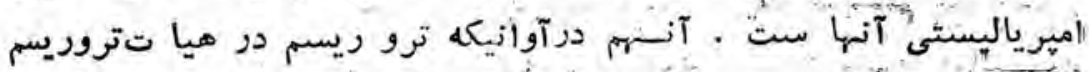

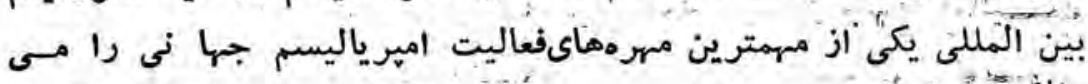
س

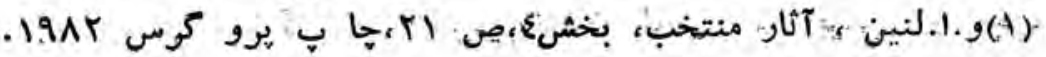

$$
-19 r-i=
$$




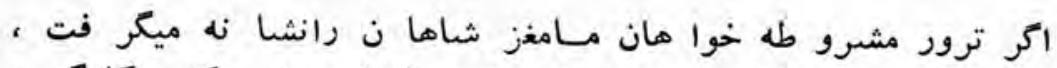

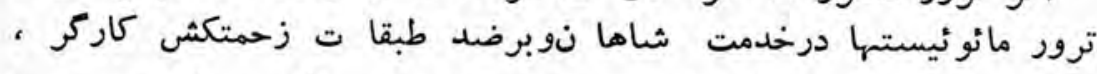

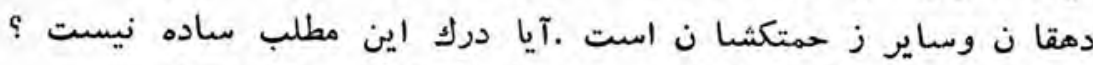

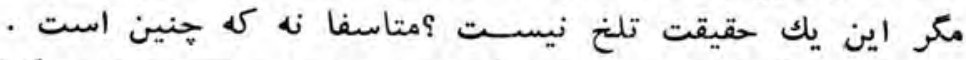

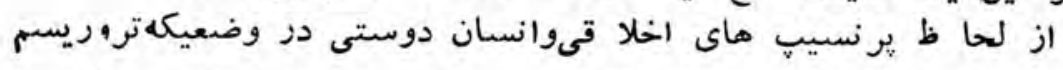

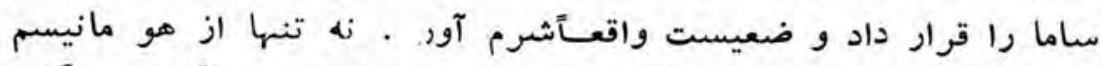

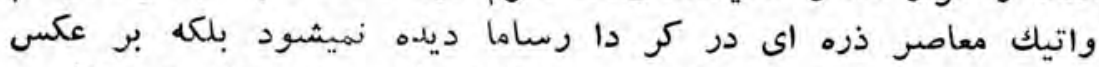

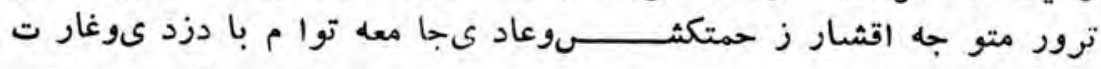

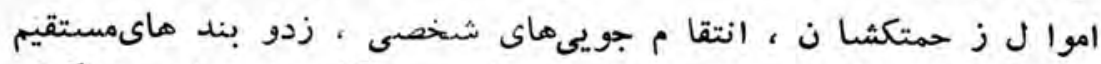

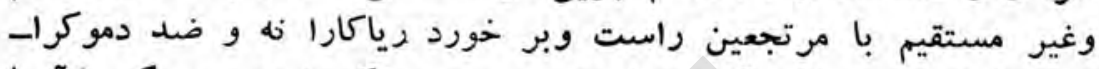

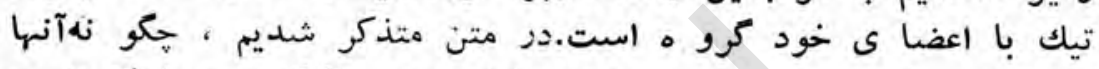

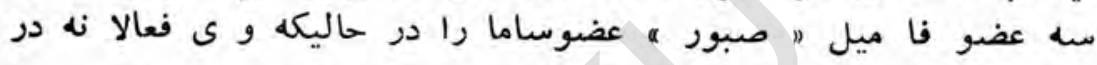

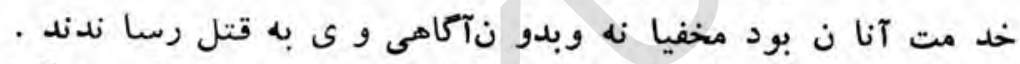

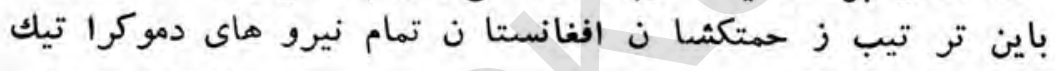

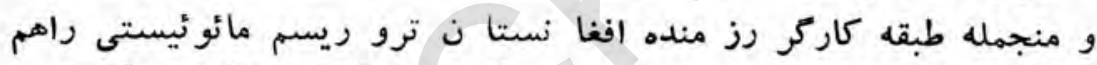

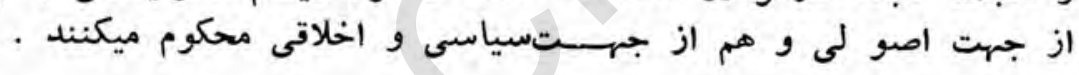

زحمتكشانبه تروريسموخشونت "نها، ميكو يند :

كشتار انقلاب نيست ؛ 


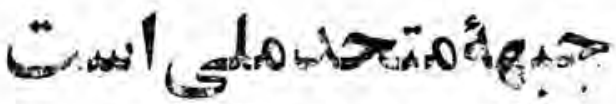
intis

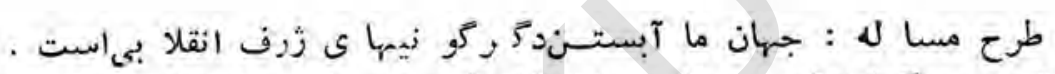

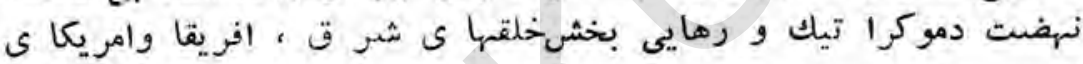

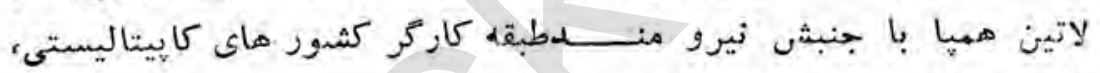

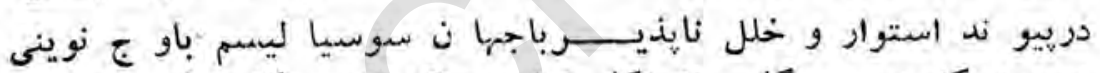

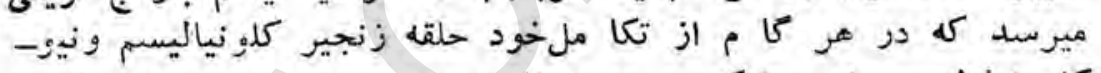

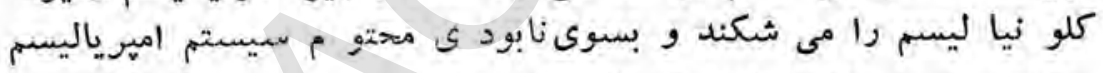

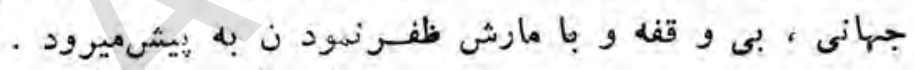

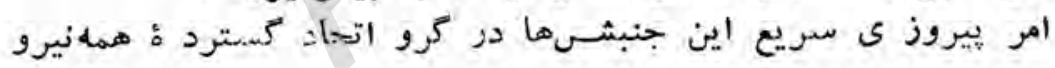

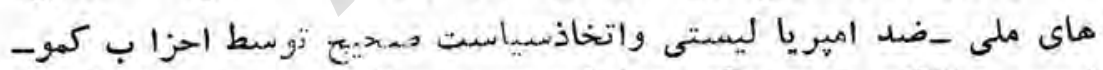

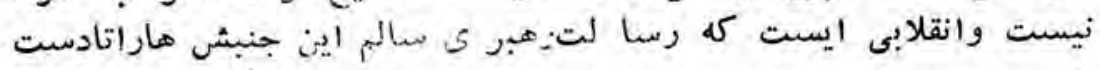

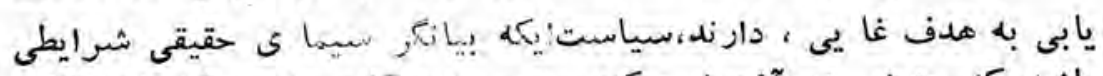

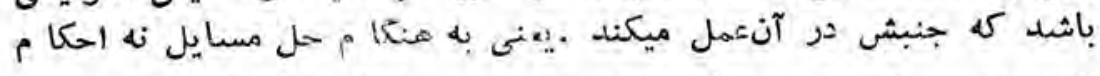

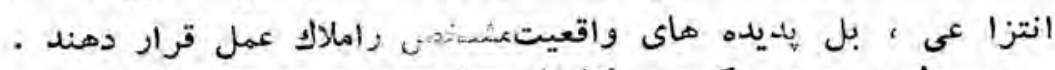

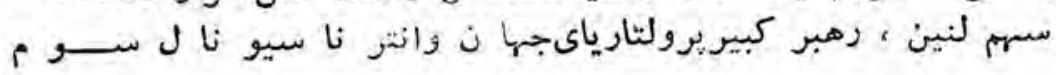

$-19 \varepsilon-$ 
(كمينترن) در تدوين اصول استرا تيزيك و تاكتيكى احزا ب كمونيست

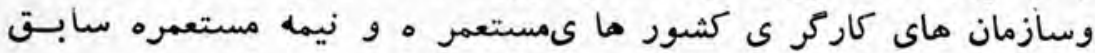

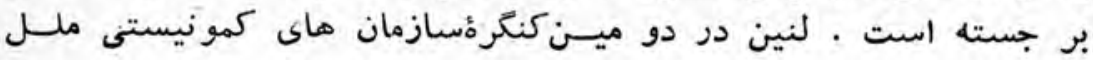

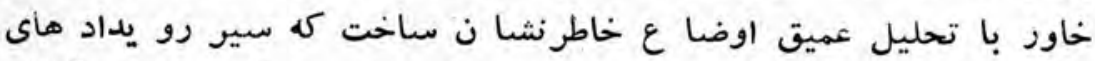

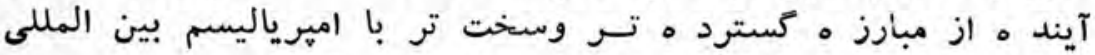

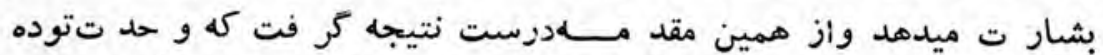

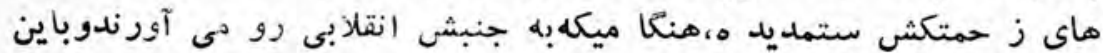

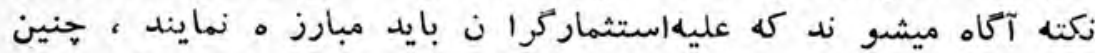

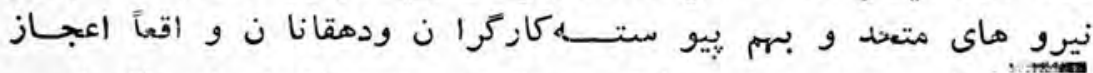

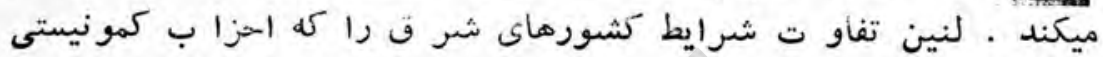

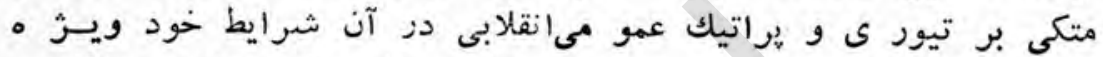

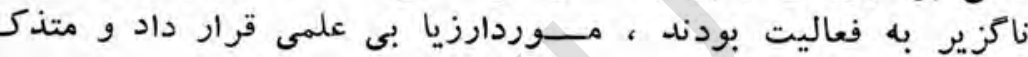

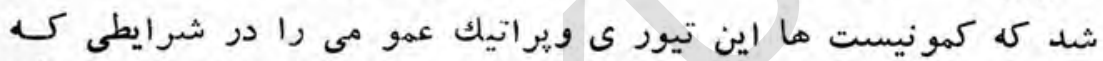

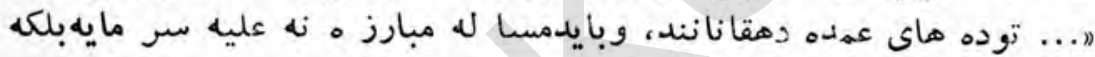

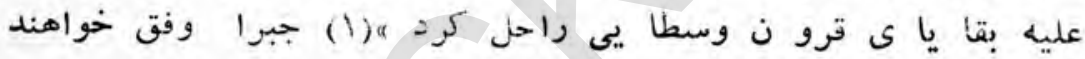
داد

رهبر اكتبر در دو مين كنكـر :كمينتر ن ، تو جه كمونيست هارابه

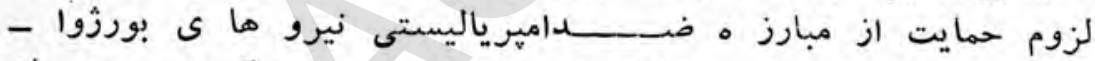

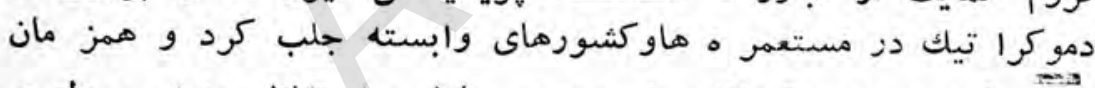

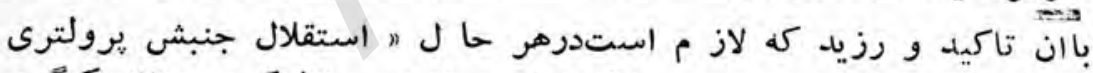

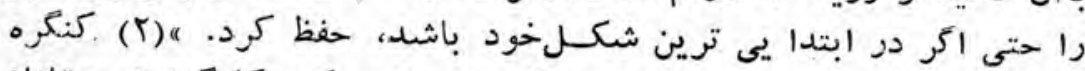

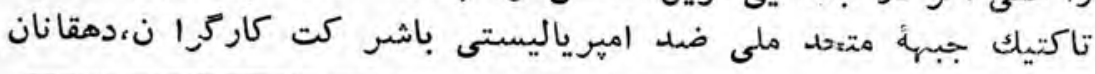

$$
\text { (1)و. 1.لنين ، منتخبا ت ، جلدسوم ، صبrr. }
$$

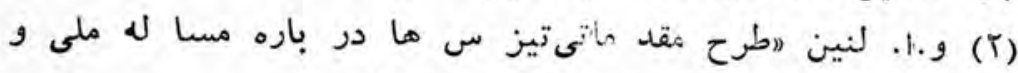

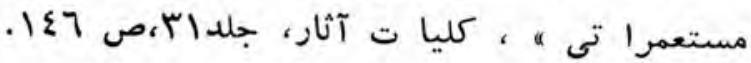


خرد ه بودزواز ى شهروبوزئواز ىملى كه شالود ه آنرا اتحاد كاركران

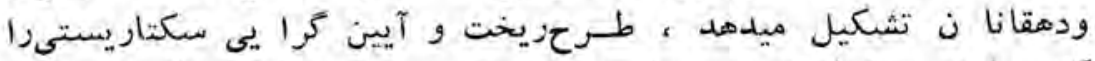

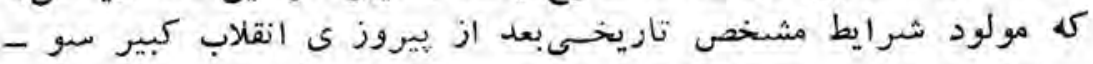

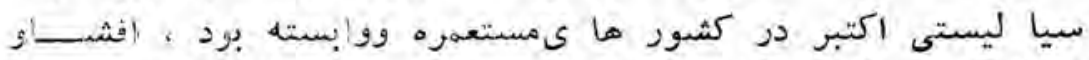

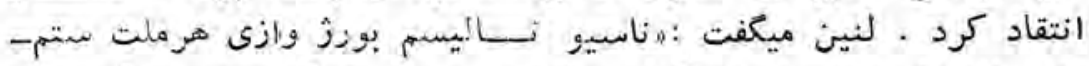

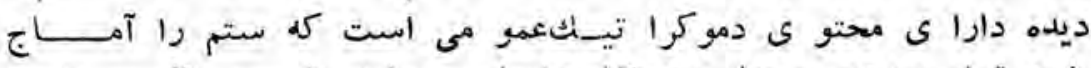

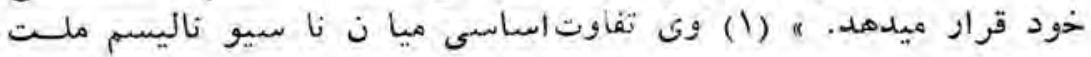

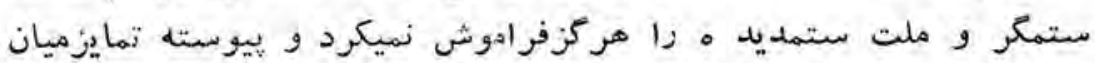

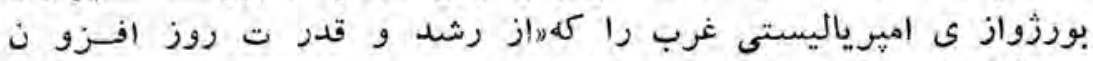

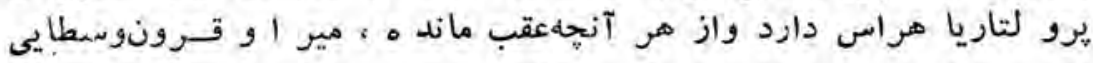

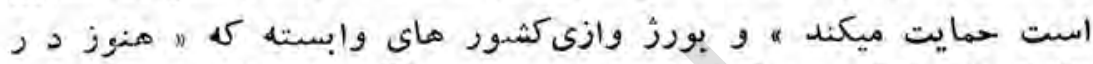

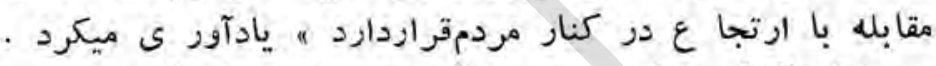

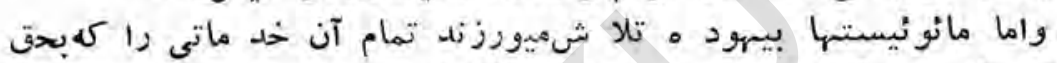

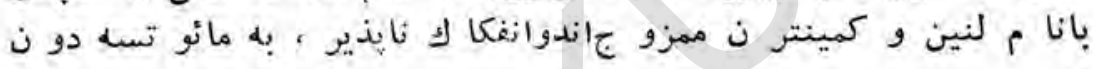

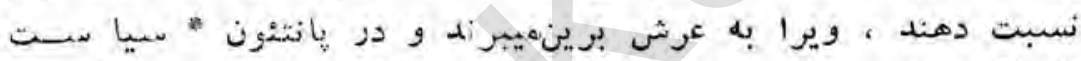

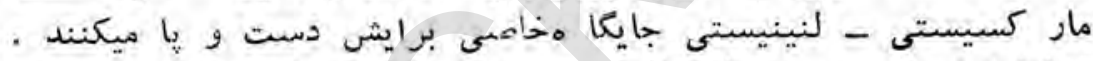

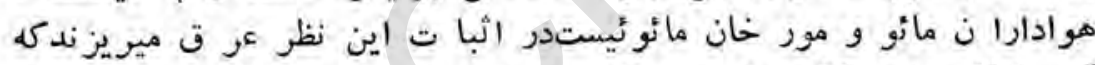

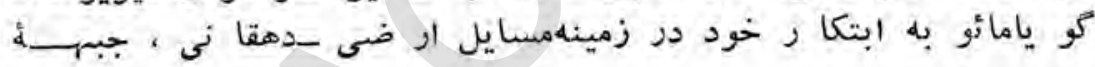

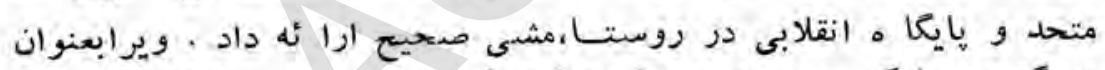

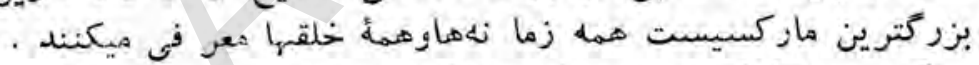

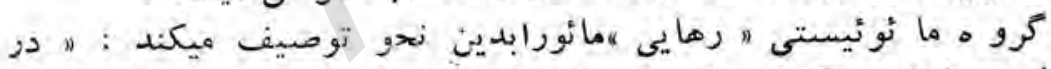

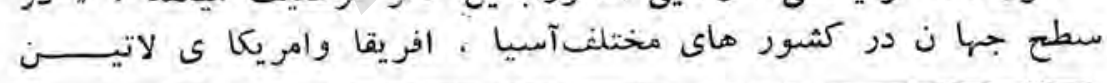

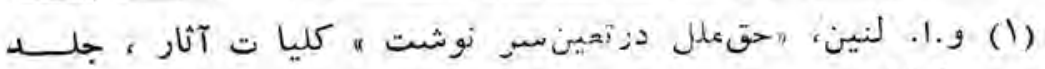
Elर ص. T.

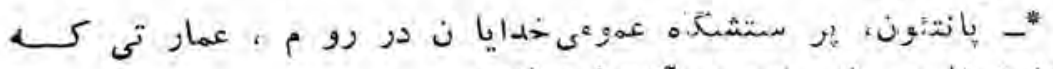

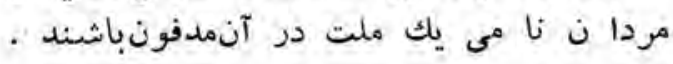




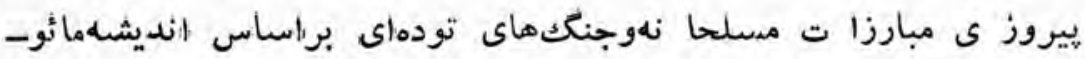

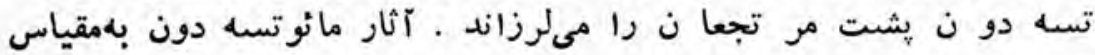

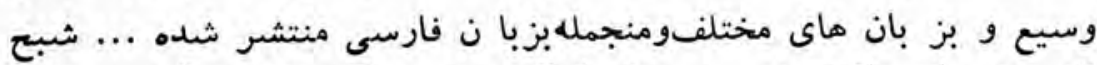

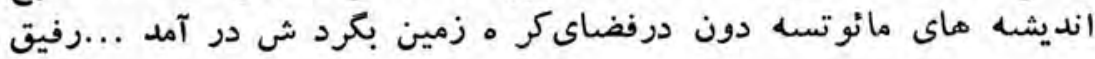

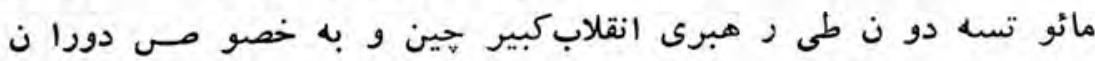

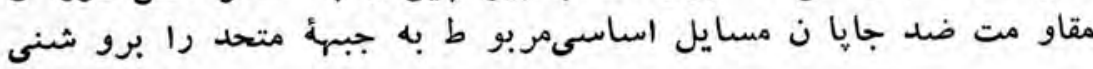

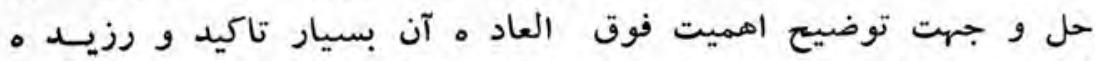

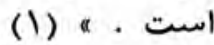

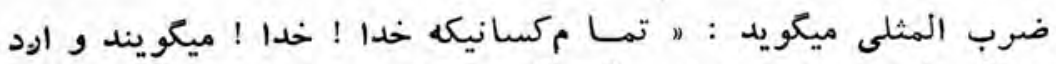

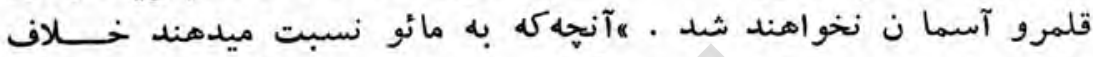

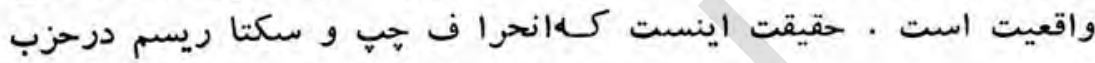

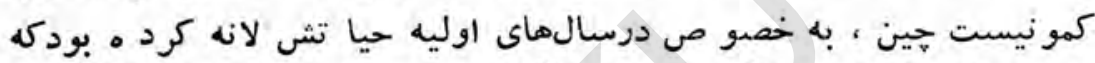

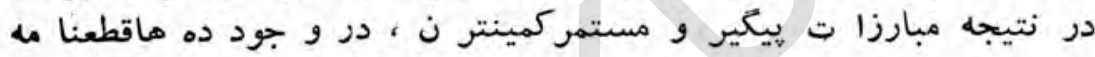

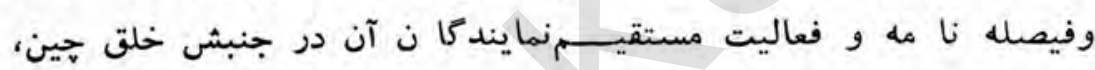

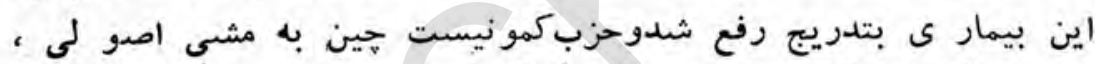

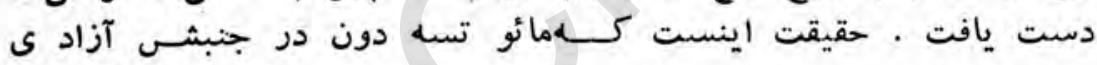

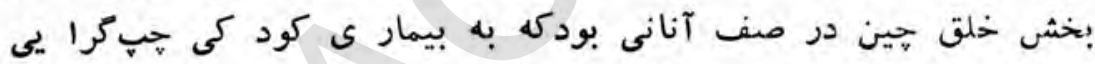

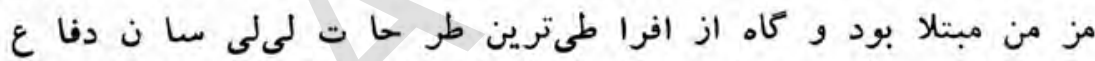

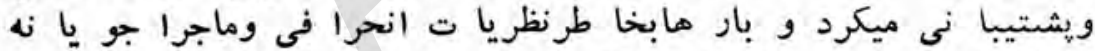

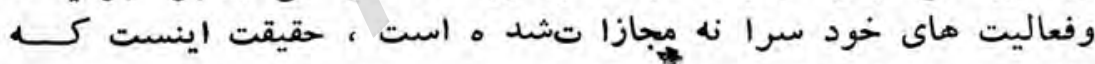

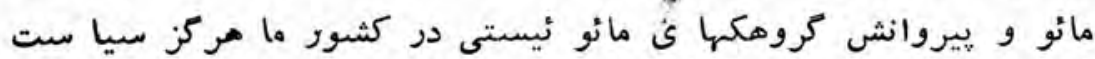

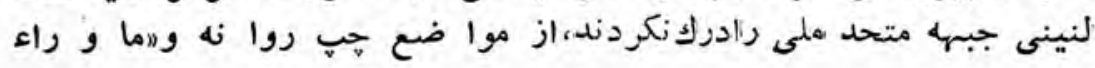

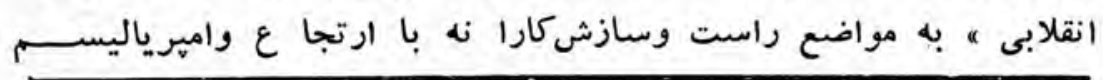

(1)(با طرد ايور تو نيسم درراهانقلاب سر خ به بيش رويم ،مفحات ^وרז. تكيه رو ى كرد كلماتازماست. 


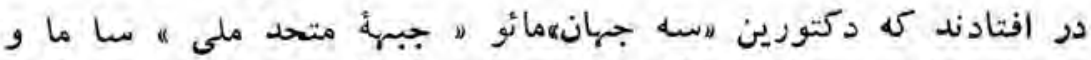

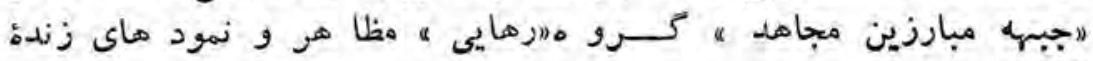

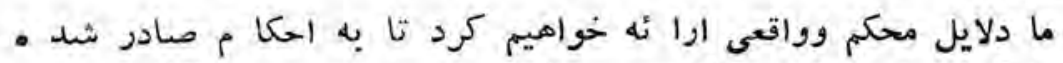

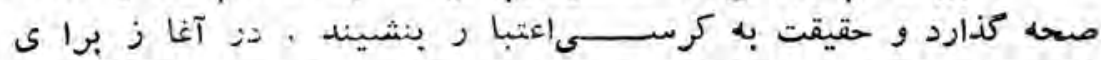

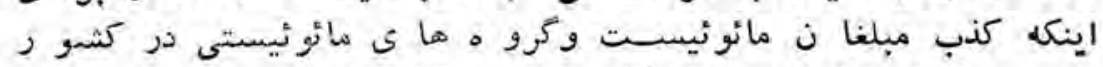

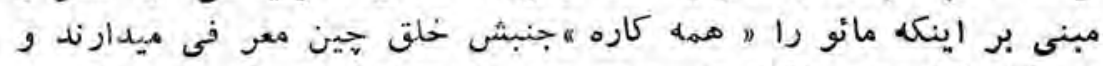

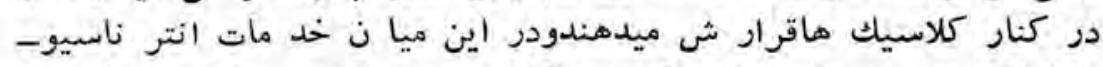

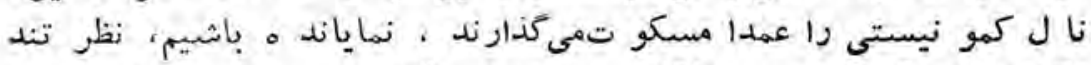

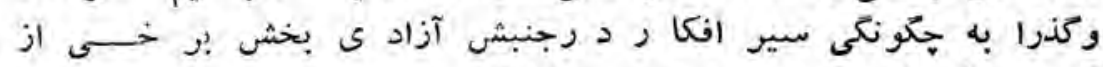

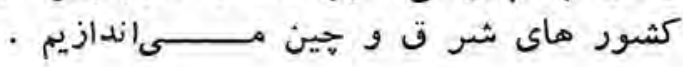

\section{米}

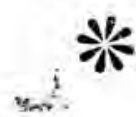

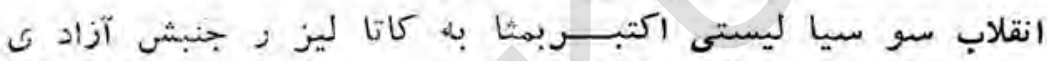

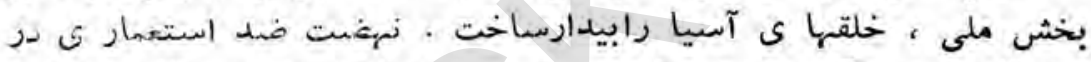

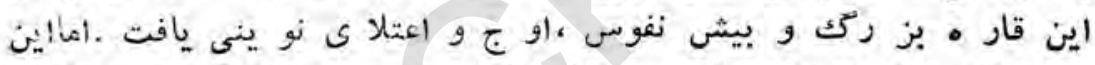

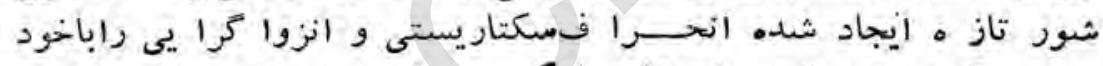

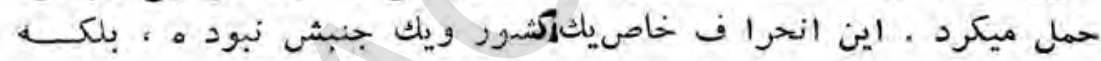

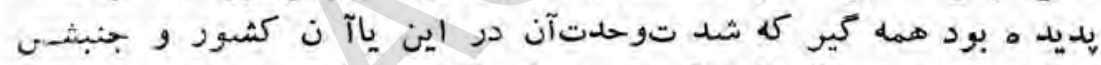

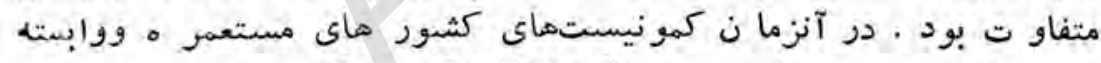

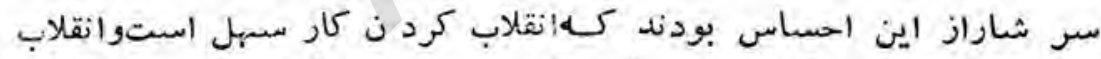

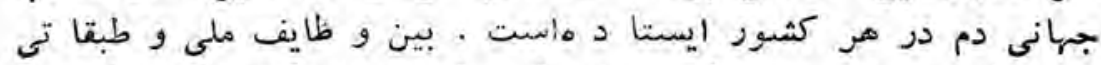

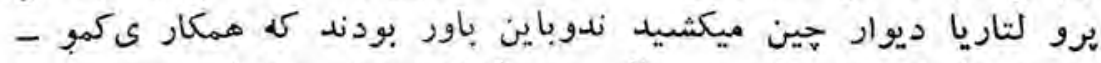

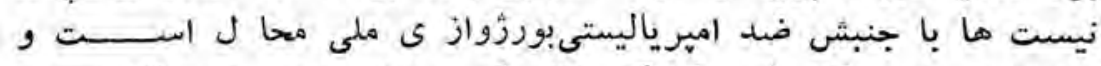

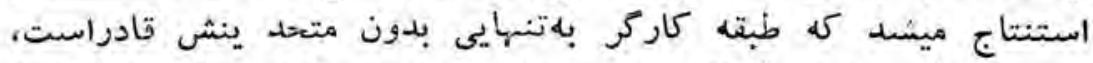

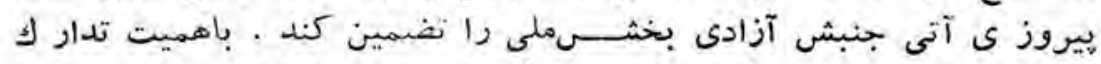

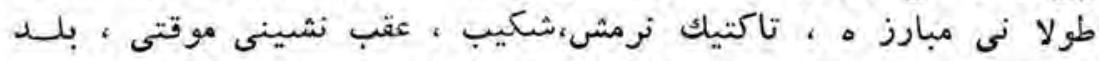

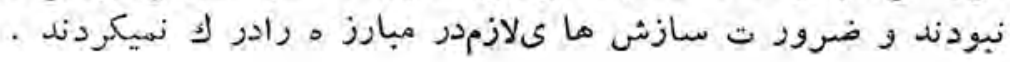




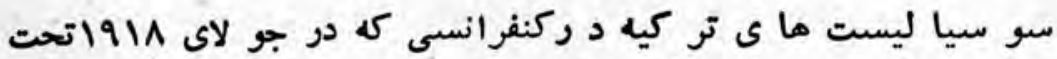

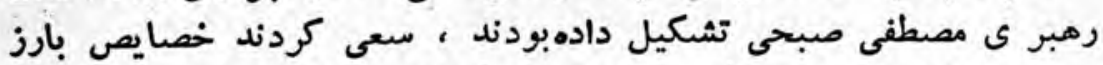

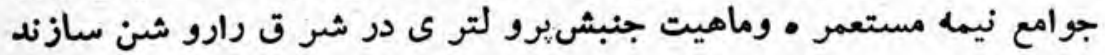

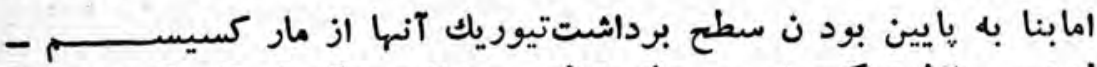

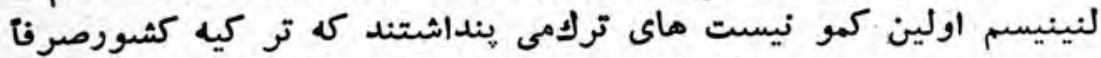

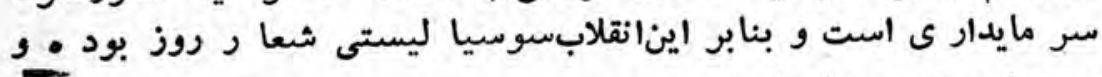

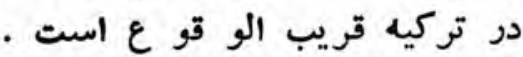

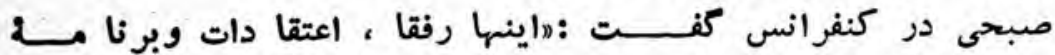

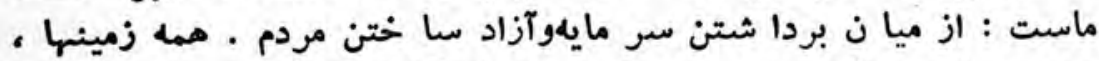

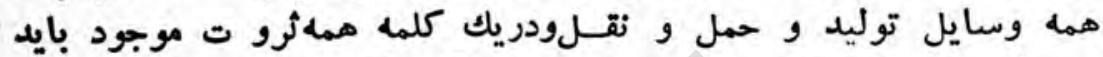

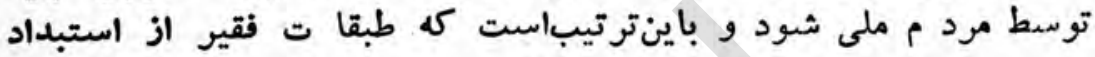

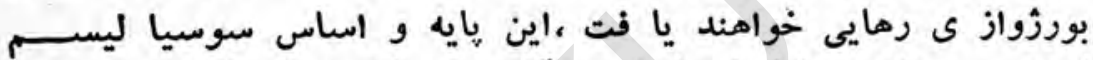

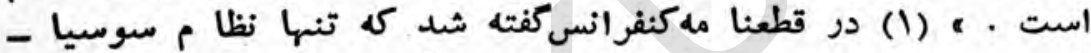

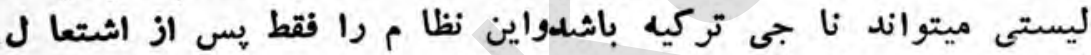

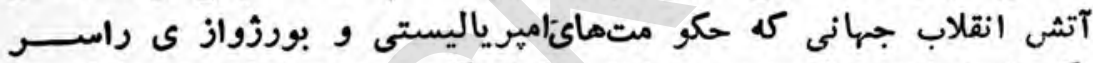

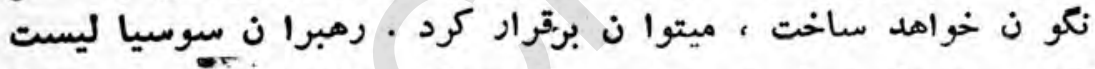

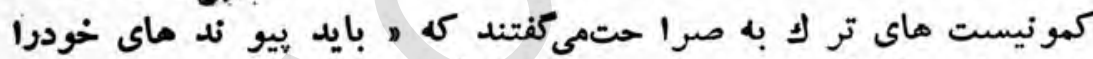

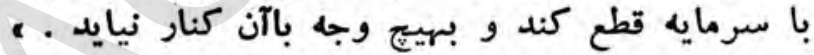

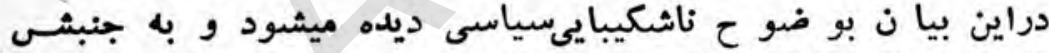

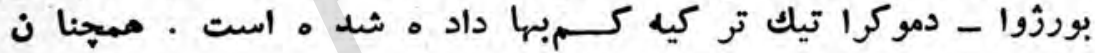

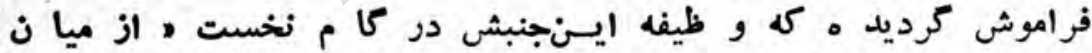

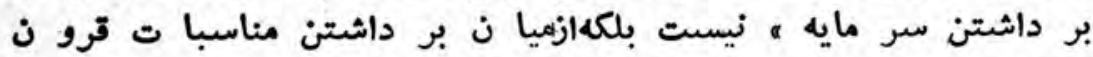

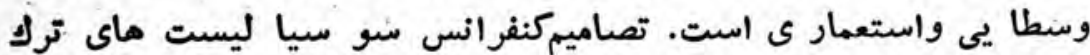

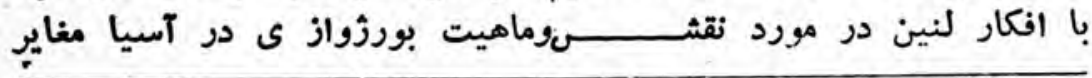

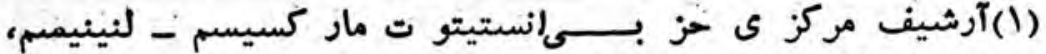

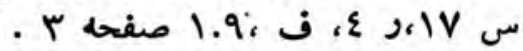




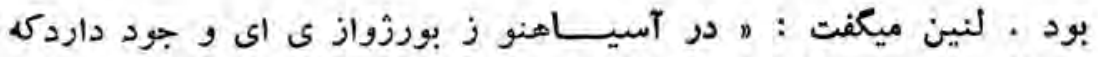

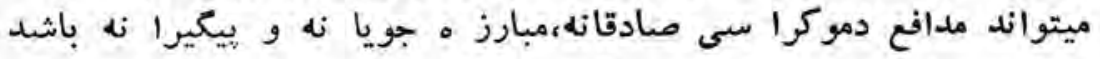

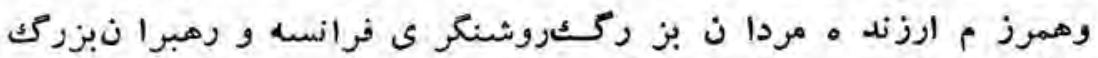

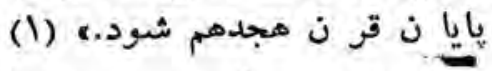

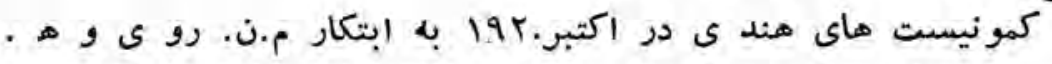

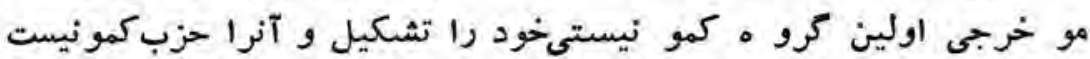

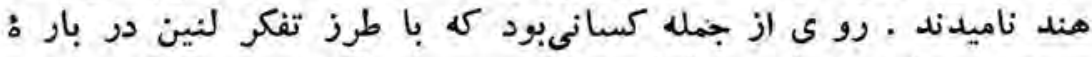

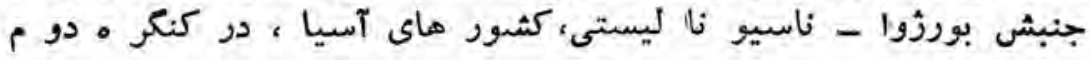

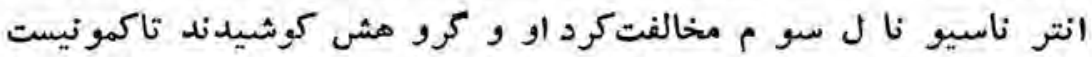

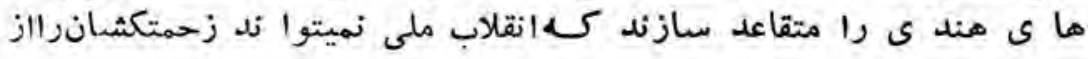

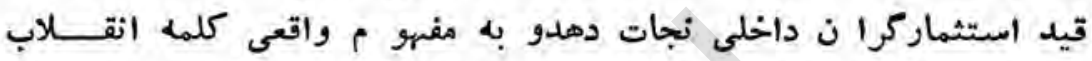

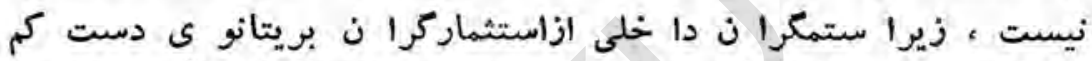

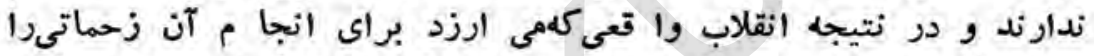

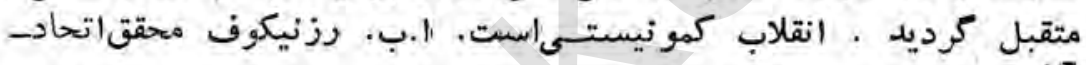

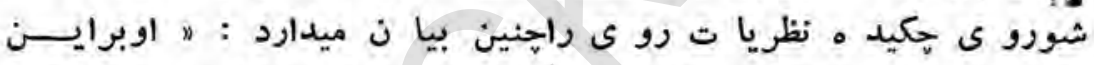

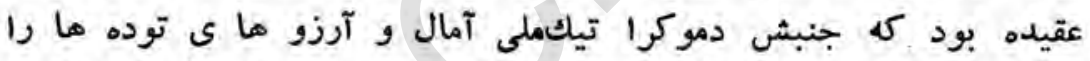

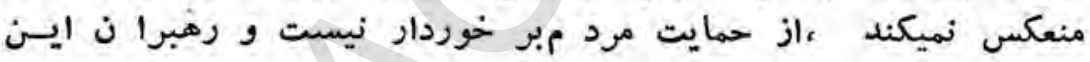

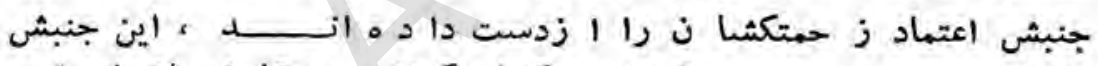

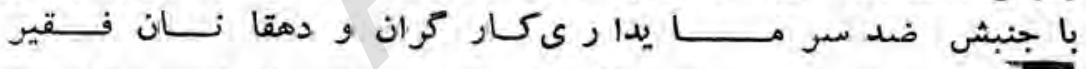

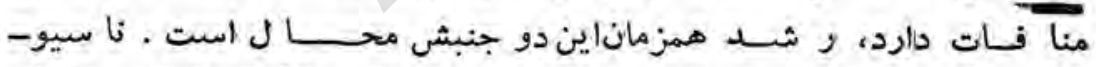

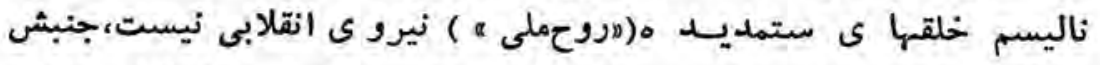

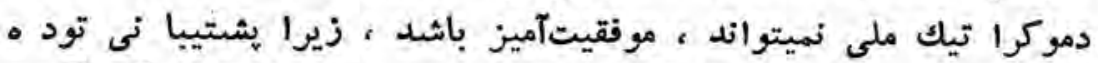

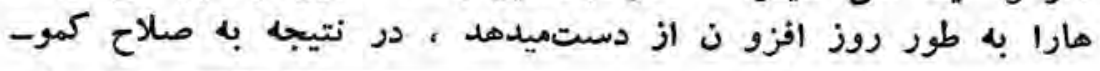

(1)و.ا.لنين " دموكراسى و ناروديسم در جيين ه ، كليا ت آثار ،جلد

هجد مـ صفحه 170. 


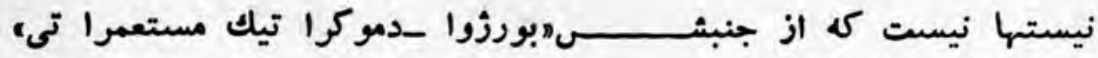

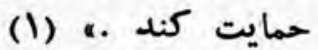

لنين بانى انتر نا سيو نا ل مبوما زديد كا ملا متفاو تى به انتـلاب

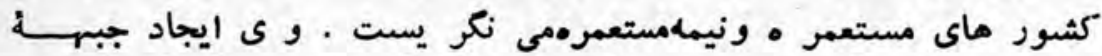

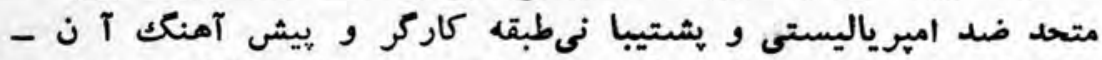

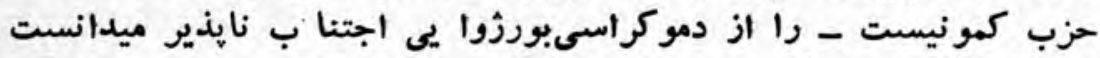

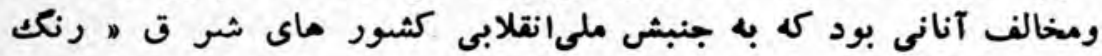

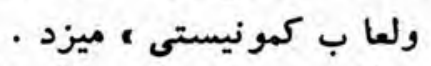

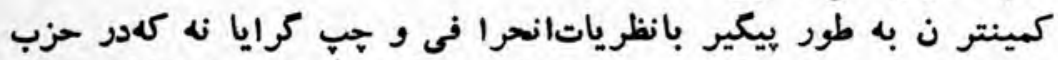

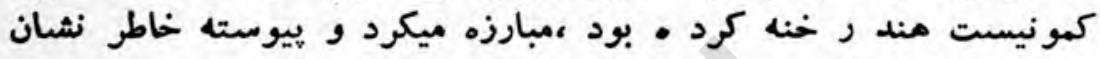

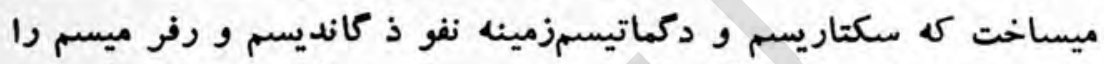

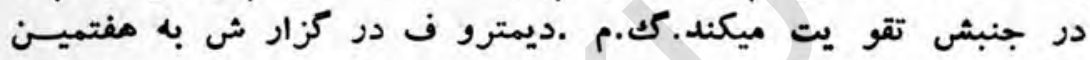

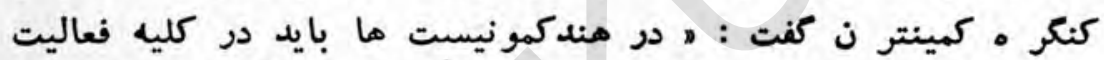

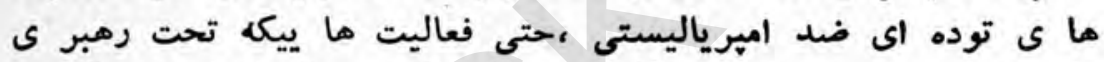

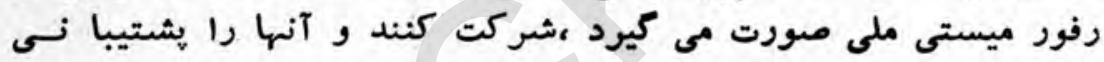

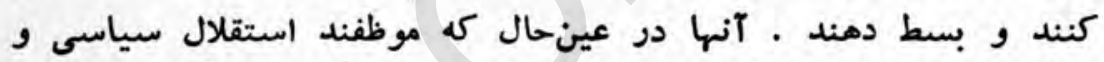

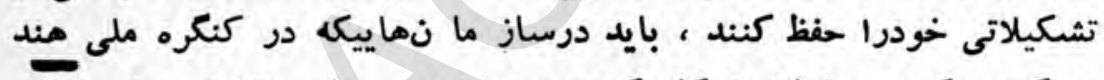

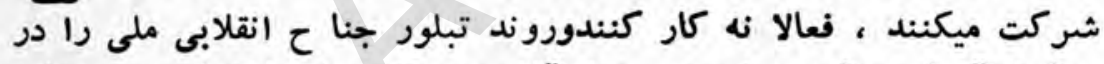

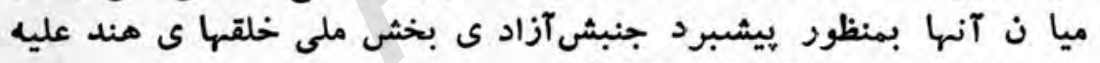

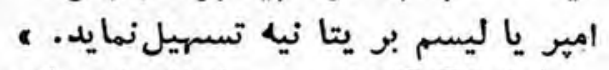

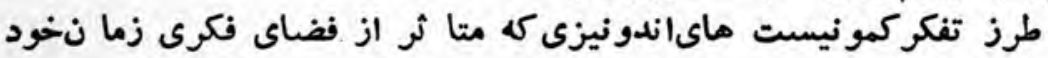

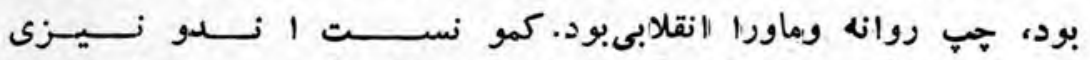

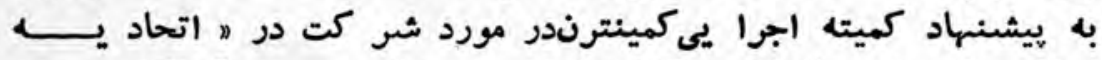

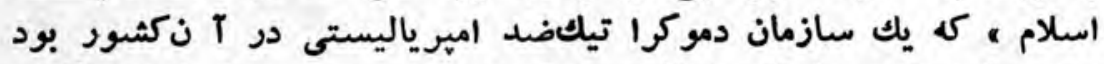

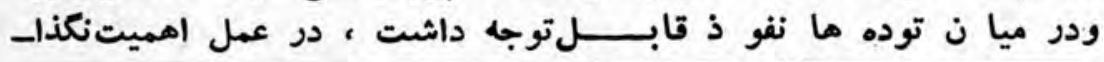

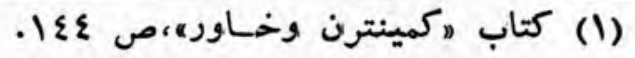




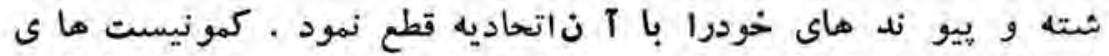

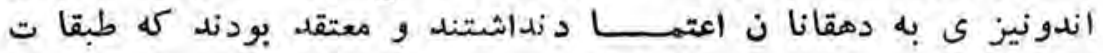

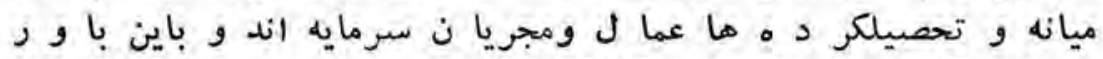
اشتبا ه آميز بودند كه طبقه كاركر به تنها يى و بدون اتهان اتحاد با دهقانان

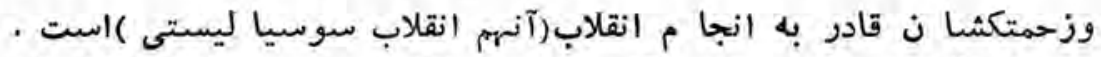

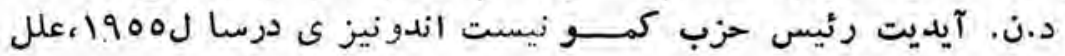

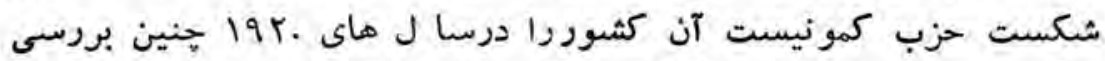

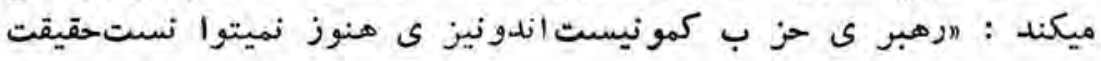

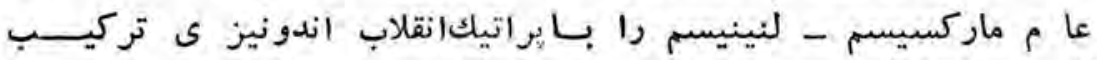

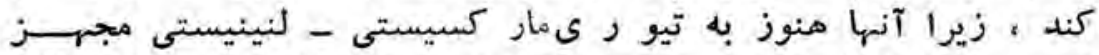

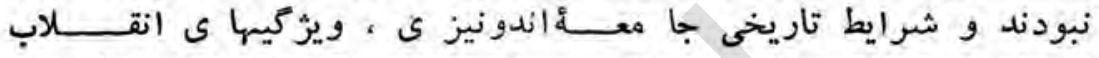

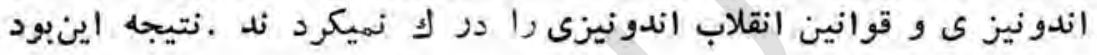

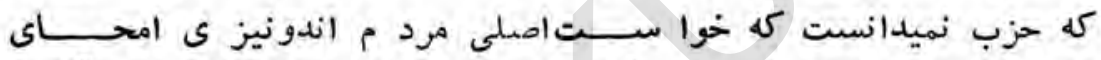

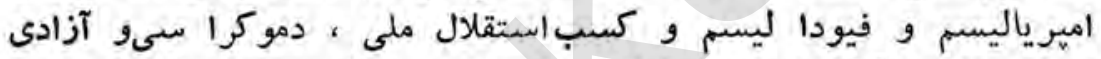

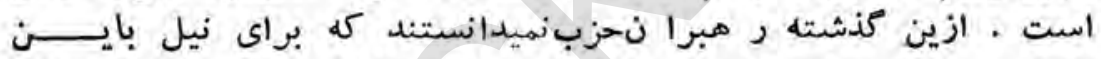

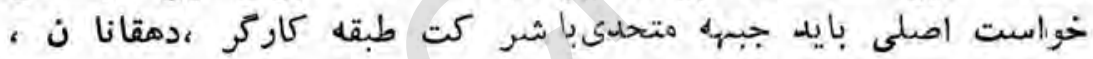

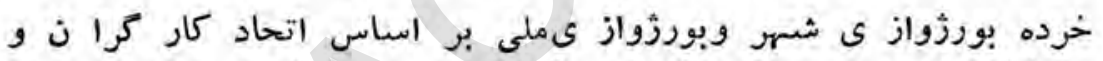

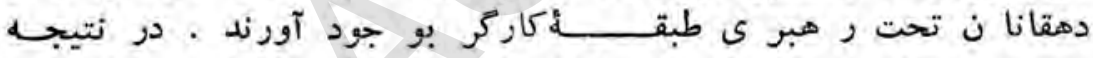

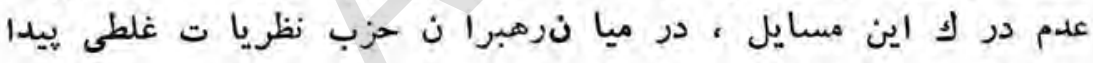

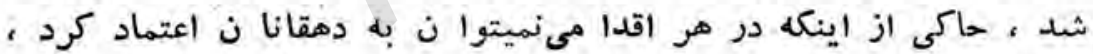

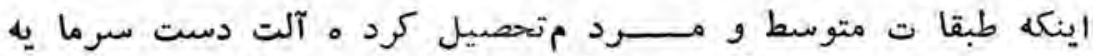

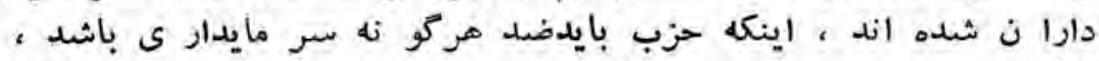

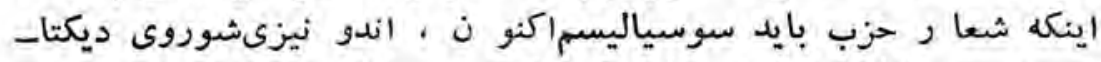

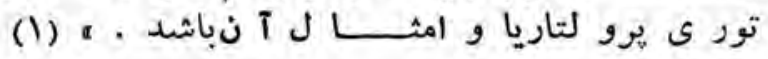

(1) د.ن. آيديت ، تاريخ حز بكمونيست اندونيز يا ، دهلى جديد، 11-1900 ، 11900 


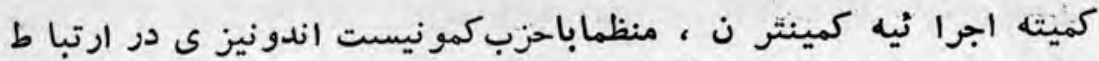

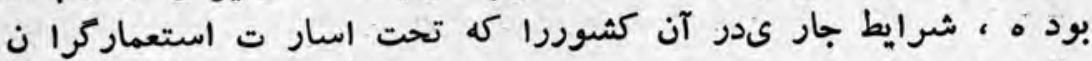

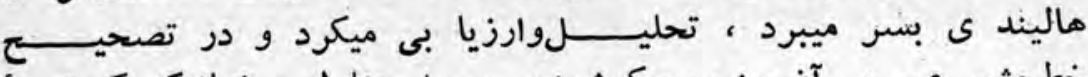

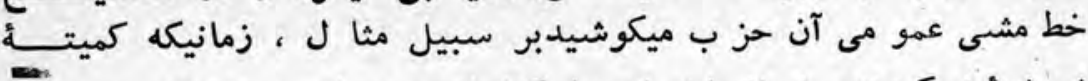

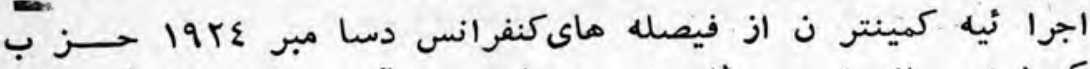

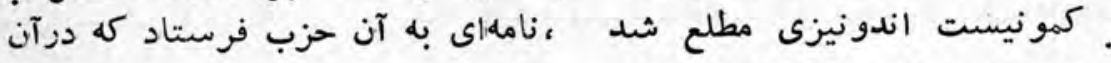

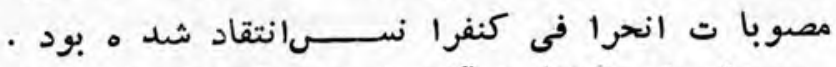

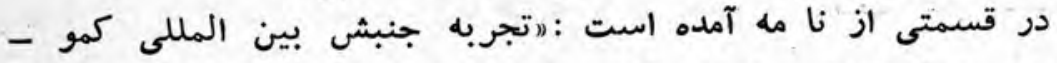

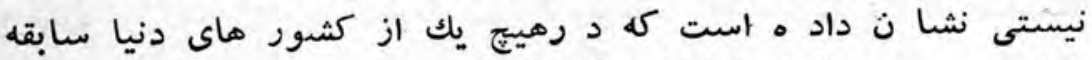

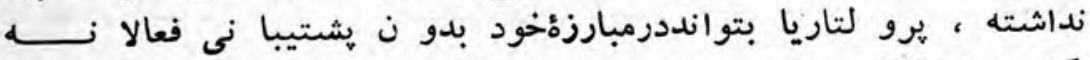

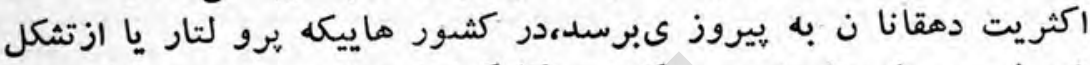

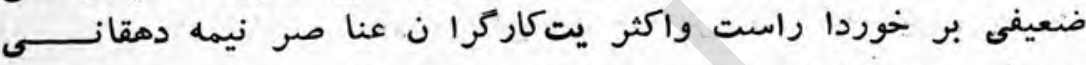

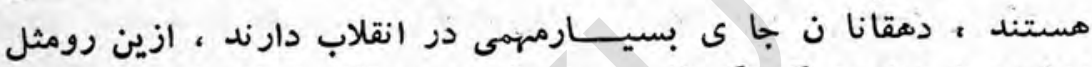

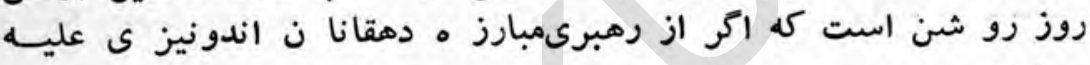

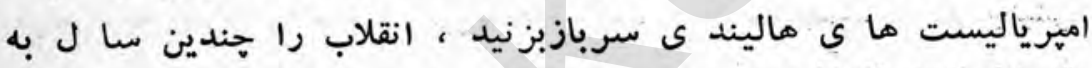

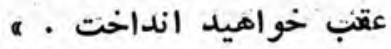

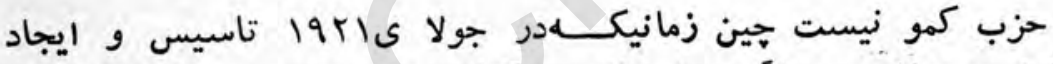

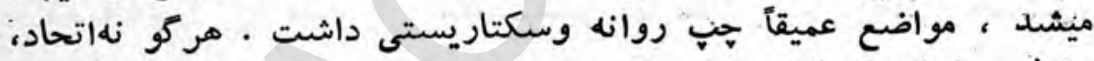

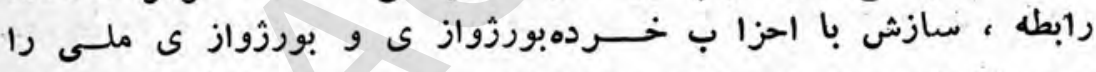

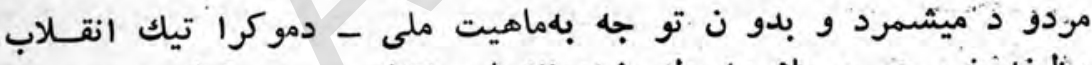

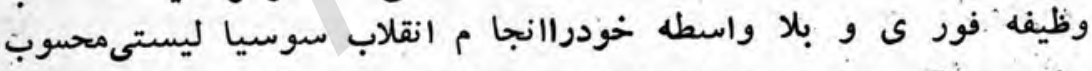

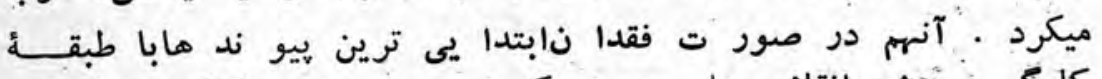

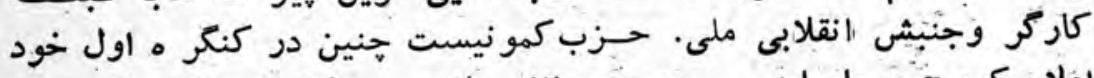

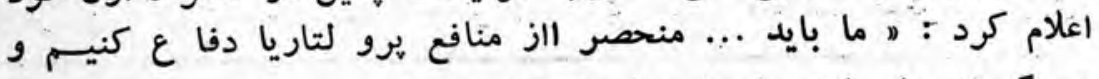

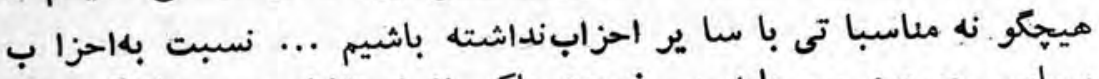

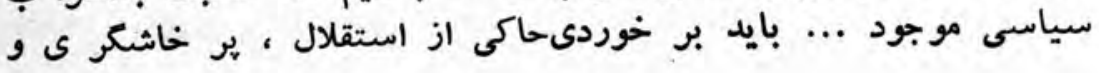




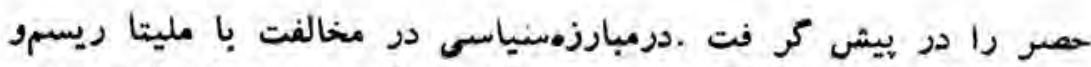

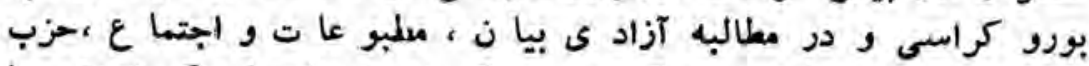

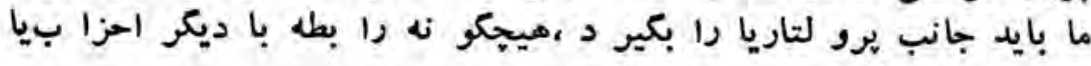

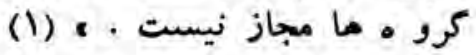

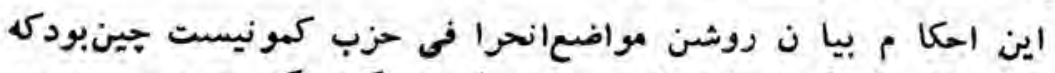

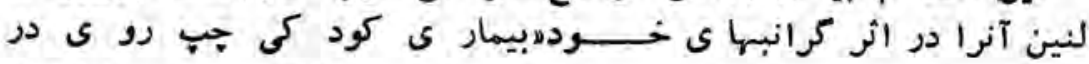

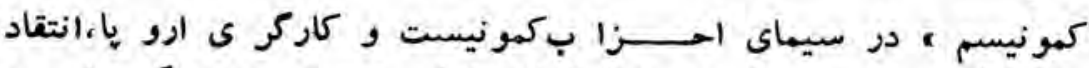

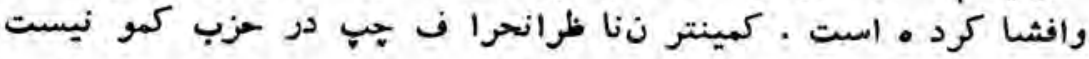

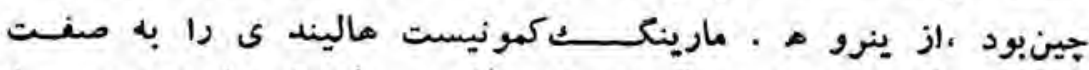

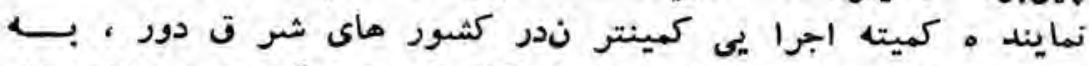

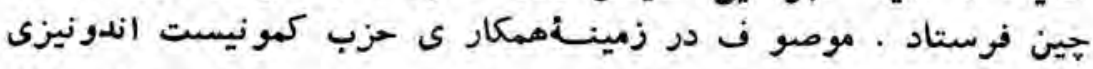

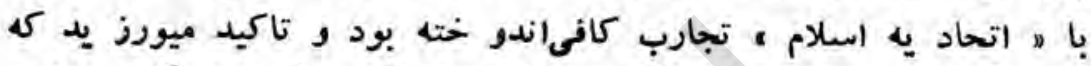

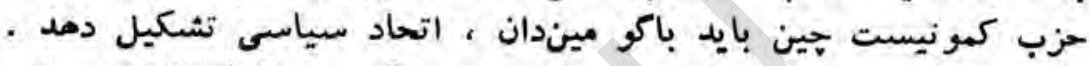

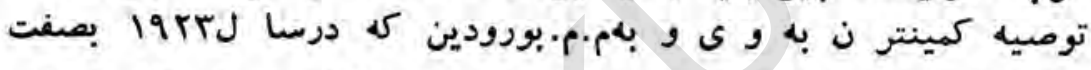

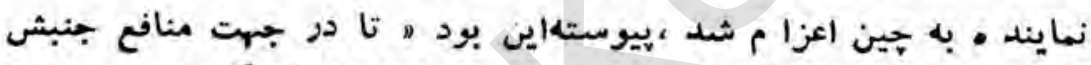

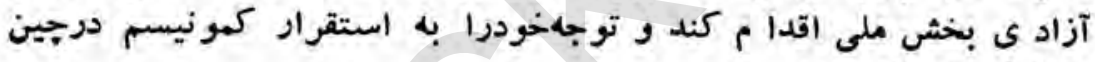

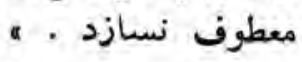

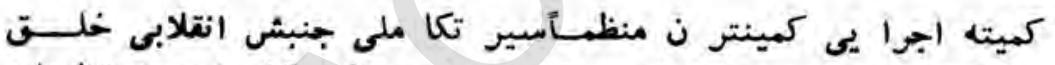

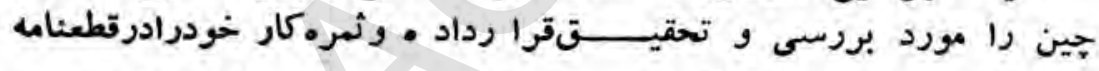

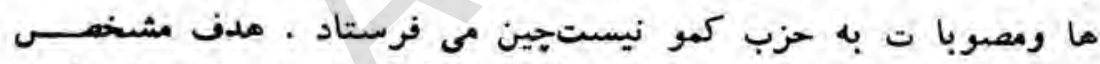

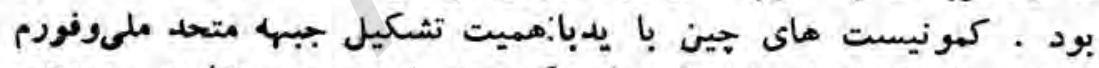

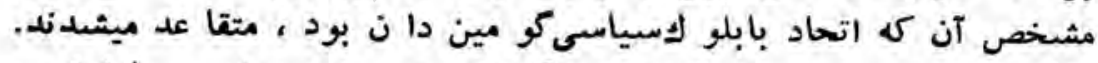

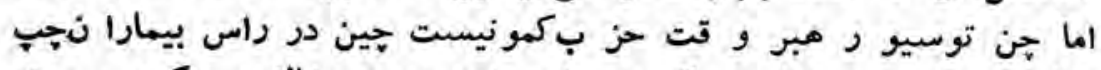

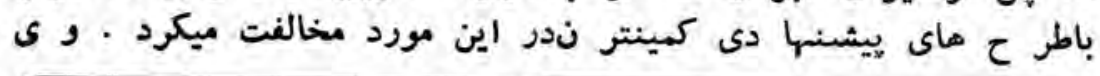

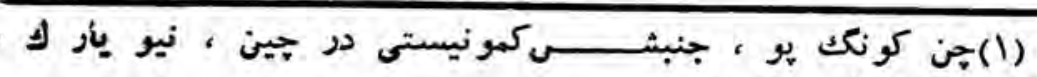

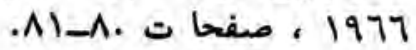




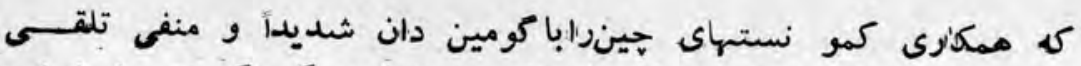

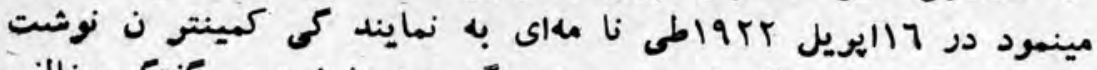

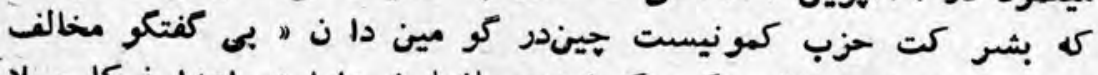

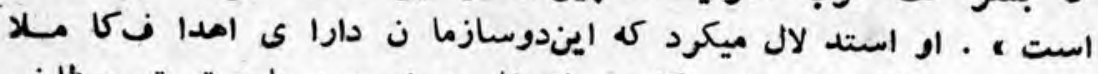

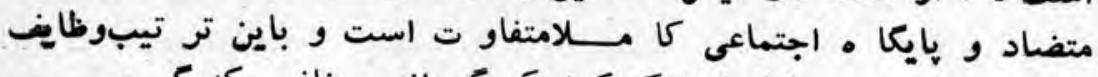

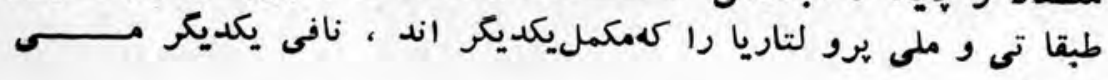

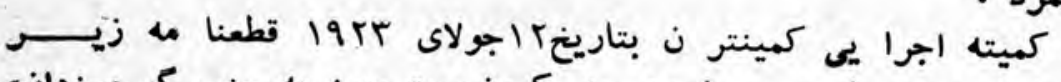

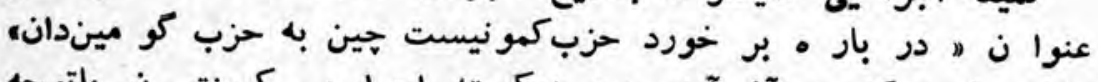

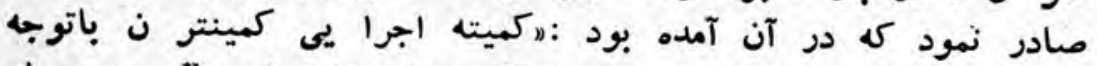

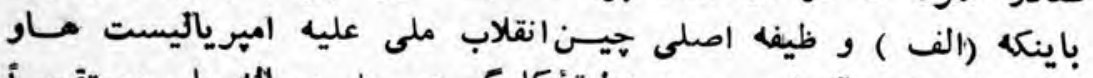

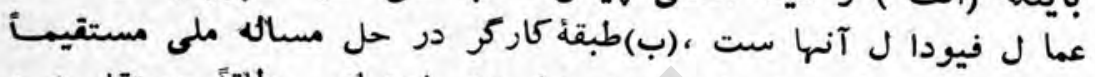

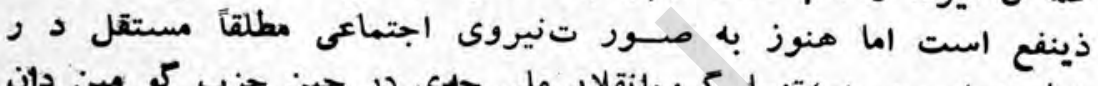

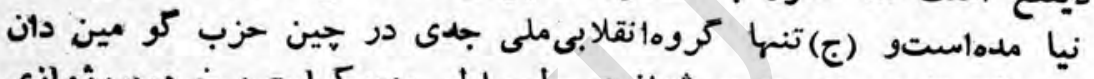

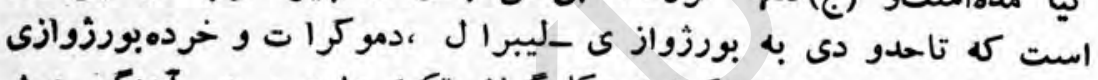

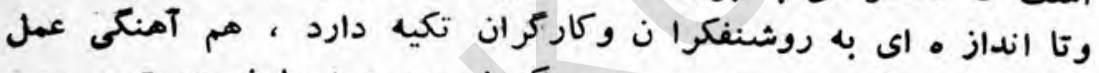

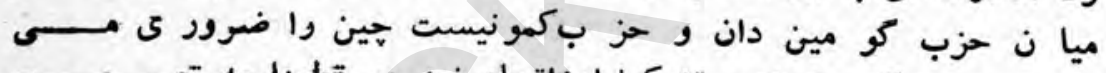

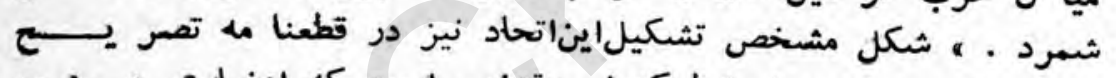

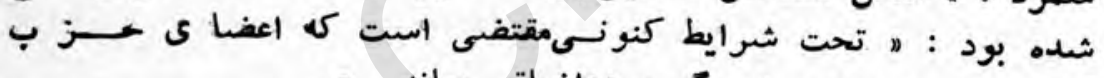

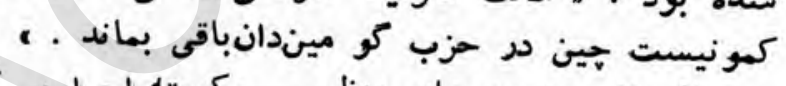

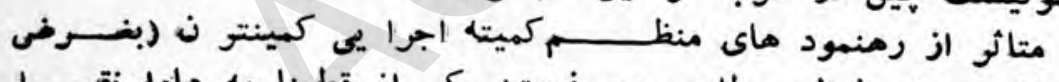

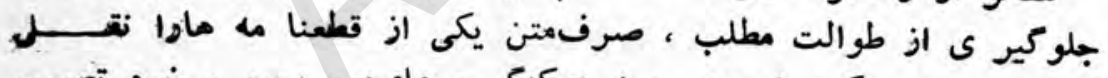

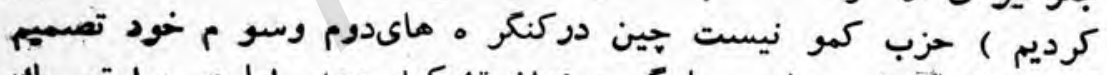

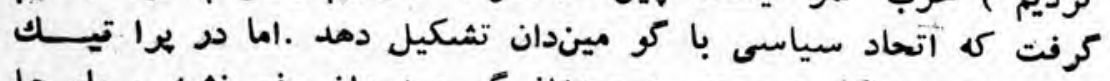

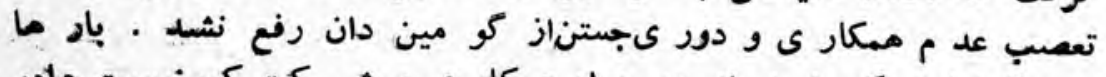

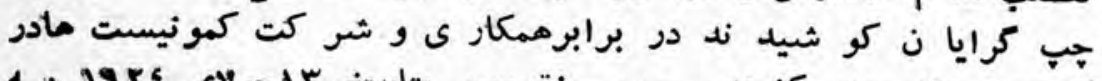

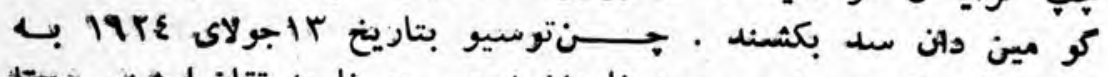

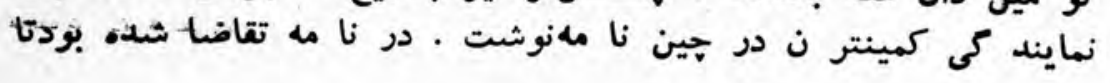




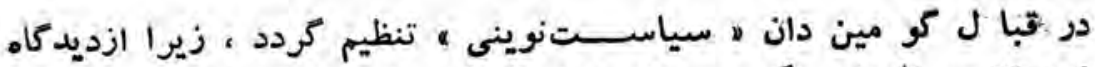

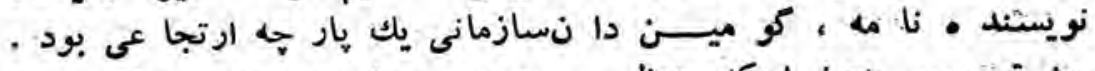

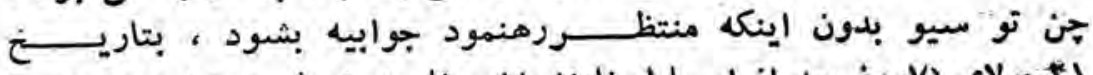

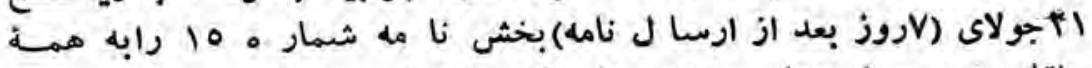

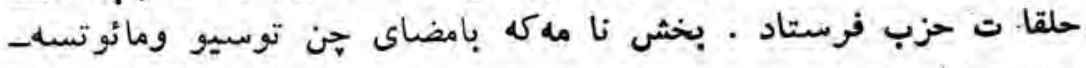

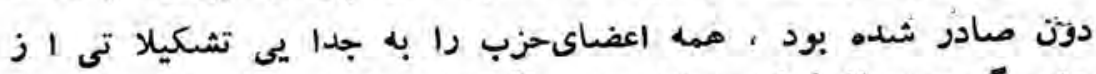

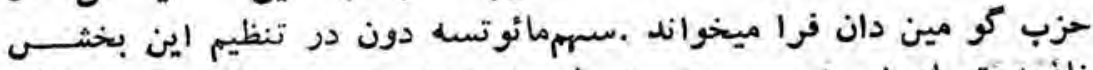

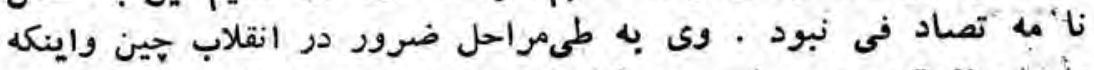

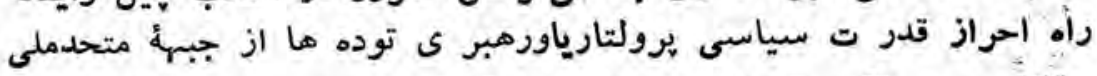

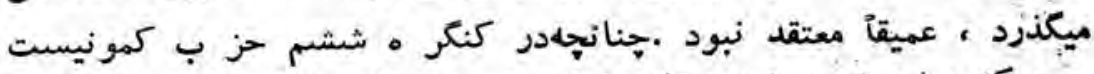

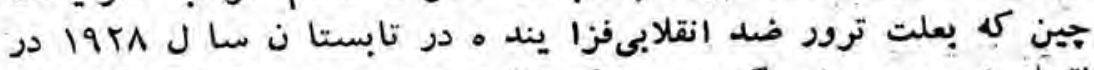

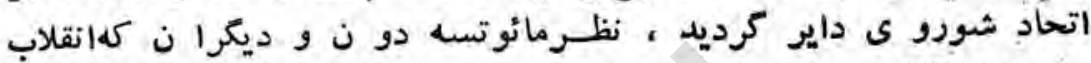

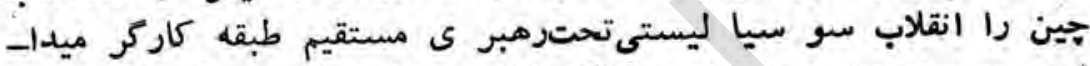

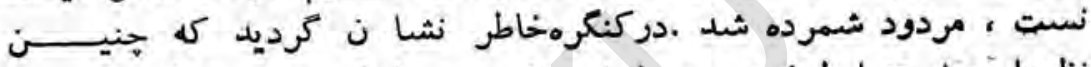

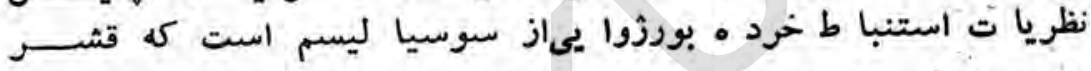

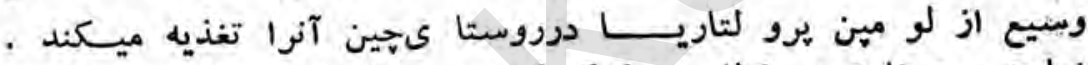

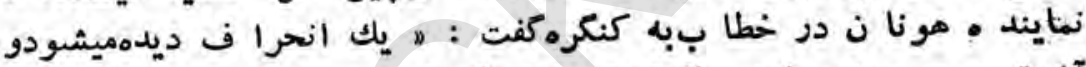

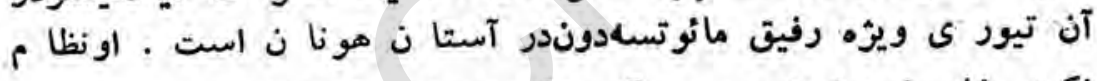

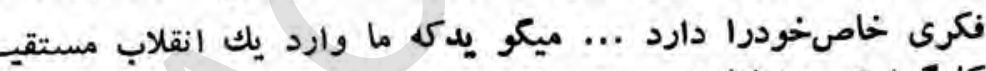

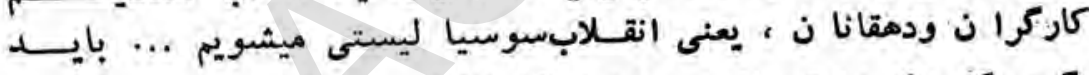

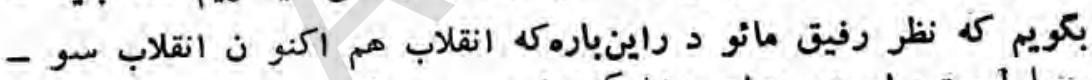

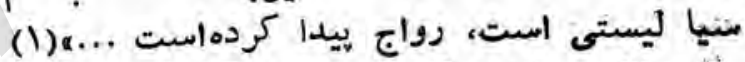

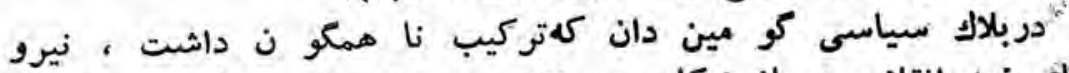

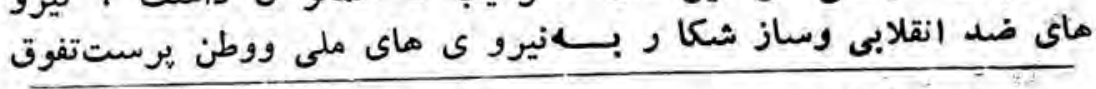

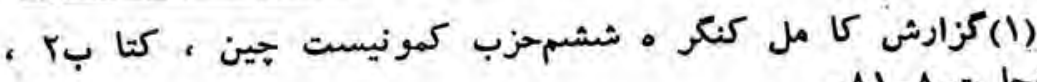
صفحا ت.ی-1). 


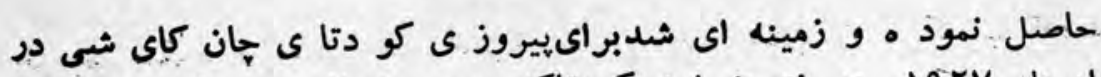

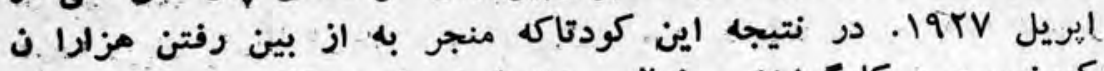

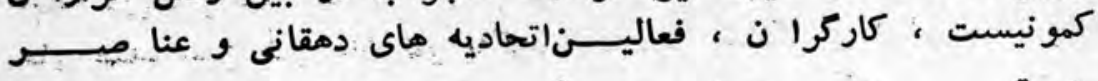

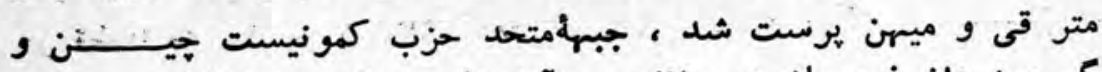

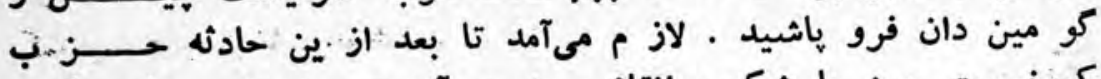

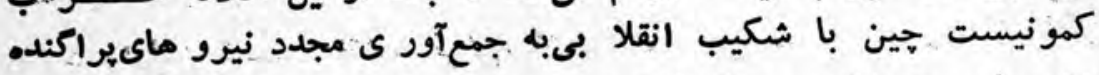

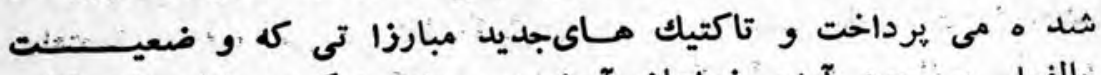

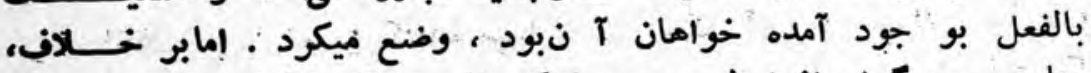

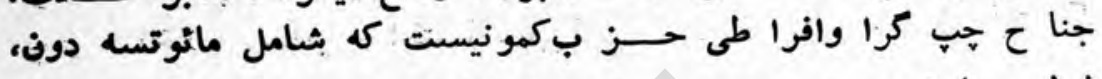

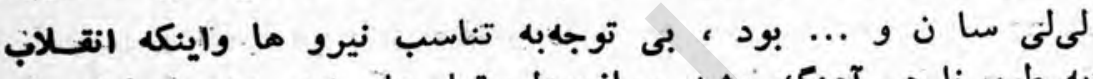

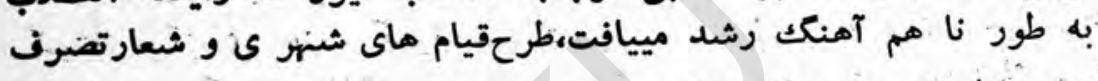

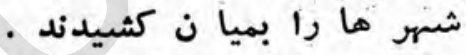

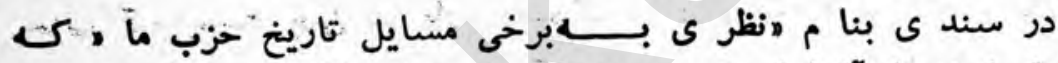

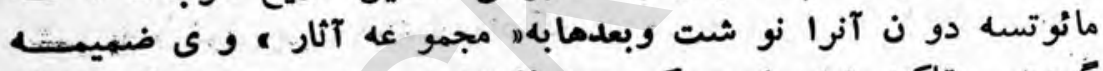

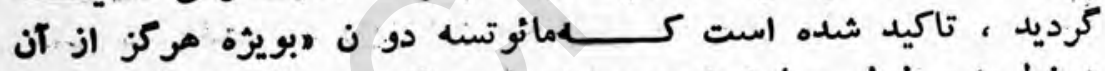

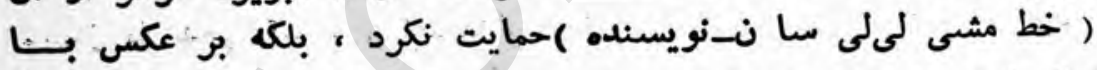

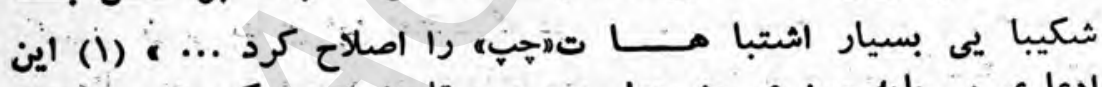

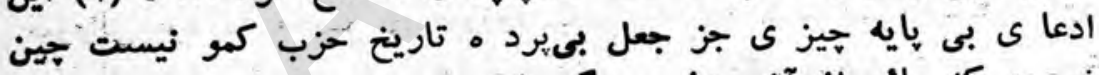

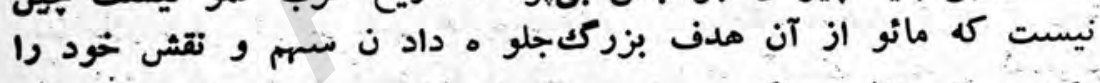

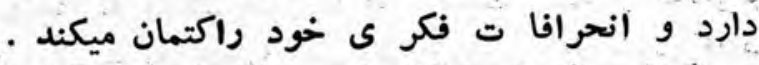

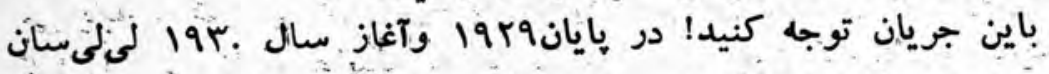

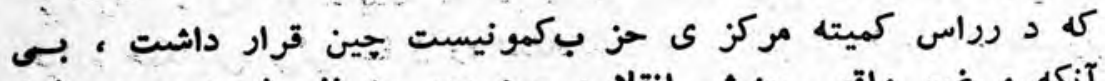

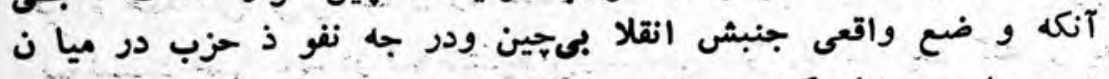

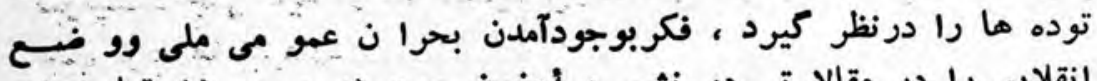

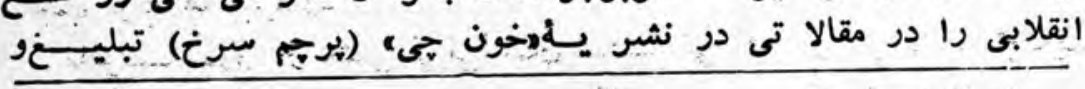

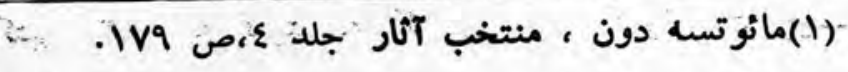




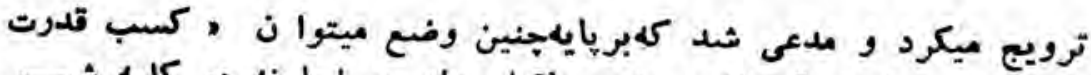

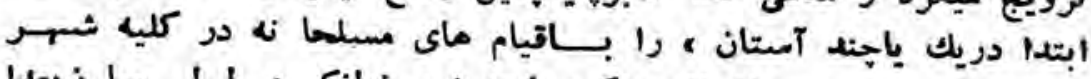

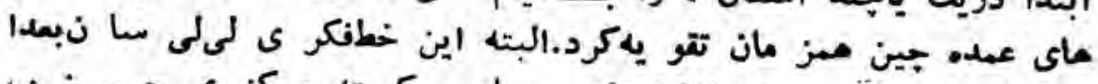

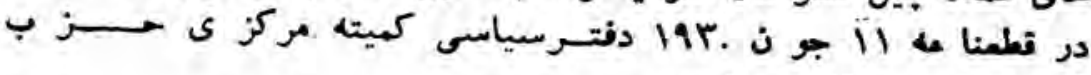

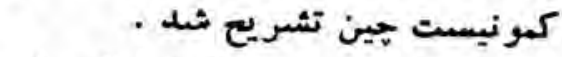

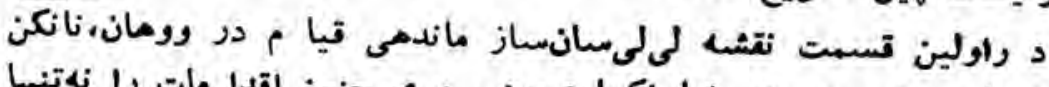

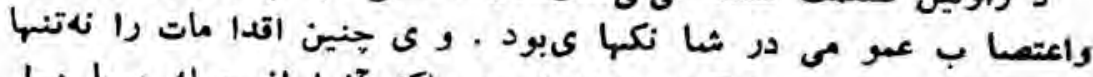

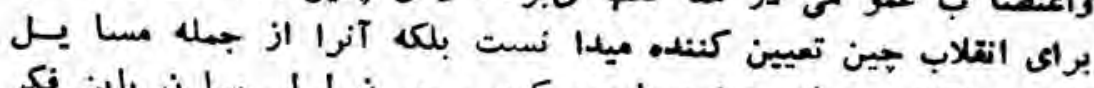

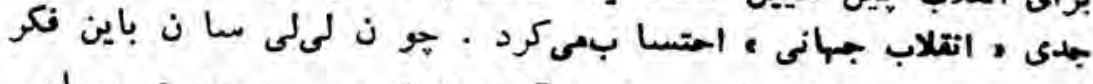

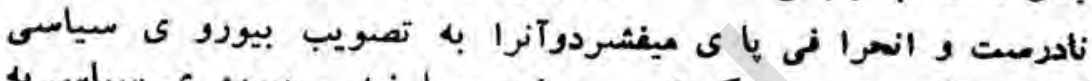

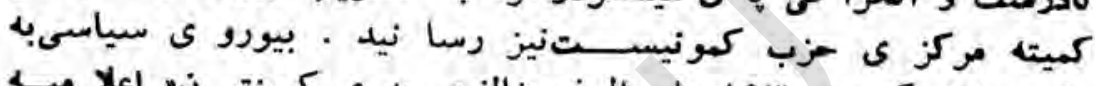

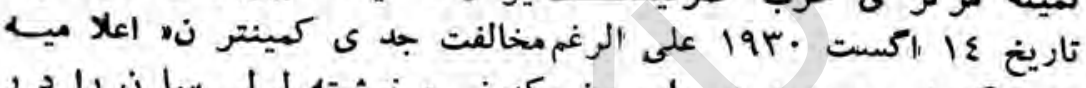

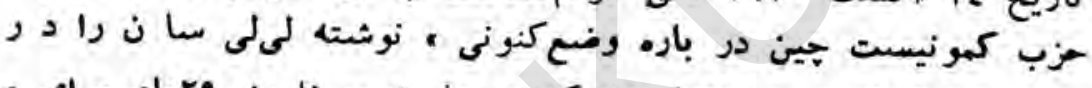

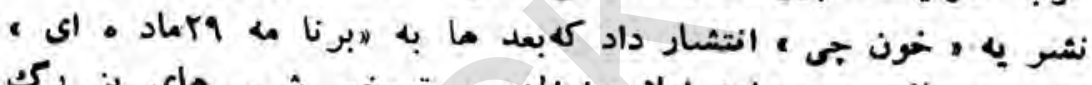

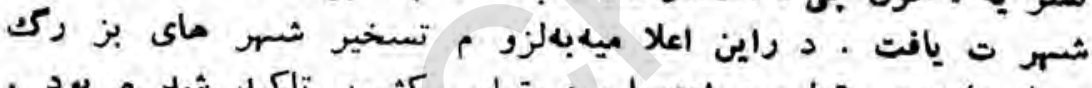

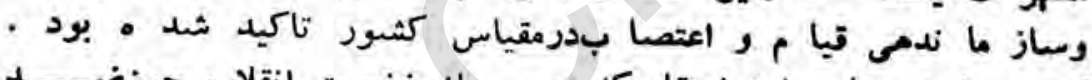

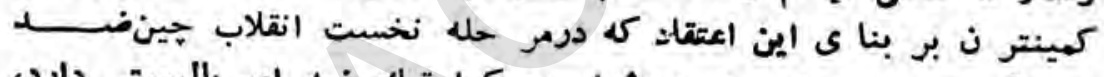

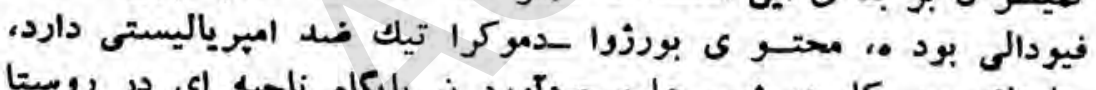

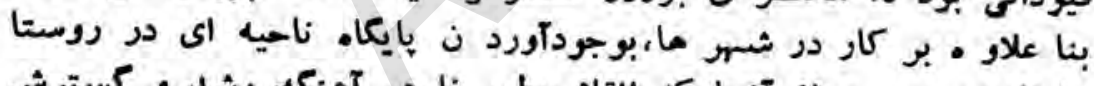

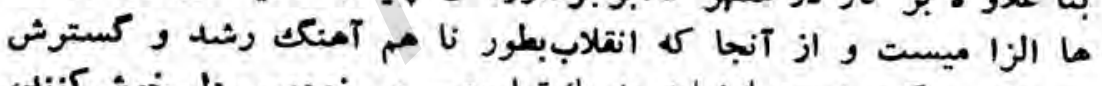

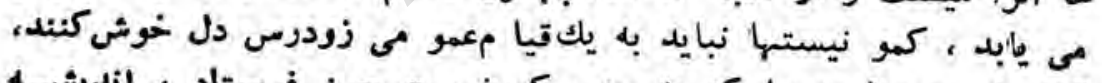

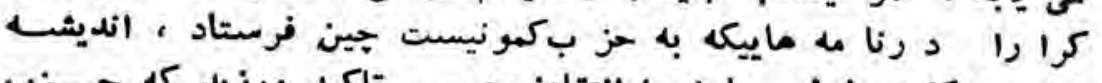

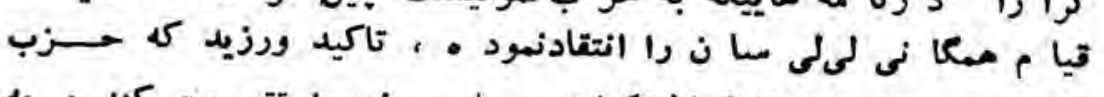

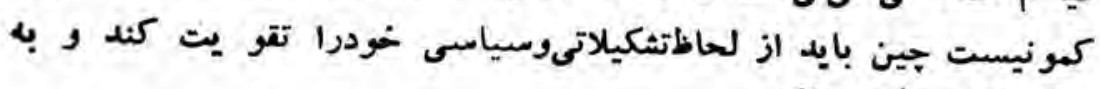

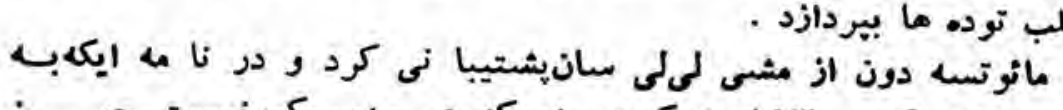

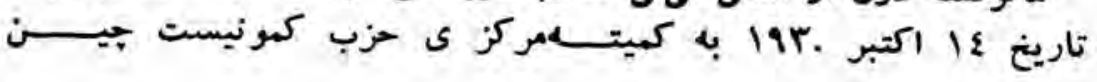




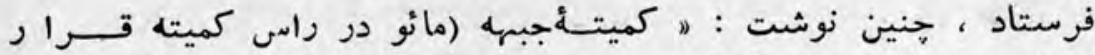

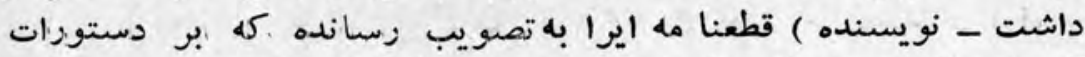

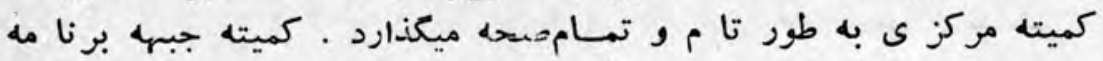

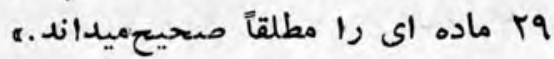

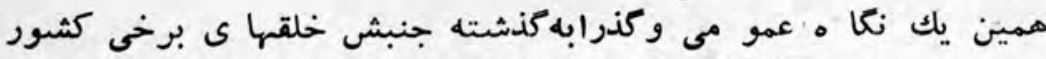

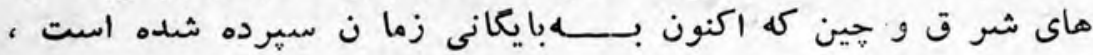

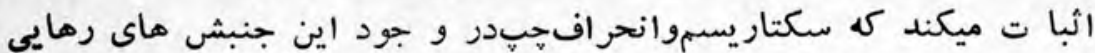

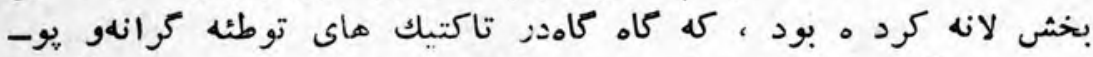

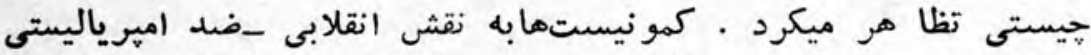

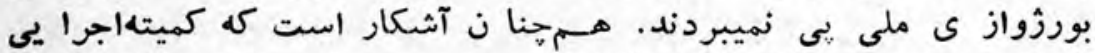

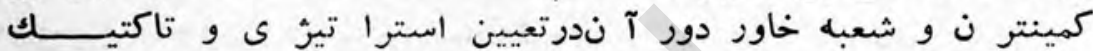

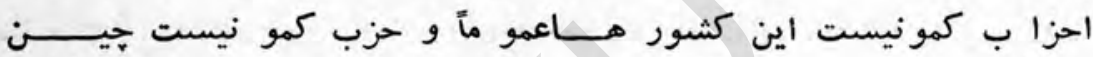

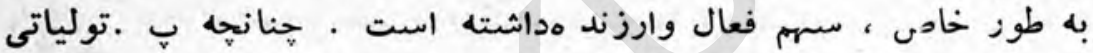

$$
\text { مينويسد : }
$$

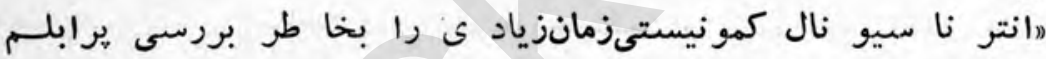

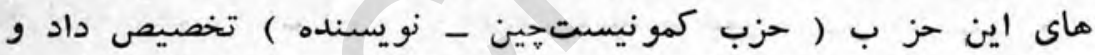

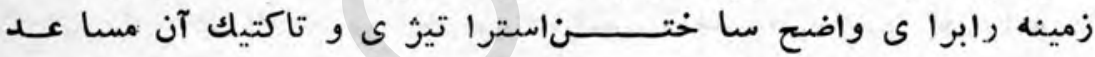

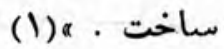

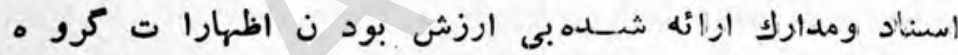

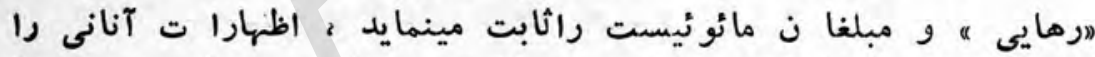

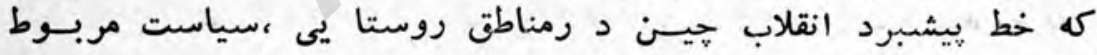

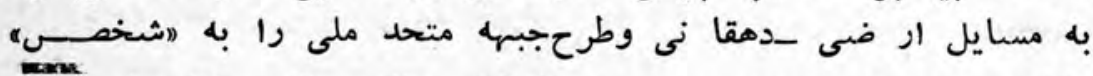

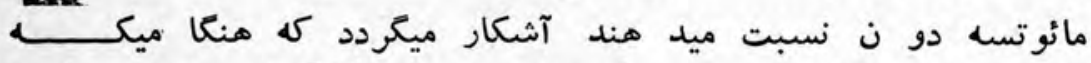

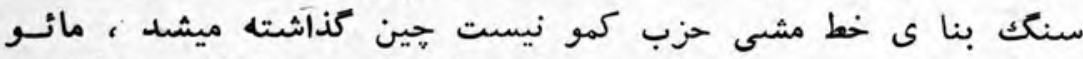

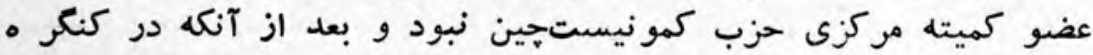

(1) مسايل صلح و سو سياليسمشماره 1909، 1999 11 


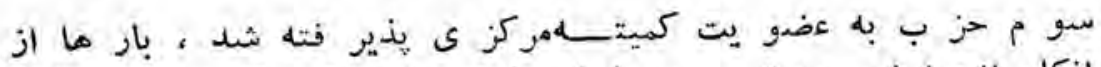

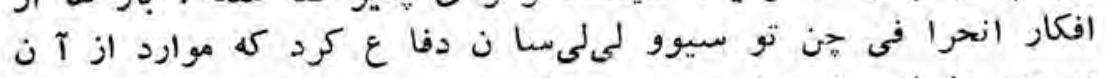

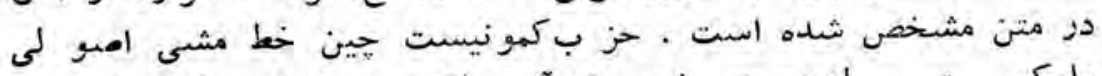

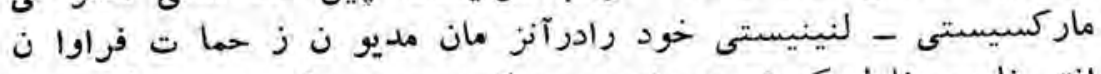

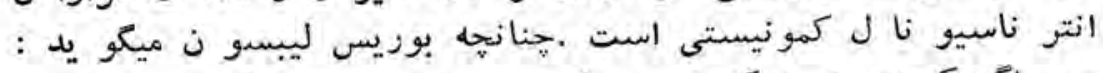

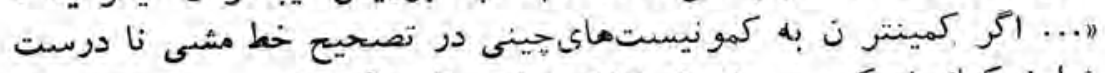

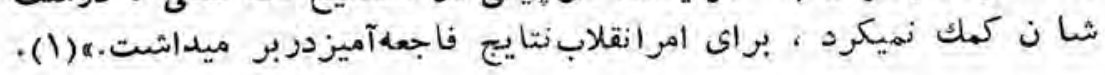

\section{米}

\section{米}

*

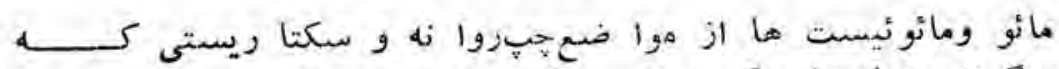

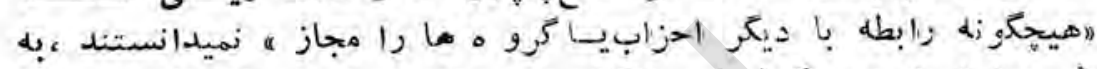

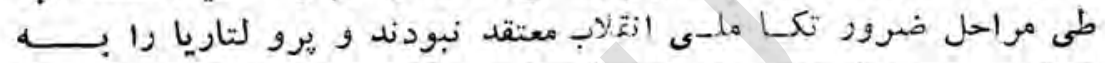

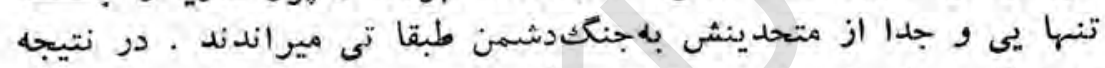

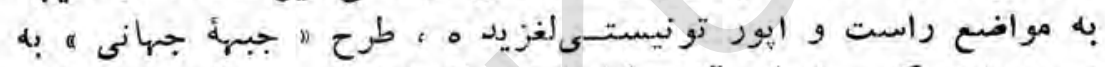

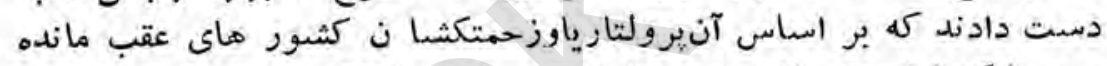

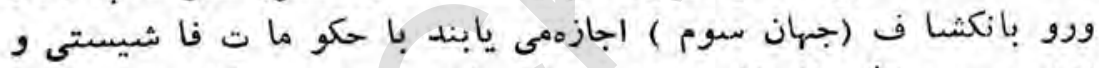

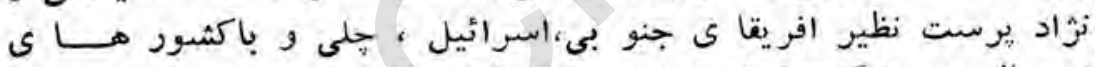

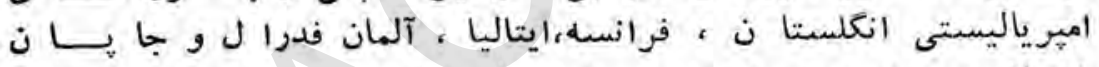

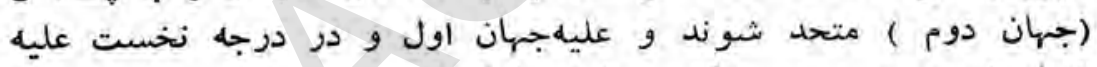

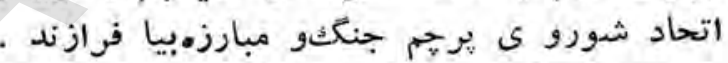

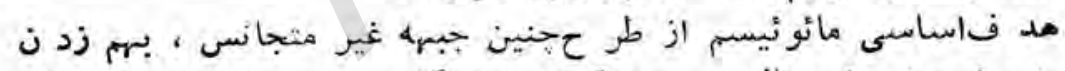

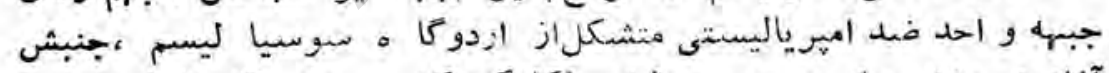

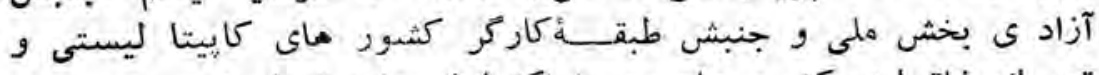

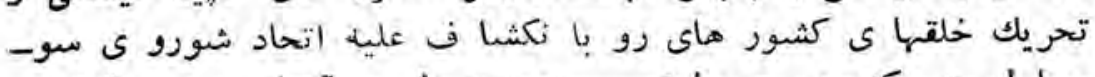

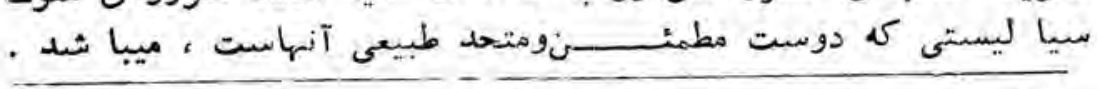

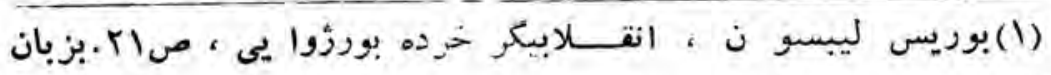
فارسى . 


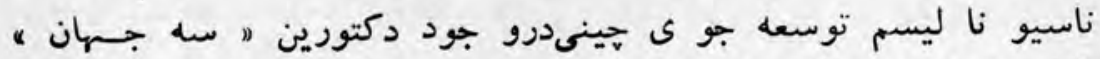

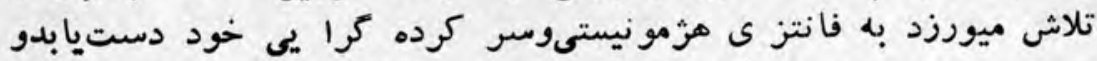

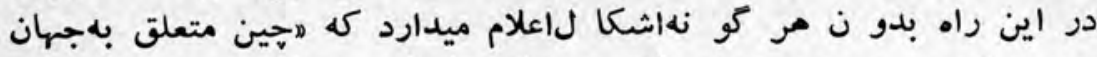

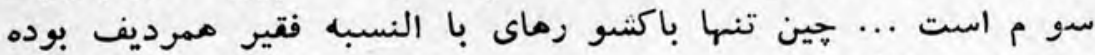

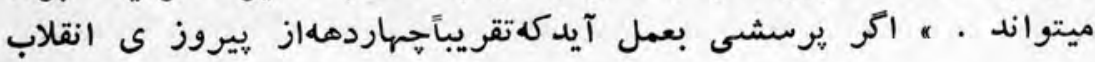

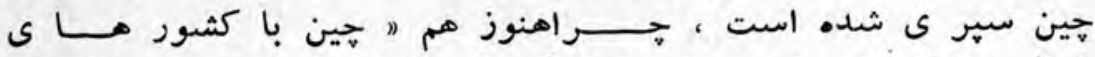

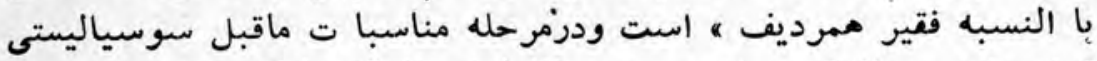

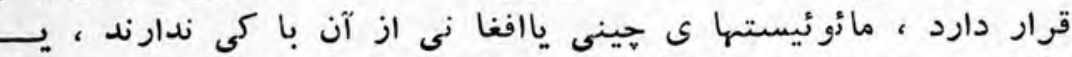

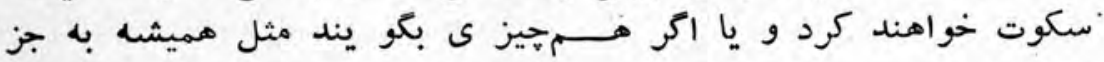

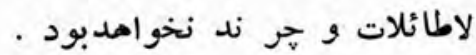

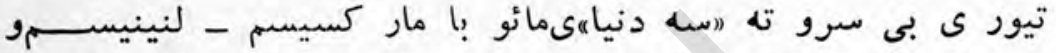

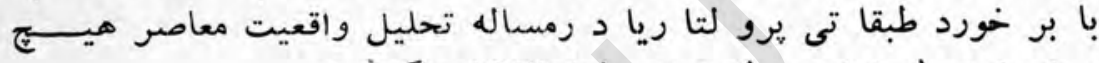

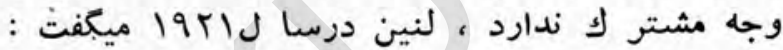
״امووز در سطح كيتى دو جهانوجود دارد . جها ن كهن يعنى جهان

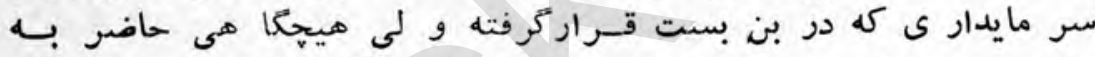

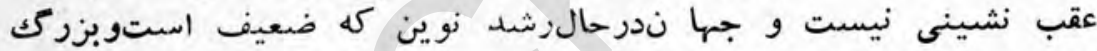

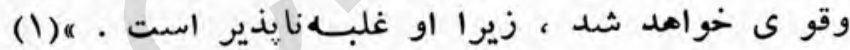

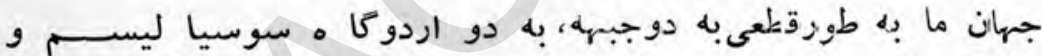

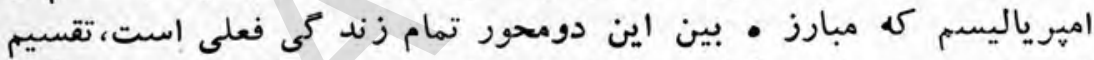

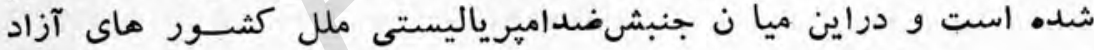

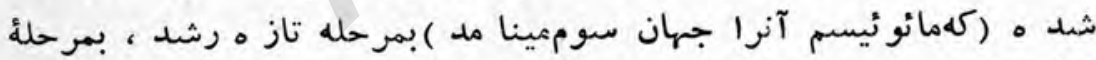

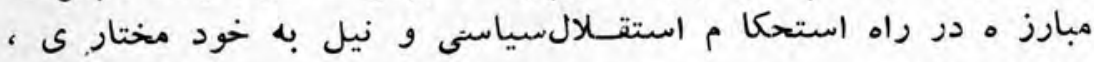

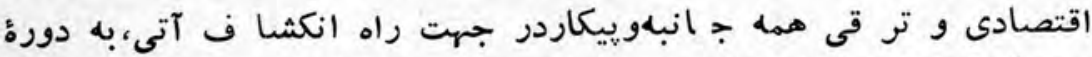

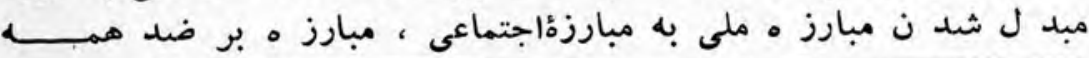

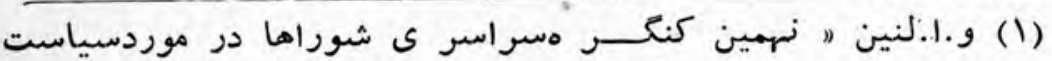

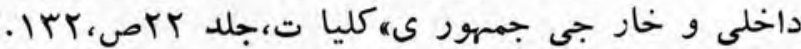




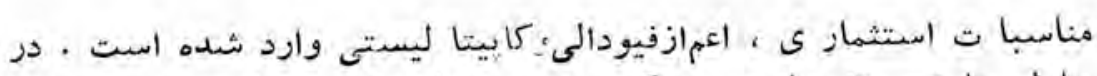

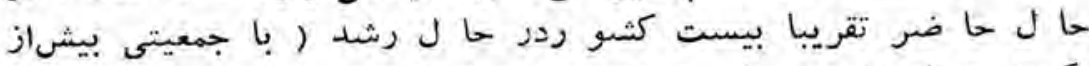

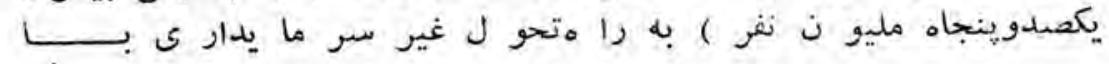

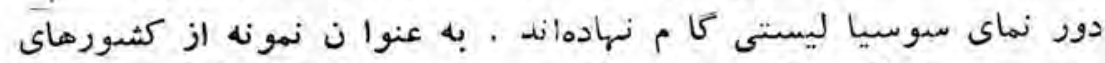

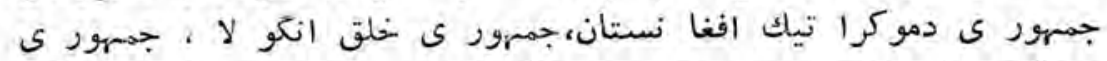

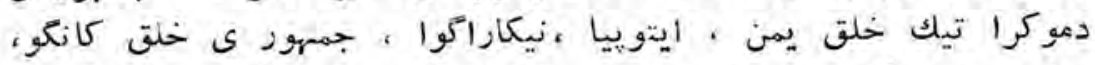

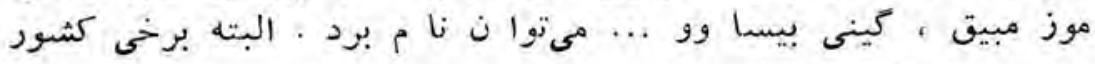

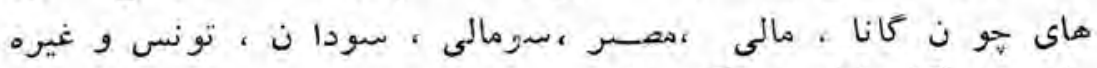

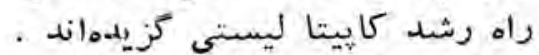

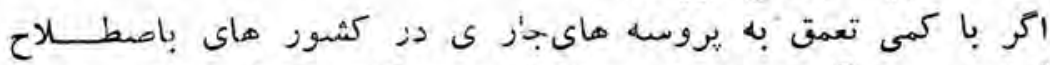

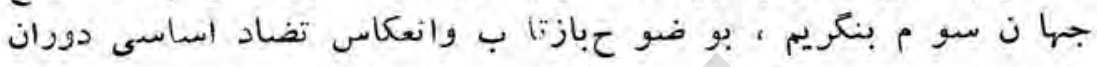

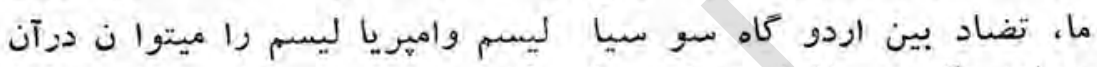

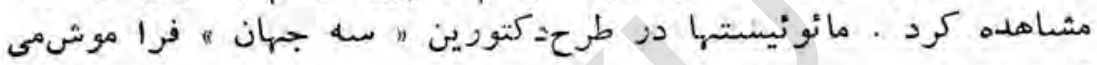

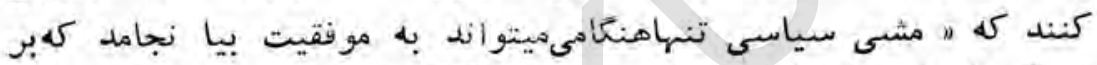

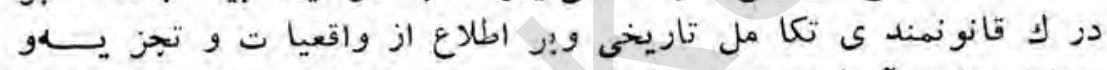

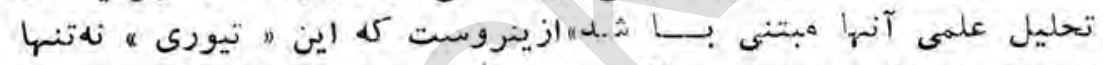

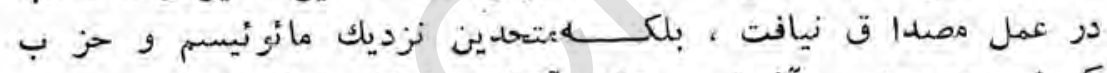

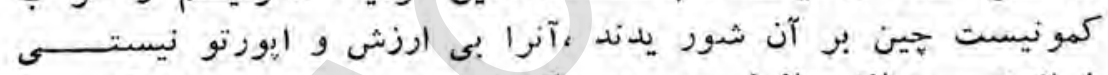

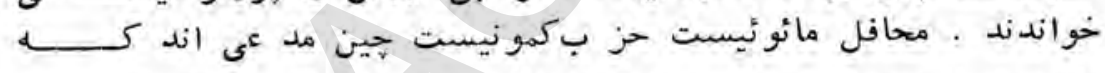

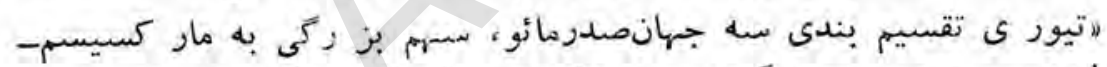

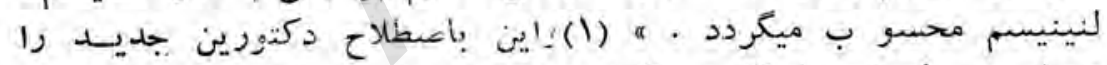

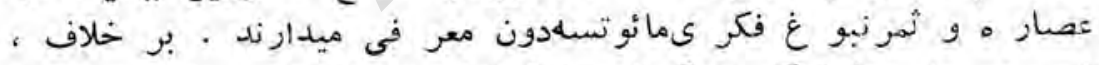

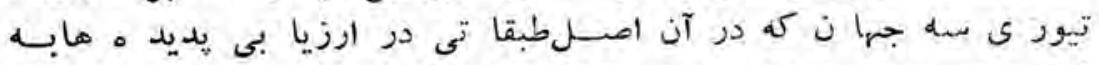

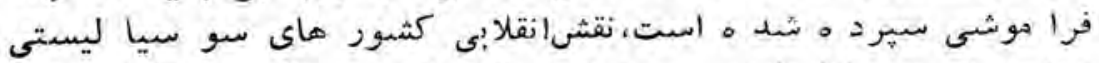

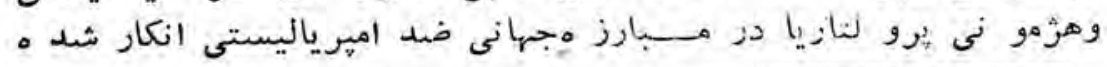

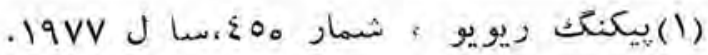




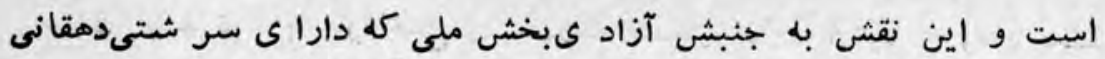

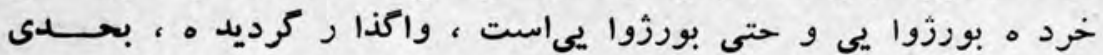

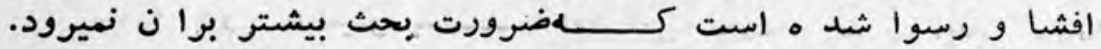

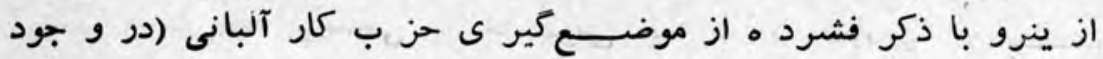

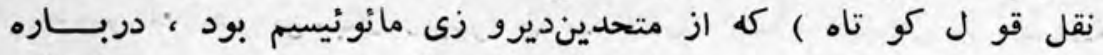

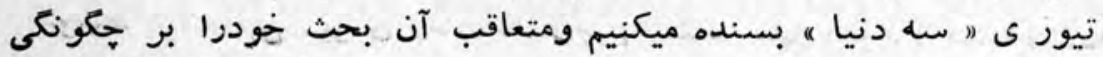

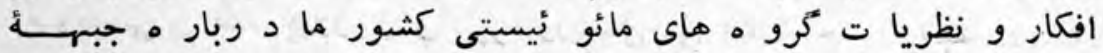

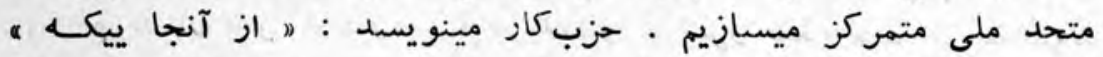

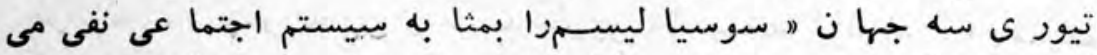

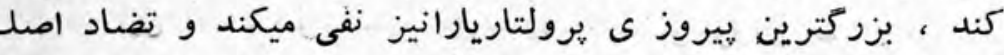

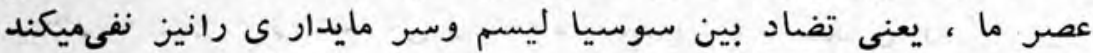

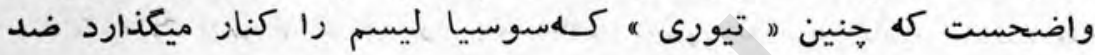

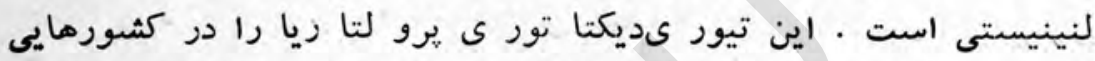

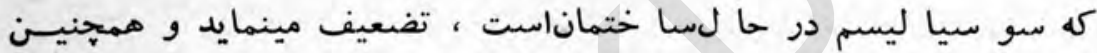

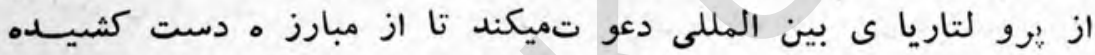

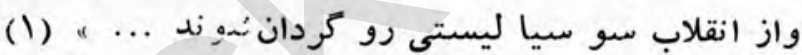

\section{* * *}

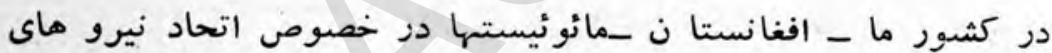

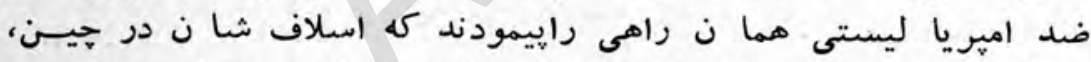

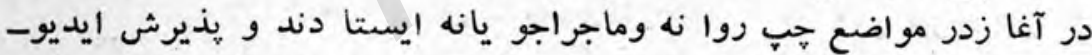

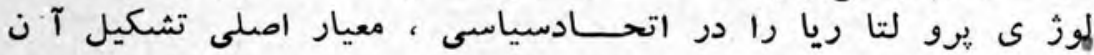

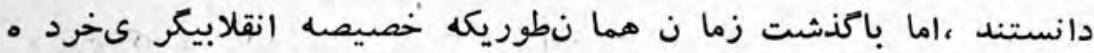

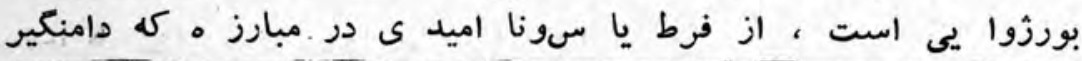

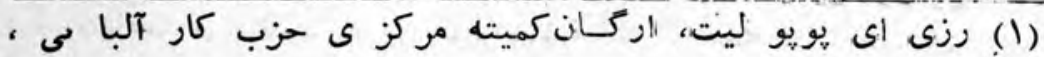

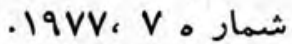


شا ن ميشود ، به موا ضع راستوسازشكارا نه با ارتجا ع واميرياليم سقوط نمودند . ميثود ،

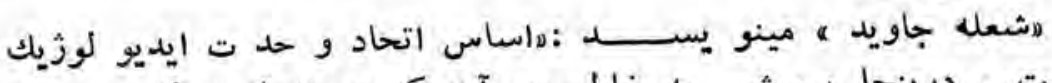

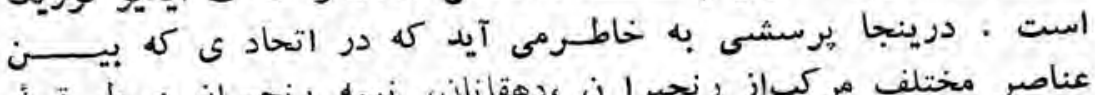

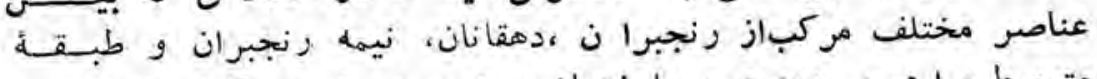

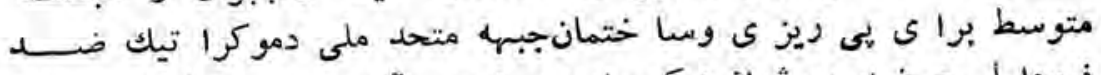

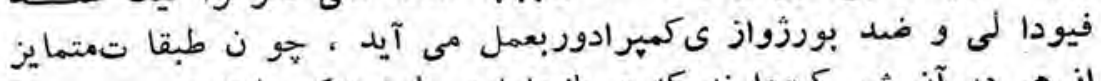

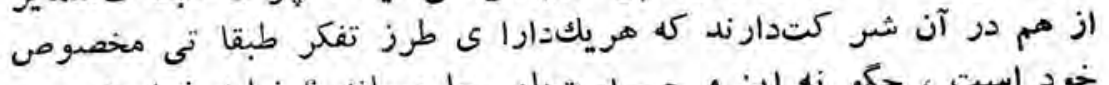

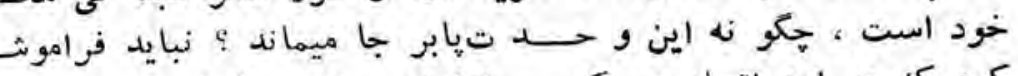

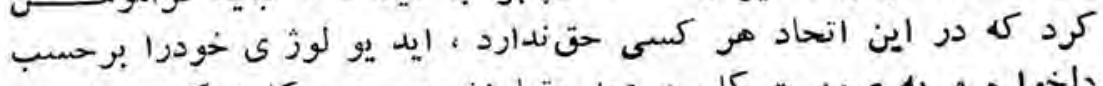

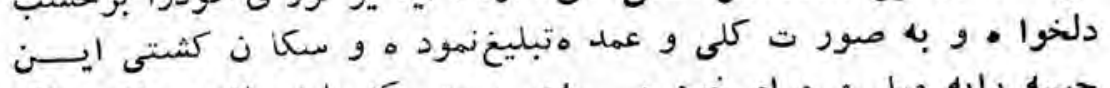

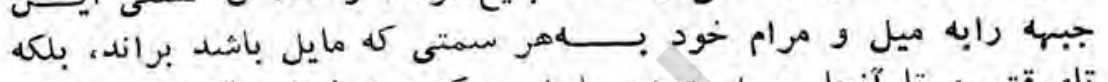

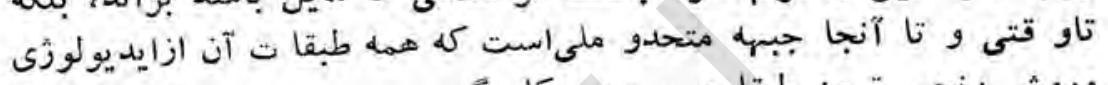

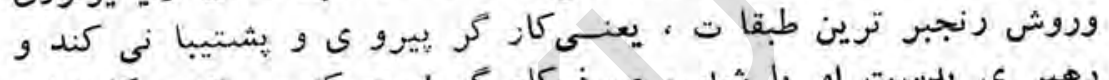

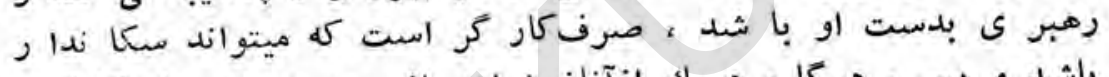

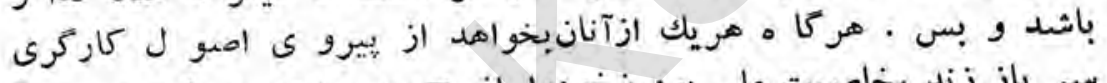

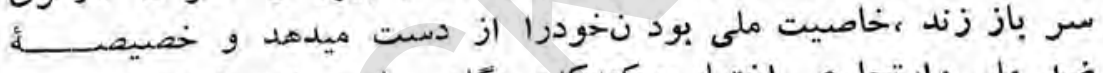

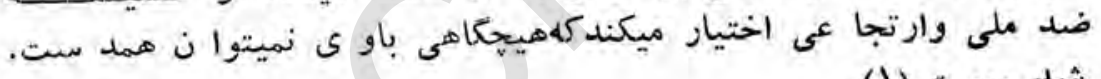

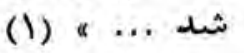

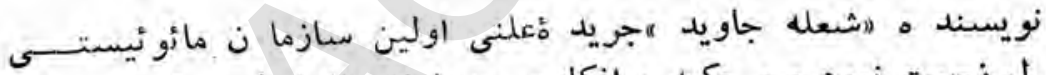

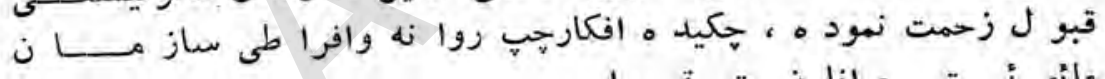

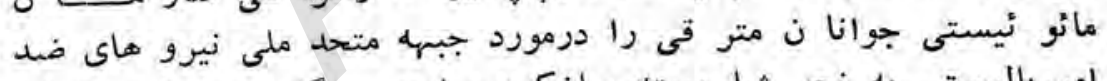

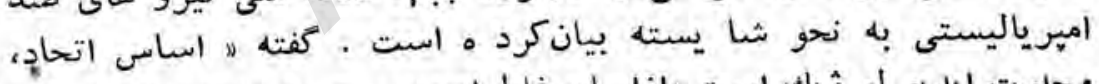

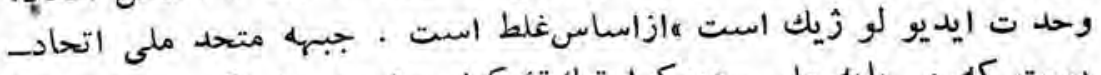

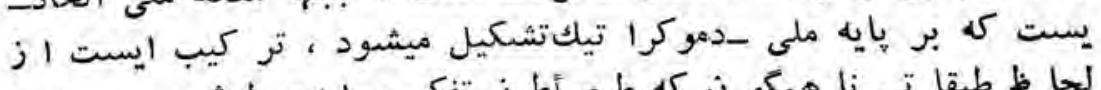

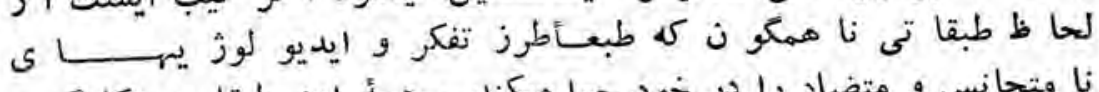

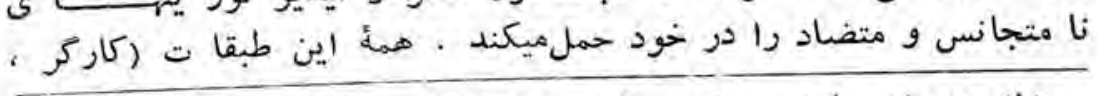

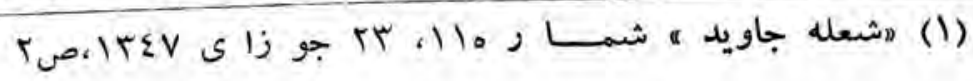


دمقان ، خرد ه بورزواز ى وبورزوازىملى ) با استقلال فكر ى وايديولو-

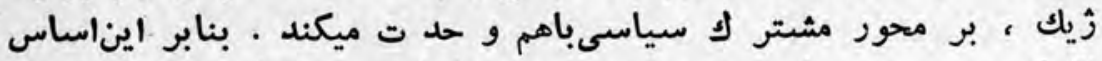

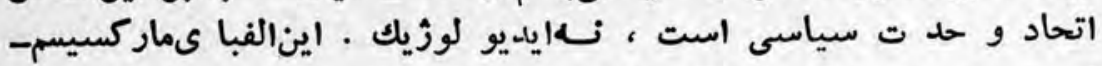

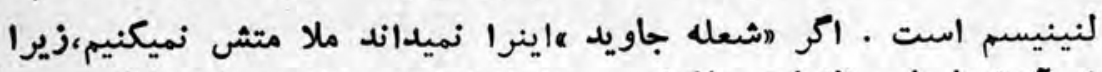

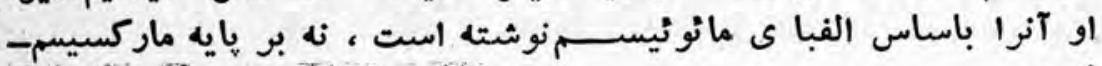

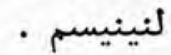

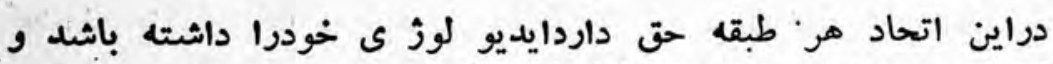

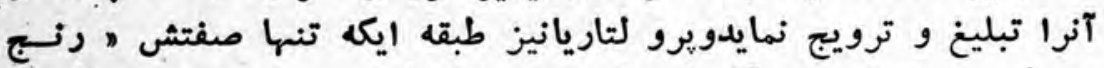

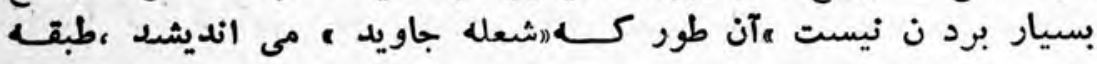

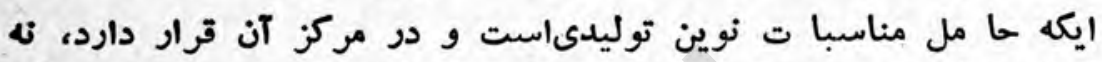

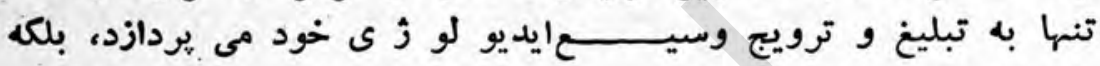

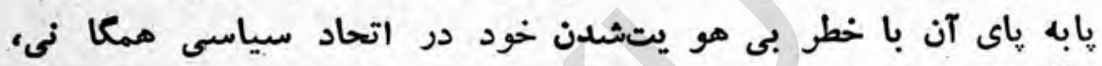

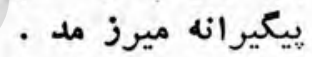

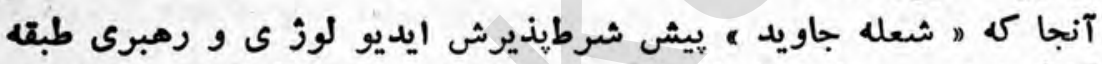

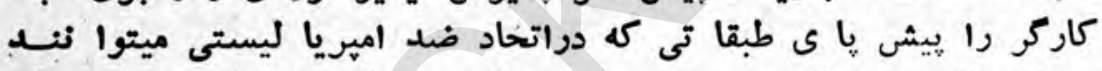

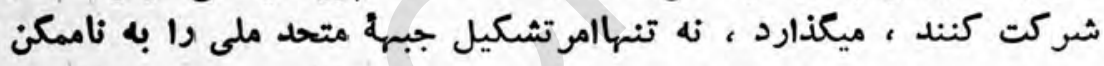

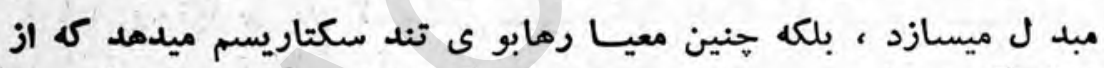

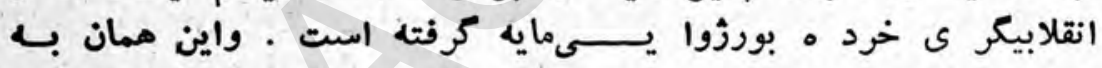

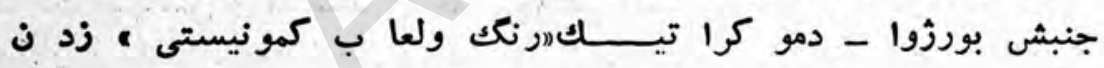

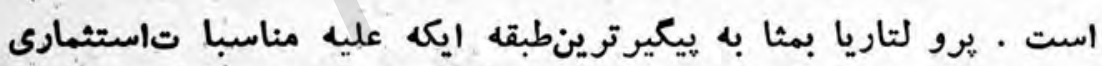

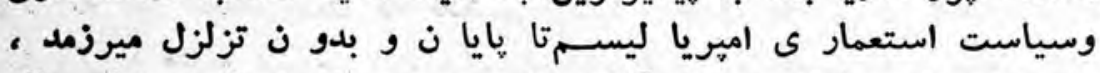

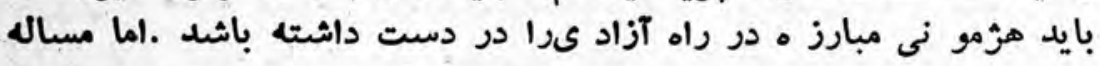

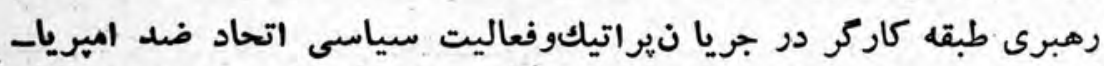

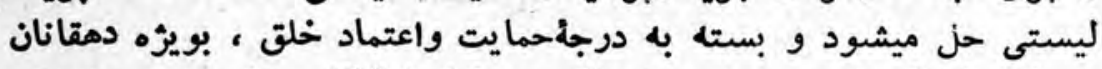

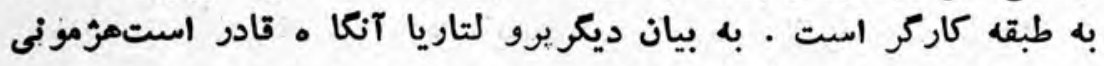
رابه جنكك آورد كه يشتيبا نىوسيعدهقانا ن را جلب كند ـ ـ اين محسور

- Ylo 


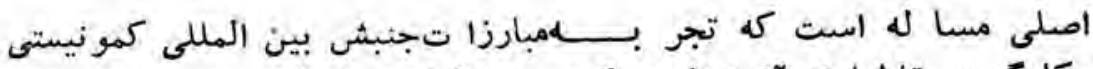

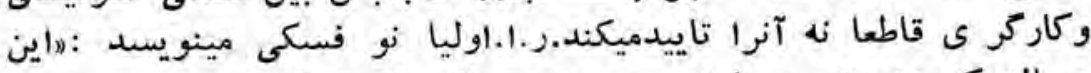

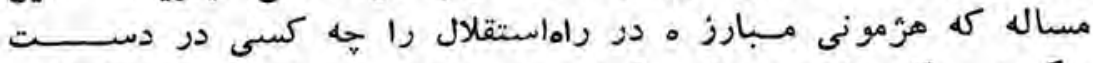

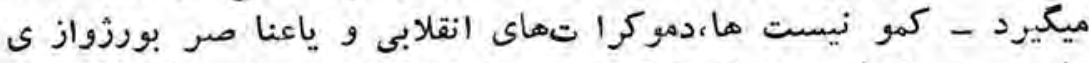

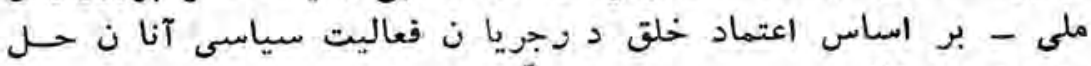

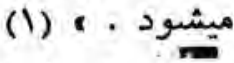

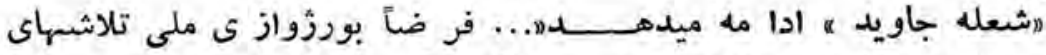

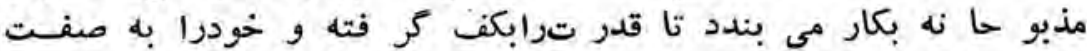

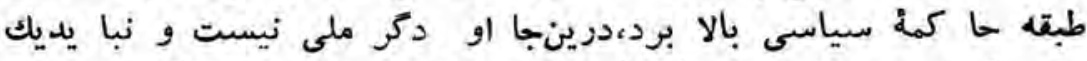

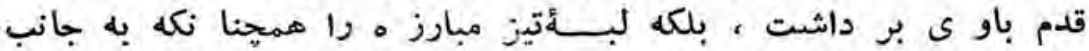

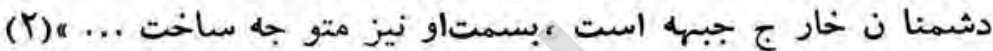

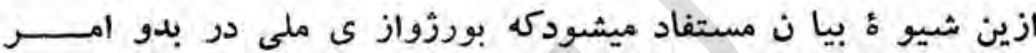

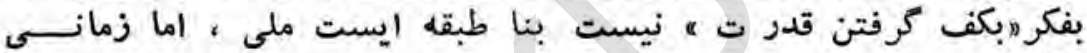

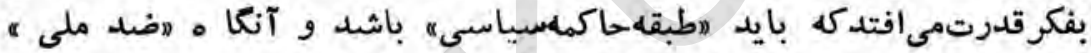

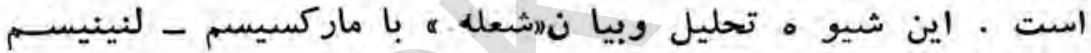
بيكانه است . المن

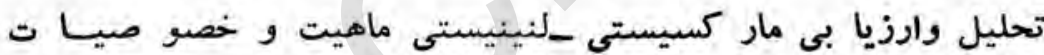

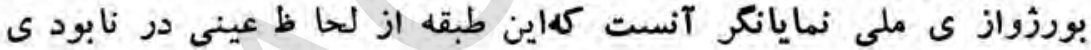

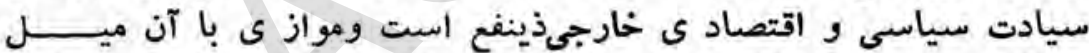

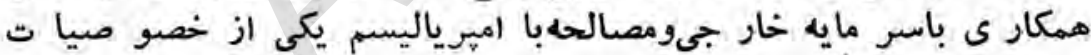

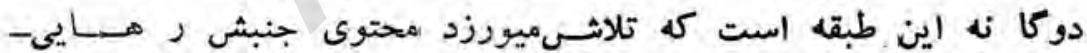

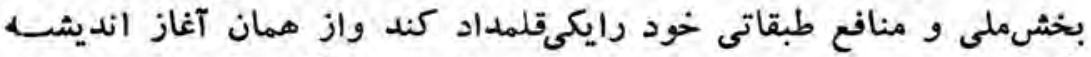

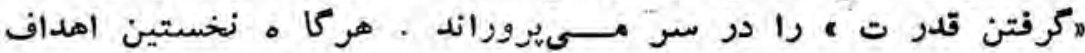

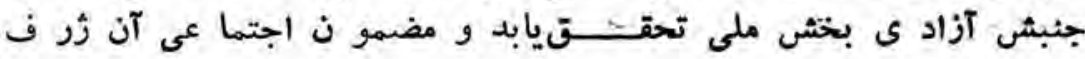

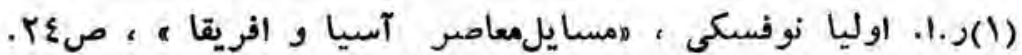

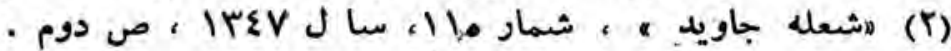




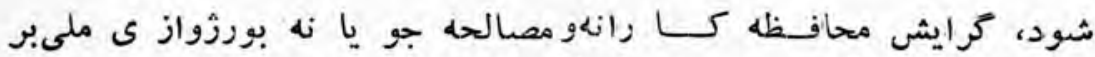

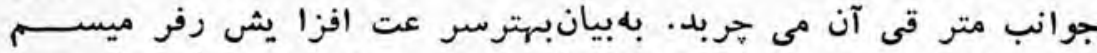

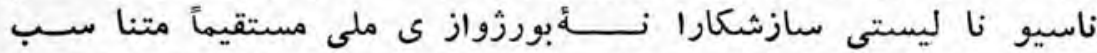

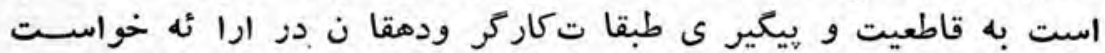

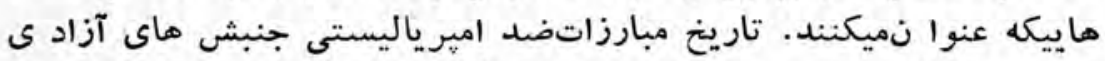

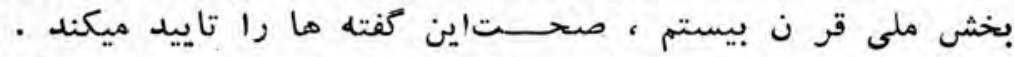

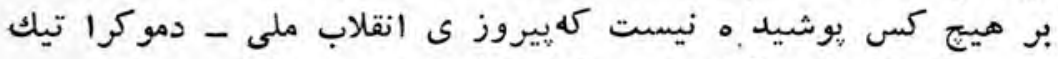

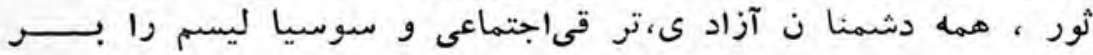

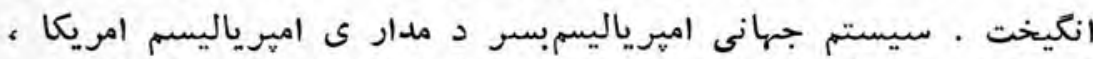

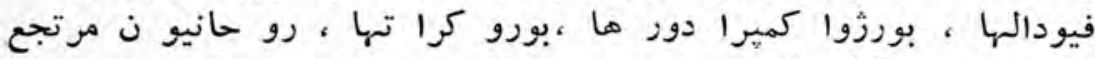

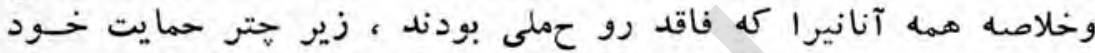

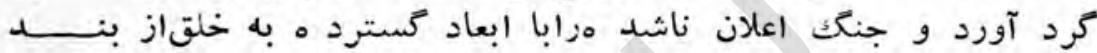

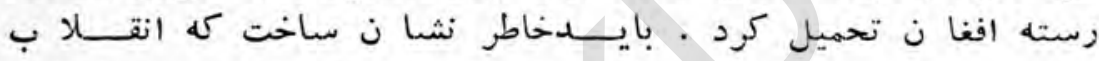

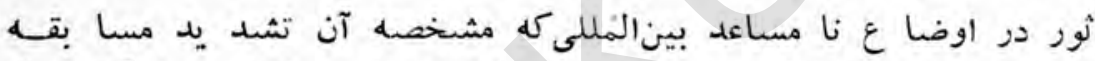

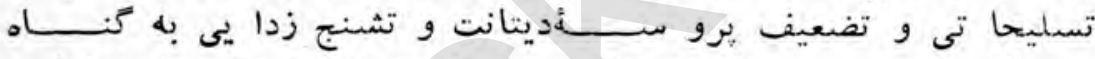

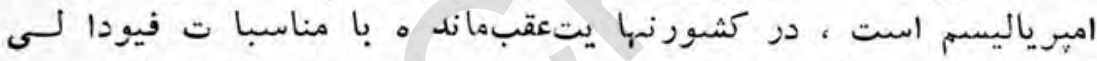

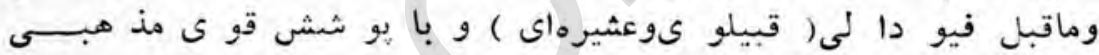

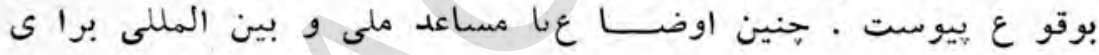

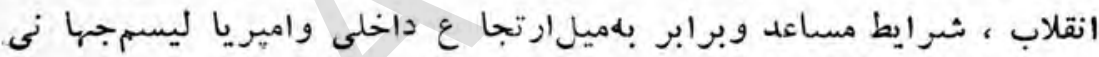

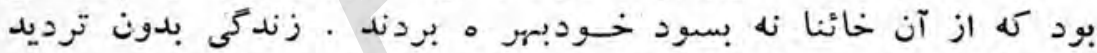

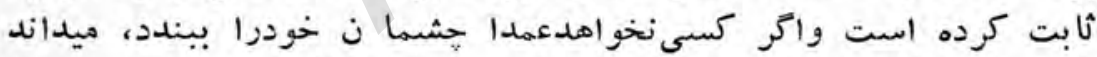

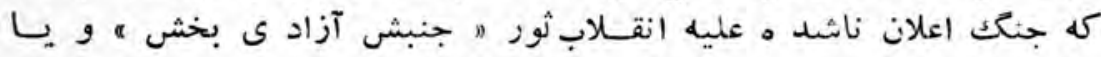

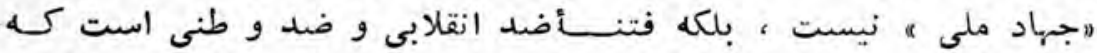

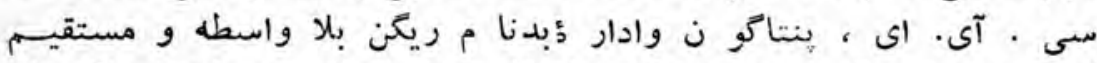

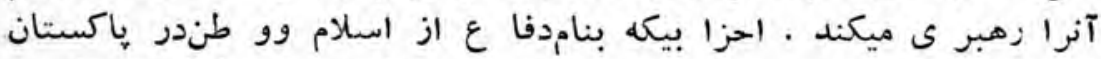

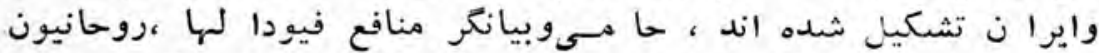

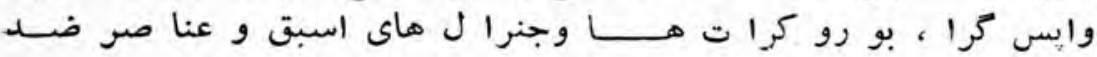




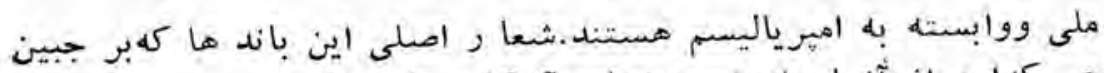

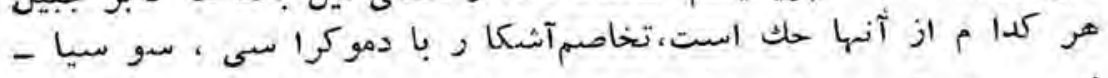

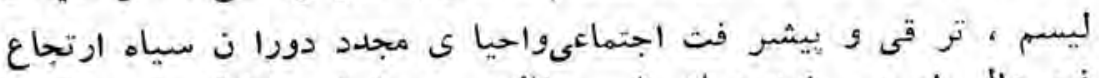

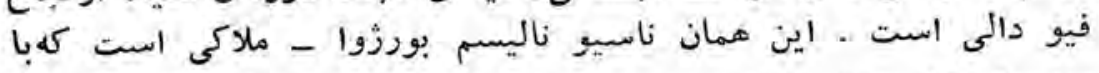

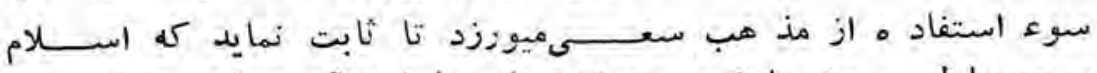

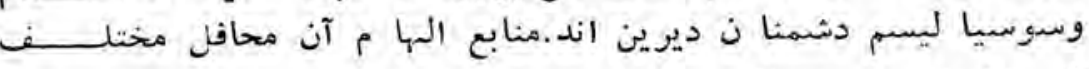

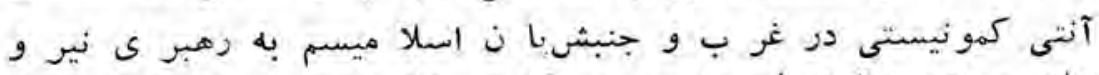

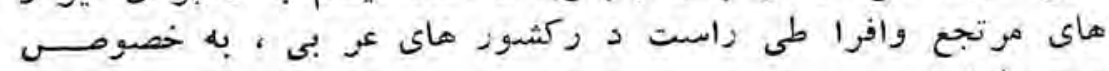

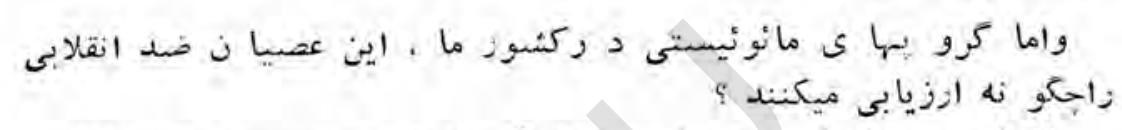

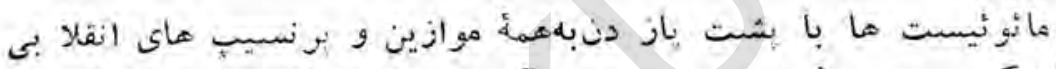

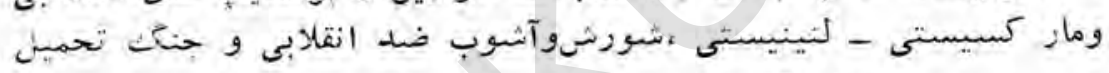

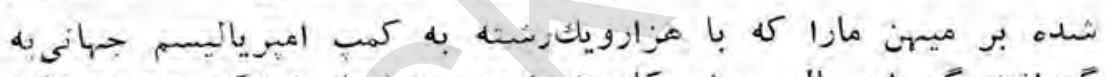

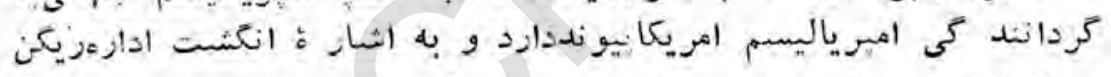

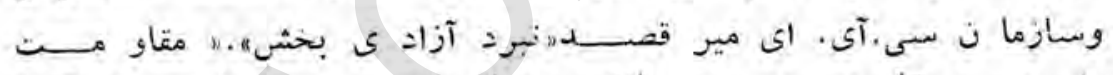

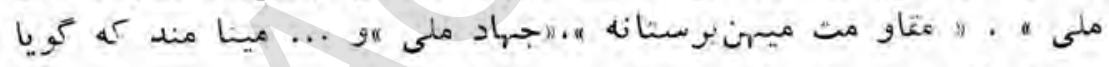

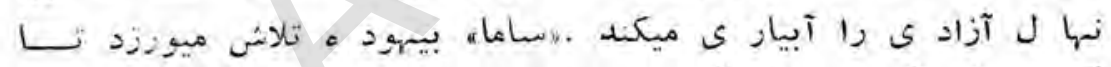

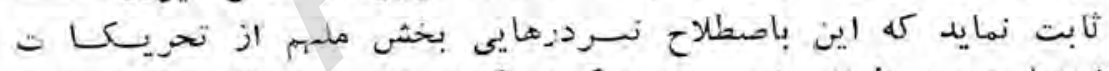

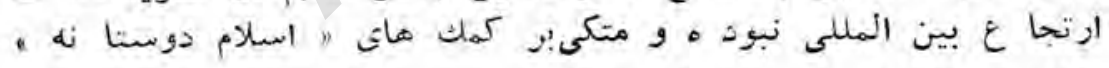

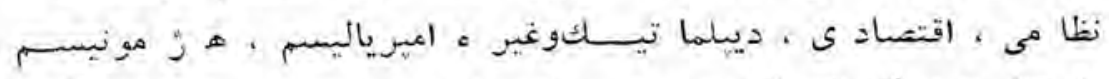

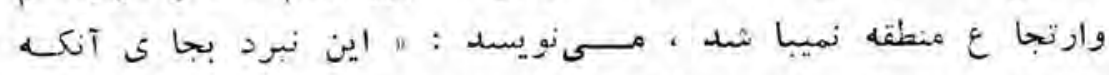

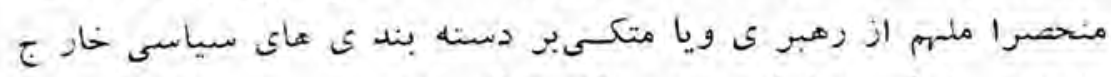

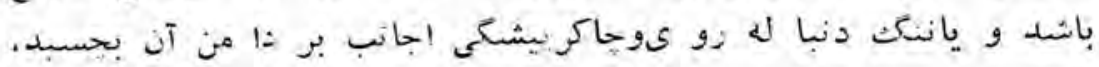

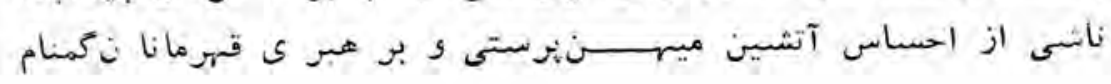




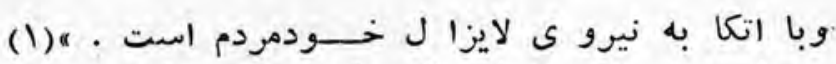

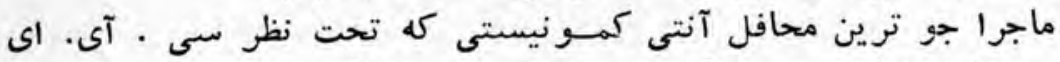

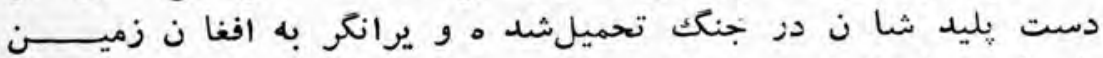

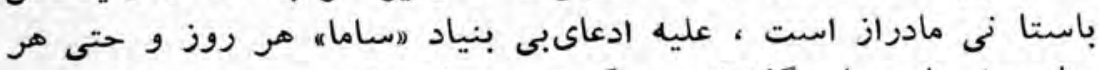

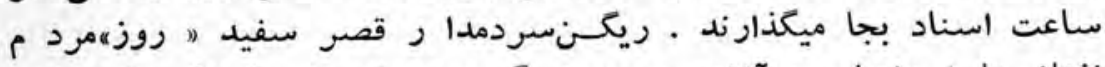

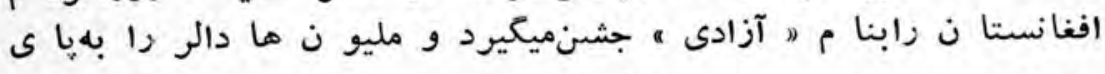

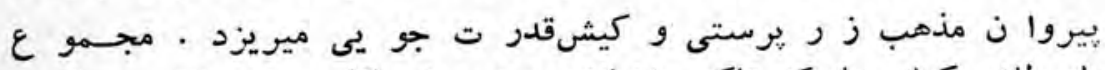

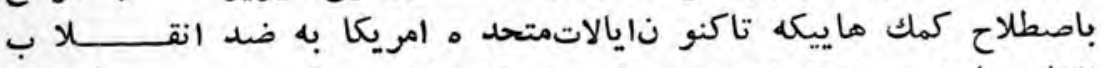

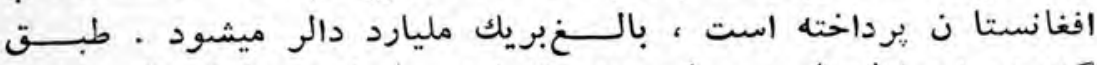

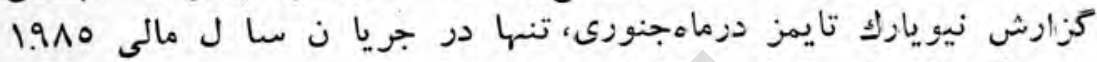

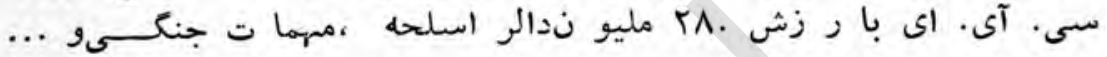

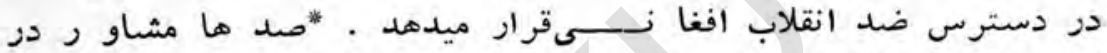

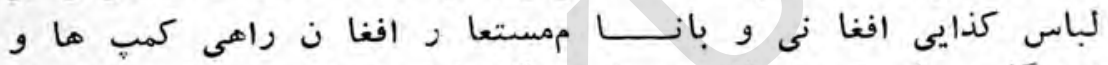

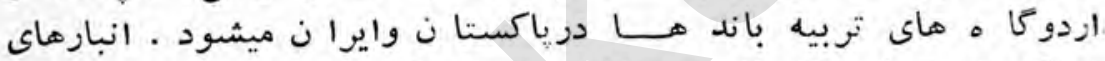

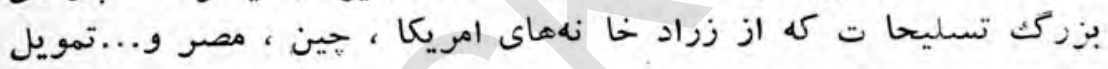

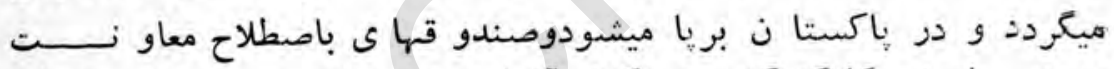

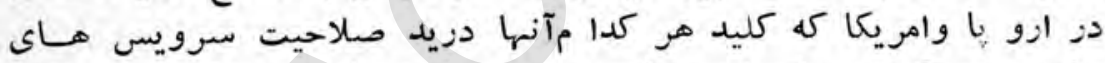

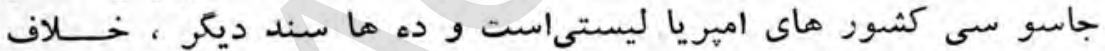

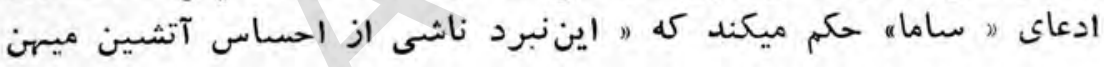

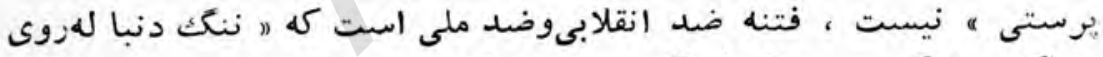

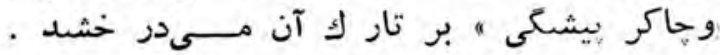

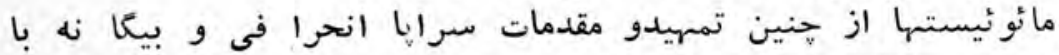

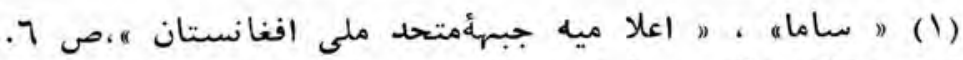

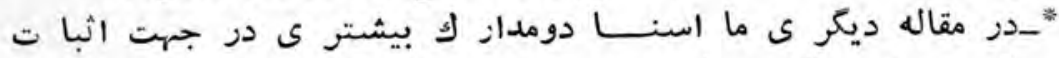

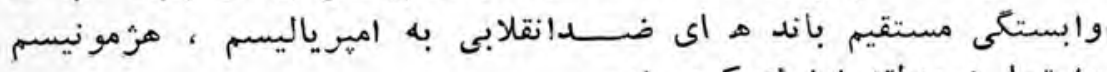

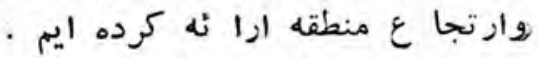




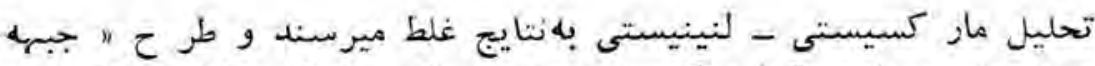

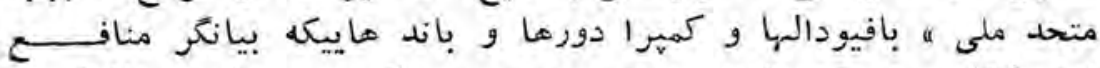

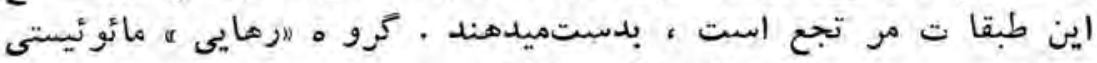

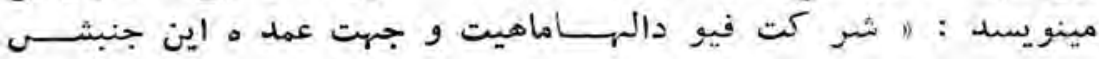

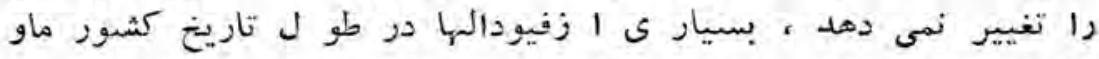

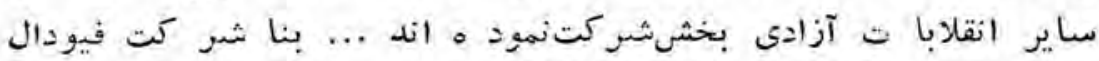

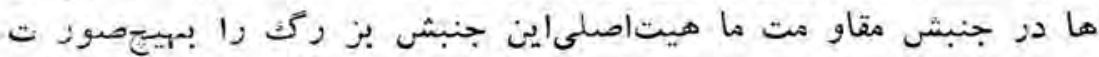

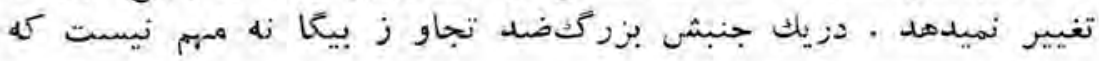

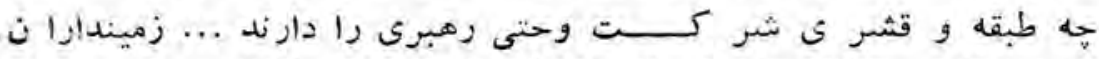

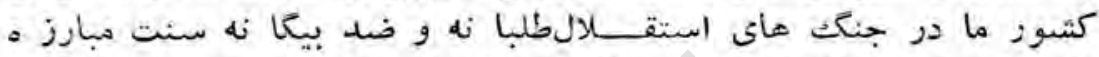

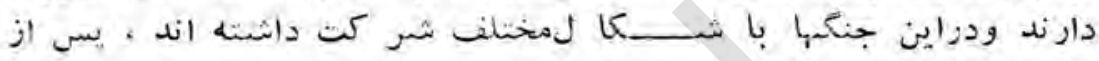

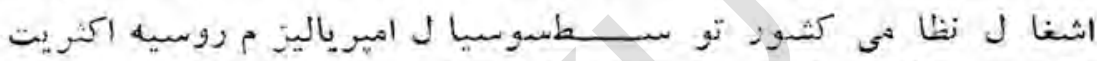

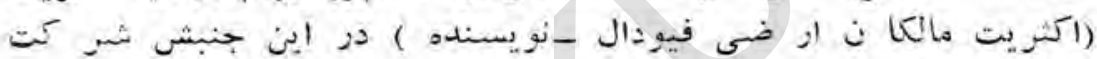

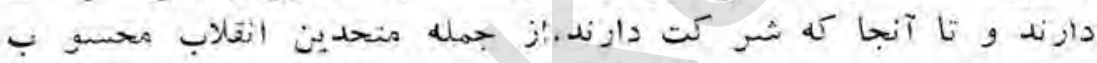

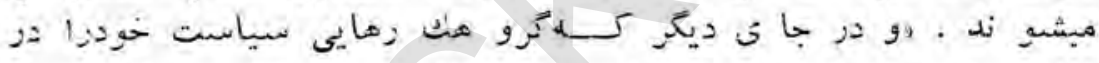

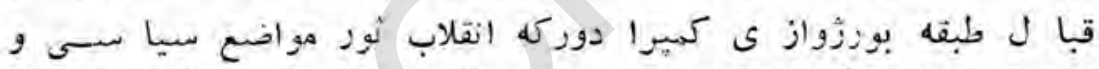

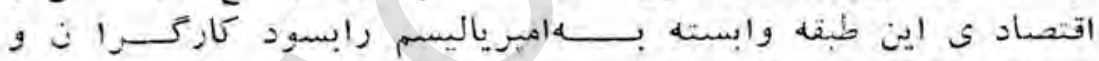

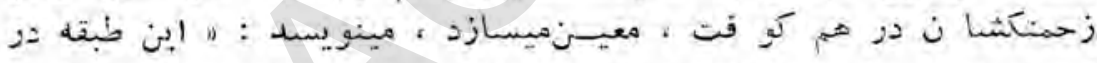

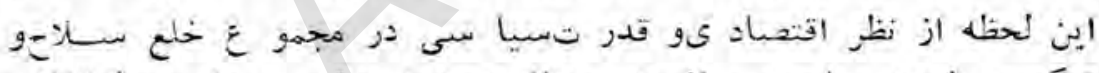

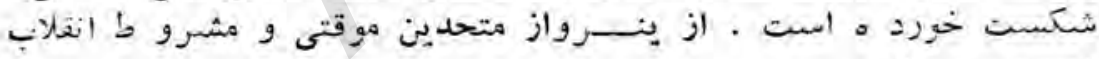

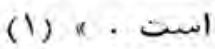

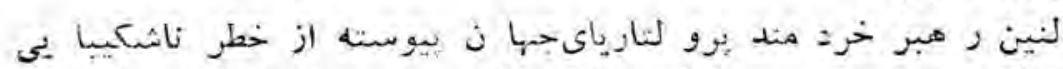

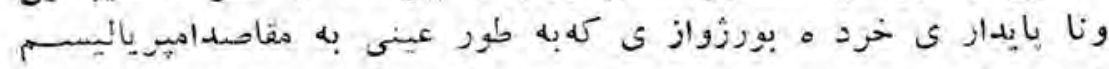

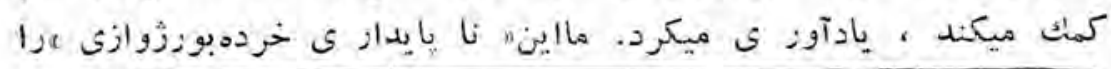

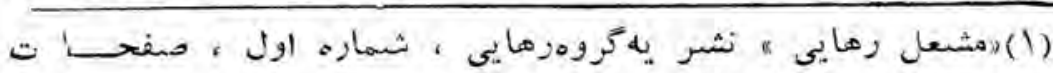

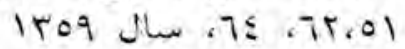




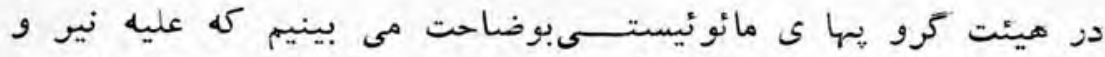

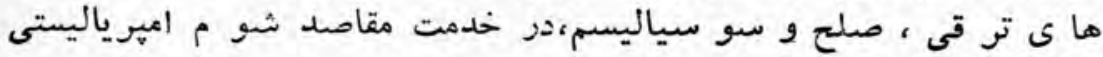

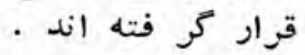

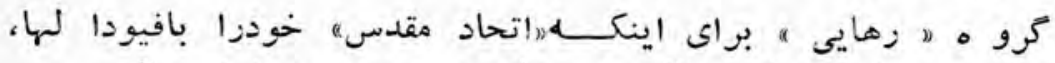

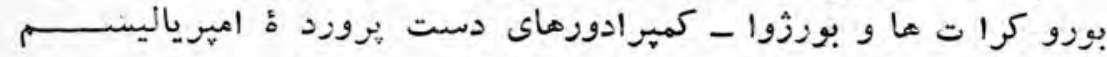

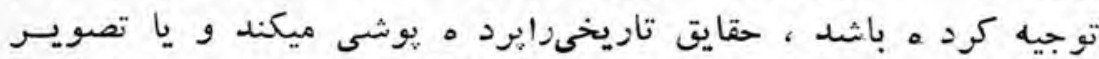

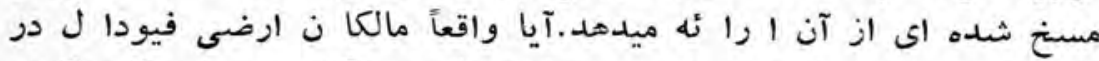

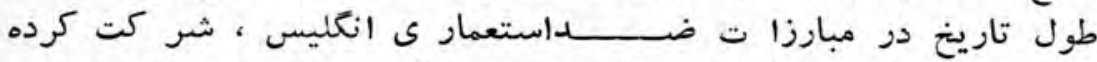

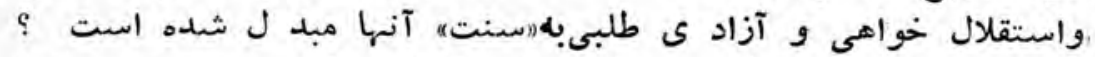

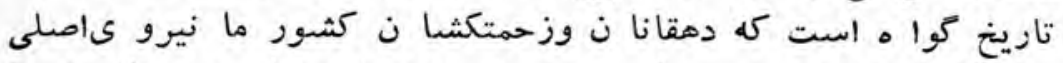

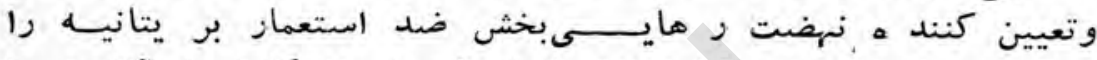

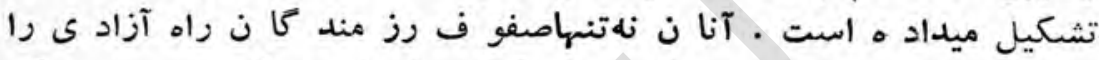

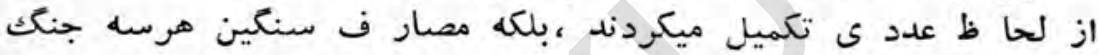

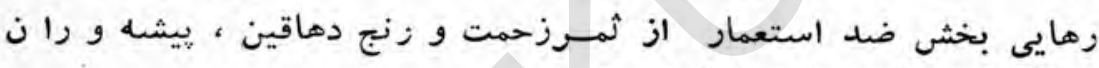

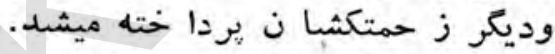

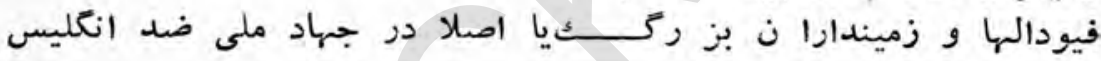

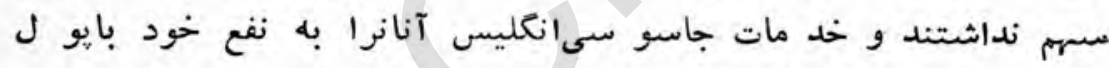
شبار ميكرد *و يا اكر عده ا ى ازآنها بخا طر حراست از منافعشخى

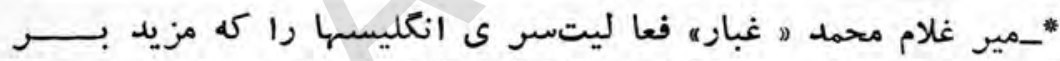

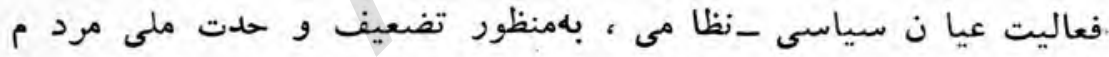

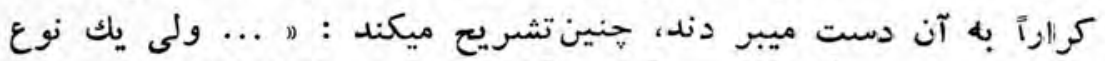

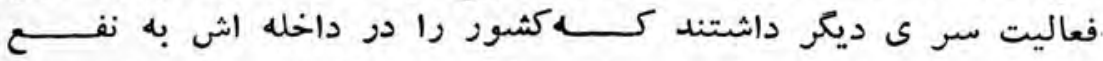

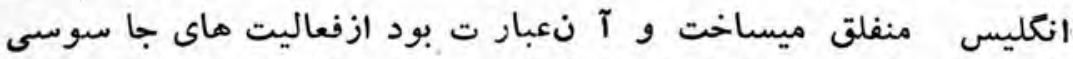

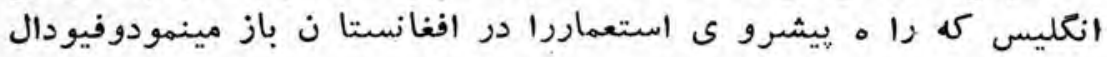

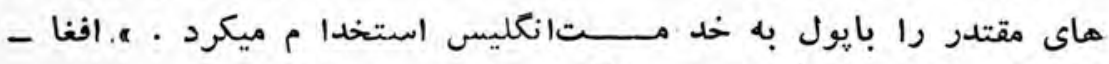

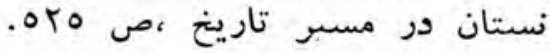




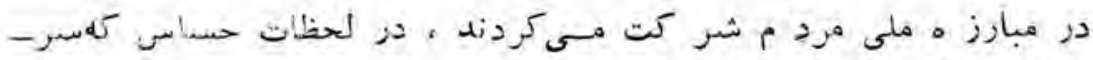

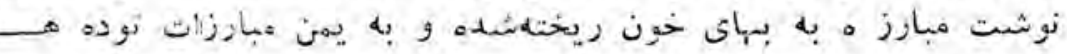

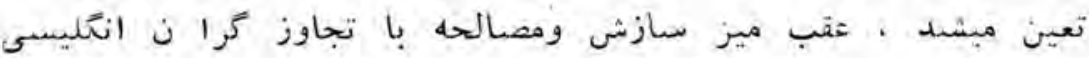

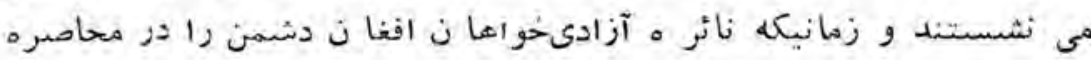

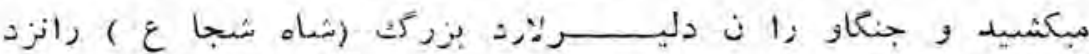

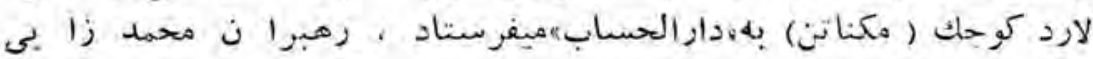

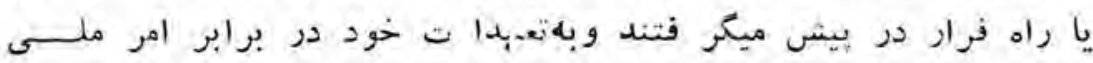

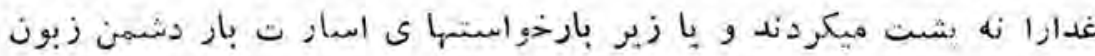
وناتوا ن شنده ، كمر خم ميكردند.

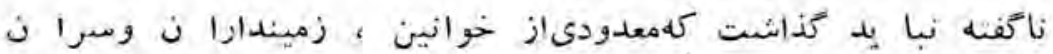

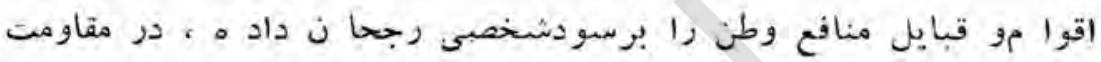

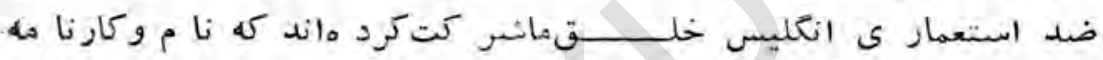

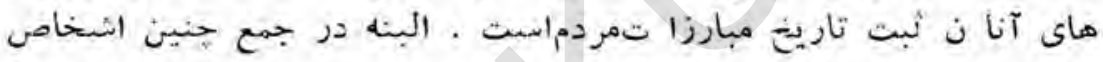

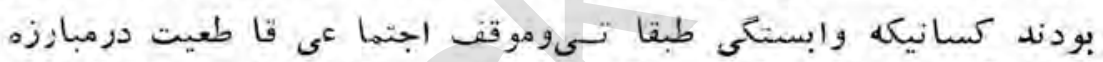

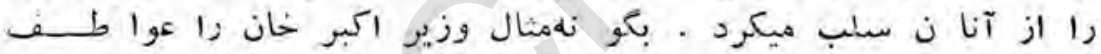

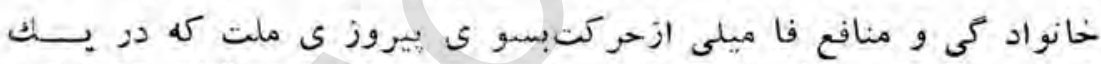

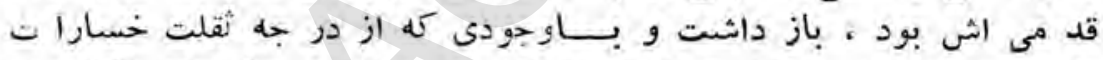

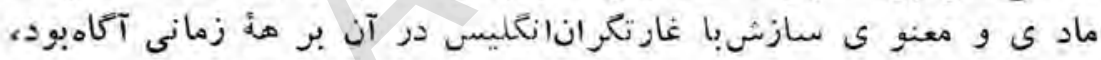

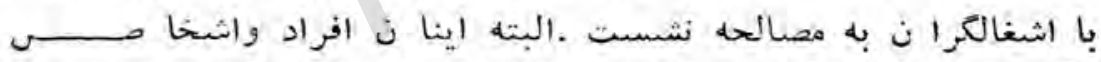

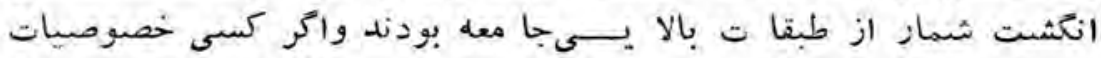

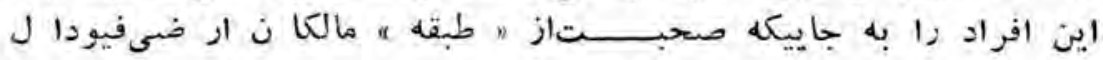

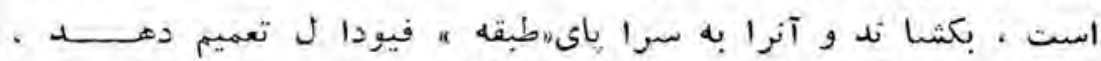

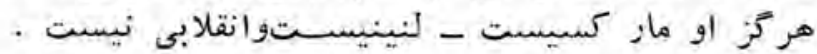

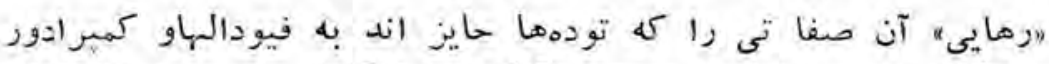

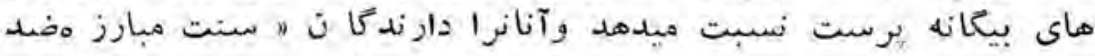


بيكانه " ميداند ، بز حمتكشا ن وشهدا ى راه آزاد ى و استقــل ل ل

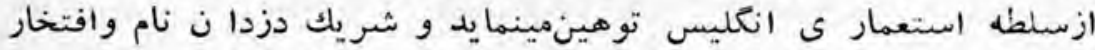

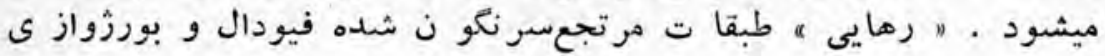

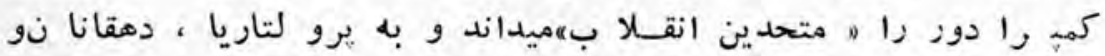

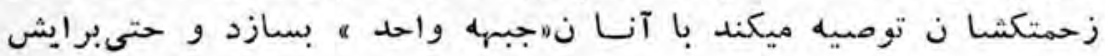

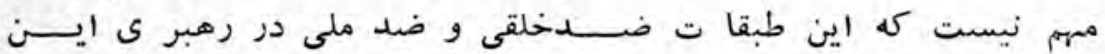

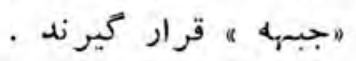

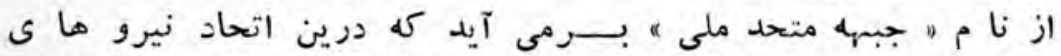

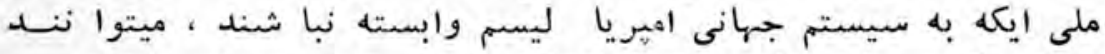

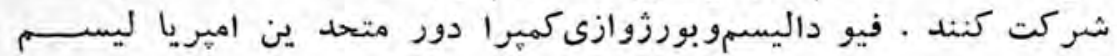

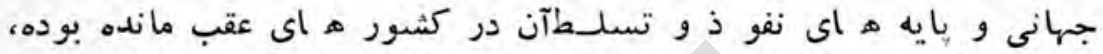

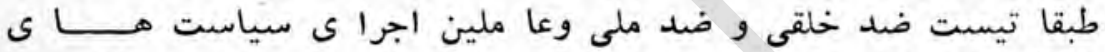

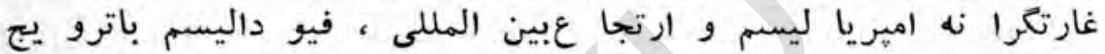

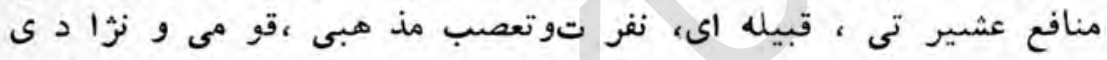

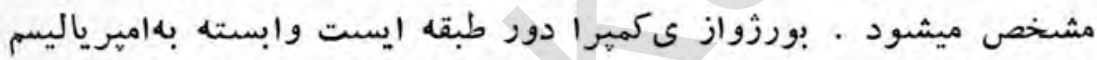

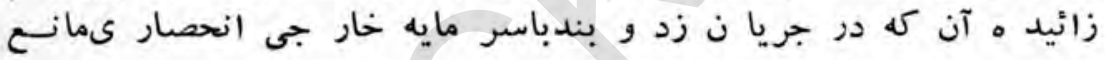

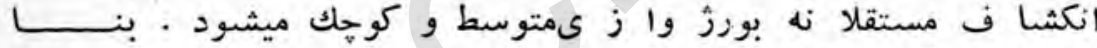

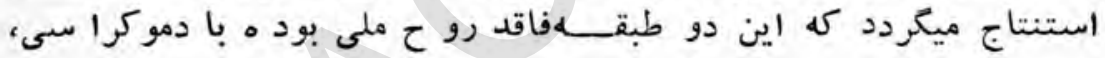

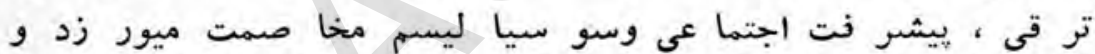

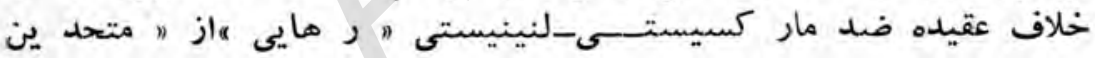

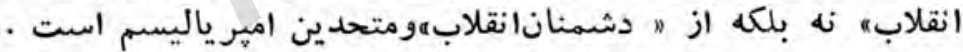

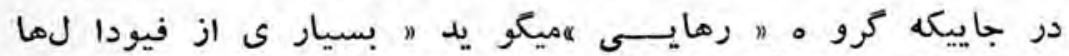

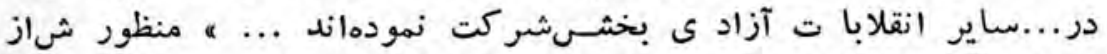

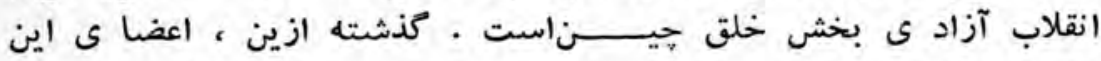

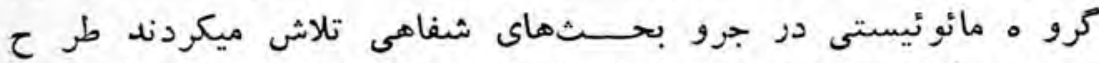

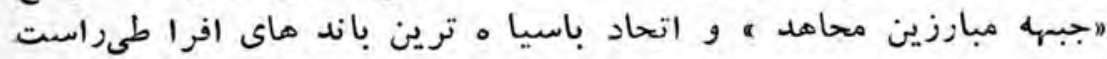




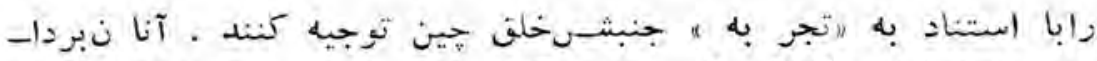

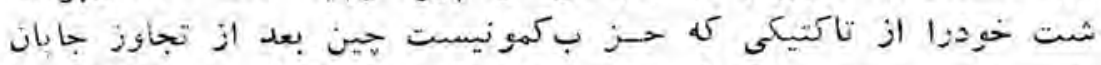

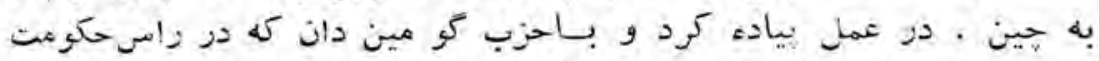

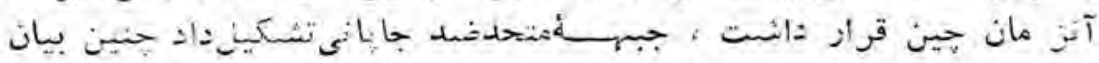

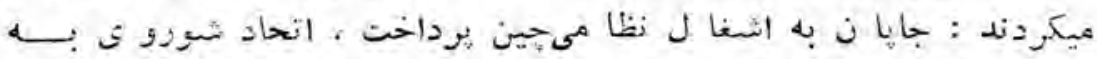

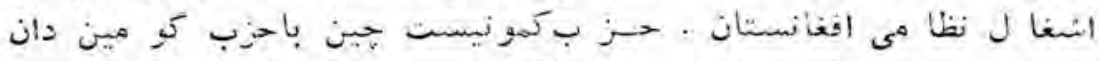

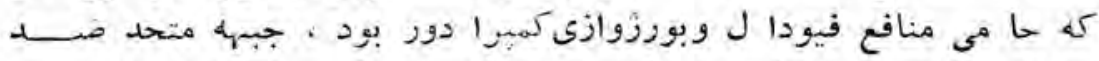

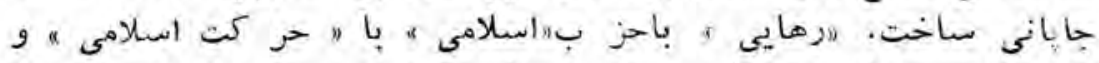

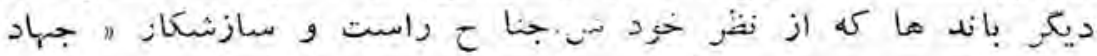

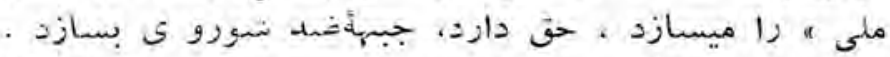

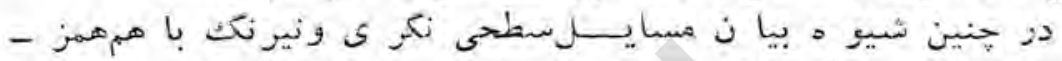

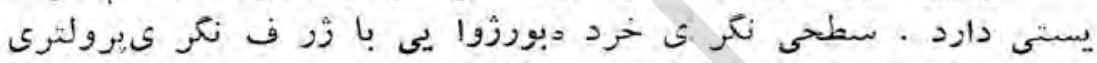

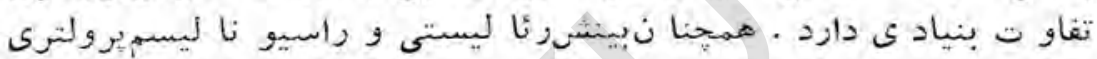

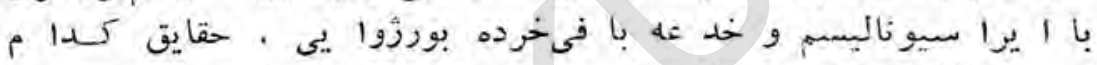

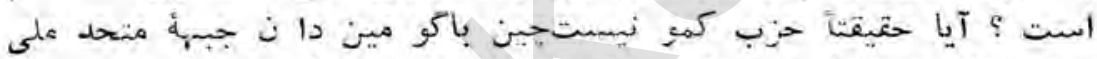

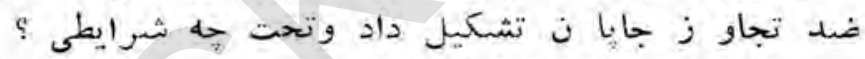

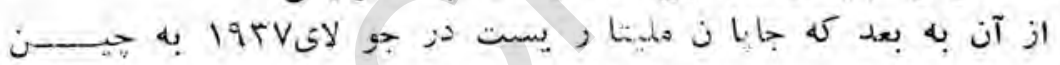

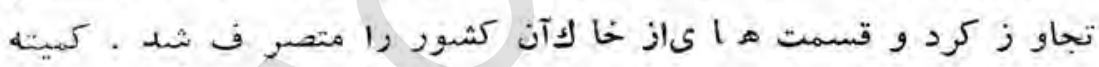

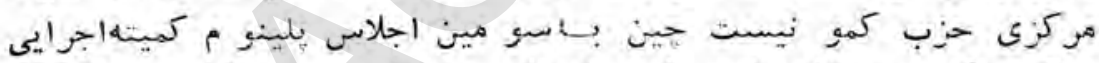

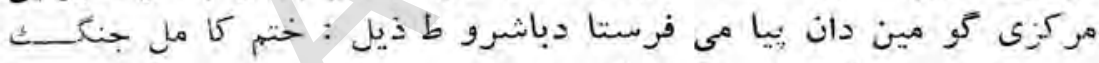

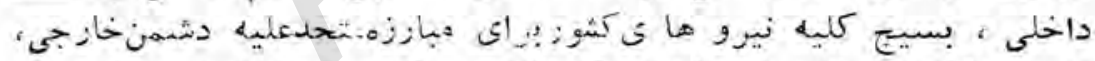

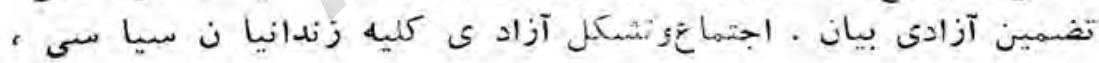

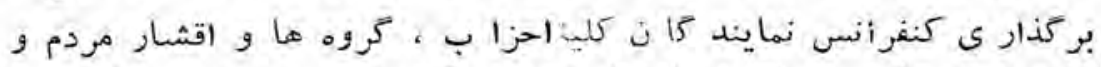

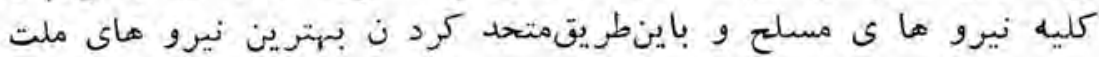

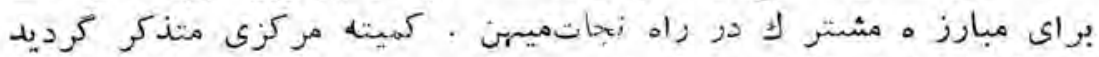

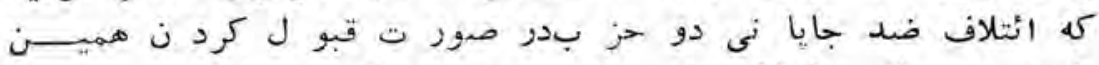

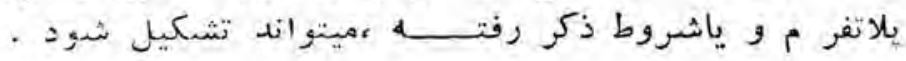




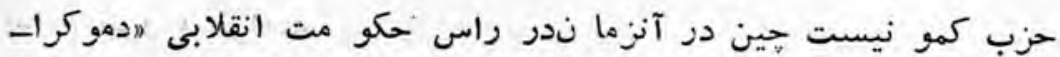

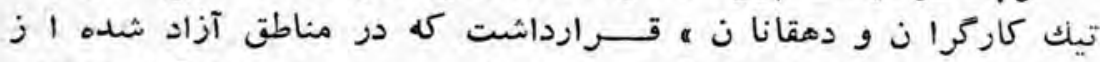

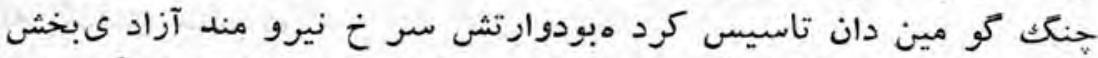

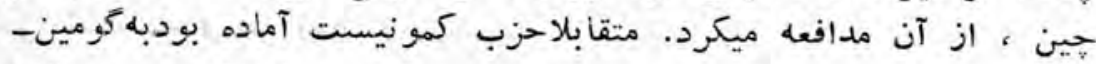

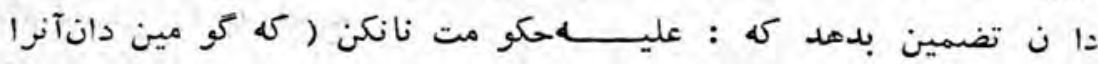

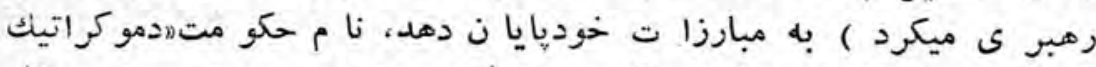

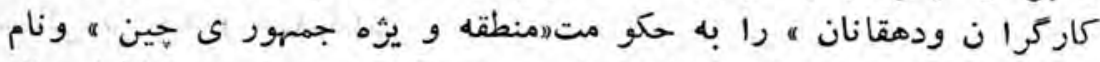

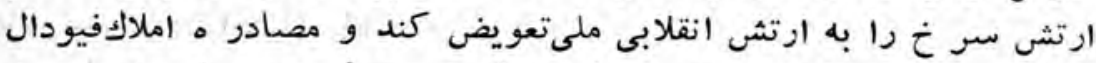

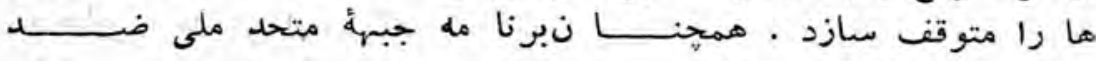

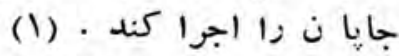

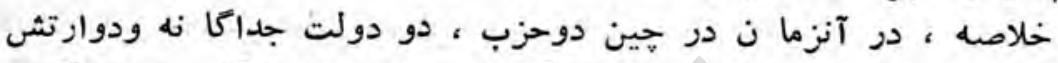

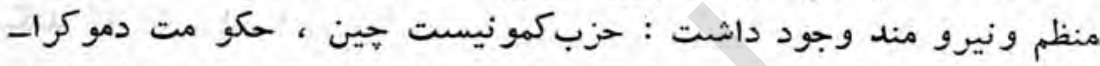

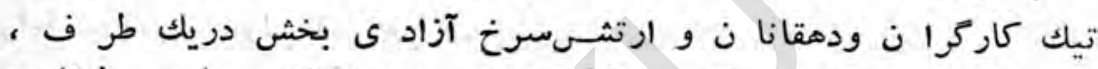

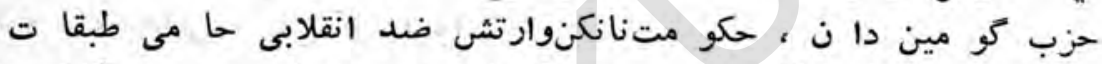

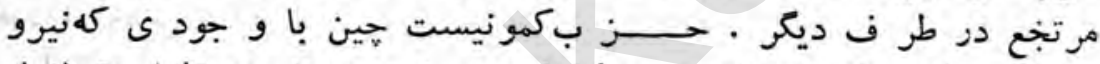

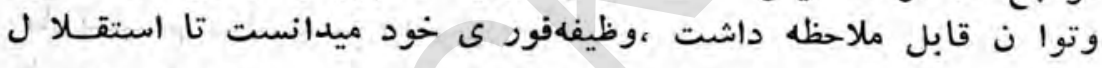

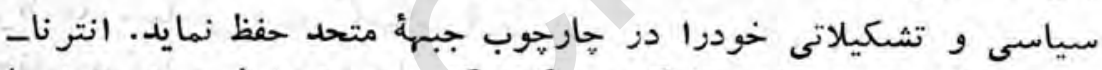

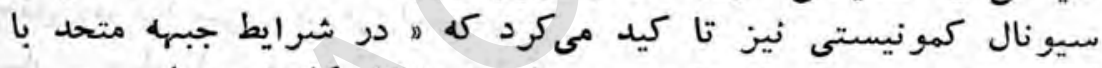

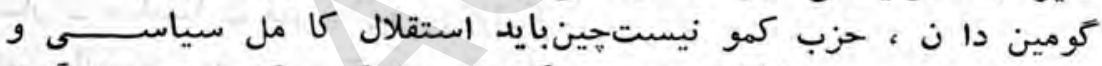

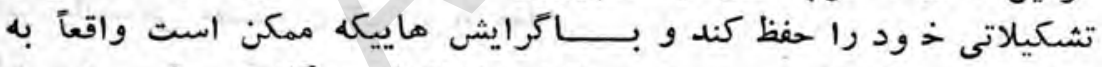

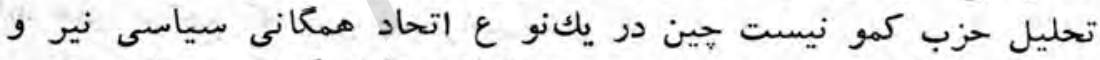

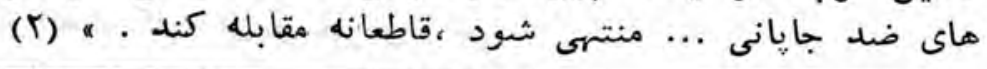

(1) مواد در بار ه تاريخ انقلا بجين جلد سو م ، صفحا ت 1119.19.

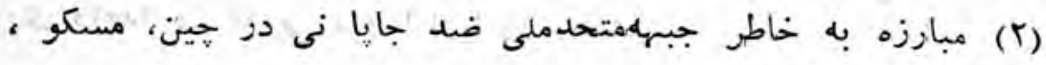

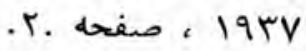




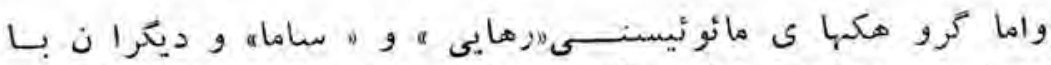

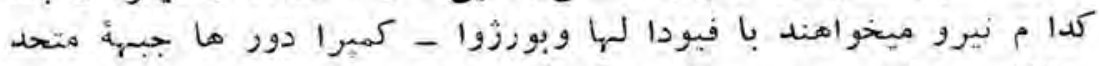

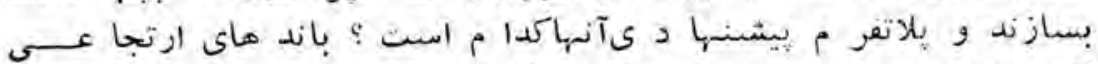

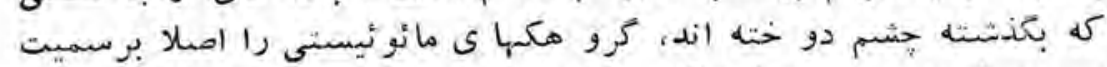

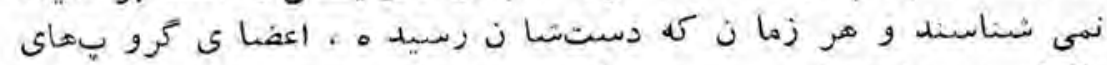

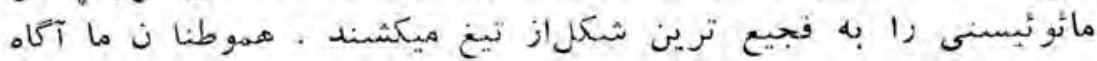

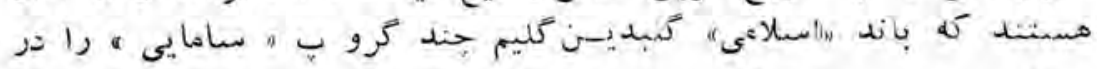

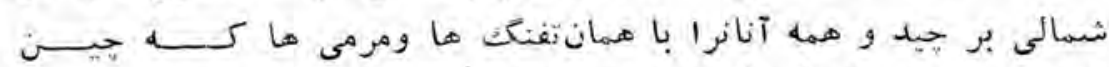

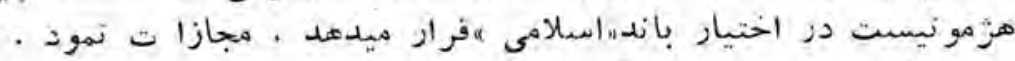

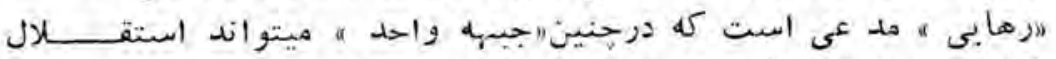

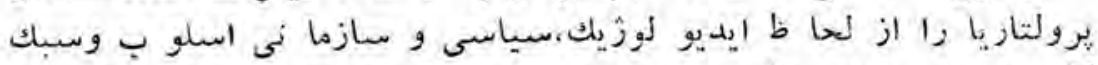

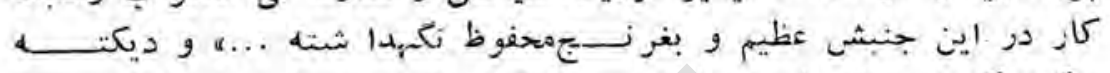

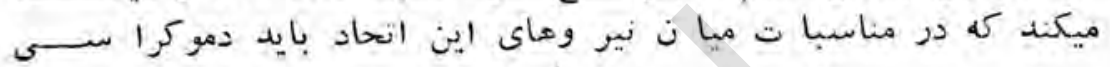

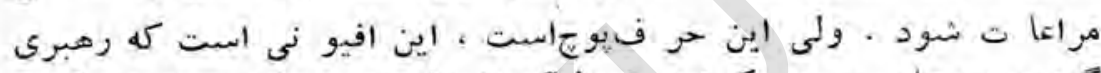

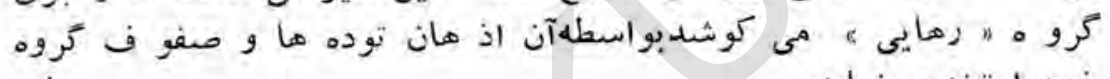
خودرا تخدير نهايد ماهن

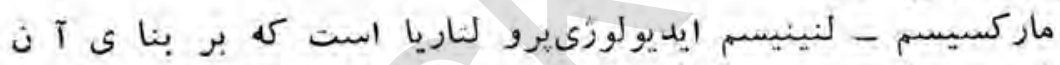

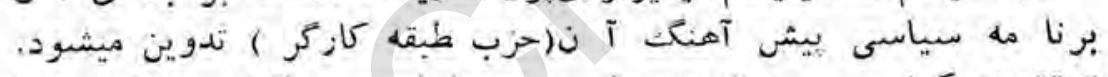

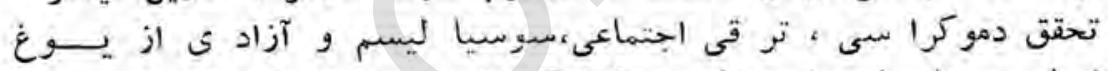

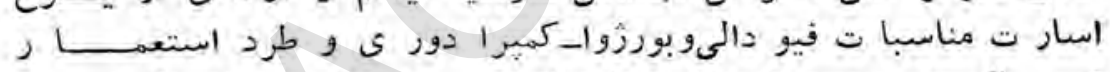

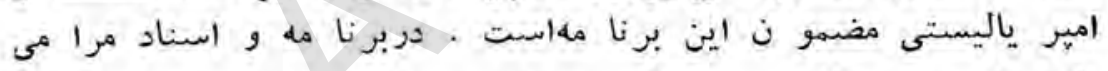

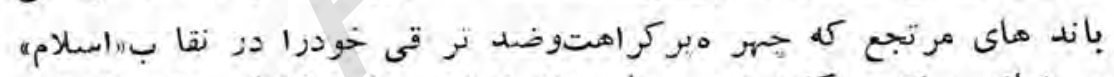

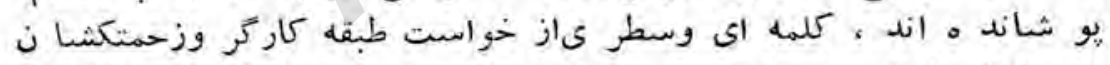

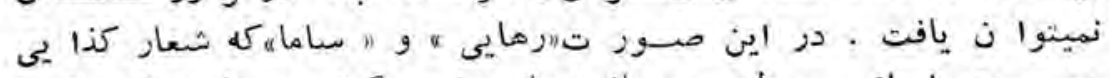

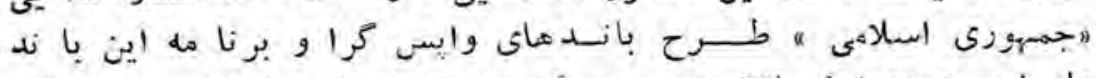

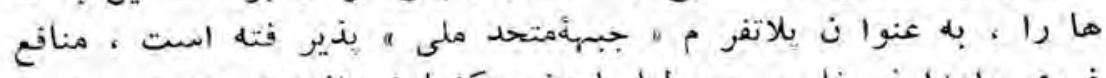

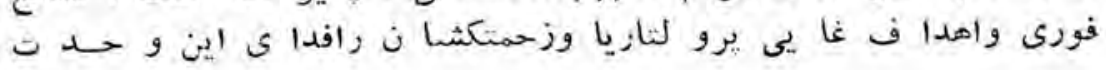




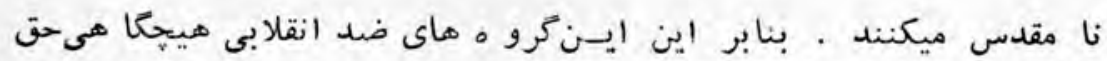

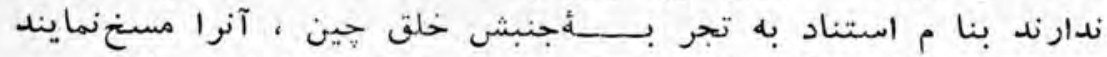

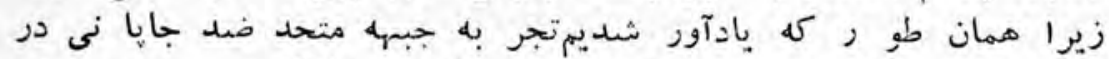

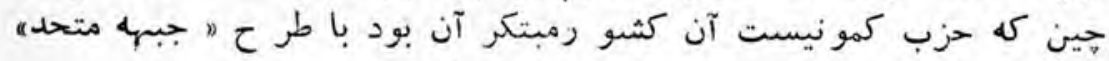

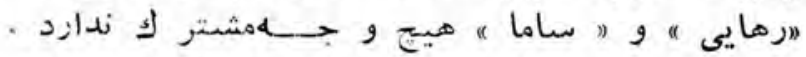

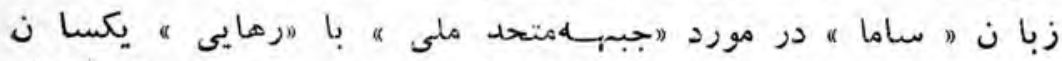

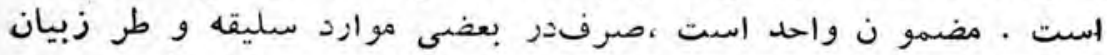

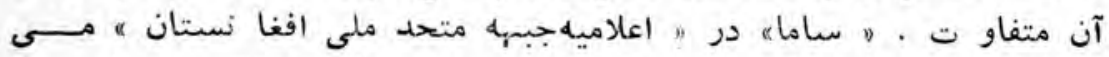

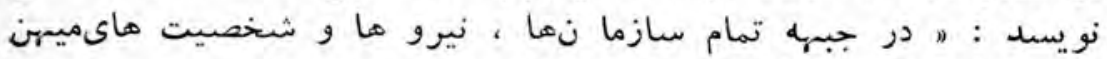

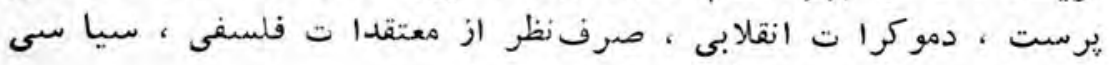

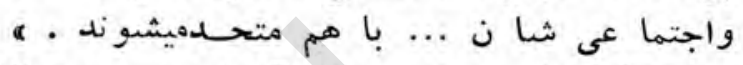

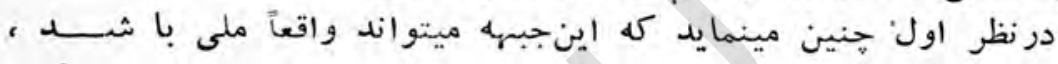

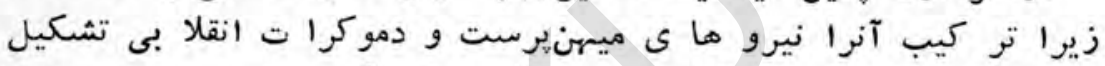

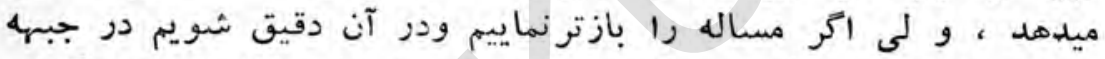

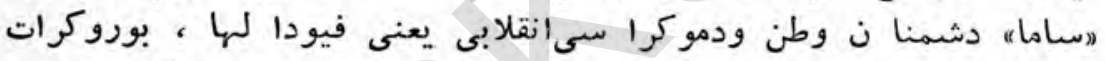

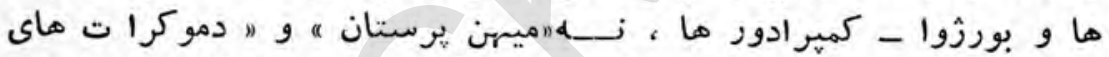

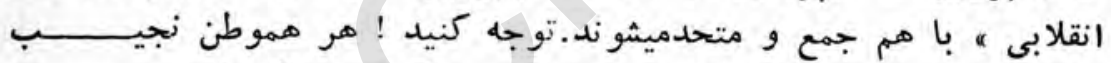

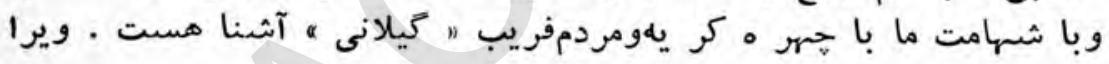

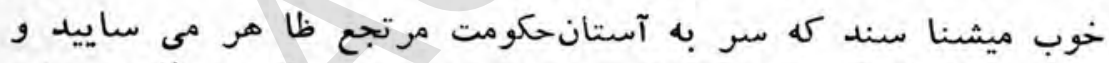

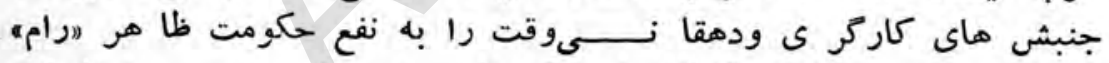

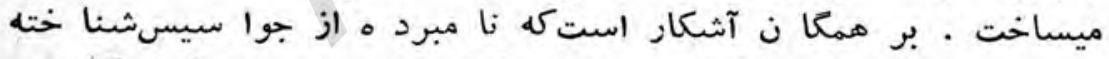

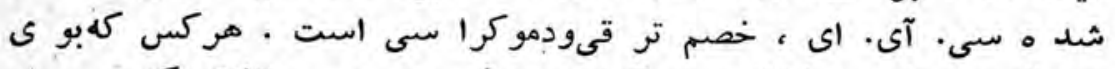

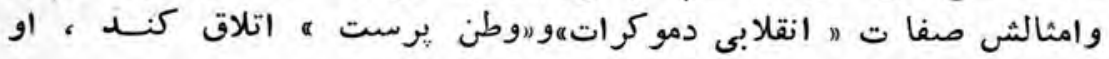

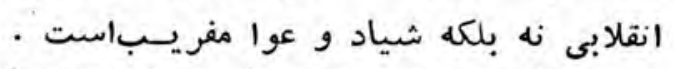

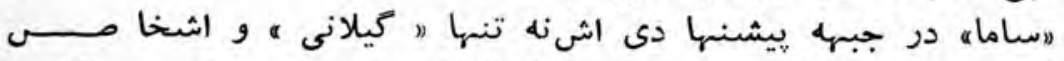

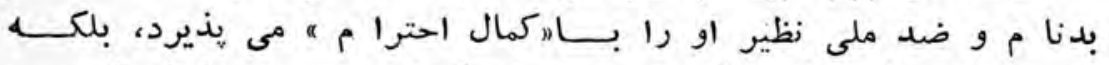

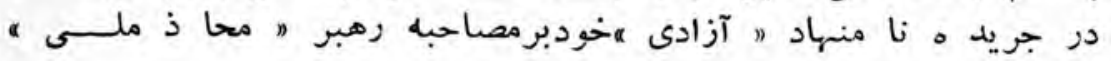




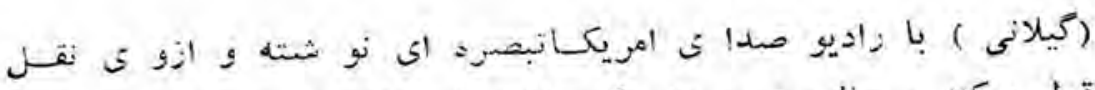

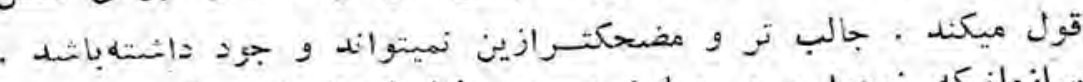

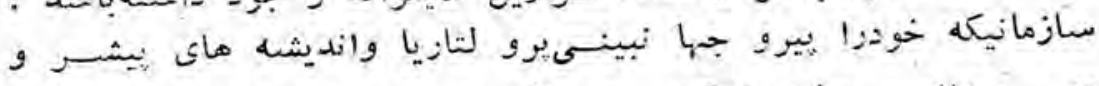

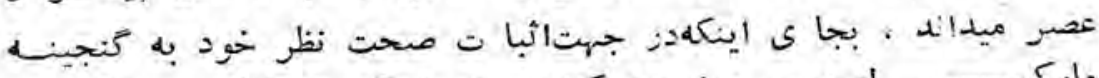

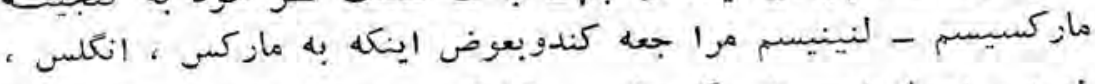

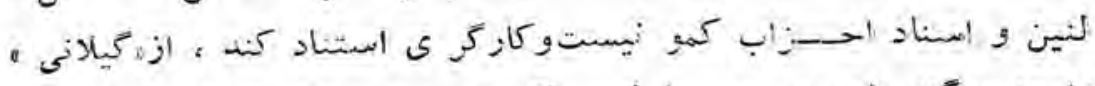

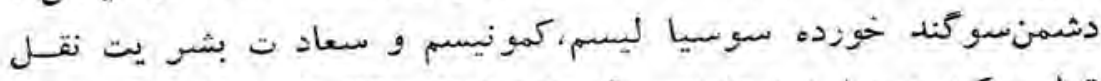

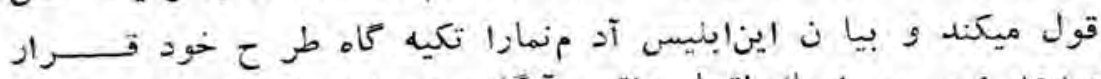

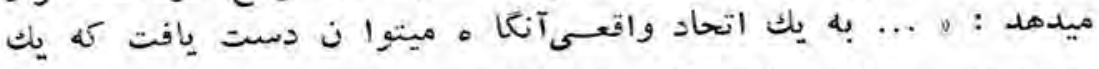

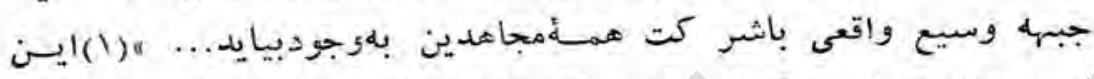

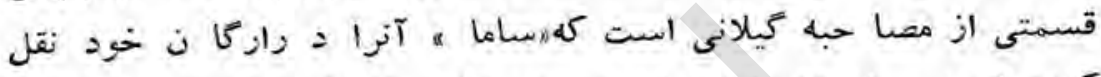

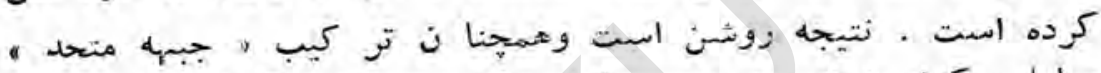

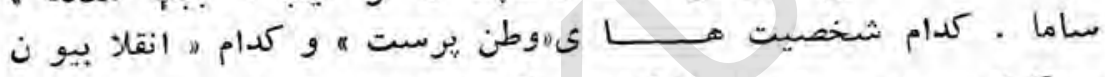

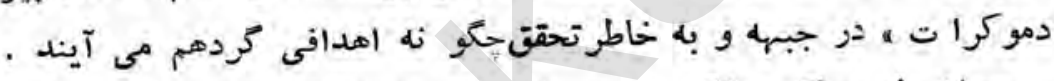

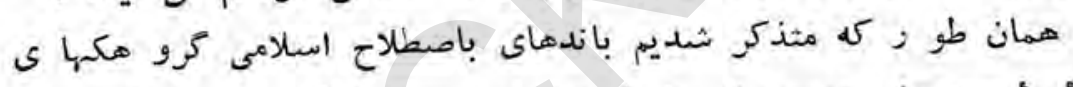

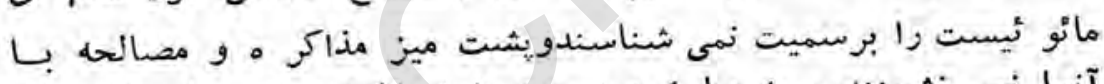

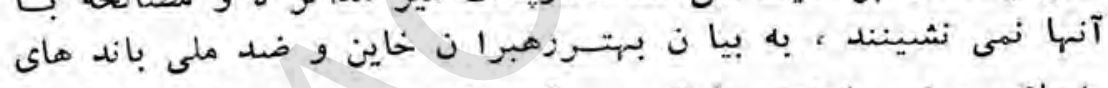

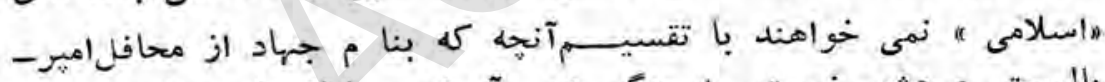

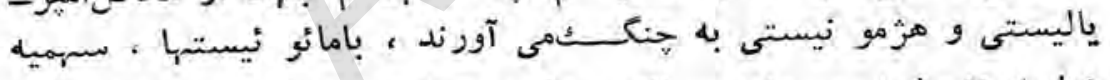

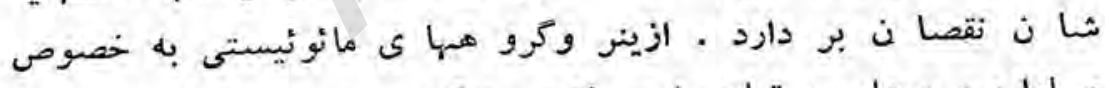

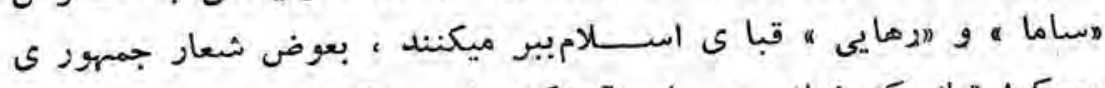

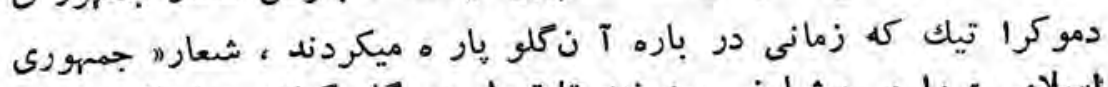

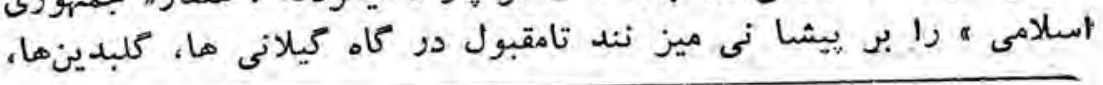

(1) "iنداي آزادى " شمار 00و7،سا J .7ז1 


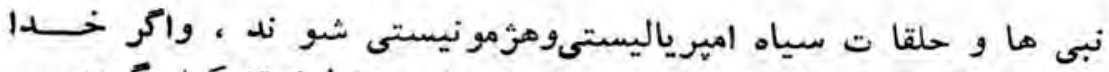

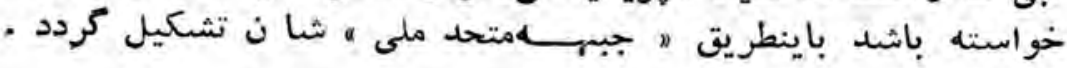

\section{*}

\section{米}

米

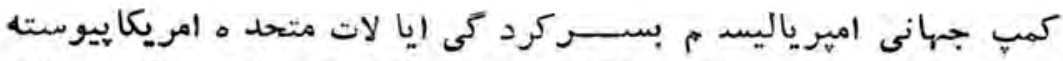

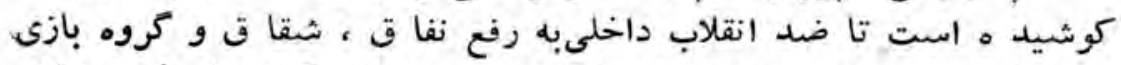

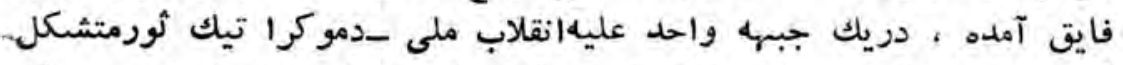

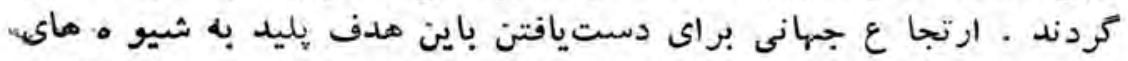

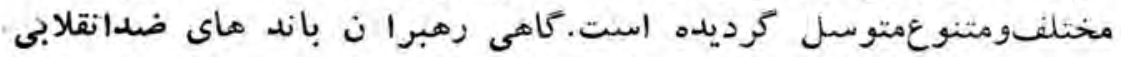

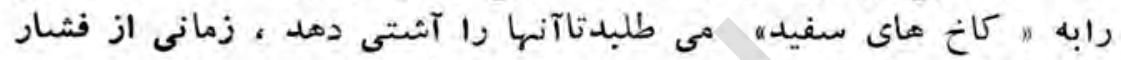

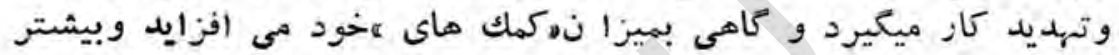

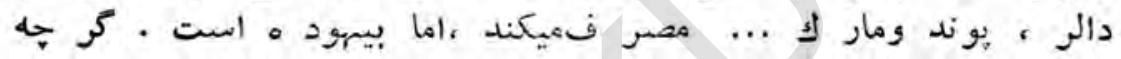

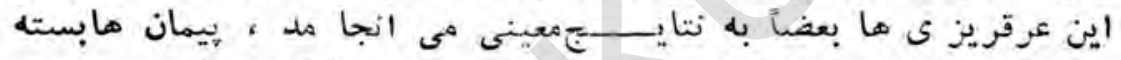

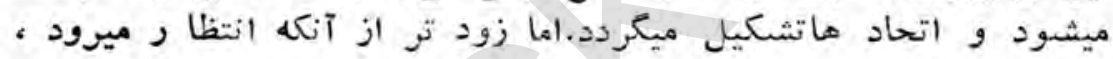

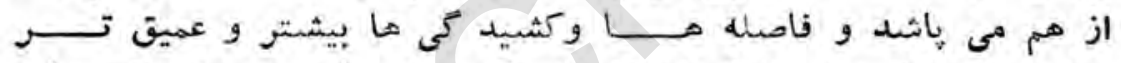

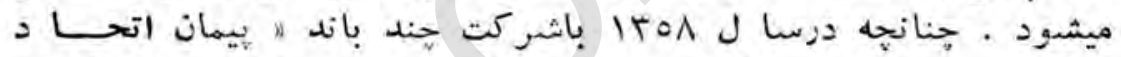

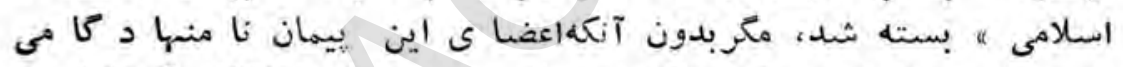

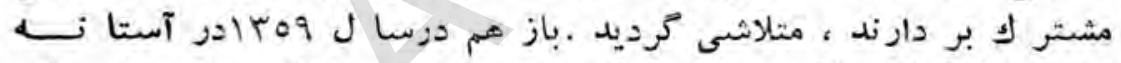

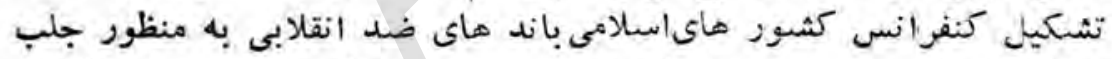

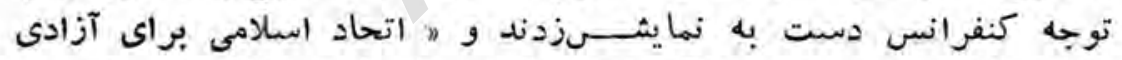

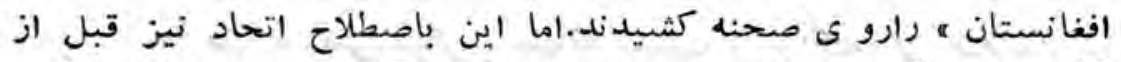

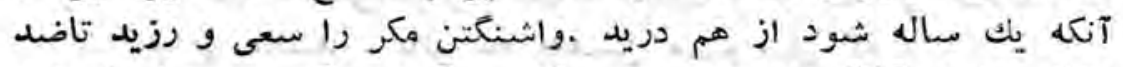

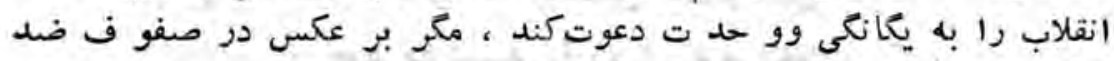

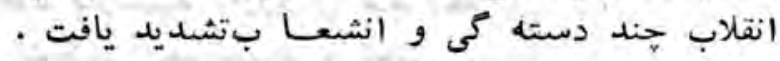

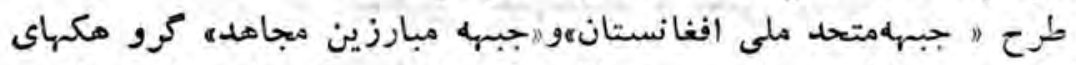

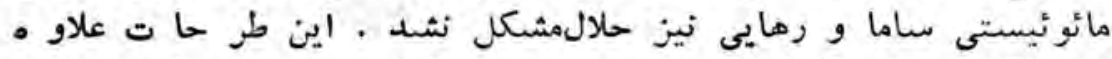

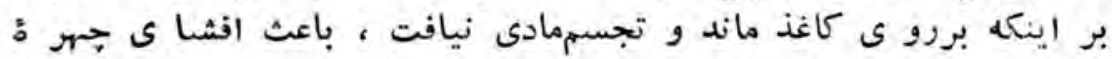




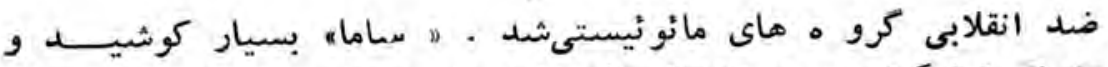

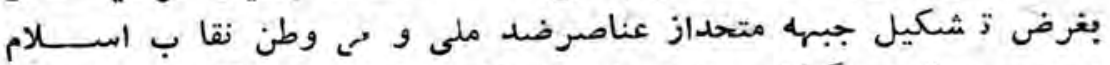

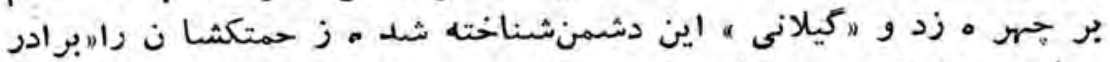

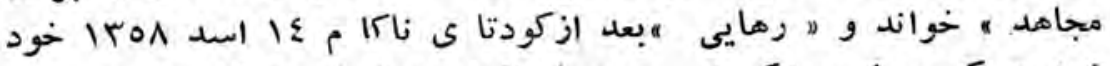

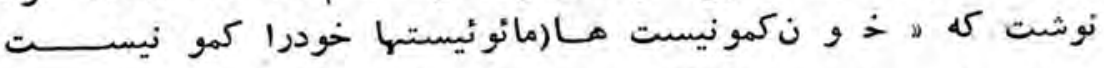

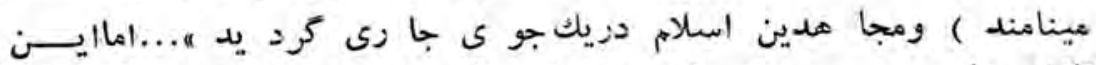

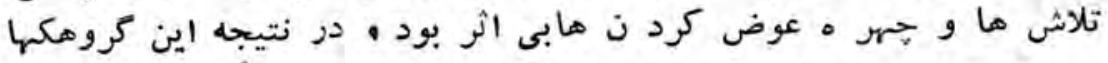

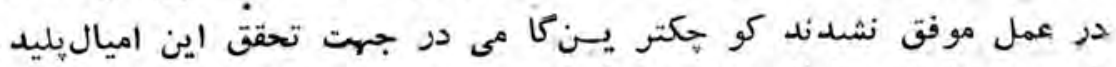

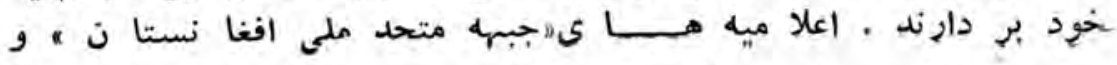

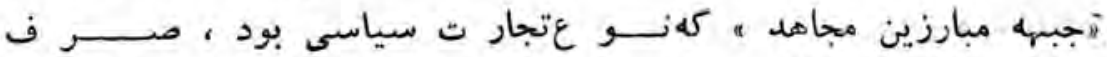

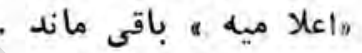

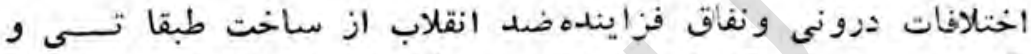

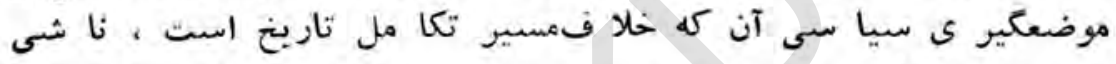

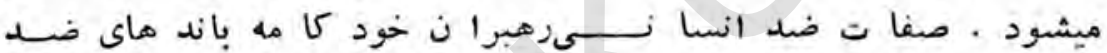

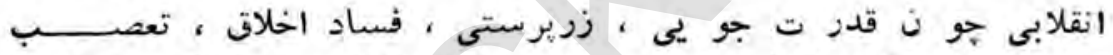

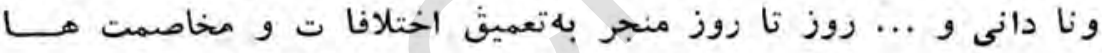

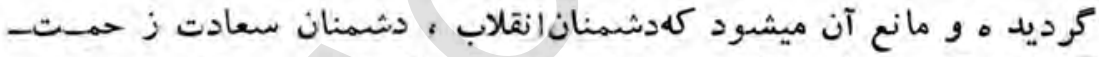

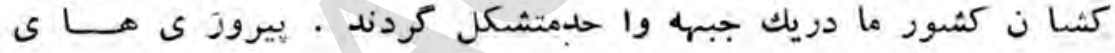

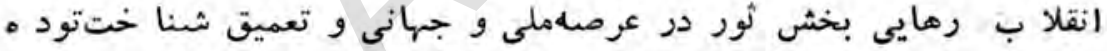

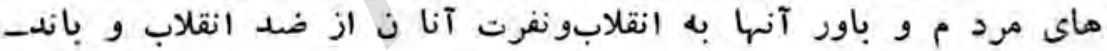

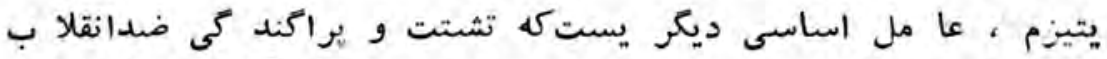

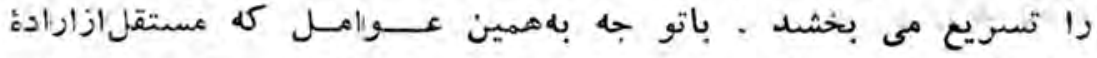

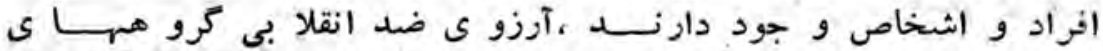

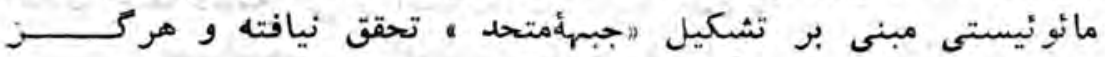
جا مله عمل نخواهد بوشيد . نجل 


\section{》رهائى"ياو ابستيكى}

انقلاب اجتما عى در جوامع مبتنى بر تضاد هـ ای آشتى نايذير طبقا تى إنى

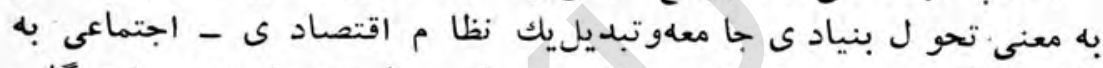

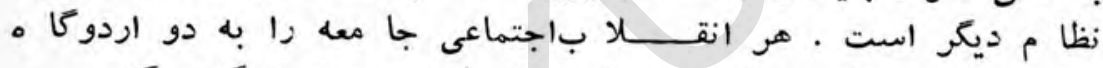

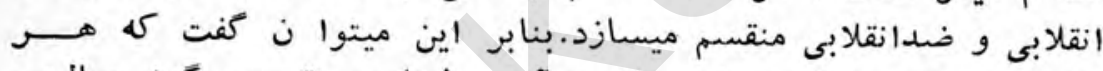

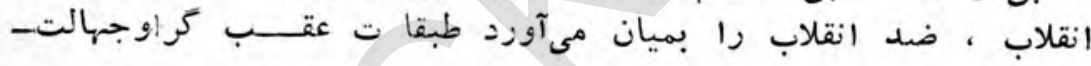

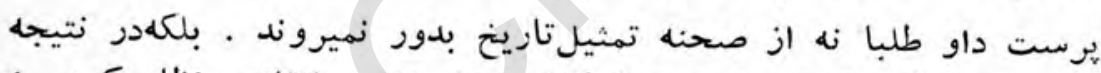

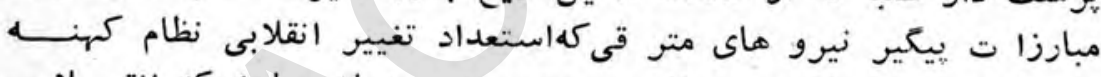

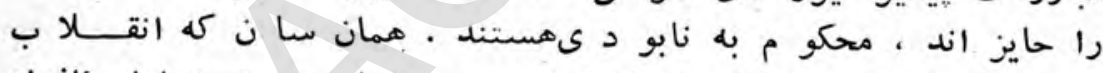

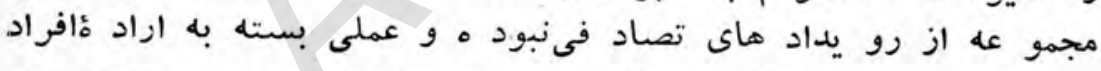

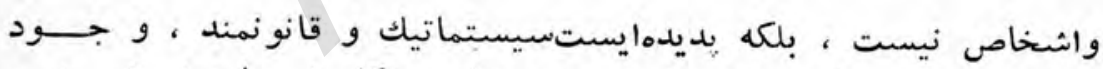

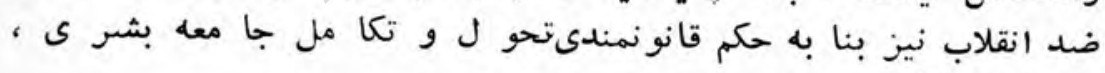

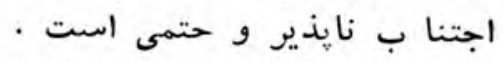

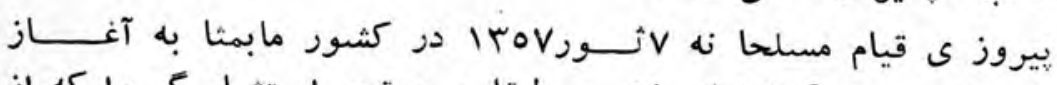

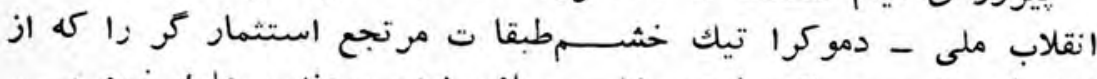

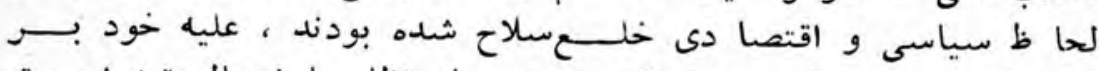

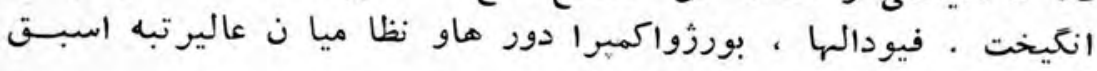




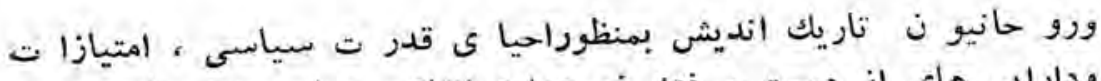

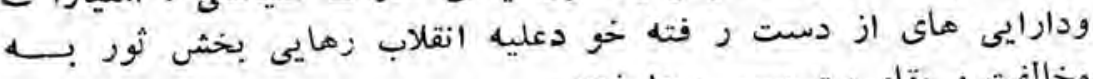

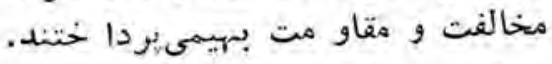

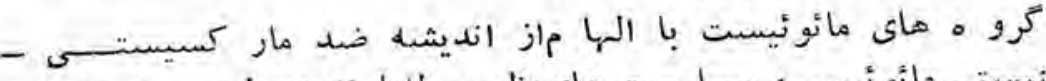

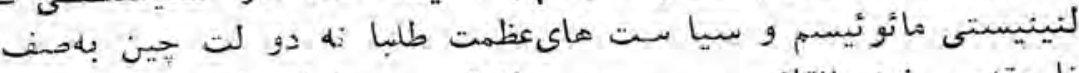

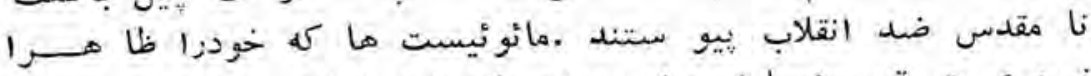

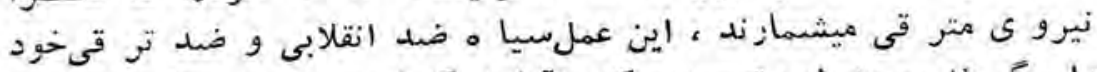

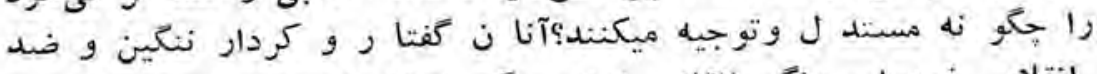

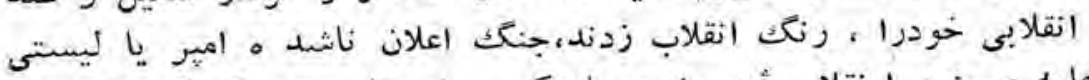

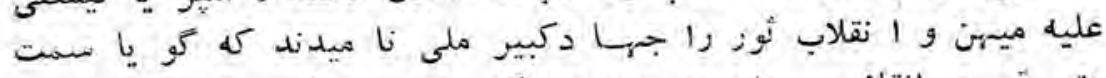

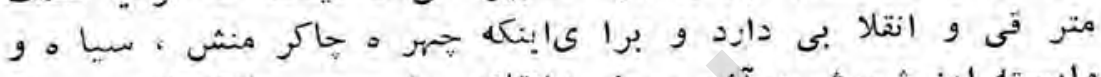

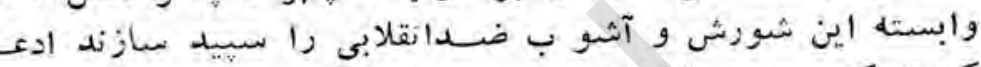

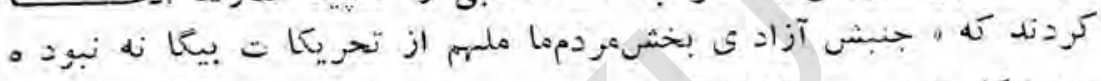

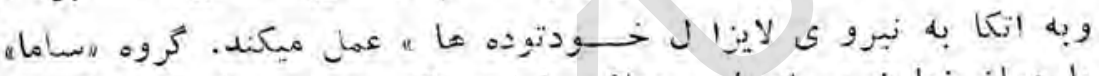

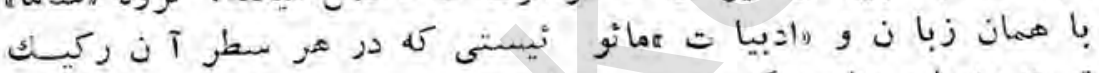

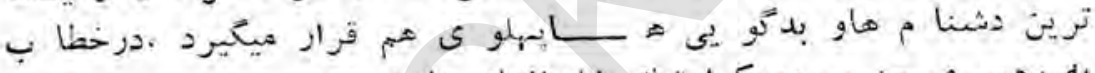

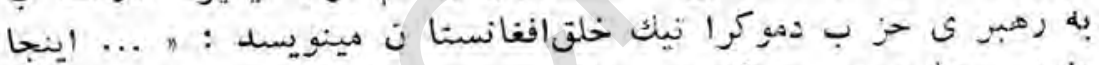

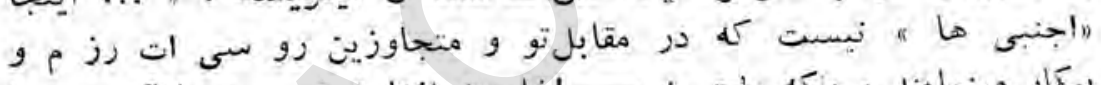

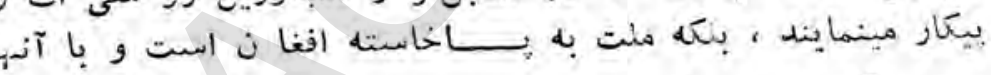

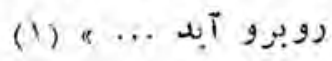

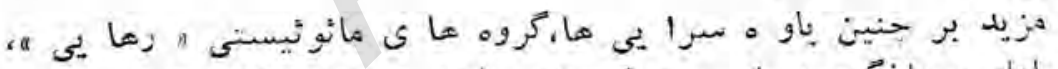

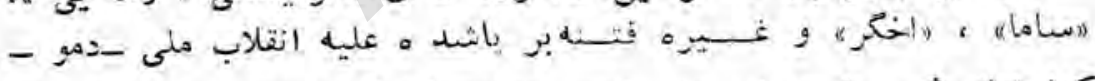

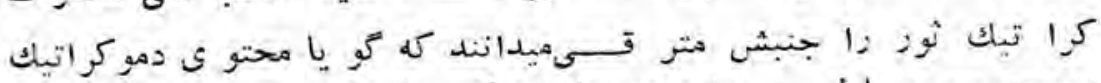

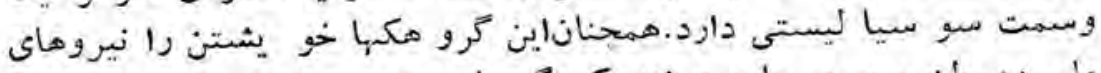

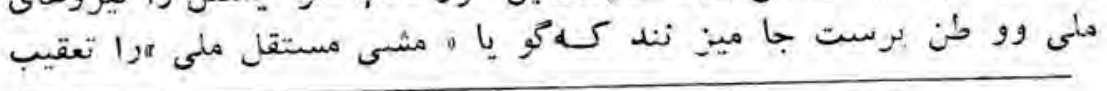

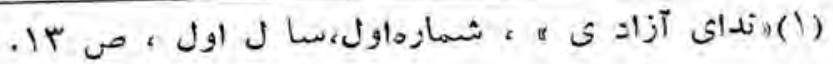


كرد ه و بدور از هركو نه بيعا نهيرستى و مزدور منشى در راهآزادى

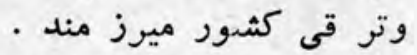

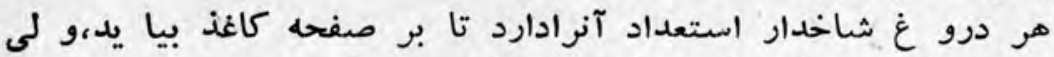

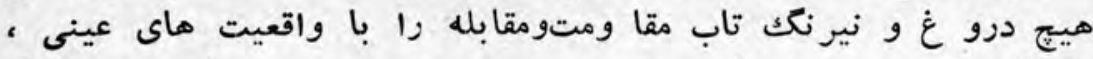

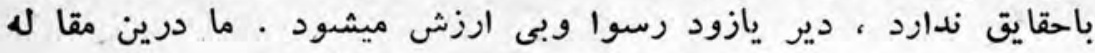

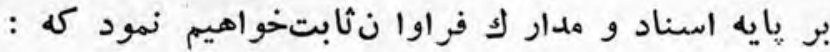

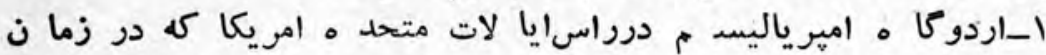

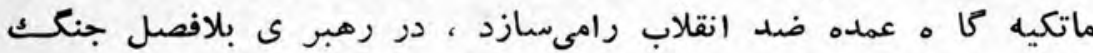

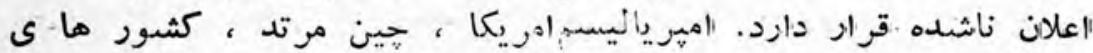

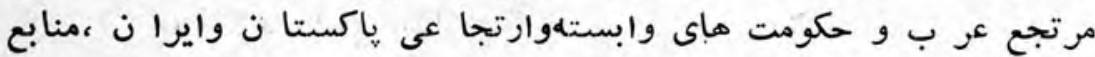

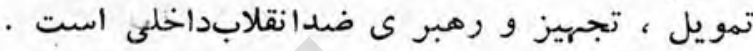

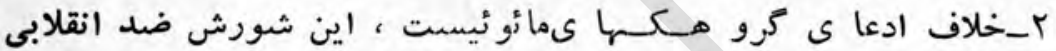

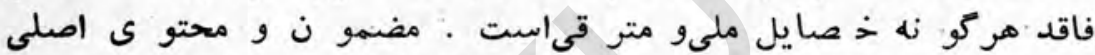

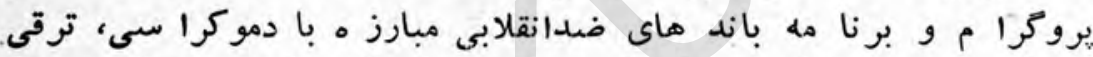

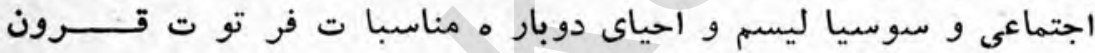

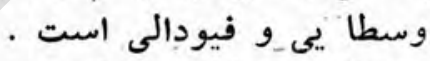

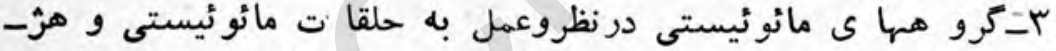

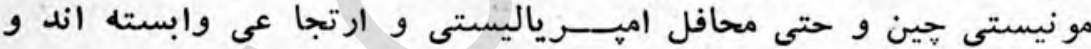

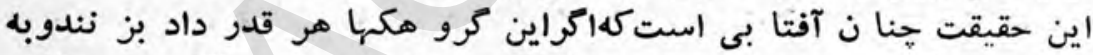

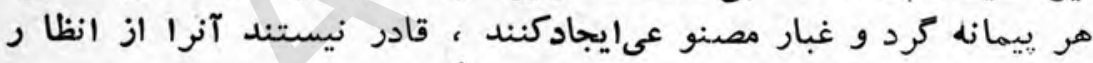

anos.

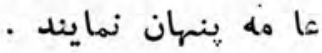

$$
\text { *: : - 类 }
$$

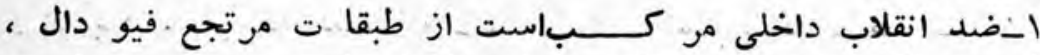

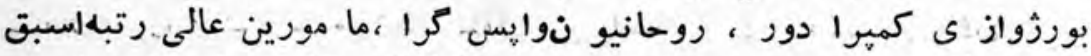

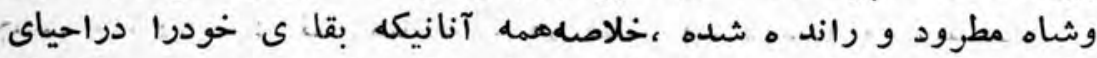

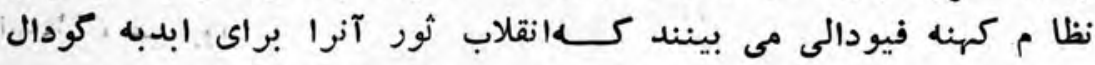




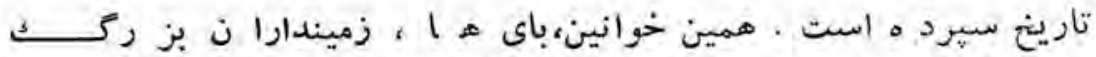

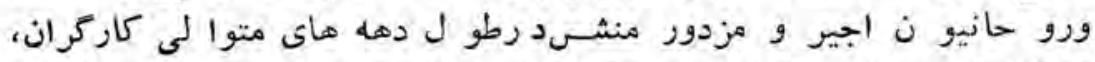

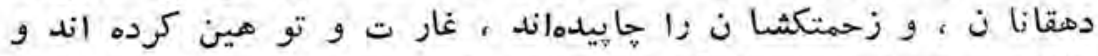

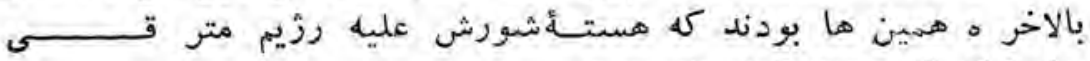

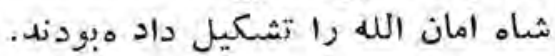

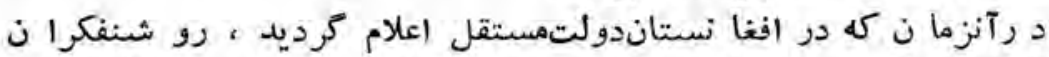

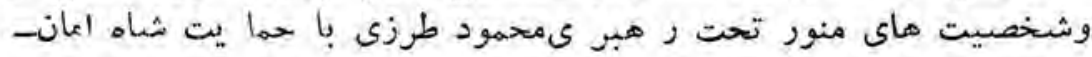

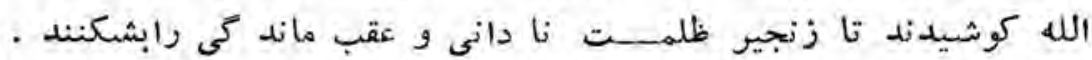

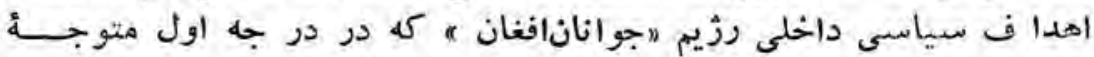

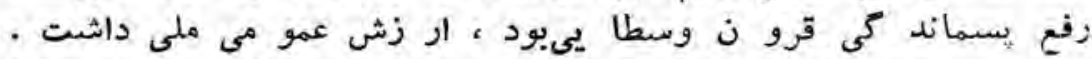

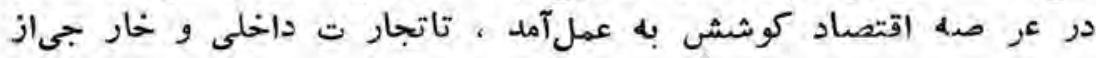

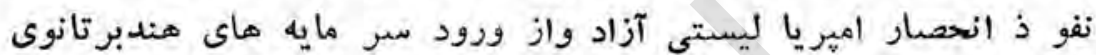

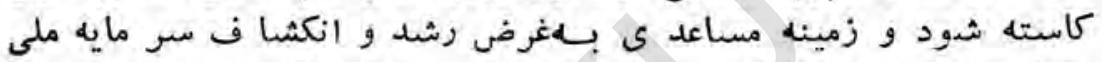

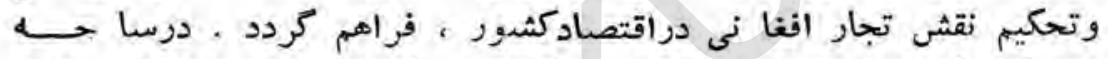

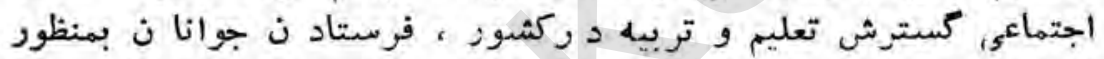

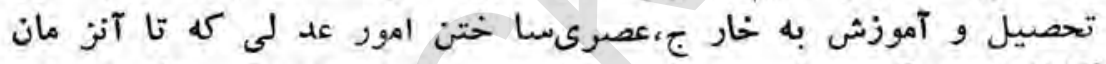

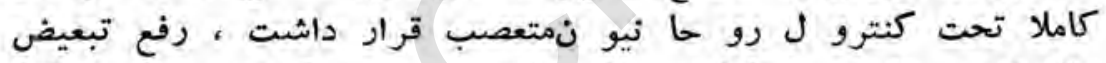

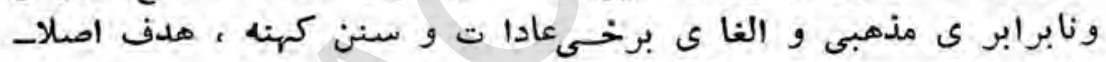

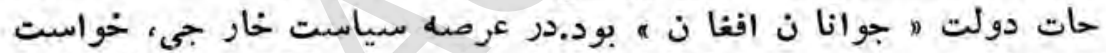

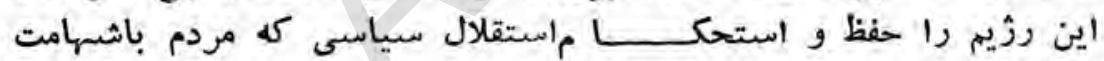

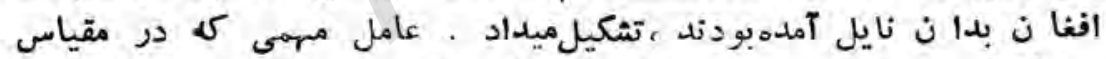

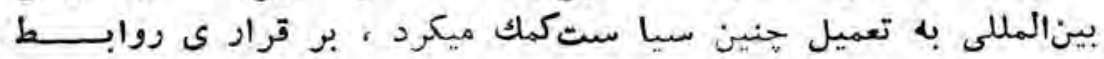

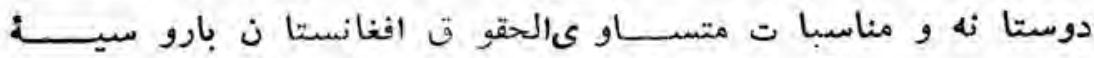

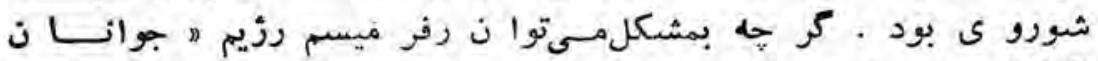

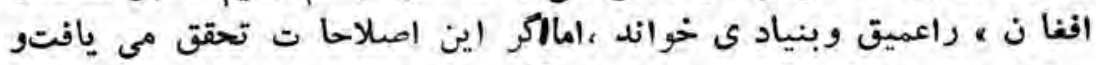

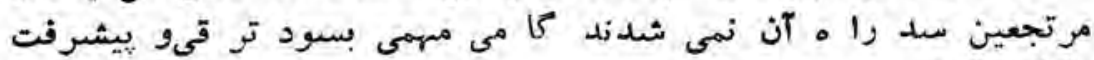

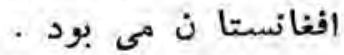




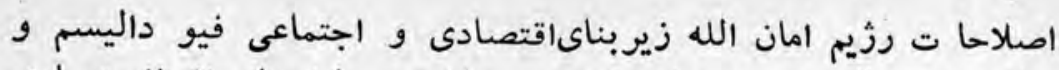

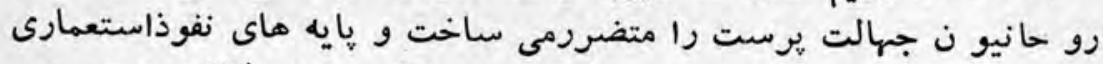

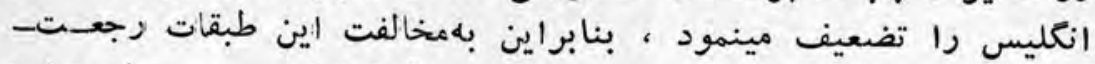

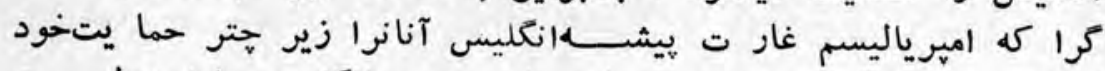

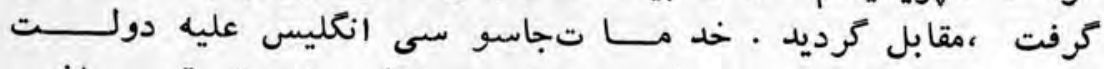

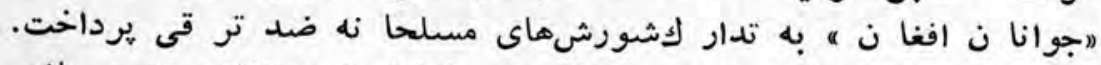

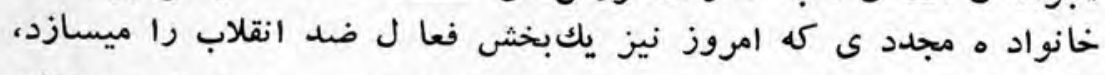

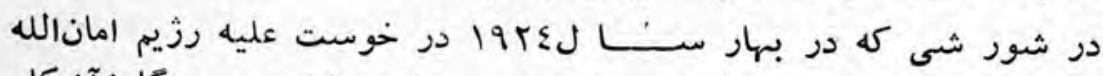

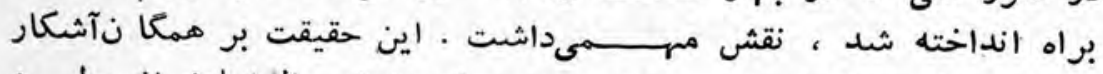

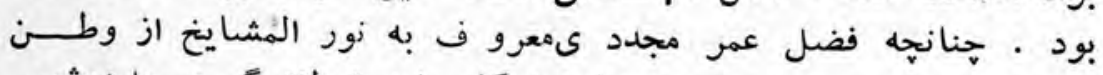

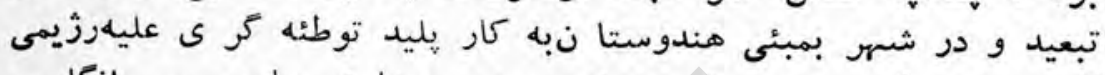

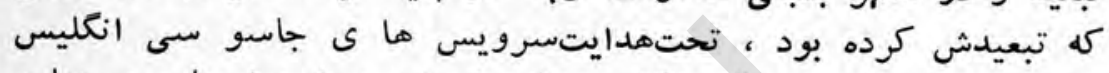

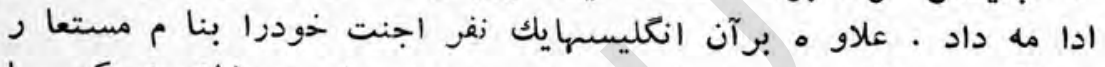

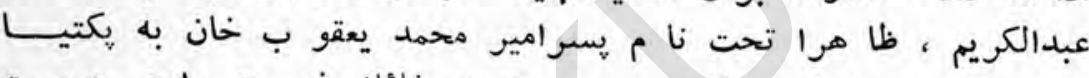

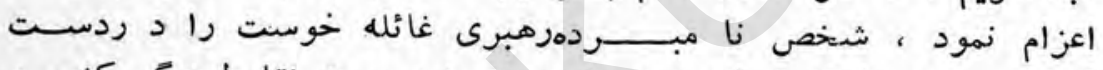

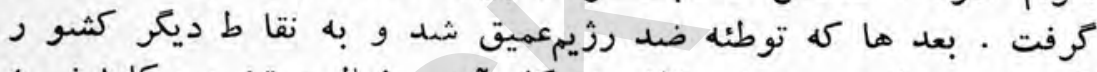

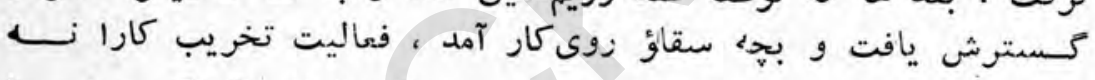

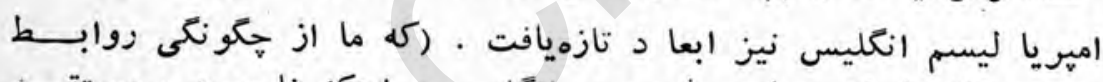

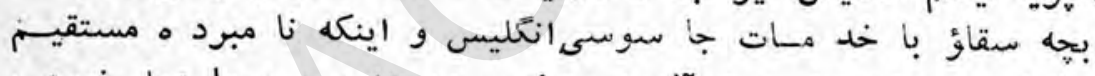

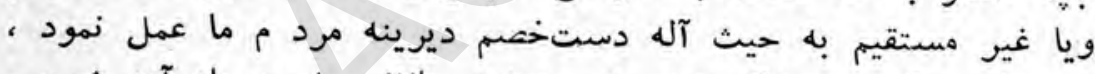

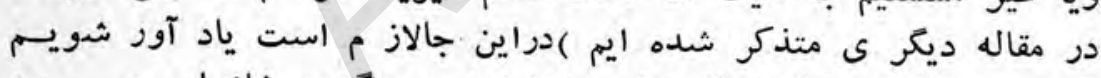

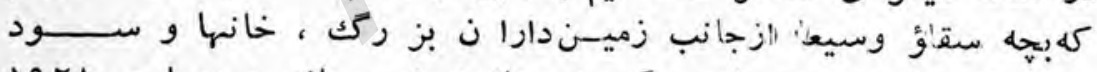

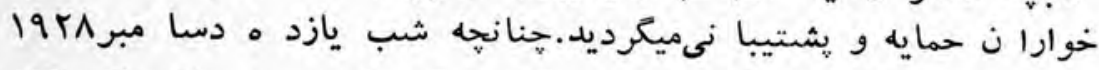

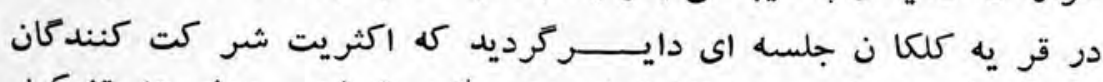

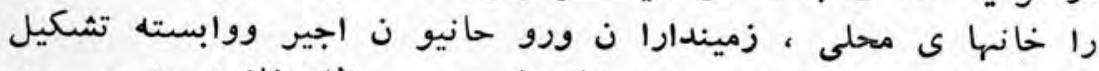

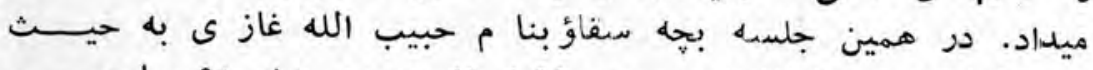

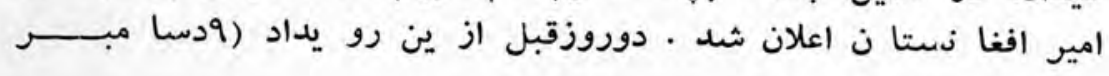




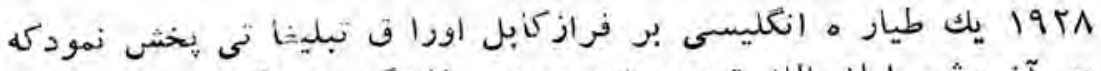

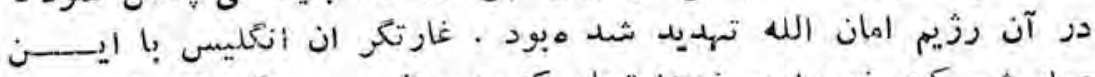

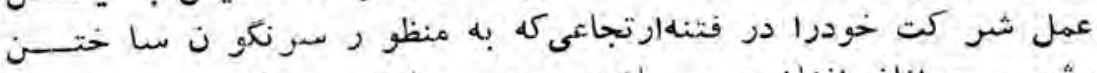

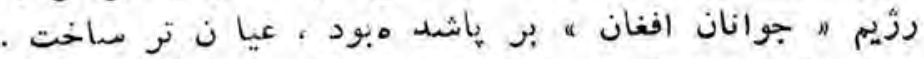

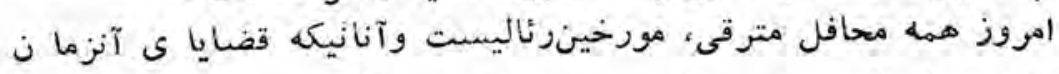

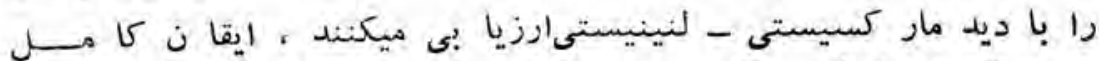

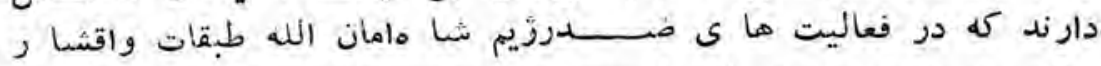

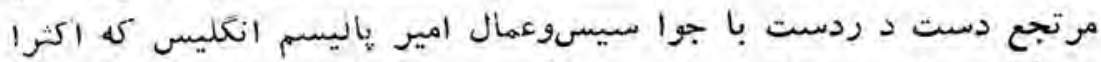

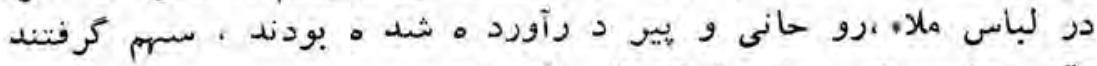

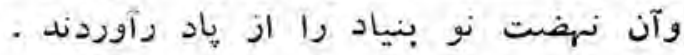

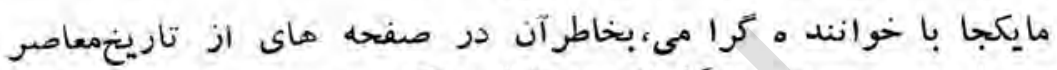

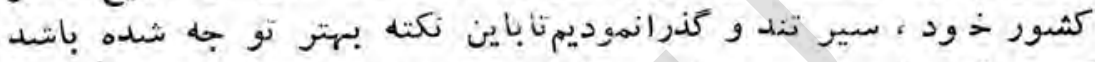

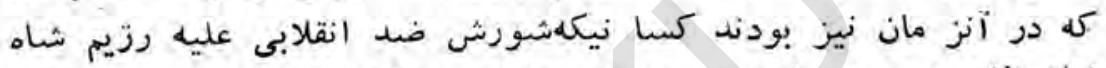

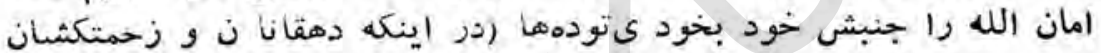

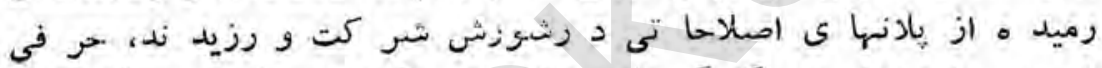

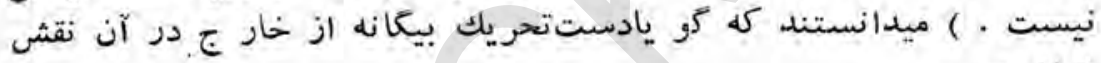

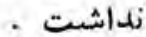

جانبدارا ن اين نظر يه آكا هانهيا نا أناهانه نقشى اساسى فيودا ل

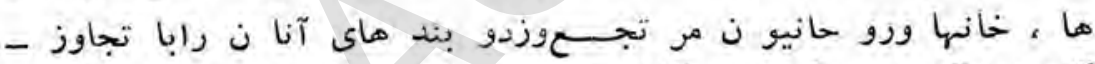

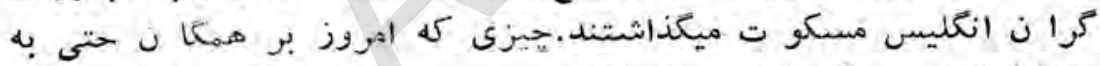

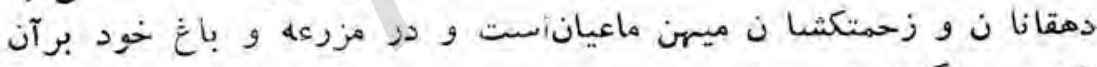

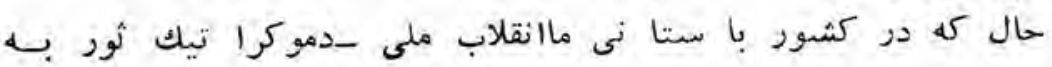

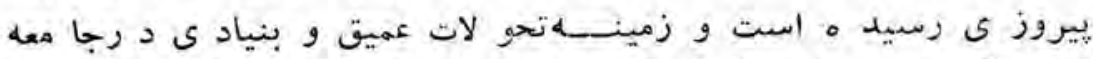

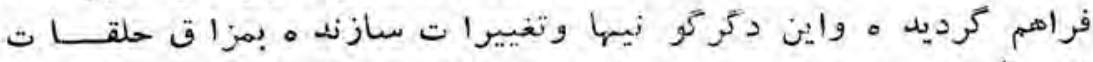

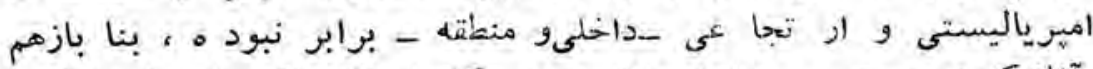

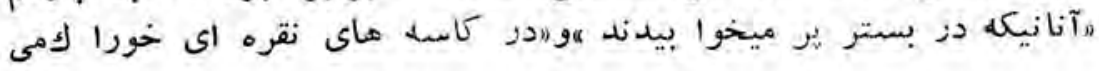




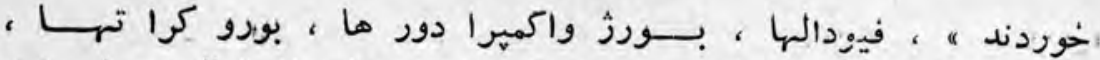

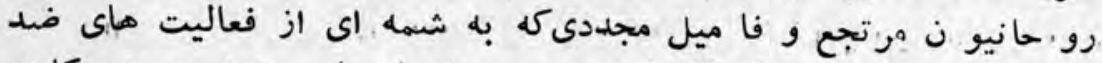

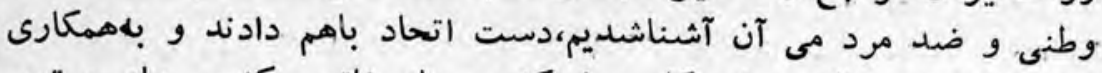

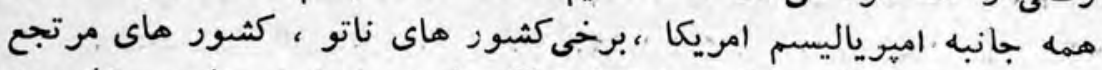

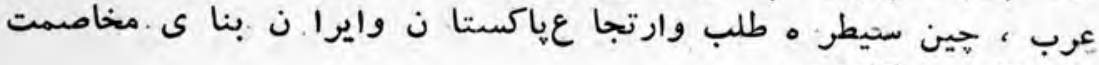

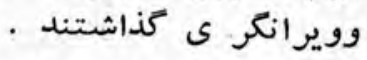

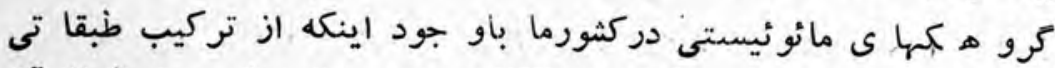

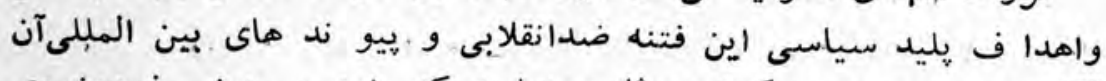

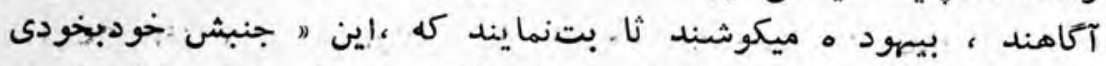

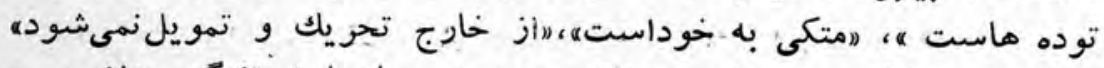

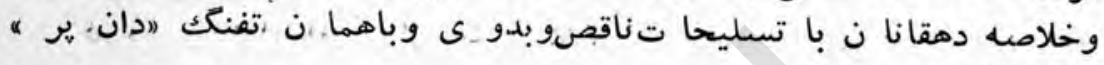

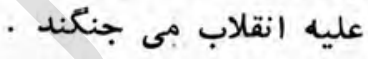

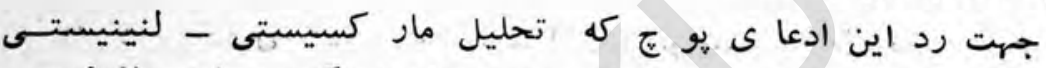

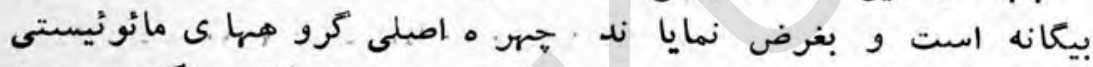

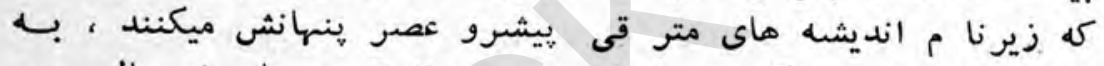

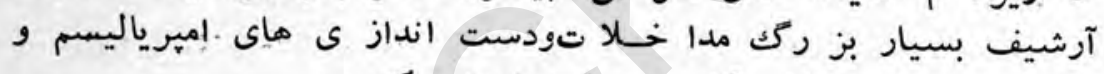

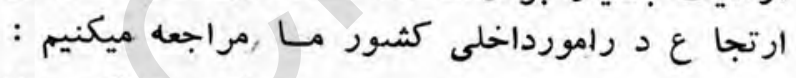

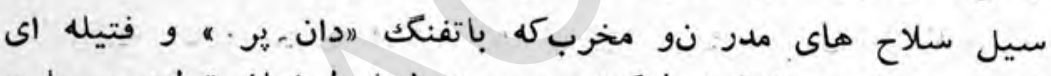

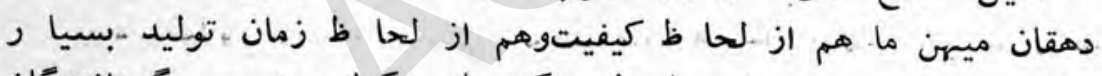

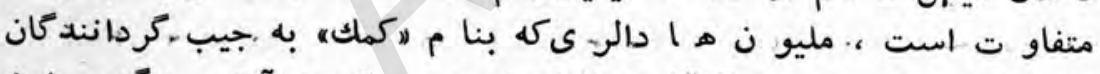

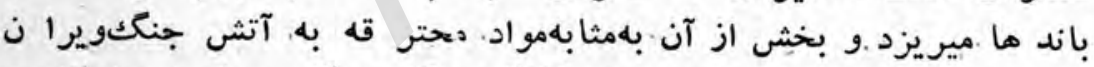

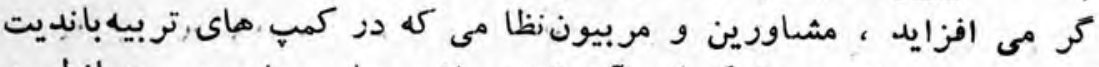

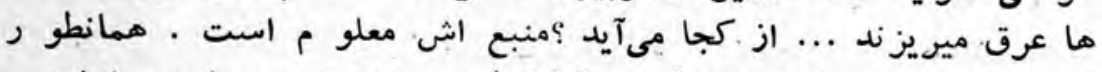

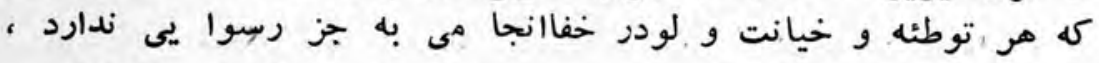

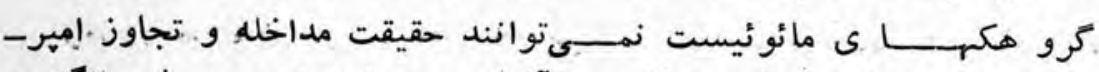

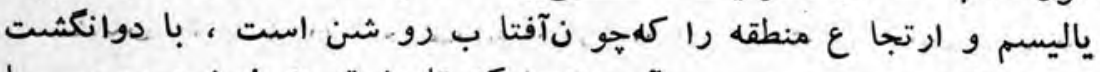

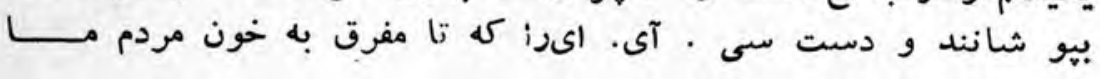




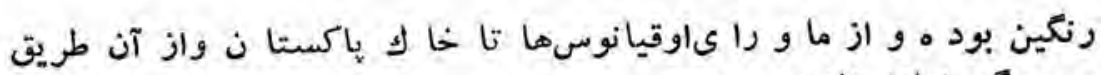

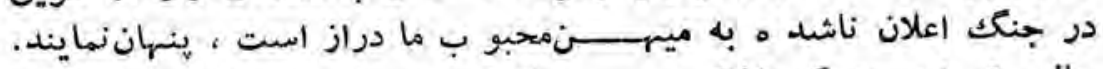

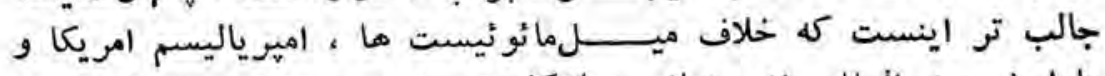

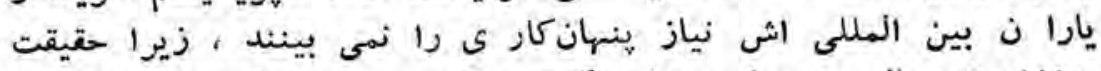

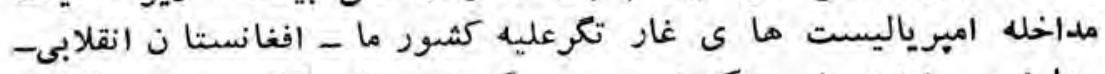

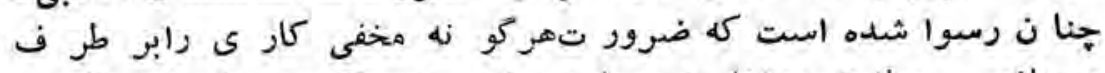

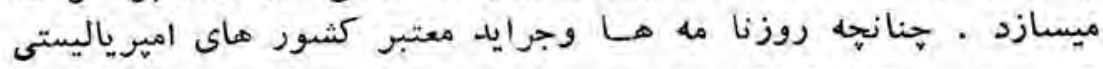

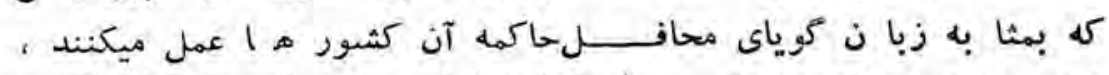

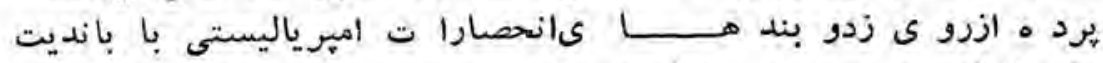

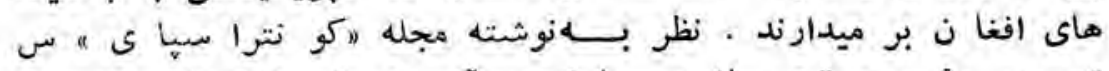

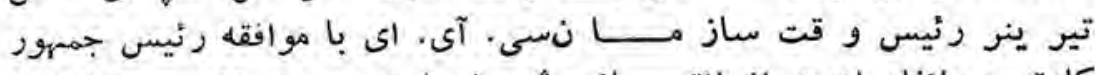

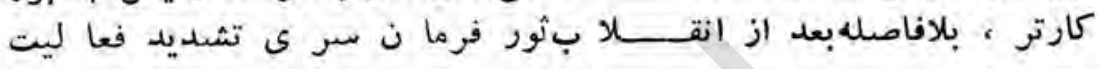

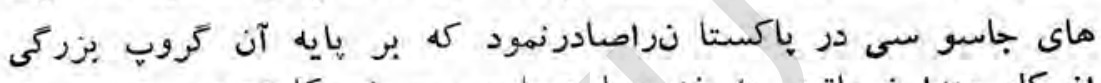

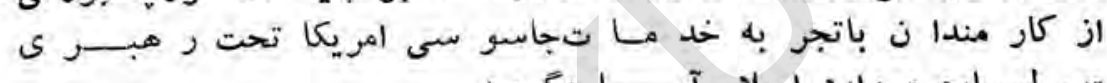

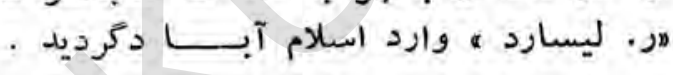

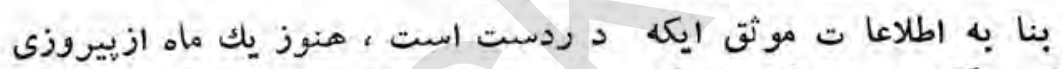

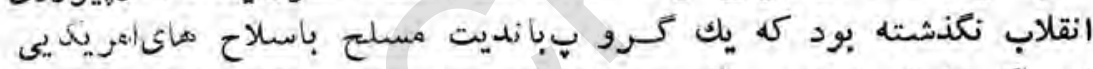

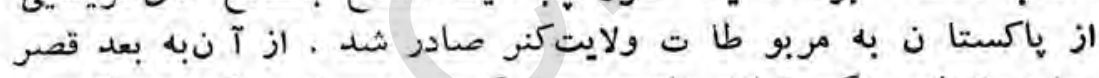

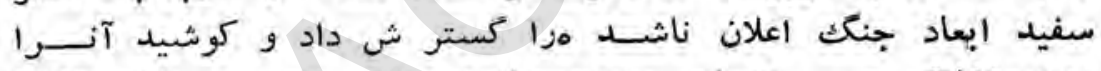

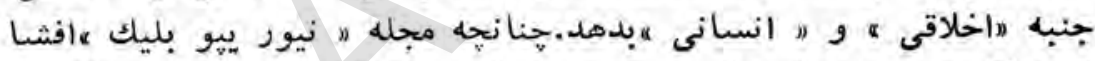

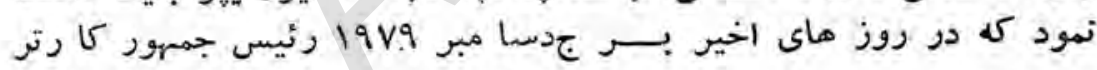

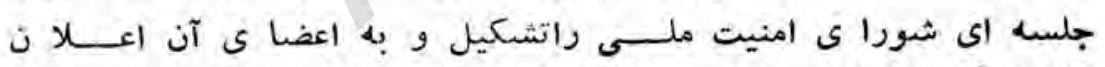

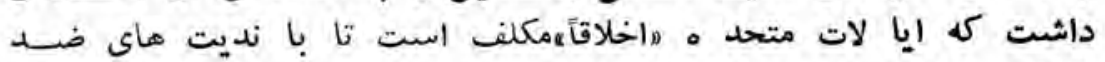

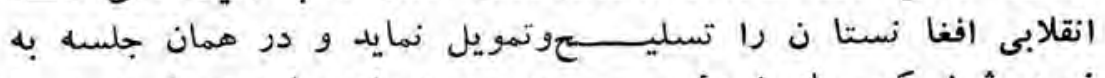

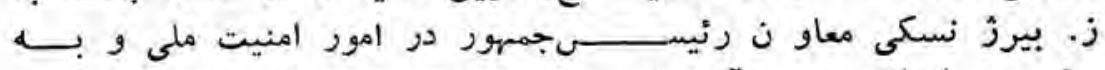

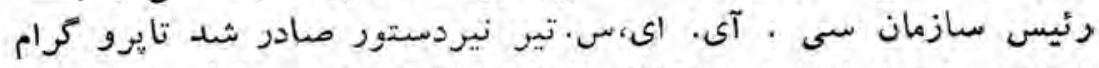

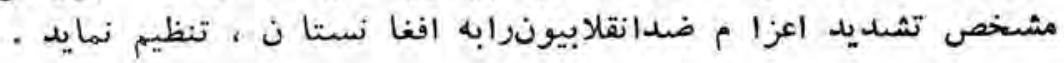




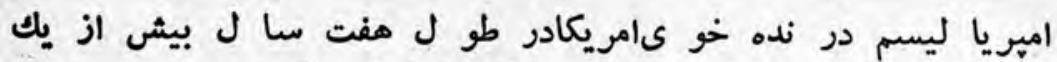

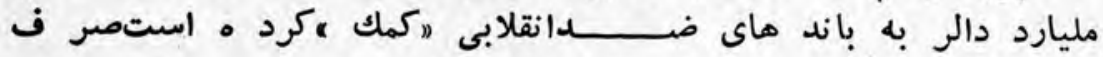

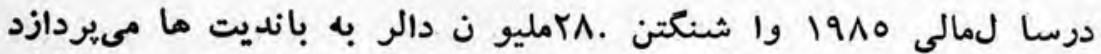

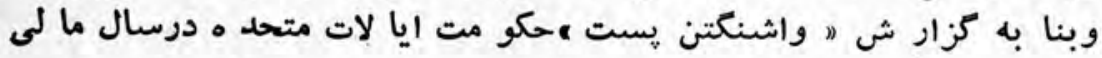

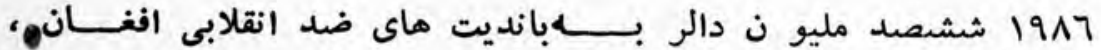

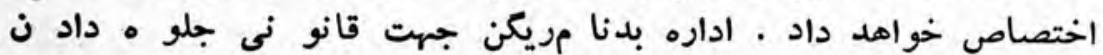

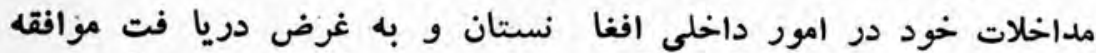

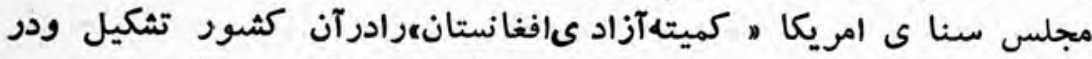

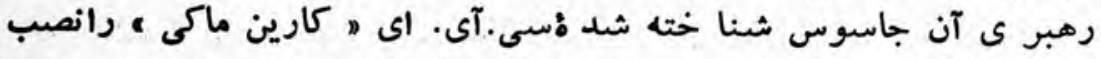

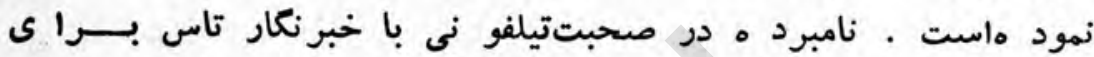

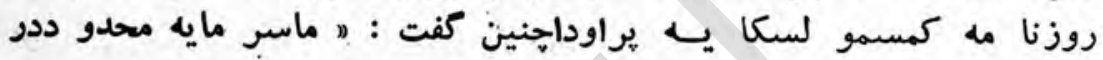

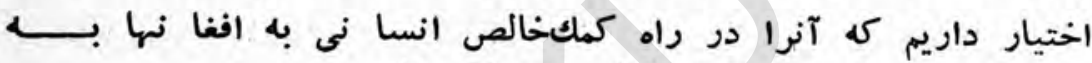

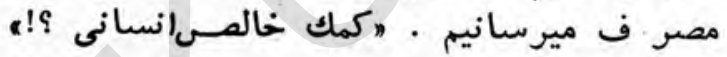

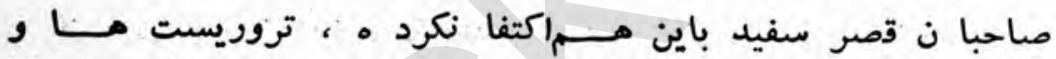

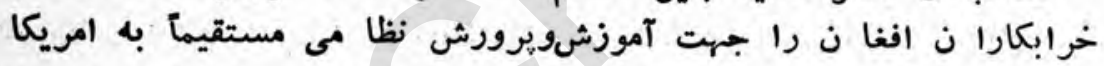

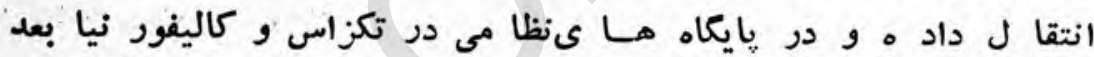

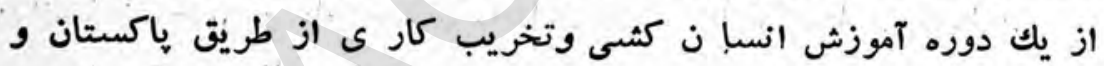

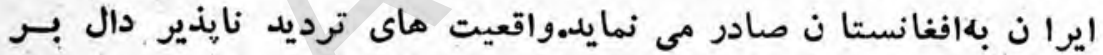

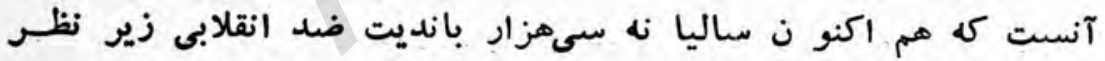

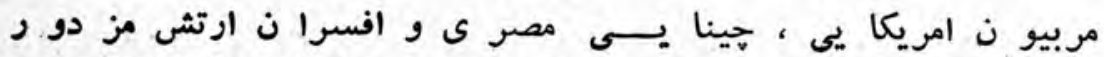

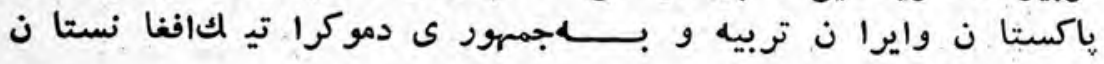
همان طوريكه كفته آمديم ،اميرياليسم امريكا در جنك اعلان ناشبه

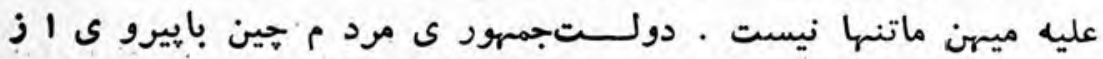

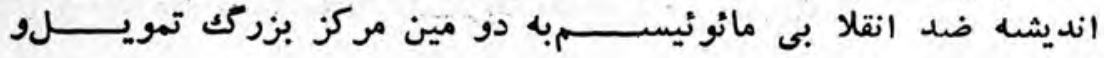




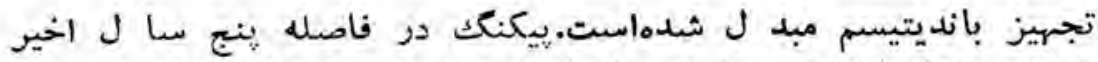

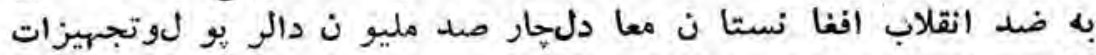

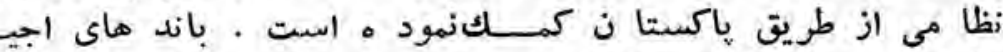

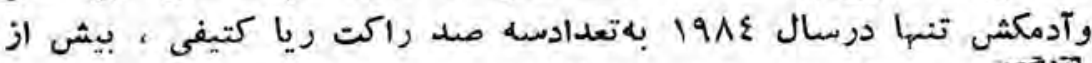

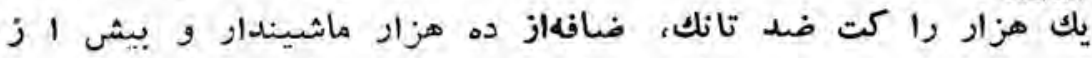
بيسه| هزار صندوق مهها تازمنابعجينى در يافت كردمانداند . هم اكنون

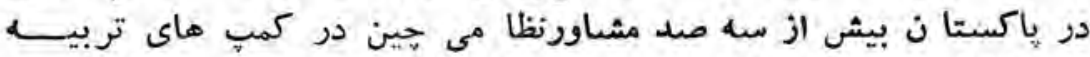

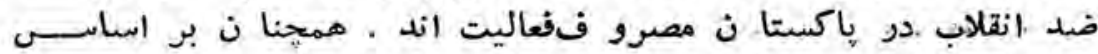

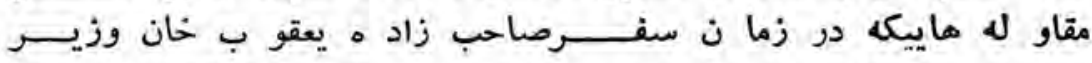

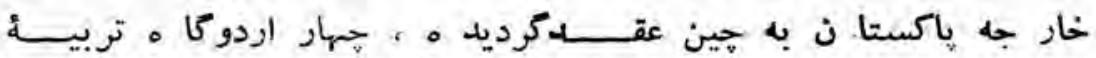

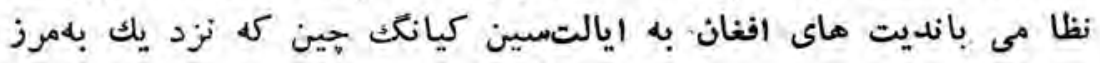

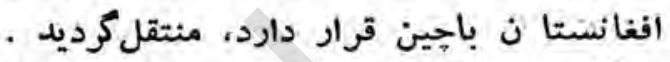

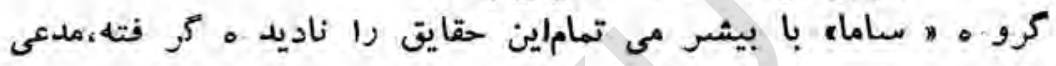

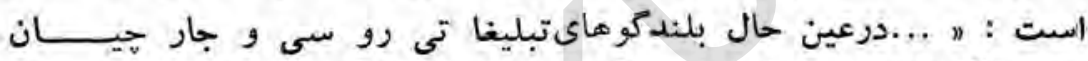

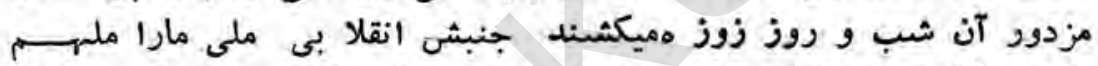

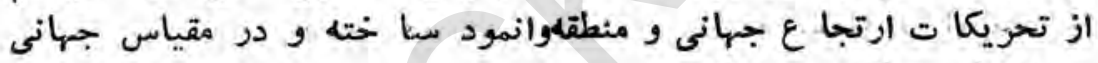

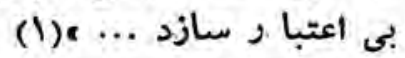

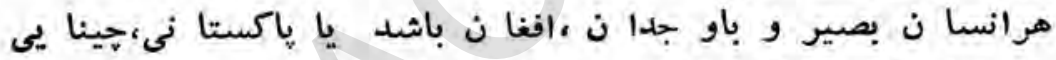

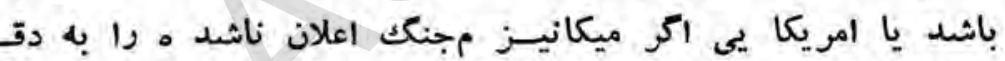

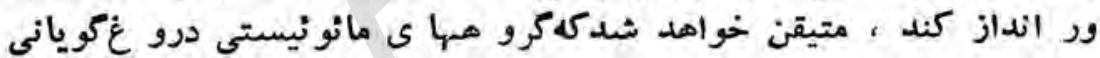

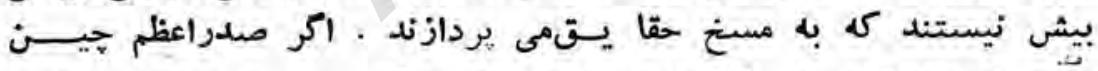

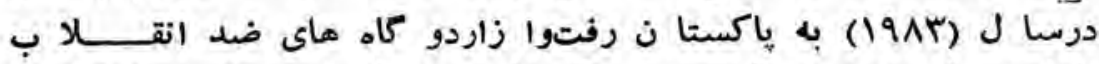

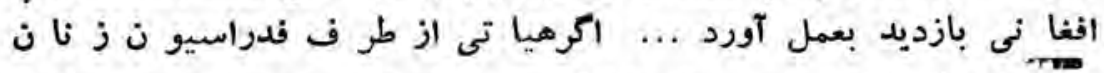

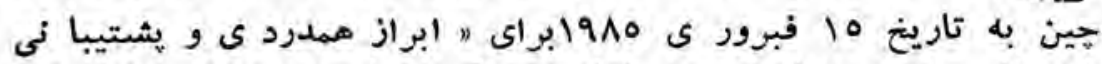

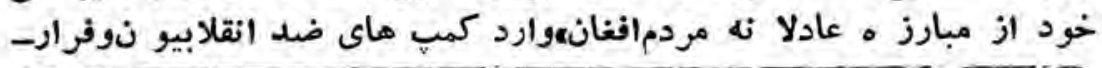

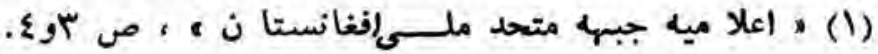




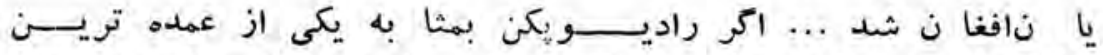

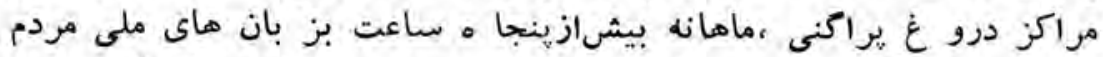

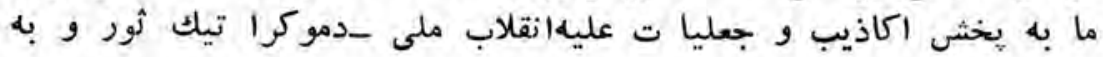

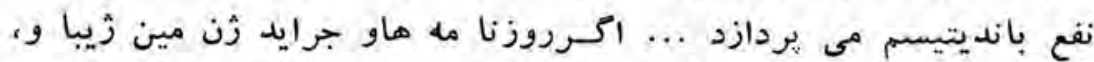

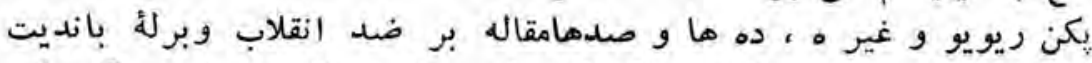

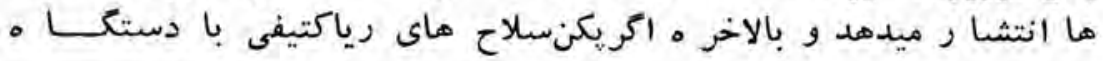

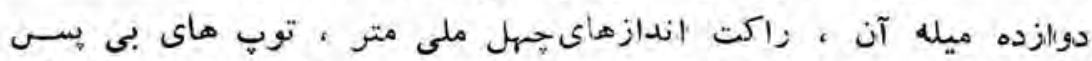

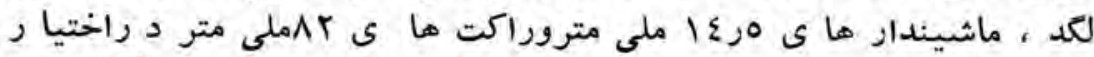

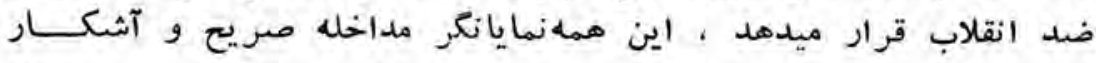

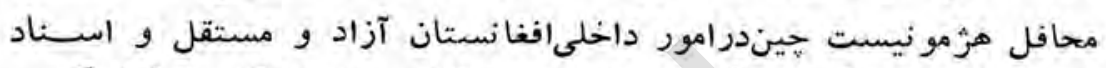

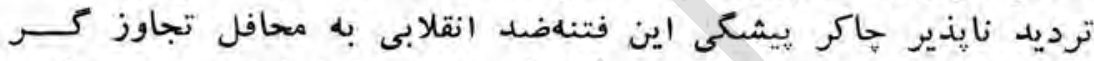

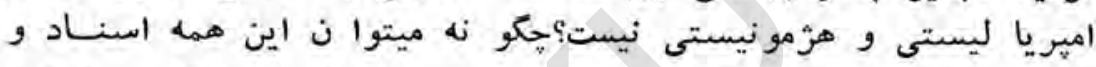

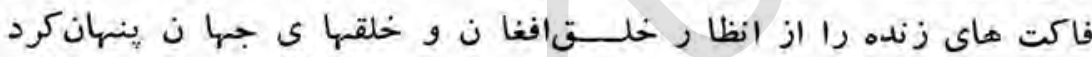

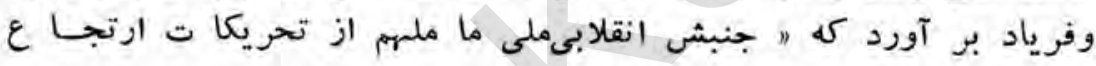

جهانى و منطقها نيست

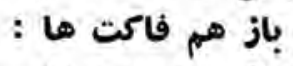
حكو مث شبه فاشيستى دموكراتهاي مسيحى در آلما ن فدرا لـ ازمار

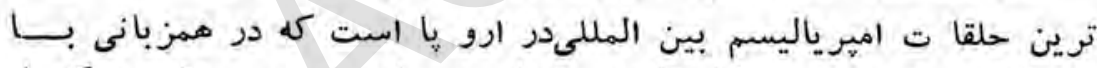

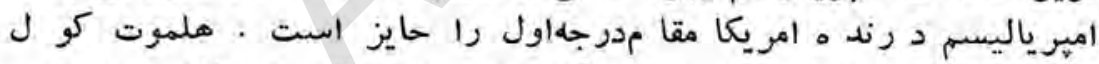

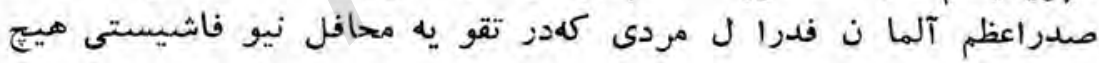

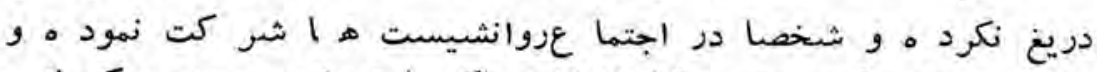

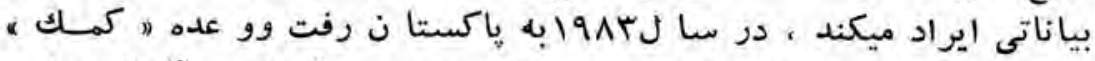

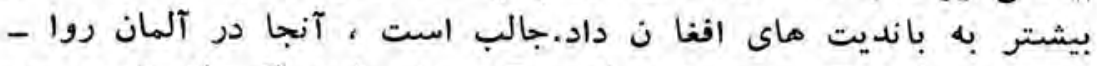

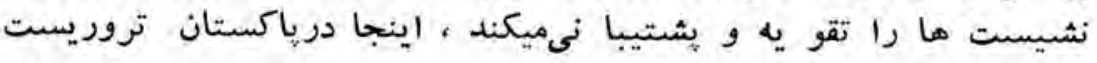

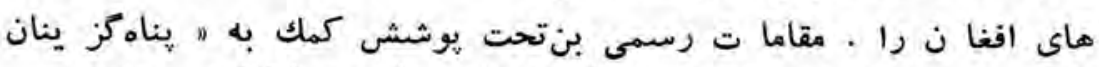

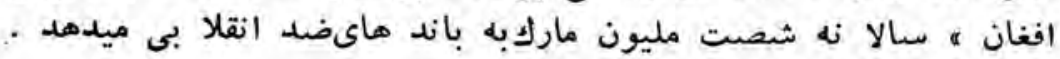




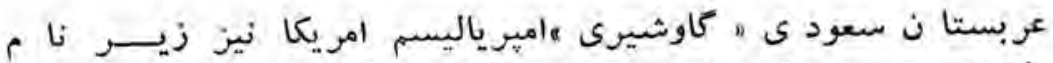

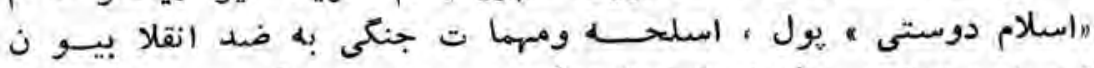

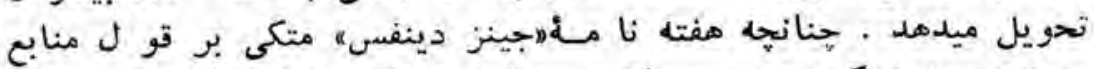

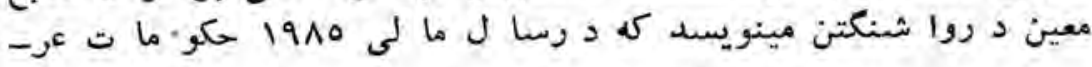
بستا ن سعود ى ؛ اسرا ئيلو هينهدو د دوصد مليو ن دالر دردسترسى

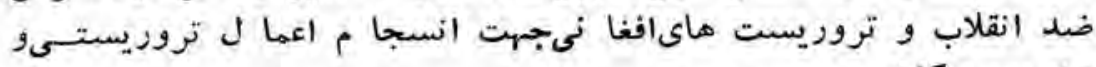

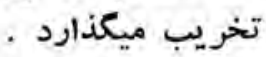

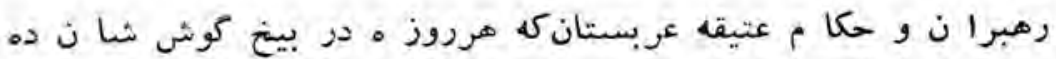

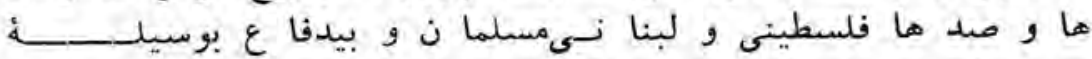

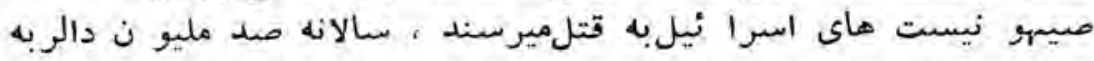
ضد انقلاب افغانستا ن ميدهد

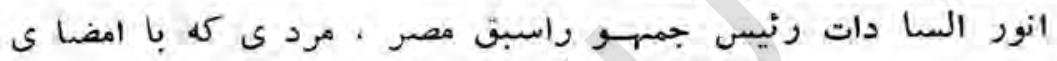

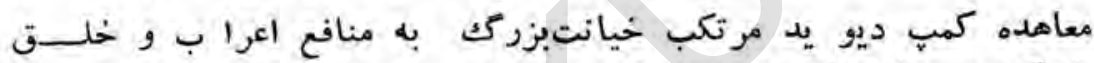

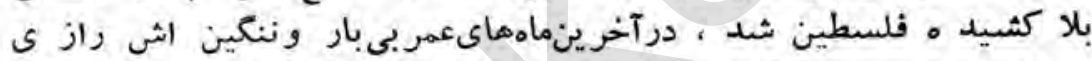

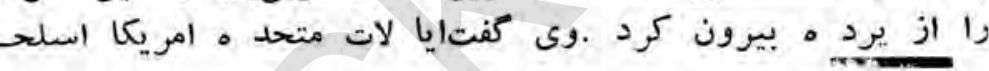

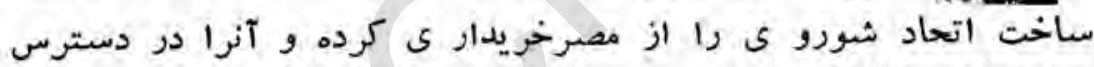

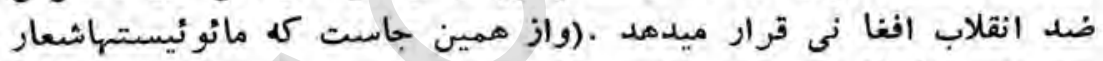

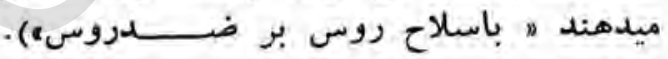

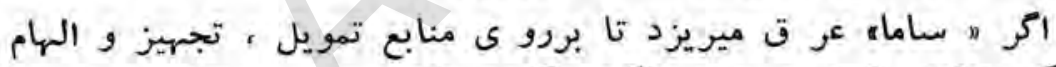

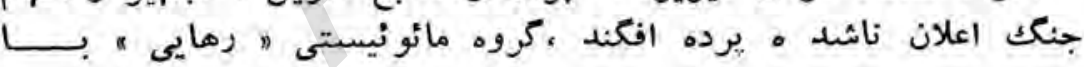

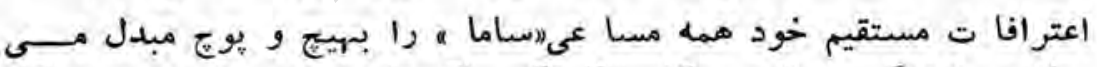

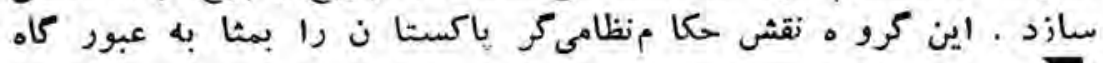

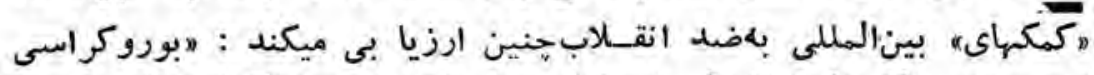

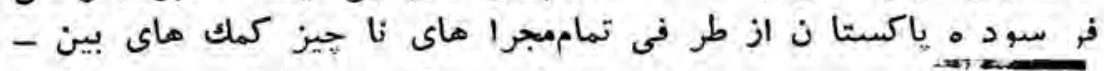

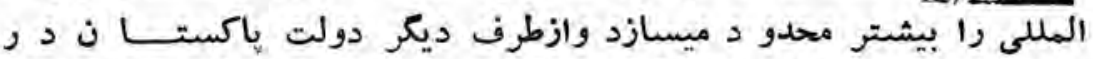

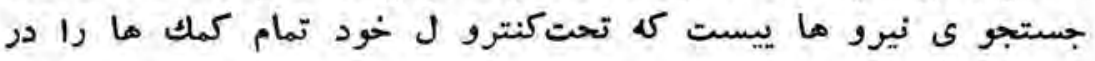


انحصار آنها قرار دهد . ، (1) اينييان حاو ى مله مطلب مهم است :

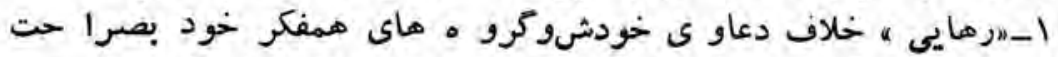

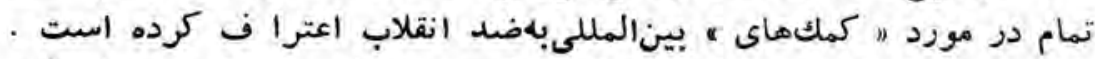

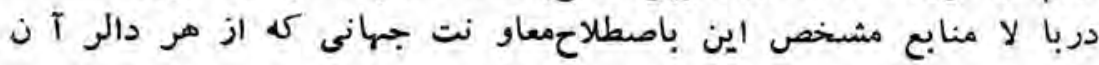

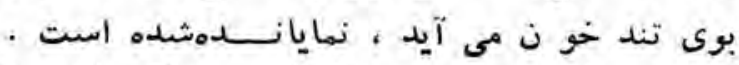

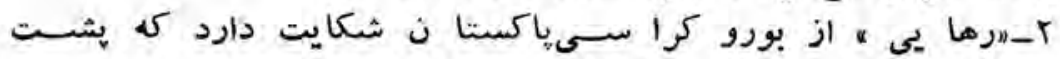

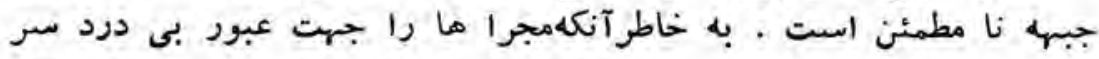

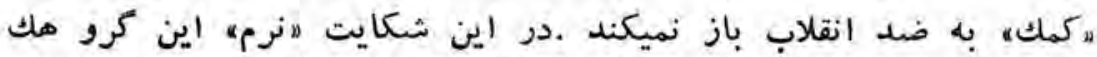

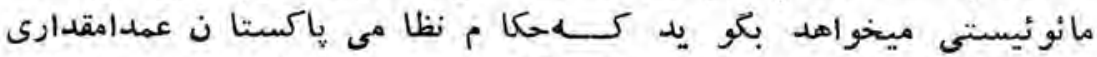

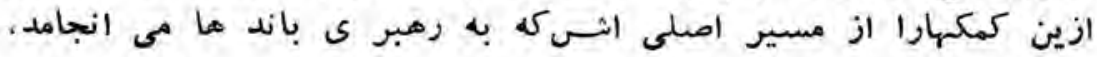

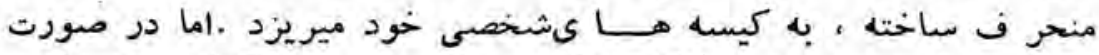

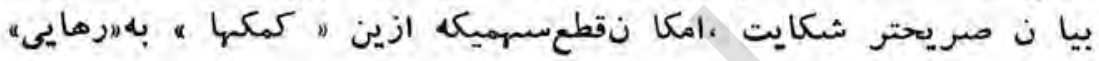

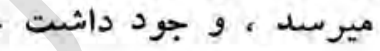

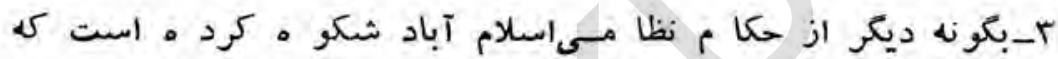

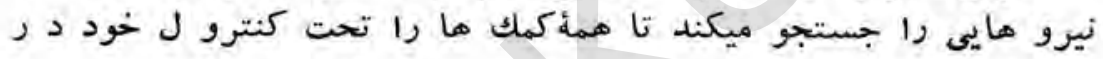

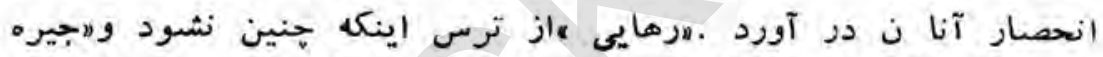

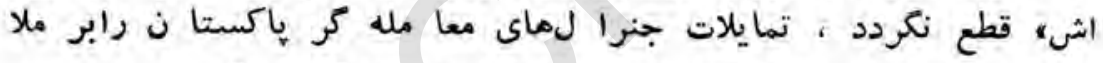

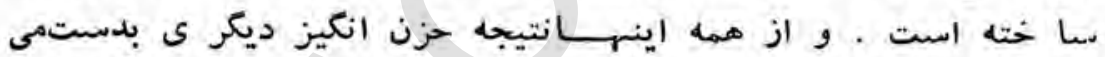

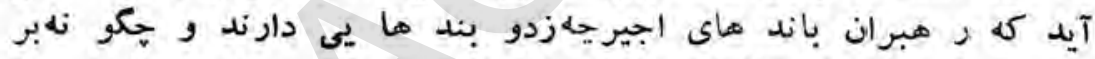

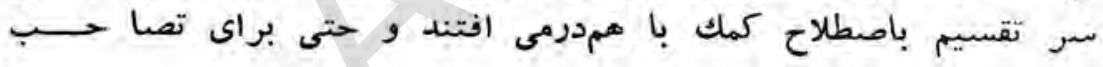

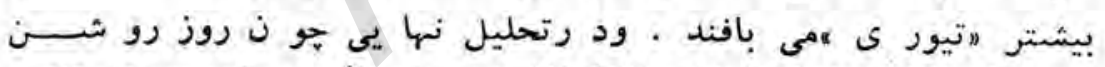

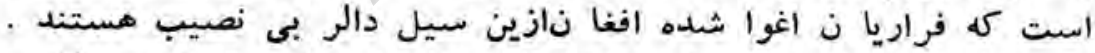

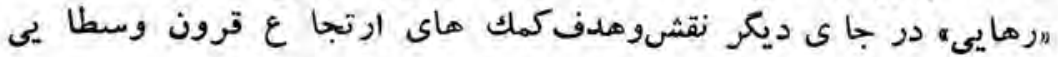

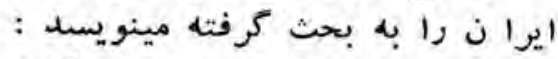

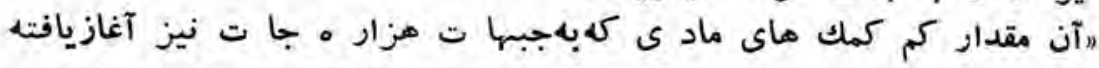

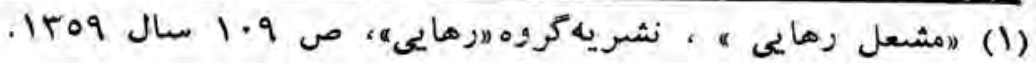




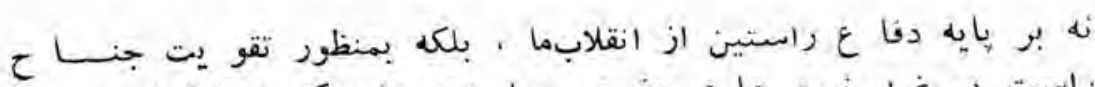

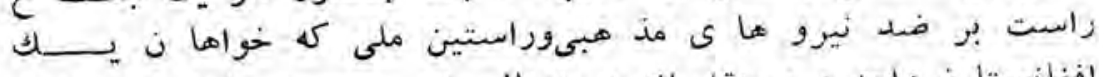

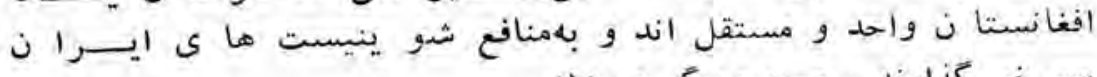

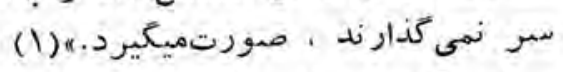

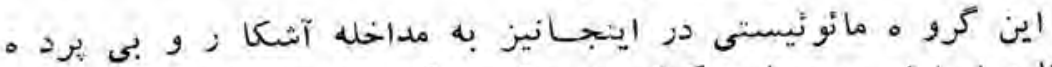

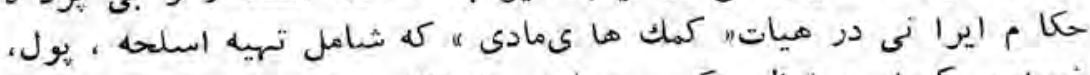

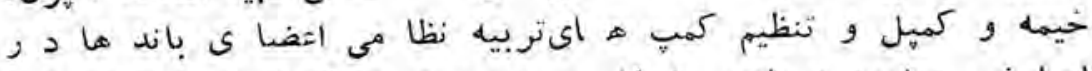

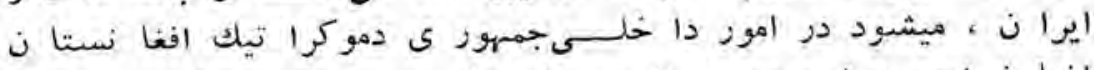

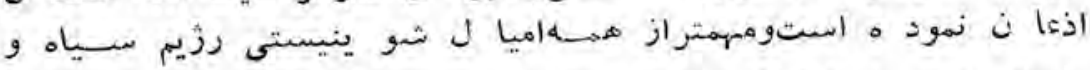

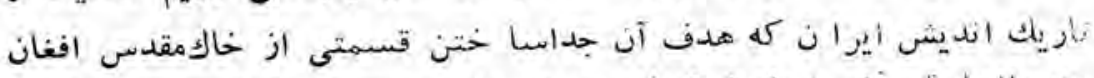

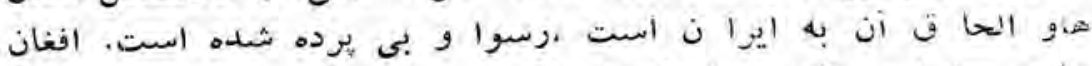

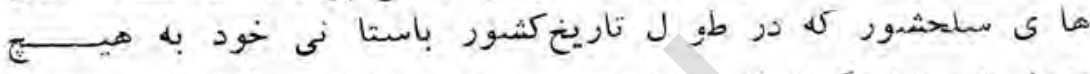

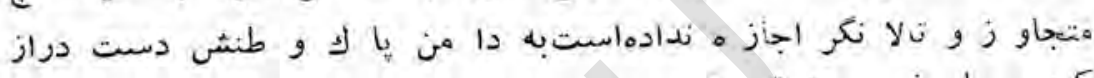

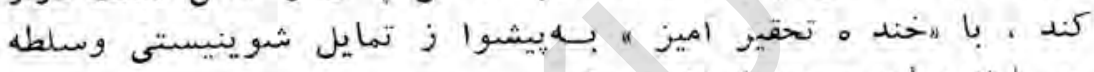

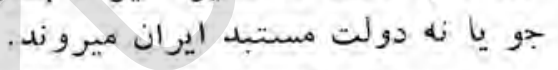

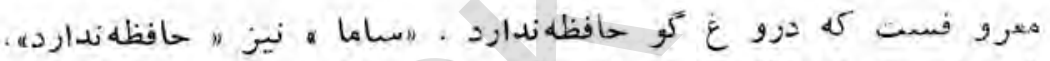

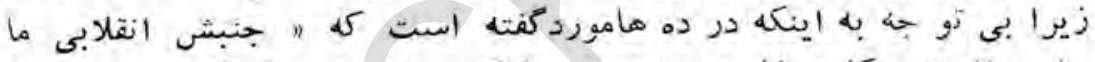

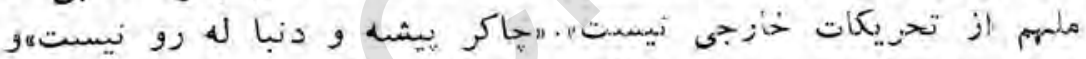

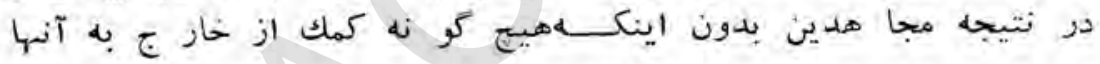

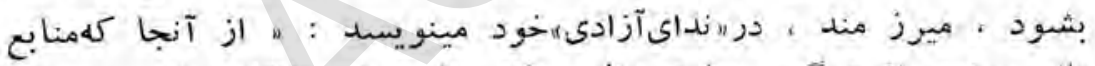

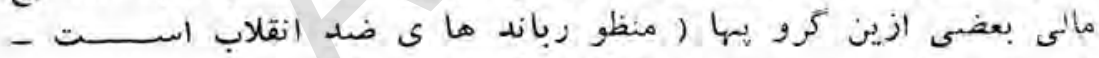

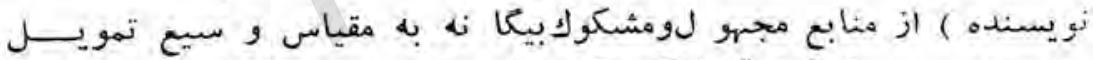

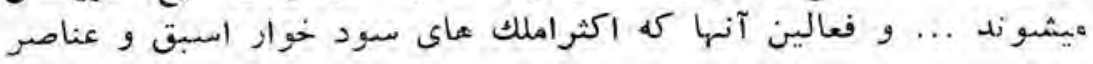

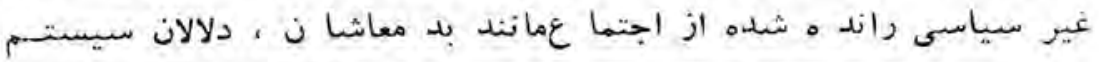

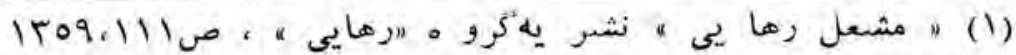
كيه از ماست 
دولتى اسبق ، قما ربازا ن،لومينانودارند ـ كا ن سوابق بد اخلا قى انى

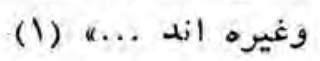

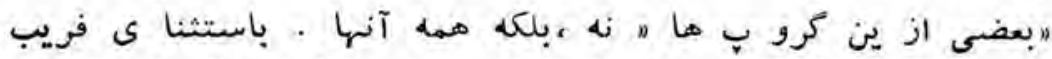

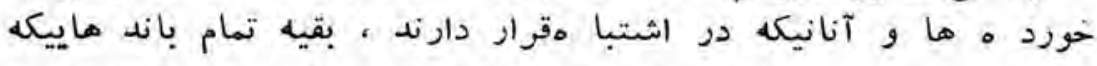

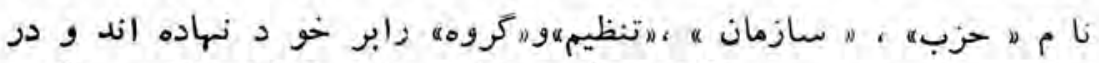

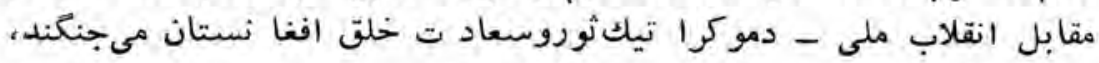

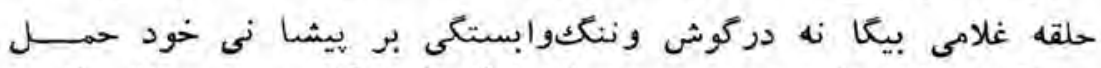

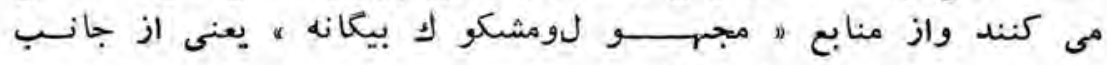

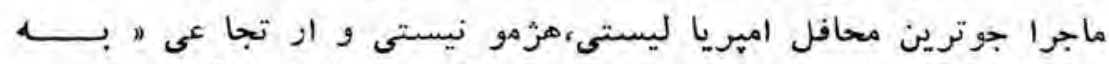

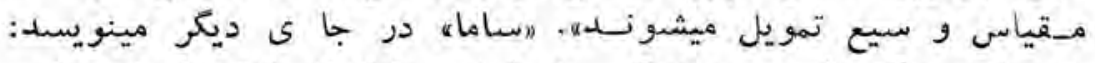

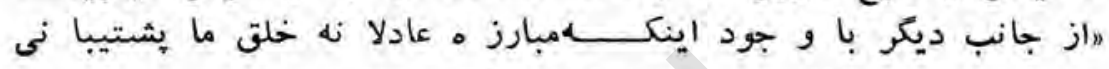

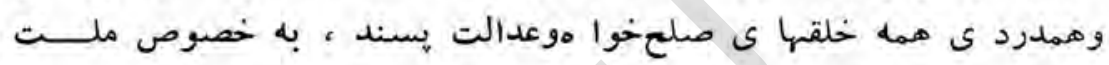

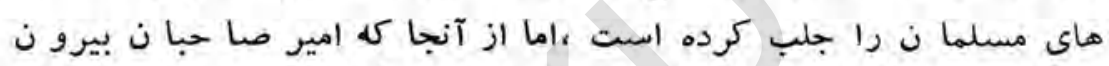

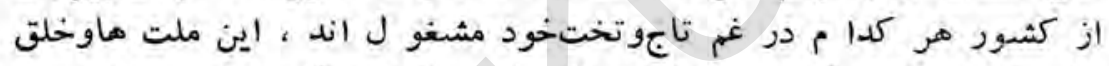

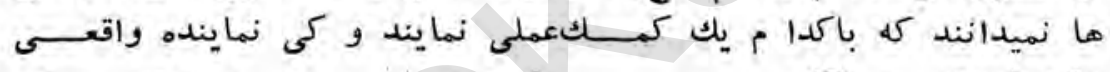

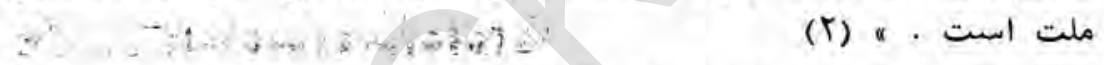

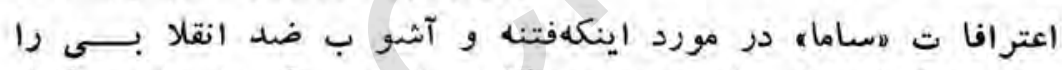

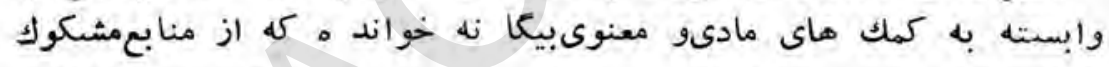

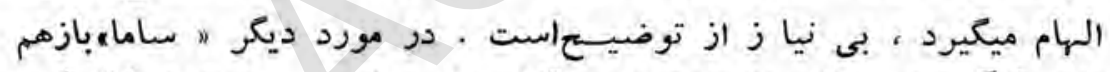

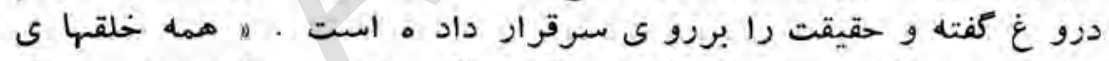

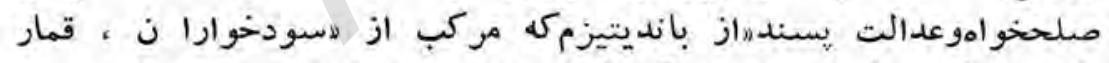

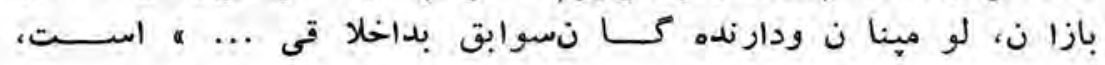

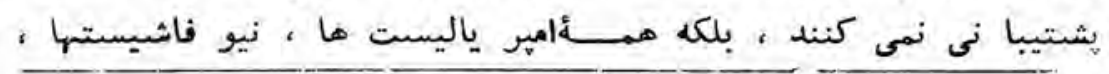

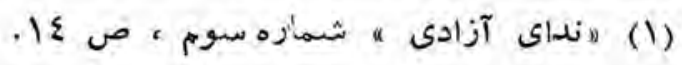

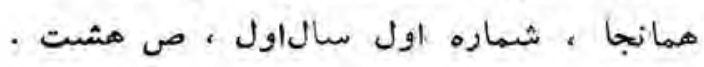


شو ينيستها ، مستبدين و مر تجعيزمنطقه و و جها ن ، ، ريكن ما، تاجهر

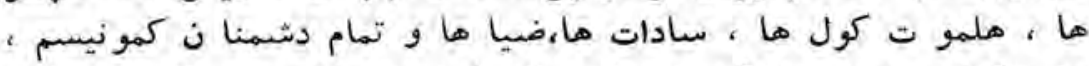

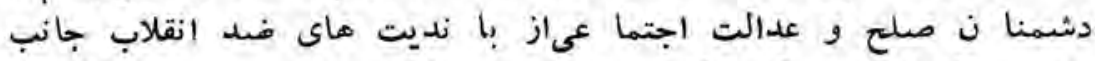

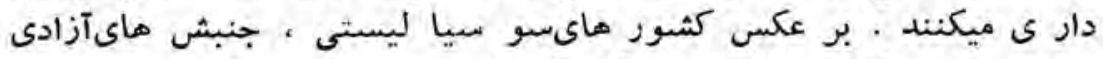

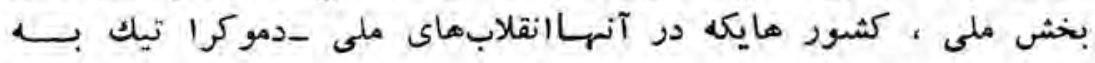

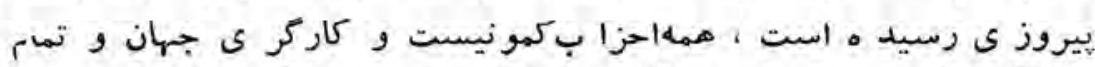

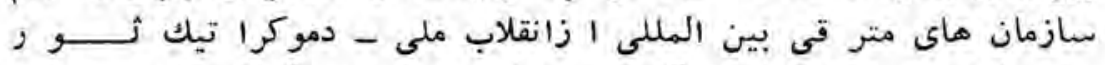

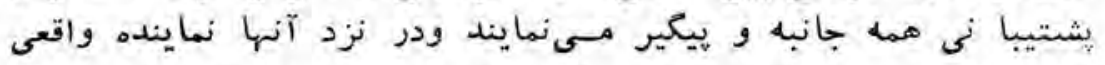

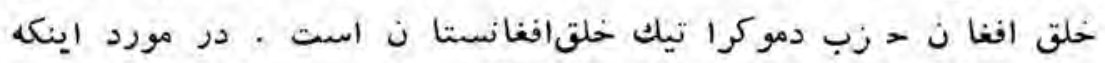

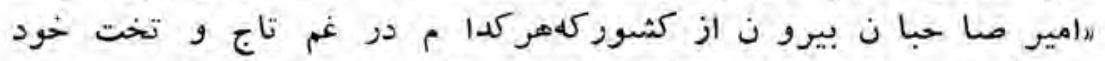

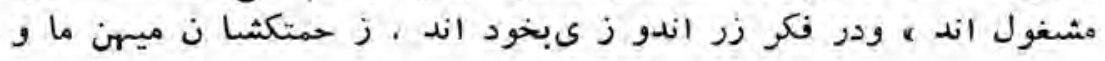

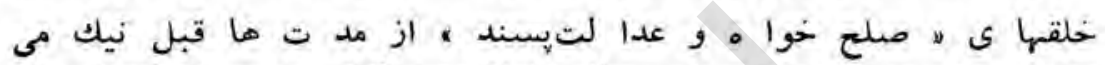

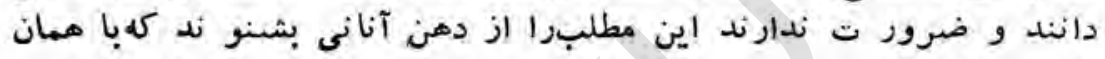

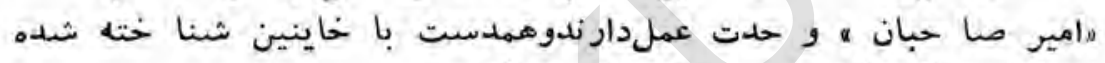

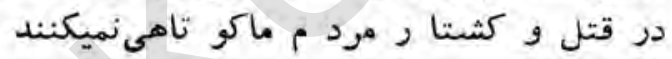

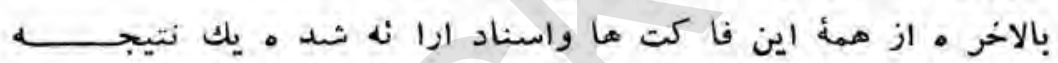

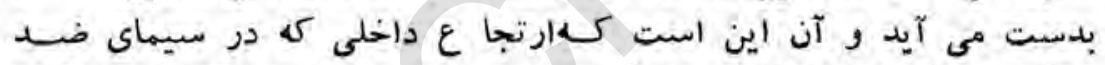

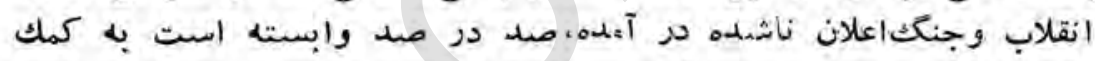

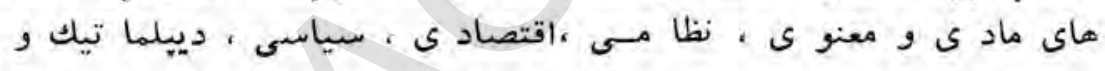

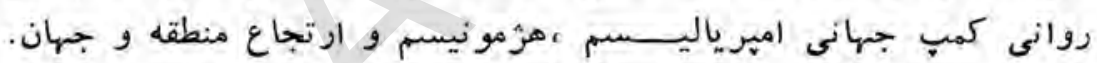

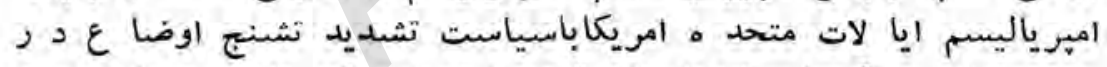

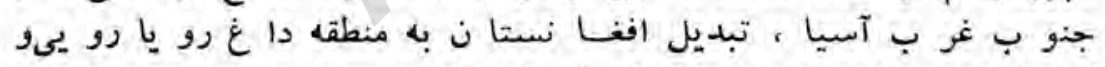

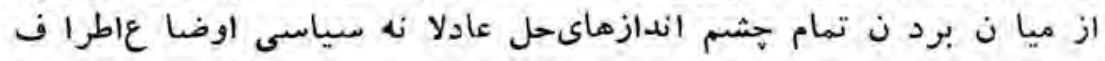

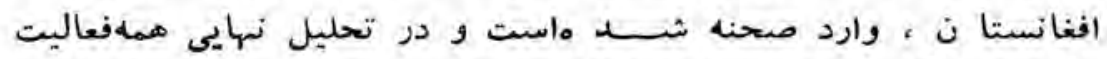

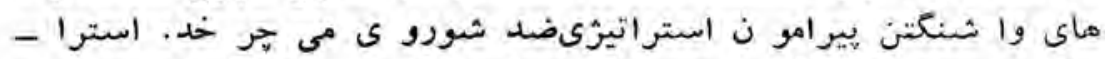

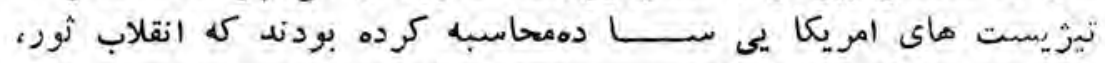

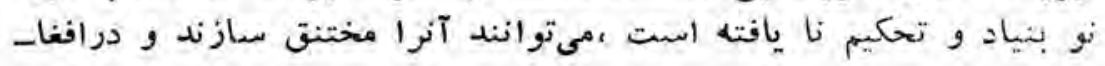




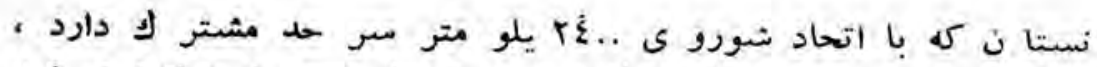

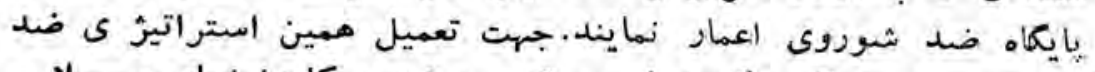

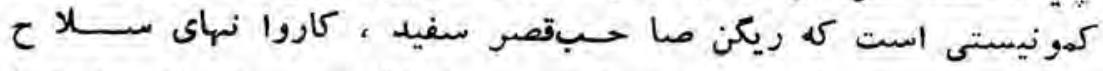

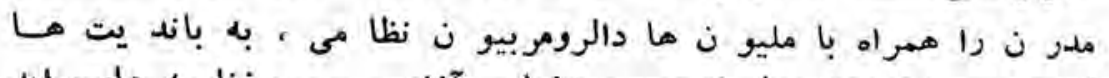

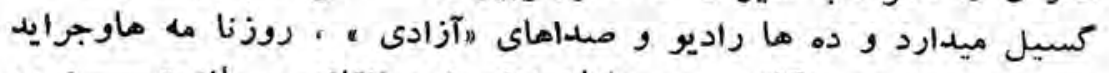

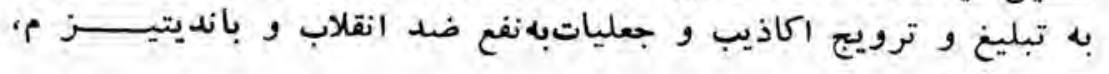

\section{* * * *}

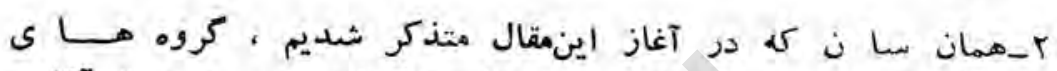

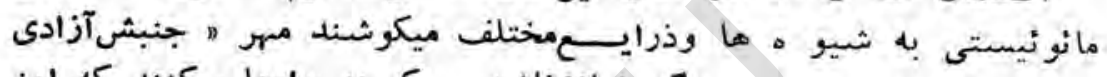

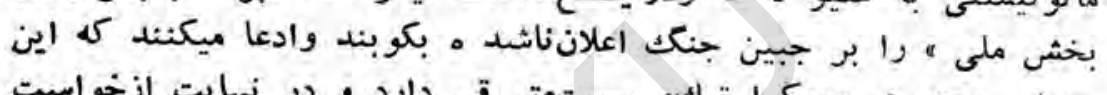

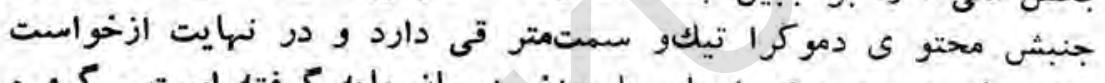

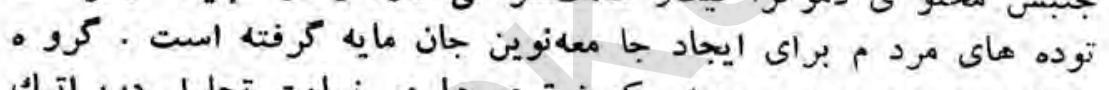

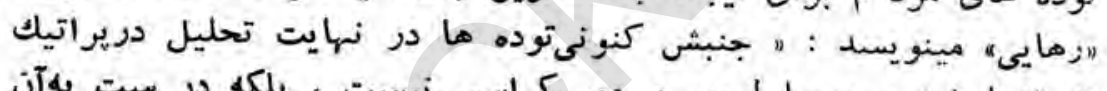

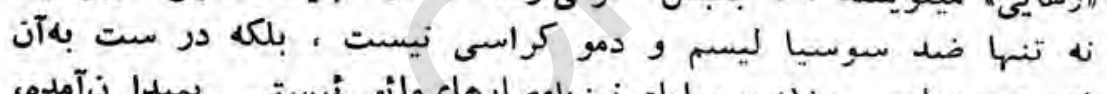

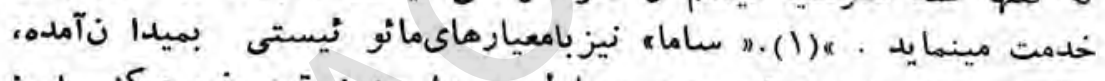

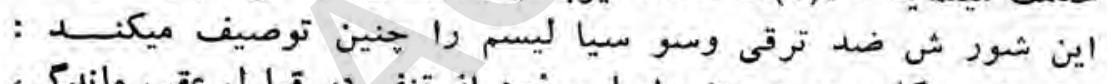

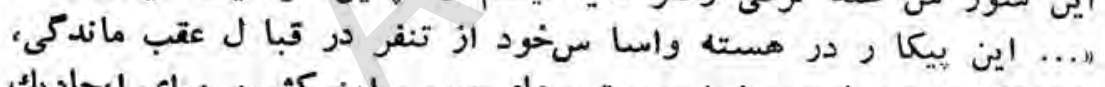

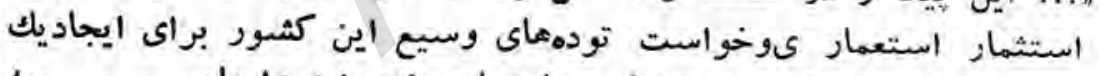

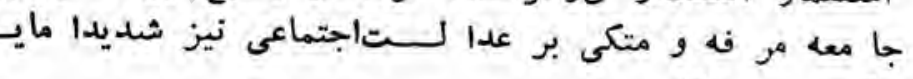

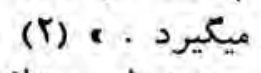

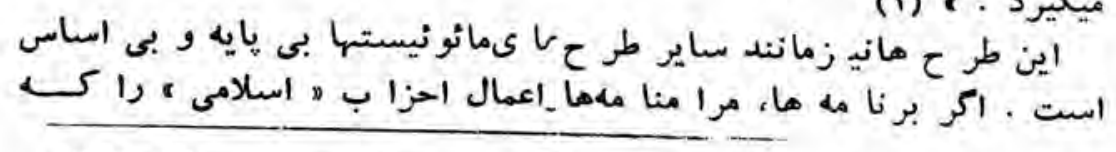

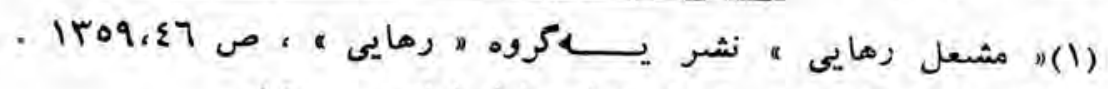

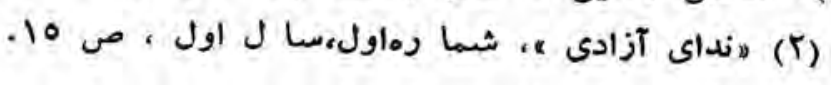




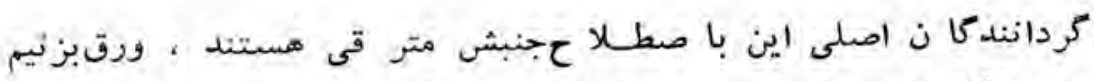

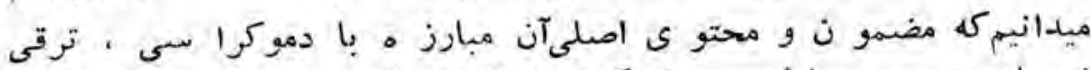

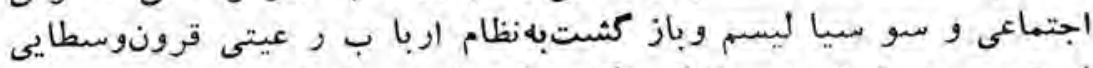

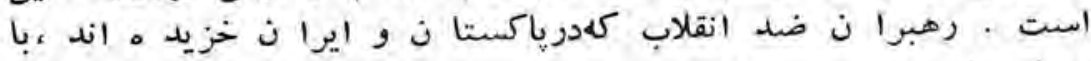

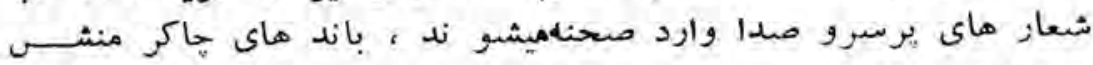

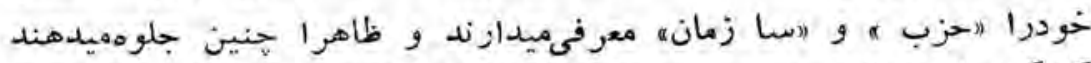

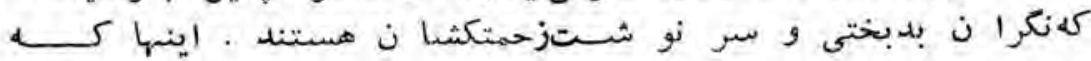

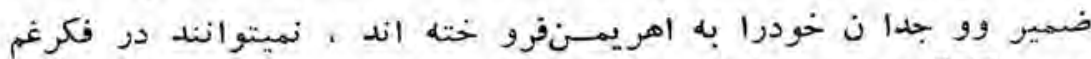

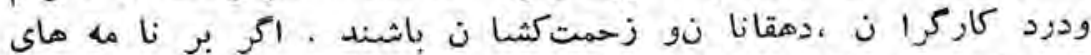

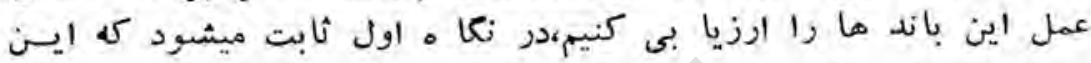

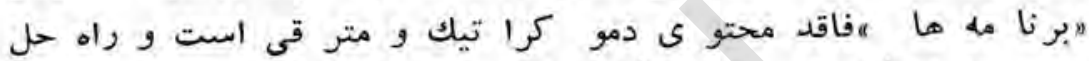

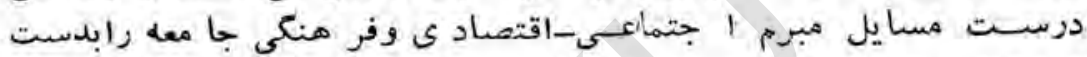

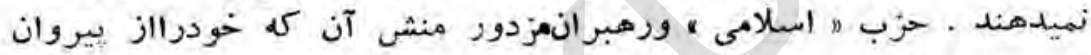

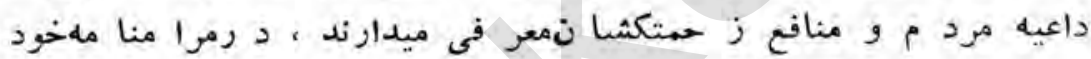

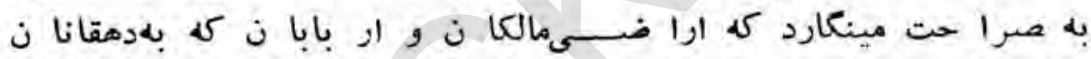

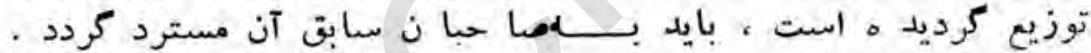

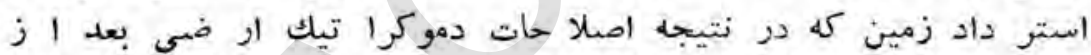

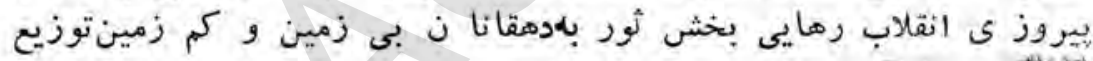

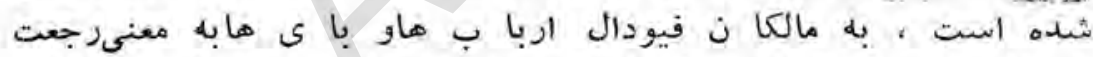

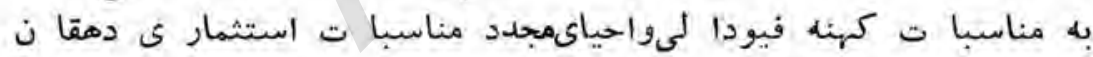

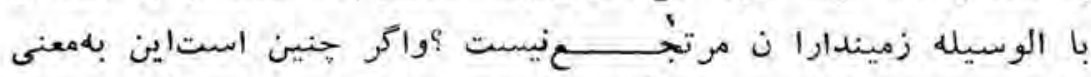

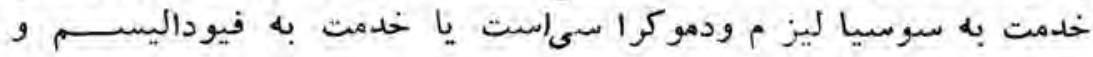

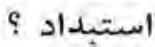

كلبدين ،خاين ملى ، رهبر با نداسلامى در برنا مه خون بود مينكارد كه

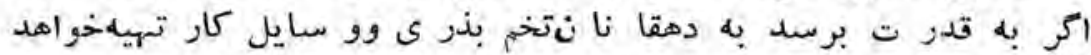

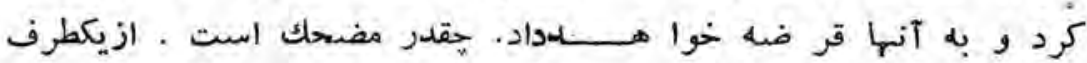




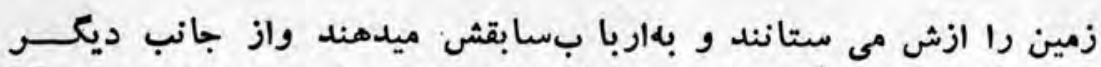

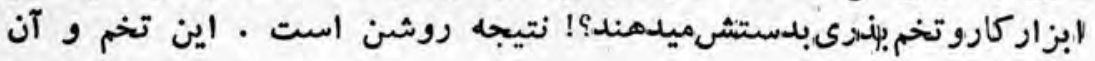

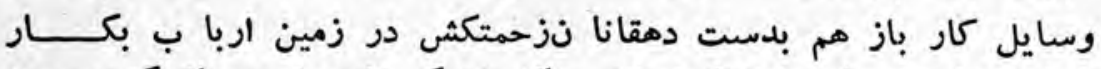

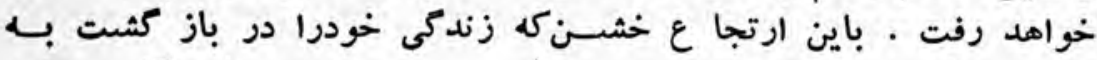

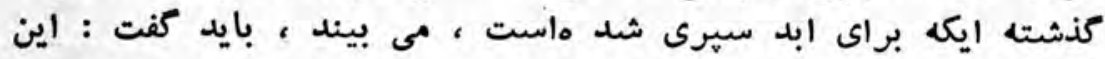

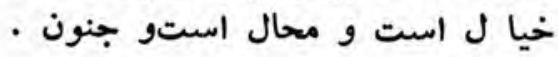

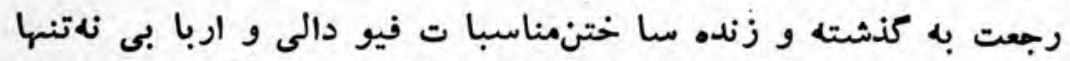

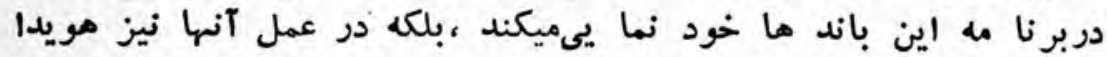

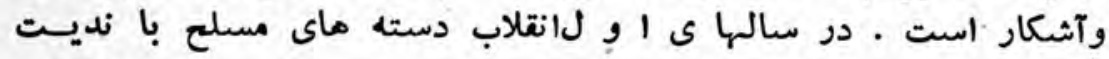

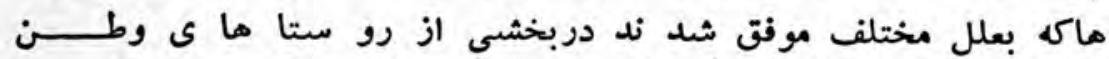

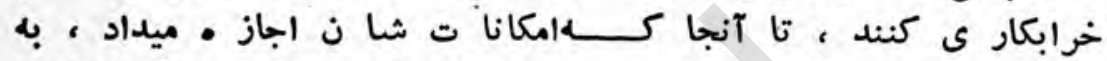

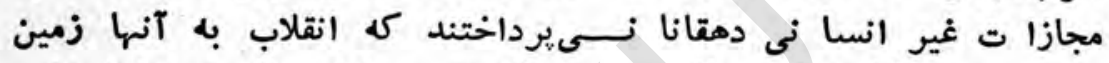

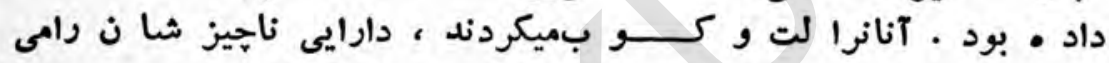

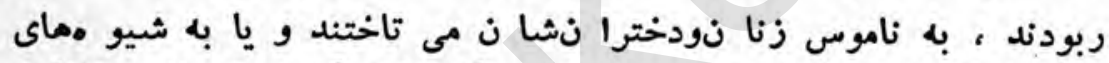

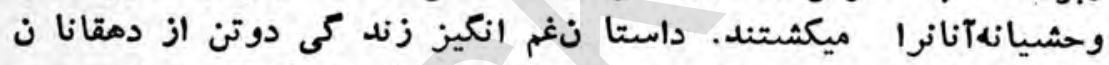

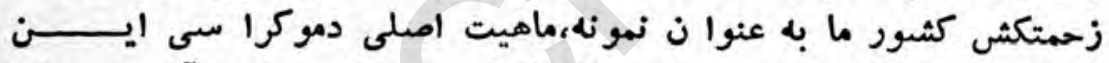

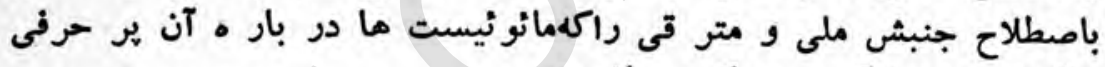

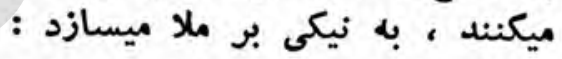

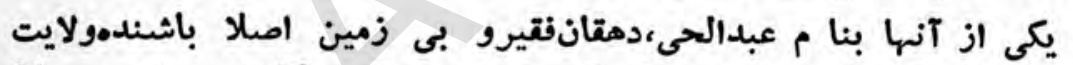

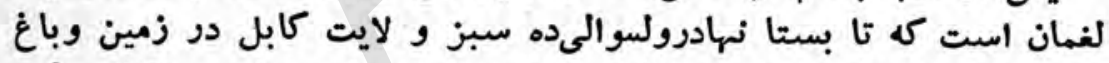

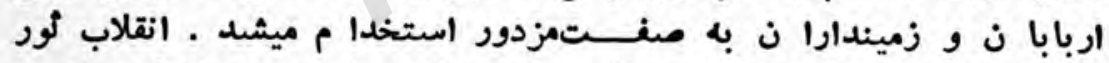

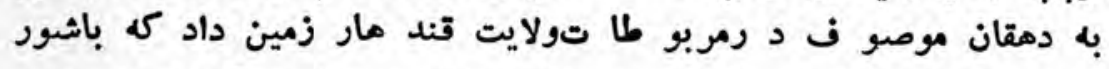

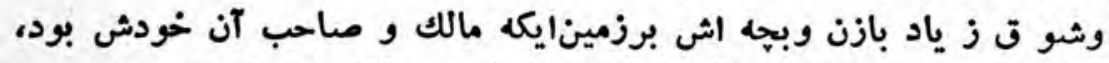

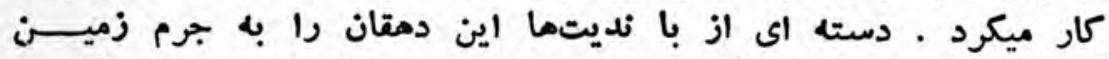

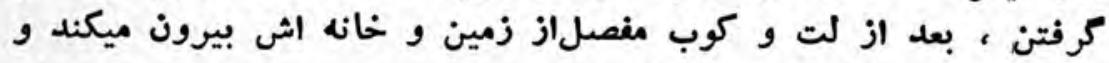

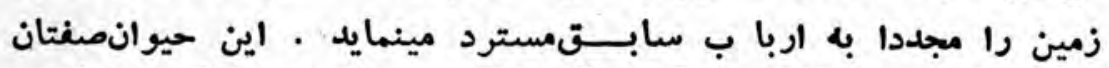

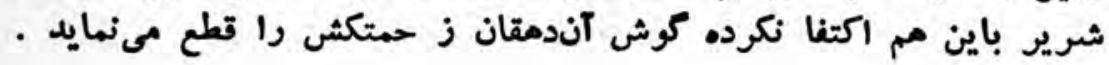




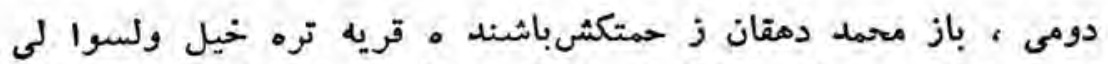

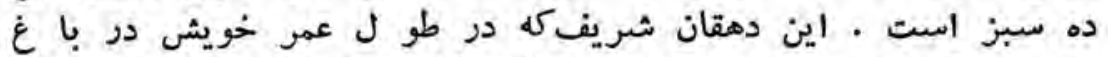

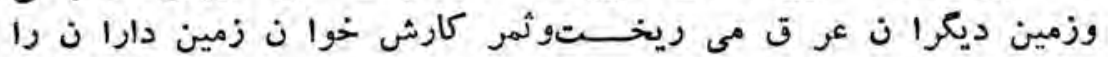

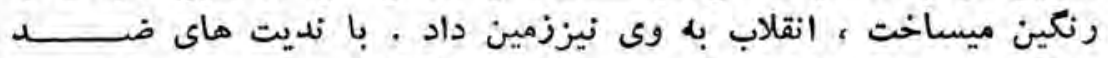

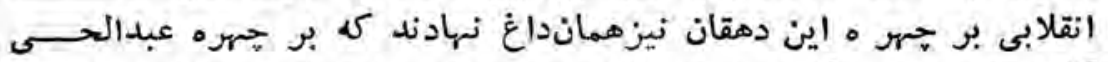

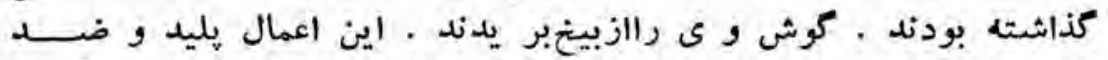

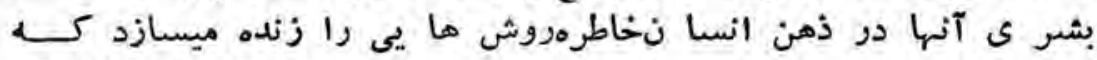

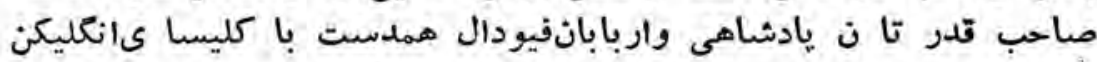

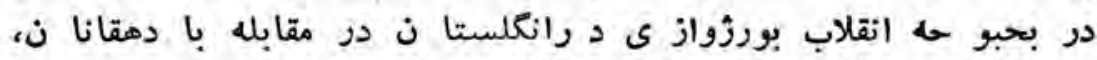

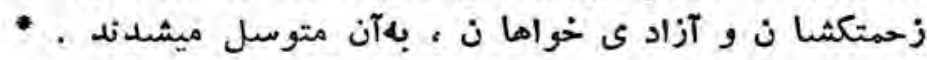

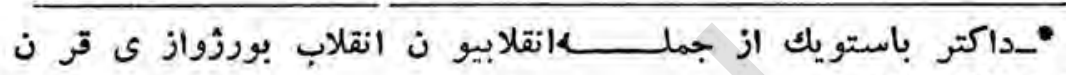

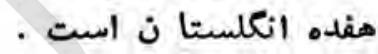

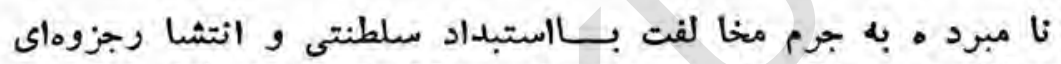

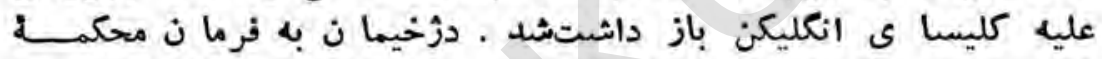

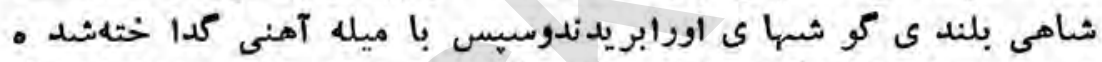

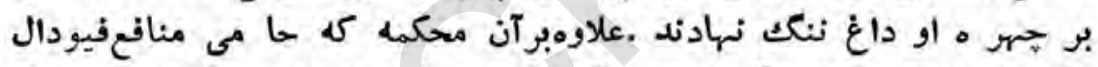

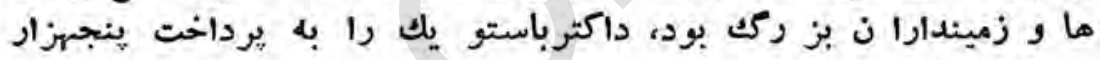

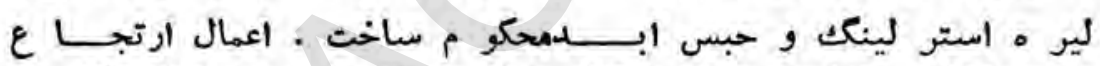

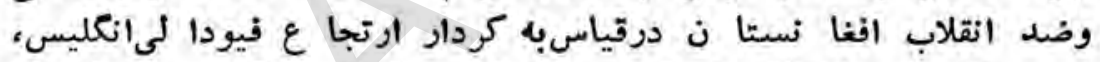

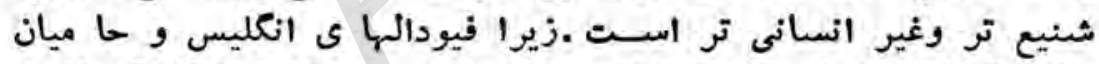

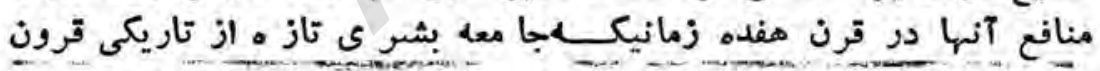

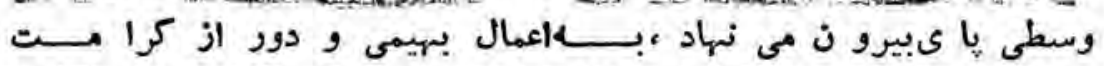

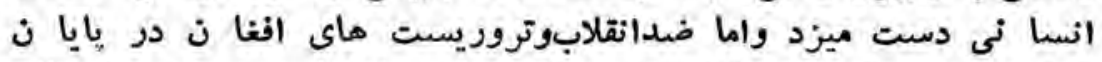

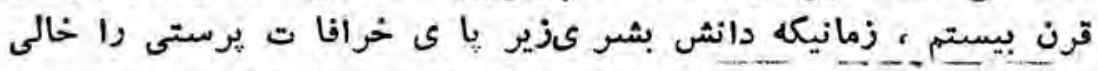

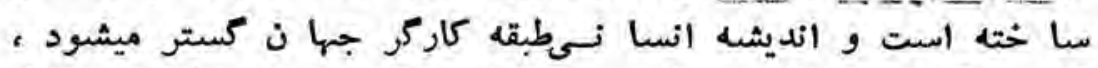

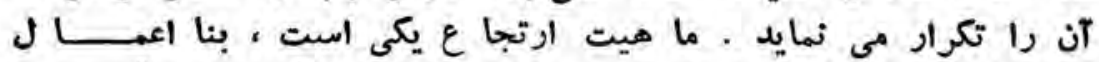

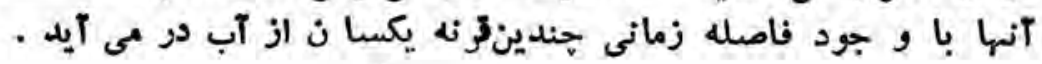

-ro.- 
ادعا ى بهساز ى زند كىى كـــاركرا ن ، دمقانا ن وساير ز حمتكشان

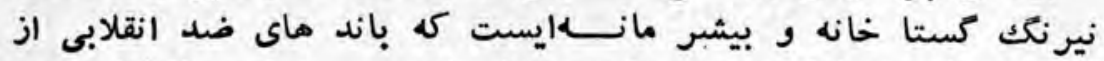

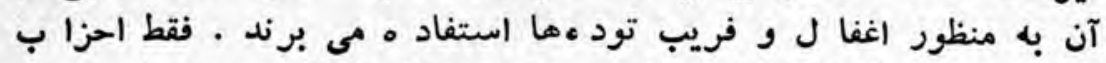

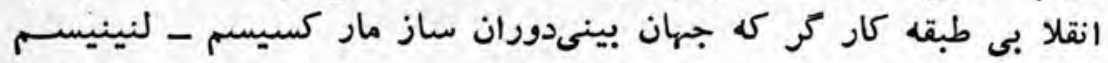

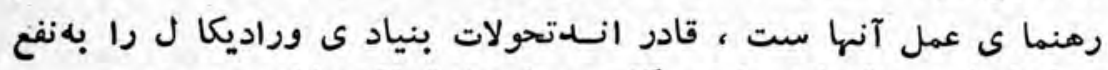

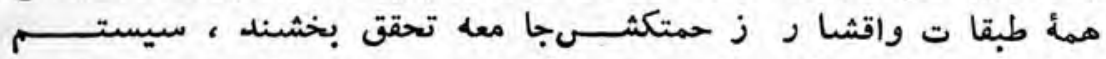

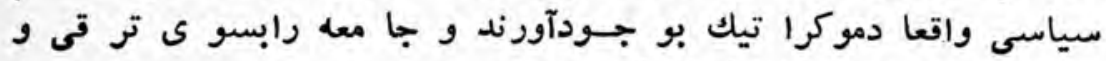

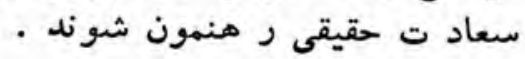

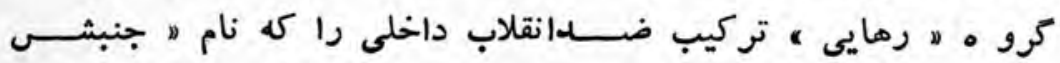

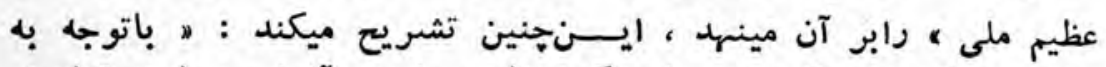

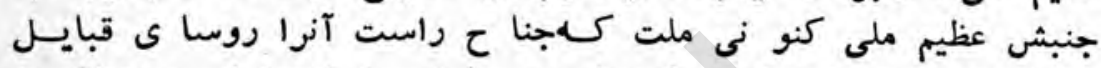

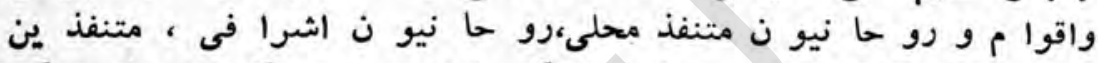

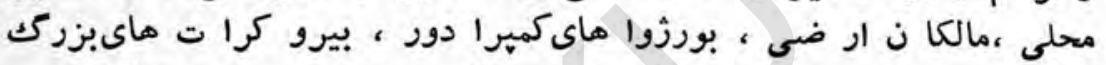

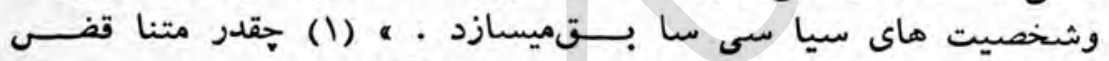

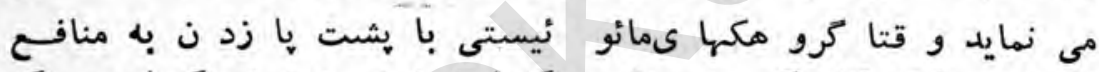

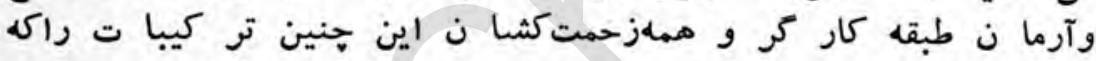

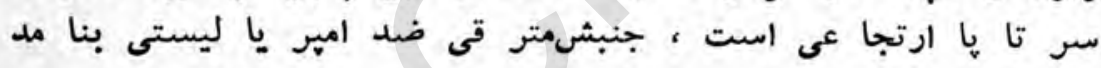

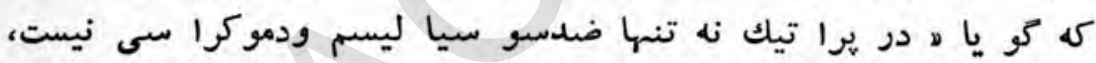

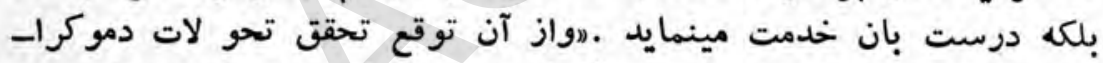

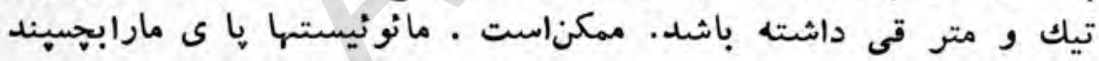

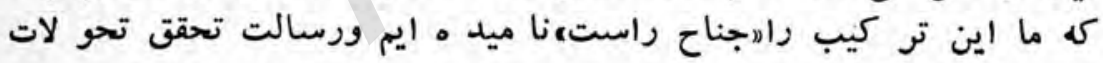

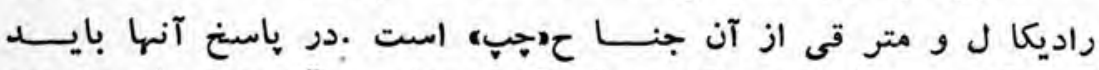

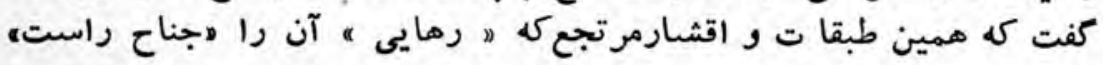

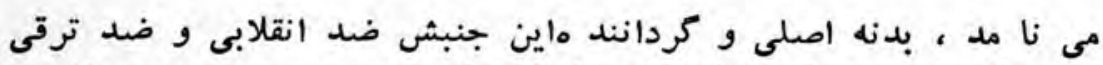

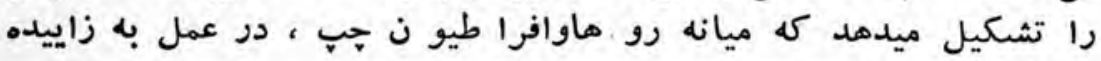

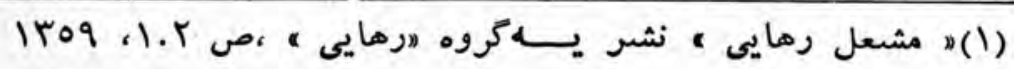

-rol- 


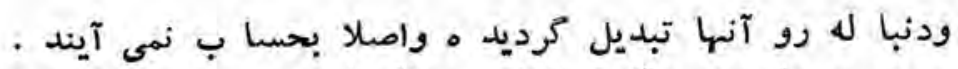

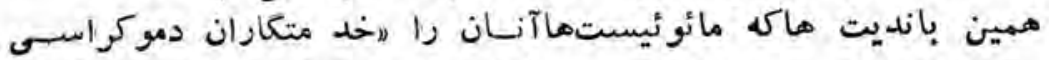

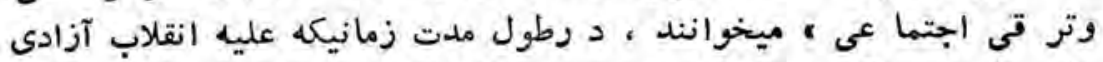

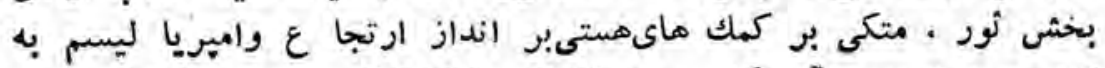

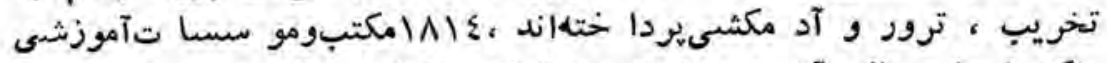

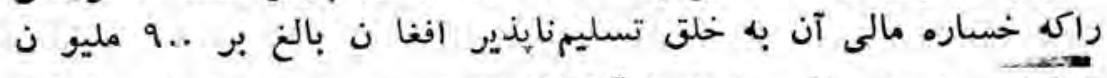

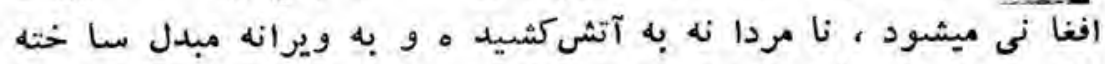

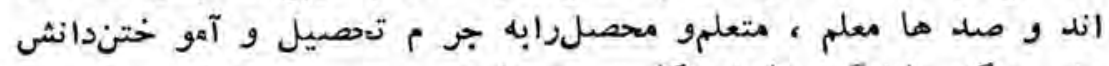

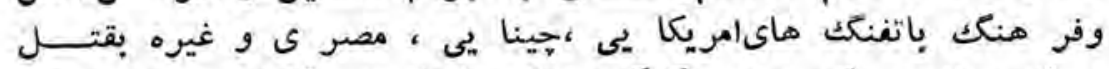

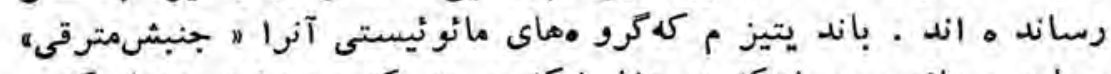

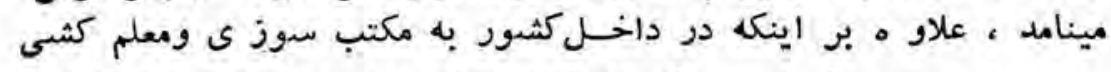

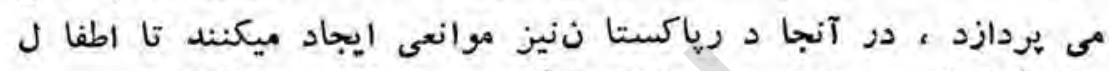

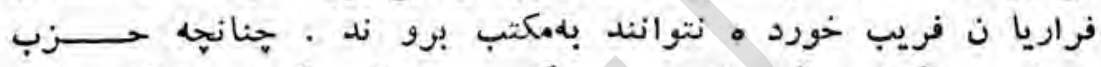

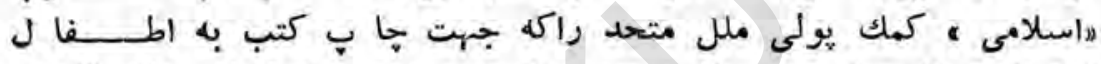

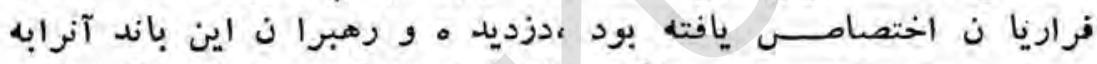

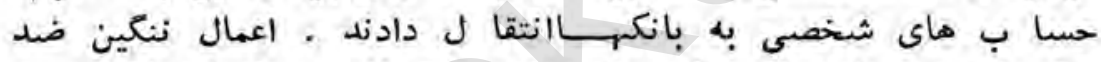

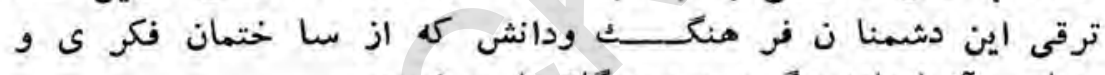

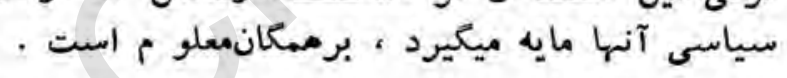

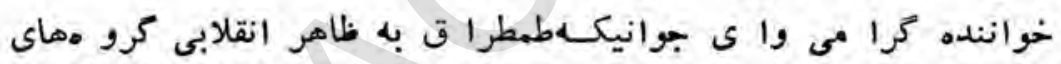

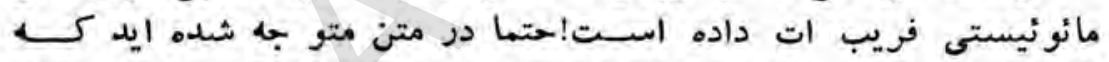

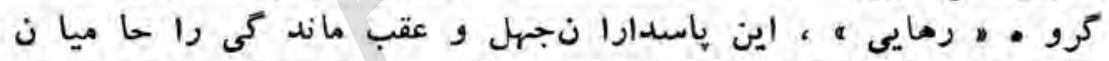

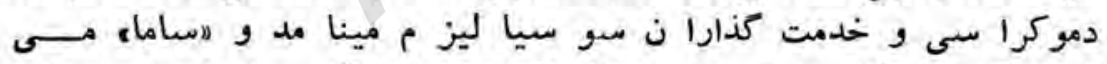

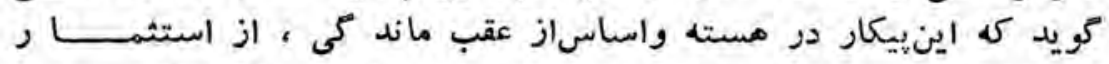

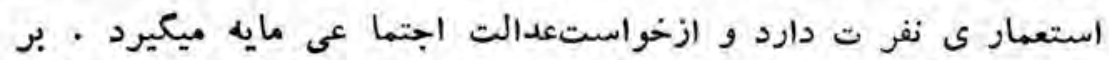

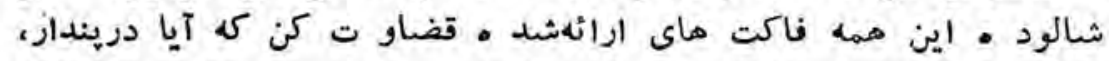

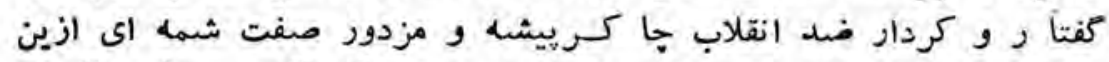

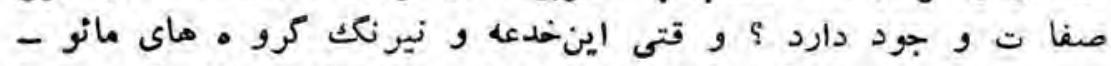

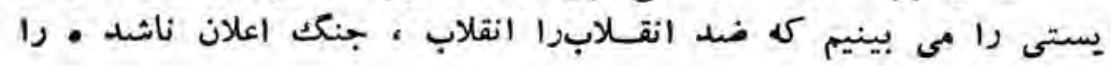




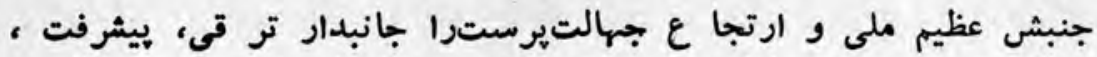

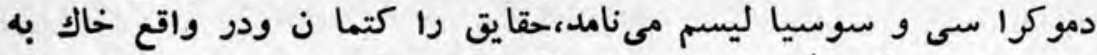

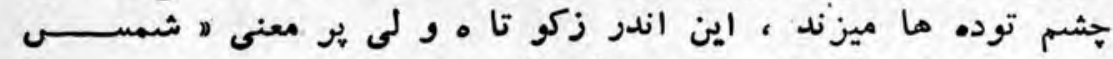

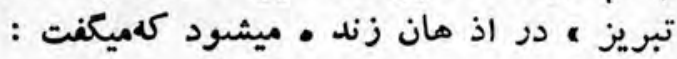

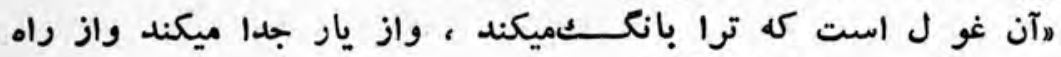

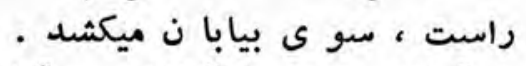

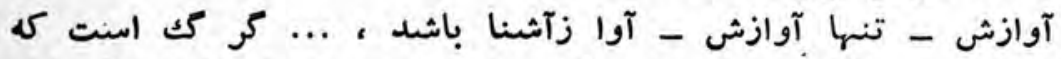

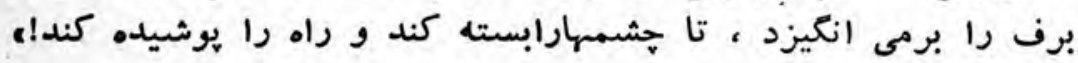

\section{*}

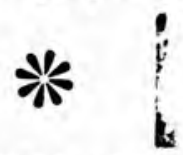

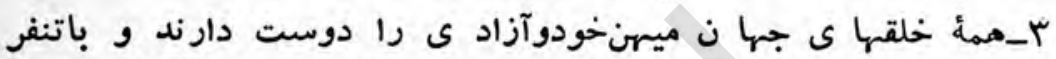

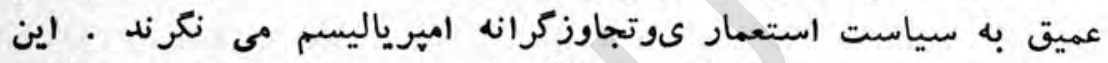

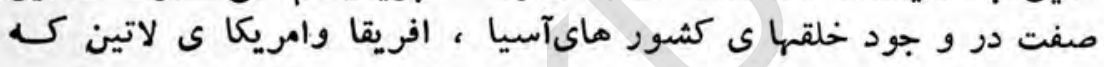

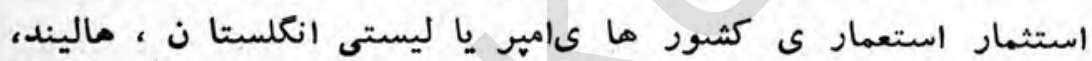

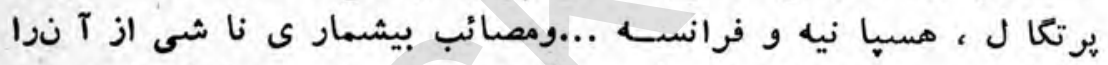

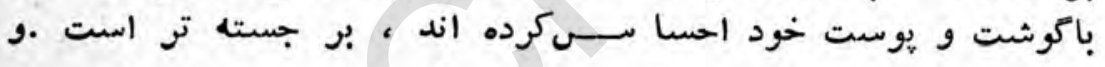

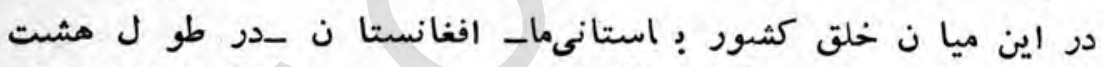

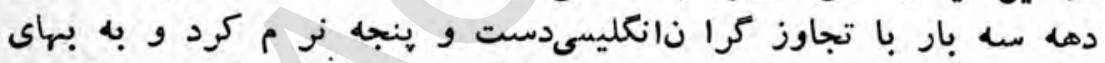

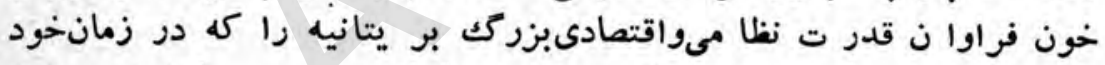

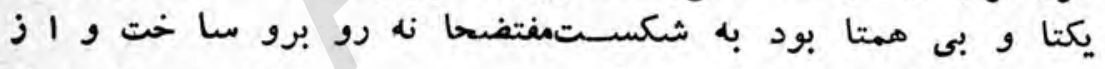

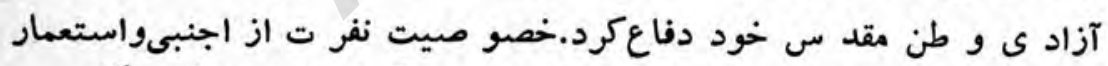

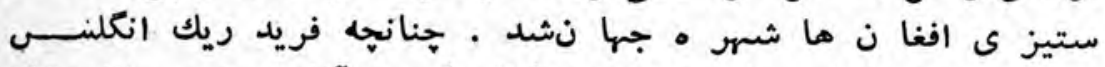

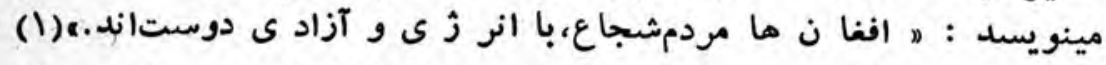

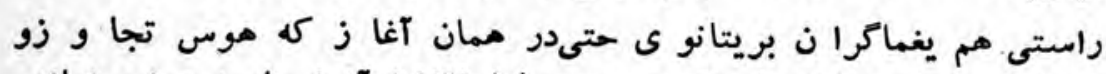

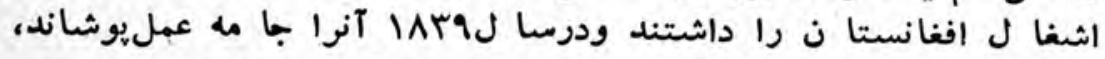

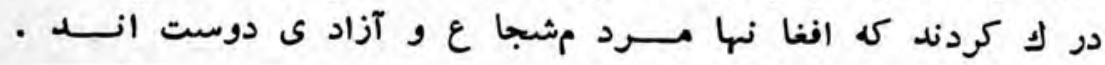

(1) (1از كتا ب " ماركس و انكلسييرامو ن استعمار ه. -ror_ 
استعمار كرا ن اكر حيله و نيرنكثبكار برد و به تشديد تفر قه و ونفاق

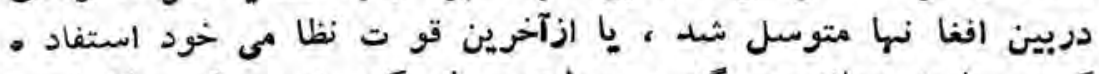

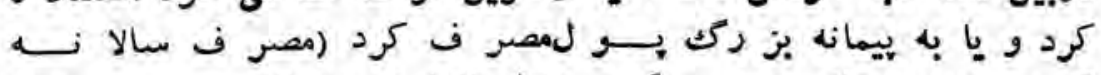

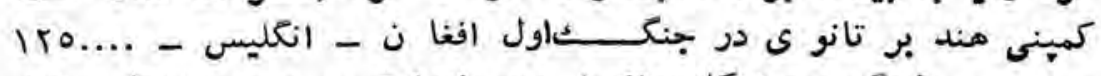

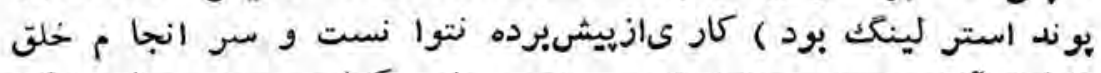

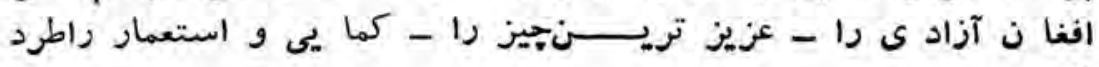

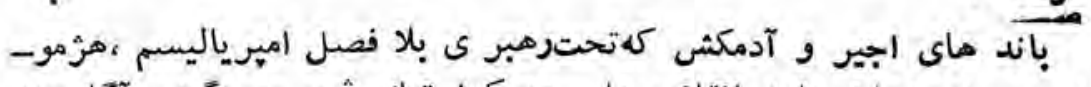

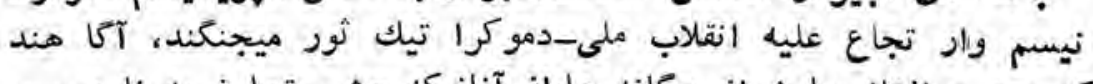

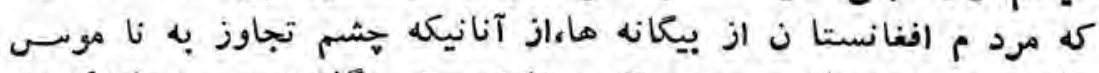

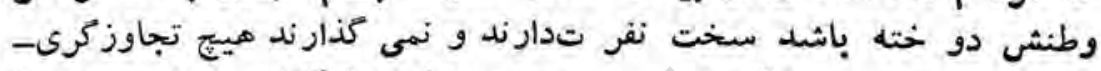

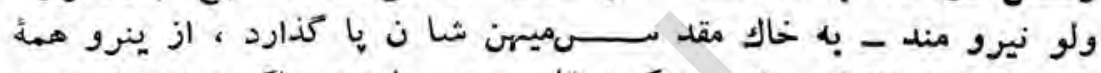

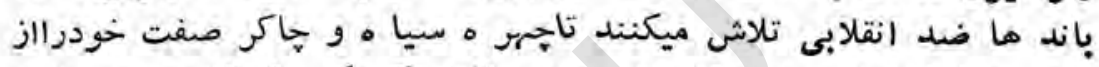

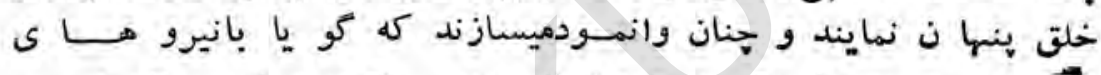

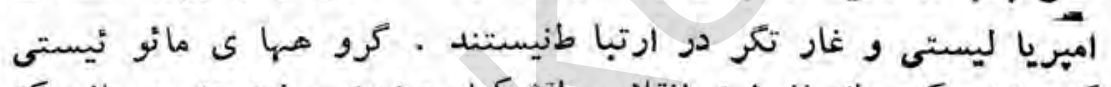

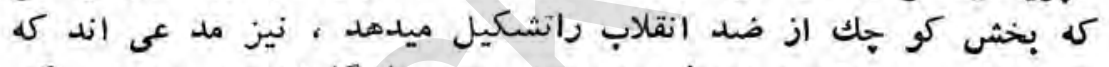

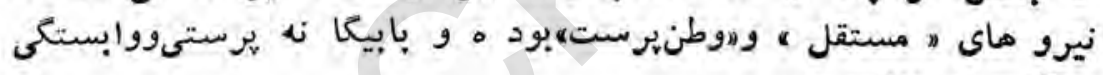

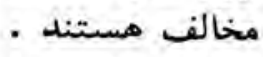

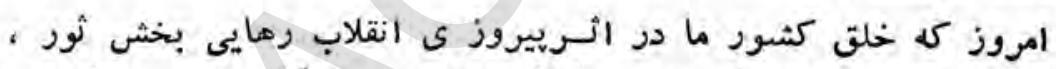

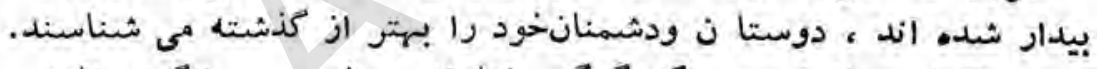

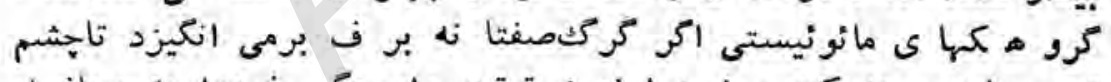

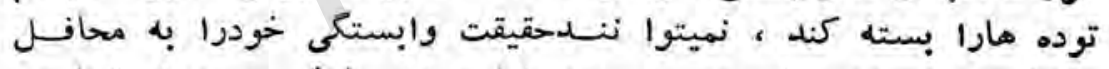

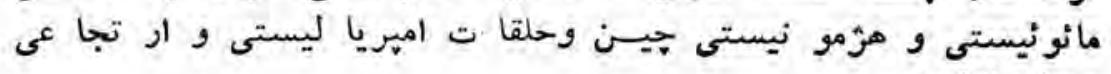
- مينهان نمايند

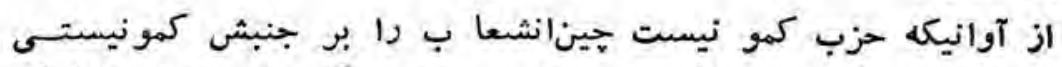

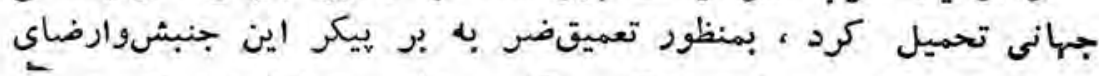

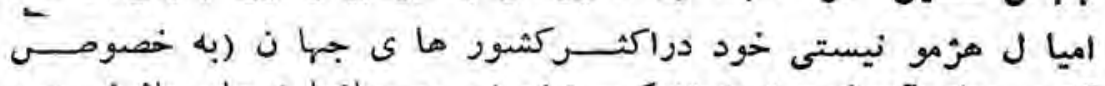

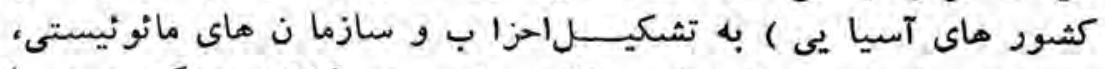

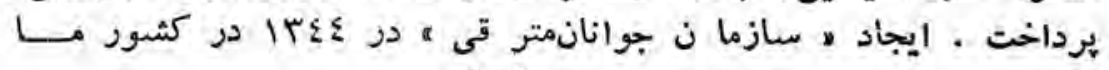
- rok_ 
نمو نه ازين تلا ش خاينا نهمائو جبينآنهويدا بود.يكى از دلايل مهم

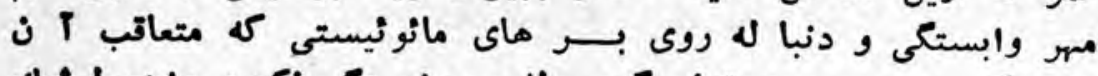

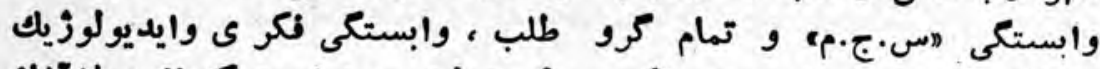

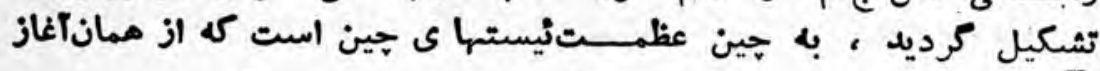

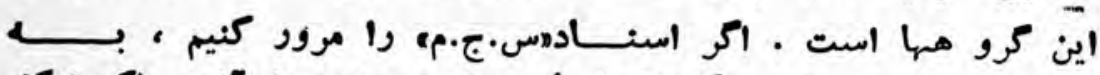

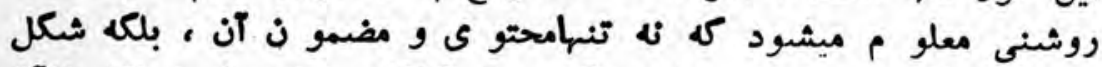

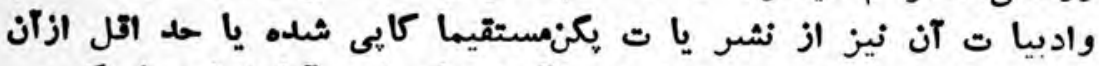

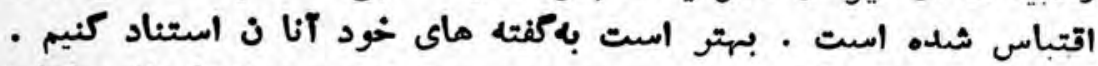

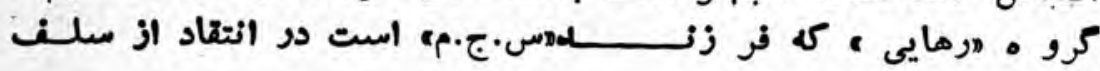
خود مينويسل : مرو هايف

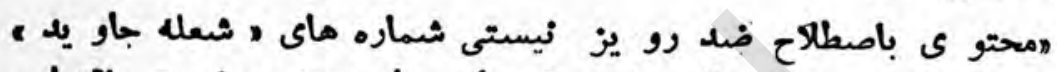

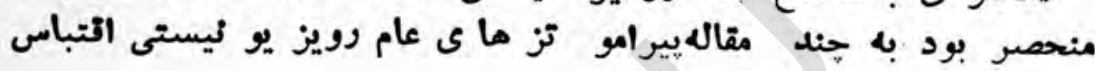

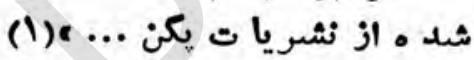

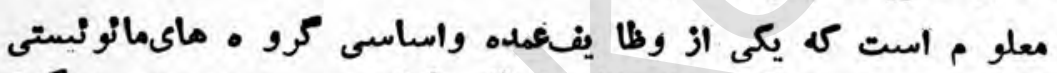

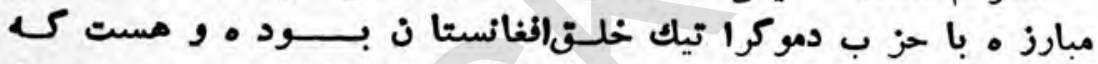

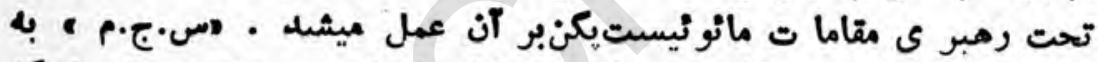

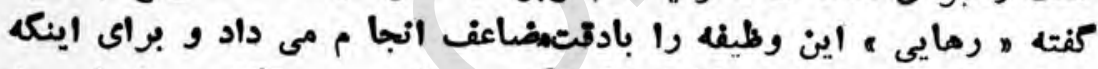

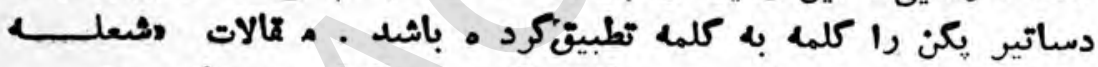

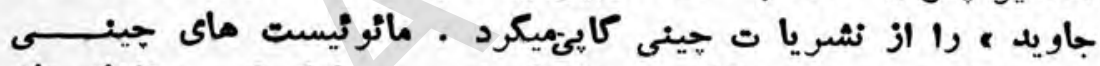

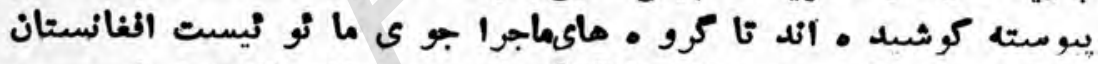

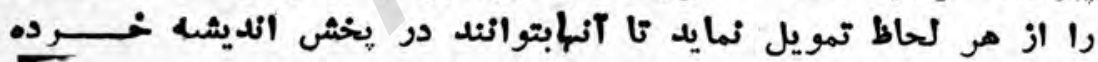

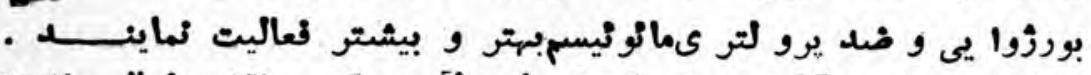

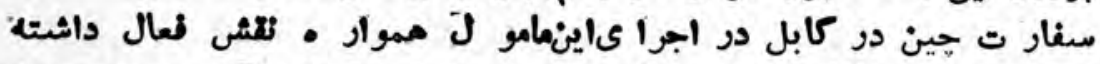

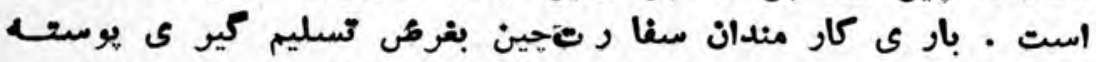

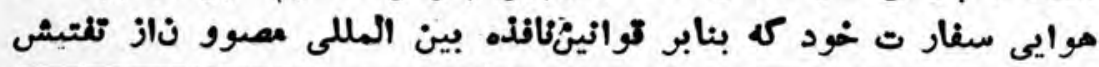

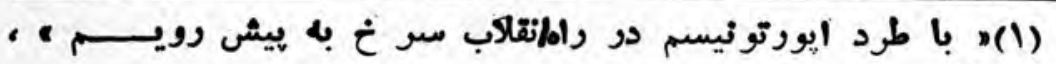

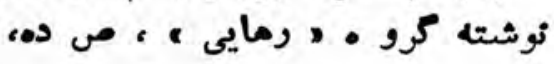

-roon 


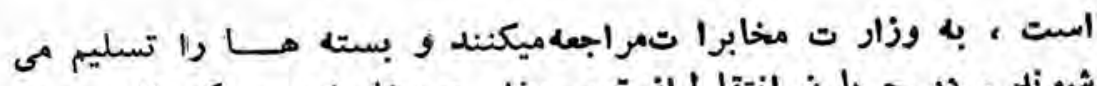

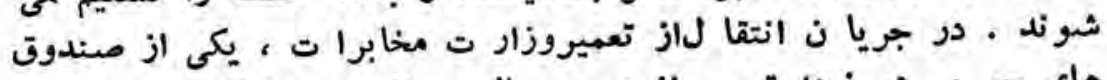

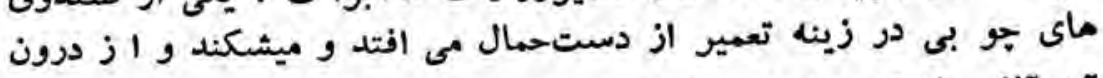

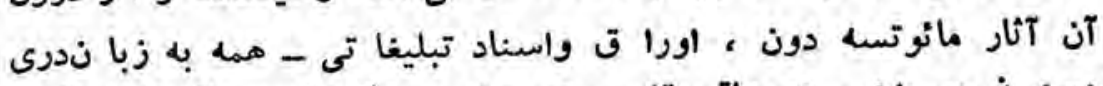

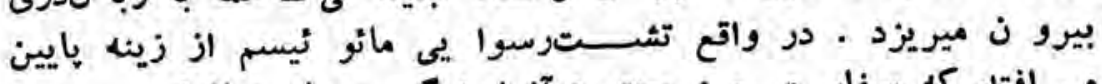

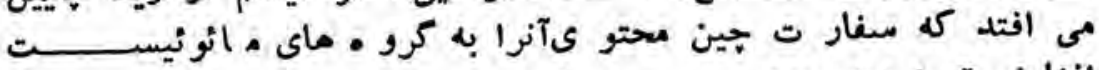

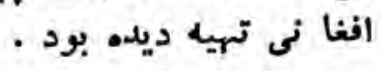

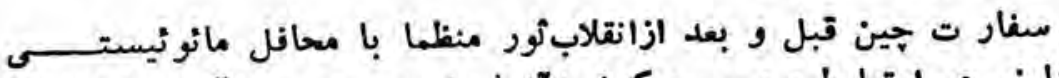

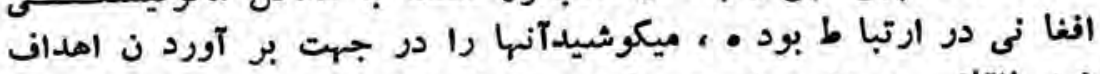

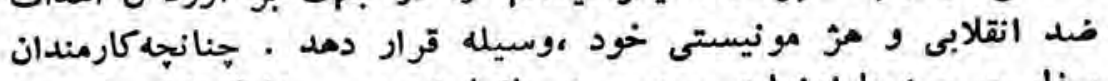

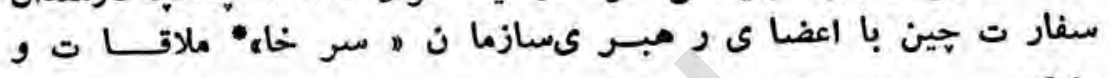

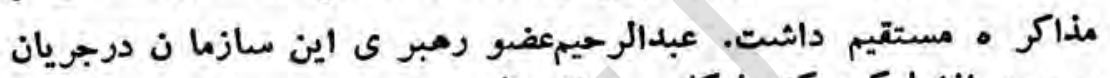

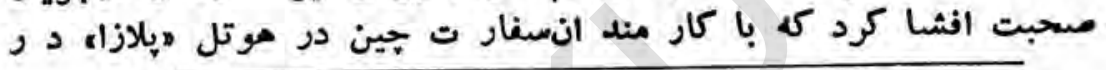

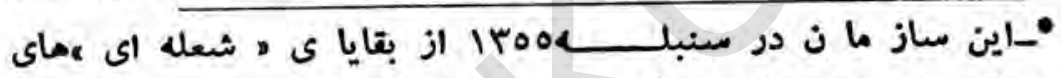

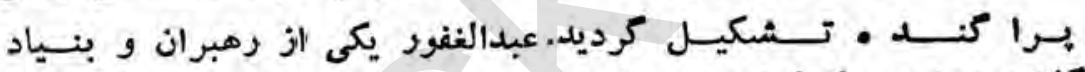

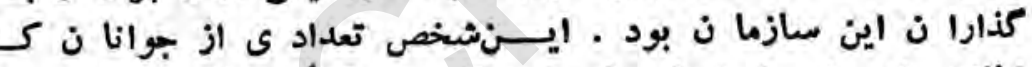

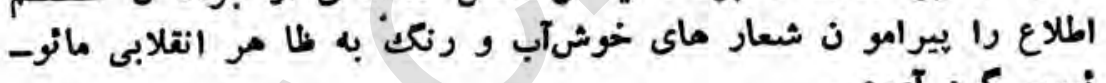
نيسم كرد آورو

اكثريت اعضا ى اين سازما ن دربوج حو ت ما د ل

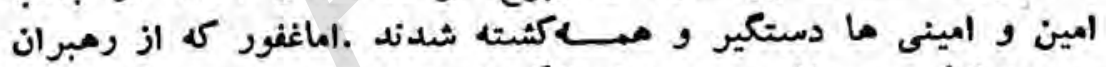

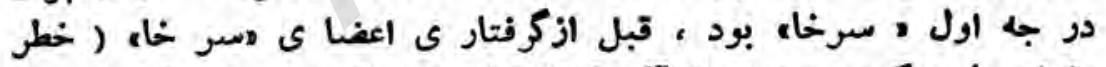

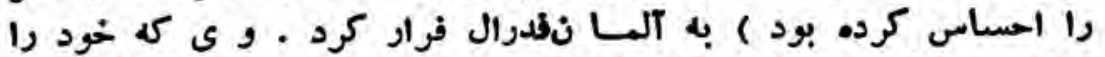

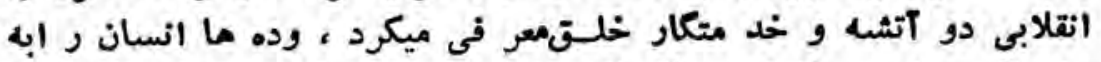

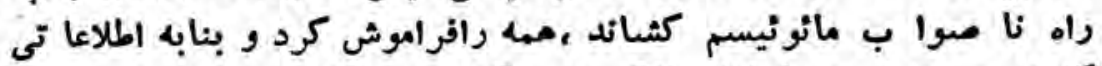

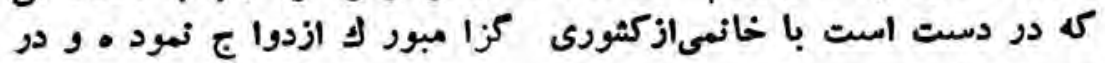
كشور ماى غر بى به خوث كذرا نى معرو ف است . ننك و و نفرين به

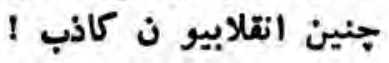




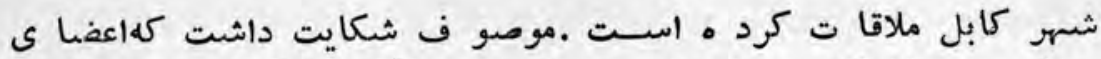

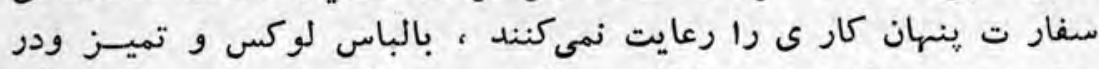

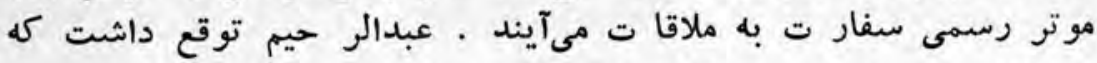

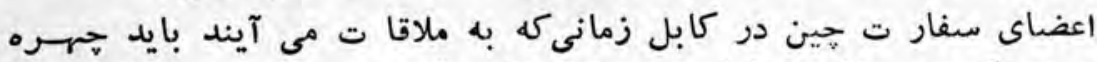

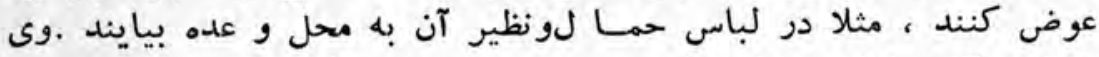

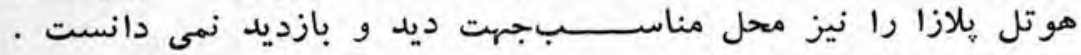

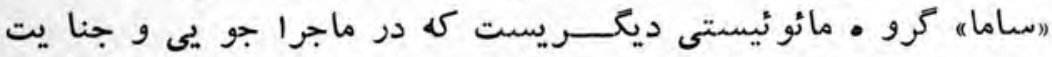

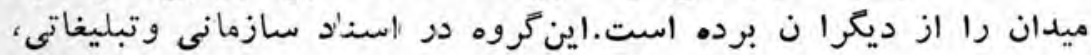

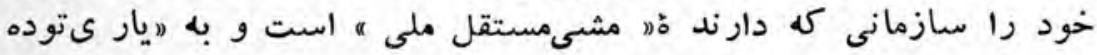

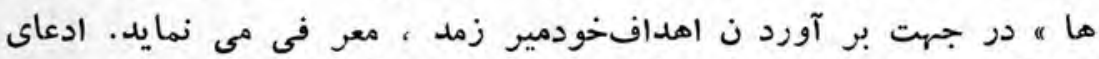

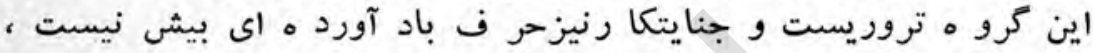

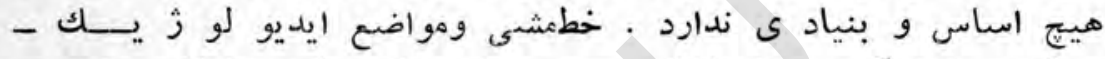

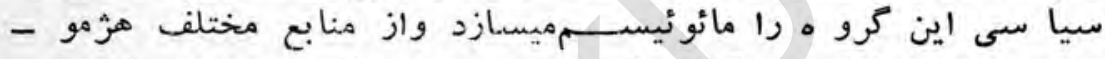

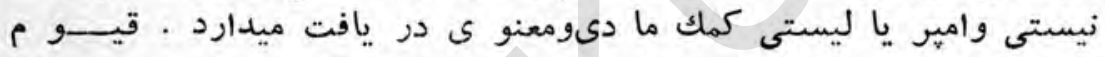

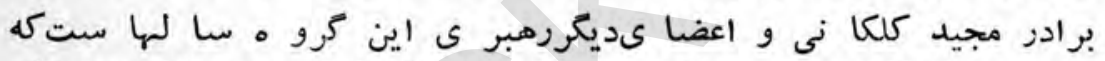

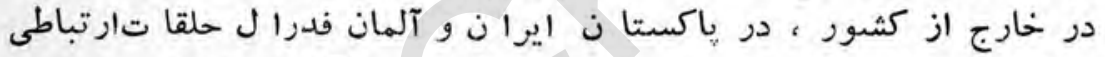

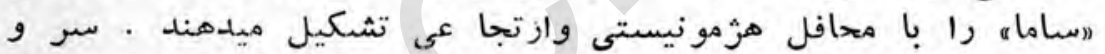

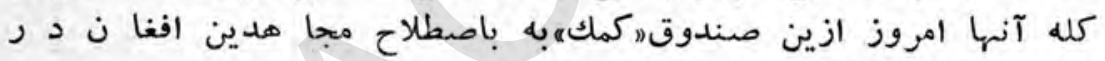

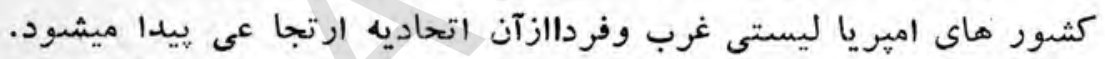

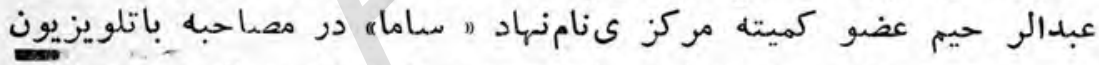

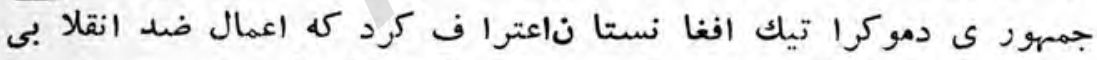

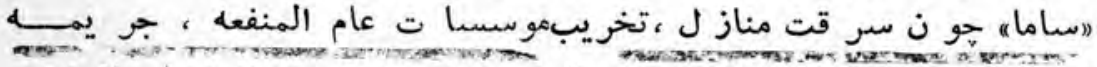
كرد ن مرد م و ... علاو ه بر اينكهبر اساس انديشه افرا طىمائو نُيسم

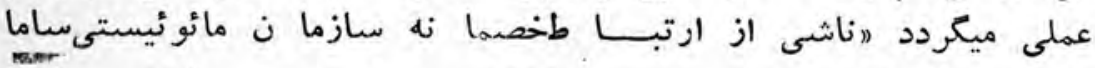

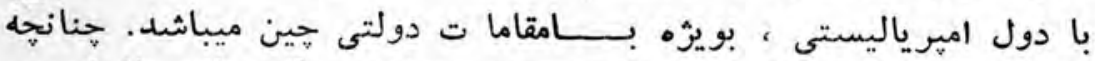
هموار • كمكما لى از طر ف كشورجين به نمايند كى بإنى باند مائو ئيستى 
ساما دز باكسيتا ن غرض تقو يهبنيهمالى صور ت ميكيرد . ممجنا نهآنها

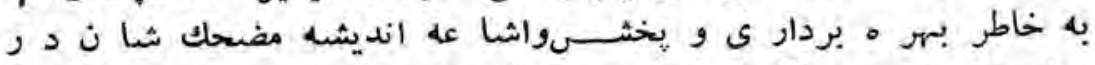

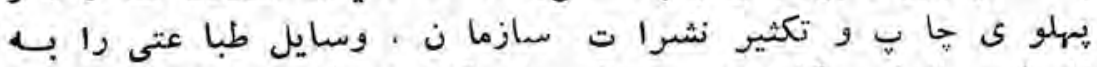

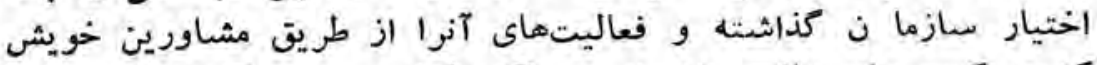

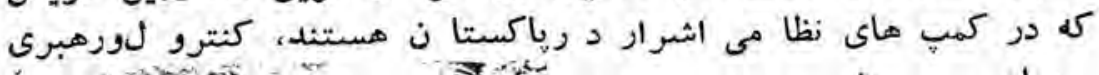

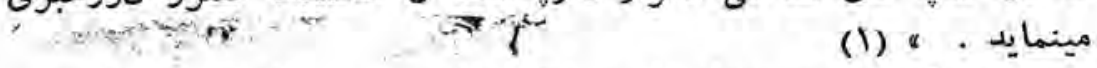

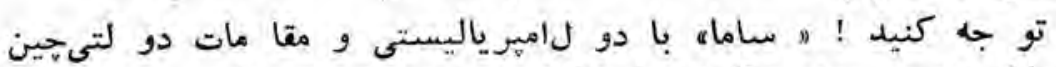

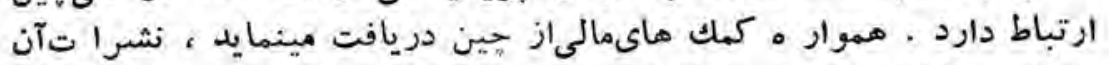

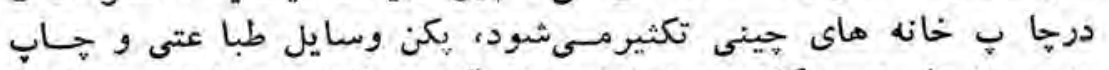

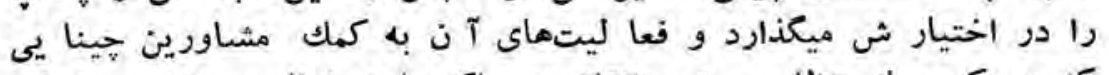

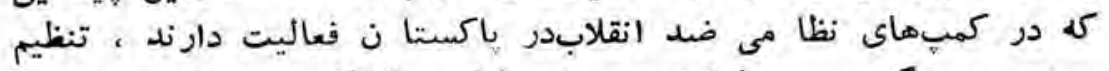

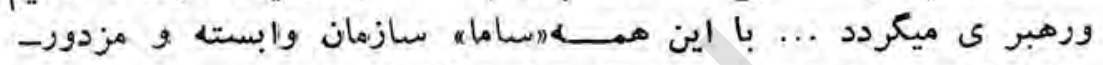

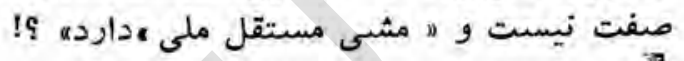

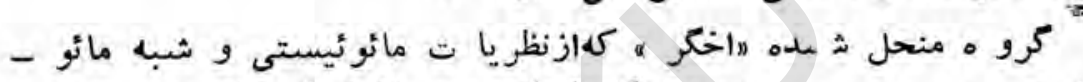

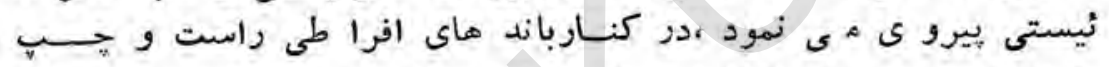

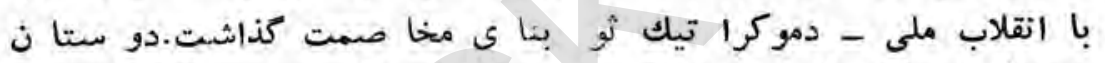

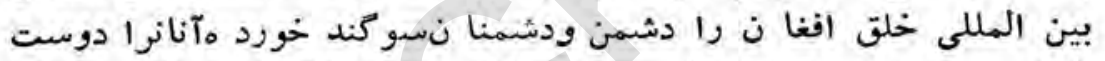

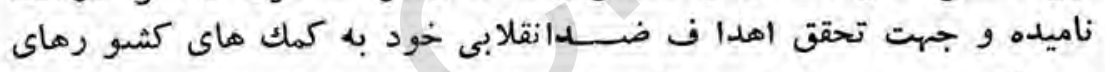

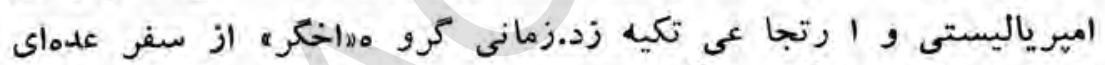

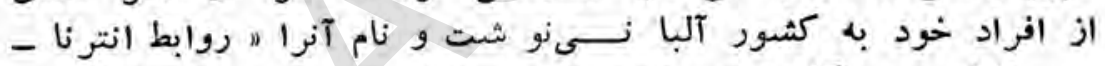

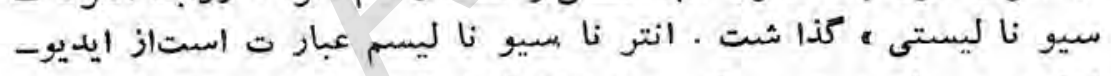

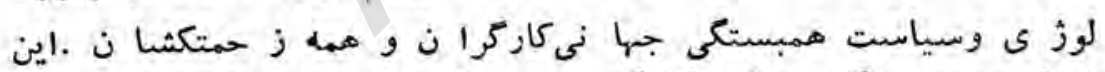

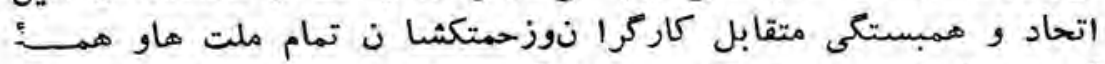

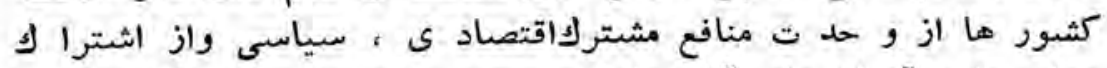

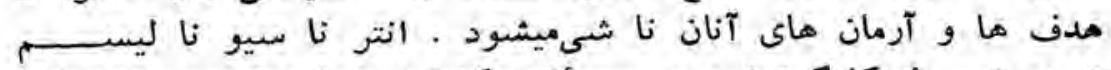

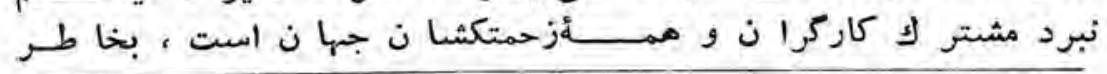

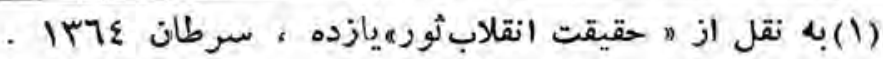


ازميانبردنستمطبقاتىوملىو استثماراستعمار ى اميريا ليسم ، به خاطر

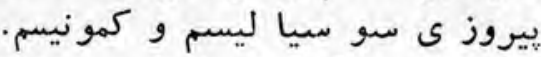

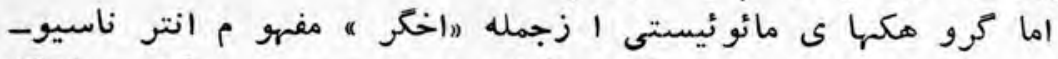

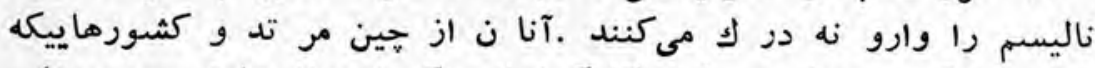

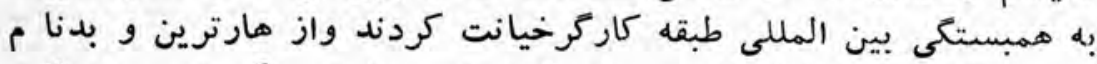

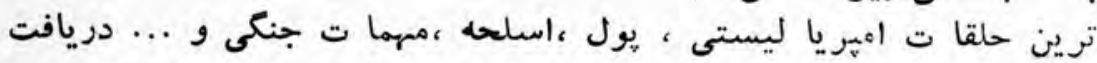

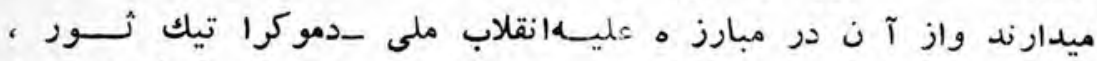

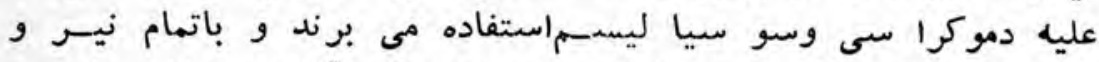

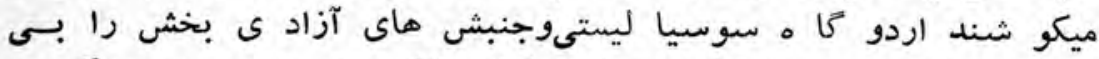

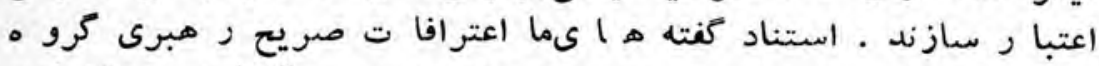

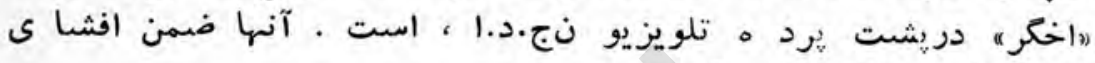

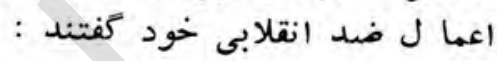

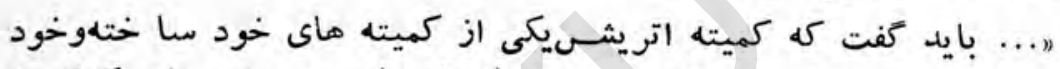

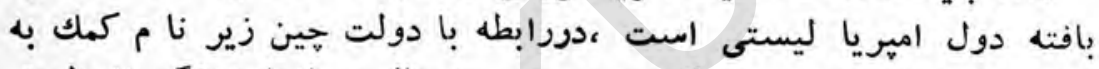

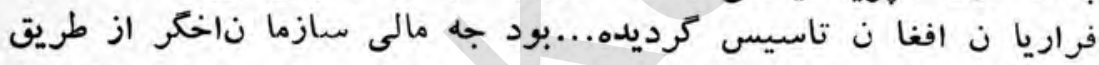

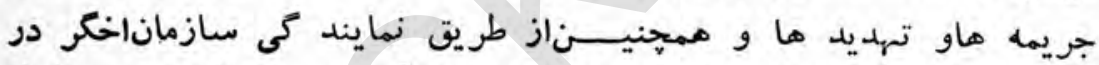

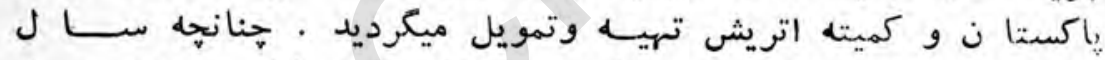

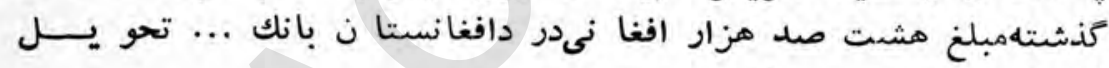

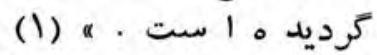

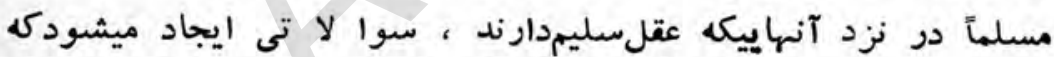

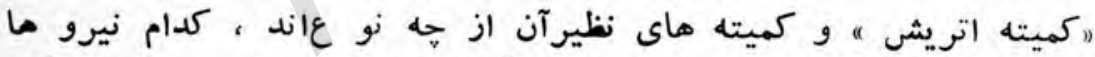

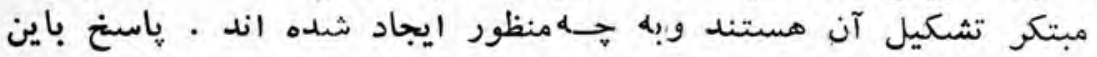

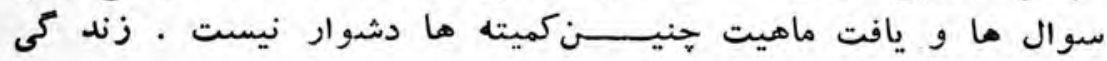

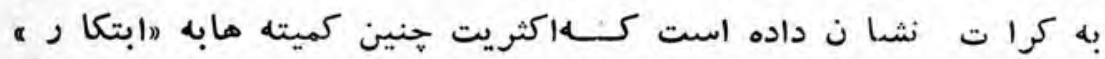

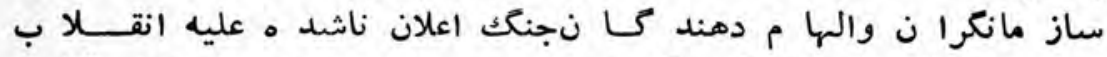

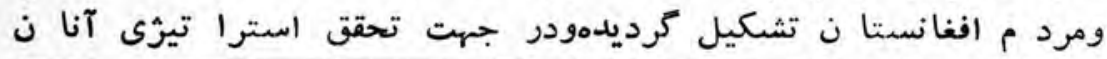

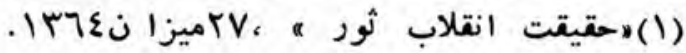




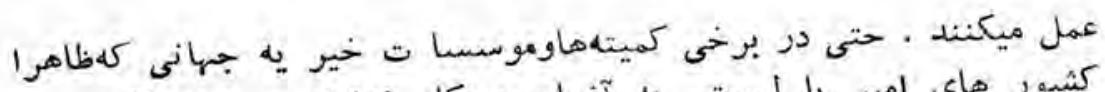

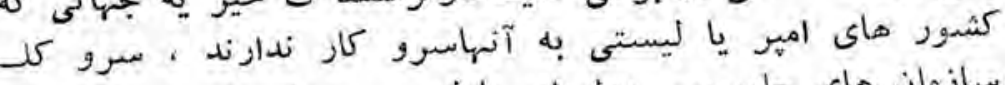

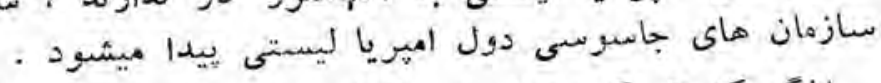

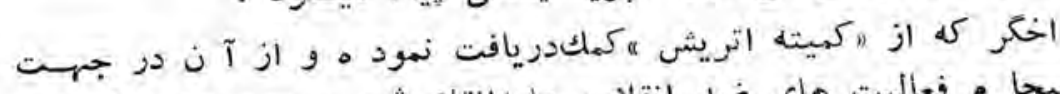

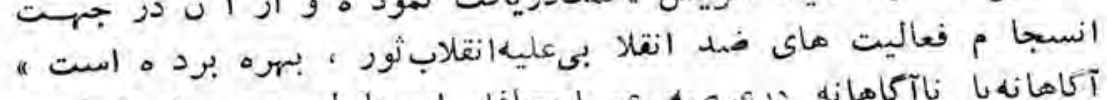

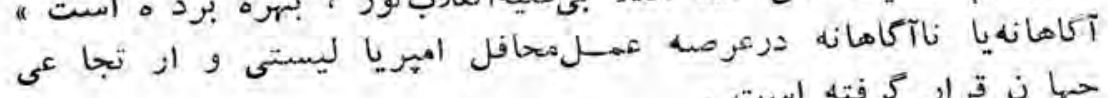

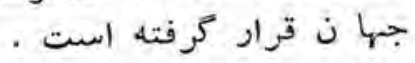

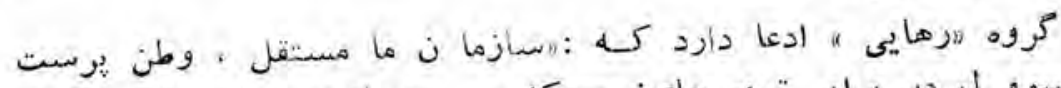

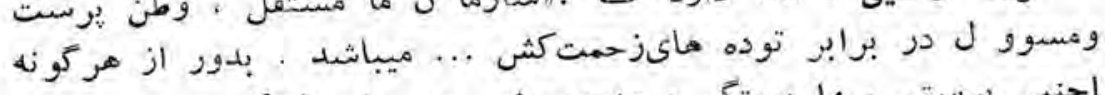

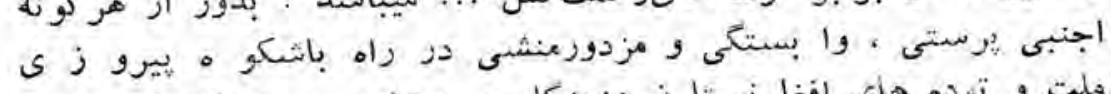

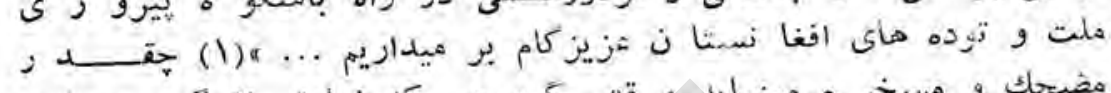

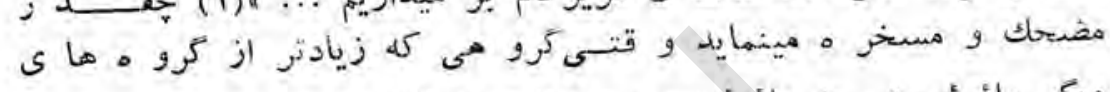

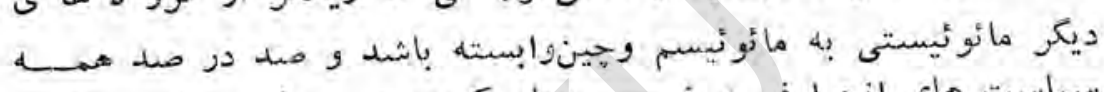

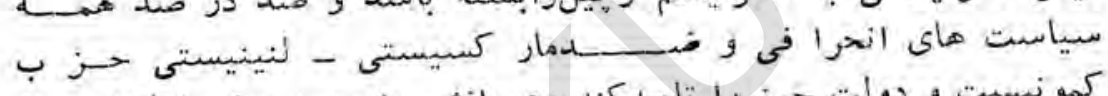

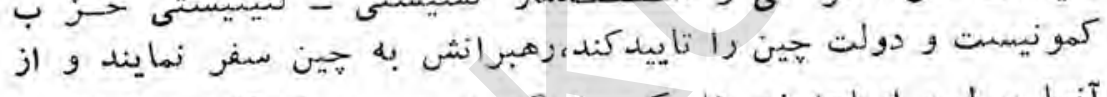

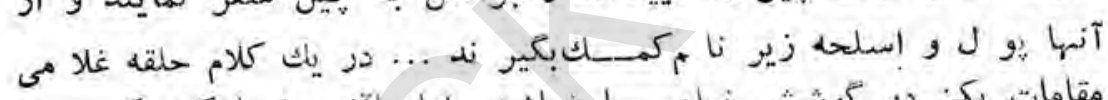

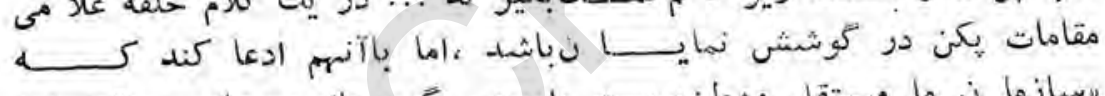

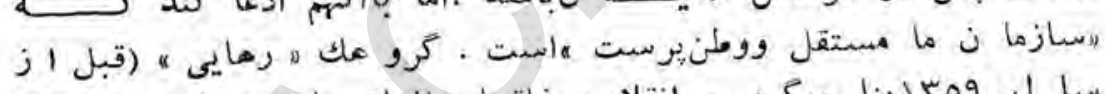

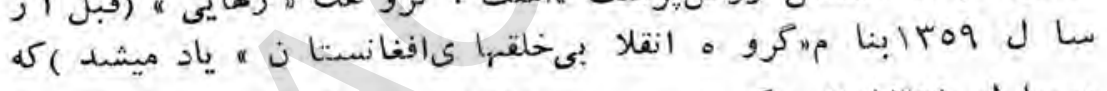

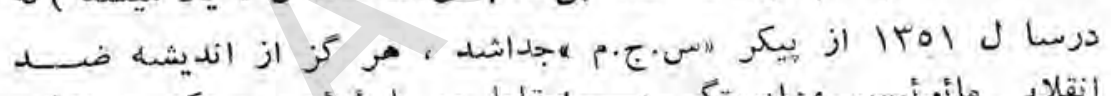

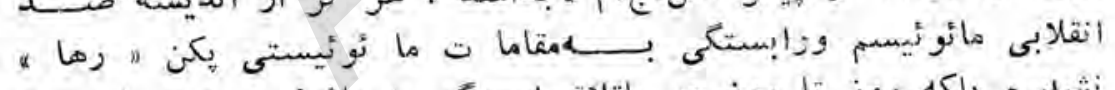

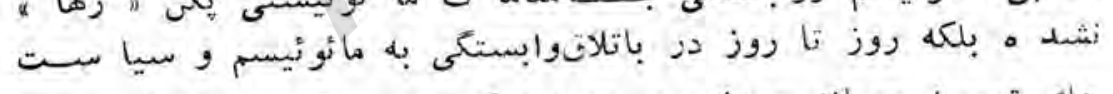

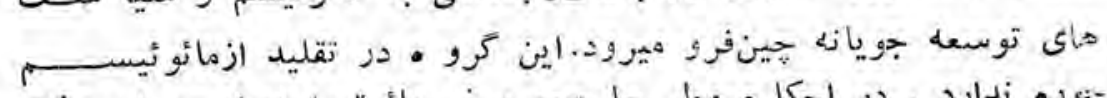

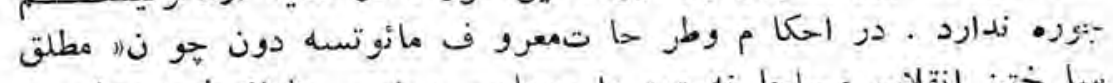

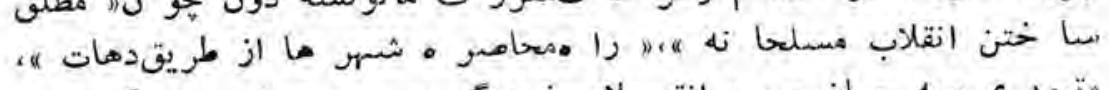

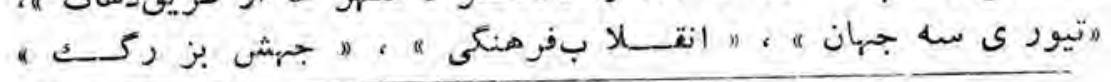

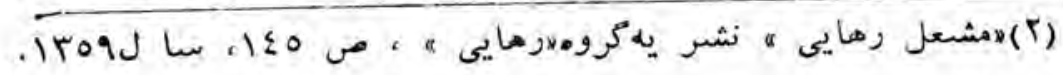
-r7.- 


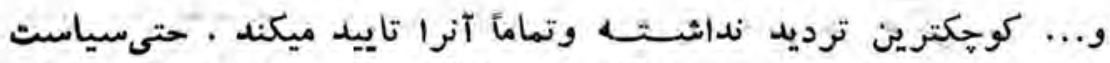

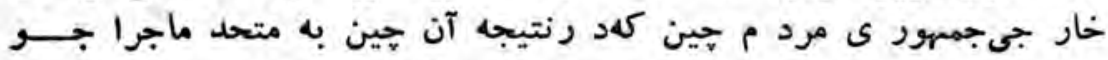

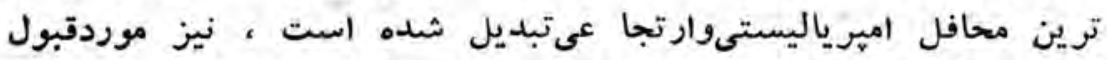

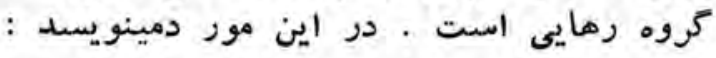

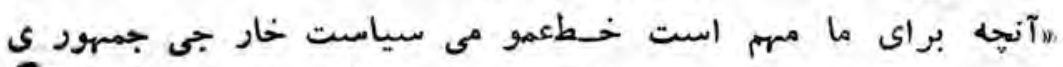

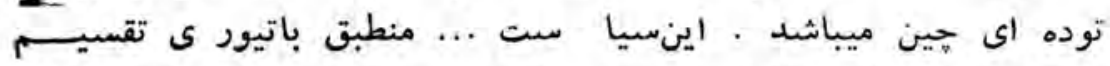

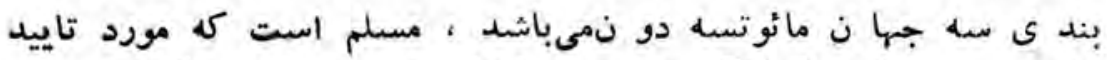

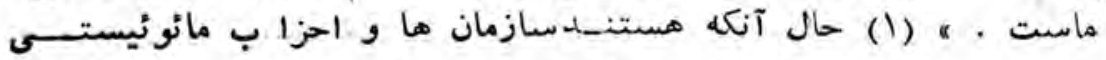

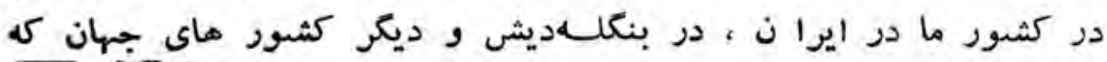

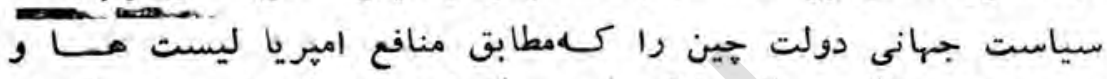

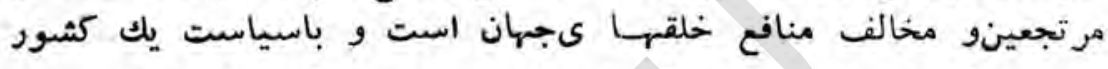

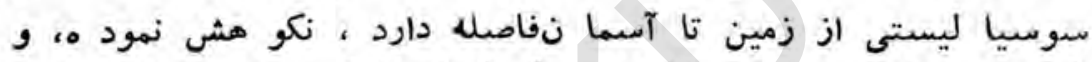

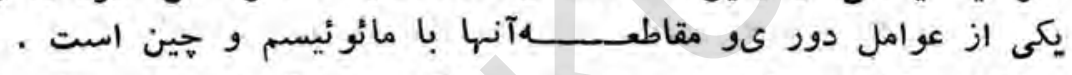

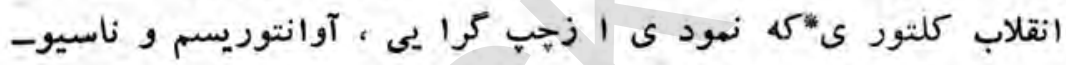

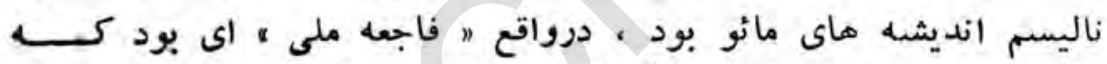

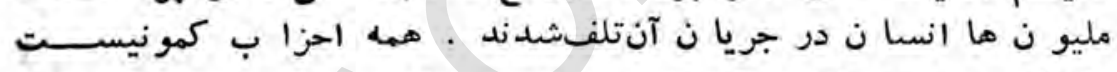

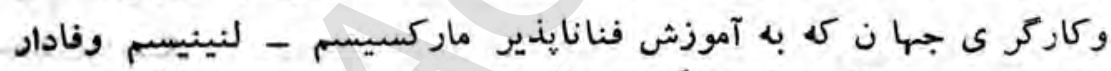

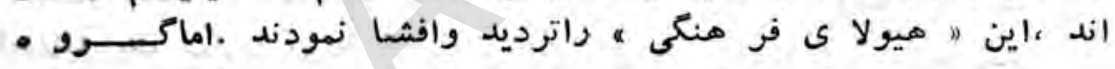

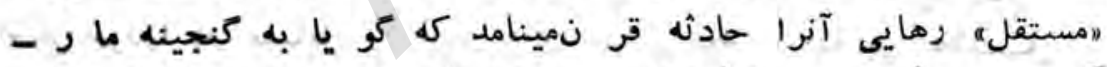

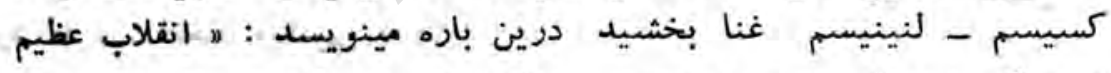

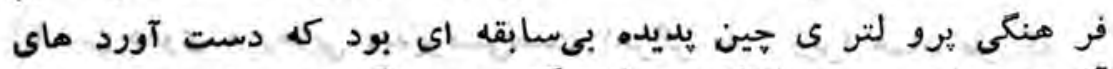

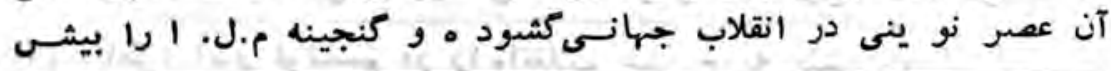

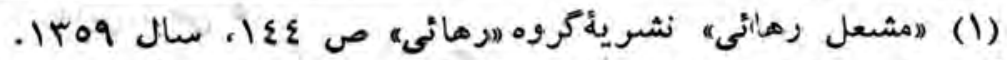

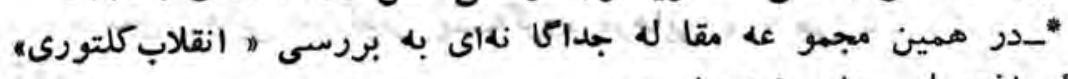
مائو اختصاص داده شده مده است مقاس . 


\section{ف2}

از ييش غنا بخشيد ...... (1) آرى،اين باصطلاح انقلاب فر هنكى بمثابه

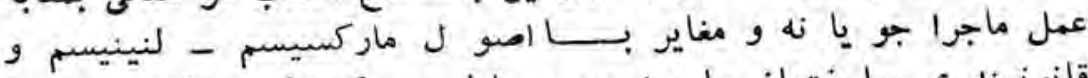

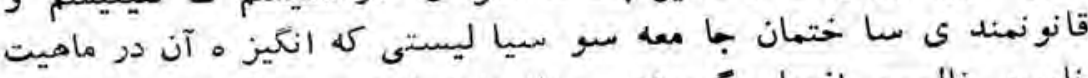

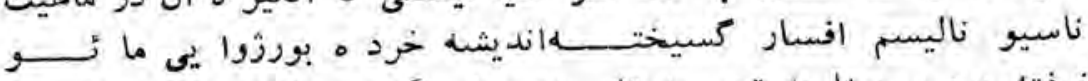

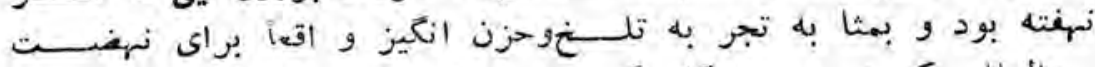

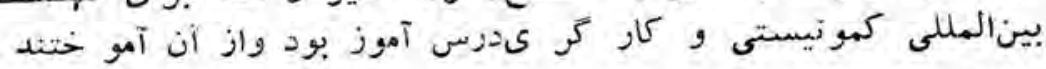

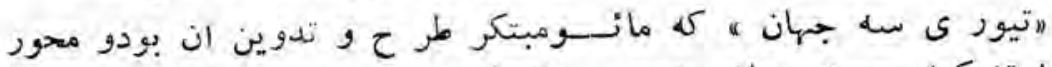

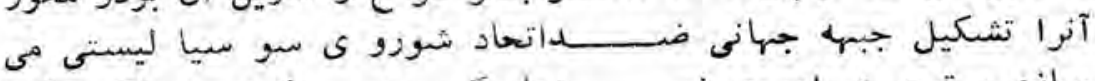

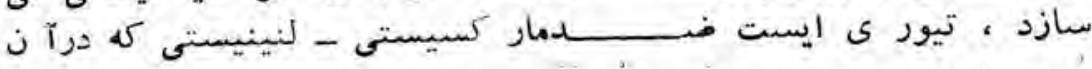

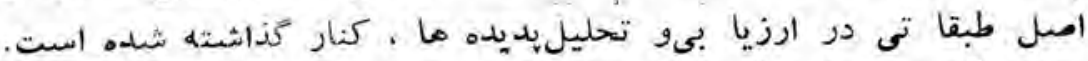

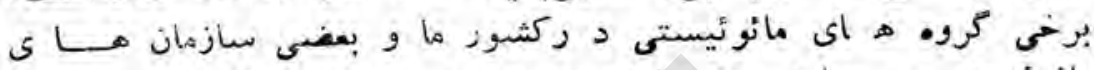

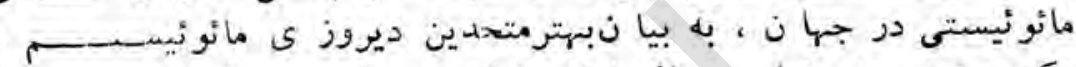

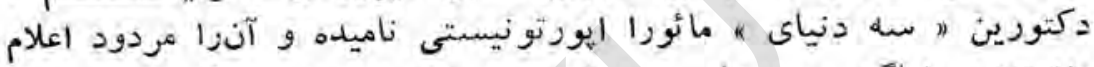

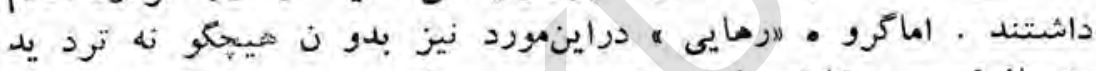

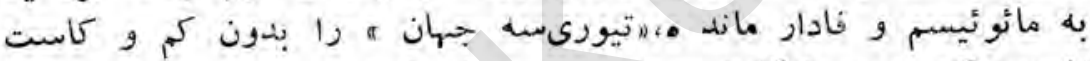

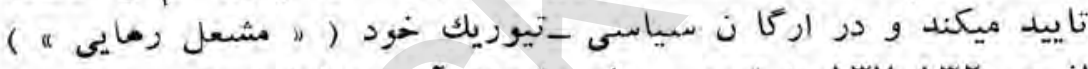

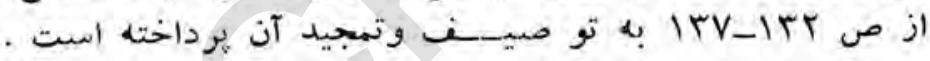

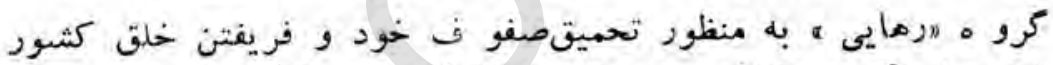

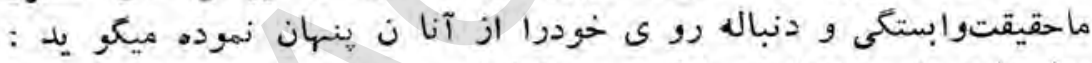

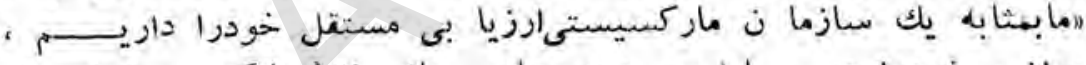

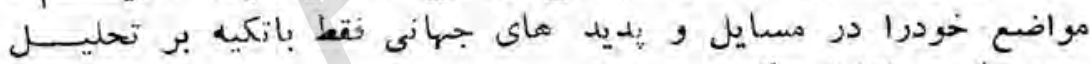

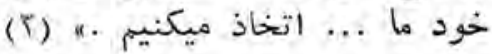

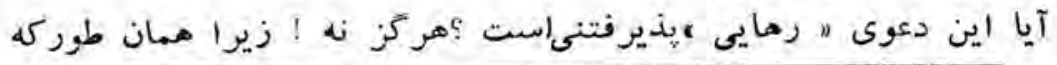

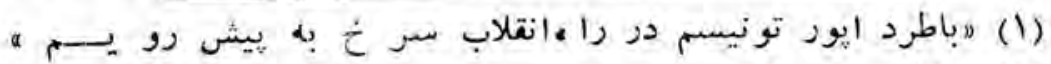

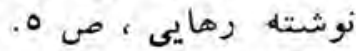

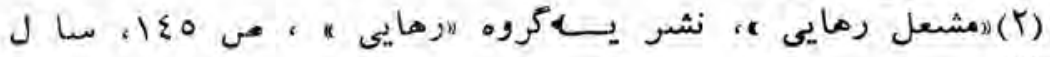




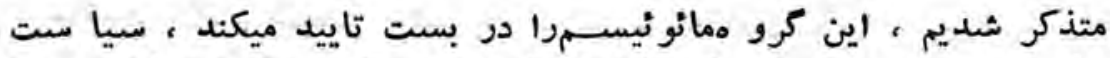

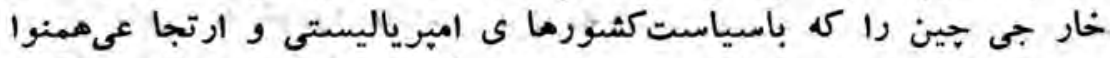

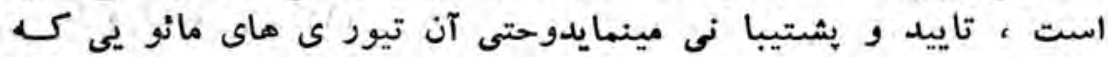

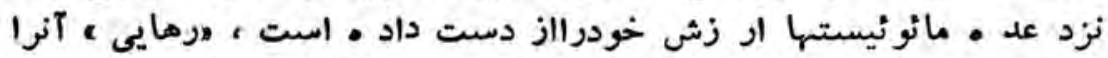

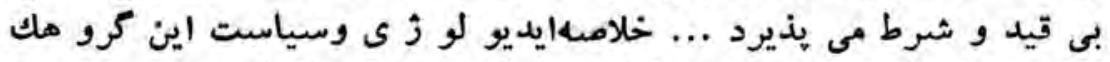

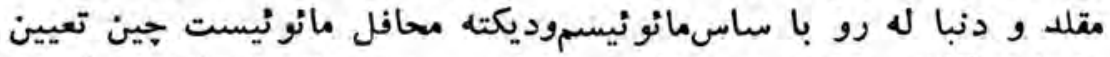

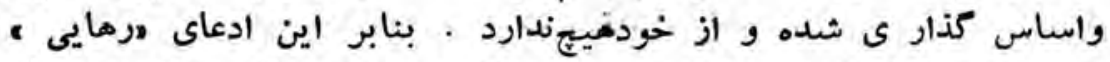

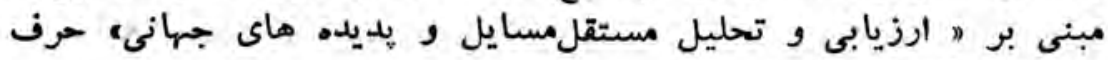

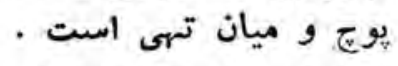

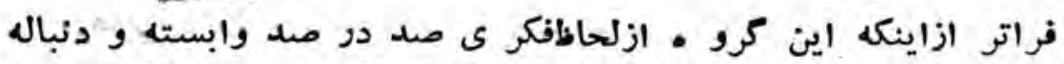

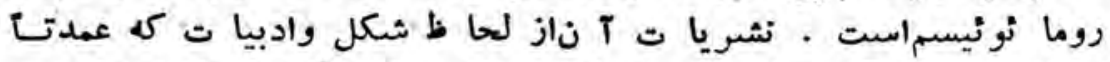

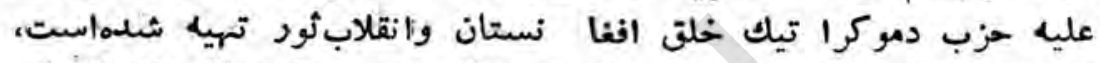

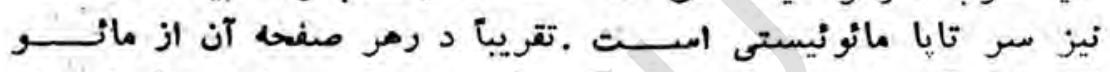

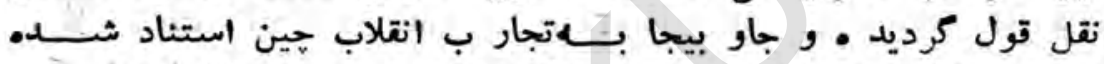

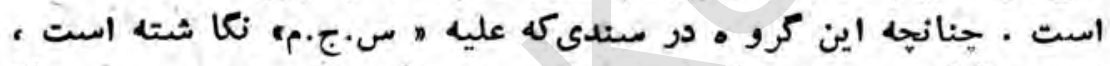

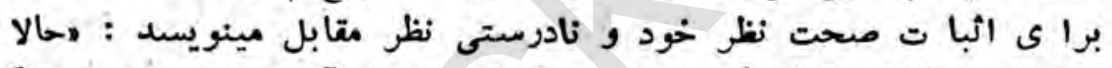

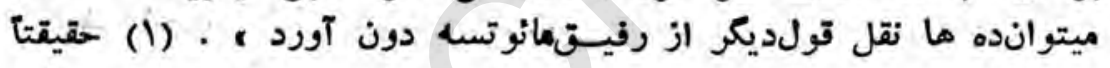

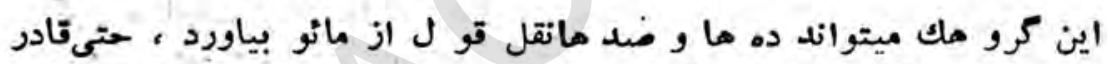

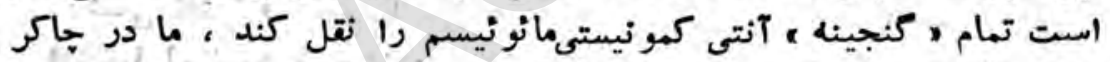

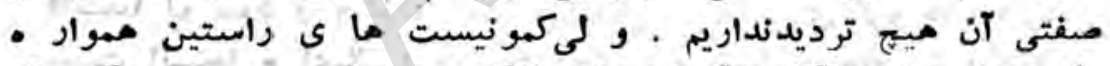

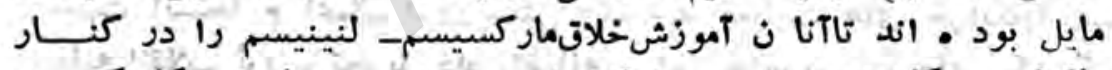

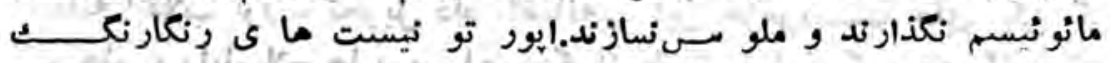

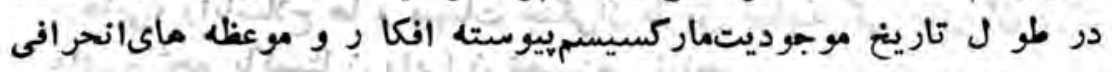

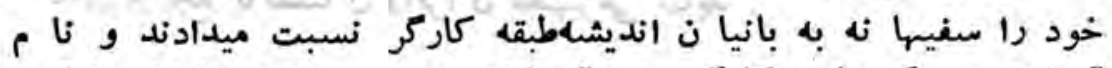

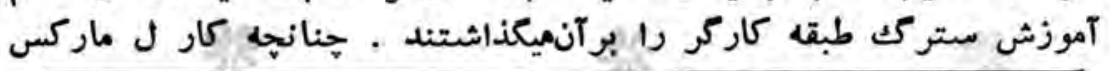

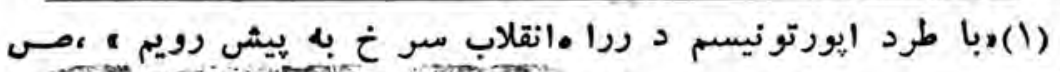

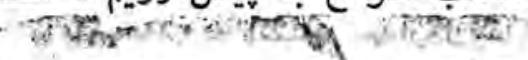

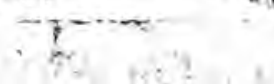




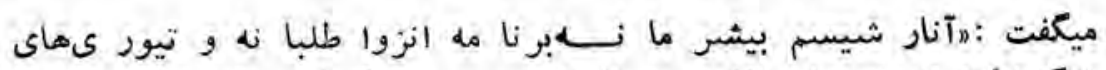

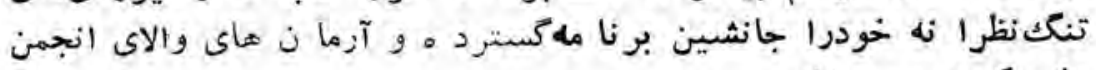

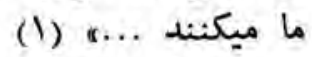

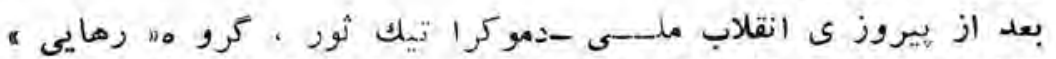

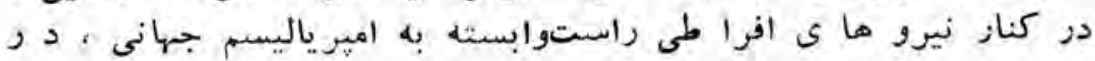

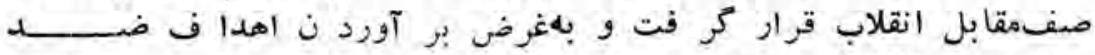

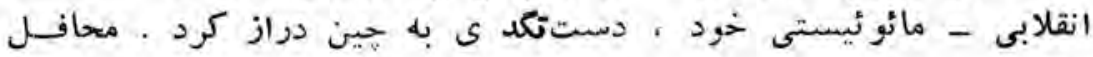

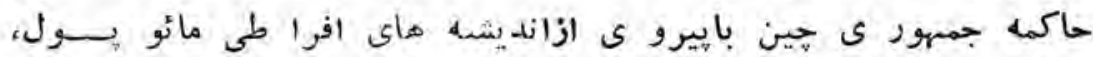

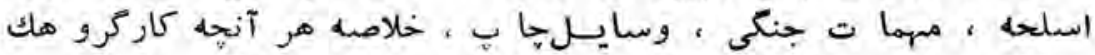

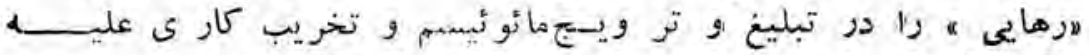

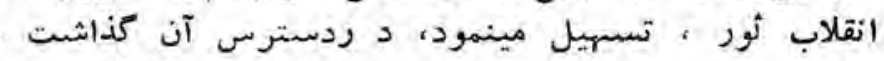

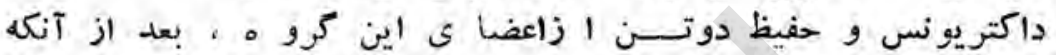

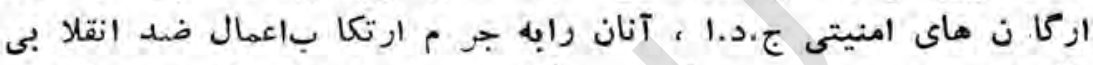

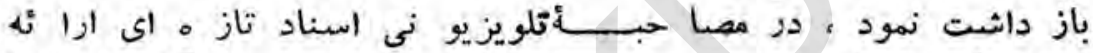

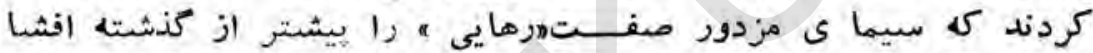

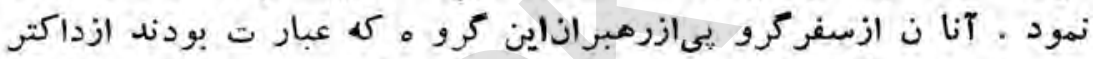

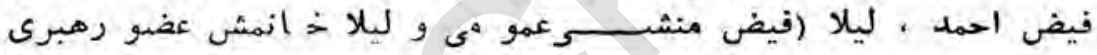

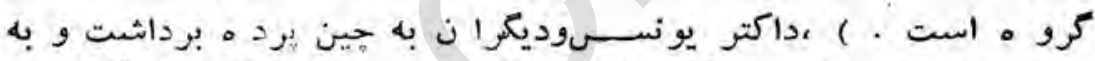

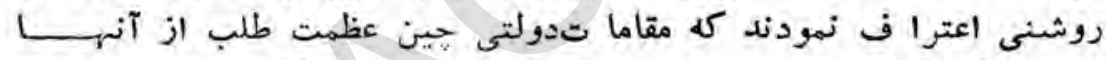

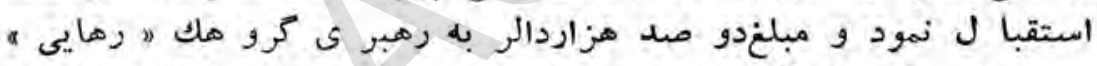

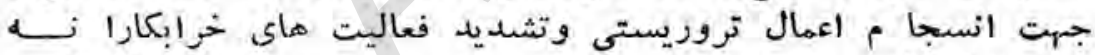

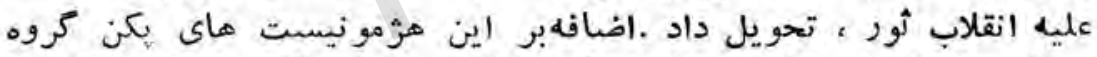

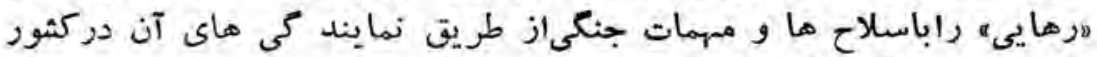

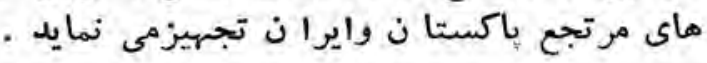

\section{米}

\section{*}

米

باتوجه به اسناد ،مدار لكوفاكتهاى مستند ارا ئه شده ميتــوا ن

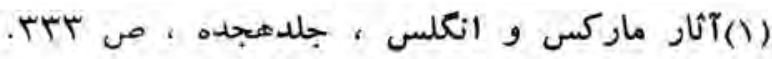




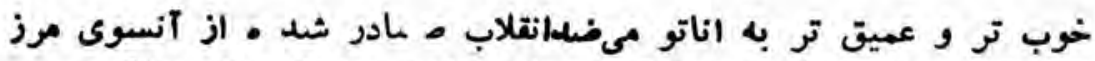

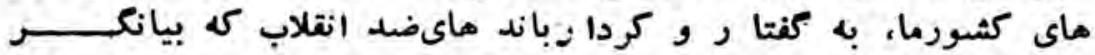

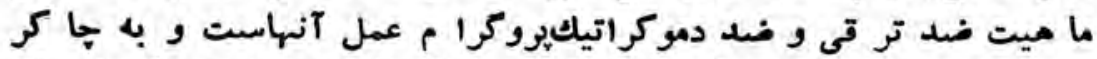

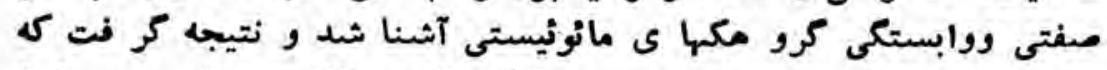

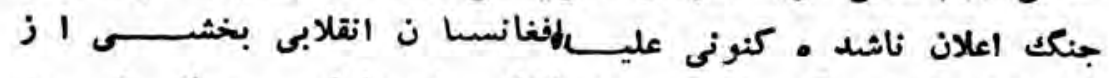

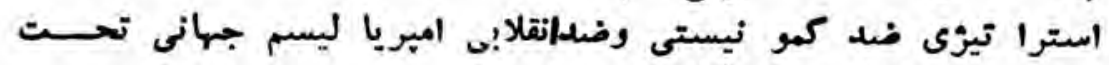

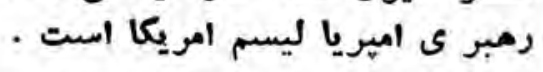

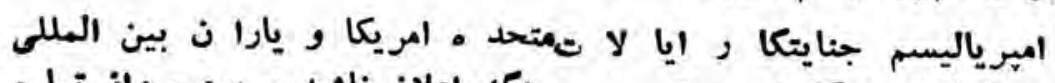

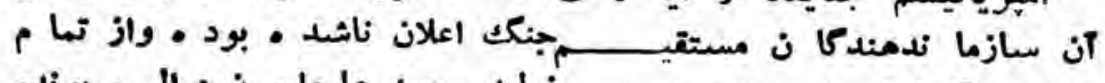

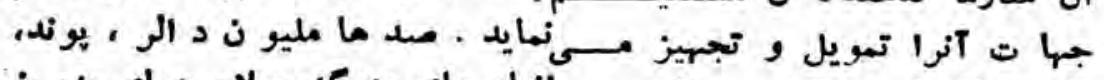

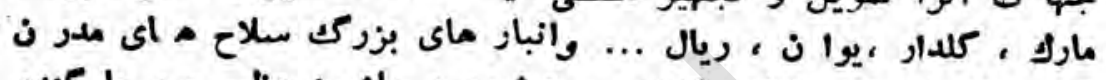

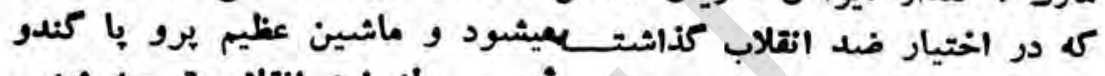

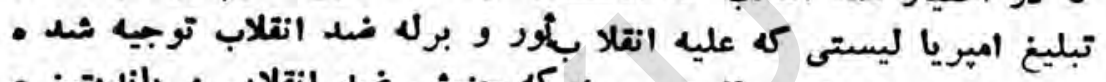

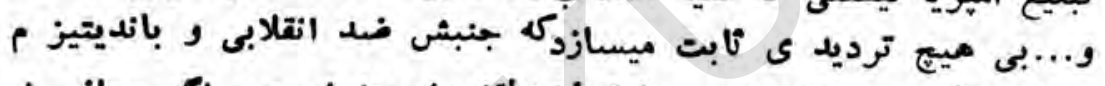

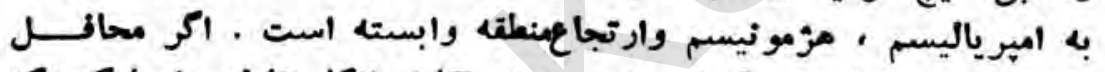

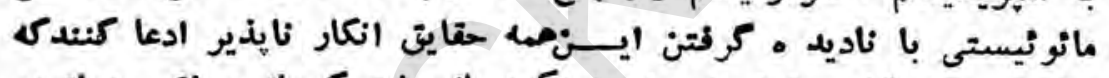

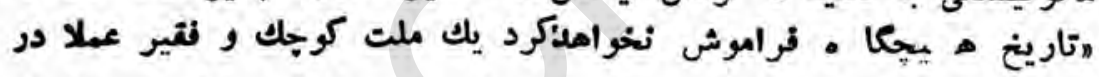

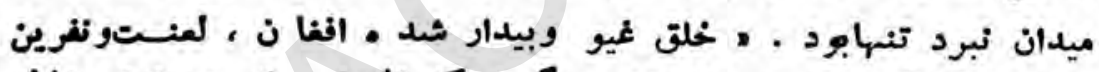

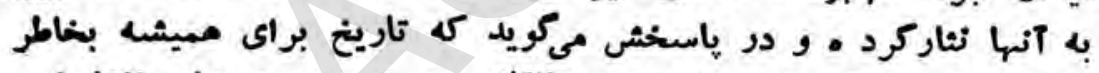

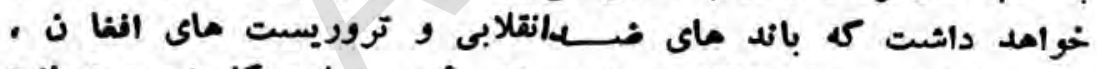

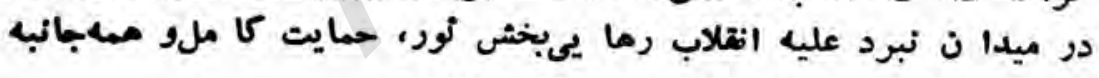

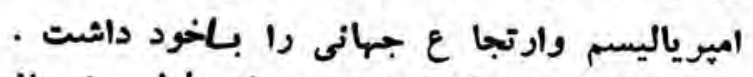

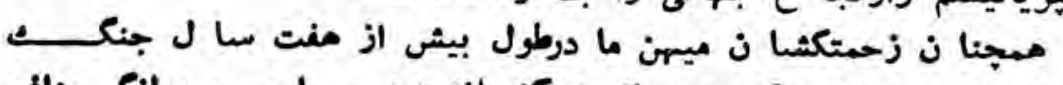

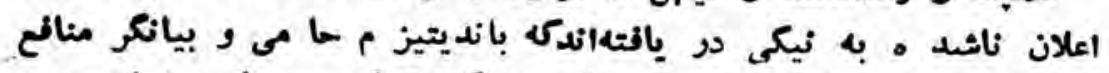

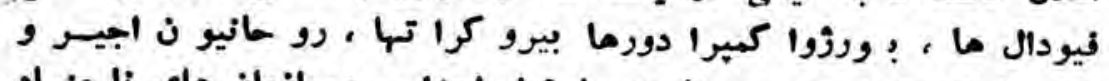

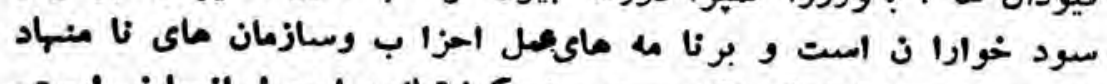

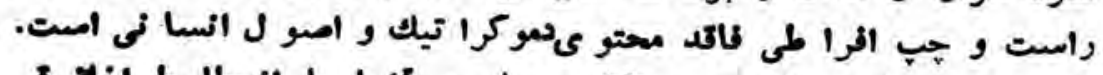

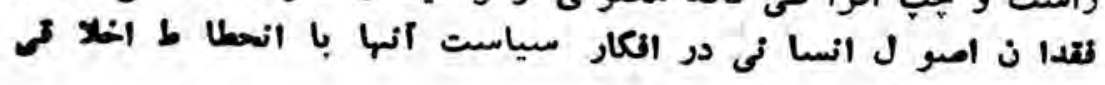


رهبراً ن و فعالين باند ها مشخصميشود . بيشترين قر بانيا ن اعمال

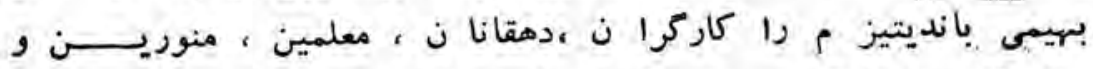

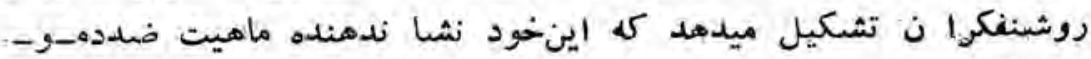

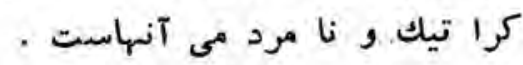

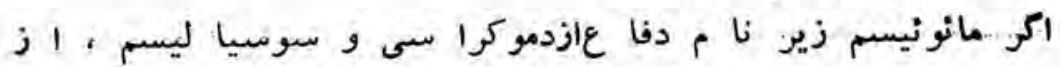

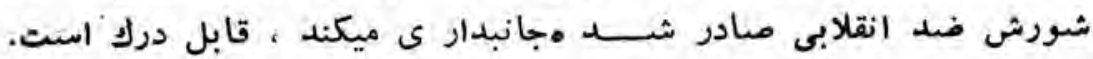

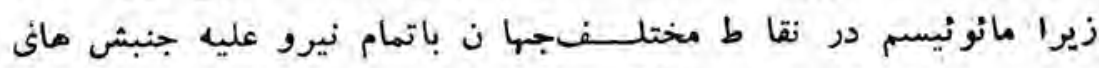

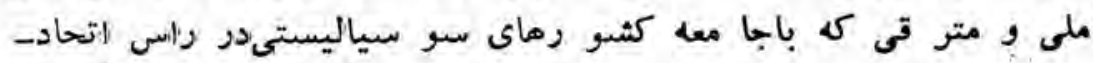

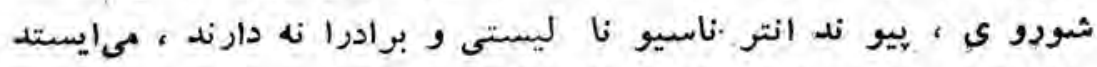

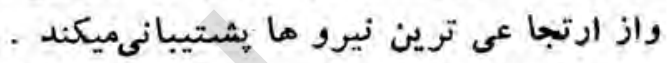

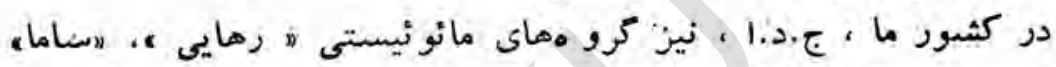

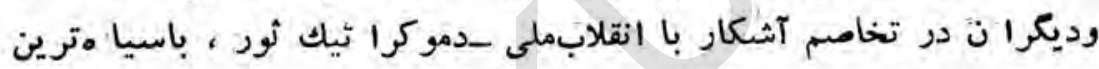

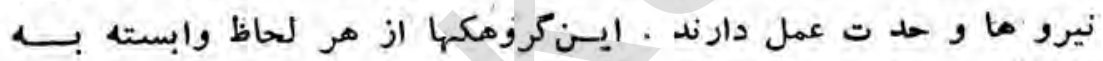

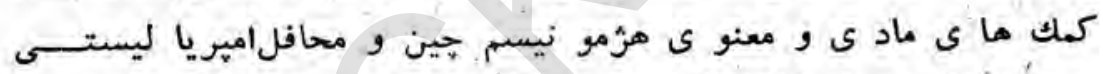

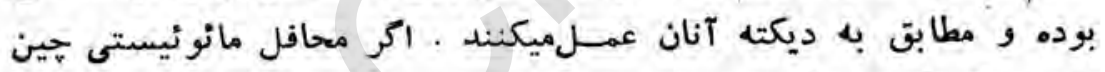

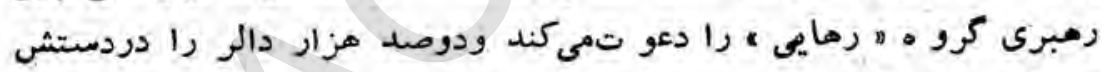

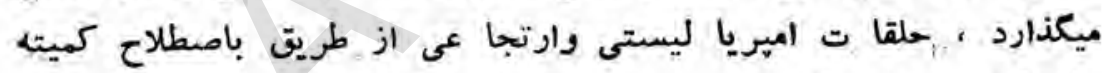

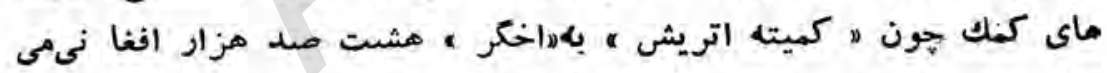

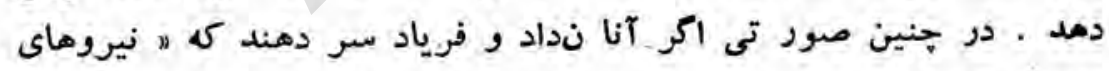

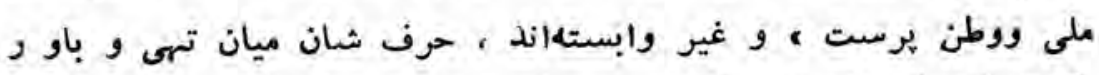

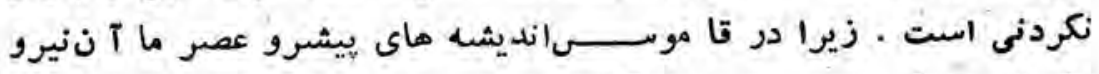

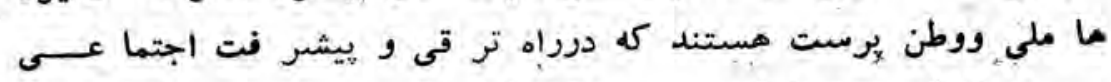

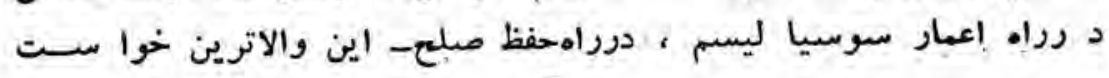




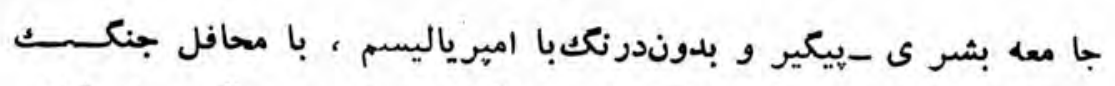

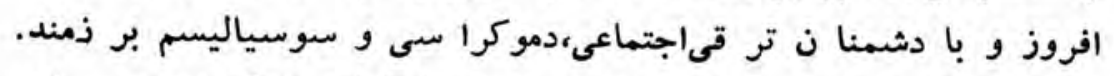

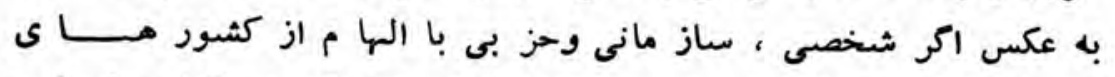

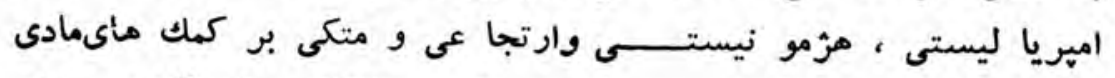

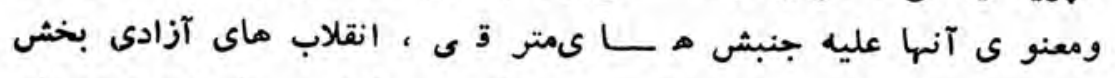

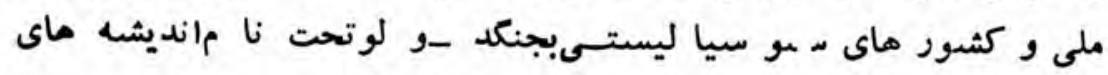

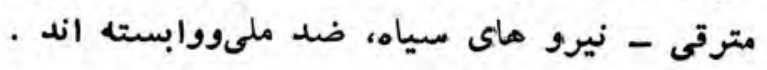

-riv_ 
"يرولتر ما دور كليه كثود مـا،

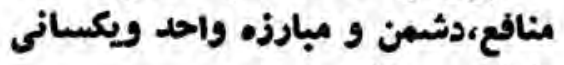

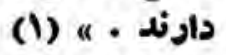

\section{ناسيونا ليسمخرده بورزوائىو

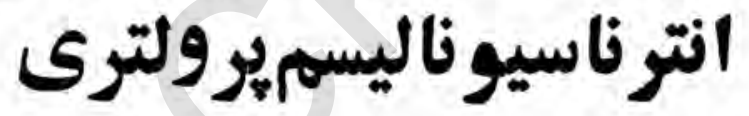

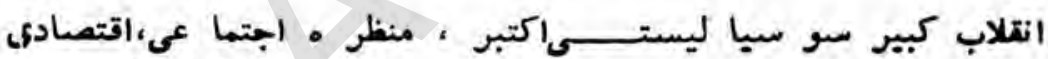

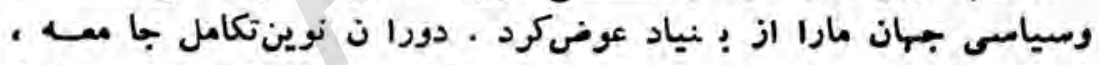

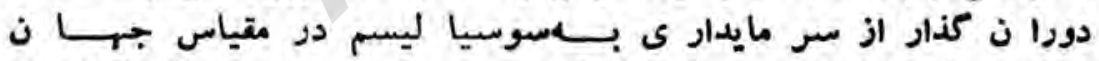

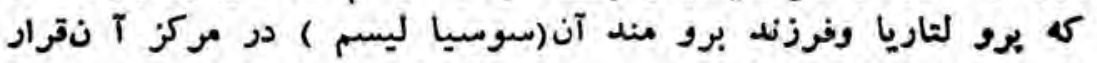

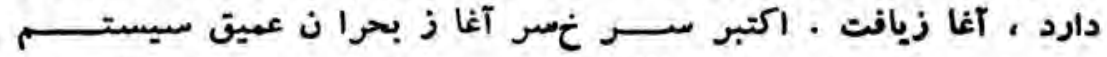

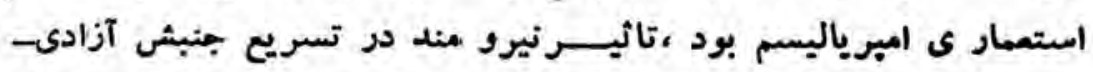
(1) 
بخَّ ملى و مجمو عه فرايند انقلابجهانى كذأَشت ودر مهه جاشور ى

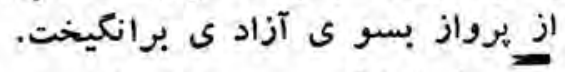

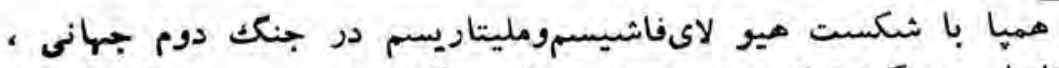

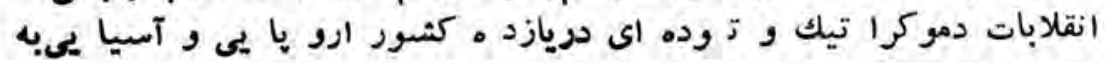

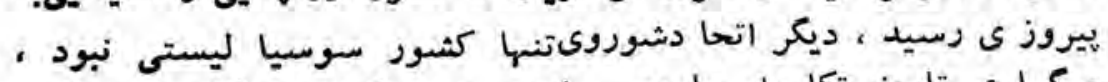

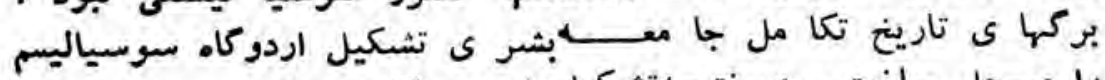

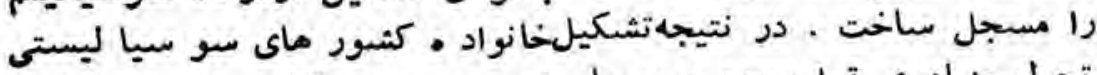

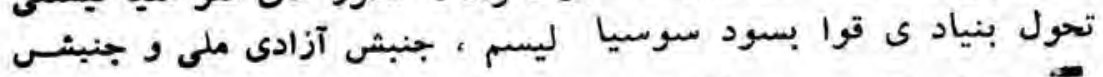

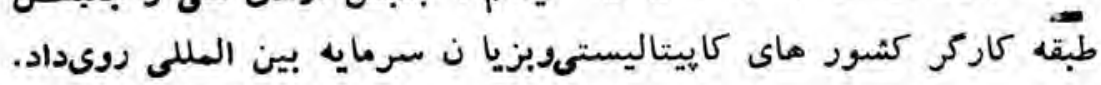

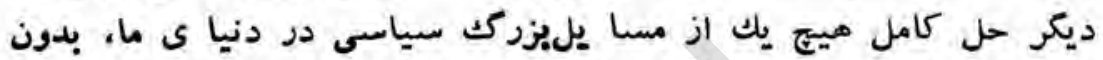

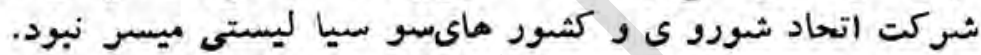

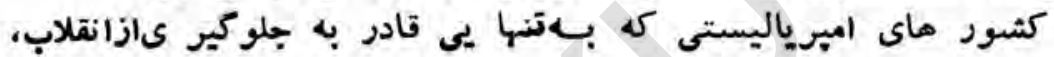

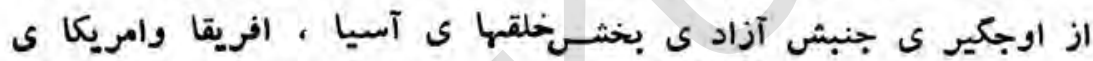

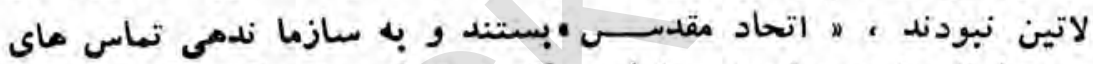

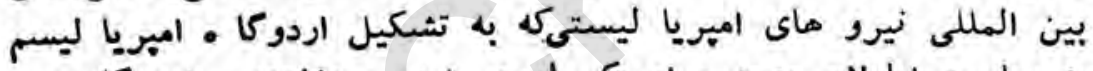

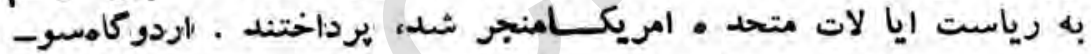

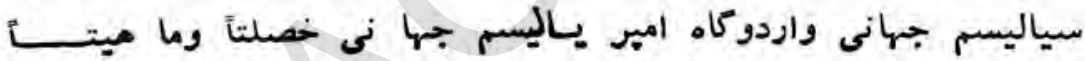

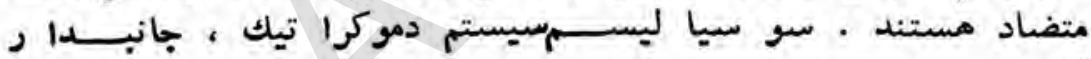

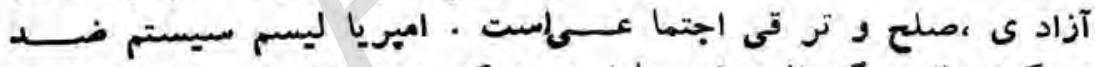

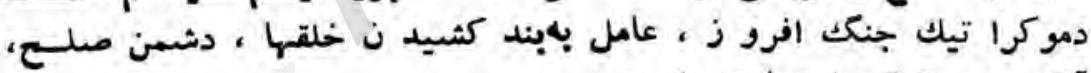

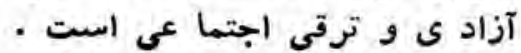

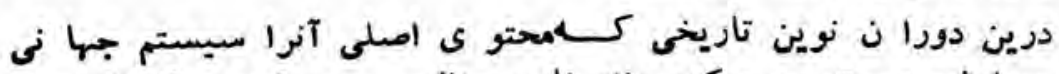

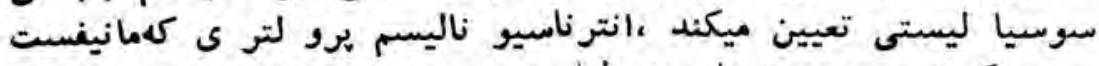

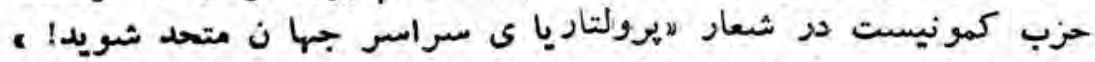

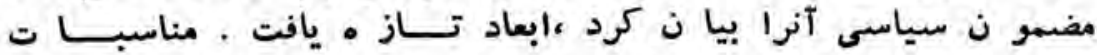

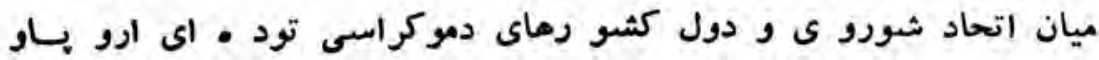

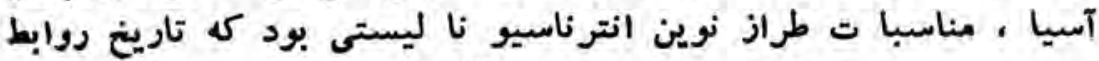
- rาq- 


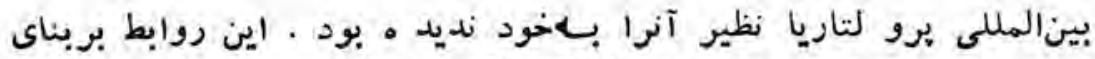

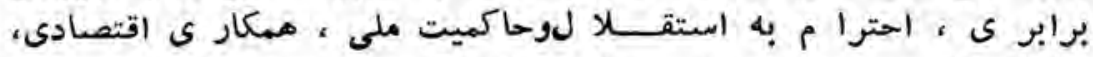

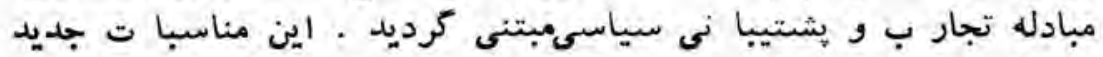

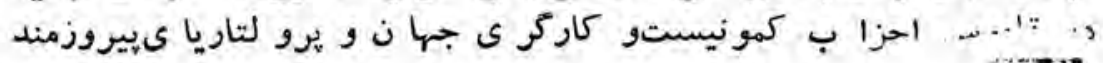

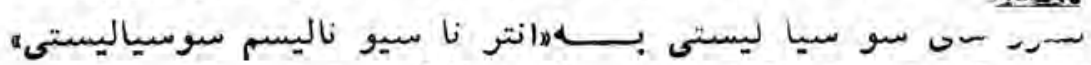

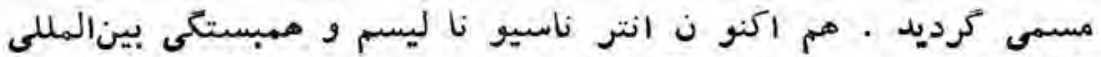

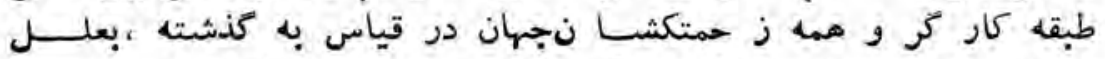

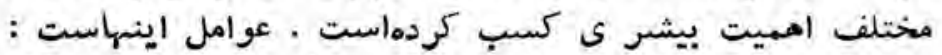

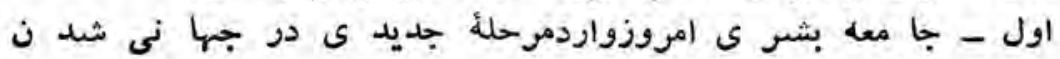

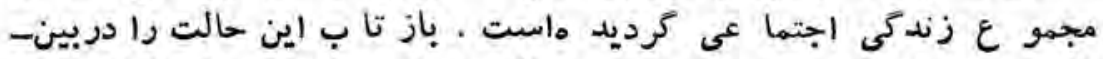

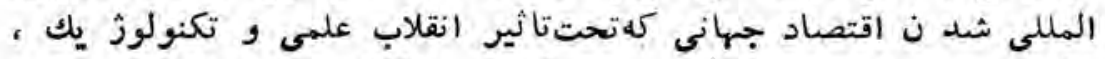

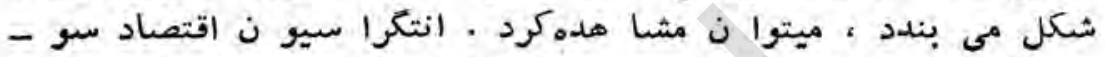

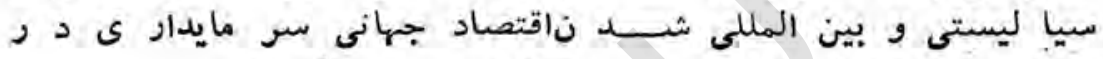

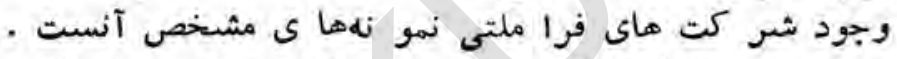

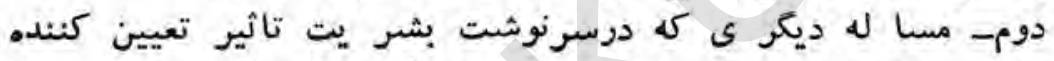

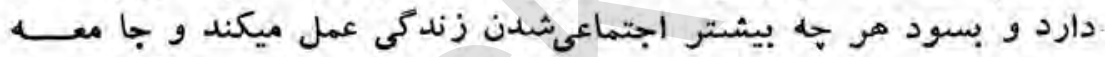

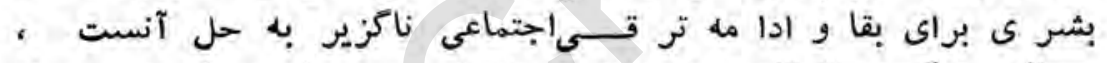

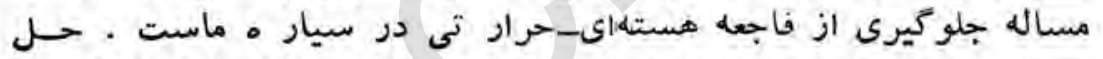

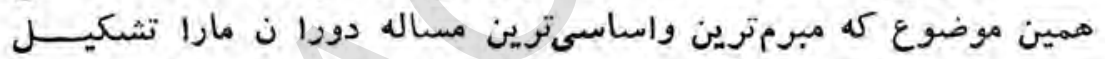

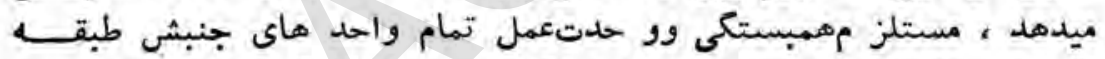

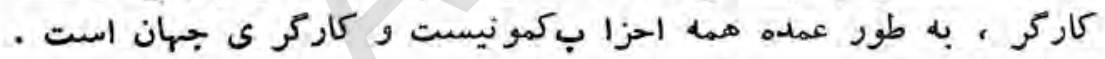

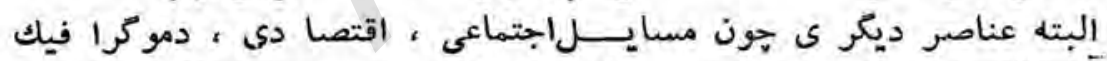

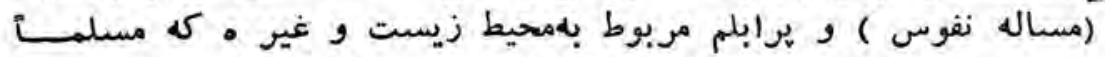

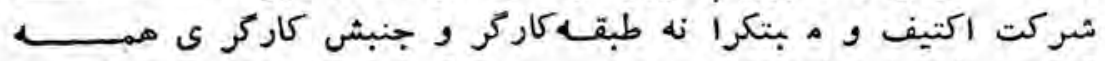

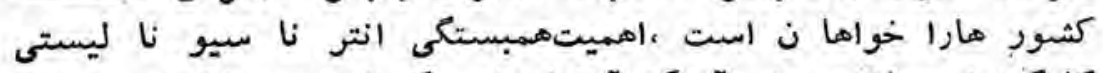

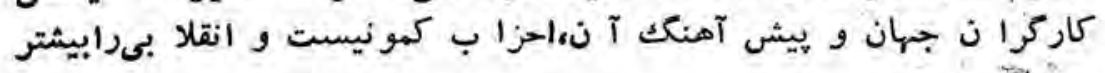

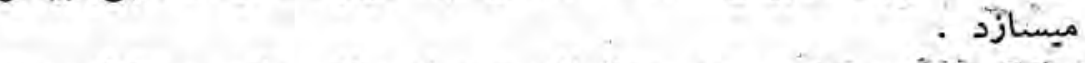
همجناً نُ در وضع جديد بينالمللىمسوو ليت انتر نا سيو نا ليستسى -rV._ 


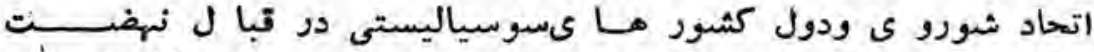

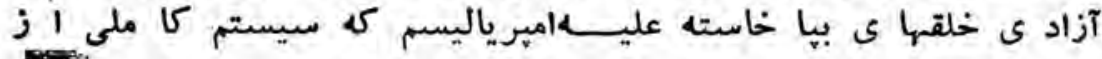

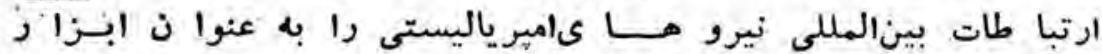

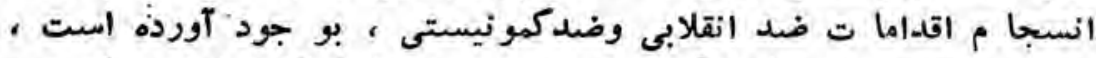

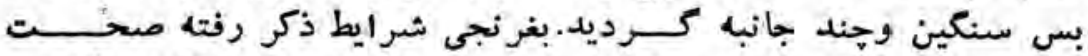

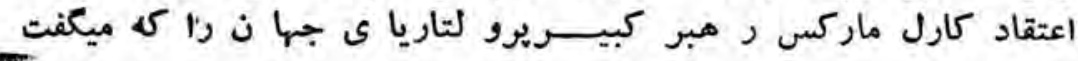
$-$

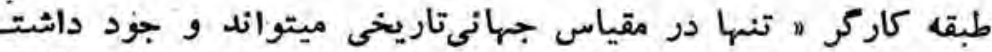

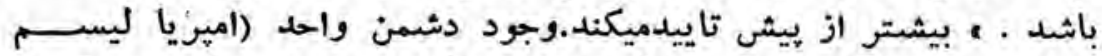

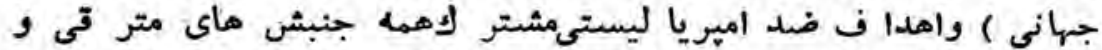

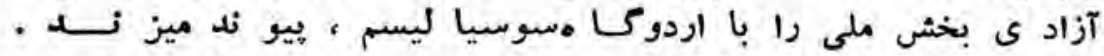

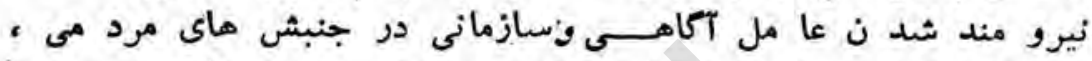

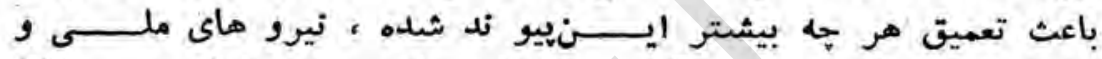

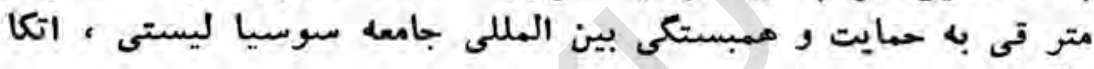

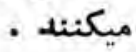

\section{*}

\section{米}

\section{*}

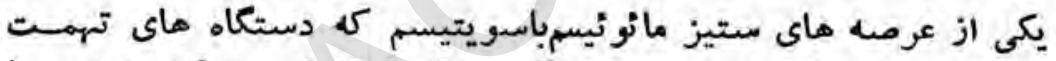

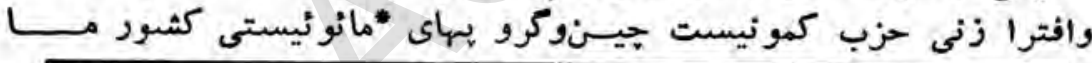

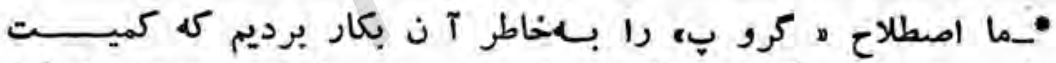

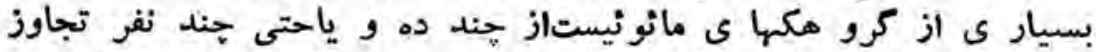

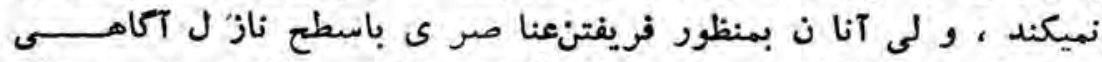

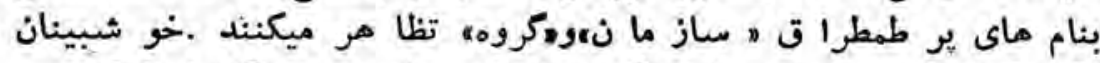

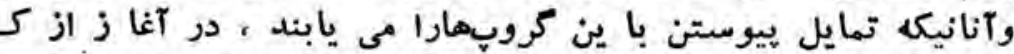

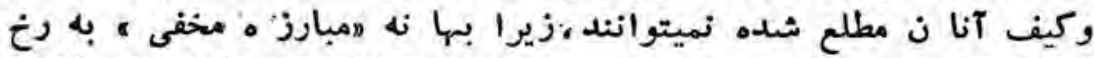

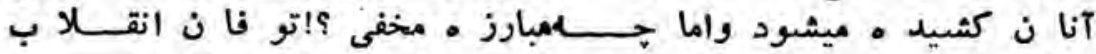

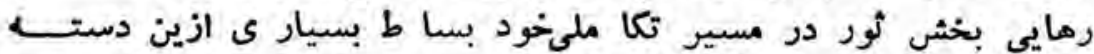

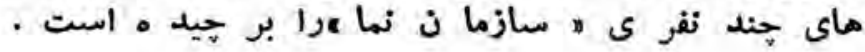
-rVI- 


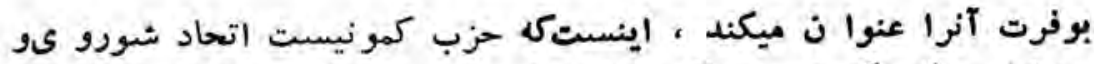

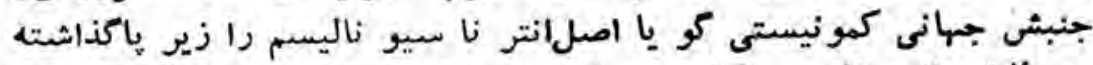

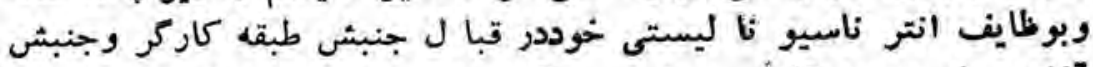

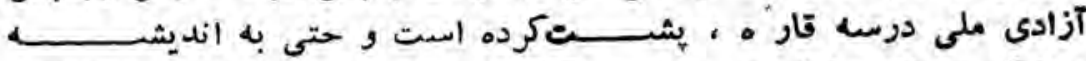

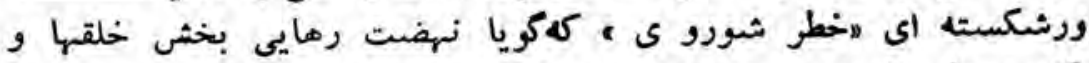

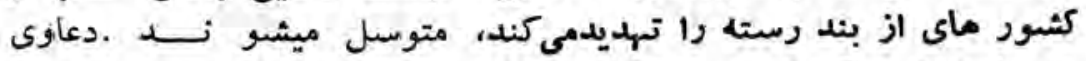

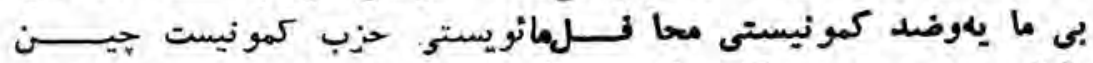

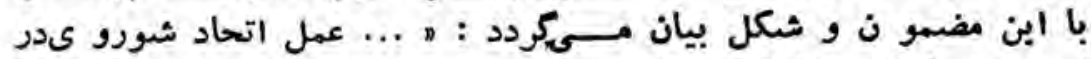

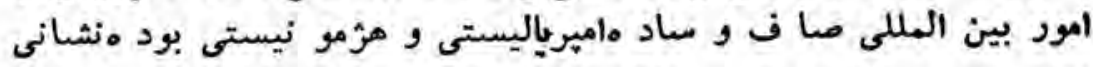

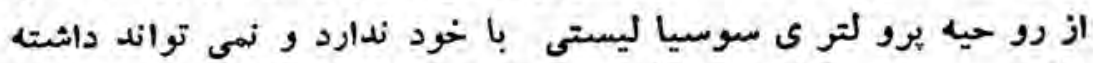

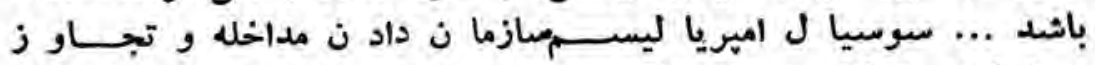

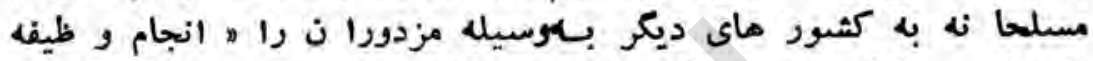

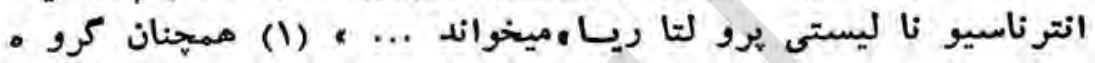

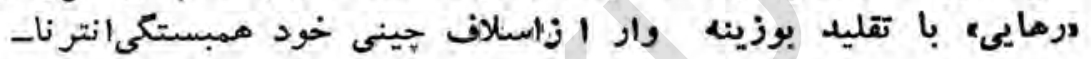

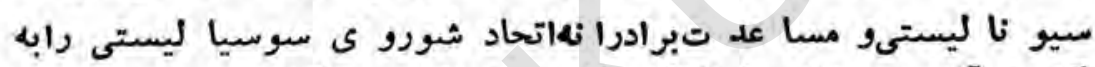

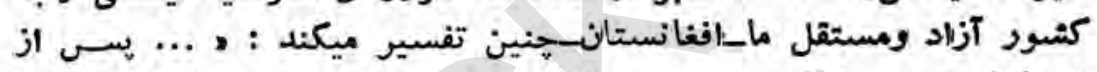

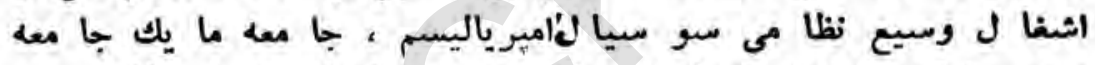

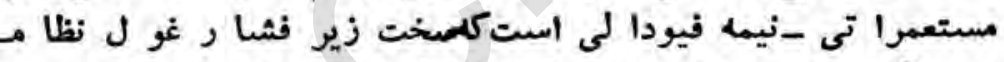

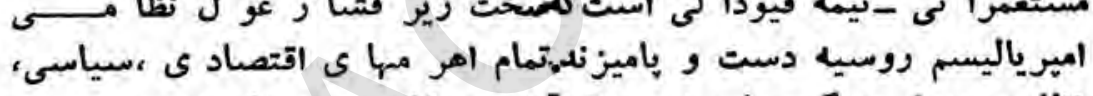

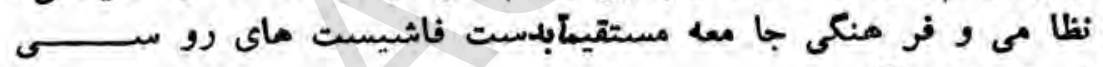
(r)

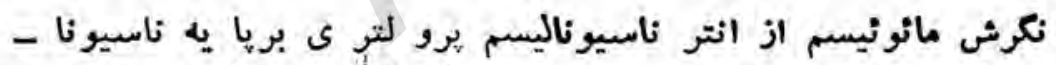

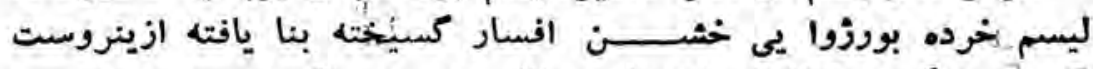

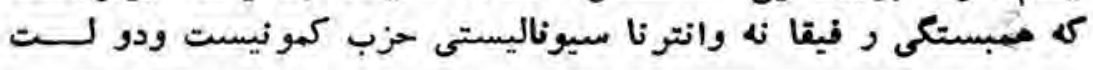

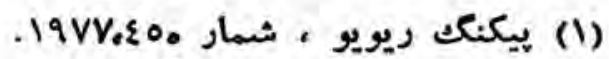

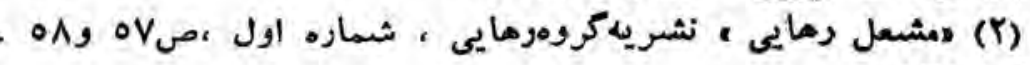
مال -rvt- tor. 


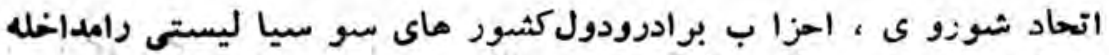

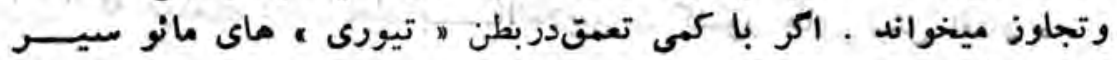

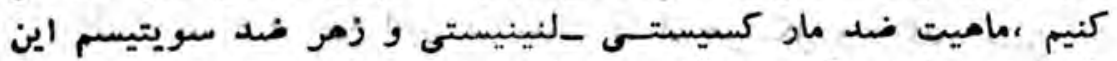

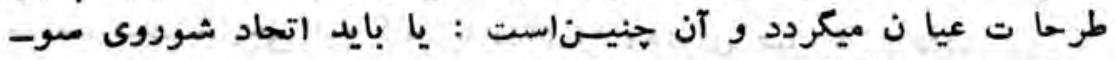

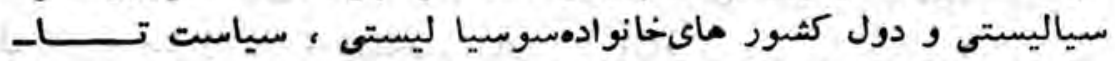

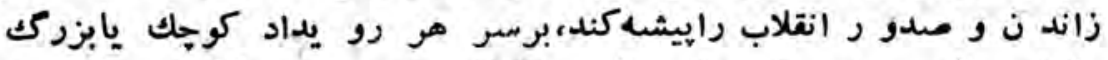

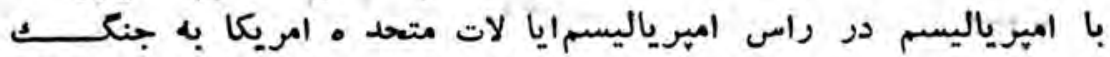

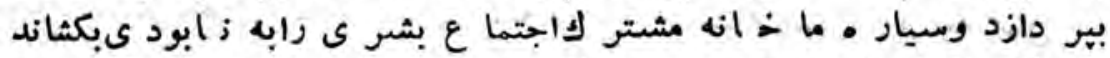

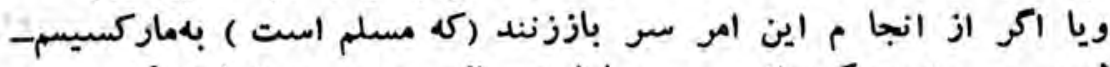

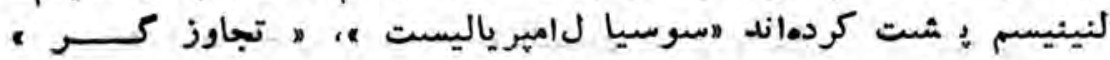

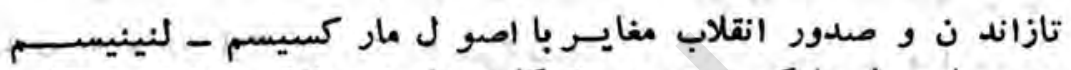

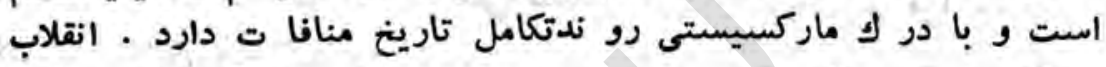

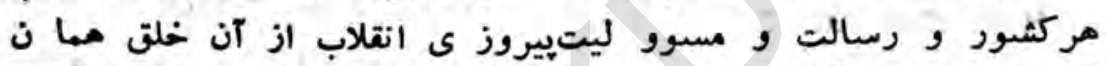

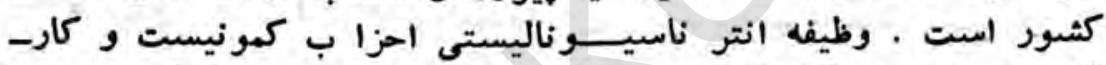

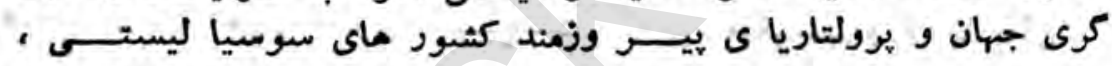

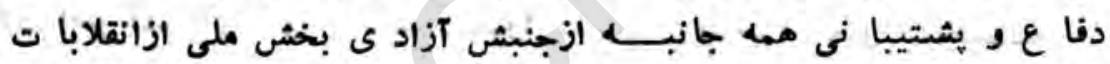

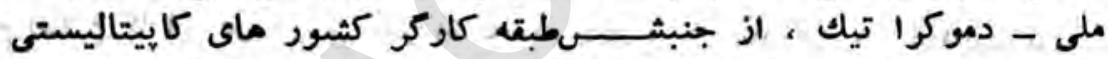

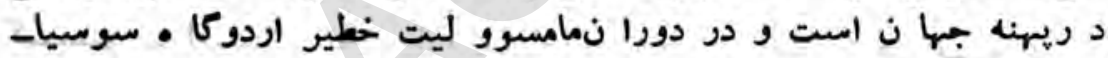

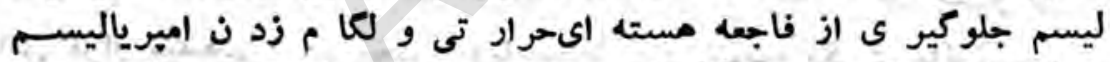

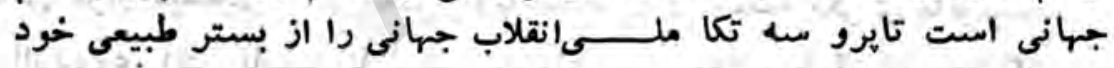

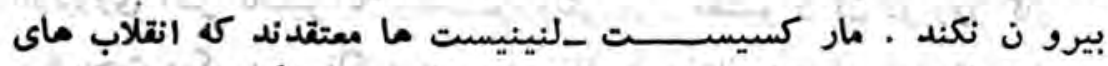

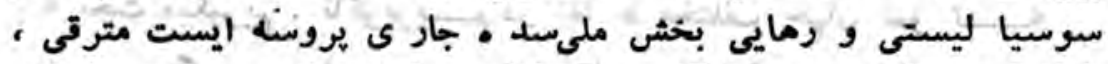

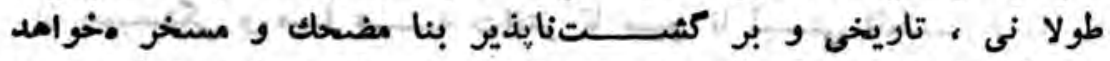

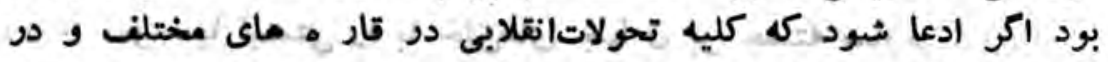

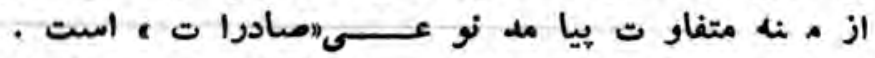

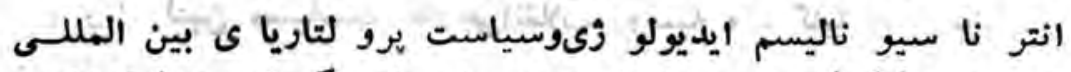

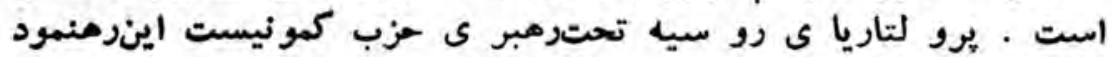




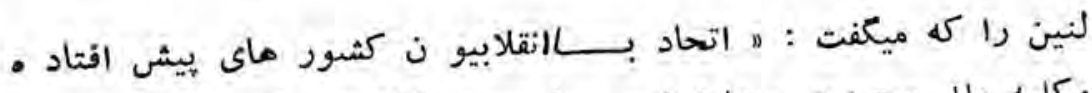

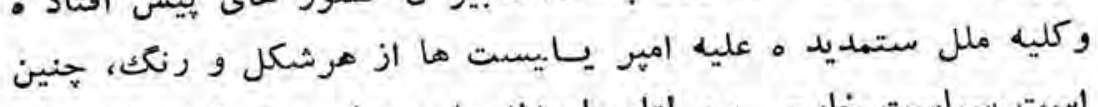

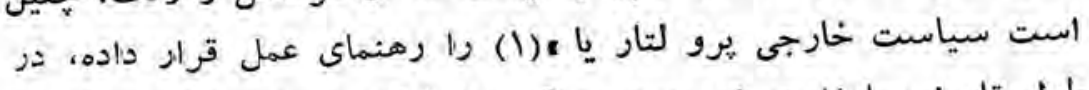

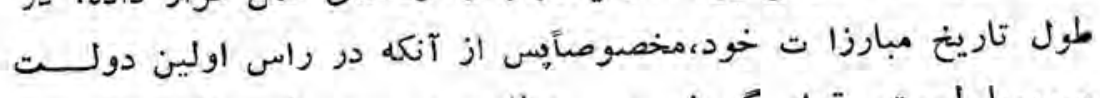

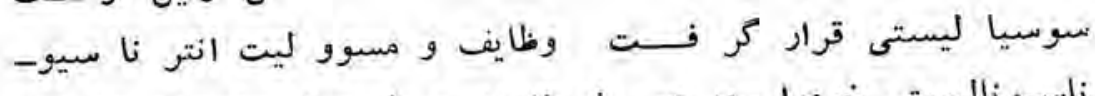

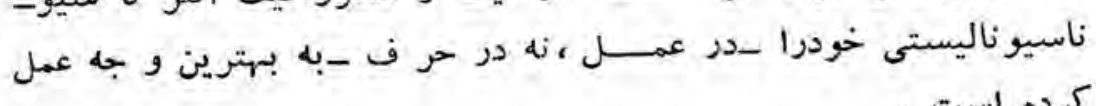

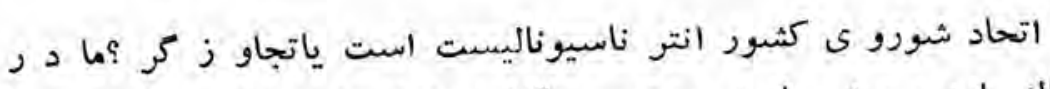

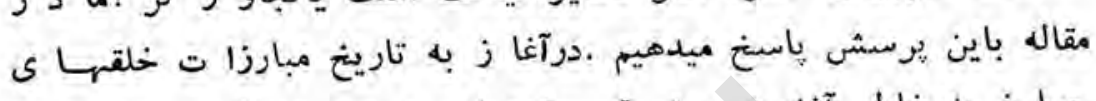

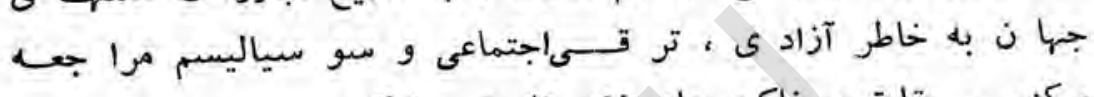

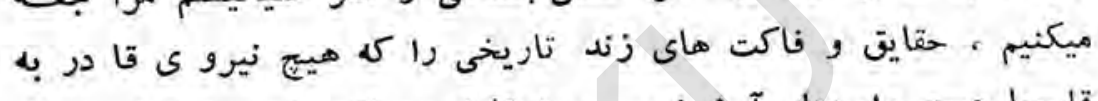

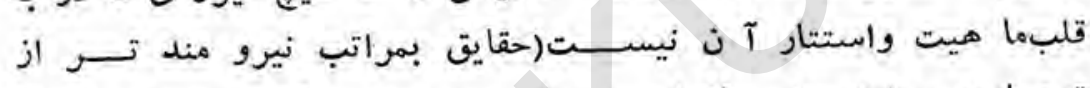

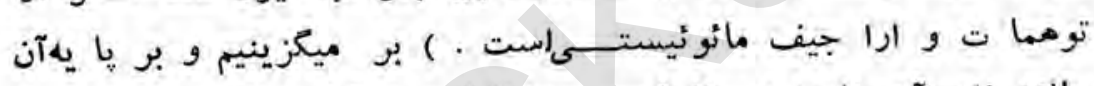

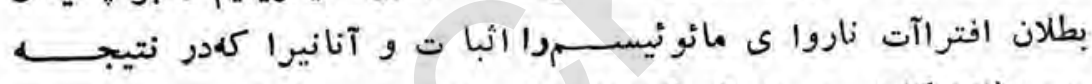

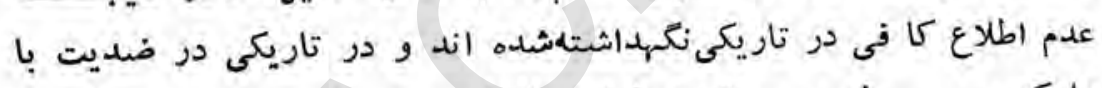

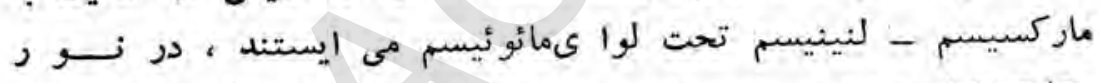

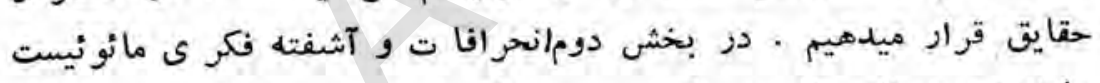

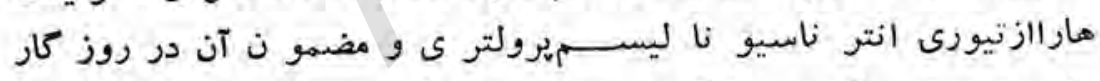

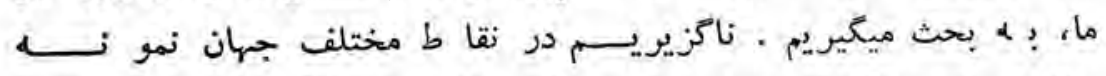

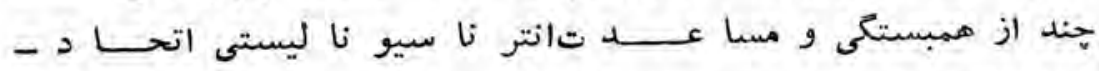

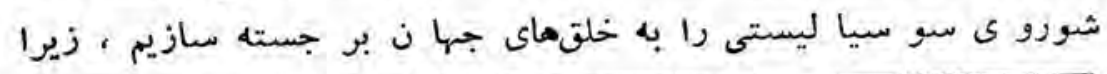

(1) و.1. لنين "مسياست خارجىانقلاب روسيه ، ، كليا ت ، جلــــ OT 79.79 


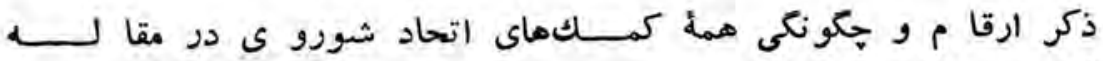

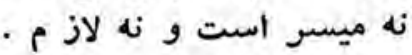

象

米

米

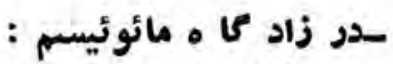

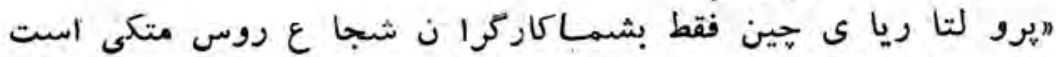

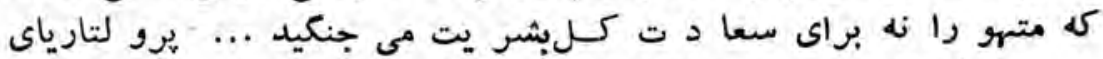

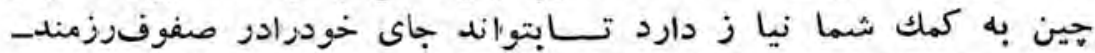

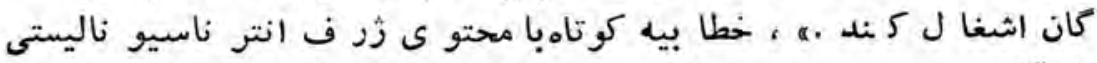

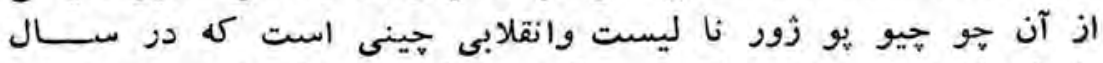

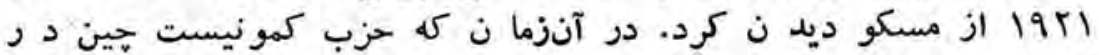

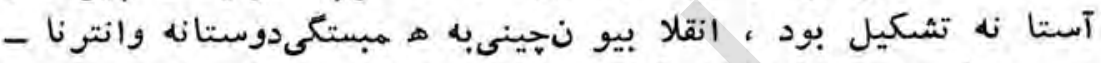

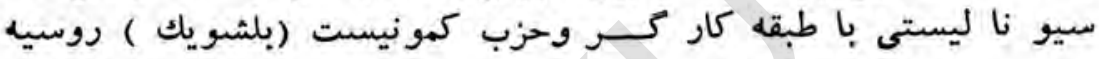

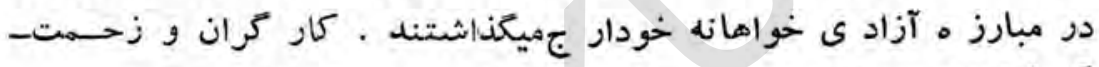

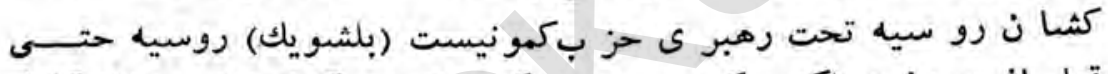

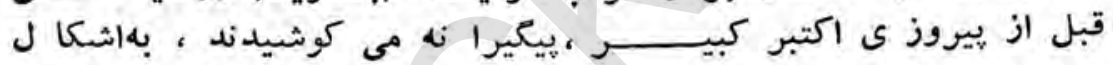
متنو ع به جنبش خلقها ى خاور وخلق خين همكار ى و يار ى نم نمايد.

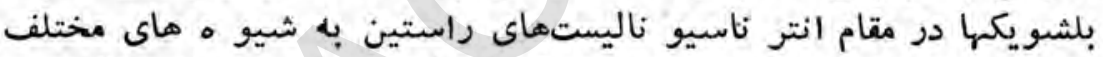

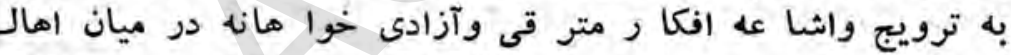

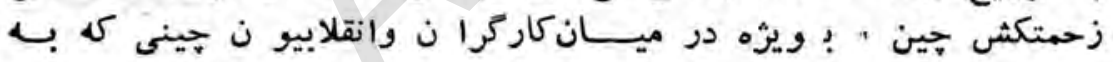

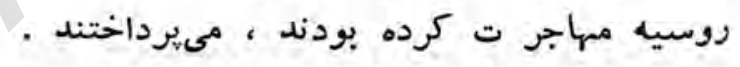

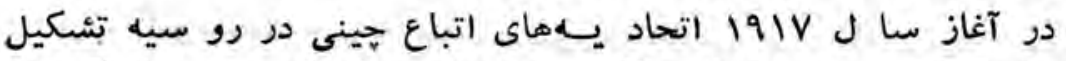

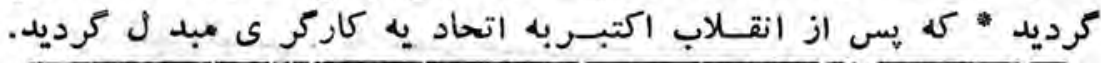

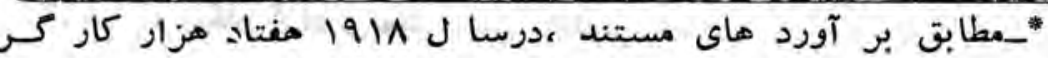

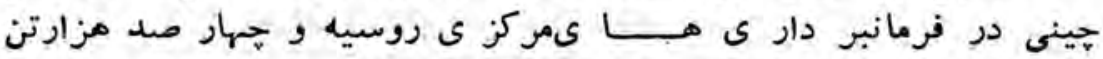

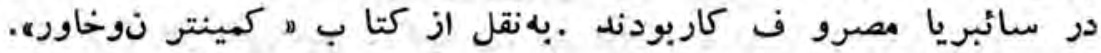




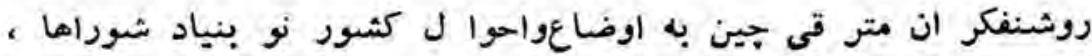

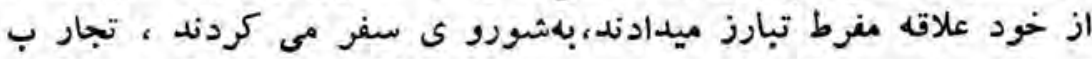

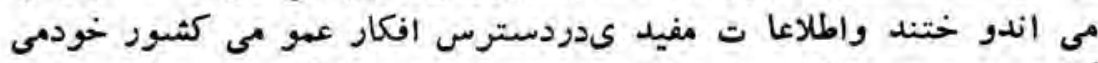

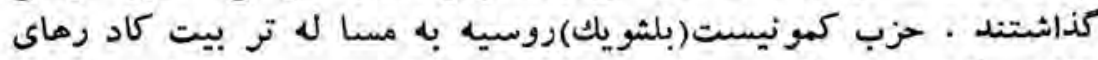

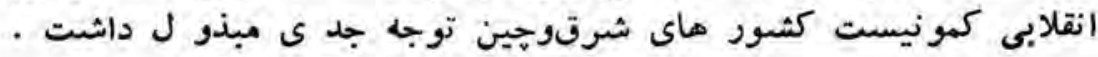

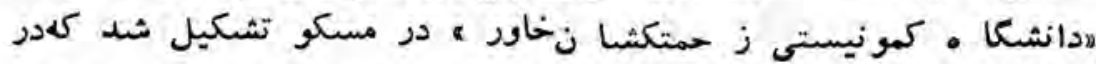

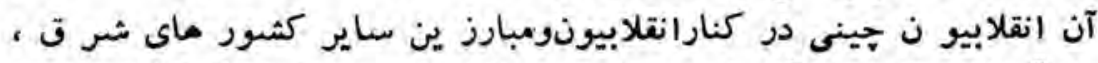

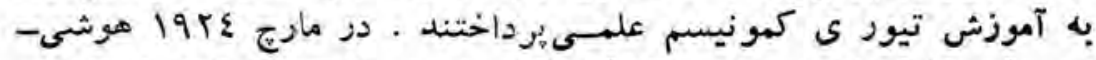

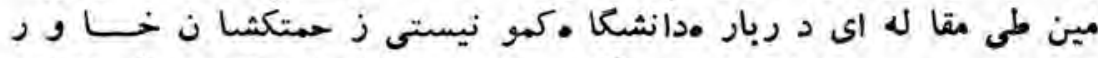

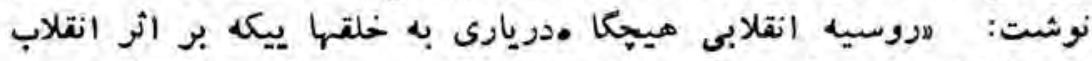

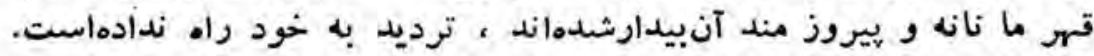

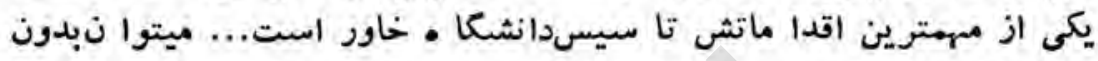

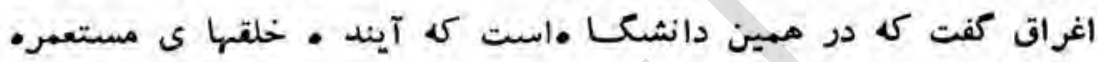

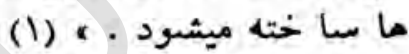

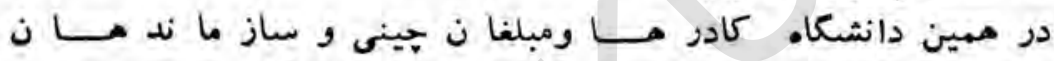

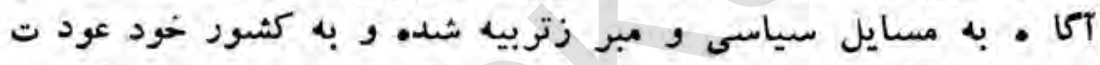

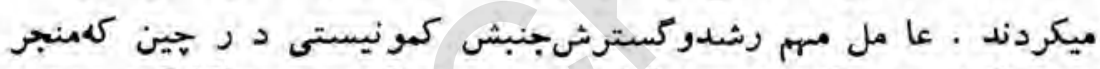

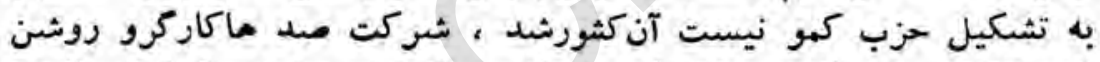

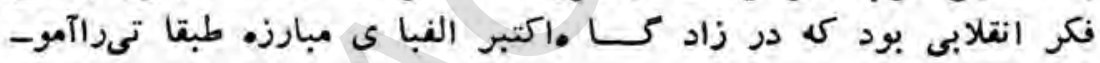
خته بودند . نملابى

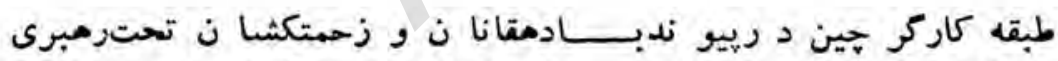

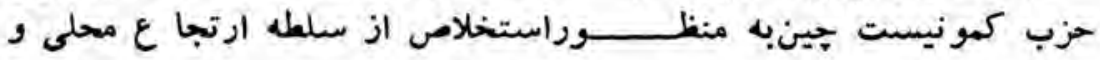

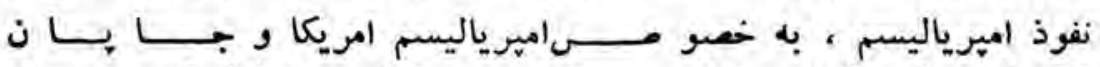

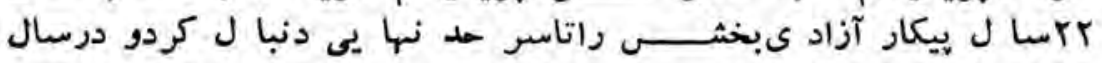

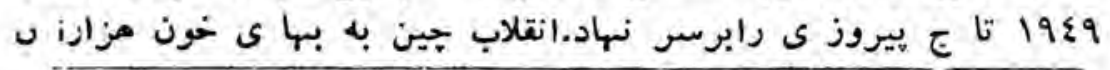

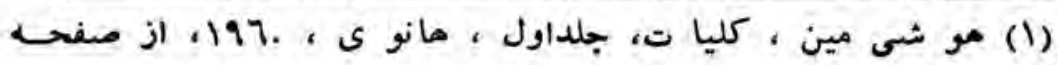

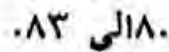




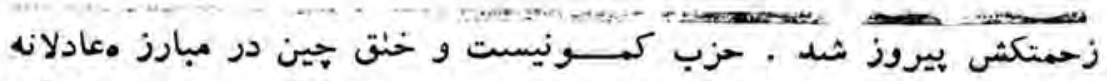

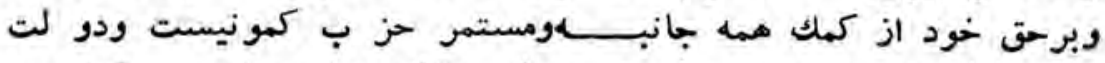

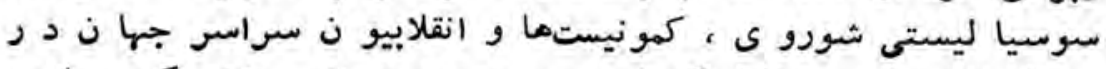

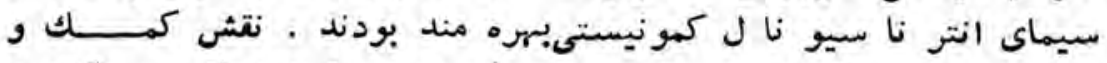

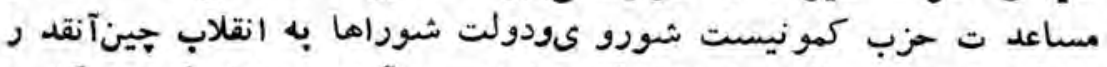

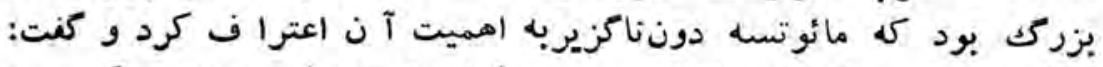

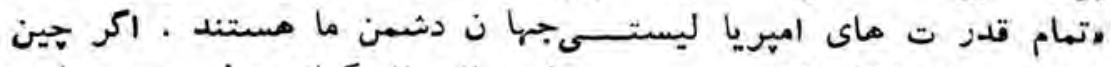

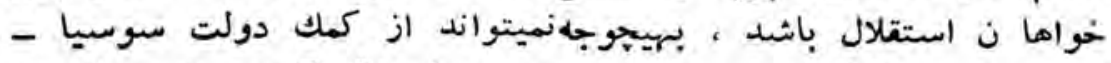

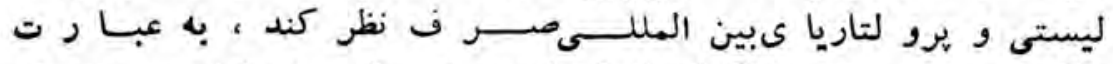

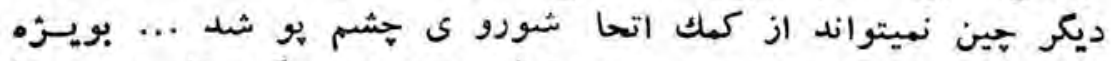

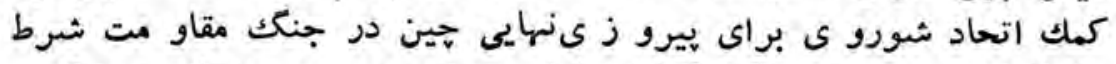

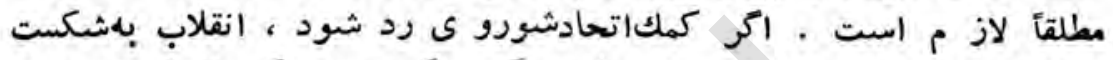

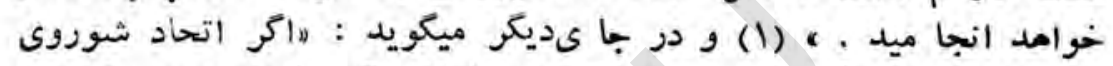

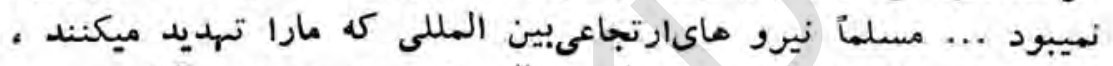

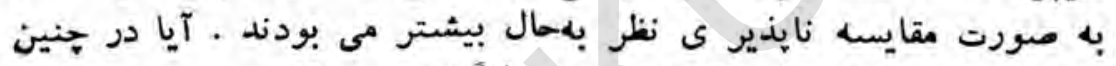

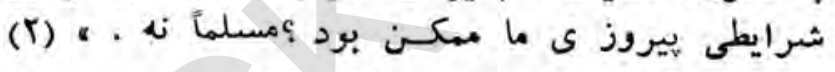

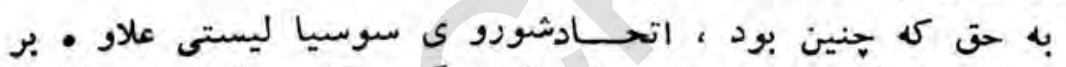

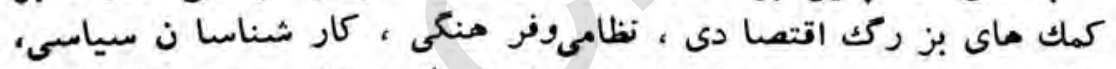

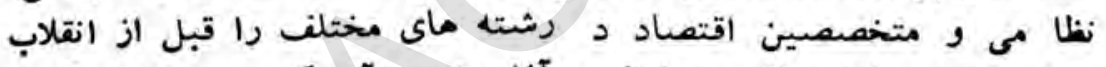

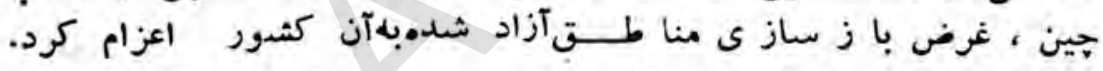

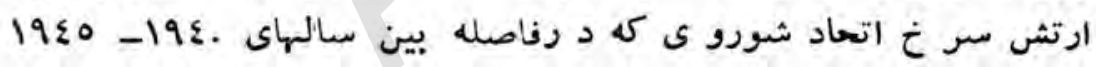

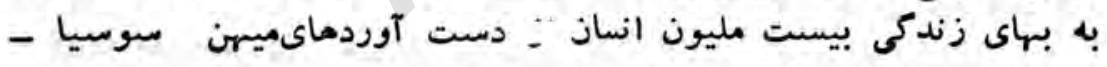

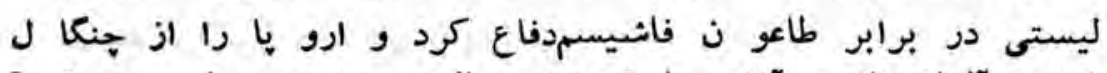

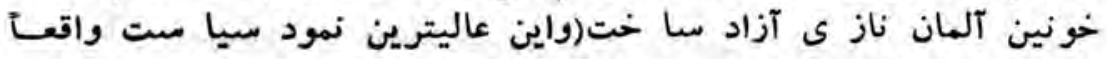

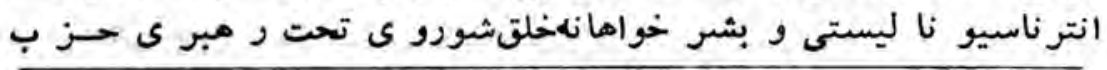

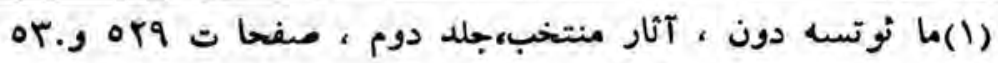

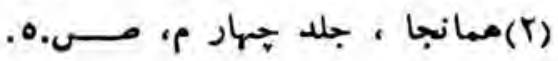


كمونيست لنينى آنست كل هتىمورداذعان دشمنا ن سوسيا

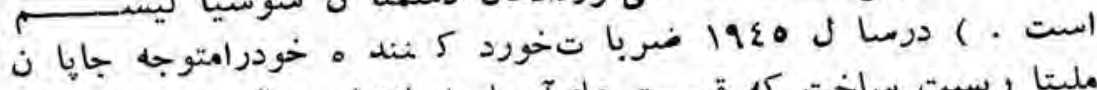

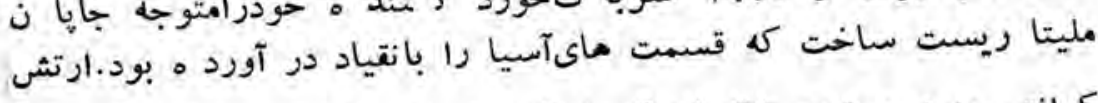

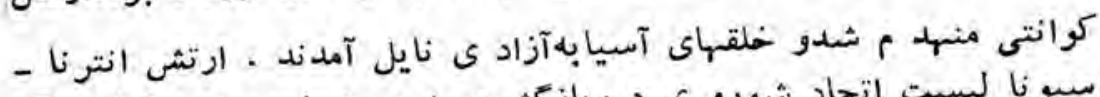

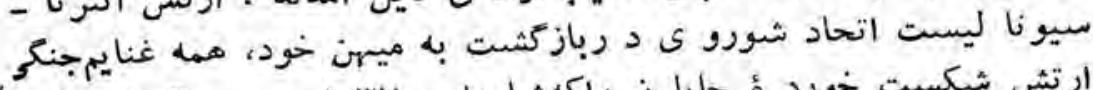

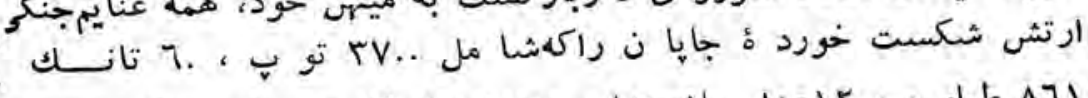

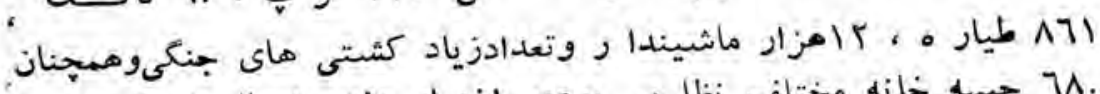

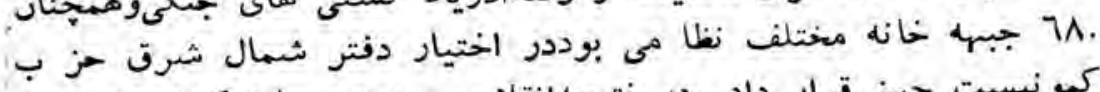

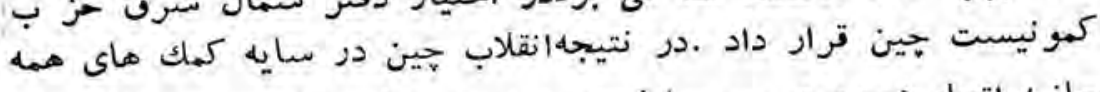

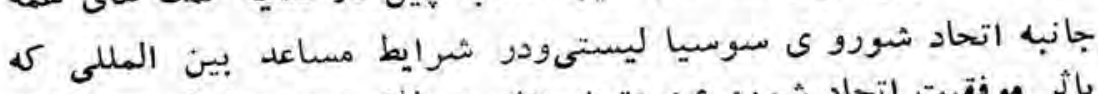

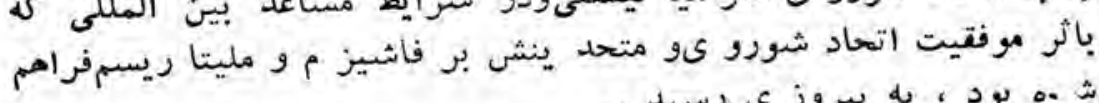

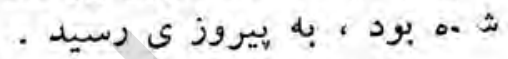

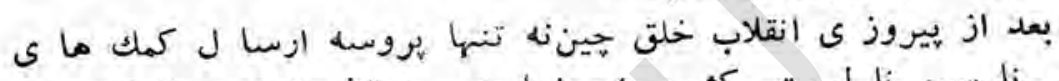

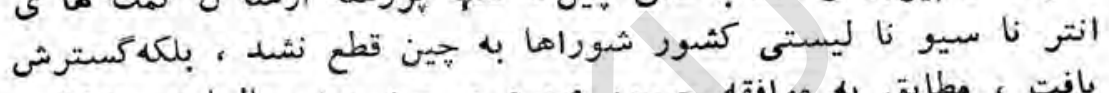

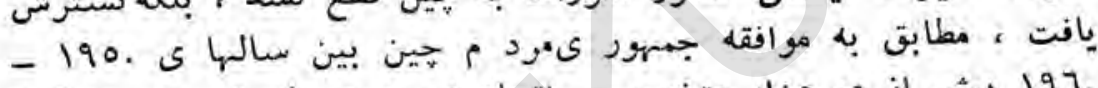

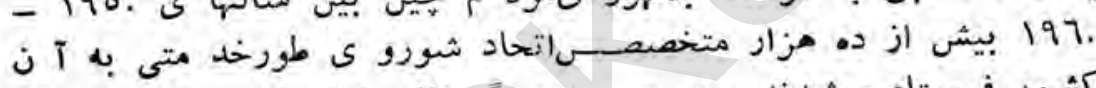

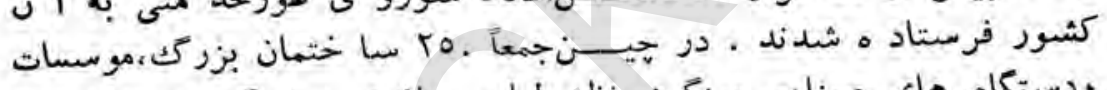

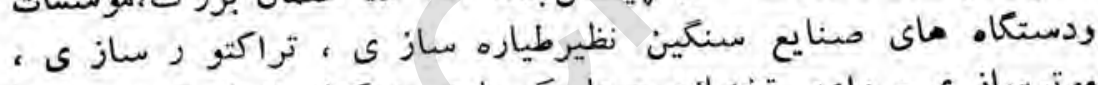

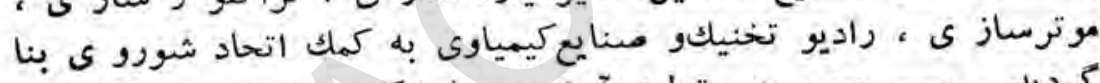

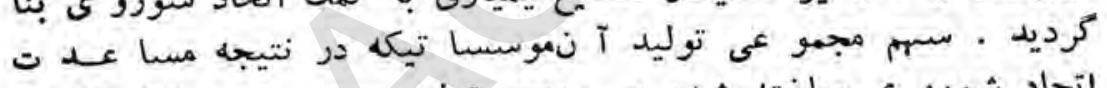

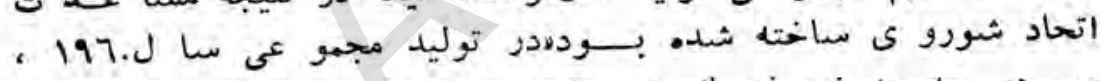

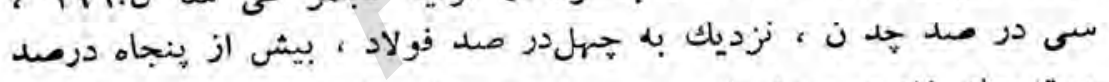

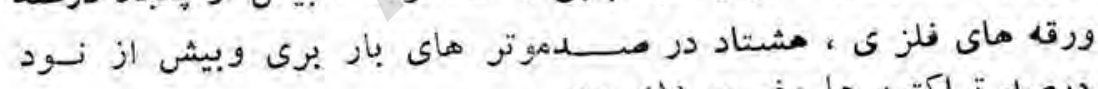

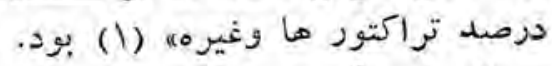

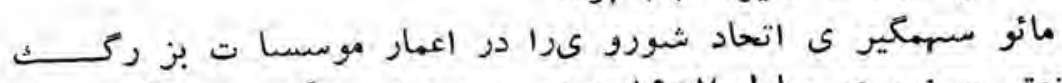

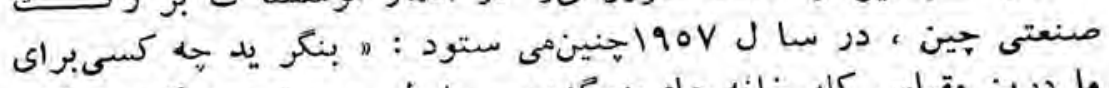

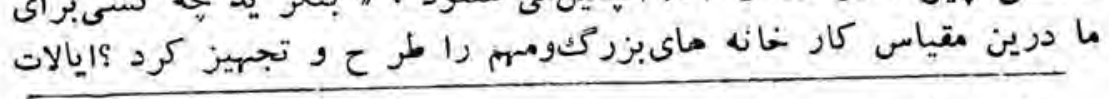

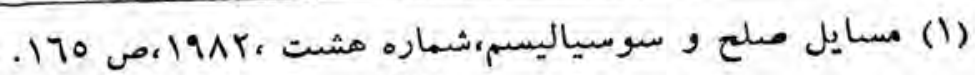
-rVA- 
متحد • يا انكلستان ؟بهيجو جه .فقط اتحاد شورو ى ائن كاررالنام (1) 4 a...

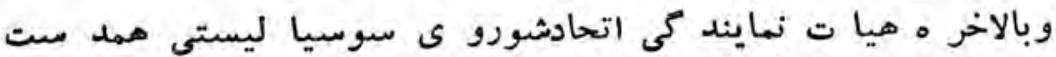

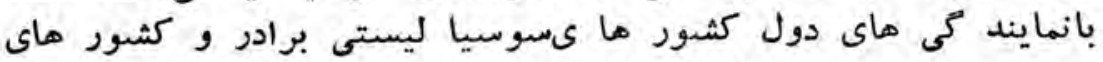

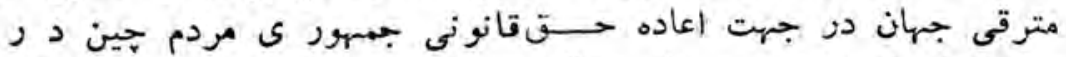

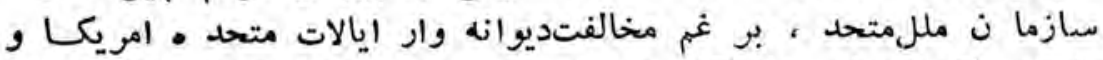

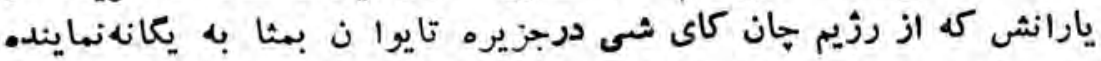

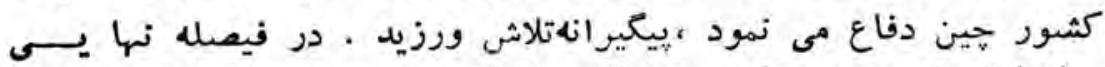

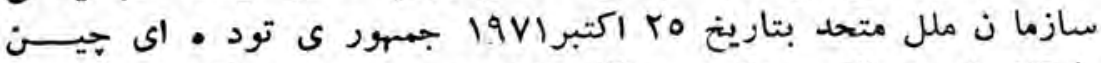

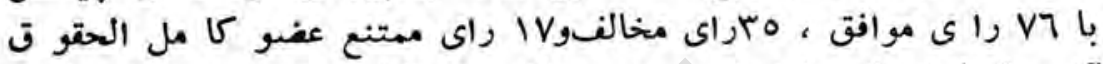

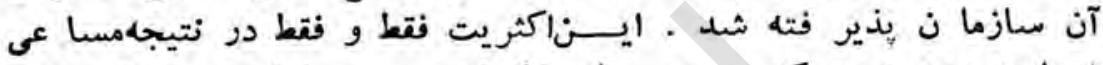

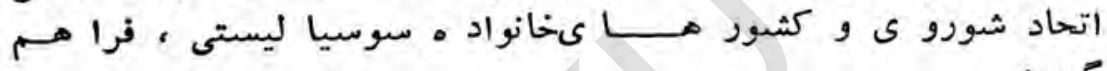
كرديد . ماد ثرد

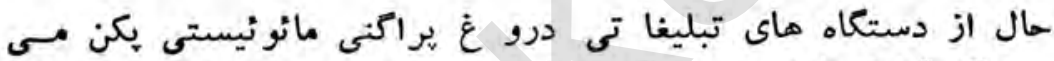

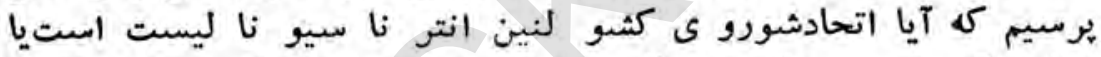

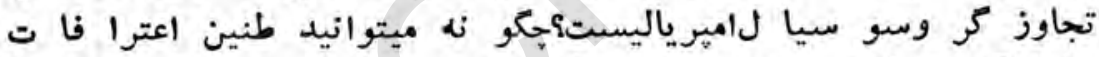

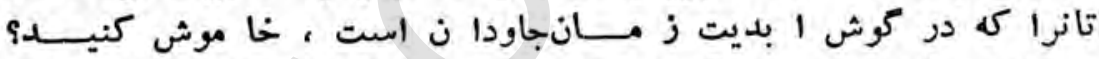

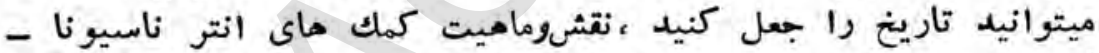

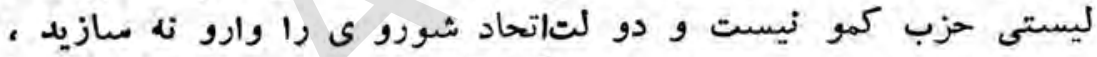

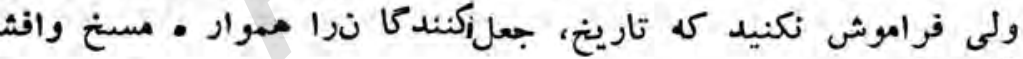

\section{- مدرنيمكر ه غربى :}

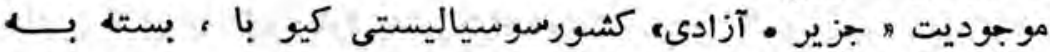

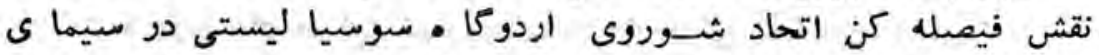

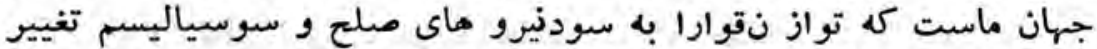

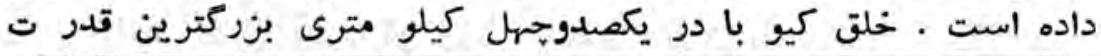

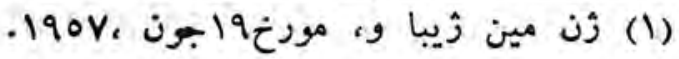




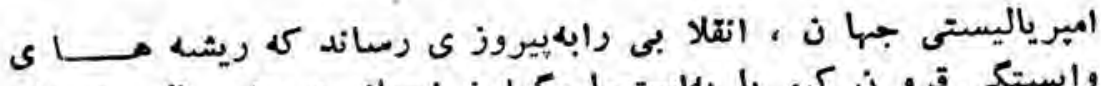

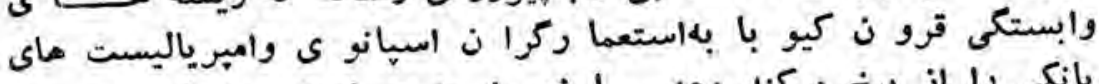

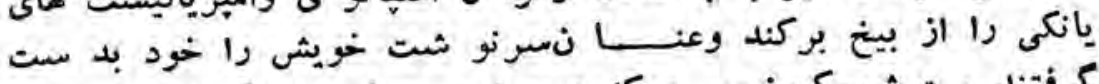

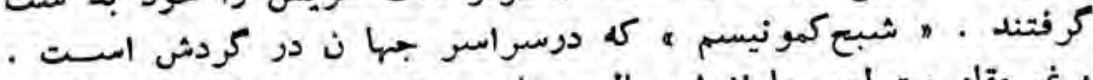

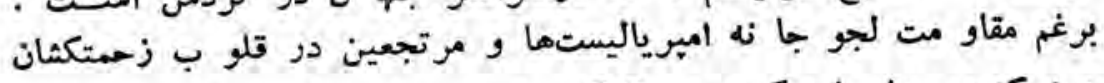

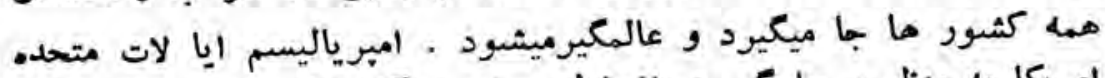

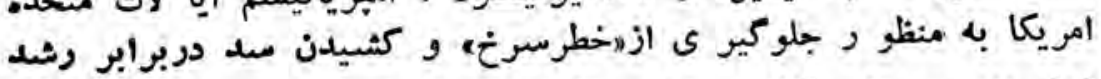

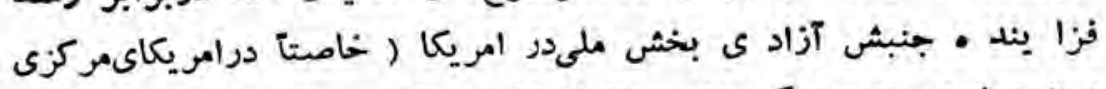

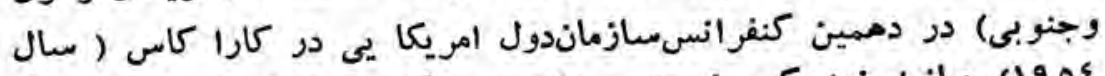

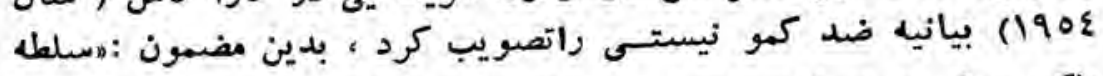

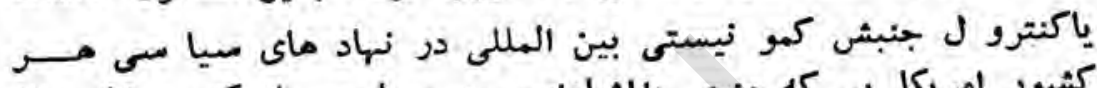

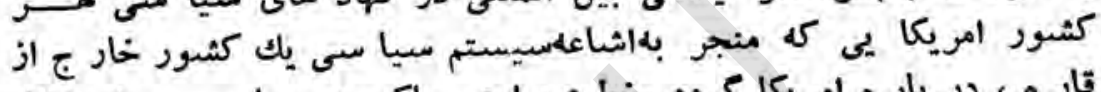

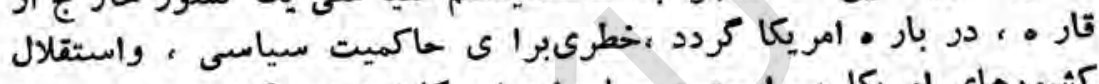

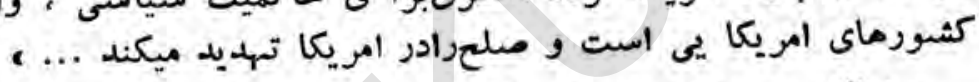

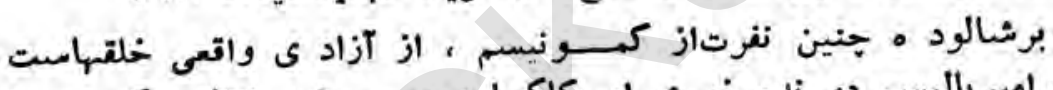

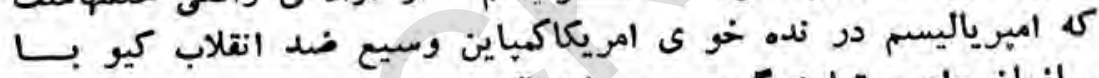

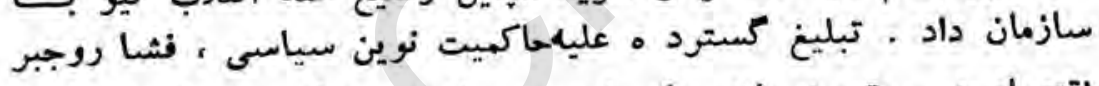

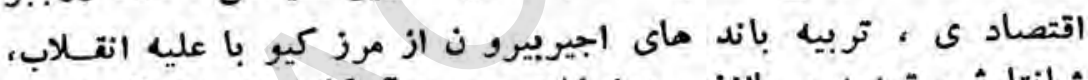

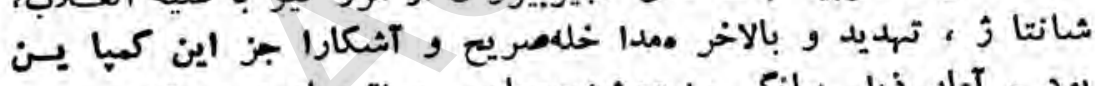

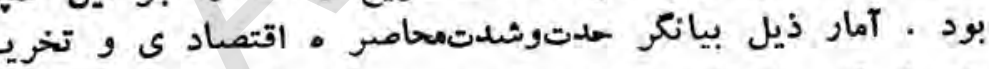

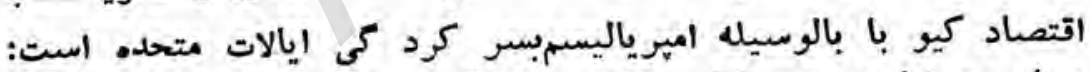

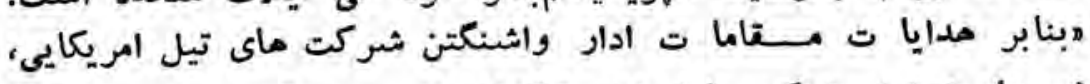

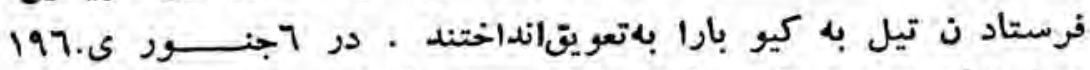

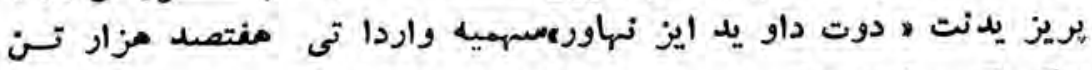
شكر كيو با را تطع تمود . در بانوامبر .

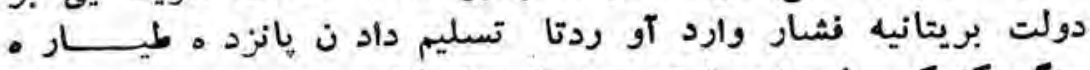

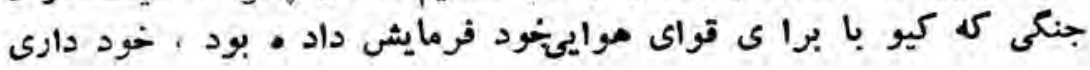


كند . در ب جنور ى .197 ، ريزيدنتايز نهاور تمام مناسبا ت دييلوماتيك

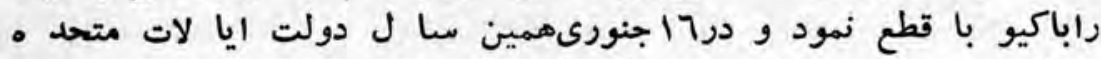

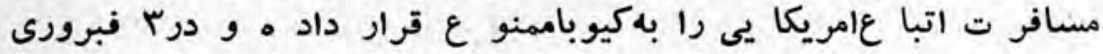

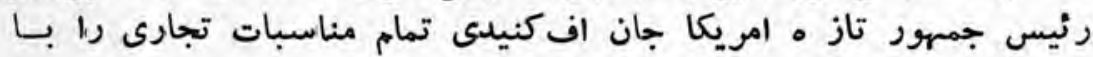

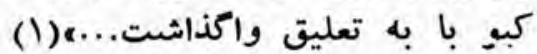

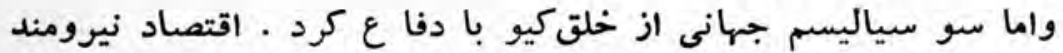

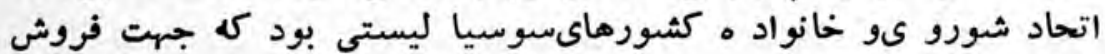

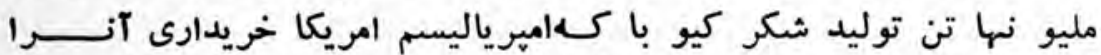

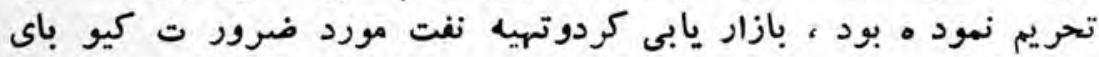

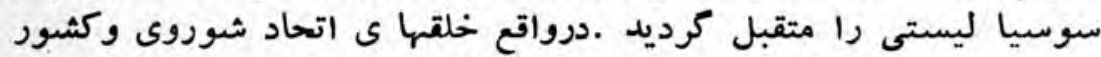

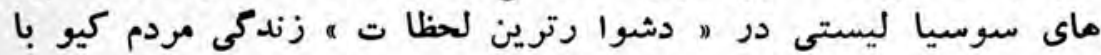

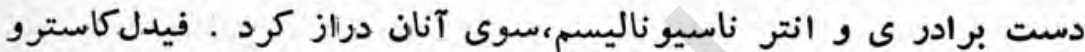

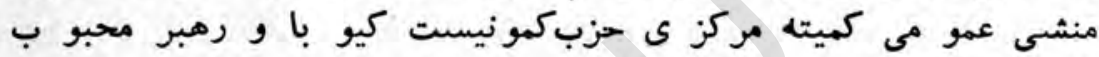

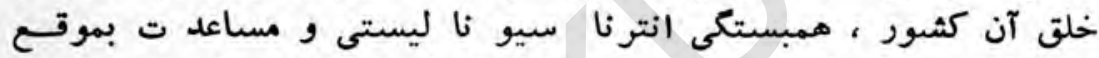
اردوكا ه سو سياليسم ، در در جهاول اتحاد شورو ى را جنين ستاعت ستوده

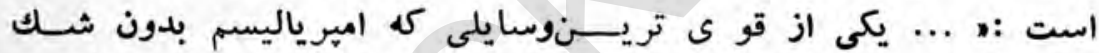

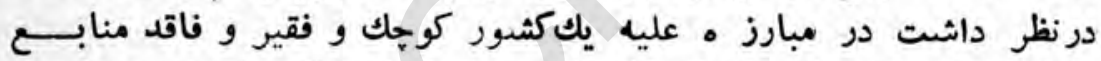

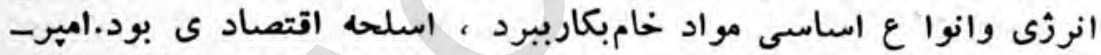

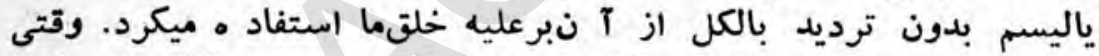

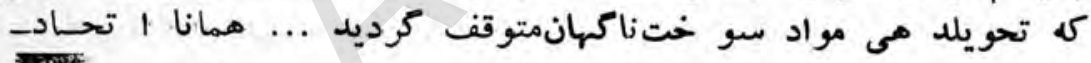

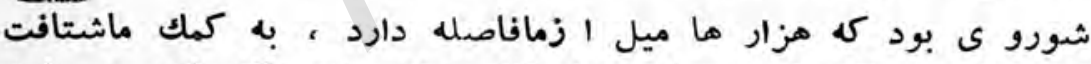

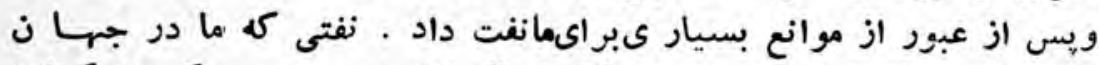

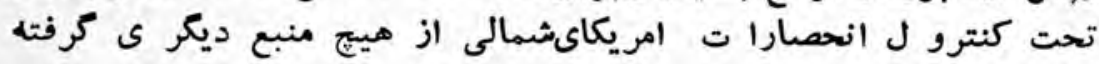

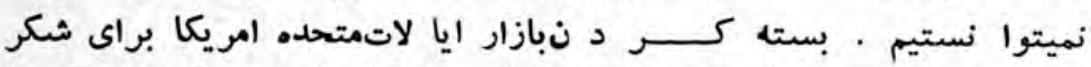

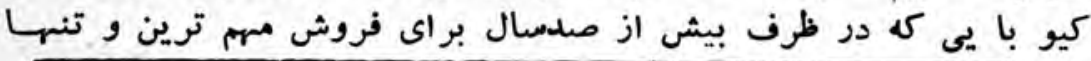

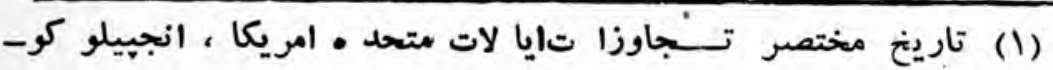

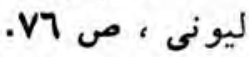


محصولات مان متشكل ميكشتهاست،دومين ضر به محكم بر بر بيكر اقتصاد

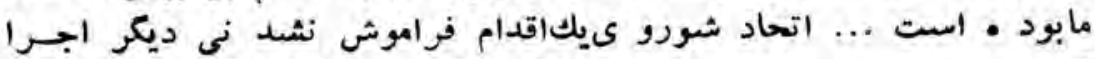

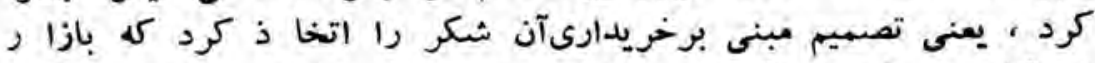

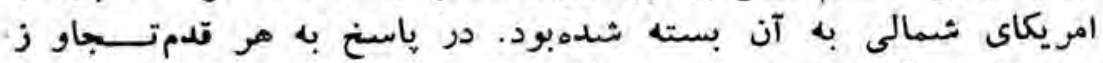

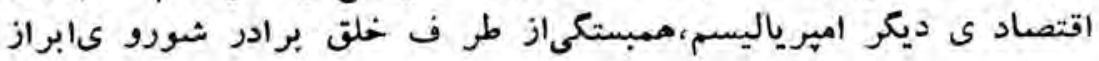

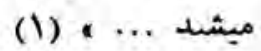

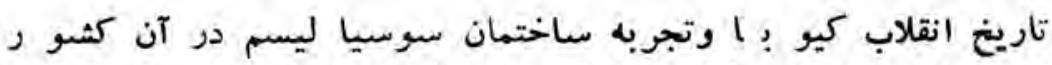

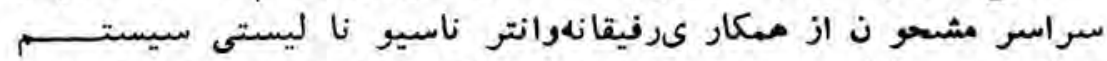

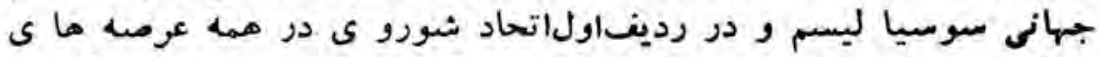

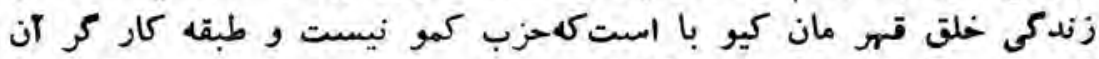

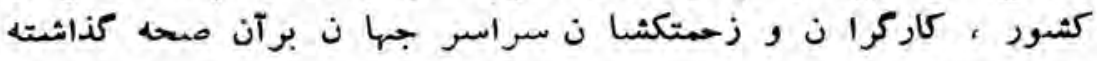

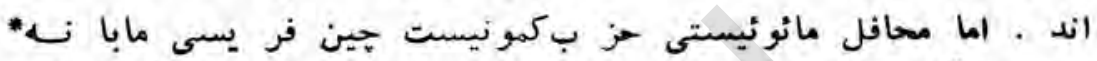

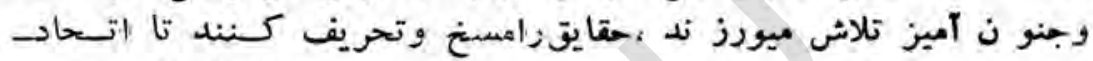

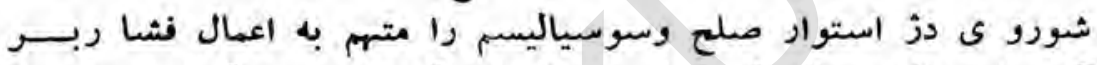

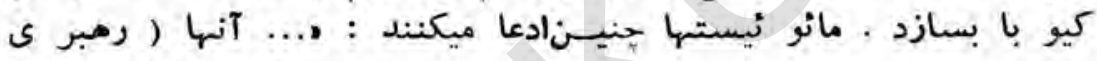

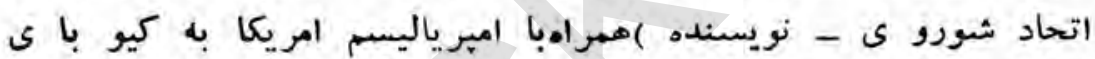

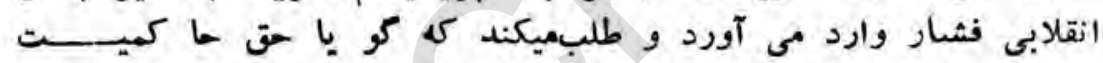

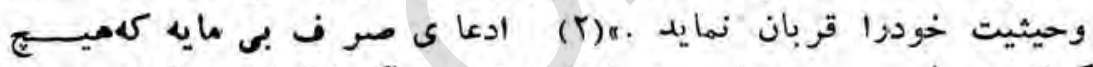

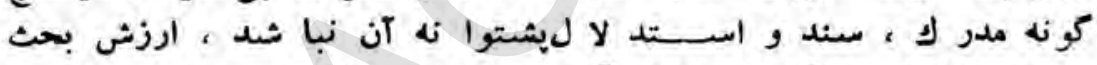

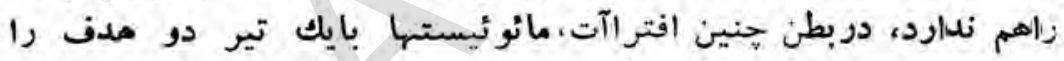

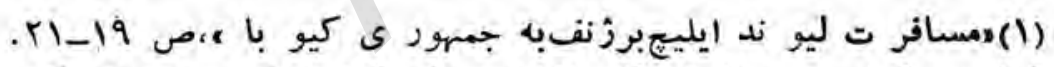

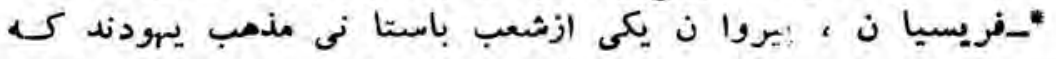

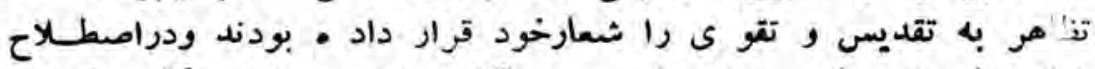

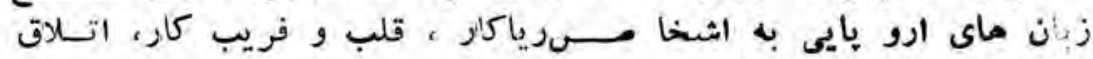

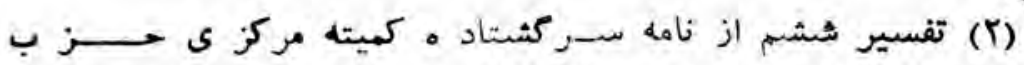
ميكردد - مان.

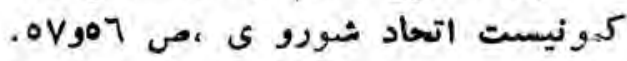




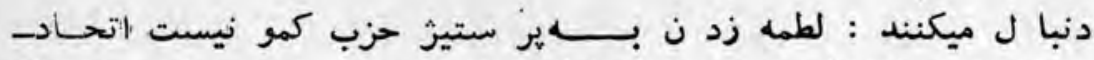

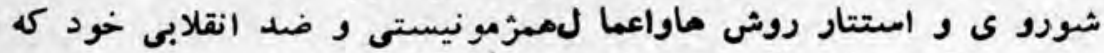

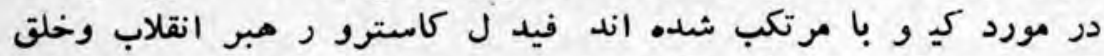

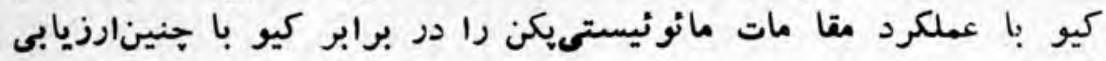
كردماست :

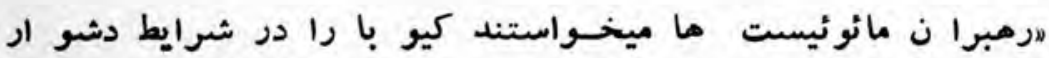

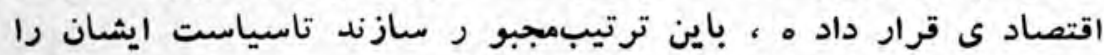

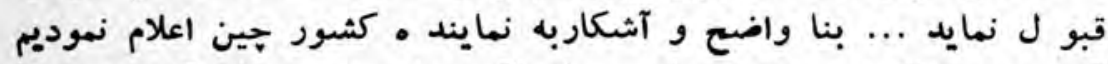

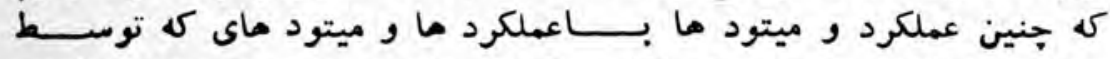

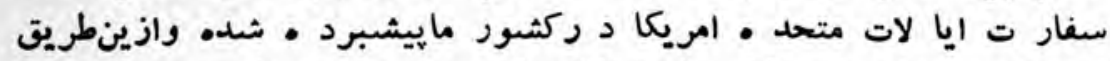

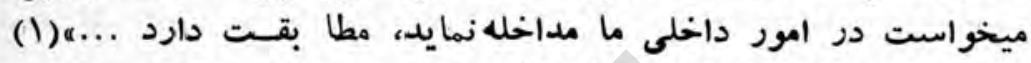

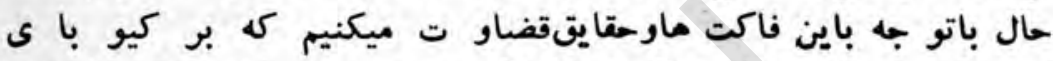

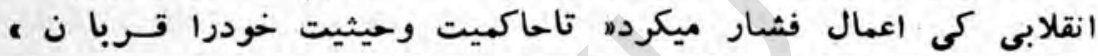

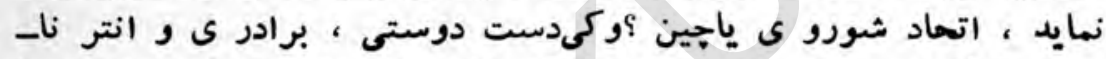

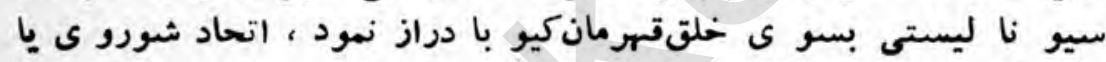
جين ؟

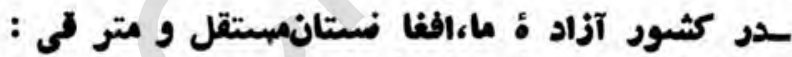

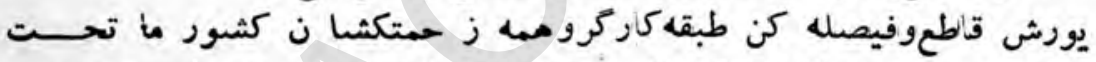

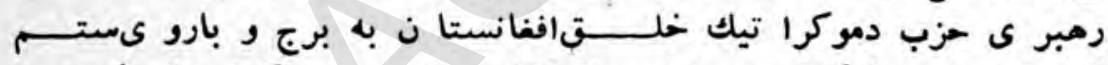

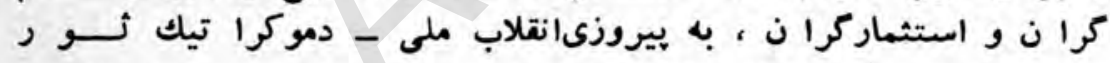

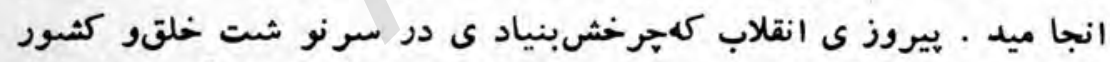

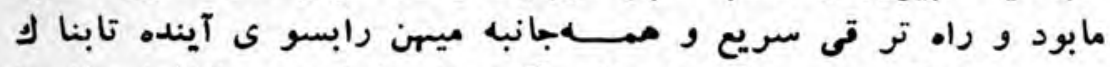

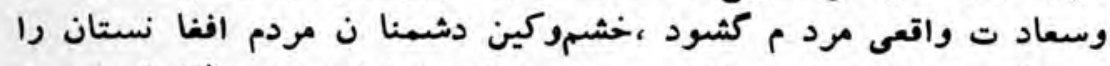

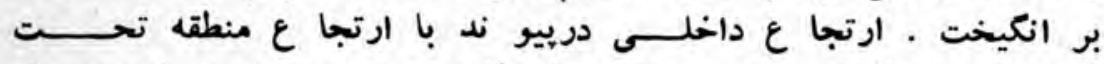

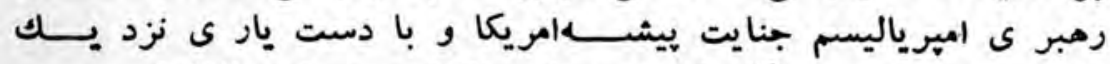

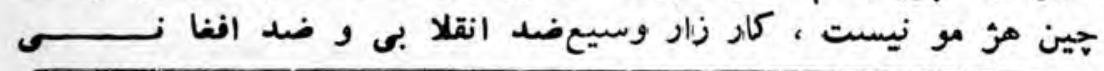

كرانما، 7977 فبرورى 1977 


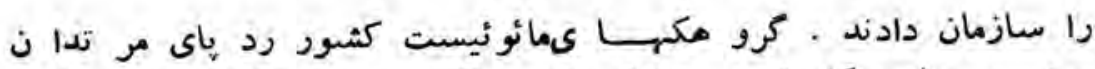

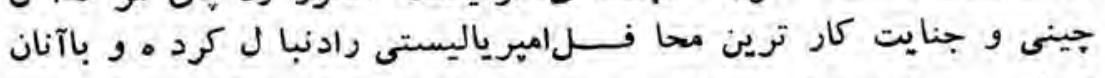

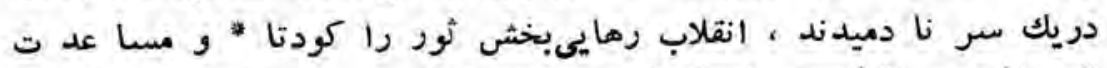

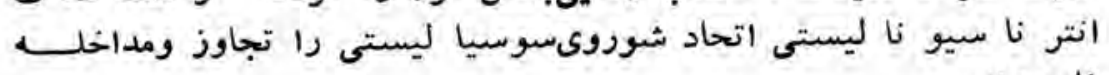
نا ميدند

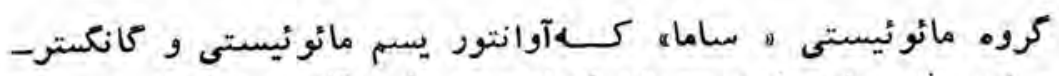

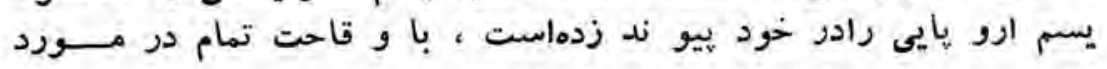

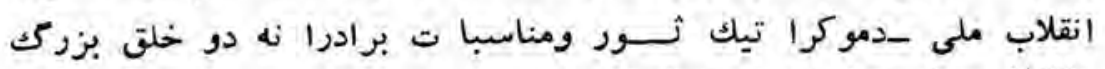

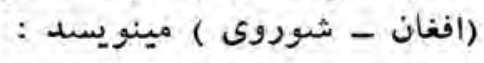

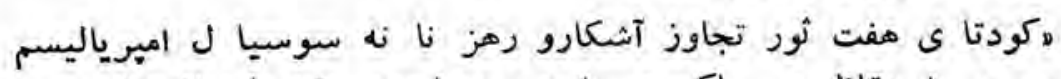

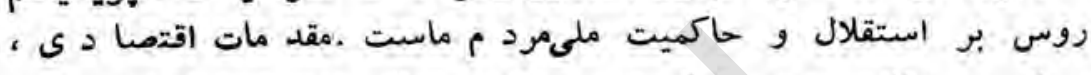

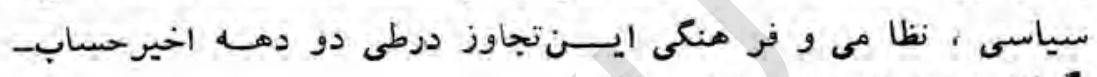

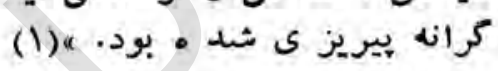

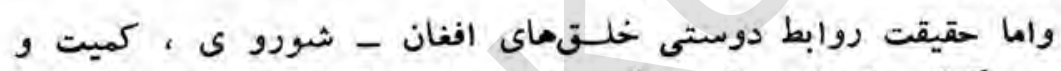

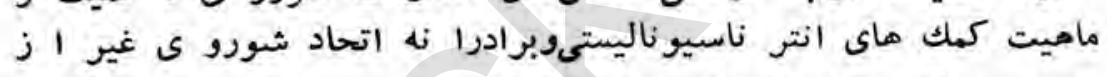

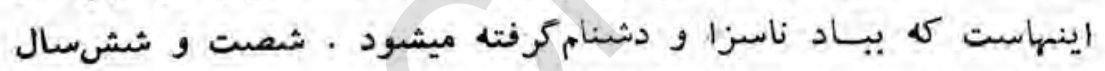

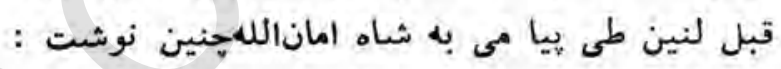

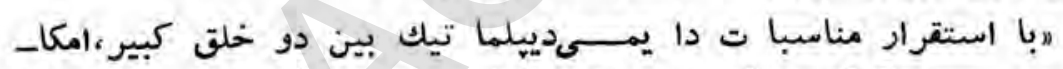

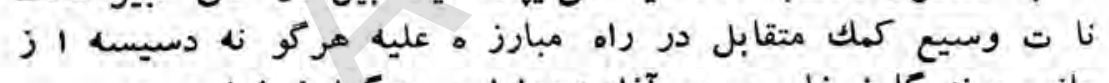

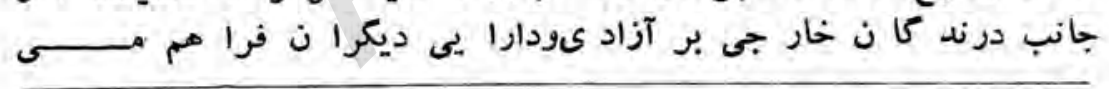

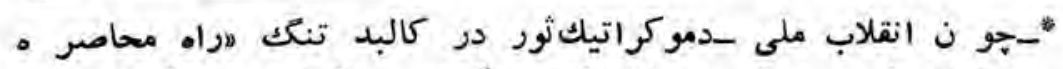

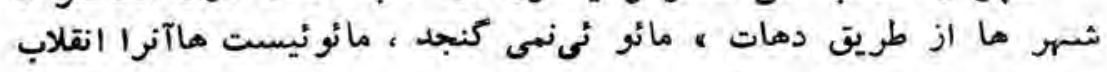

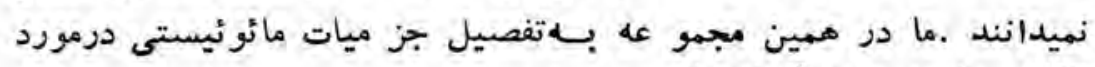

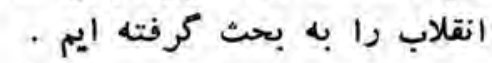
(1) 
كردند. ، (1) بيش از شش دمه افمناسبا ث دوستى استوار و تفاهم

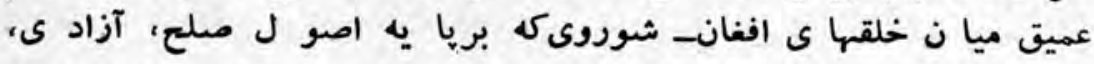

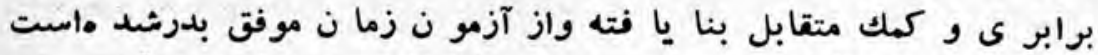

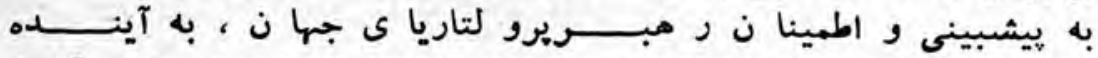

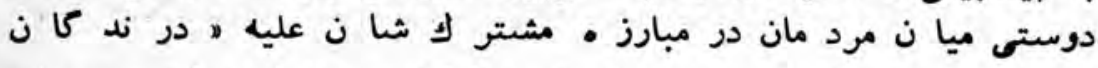

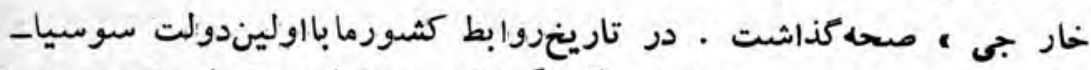

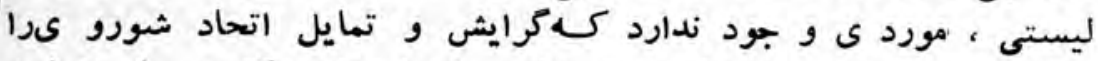

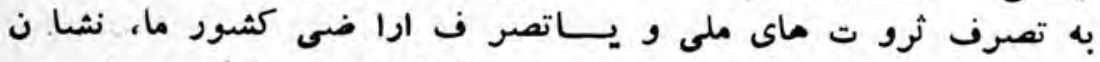

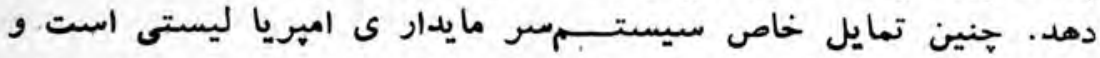

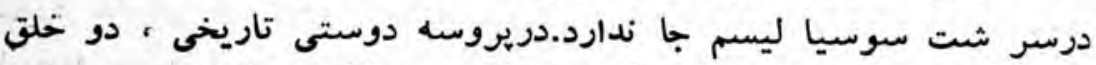

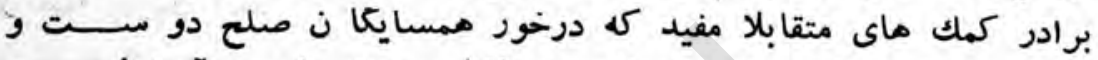

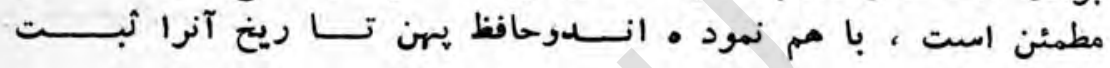

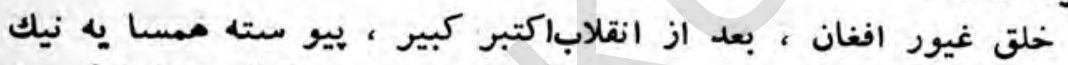

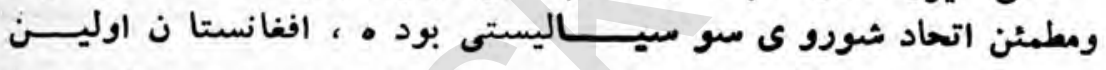

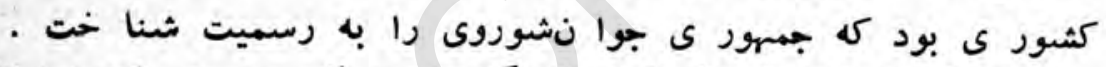

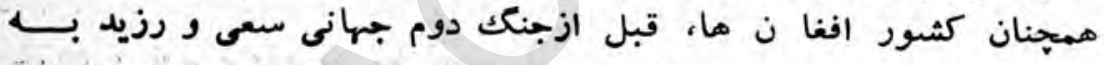

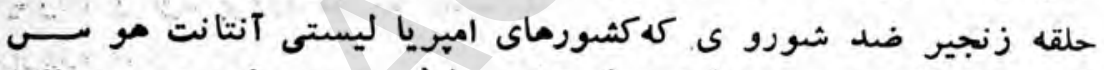

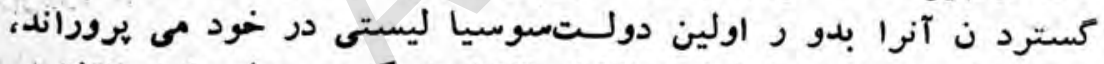

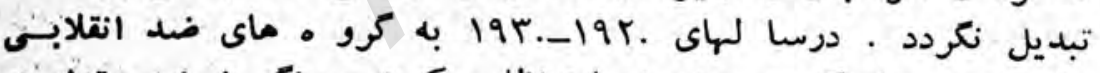

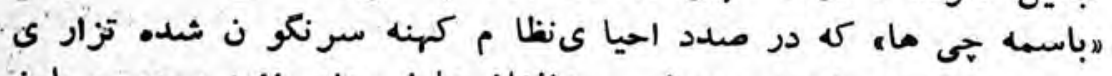

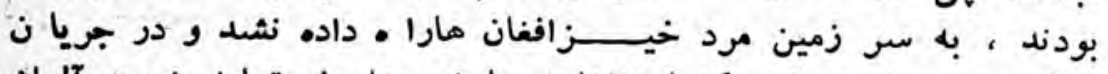

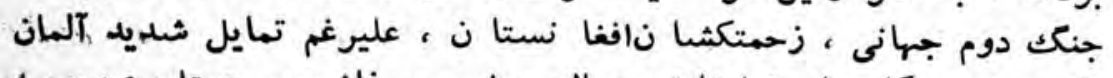

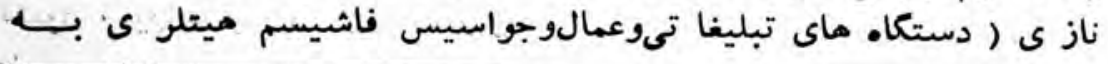

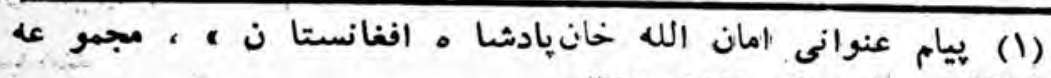

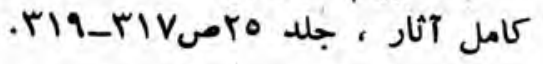


منظور دست يابى به امي ال هليد وضد بشر ى خود ، ، باسوء استفاده

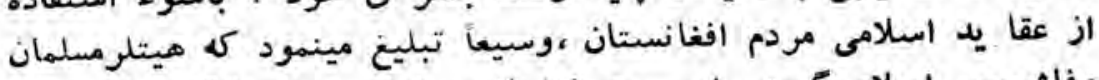

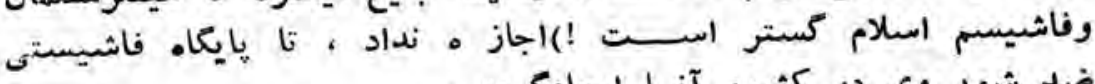

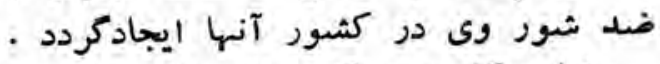

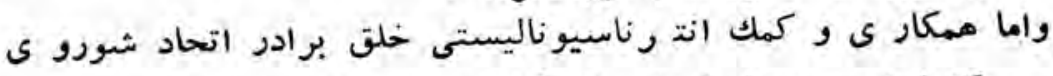

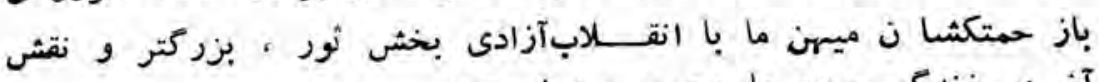

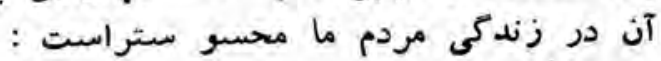

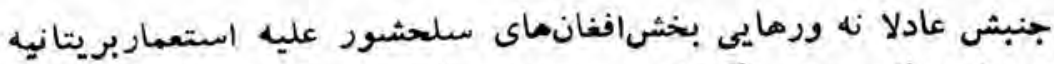

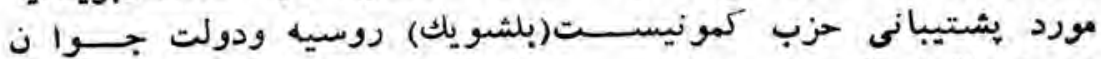

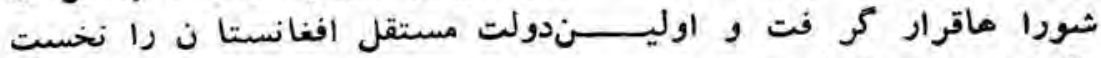

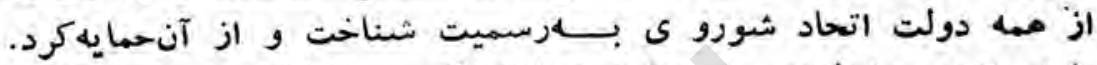

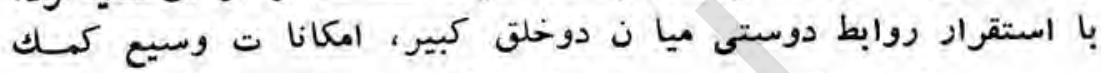

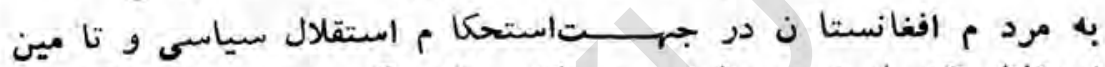

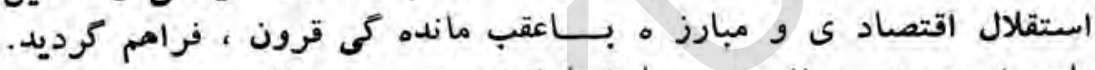

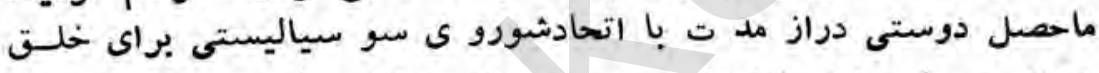

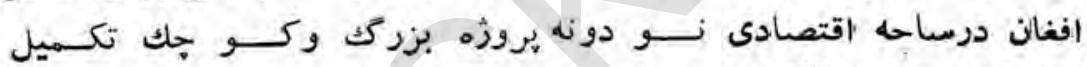

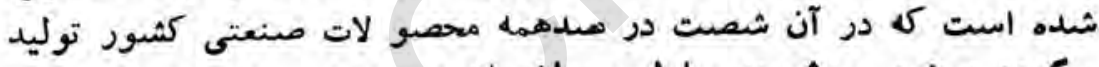

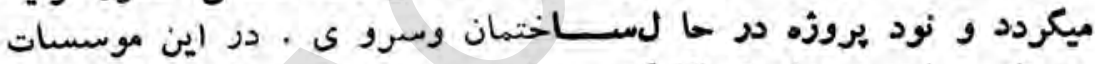

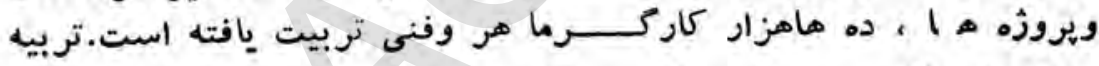

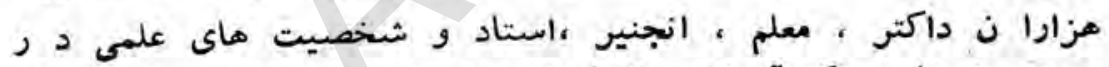

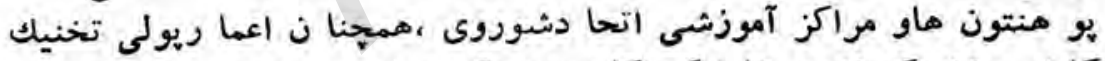

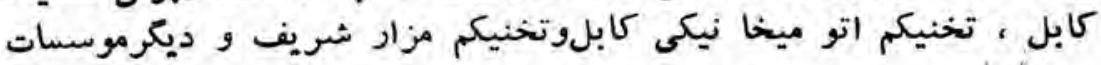

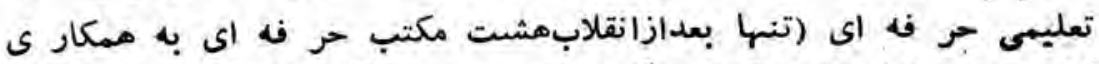

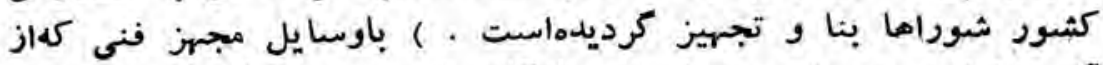

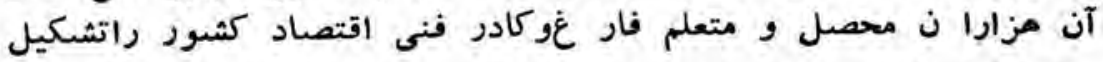

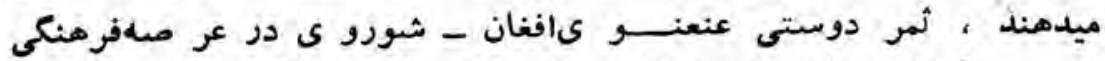

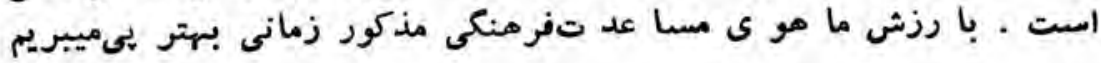




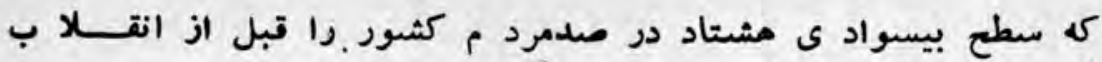

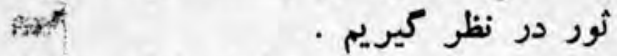

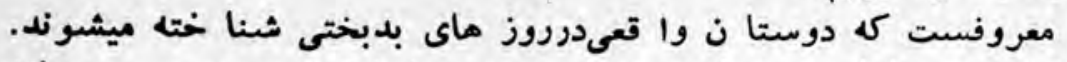

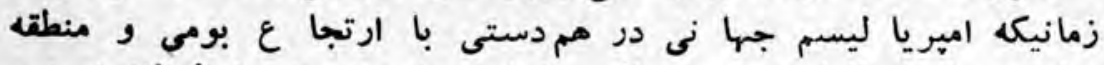

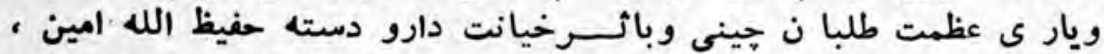

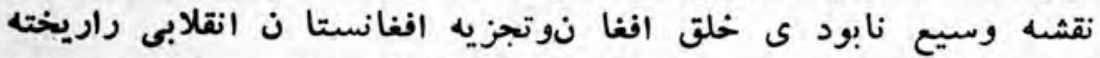

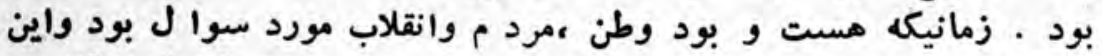

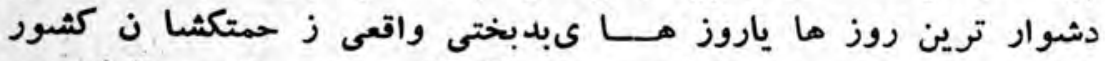

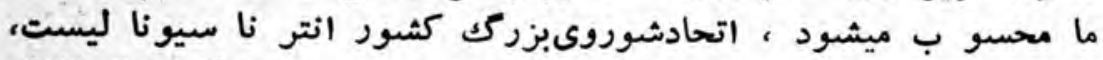

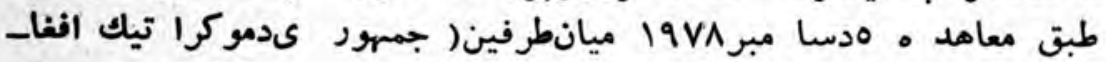

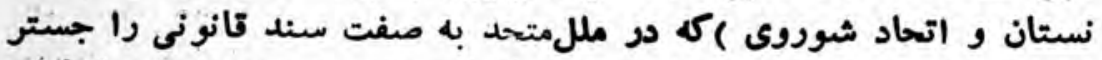

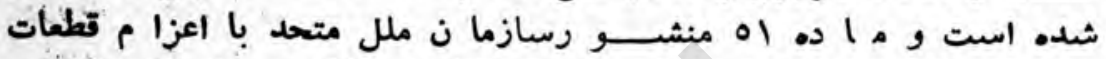

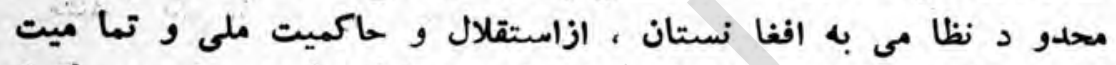

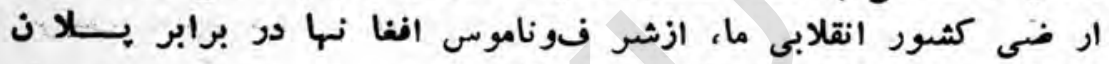

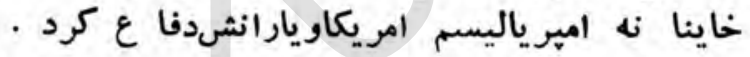

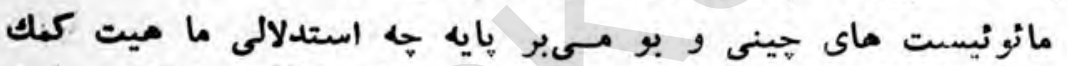

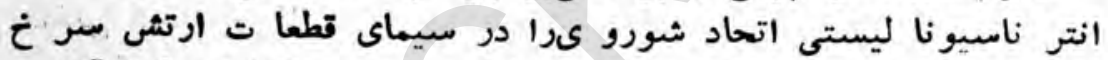

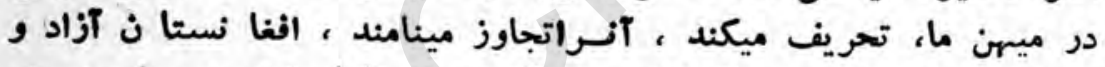

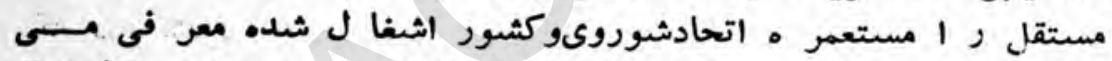

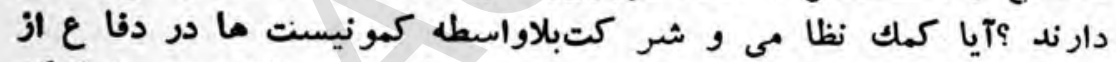

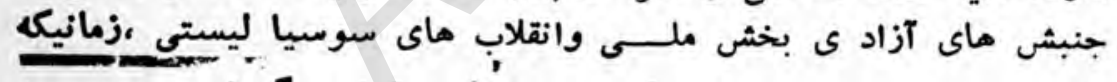

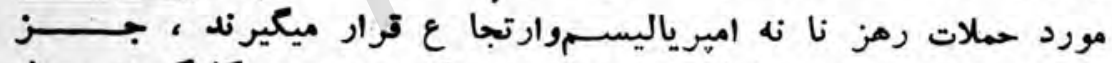

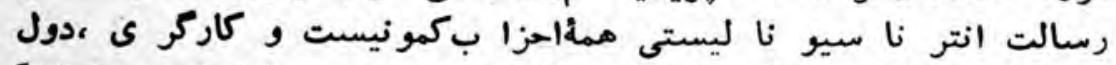

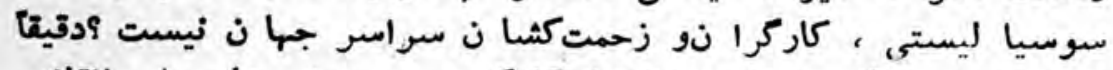

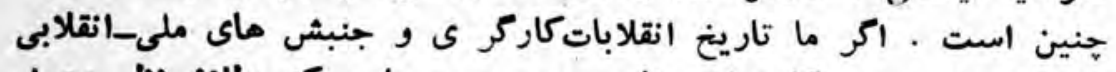

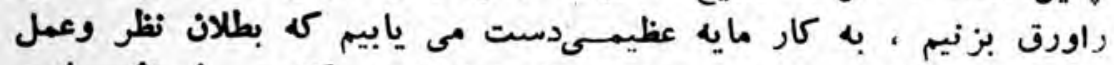

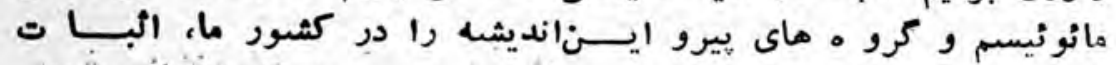
ميكند مائر 
قبل از انقلاب اكتبر، بعلتاينكعروسيه تزار ى ، بابسيار ىاز كثور

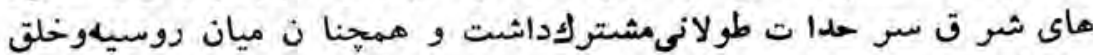

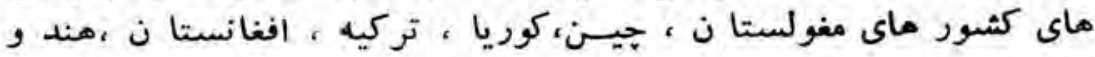

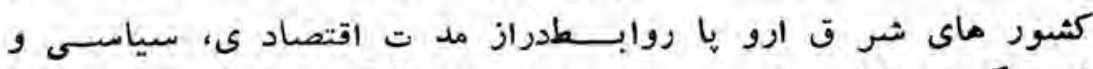

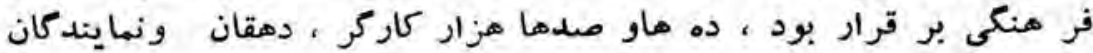

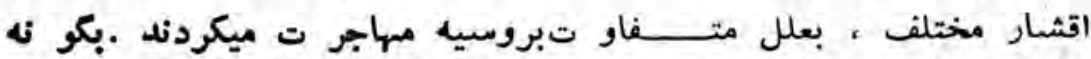

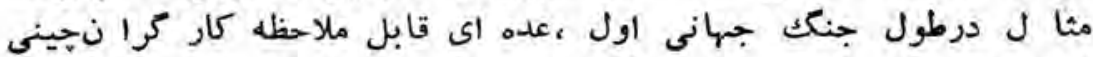

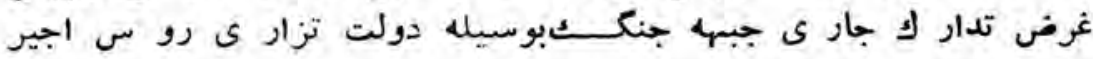

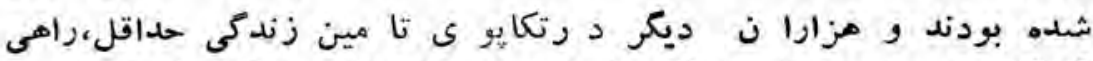

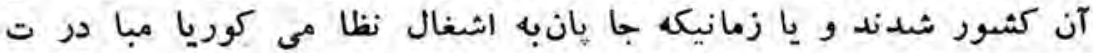

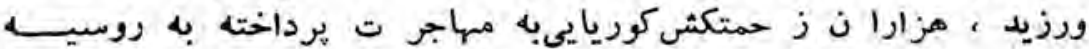

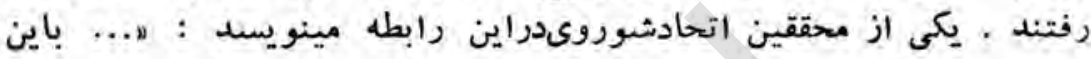

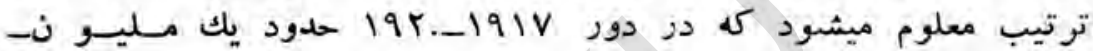

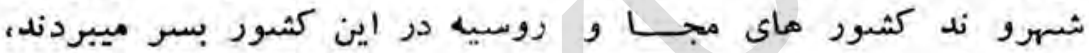

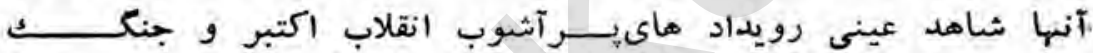

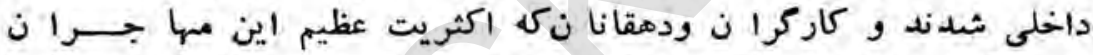

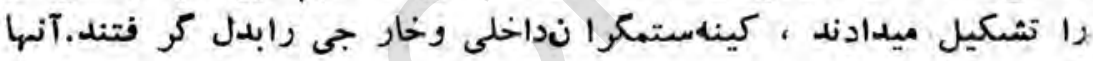

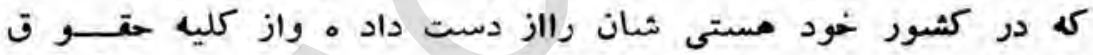

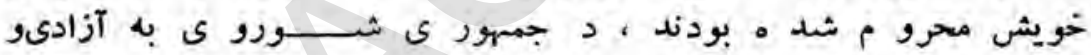

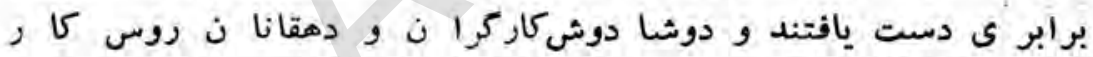

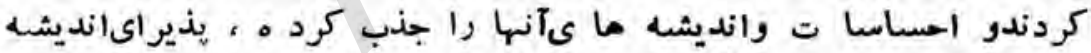

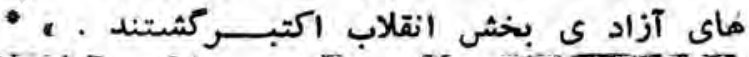

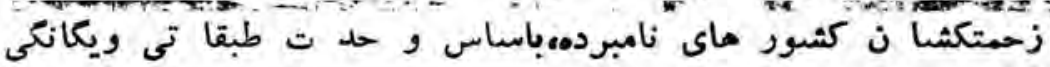

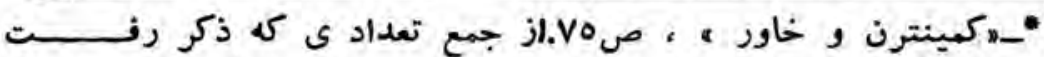

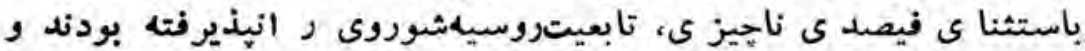

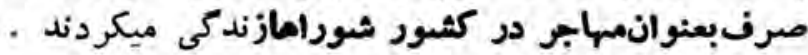




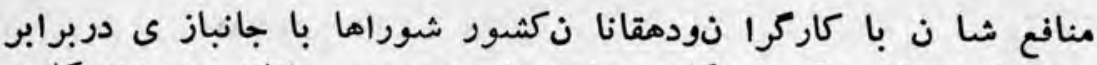

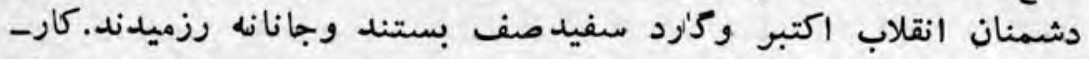

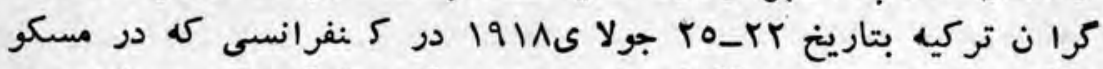

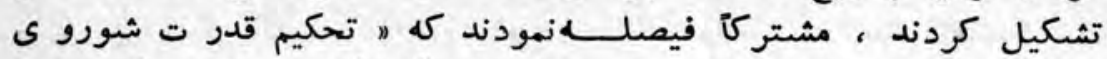

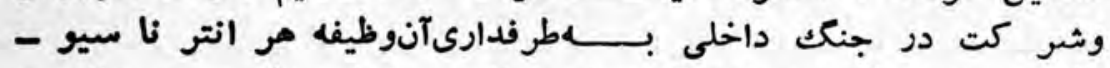

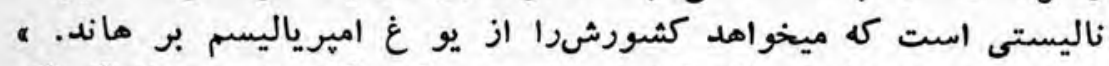

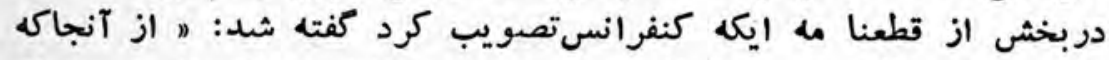

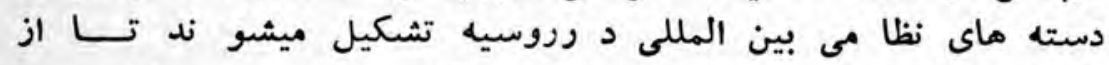

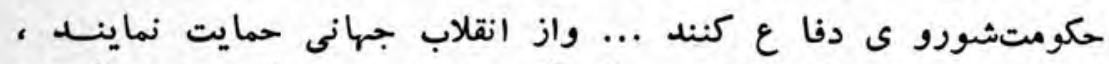

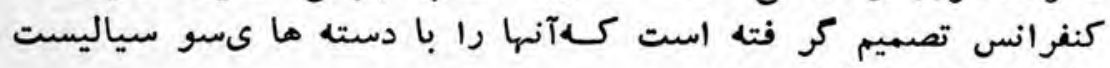

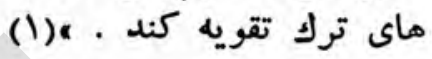

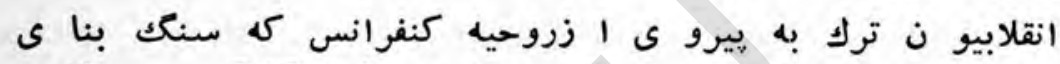

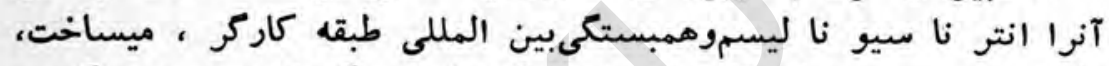

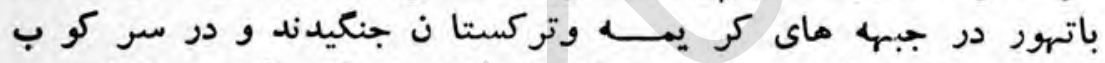

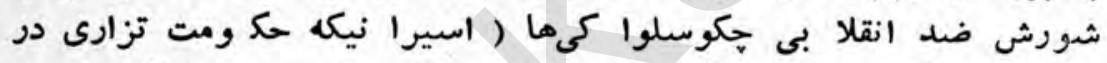

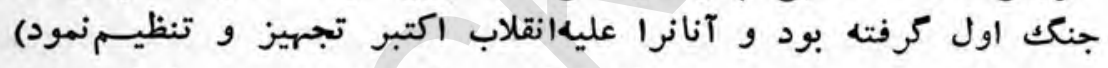

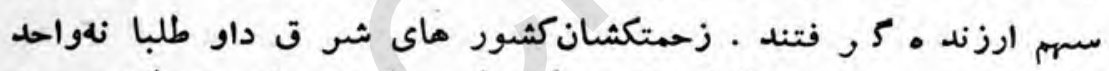

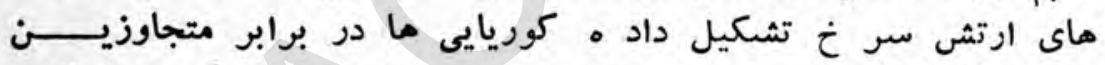

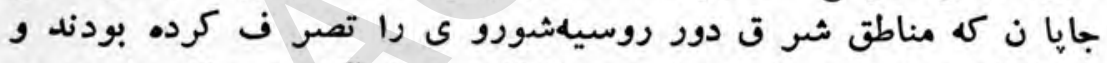

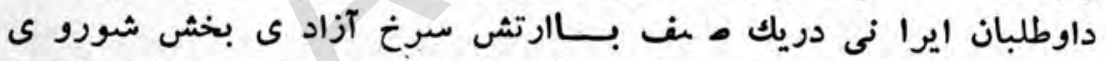

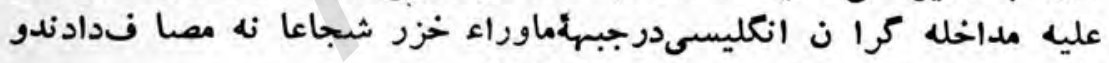

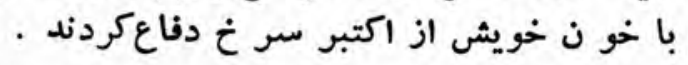

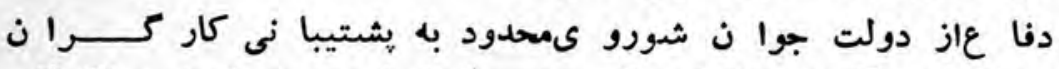

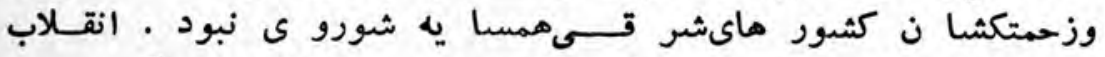

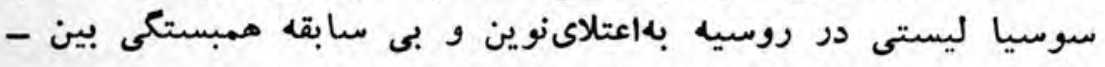

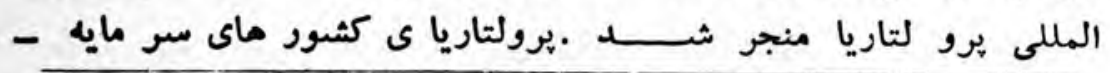

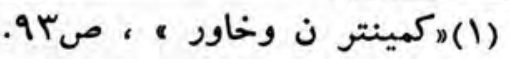




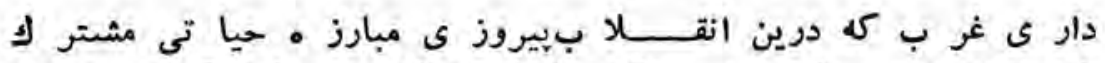

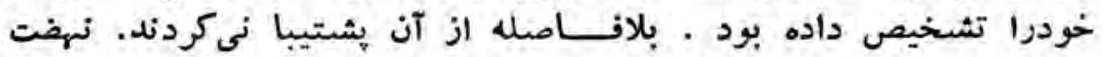

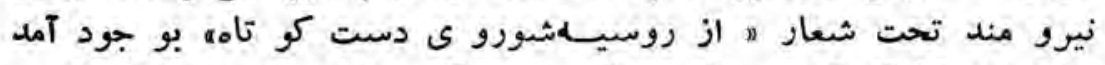

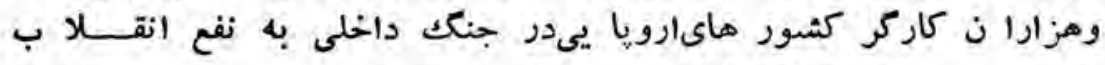

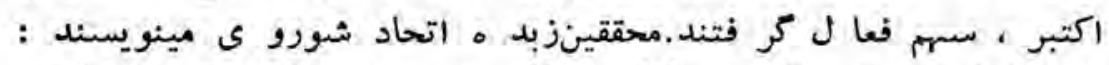

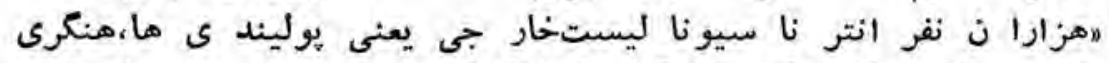

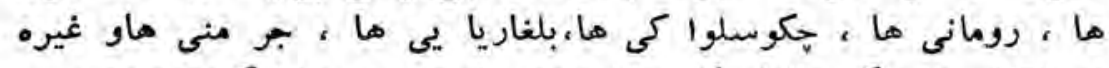

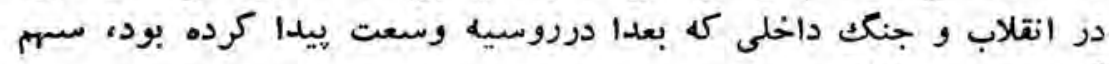

$$
\text { (1).... كرفتيند }
$$

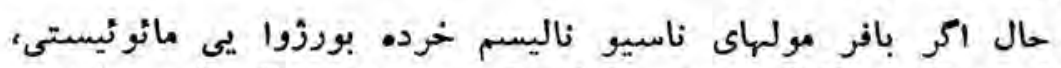

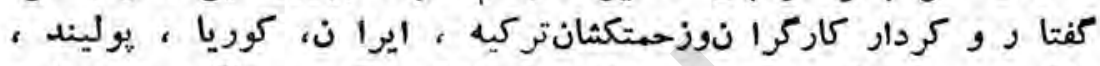

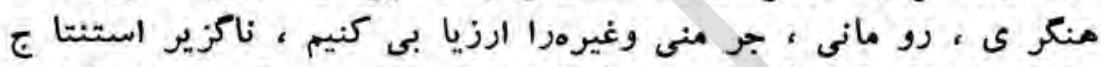

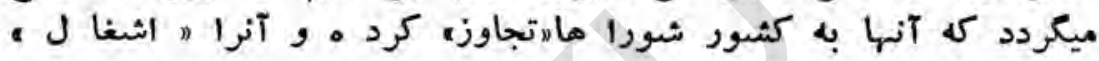

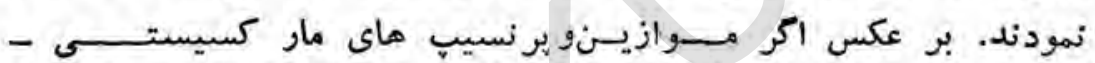

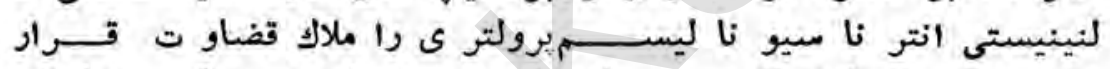

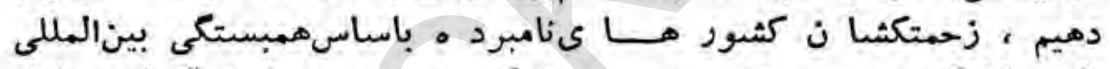

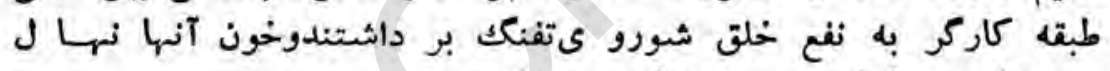

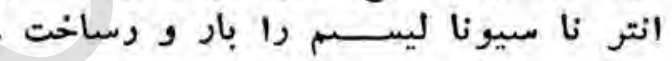

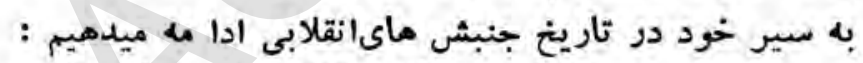

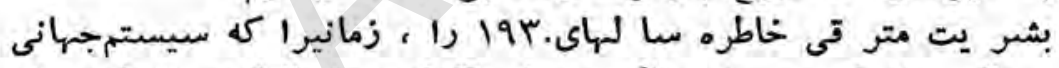

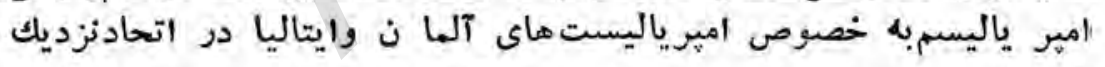

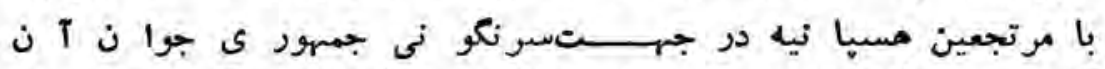

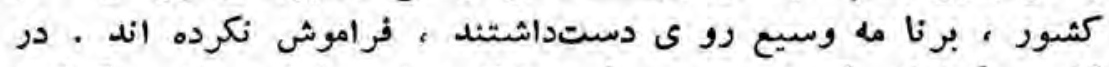

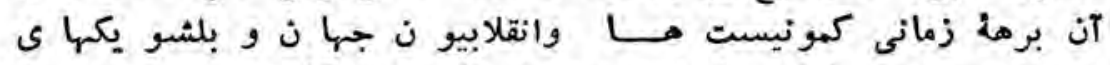

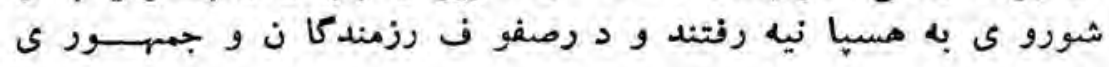

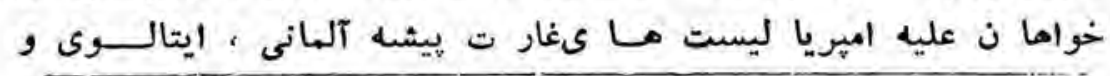

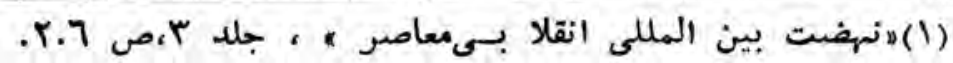


ارتجا ع محلى هسيا نيه بر هبر ى إجنرا ل فرانكو قهر ما نانهرزميدندو

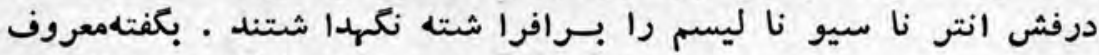

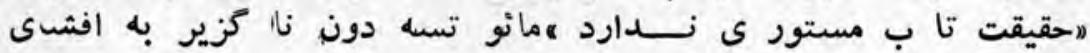

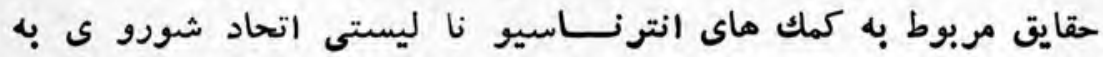

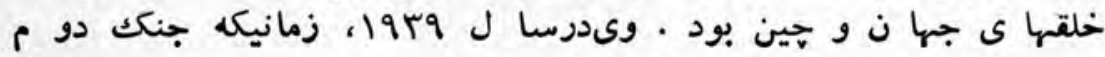

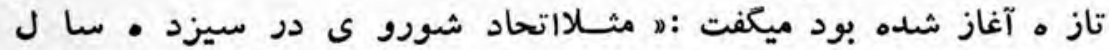

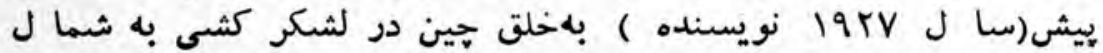

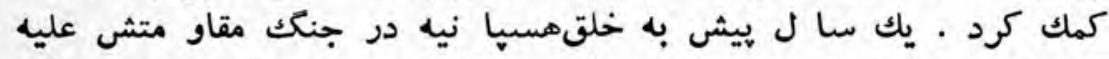

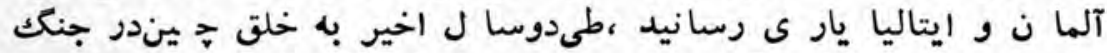

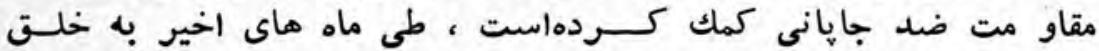

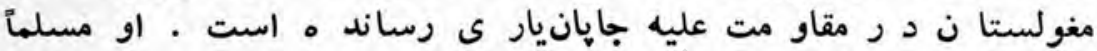

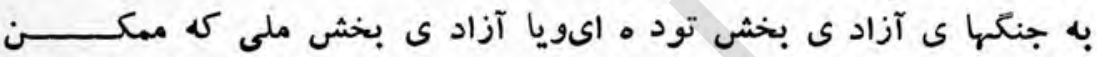

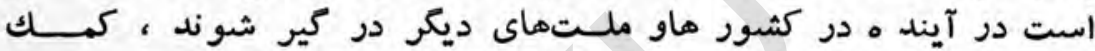

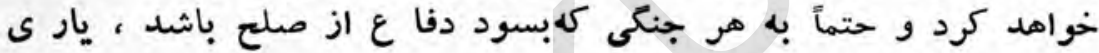

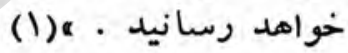

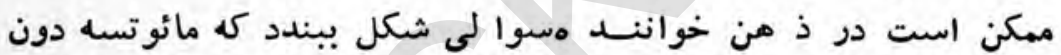

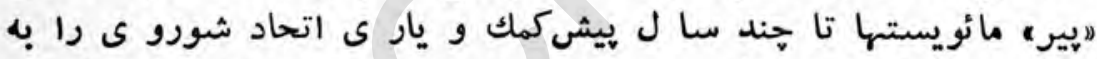

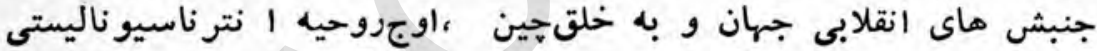

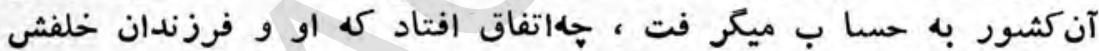

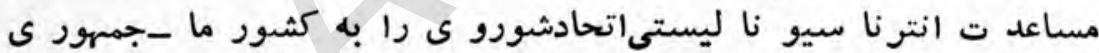

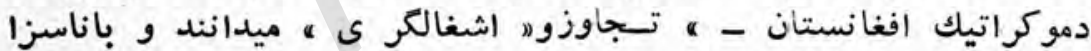

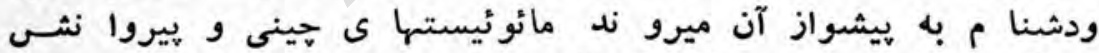

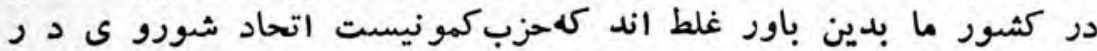

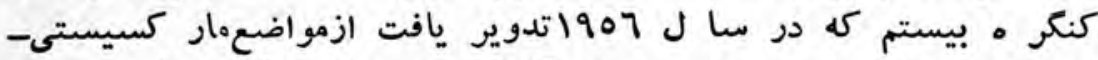

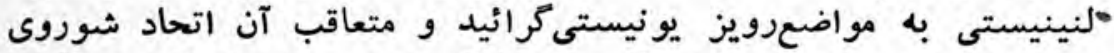

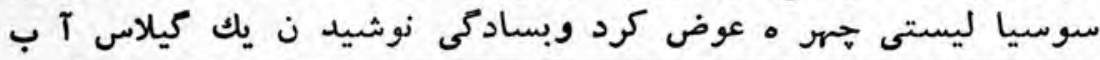

(1)مائوتسه دون ، منتخبا ت جلد دوم ، صباعع. 


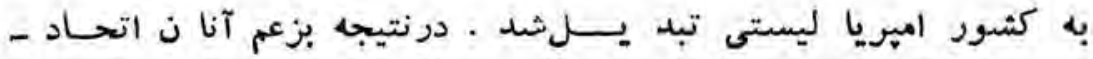

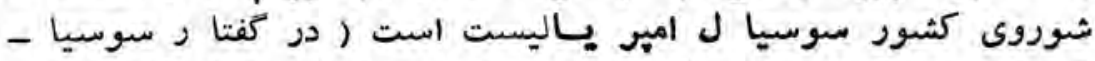

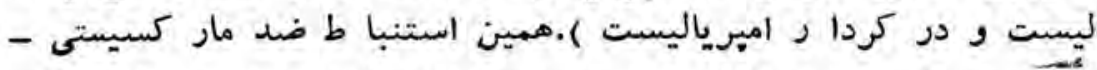

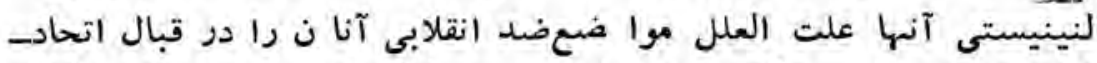

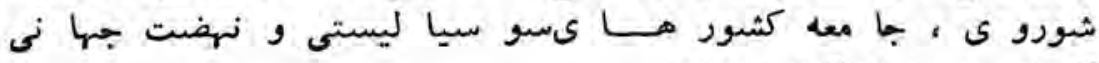

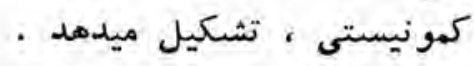

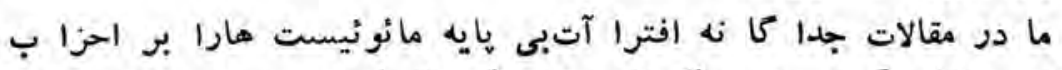

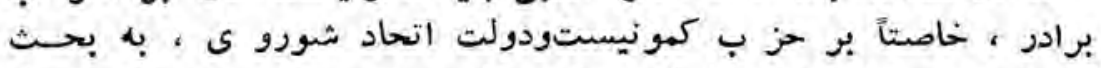

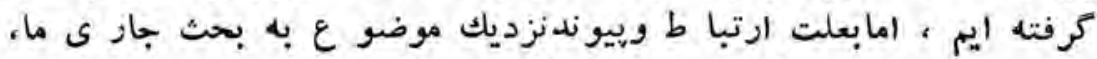

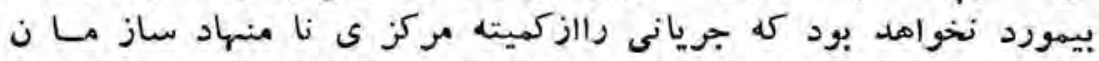

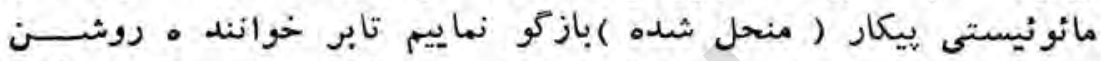

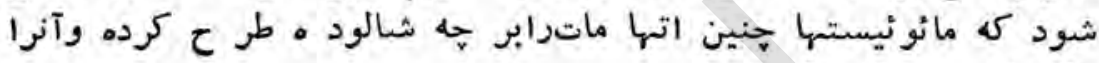

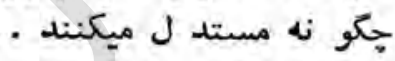

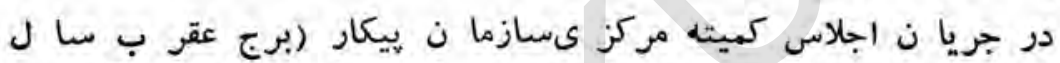

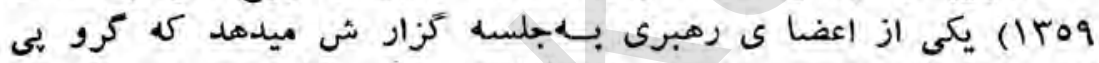

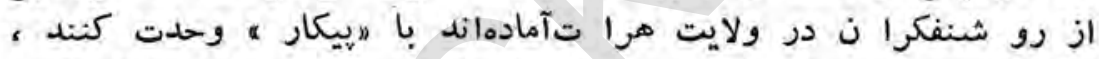

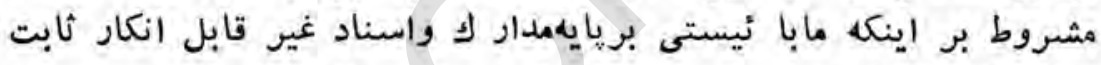

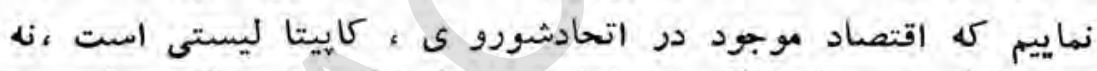

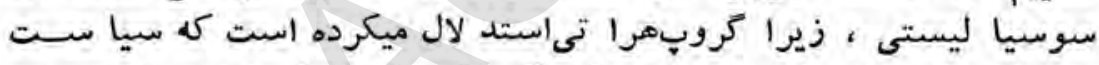

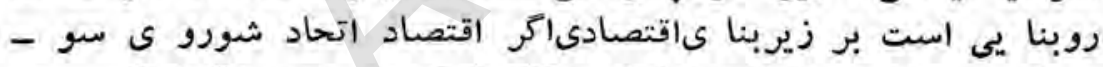

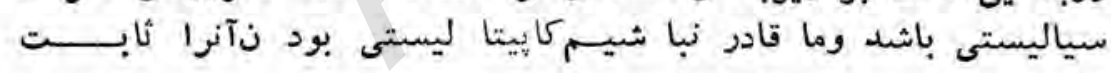

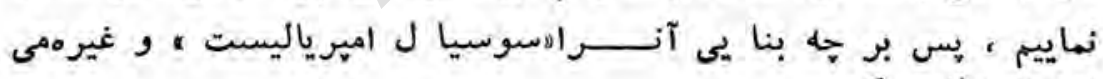

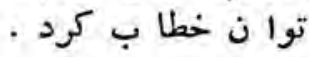

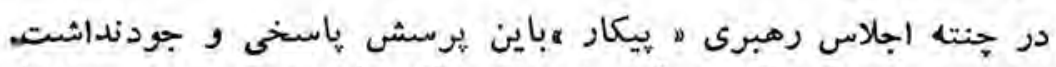

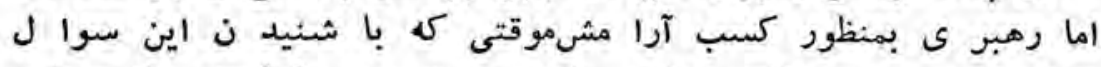

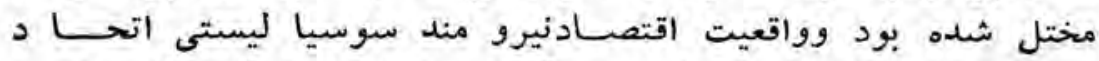

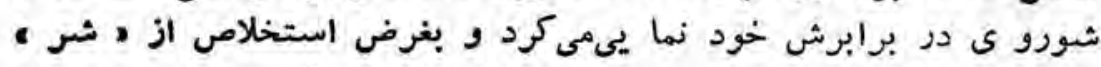




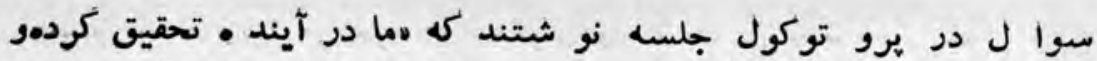

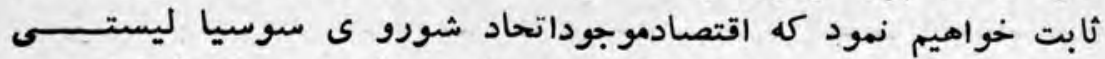

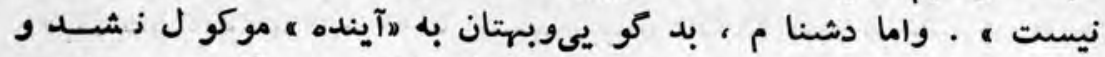

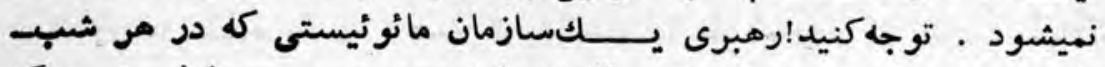

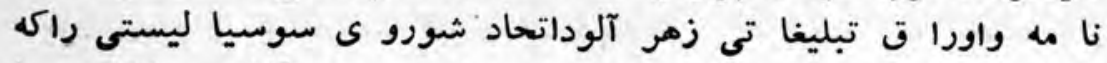

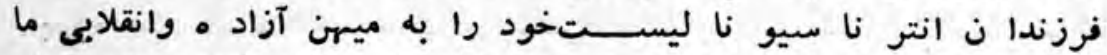

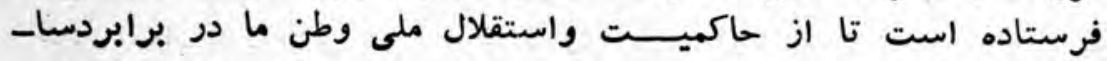

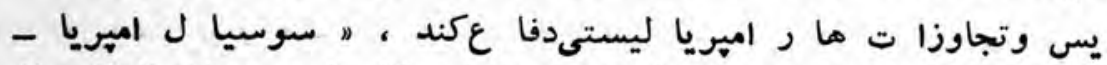

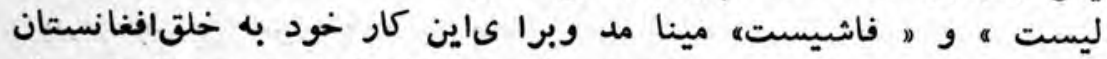

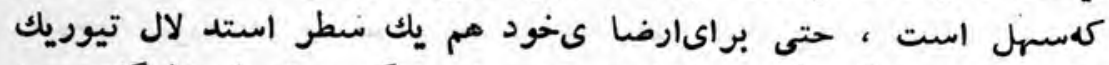

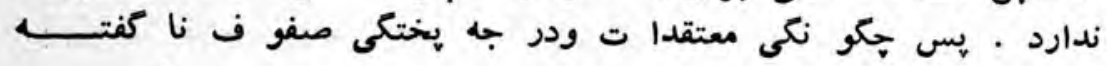

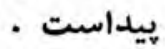

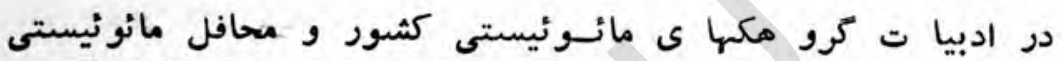

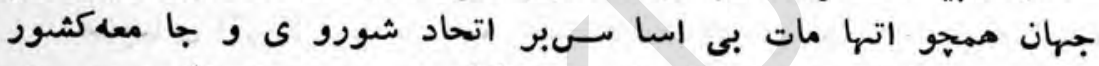

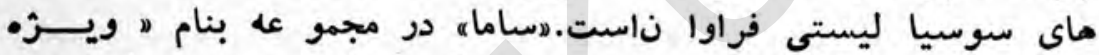

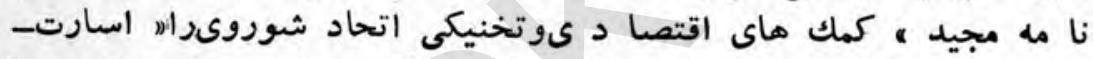

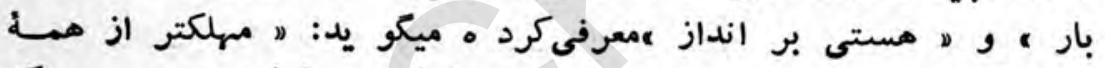

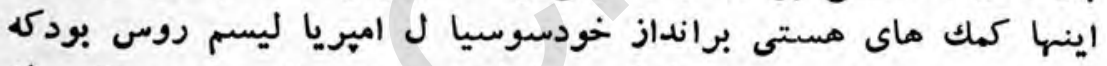

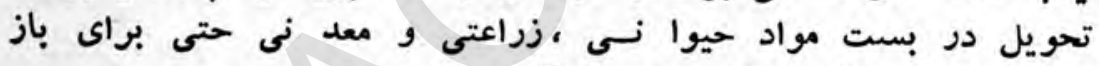

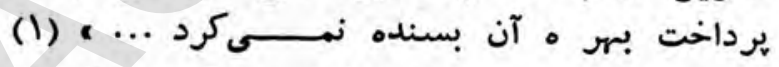

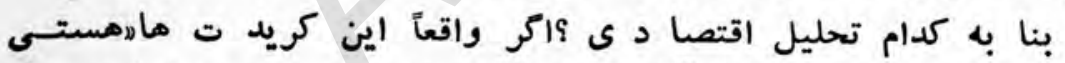

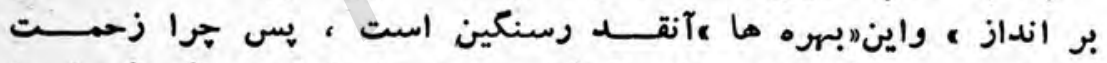

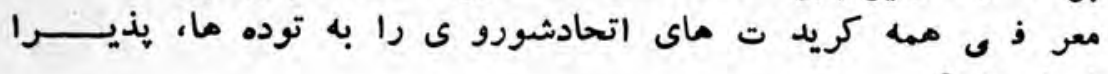
نميشويد ؟ معر

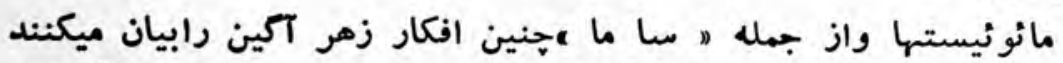

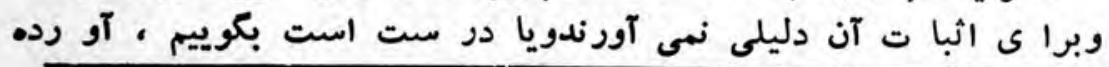

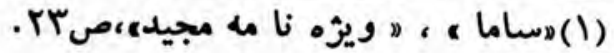




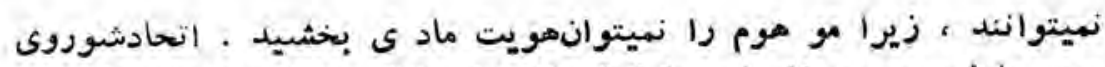

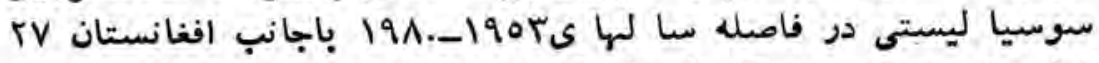

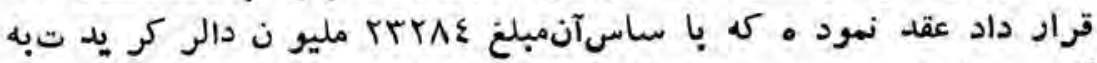

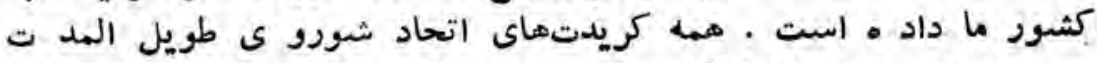

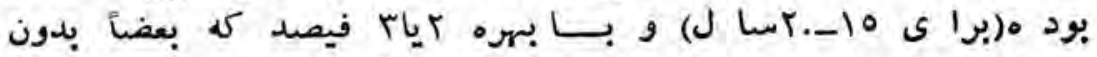

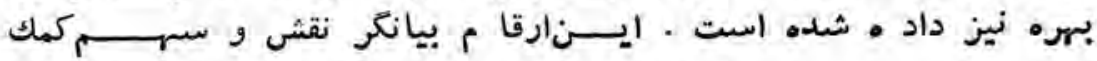

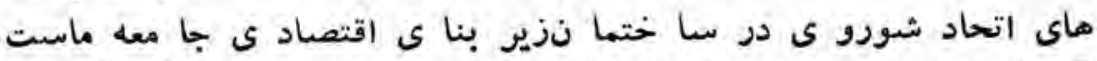

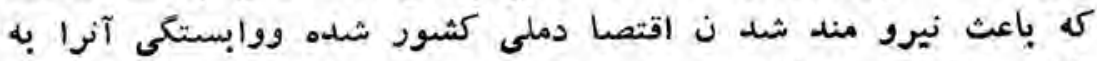

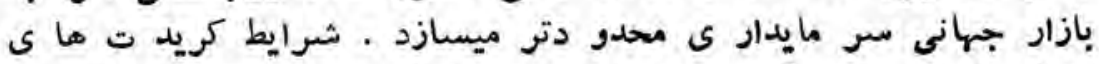

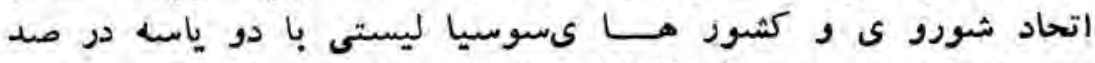

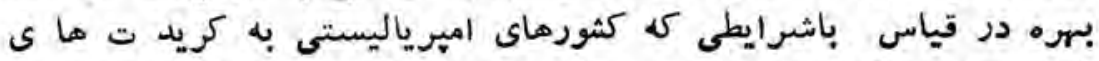

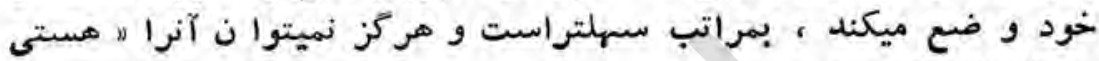

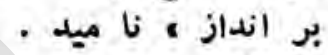

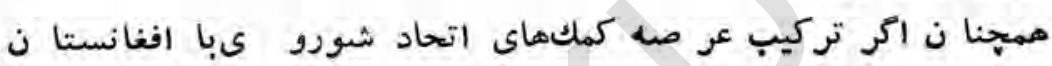

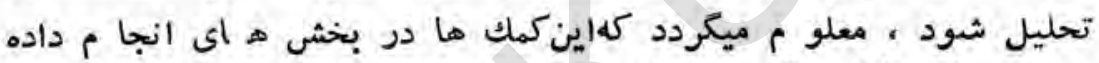

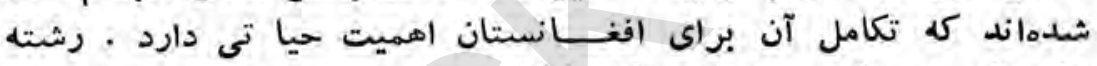

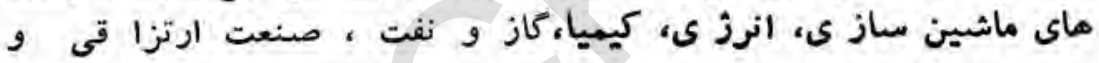

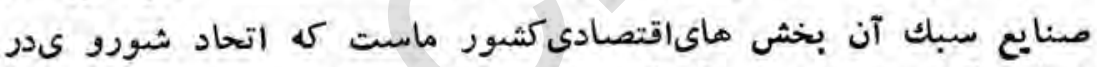

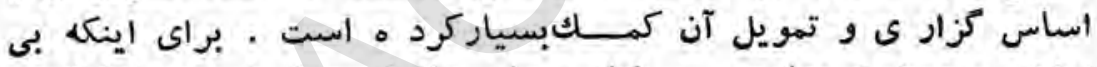

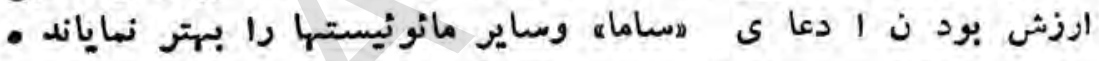

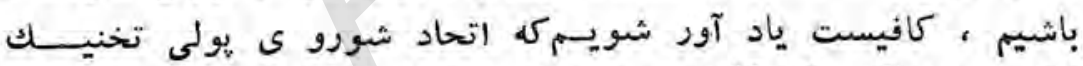

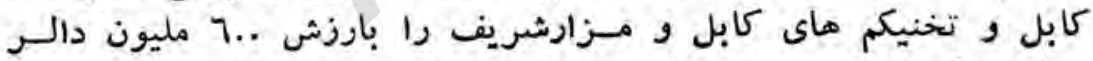

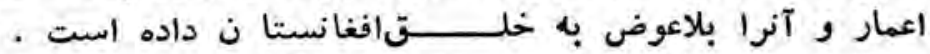

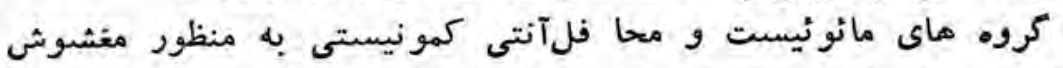

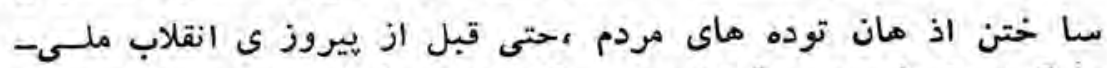

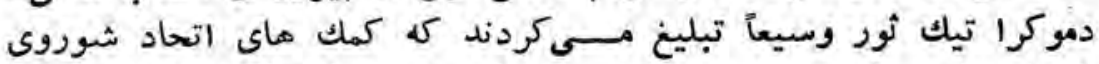

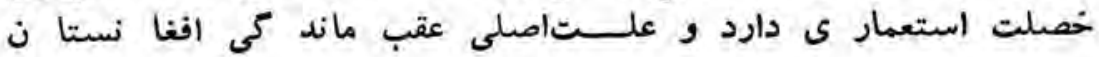




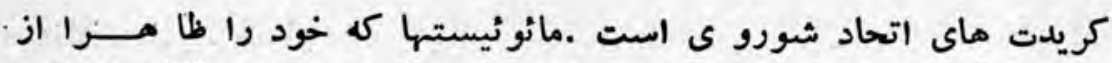

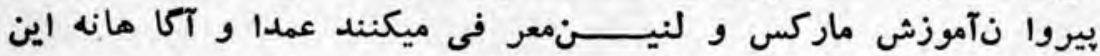

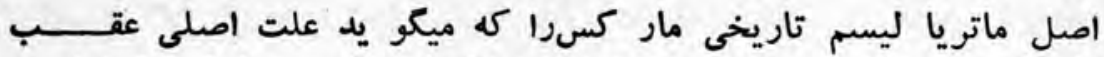

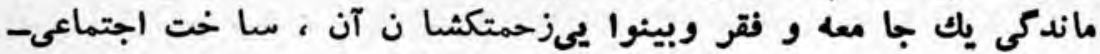

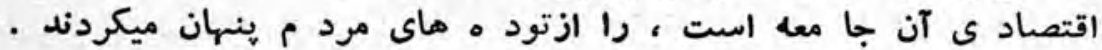

\section{انت رنا سيو ناليسم در قا موسـمائوئيسم :}

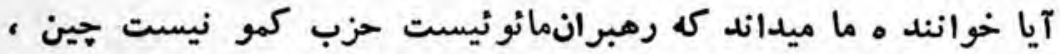

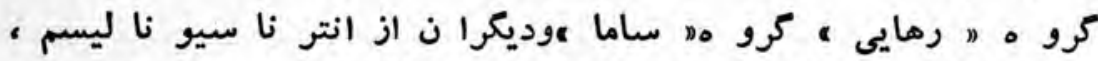

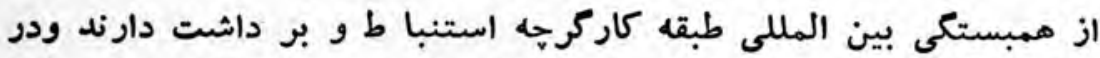

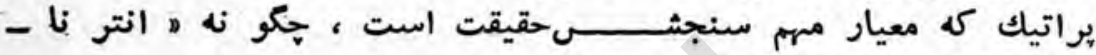
سيو ناليست ، بودهاند ؟ معار

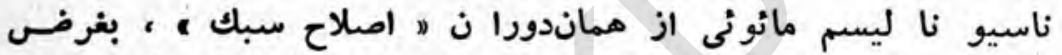

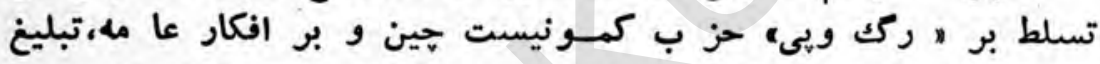

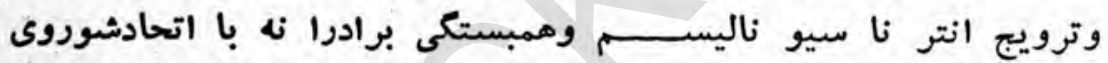

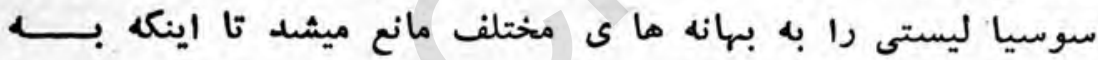

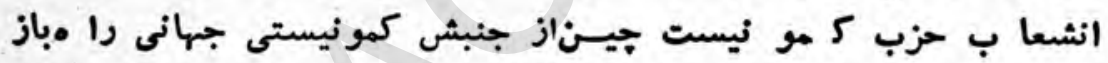
كرده باشد ، به بيا ن بهتر ناسيوناليسم جينى را در برابر انتر نالـ

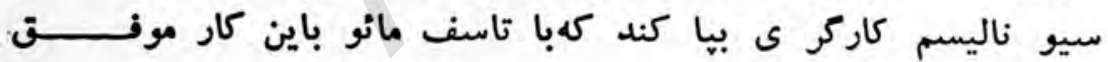

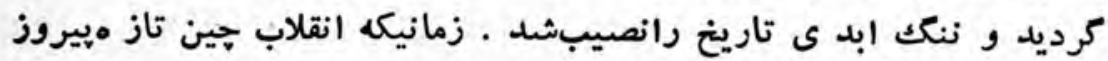

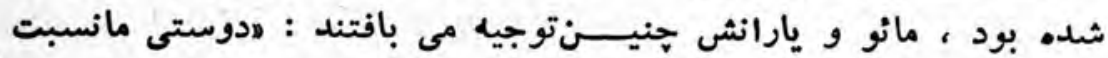

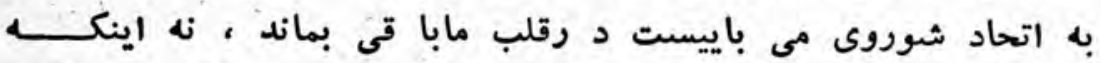

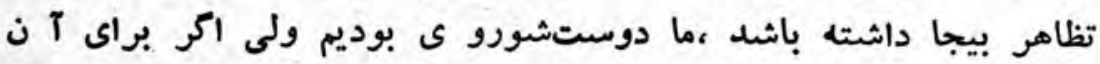

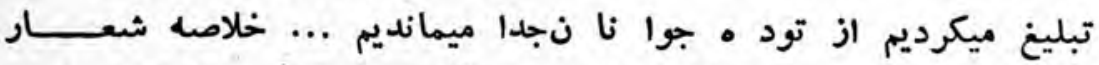

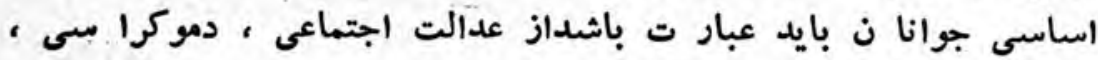




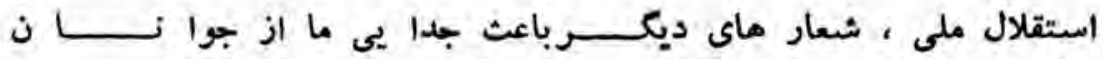

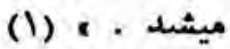
آيا جلوكير ى از تبليغ و ترويجانتر ناسيو نا ليسم ، تبليغو ترويج

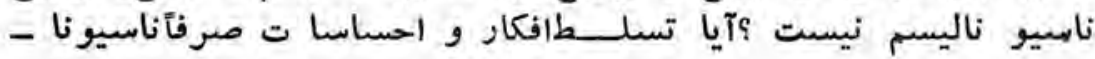

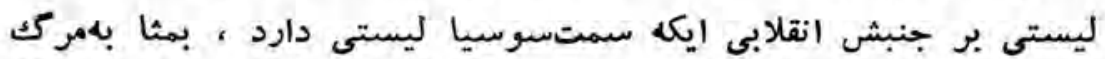

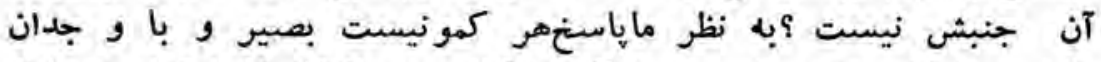

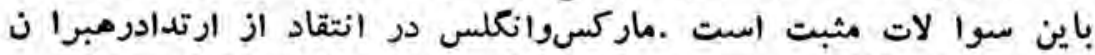

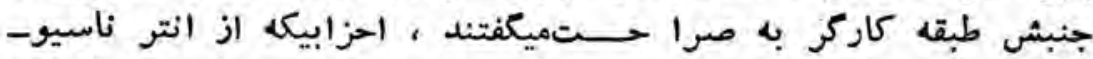

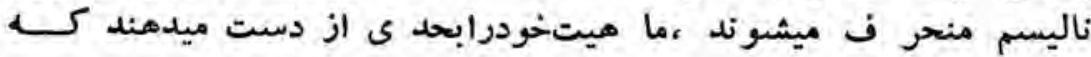

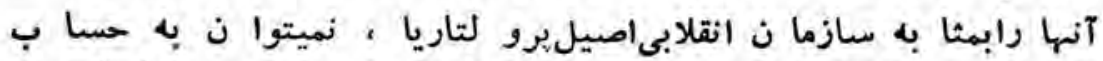

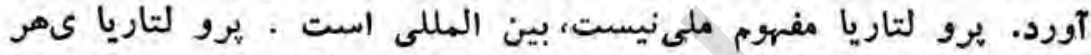

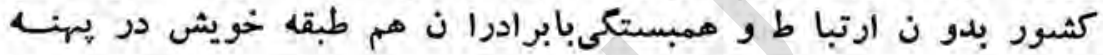

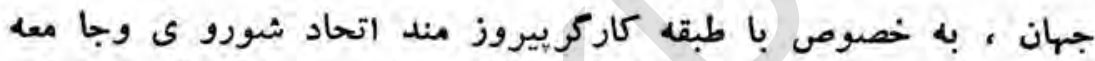

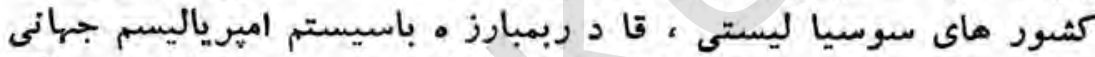

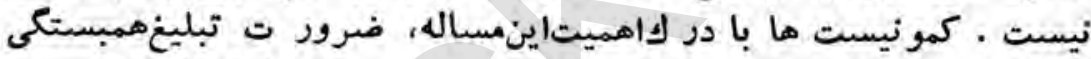

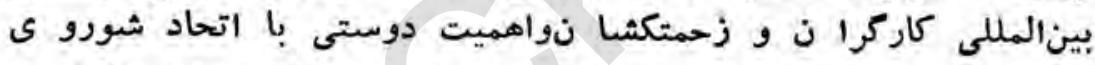

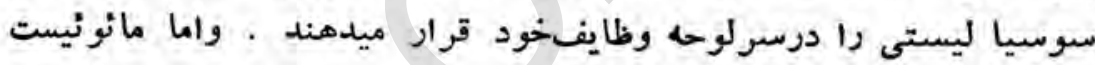
ما آنرا در لاقلب ، خودنكهميدارند.

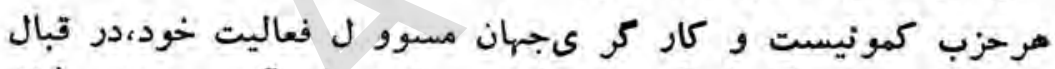

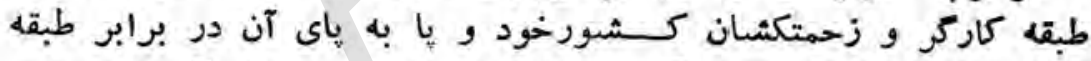

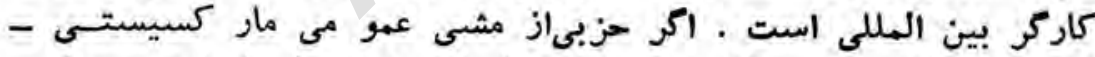

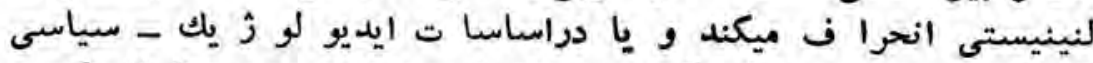

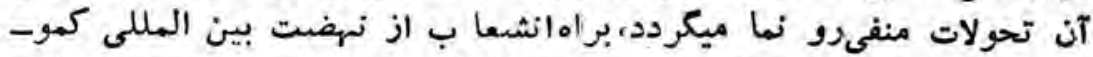

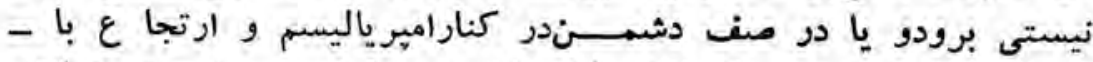

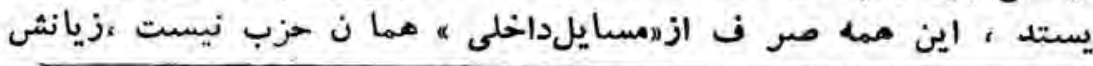

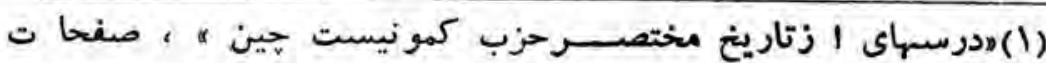




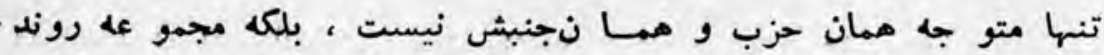

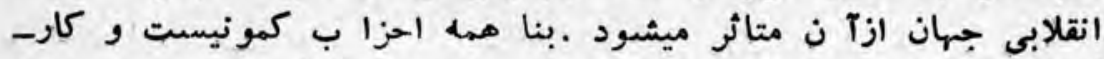

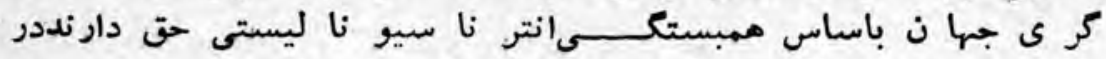

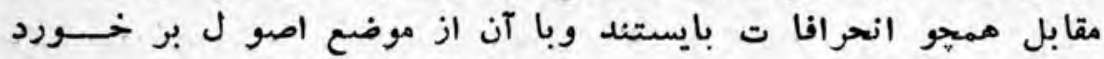

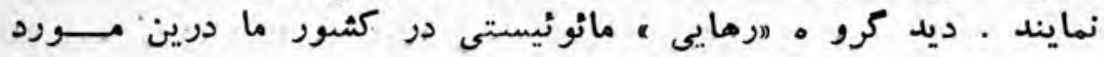

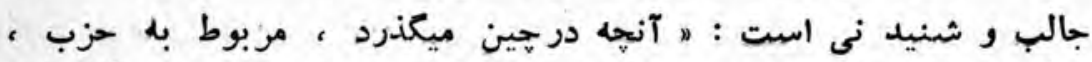

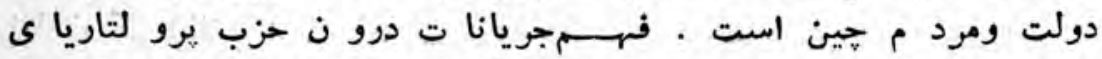

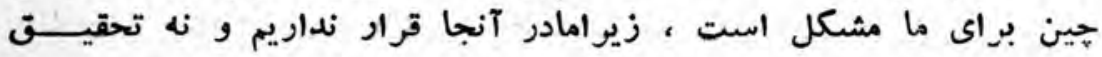

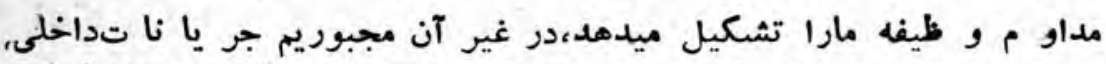

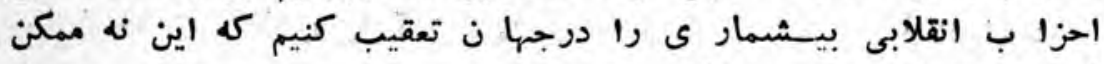

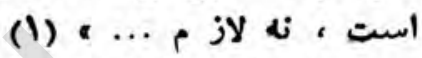

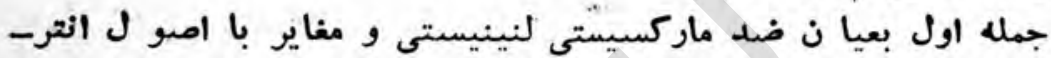

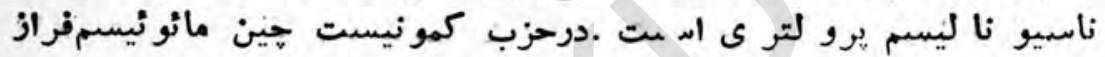

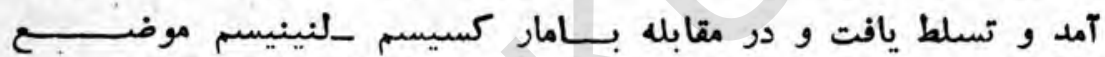

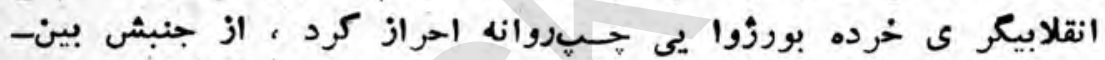

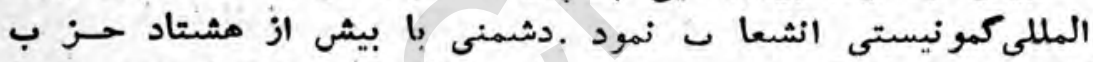
كمونيست و كارك

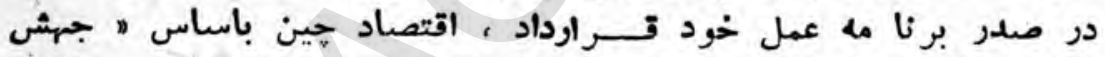

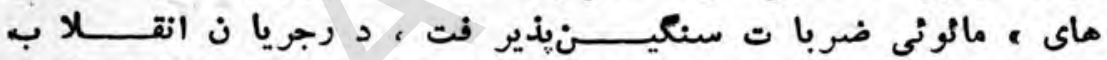

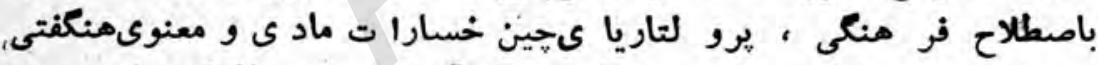

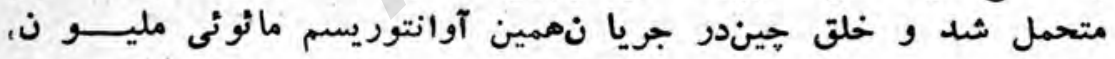

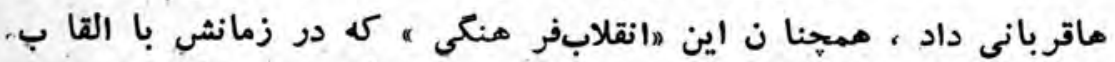

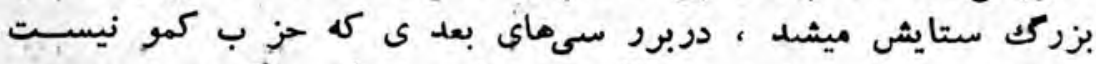

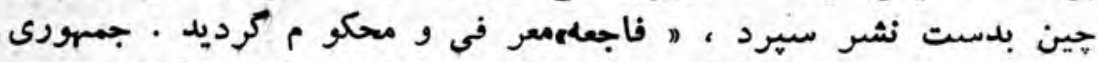

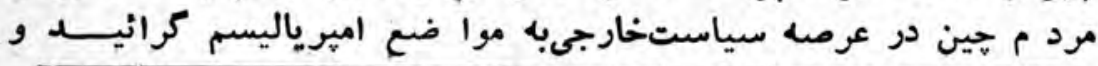

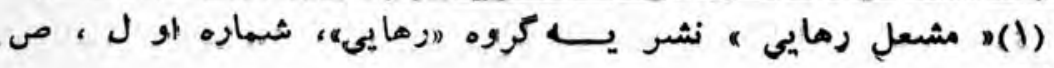

- $\mid \varepsilon \varepsilon$

- rqV- 


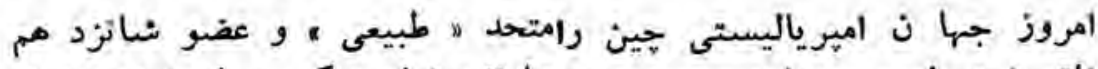

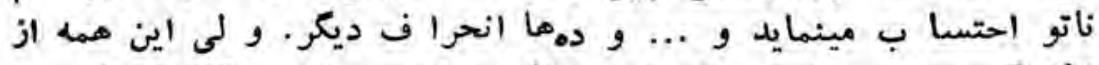

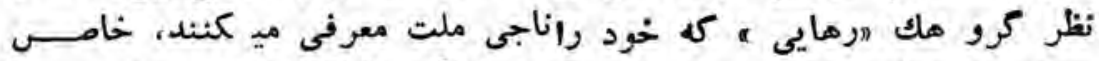

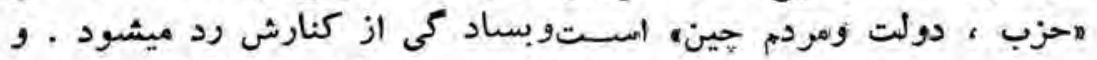

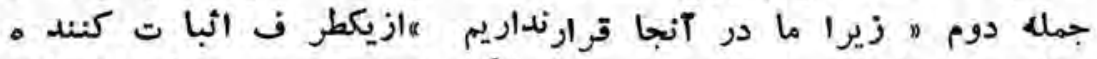

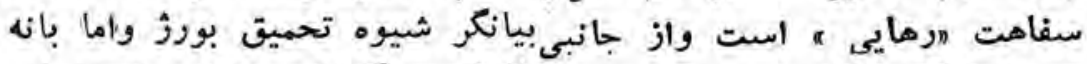

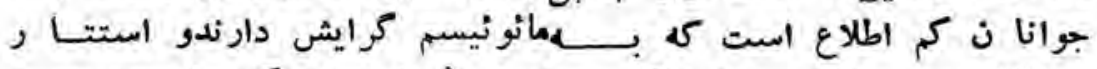

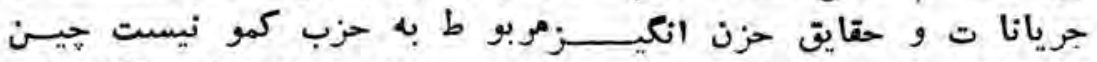

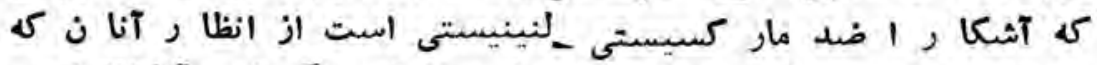

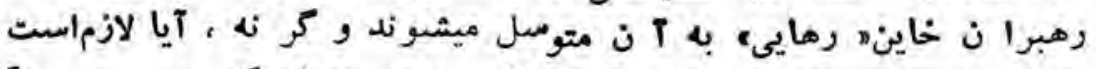

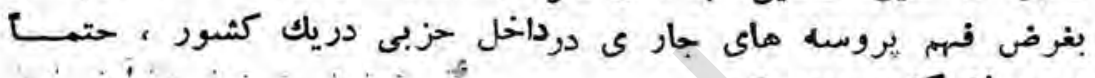

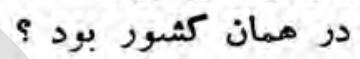

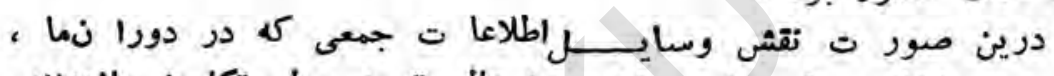

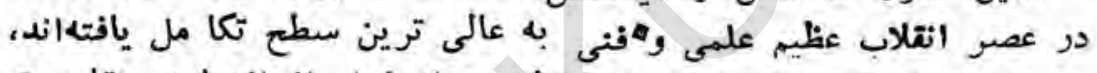

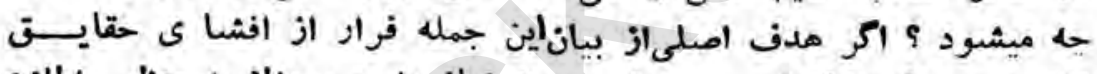

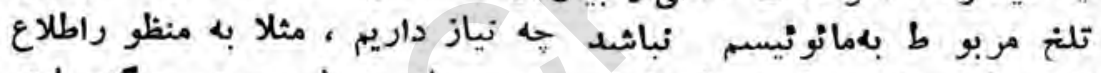

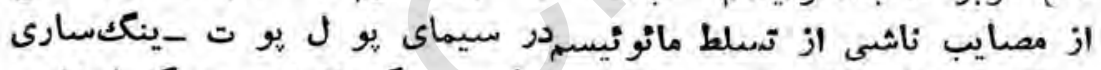

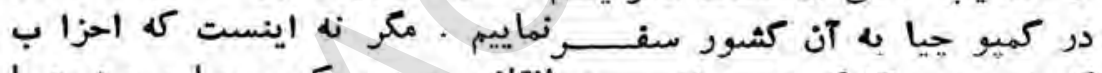

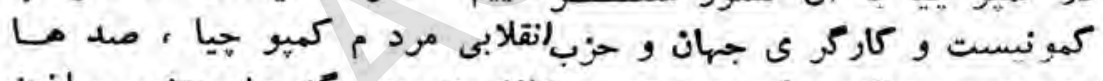

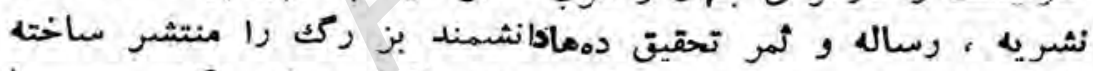

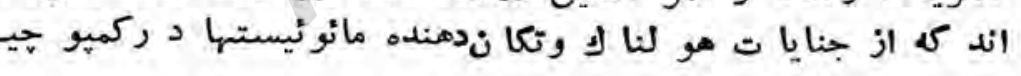

$$
\text { مرده بر ميدارد ماند }
$$

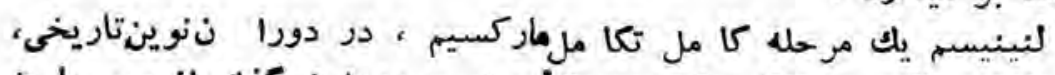

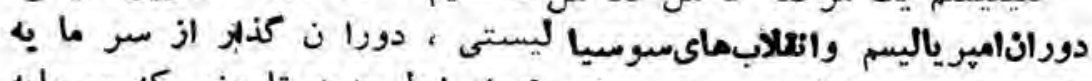

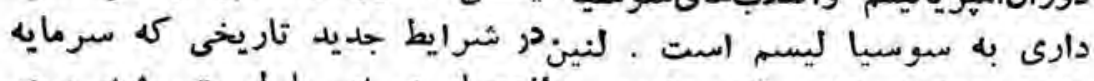

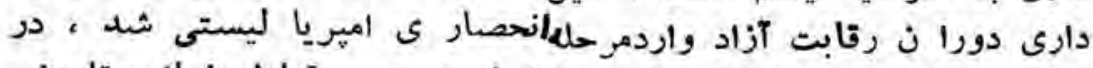

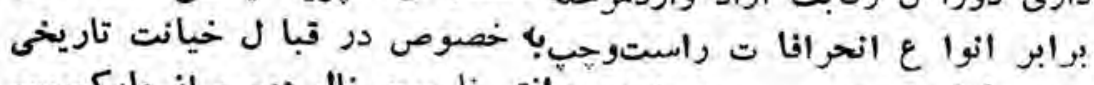

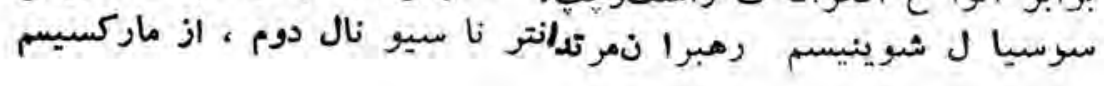




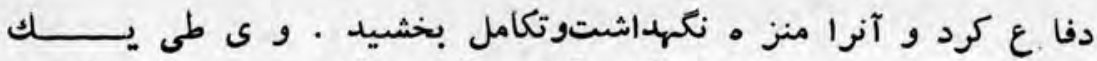

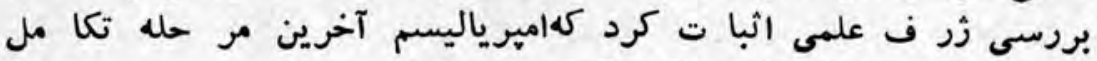

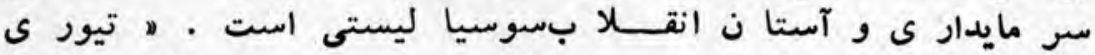

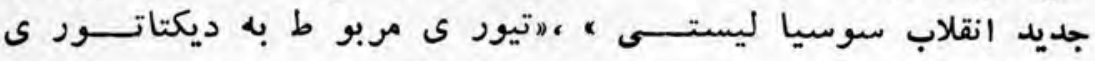

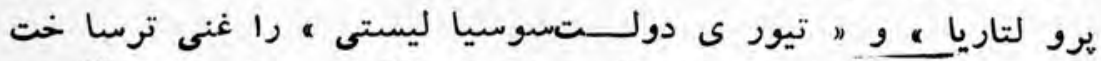

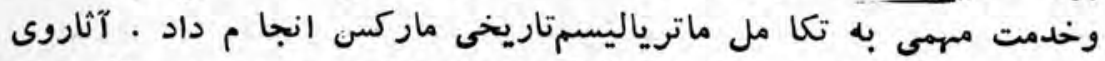

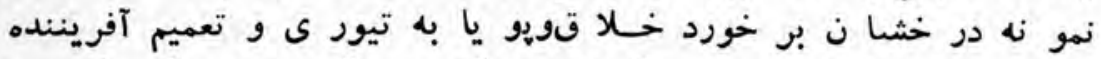

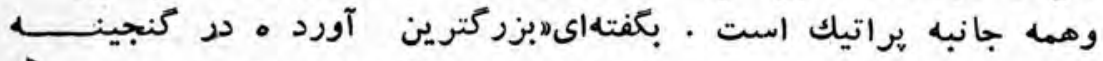

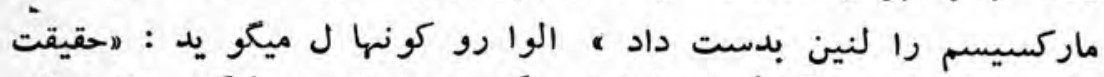

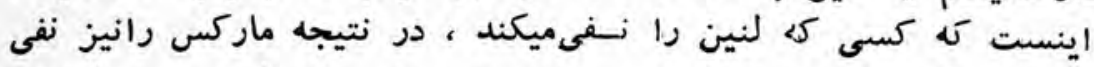

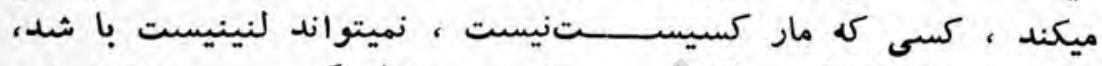

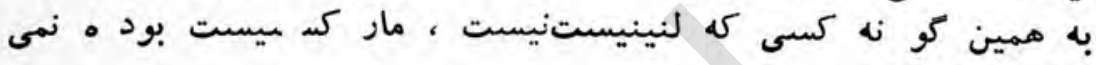
تواند . a (1)

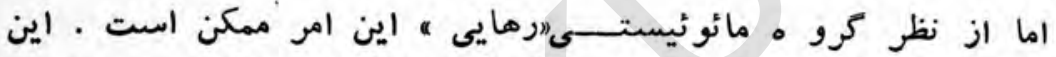

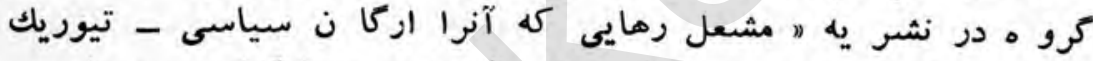

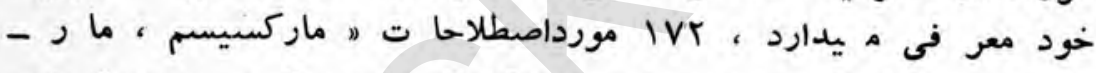

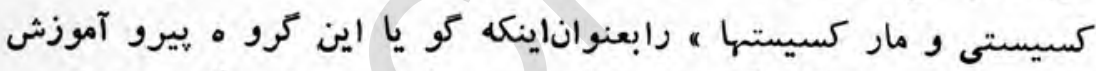

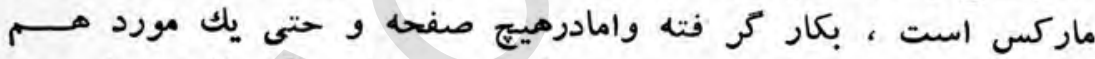

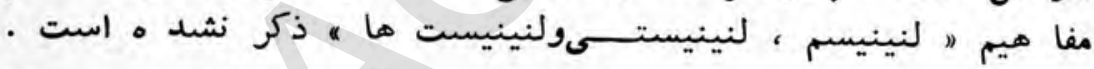

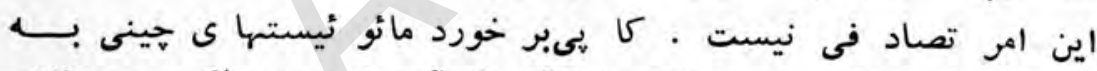

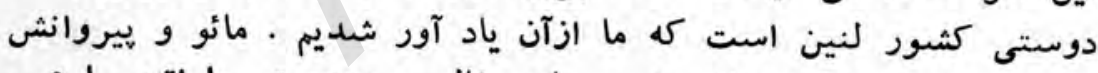

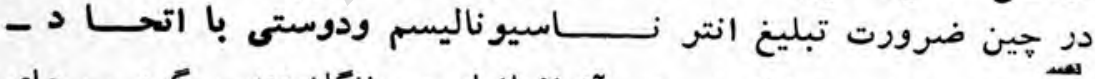

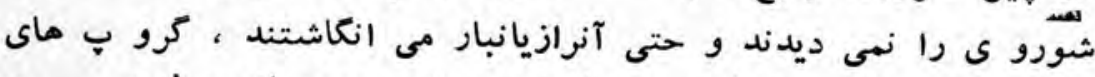

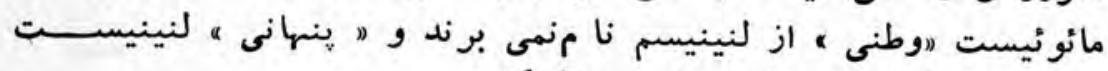

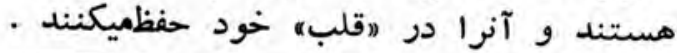

(1)،سا ختمان سوسيا ليسمبم وكمونيسم وانكشا ف جهانى، سوفيه، rr7 ص.19v9 


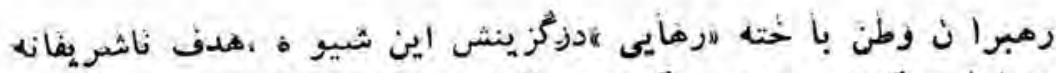

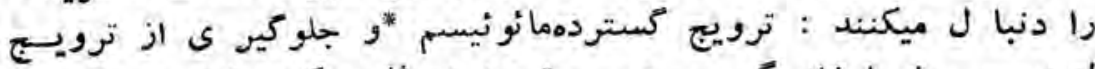

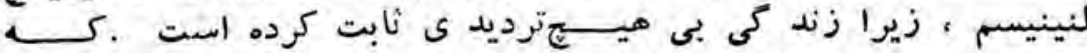

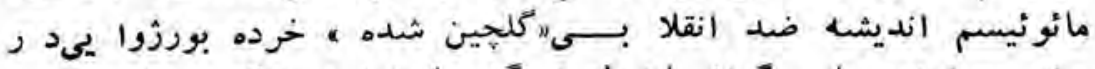

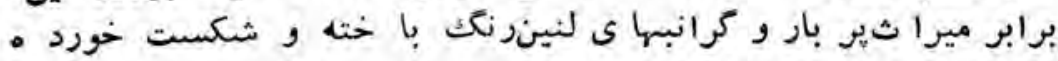

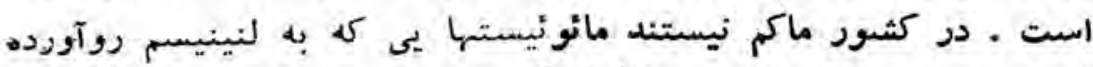

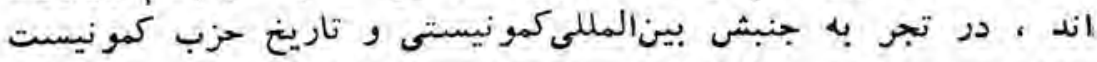

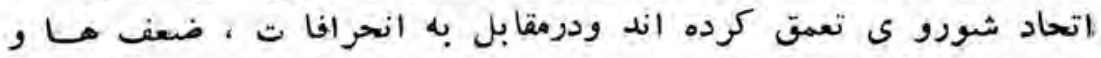

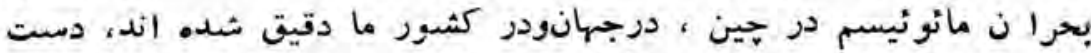

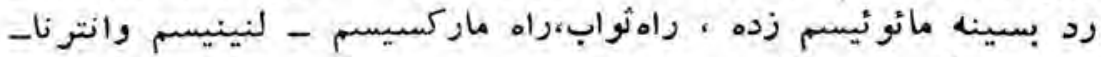

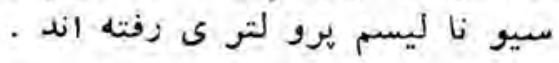

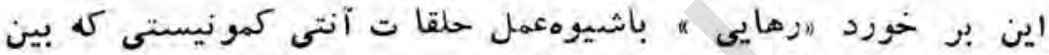

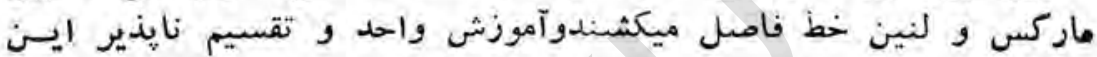

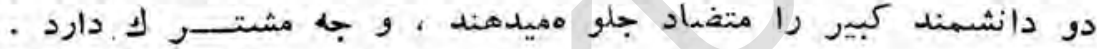

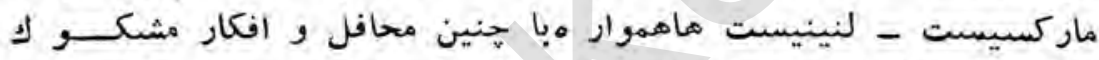

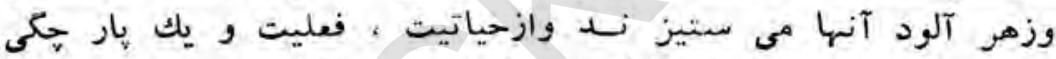

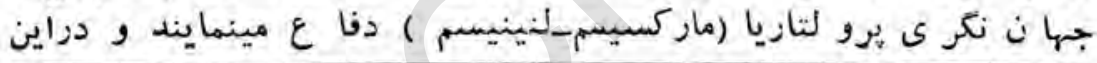

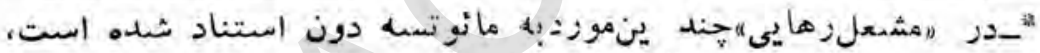

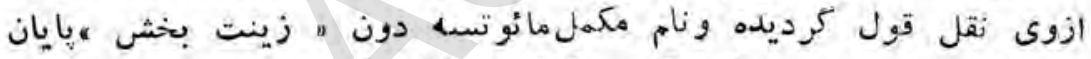

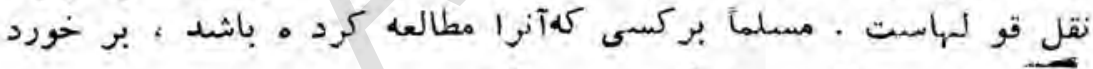

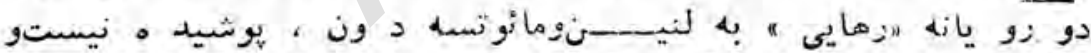

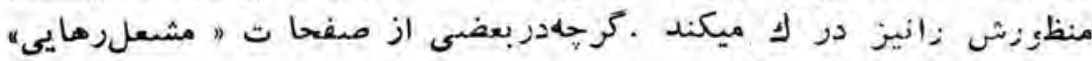

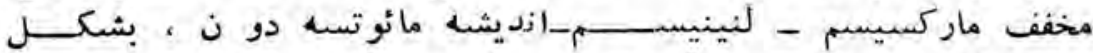

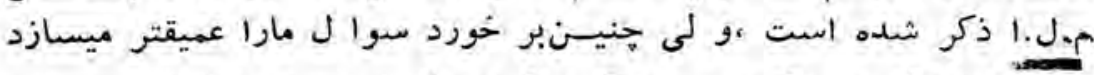

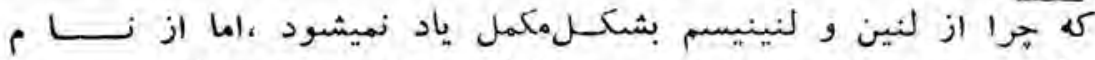

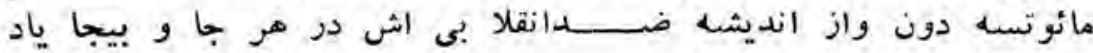

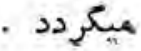




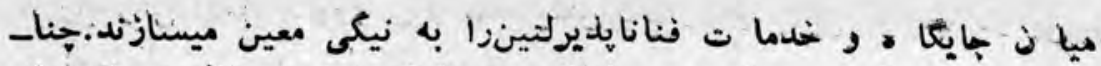

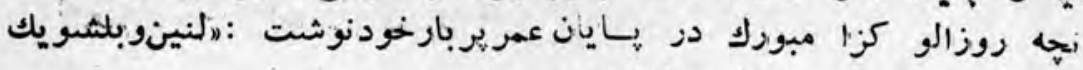

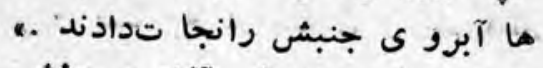

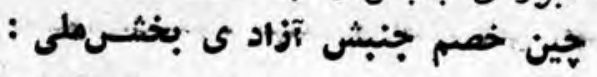

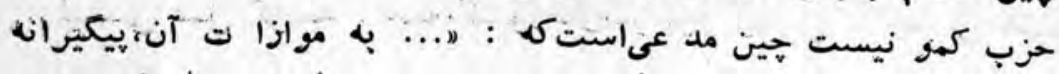

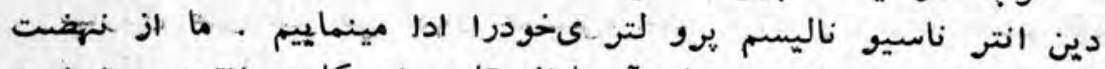

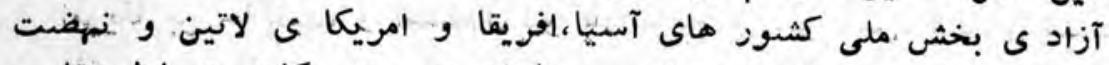

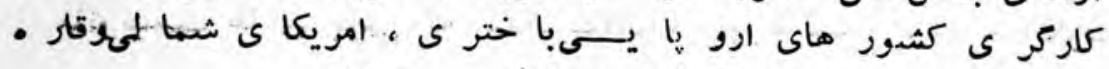

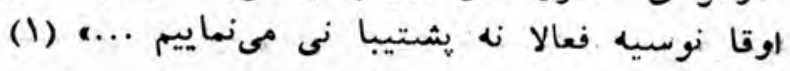

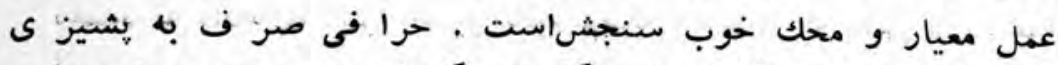

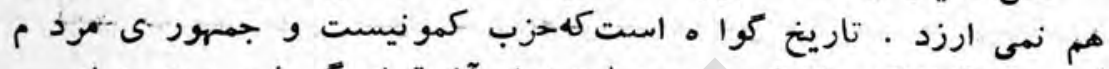

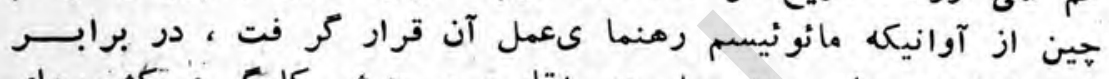

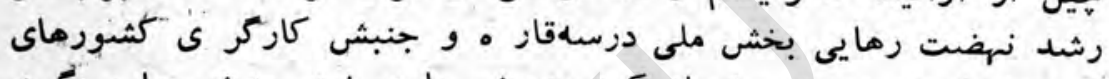

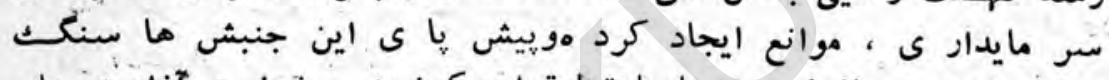

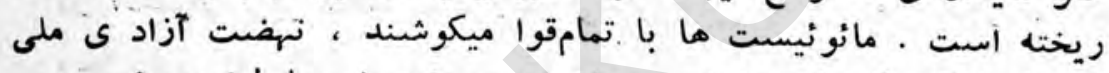

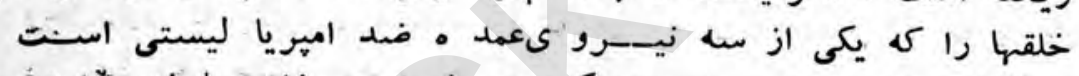

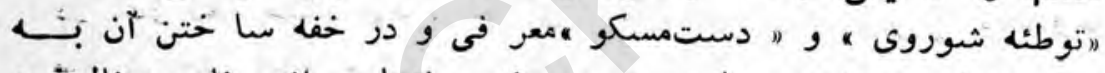

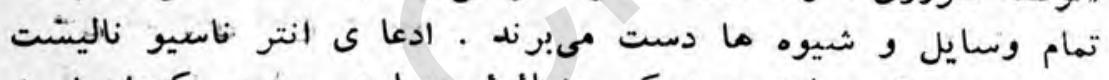

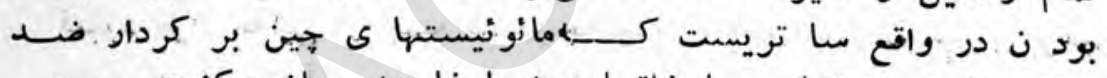

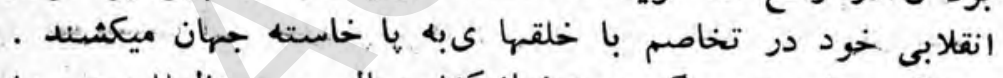

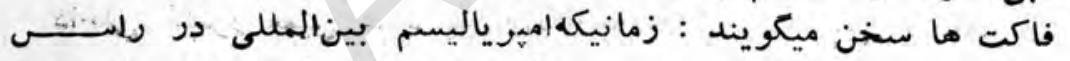

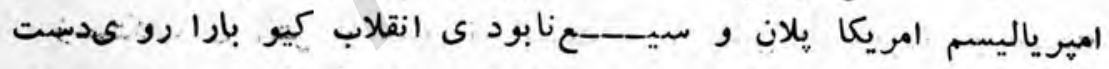

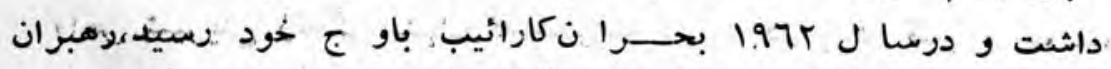

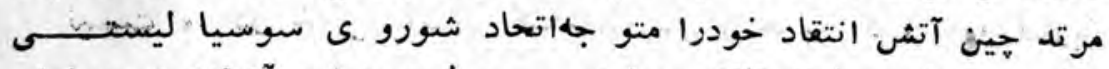

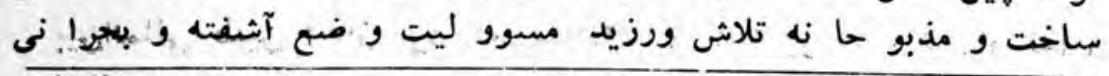

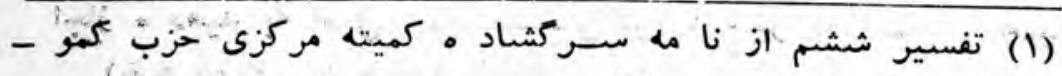

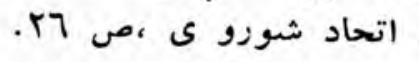


رابدوش اتحاد شورو ى و متحديثشبياندازد و بدين ترتيب در يىتبرنه

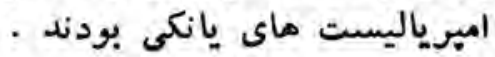

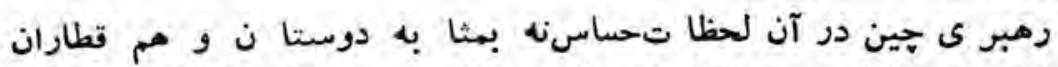

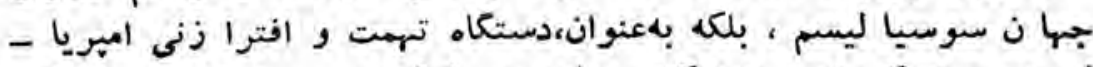

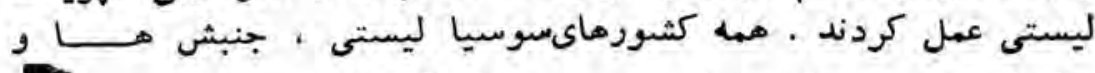

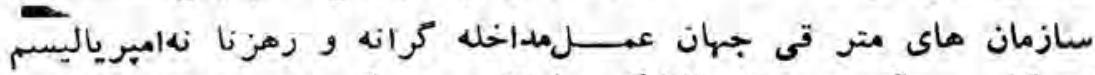

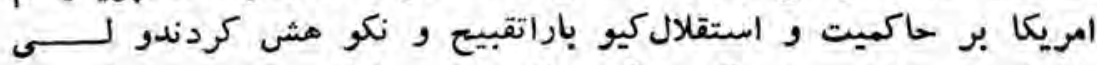

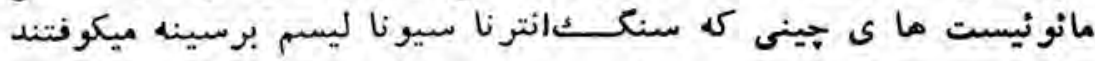

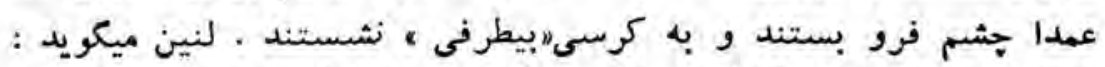

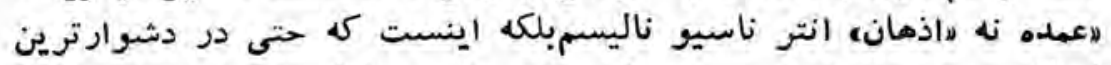

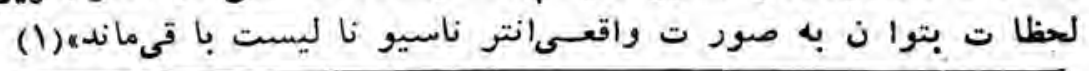

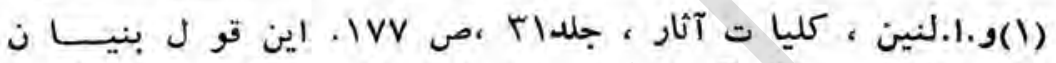

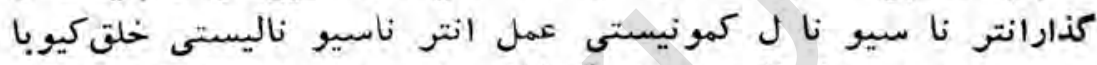

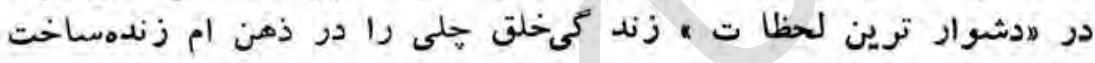

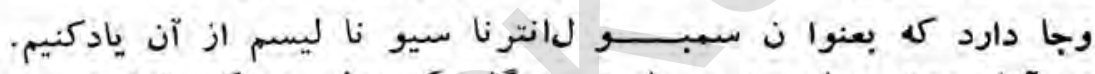

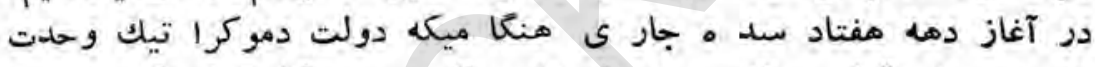

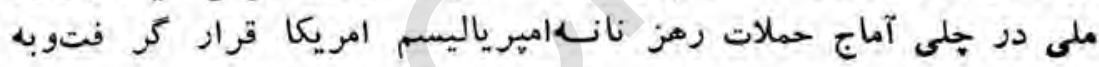

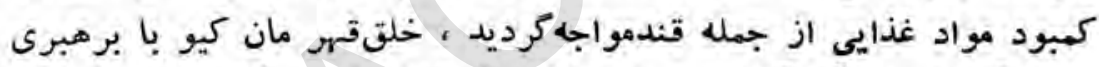

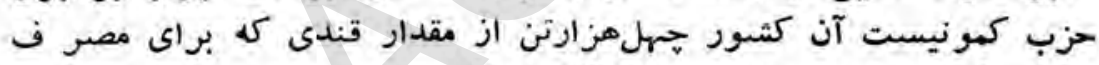

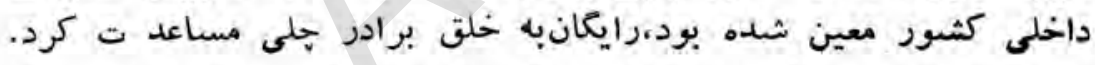

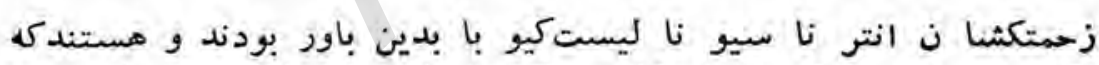

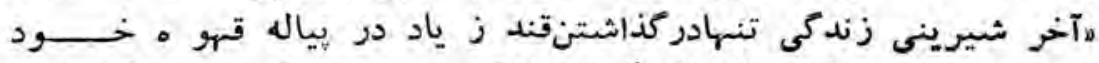

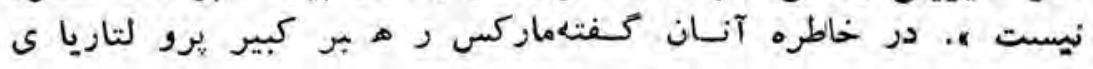

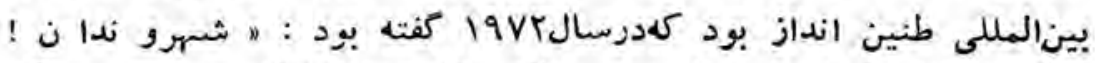

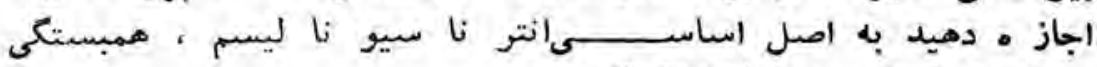

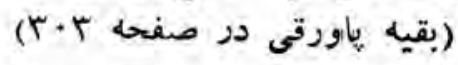




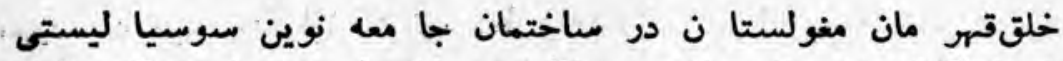

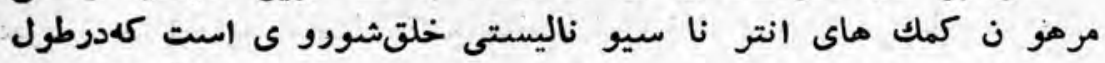

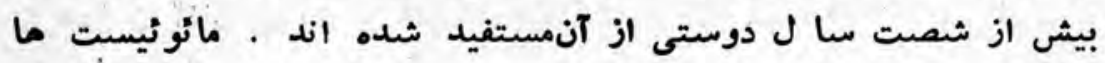

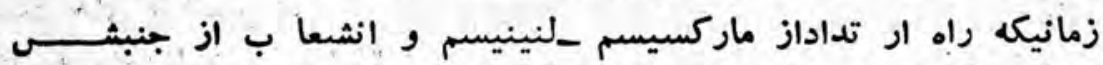

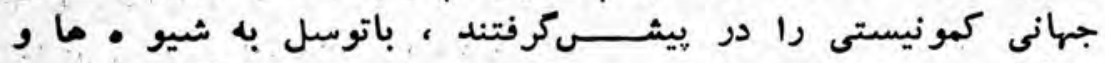

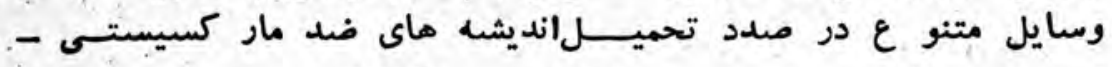

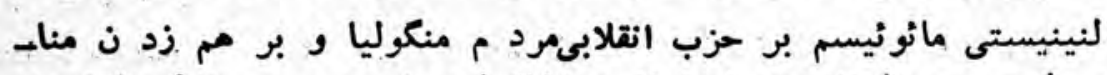

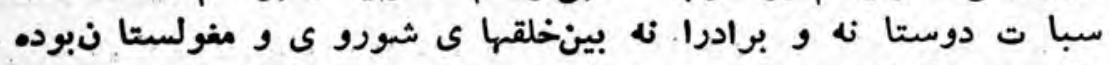

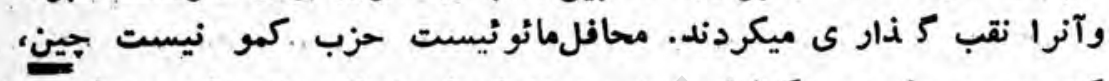

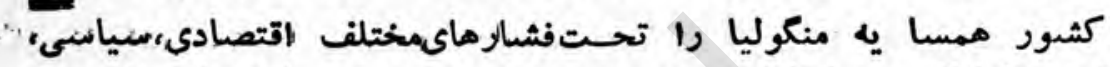

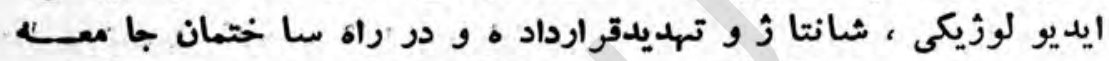

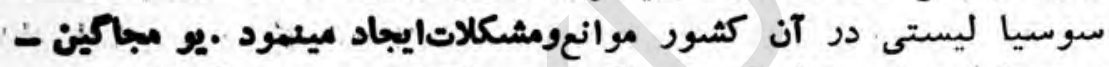

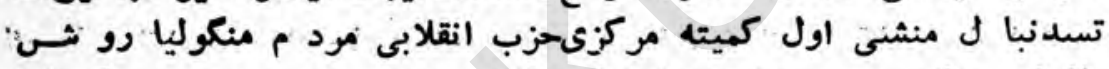

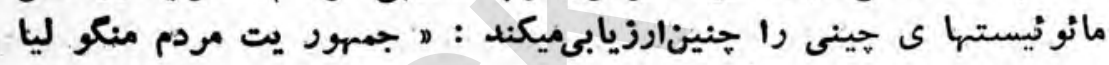

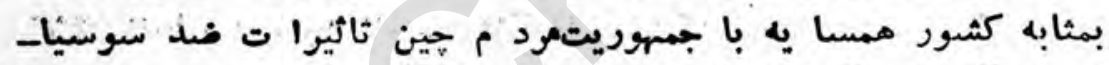

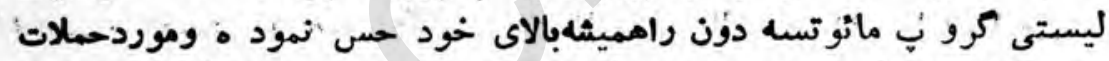

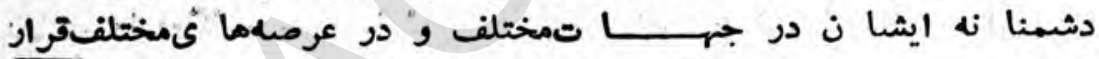

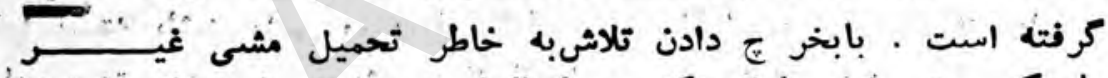

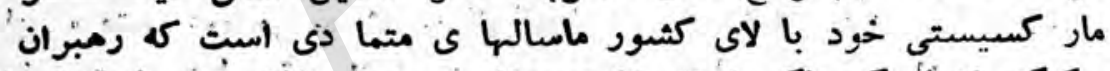

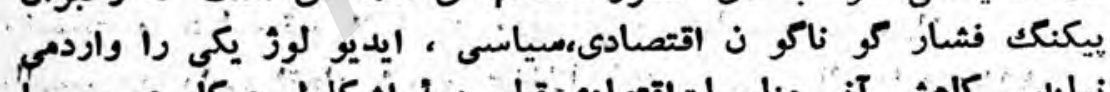

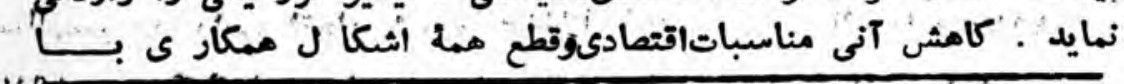

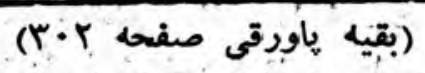

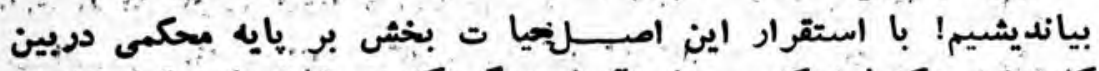

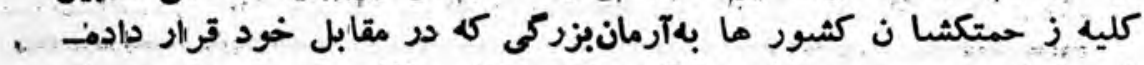

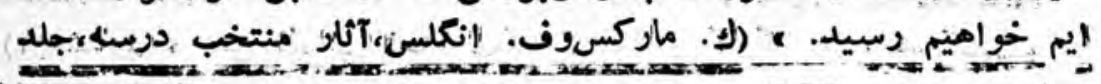

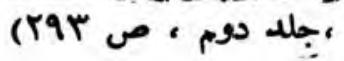

$$
-r \cdot r
$$




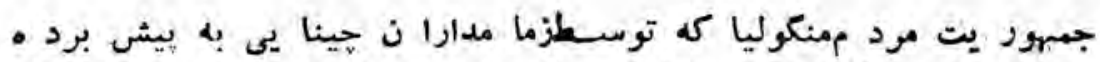

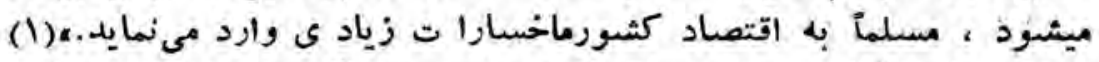

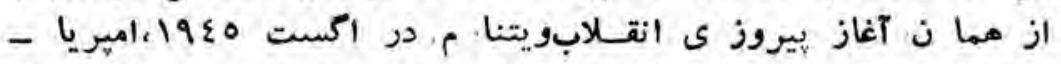

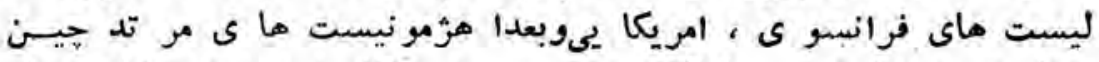

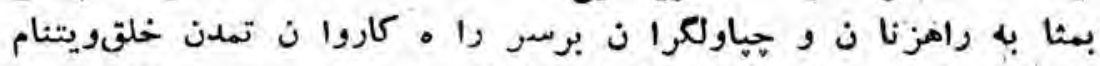

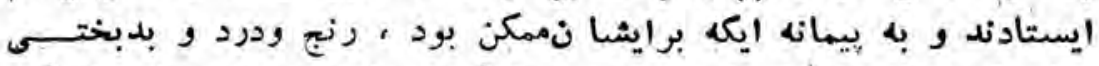

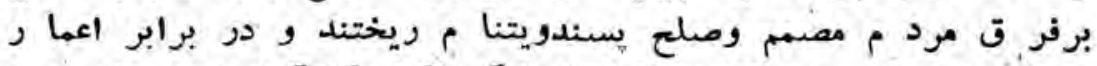

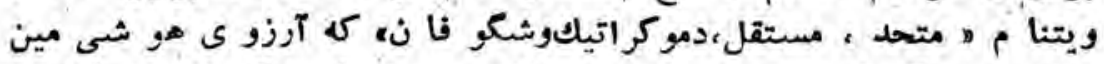

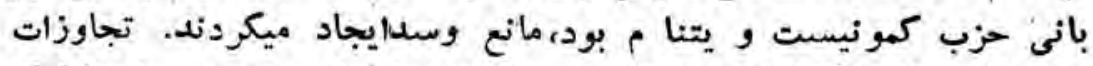

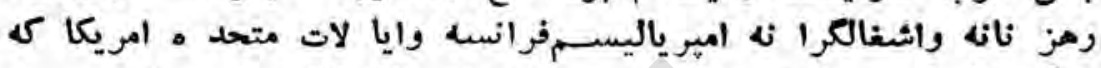

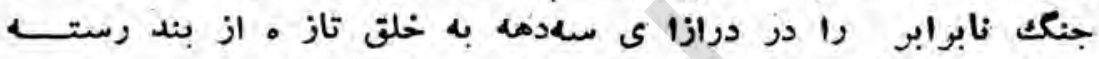

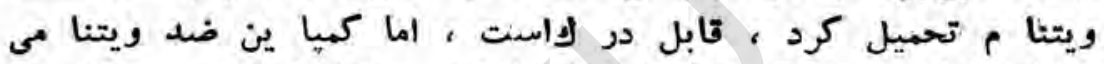

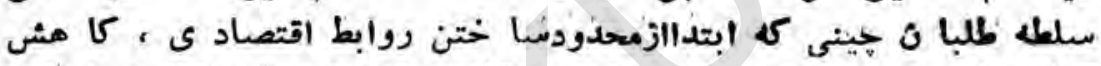

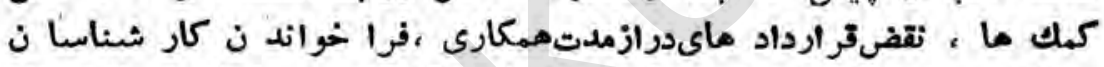

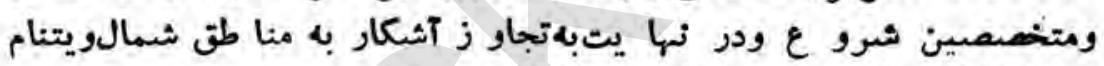

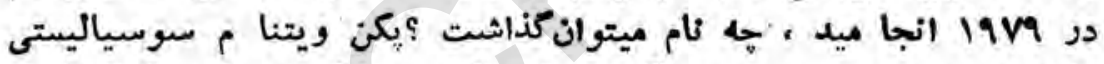

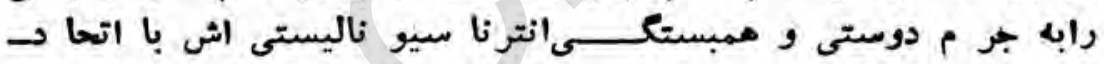

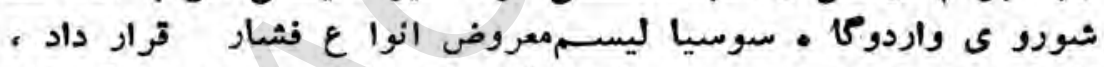

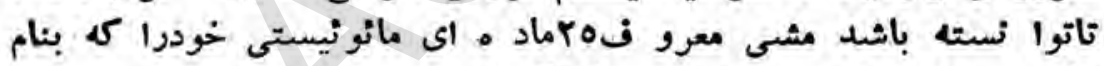

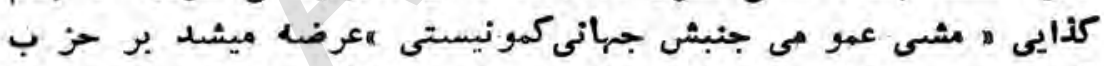

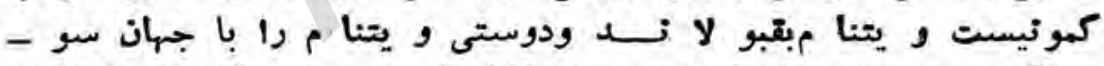

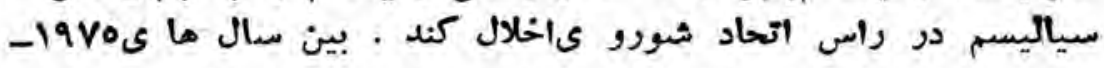

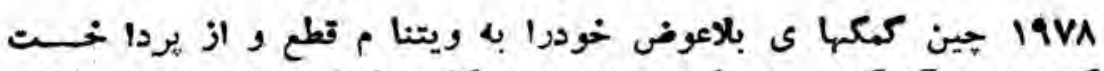

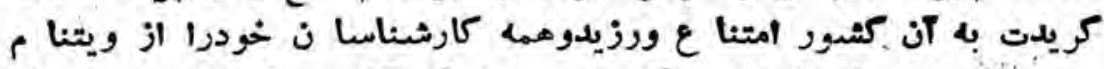

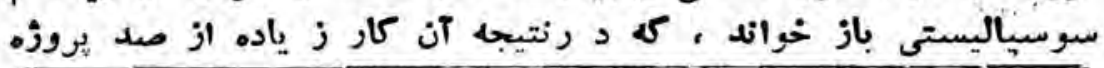

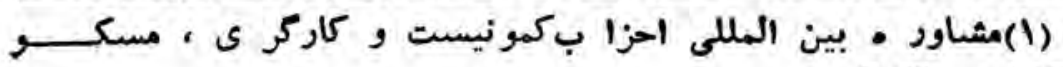
.7or a.1979

$-r \cdot \varepsilon-$ 


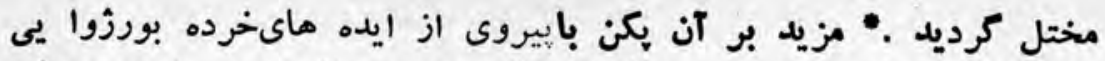

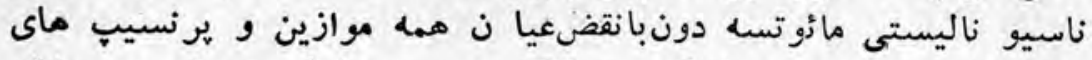

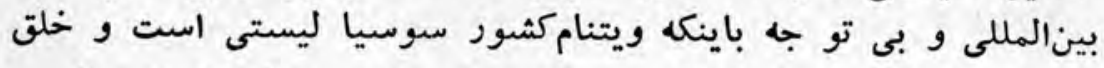

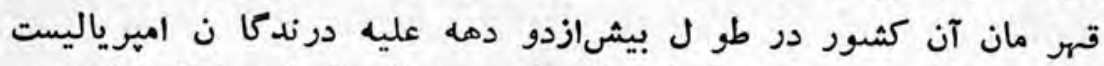

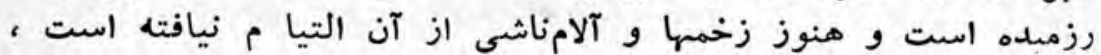

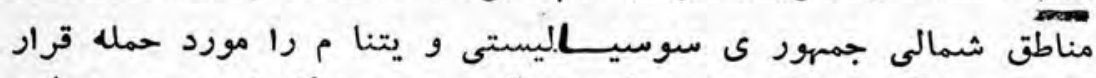

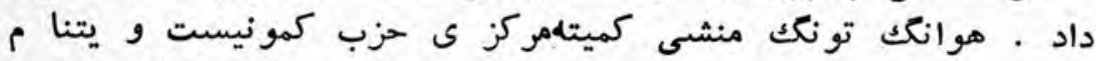

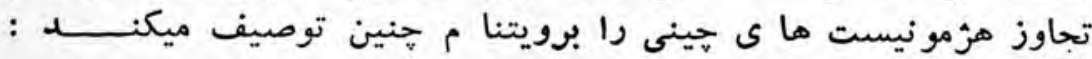

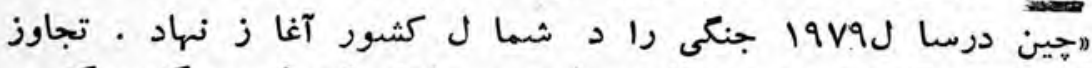

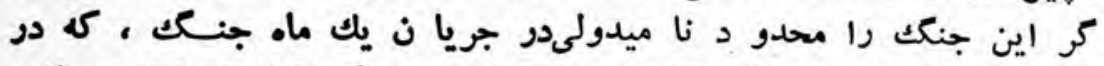

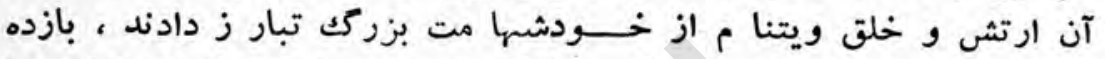

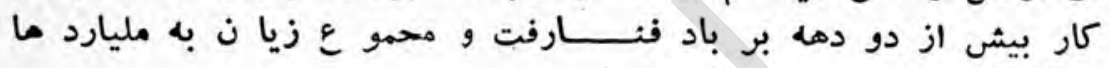

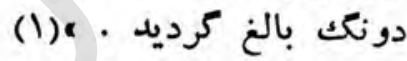

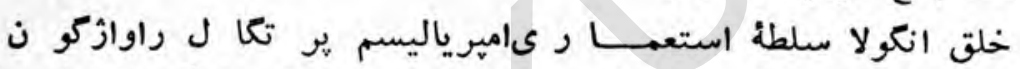

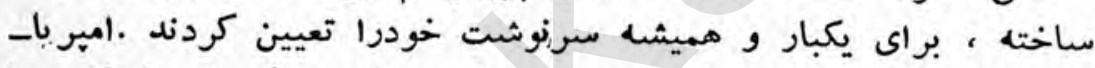

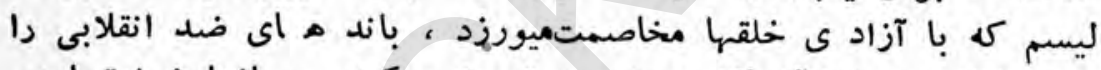

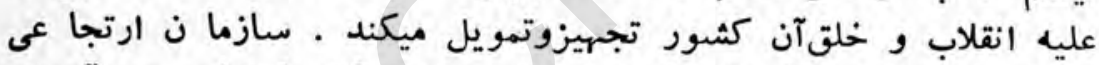

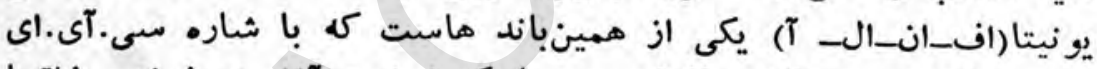

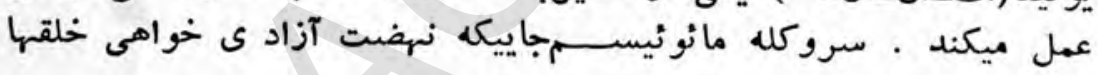

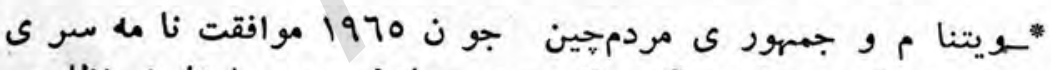

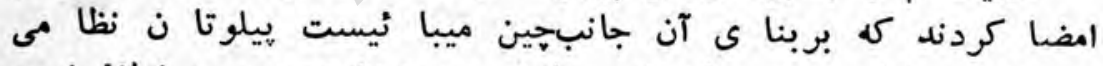

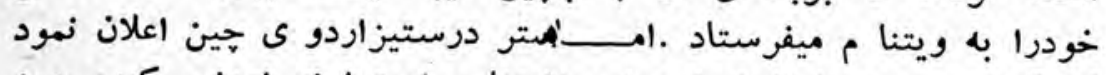

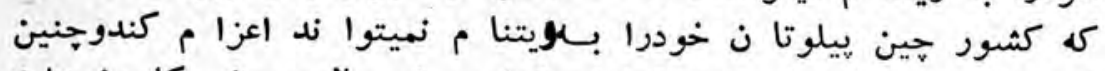

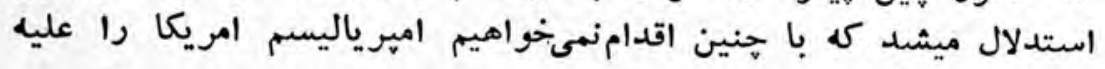

$$
\text { خود تحريك كنيم }
$$

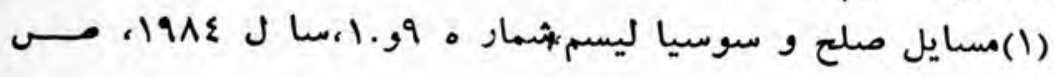




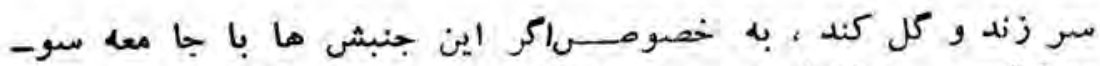

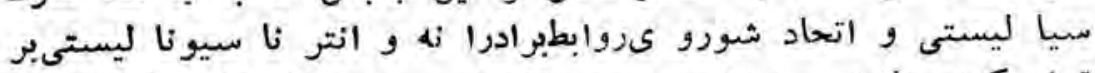

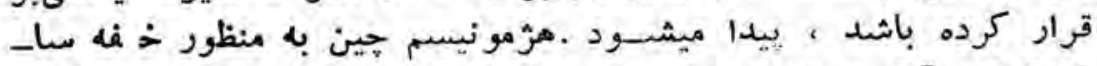

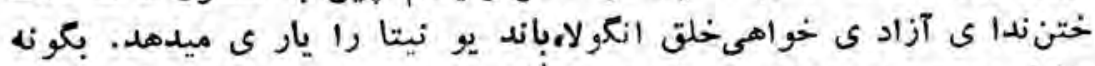

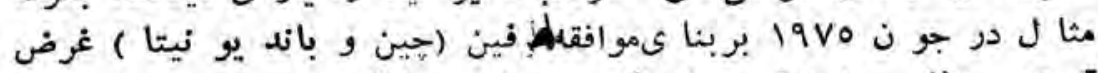

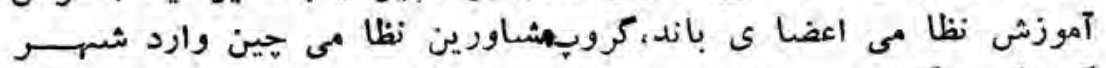

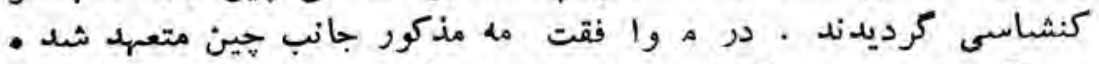

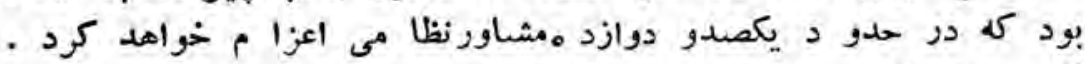

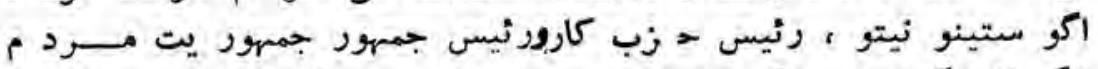

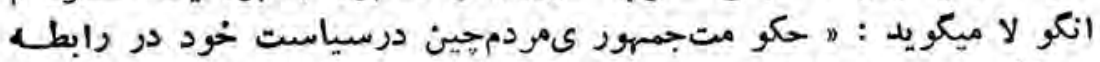

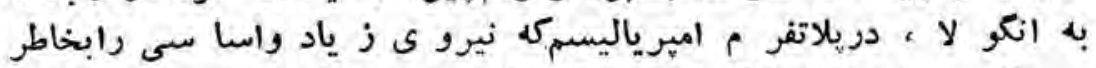

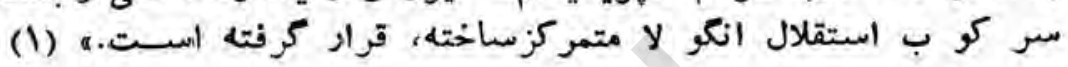

米

*

米

جها ن ما به طور اساسى به دوجبهه ، به دو اردوكا ه . بسوسيا -

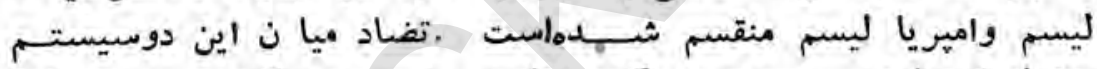

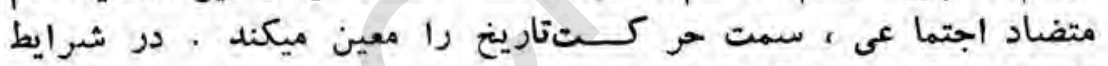

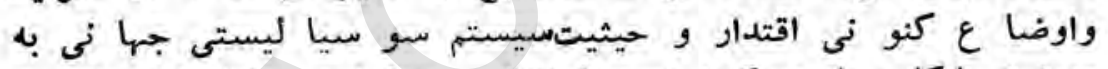

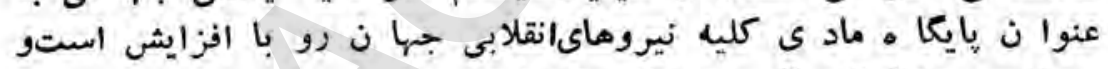

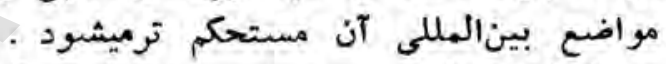

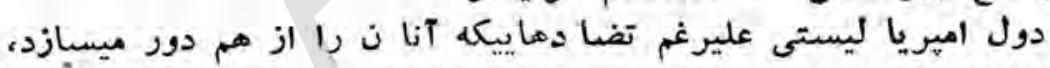

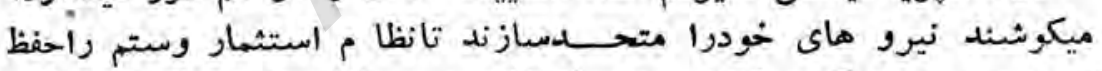

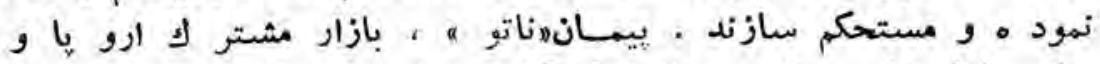

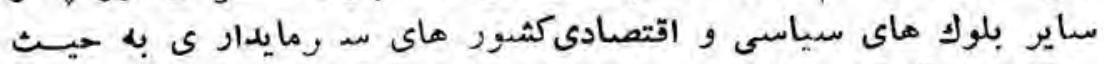

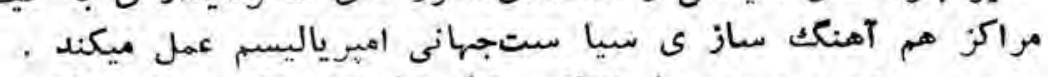

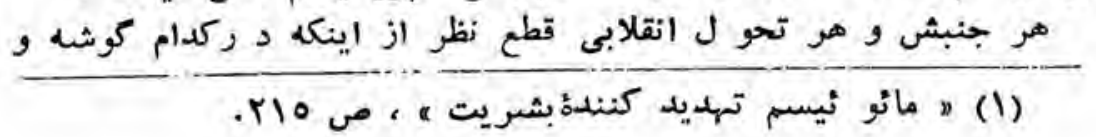

$-r \cdot 7$ 


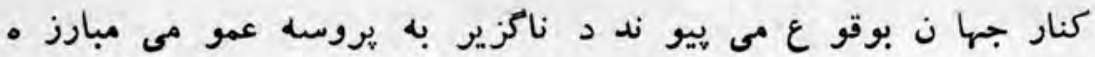

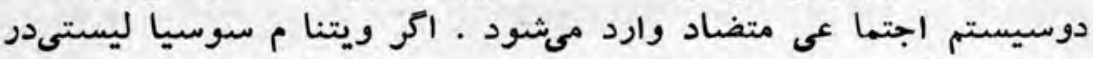

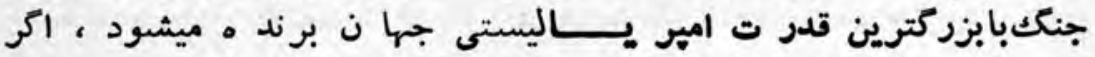

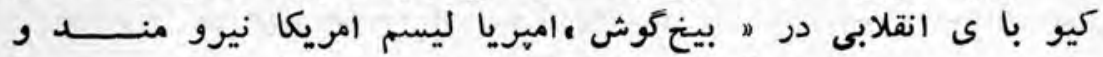

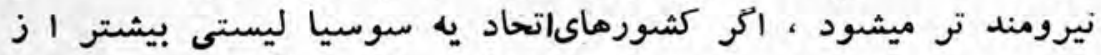

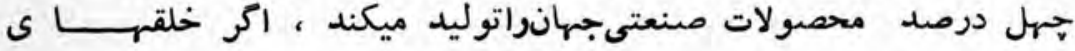

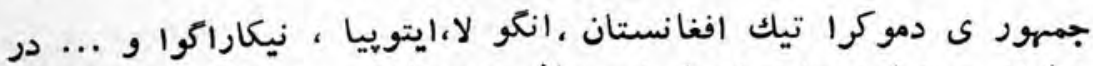

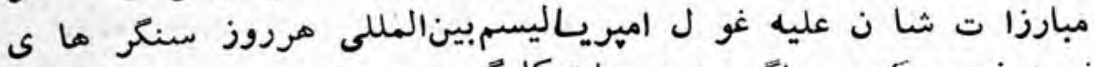

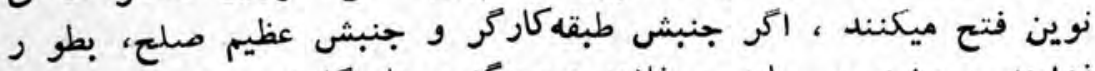

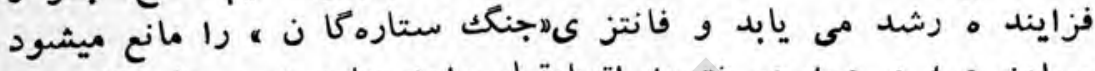

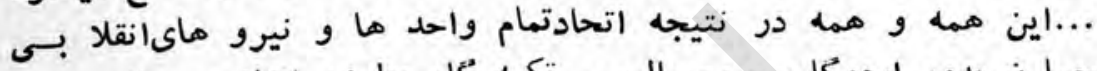

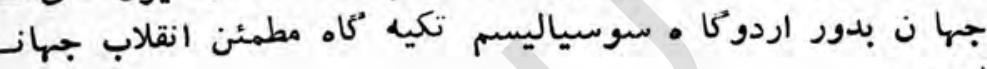

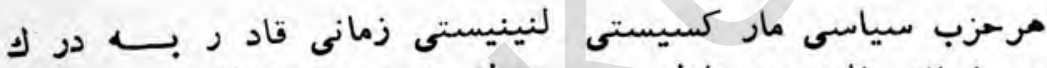

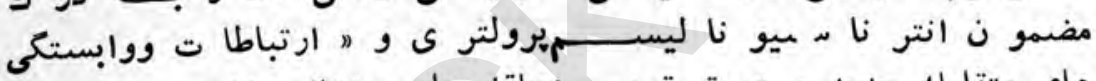

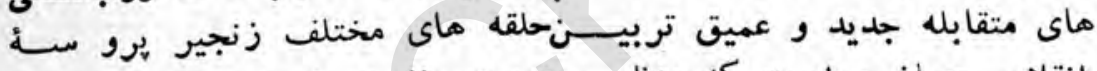

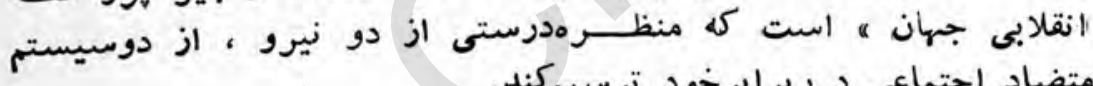
متضاد اجتماعى د ربرابن ابرخود الو ترسيمكند.

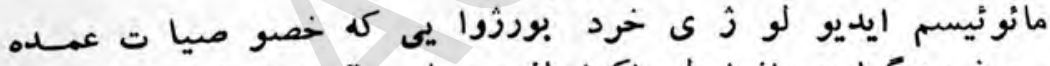

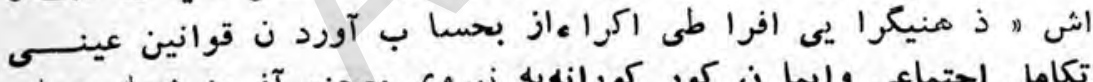

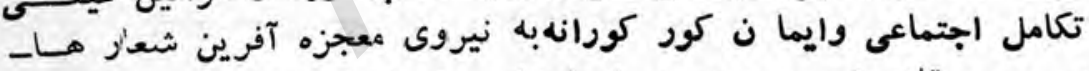

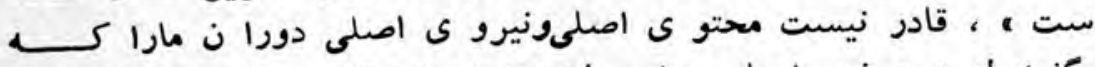

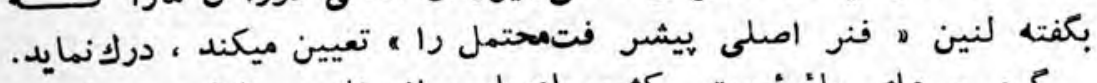

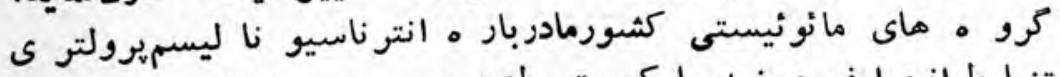

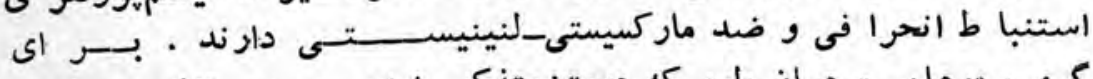

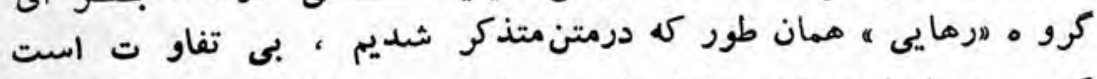

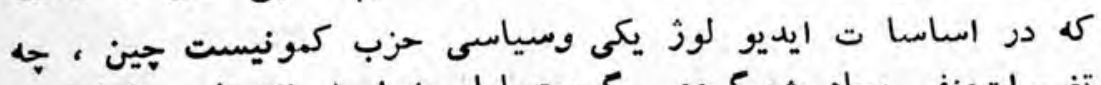

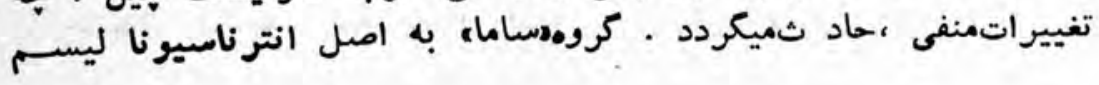




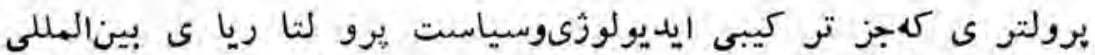

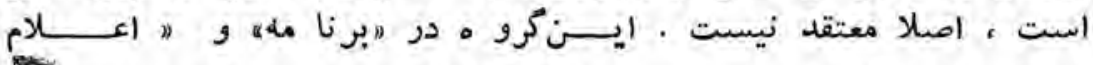

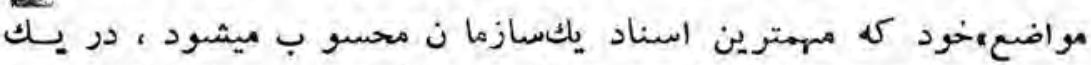

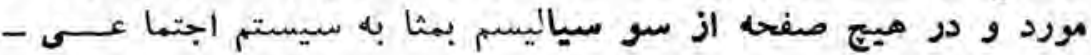

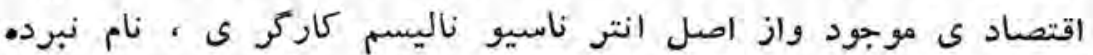

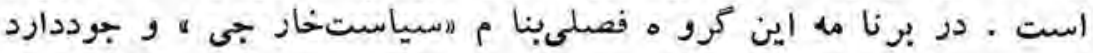

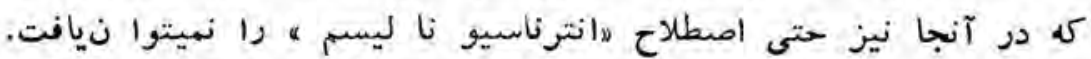

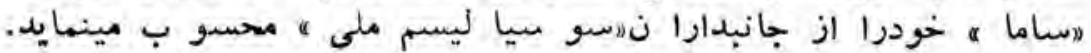

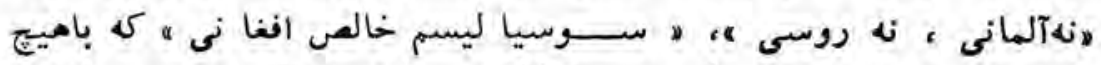

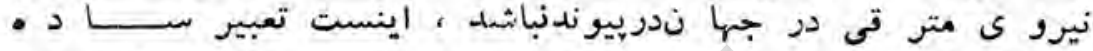

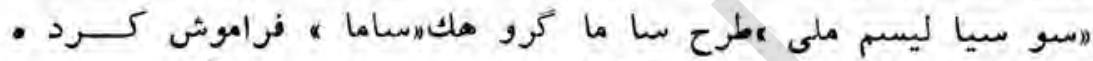

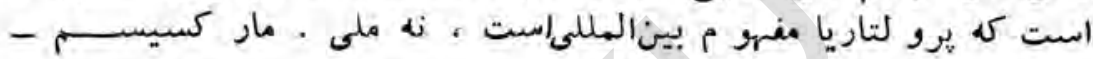

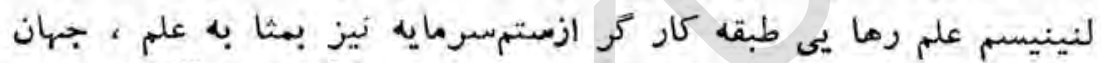

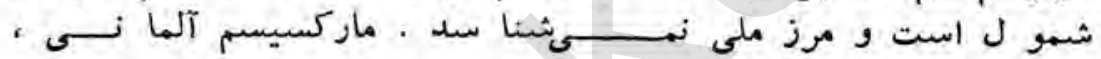

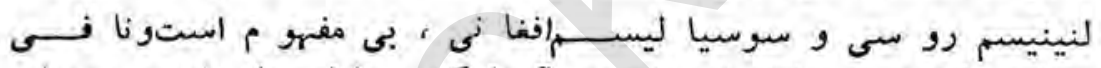

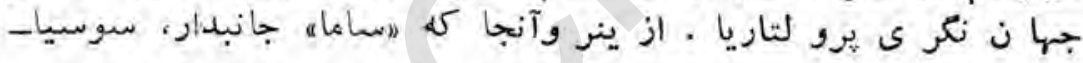

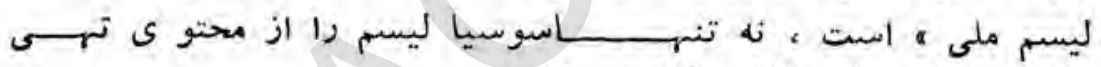

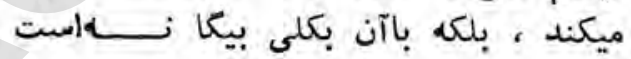

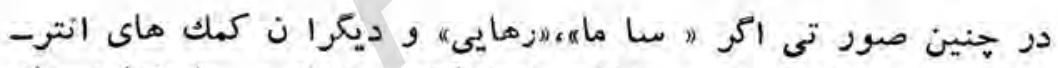

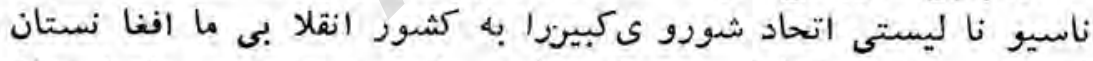

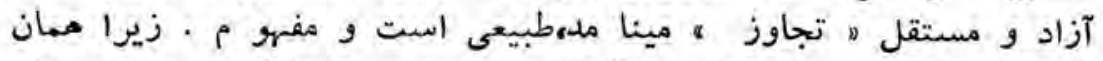

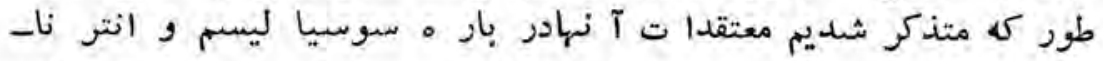

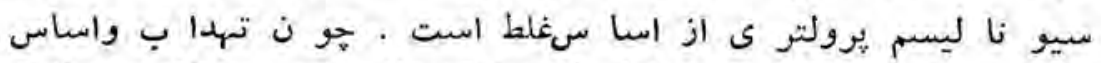

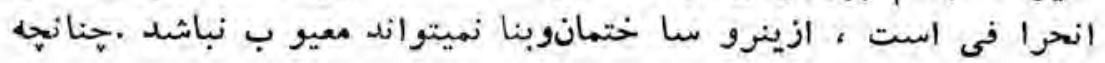

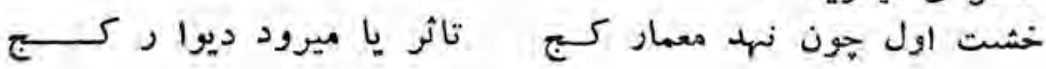

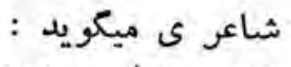
$-r \cdot \Lambda$ 
همبارز • طبقا تى به راستى همرك

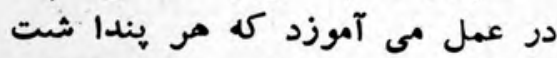

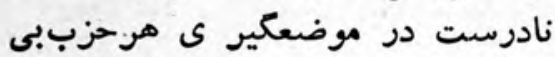

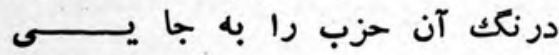

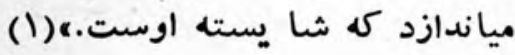

\section{سيماىديكرىازفاشيسم}

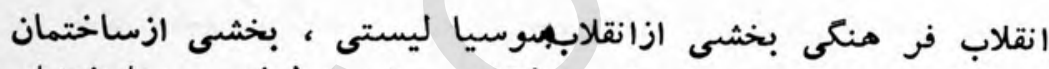

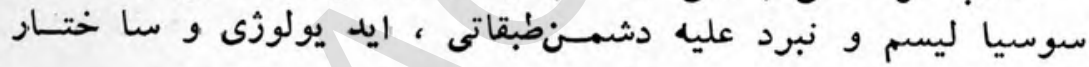

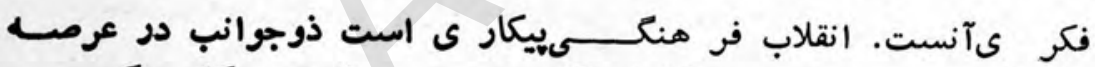

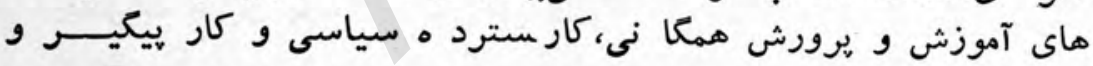

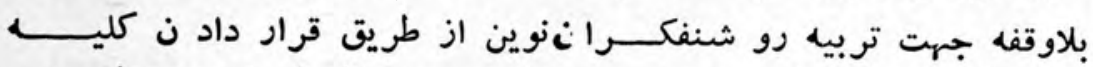

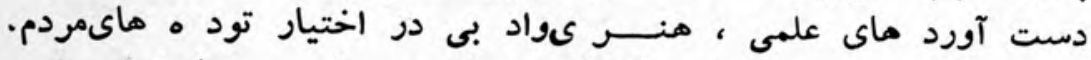

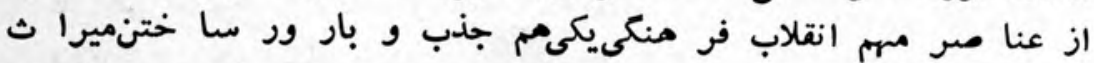

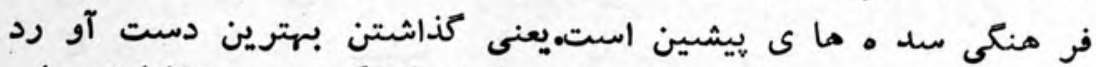

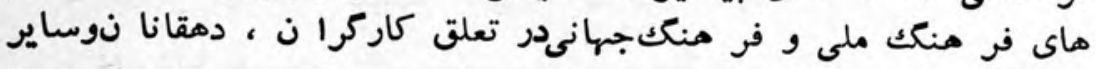

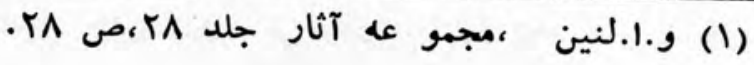




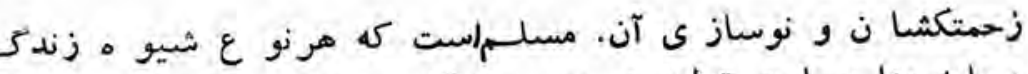

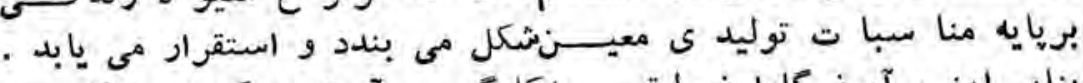

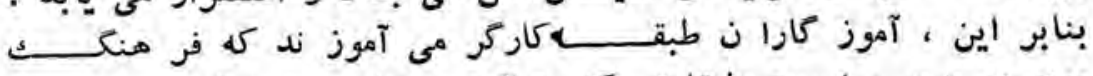

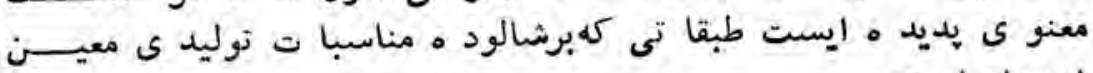

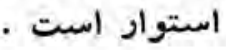

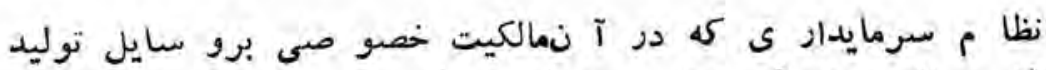

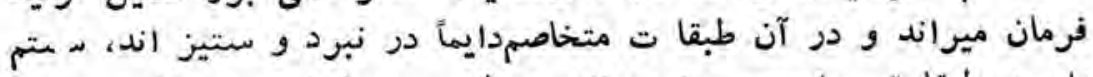

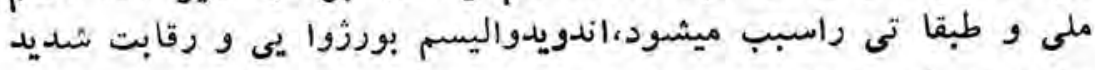

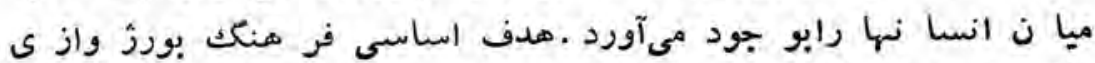

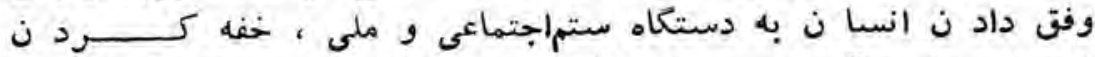

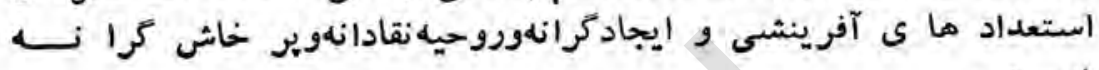

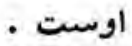

بورزواز ى باييرو ى ازذرو ح فــردمرايى ،منافع أنى يا آتى خودرامعيار

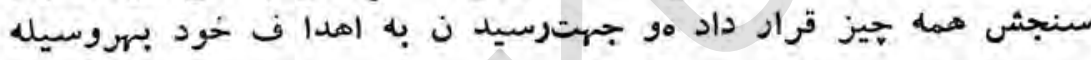

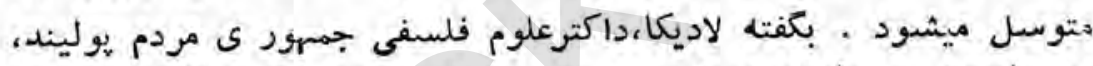

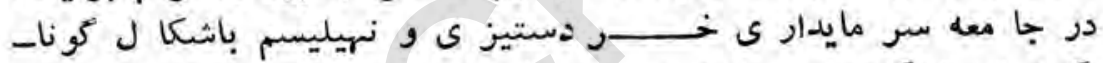

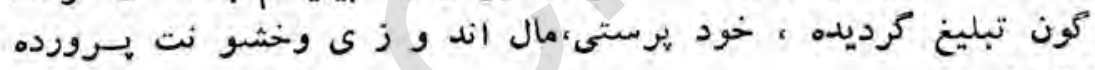
ميشود . مئمن

شارل فور يه از بنيانكــارا نمعرو ف في تفكر سونسيا ليسم تخيلى

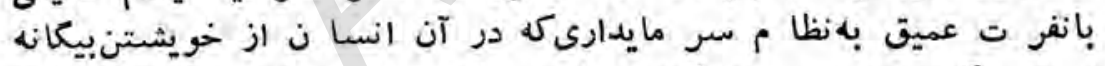

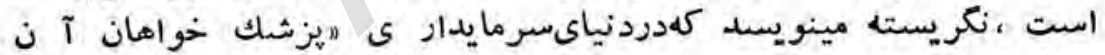

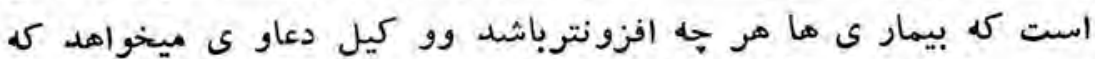

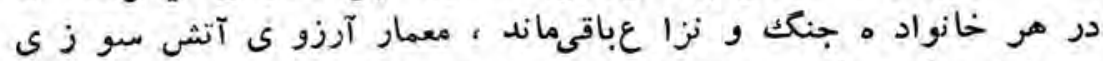

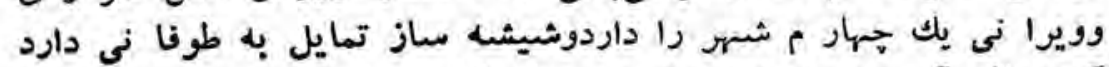

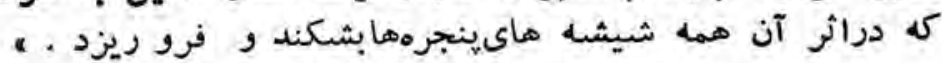

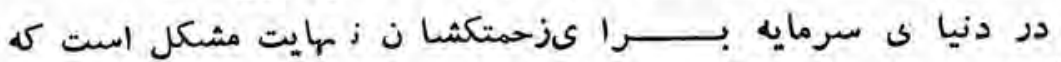

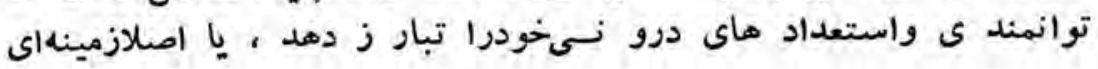


برا ىاينكا ر و جود ندارد.بو عكسطبقا ت حاكم ومالكا ن سيم و زردر

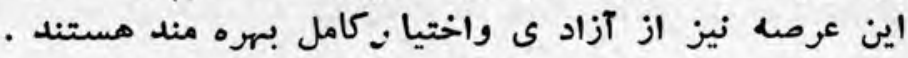

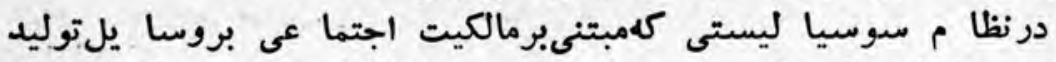

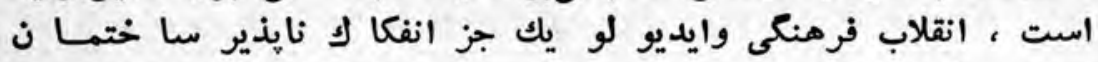

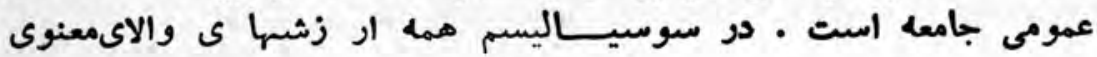

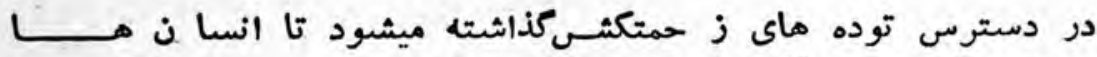

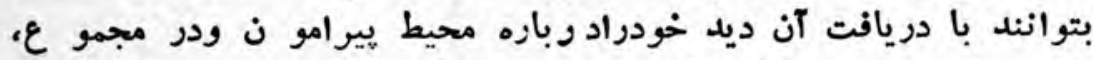

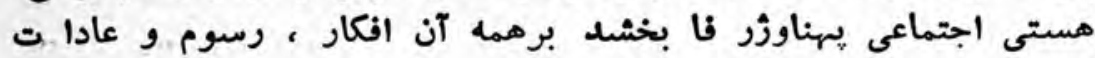

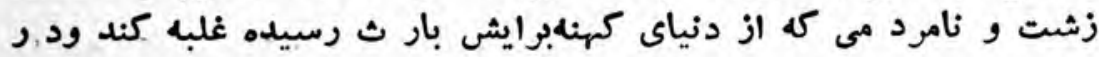

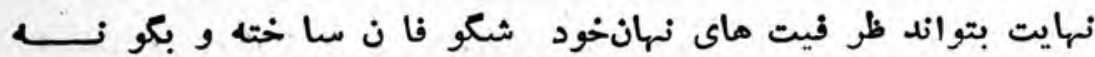

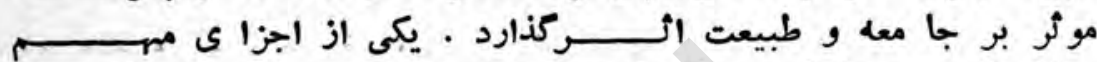

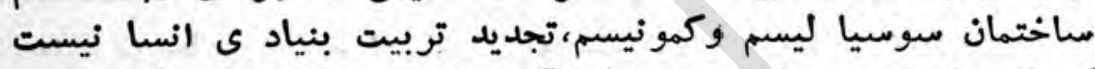

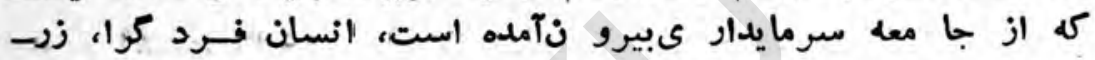

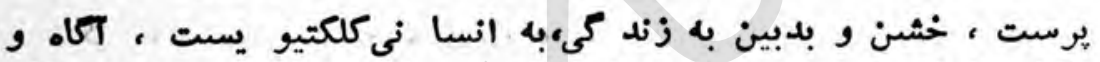

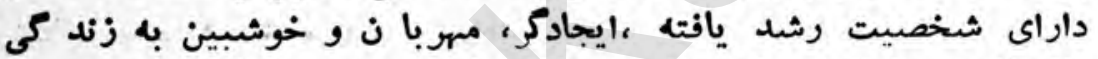

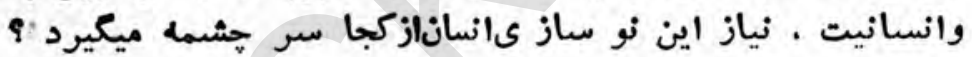

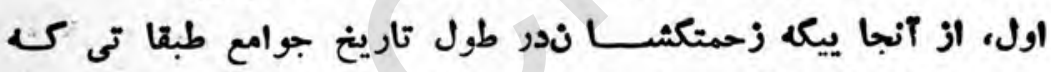

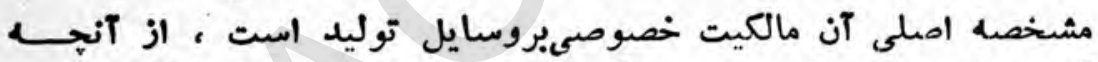

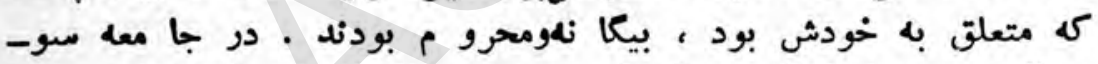

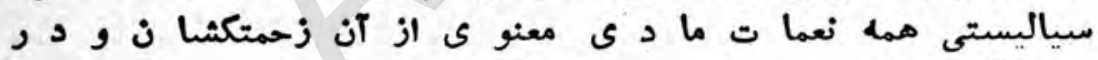

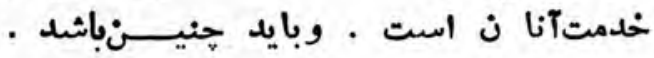

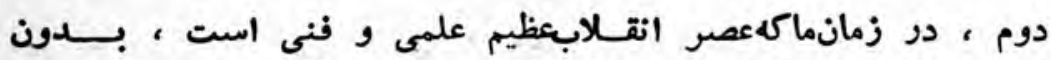

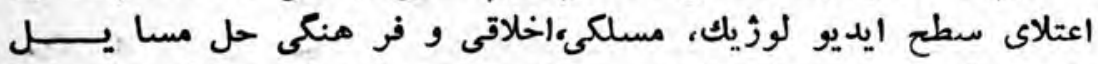

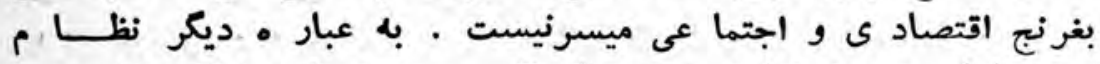

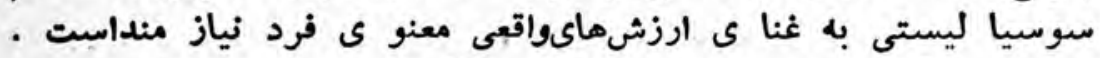

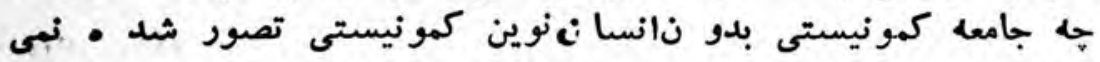

تواند .

-rII_ 


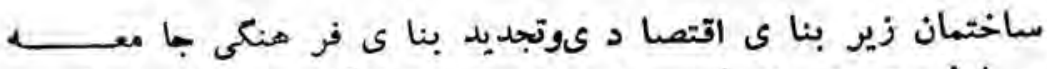

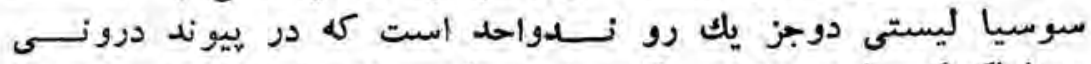

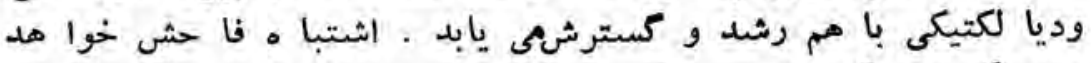

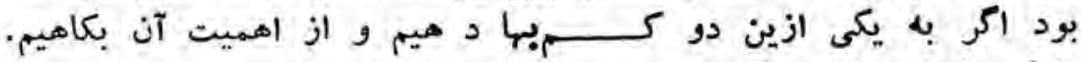

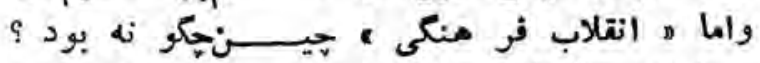

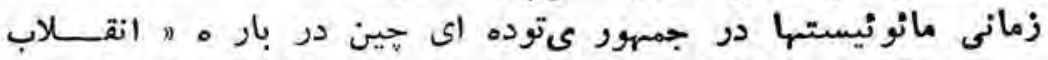

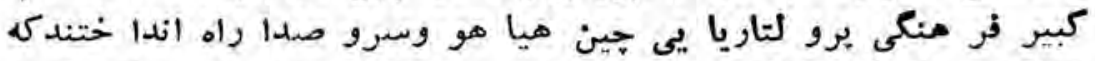

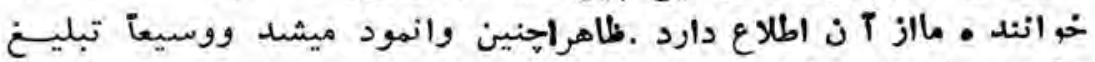

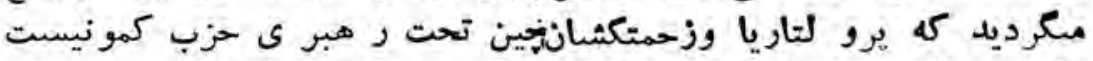

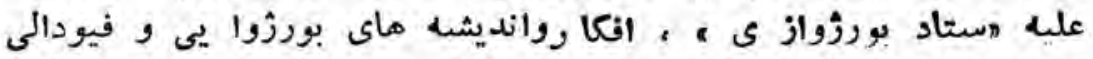

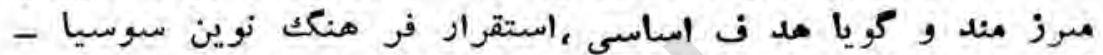

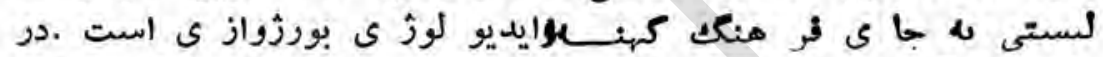

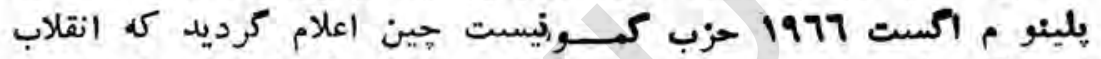

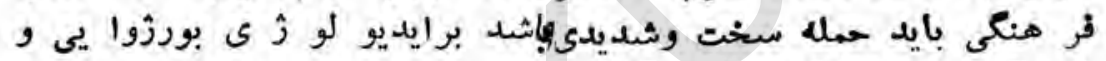

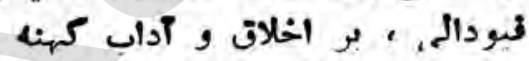

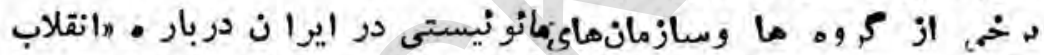

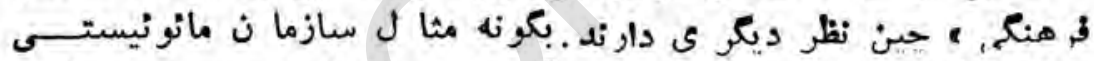

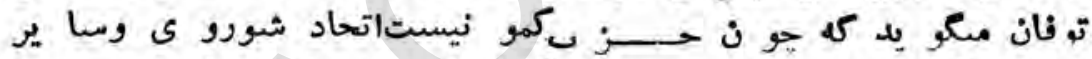

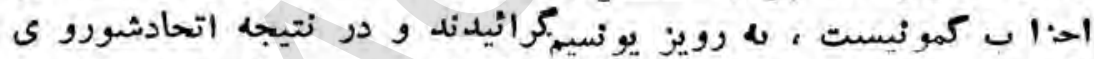

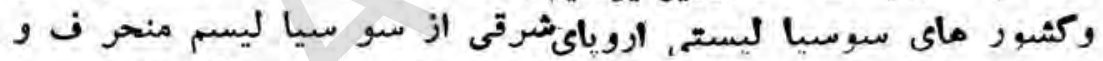

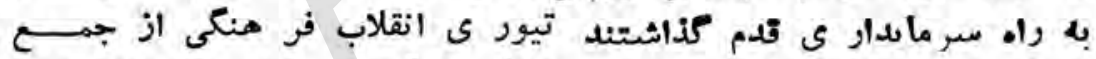

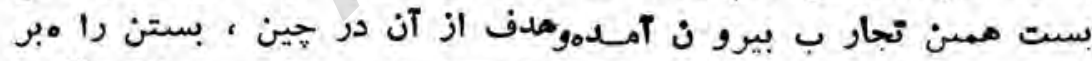

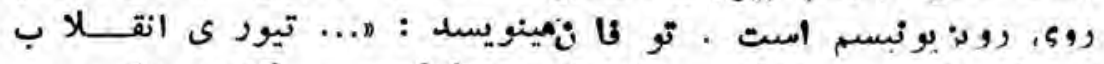

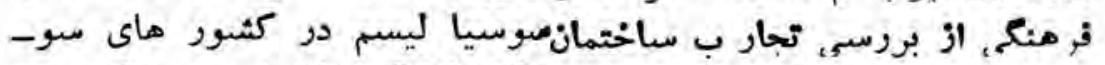

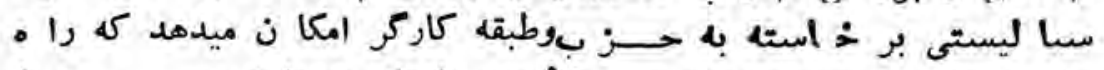

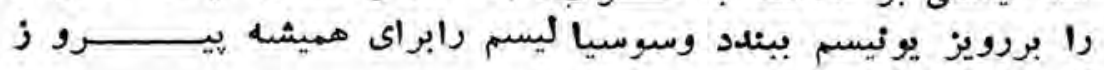
(1). كرداند

(1) فا ن ، , رويز يونيسم دوتيور ى و در عهل ه. 


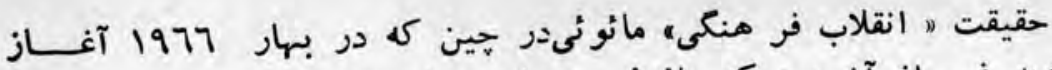

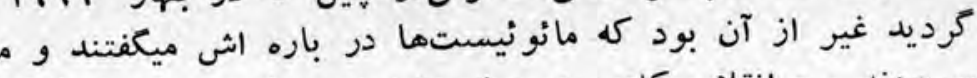

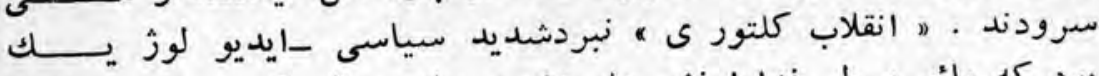

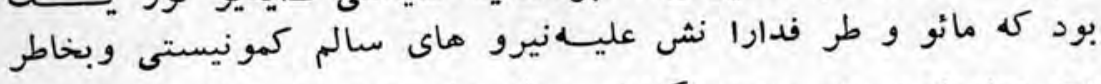

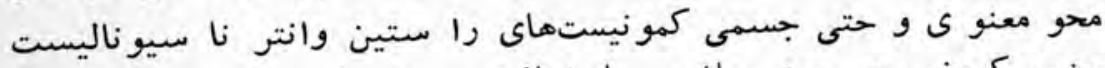

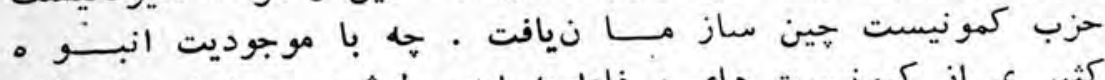

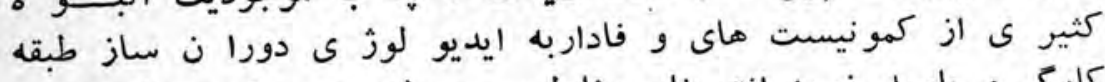

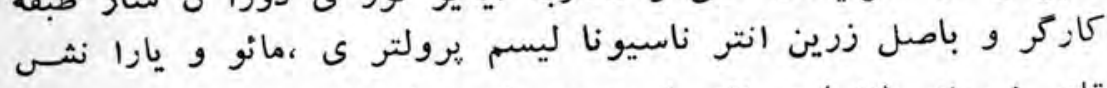

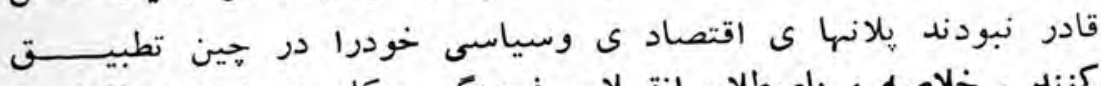

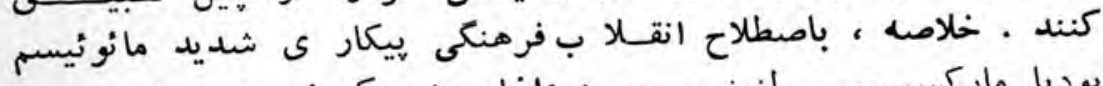

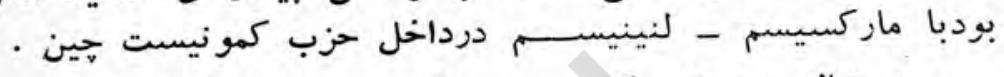

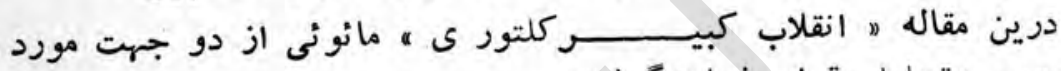
برزسى وتحليل قرار خوراهدكرفت:

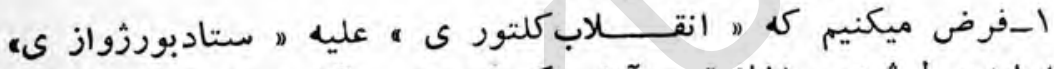

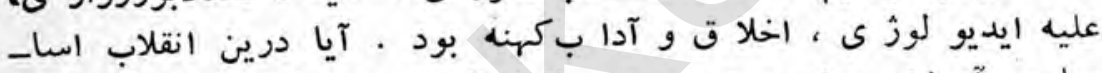

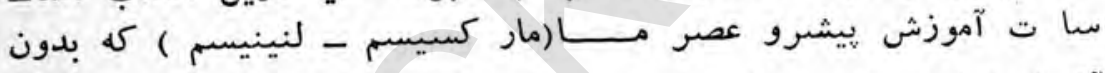

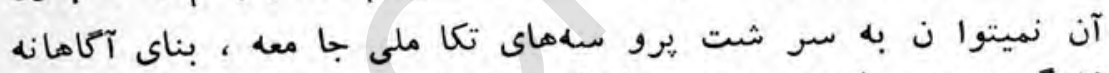

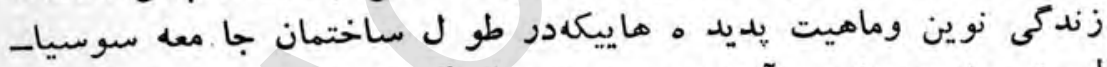

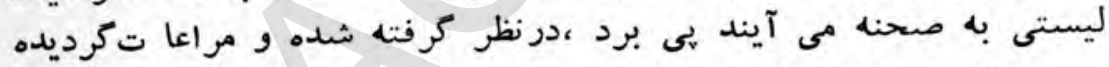

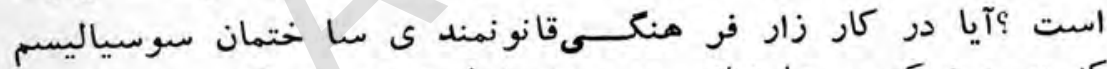

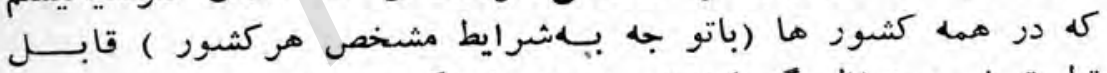

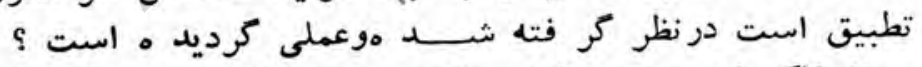

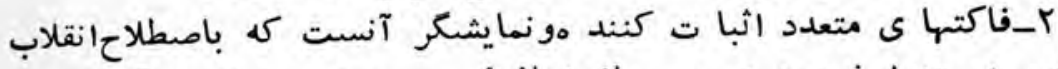

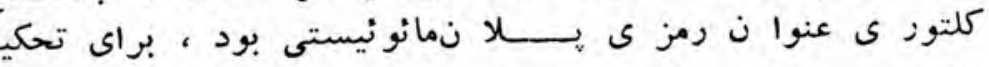

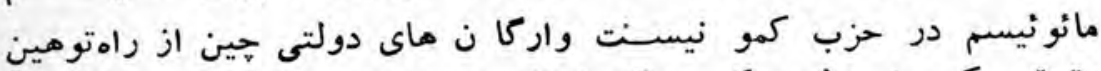

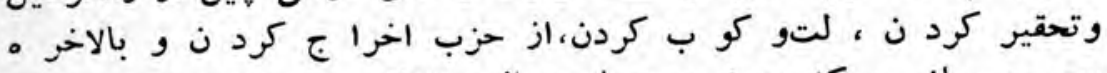

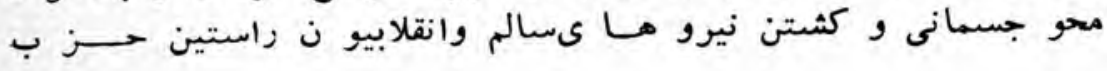


كمونيست جين ، فرا هم آو ر ى.زمينها جهت ترويج وكسترش مائو-

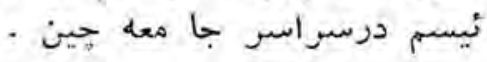

*

米

米唡

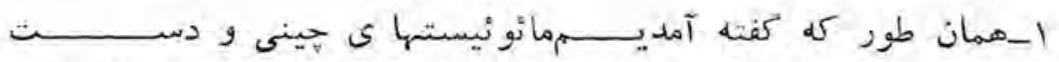

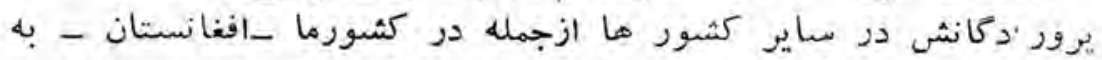

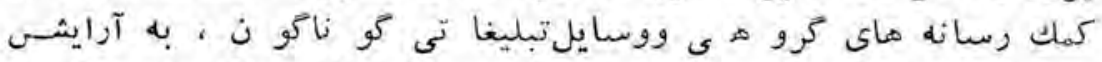

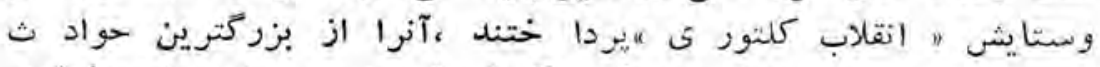

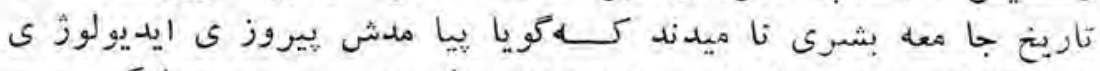

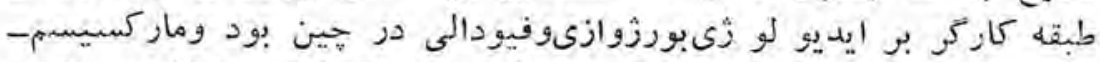

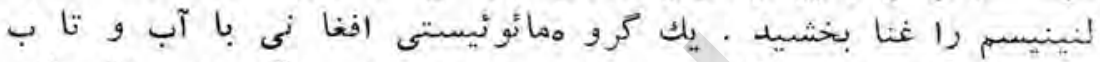

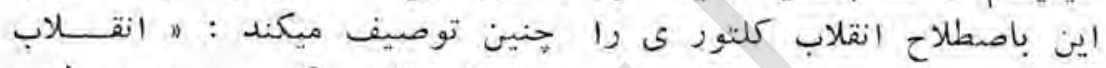

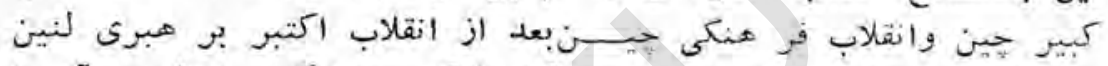

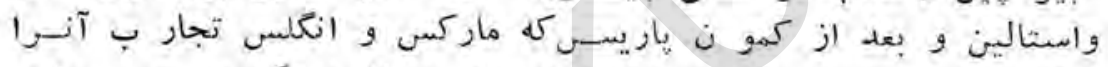

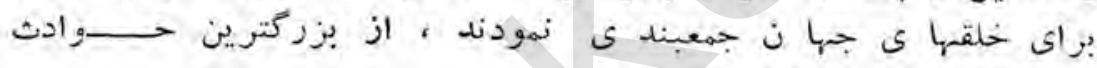

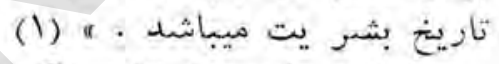

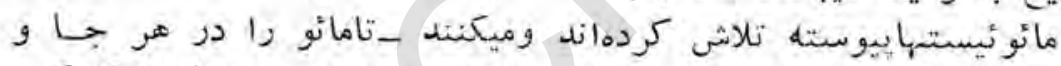

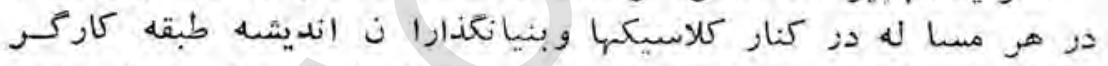

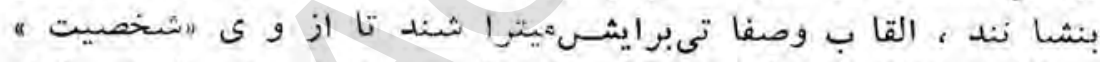

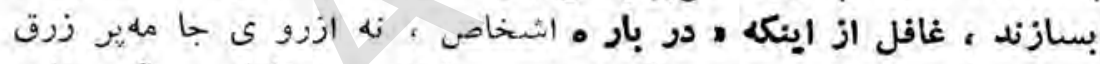

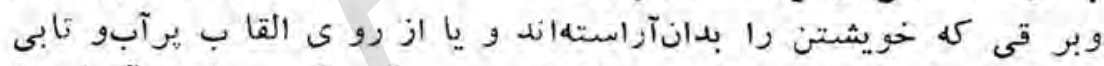

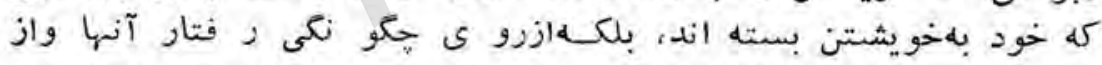

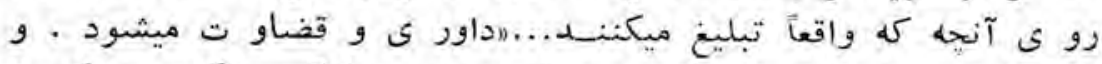

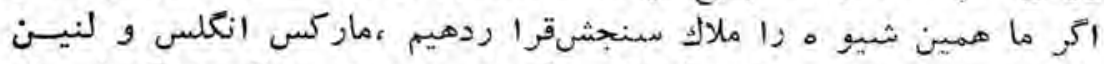

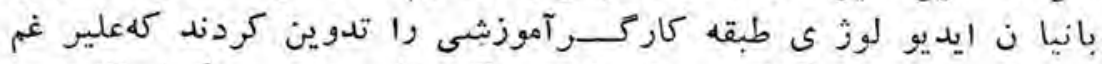

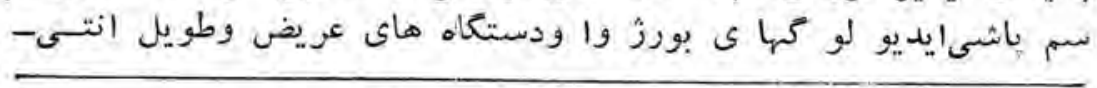

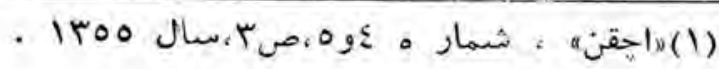
$-\mathrm{HIS}$ 


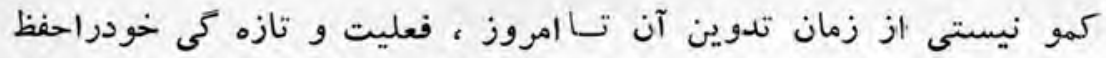

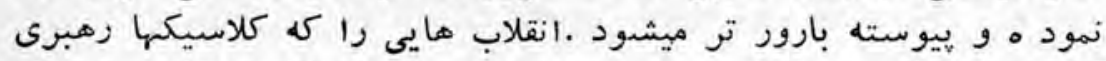

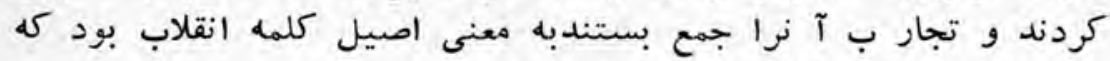

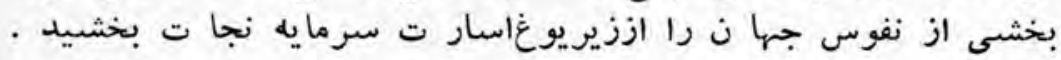

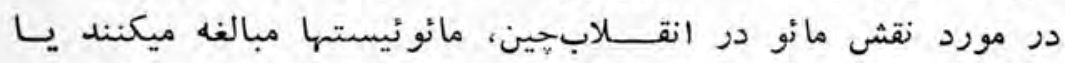

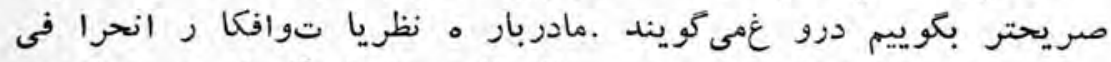

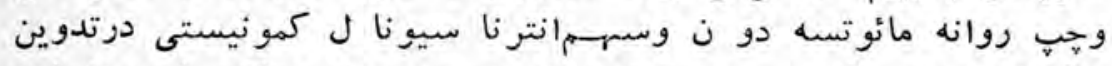

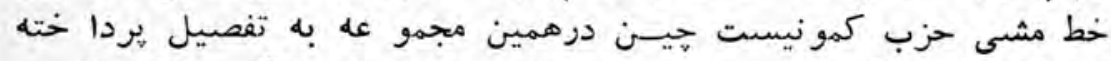

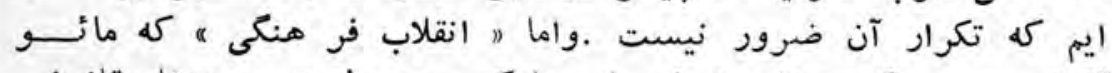

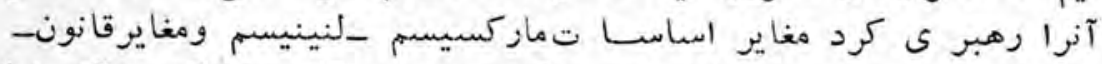

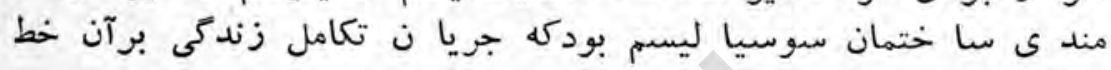

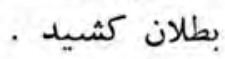

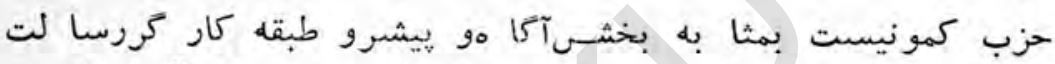

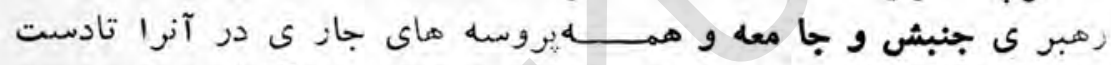

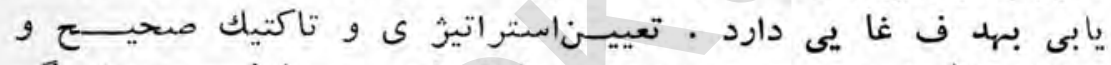

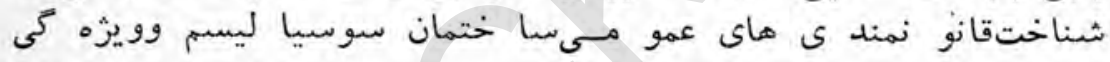

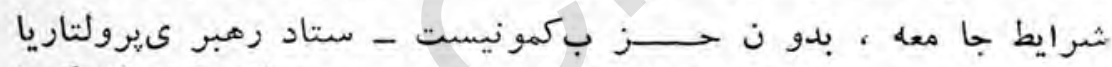

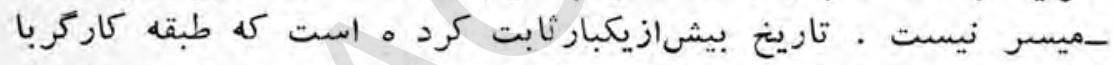

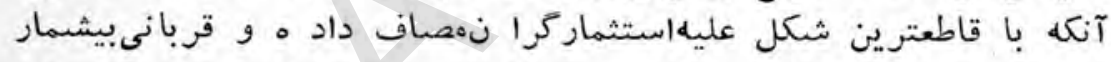

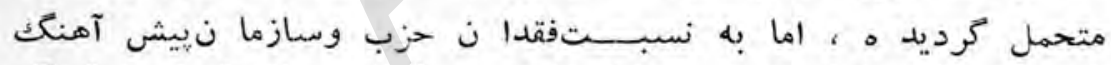

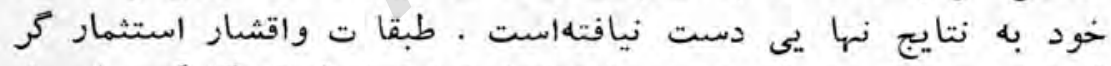

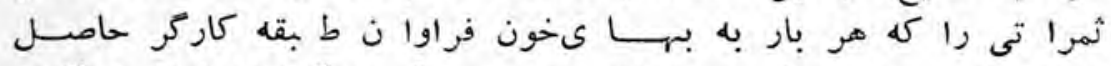

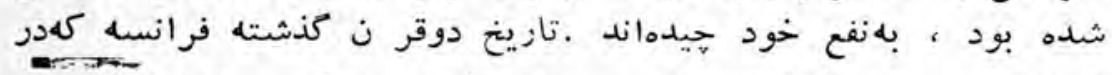

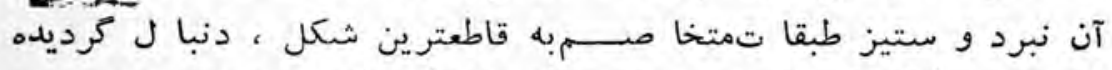

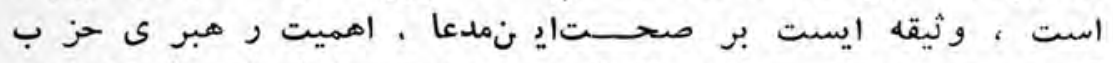

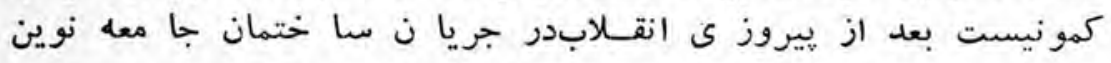

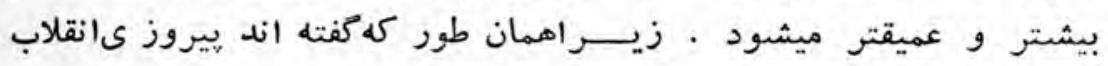




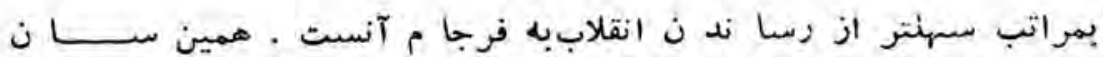

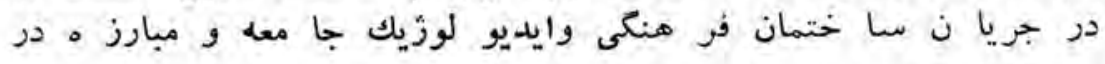

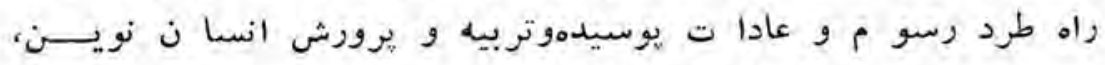

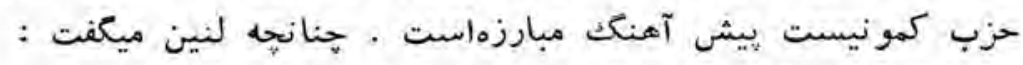

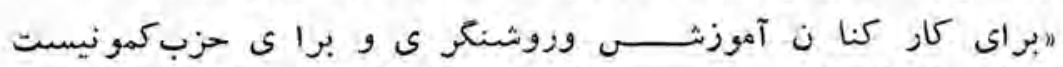

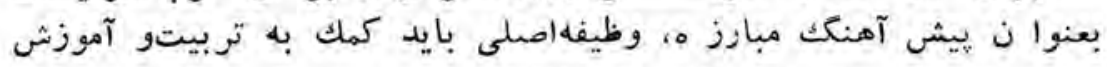

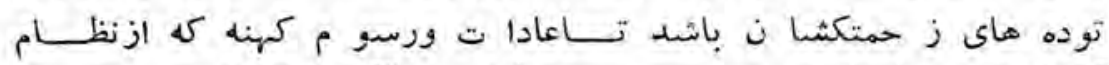

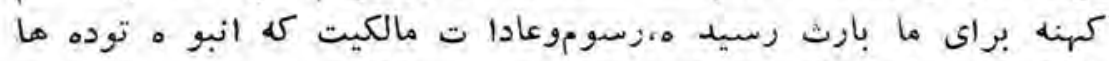

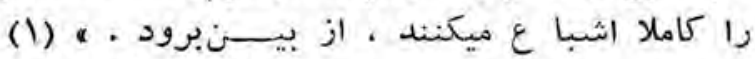

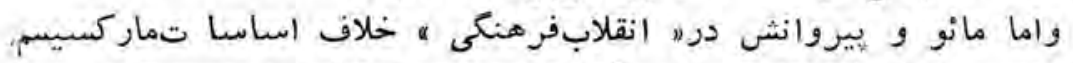

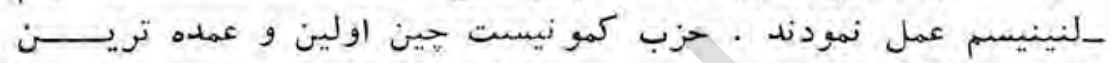

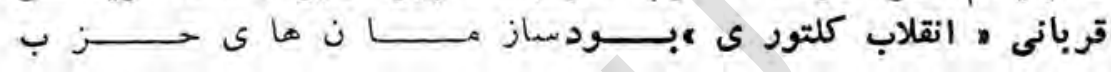

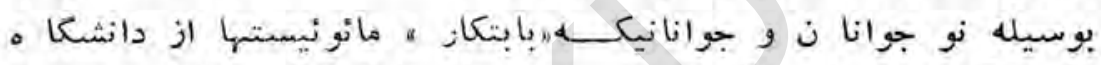

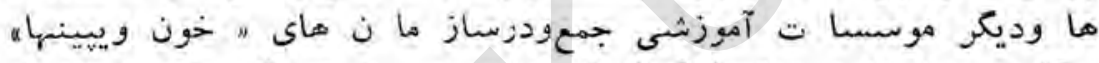

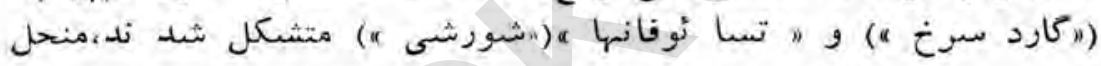

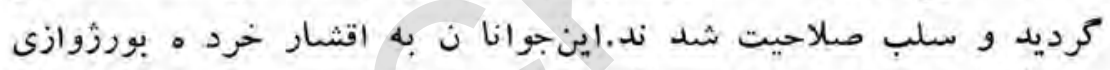

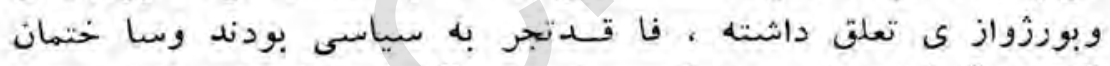

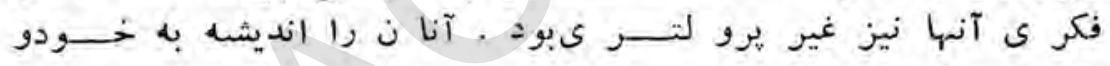

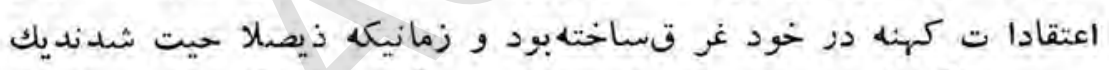

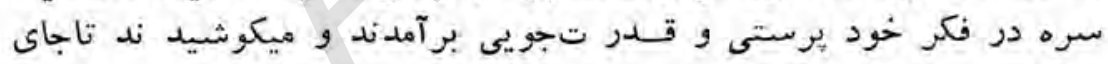

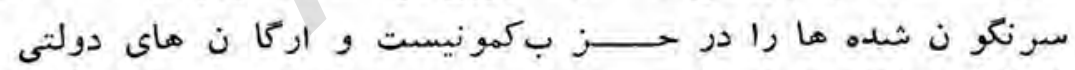

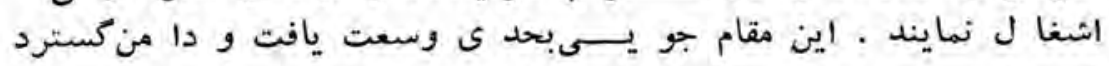

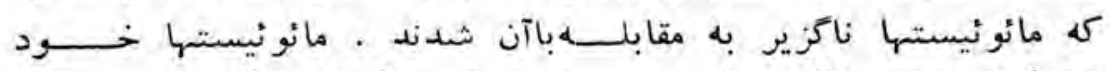

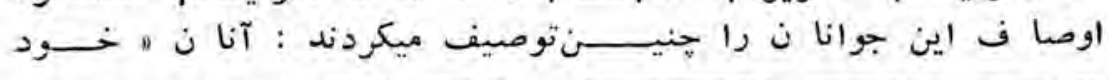

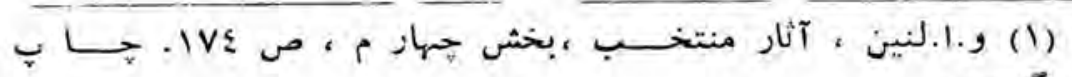

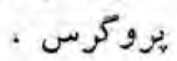




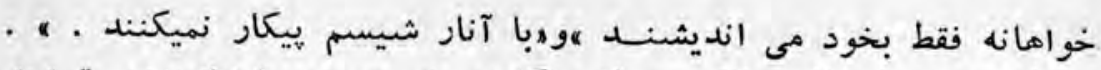

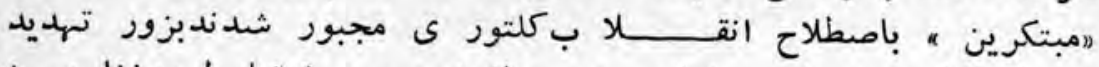

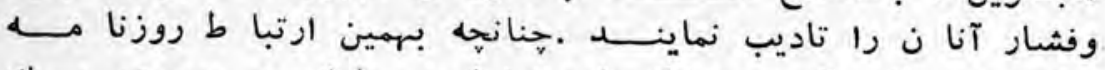

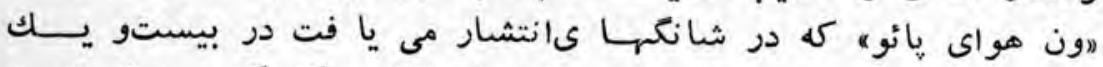

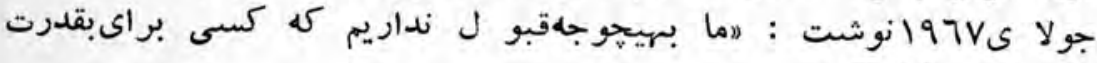

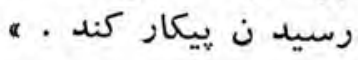

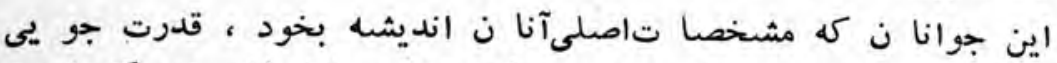

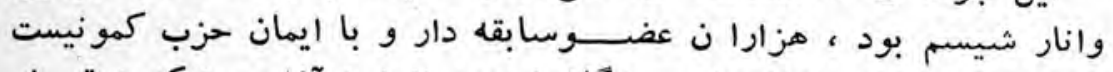

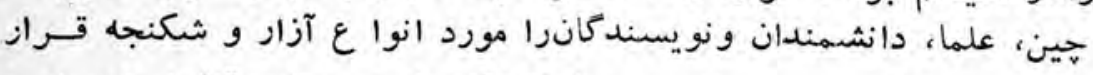

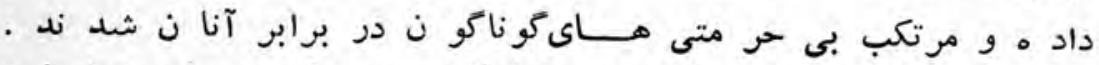

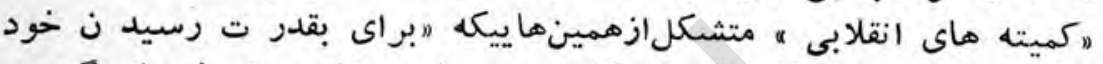

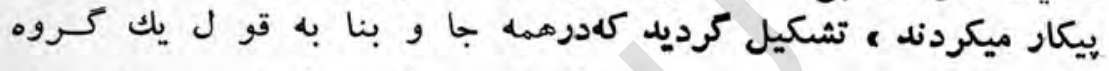

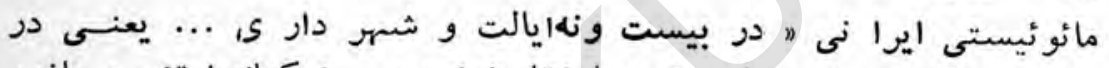

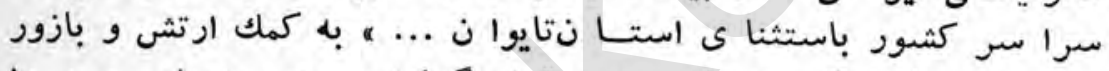

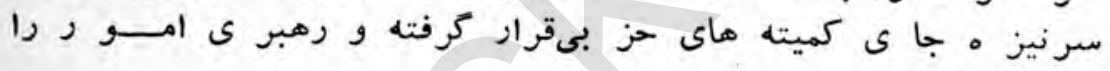
غصب كردند .

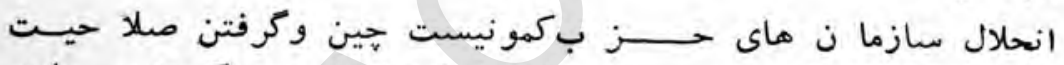

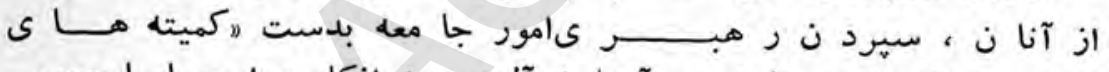

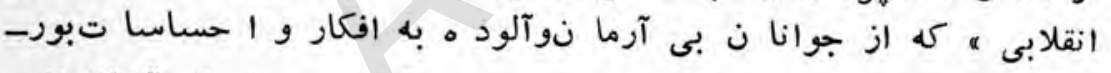

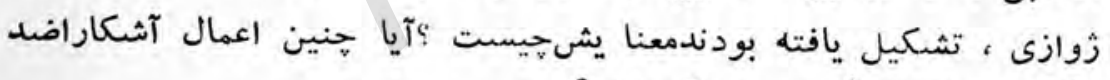

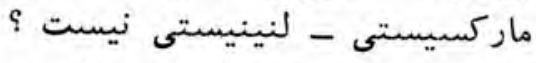

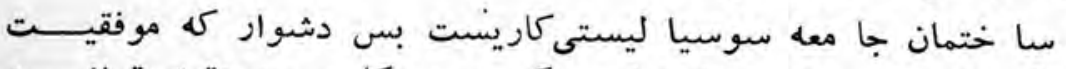

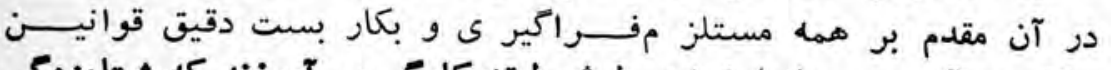

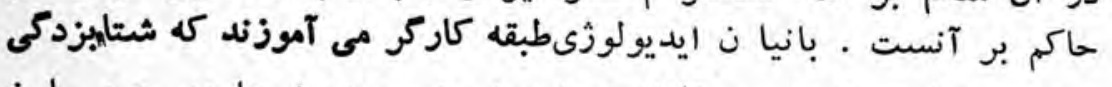

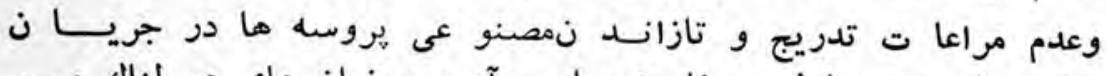

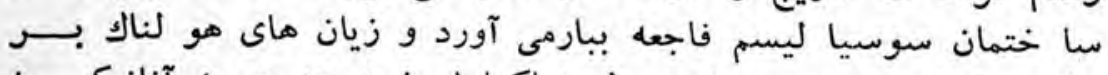

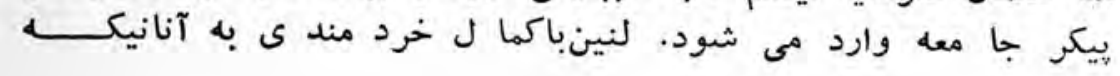




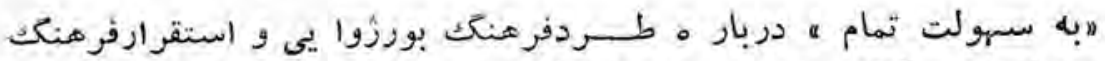

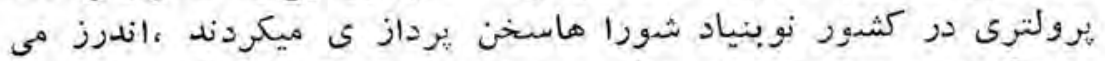

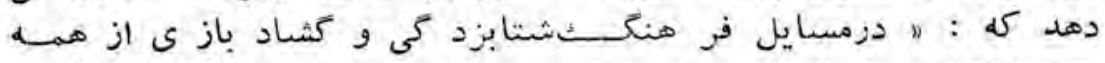

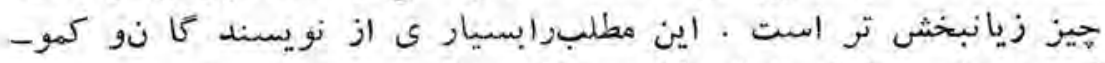

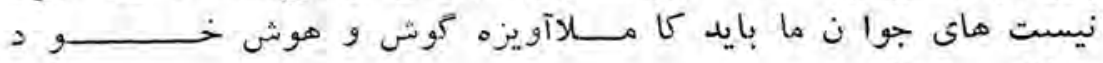

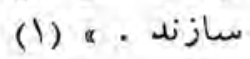

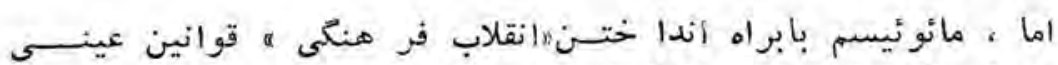

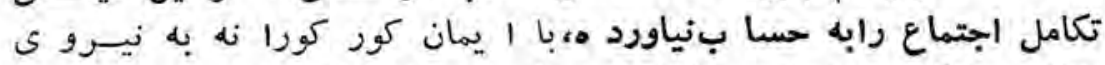

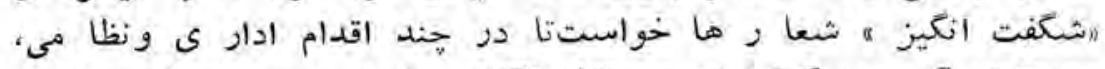

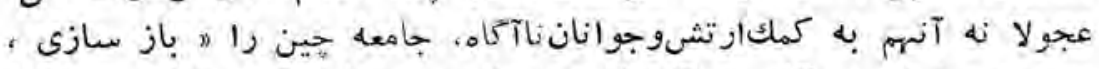

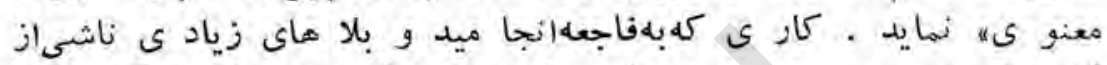

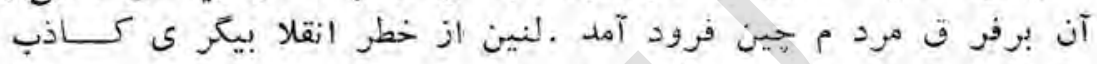

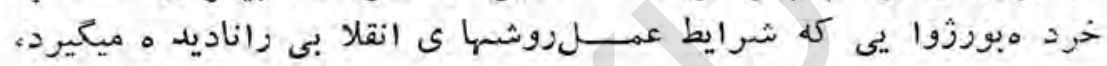

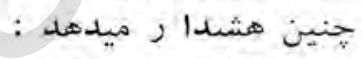

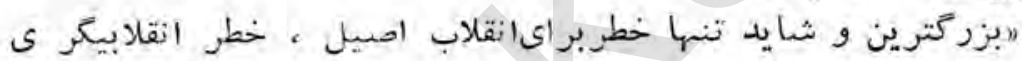

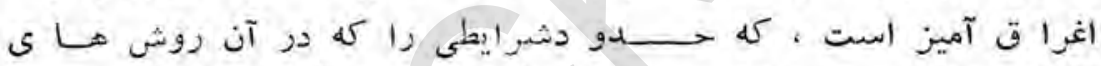

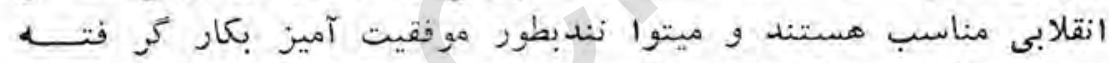

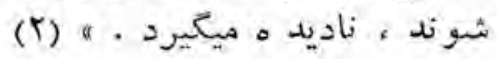

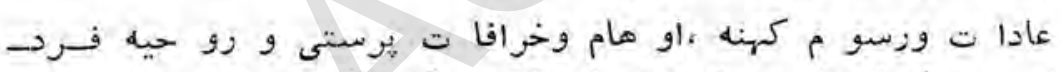

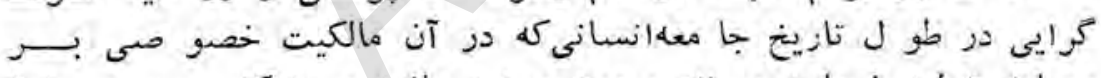

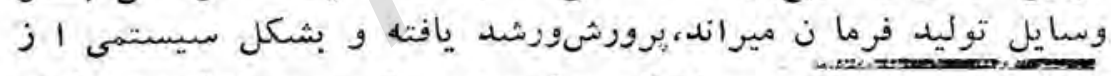

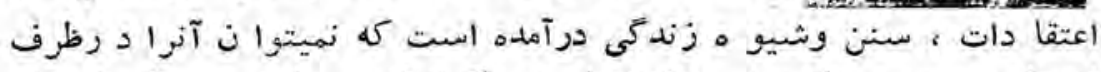

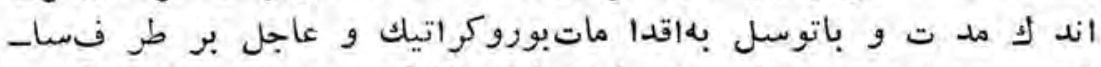

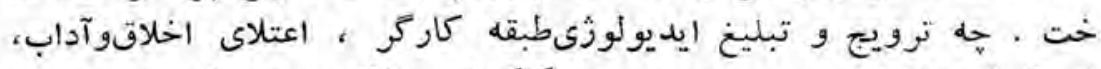

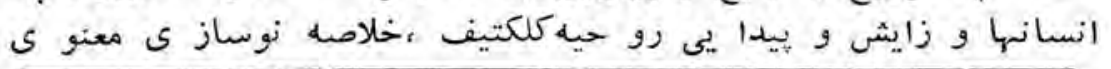

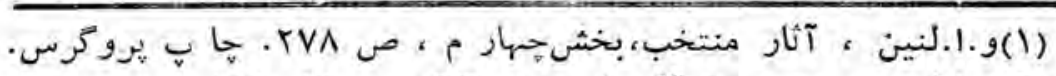

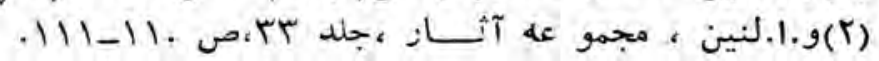




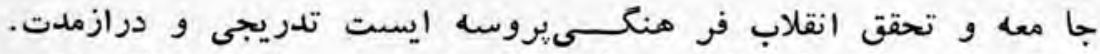

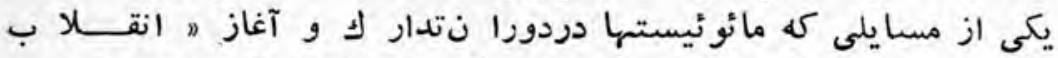

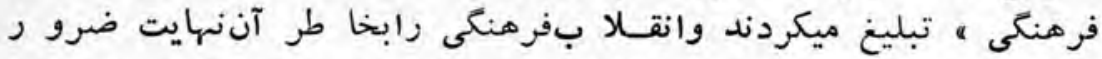

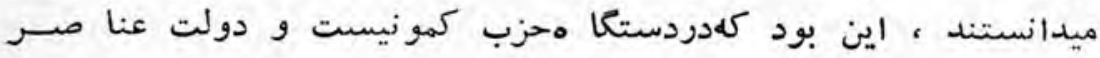

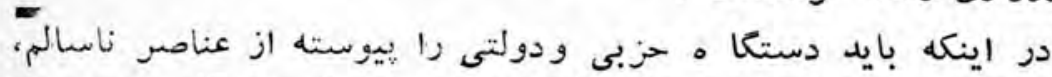

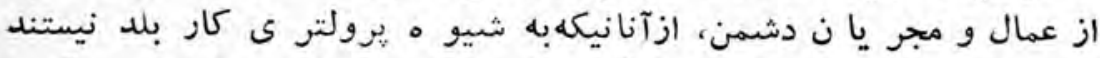

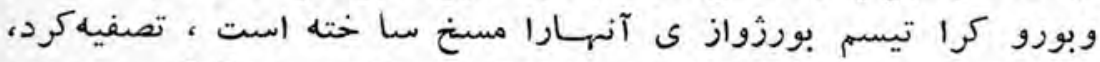

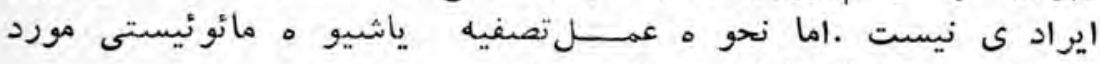

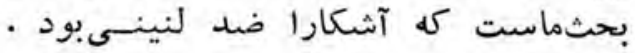

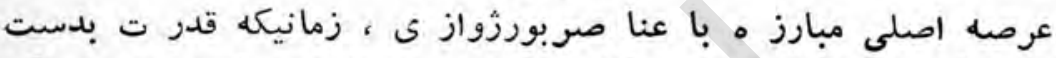

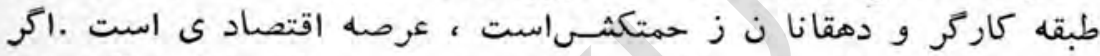

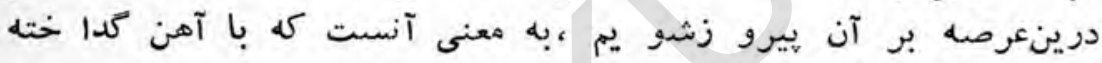

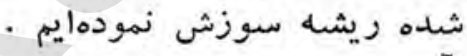

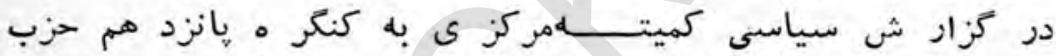

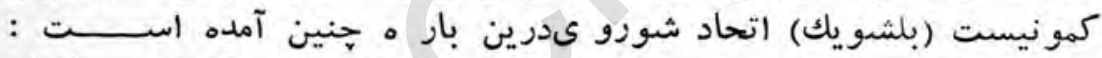

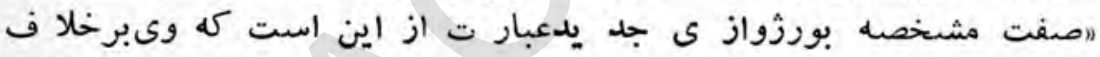

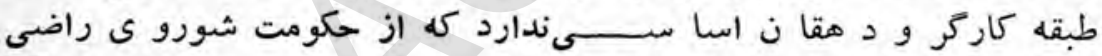

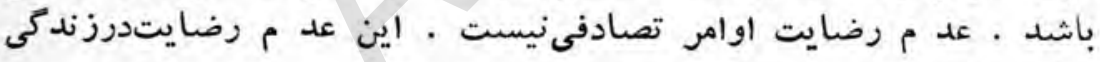
ريشه دارد . ماثل

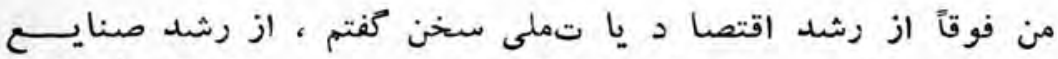

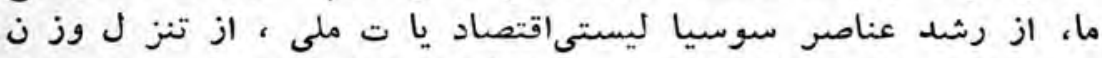

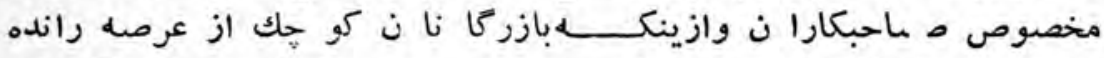

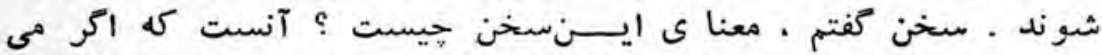

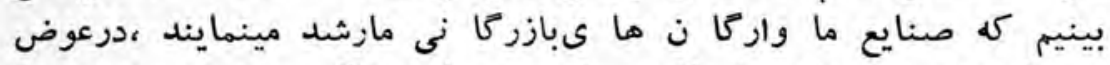

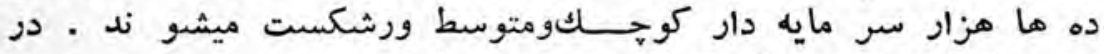

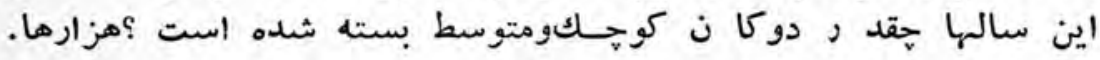




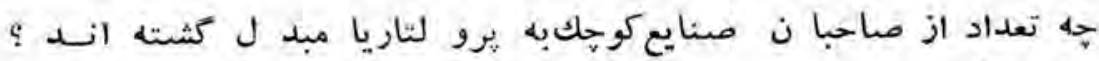
هزار ها تعداد ان صاع

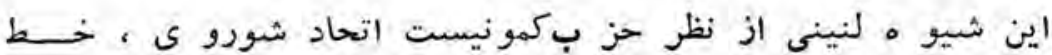

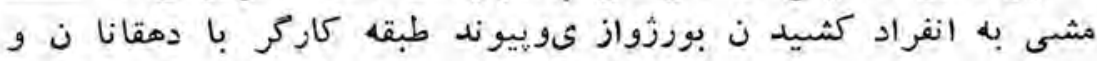

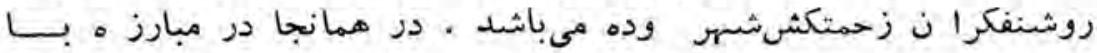

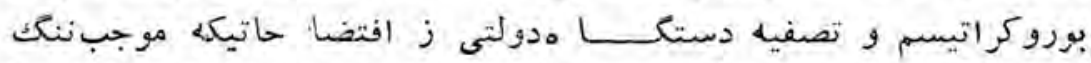

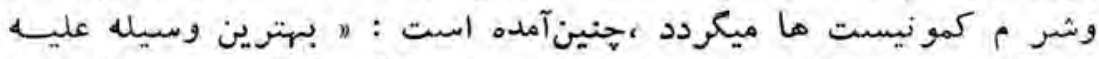

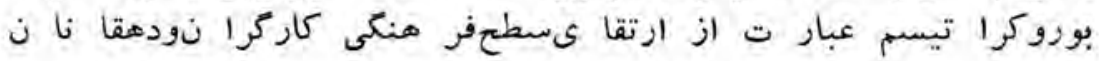

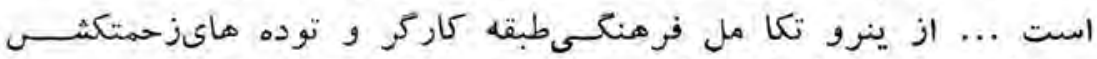

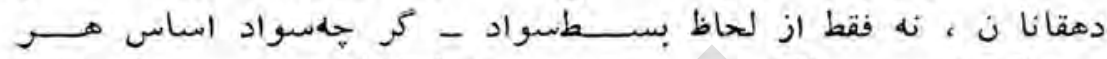

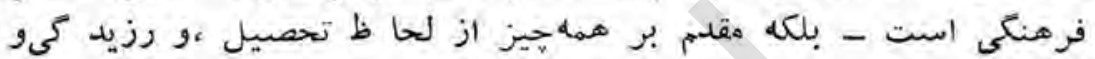

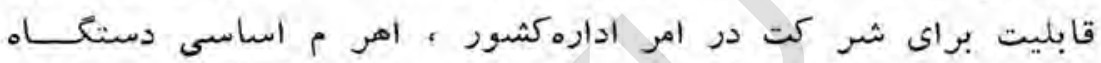

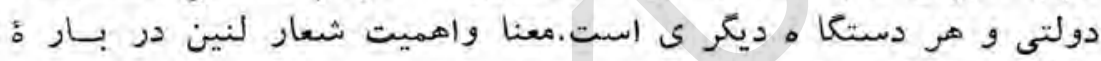

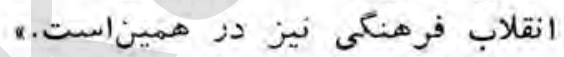

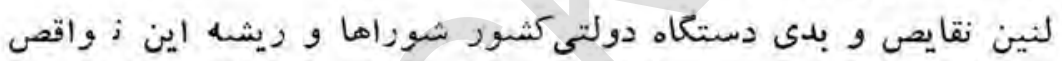

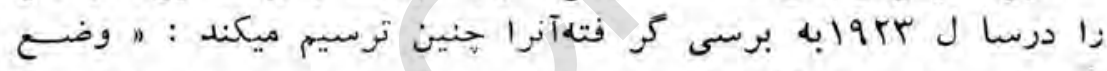

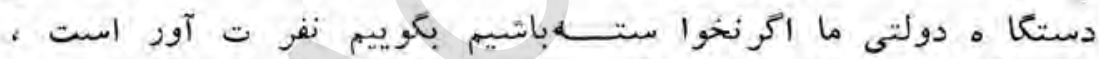

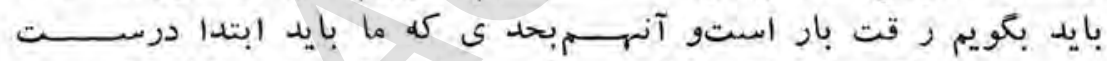

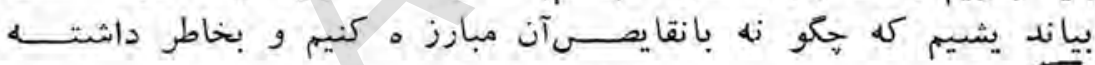

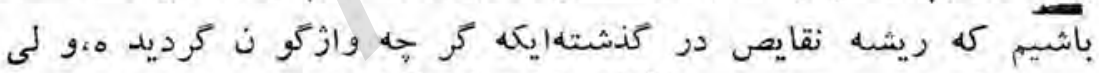

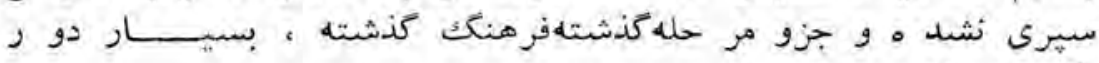

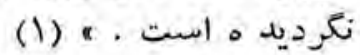

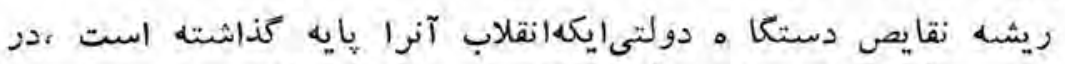
كذشته وازكو ن شده است كمهنوزاز مابسيار دور نكرديد هـ ودر نتيجها

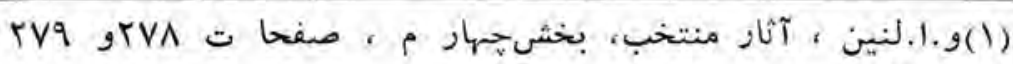
حاب يُور كرس ، 


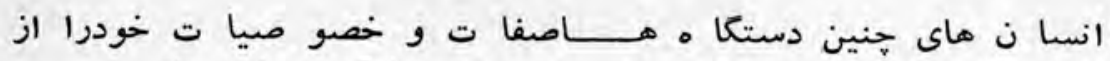

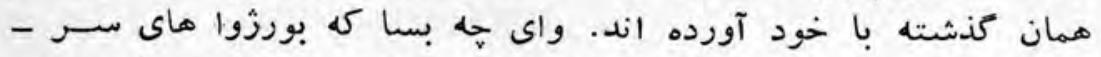

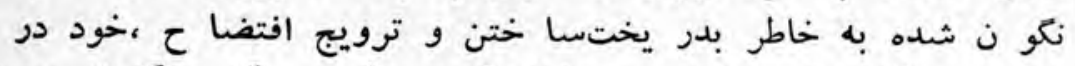

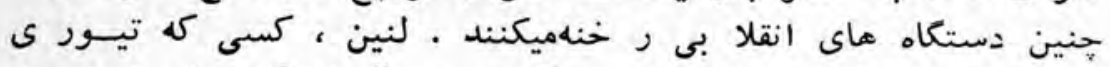

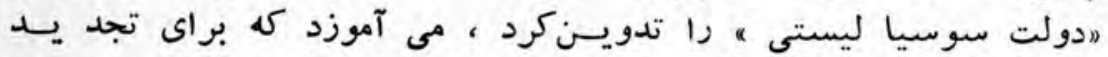

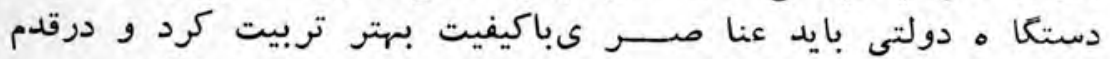

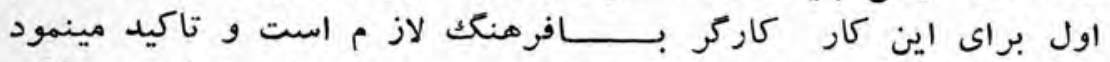

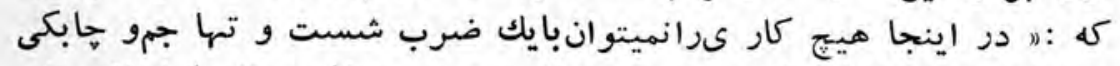

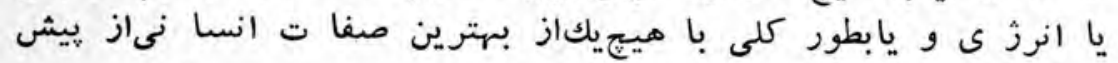
(1) برد ان (1)

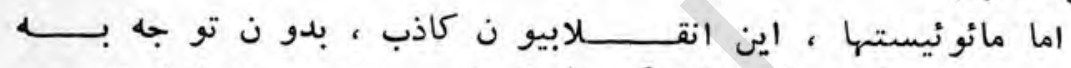

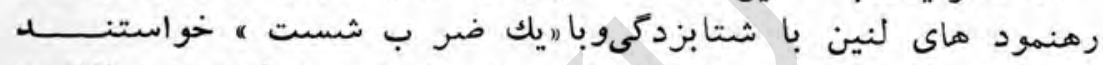

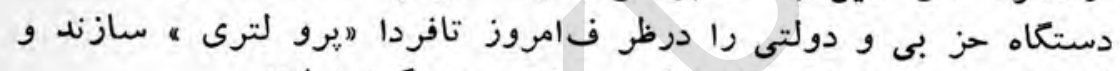

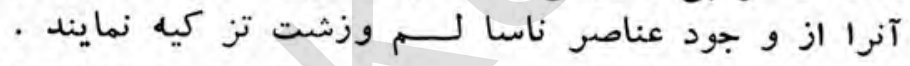

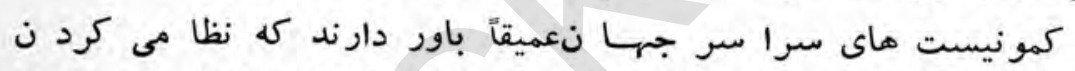

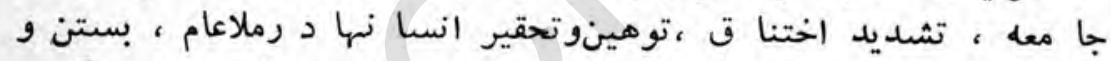

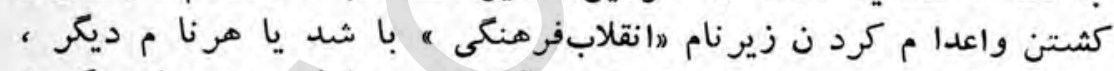

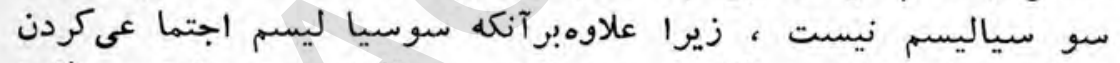

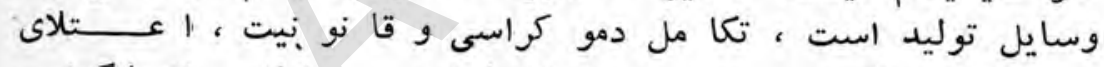

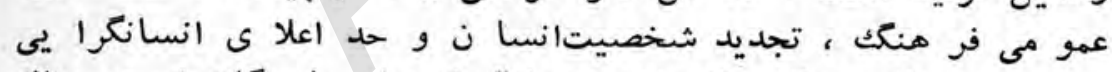

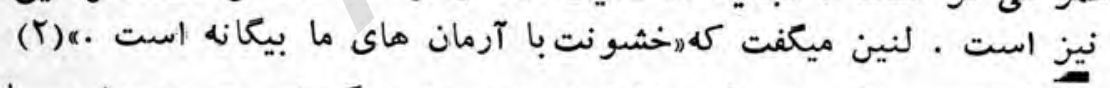

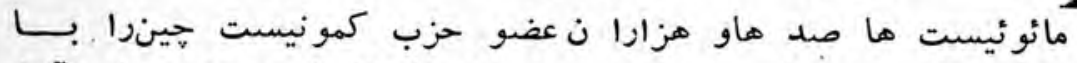

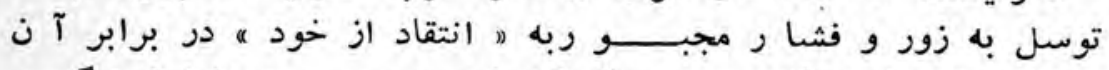

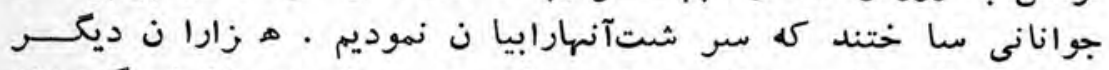

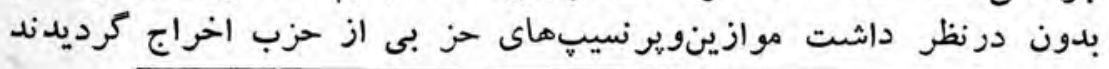

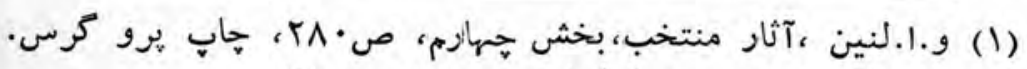

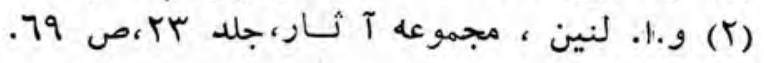




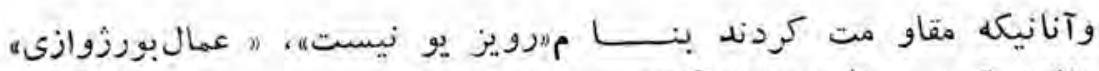

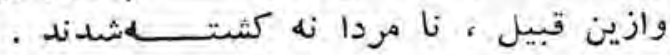

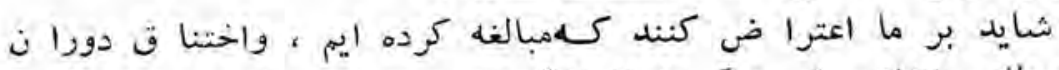

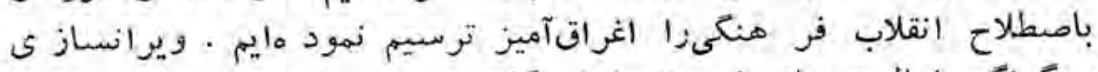

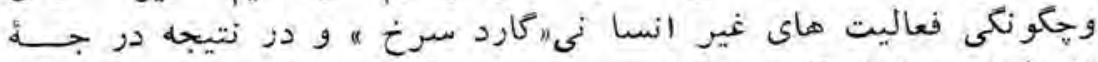

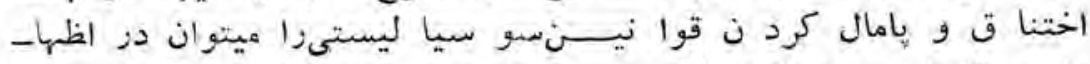

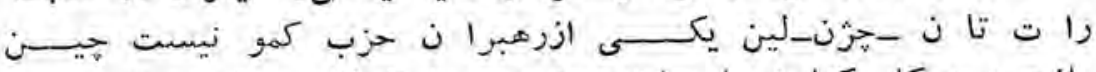

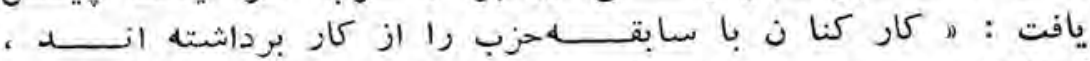

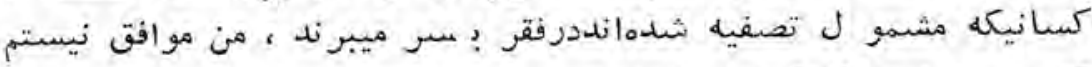

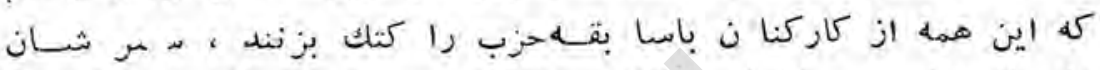

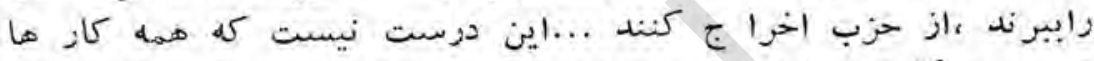

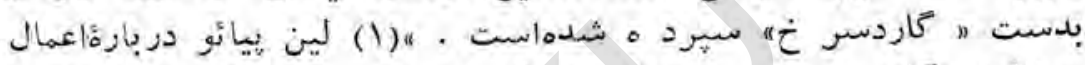

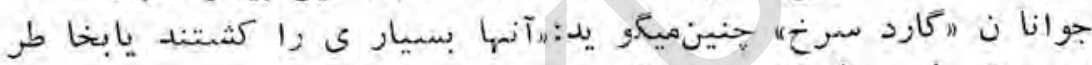
اهر حق يا بر أثى اشتباهنه

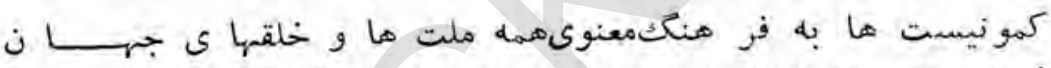

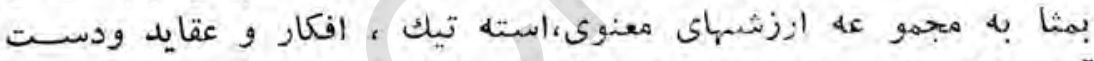

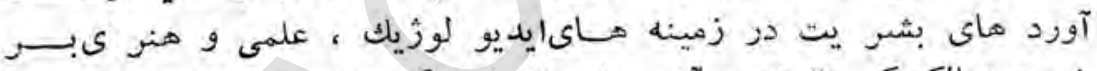

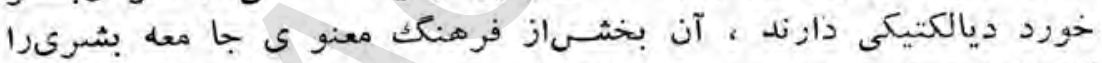

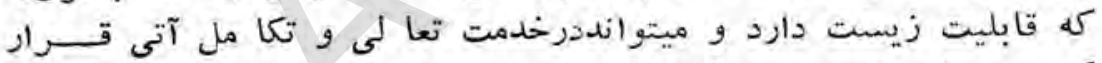

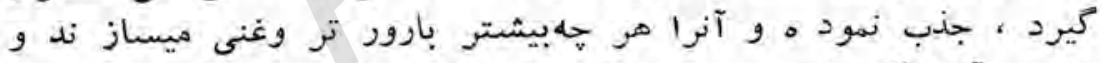

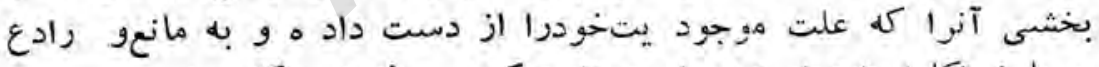

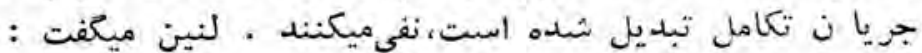

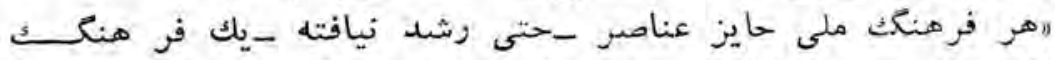

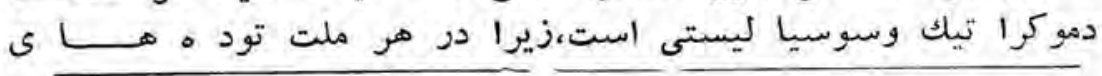

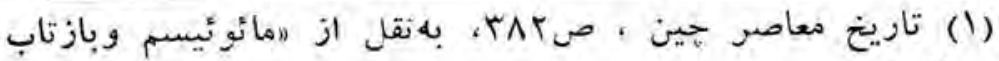
آن درايران ه ه . .

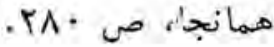


زحمتكش و استشمار شده و جود دارند كه شرايط زندكى شا نبطور

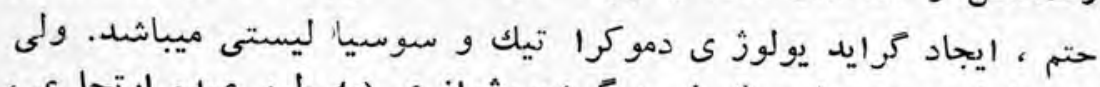

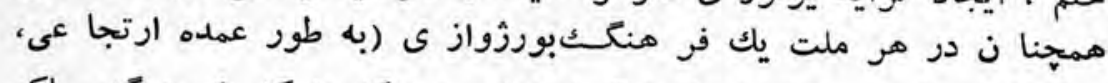

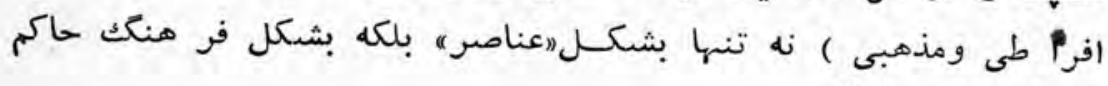

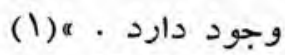

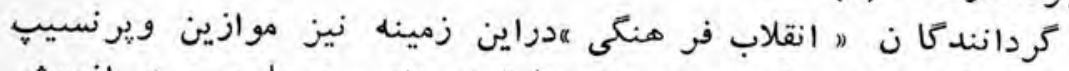

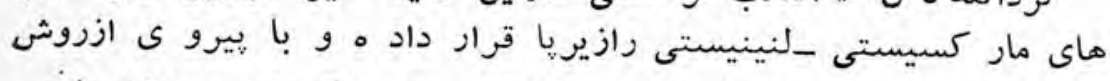

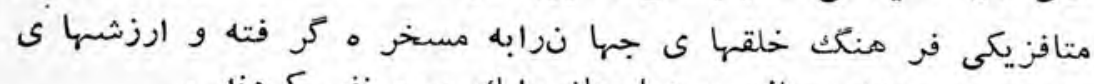

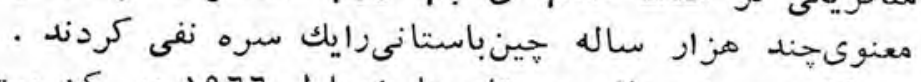

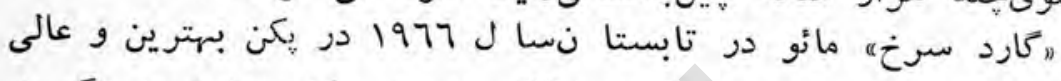

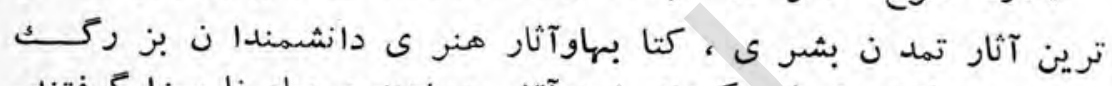

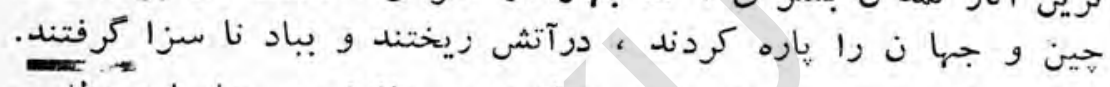

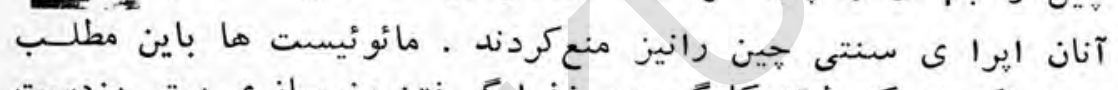

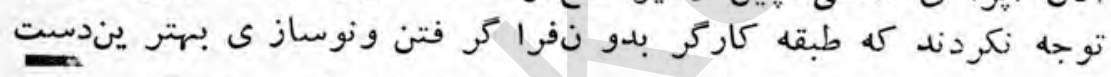

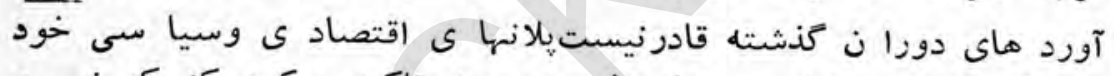

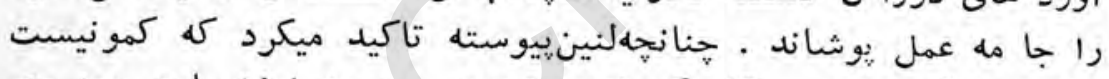

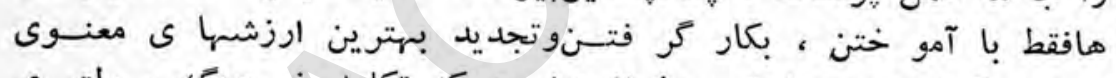

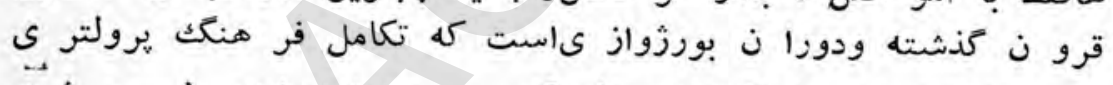

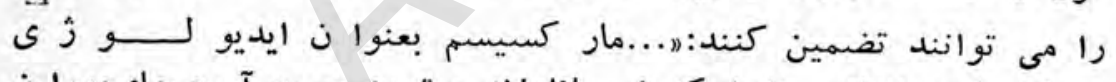

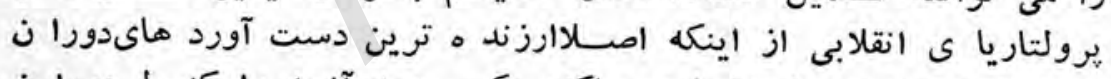

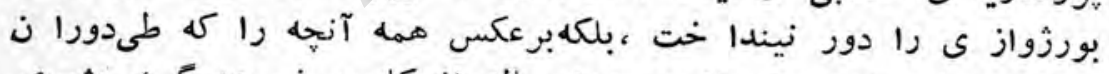

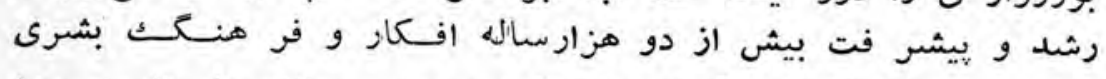

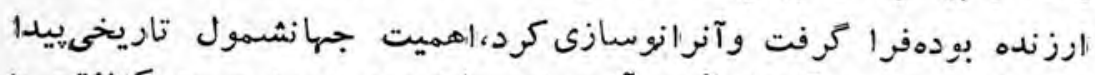

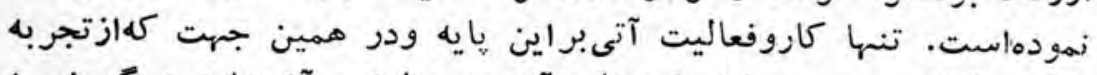

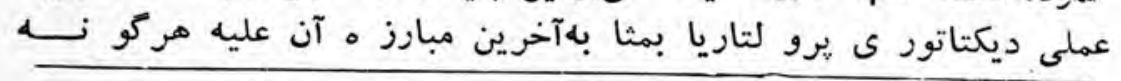

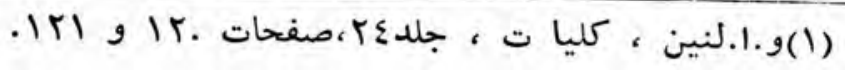




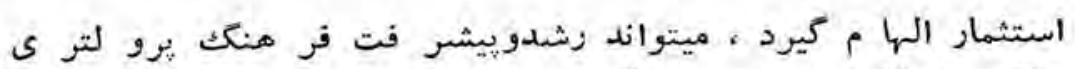

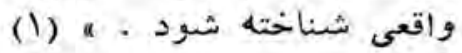

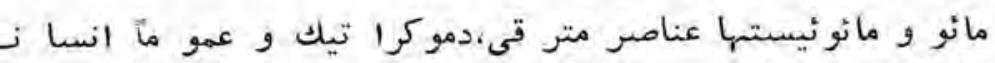

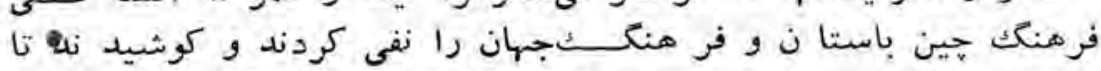

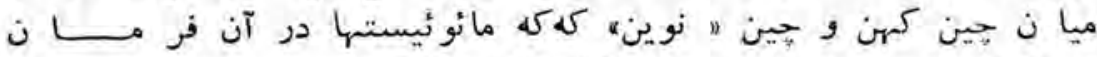

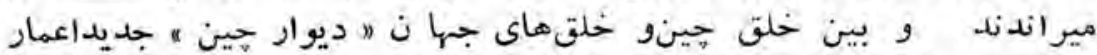

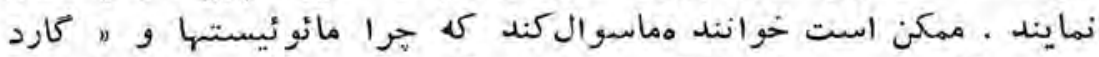

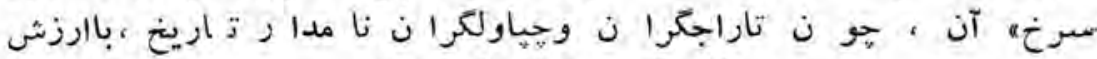

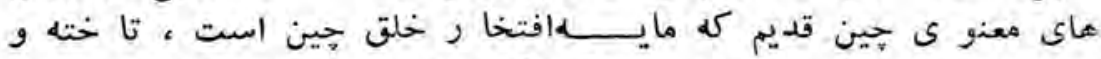

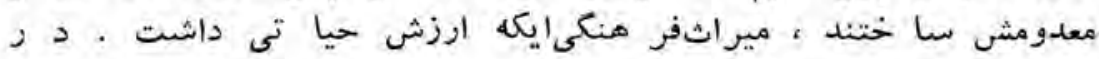

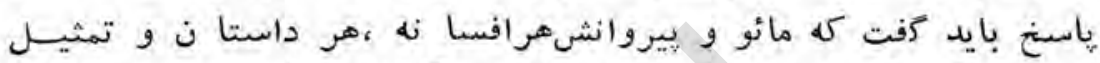

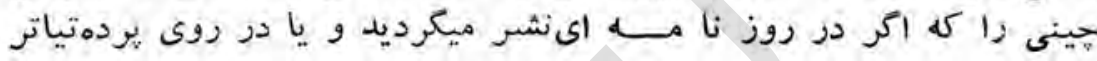

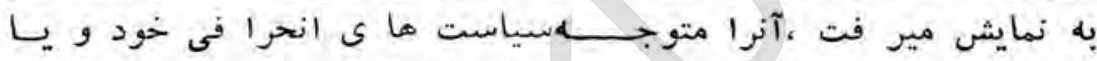

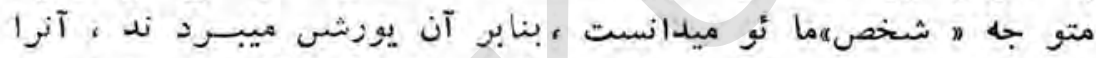

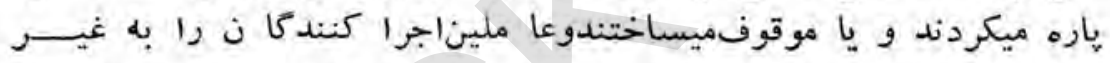

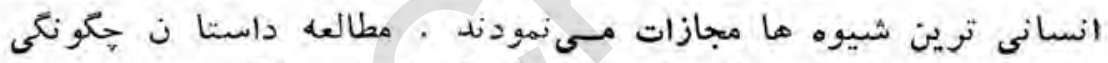

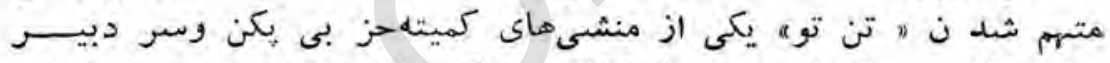

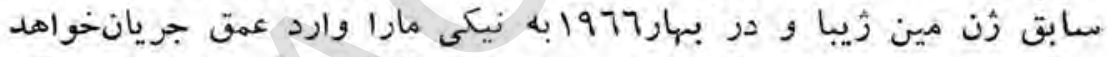

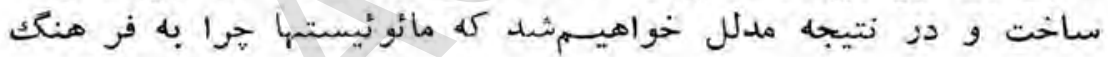

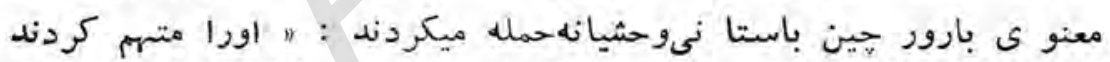

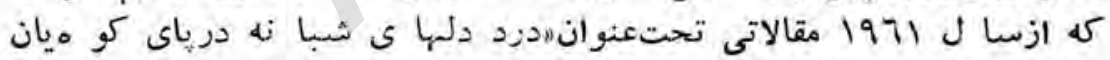

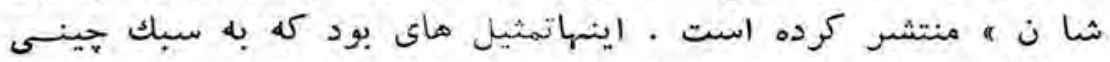

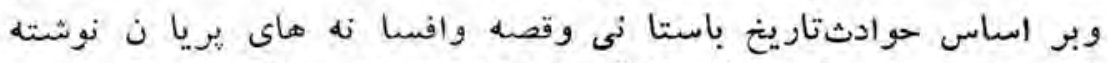

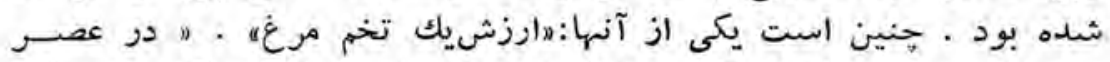

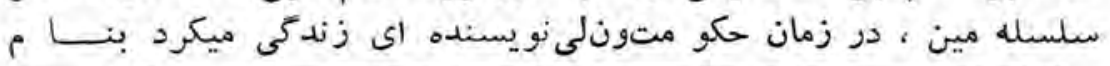

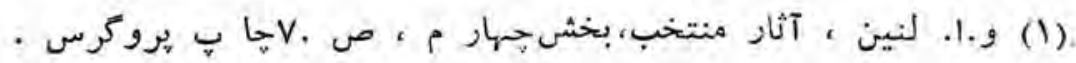


جيان اين هى. درمجموعه قصه ما ىاوبنا م رقصه ماى سو تانوه جكايت $\rightarrow$ زير ذكر شده است : زئ

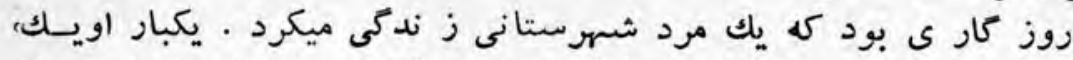

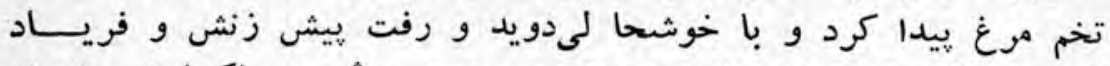

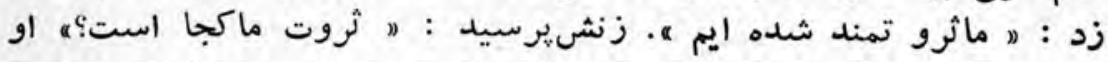

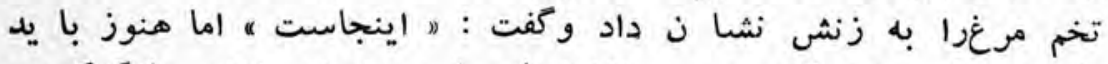

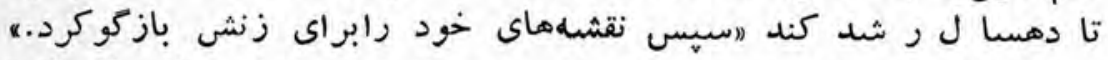

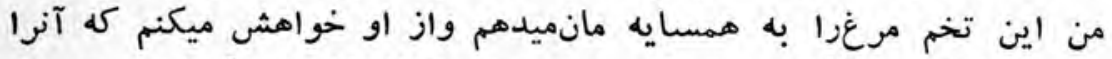

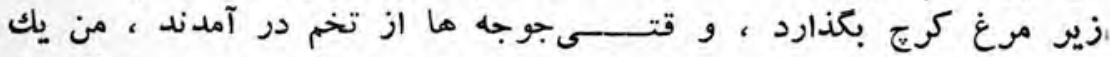

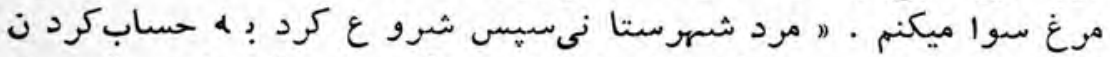

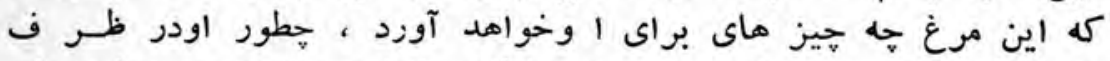

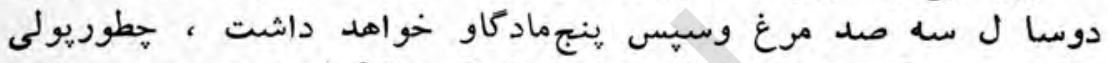

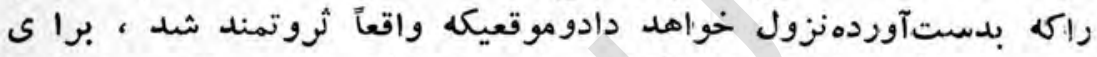

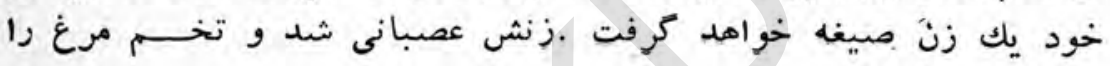

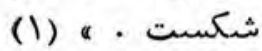

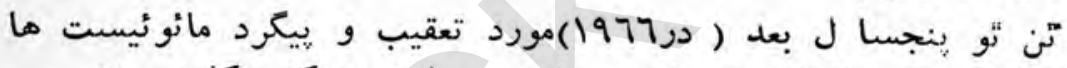

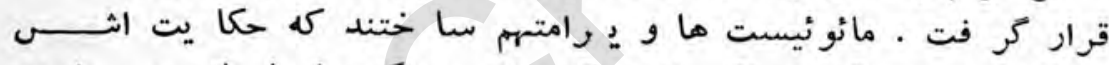

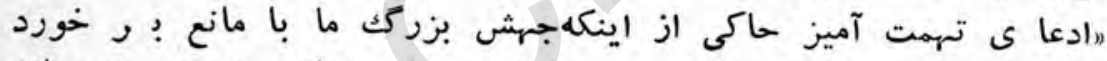

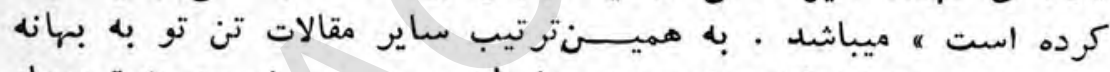

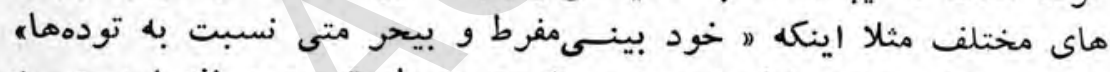

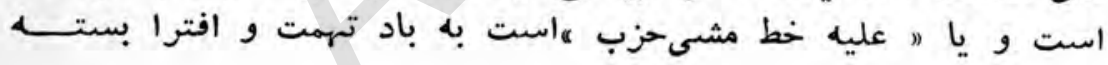

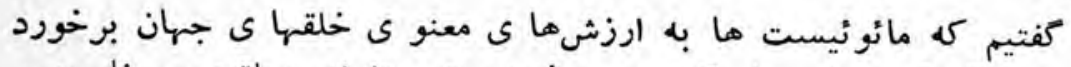

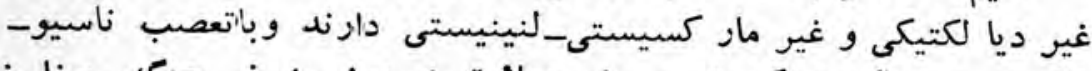

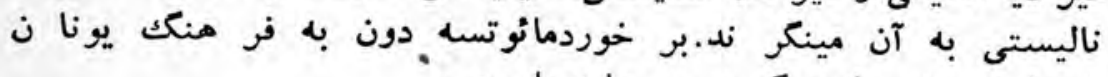

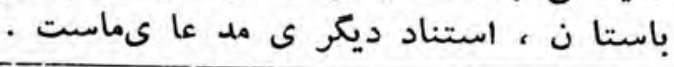

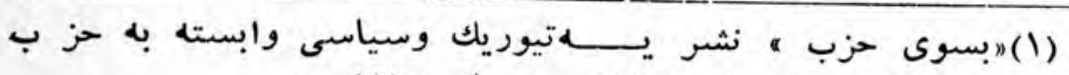

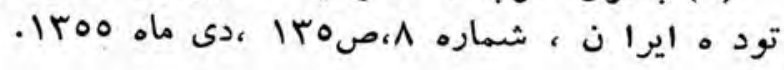
-rTO_ 


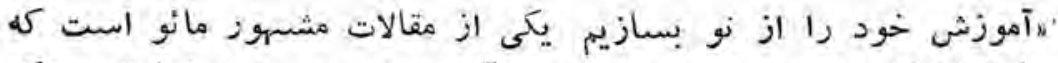

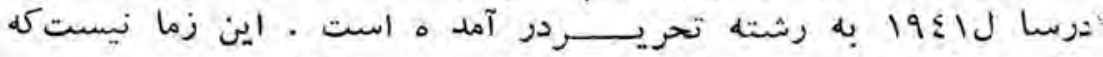

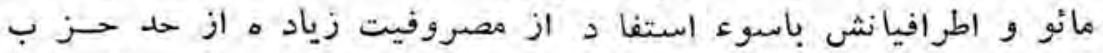

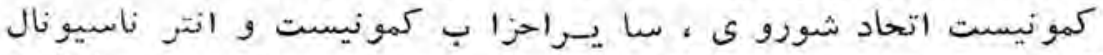

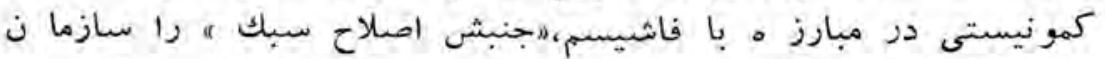

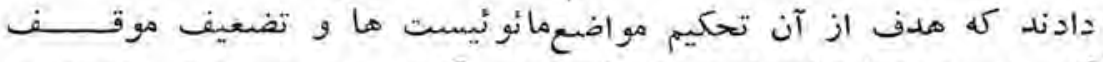

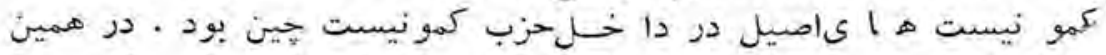

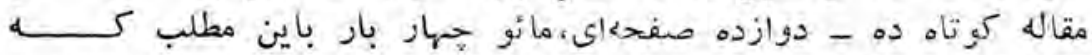

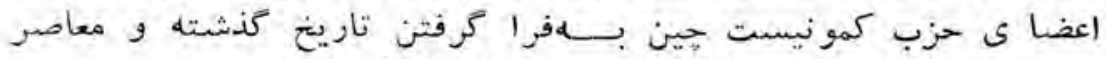

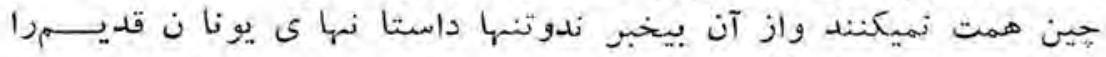

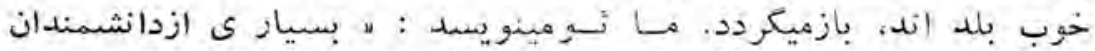

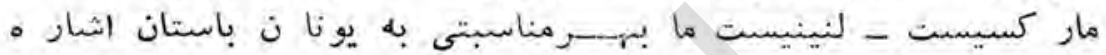

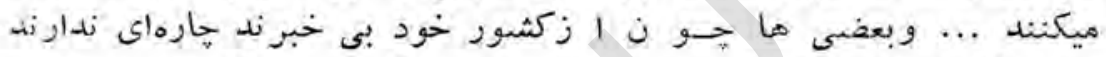

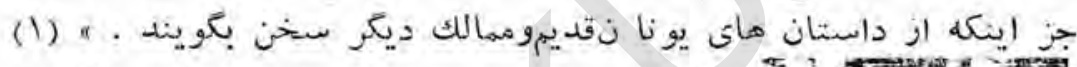

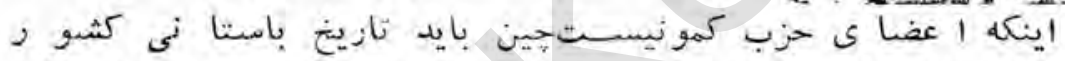

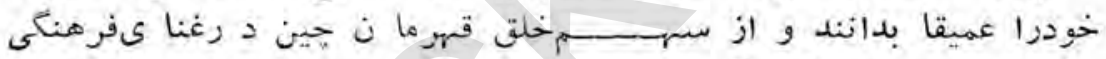

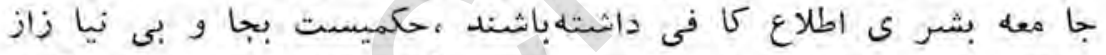

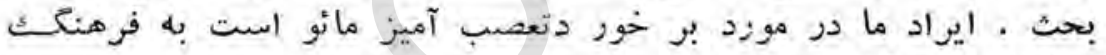

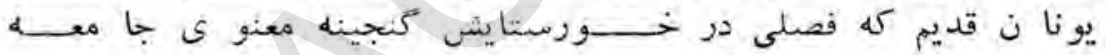

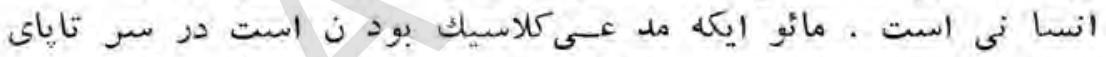

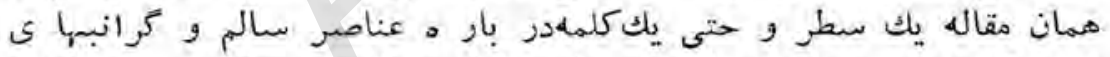

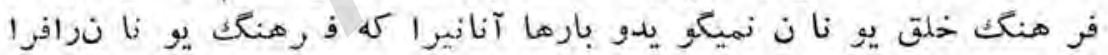

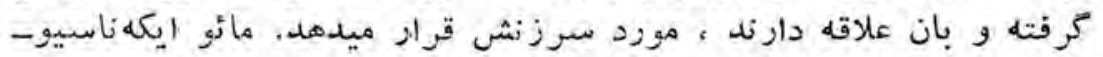

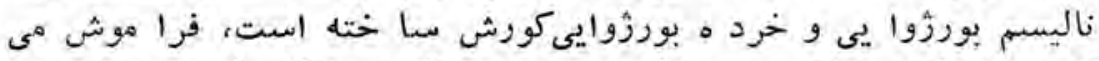

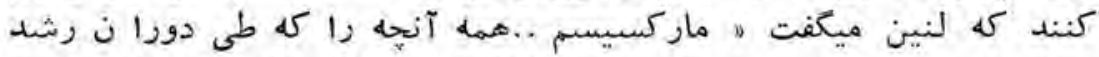

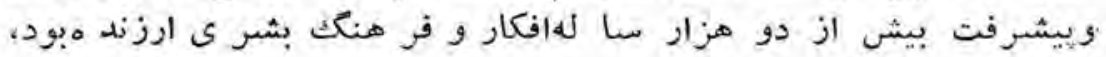

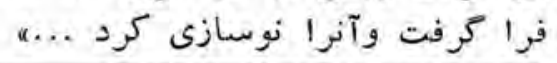

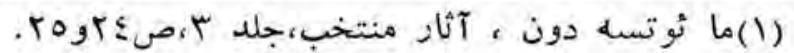
-rrר_ 


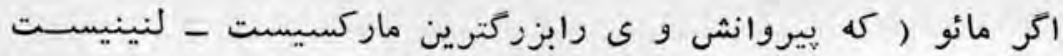

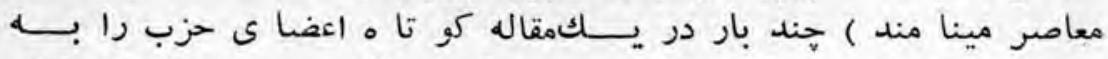

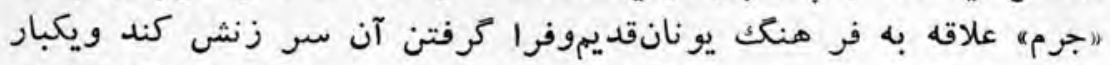

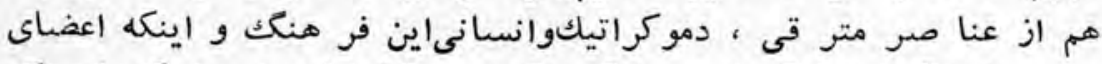

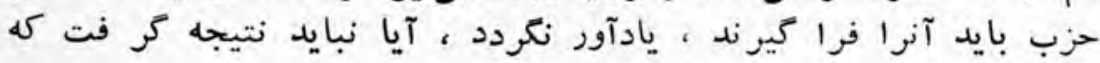

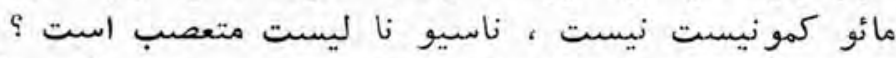

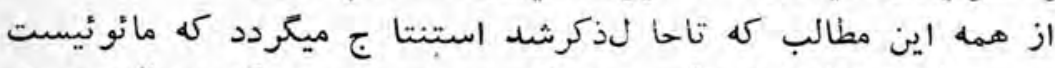

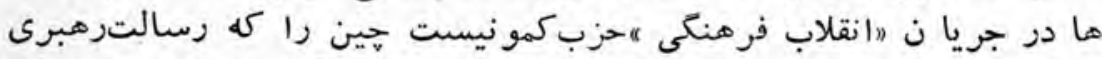

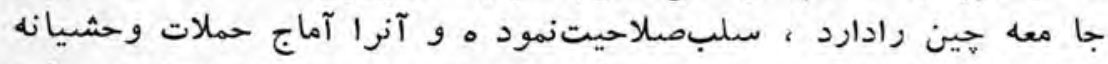

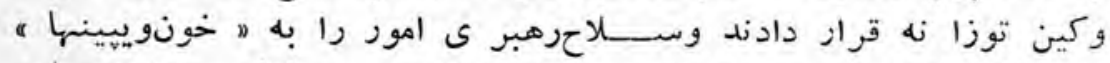

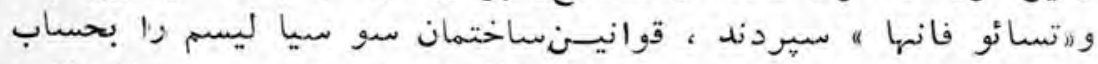

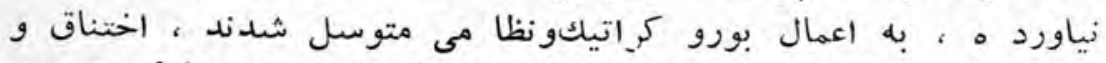

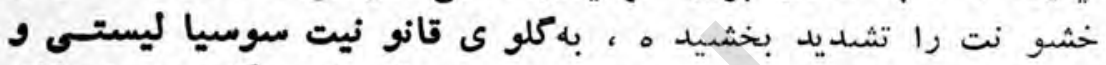

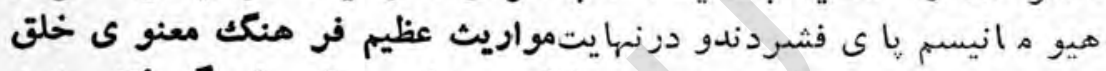

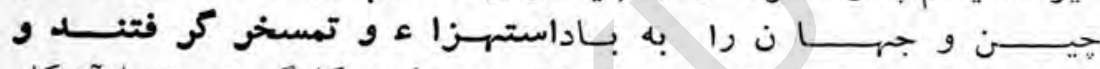
نام اين كار زار ضد انقلابى را كهبالنديشه طبقه كاركر در تضادآشكار

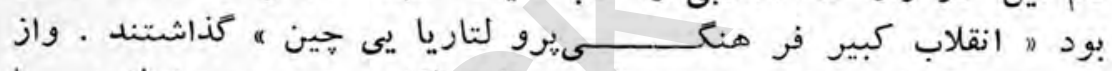

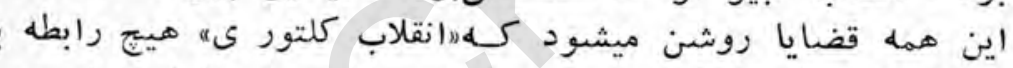

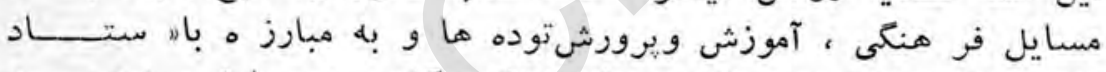

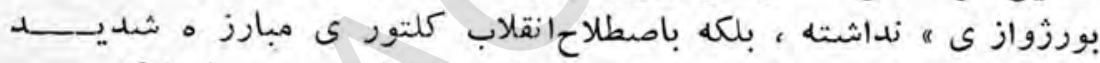

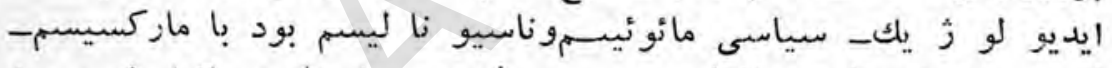

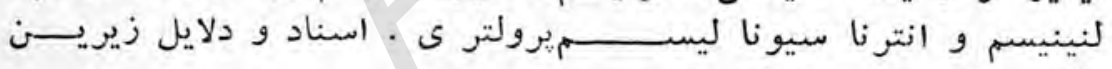
اثبا ت كنيد ه اين مطلب است است الناست

\section{米}

\section{米}

米

r-بعد ا زيّروز ى هر انقـلابكه در نتيجه آن ق لـ، ت سياسىبه طبقه كاركر ودهقانا ن ز حمتكثـانتقال مى يابد ، مدافعا ن نظم ككن 


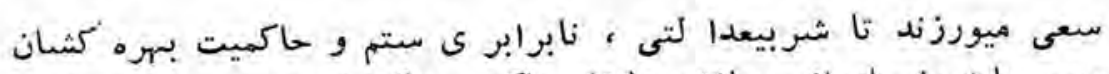

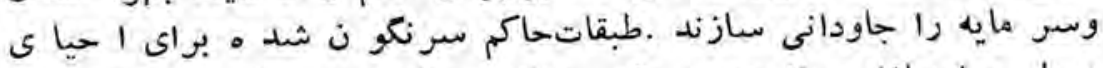

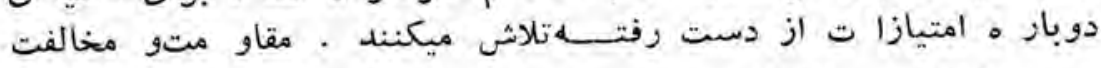

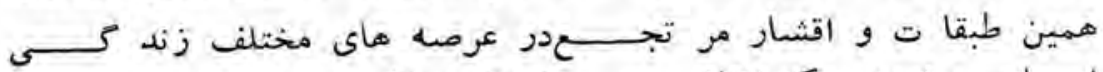

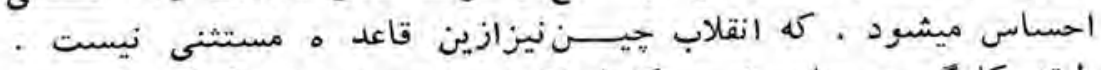

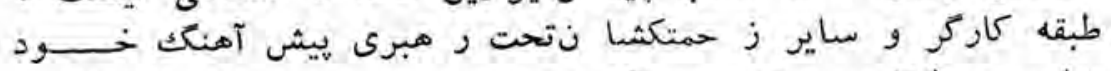

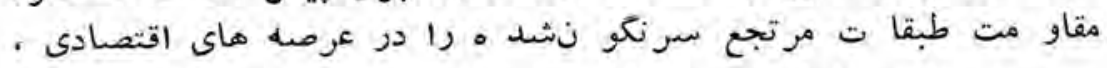

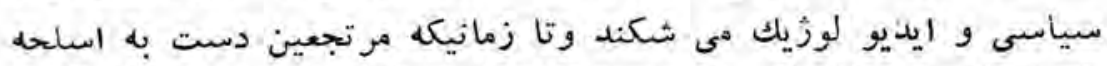

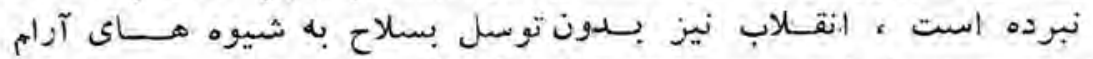

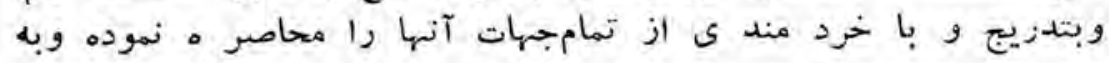

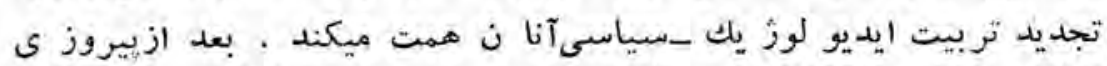

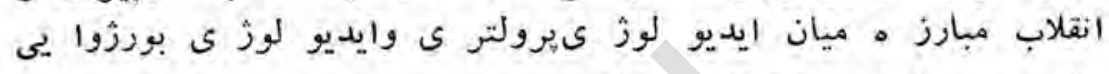

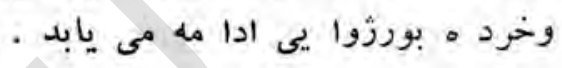

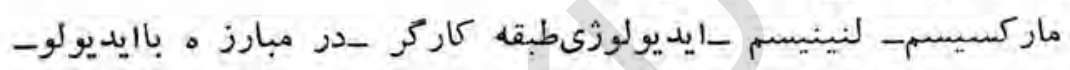

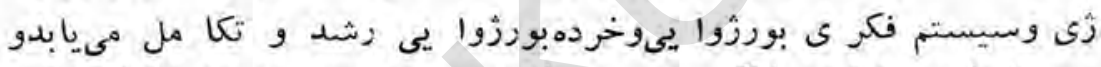

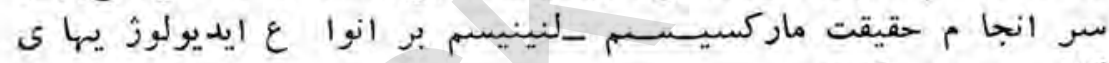

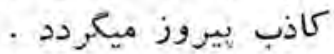

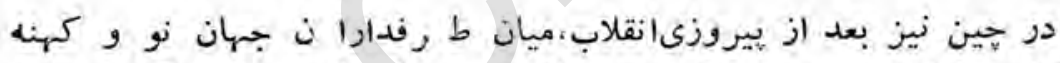

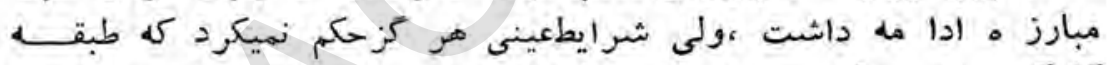

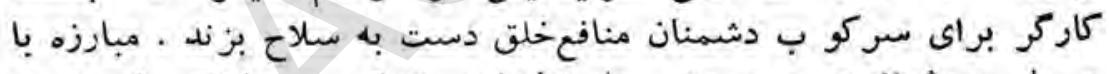

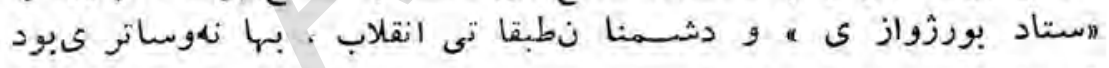

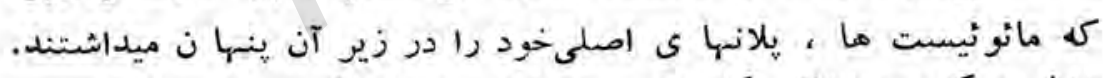

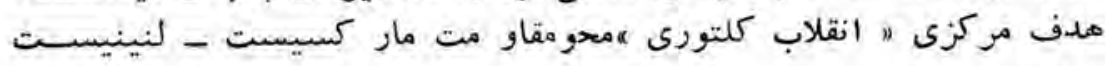

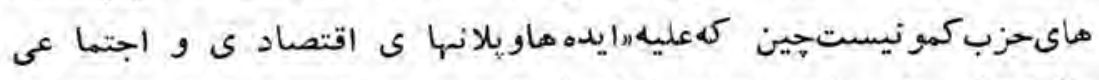

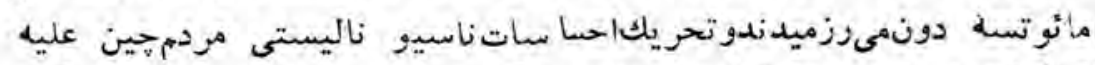

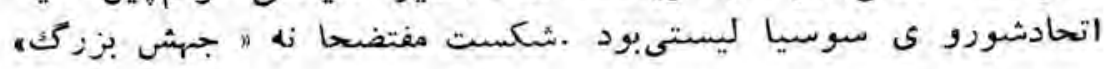




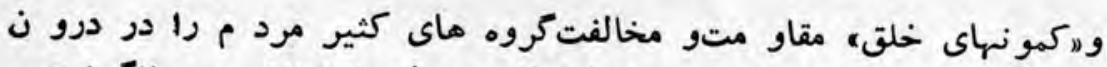

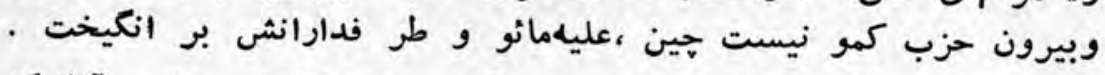

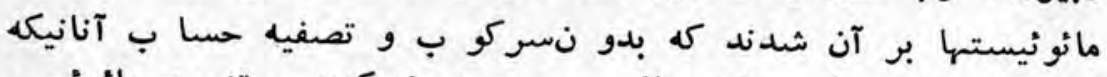

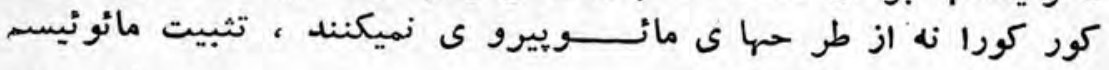

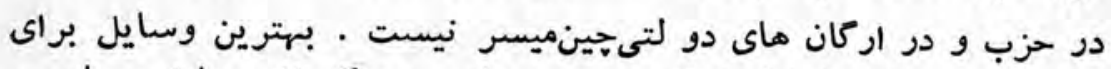

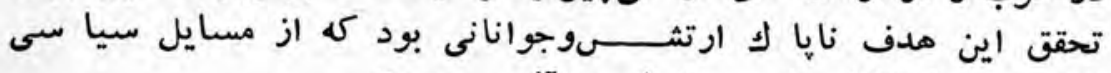

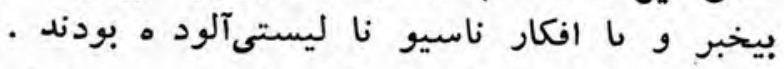

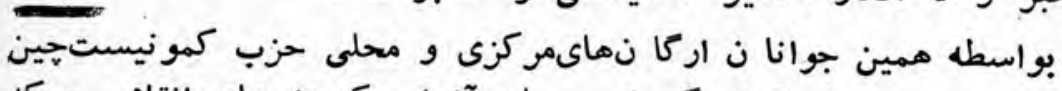

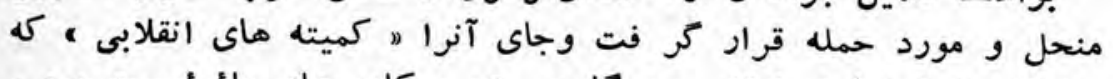

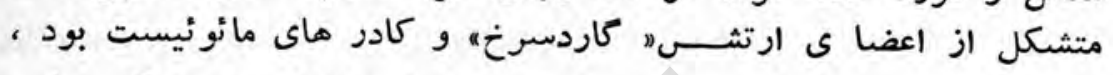

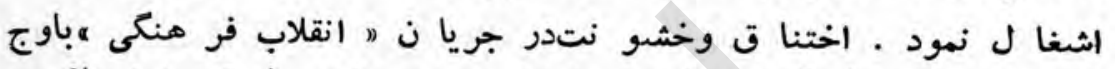

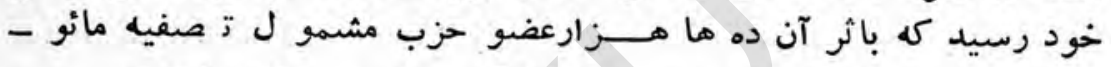

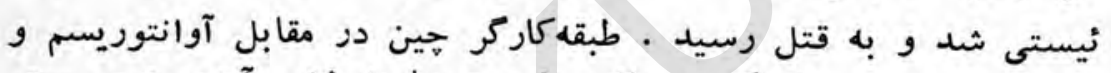

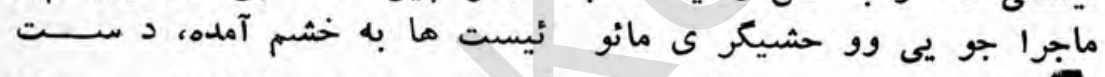

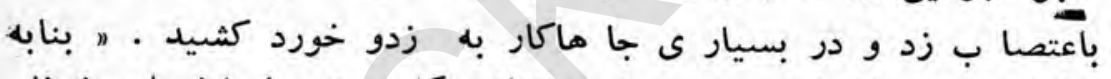

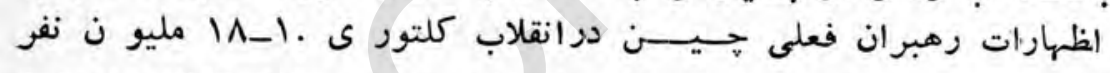

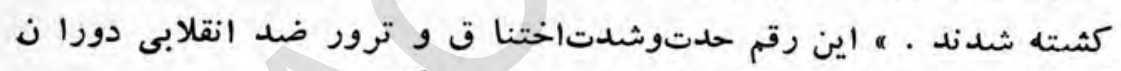

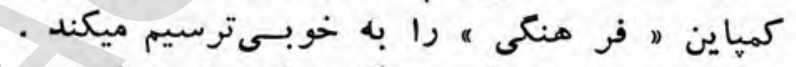

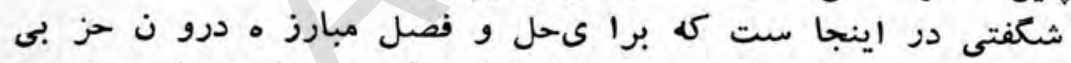

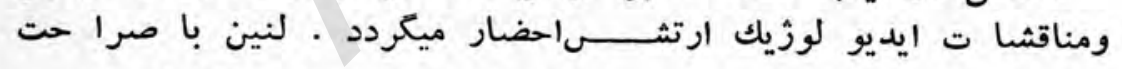

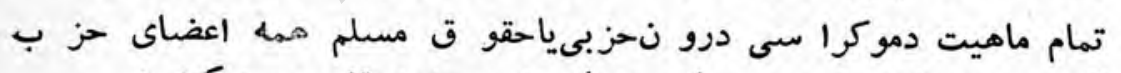

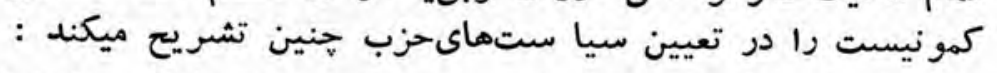

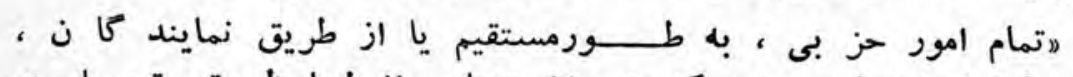

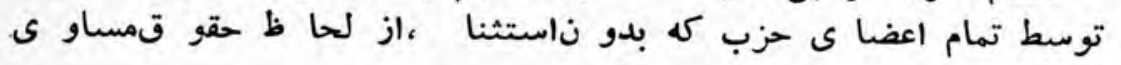

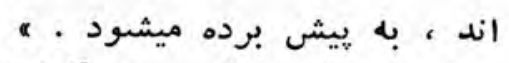
اصل سانترا ليسم دموكرا تيك ميثه بر بايه آ نساخت ساز مانــى 


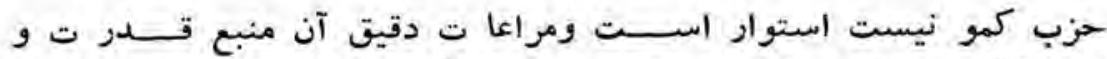

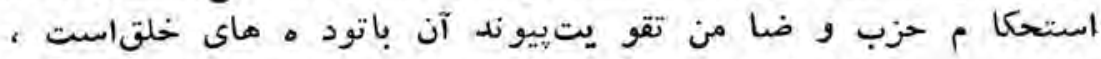

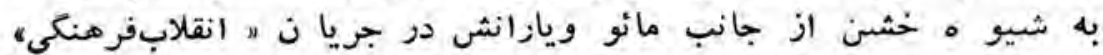

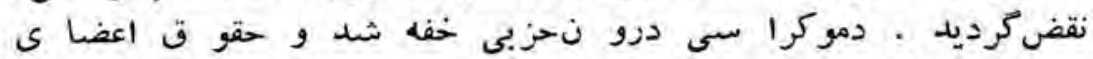
حزب سلب كرديد موديد

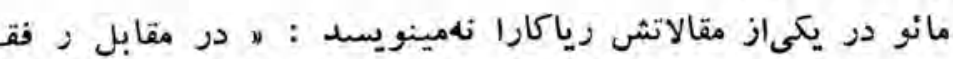

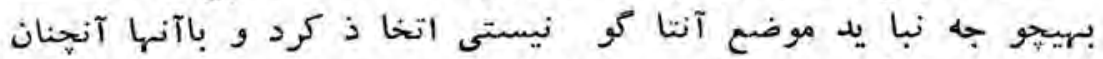

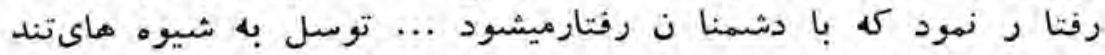

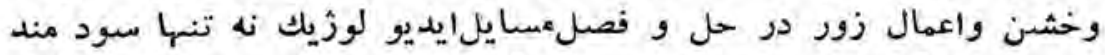

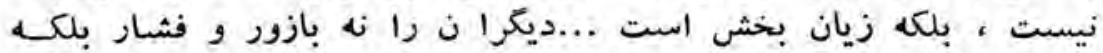

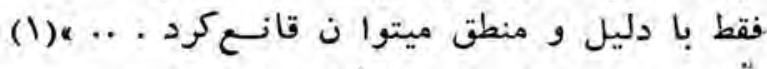

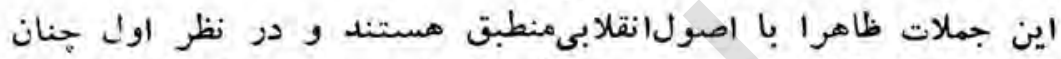

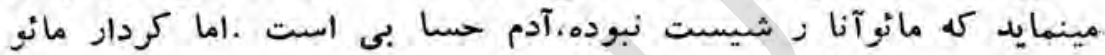

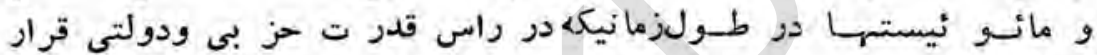

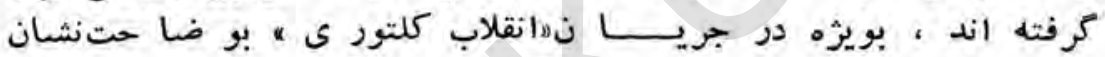

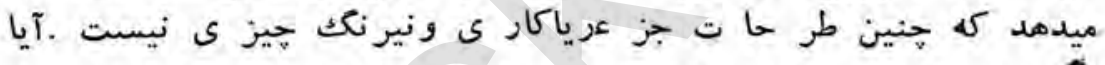

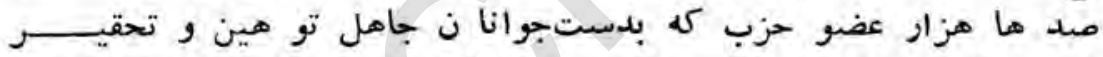

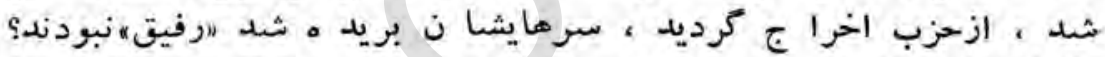

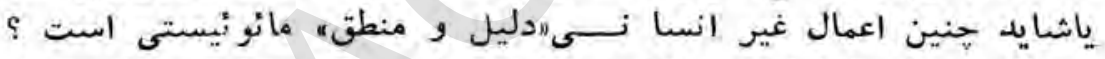

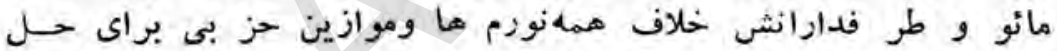

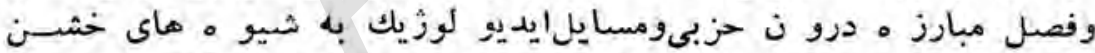

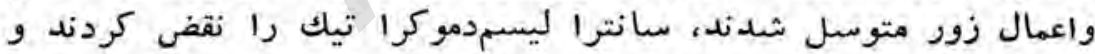

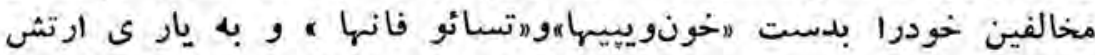

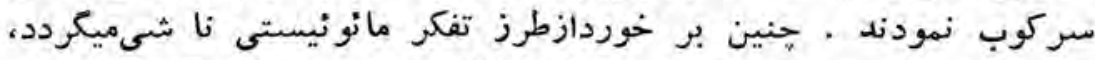

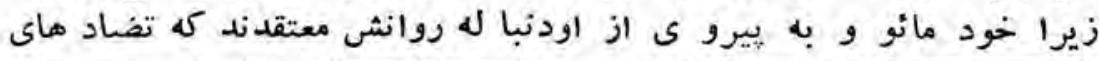

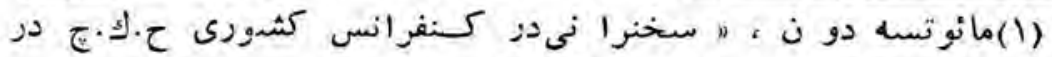

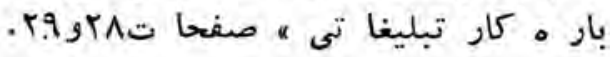




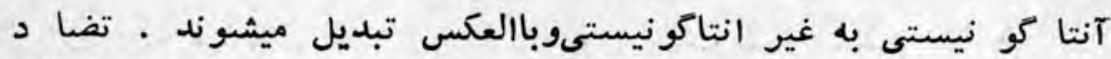

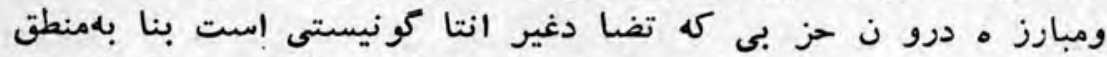

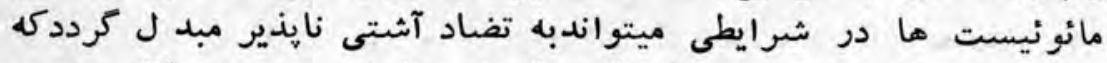

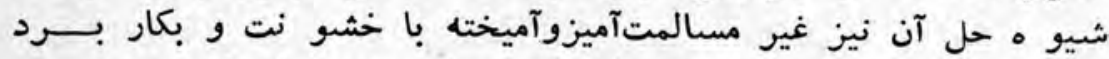

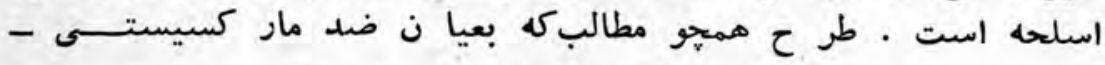

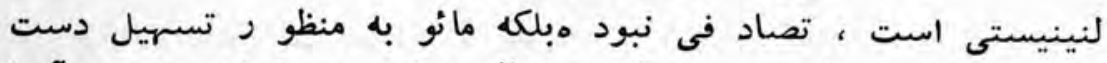

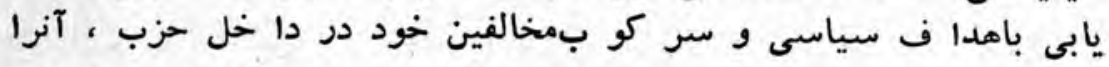

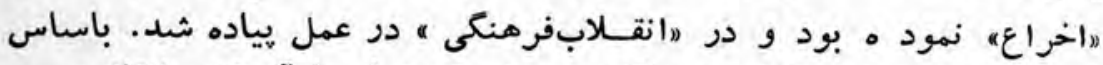

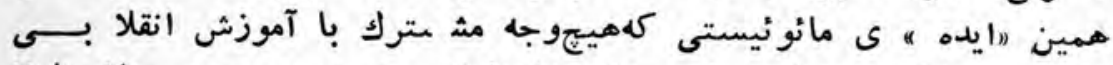

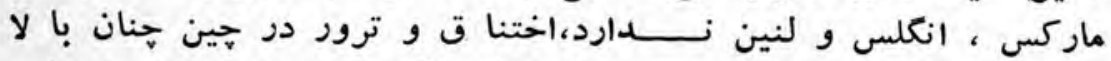

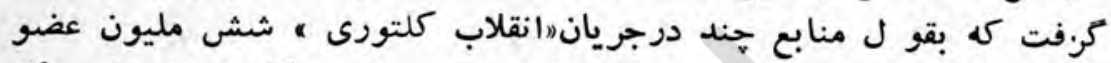

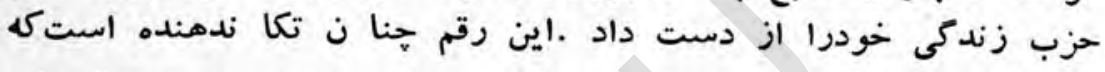

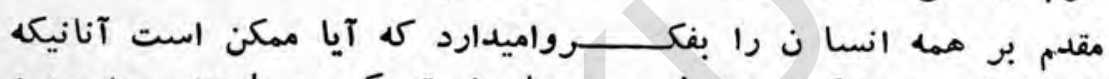

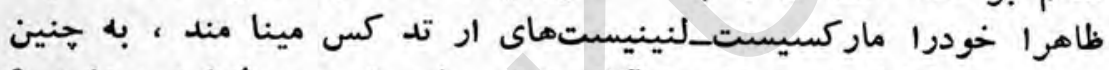

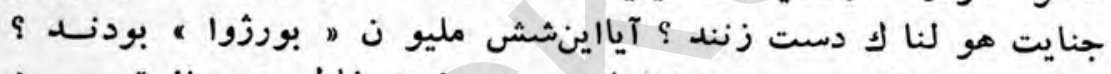

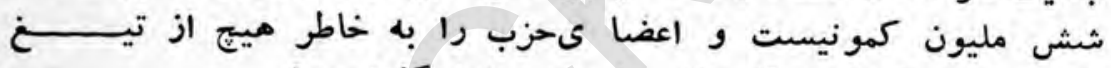

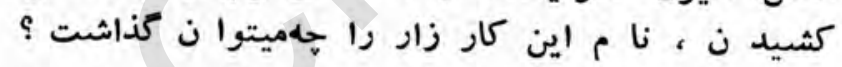

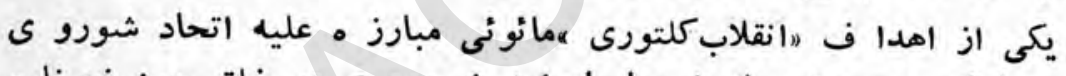

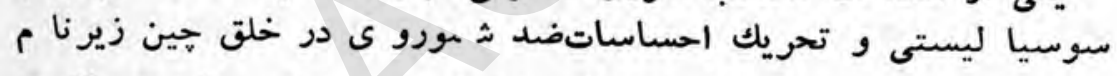

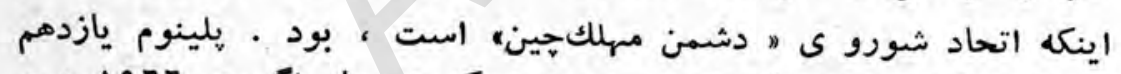

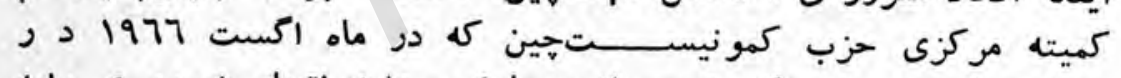

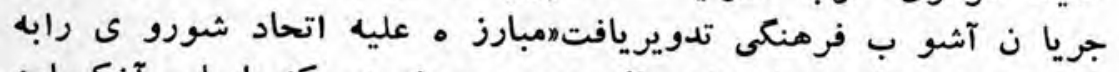

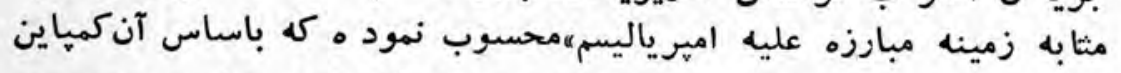

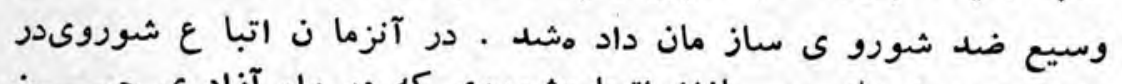

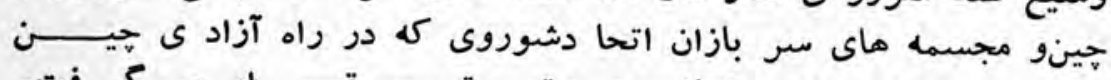

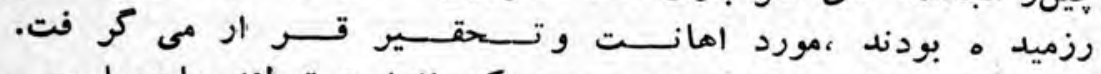

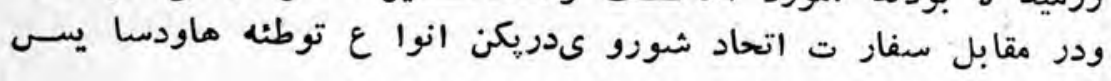




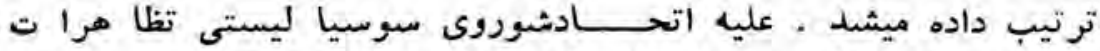

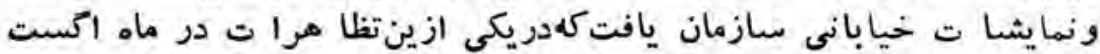

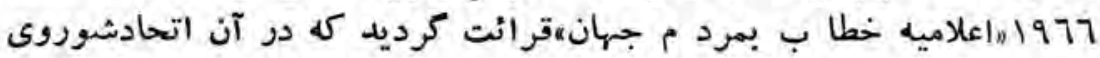

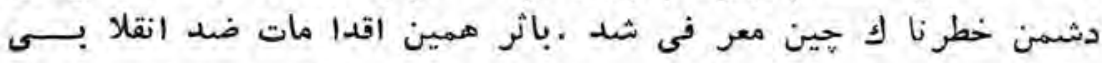

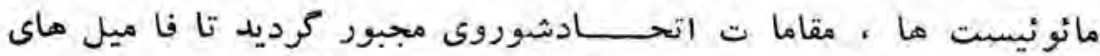

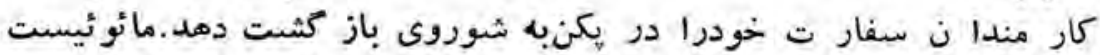

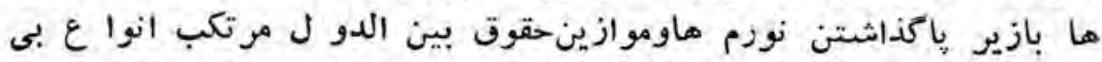

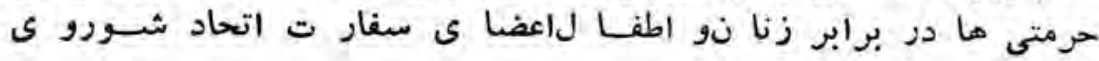
. شبدند

\section{*}

\section{米}

米

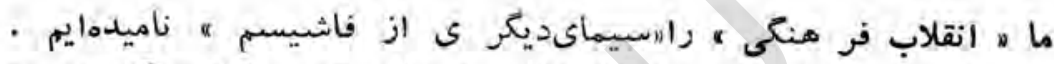

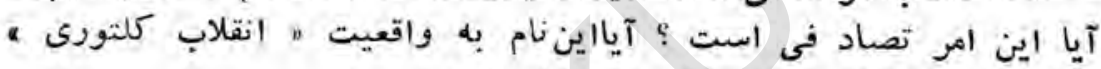

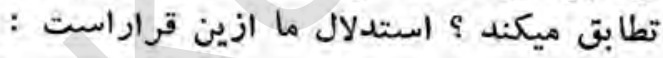

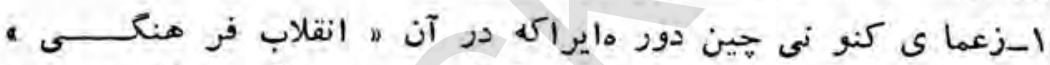

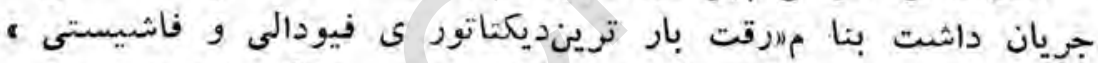

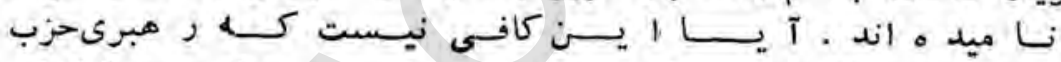

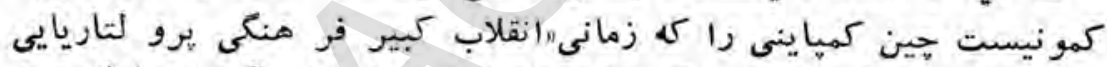

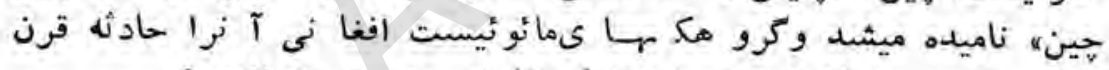

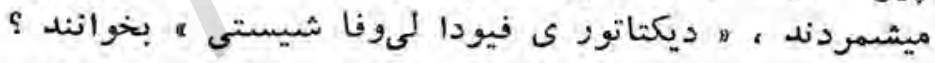

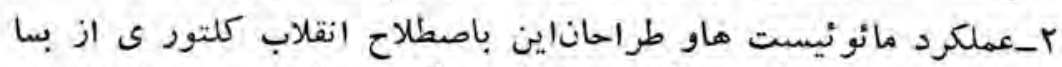

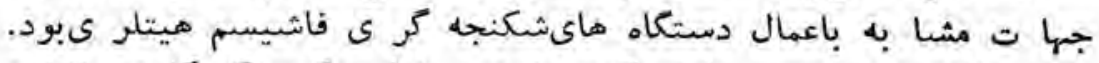

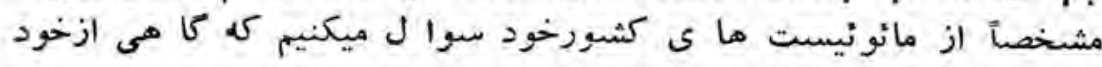

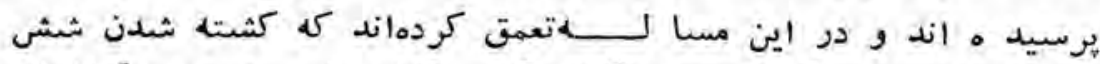

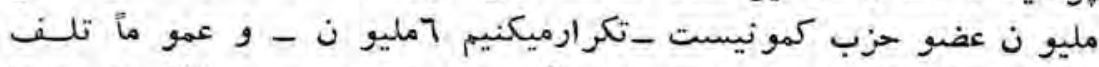

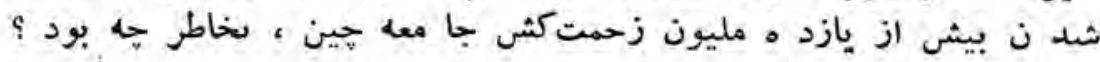


اתر اين همه بورزوا و دشمن خلـقبودند ، يس صحبت كرد ن ن در مورد

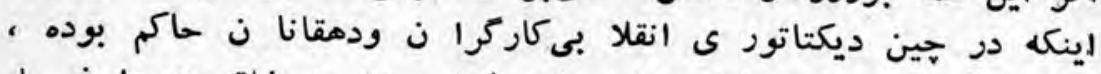

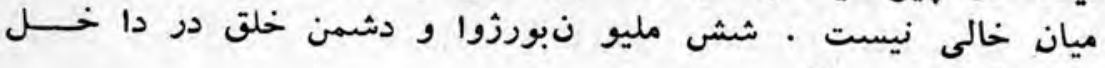

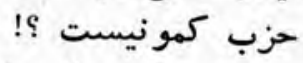

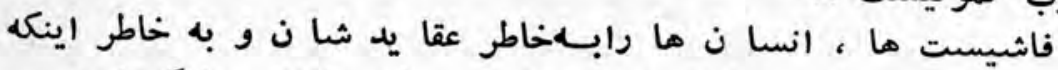

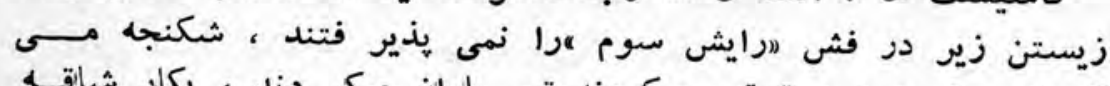

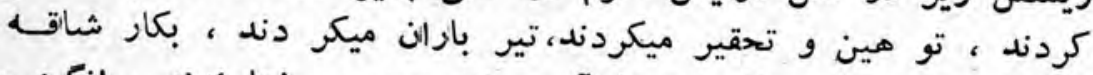

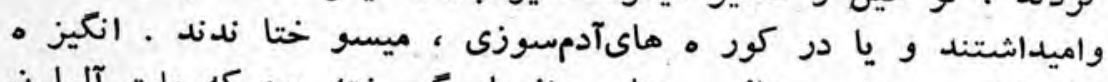

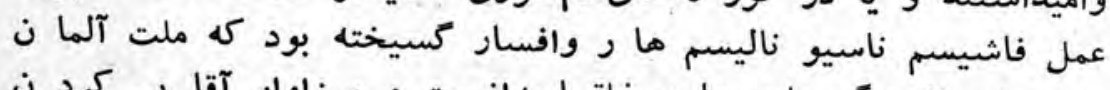

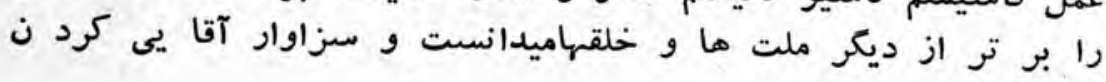

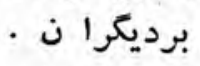

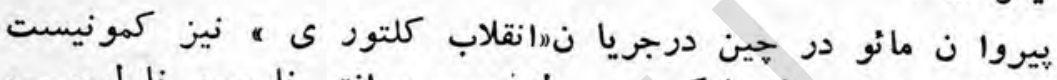

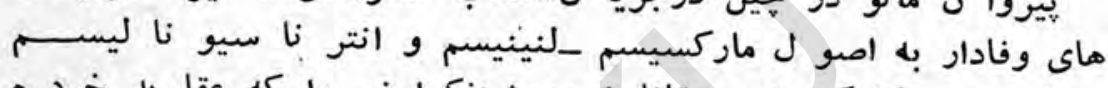

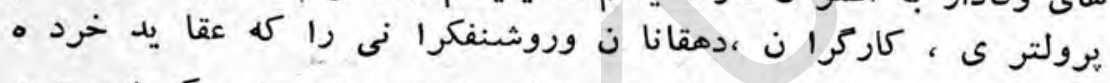

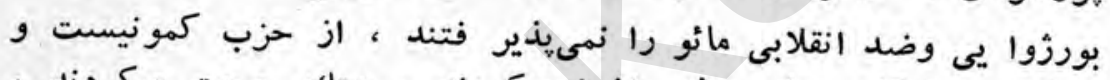

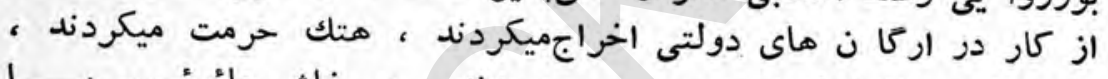

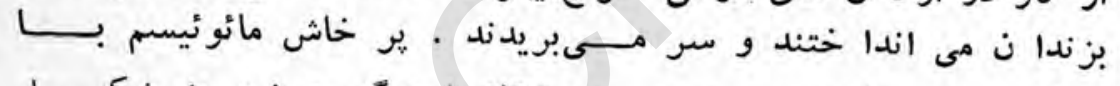

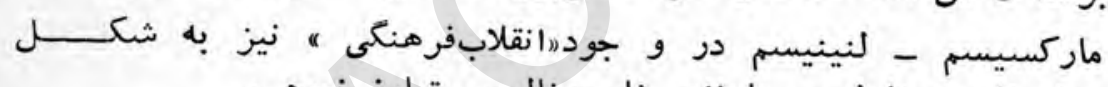

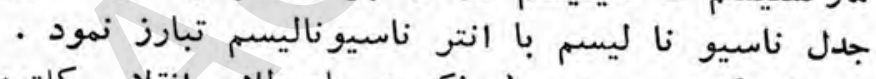

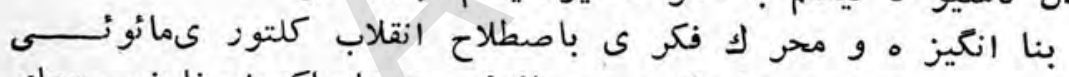

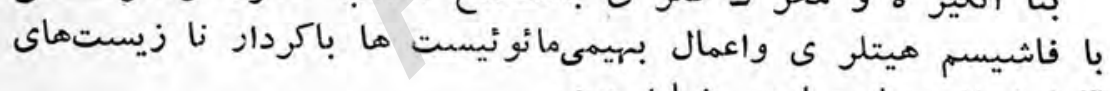

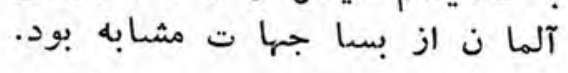

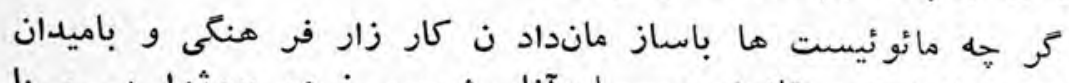

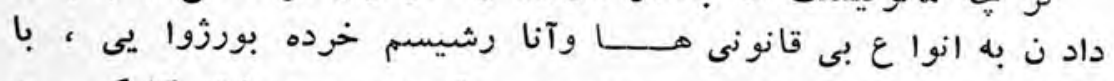

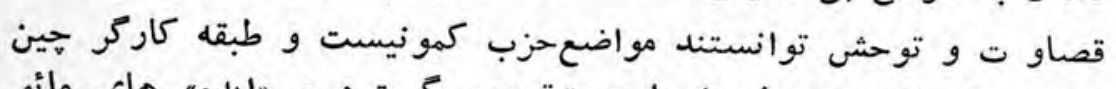

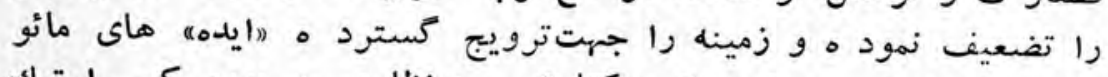

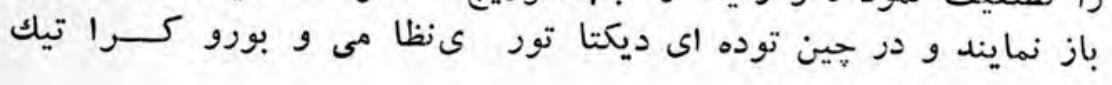




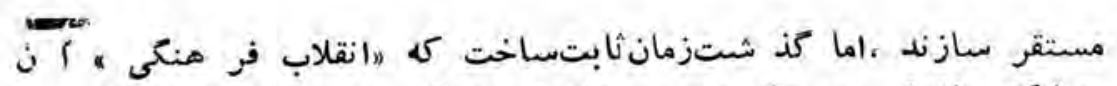

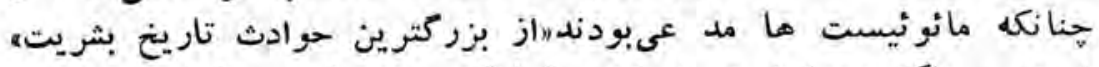

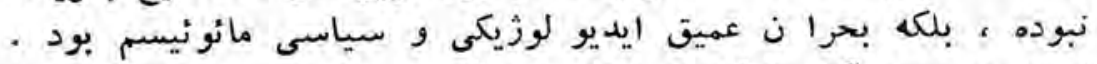

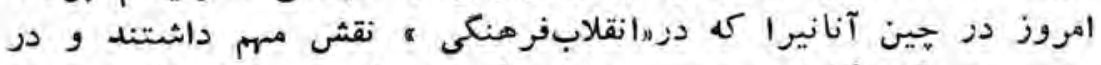

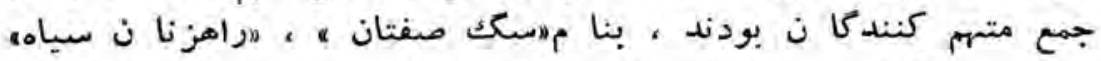

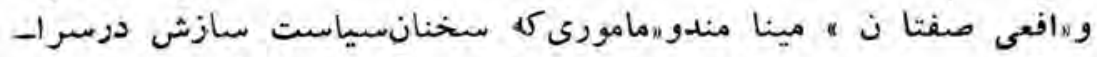

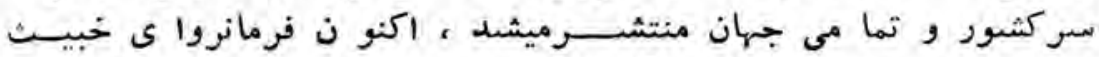

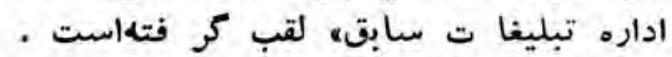

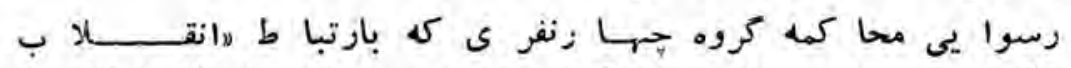

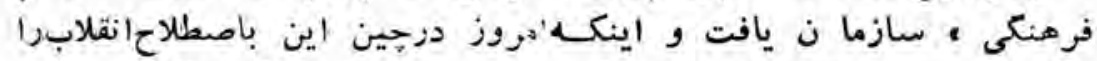

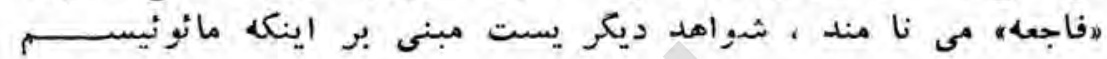

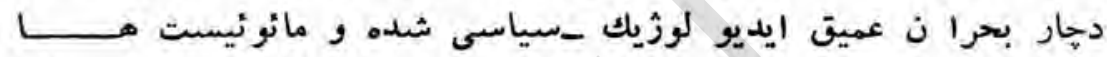

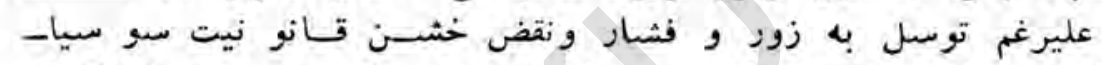

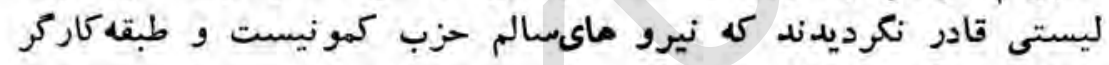

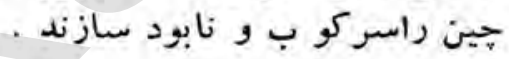




\section{صلحوجنكى \\ (ما ئوئيسمومسئله مر كزى صدورانما)}

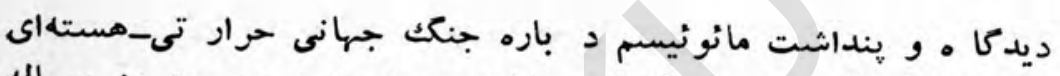
زيست ؟

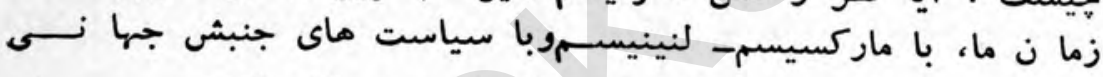

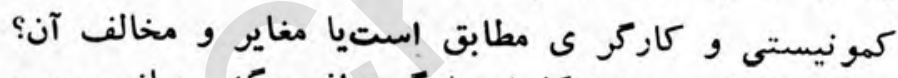

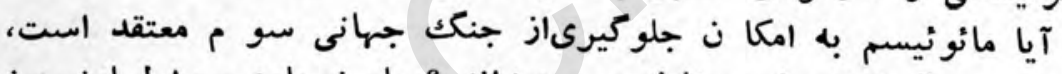

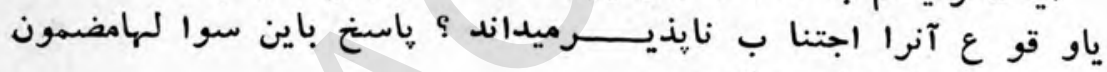

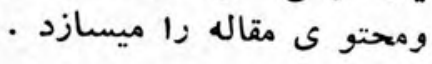

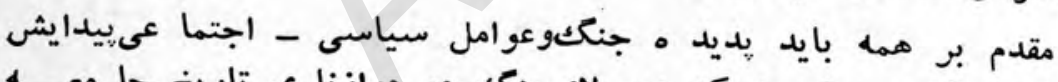

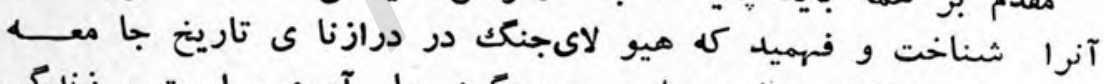

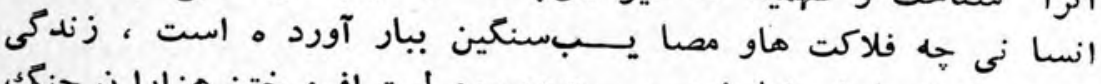

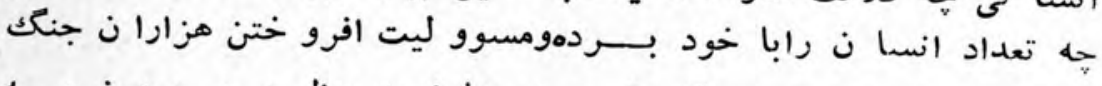

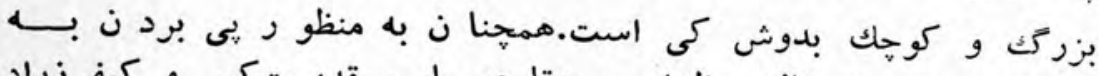

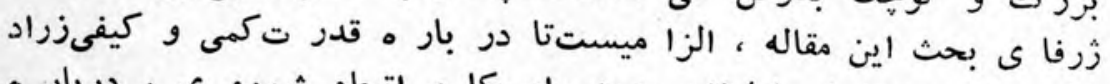

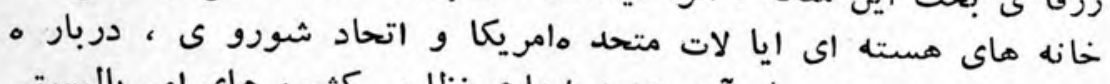

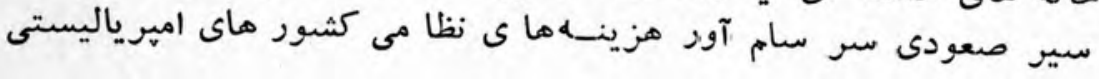


كه با سطع بعد از جنكك دوم اصـلاقابل قياس نيست و و بالاخر مدرباره

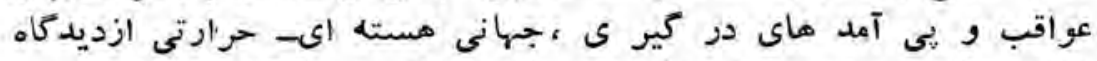

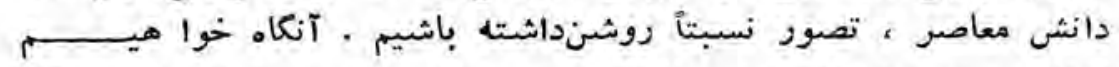

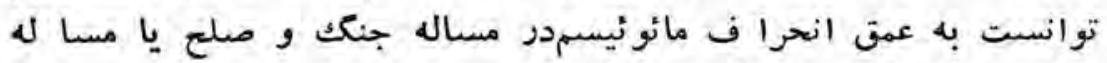

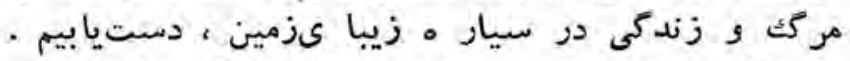

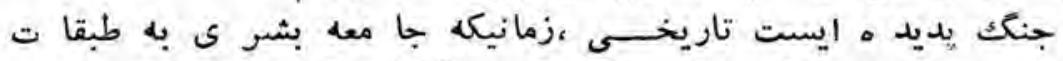

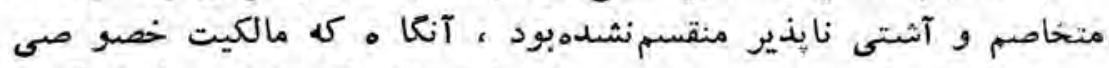

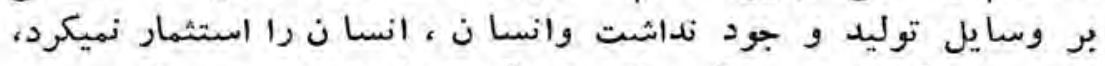

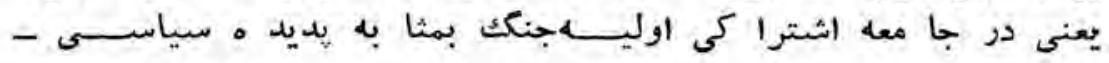

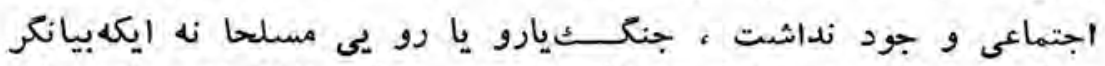

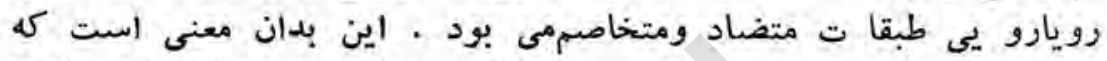

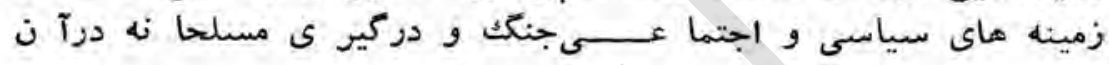

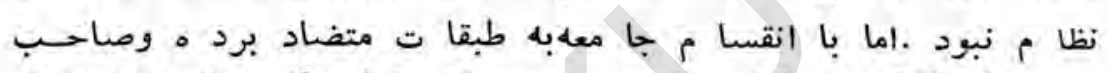

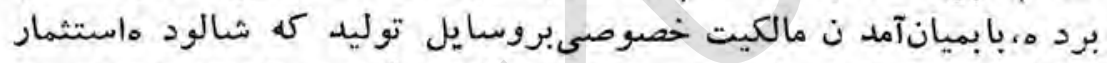

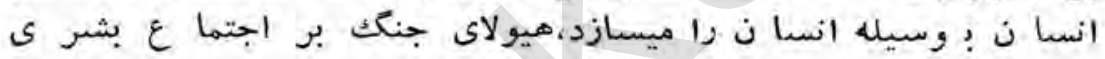

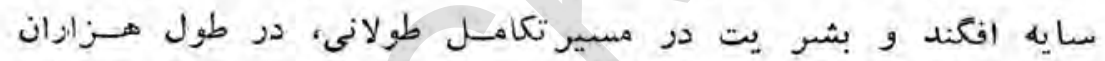

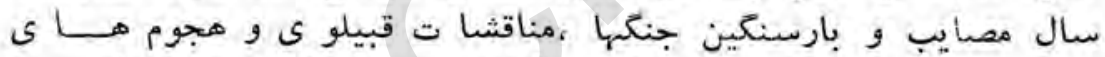

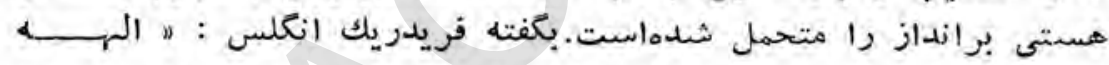

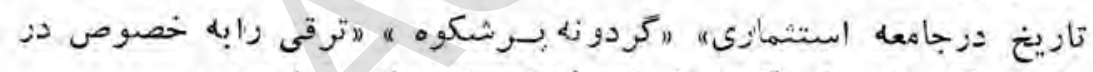

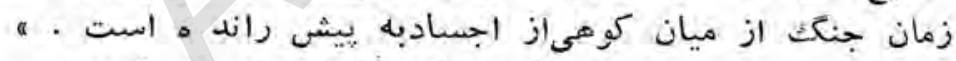

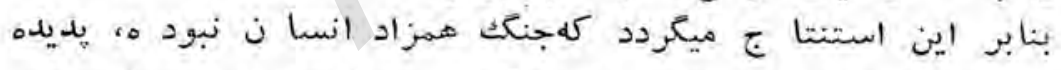

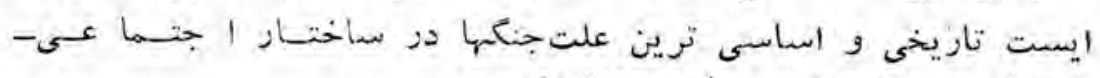

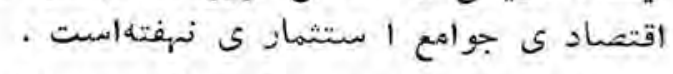

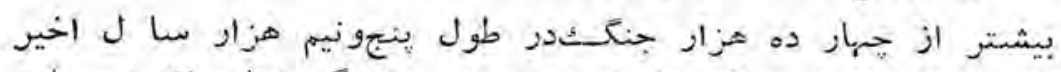

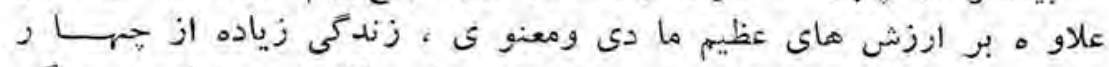

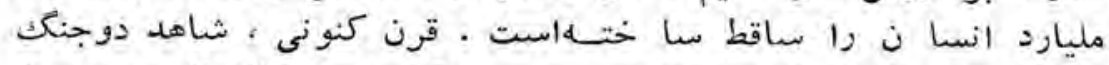

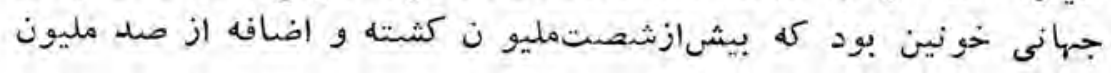




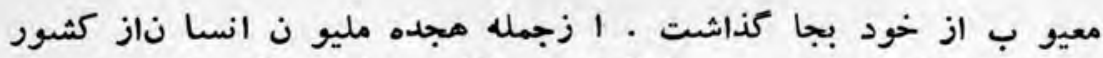

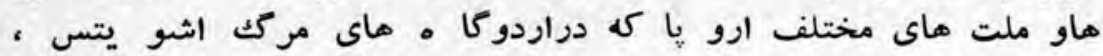

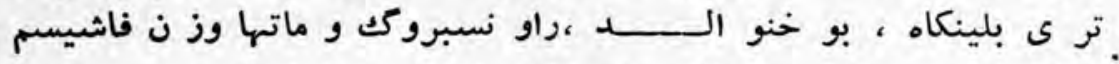

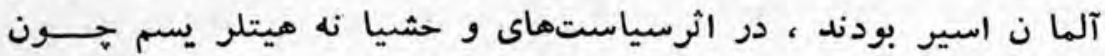

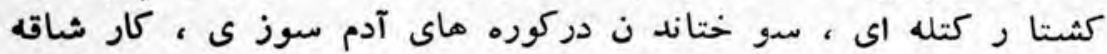

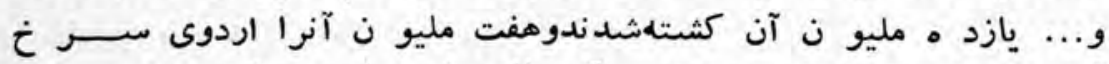

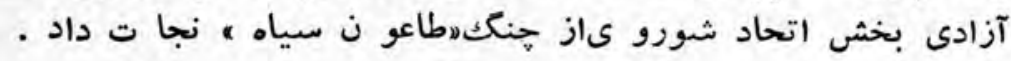

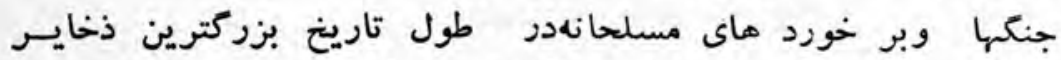

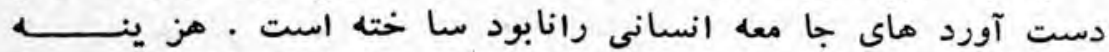

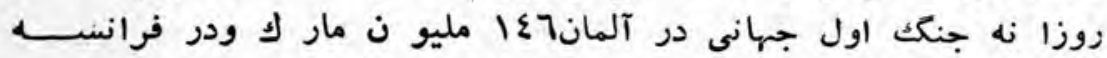

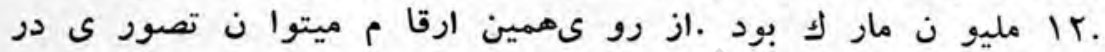

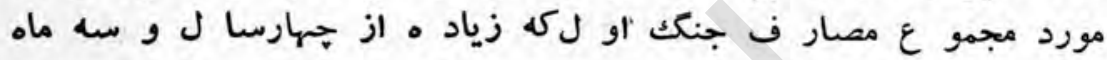

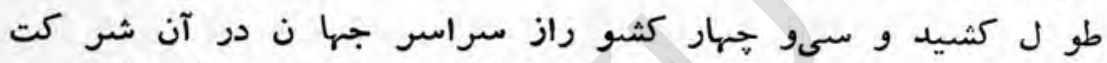

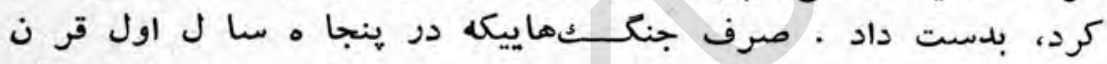

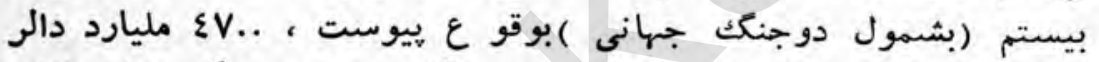

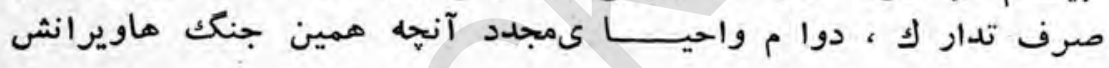

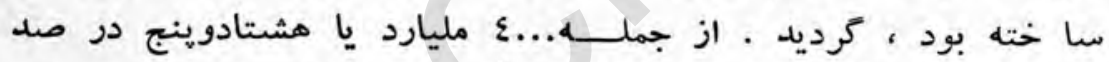

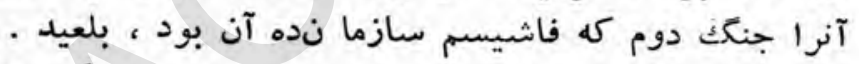

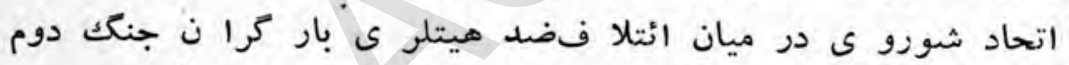

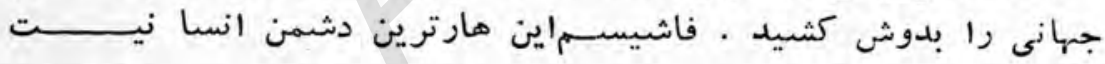

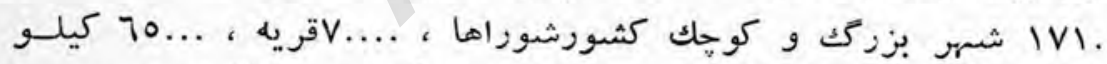

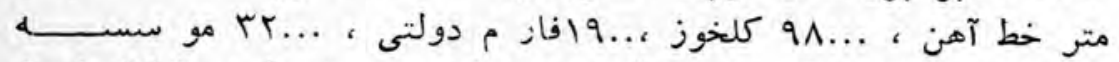

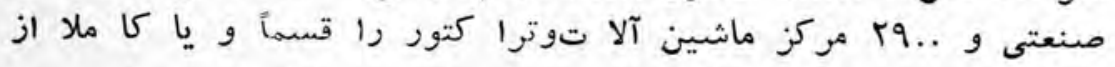

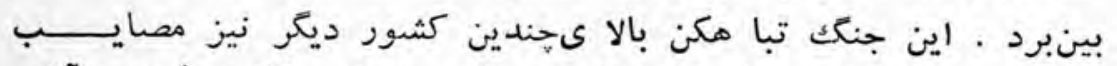

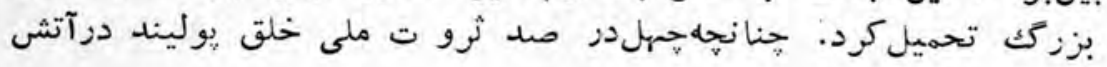

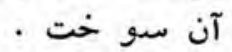

ازسا ل 1950 باينسو نيزسيارهما از آتش جنكك در امان نبود ـ. 


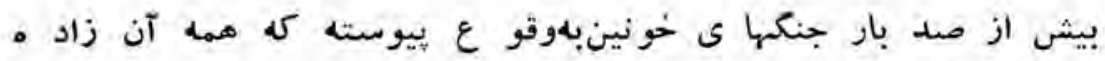

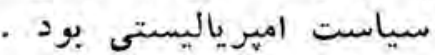

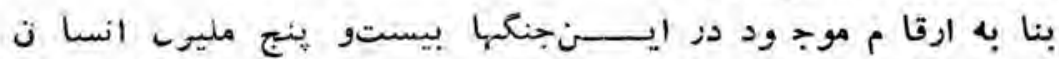

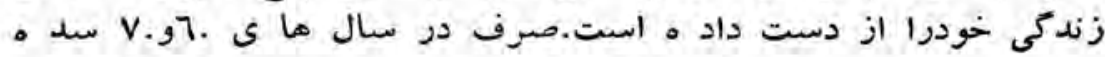

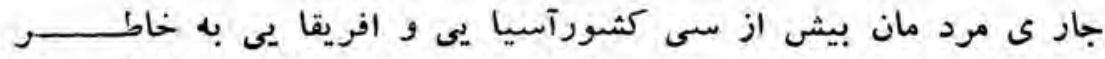

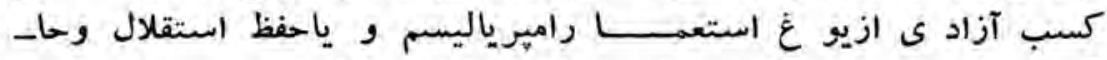

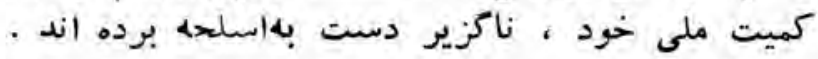

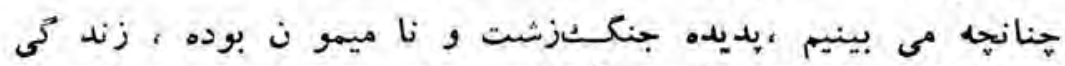

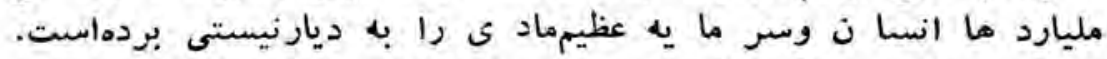

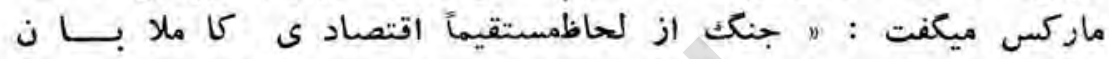

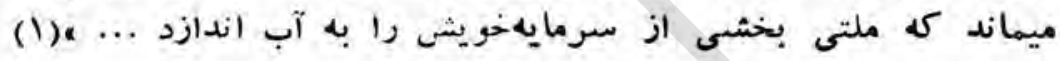

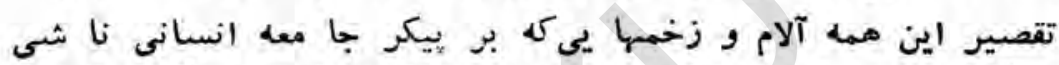

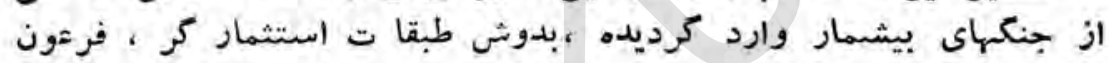

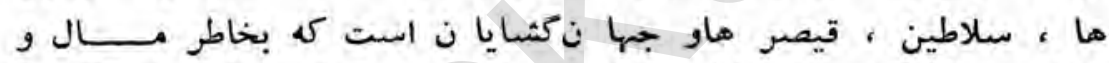

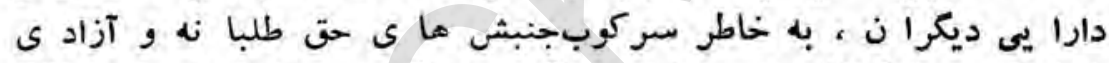

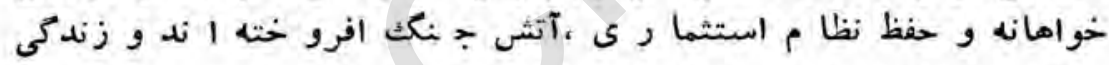

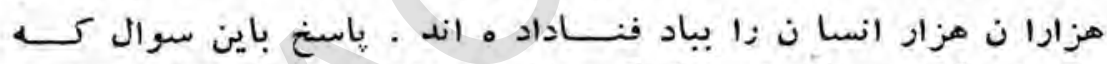

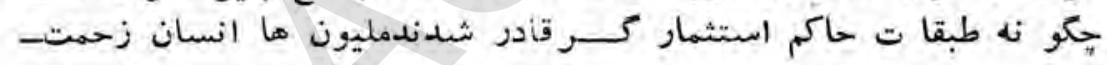

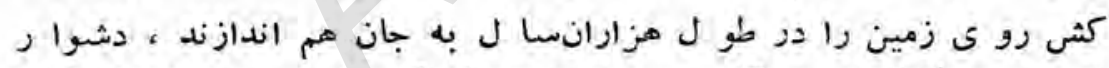

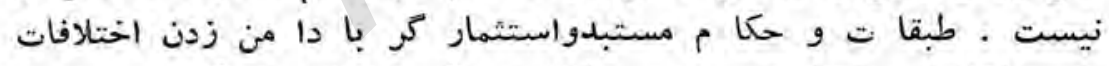

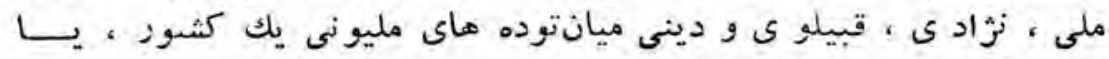

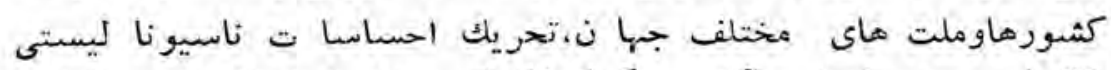

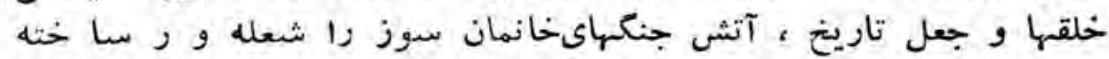

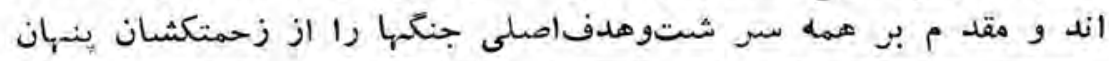

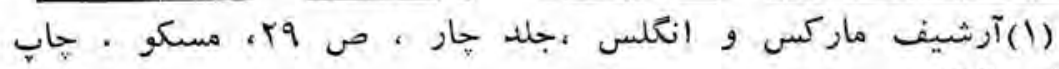




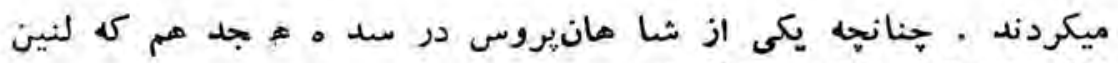

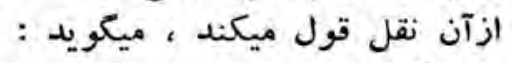

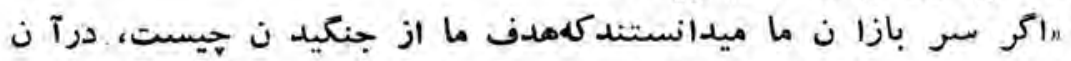

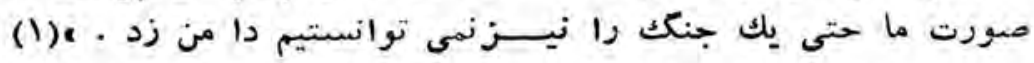

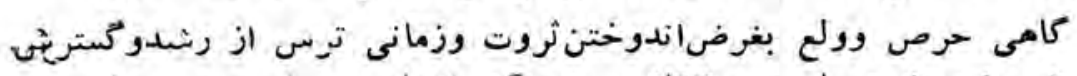

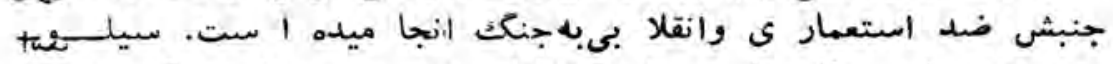

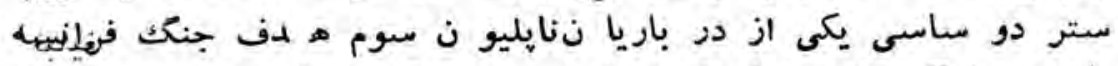

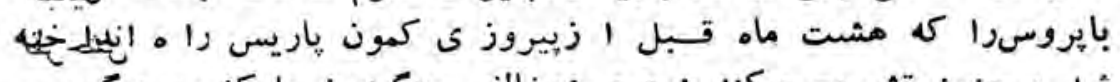

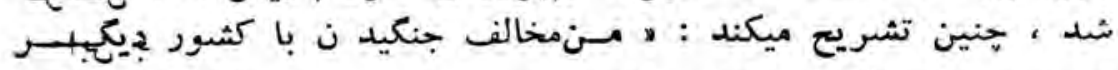

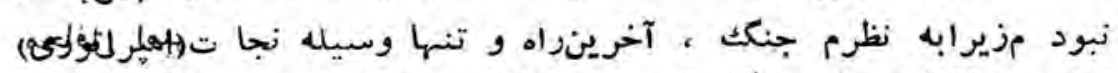

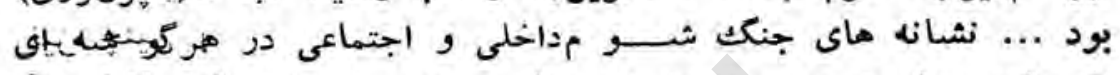

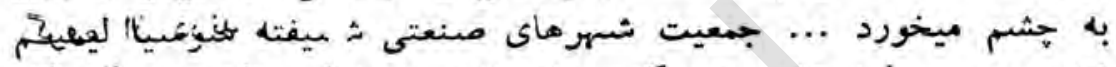

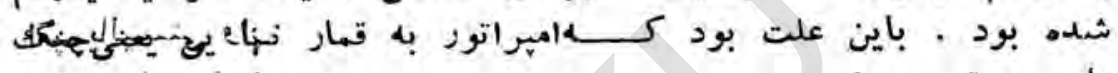

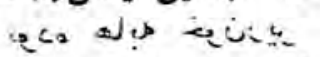
بإيروس تن در داد بـ....

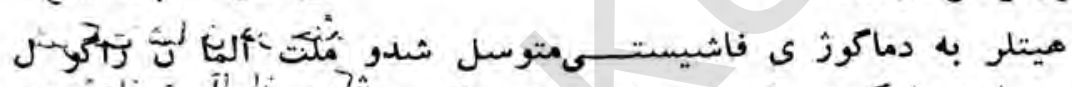

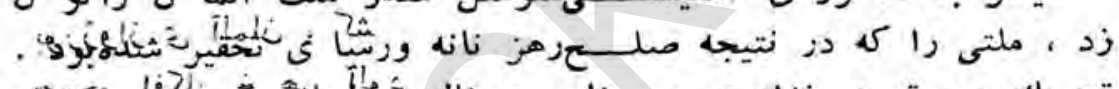

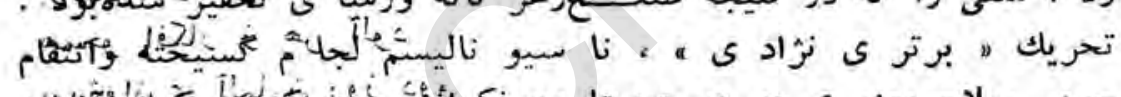

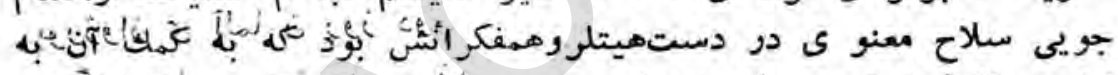

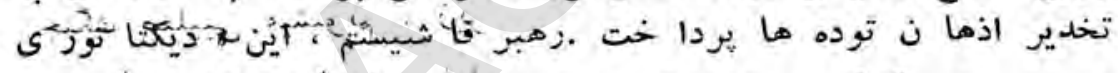

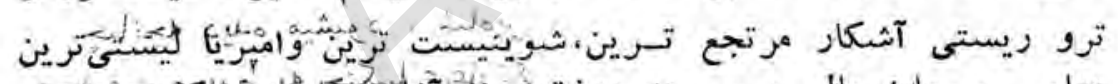

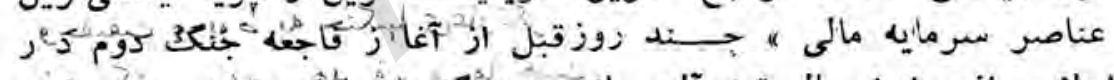

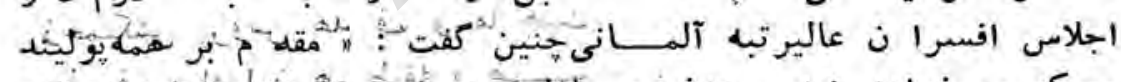

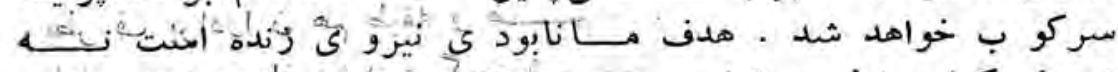

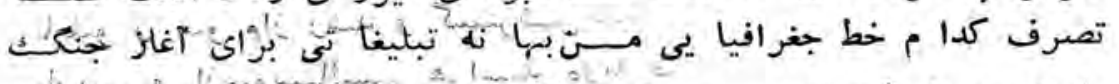

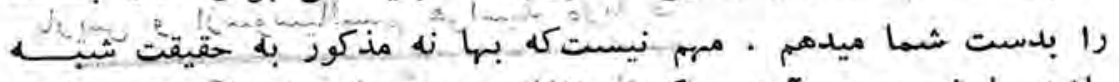

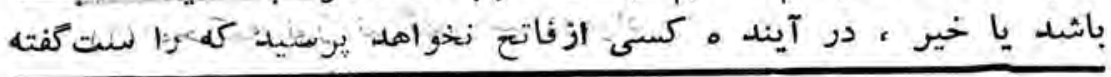

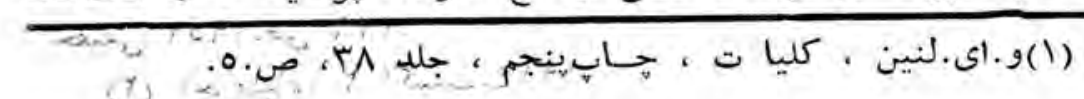




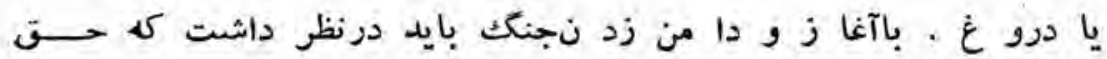

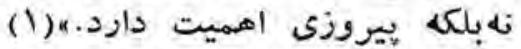

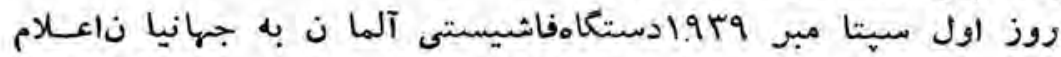

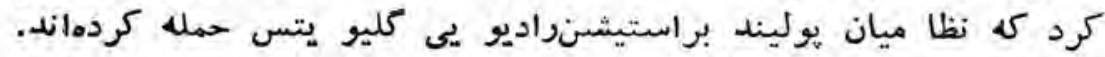

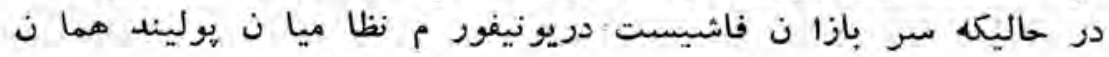

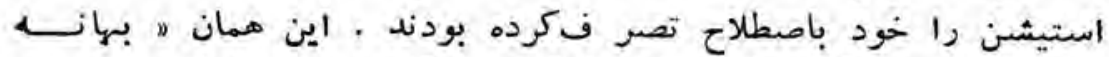

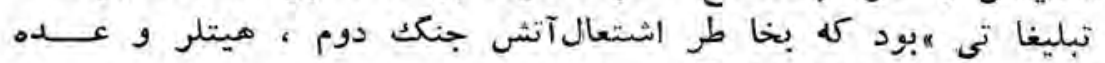

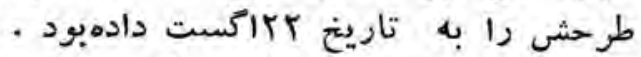

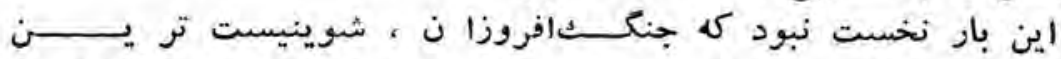

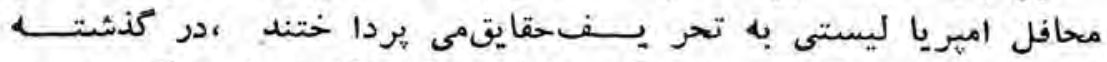

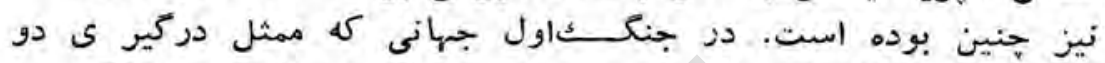

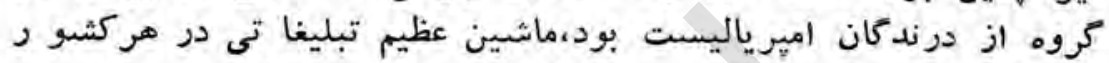

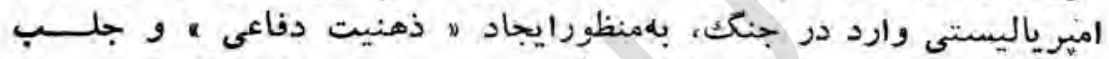

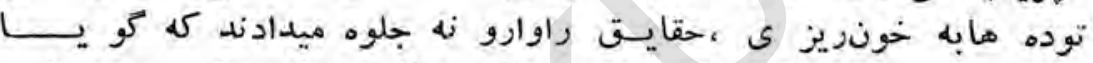

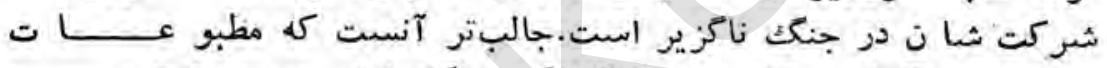

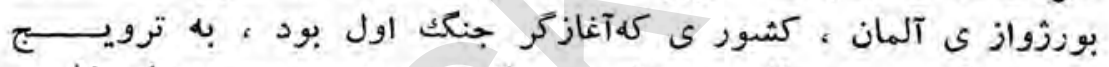

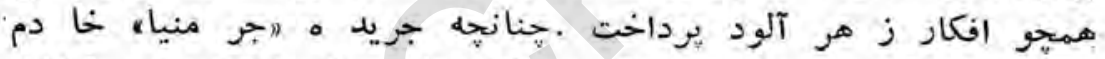

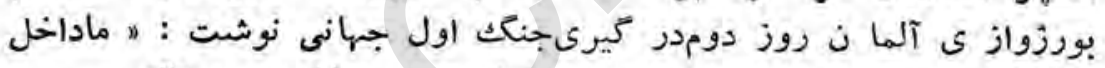

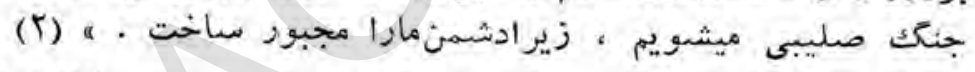

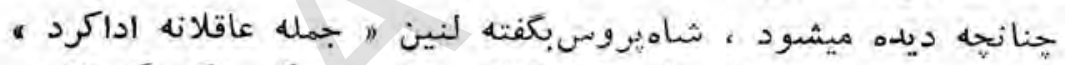

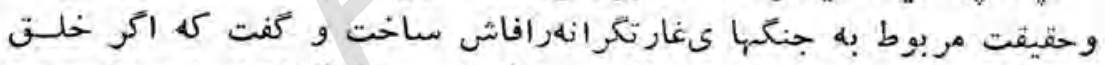

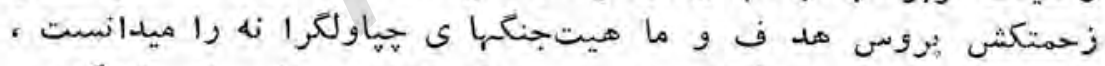

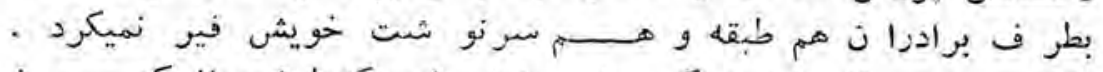

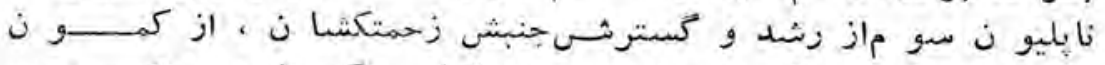

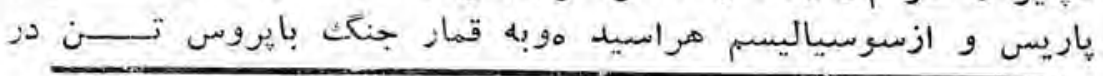

بارسي

$$
\begin{aligned}
& \text { حقيقى 190r } \\
& \text { "جرعياه، بكن اكست، }
\end{aligned}
$$




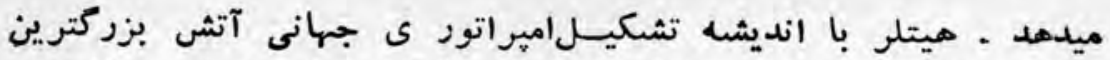

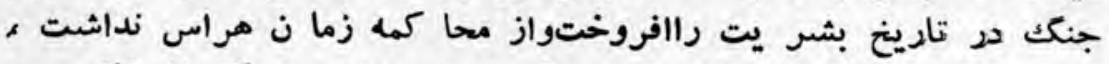

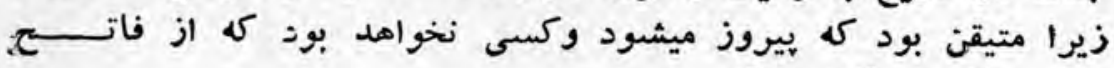

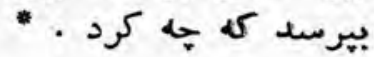

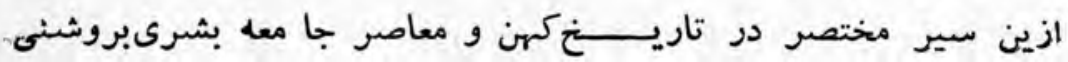

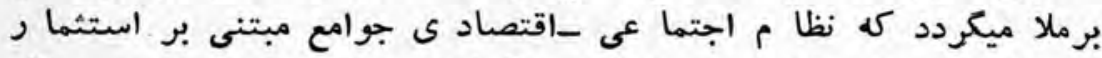

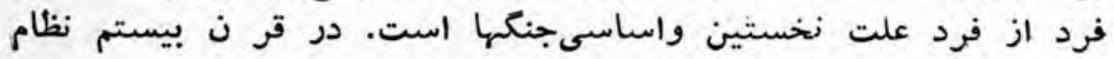

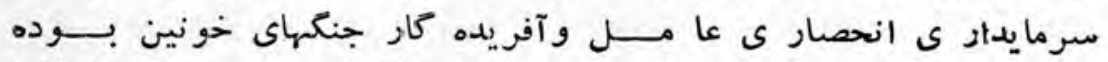

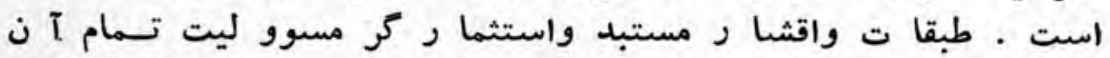

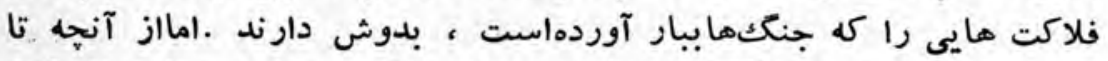

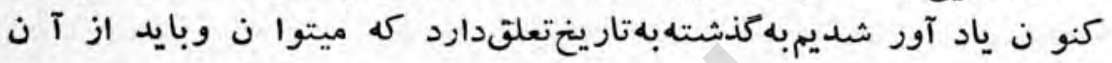

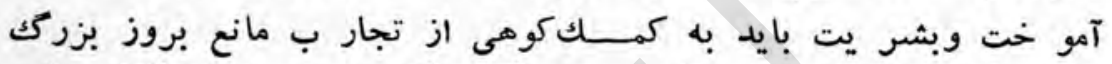

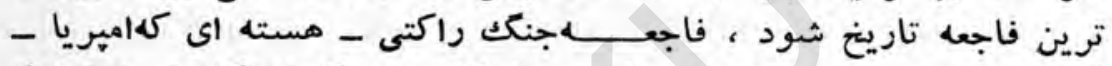

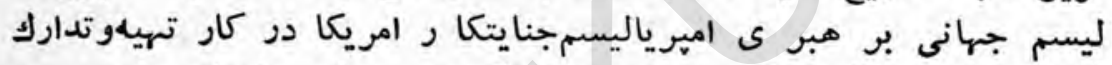

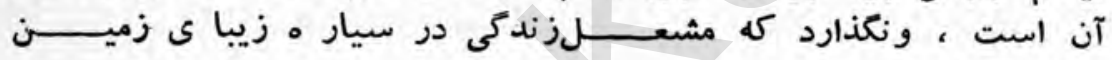
خاموش شود آن

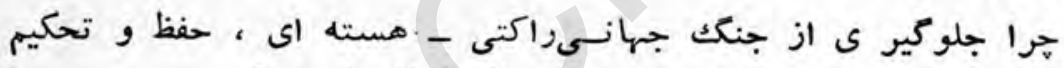

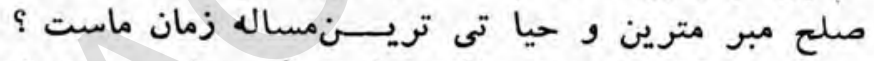

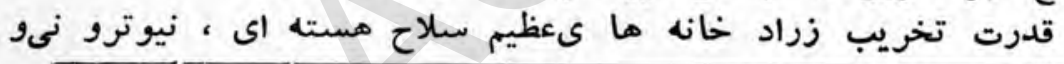

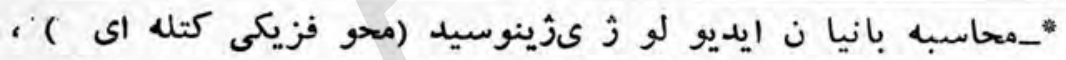

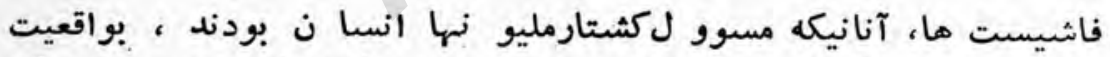

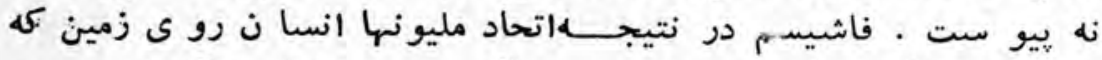

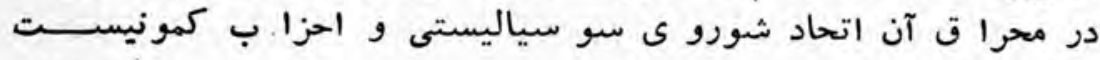

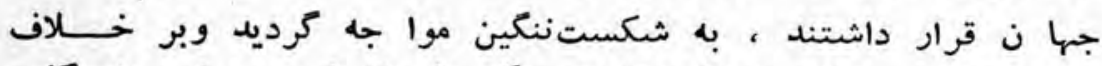

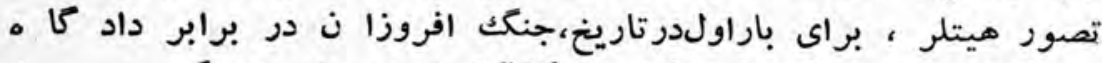

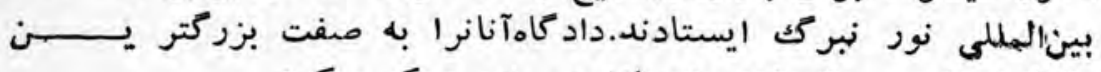

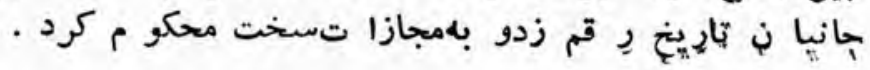




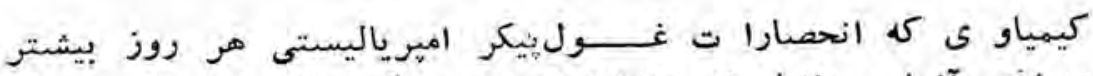

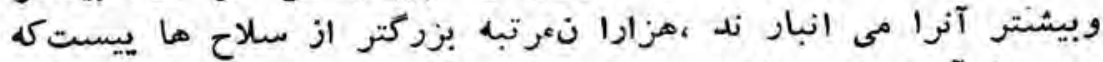

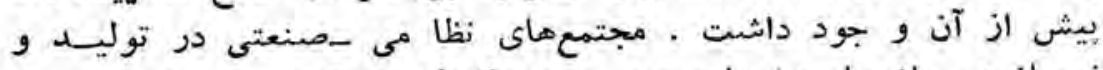

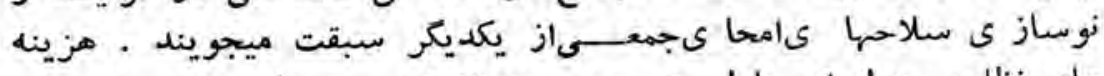

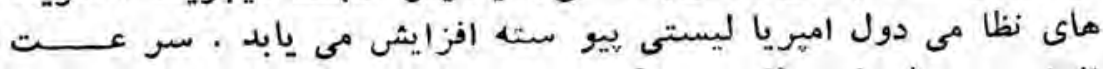

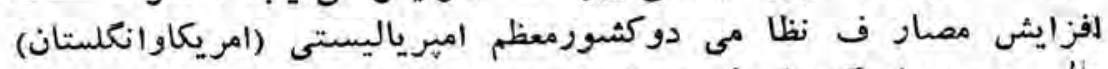

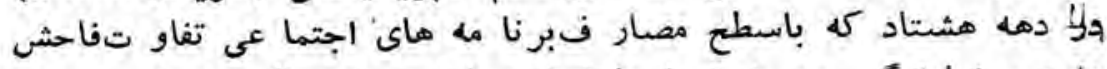

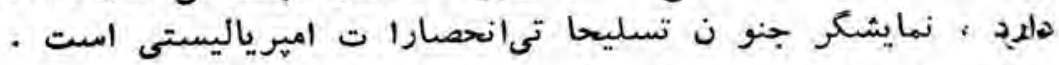

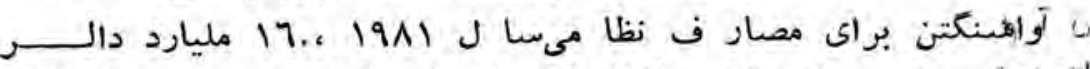

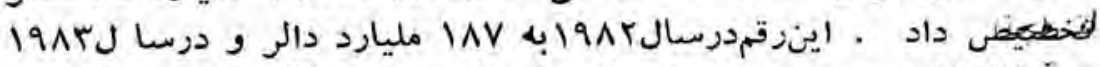

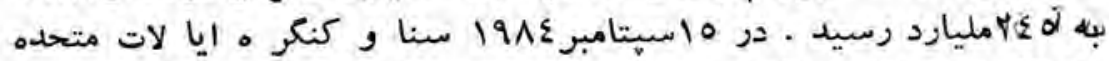

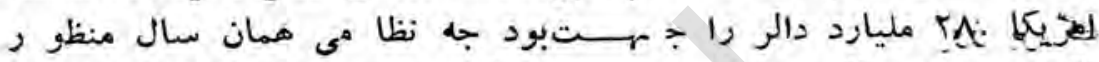

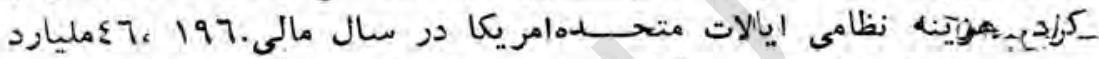

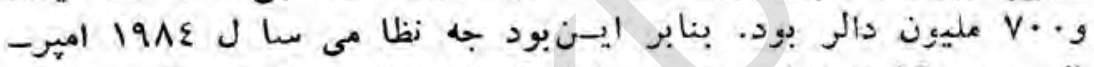

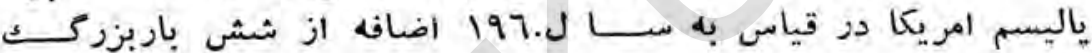

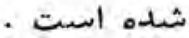

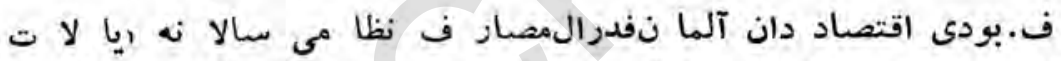

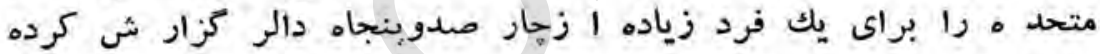

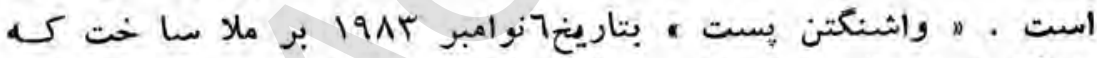

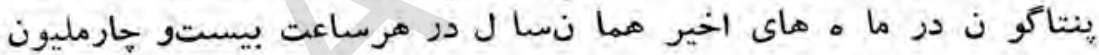

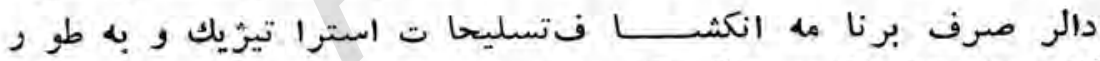

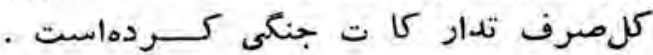

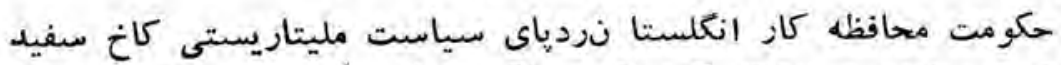

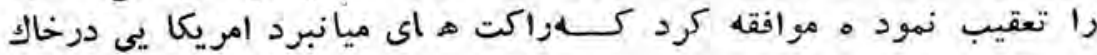

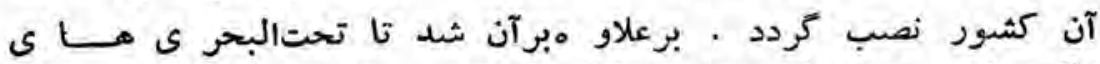

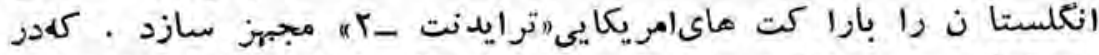

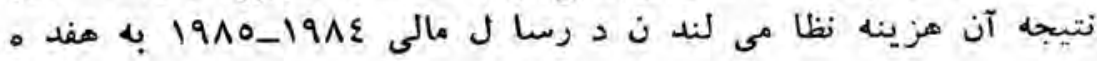




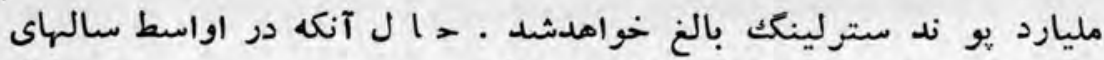

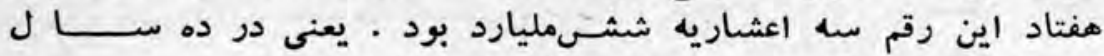

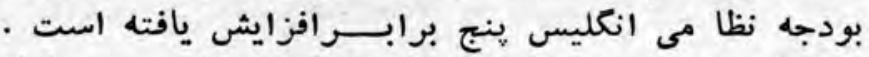

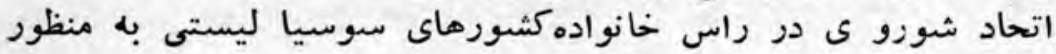

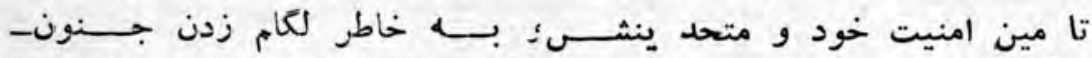

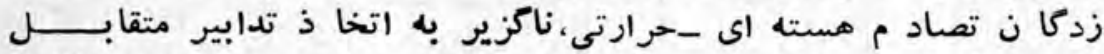

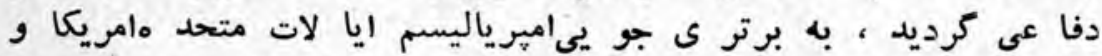

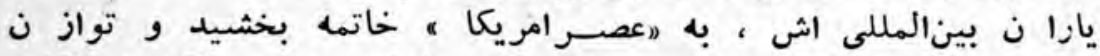

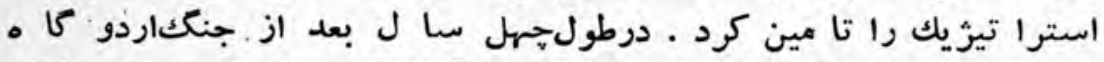

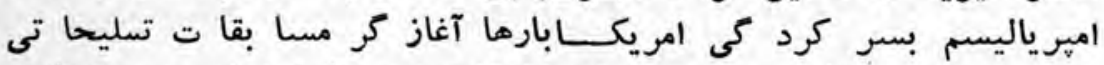

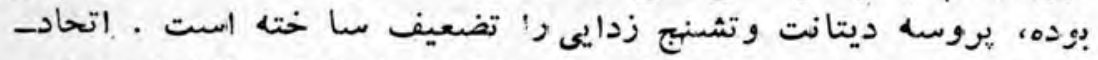

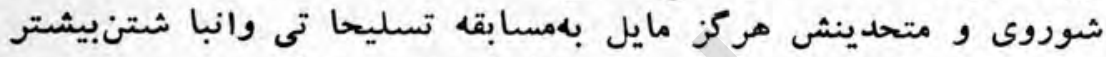

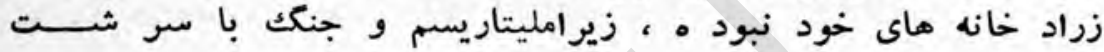

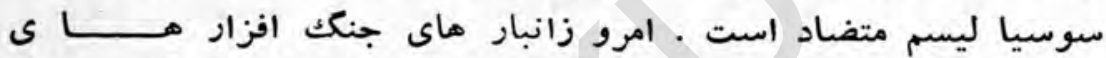

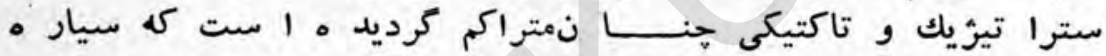

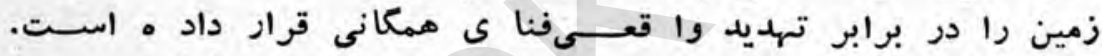

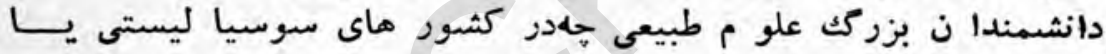

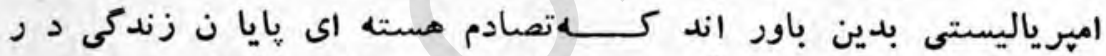

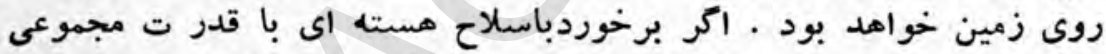

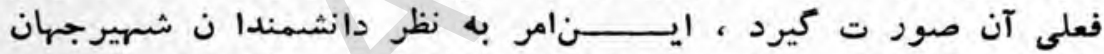

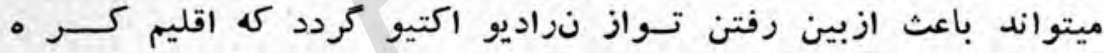

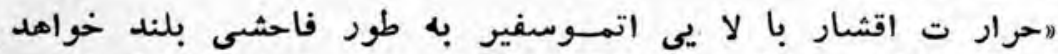

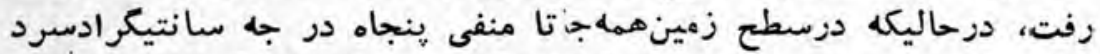

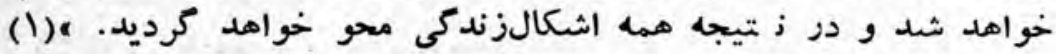
اين كزا فه نيست ، حقايق علمىاست كع در نتيجه تحقيقا ت درا ز

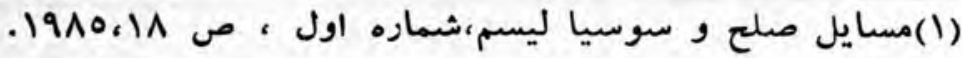




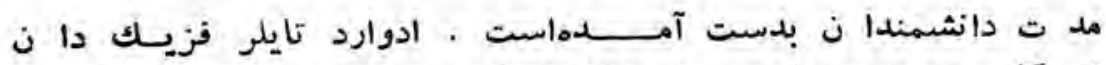

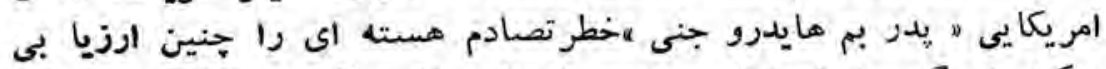

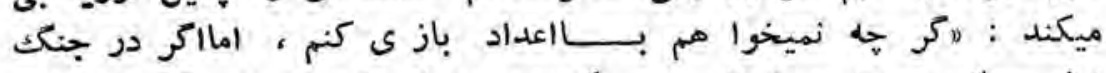

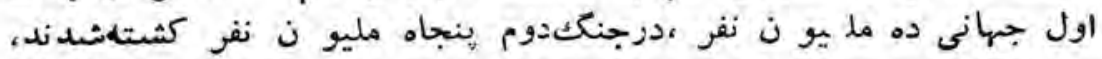

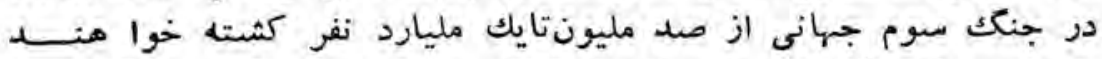

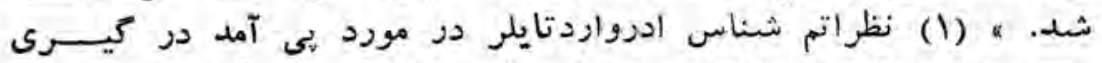

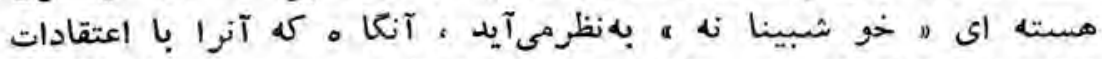

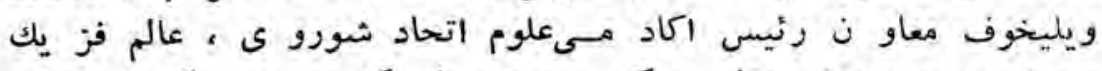

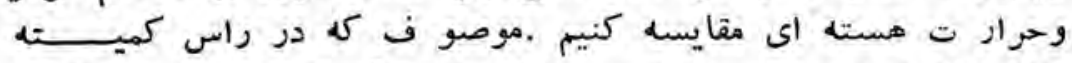

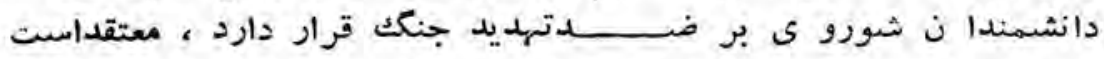

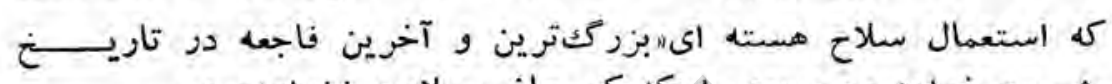

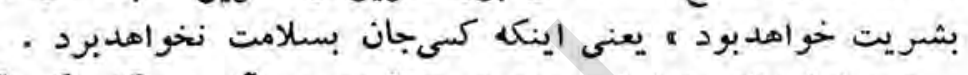

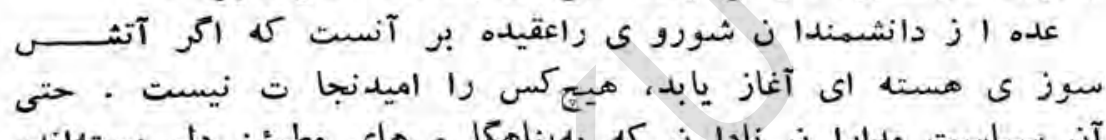

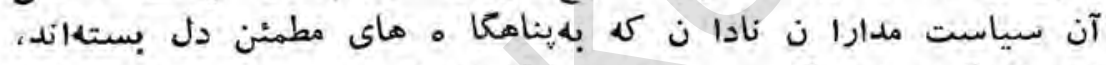

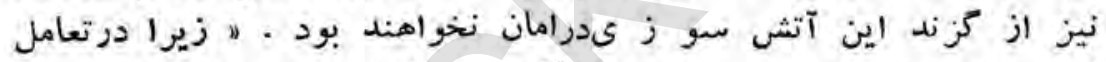

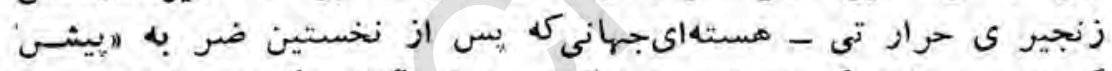

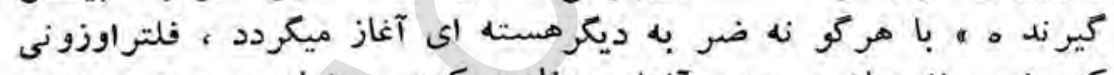

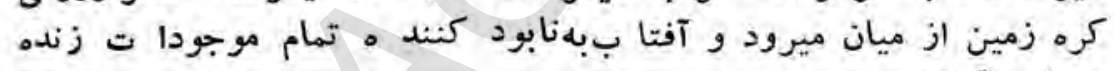

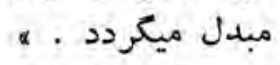

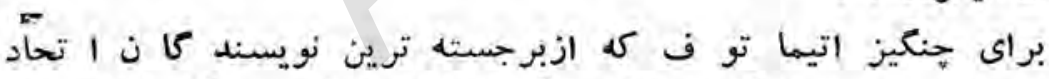

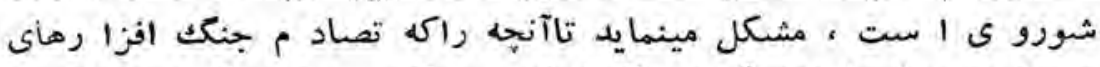

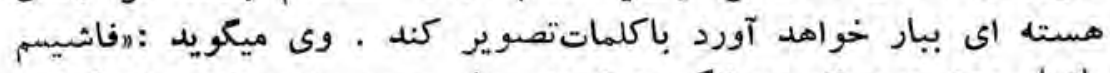

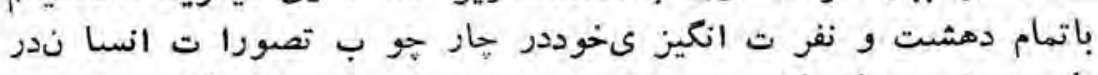

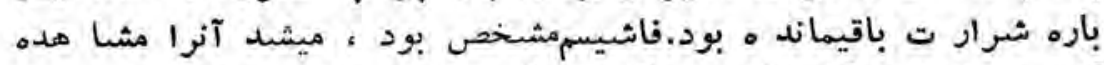

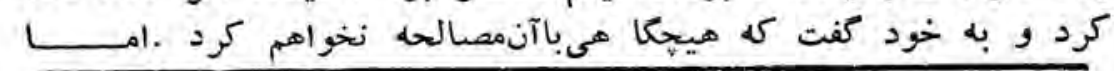

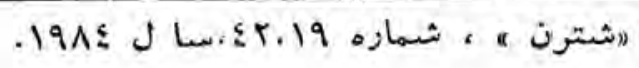




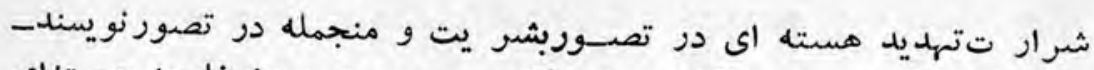

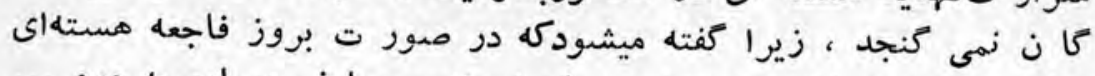

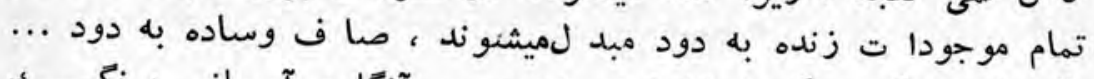

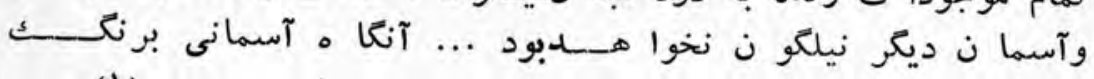

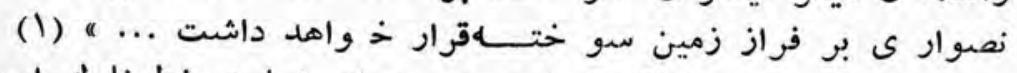

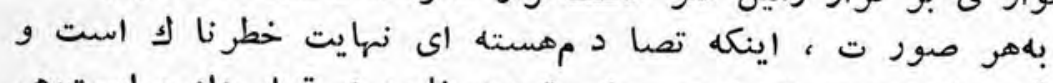

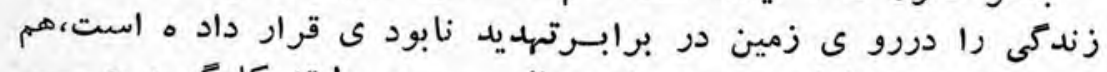

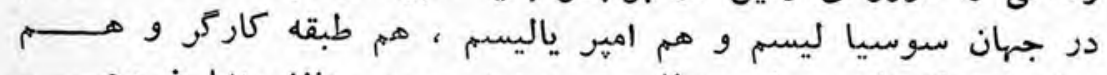

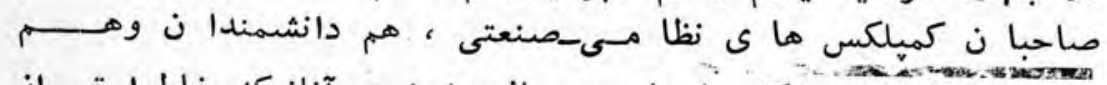

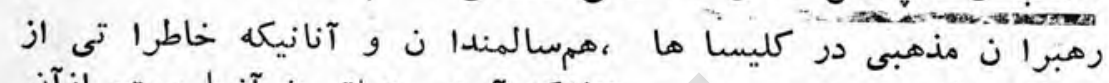

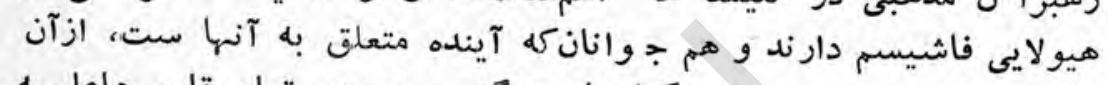

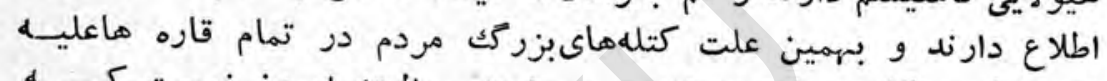

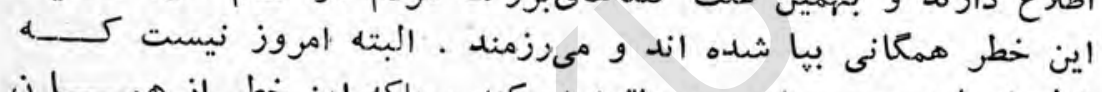

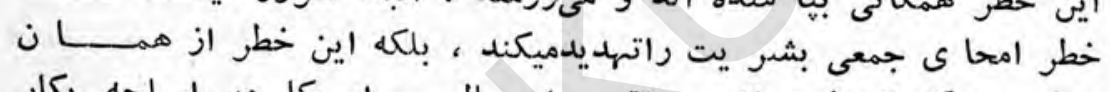

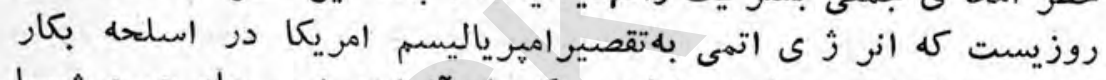

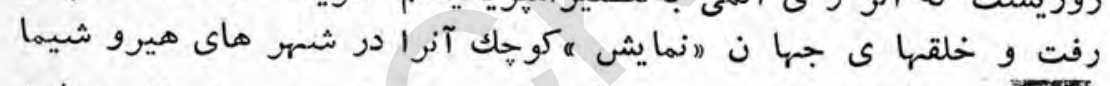

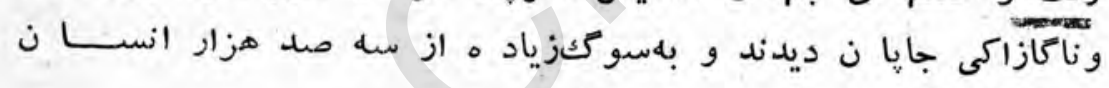

\section{*}

\section{米}

\section{类}

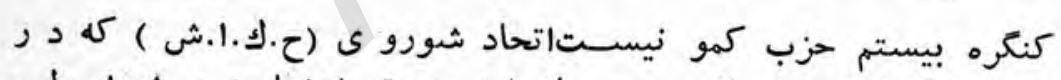

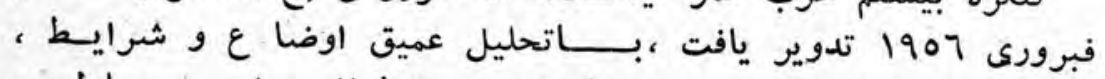

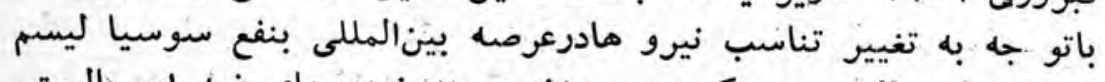

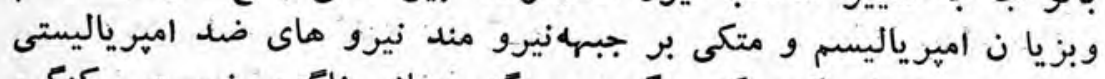

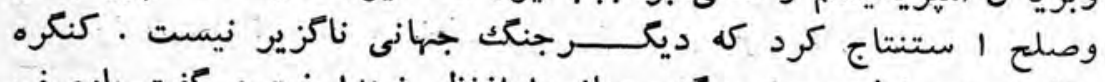

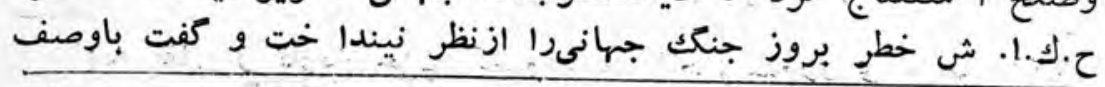

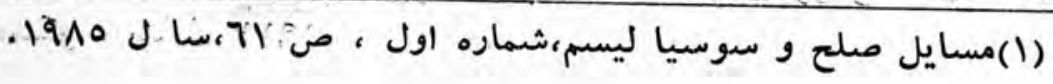




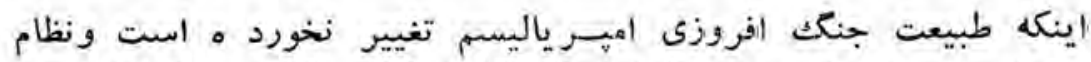

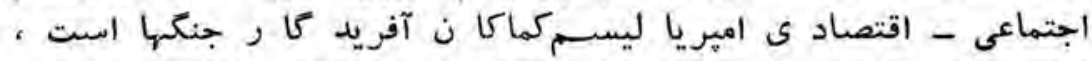

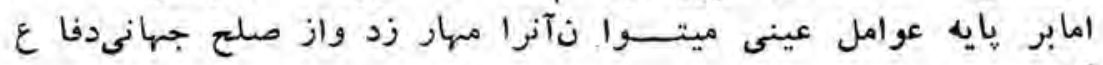

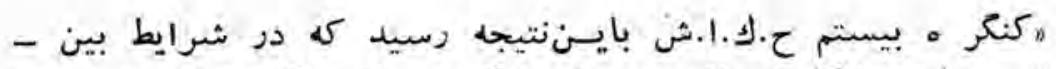

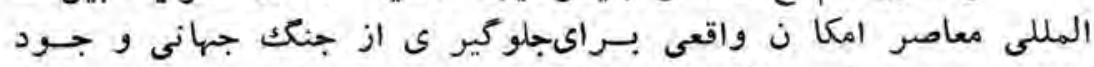

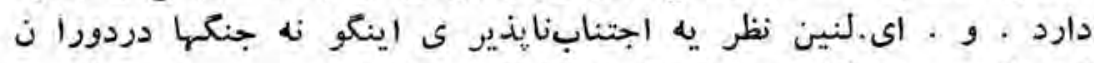

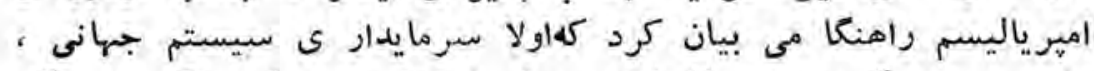

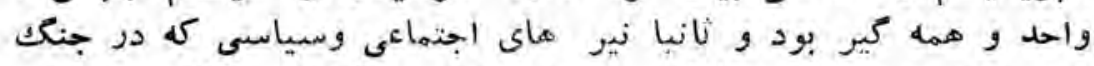

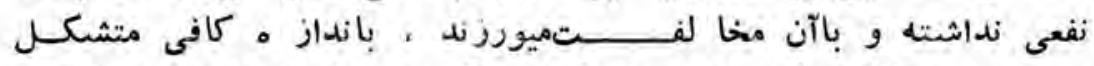

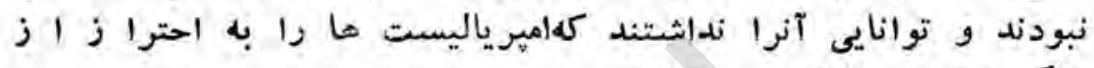
(1) I جنك مجبور سازند

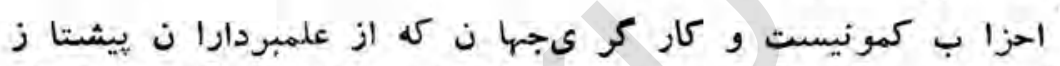

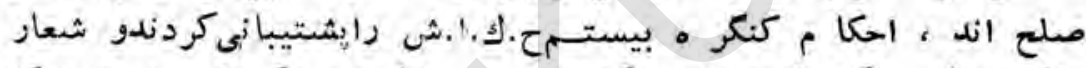

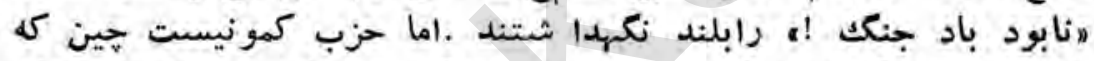

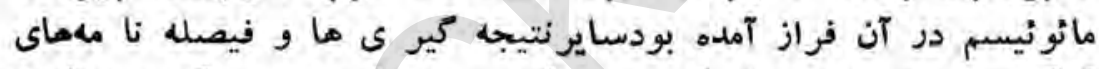

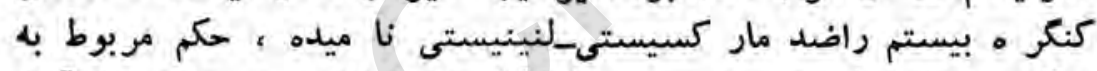

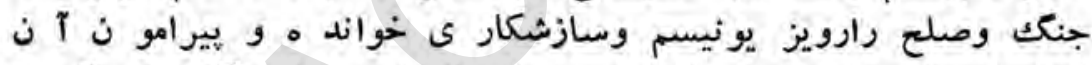

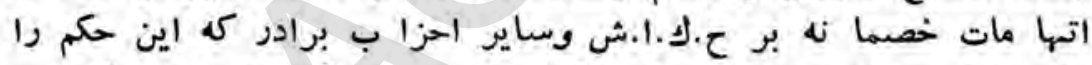

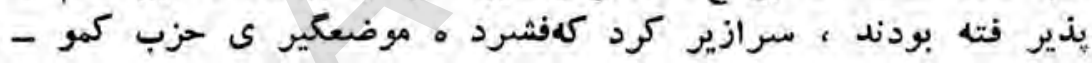

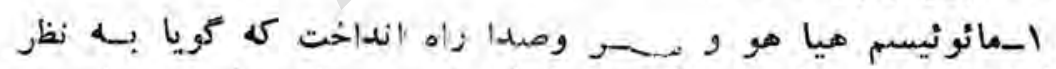

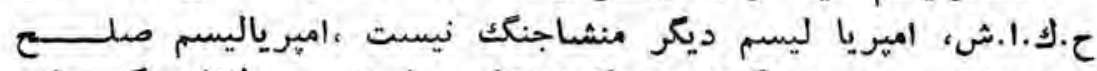

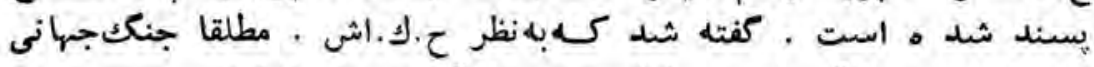

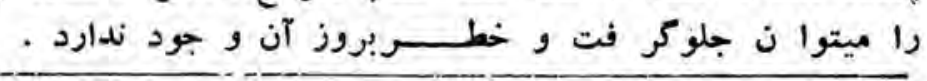

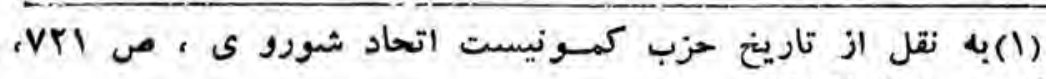

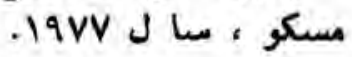




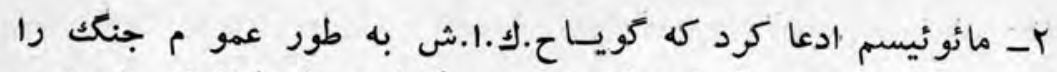

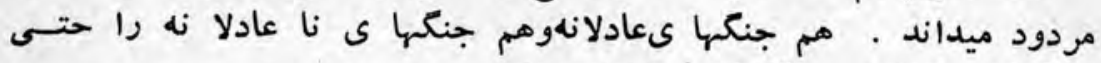

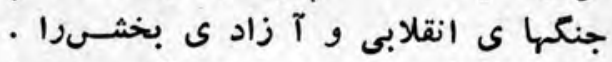

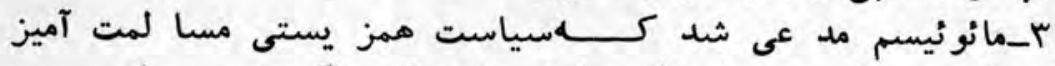

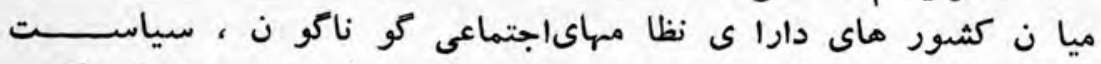

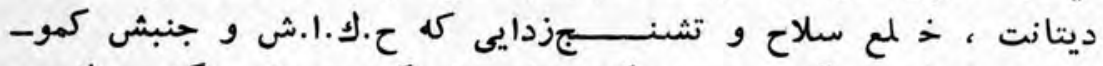

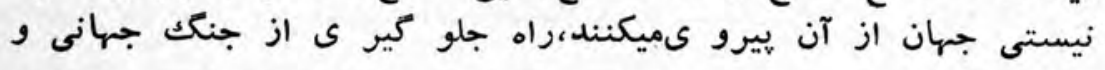

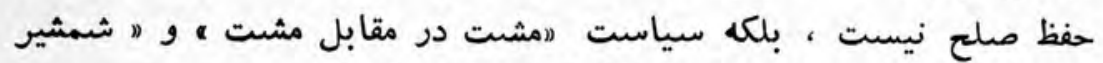

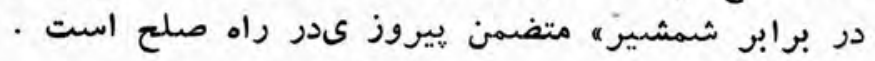

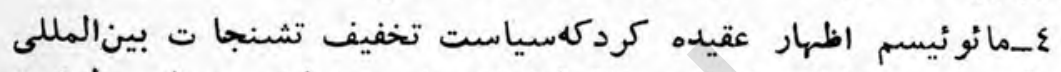

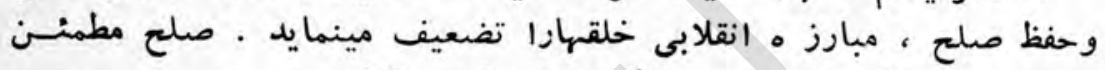

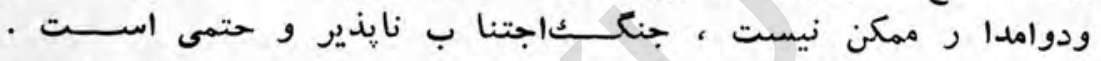

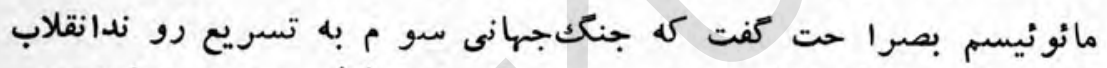

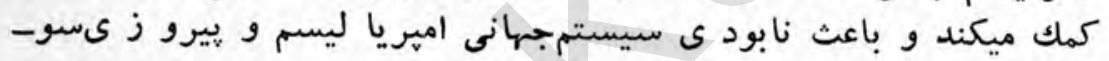

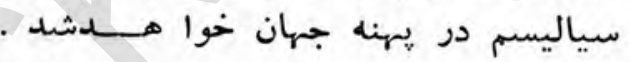

\section{है}

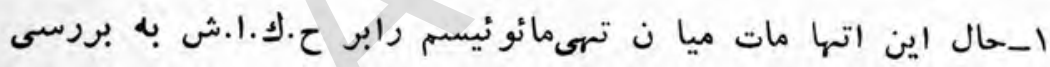

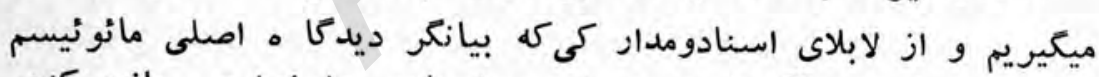

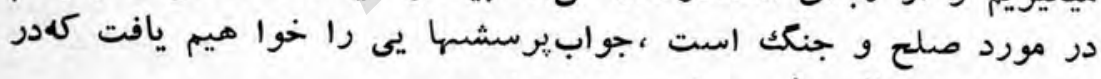

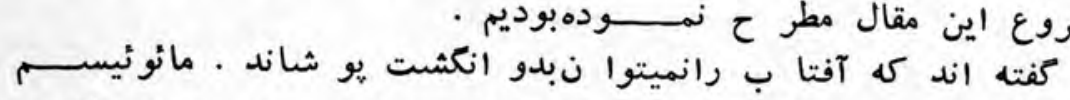

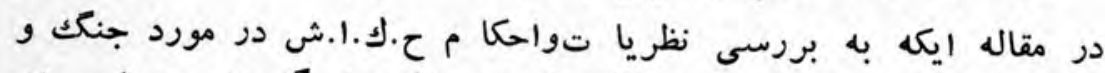

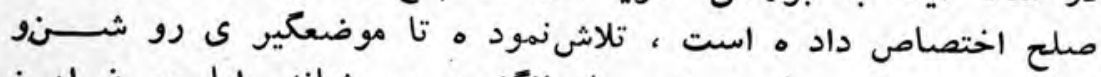

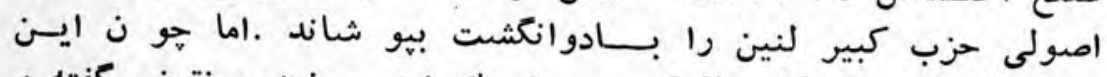

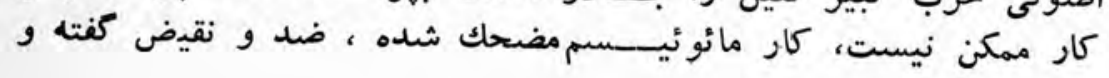




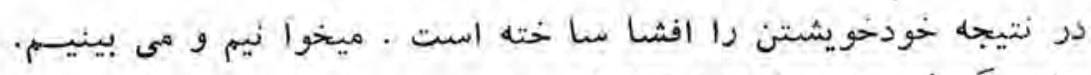

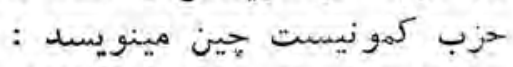

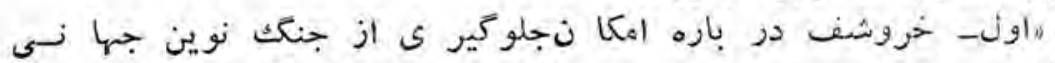

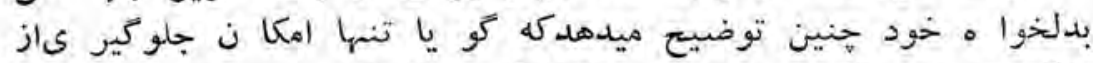

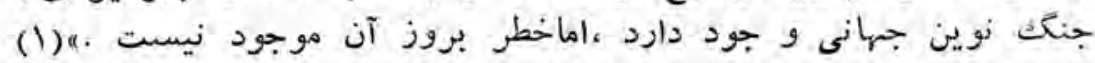

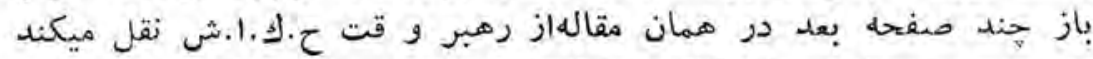

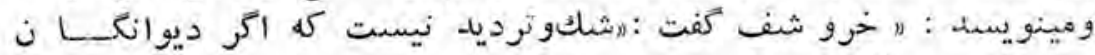

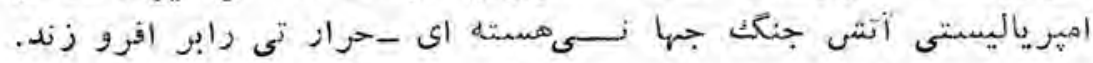

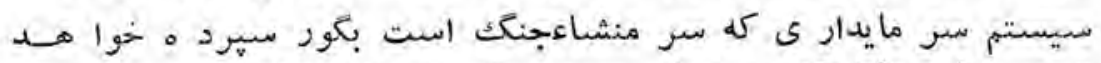

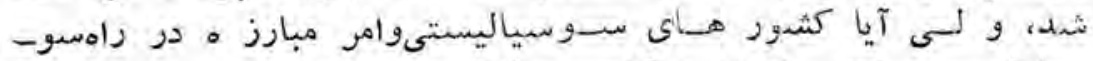

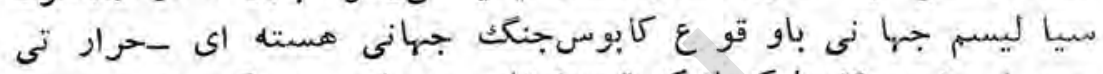

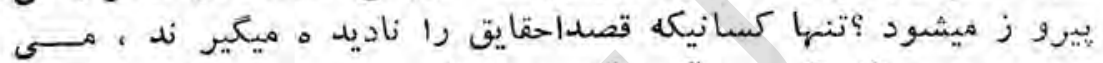

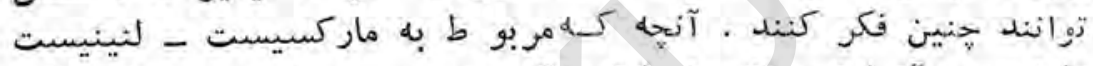

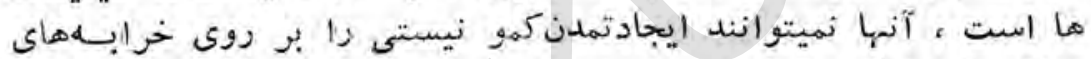

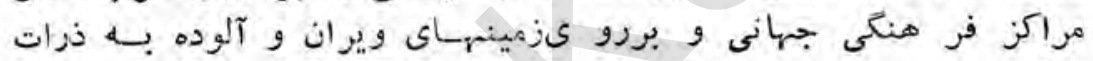

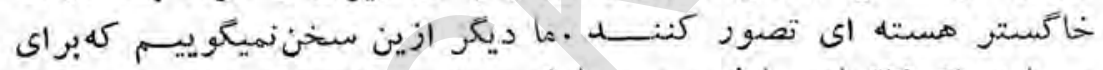

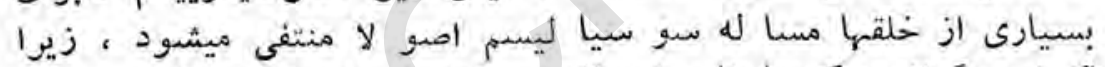

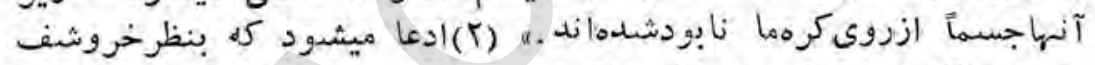

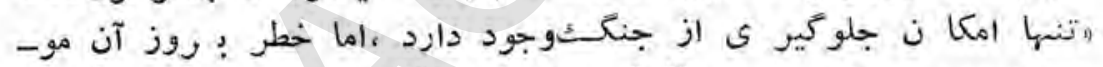

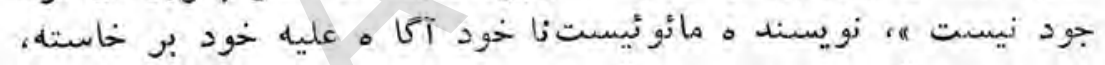

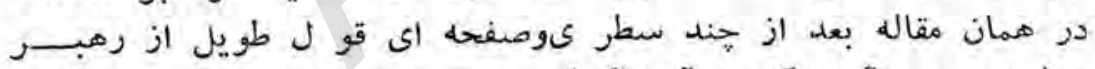

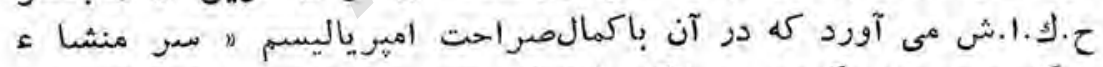

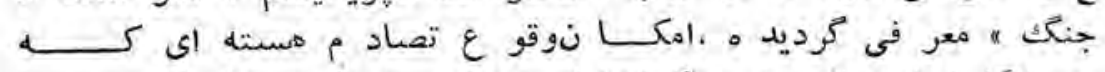

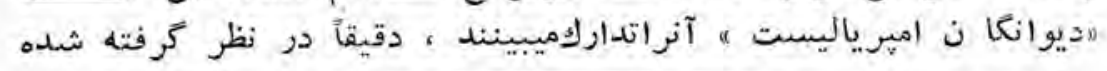

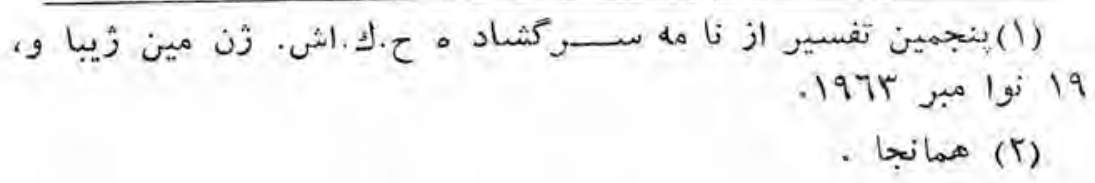




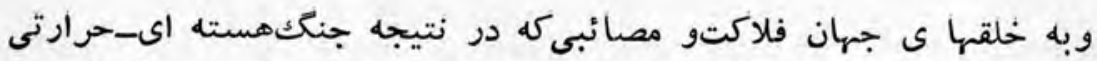

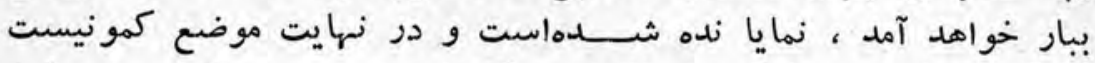

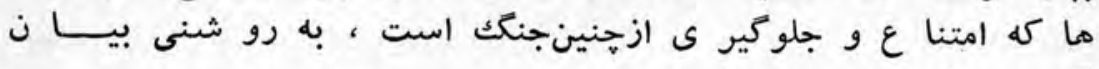

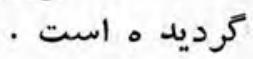

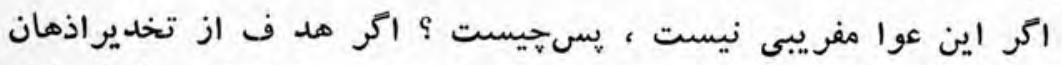

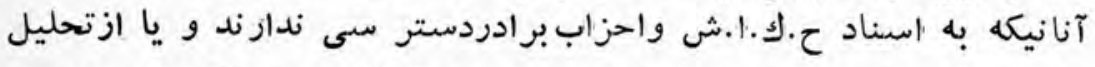

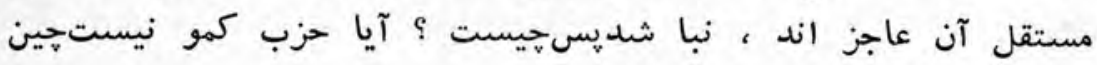

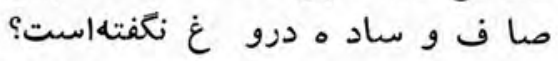

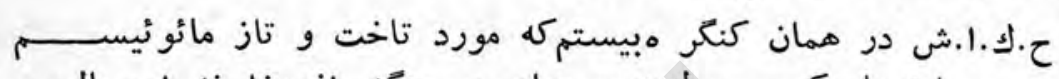

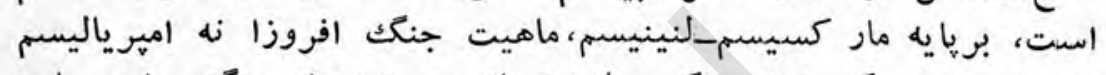

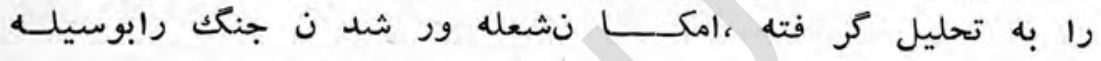

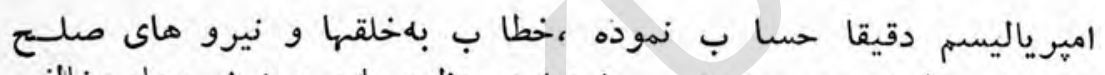

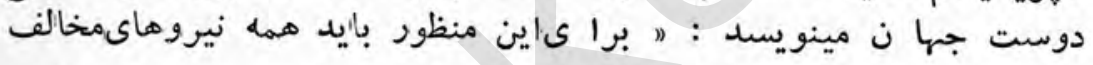

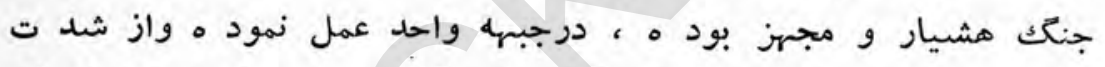

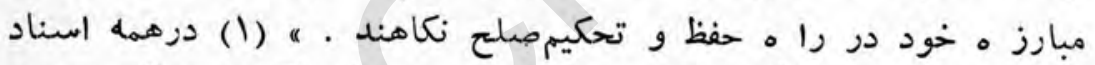

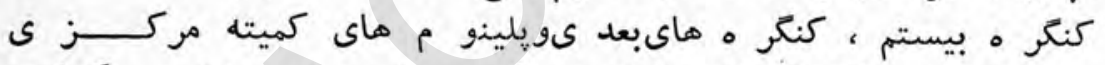

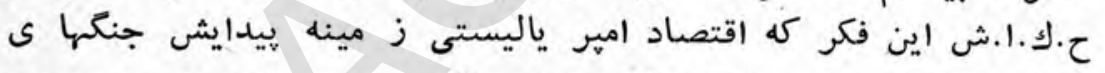

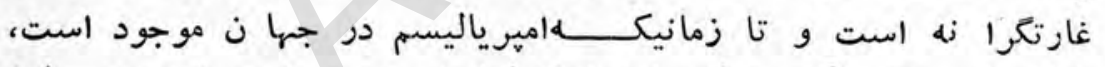

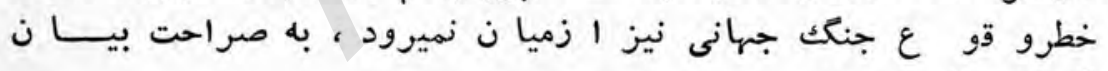

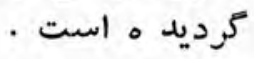

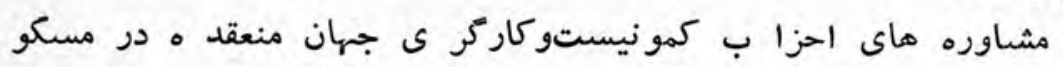

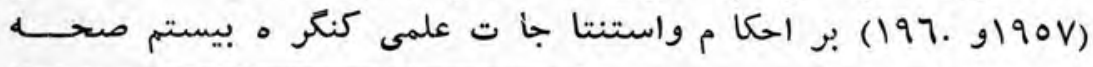

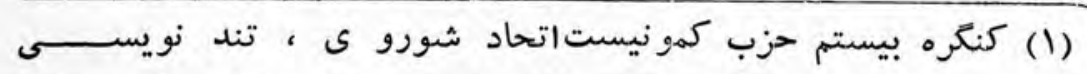

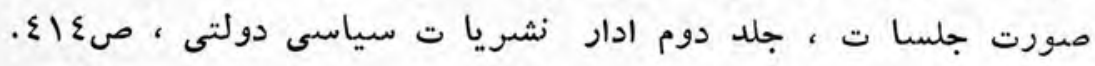
سال 1907. 


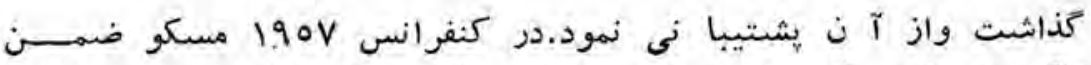

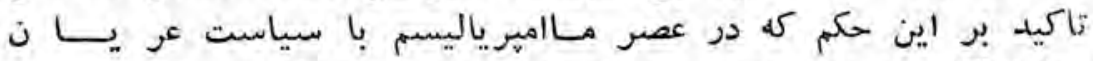

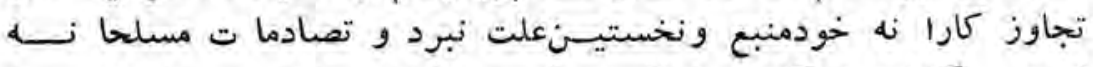

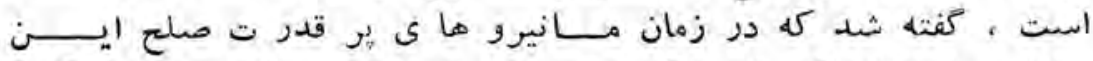

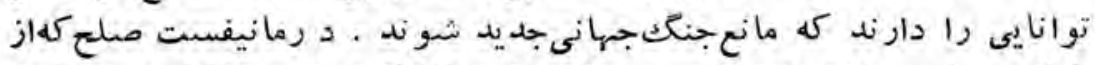

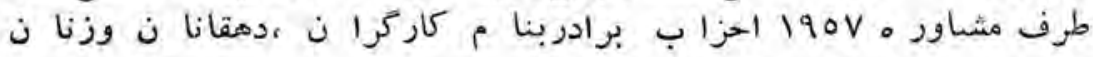

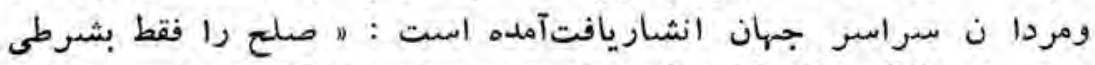

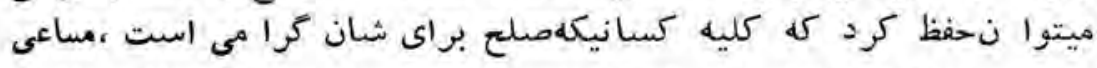

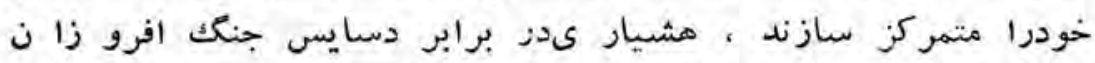

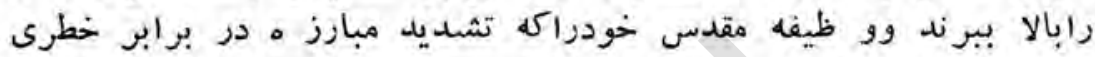

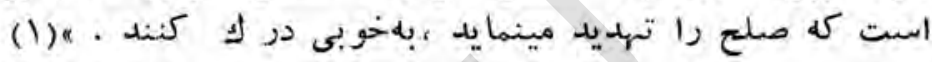

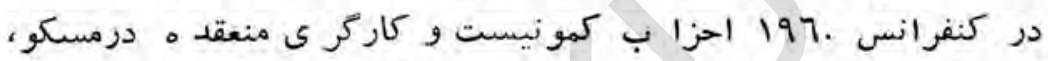

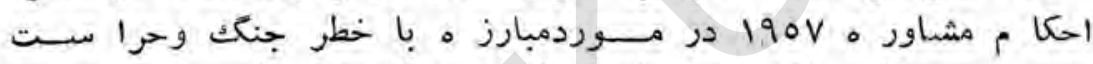

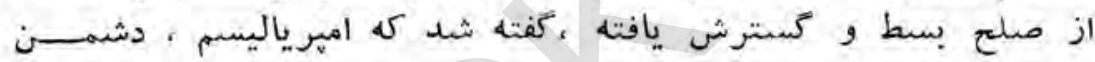

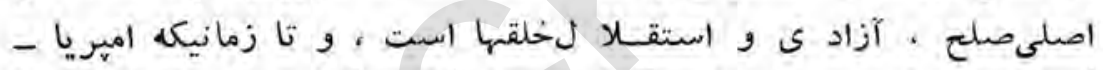

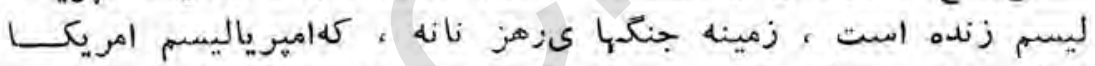

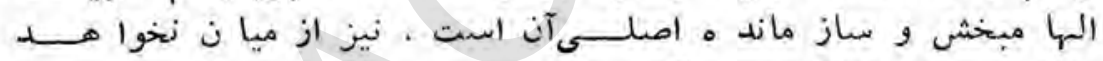

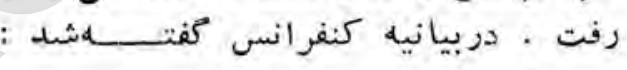

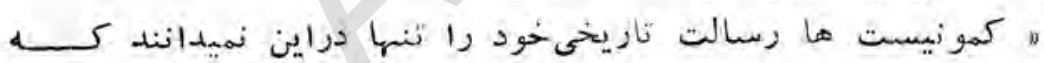

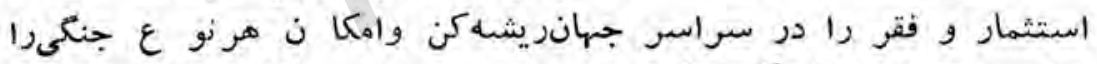

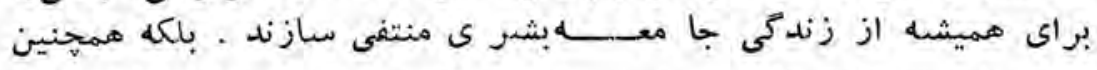

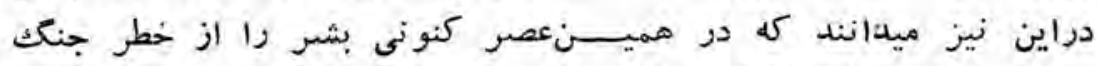
(r) جديد جهانى نجات دهن مهند

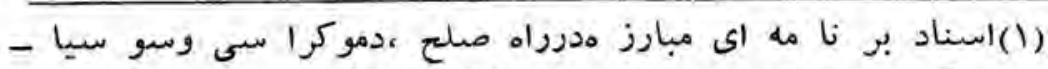

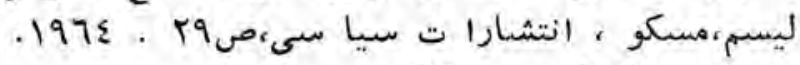
. 


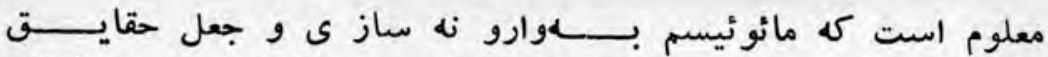

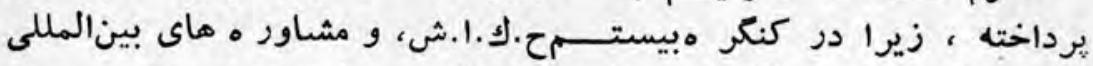

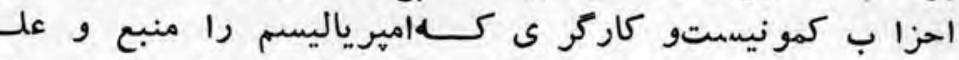

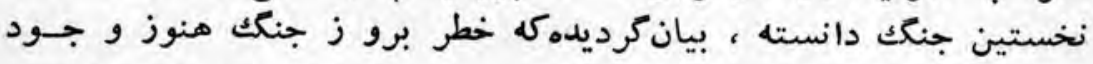

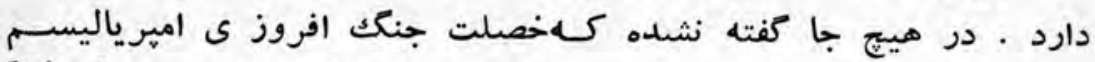

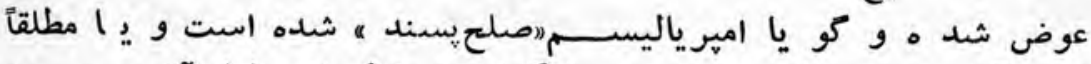

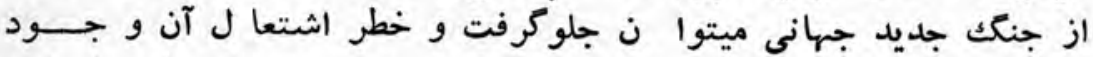

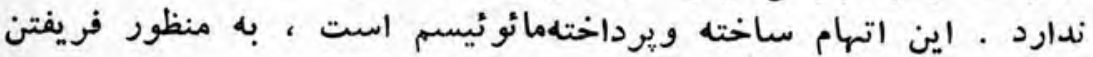

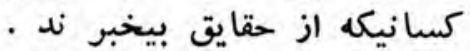

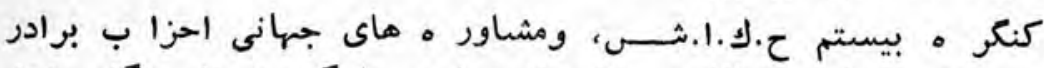

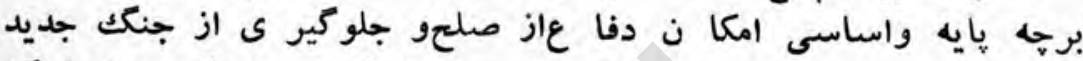

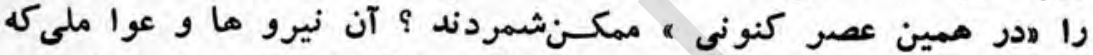

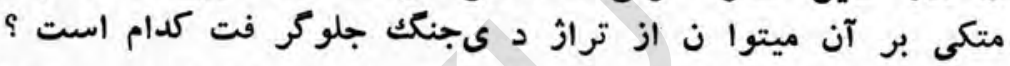

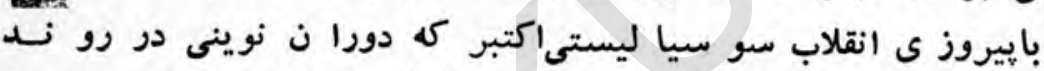

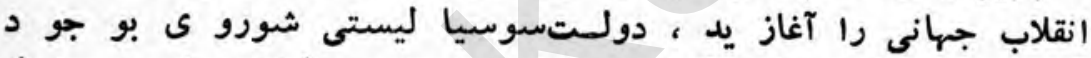

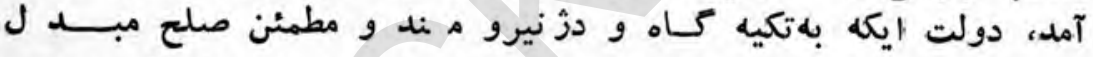

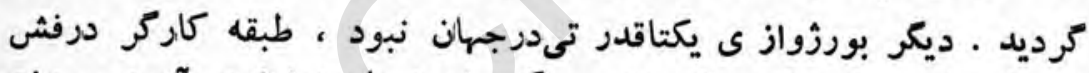

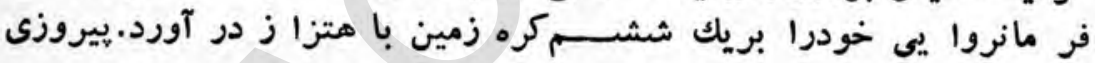

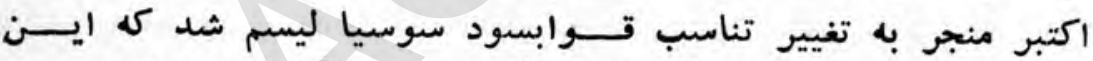

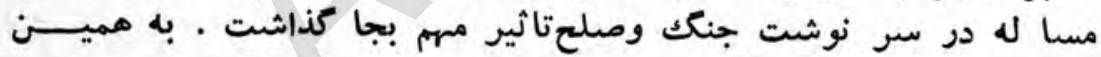

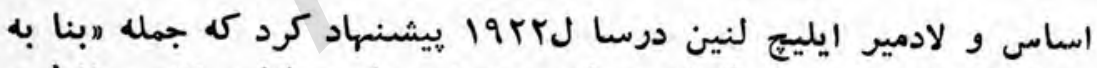

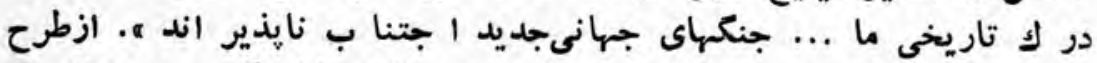

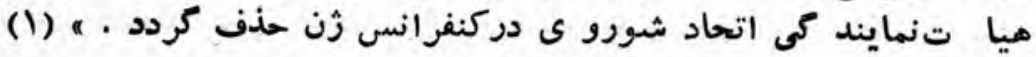

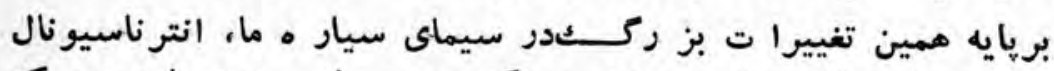

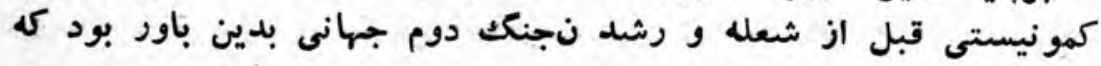

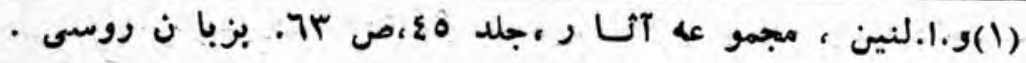




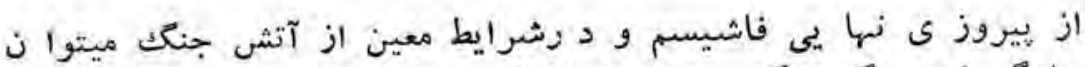

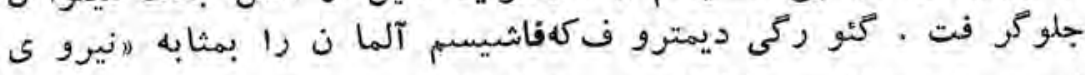

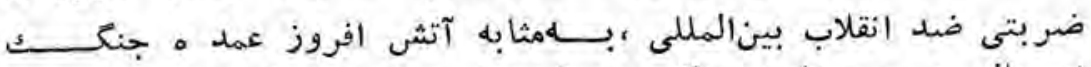

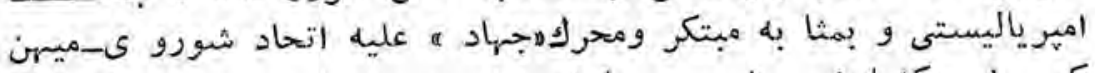

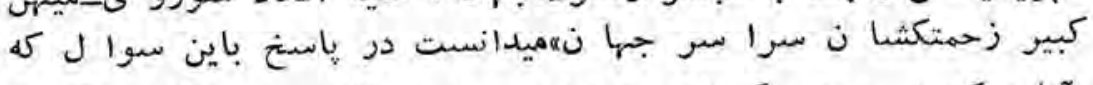

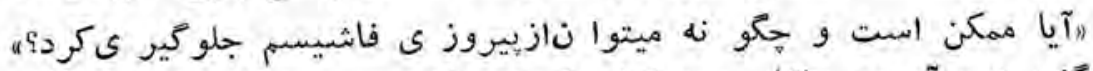

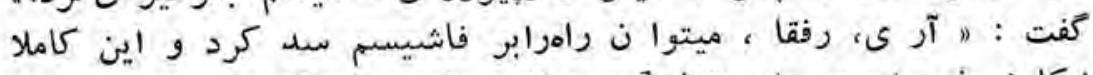

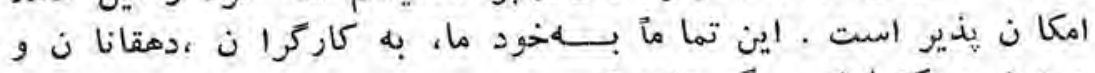

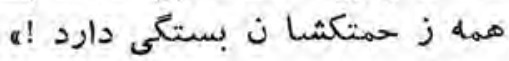

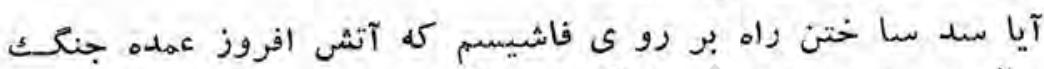

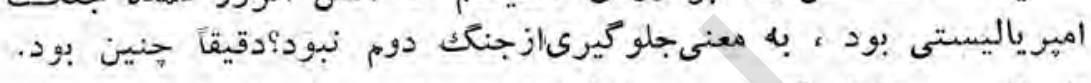

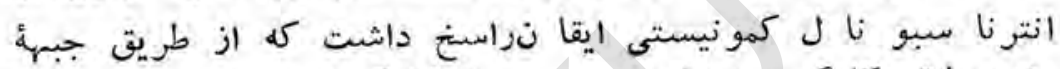

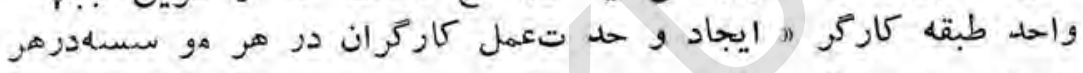

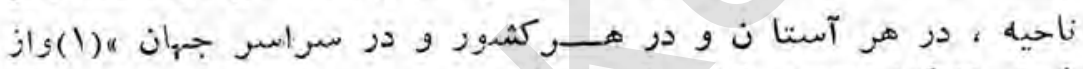

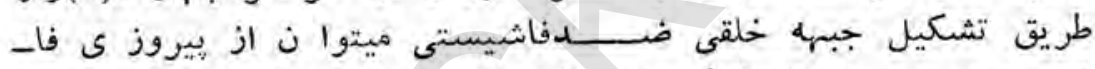

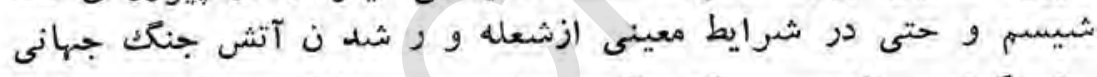

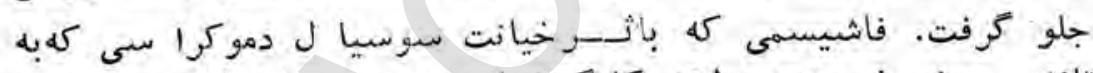

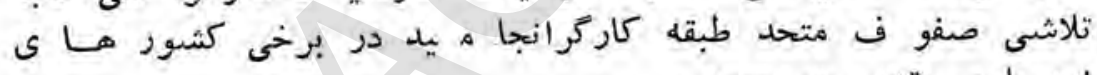

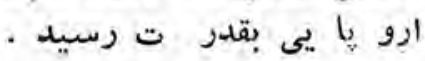

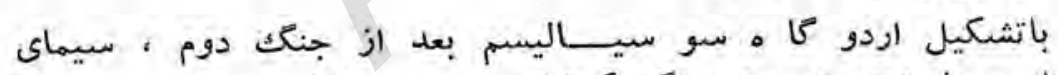

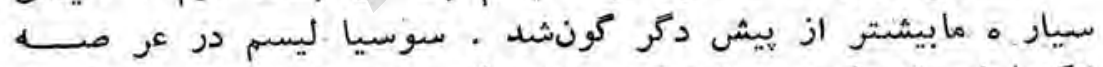

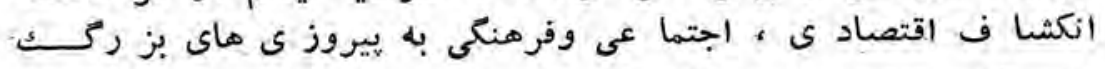

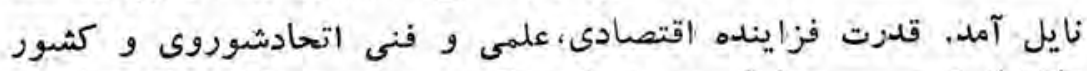

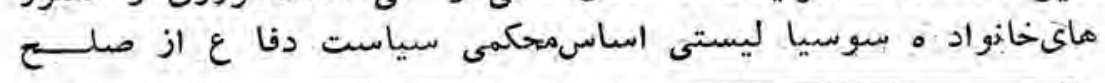

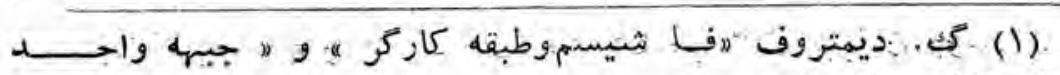

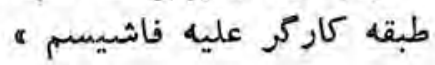




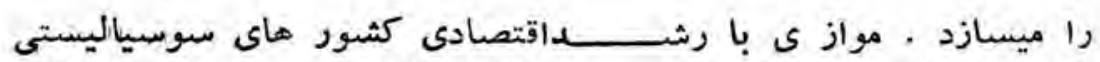

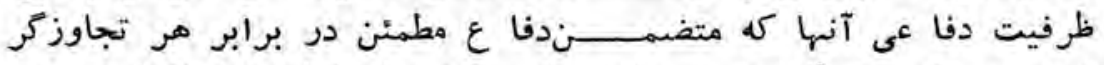

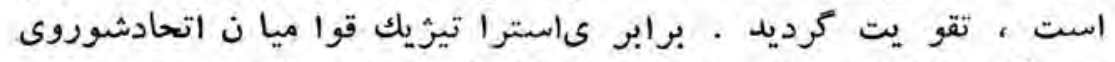

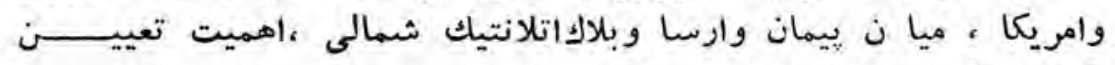

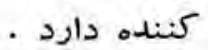

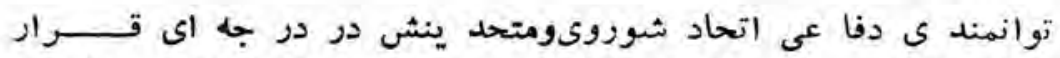

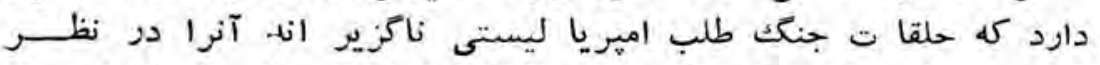

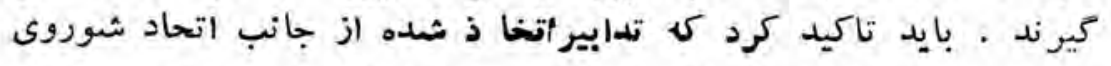

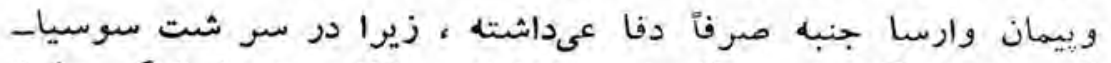

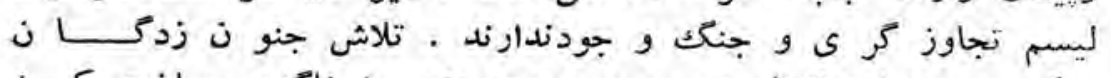

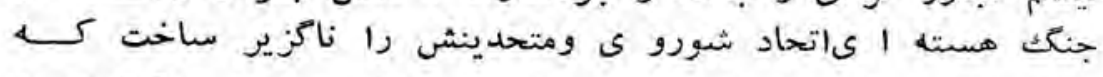

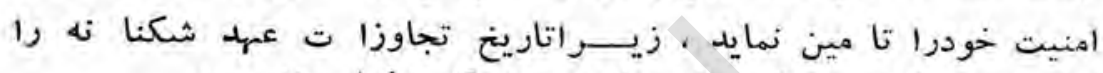

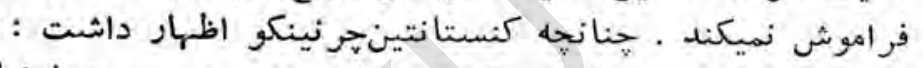

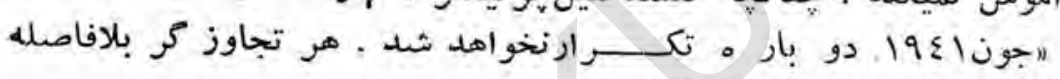

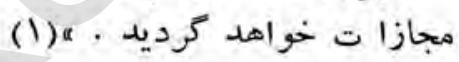

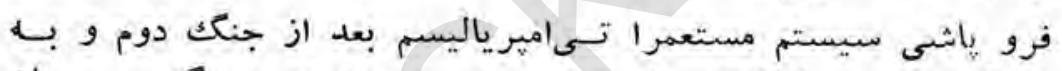

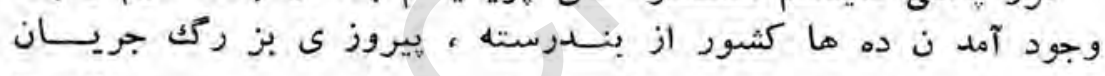

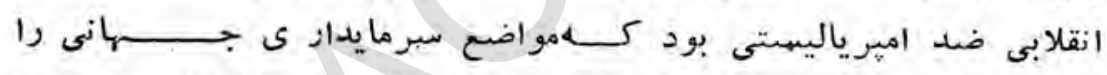

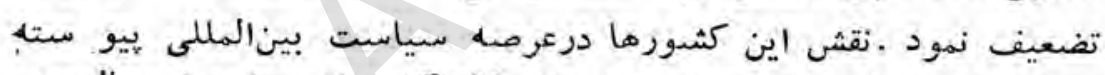

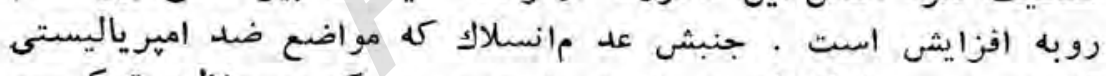

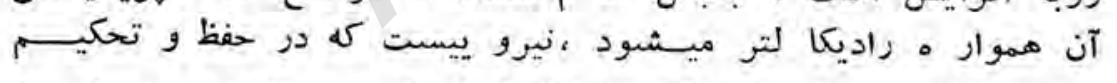

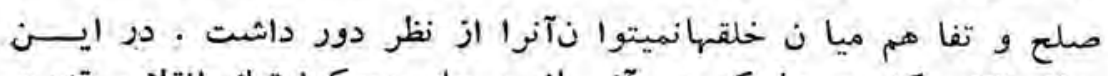

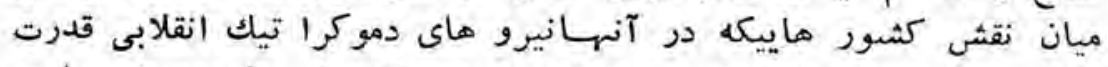

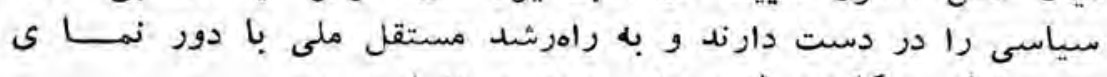

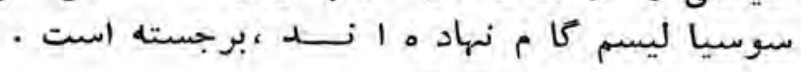

(1) -ror- 


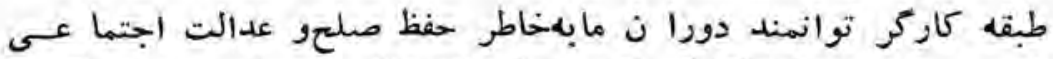

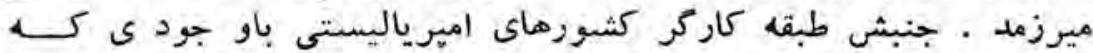

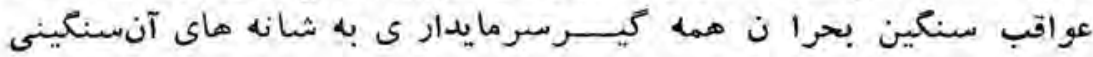

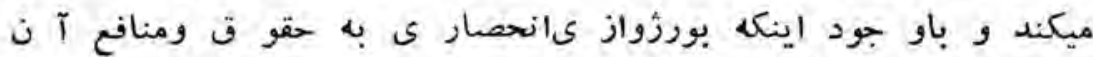

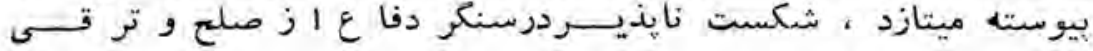

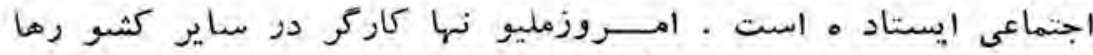
(به خصوص در ارو يا وامريكا ) برضد جنو ن هسته ائ محافل اميرياه

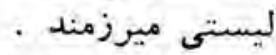

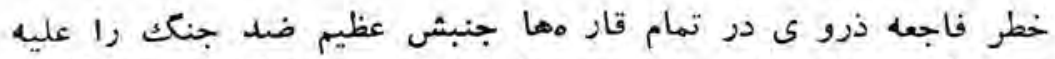

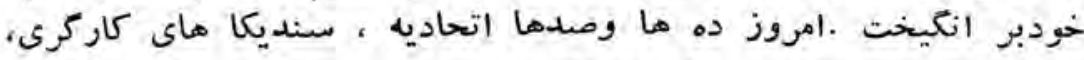

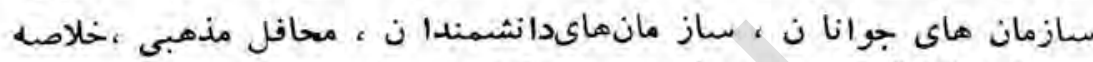

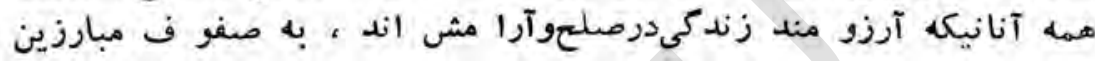

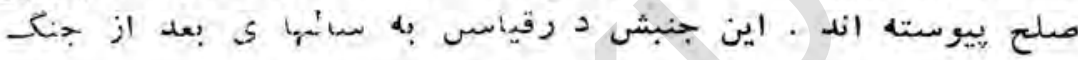

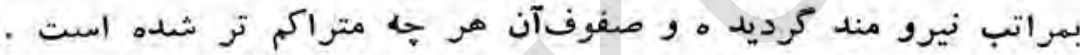

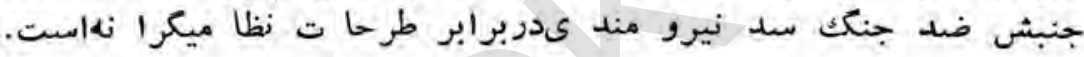

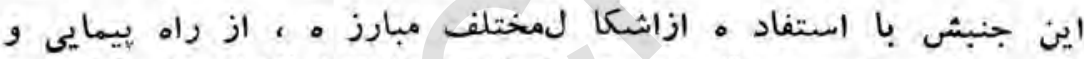

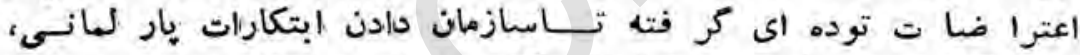

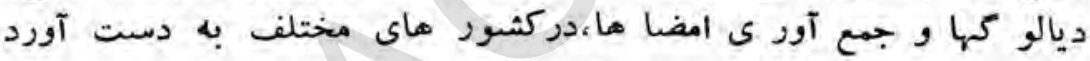

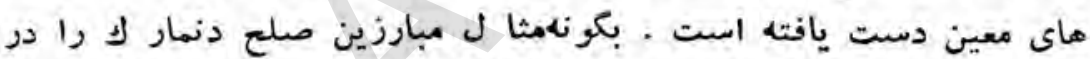

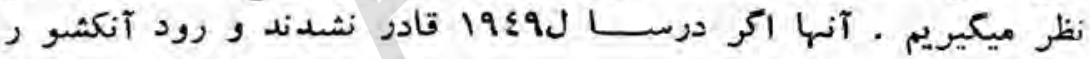

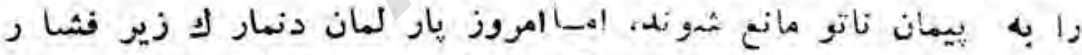

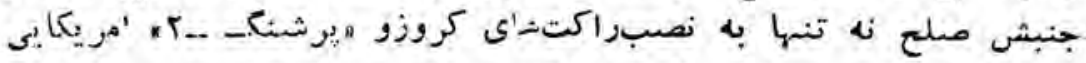

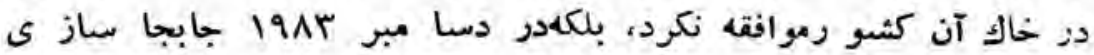

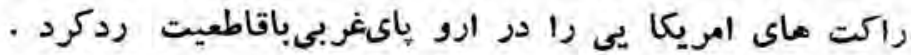

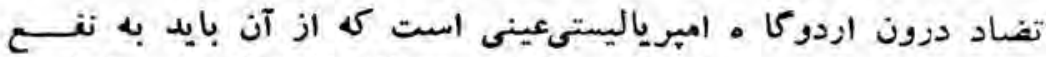

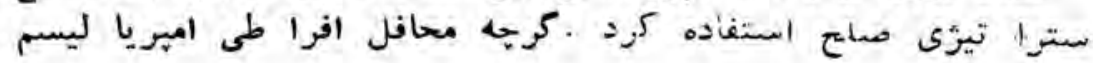




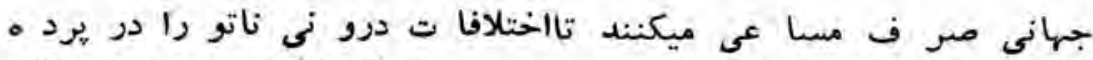

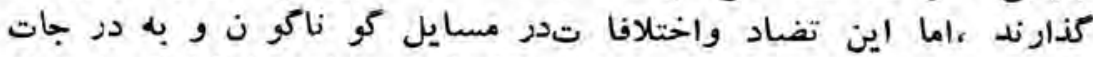

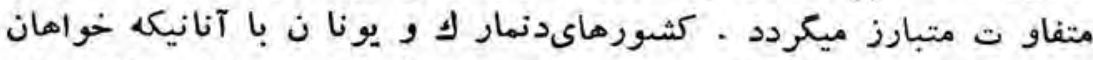

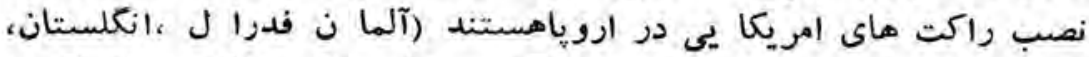

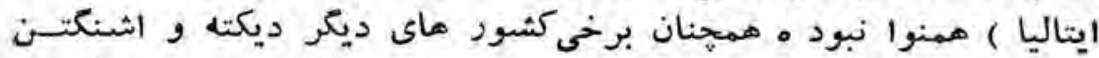

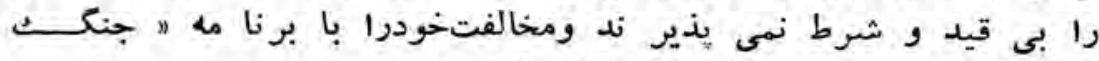
ستارهكا ن ه ريكن بشكلى ازاشعال بتبارز ميدهند .

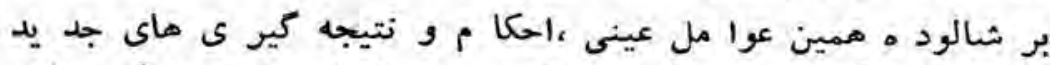

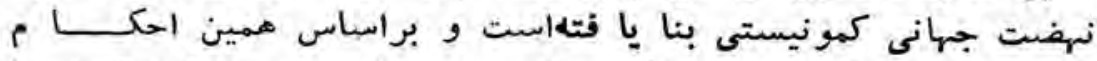

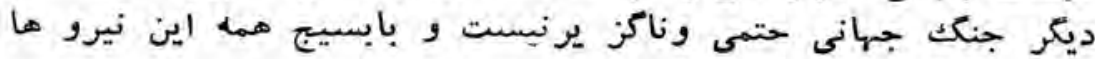

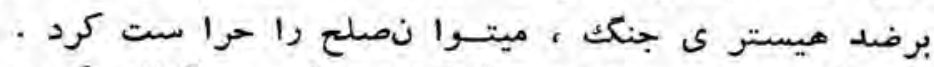

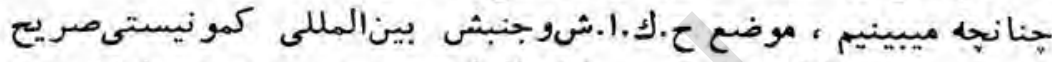

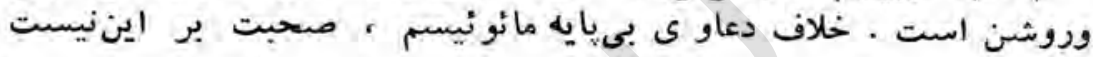

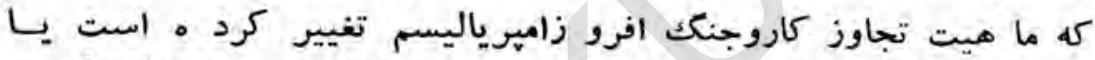

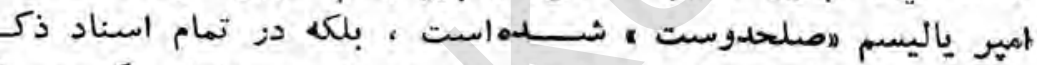

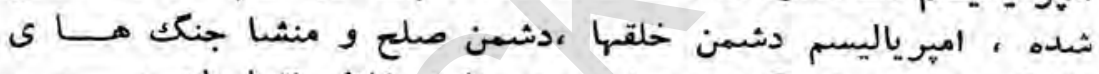

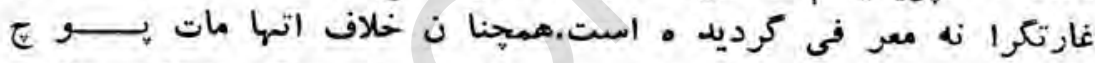

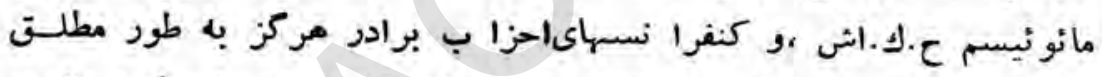

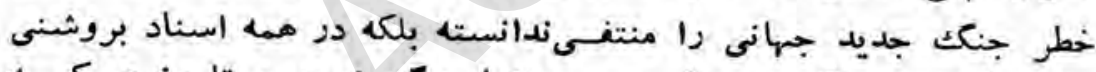

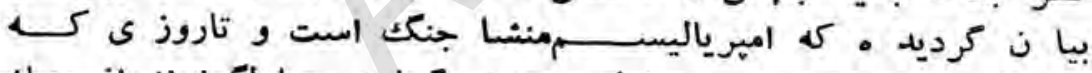

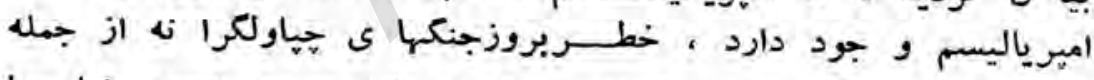

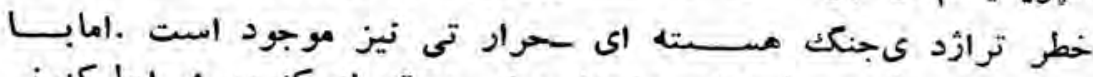

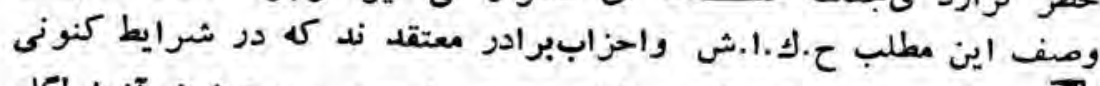

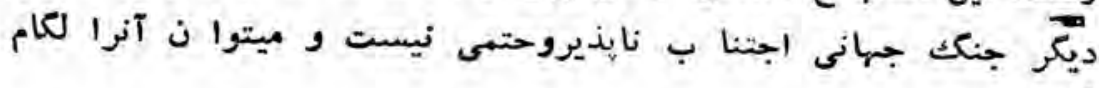
زد . - n

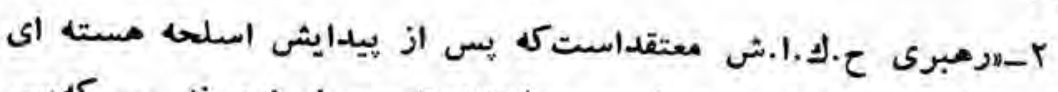

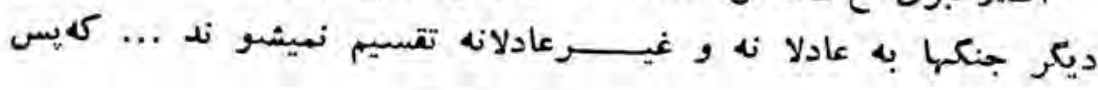




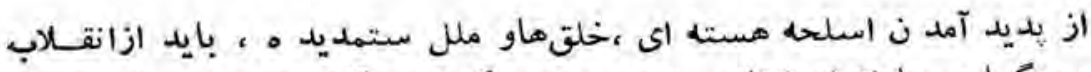

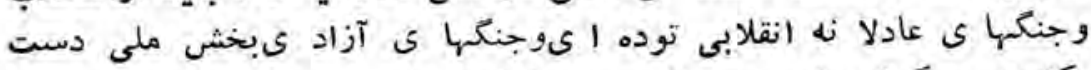

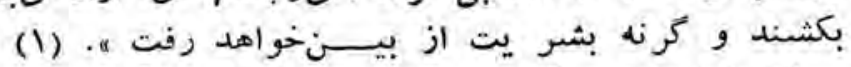

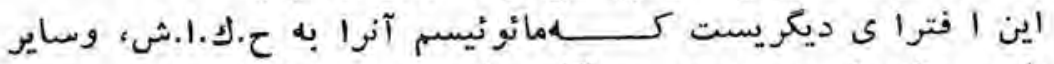

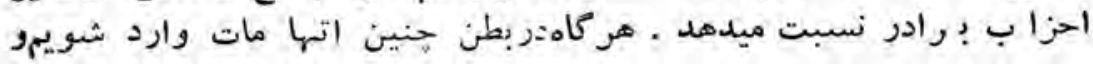

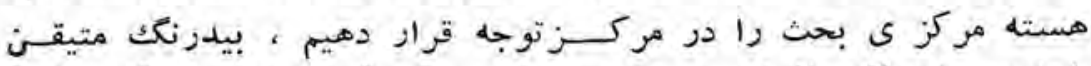

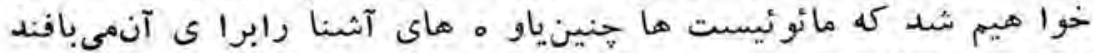

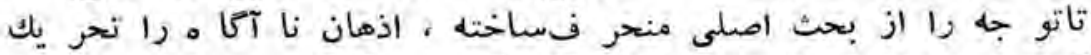

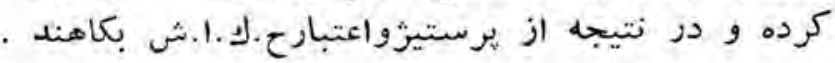

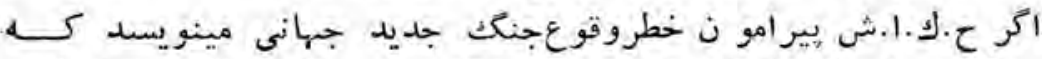

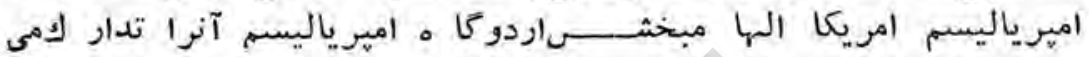

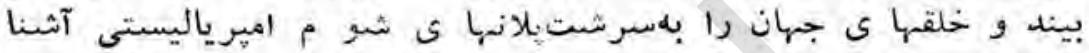

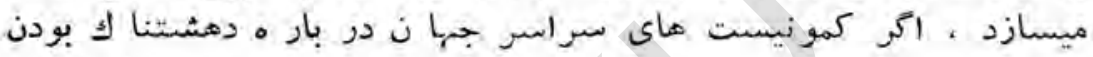

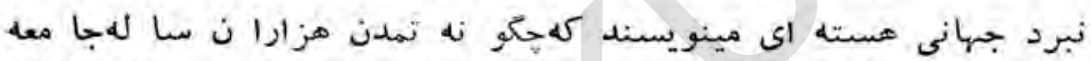

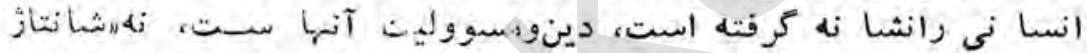

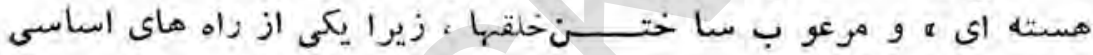
مبارز ه با خطر جنكت افشا ى يلازهاو آن تمايلات باطنى اهيرياليست

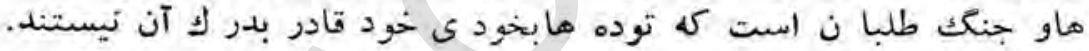

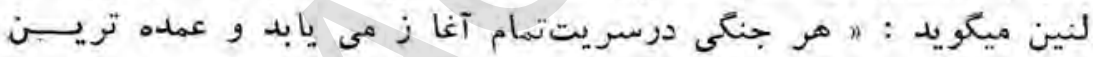

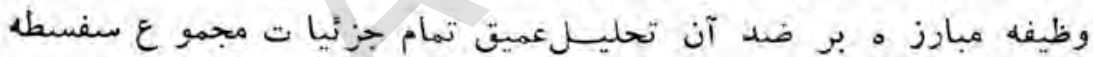

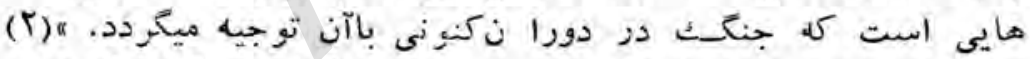

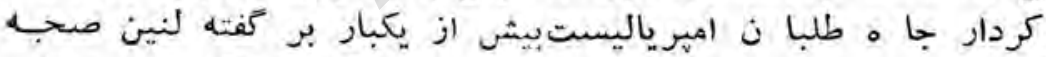

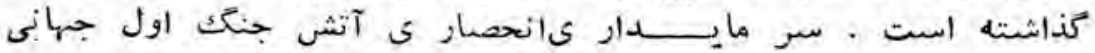

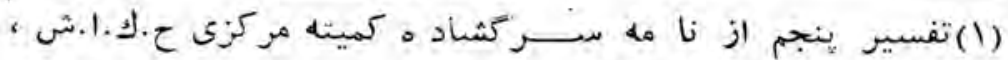

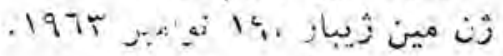

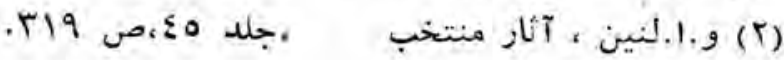




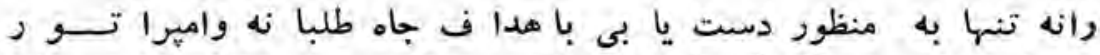

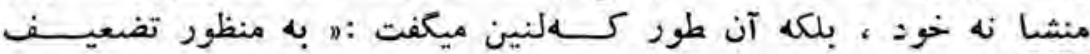

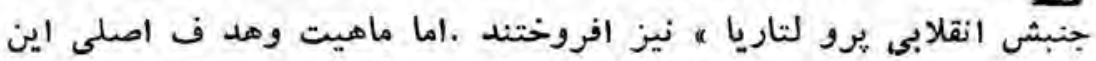

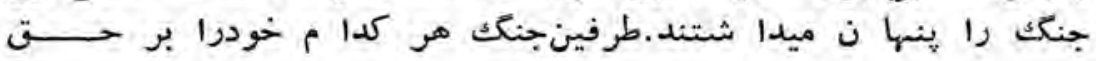

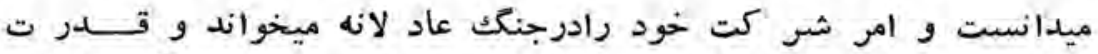

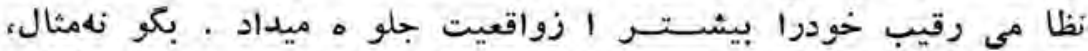

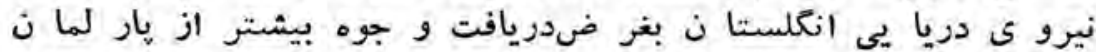

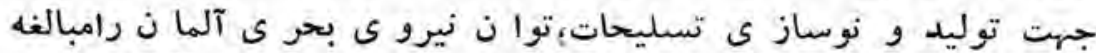

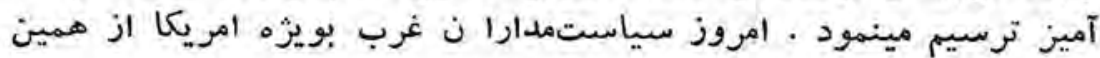

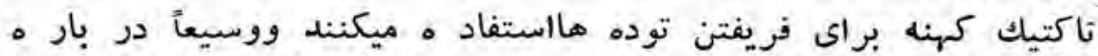

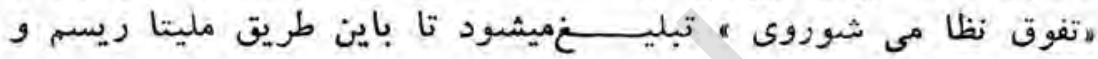

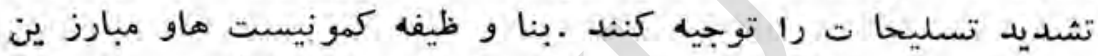

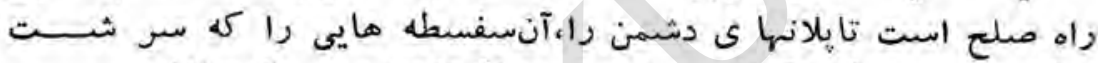

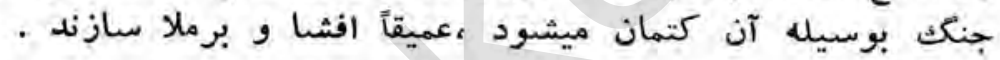

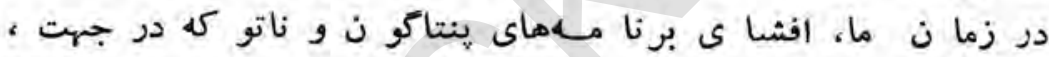

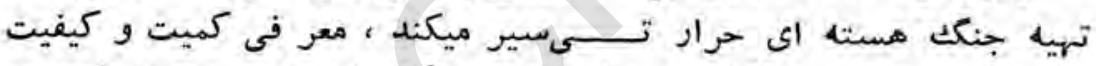

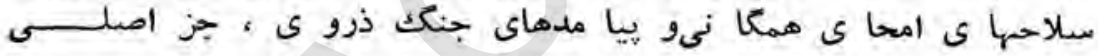

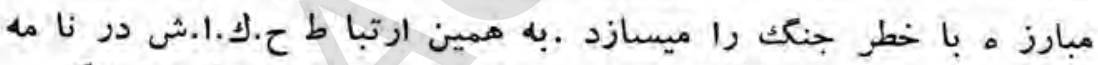

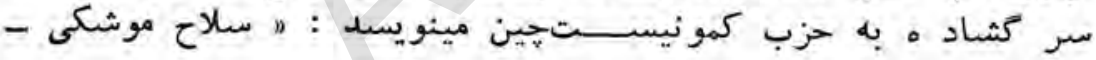

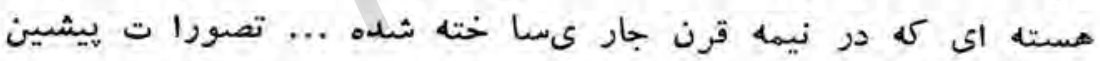

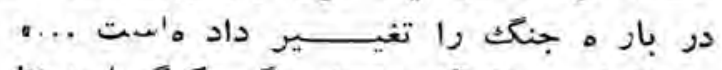

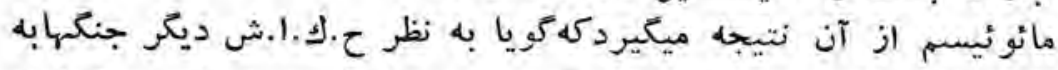

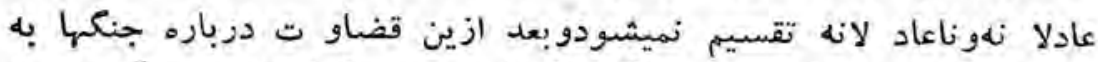

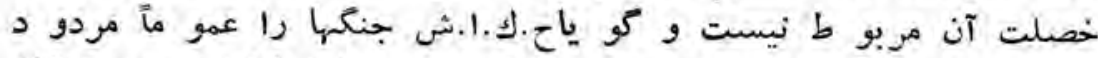

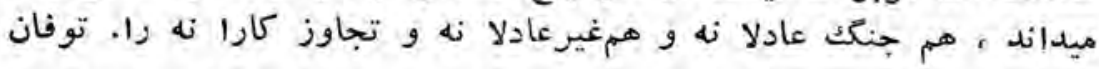

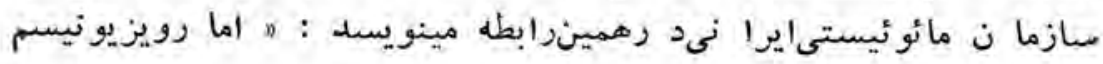




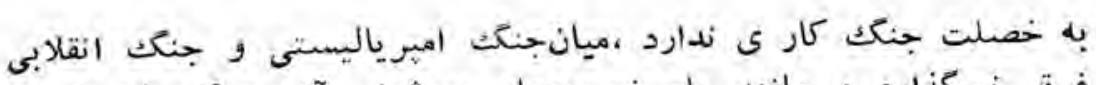

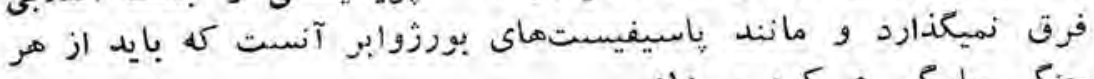

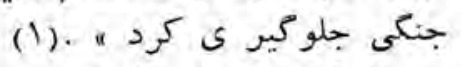

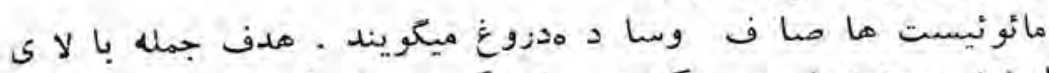

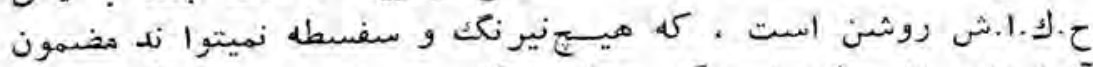

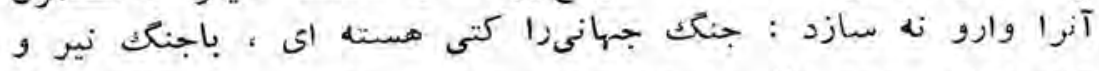

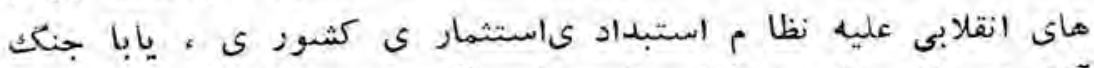

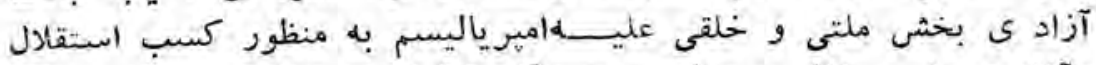

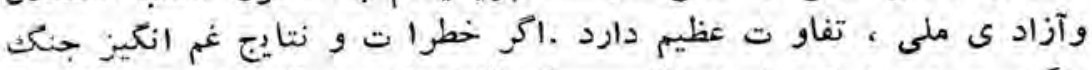

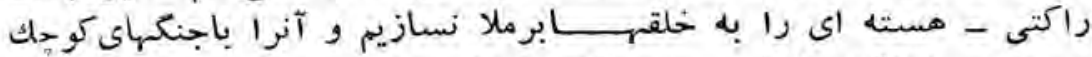

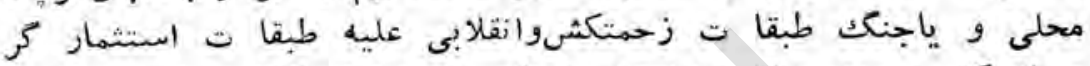

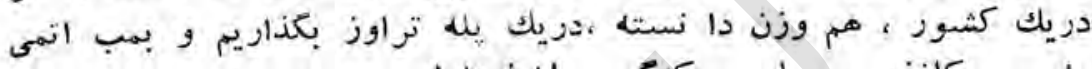

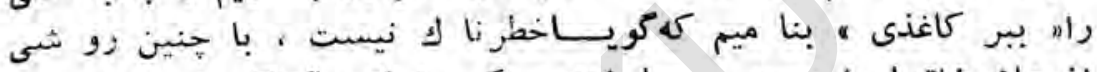

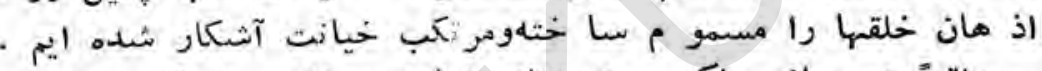

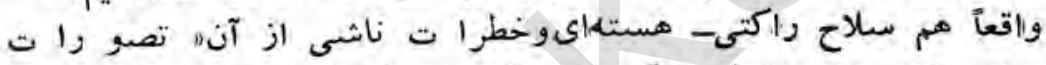

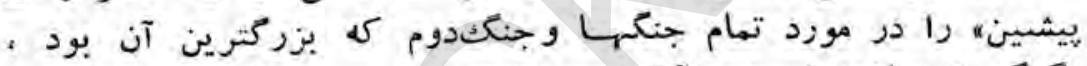

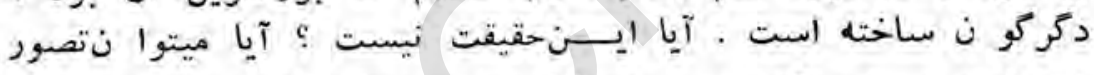

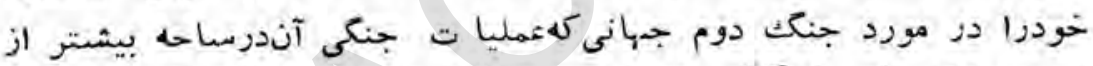

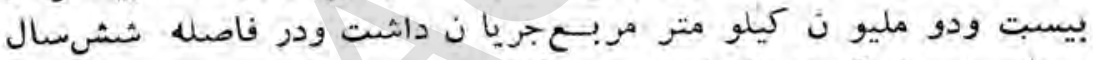

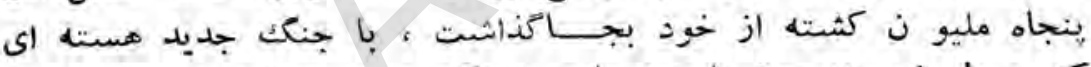

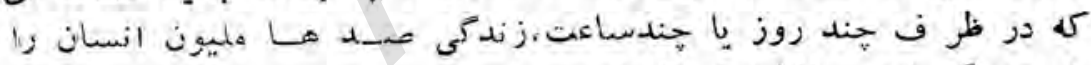

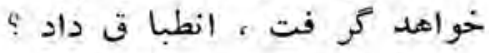

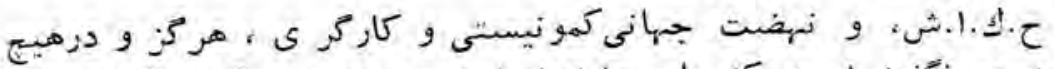

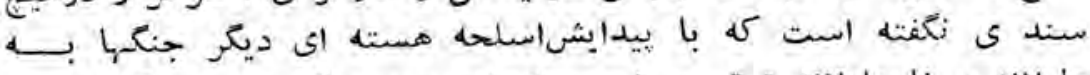

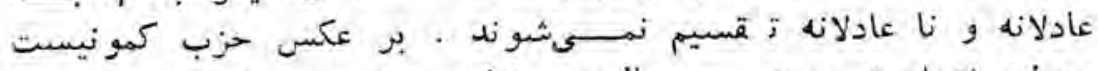

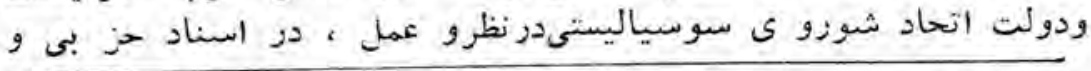

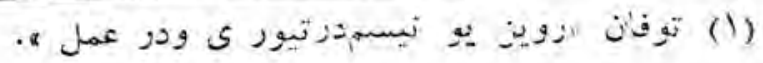




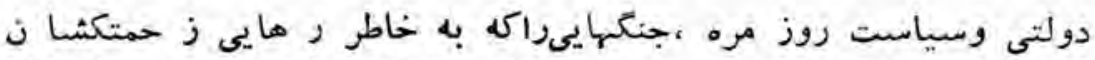

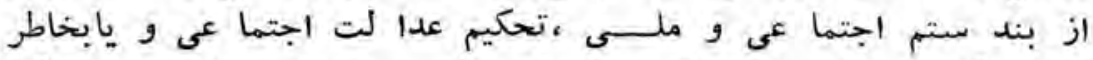

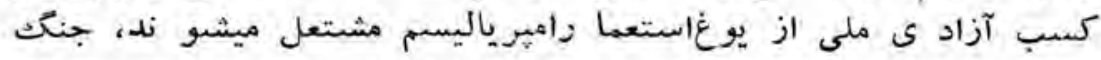

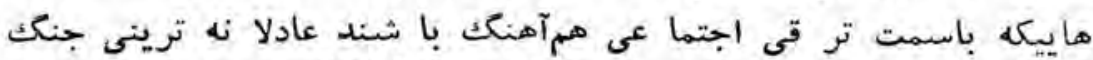

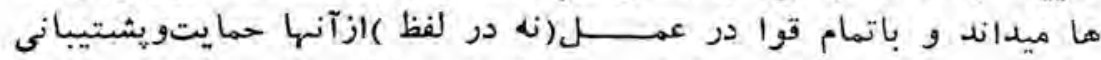

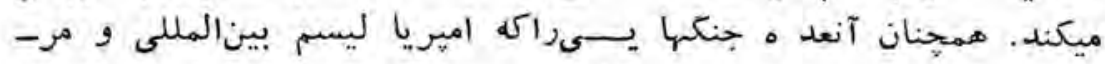

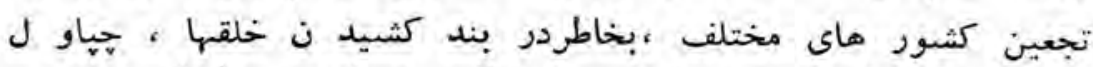

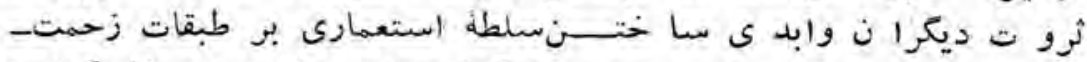

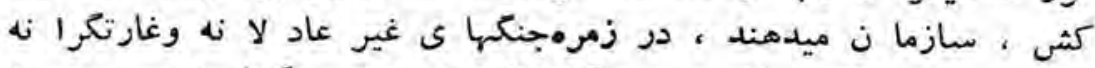

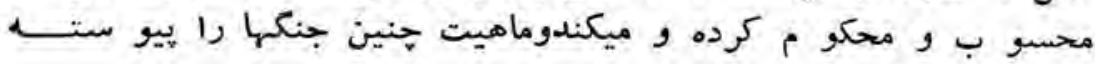
افشا سا خته است و محكو كر

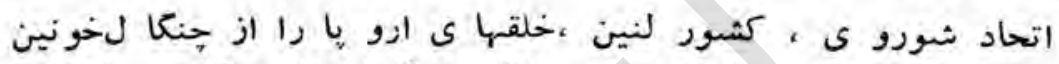

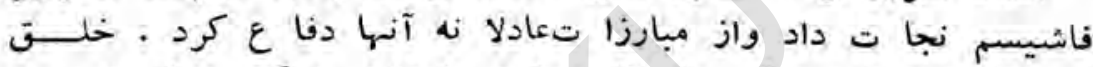

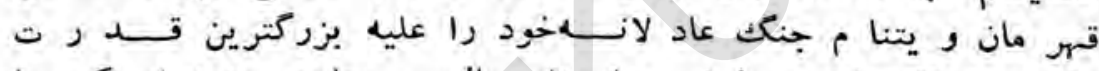

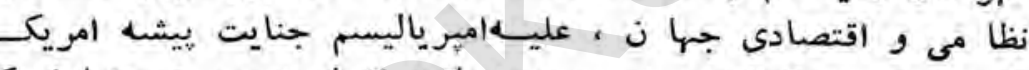

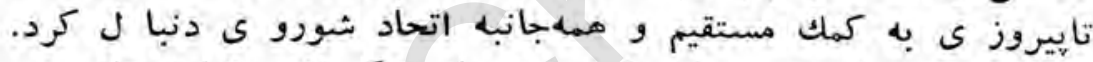

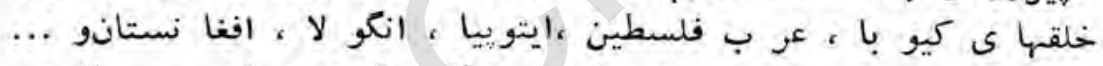

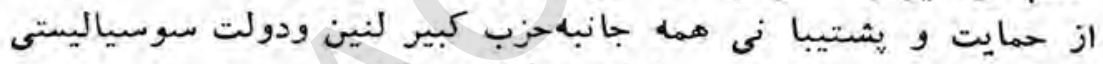

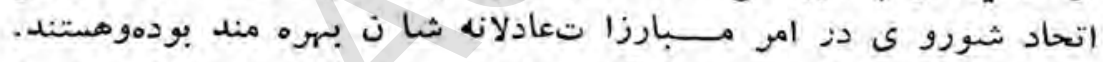

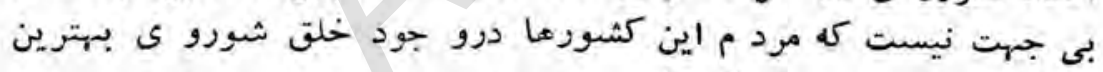

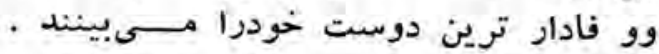

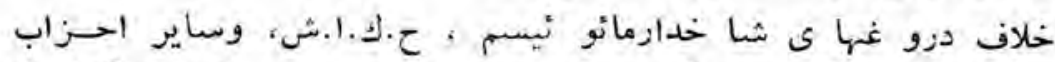

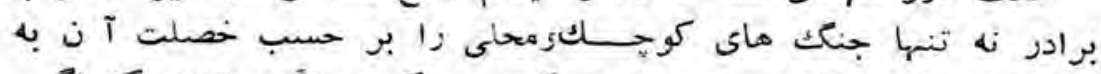

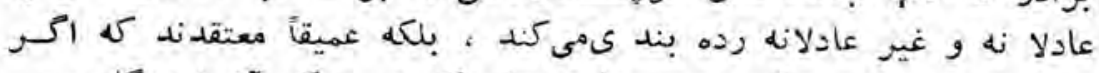

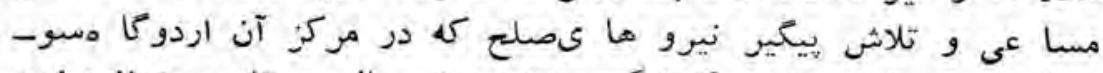

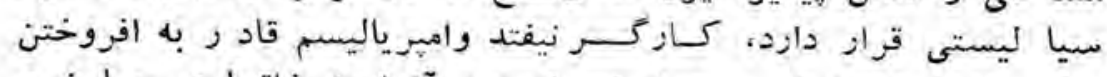

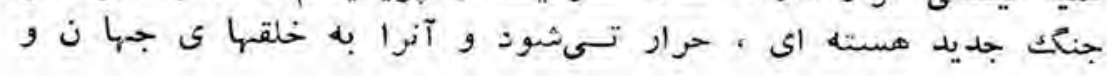




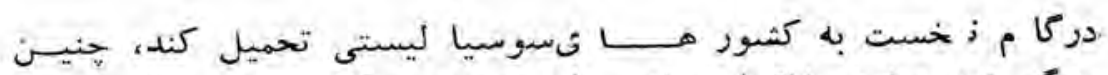

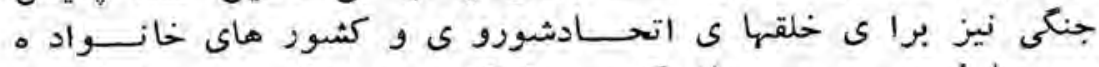

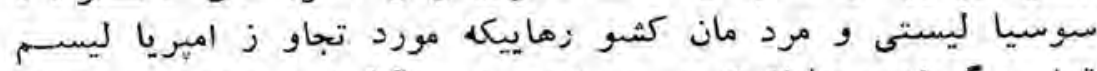

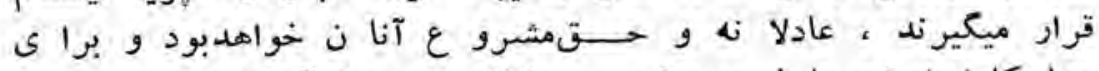

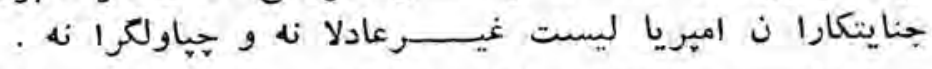

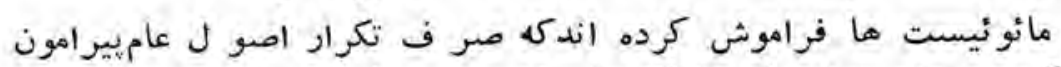

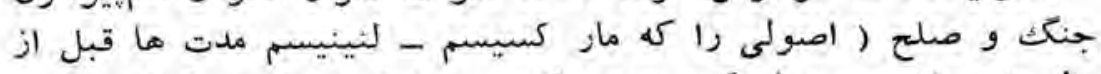

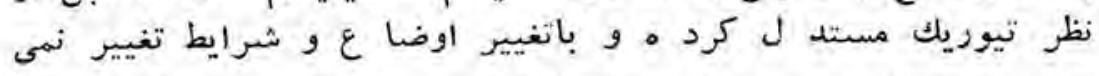

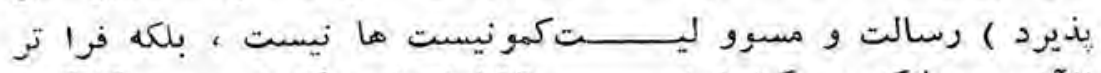

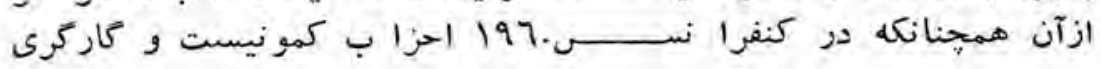

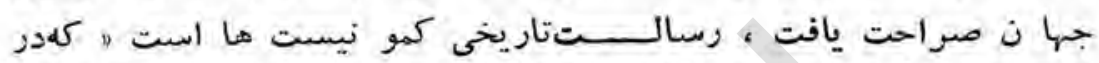

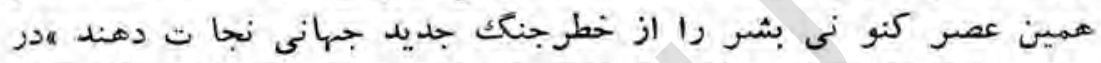

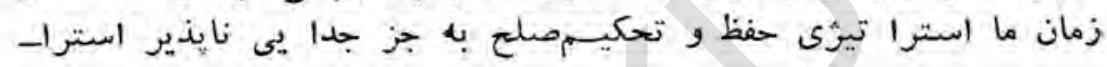

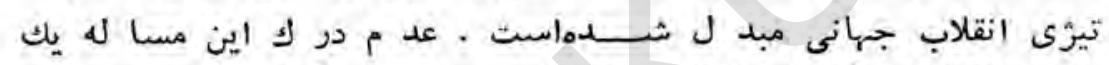

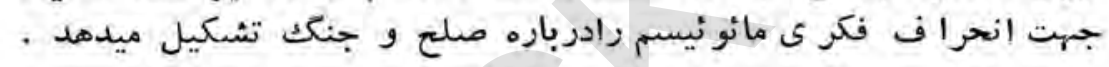

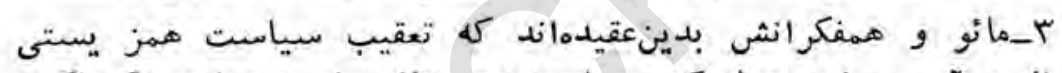

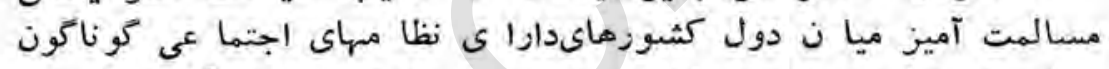

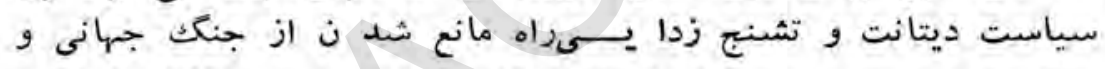

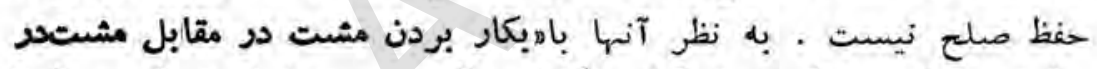

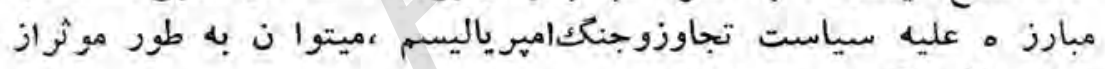
(1) ملح دفا ع كرد عليد

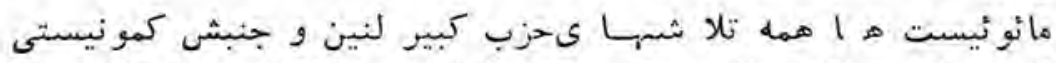

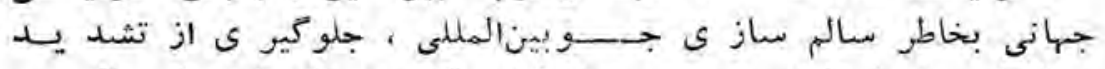

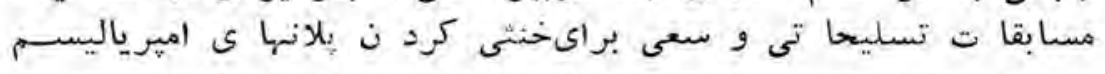

ون (1)

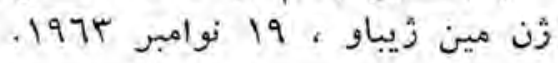




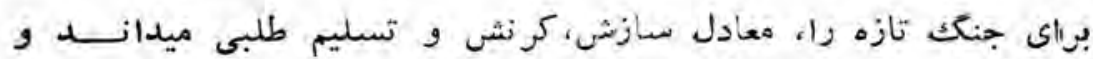

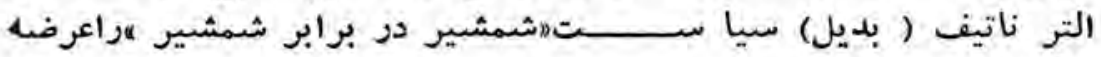
ميكند . ميند

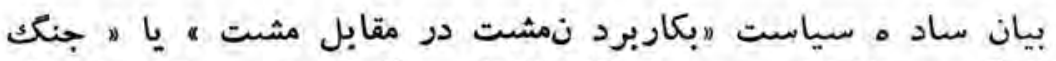

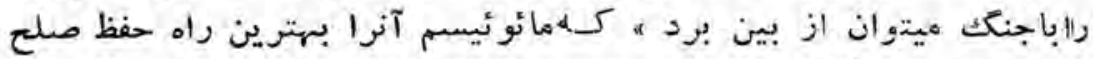

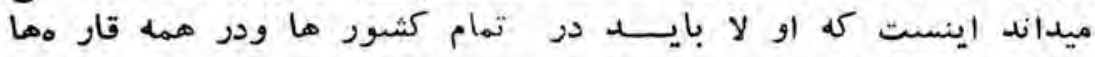

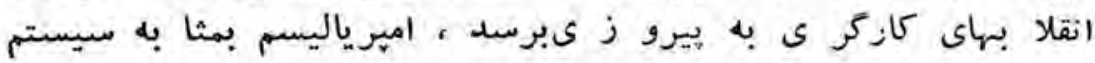

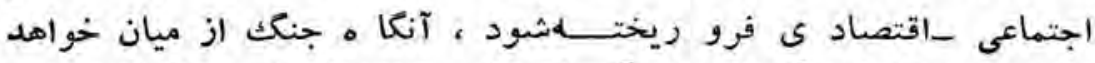

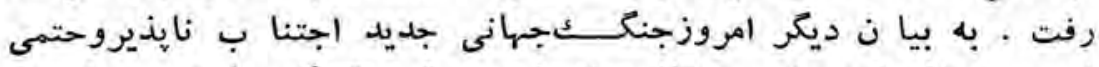

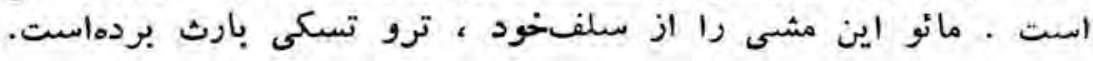

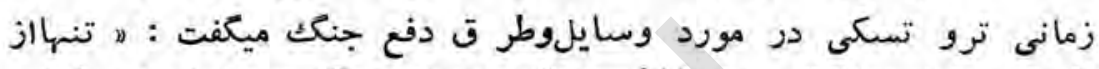

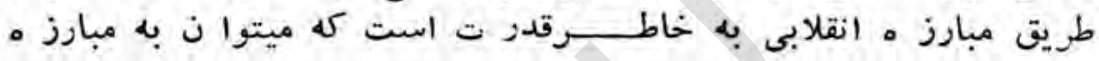

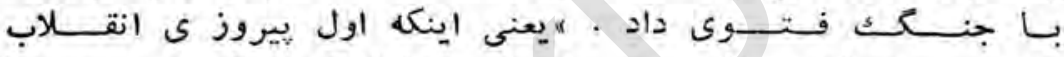

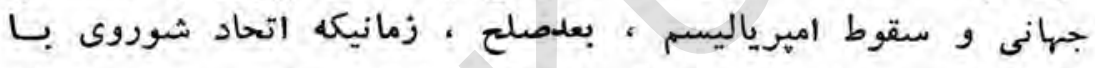

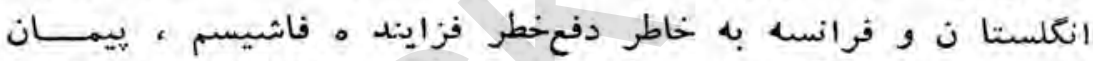

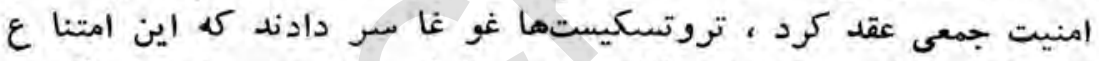

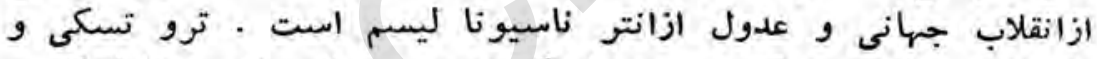

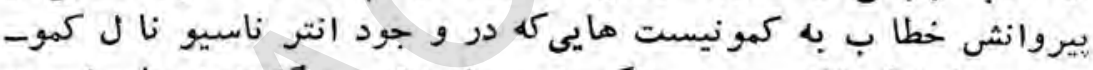

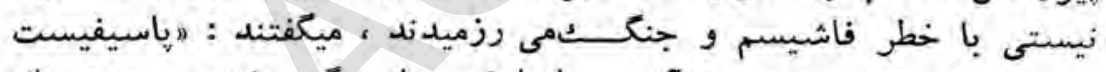

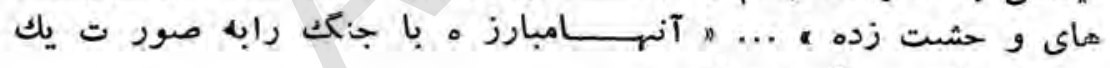

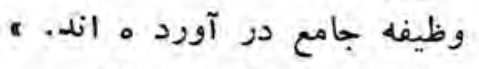

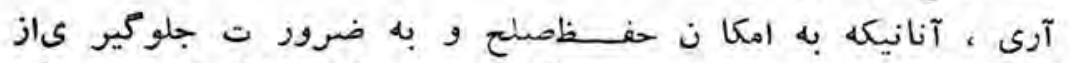

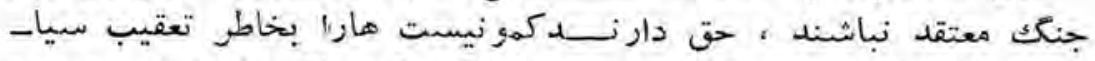

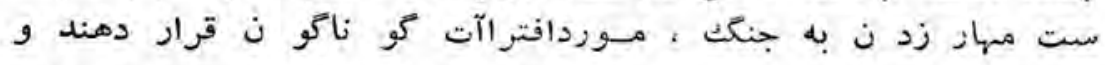

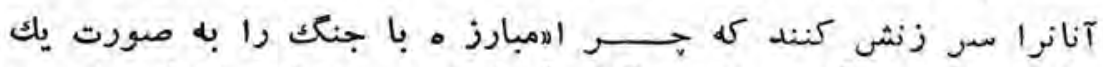

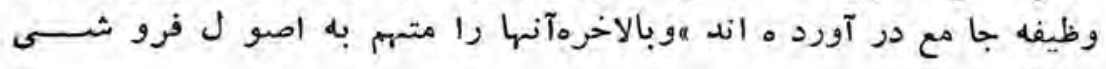
سازند . وطا 


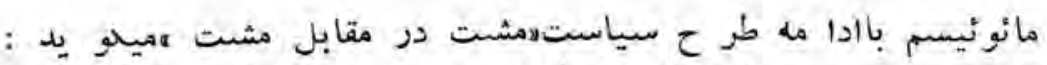

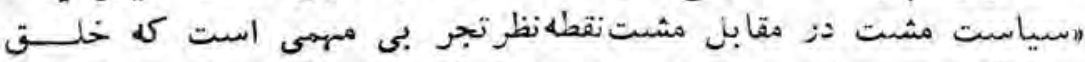

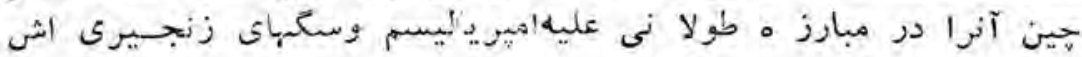

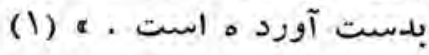

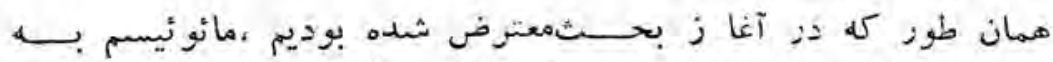

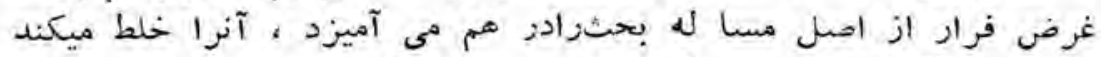

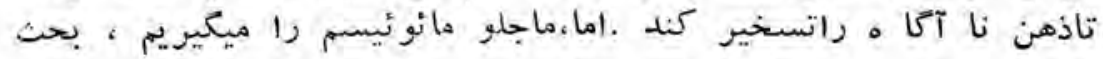

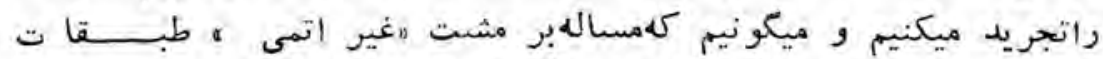

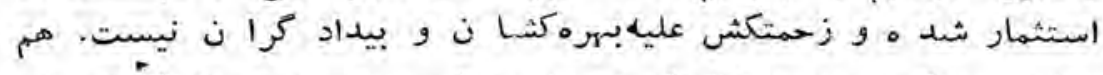

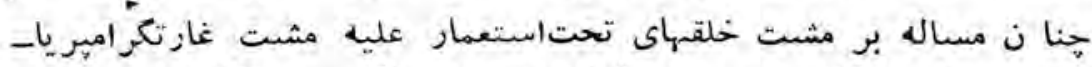

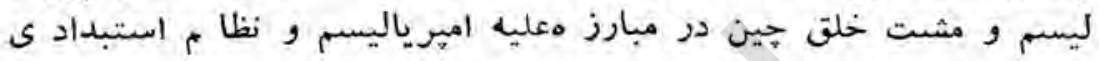

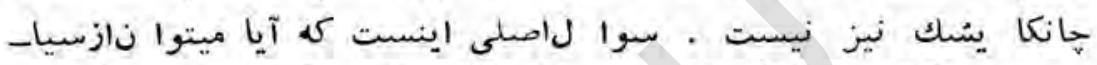

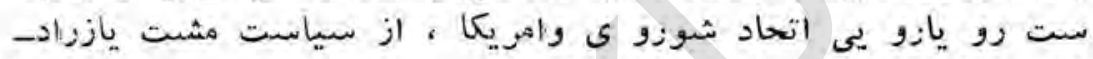

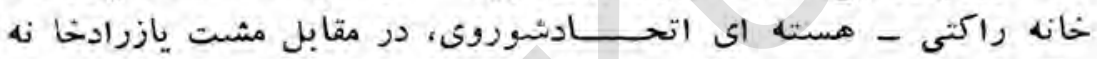

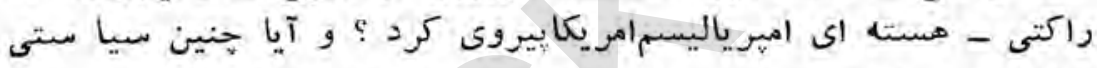

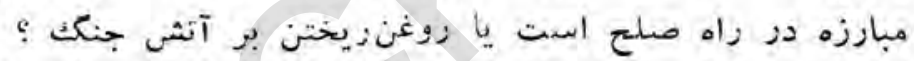

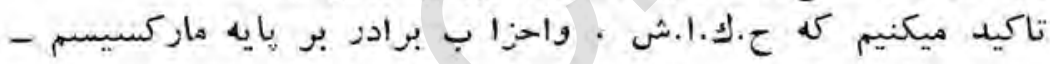

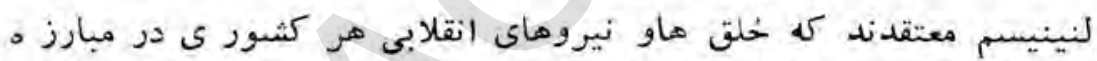

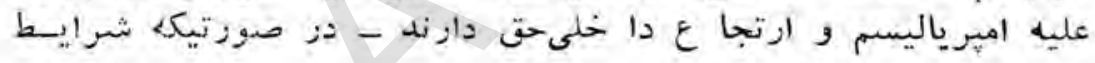

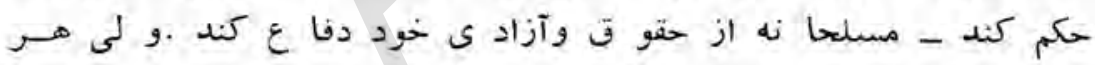

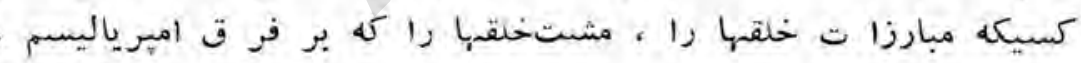

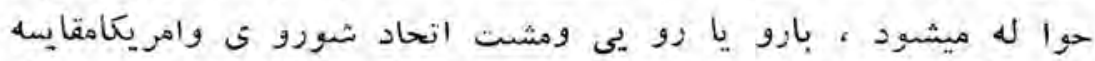

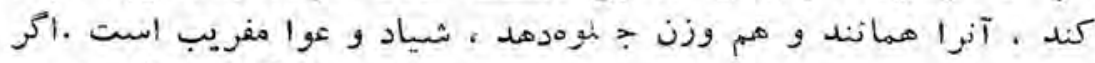

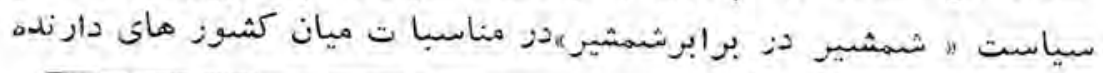

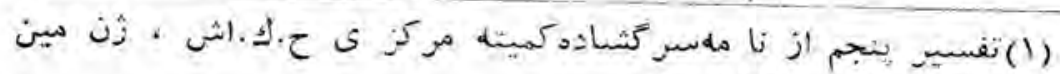

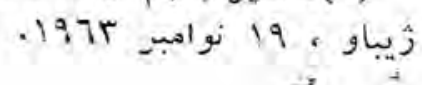
- rTr- 


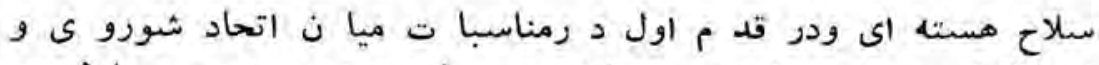

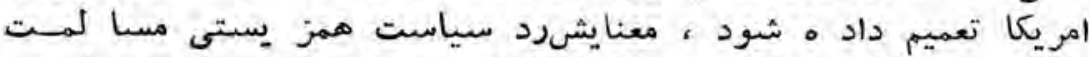

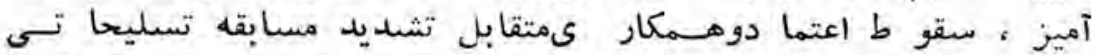
وتشديد و خا مت اوضا ع بينالمللىاست . تجنين سياستى بلدو ن ترديد

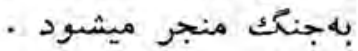

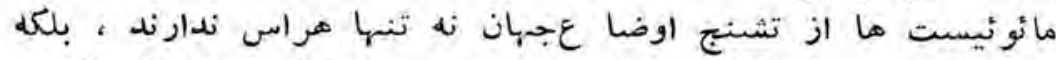

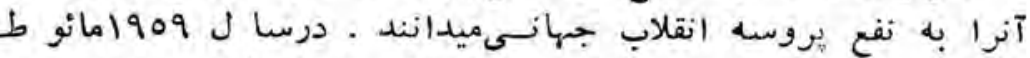

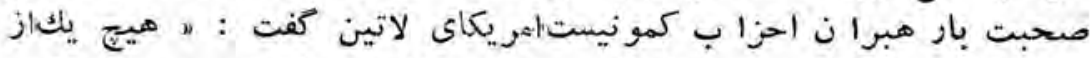

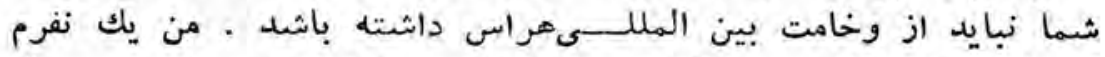

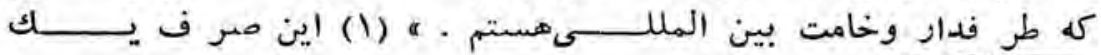

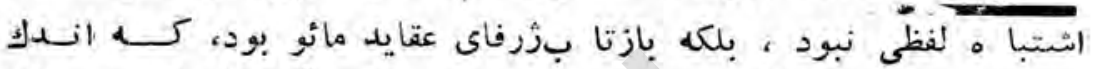

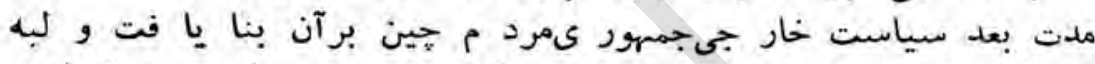

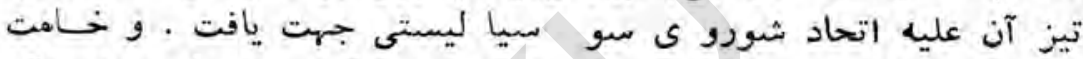

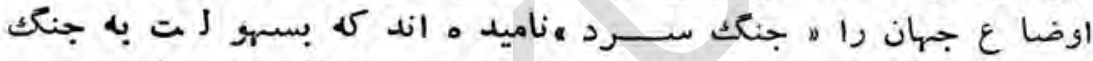

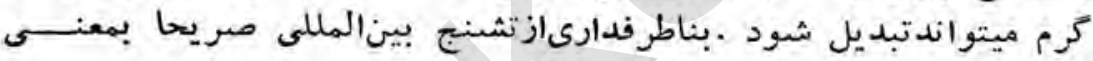

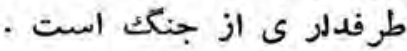

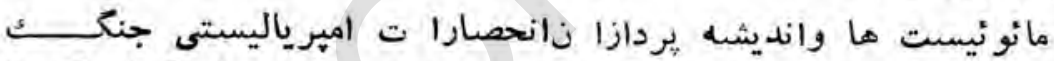

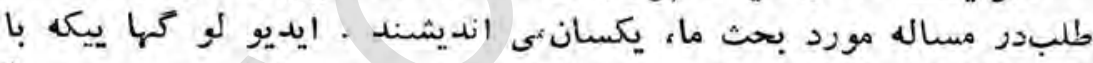

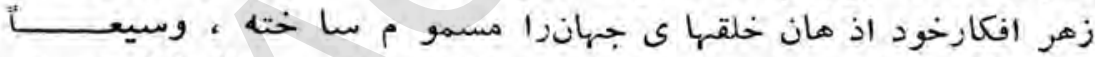

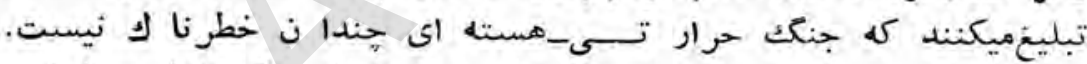

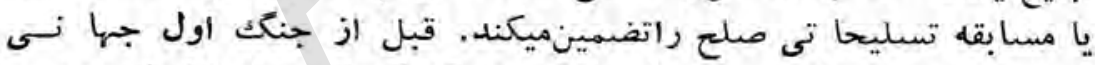

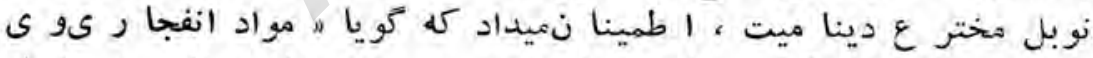

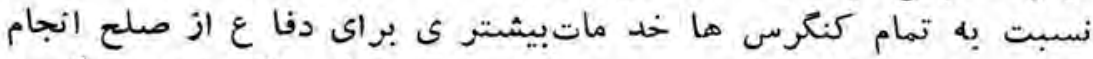

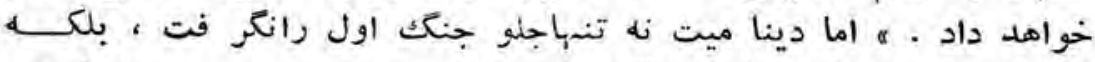

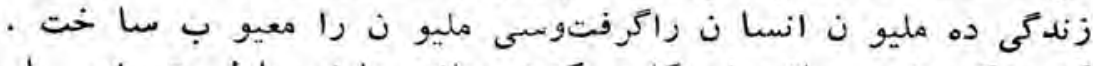

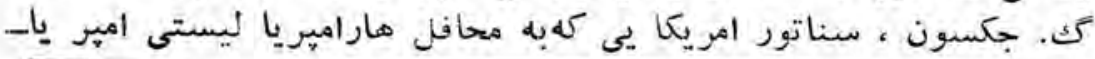

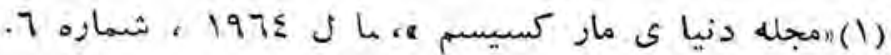




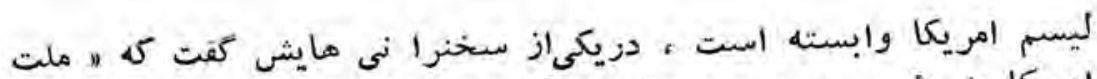

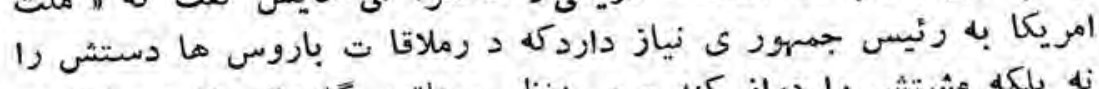

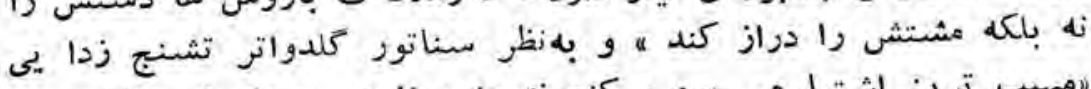

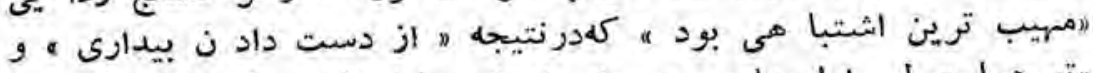

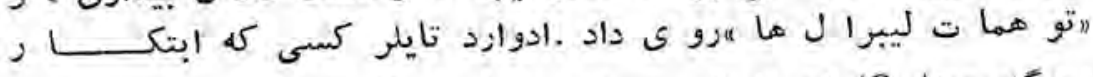

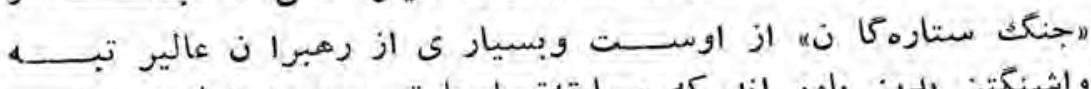

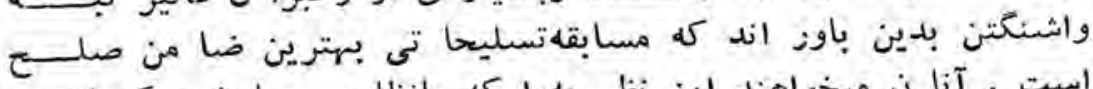

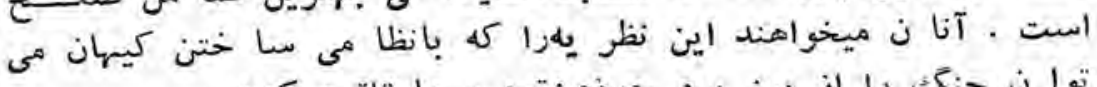

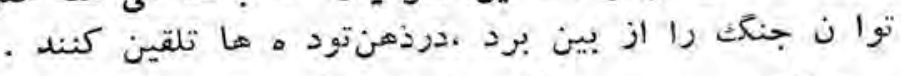

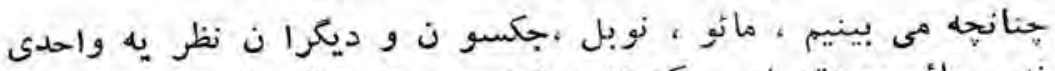

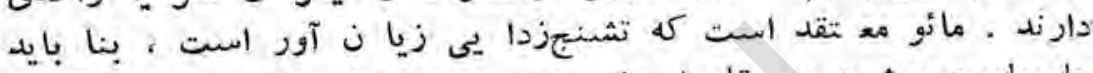

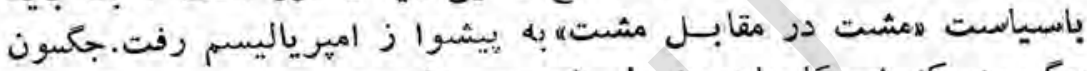

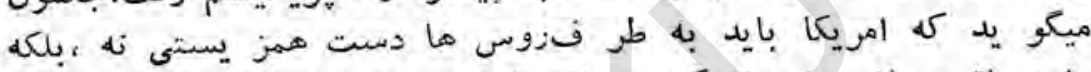

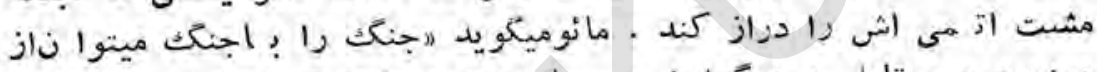

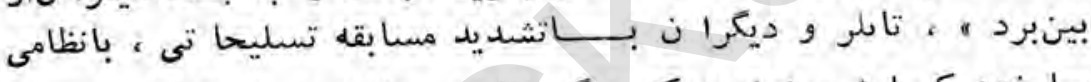

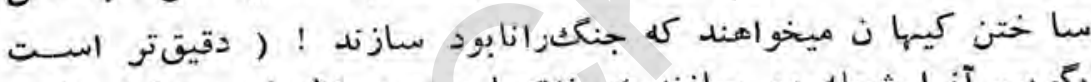

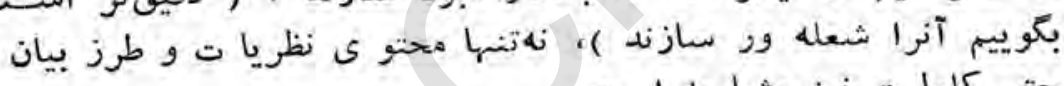

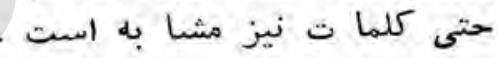

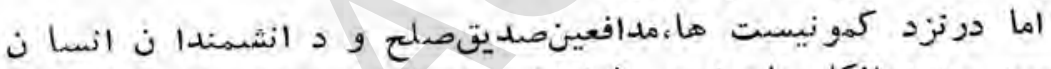

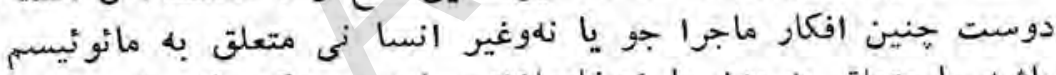

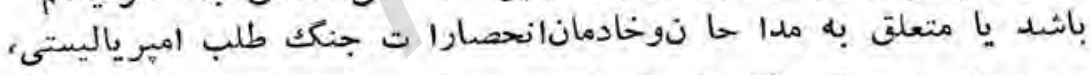

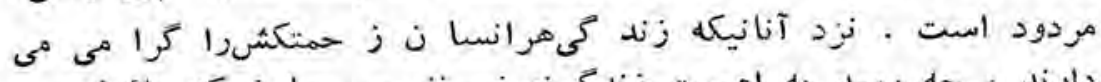

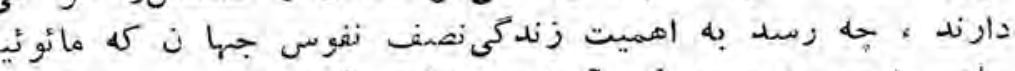

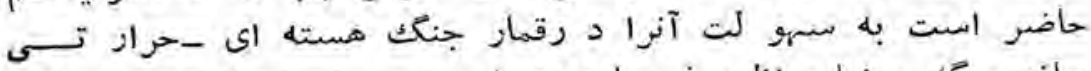

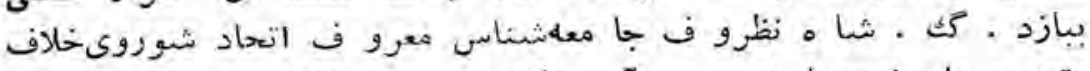

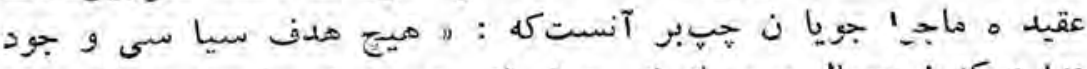

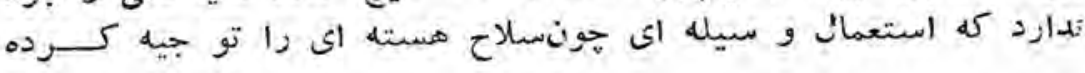




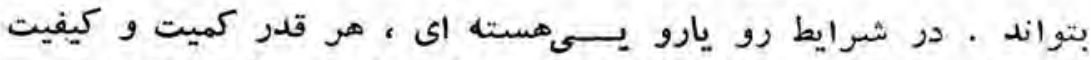

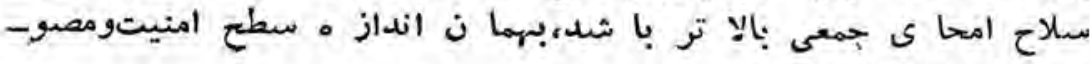
i.

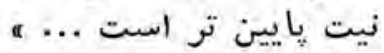

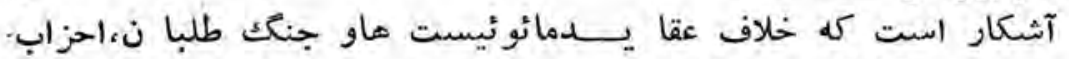

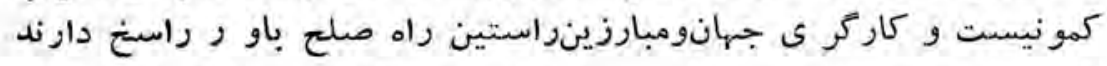

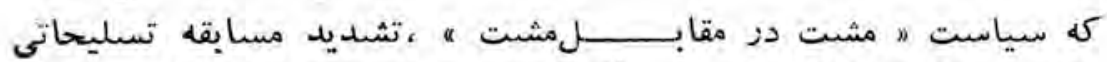

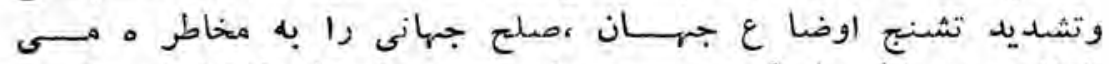

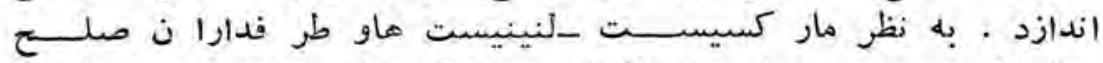

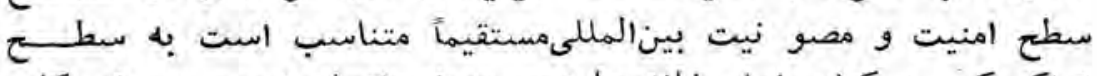

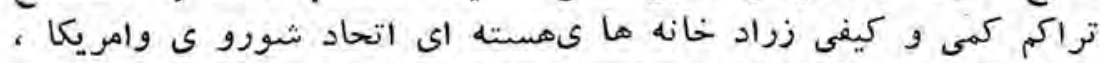

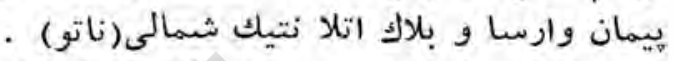

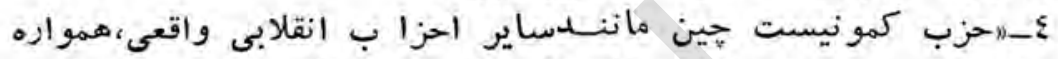

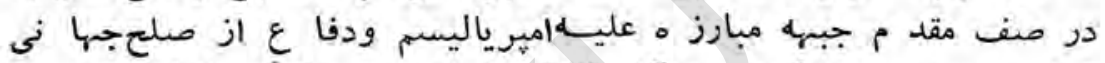

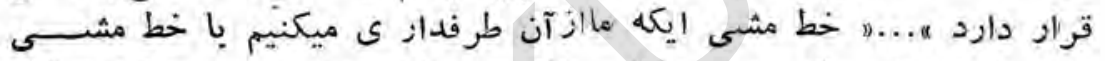

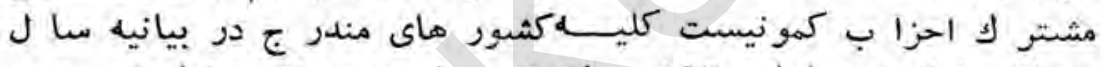

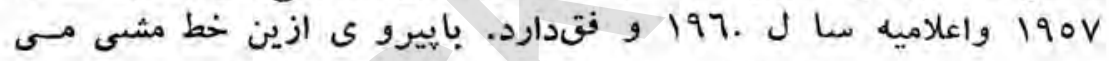

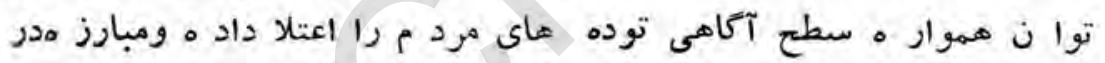

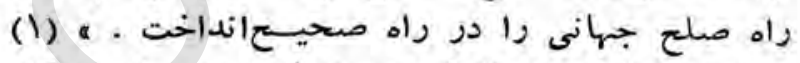

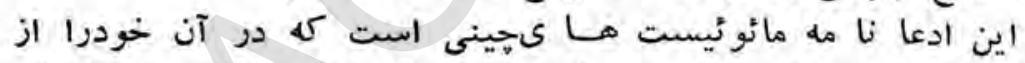

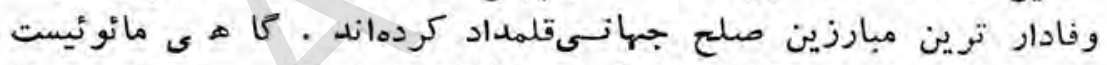

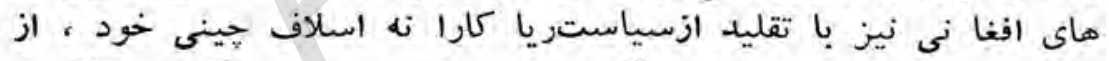

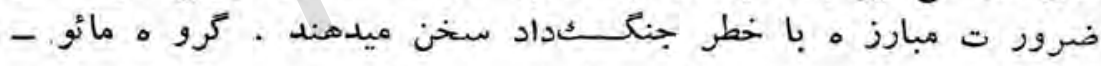

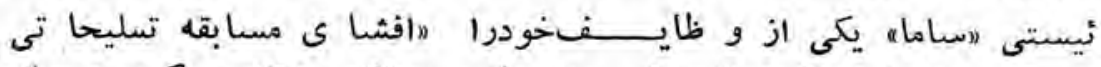

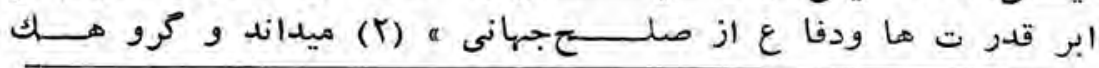

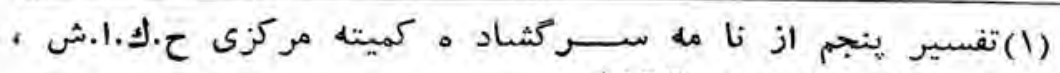

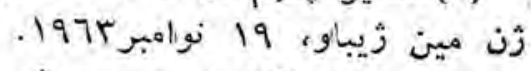

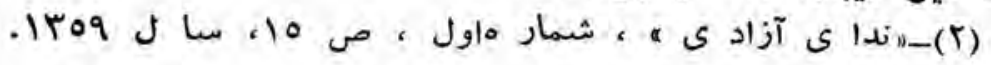
-r7o_ 


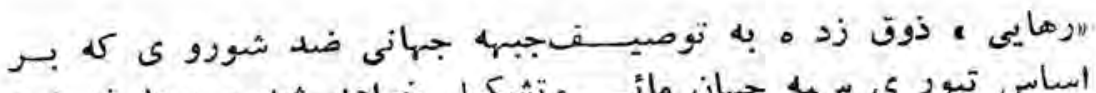

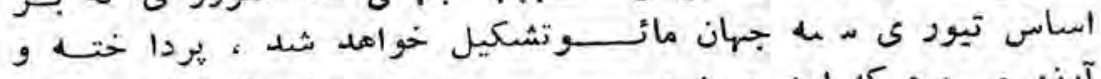

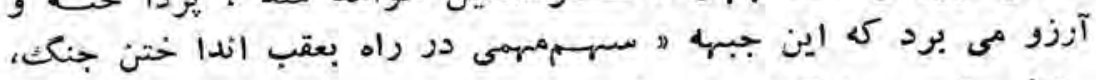

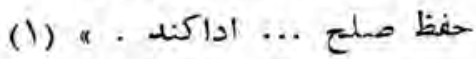

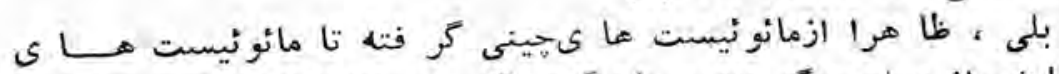

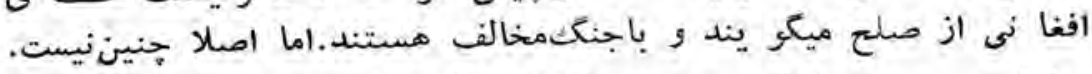

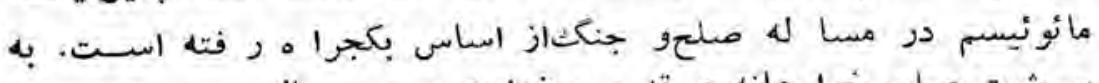

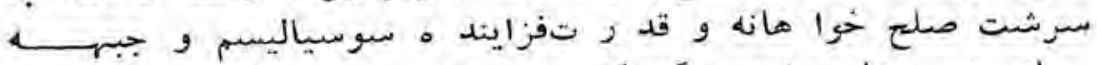

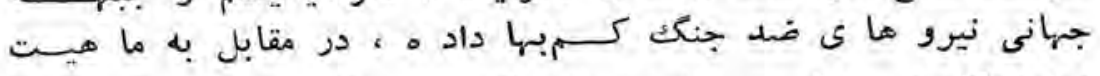

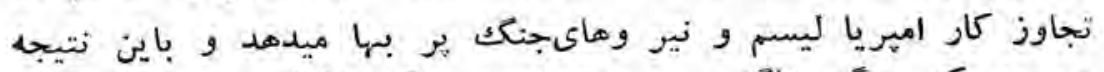

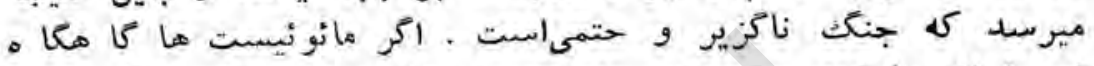

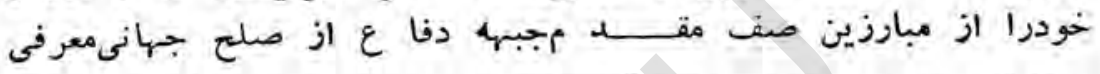

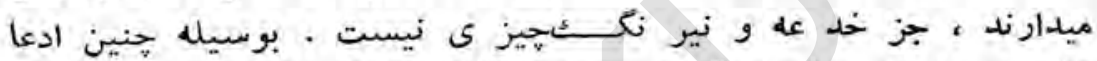

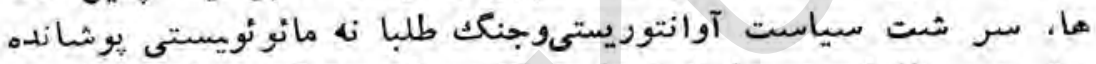

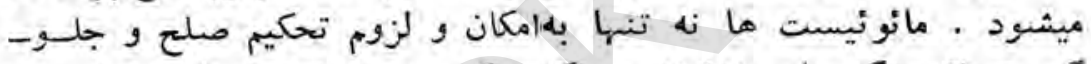

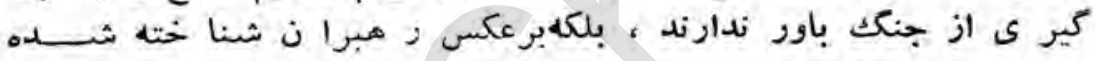

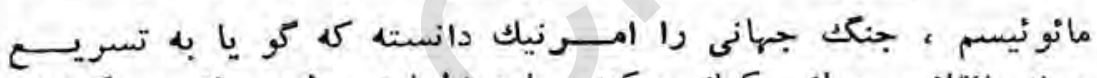

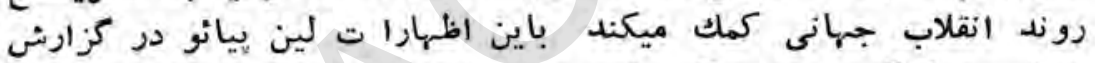

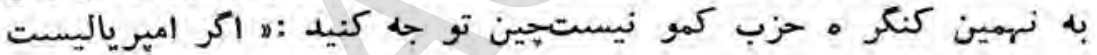

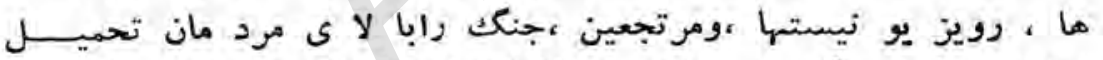

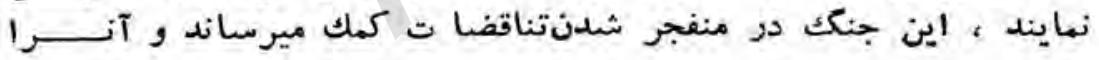

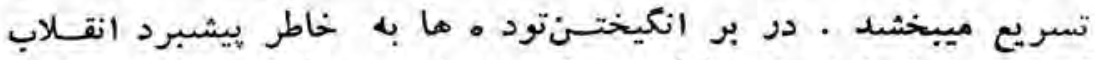

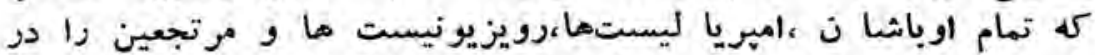

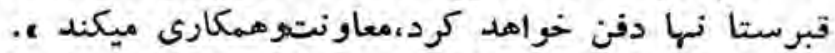

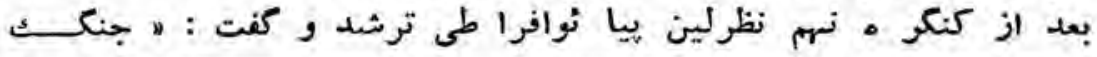

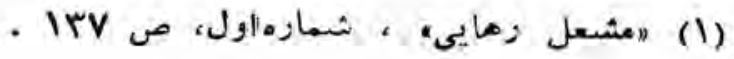




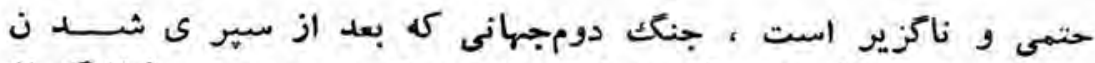

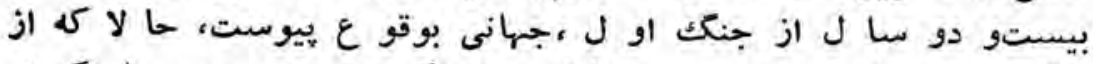

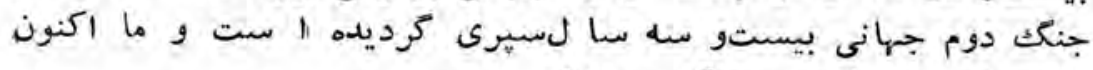

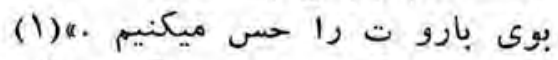

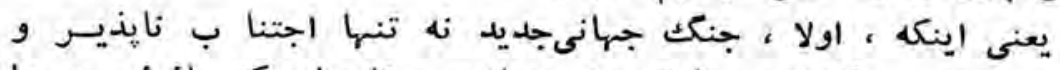

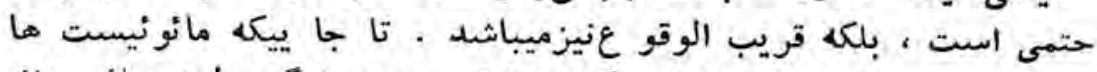

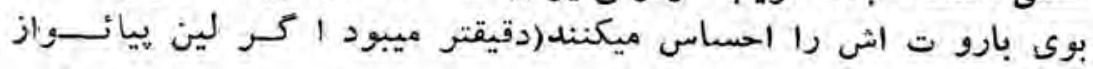

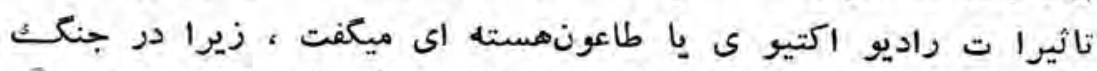

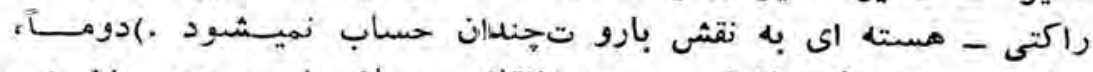

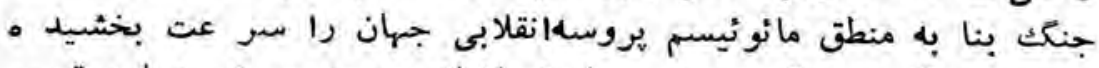

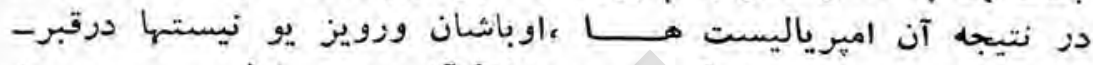

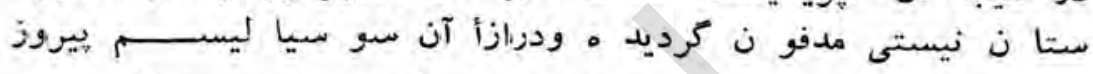

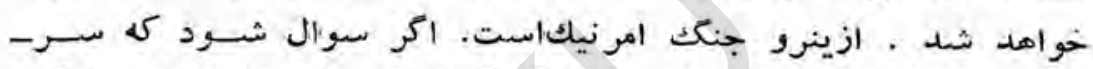

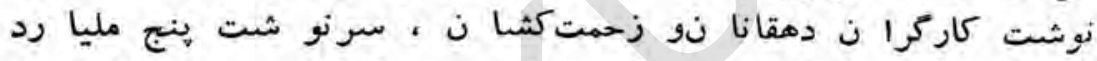

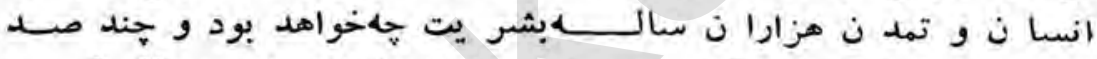

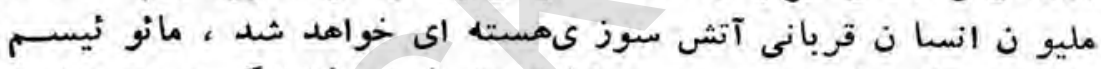

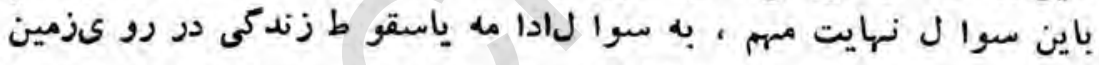

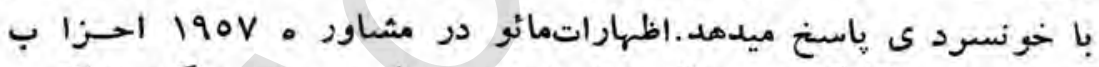

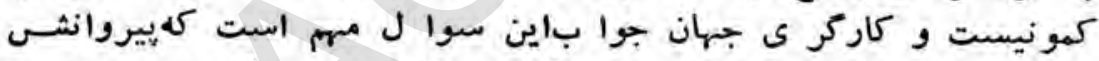

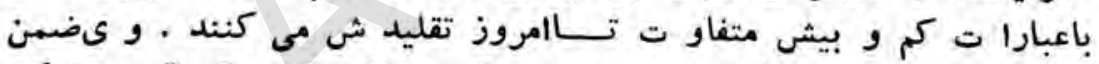

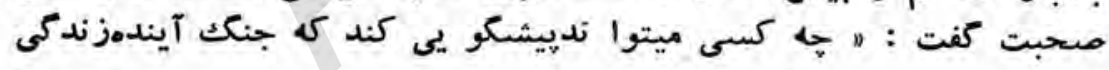

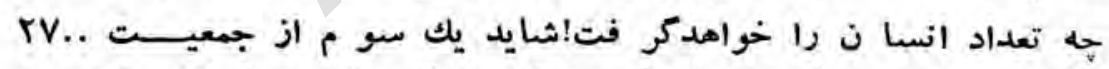

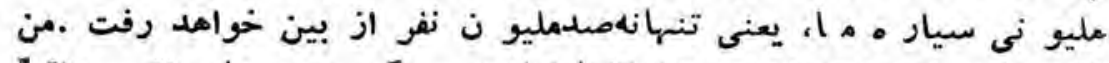

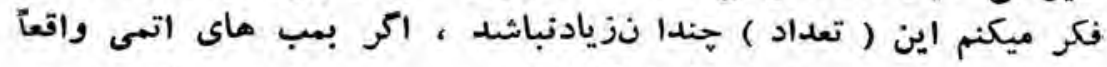

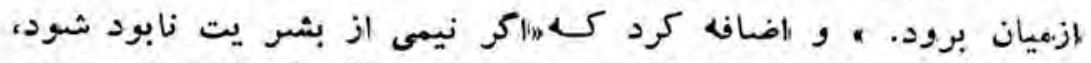

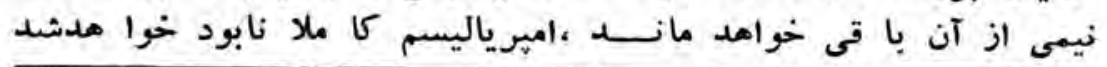

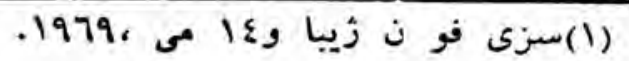




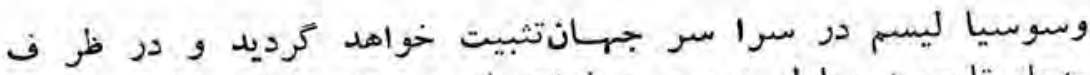

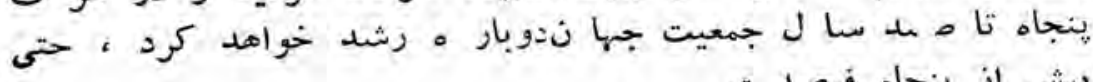

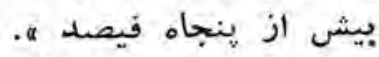

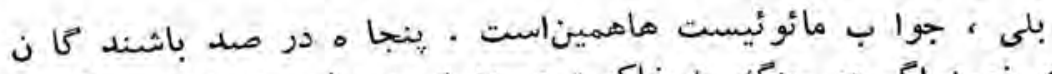

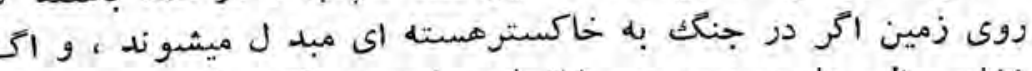

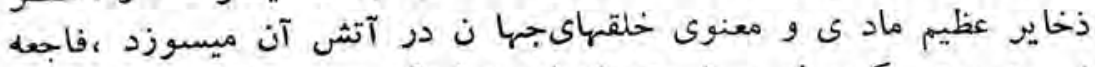

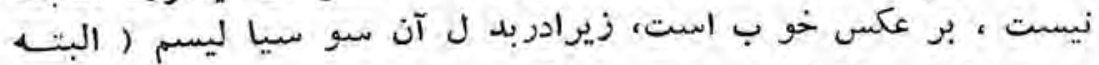

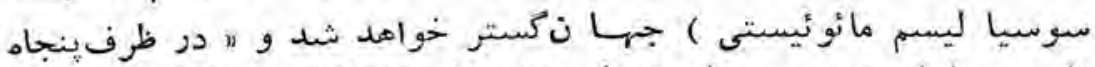

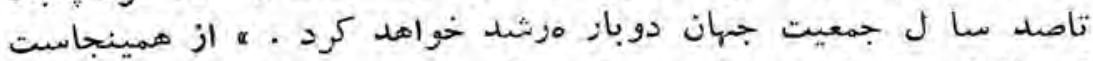

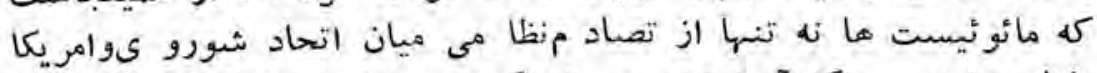

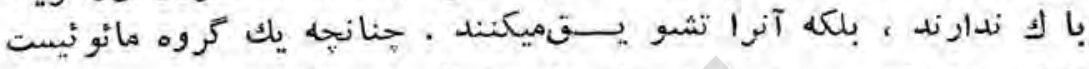

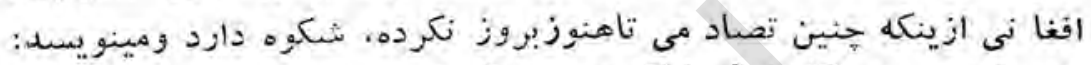

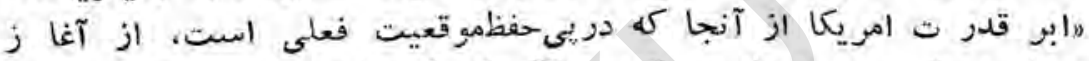

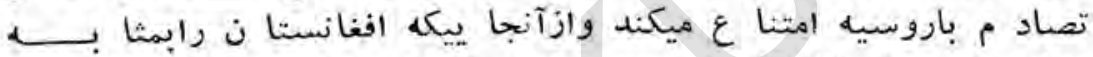

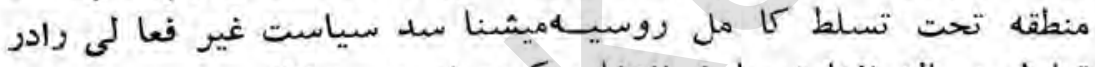

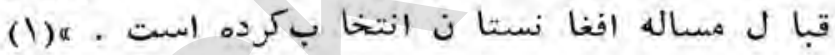

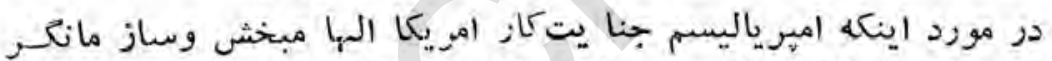

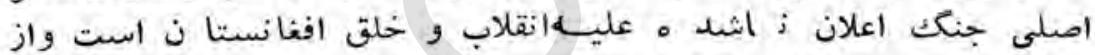

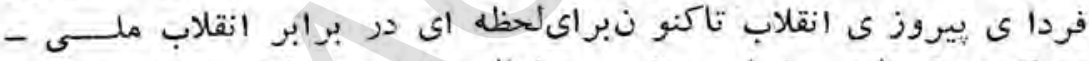

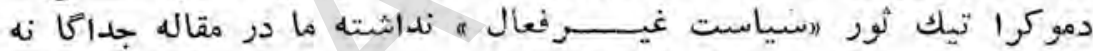

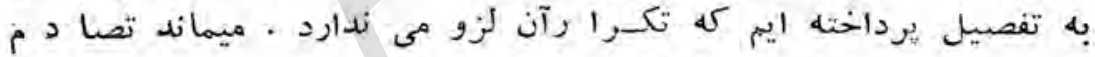

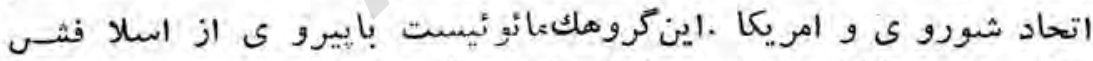

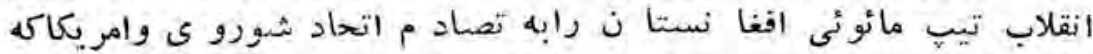

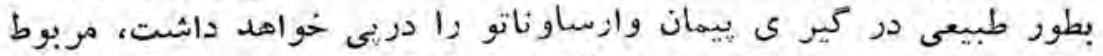

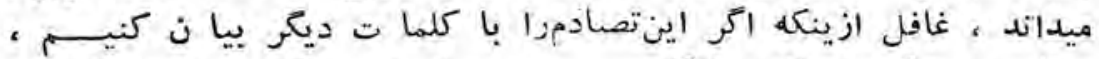

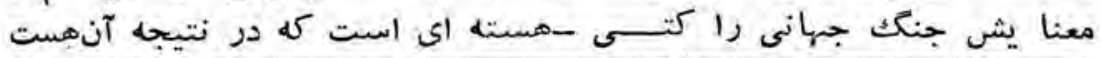

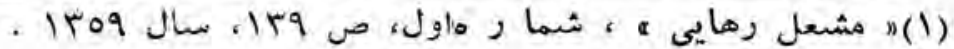

$$
-r 7 \Lambda
$$


وبود بسيار ى از خلقها ، ازجمله وخلق افغا ن مورد سوا ل قرارميكيرد

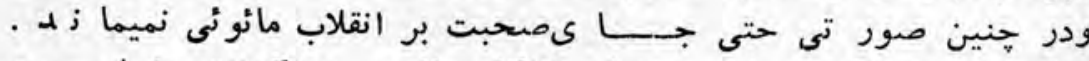

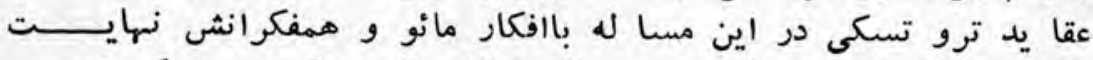

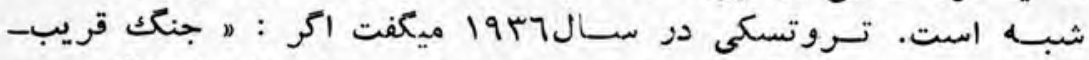

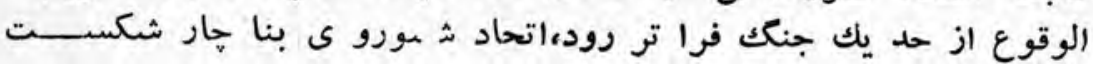

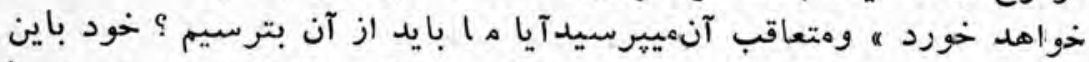

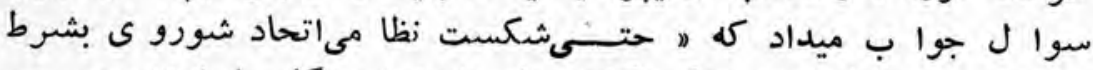

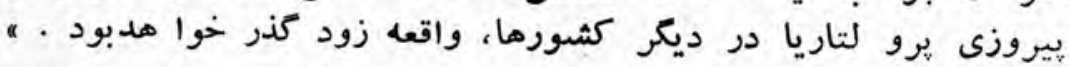

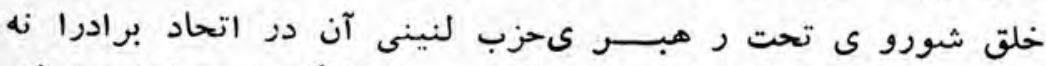

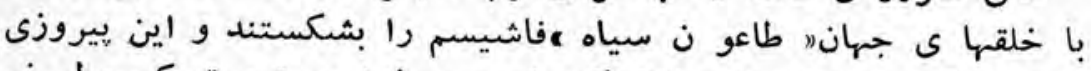

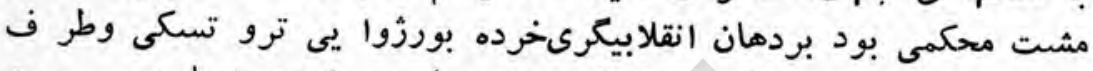

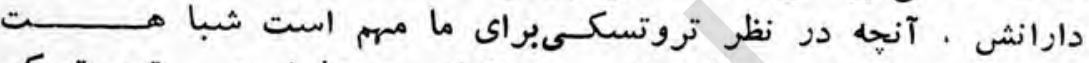

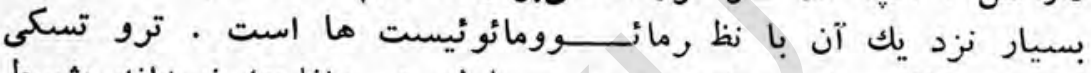

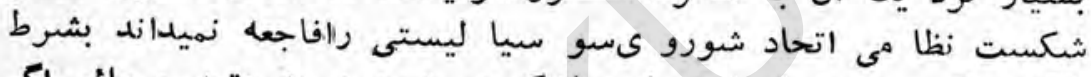

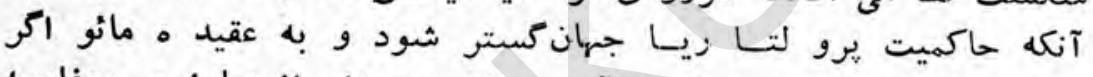

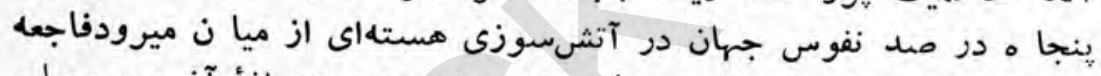

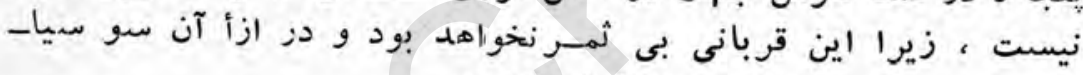

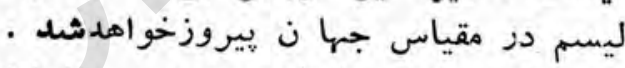

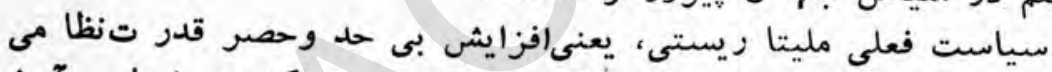

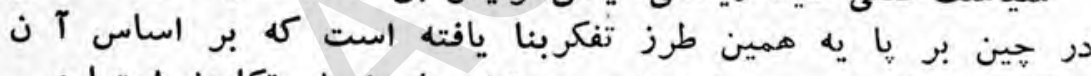

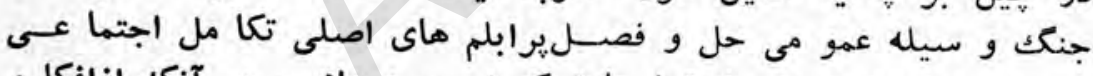

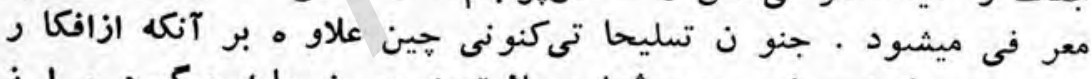

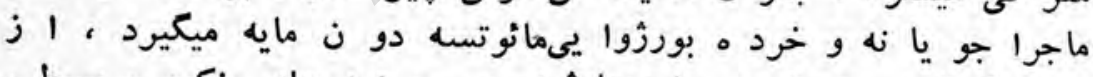

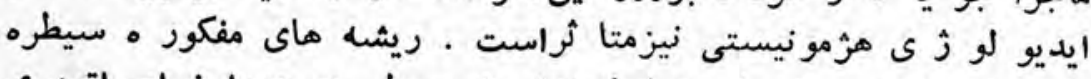

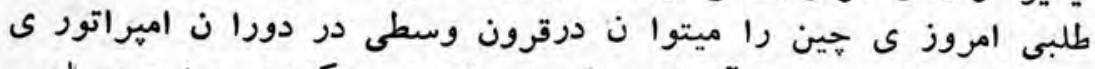

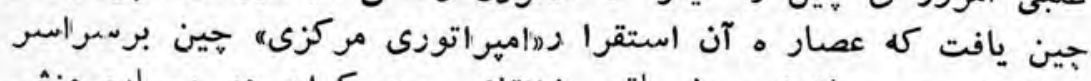

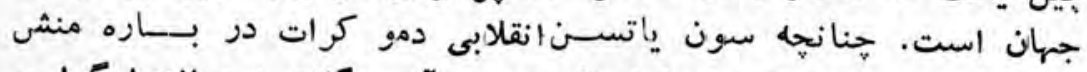

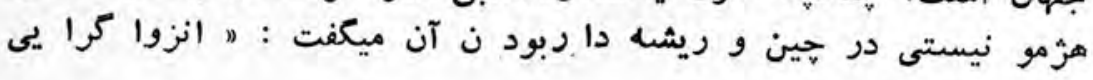




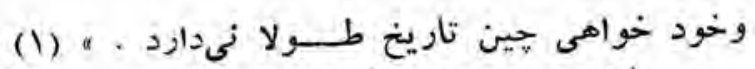

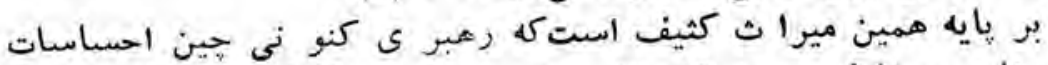

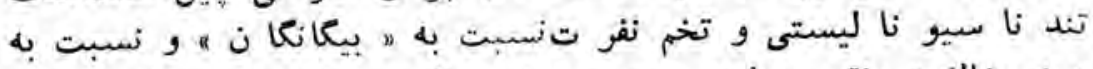

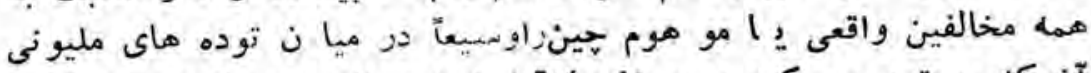

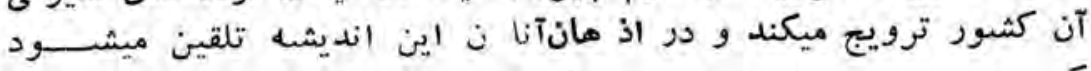

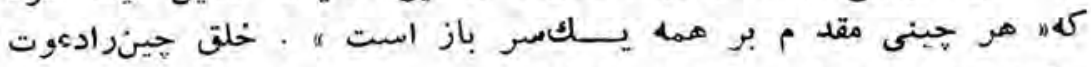

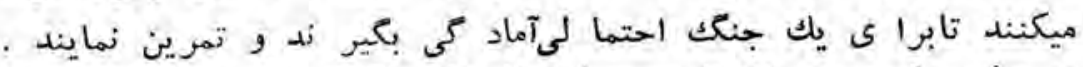

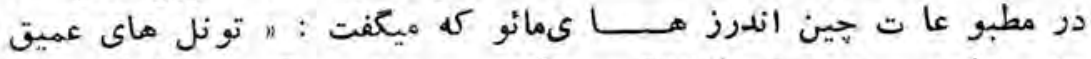

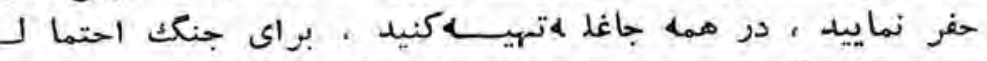

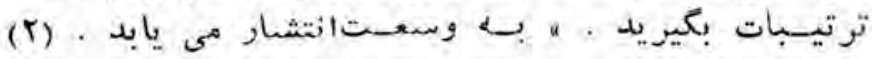

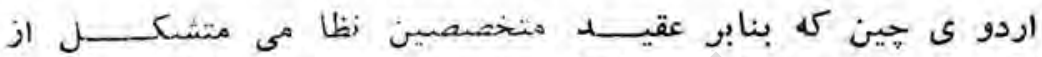

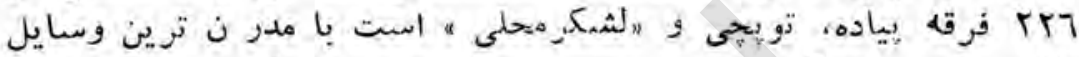

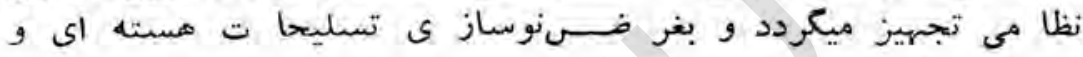

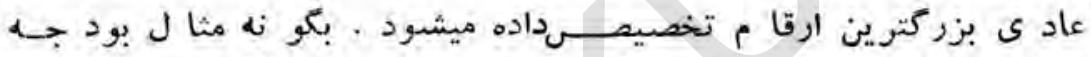

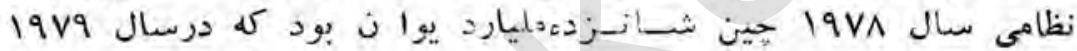

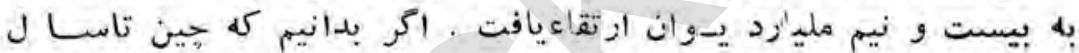

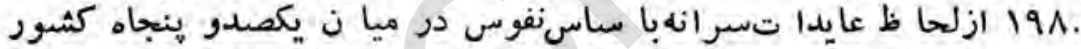

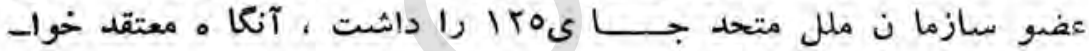

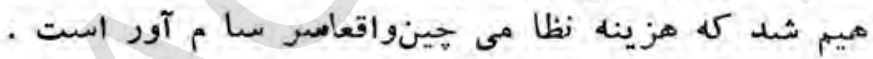

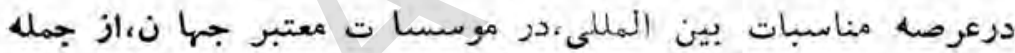

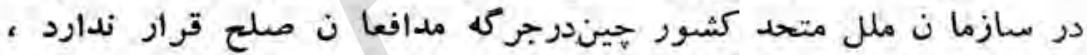

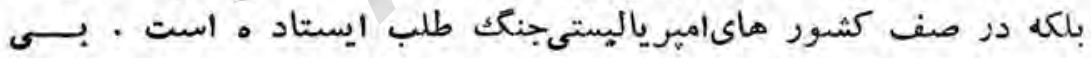

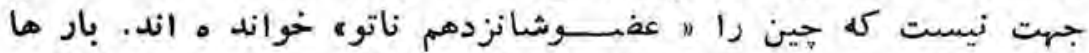

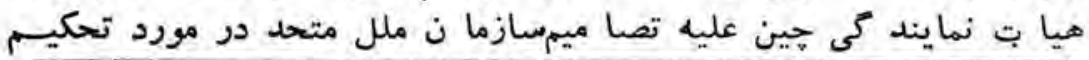

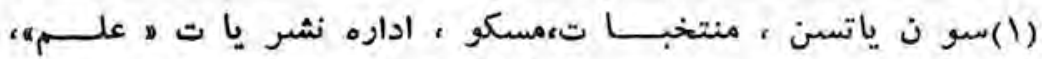
. ro. م.

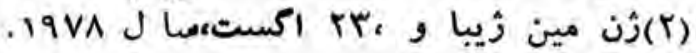


ديتانت ، تحد يد تسليحا ت و خلعسلاح قرار كر فته است ؛

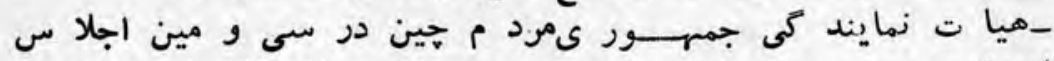

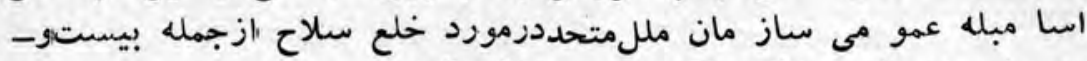

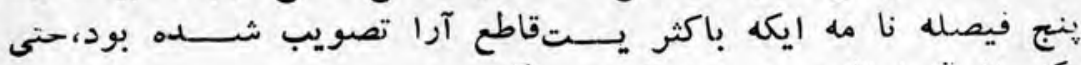

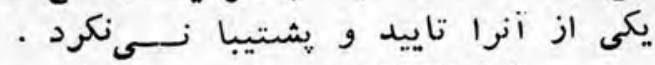

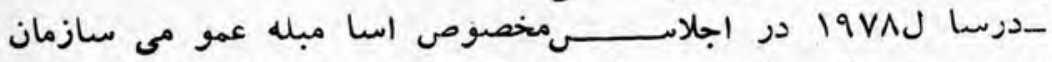

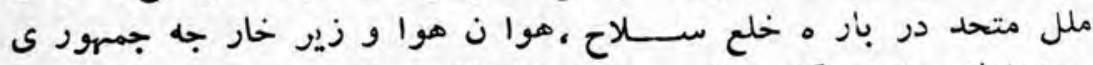

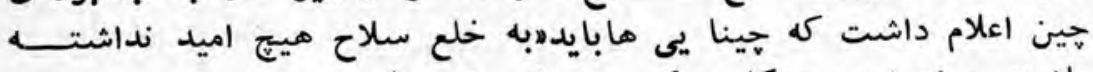

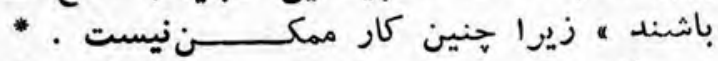

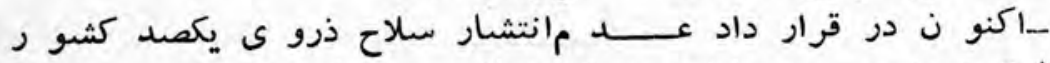

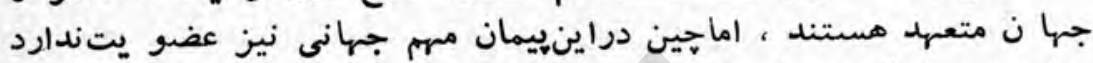

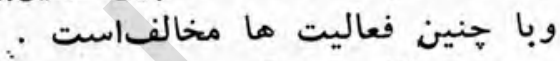

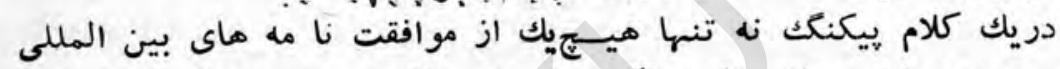

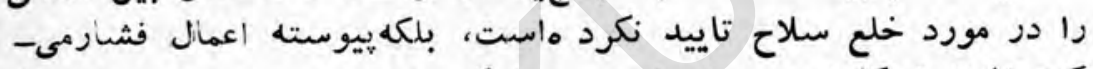

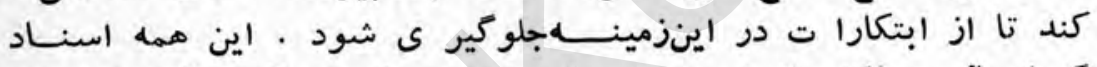

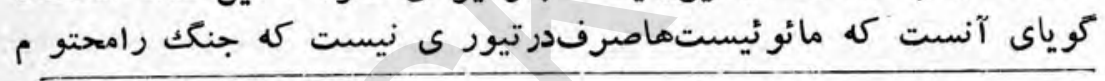

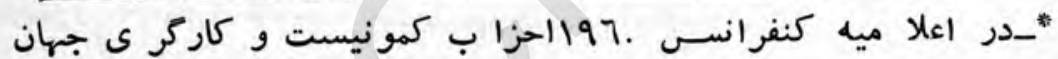

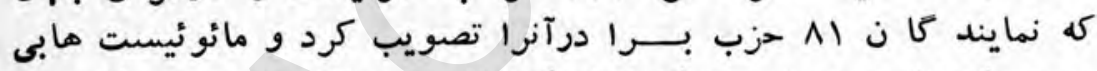

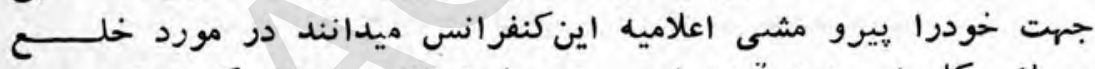

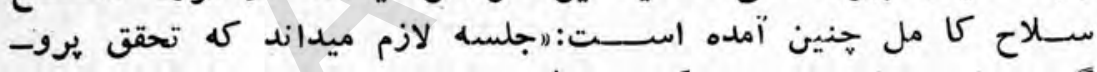

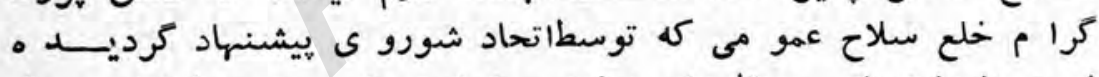

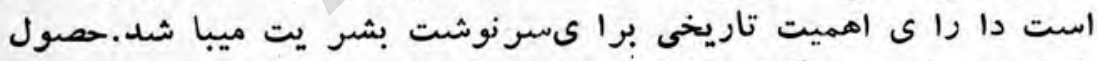

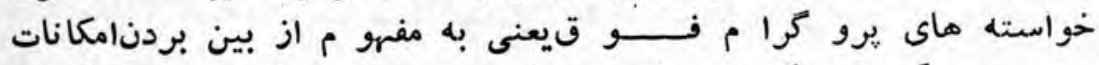

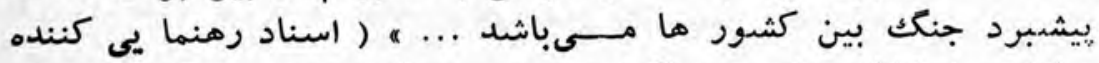

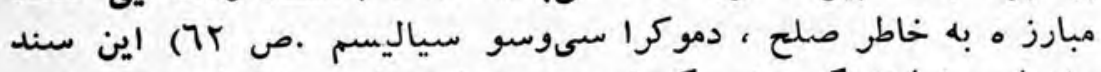

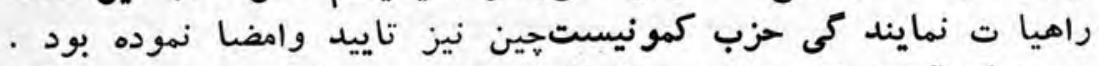

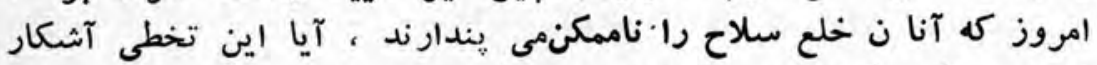

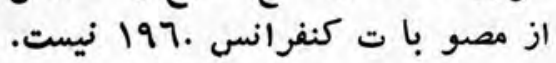




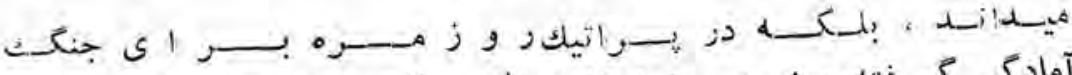

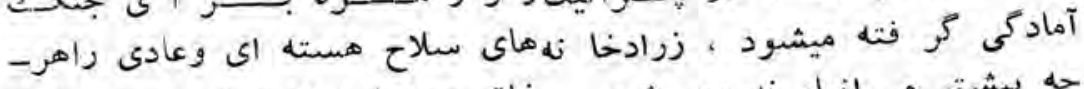

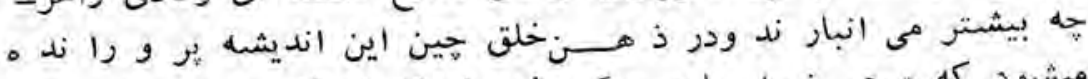

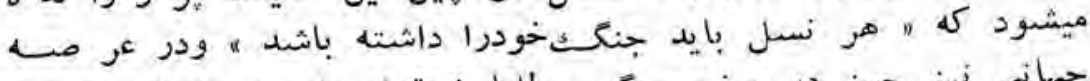

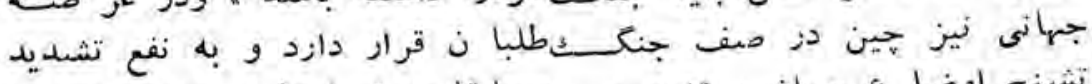

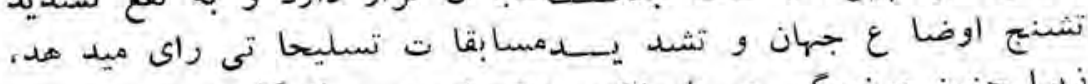

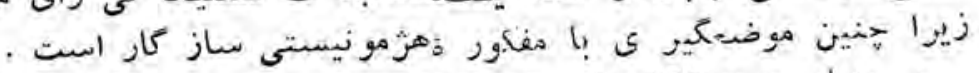

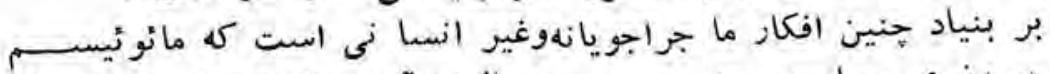

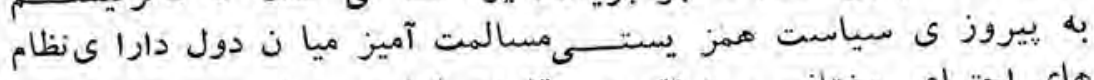

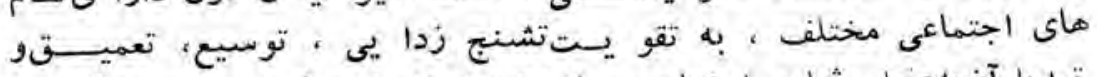

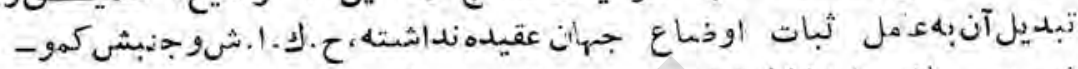

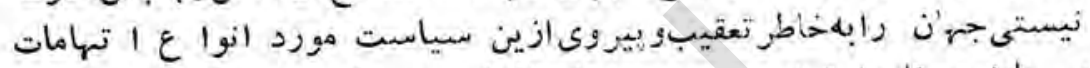

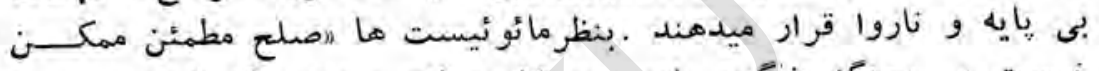

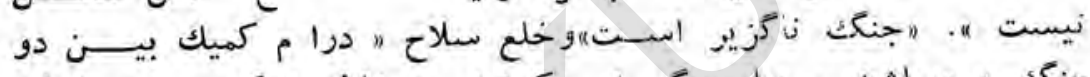

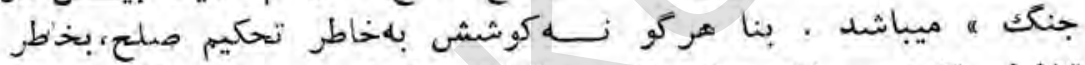

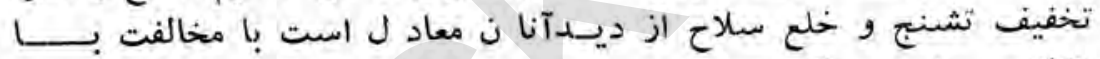

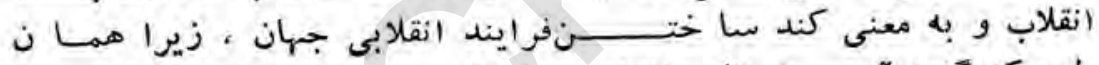

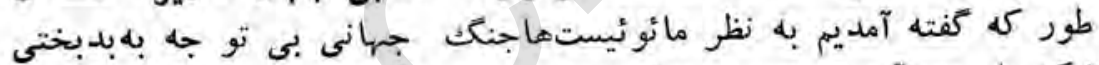

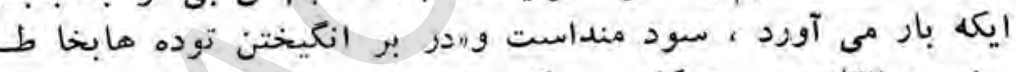

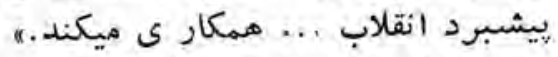

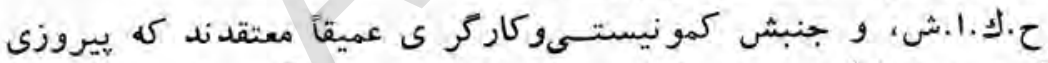

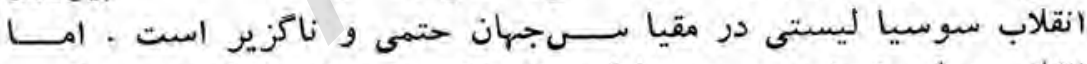

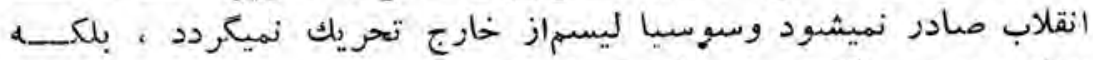

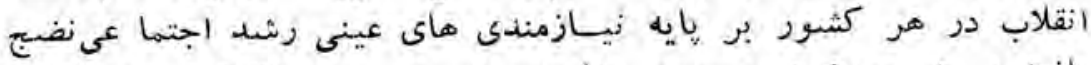

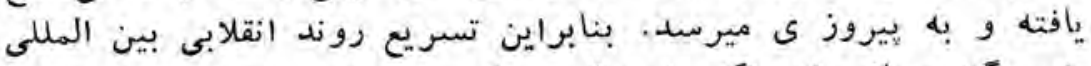

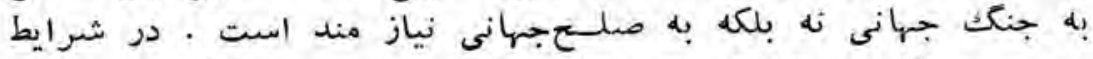

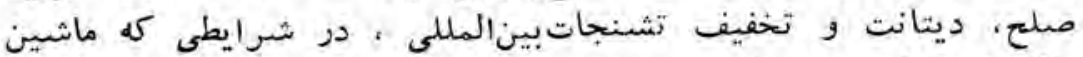

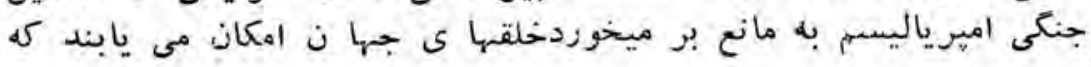




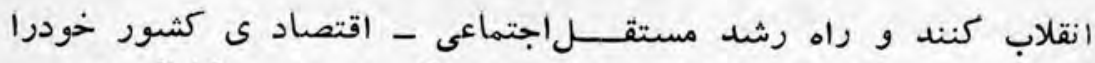

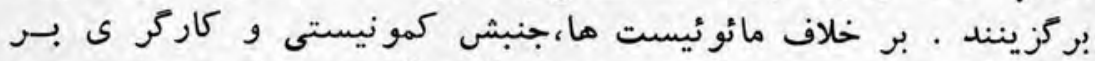

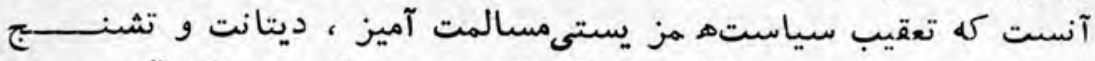

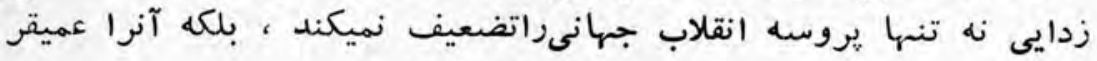

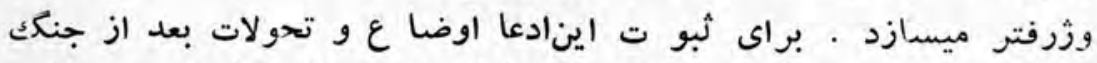

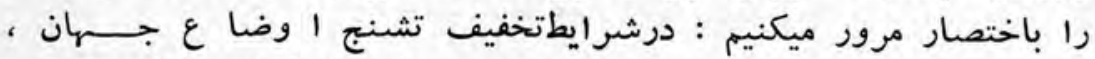

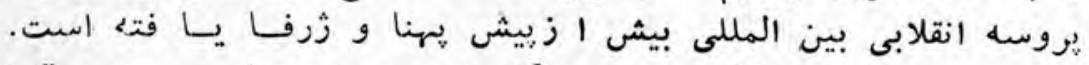

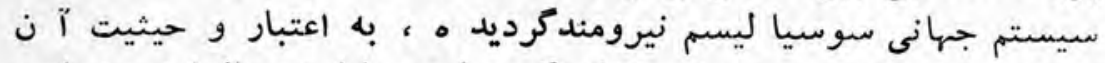

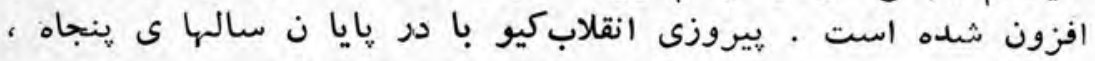

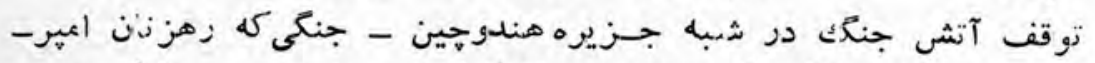

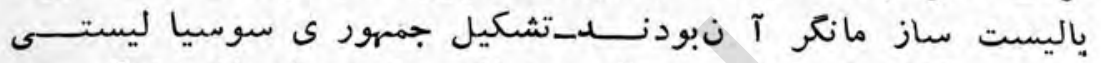

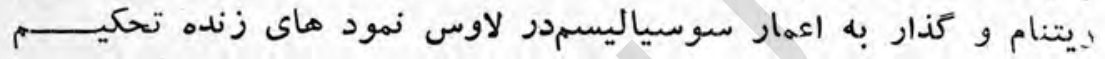

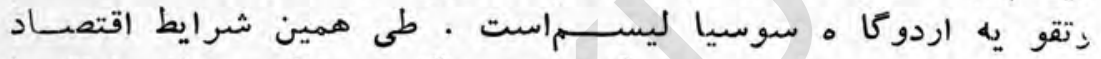

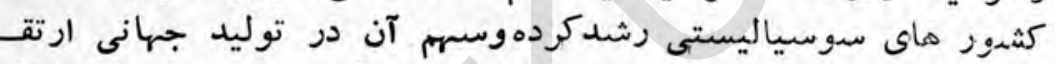

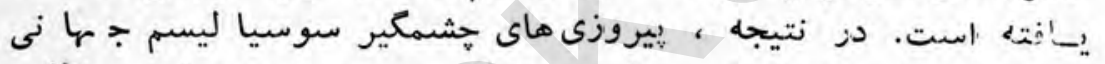

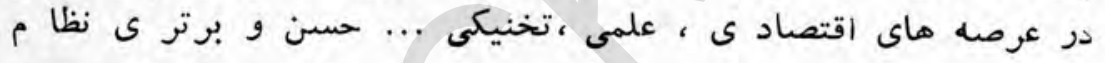

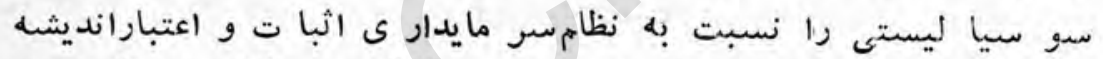

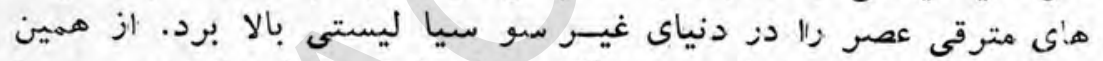

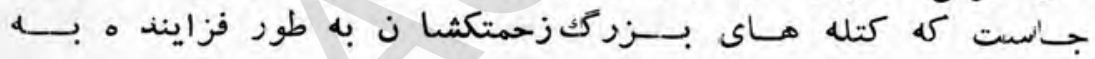

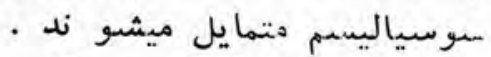

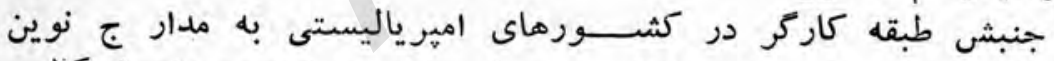

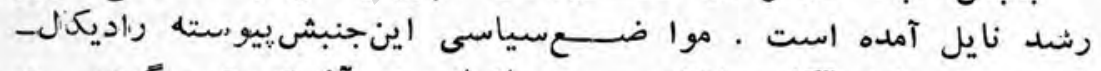

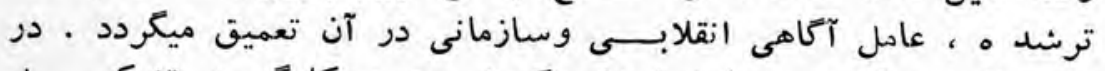

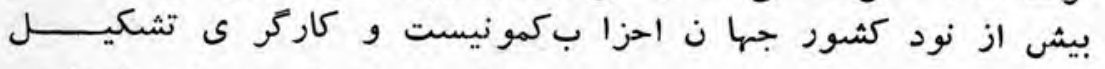

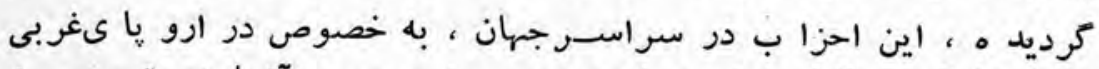

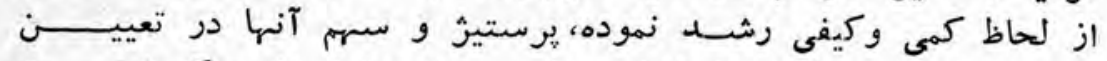

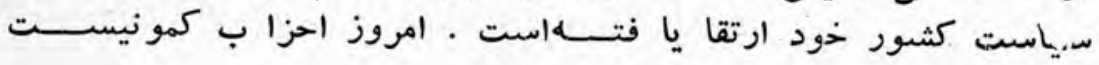


ايتاليا ، فراتسه و فنيليند در ميانطبقه كاركر و زحمتكشا ن آن كشور

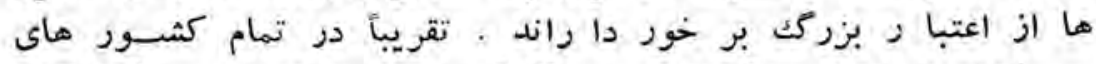

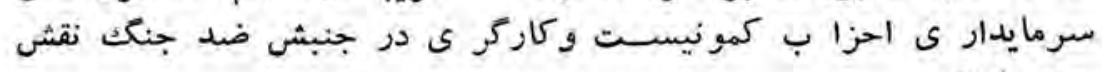

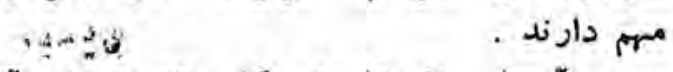

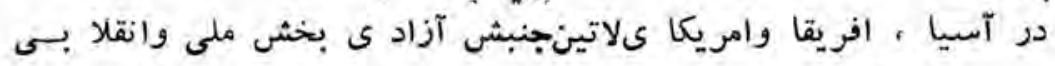

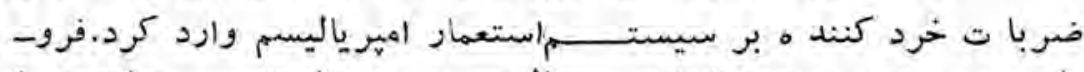

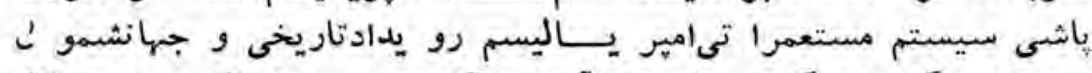

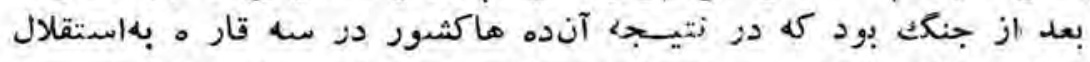

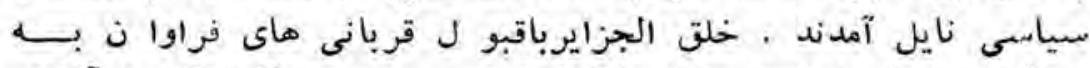

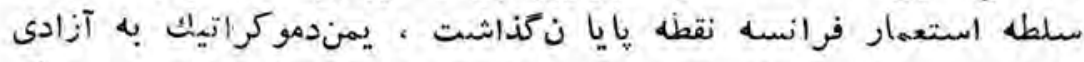

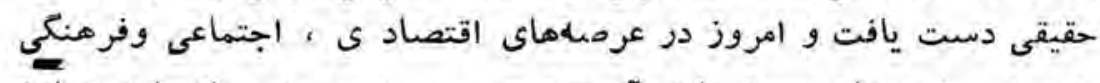

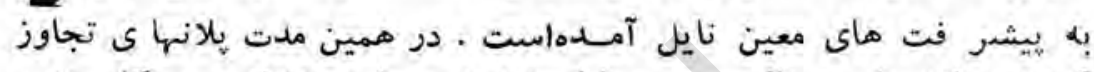

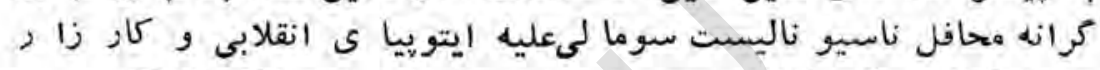

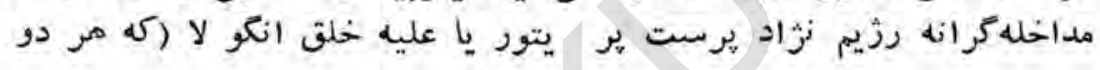

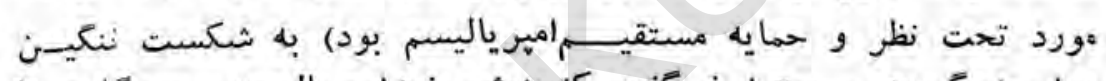

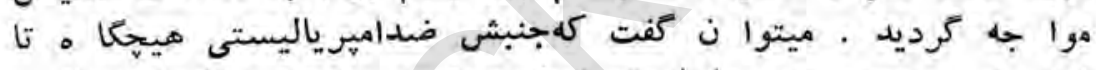

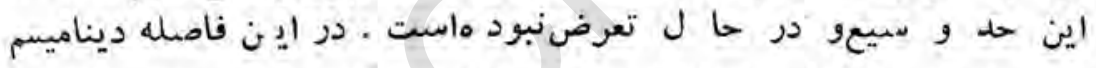

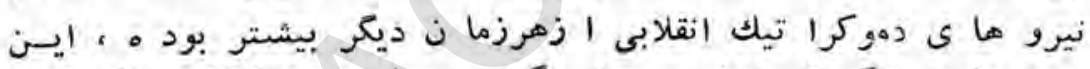

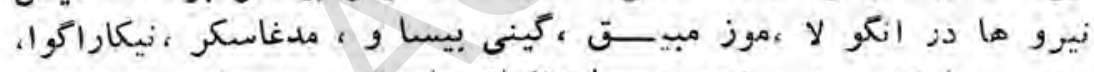

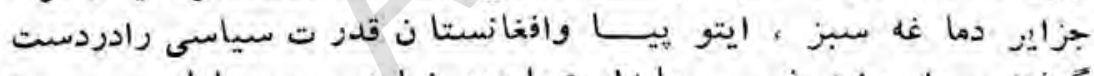

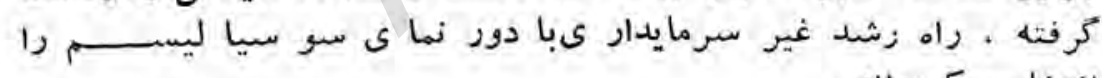

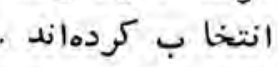

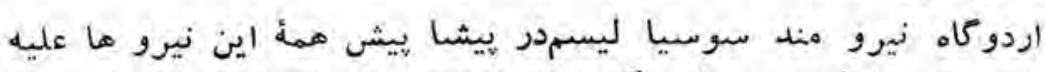

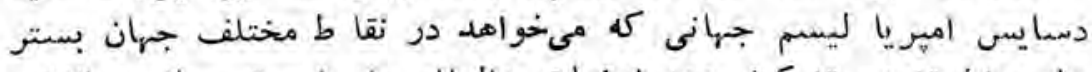

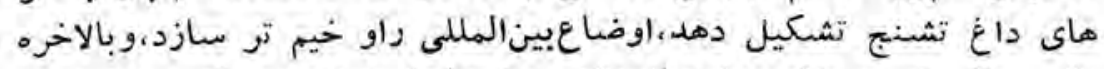

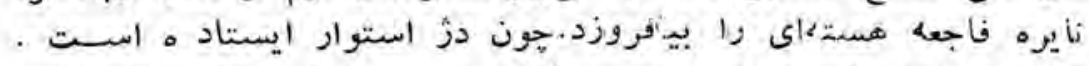

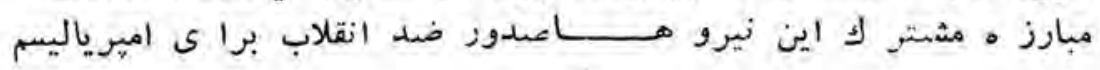




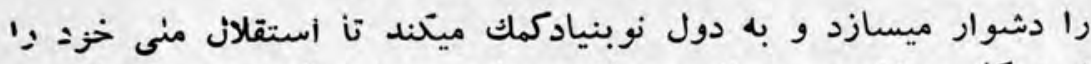

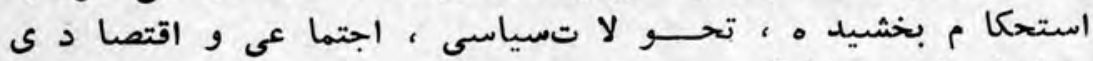

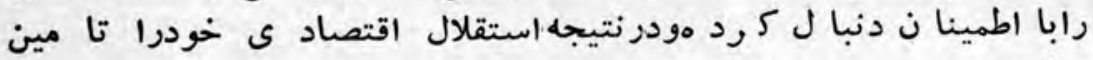
نمايند.

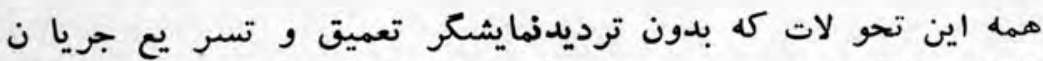

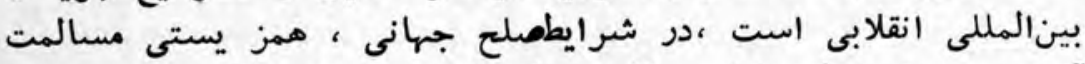

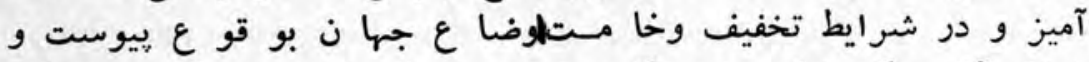

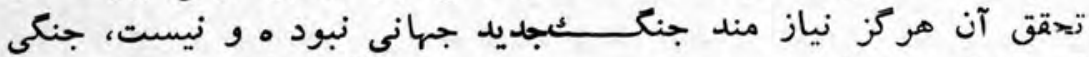

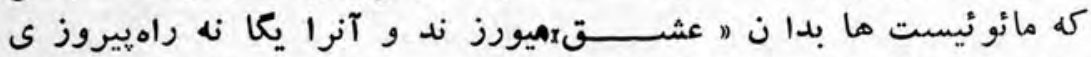

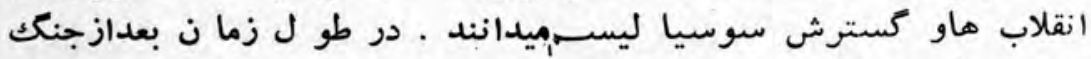

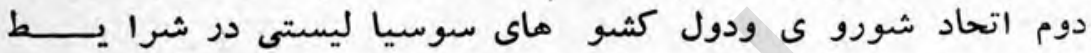

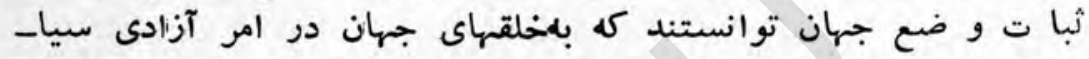

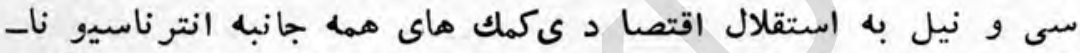

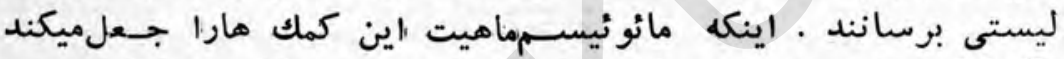

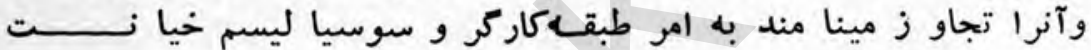
ميكنند

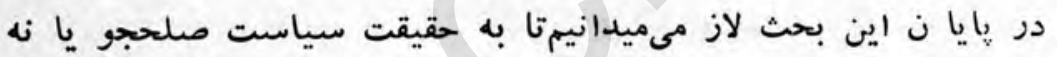

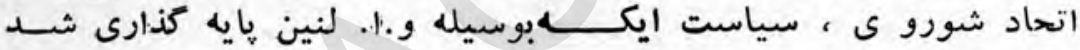

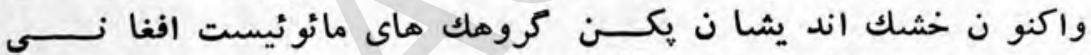

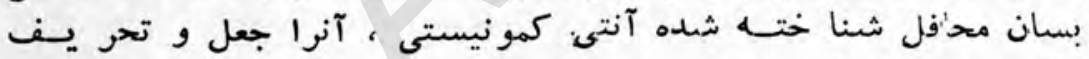

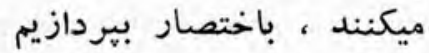

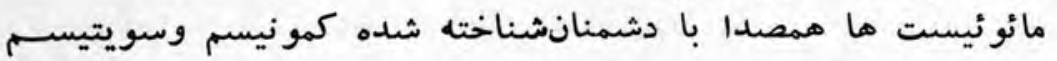

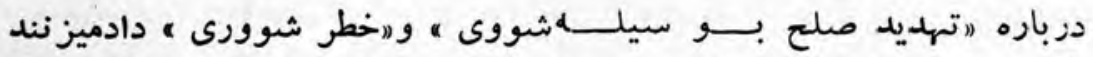

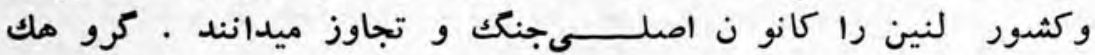

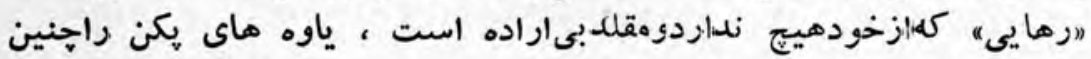

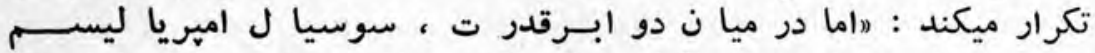

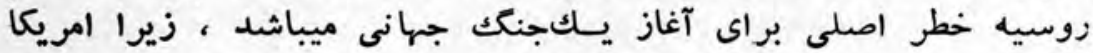


مثافع خودرا در حفظ و ضع موجو مى بيند و روسيه منافع خود را دمز

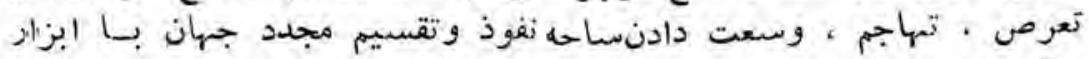

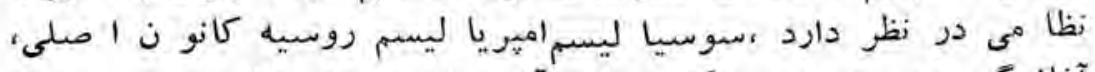

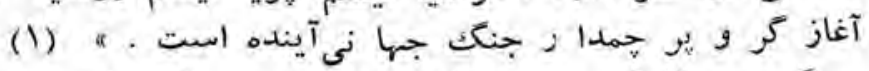

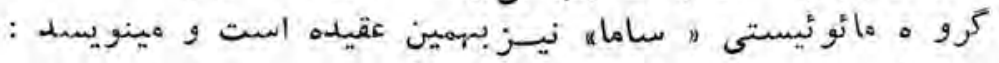

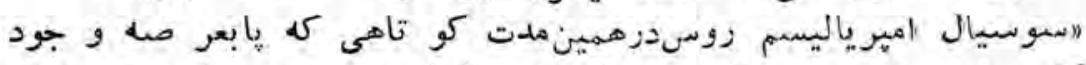

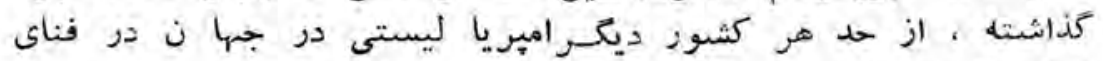

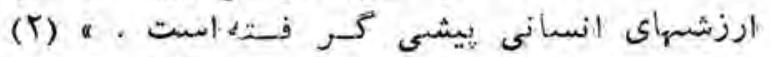

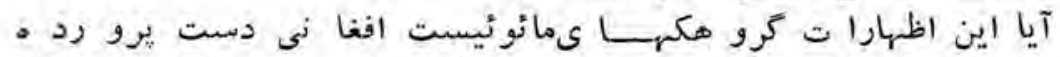

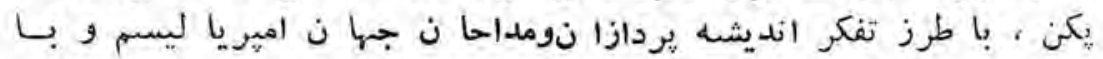

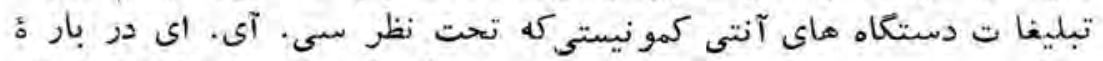

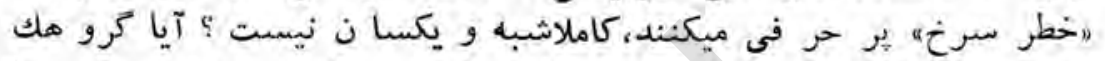

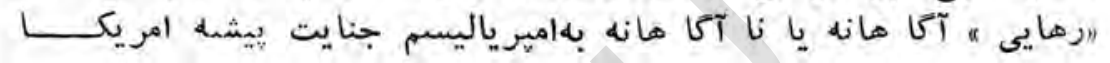

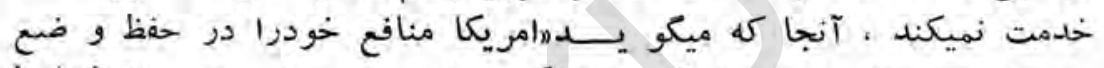

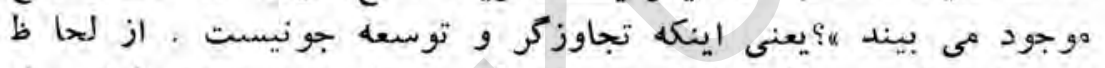

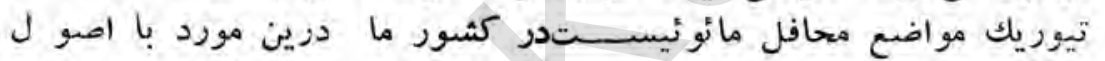

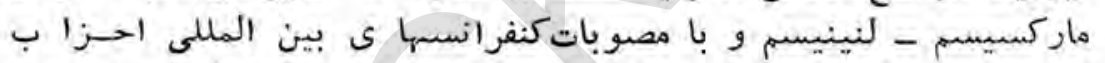

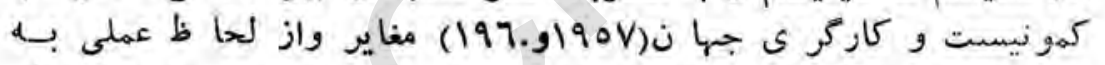

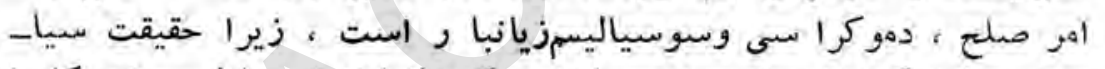

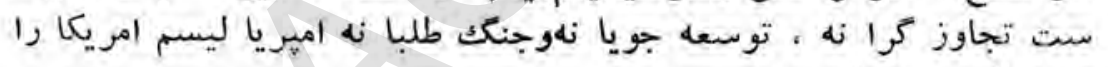

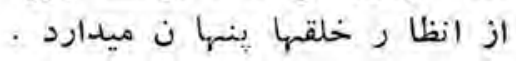

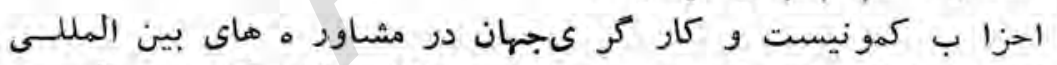

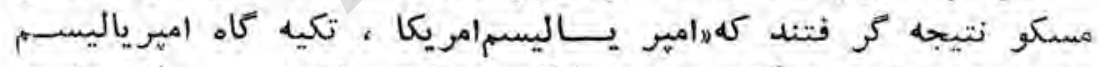

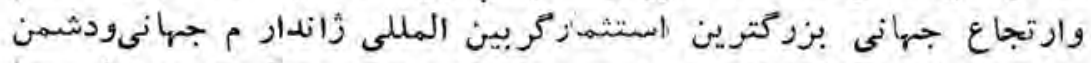

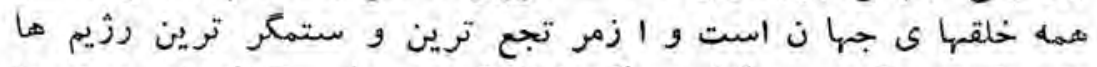

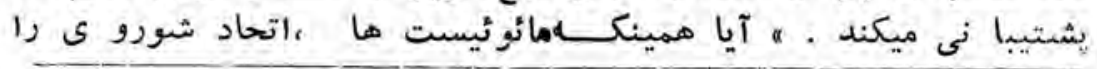

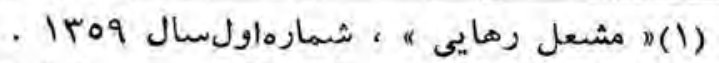

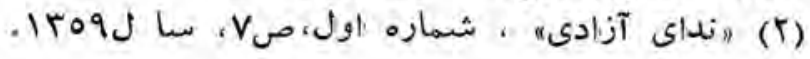


كانو ن اصلى جنك مى دانند وبرعكسامير ياليسم امريكا را در حال

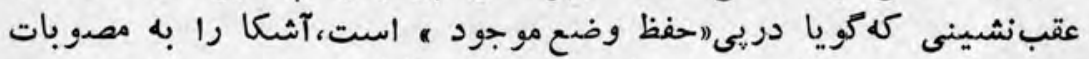

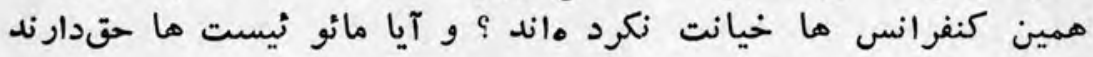

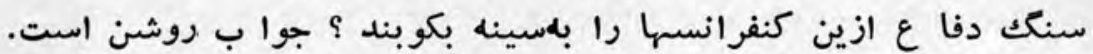

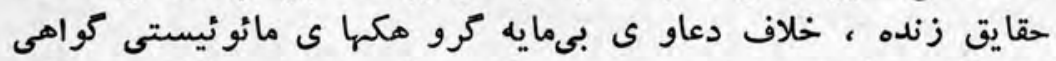

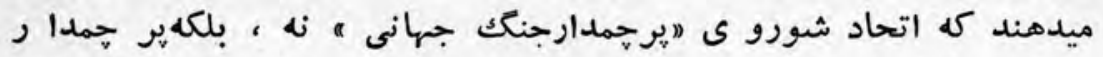

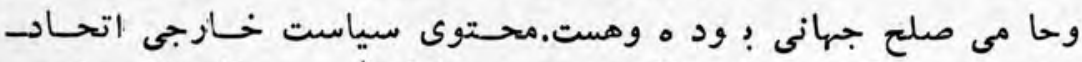

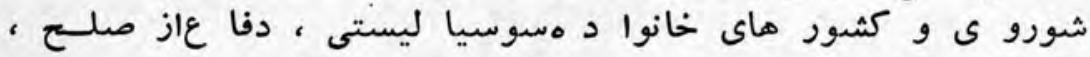

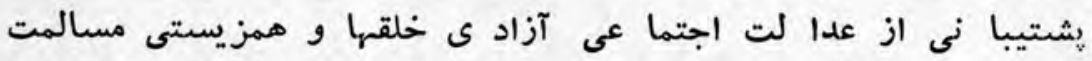

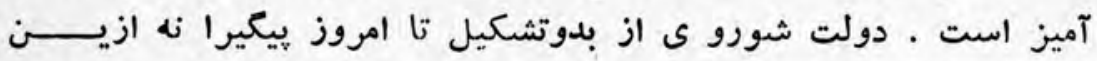

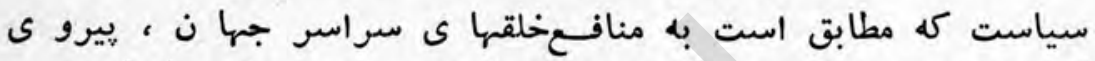

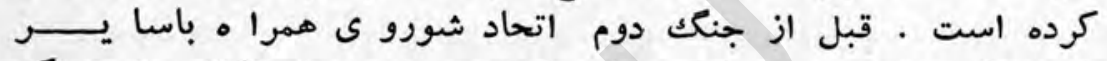

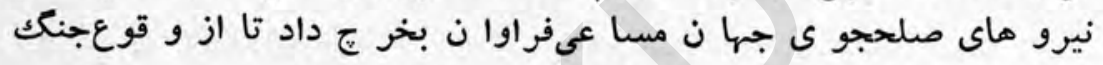

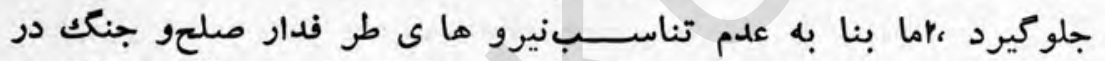

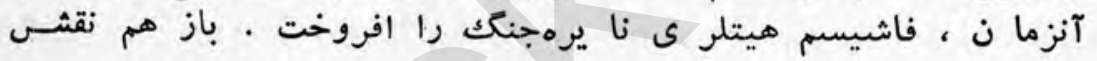

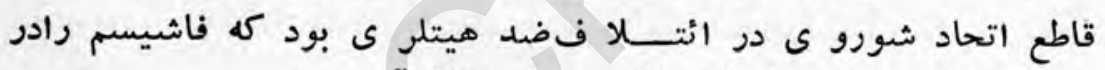

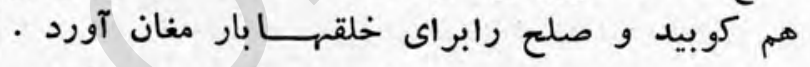

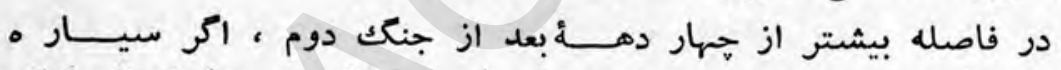

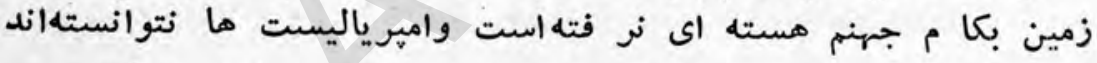

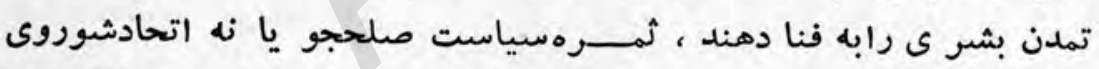

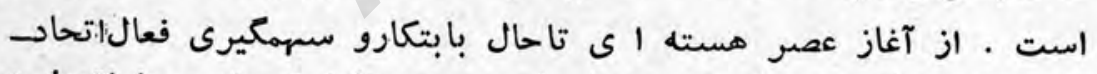

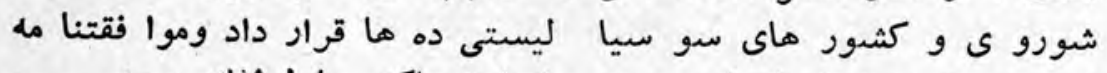

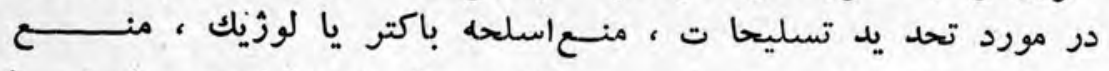

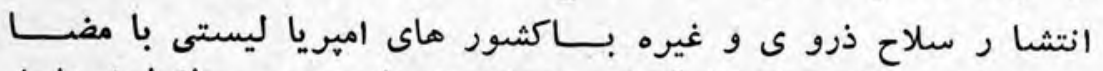

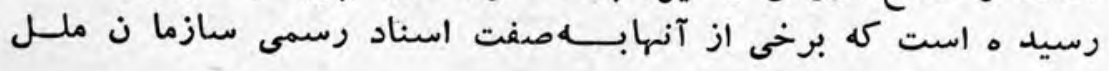
متحد تصويب و محفوظ است. بذكرجند نمونه بسنده ميكنيم : 


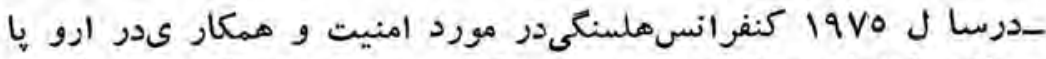

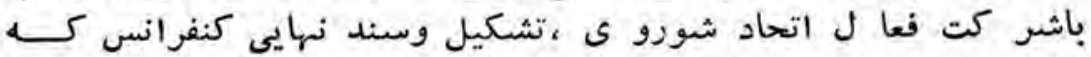

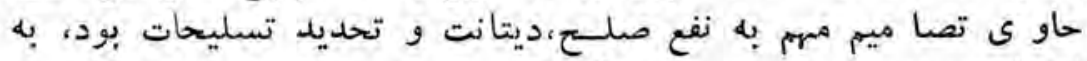

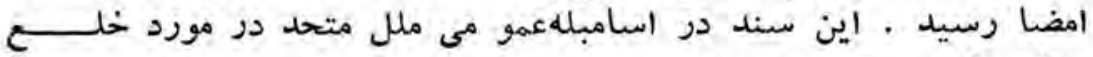

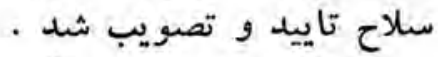

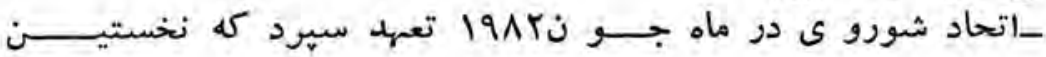

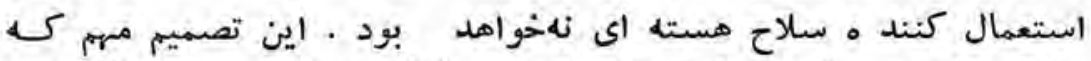

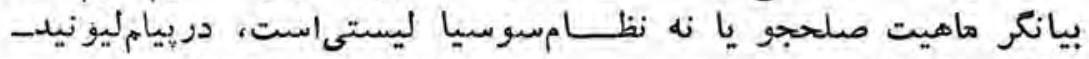

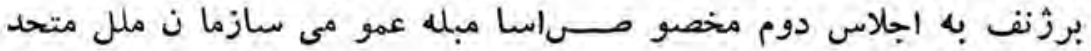

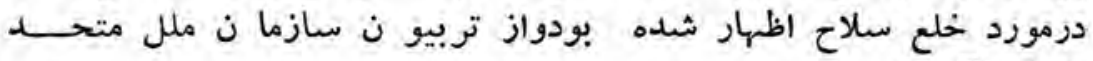
قرائت كرديد . مخلع

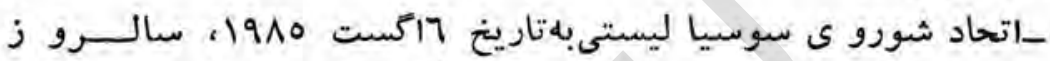

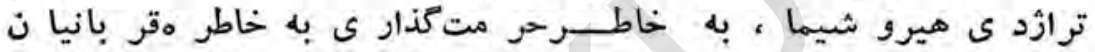

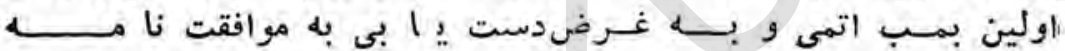

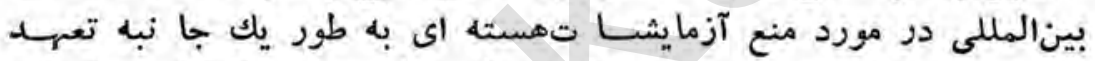

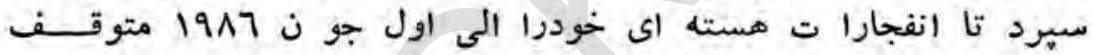

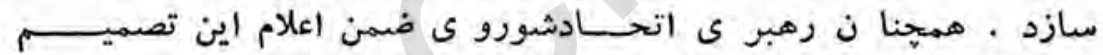

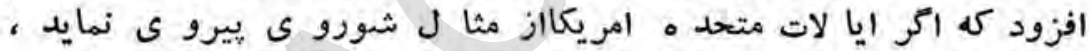

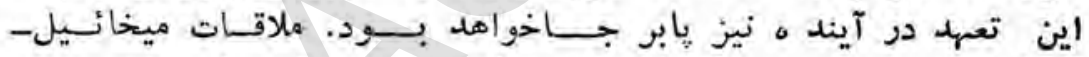

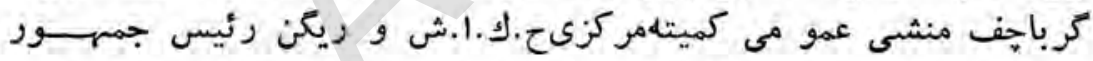

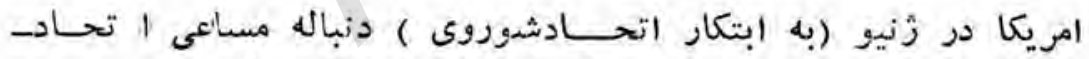

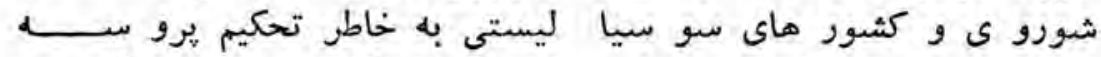

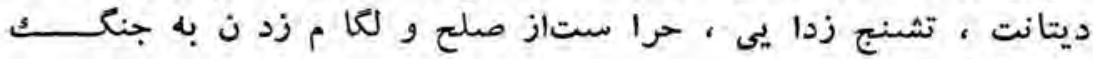

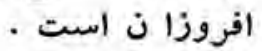

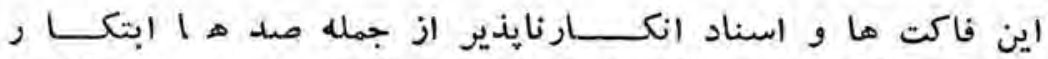

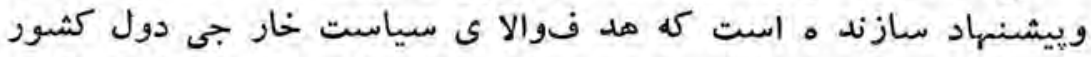
هاى خانواد هـ سوسيا ليستسى د رواس التحاد شورو في رابيا ن ميكند. 


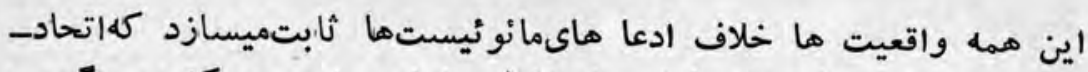

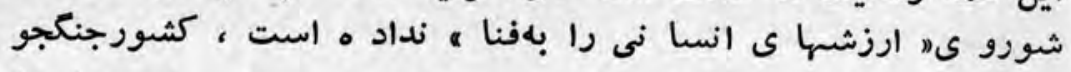

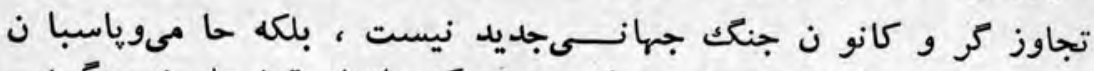

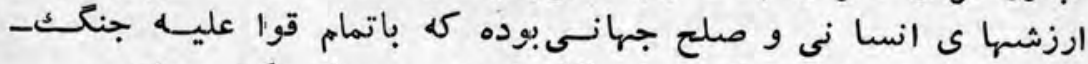

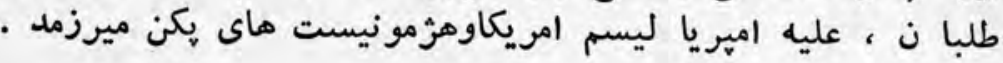

\section{*}

\section{米}

米

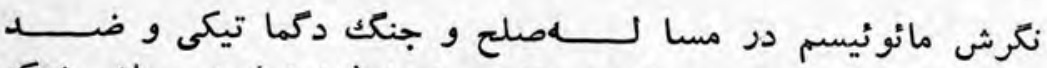

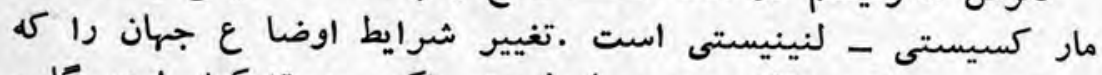

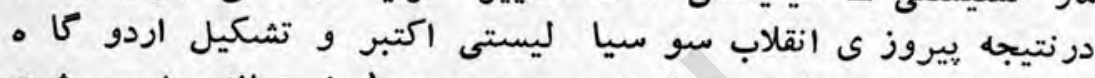

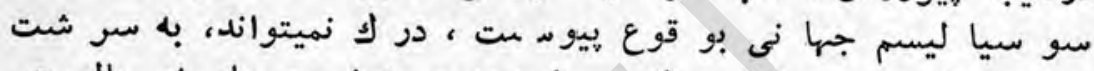

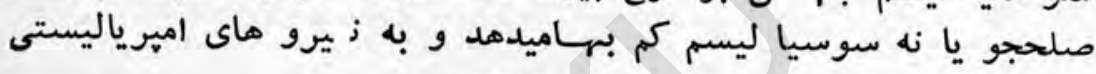

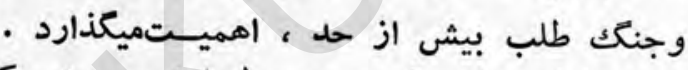

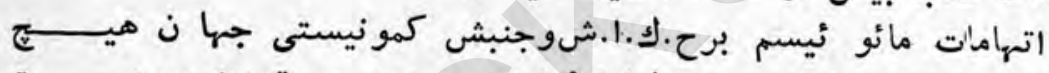

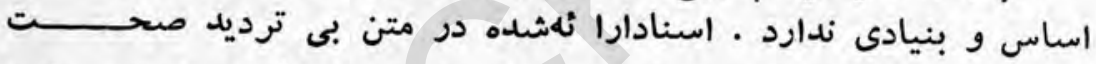

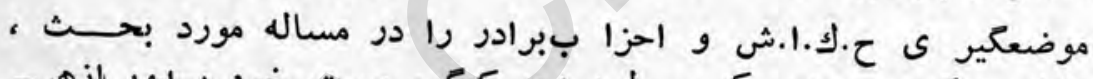

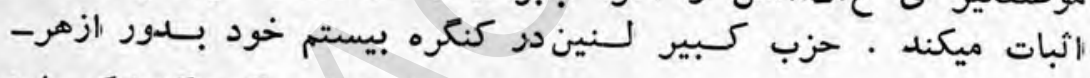

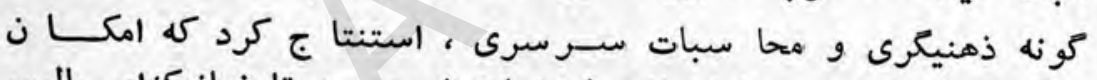

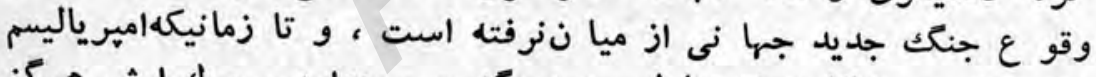

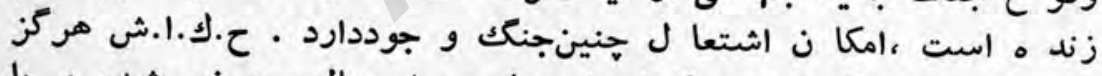

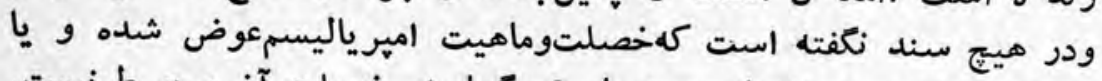

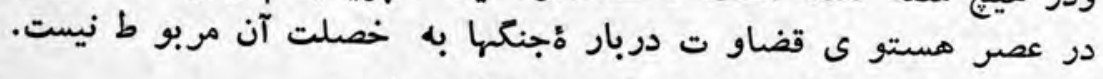

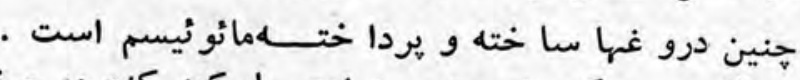

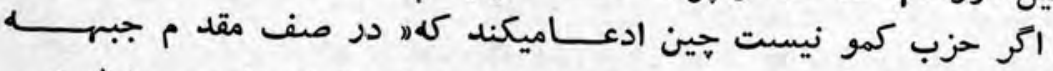

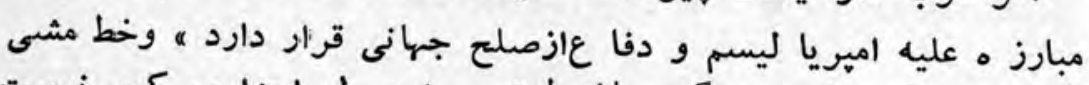

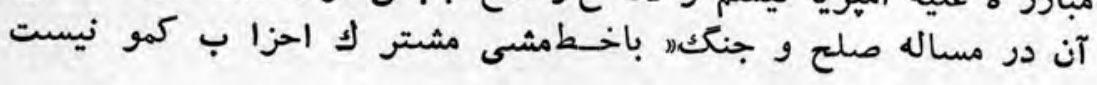




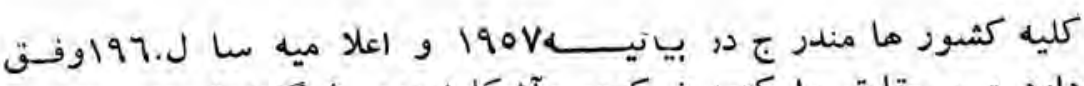

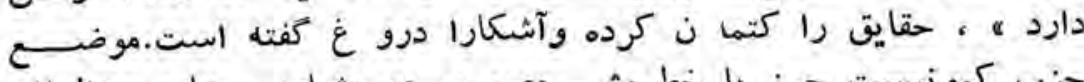

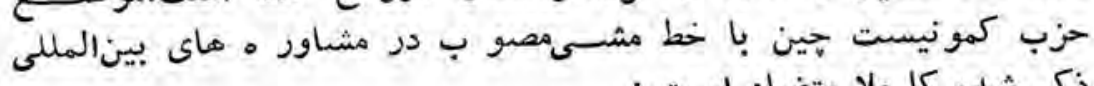
ذكر شده كو ملا ملا متضاد است :

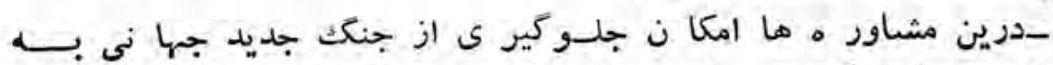

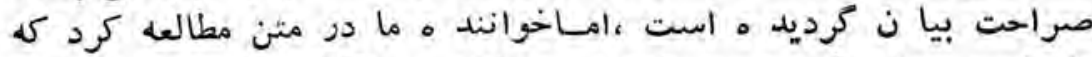

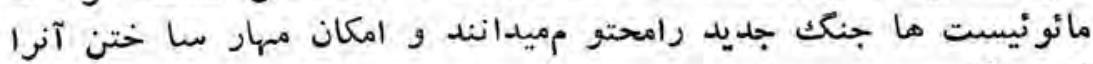
نفى ميكنين . ن مائن

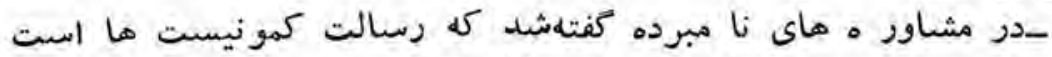

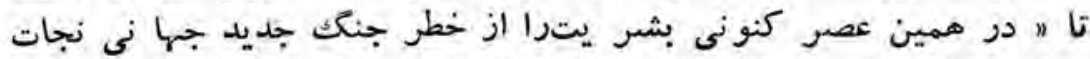

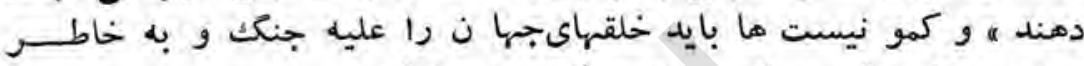

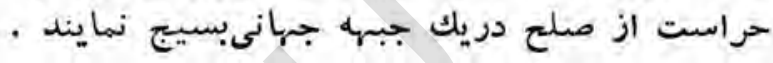

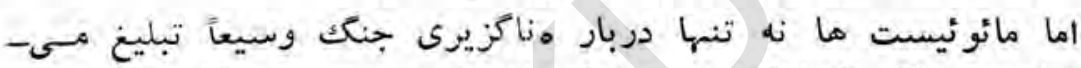

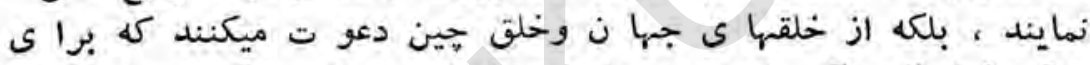

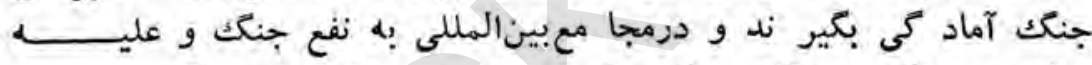

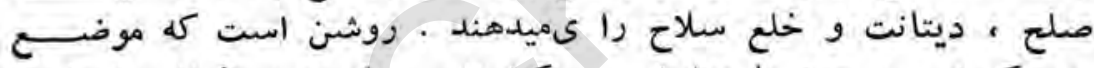

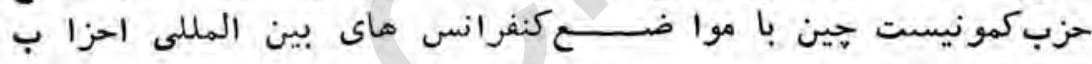

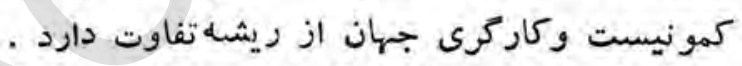

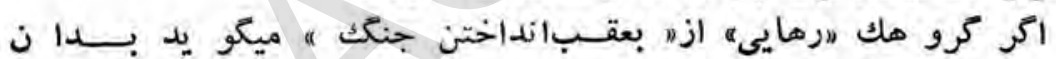

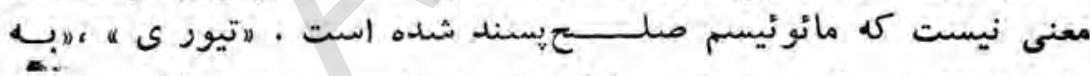

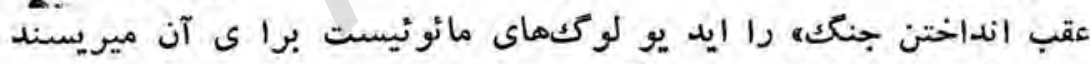

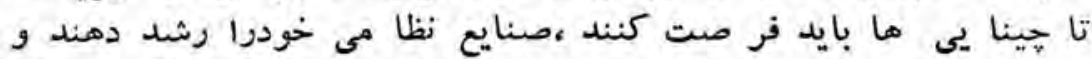

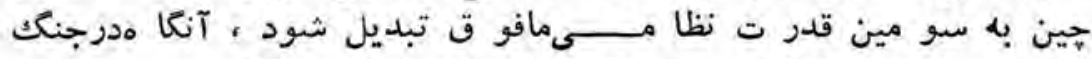

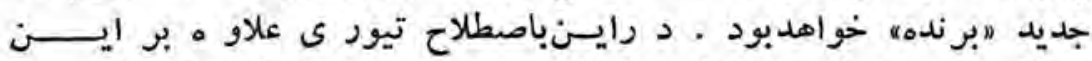

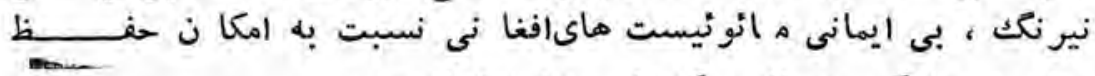

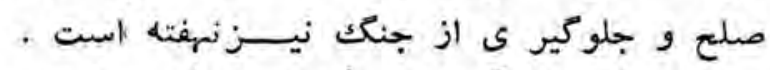

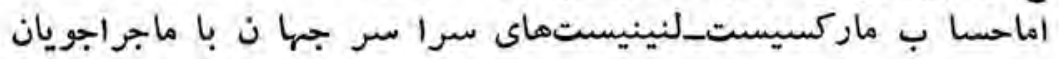




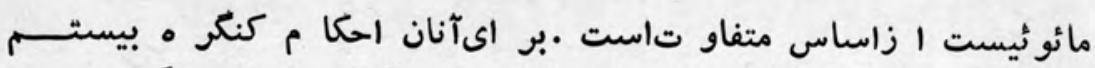

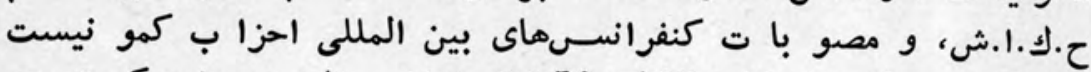

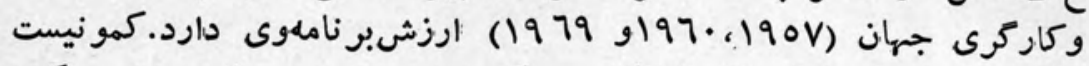

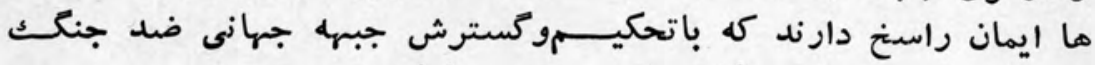

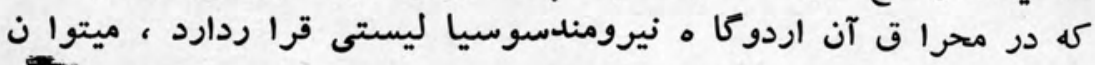

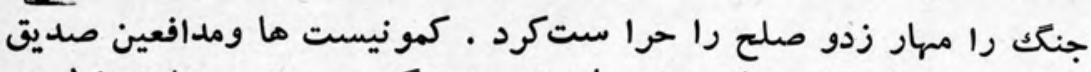

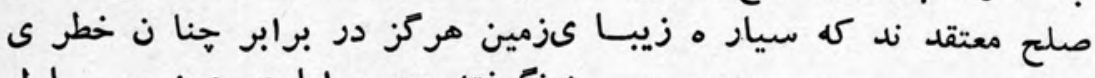

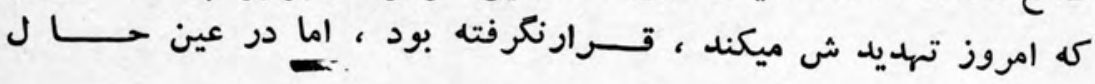

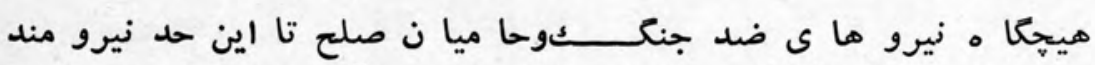

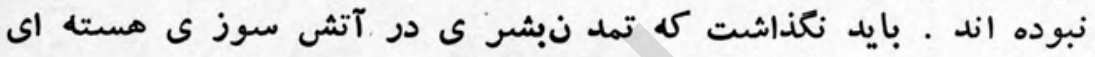

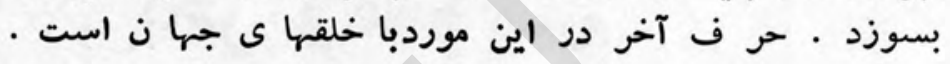




\section{بحر انمائو ئيسهم}

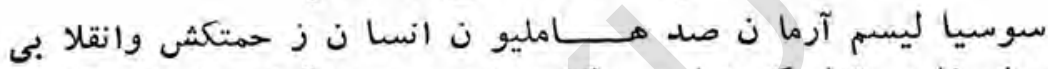

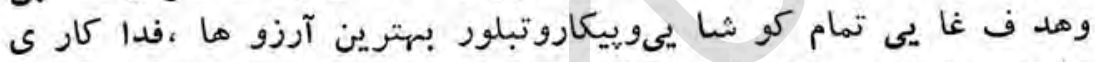

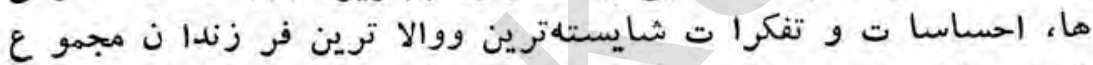

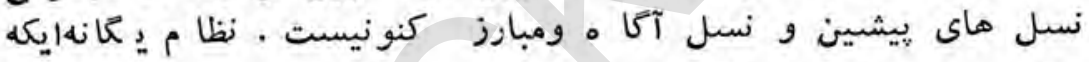

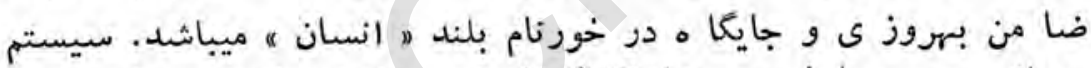

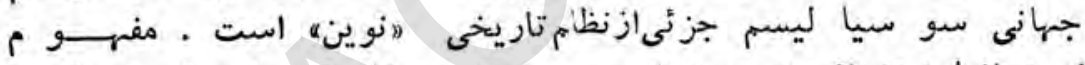

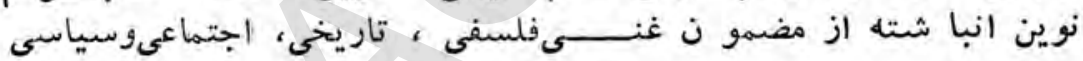

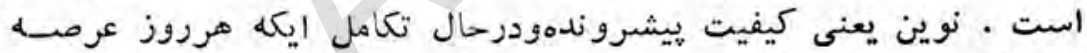

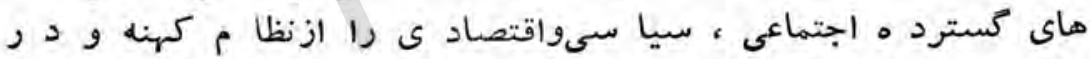

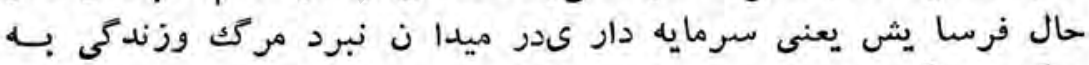

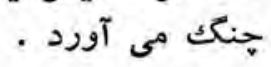

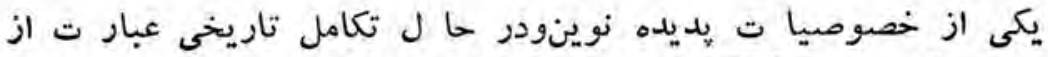

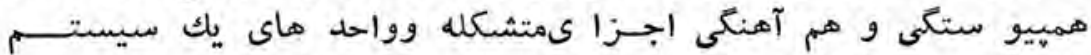

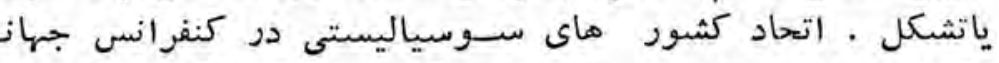

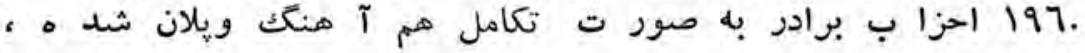




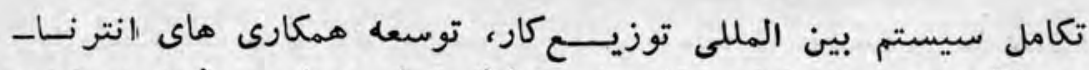

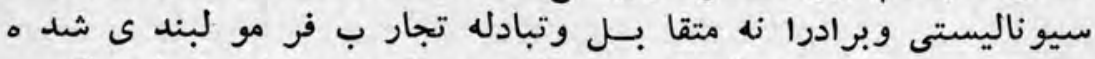

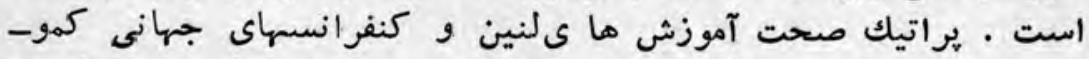

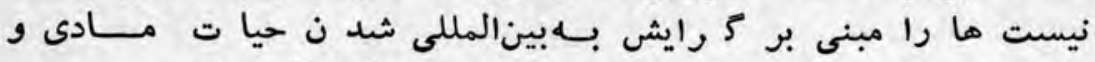

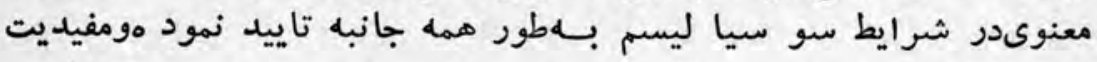

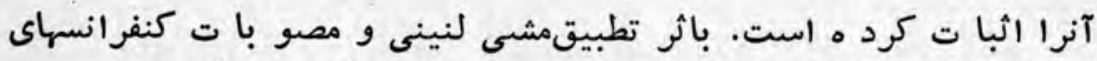

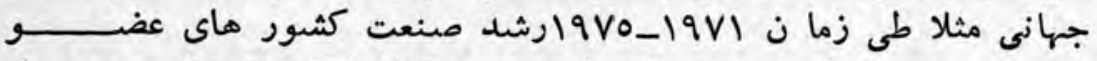

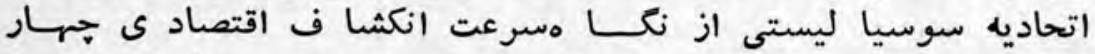

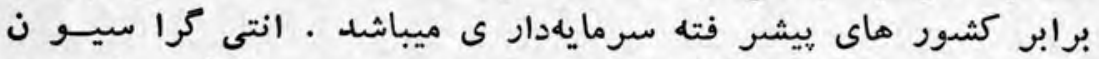

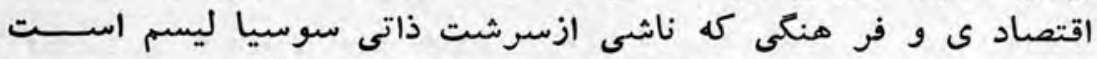

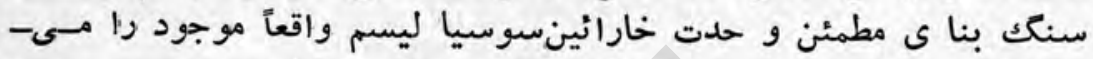

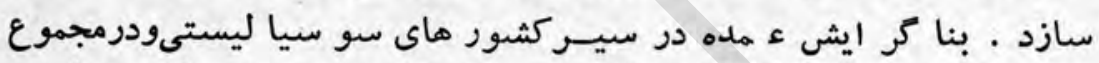

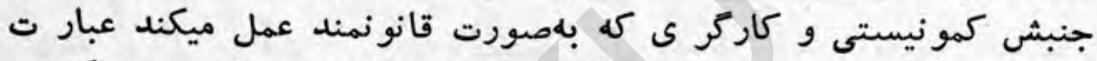

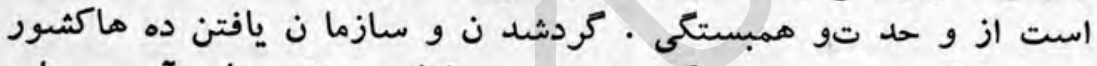

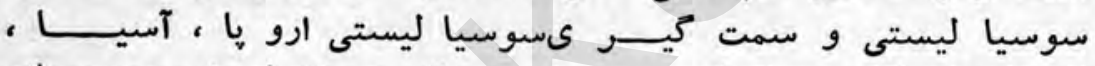

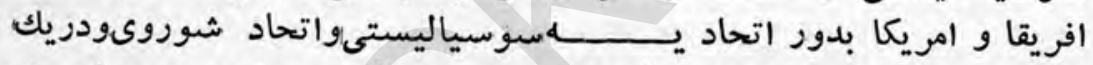

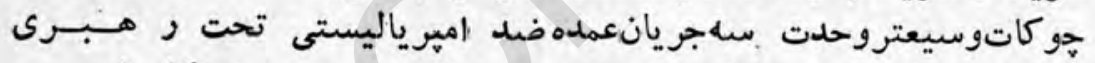

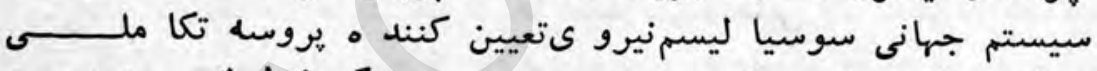

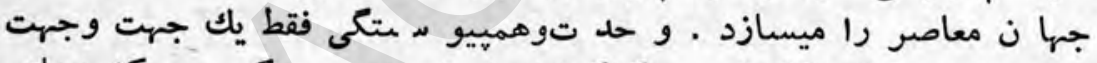

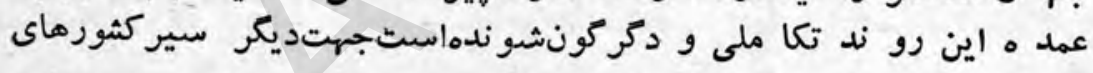

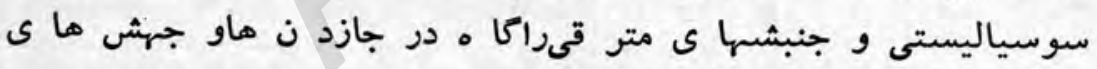
بزركى قهقر'ايى در بر بر دارد.

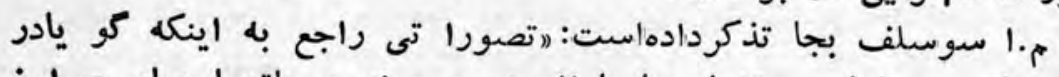

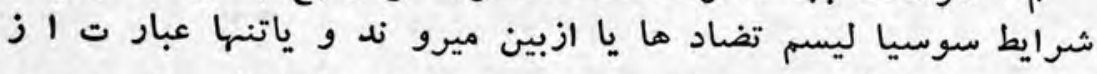

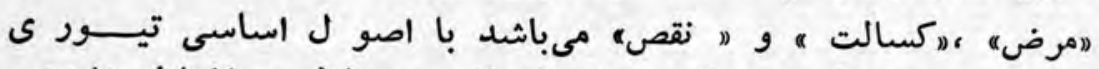

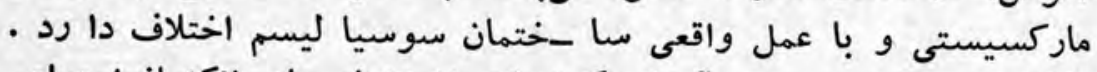

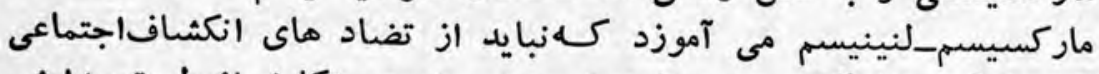

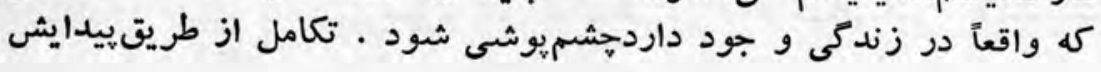




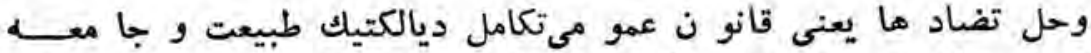

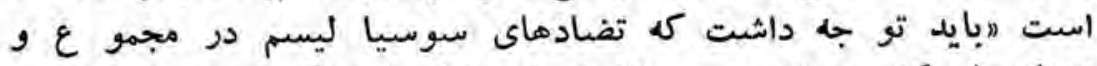

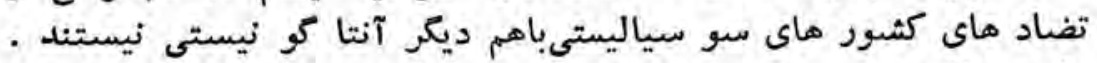

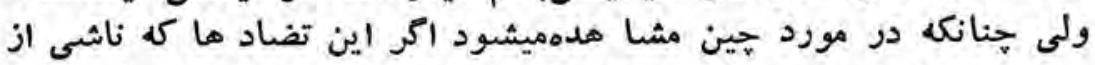

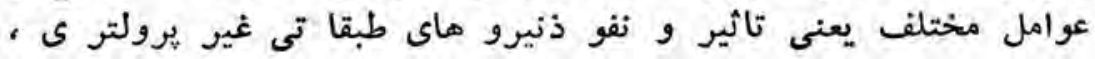

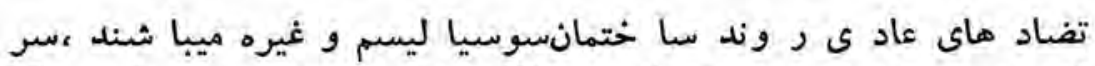

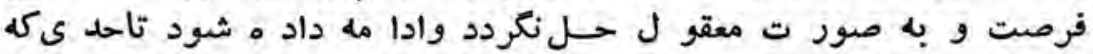

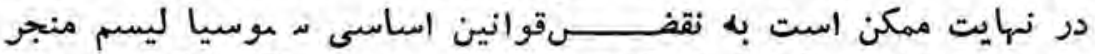

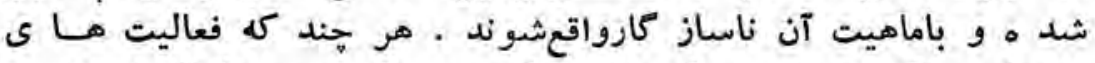
انشعا ب كرانه و ضد كمونيستى يكن در سا حها بين المللى نتوانست بطور اساسى و حد ت كشور هاىسوسيا ليستى واحزا بـ كمونيستى

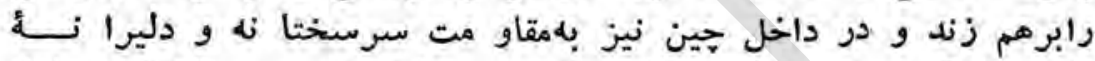

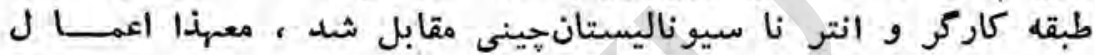

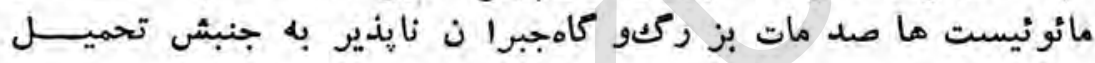
نمود

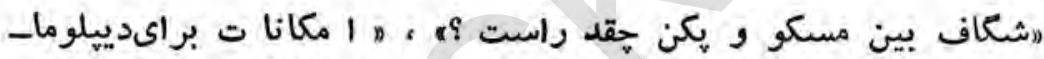

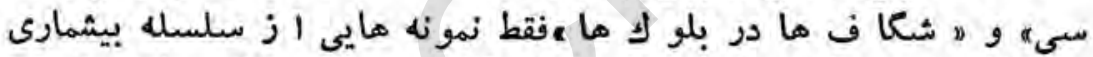

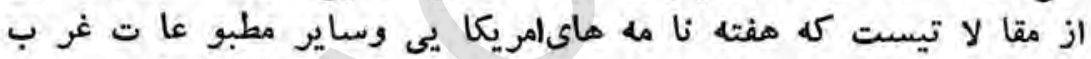

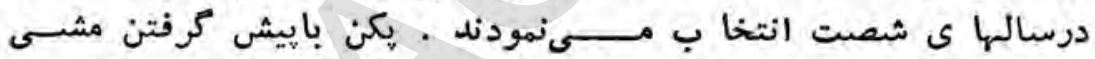

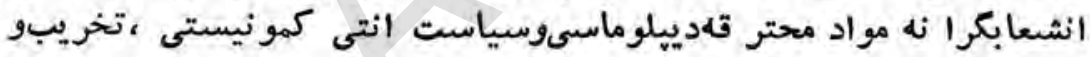

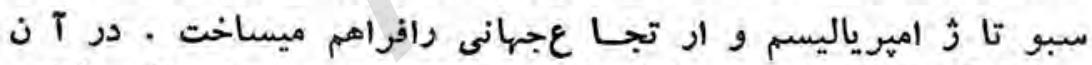

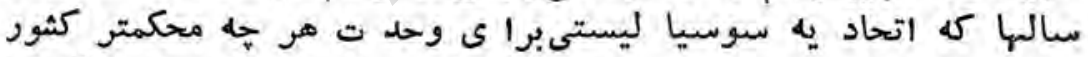

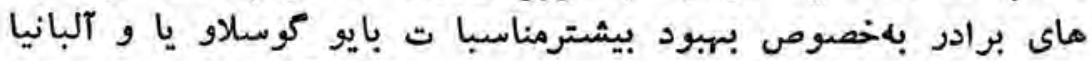

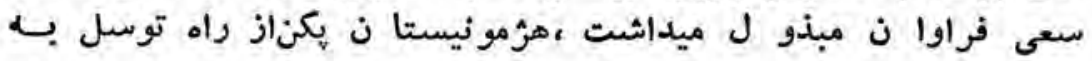

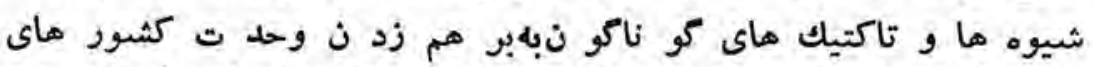

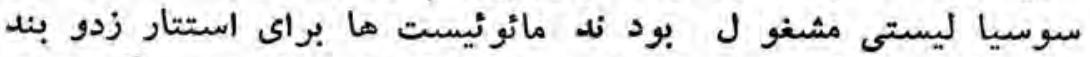

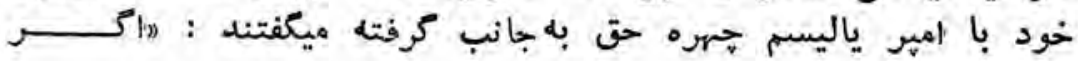




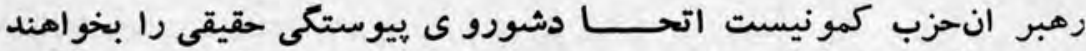

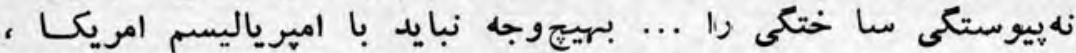
مرتجعا ن كشور هاى مختلف جها نها نودارو دسته خاين تيتو جهت مادي مبارزه

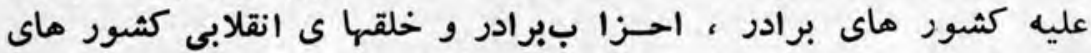

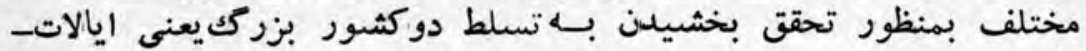

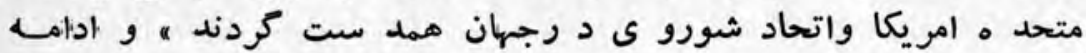

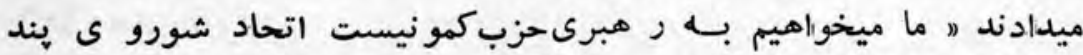

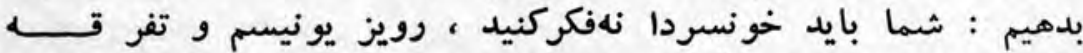

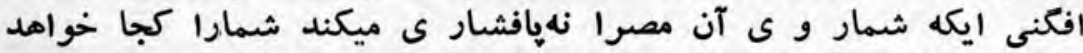

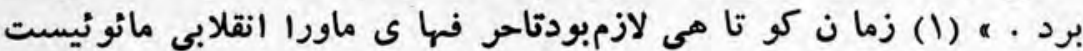

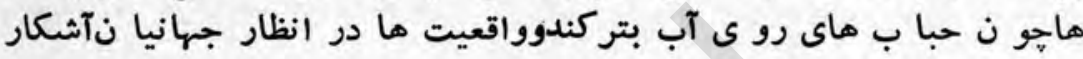

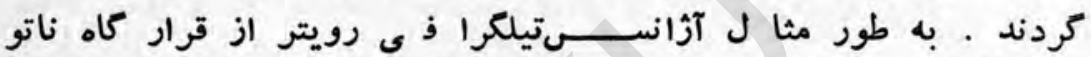

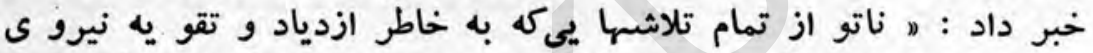

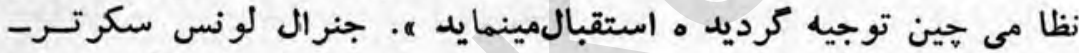

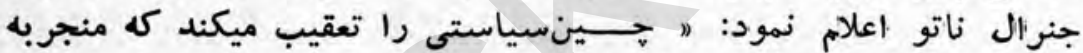

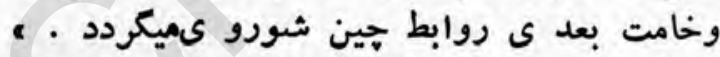
رهبرا ن يكن با النو به به دنياىغرب به كليه مرتجعين ابراز وفادارى

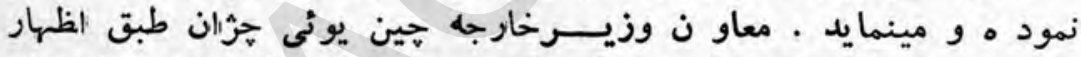

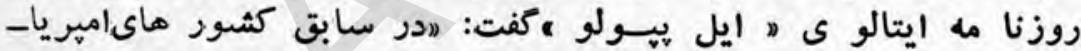

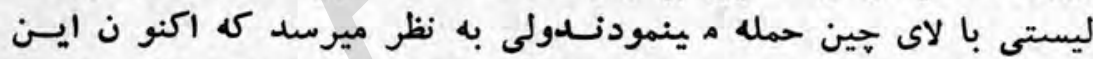

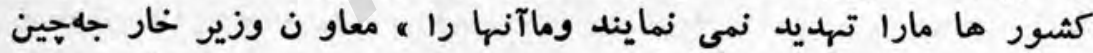

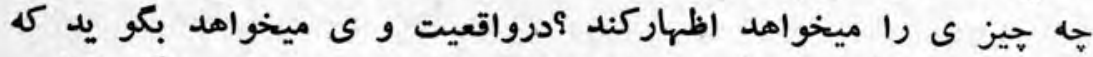

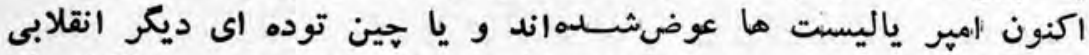

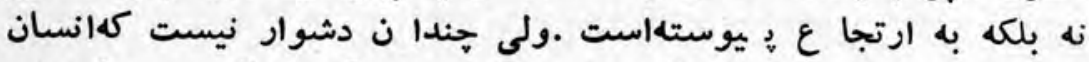

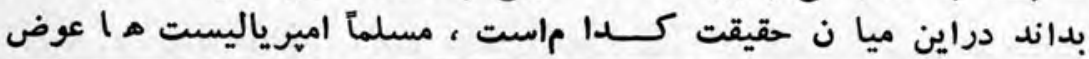

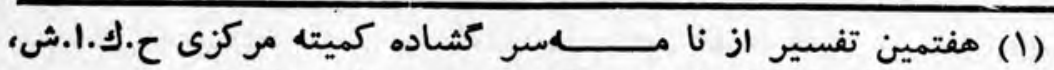

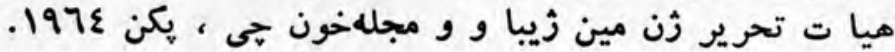




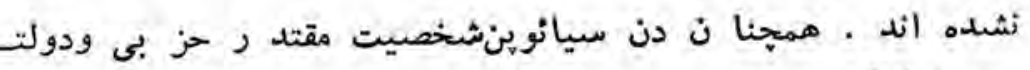

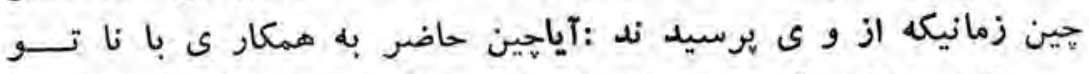

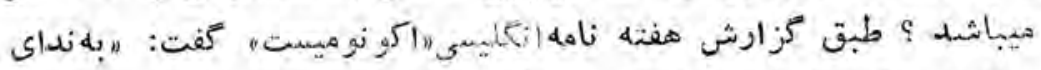

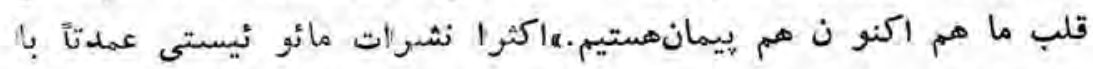

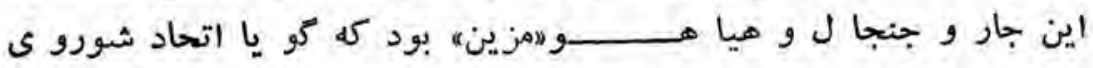

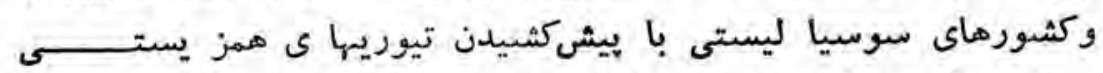

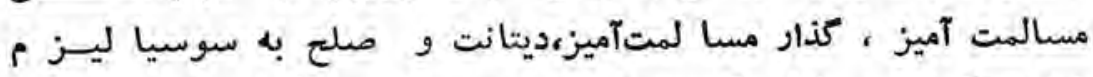

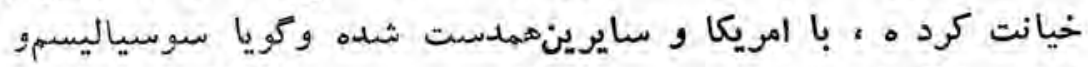

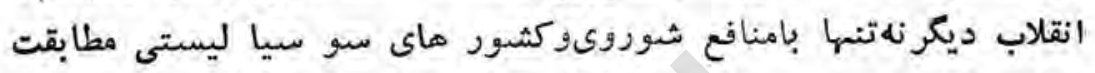

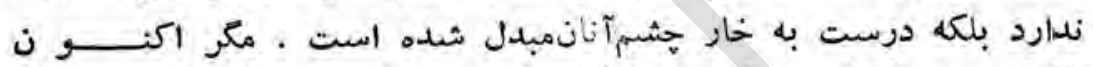

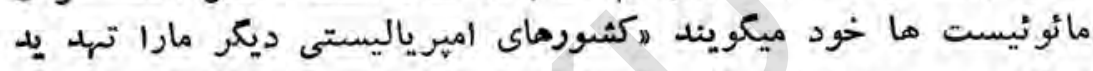

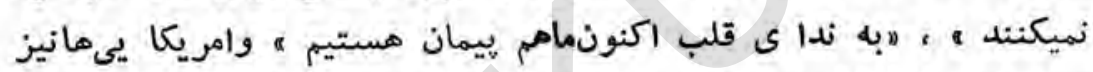

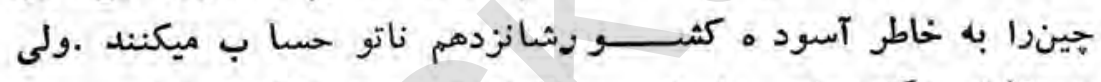

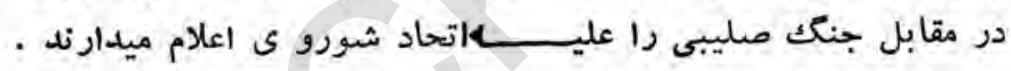

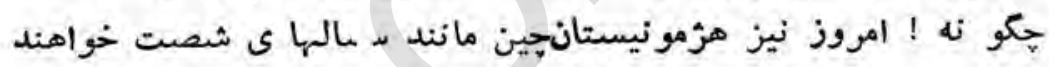

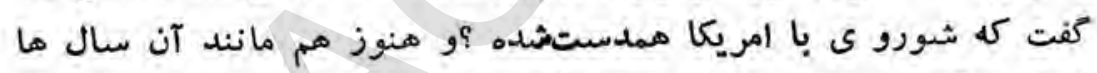

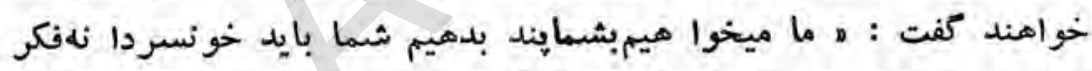

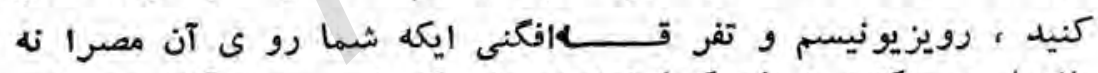

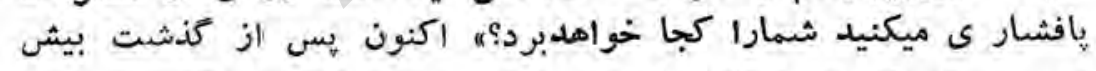

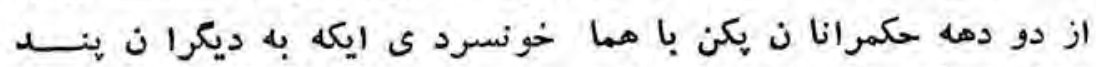

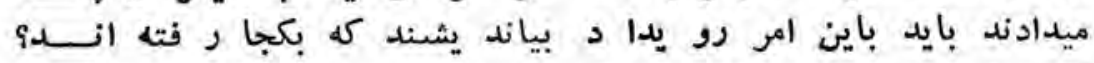

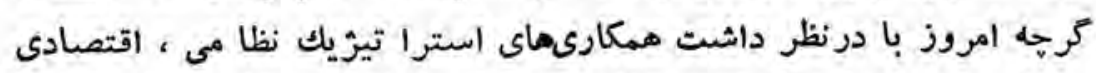

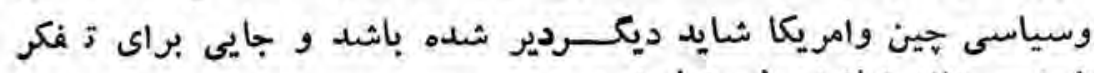
خونسر دانه نباشد ولى شا يد . 


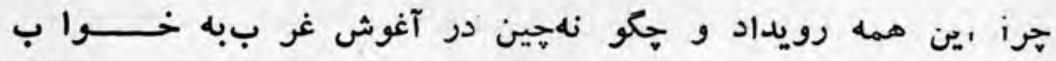
(N) $-\infty$ رفت؟ زمان

زمانيكه مائو قوانين اساسى وتجار ب تاريخى سا ختمان سوسيا-

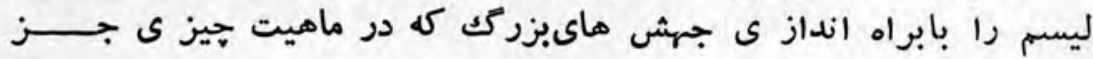

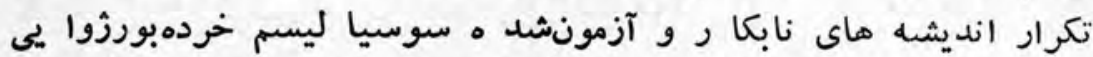

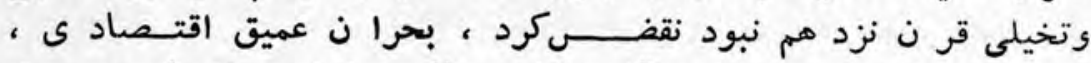

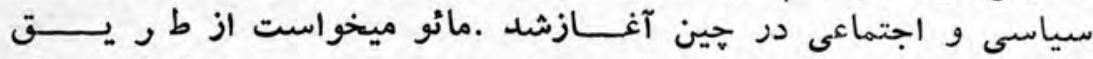

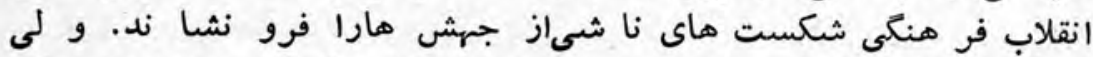

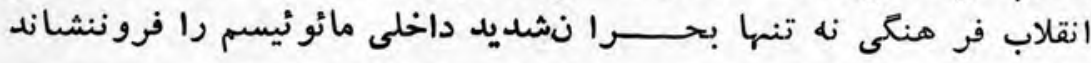

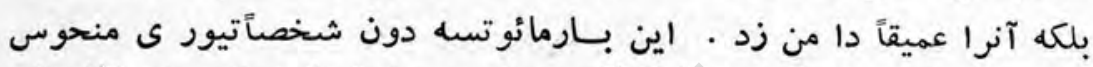

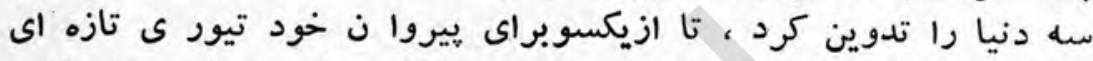

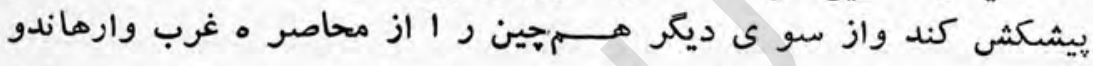

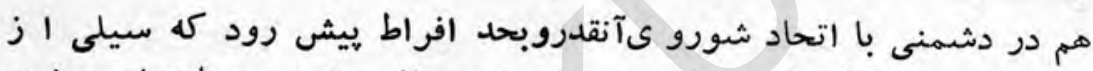

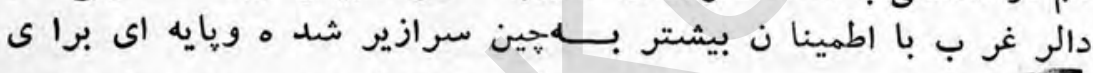

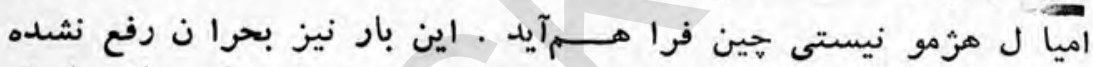

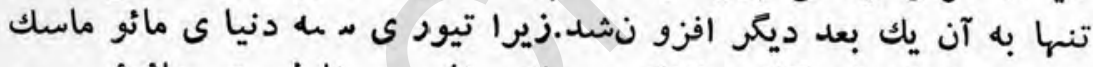

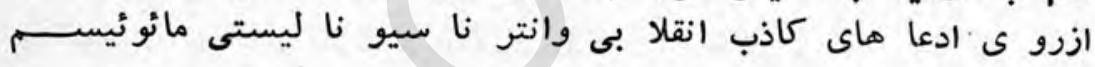

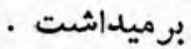

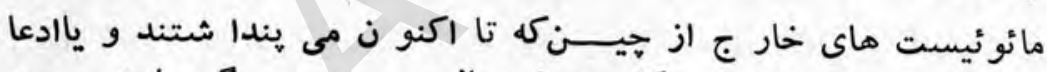

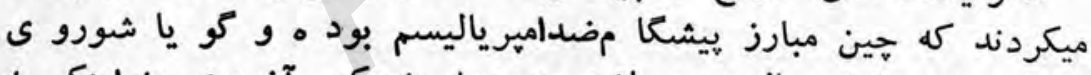

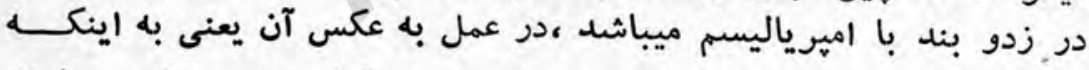

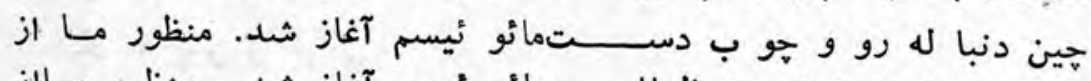

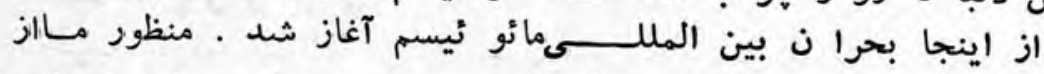

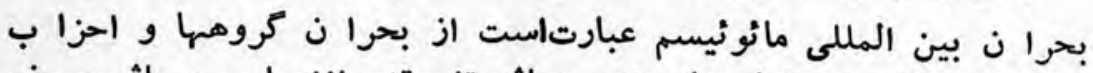

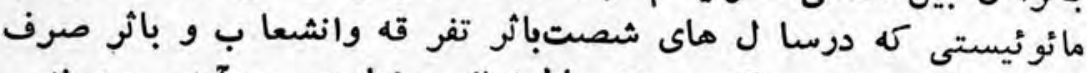

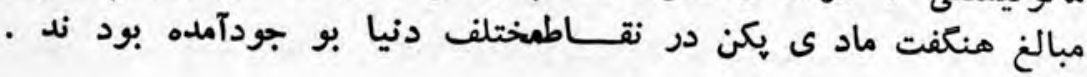


بحران همل كير ى كل عمدتأناشى ازعوامل عميق اجتما عى ، سيا سى و اقتصادى ذيل ميباشد : إندان

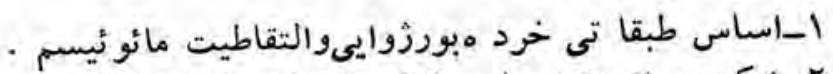

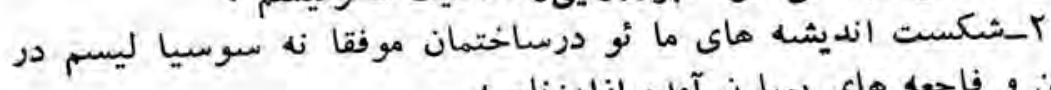

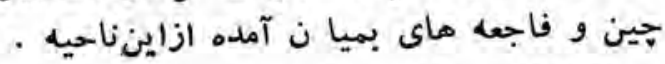

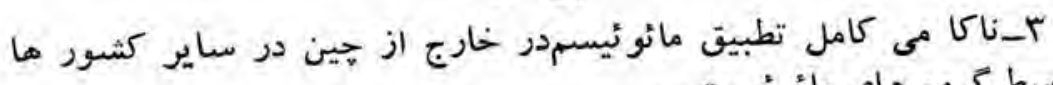

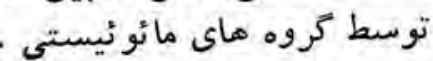

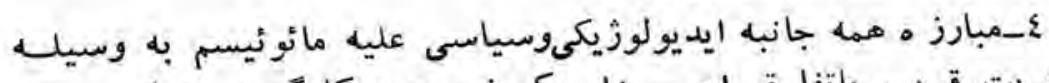

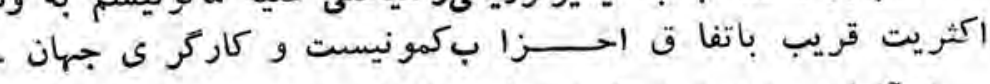

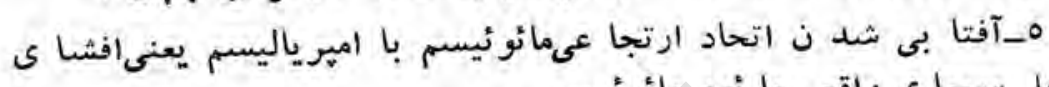
كامل سيما ى واقعى ما نو ندو مائوئيسم.

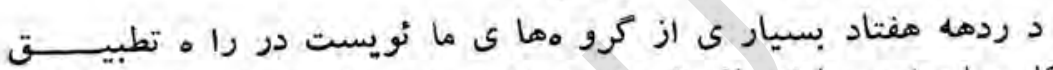

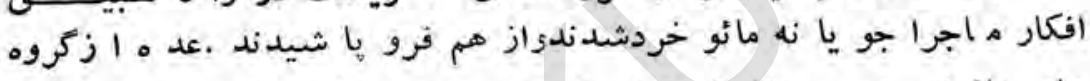

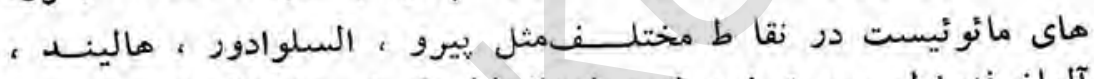

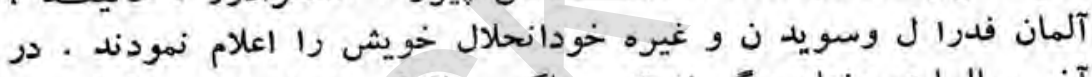

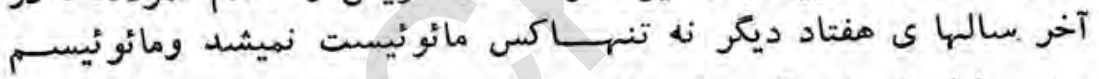

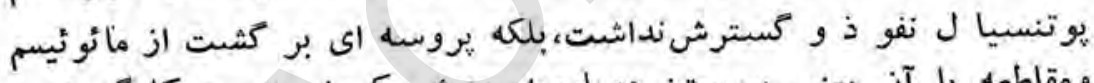

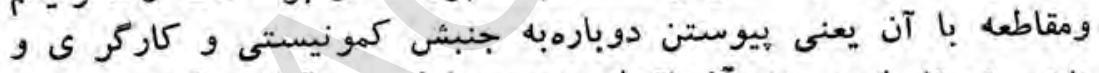

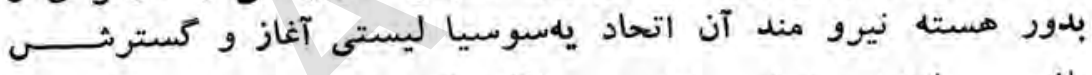

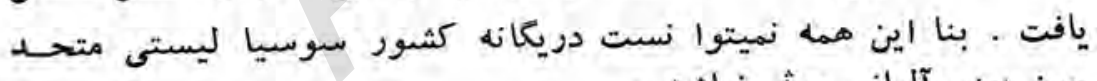

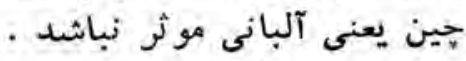

\section{مناز عه جين و آلبانى :}

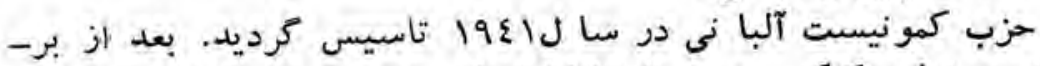

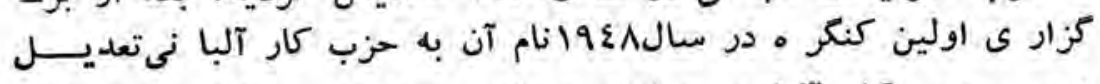

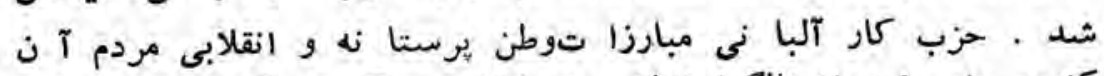

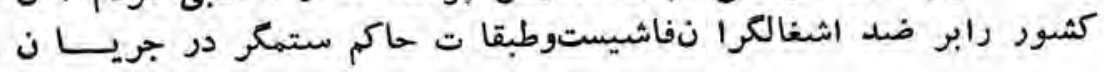


جنك دوم جهانى ر هبرى كرد .درآلبا نيا مانند يوكوسلاو يا ، بلغاريا

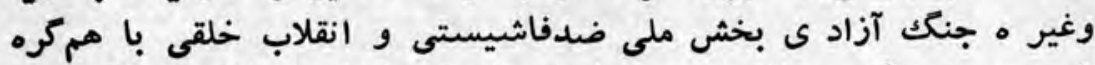

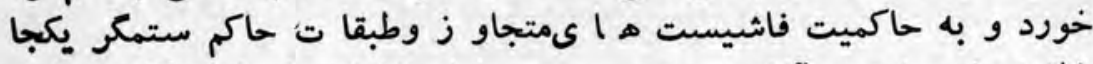

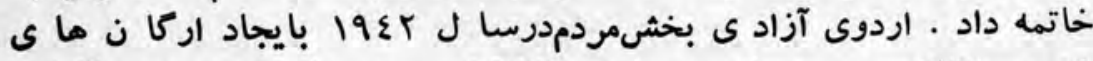

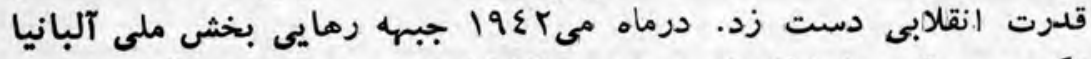

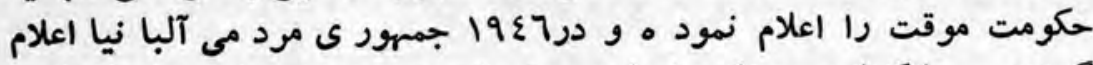

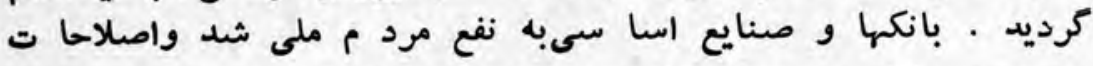

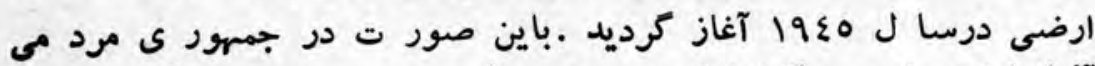

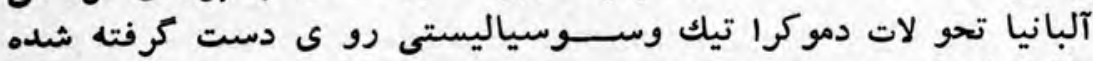

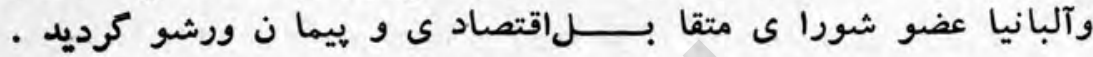

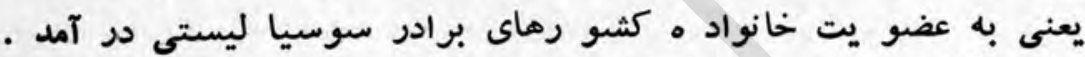

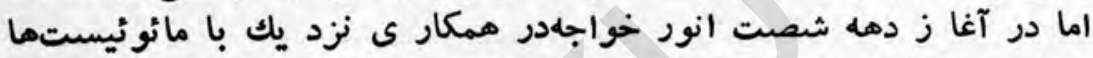

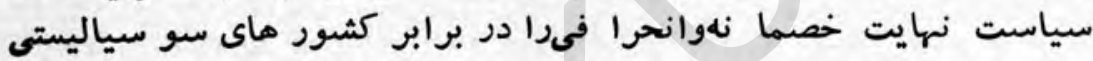

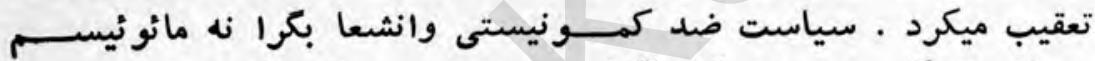

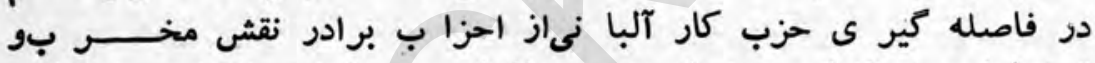

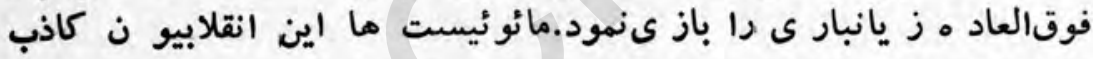

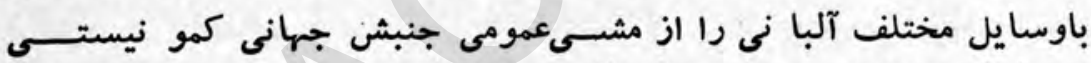

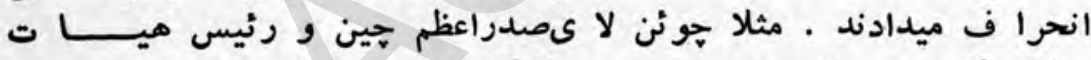

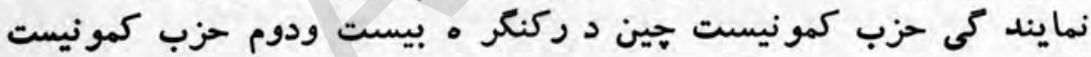

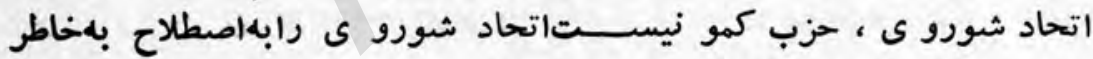

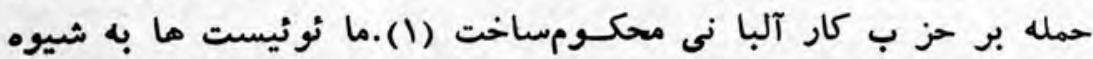

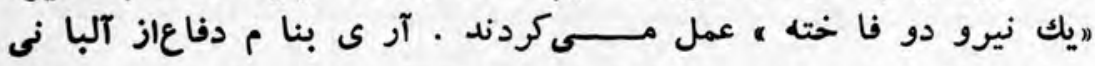

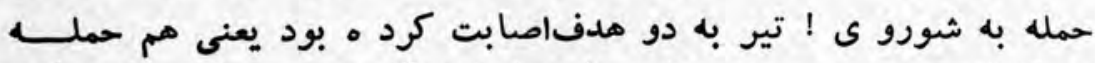

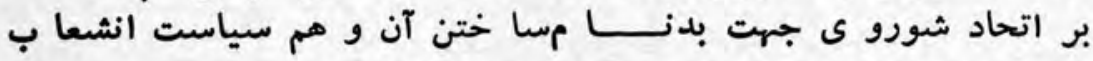

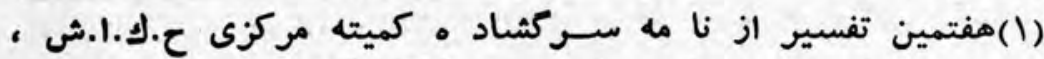

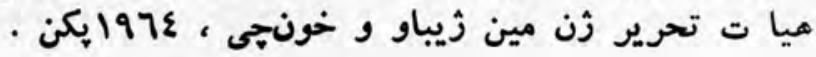




\section{速}

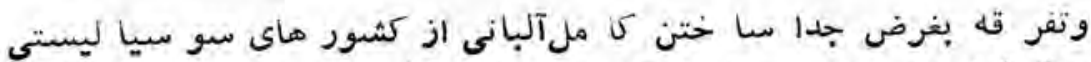

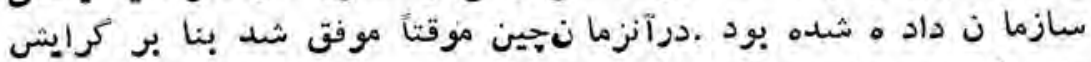

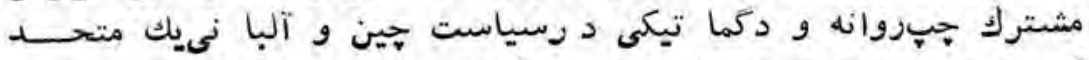

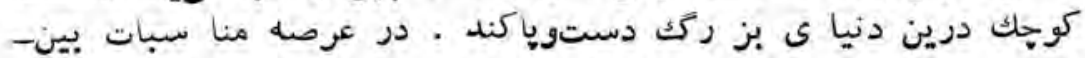

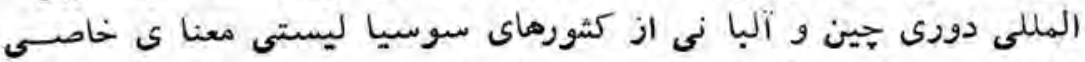

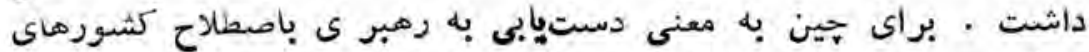

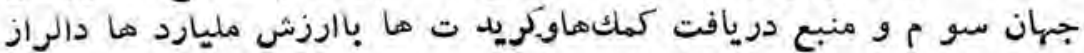

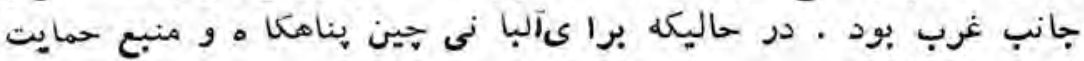

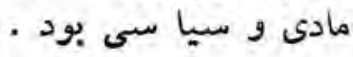

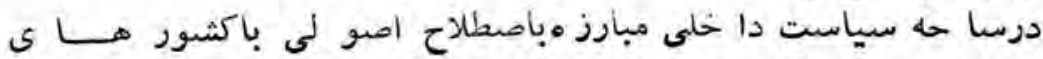

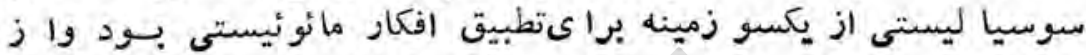

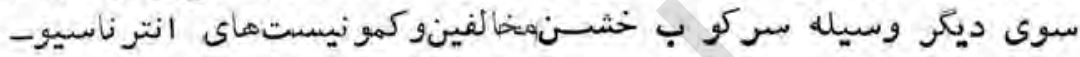

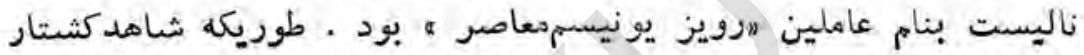

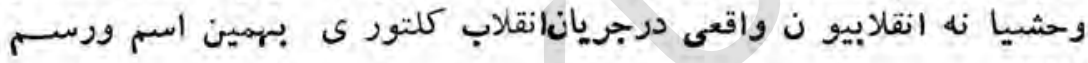

مائو حتى فرد شنا خته شده ضلدشورو مى لين ييائو را به به بهان

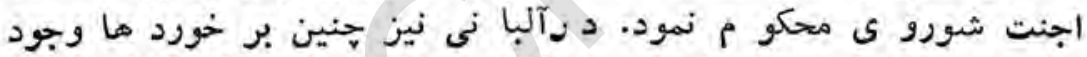

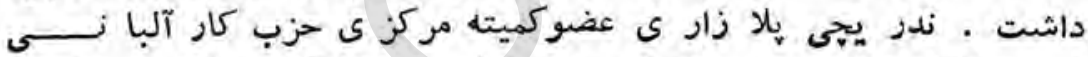

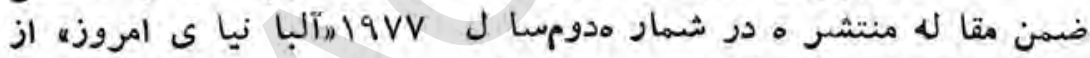

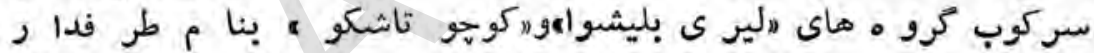

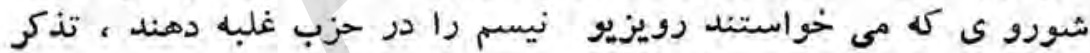

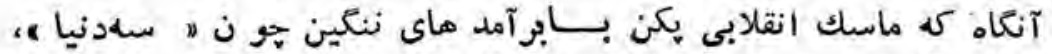

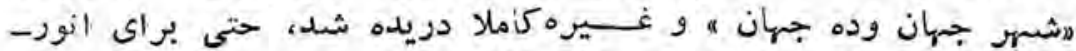

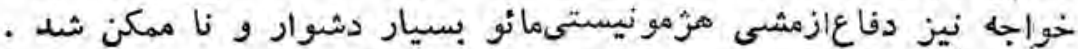

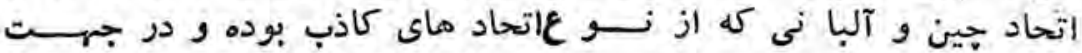

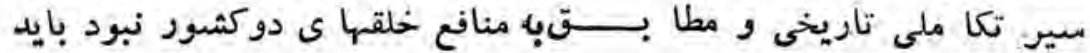
زود يادير از هم ميكست ماريت 


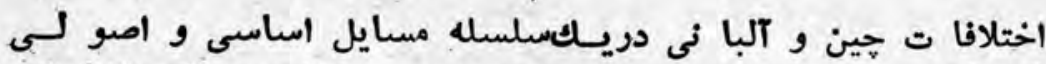

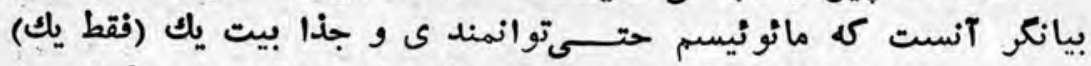

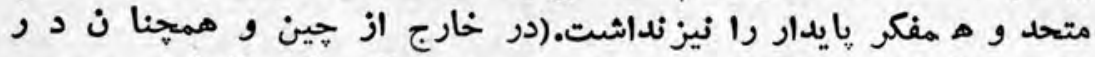

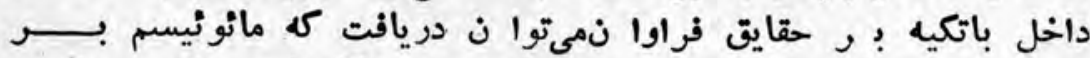

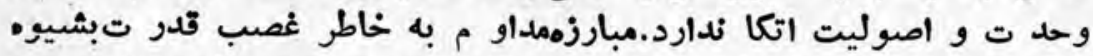

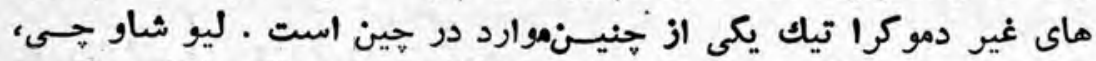

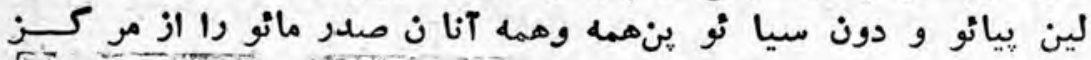

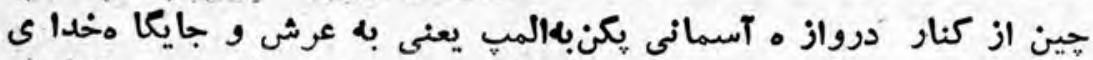

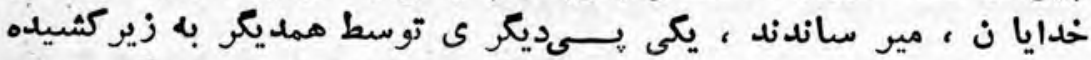

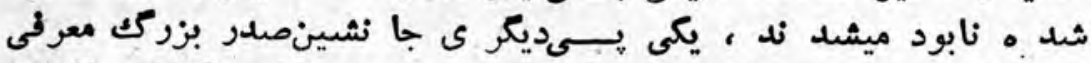

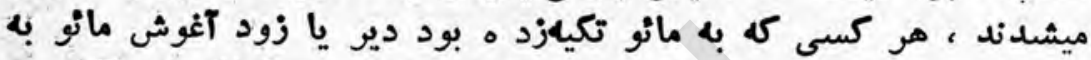

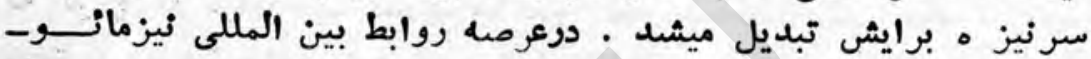

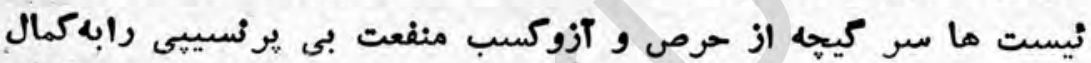

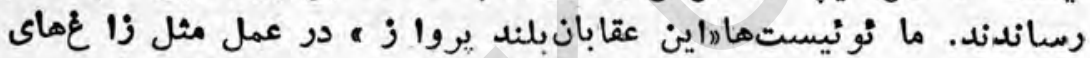

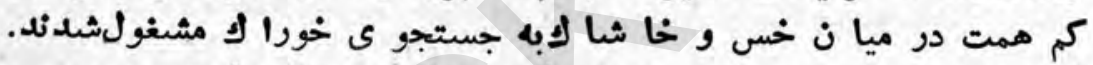

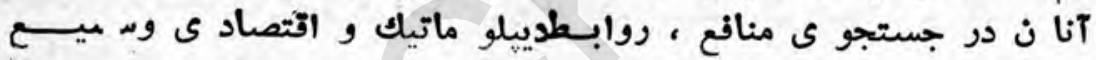

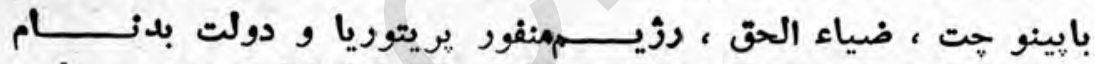

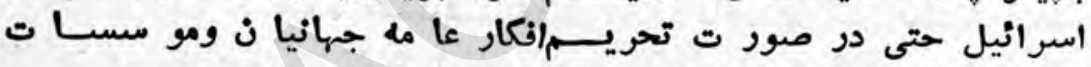

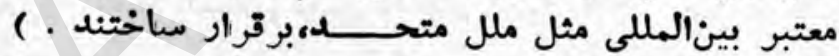

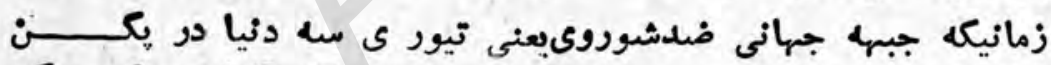

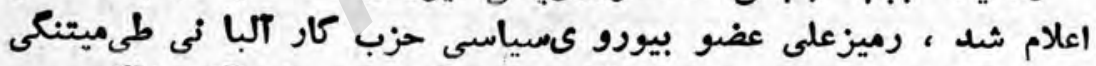

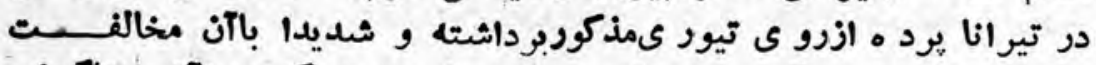

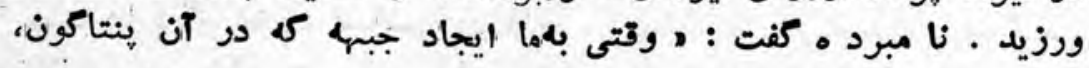

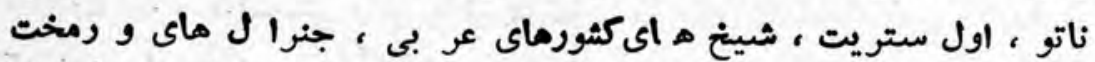

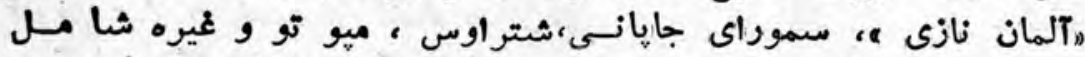

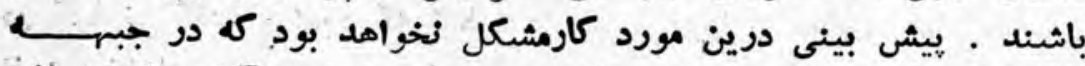

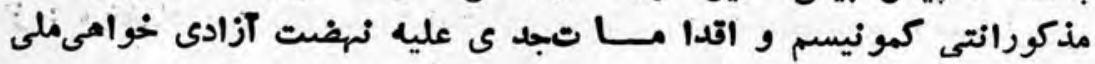

-rql 


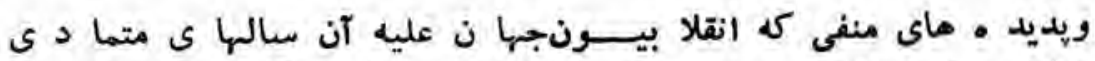

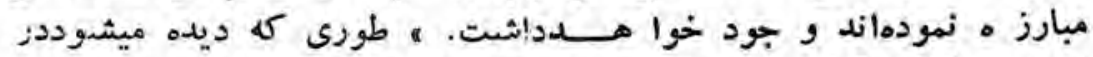

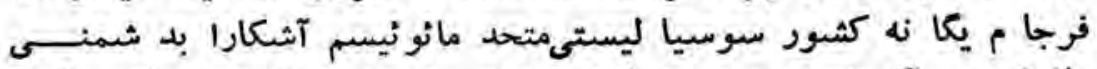

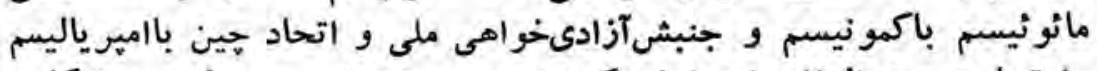

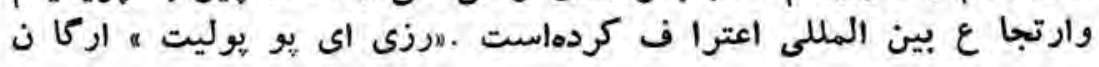

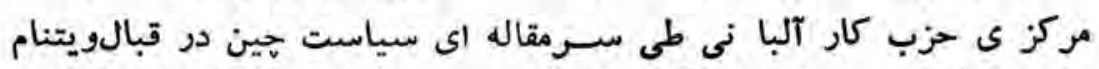

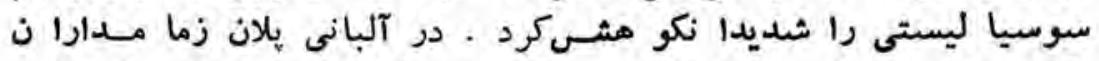

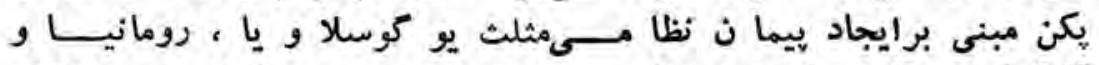

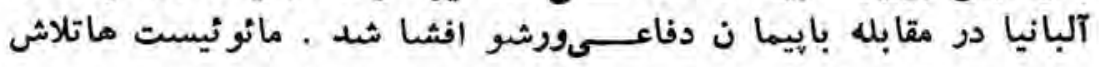

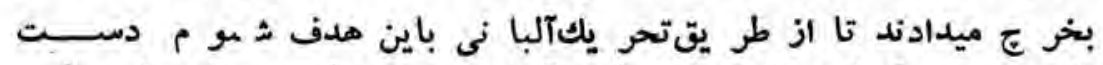

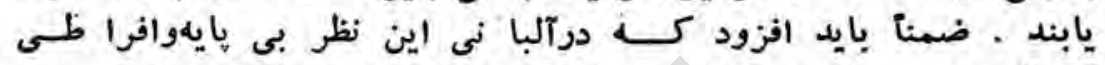

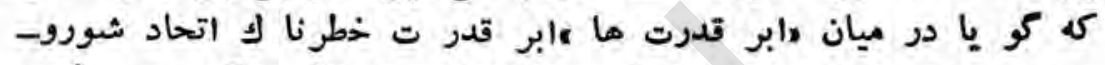

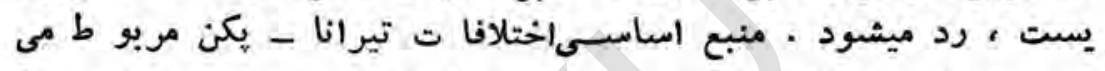

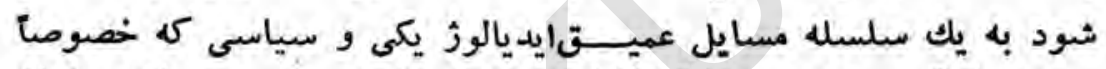

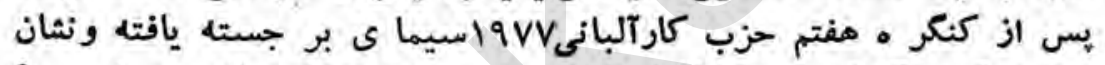

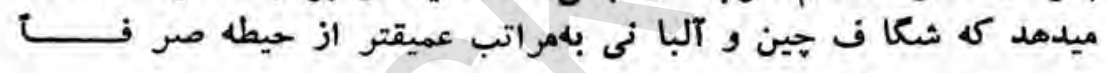

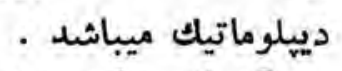

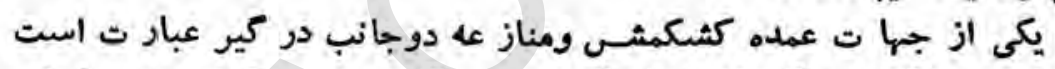

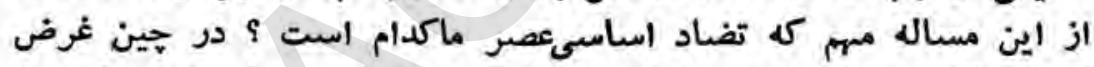

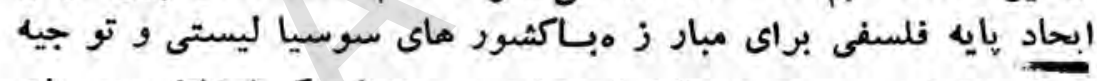

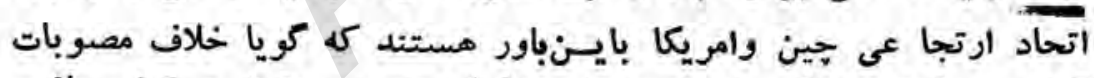

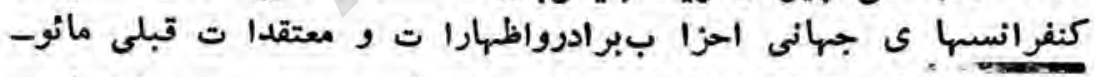

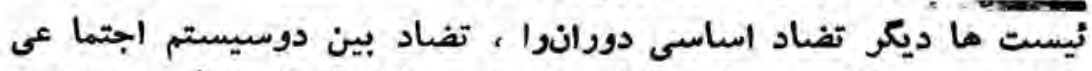

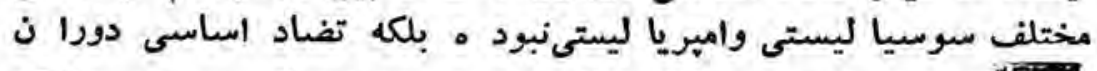

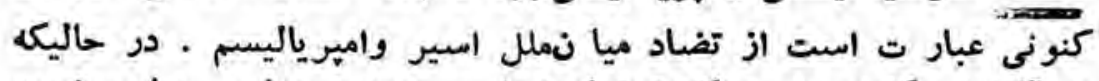

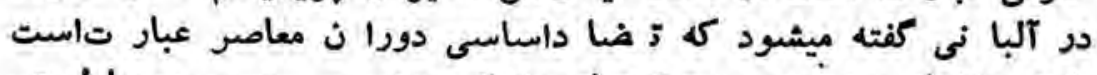

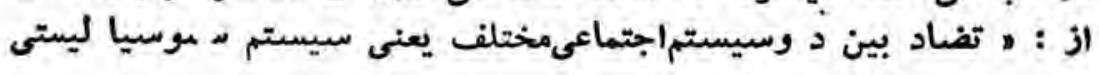


وسيستم سر مايدار ى · ه(1) جهتديكر اختلاف اساسى تيوريكومنازعه

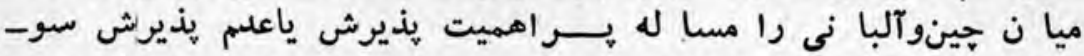

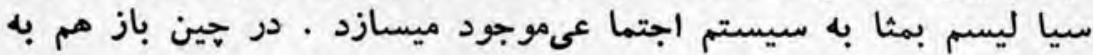

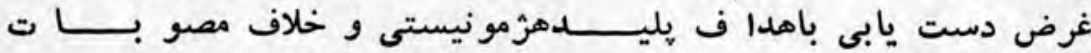

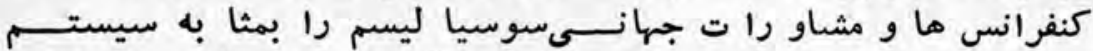

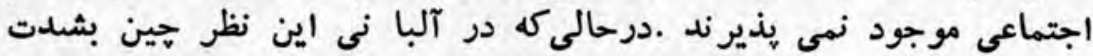

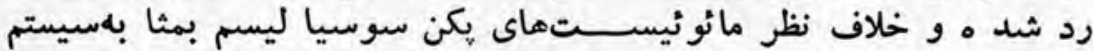

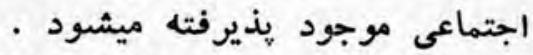

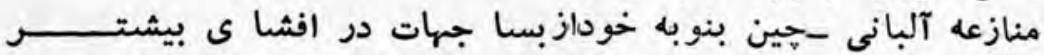

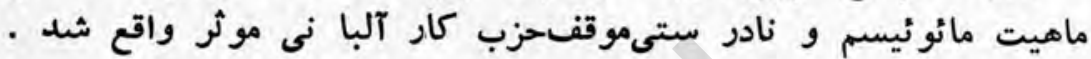

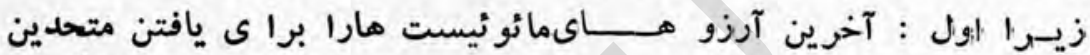

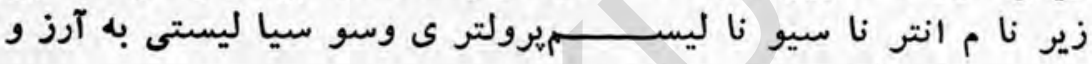

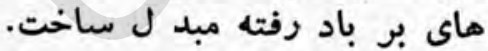

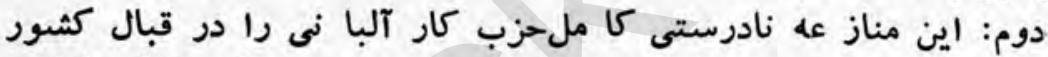

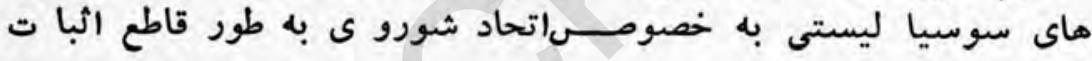

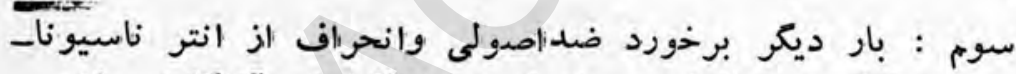

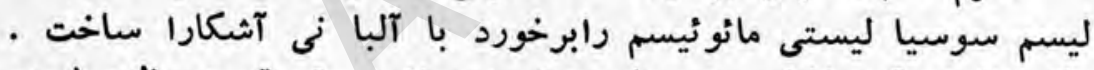

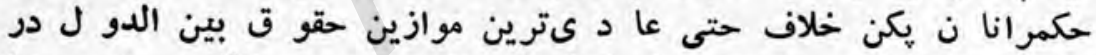

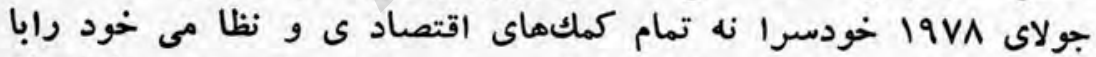

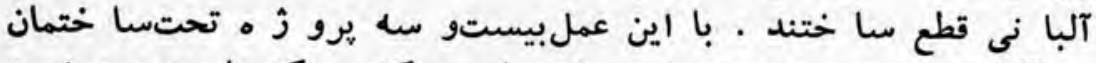

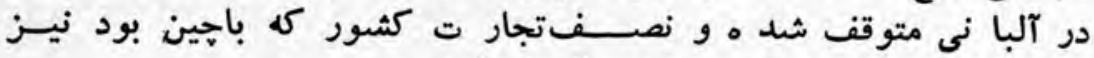

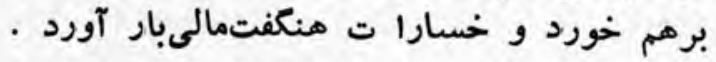

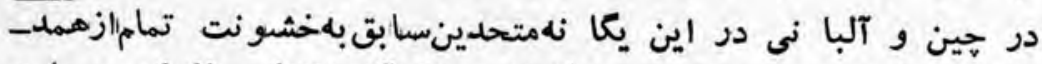

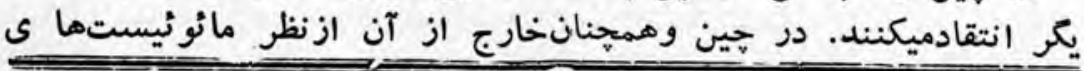

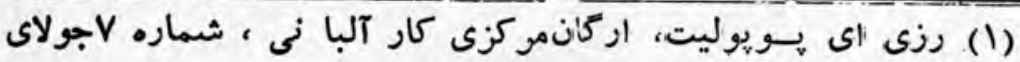




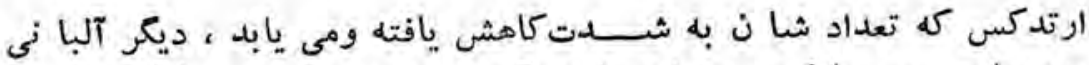

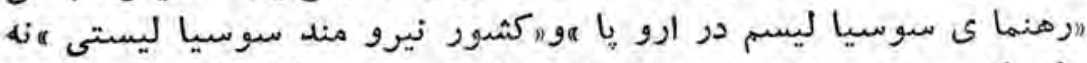

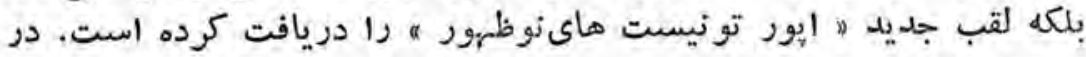

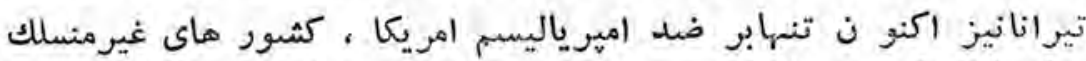

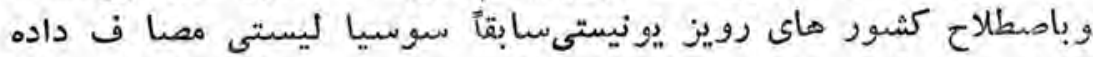

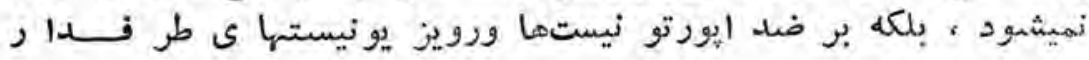

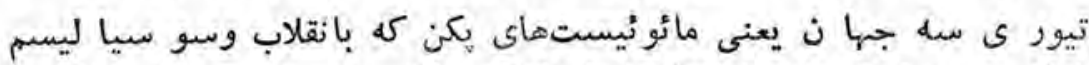

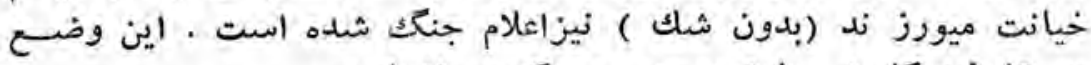

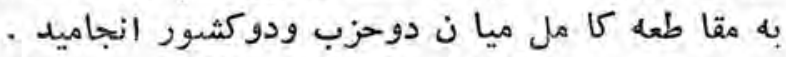

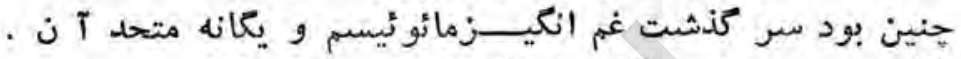

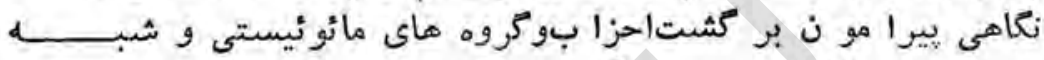

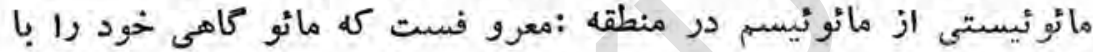

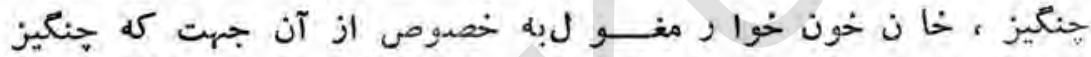

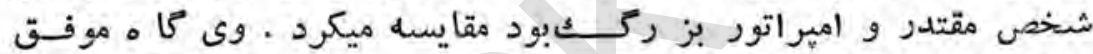

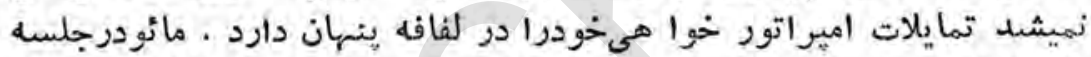

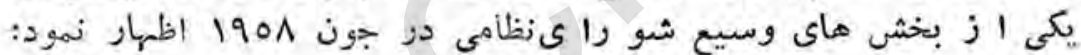

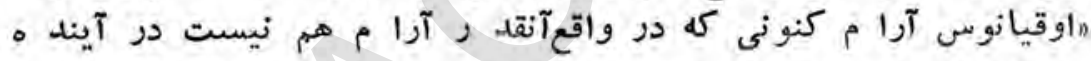

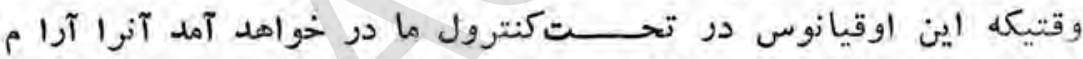

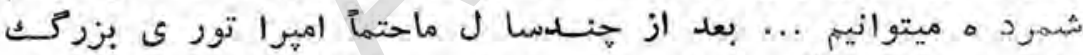

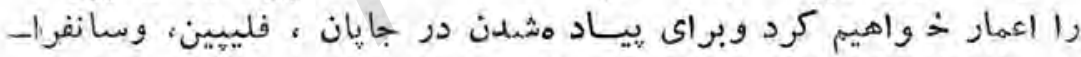

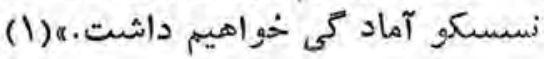

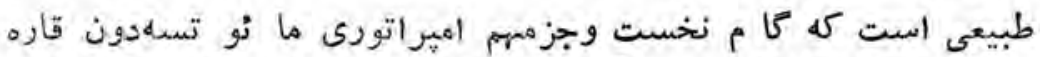

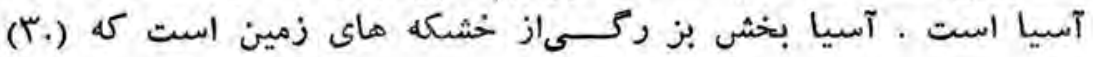

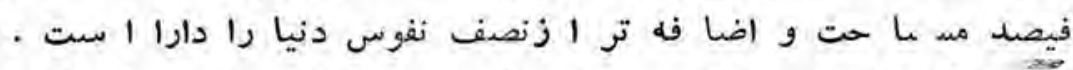

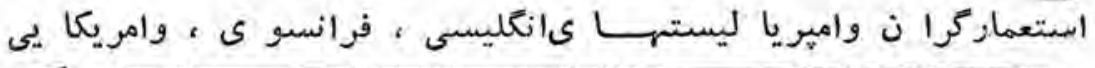

$$
\text { .19VV يراودا، }
$$




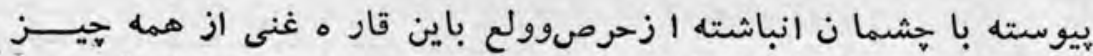

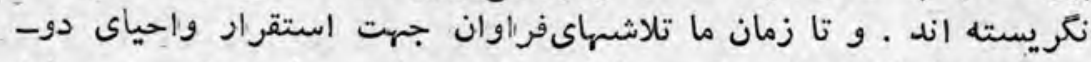

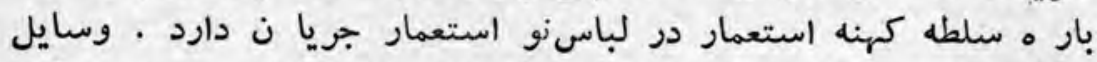

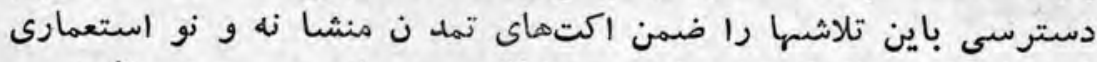

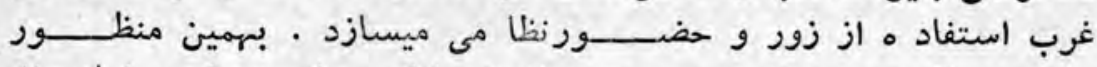

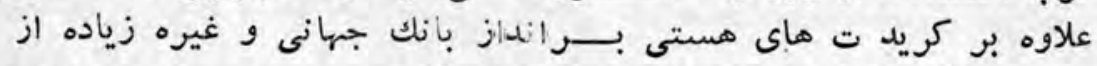

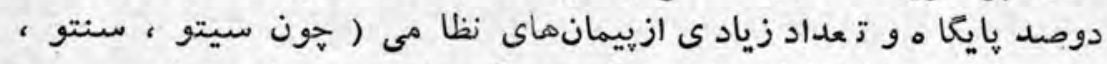

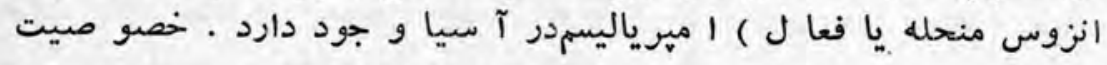

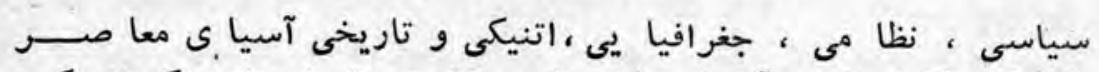

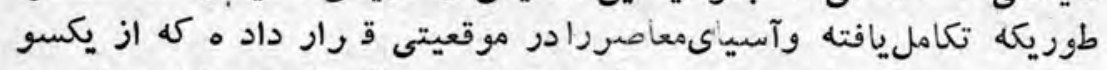

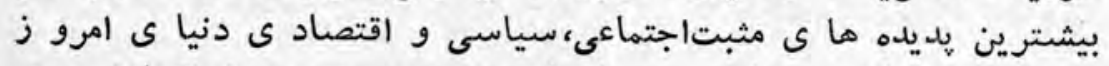

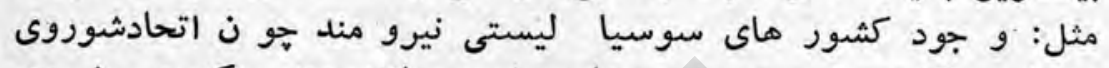

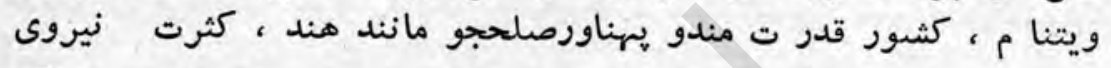

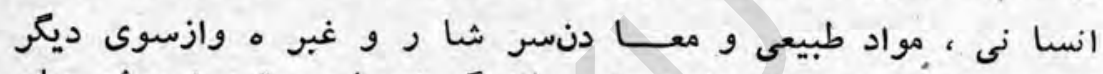

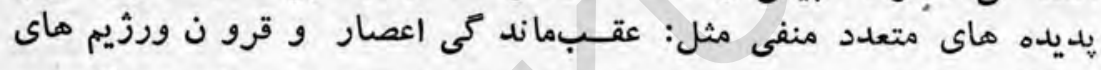

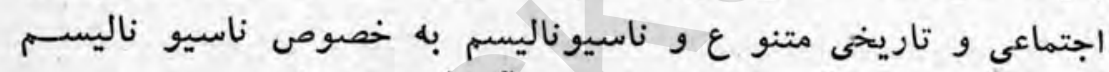

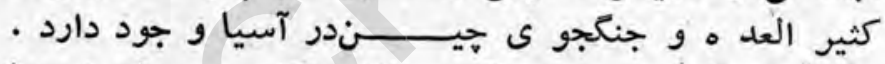

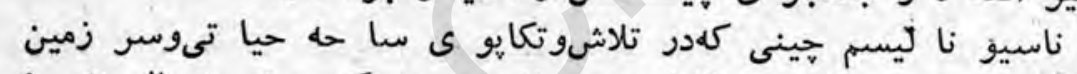

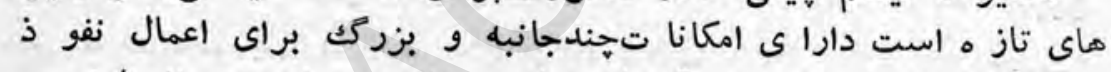

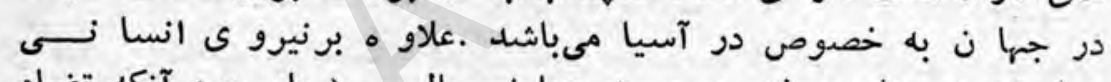

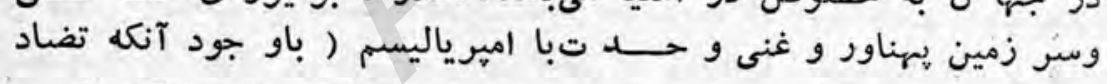

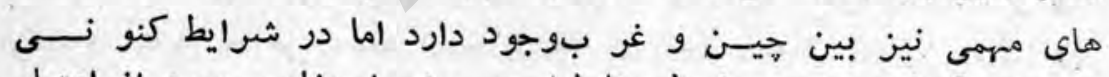

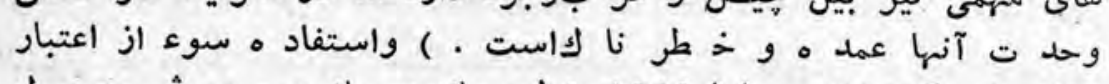

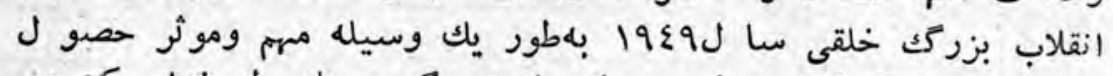

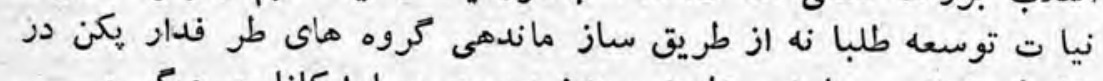

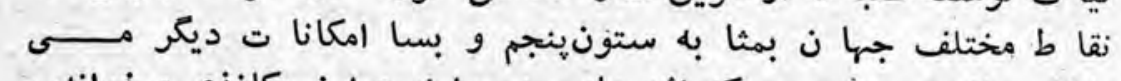

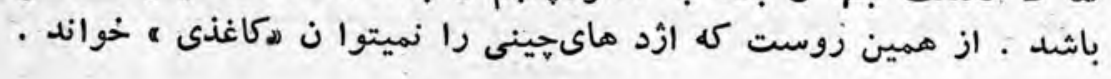




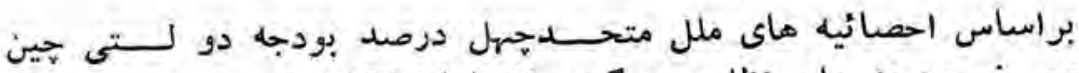

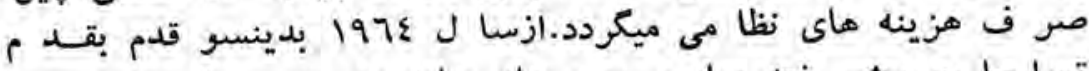

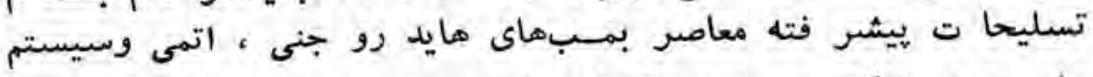

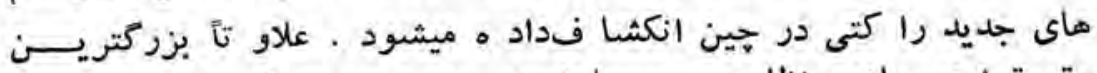

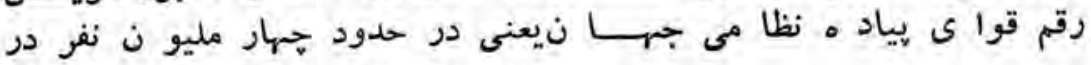

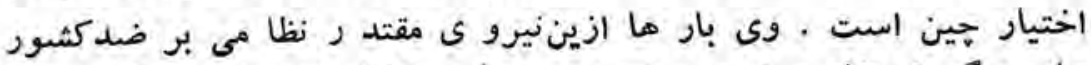

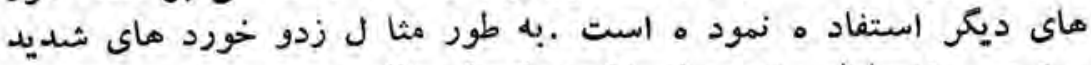

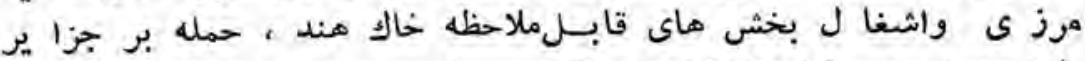

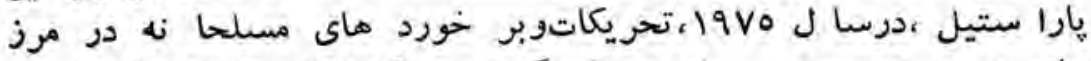

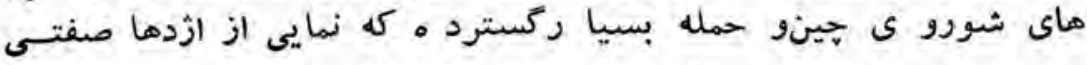

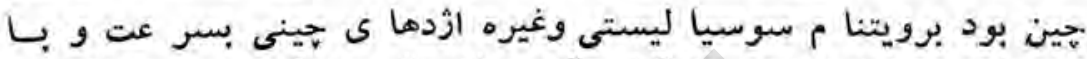

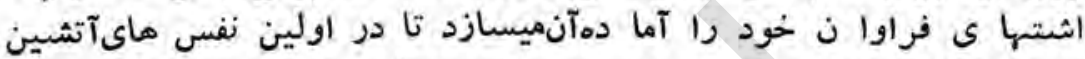

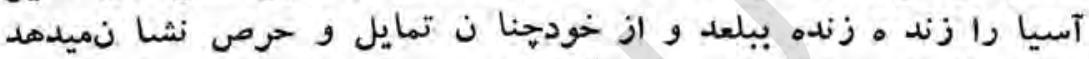

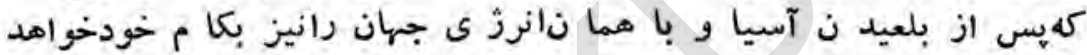

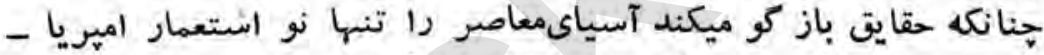

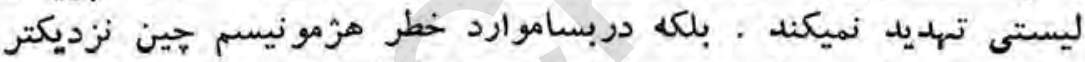

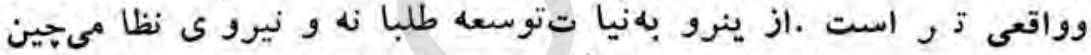

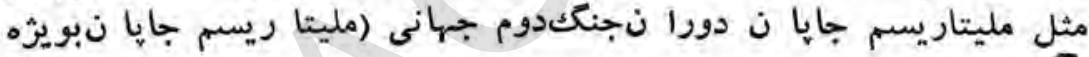

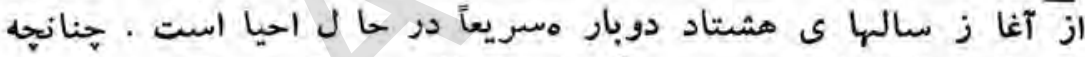

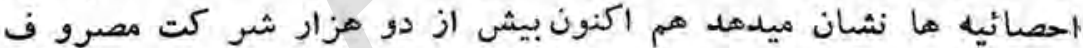

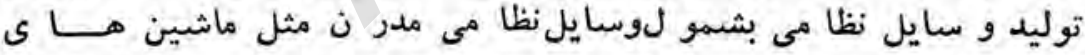

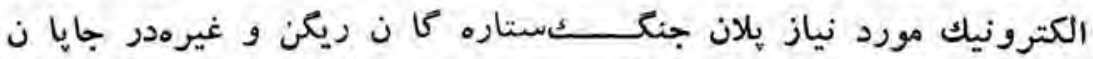

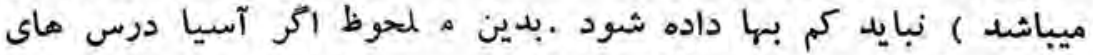

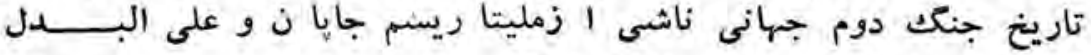

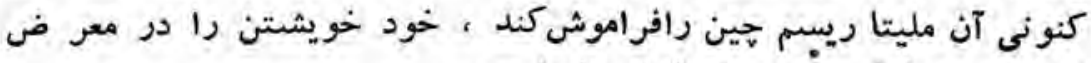

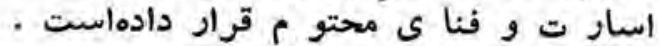




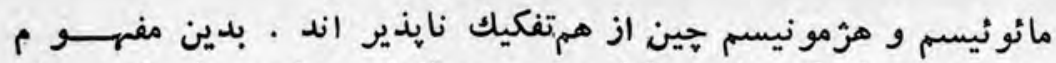

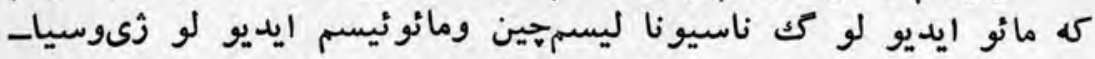

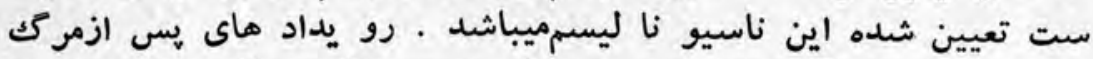

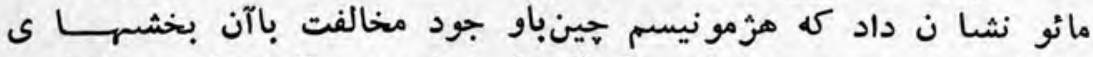

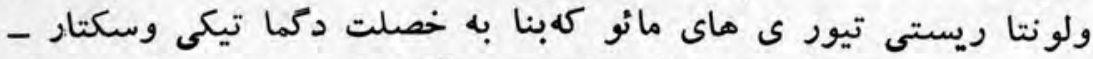

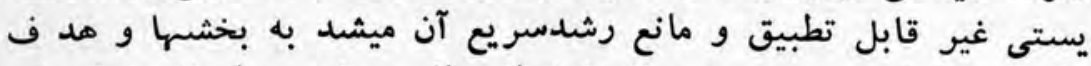

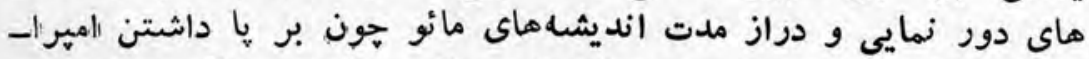

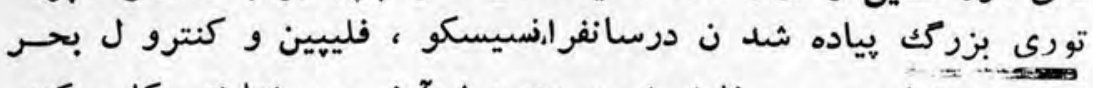

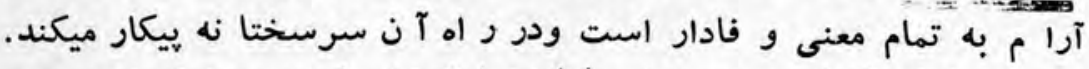

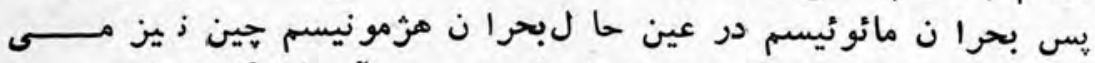

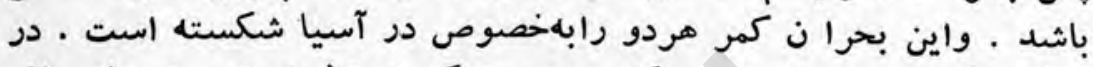

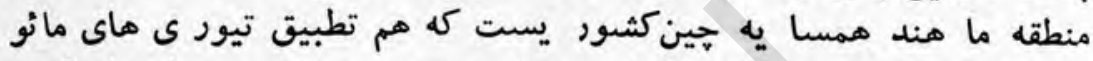

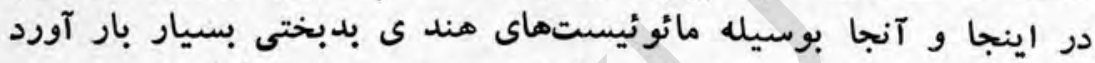

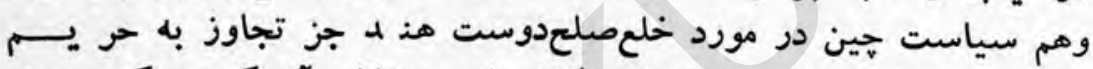

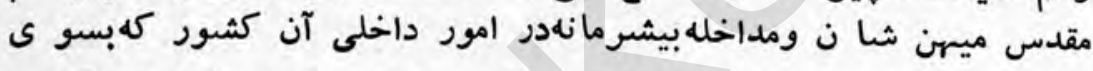

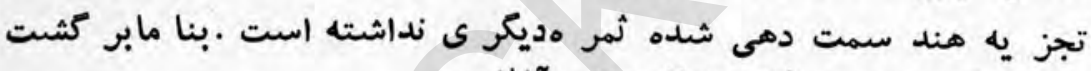

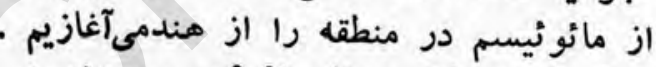

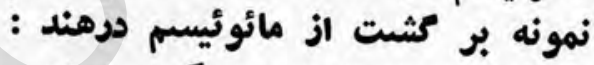

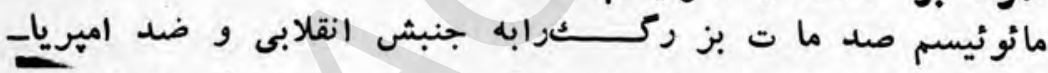

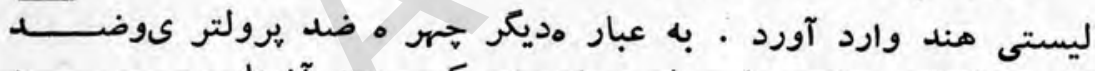

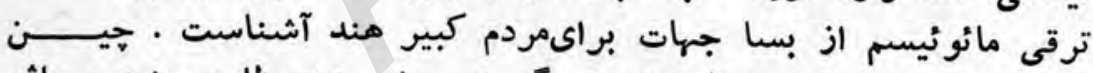

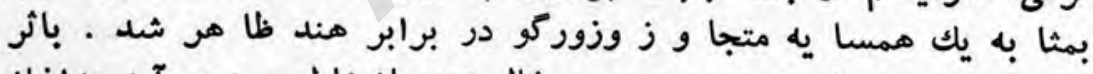

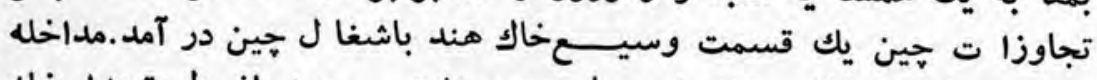

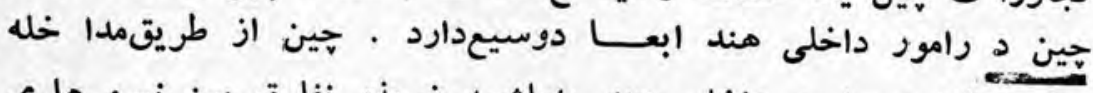

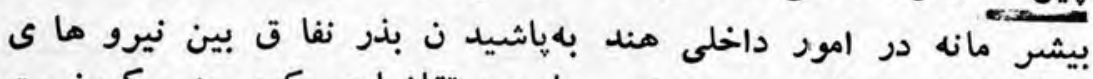

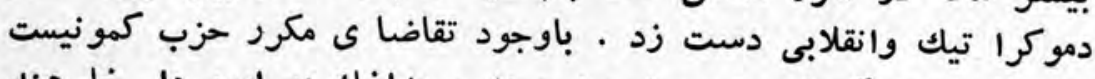

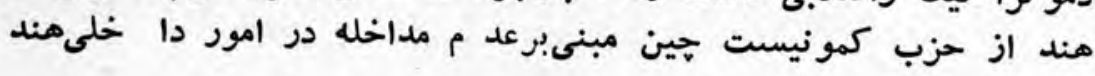




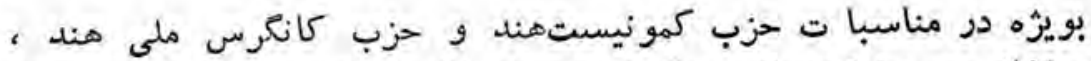

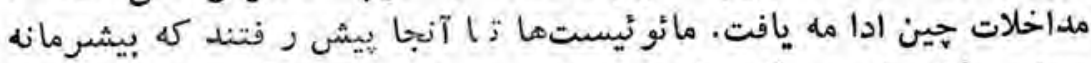

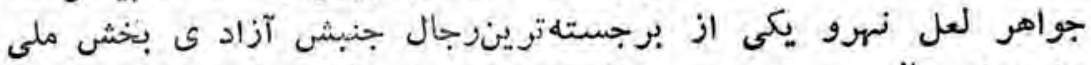

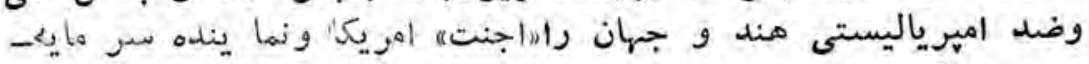

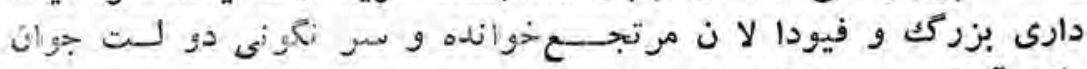

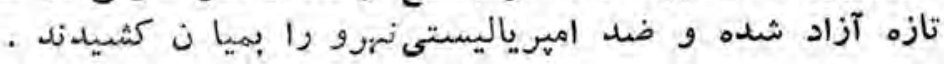

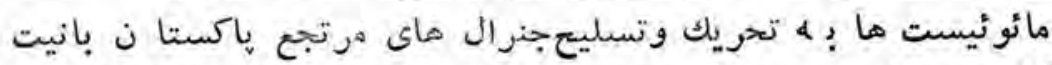

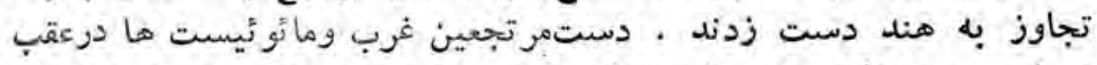

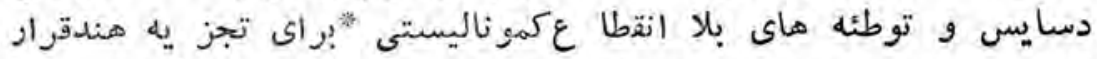

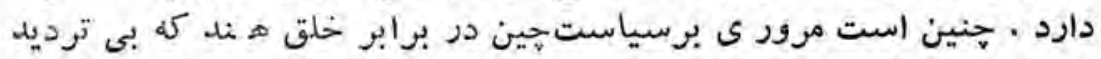

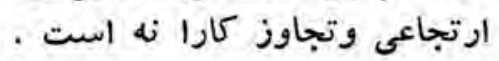

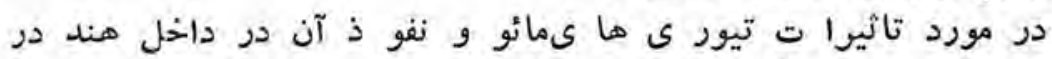

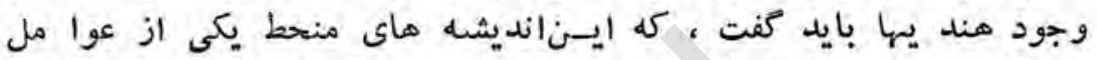

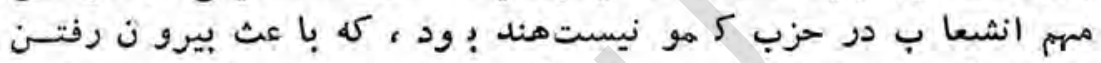

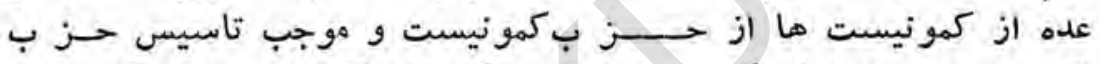

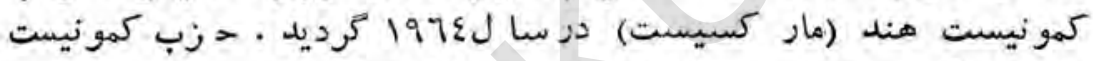

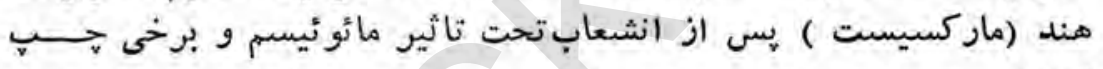

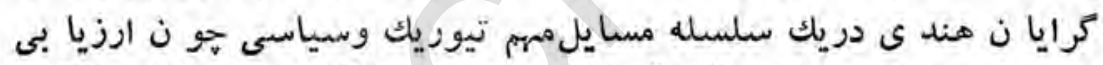

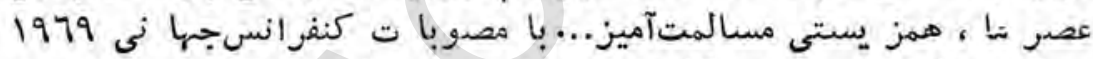

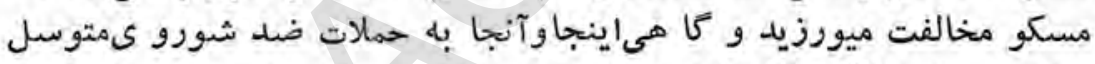

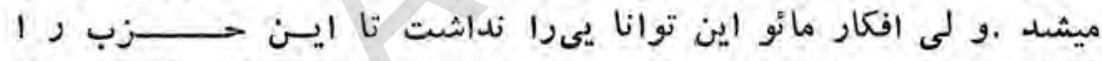

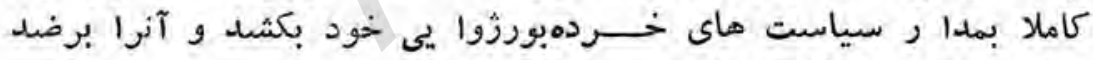
منافع مند استعمال نمايد ريد ريل

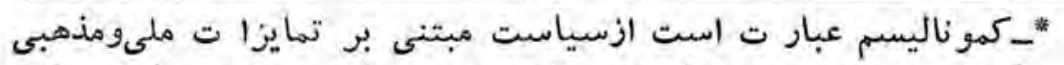

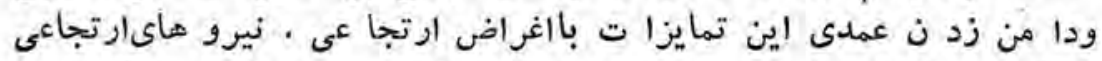

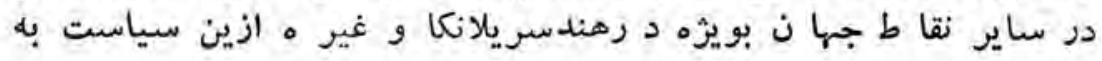

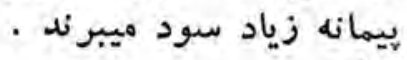




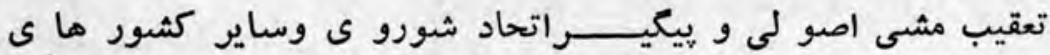

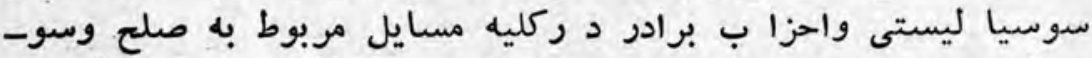

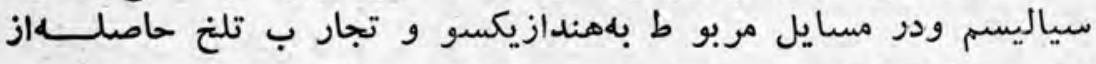

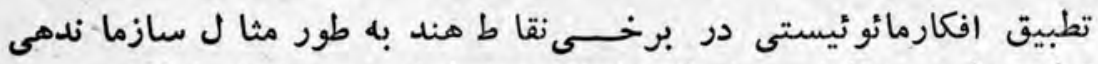

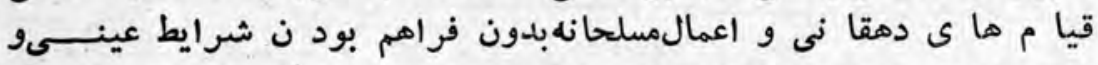

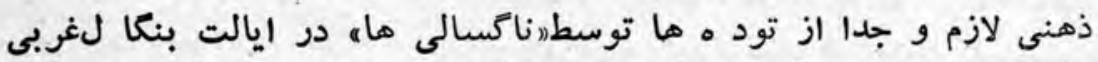

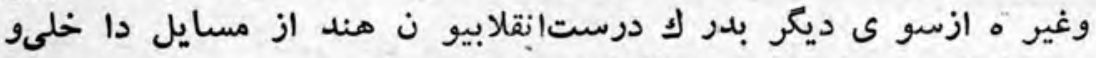

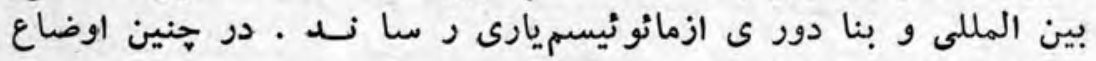

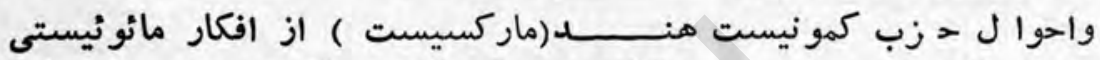

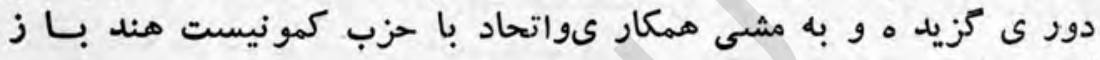
كشت كور كز

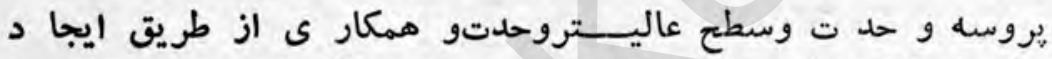

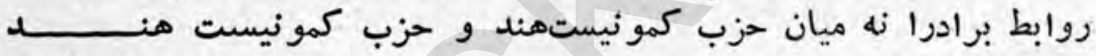

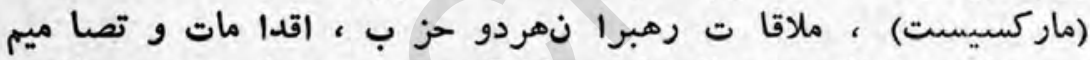

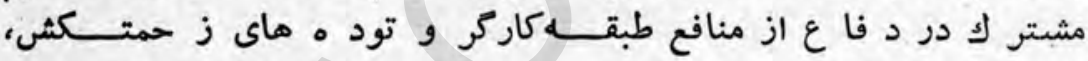

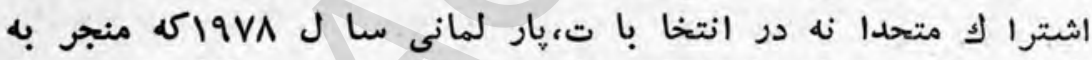

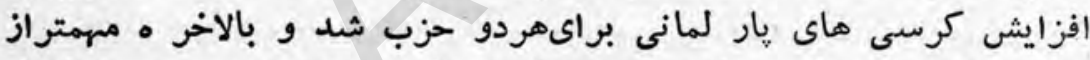

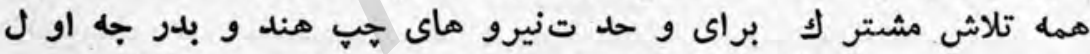

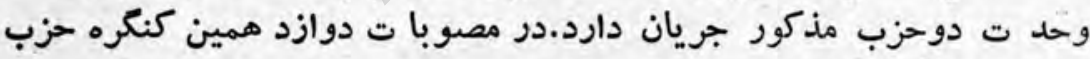

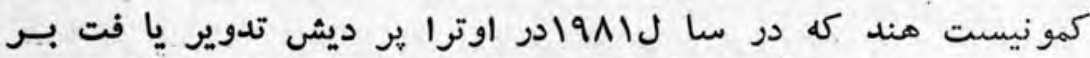

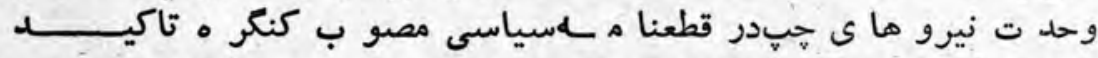

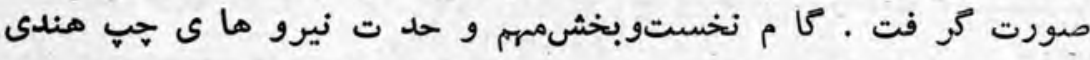

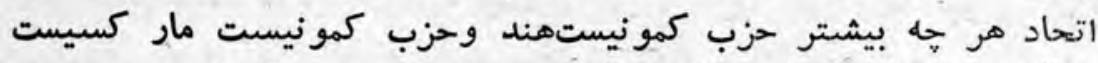

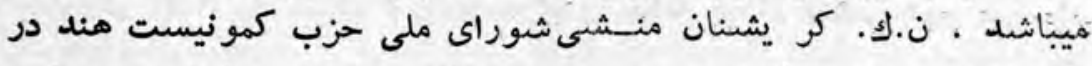

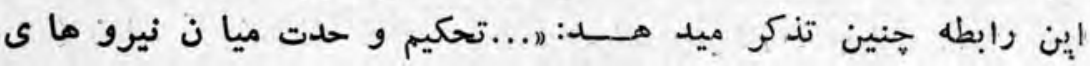

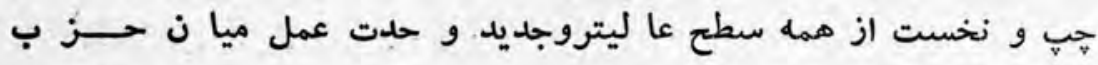




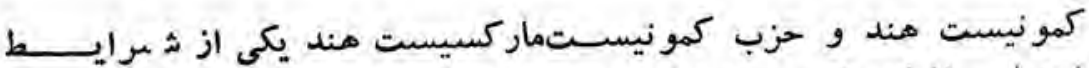

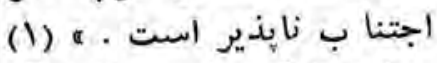

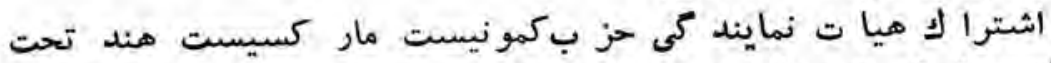

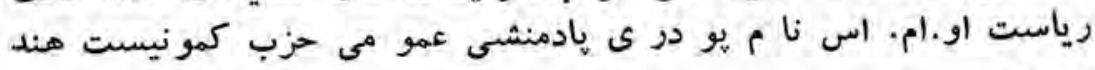

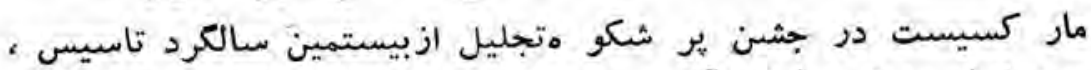

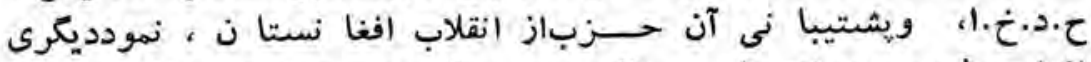

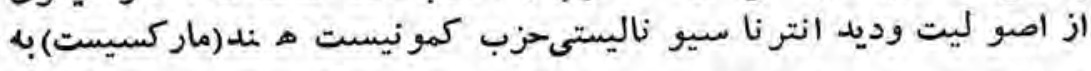

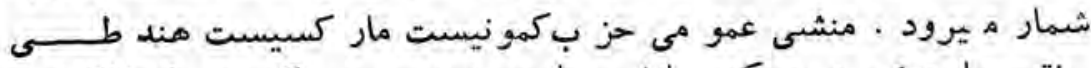

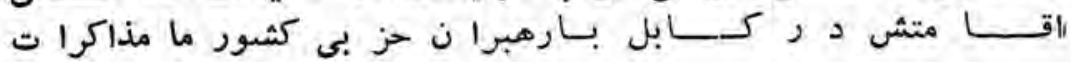

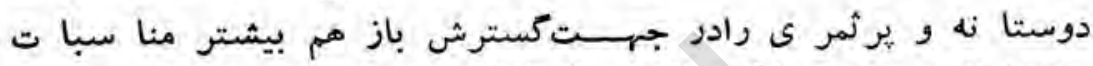

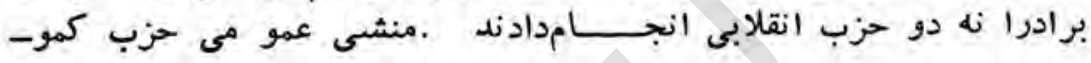

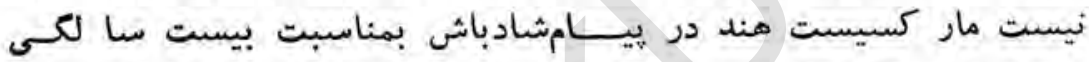

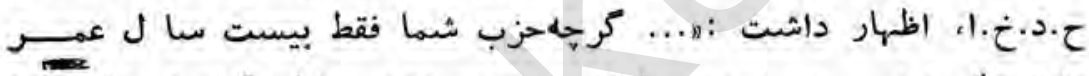

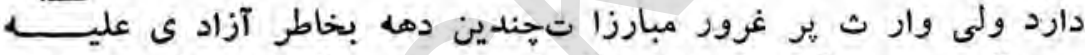

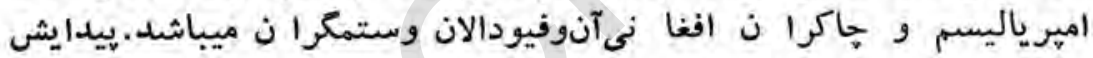

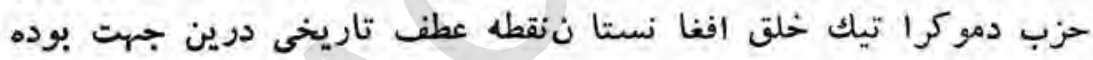

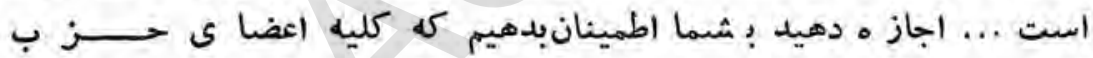

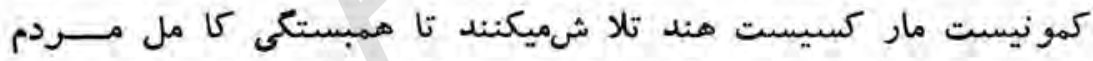

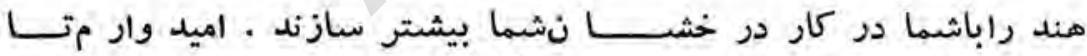

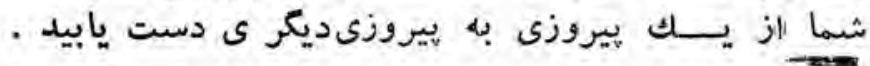

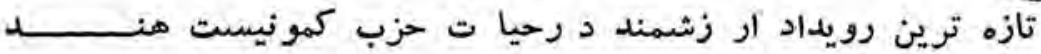

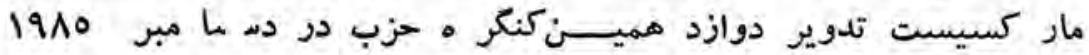
يعنى در آستا نه سا ل جديدعيسوىدر كلكته بود . منشى عمو مى حزب (1) ن.ك. كريشنان، مقاله " برناهلتحولات بنيادى ه جولاى זيو امجله

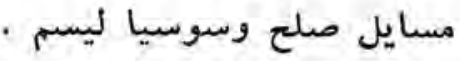




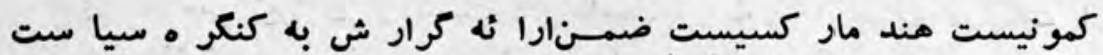

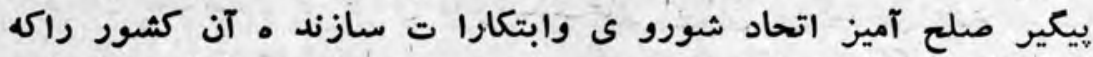

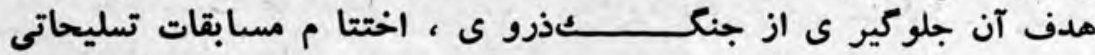

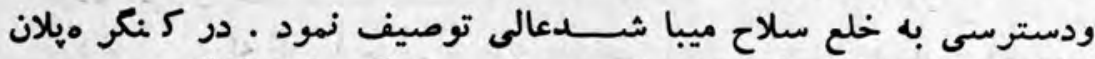

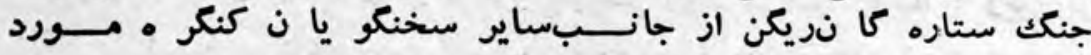

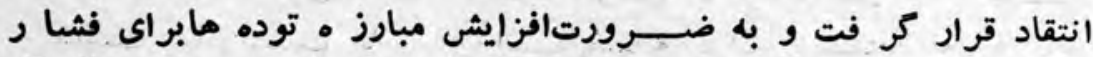

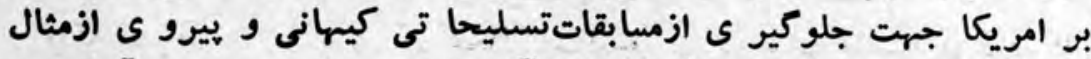

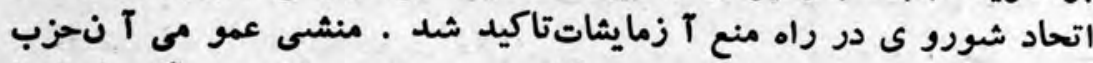

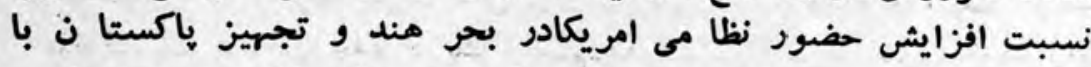

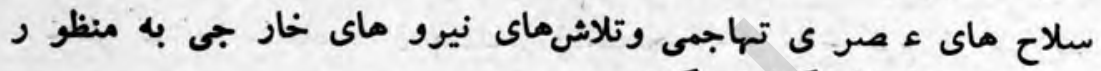

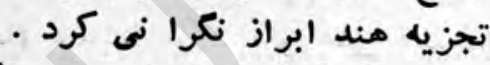

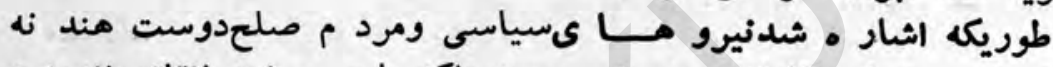

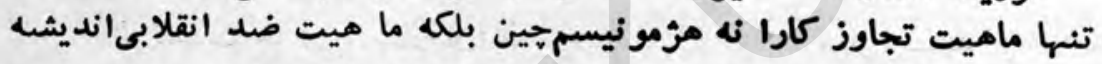

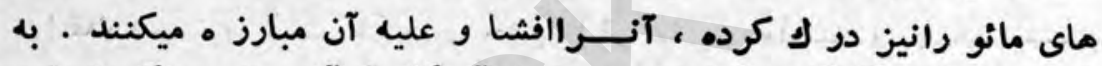

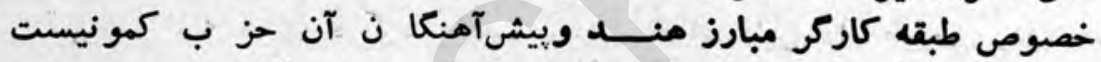

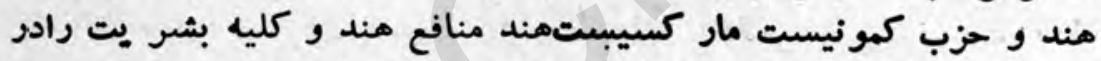

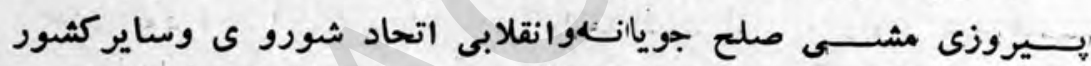

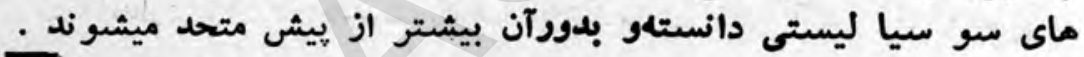

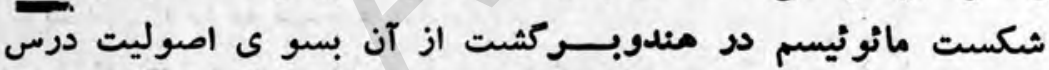

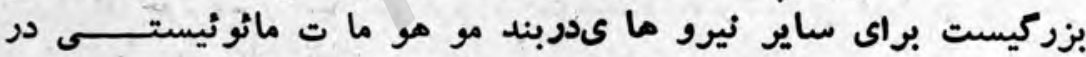
منطقه . مزوكيست

\section{نمو نه از شكست ماتوتيسم د دايرا ن):}

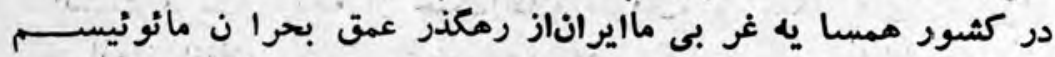

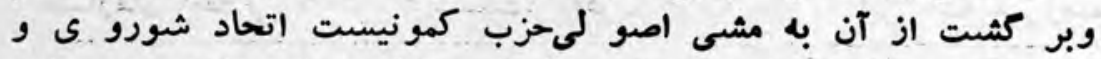

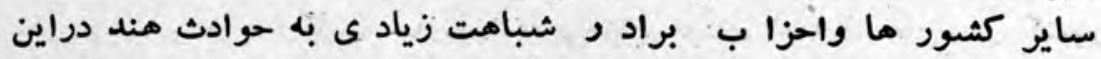

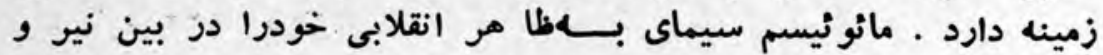




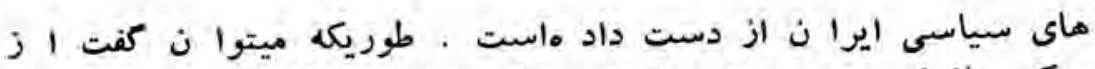

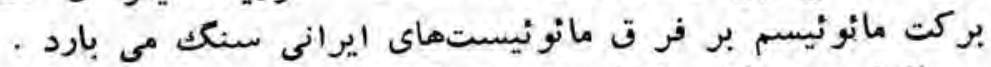

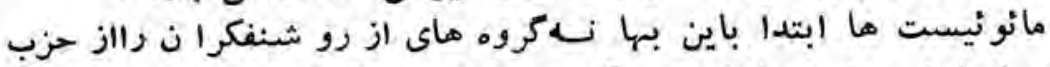

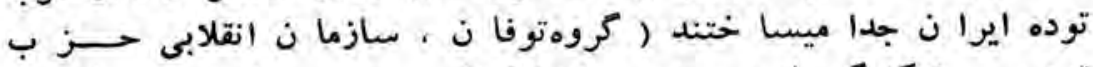

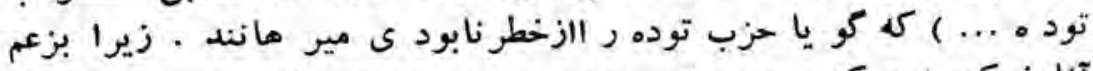

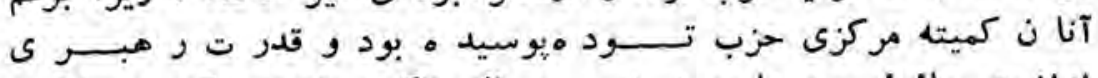

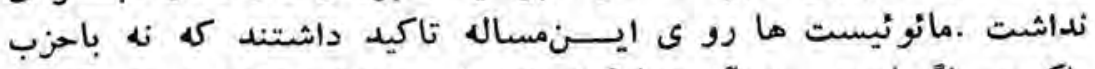

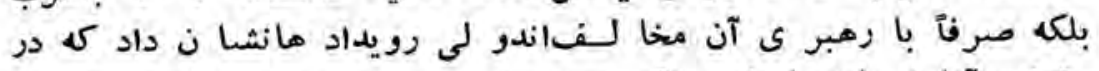

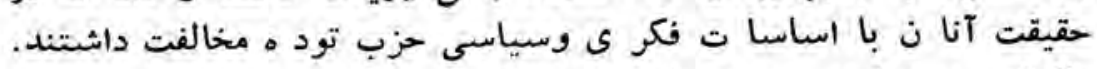

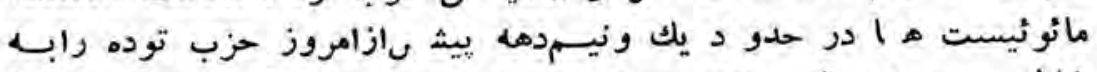

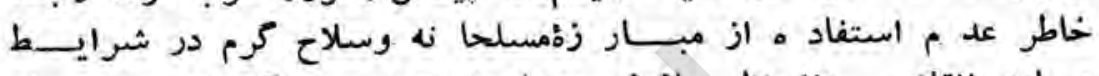

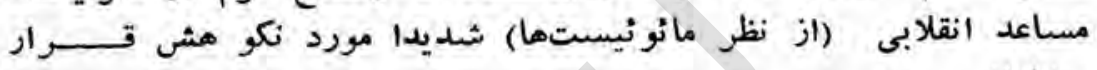
ميدادند . مياعد النمان

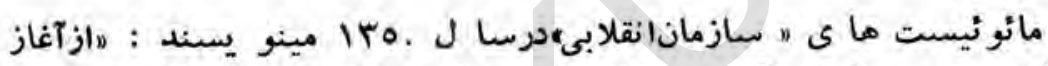

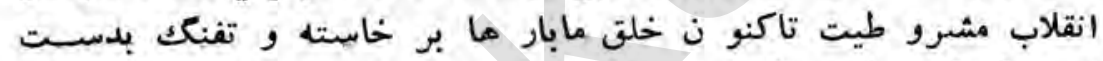

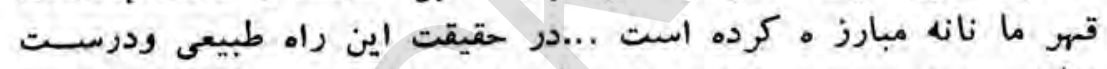

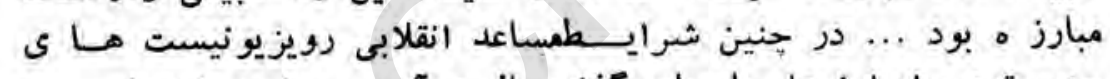

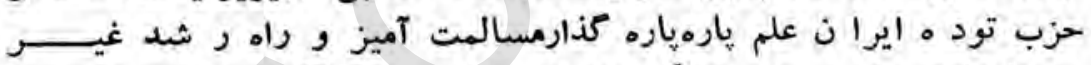

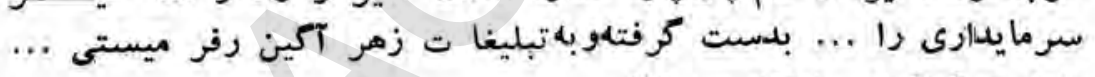

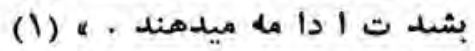

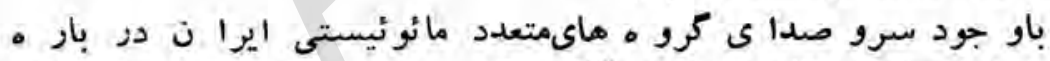

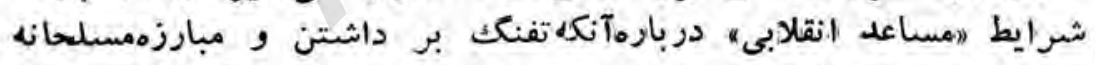

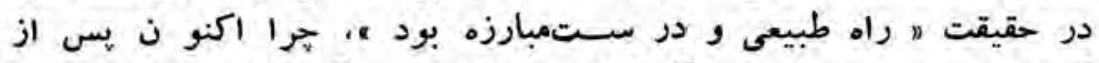

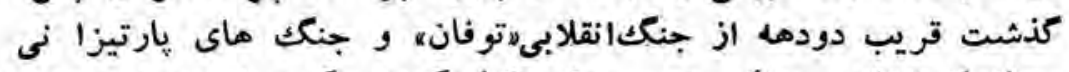

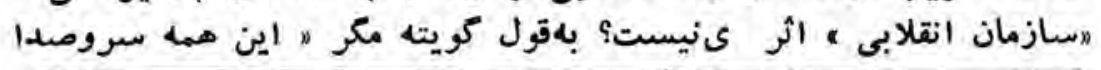

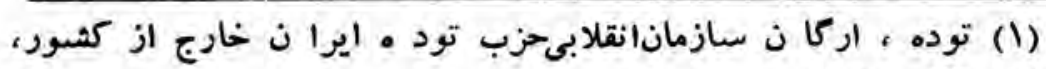

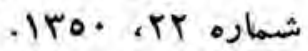




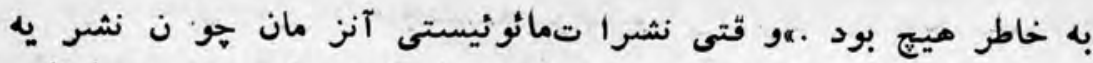

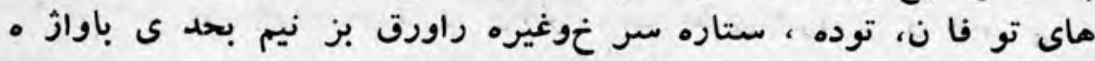

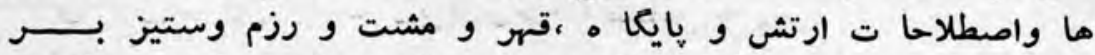

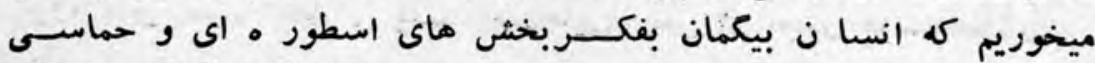

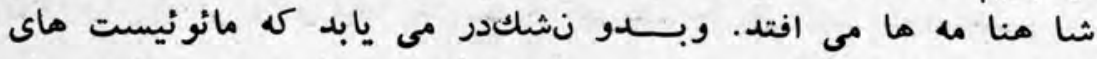

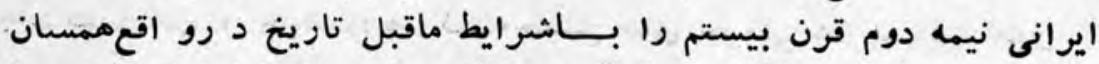

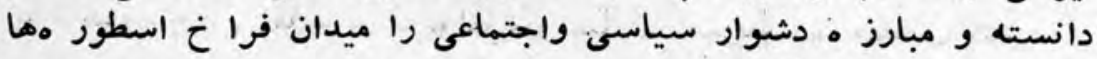

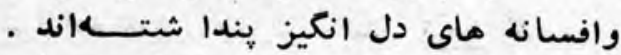

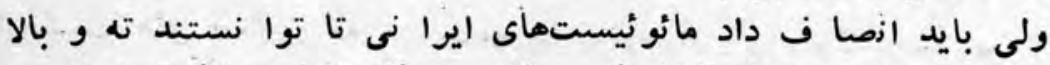

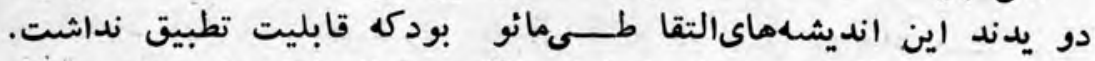

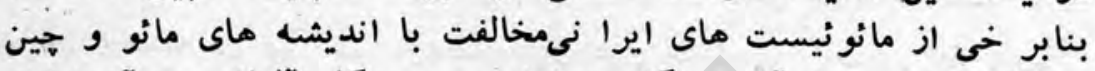

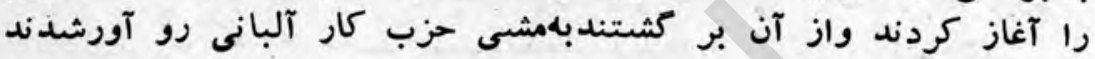

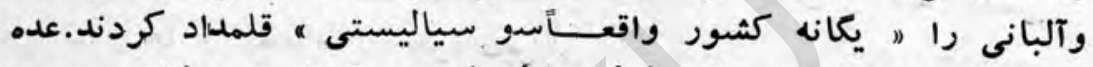

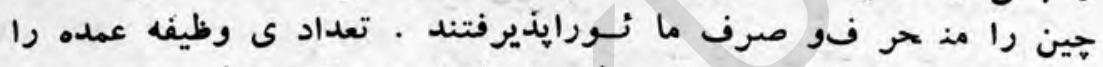

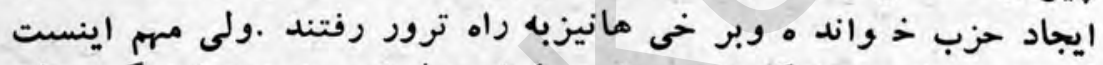

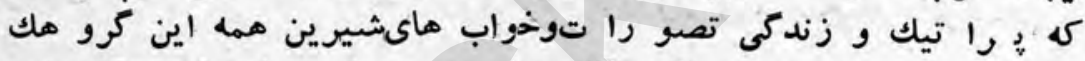

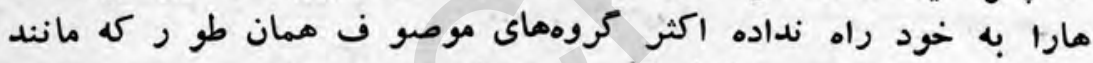

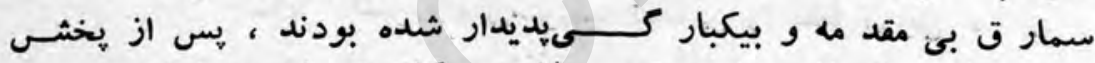

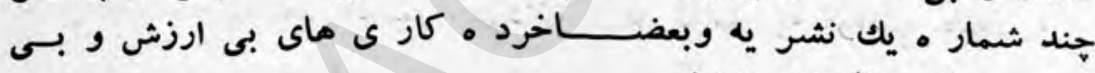

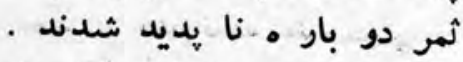

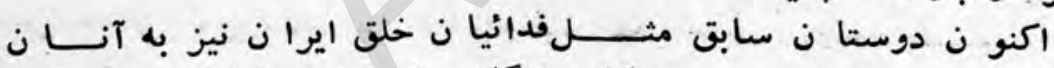

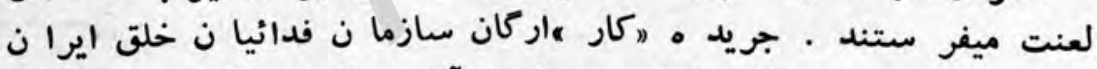

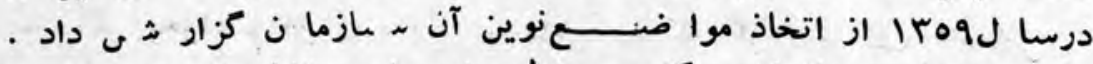

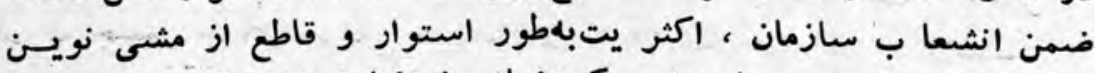

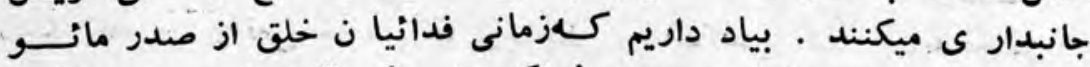

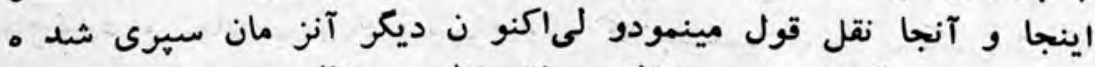

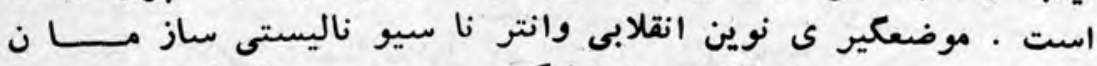

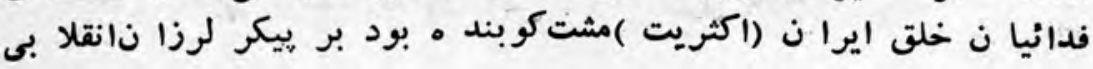




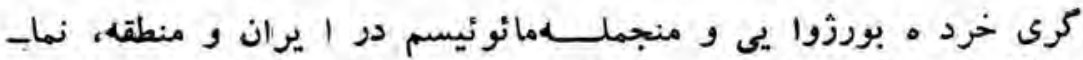

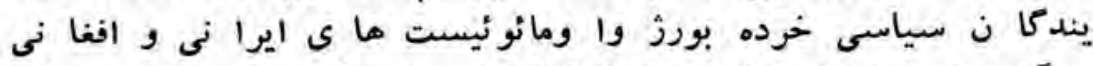

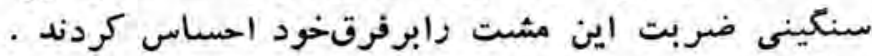

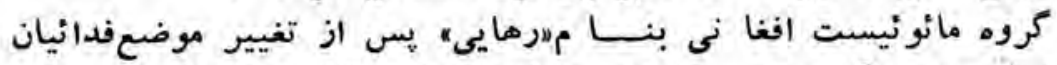

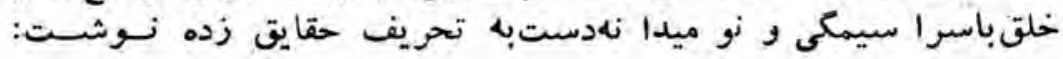

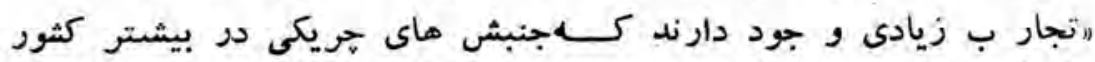

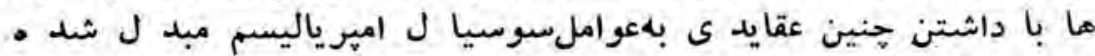

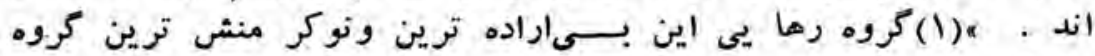

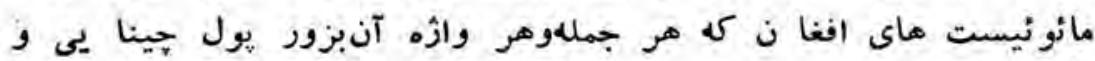

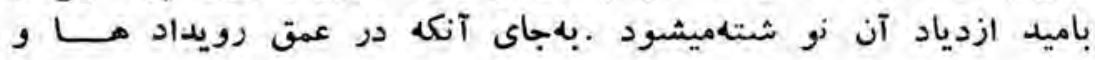

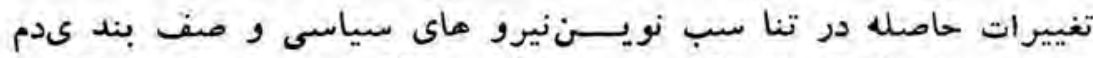

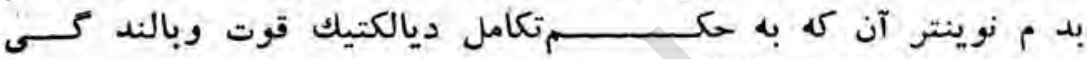

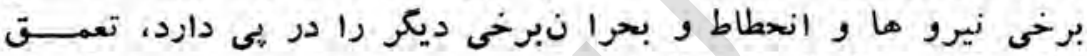

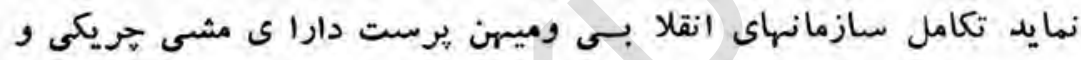

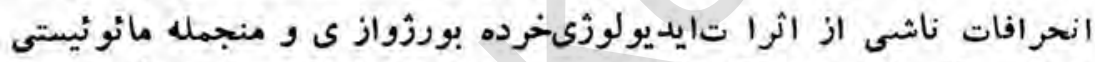

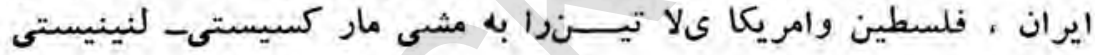

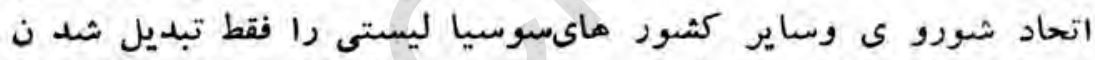

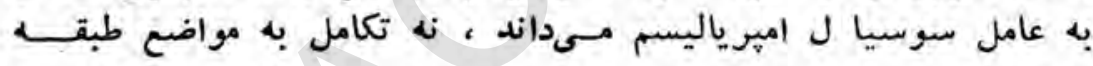

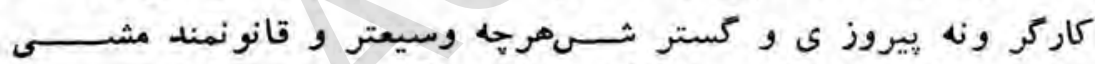

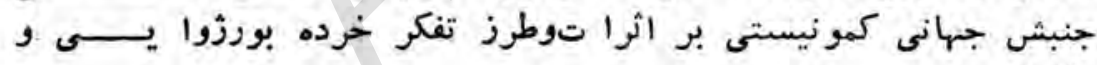

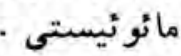

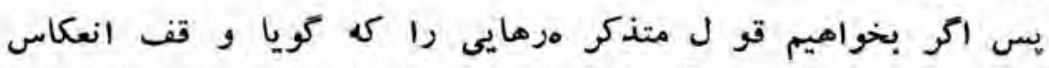

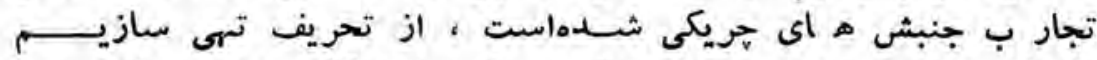

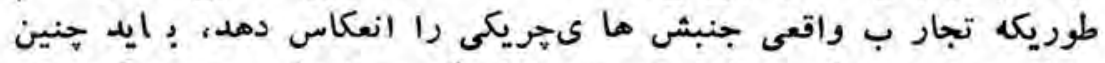

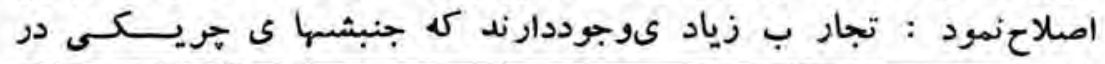

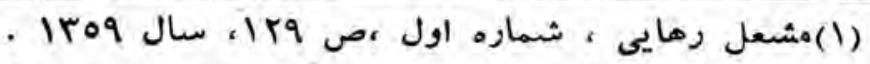




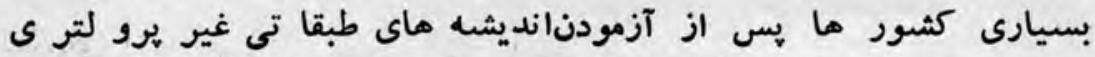

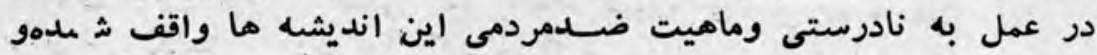

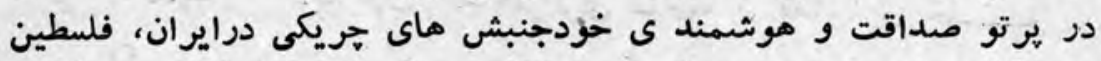

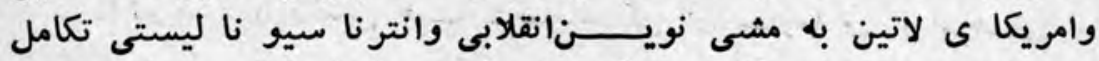

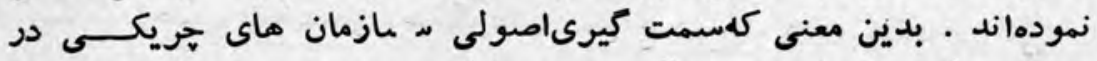

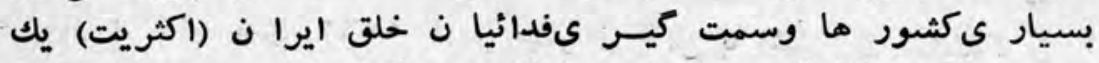

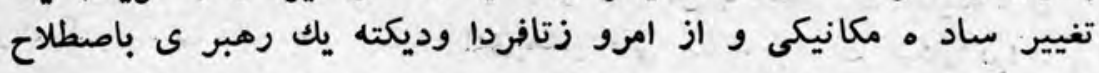

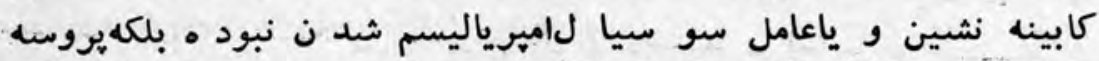

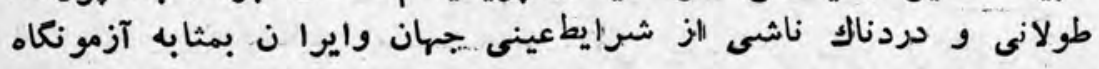

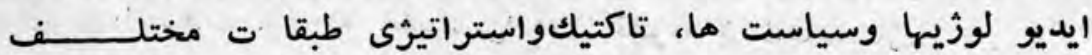

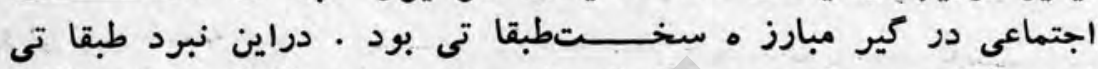

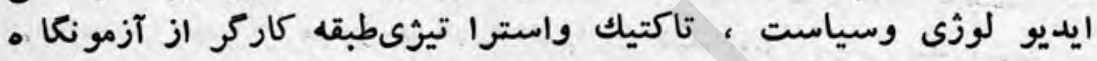

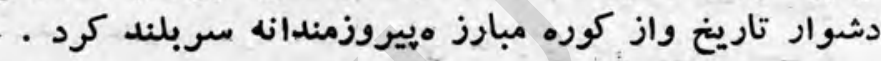

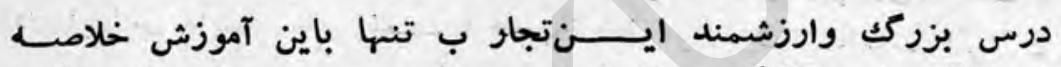

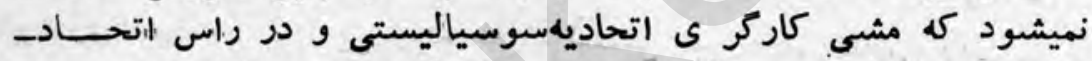

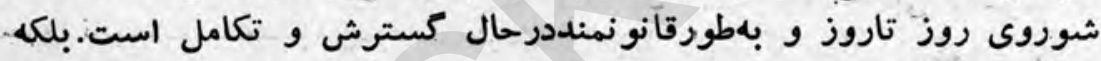

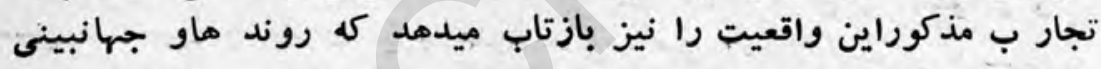

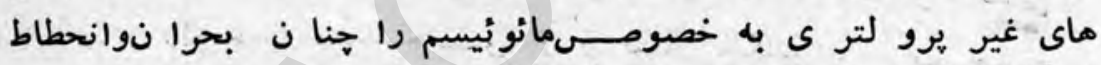

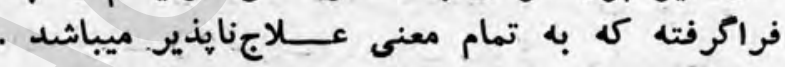

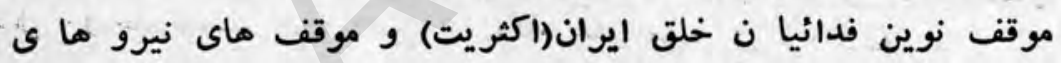

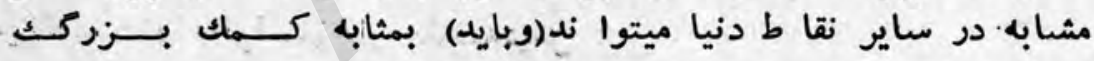

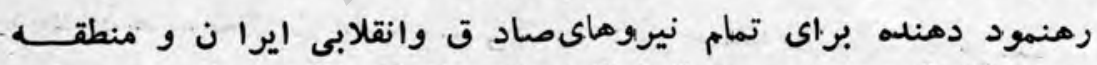

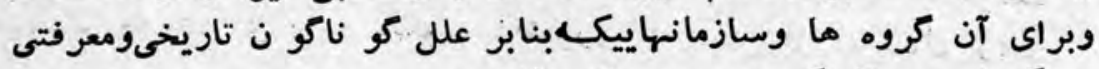

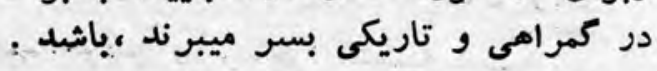

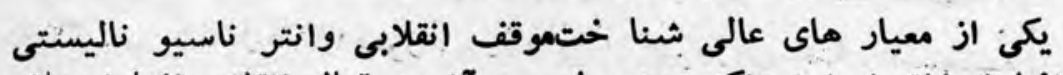

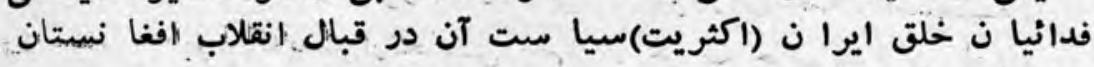




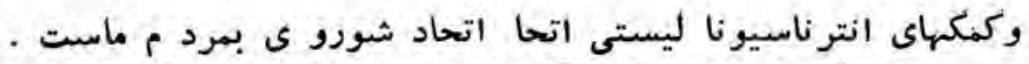

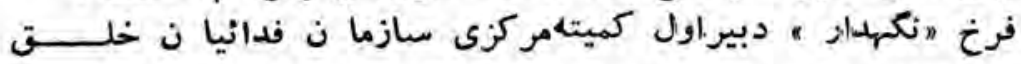

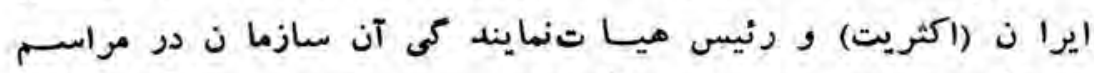

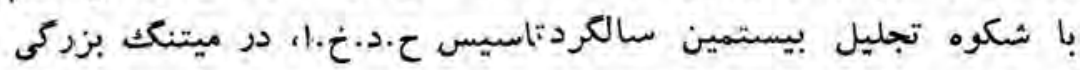

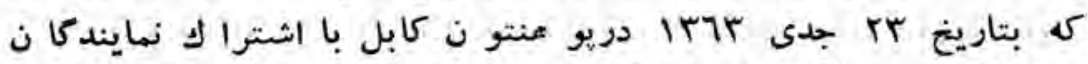

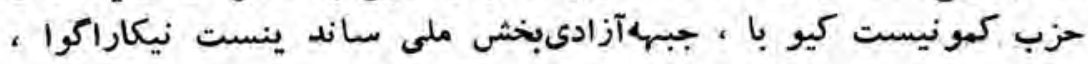

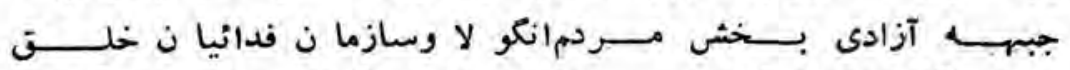

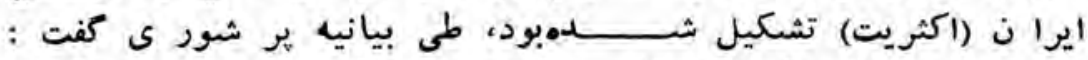

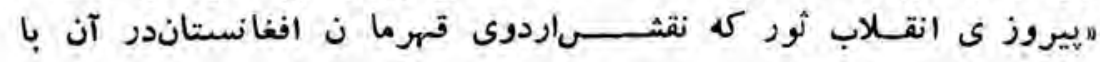

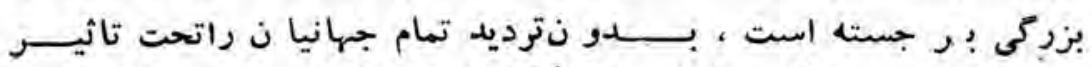

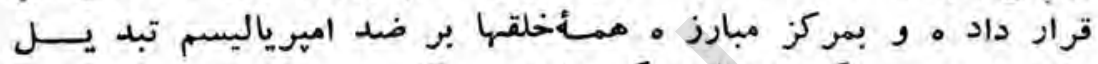

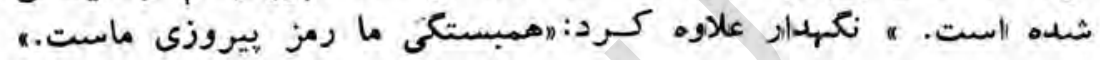

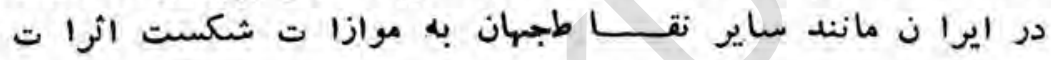

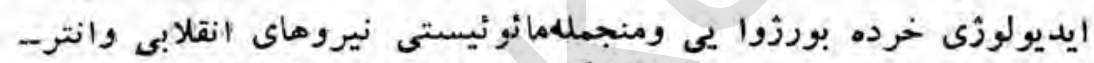

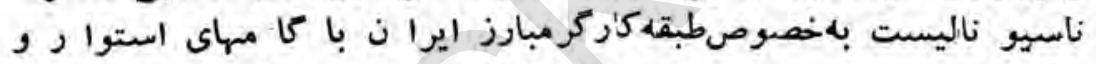

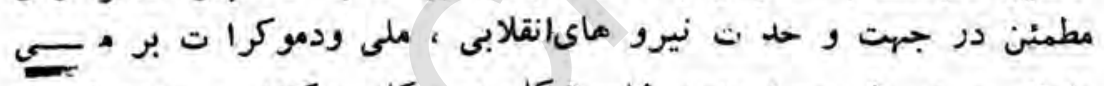

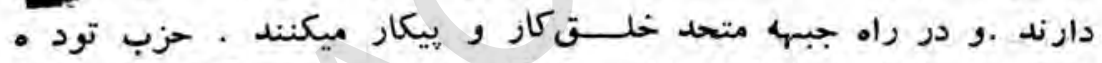

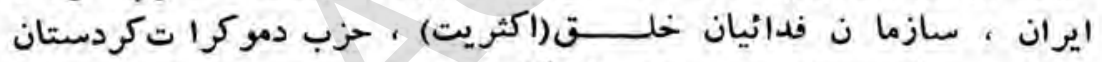

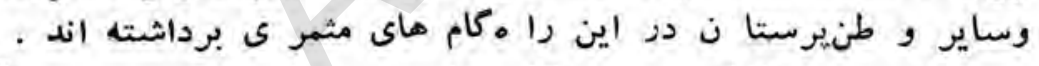

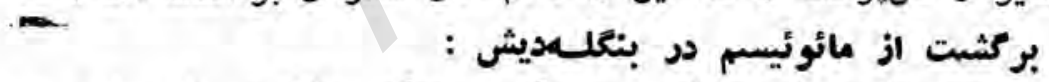

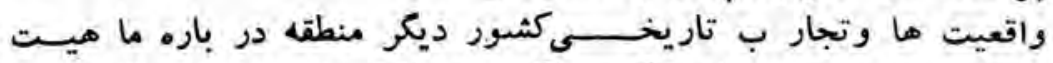

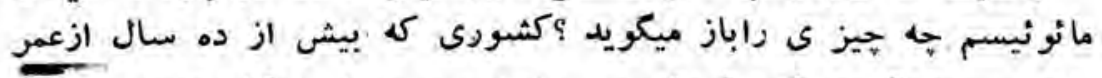

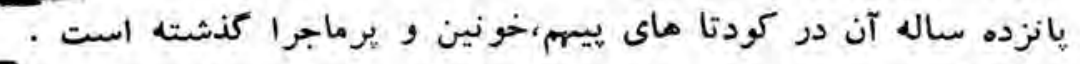

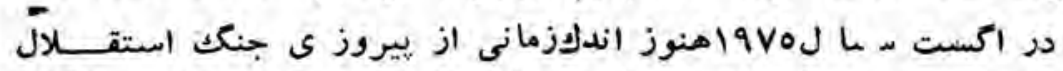

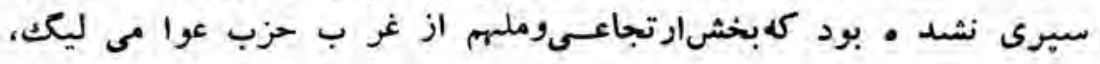


شينخ مجيب الر حمن رمبر استقلالبنكلهديش وفا ميلش را بهبيرحمانه

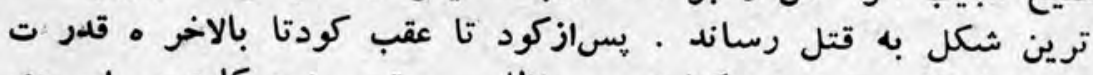

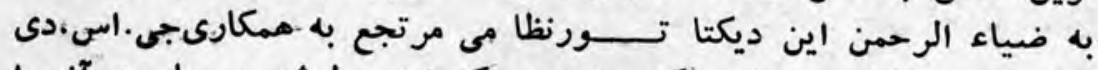

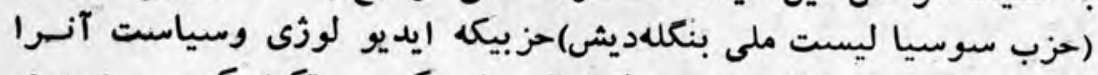

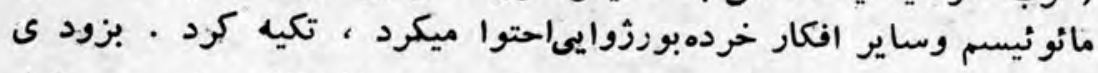

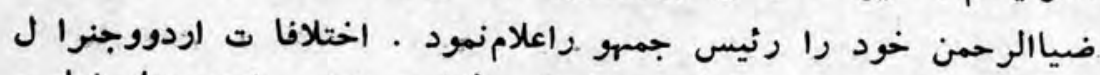

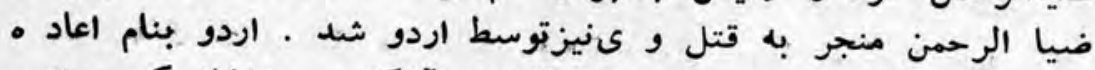

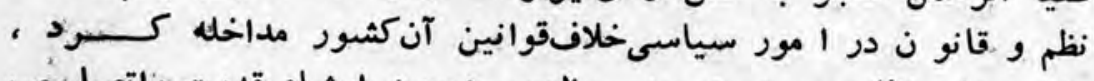

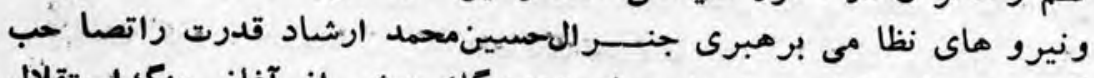

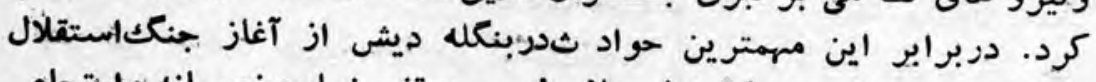

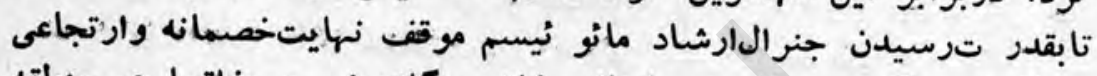

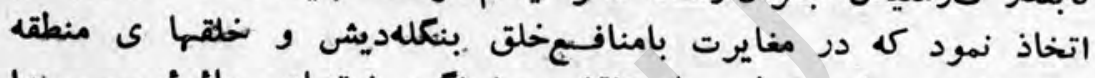

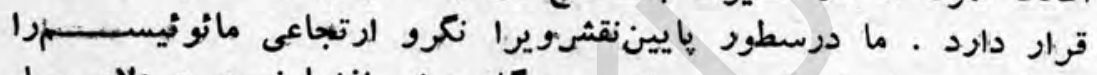

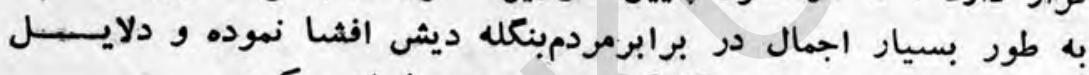

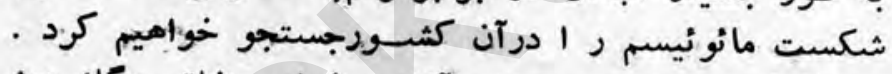

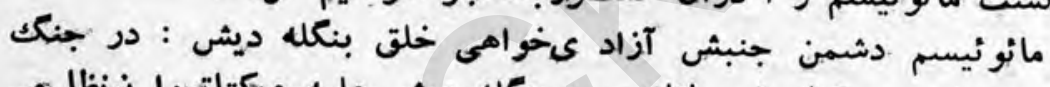

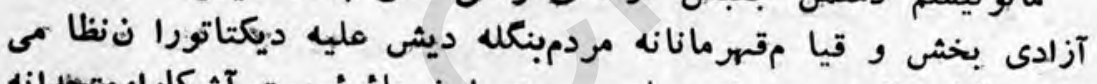

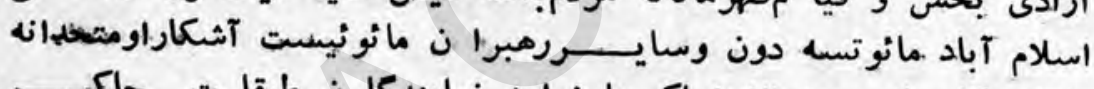

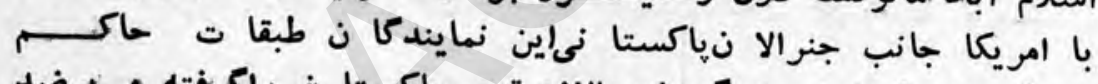

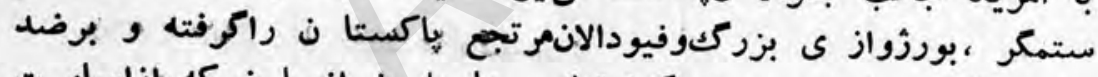

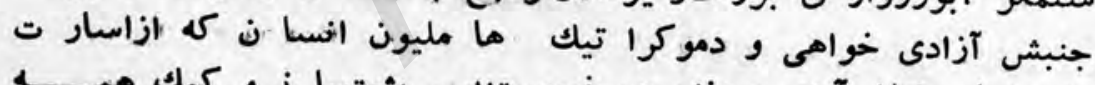

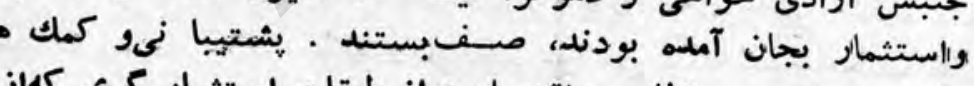

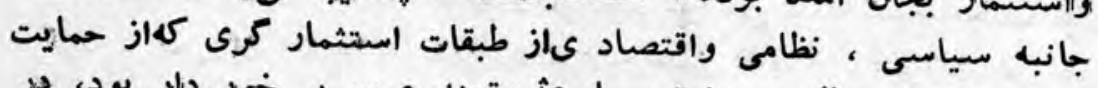

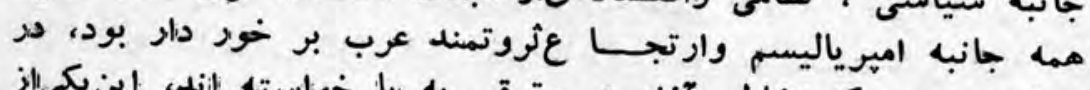

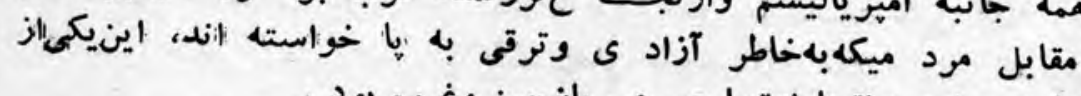

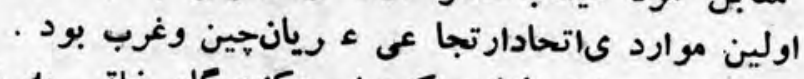

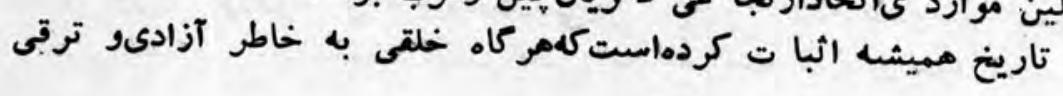

$-\varepsilon \cdot v_{-}$ 
برخاست آنكاه ديكر بيروزى حتمى!ست. در بنكلاديش نيز ديكتاتوران

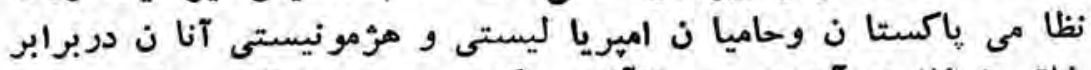

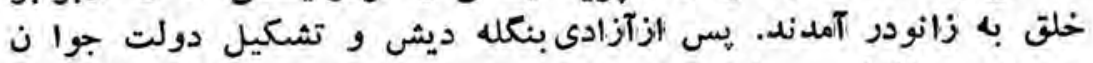

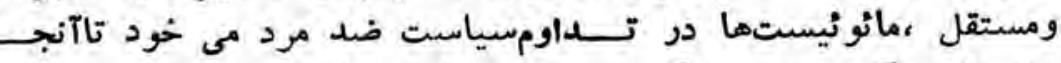

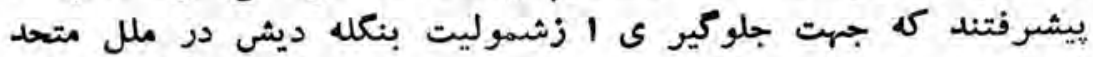

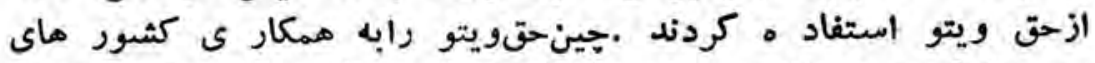

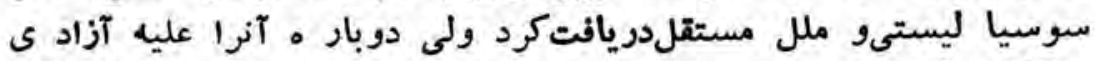

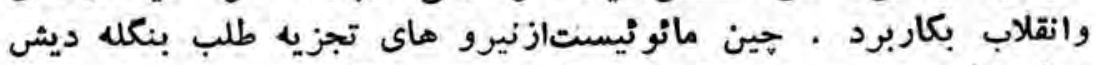

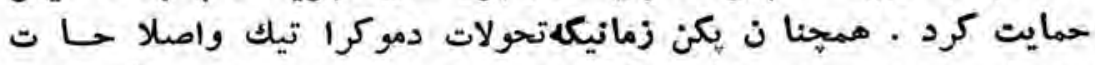

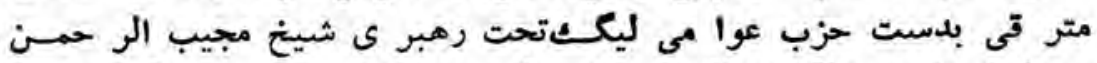

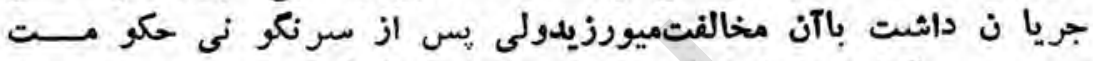

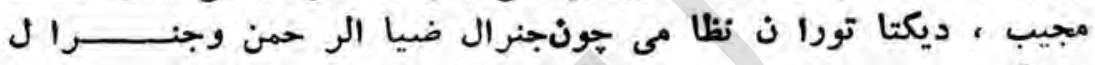

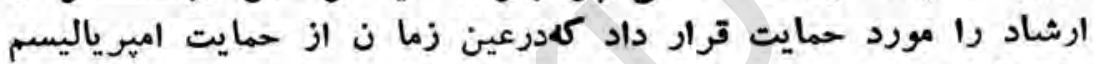

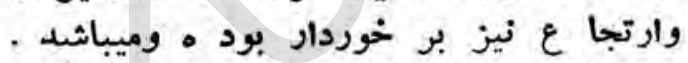

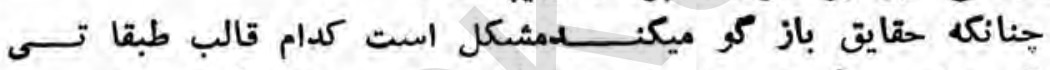

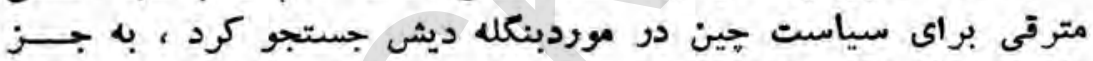

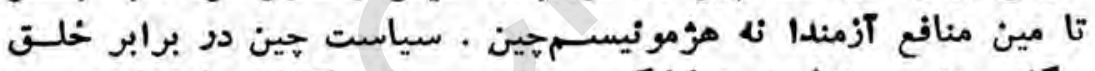

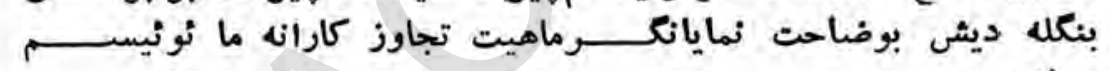

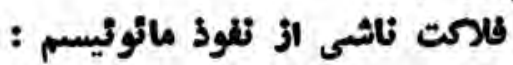

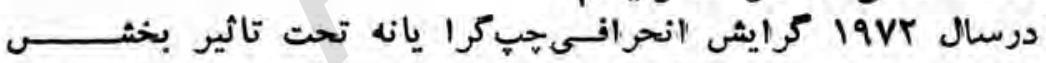

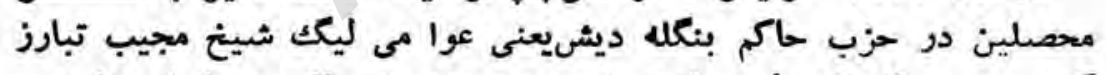

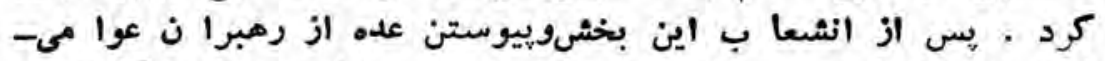

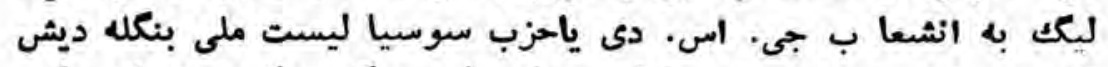

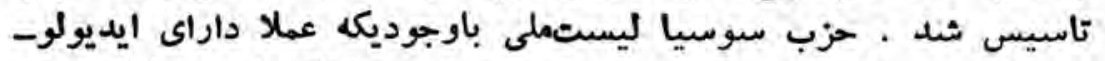

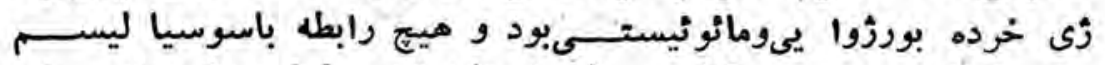

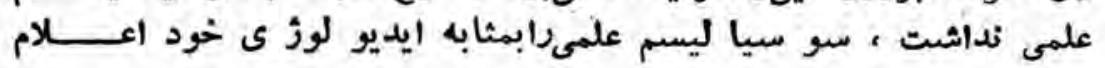




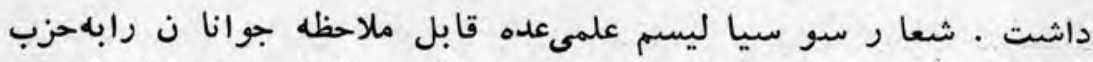

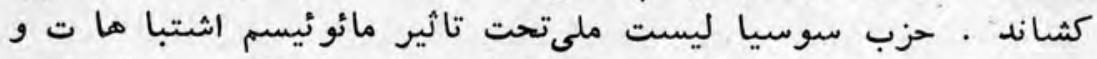
انحرافا ت جد ى را مرتكب شد وبلاياى مهلكى رابر كشور و خودفرود مائل

nover-

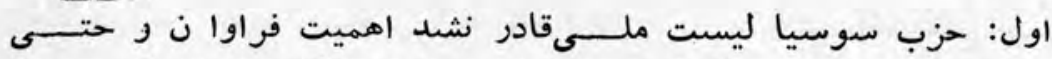

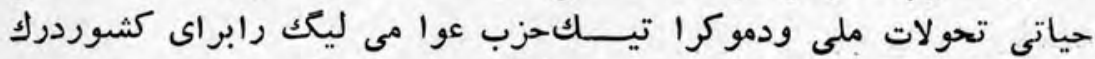

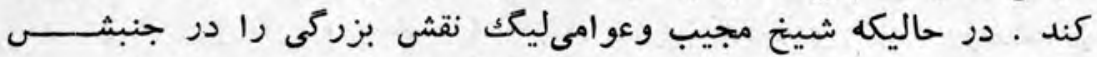

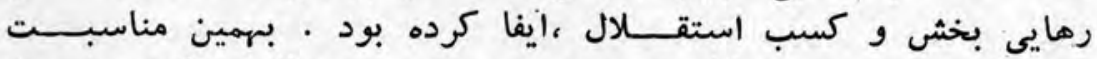

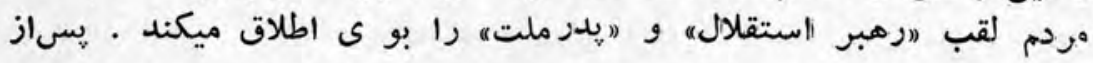

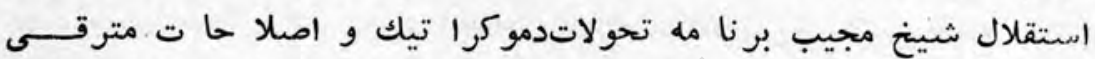

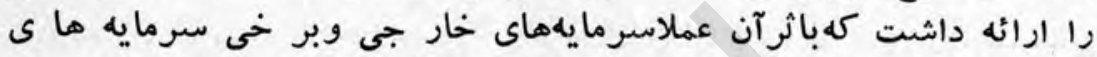

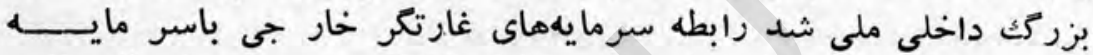

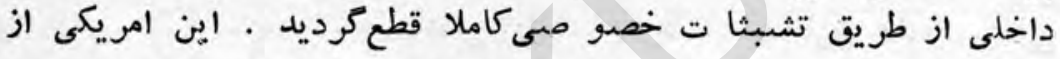
عوامل مهه تحكيم استقلال اقتصا دىوسياسى در آن كشور إسى بشمارميرود.

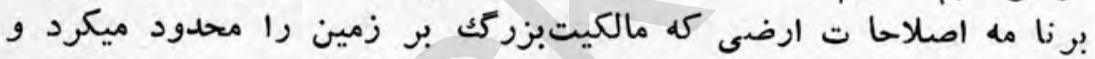

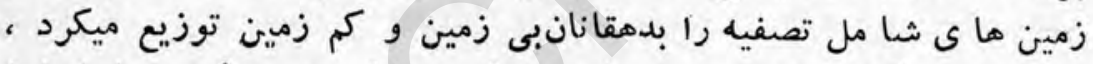

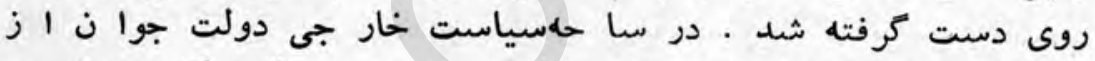

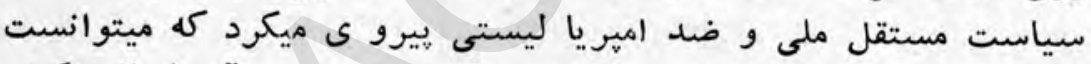

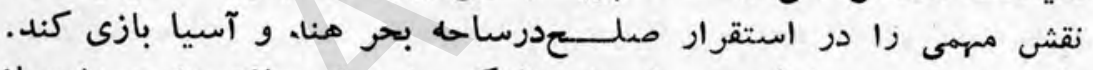

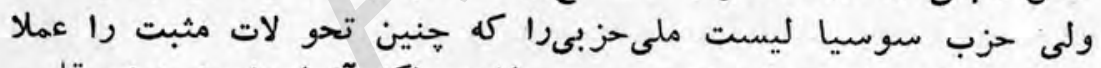

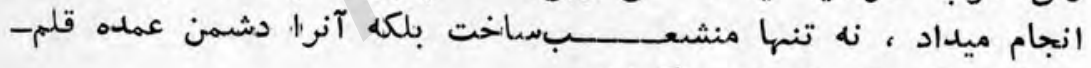

$$
\text { داد كرد كه بايد فورا سر نكونشود. }
$$

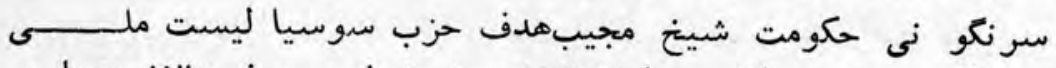

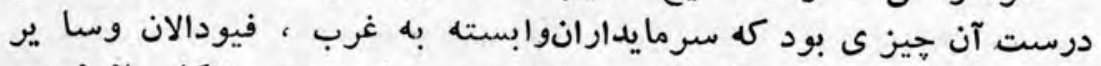

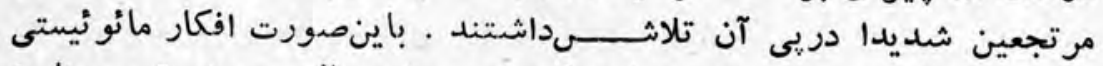

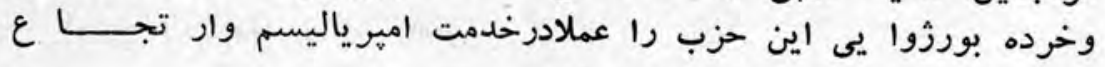
قرار داد . برده 


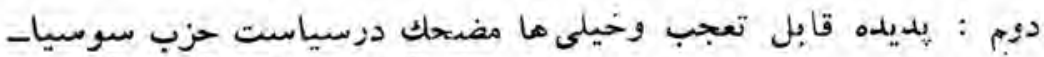

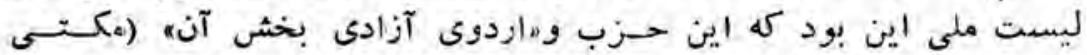

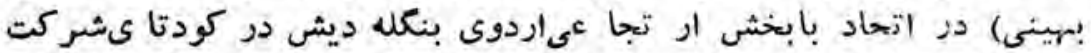

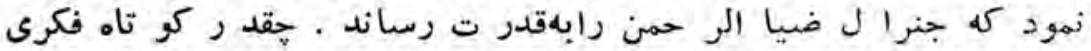

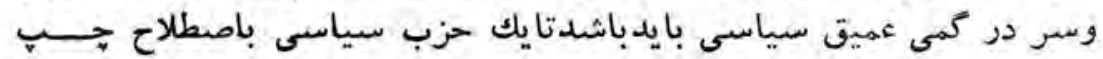

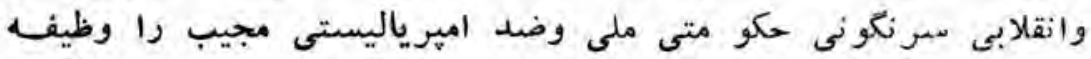

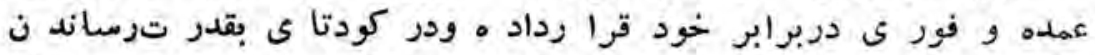

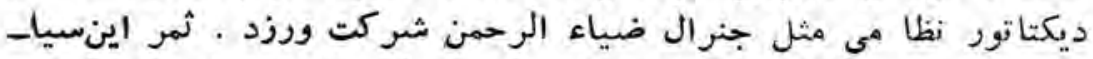

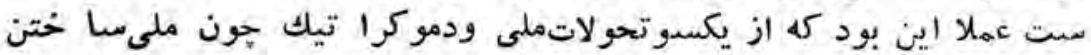

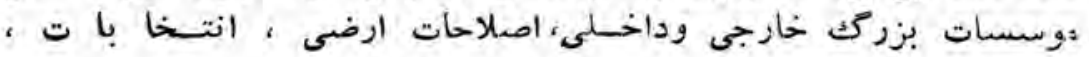

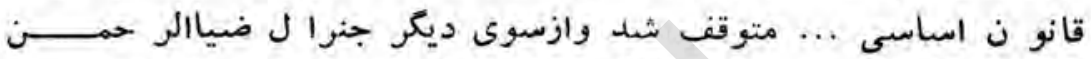

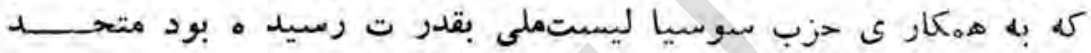

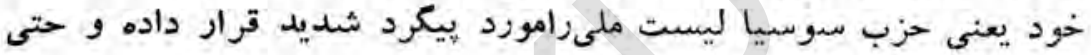

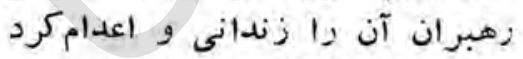

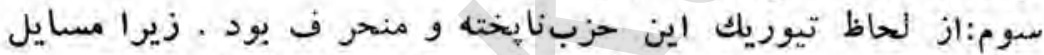

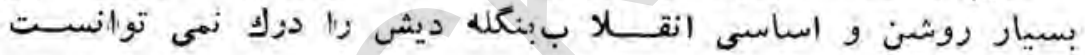

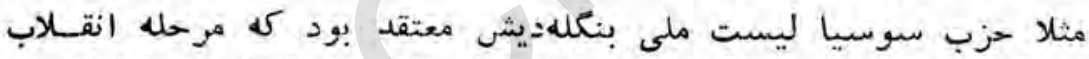

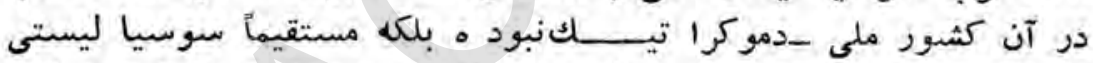

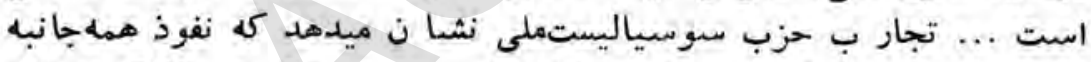

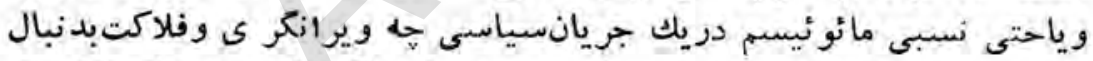

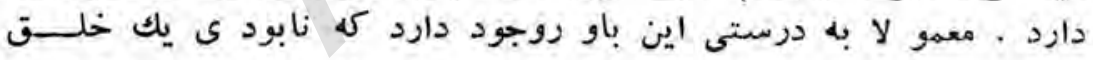

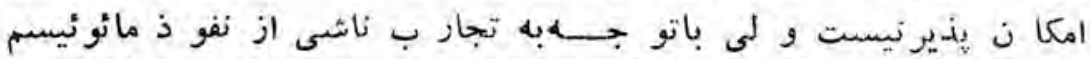

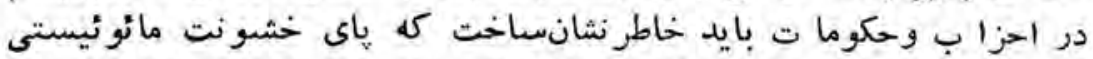

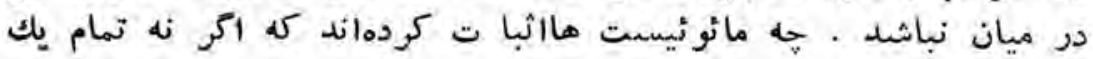

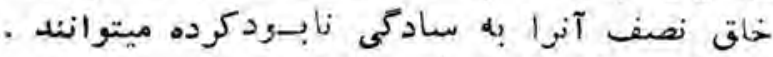

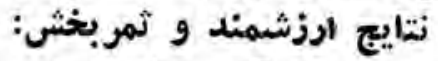

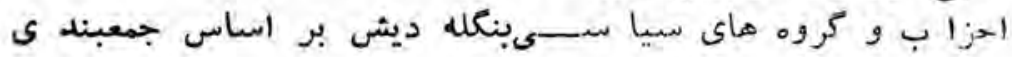




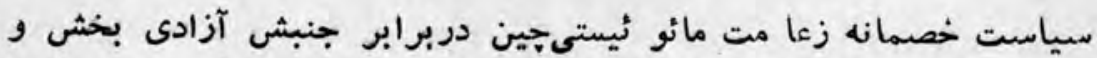

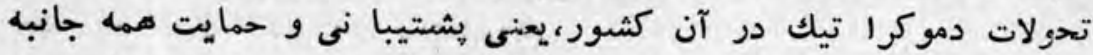

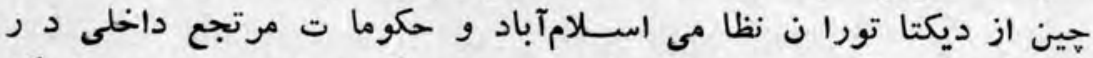

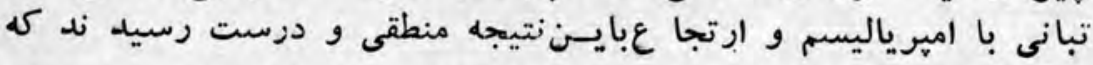

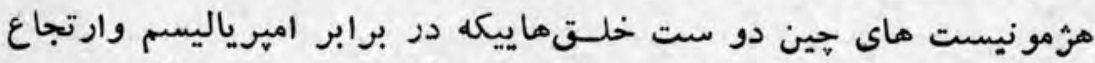
بخاطر كسب آزاد ى ونيل به ترقىنبرد ميكنند ، نبود ه هبل بلكه دشمـن آنا ن ميباشد كاب آناد

درداخل بنكله ديش نيز مشى راكلاحزا ب و و مروه مهاى مائو ئيستى طى إنى

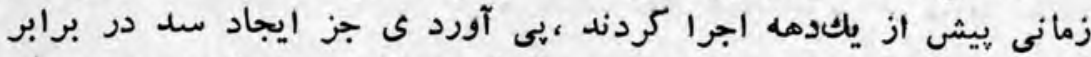

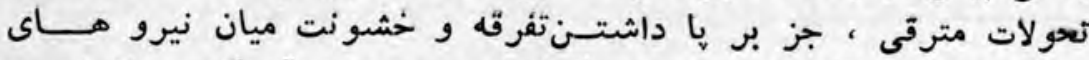

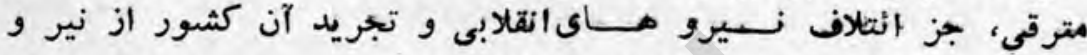

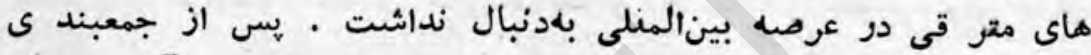

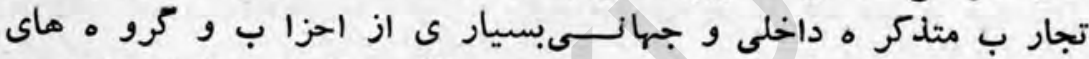

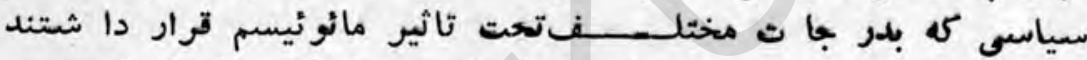

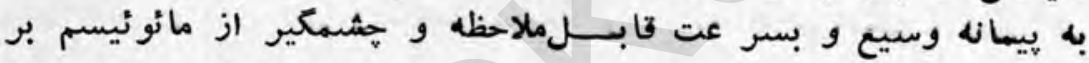

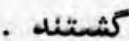

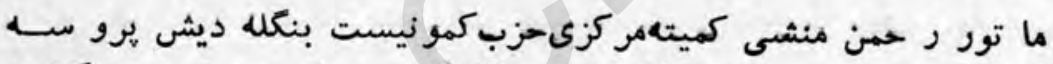

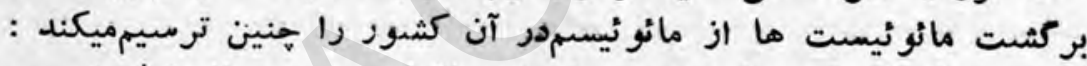

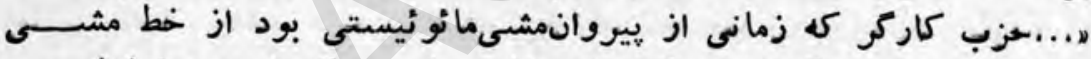

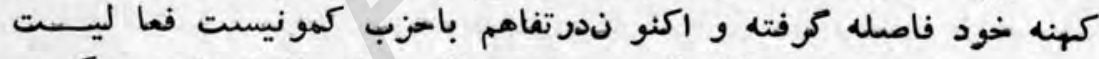

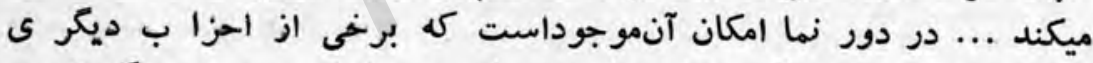

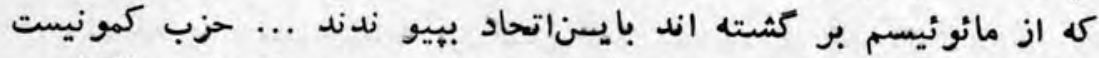

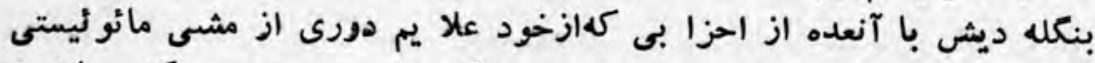

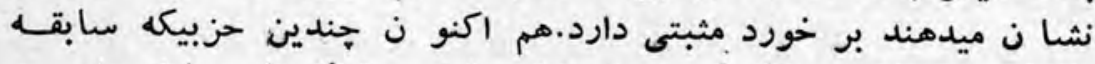

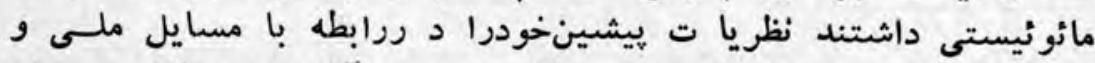

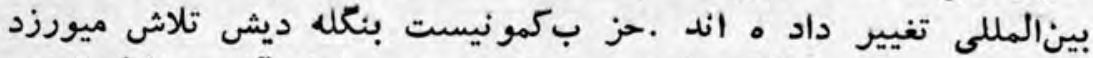

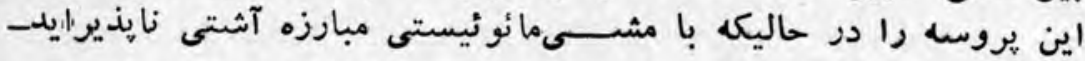


يو لوزيك دارد و هوشيار ى لازمىدر برابر احيا ى تهايلات مائو ئيستى

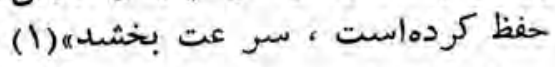

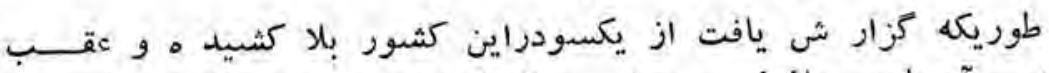

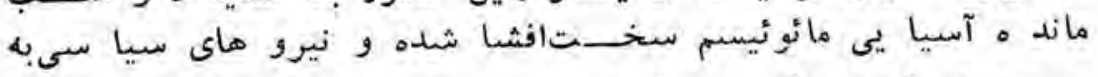

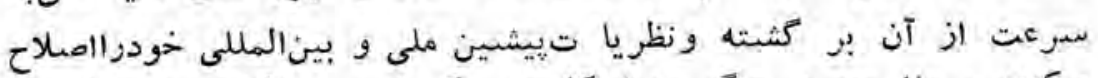

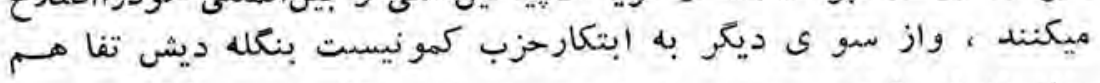

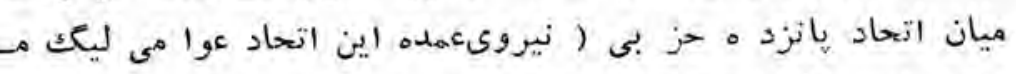

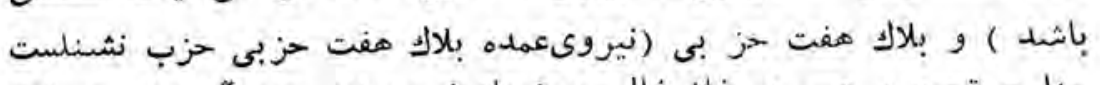

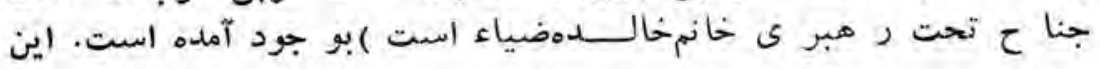

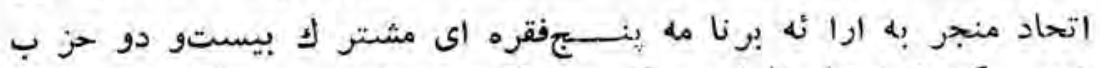

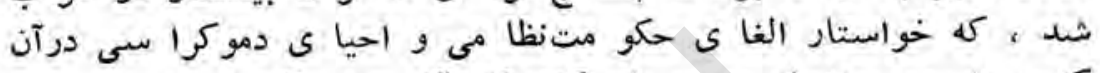

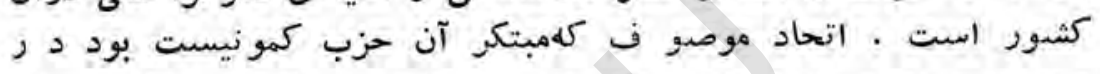

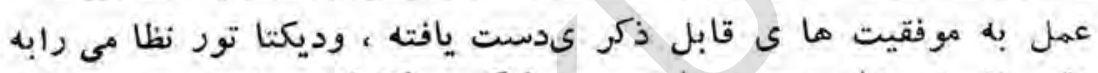

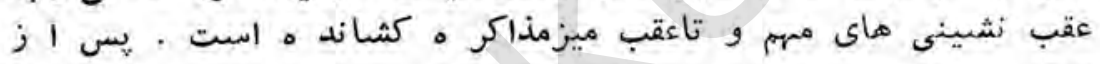

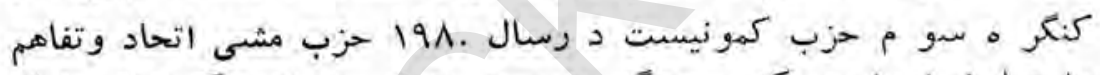

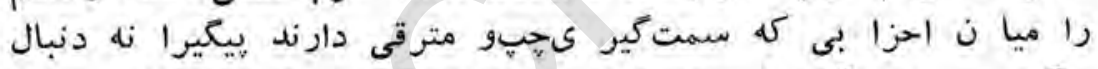

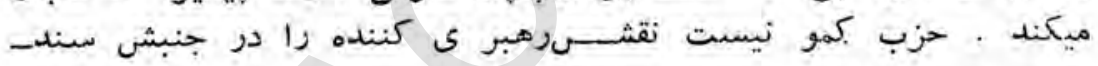

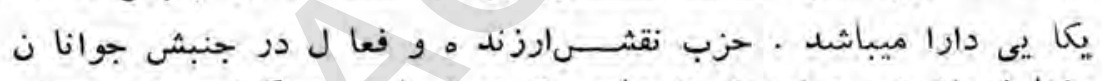

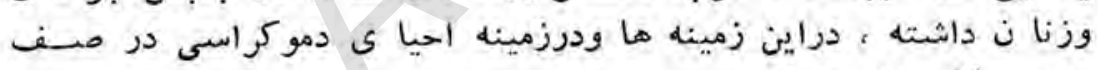

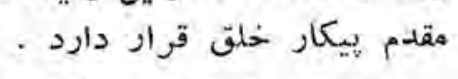

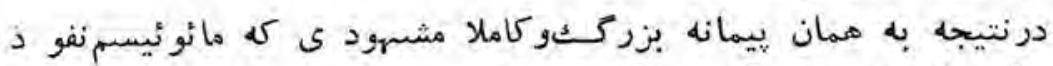

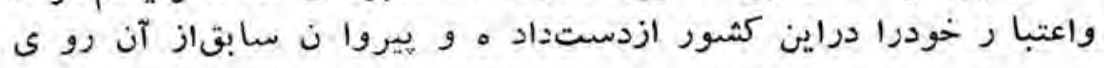

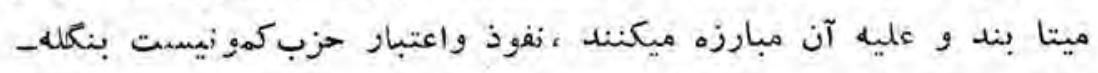

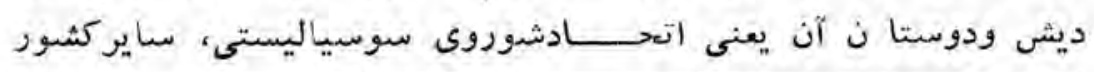

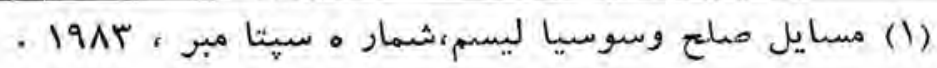




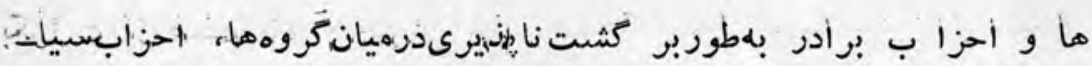

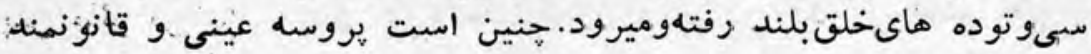

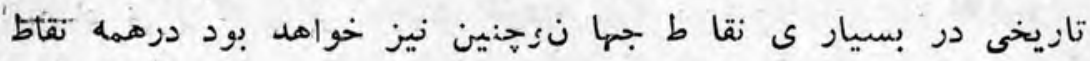

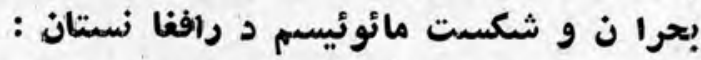

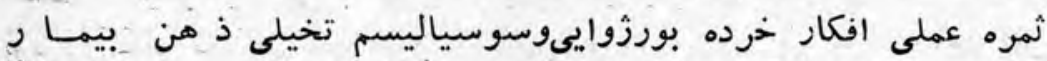

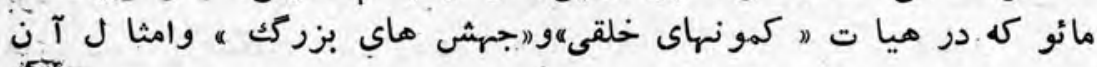

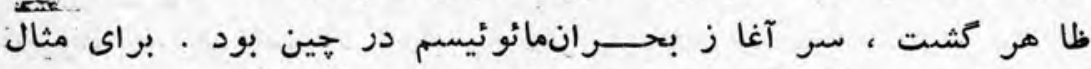

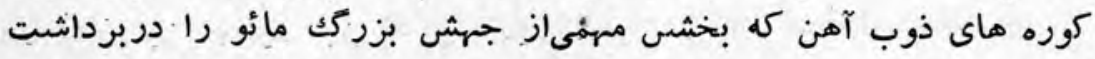

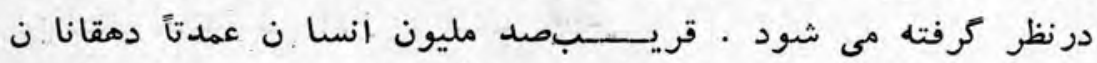

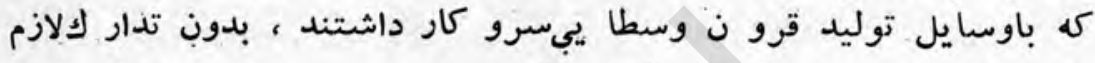

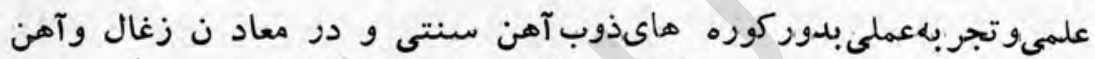

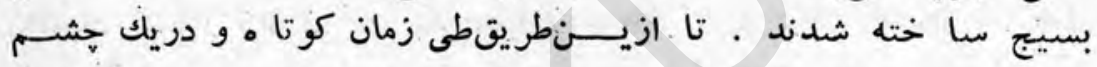

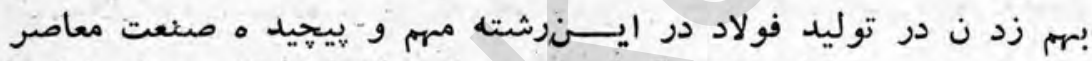

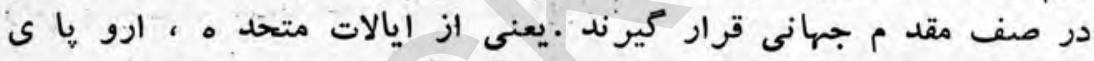

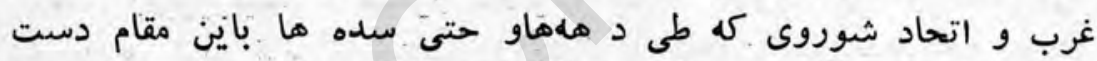

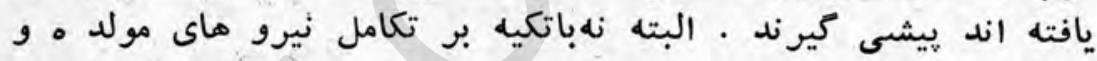

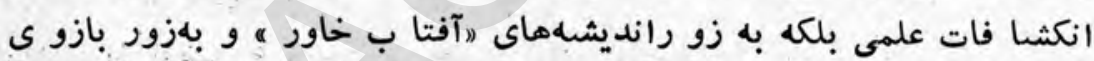

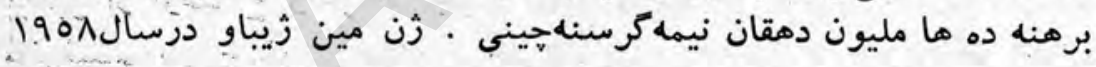

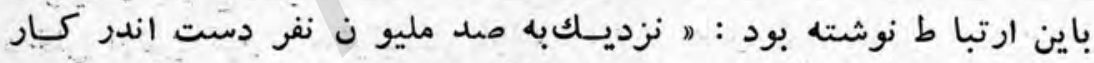

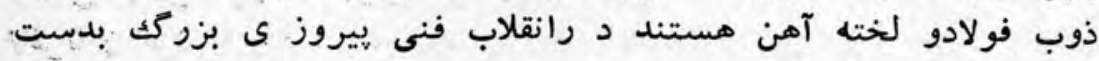

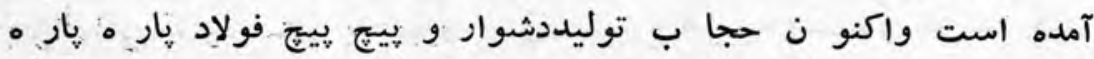

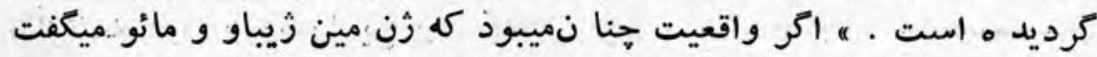

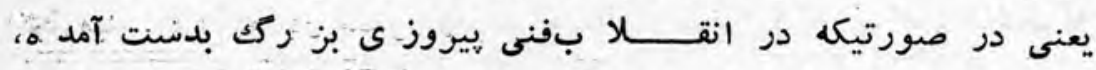

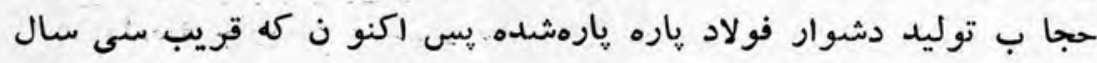

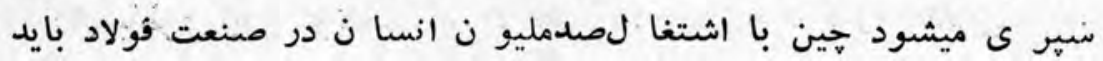




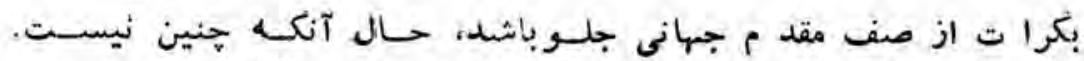

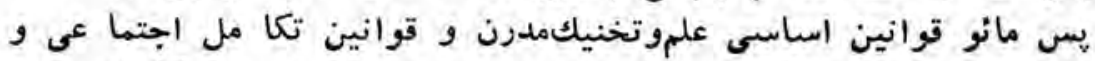

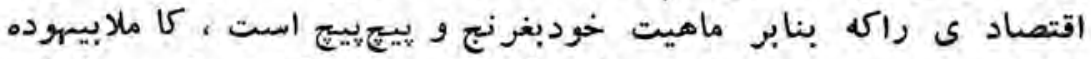

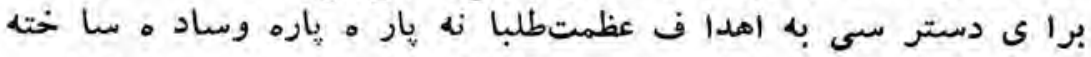

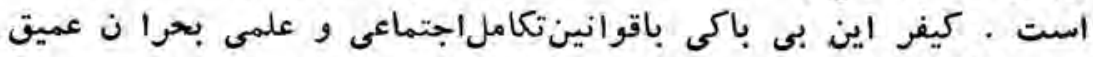

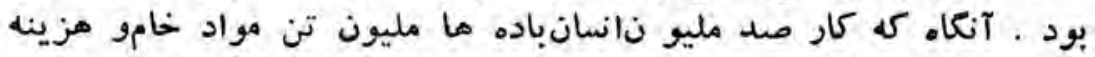

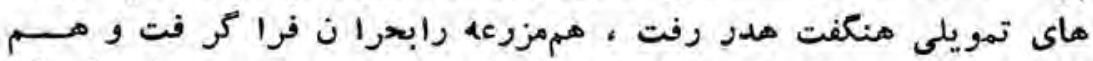

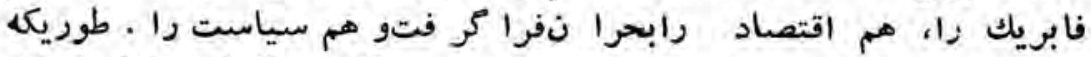

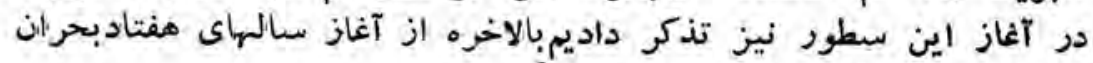

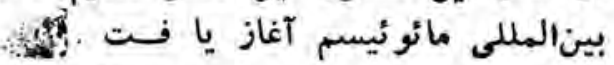

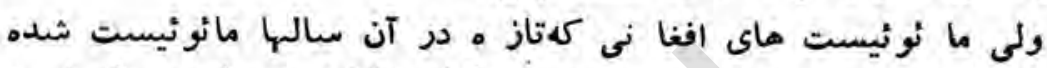

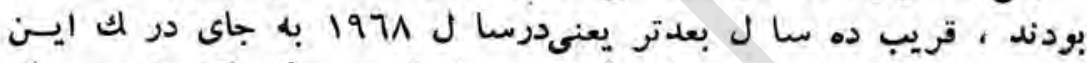

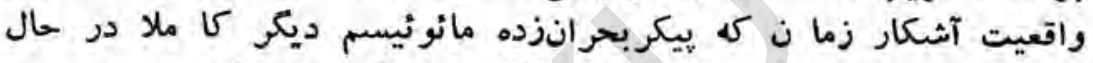

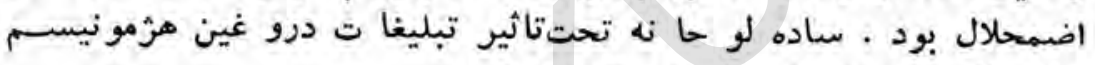

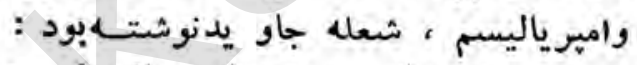

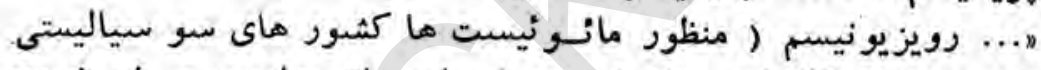

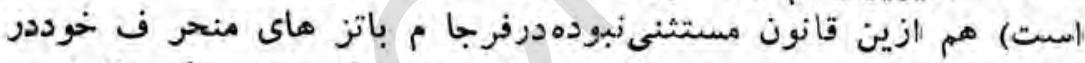

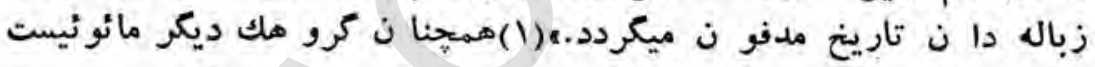

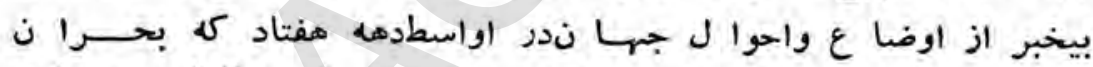

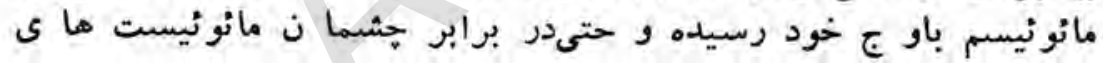

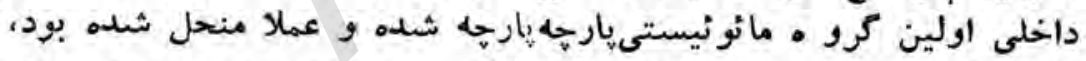

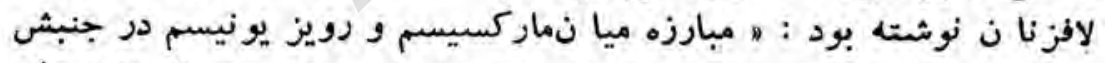

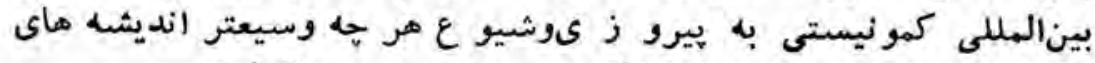

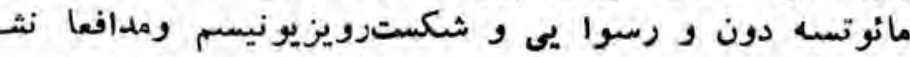

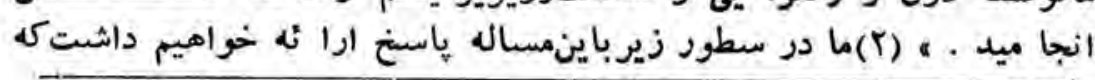

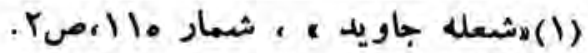

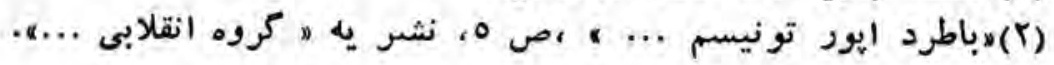




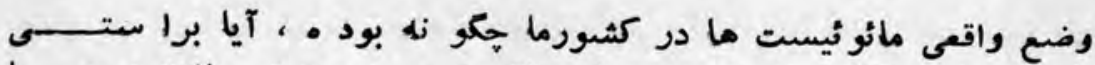

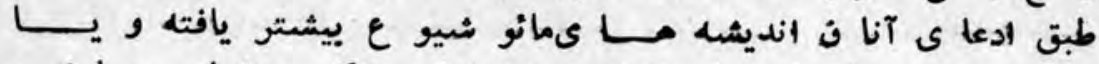

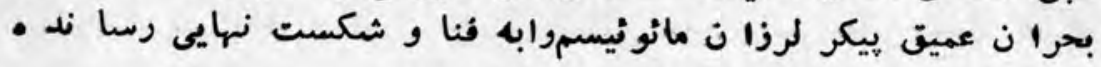

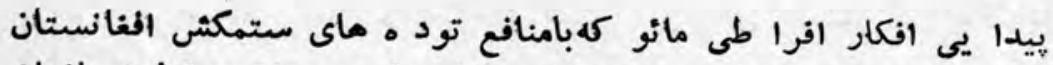

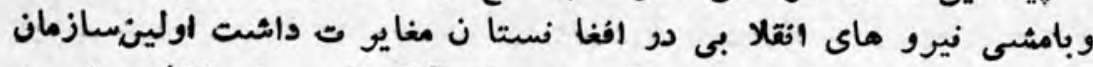

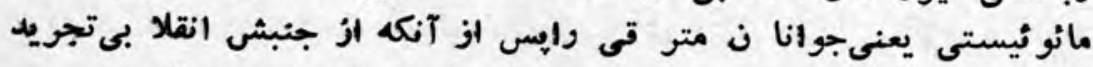

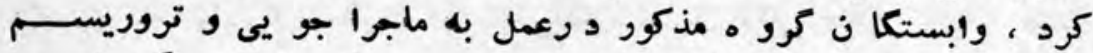

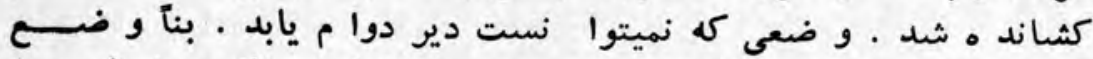

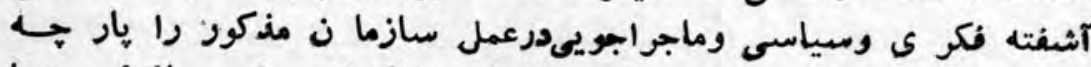

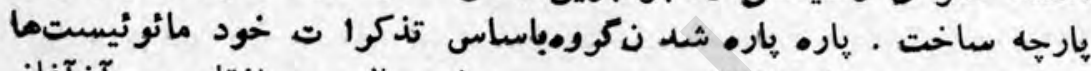

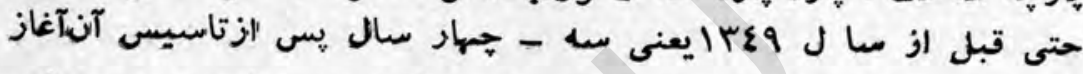

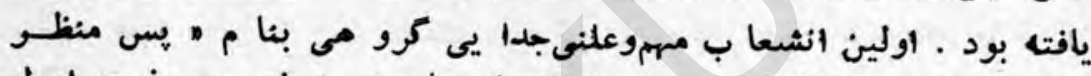

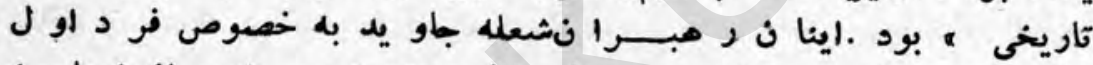

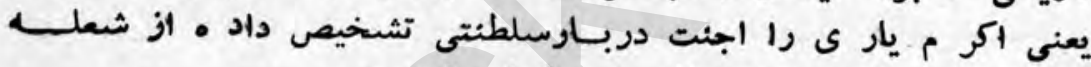

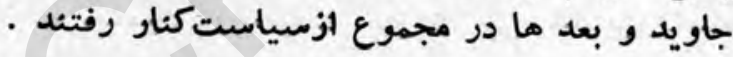

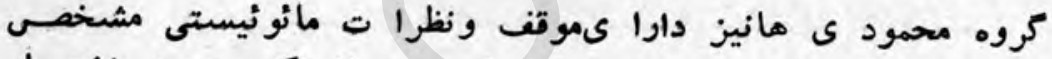

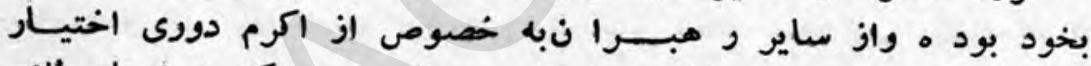

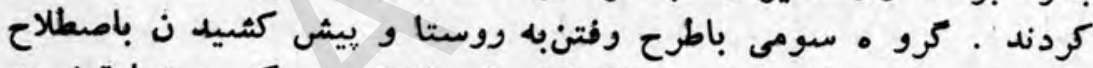

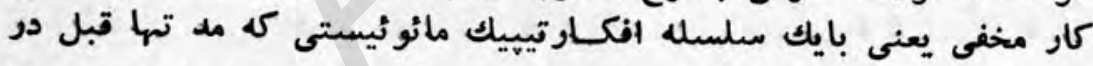

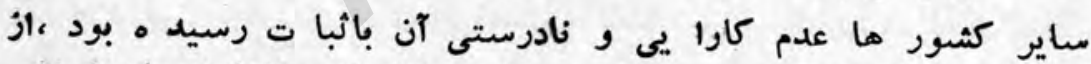

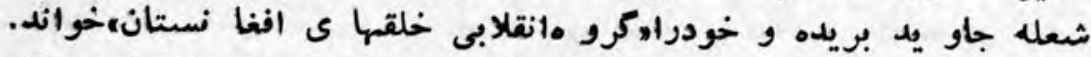

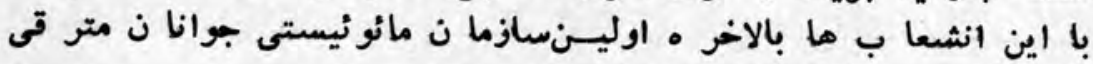

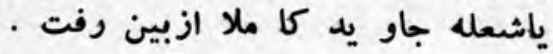

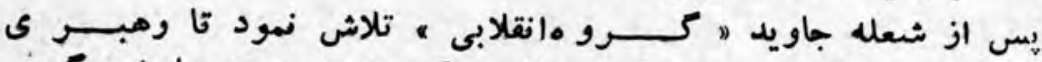

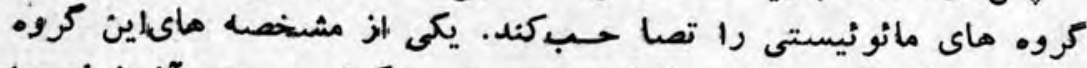

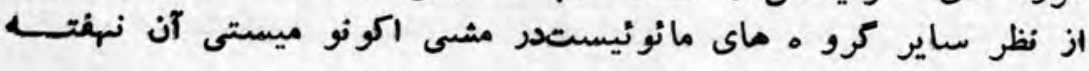




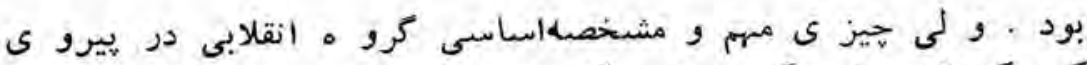

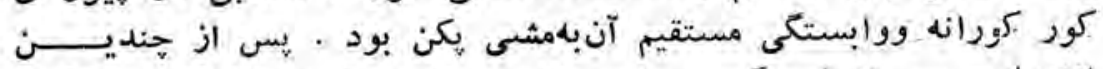

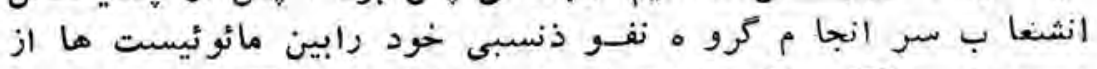

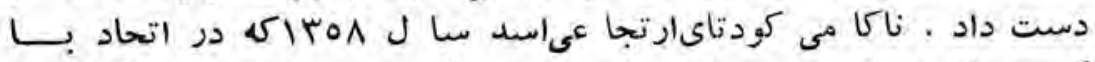

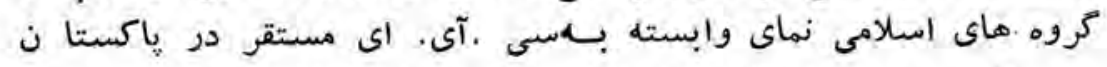

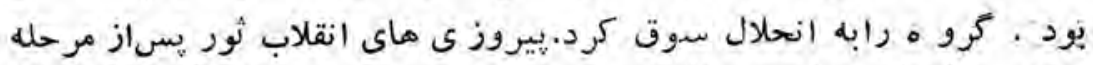

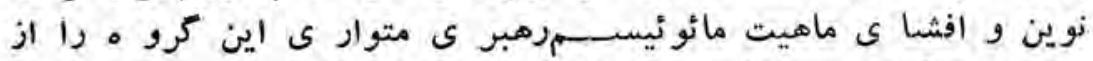

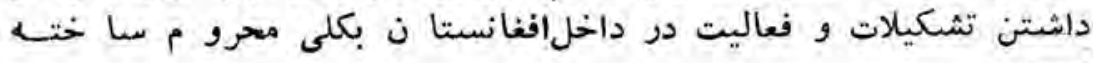

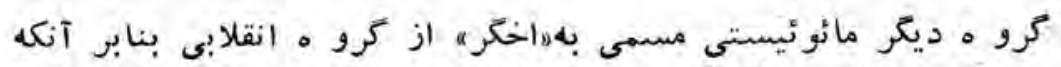

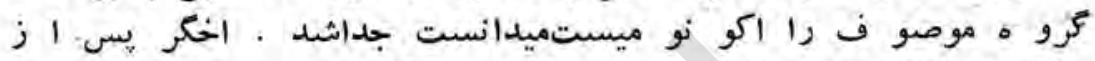

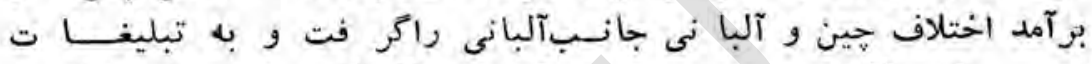

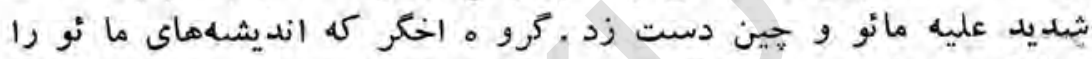

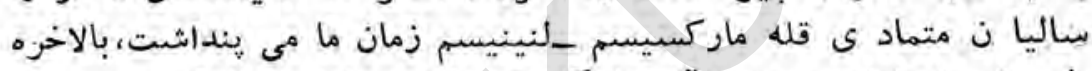

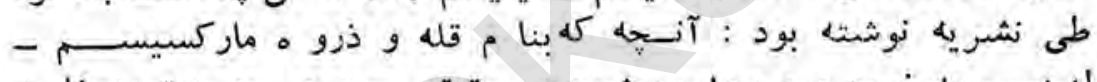

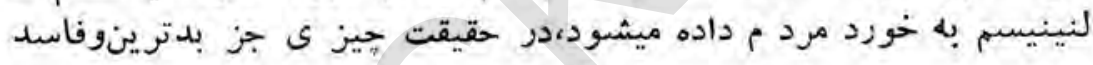

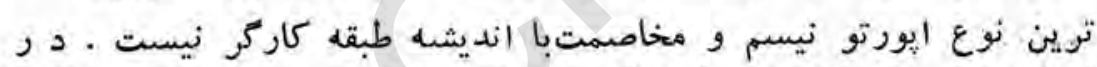

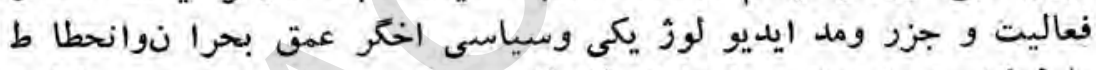

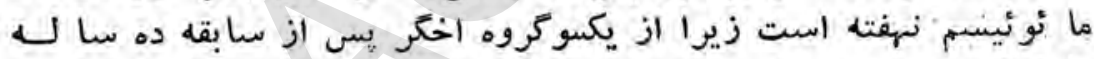

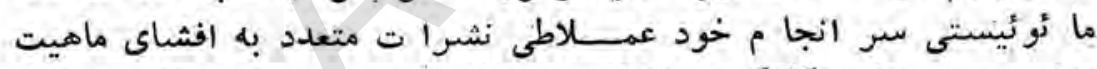

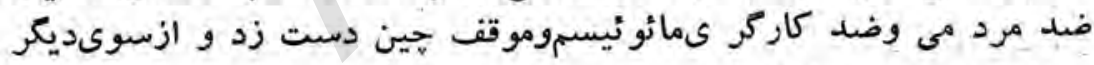

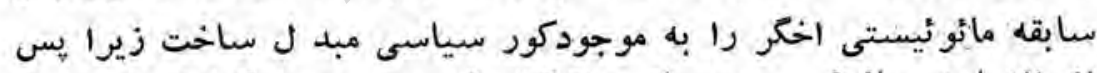

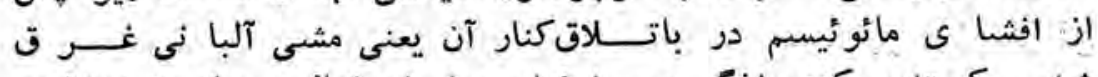

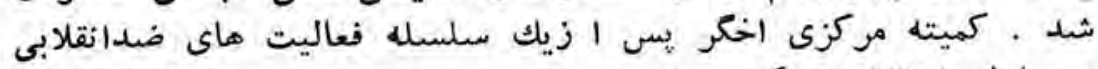

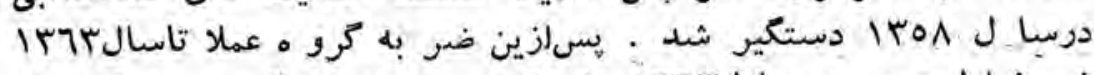

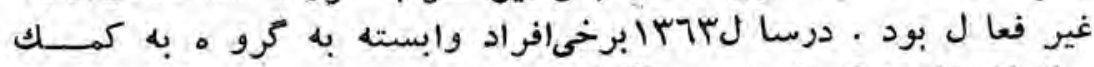

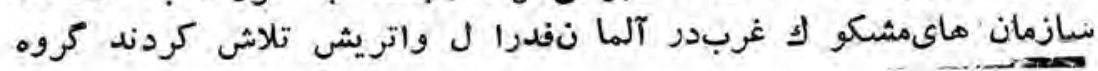




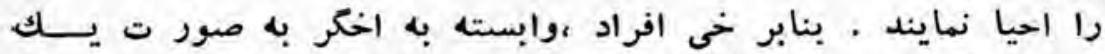

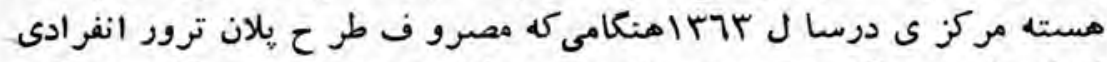

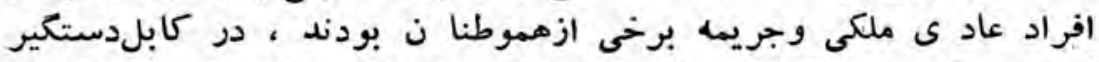

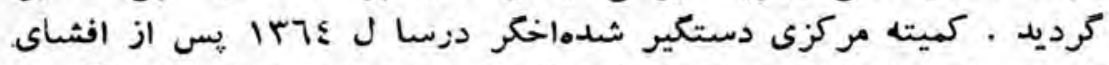

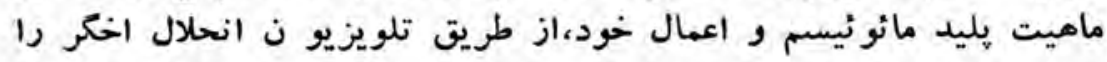

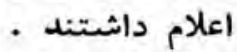

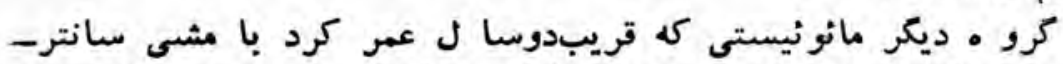

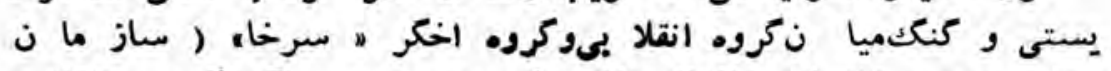

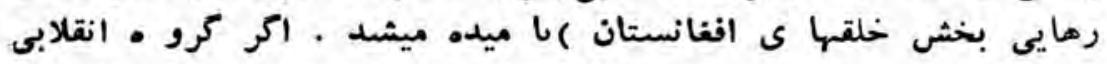

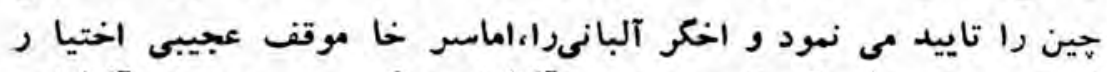

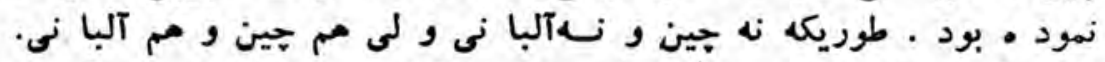

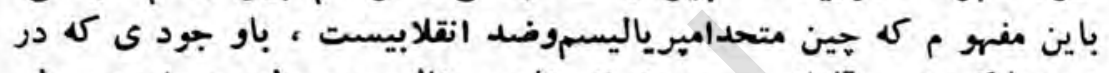

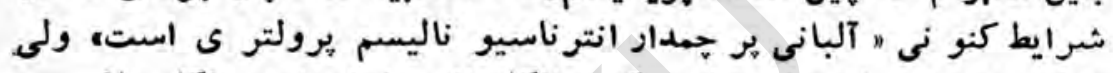

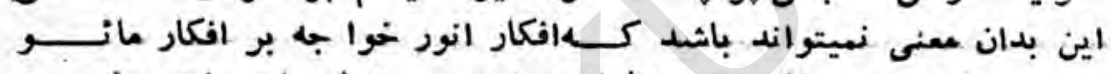

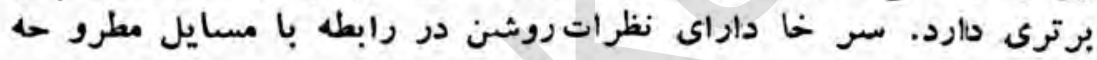

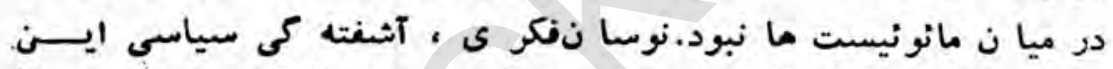

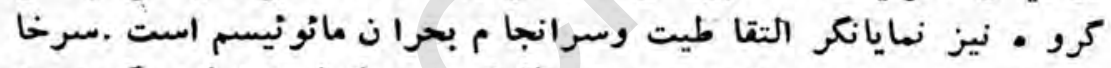

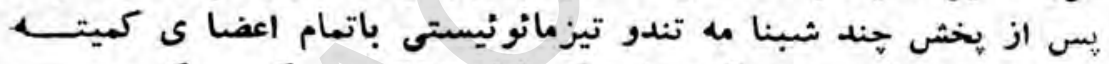

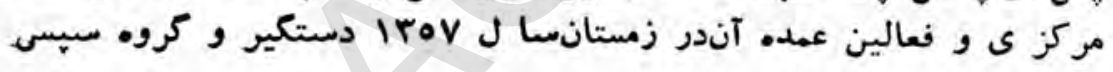

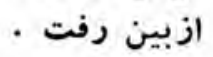

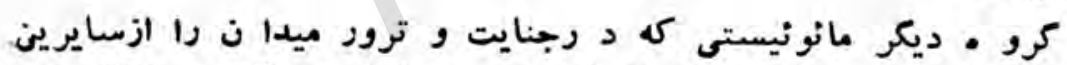

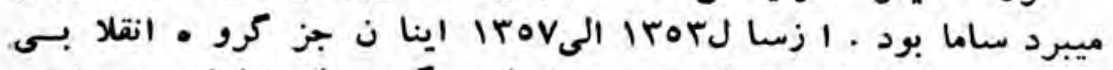

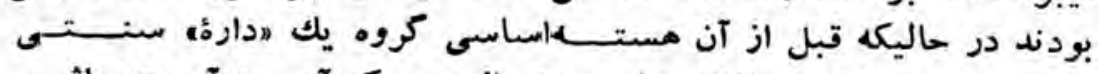

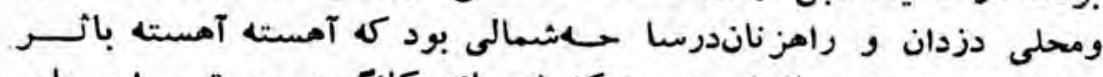

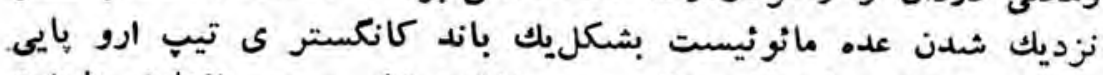

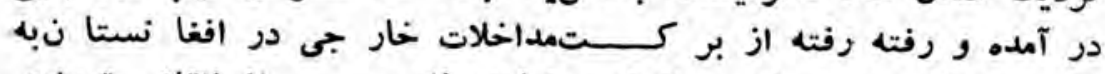

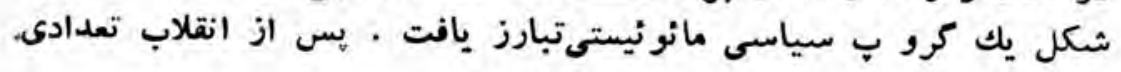




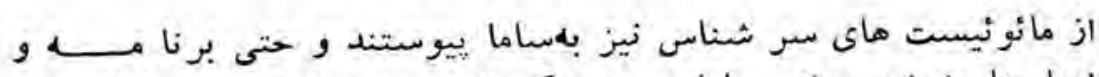

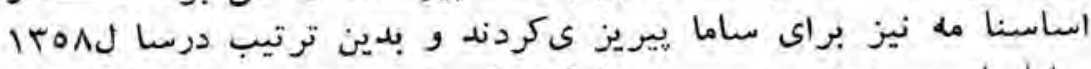

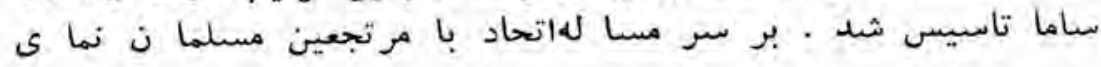

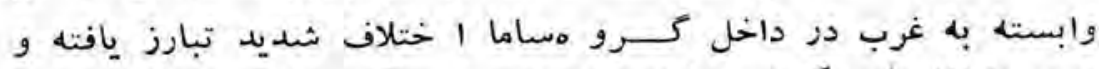

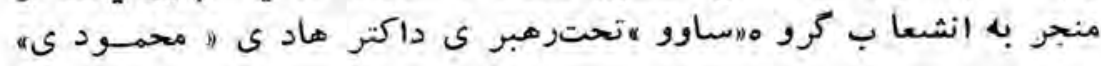

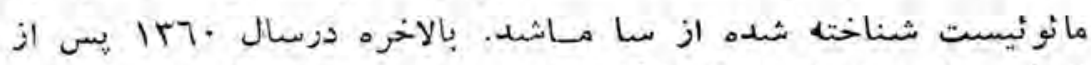

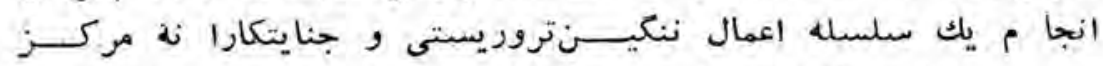

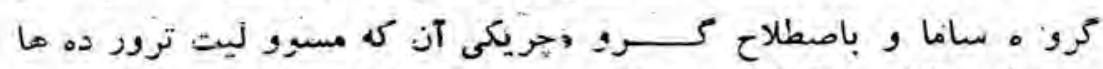

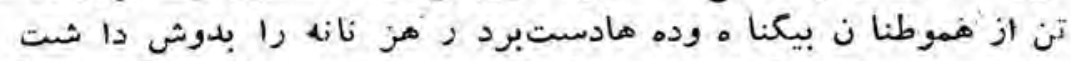

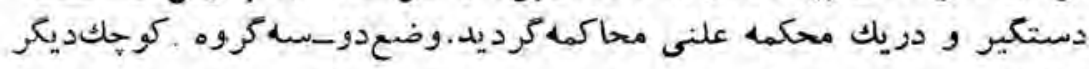

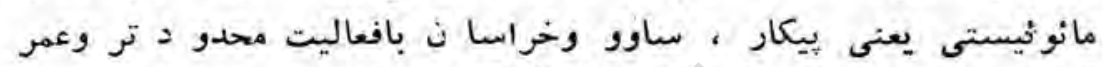

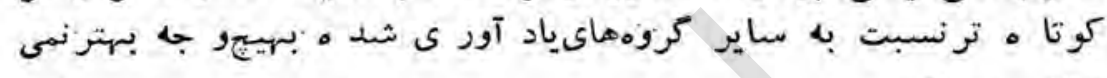

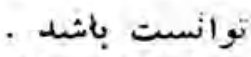

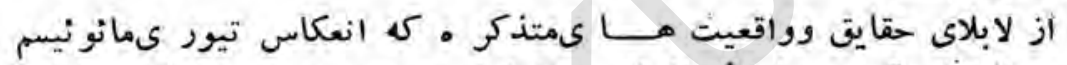

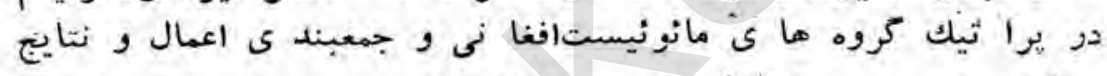

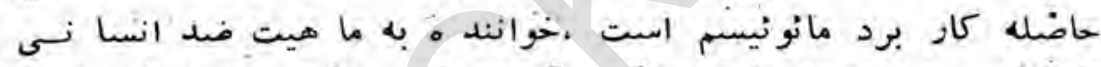

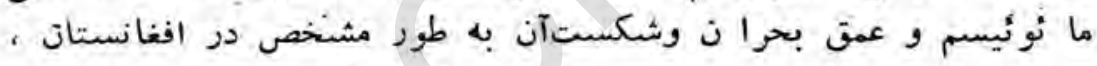

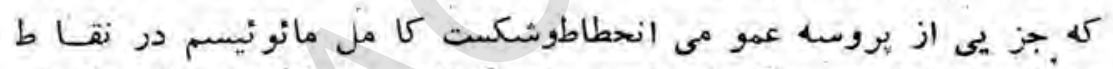

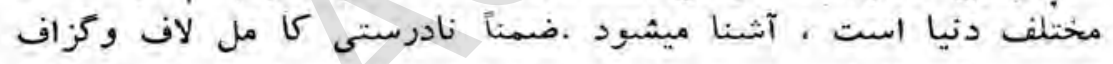

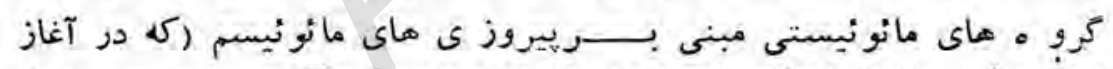

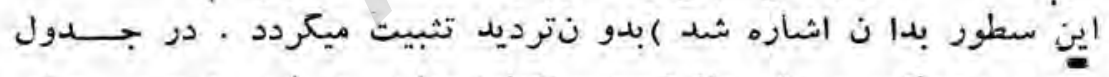

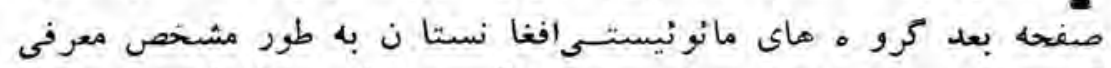

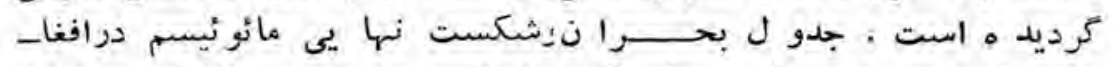

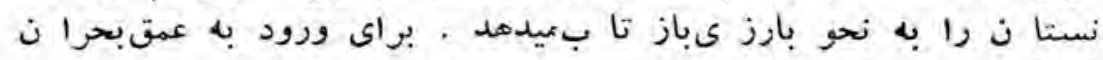

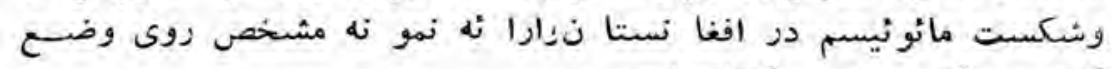

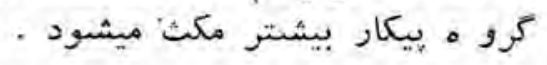




\begin{tabular}{|c|c|c|}
\hline$(0,0,0.0$. & ind 6 & $4=0, f^{l}$ \\
\hline 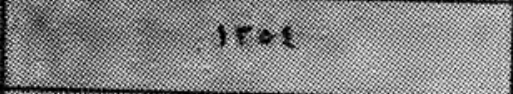 & Irte & 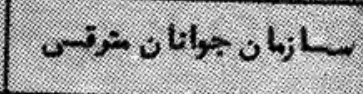 \\
\hline 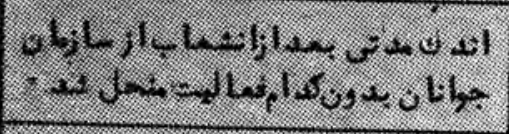 & 1r"1 & 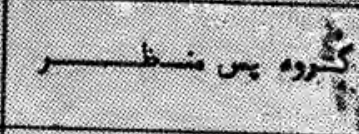 \\
\hline 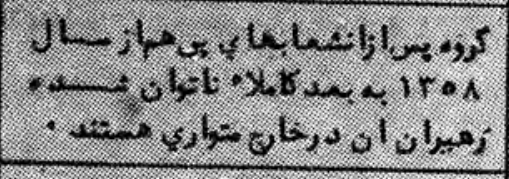 & |rot & 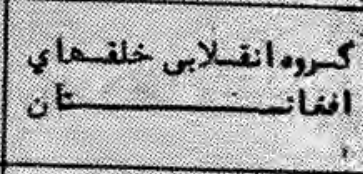 \\
\hline 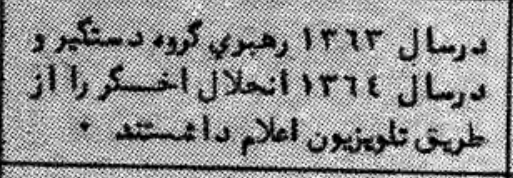 & $17+8$ & 1,5 \\
\hline 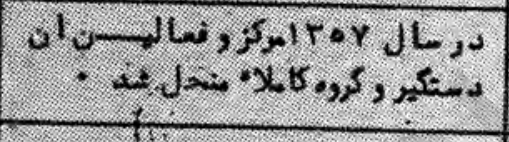 & itoo & 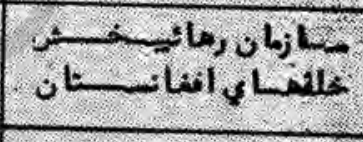 \\
\hline 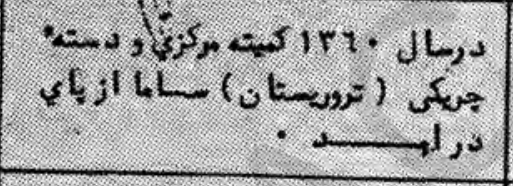 & Irod & 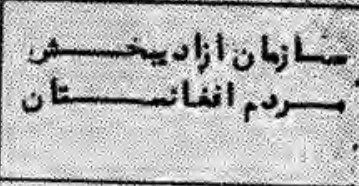 \\
\hline 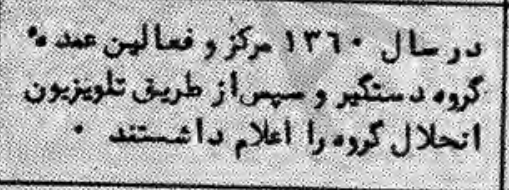 & ires & 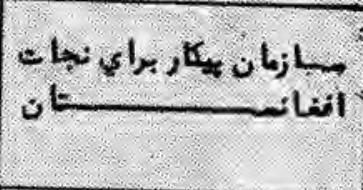 \\
\hline 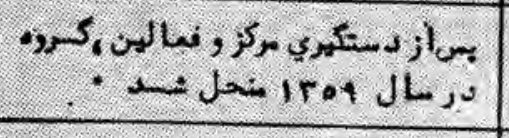 & Iret & 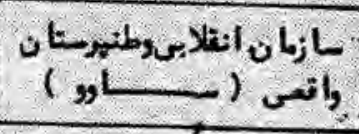 \\
\hline 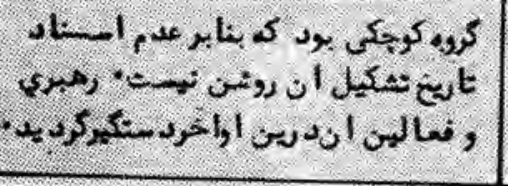 & $\therefore$ & 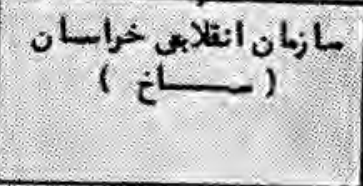 \\
\hline
\end{tabular}




\section{: نمونه مشخص بحرا ن وشكستمائوئيسم :}

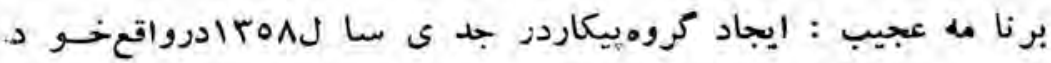
بيانكر بحران مانونيسم در افغانستانبود. زيرا محافل هتحده بنامريكسار

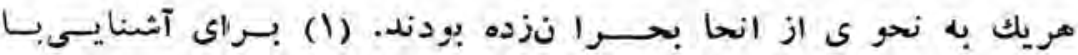

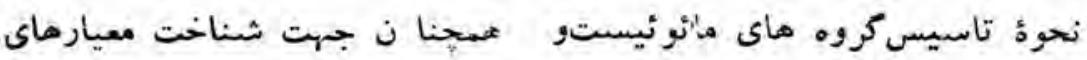

وحدت مائو ئيست ما اشار مبهجريانييوستن دو محفل به كرو • بيكا ر

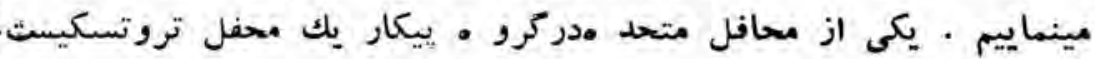

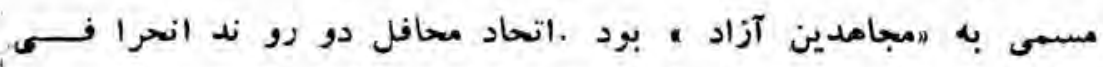

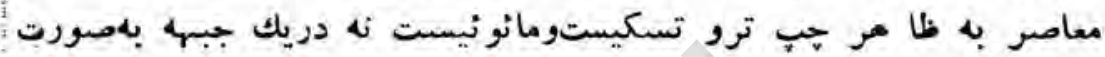
اتهاد و ائتلاف موقتى · زود كذر ومنسرو ط يا حتى درا زمدتبلكه د ر

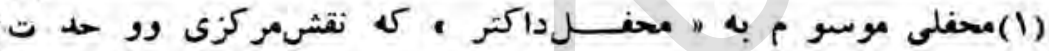

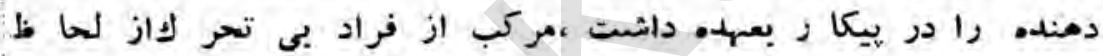

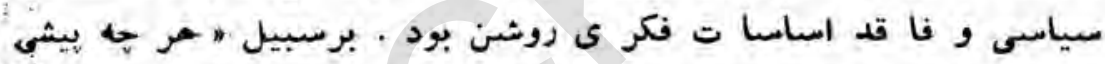

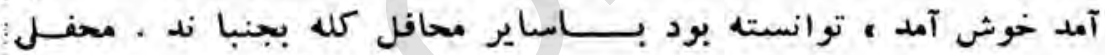

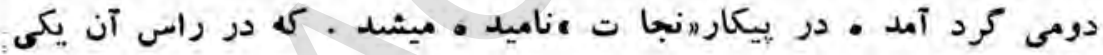
دوتن مانوئيست سابقه دار قـــرارداشت ـ اين محفل در سطع نازلتر از اولى بود . عده از دوستــــ نشخصى هم زبا ن و مم اداره راكويا

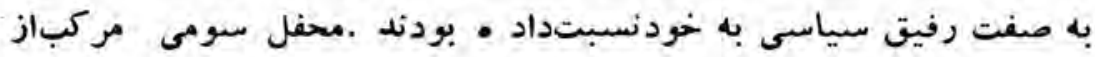
تنى جند جوانا نَ كم تجر به بقاياىكروه خورد شد ه اسمر خاء بـــــود

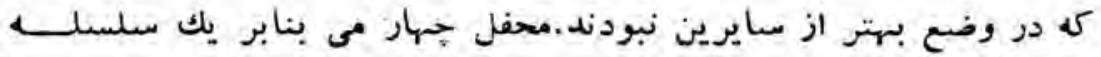

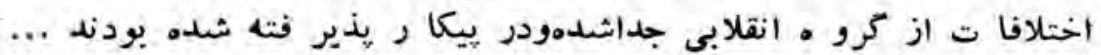




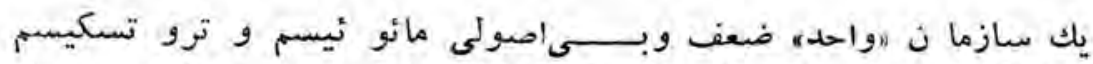

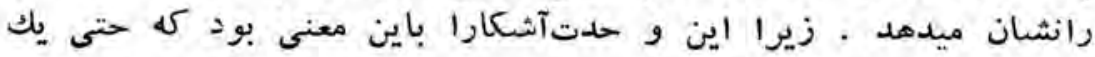

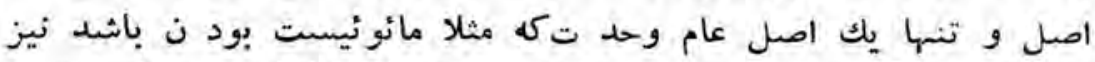

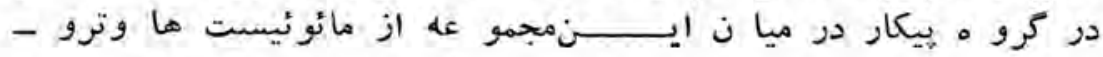

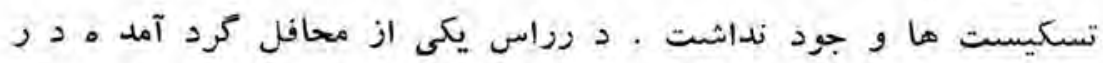

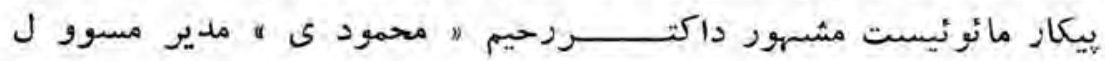

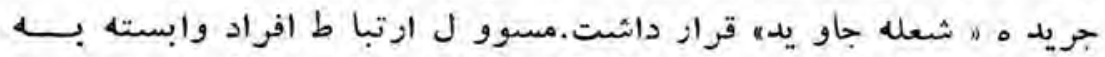

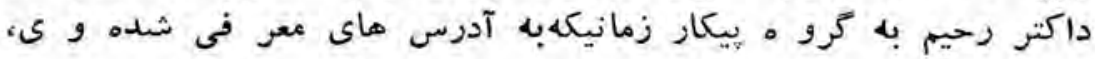

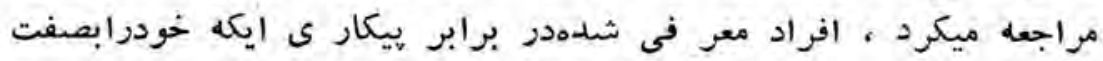

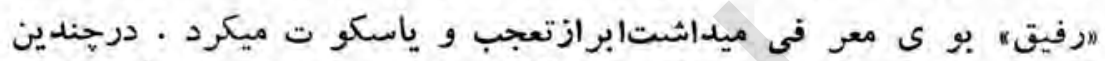

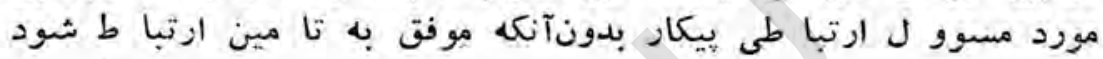

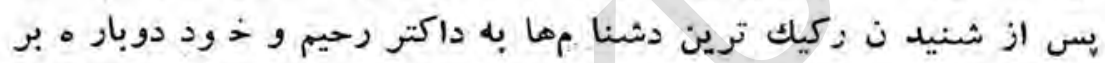

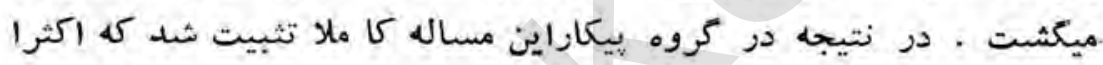

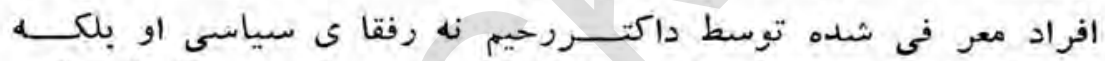

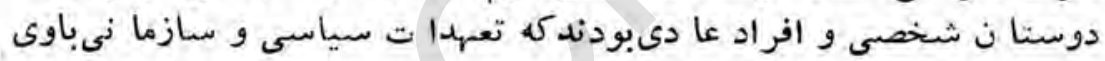

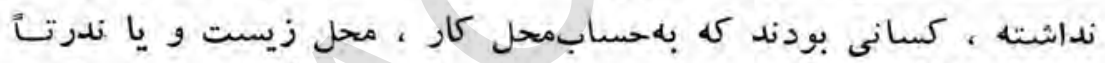

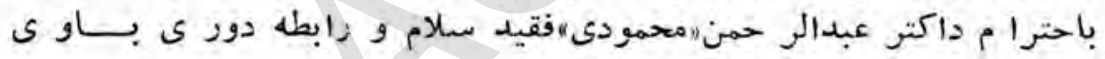
داثشتثد

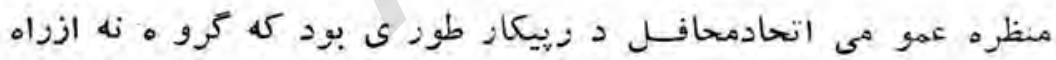

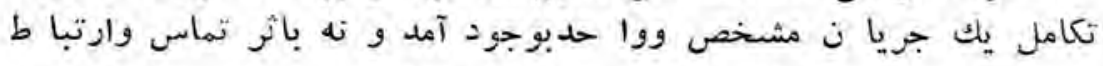

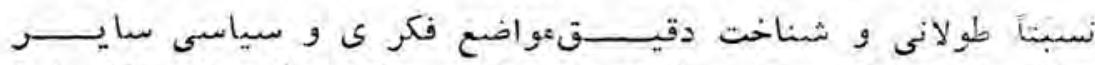

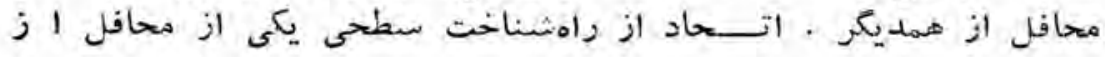

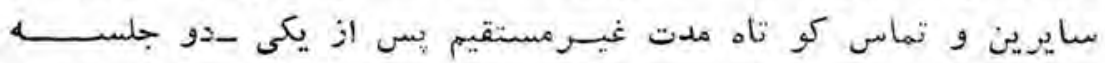

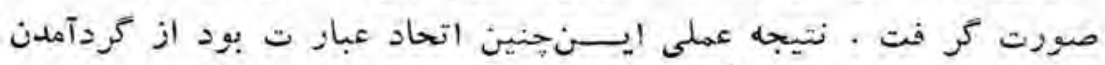

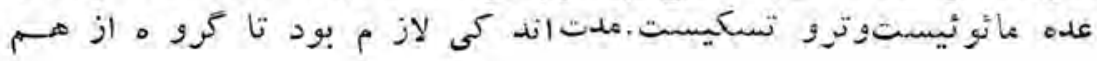




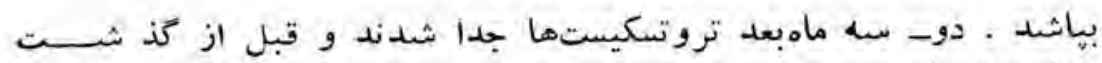

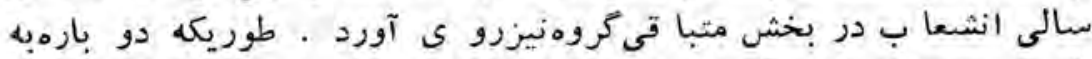

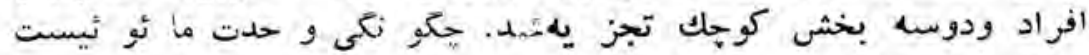

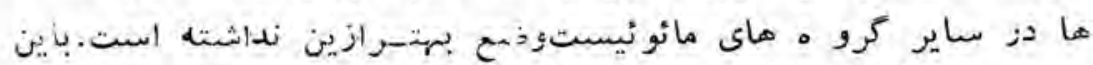

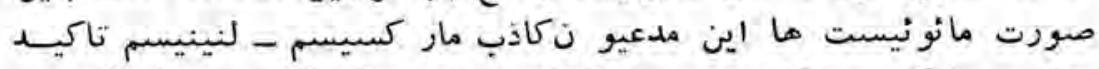

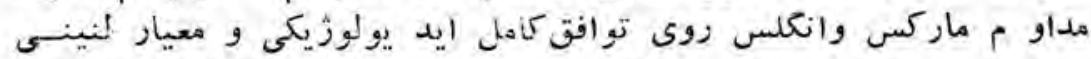

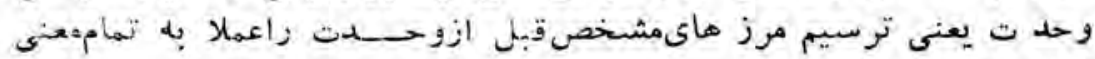

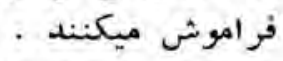

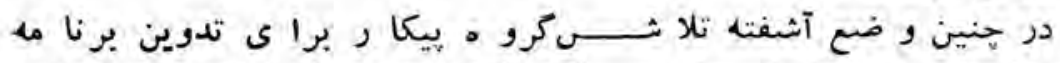

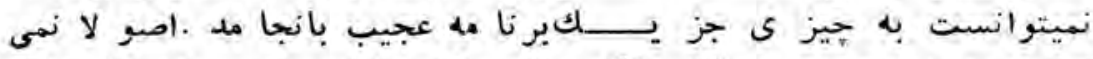

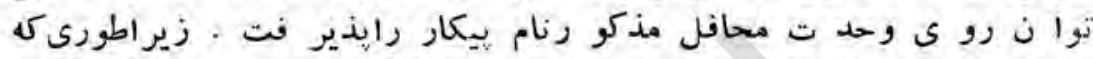

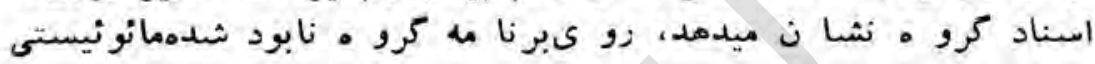

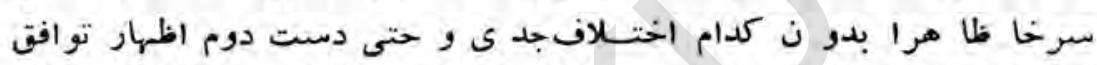

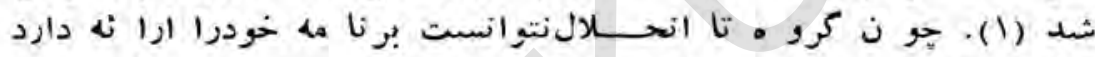

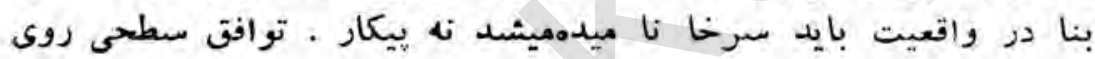

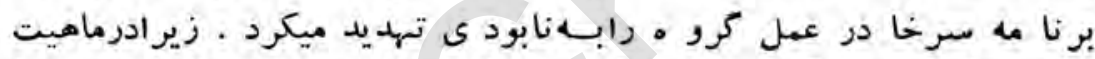

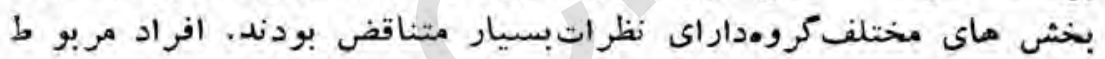

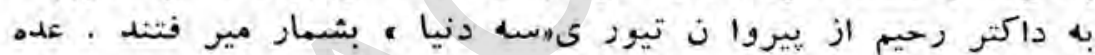

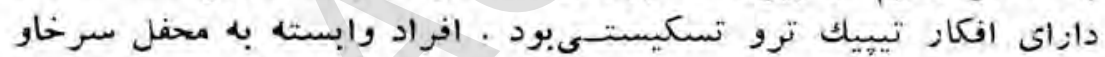

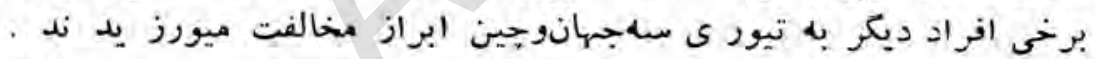

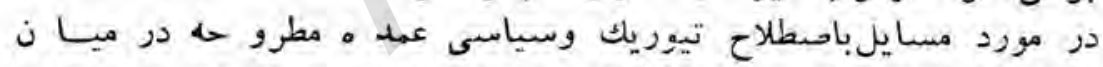

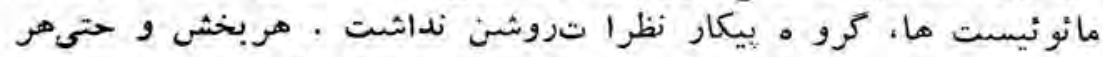

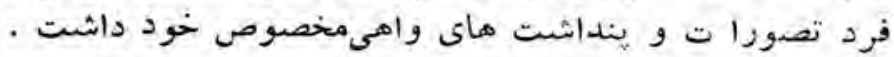

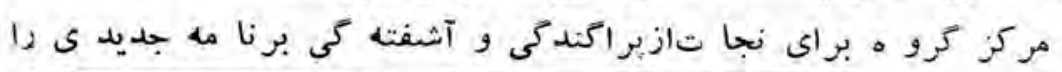

(1)

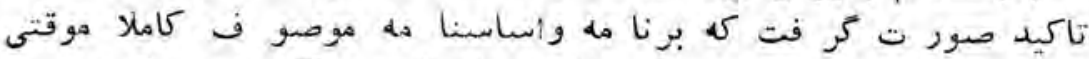

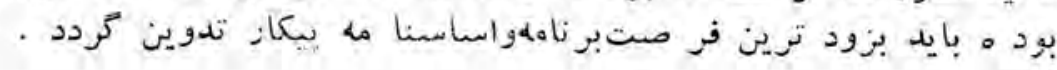




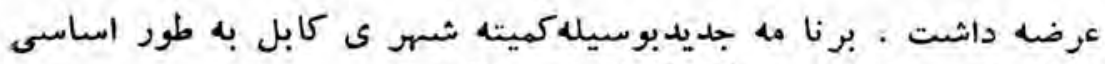

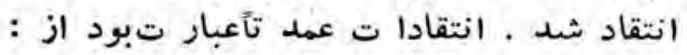

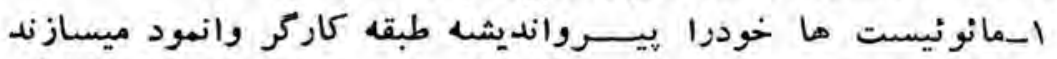

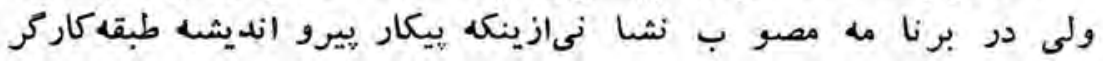

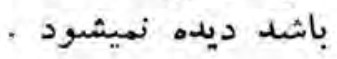

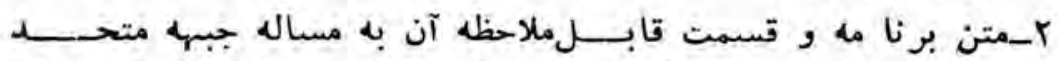

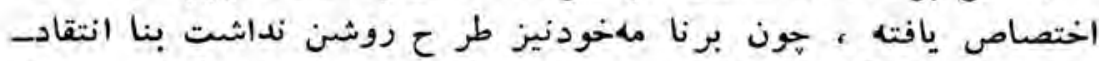

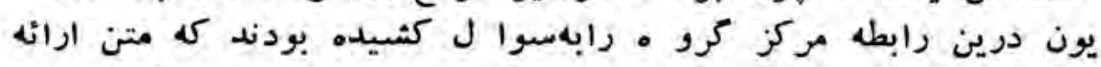

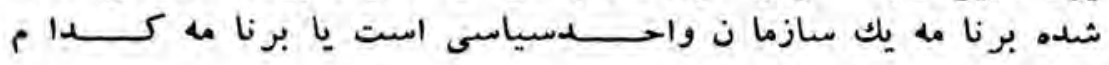
جبه ؟ بـان

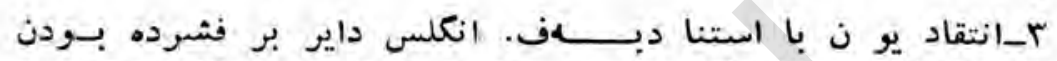

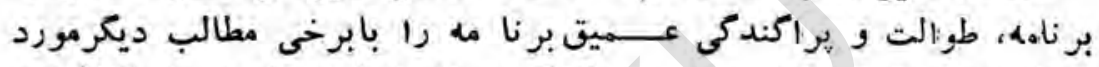

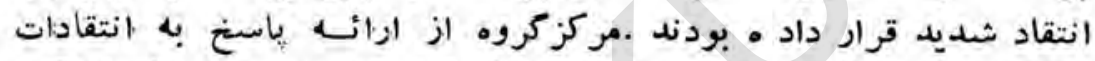

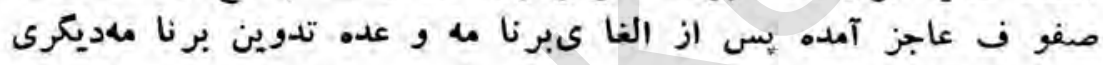

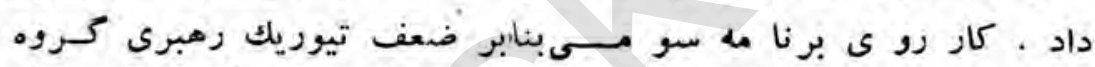

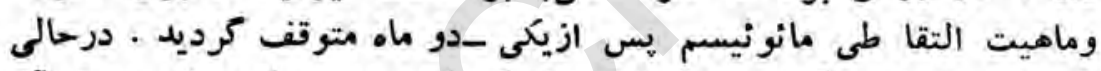

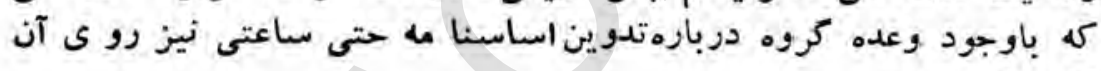
كارنشده بودود وعنده

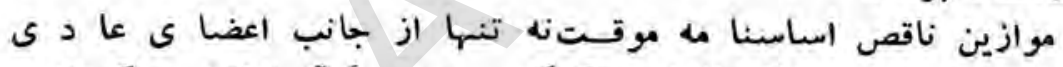

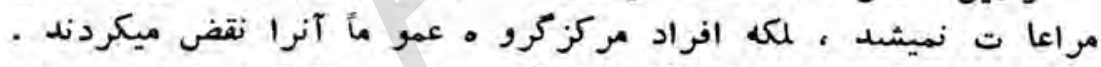

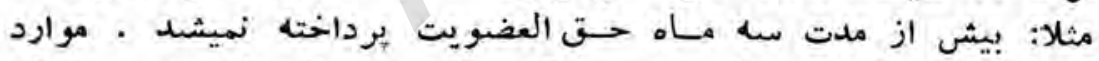

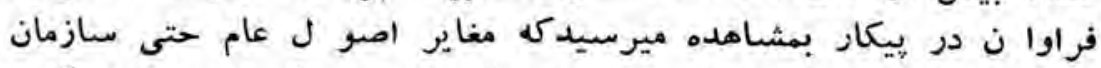

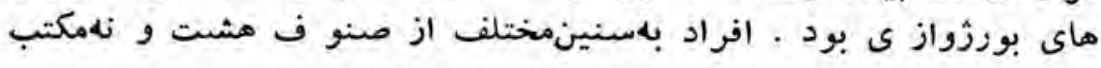

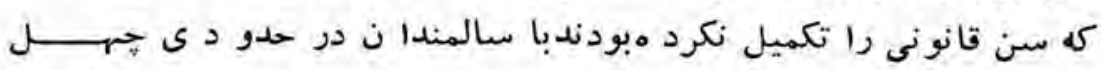

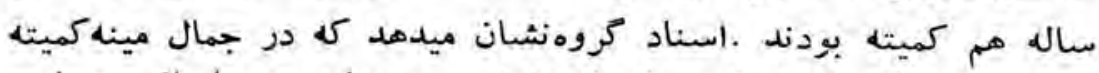

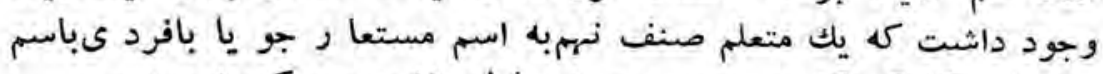

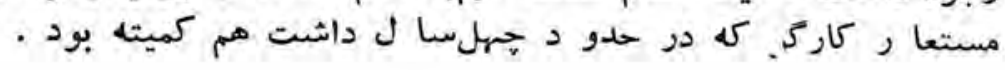




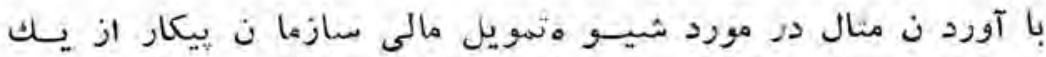

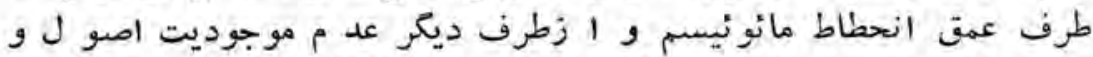

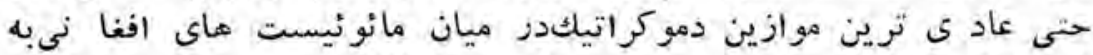

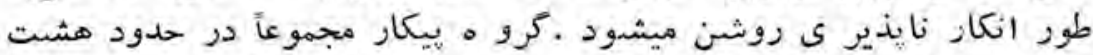

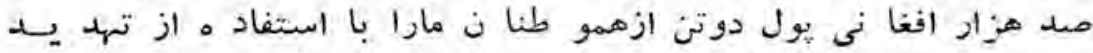

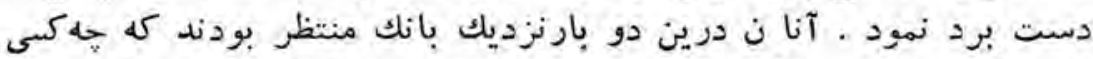

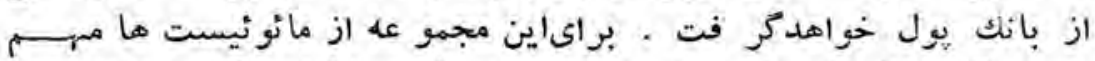

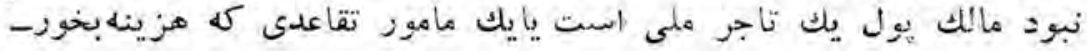

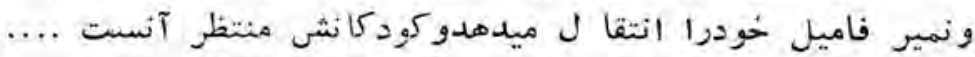

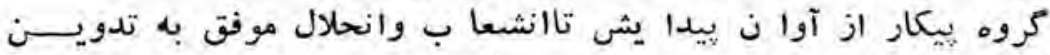

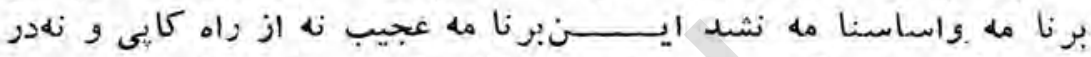

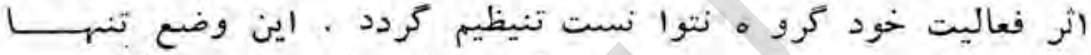

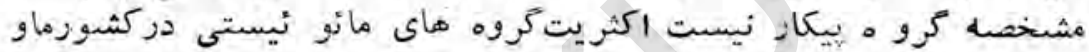

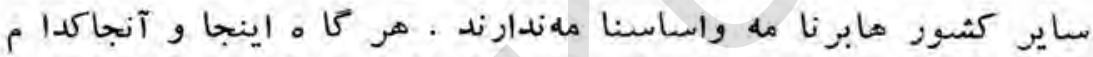

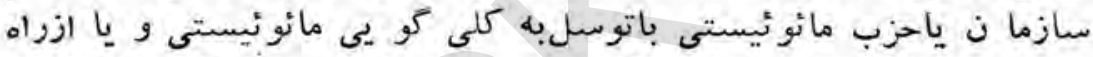

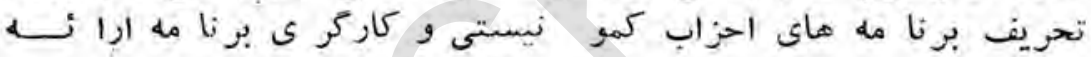

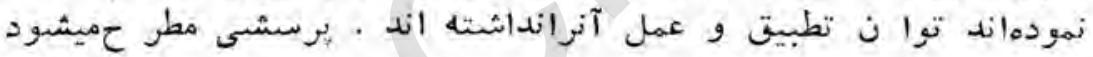

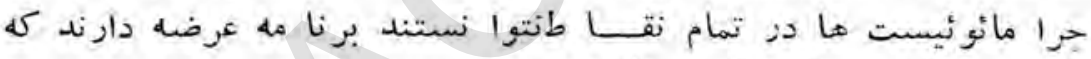

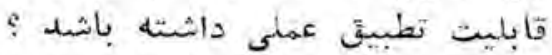

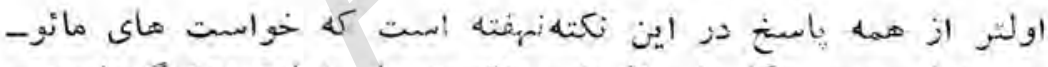

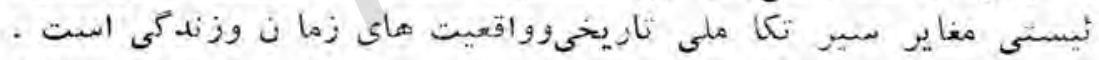

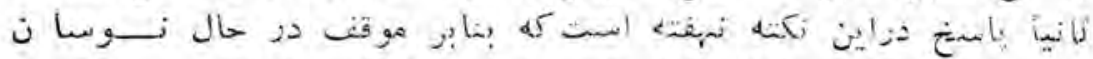

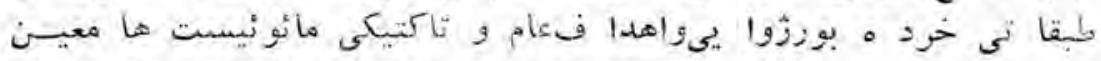

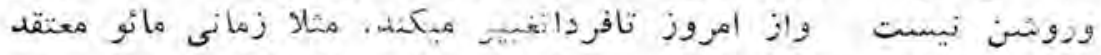

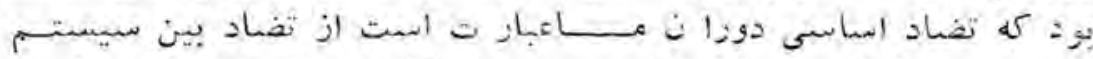

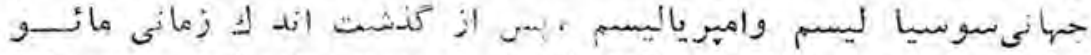

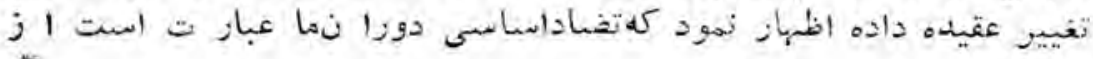




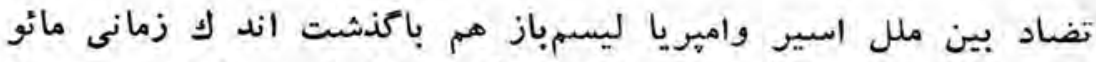

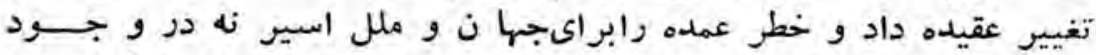

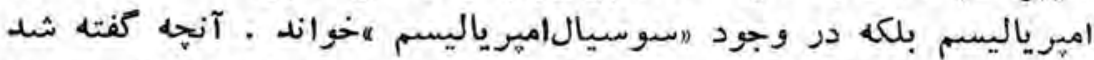

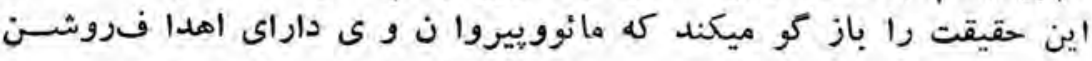

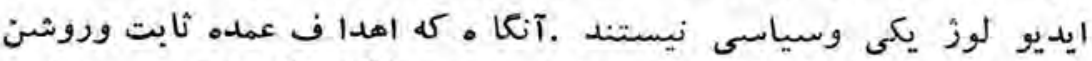

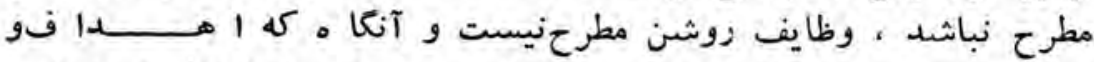
وظايف عمده مشخص و و روشنوجودندارد برنا مونا مه و واساسنا مه مشخص وعلمى نميتواند و جود داشته ونه باشد.

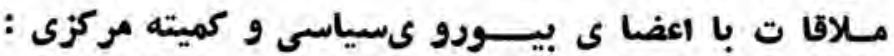

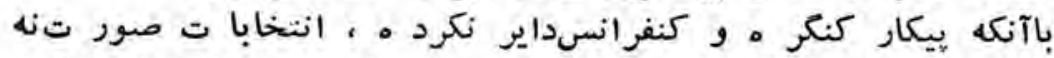

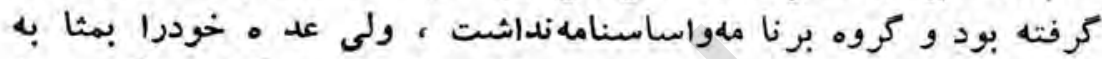

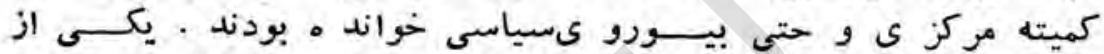

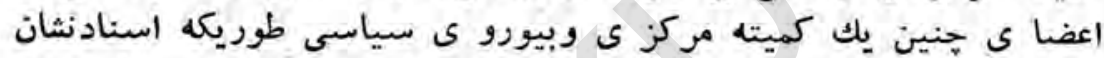

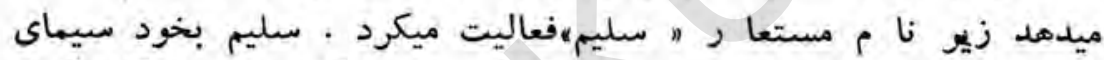

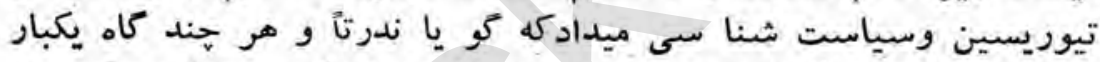

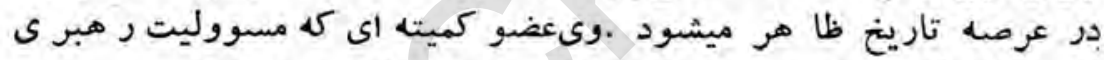

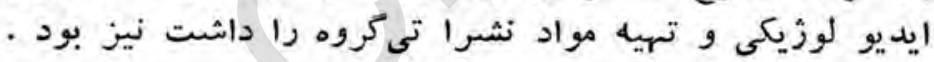

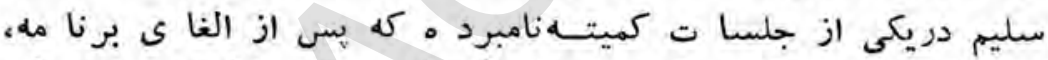

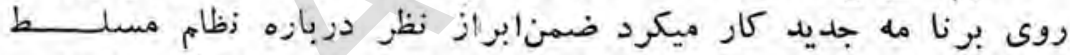

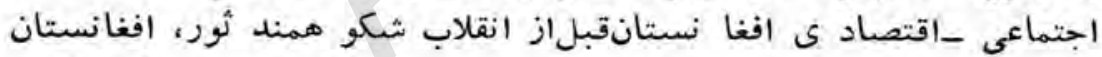

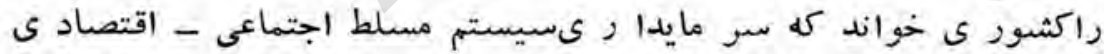

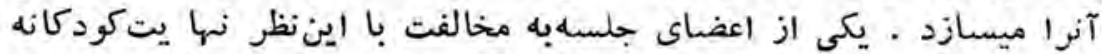

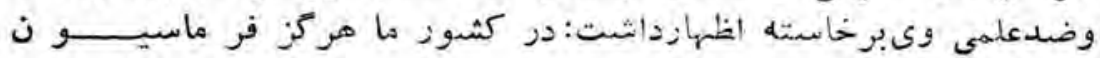

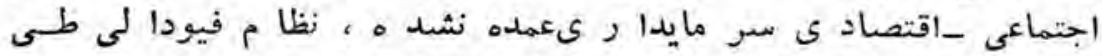

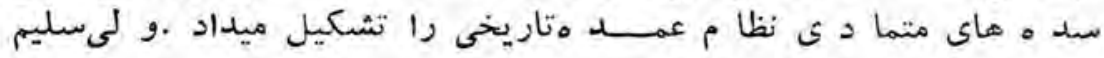

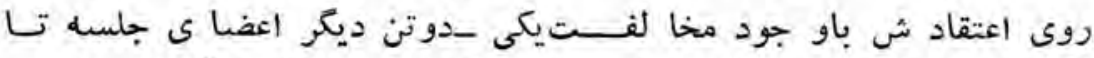

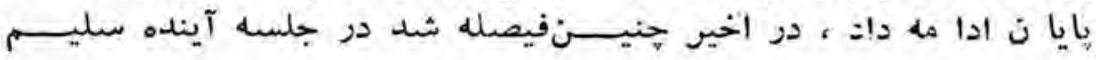




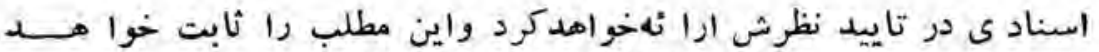

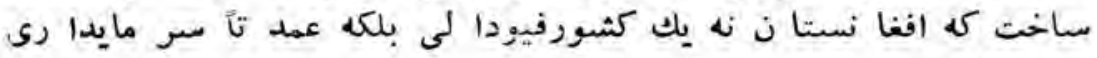

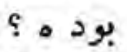

\section{"دودلت سو سيا ل دمو كــــرا تاسلامى ":}

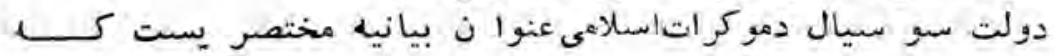

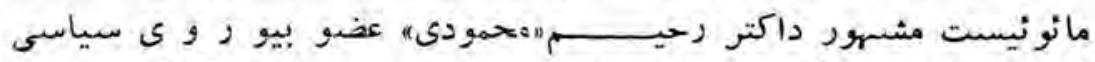

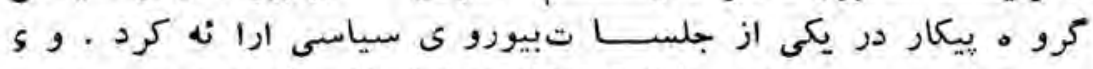

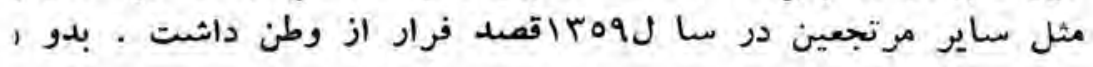

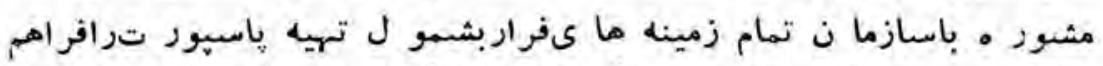

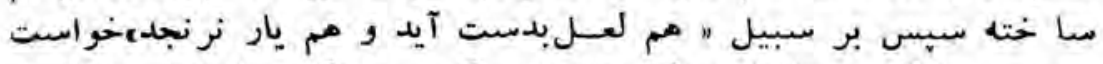

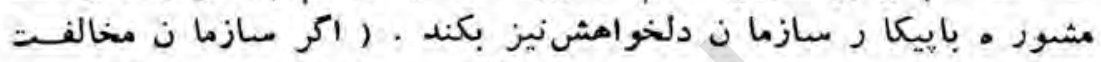

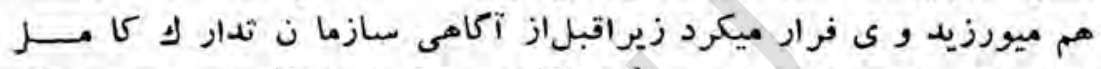

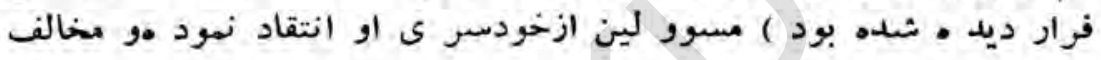

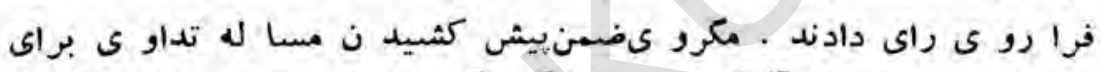

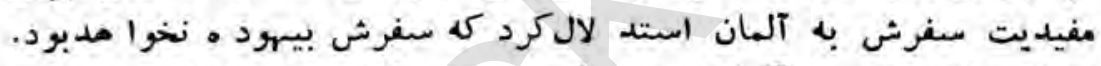

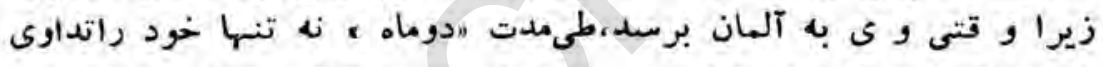

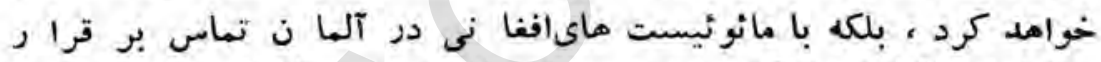

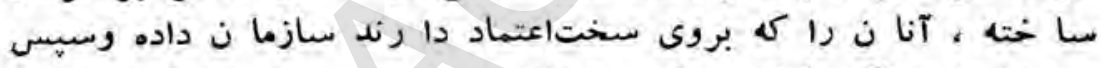

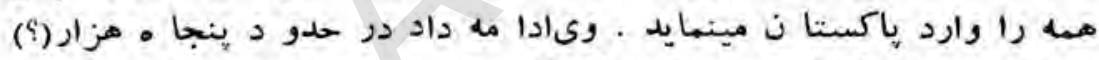

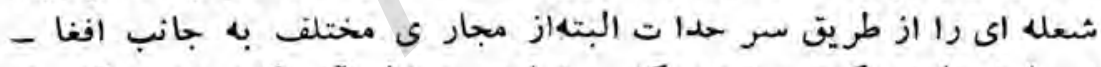

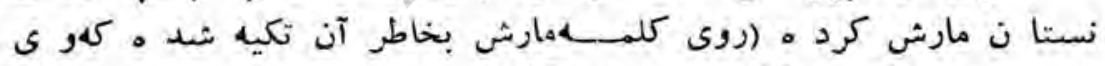

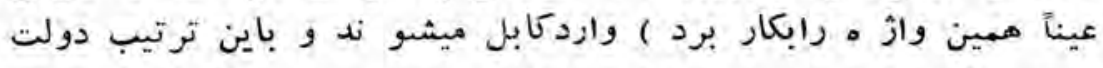

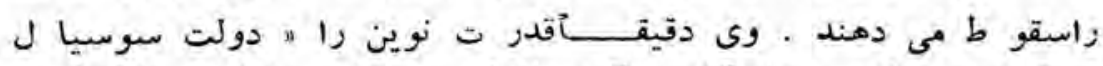

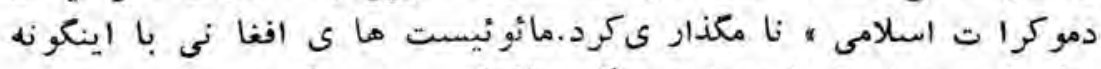

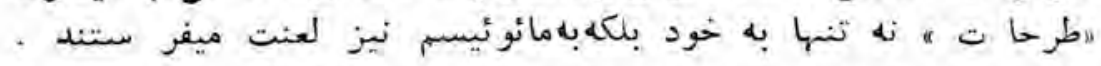

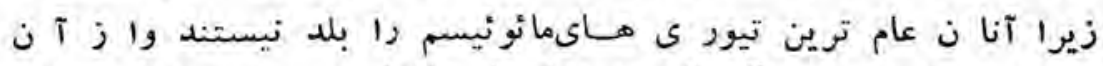

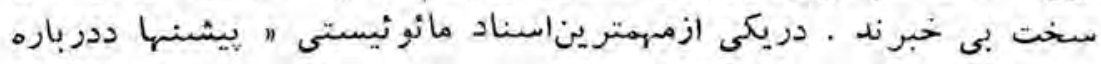




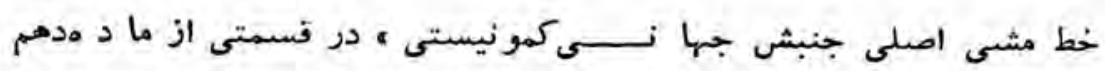

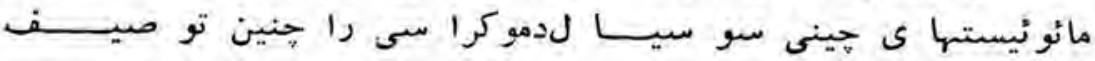

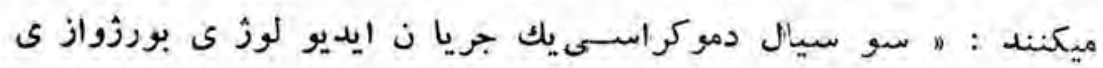

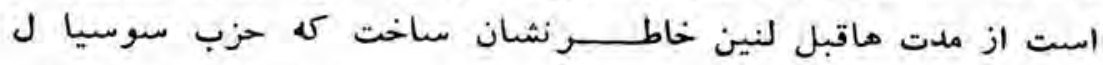

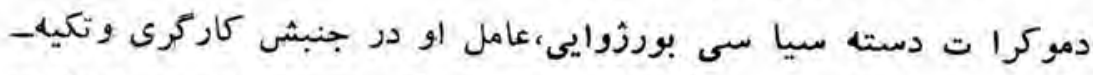

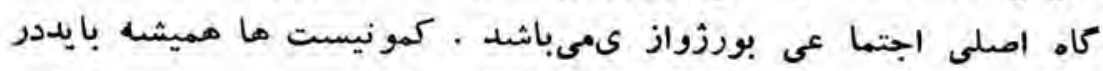

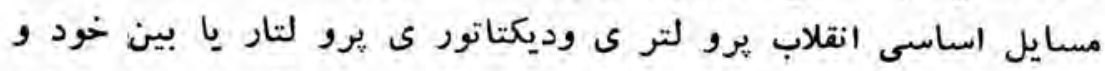

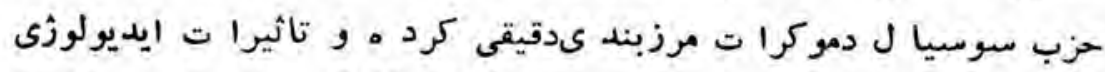

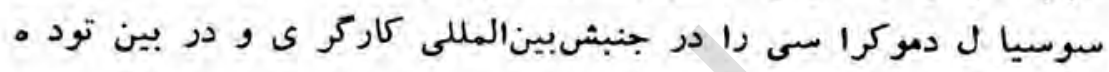

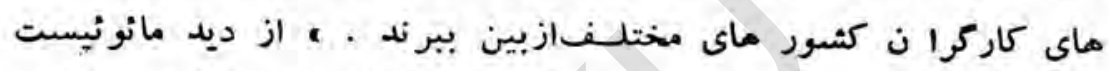

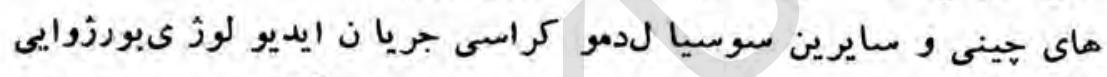

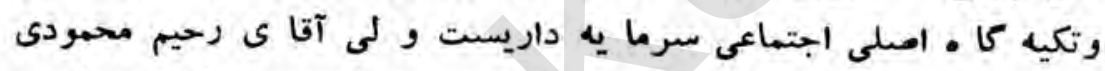

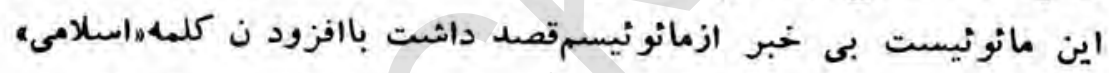

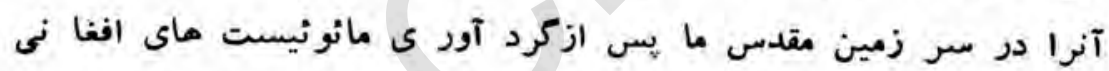

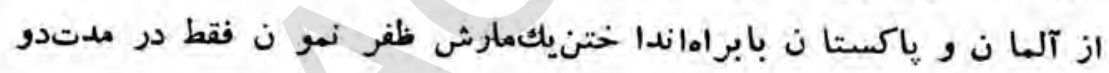
ماه مستقر سازد .

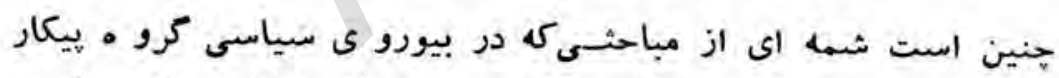

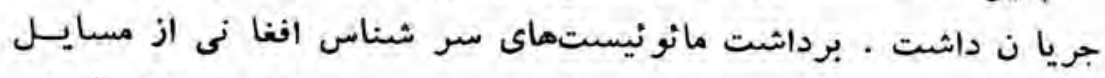

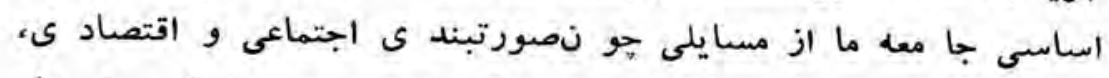

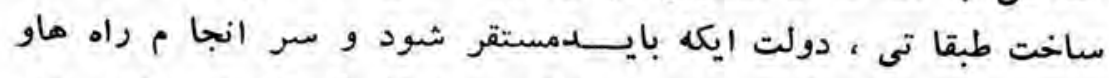

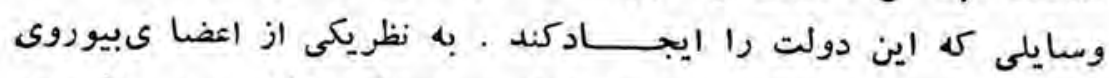

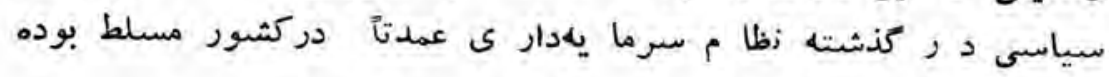




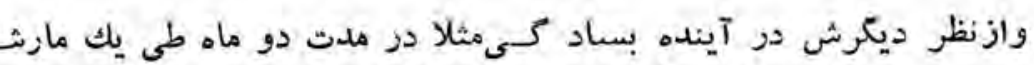

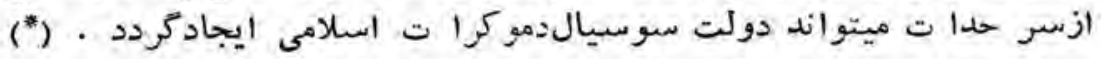

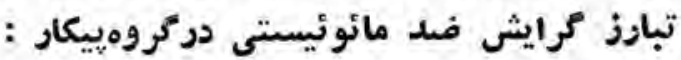

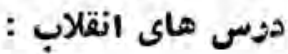

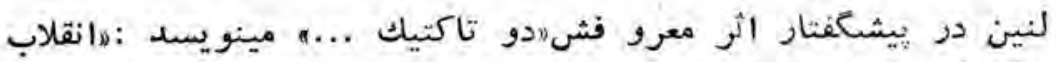

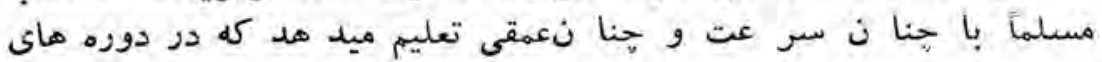

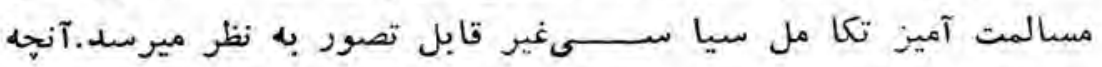

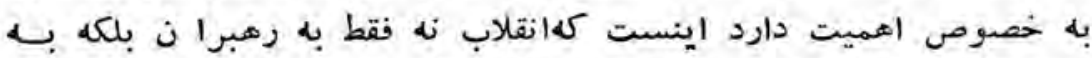

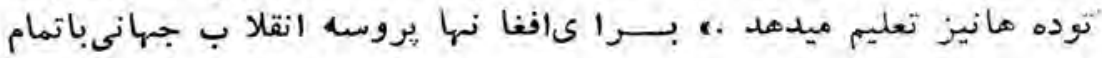

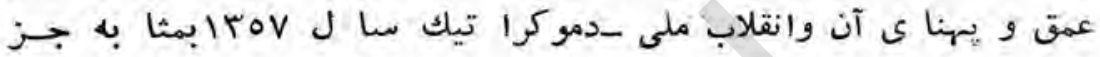

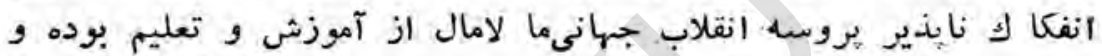

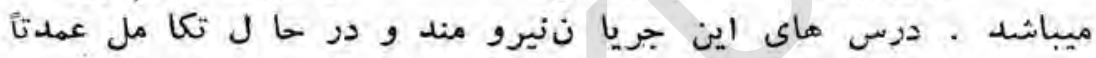

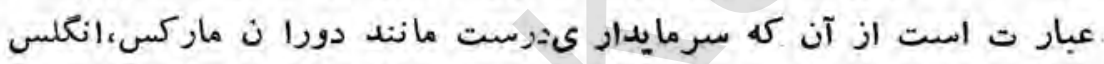

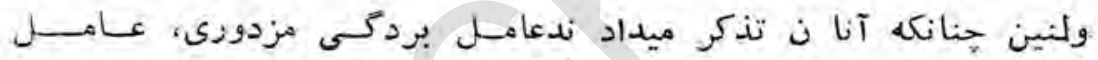

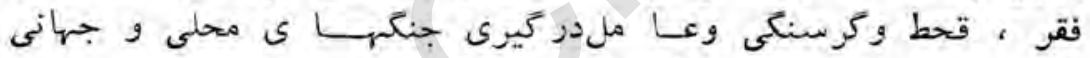

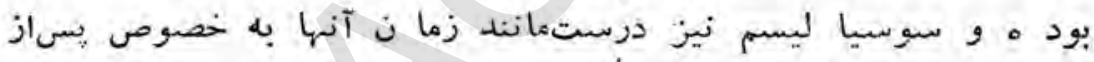

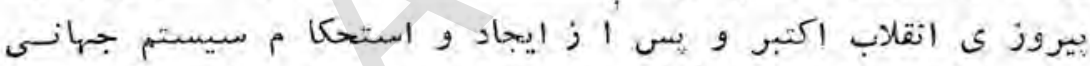

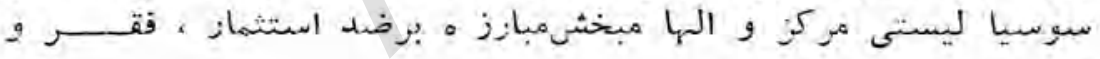

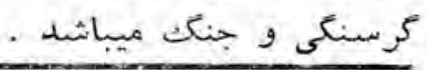

$$
\text { (") }
$$

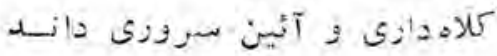

\section{مزاد نكتة بازيكتر زنو اينجاست كاد}

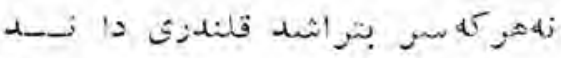

( افاف) ( ) 


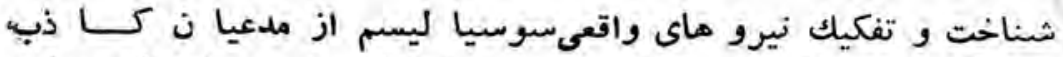

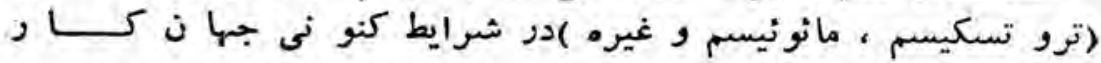

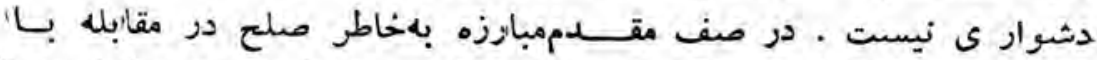

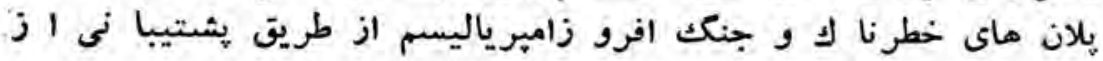

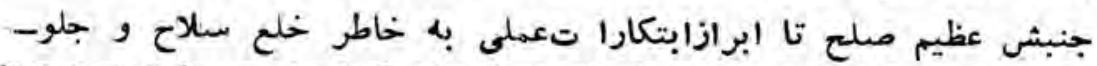

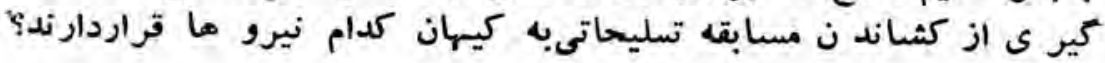

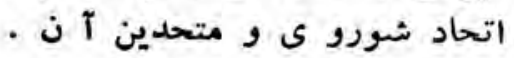

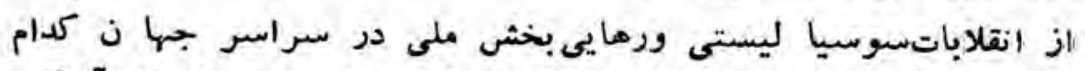

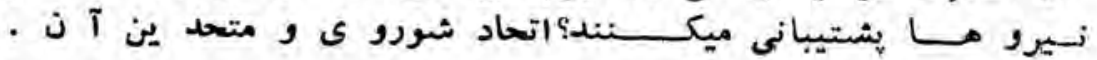

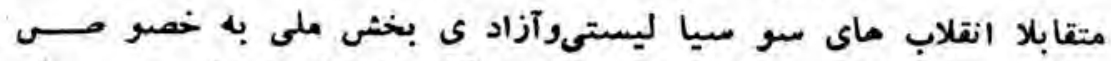

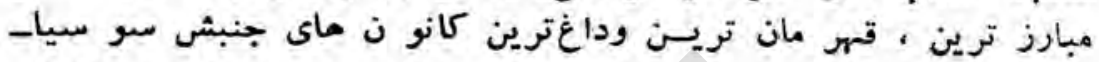

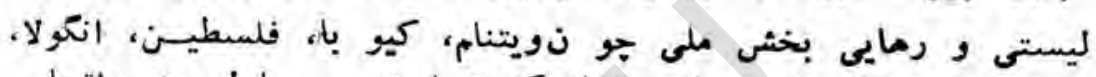

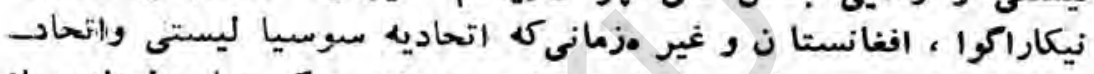

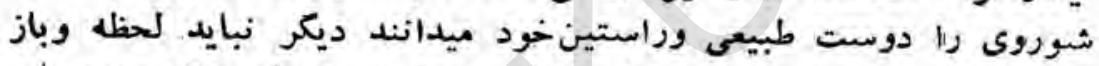

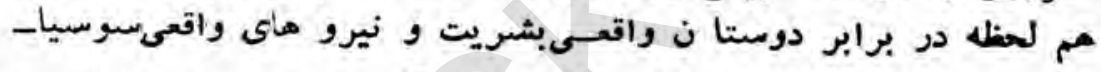

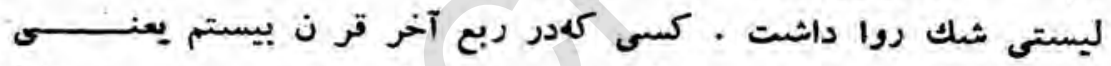

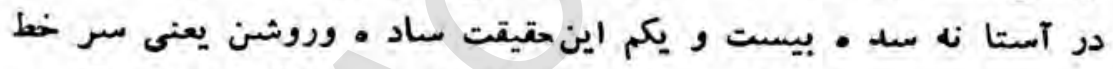

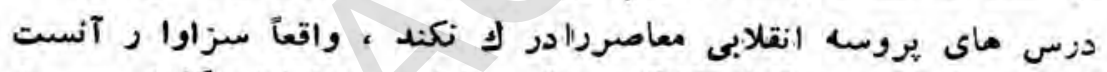

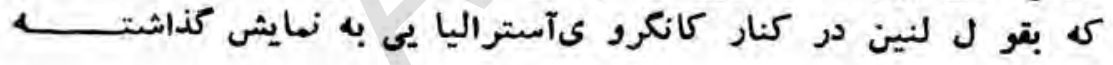

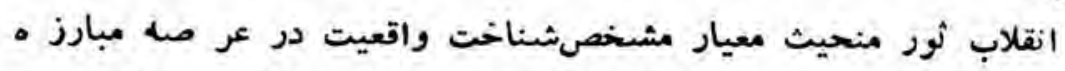

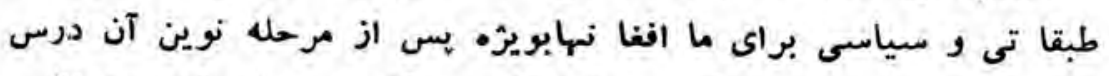

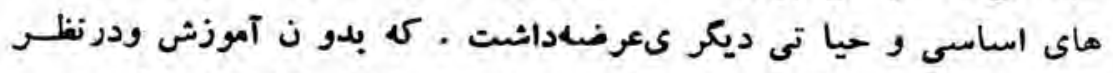

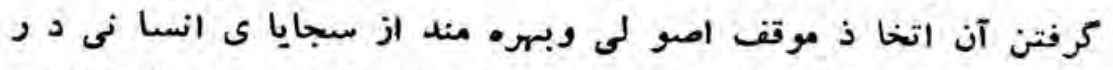

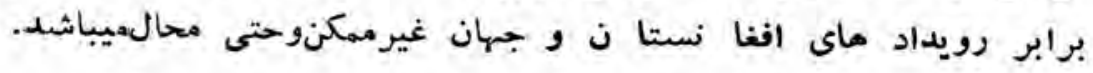




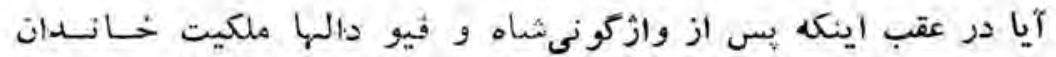

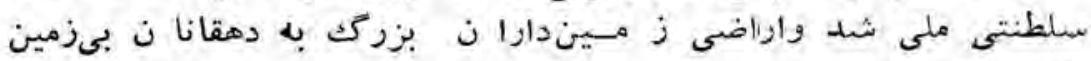

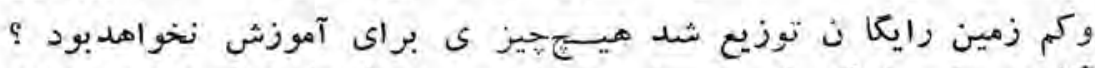

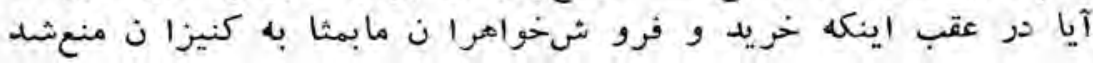

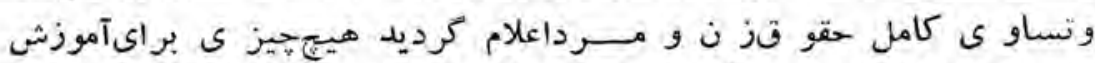

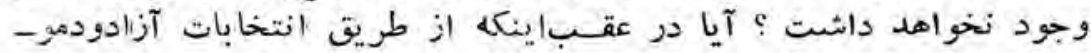

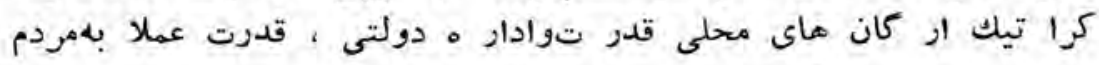

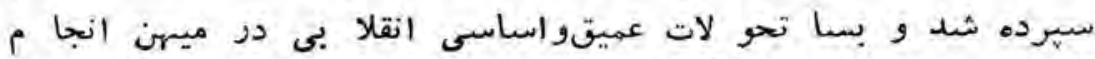

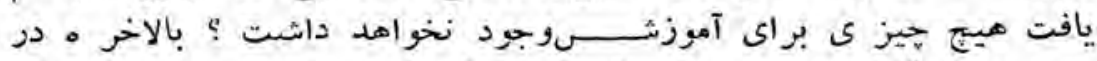

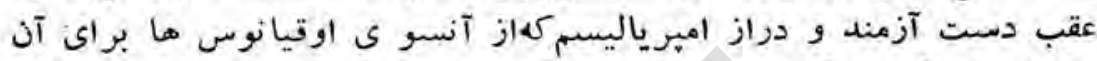

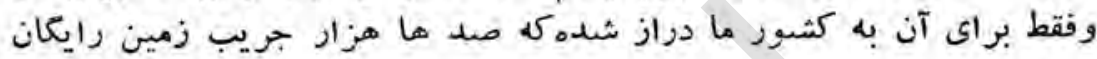

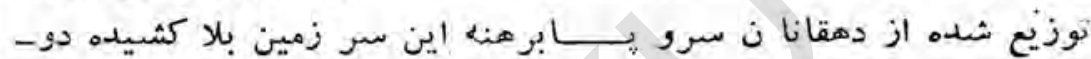

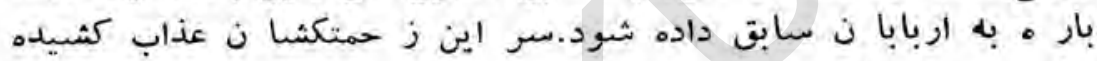

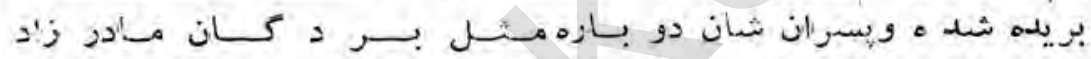

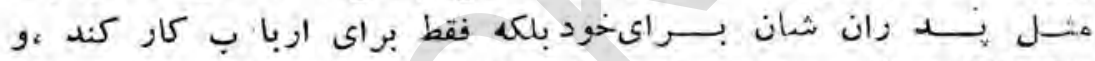

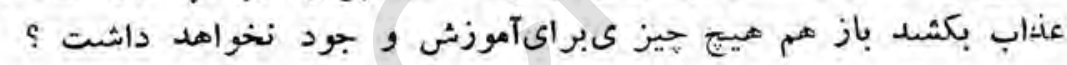

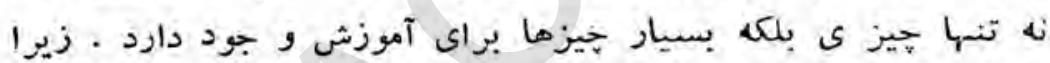

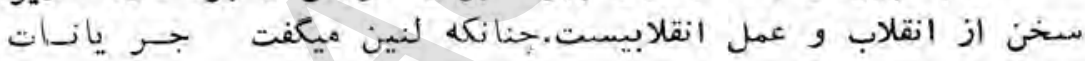

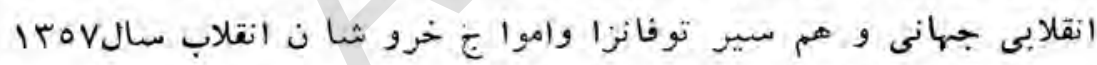

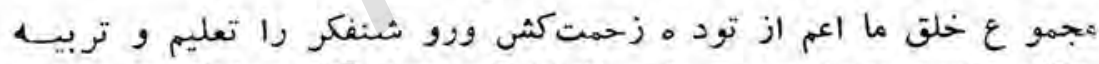

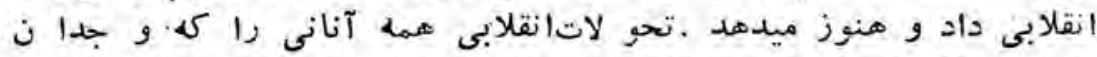

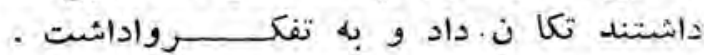

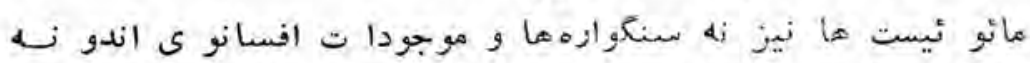

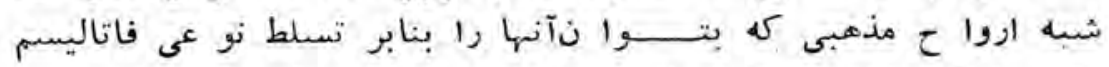

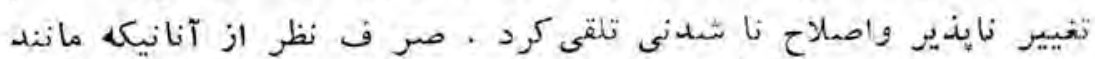

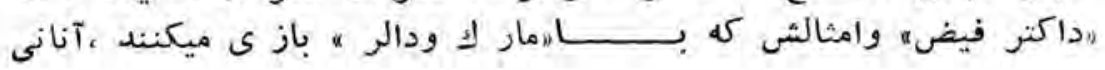




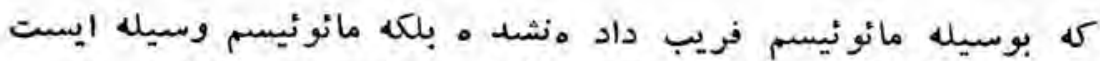

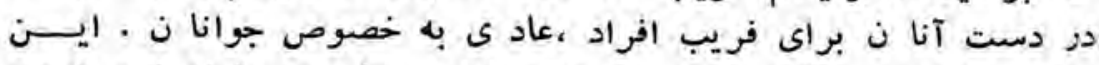

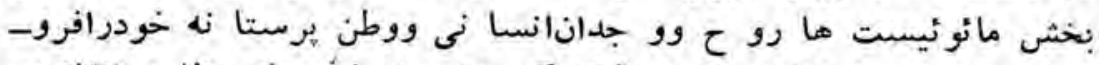

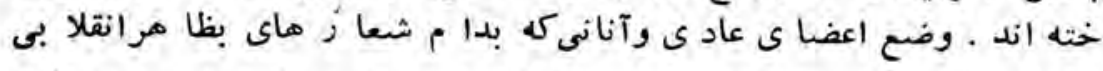

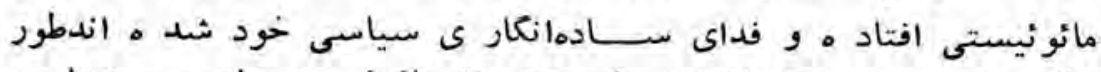

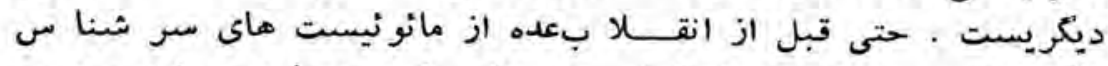

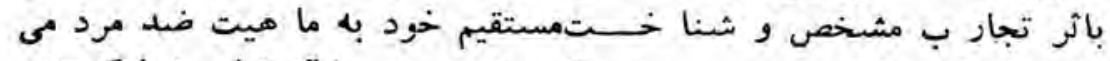

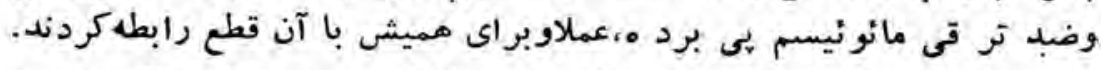

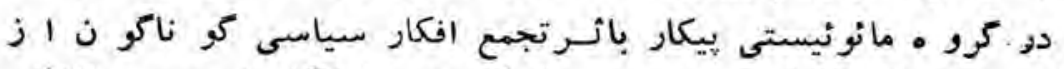

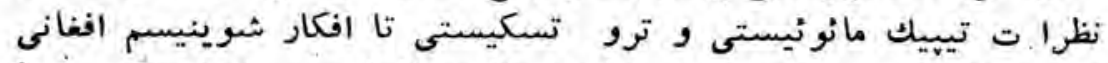

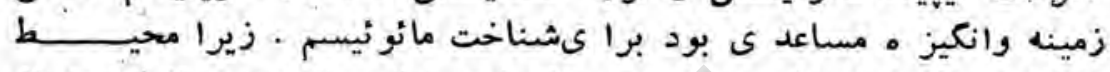

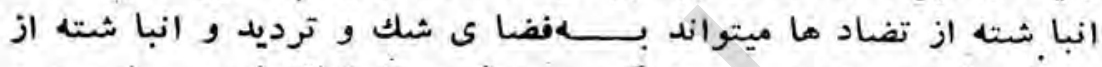

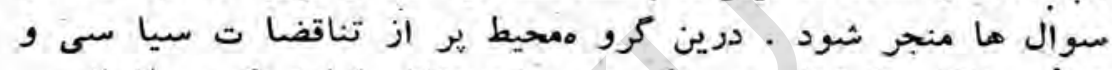

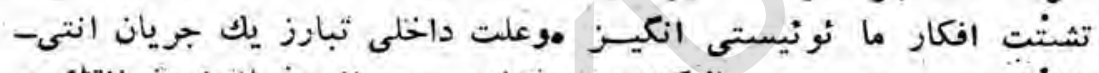

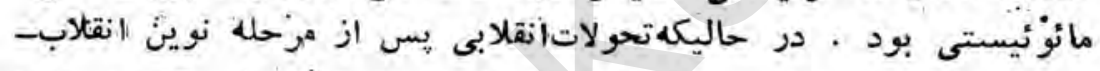

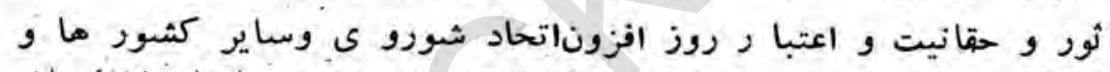

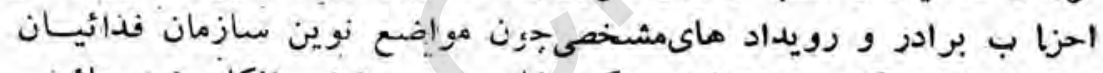

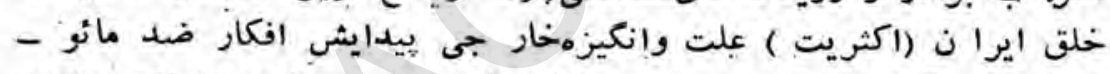

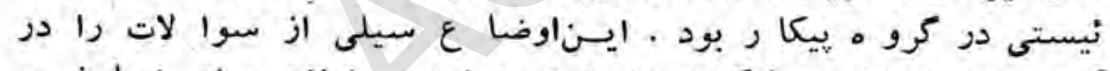

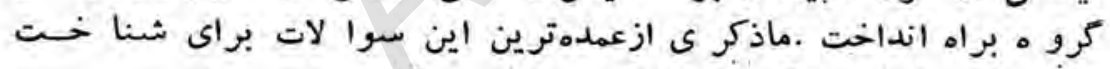

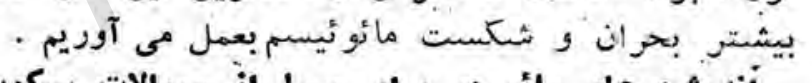

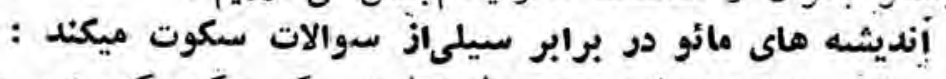

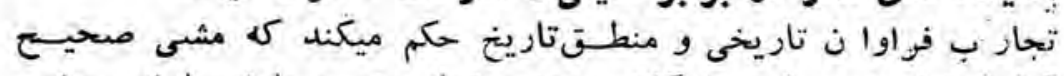

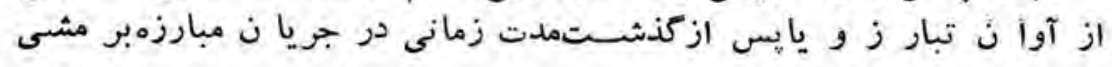

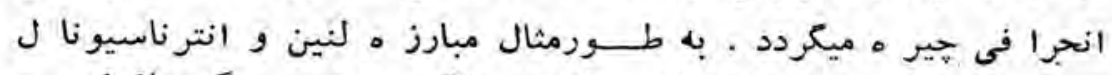

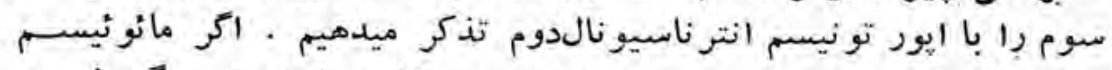

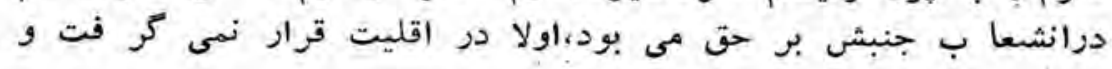




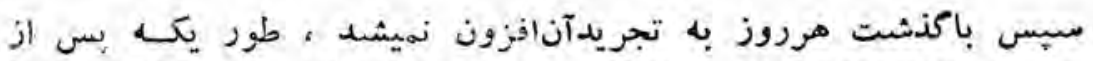

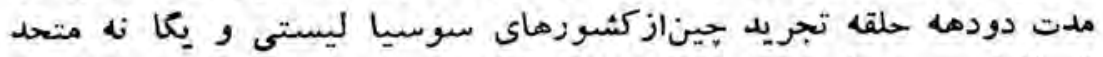

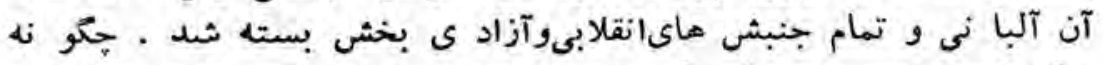

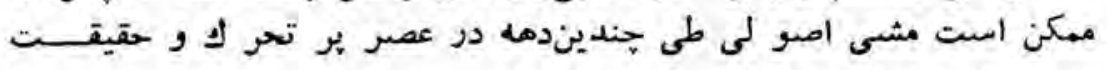

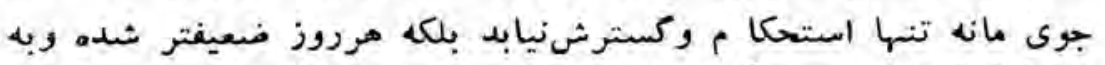

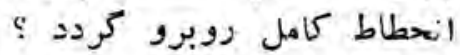

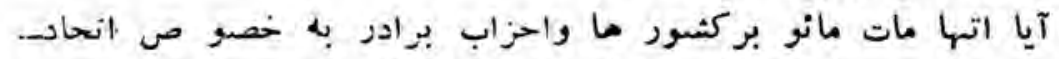

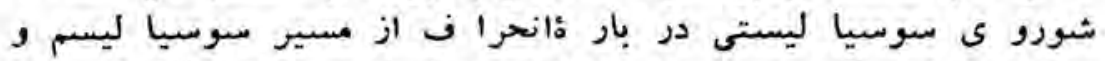

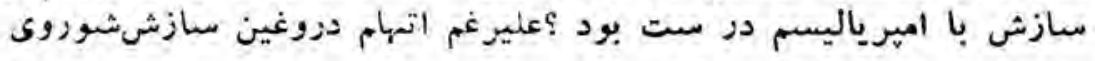

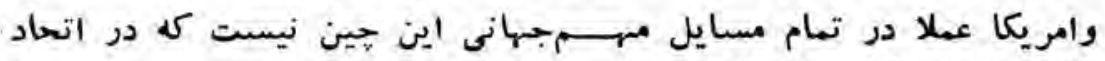
كامل با امريكا علا در ترام دارد ؟

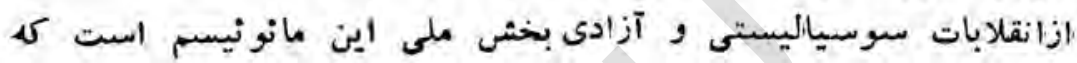

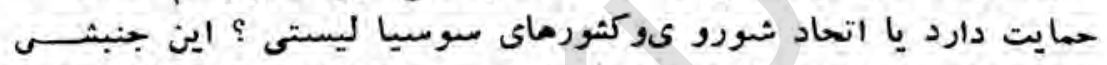

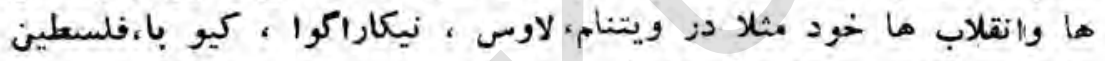

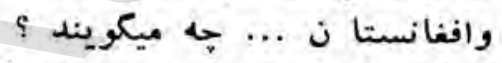

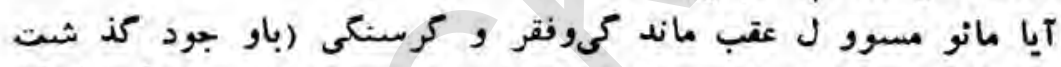

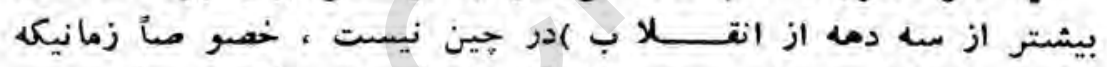

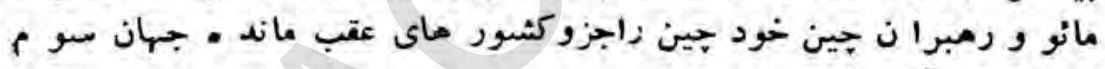

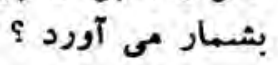

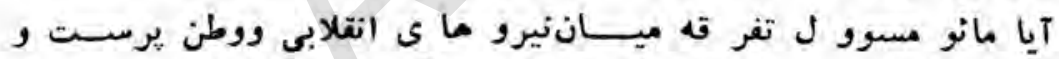

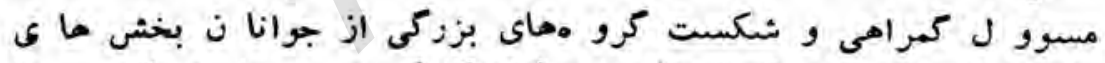

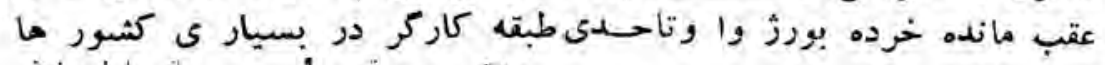

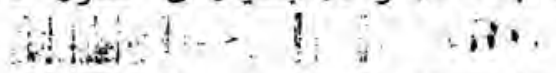

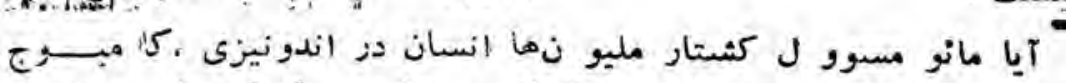

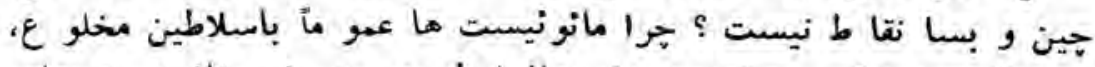

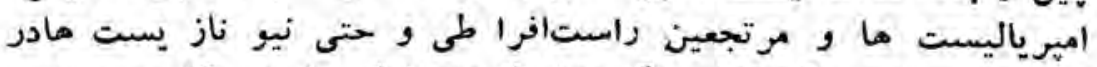

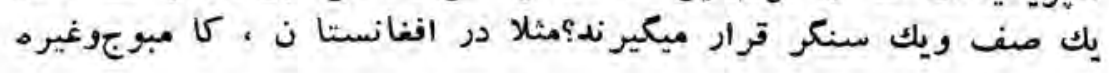




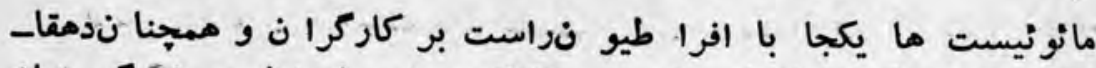

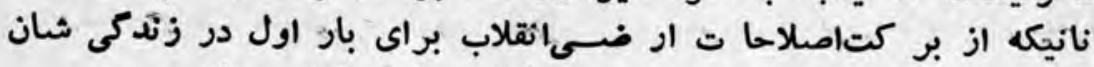

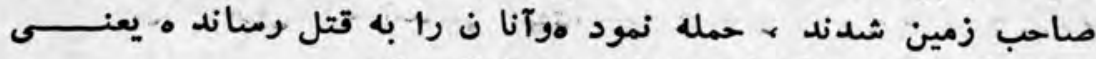

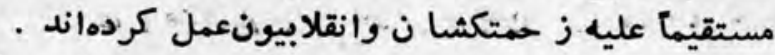

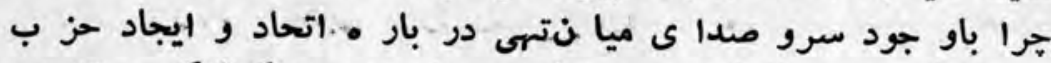

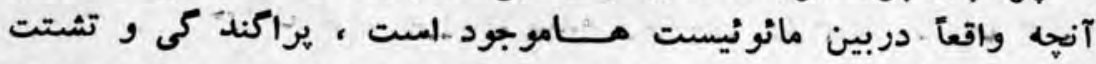

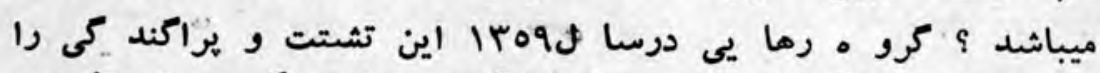

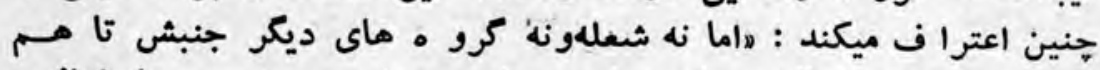

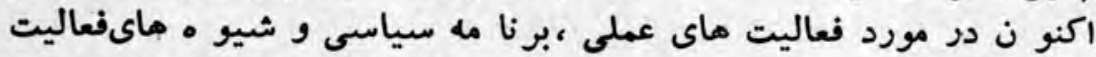

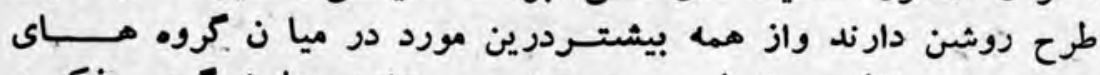

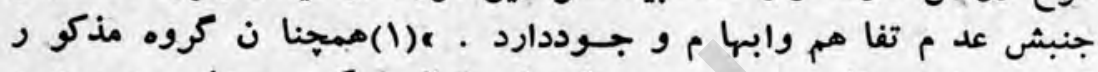

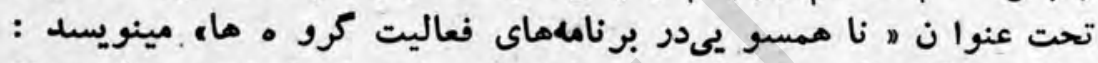

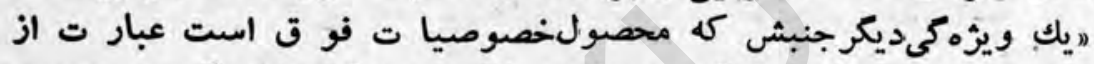

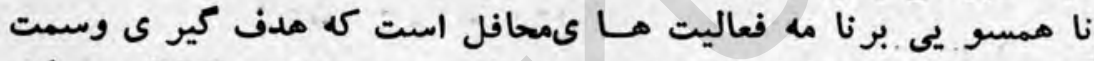

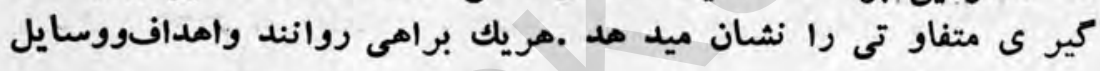

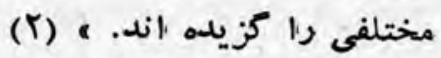

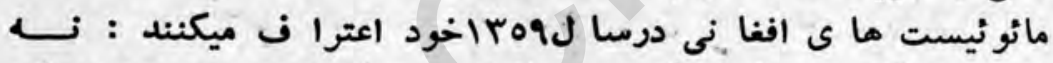

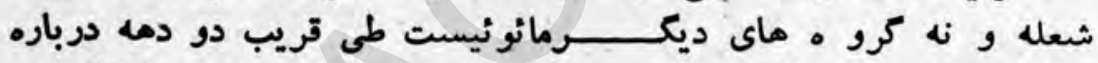

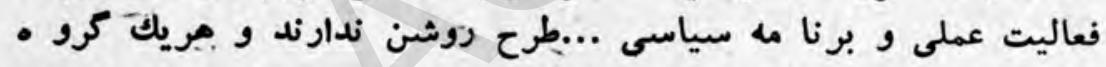

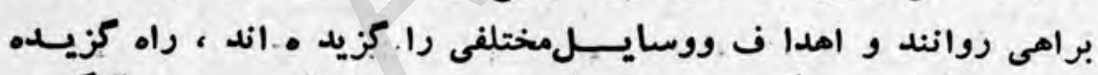

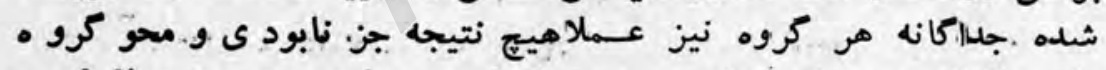

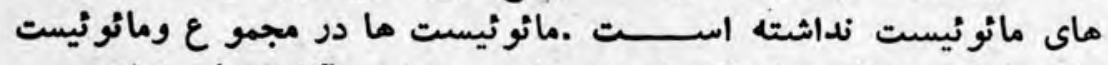

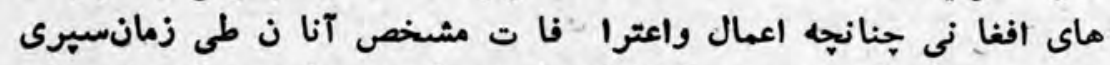

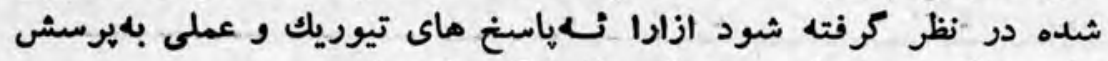

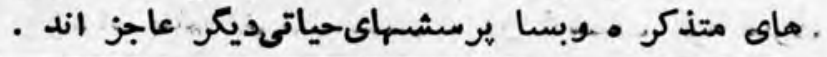

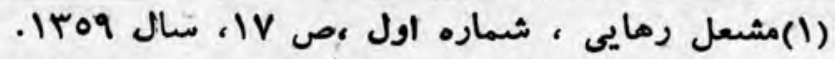

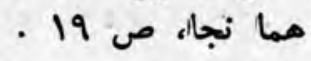




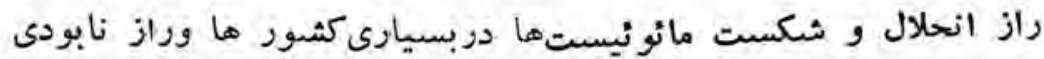

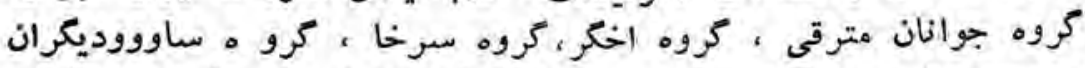

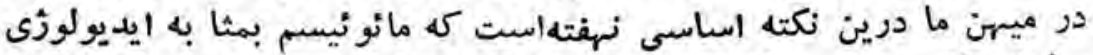

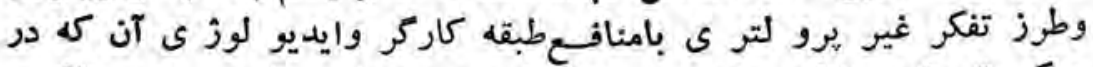

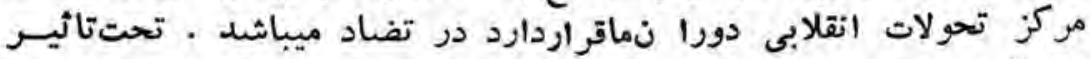

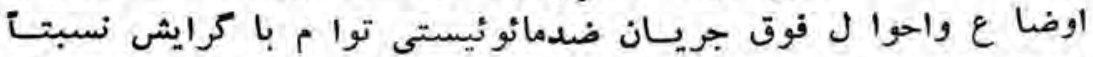

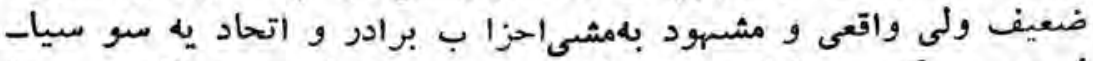

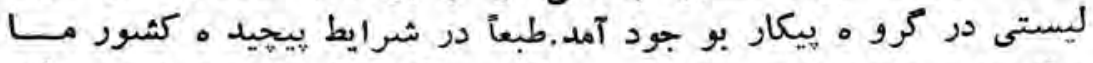

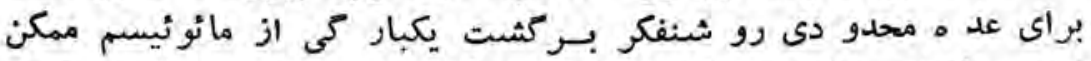

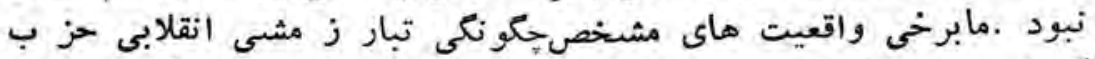

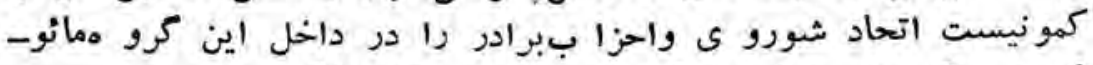

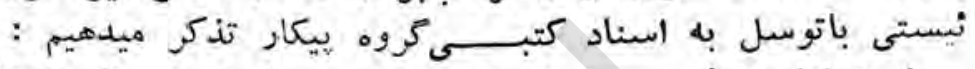

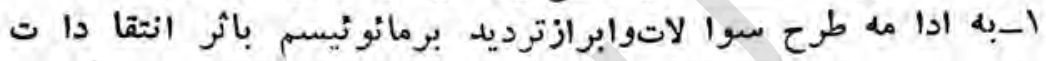

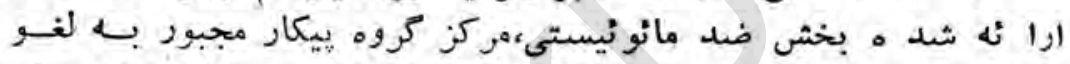

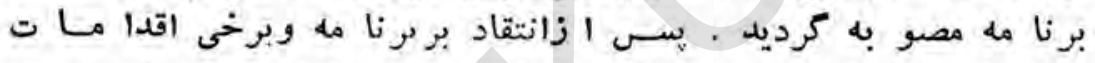

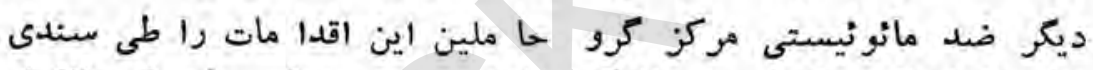

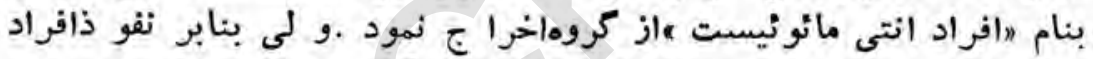

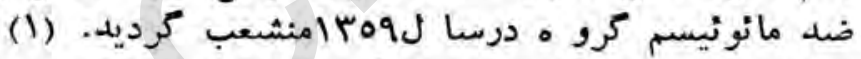

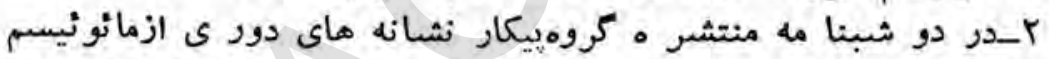

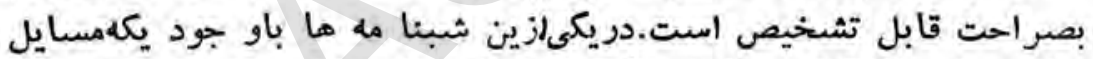

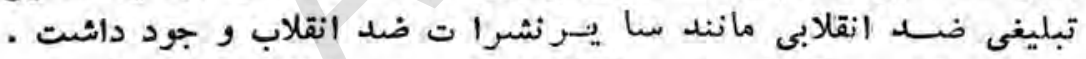

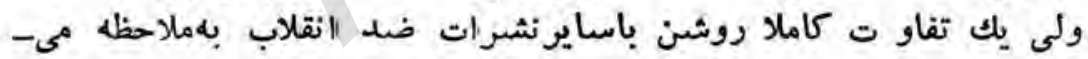

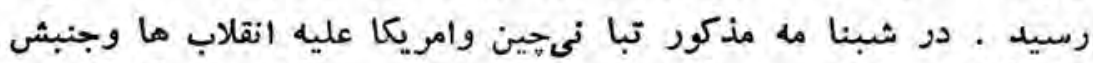

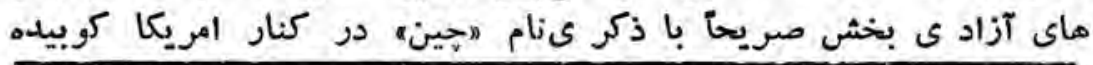

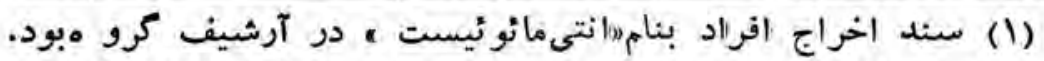

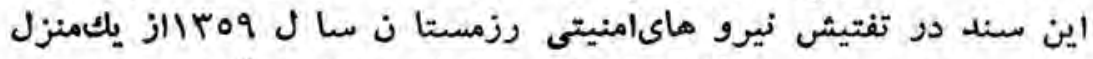
واقع حصه سو م خير خانهدراختيارنيرو ماى امنيتى درآمه . 


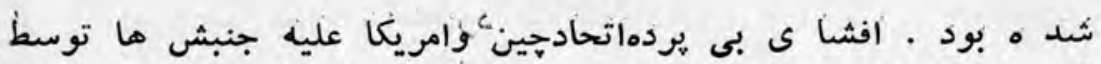

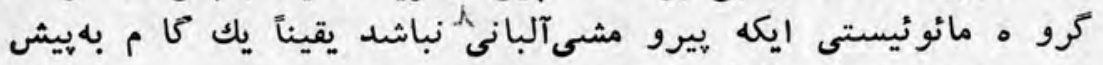

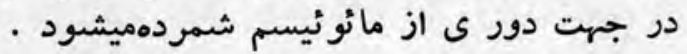

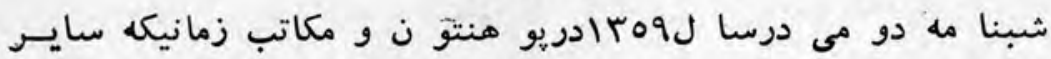

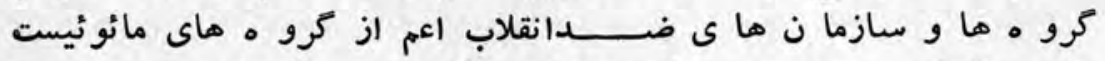

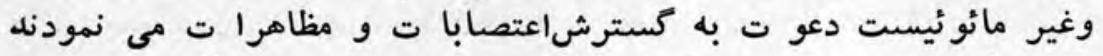

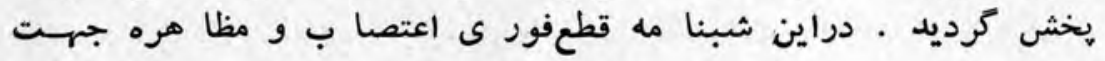

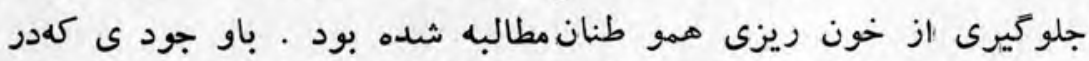

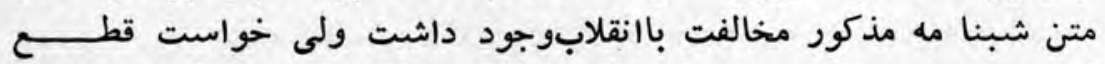

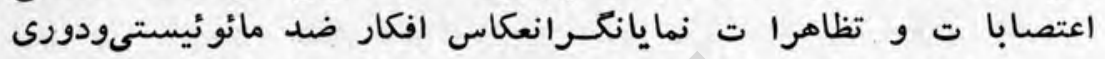

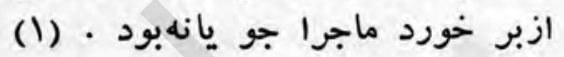

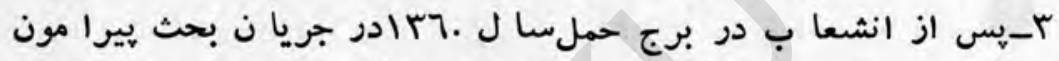

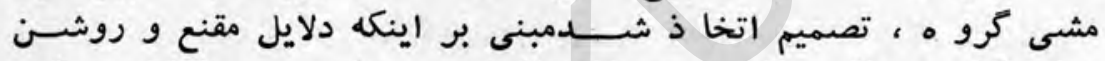

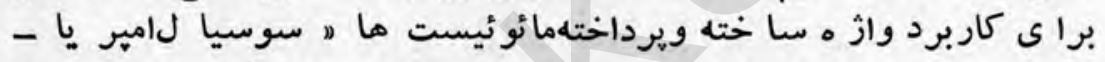

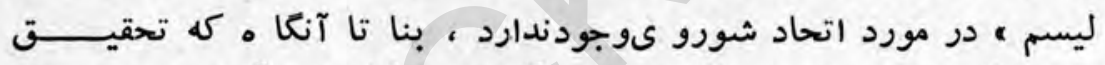

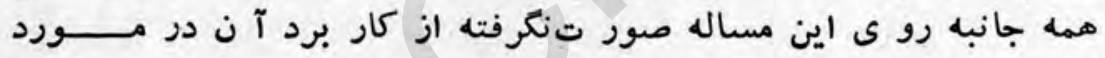

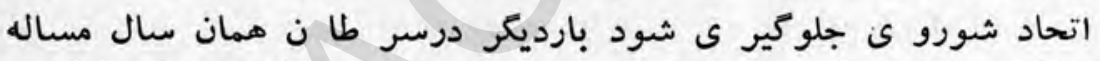

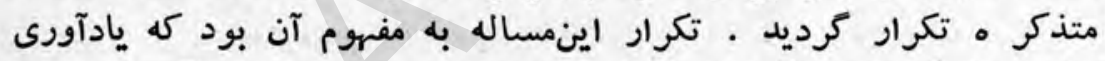

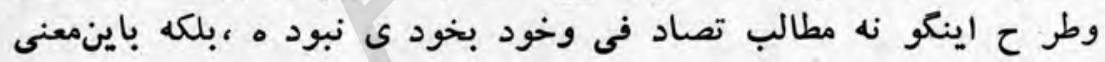

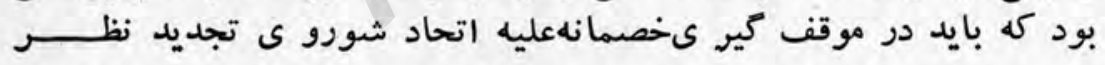

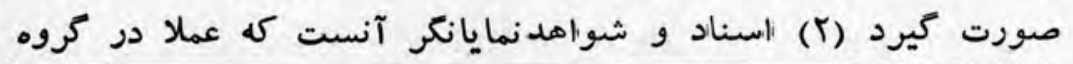

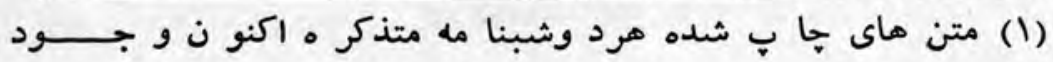

دارد .

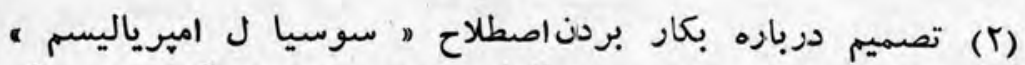

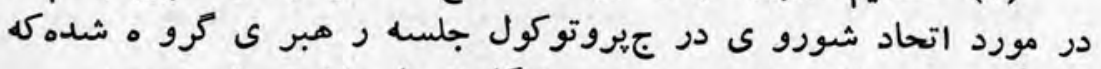

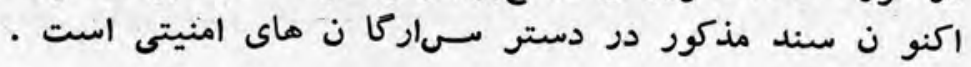

-Ero_ 


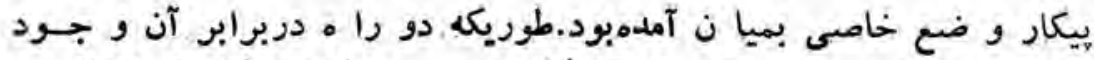

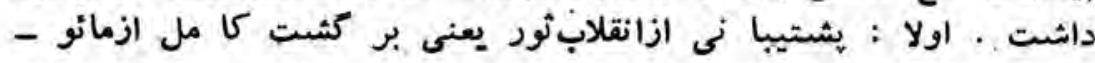

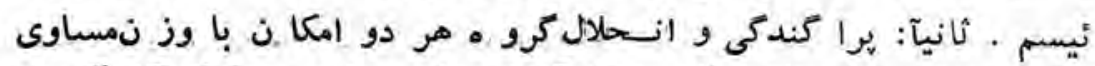

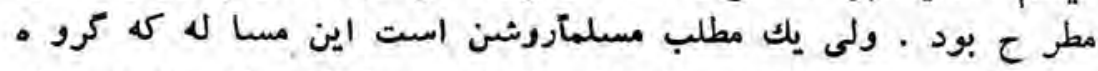

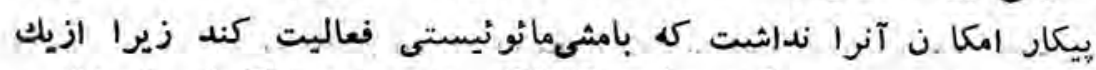

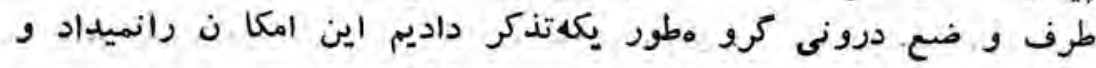

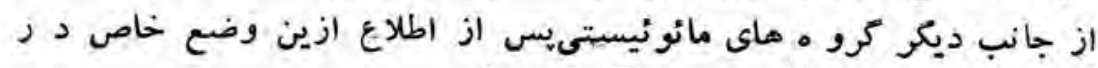

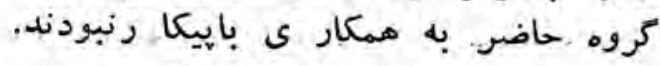

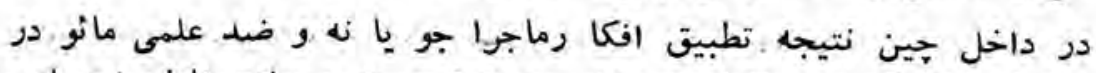

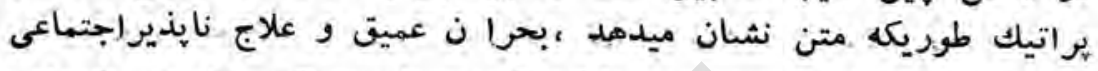

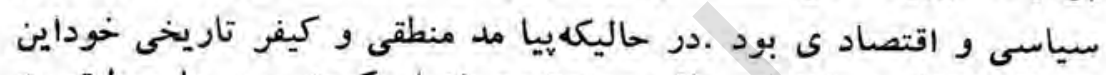

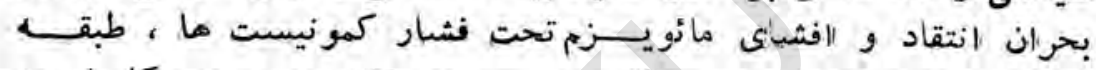

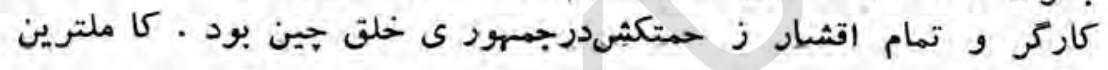

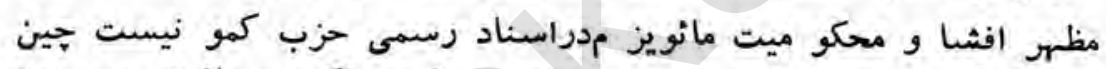

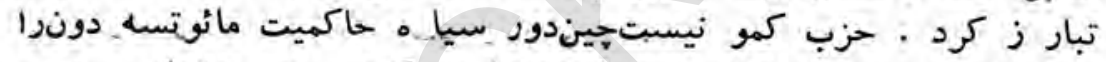

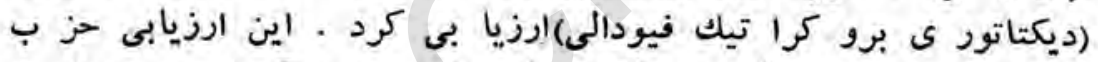

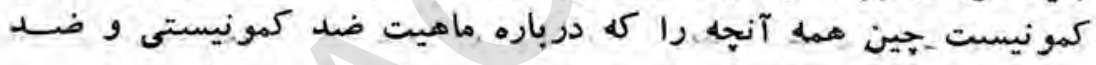

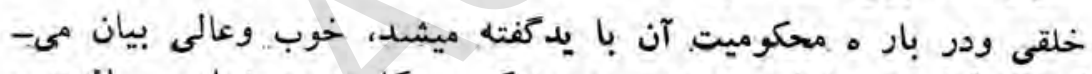

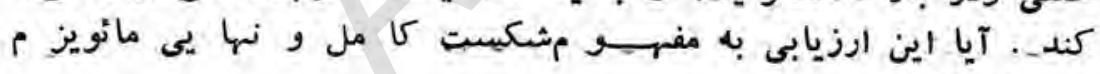
نميباشد و

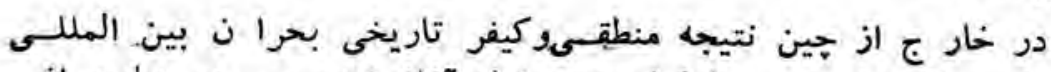

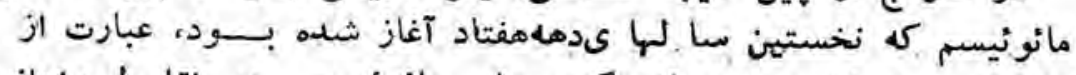

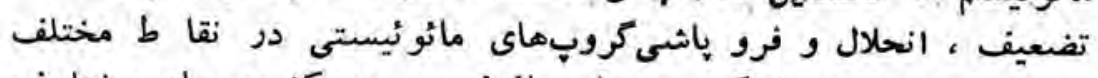

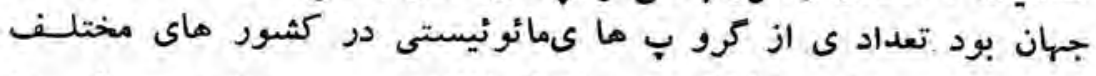

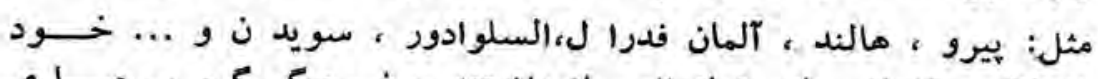

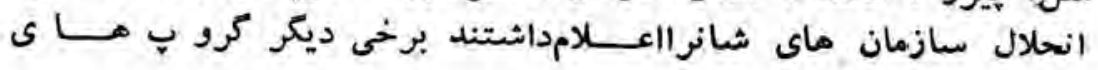




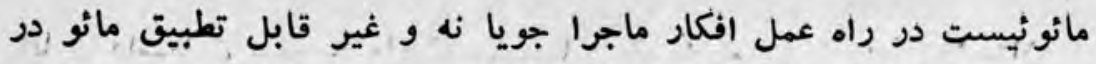

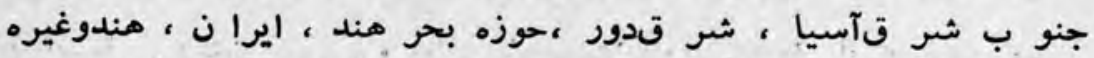

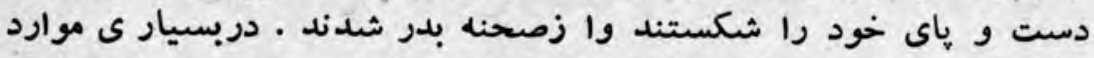

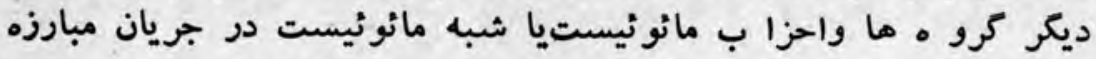

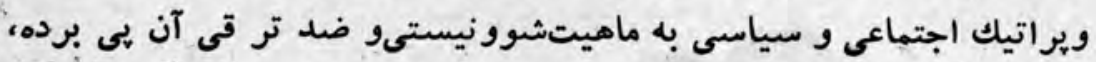

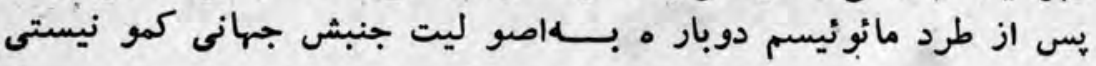

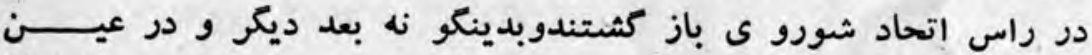

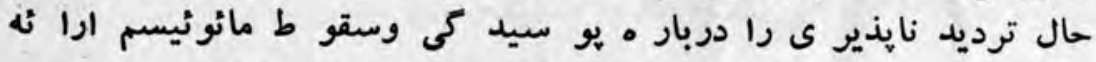

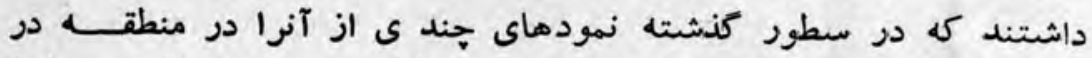

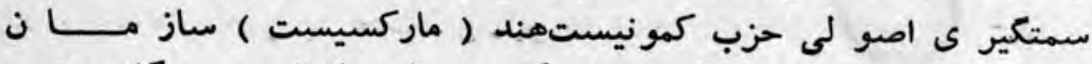

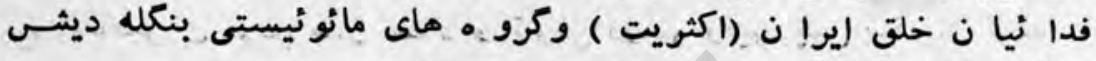

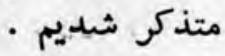

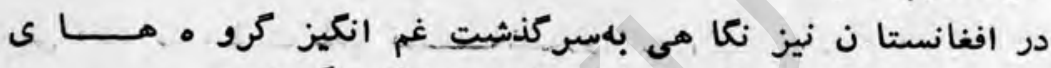

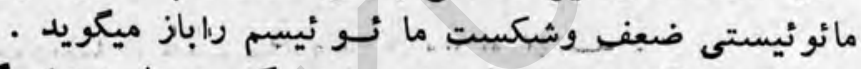

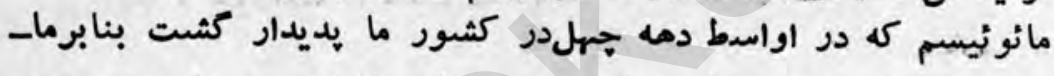

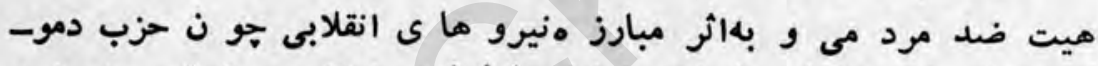

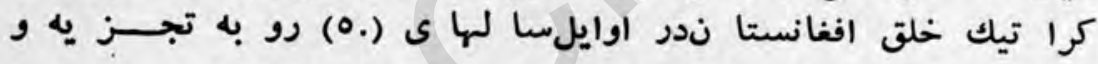

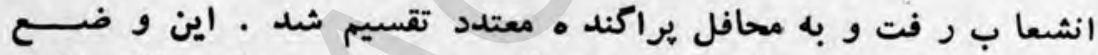

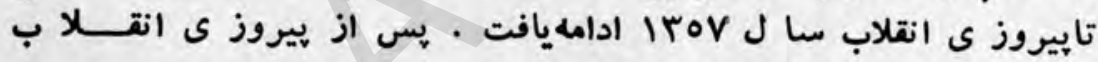

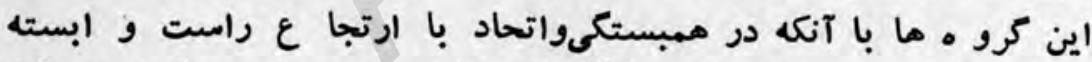

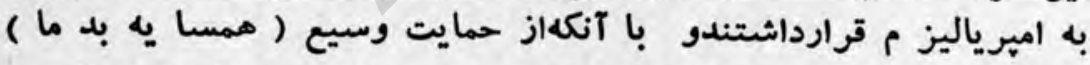

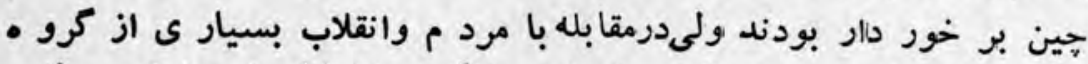

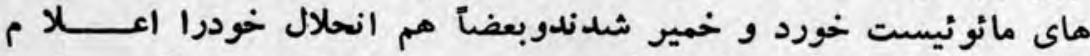

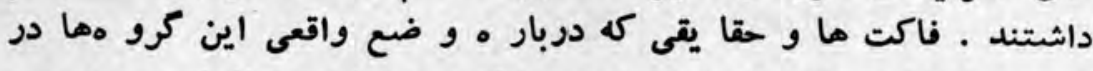

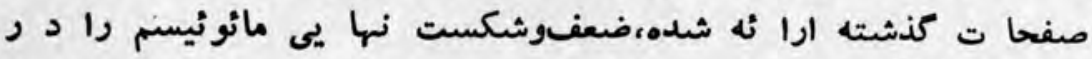

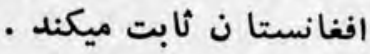


هاياً ن داستا ن سقو ط مائو ئيسمبسيا ر شبيه است به هايا نداستأن

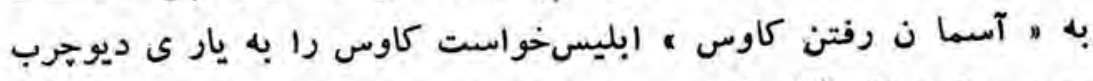

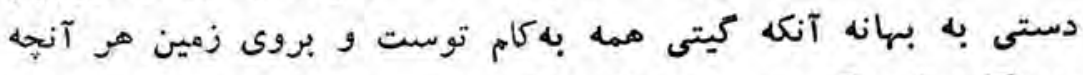

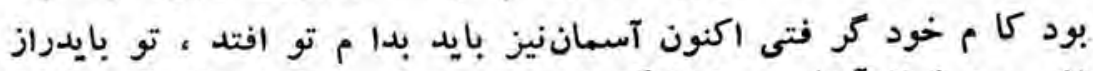

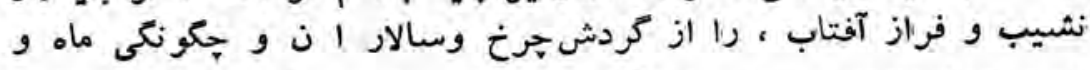

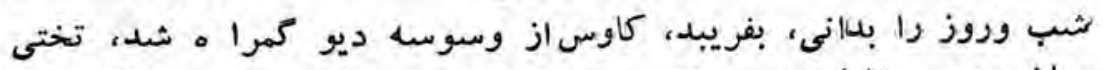

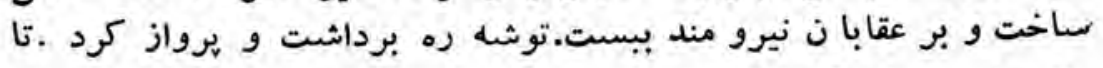

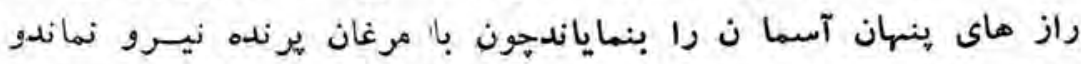

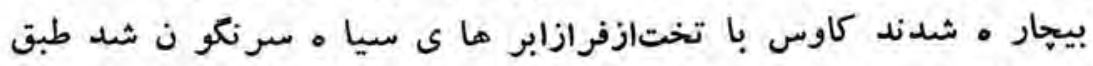

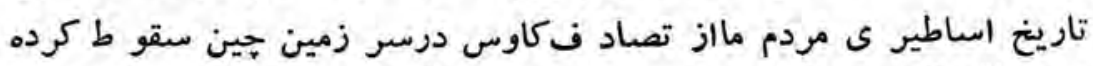

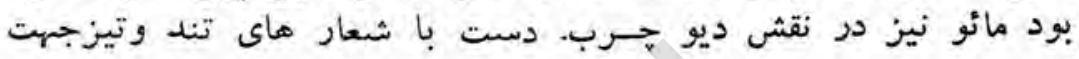

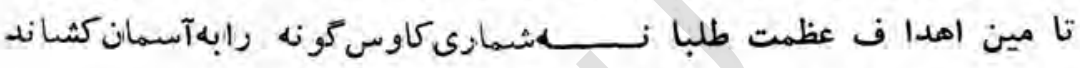
هايان

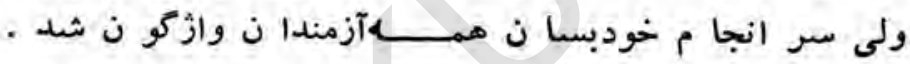

$-\varepsilon r \Lambda$ 


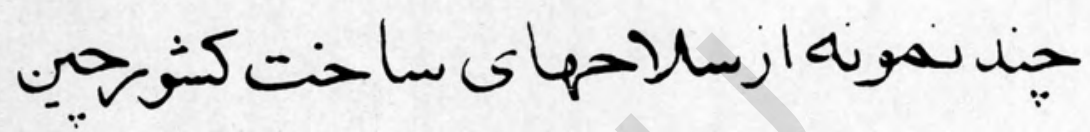
كدبسترس ضدانقلاب افناستنيا

وَإداده شنداست .

439 

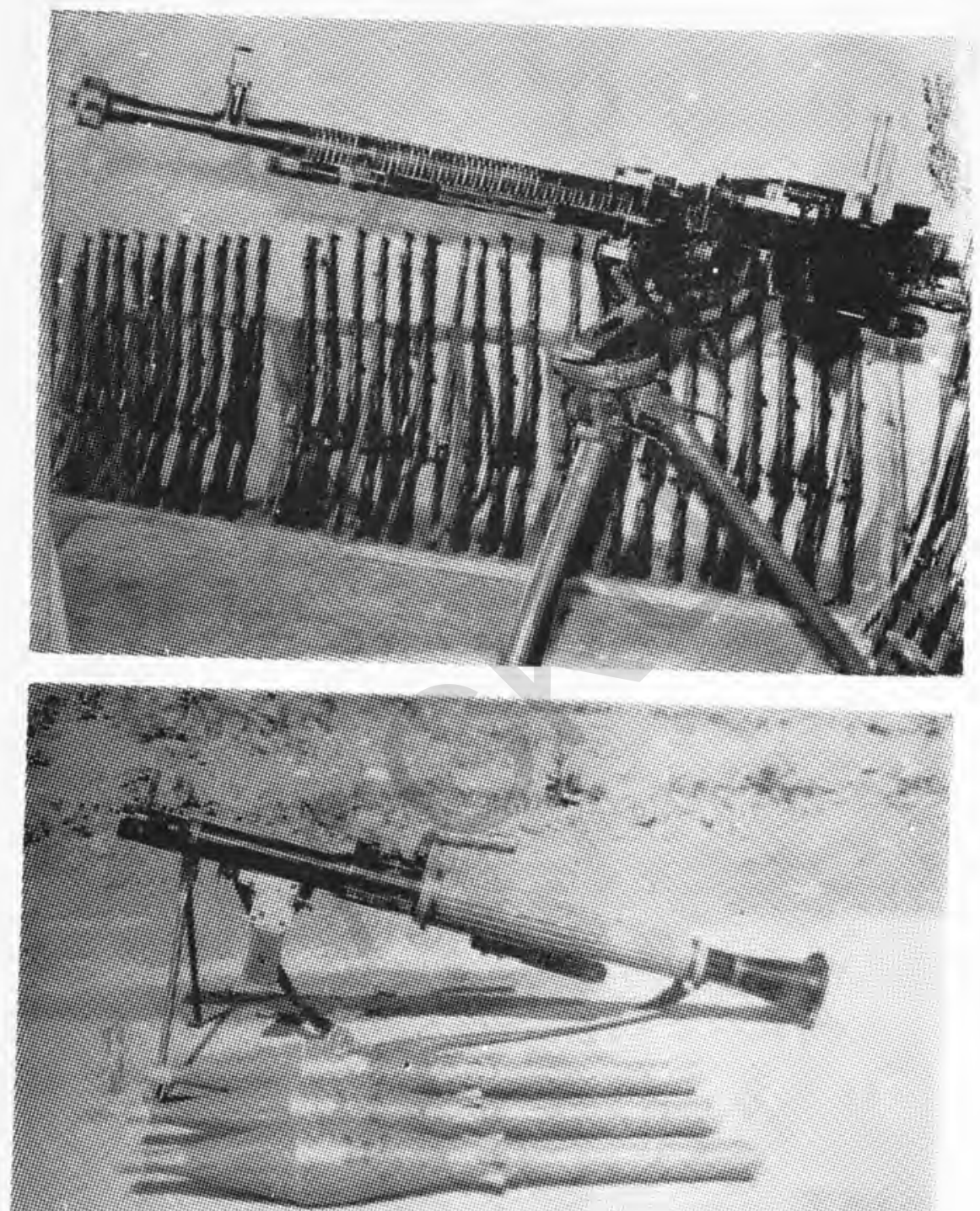

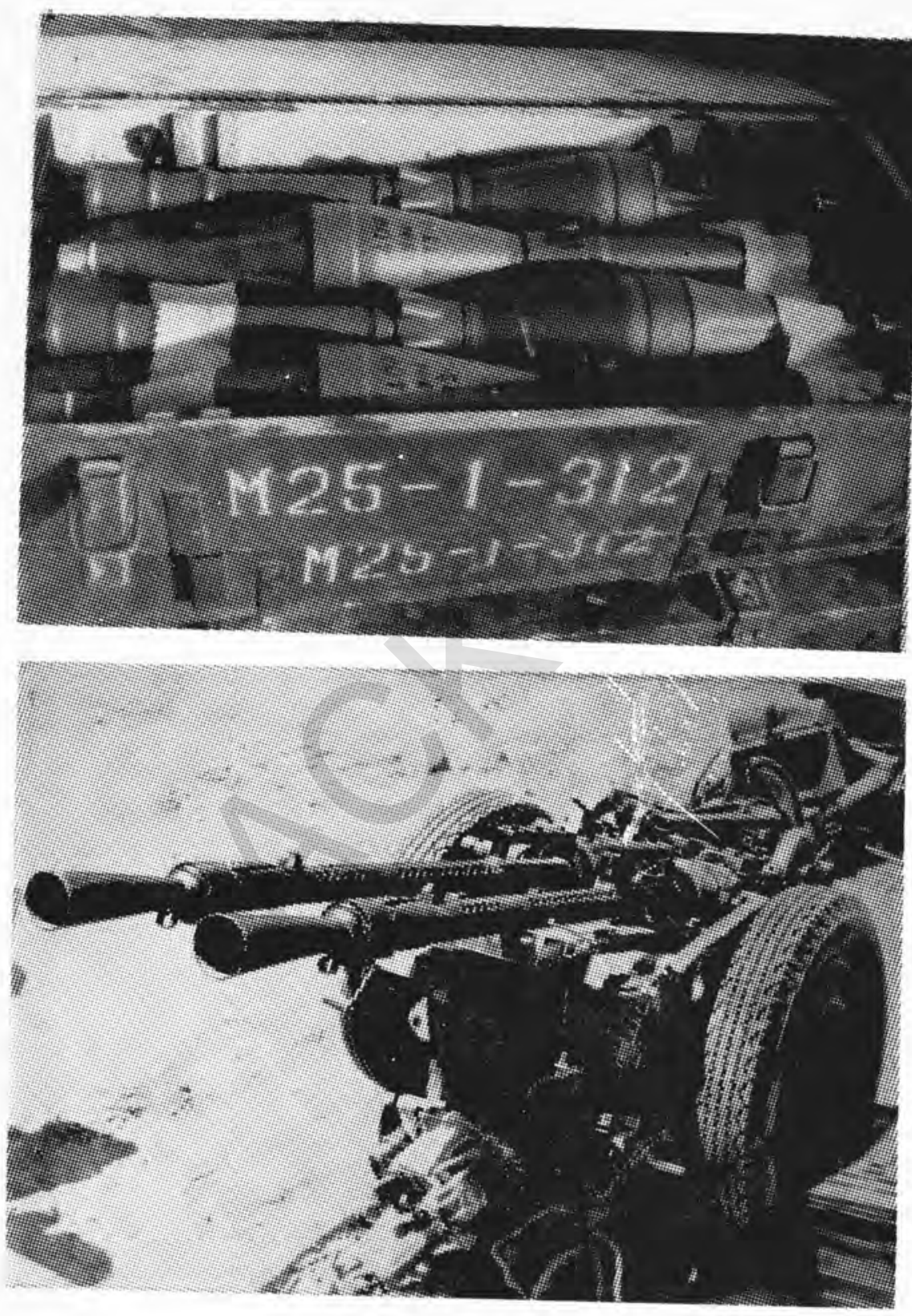

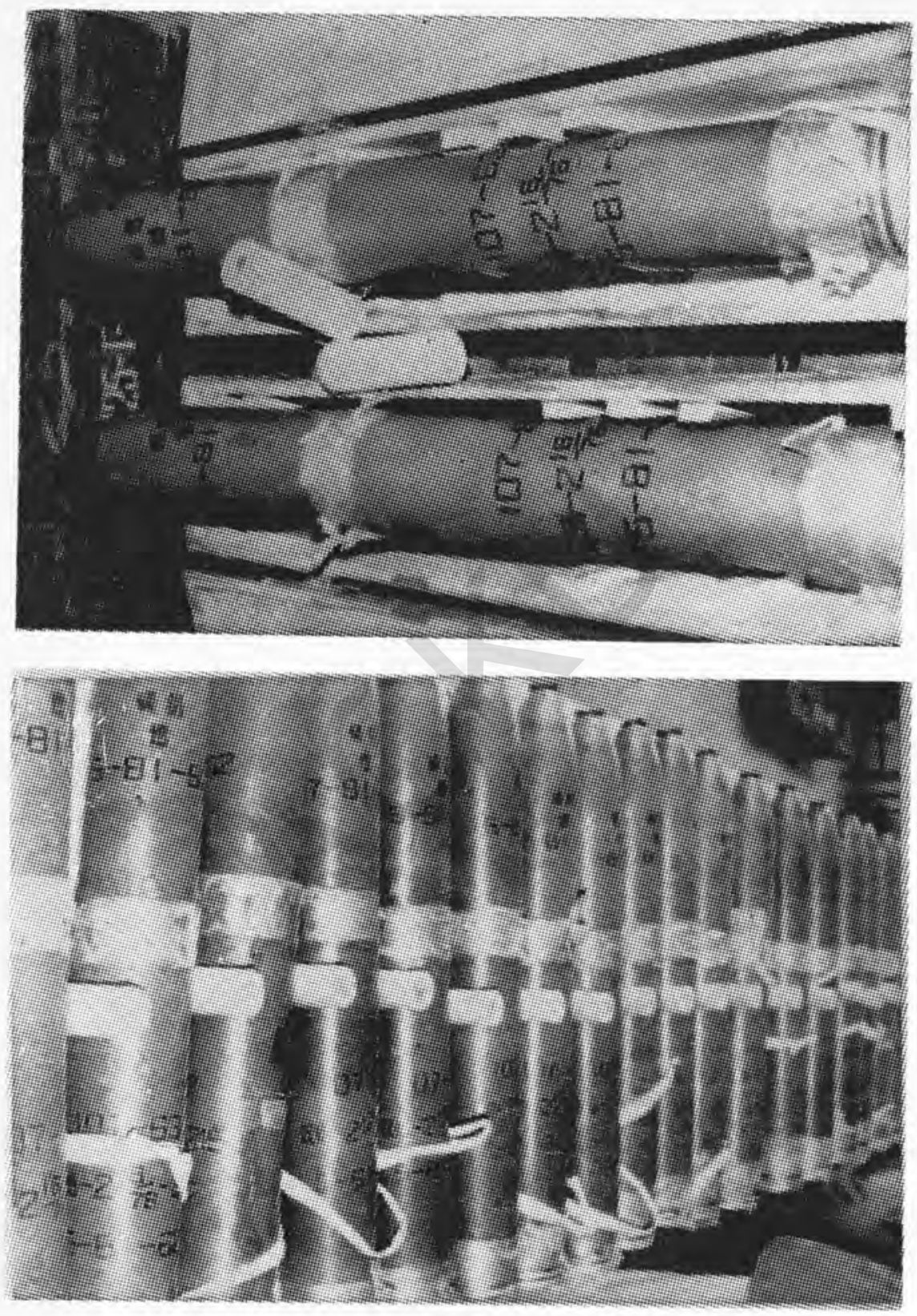

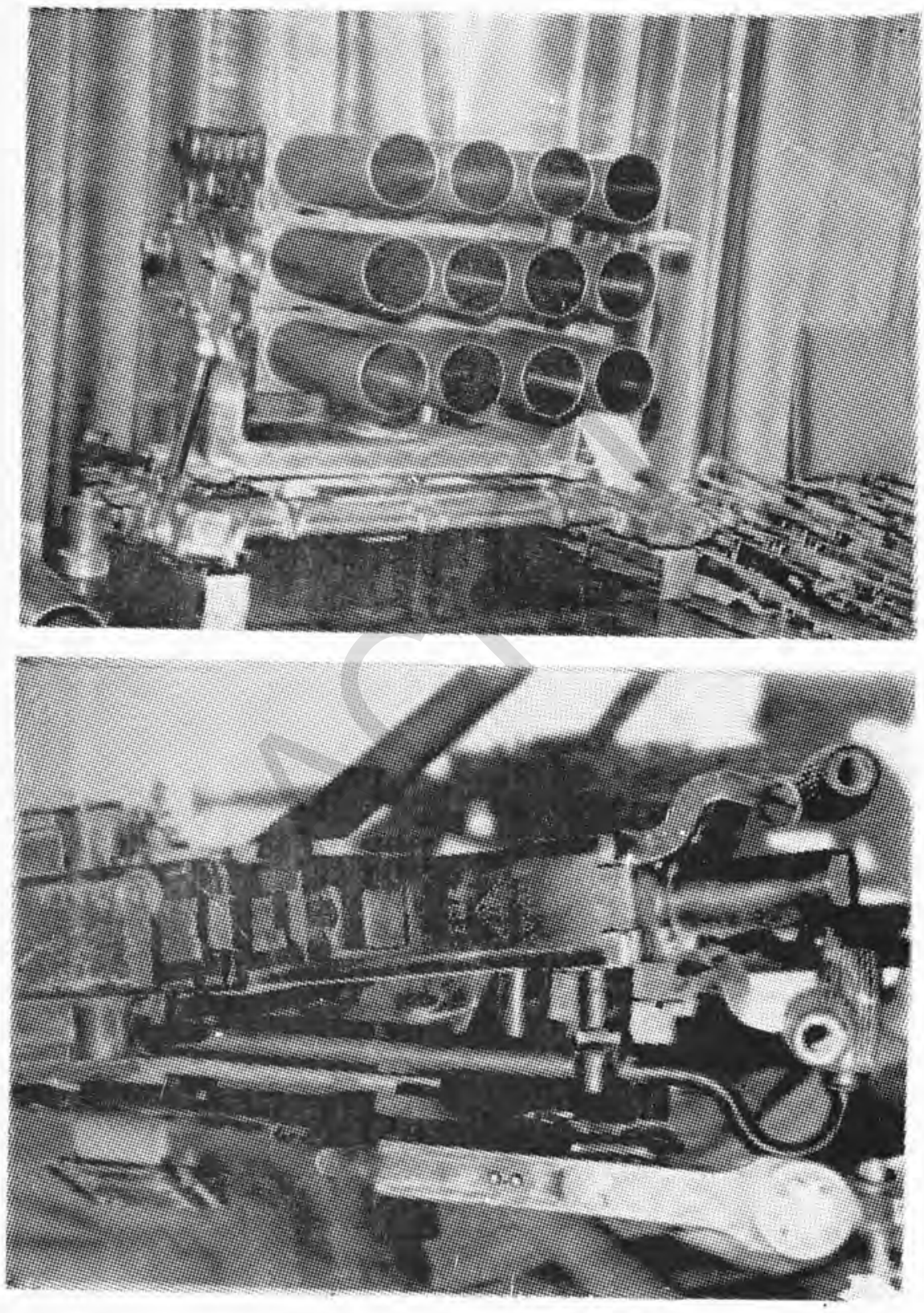
درستنامه

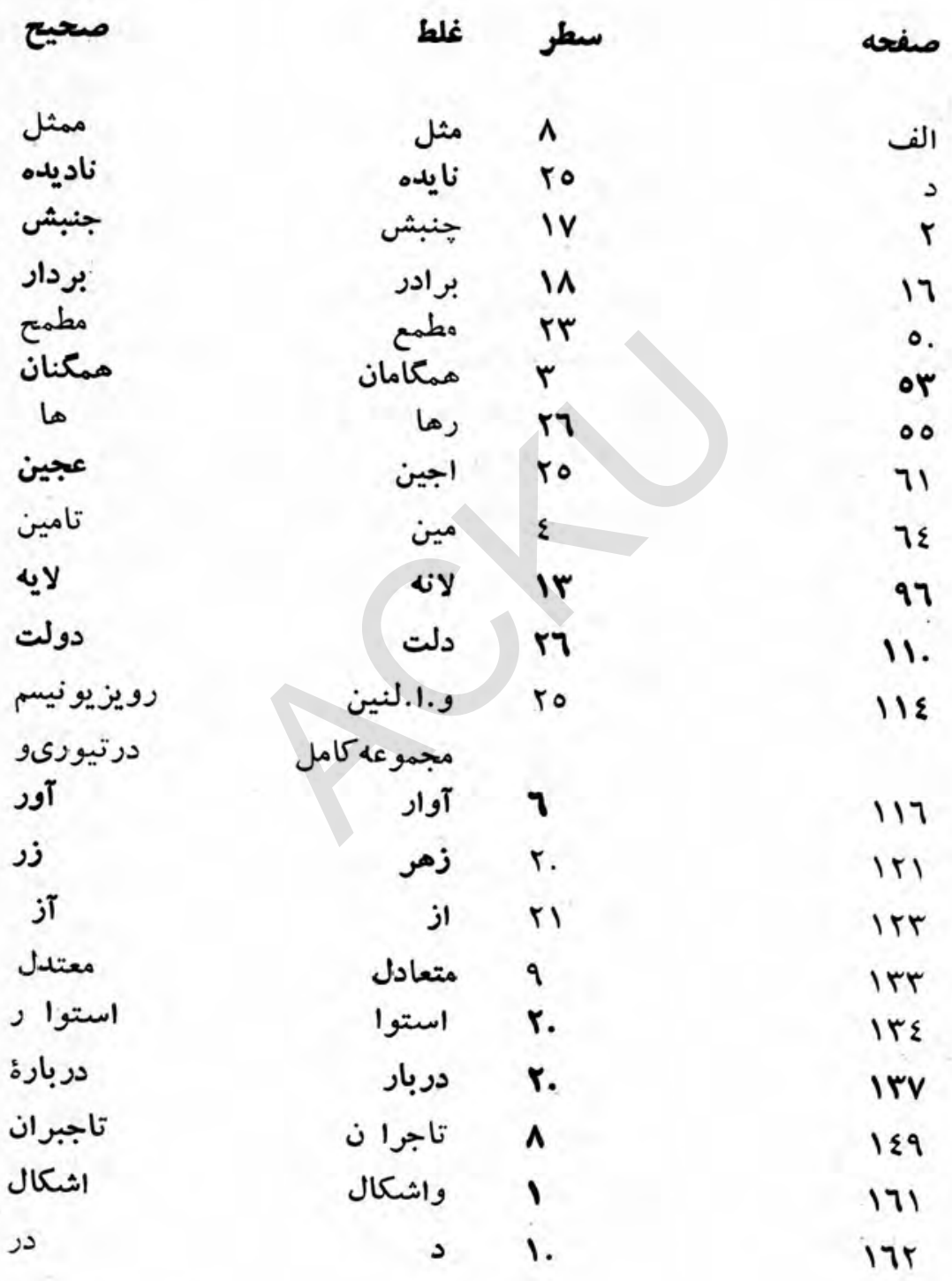

444 


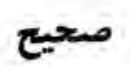

بدثانس

تورور

جنرال

كمونيستهـاى

का

$-r \leqslant r-$

\section{غ̇}
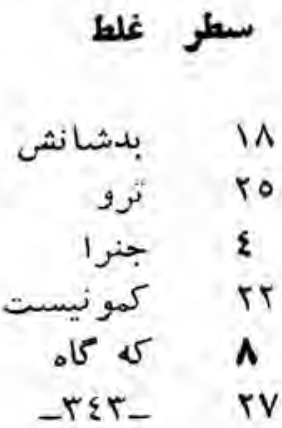

170

IV7

INT

r.

r.9

rET

roo

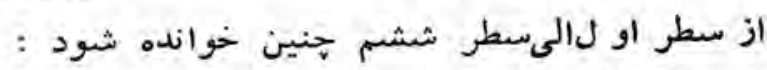

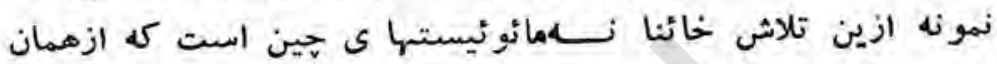

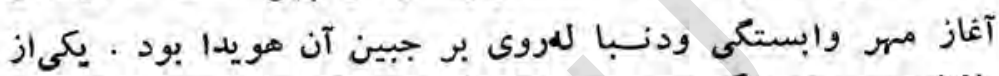

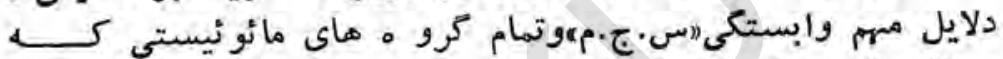

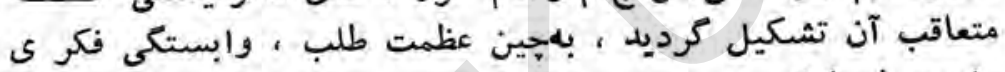

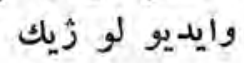

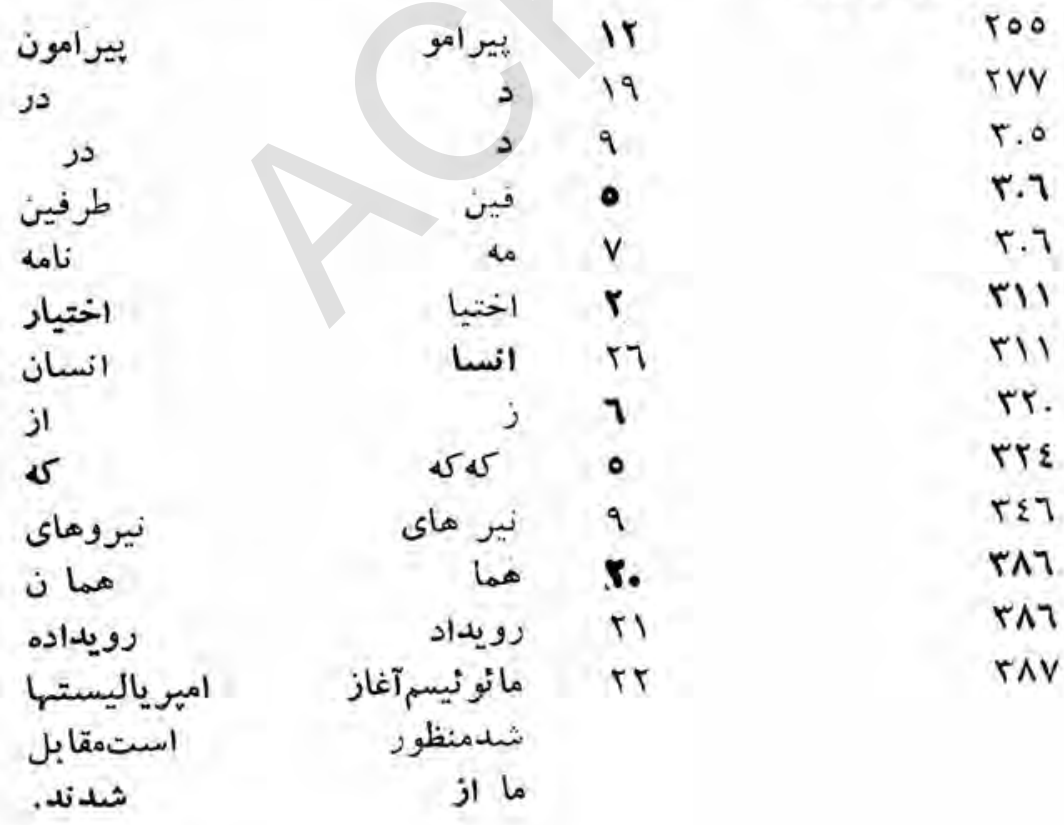



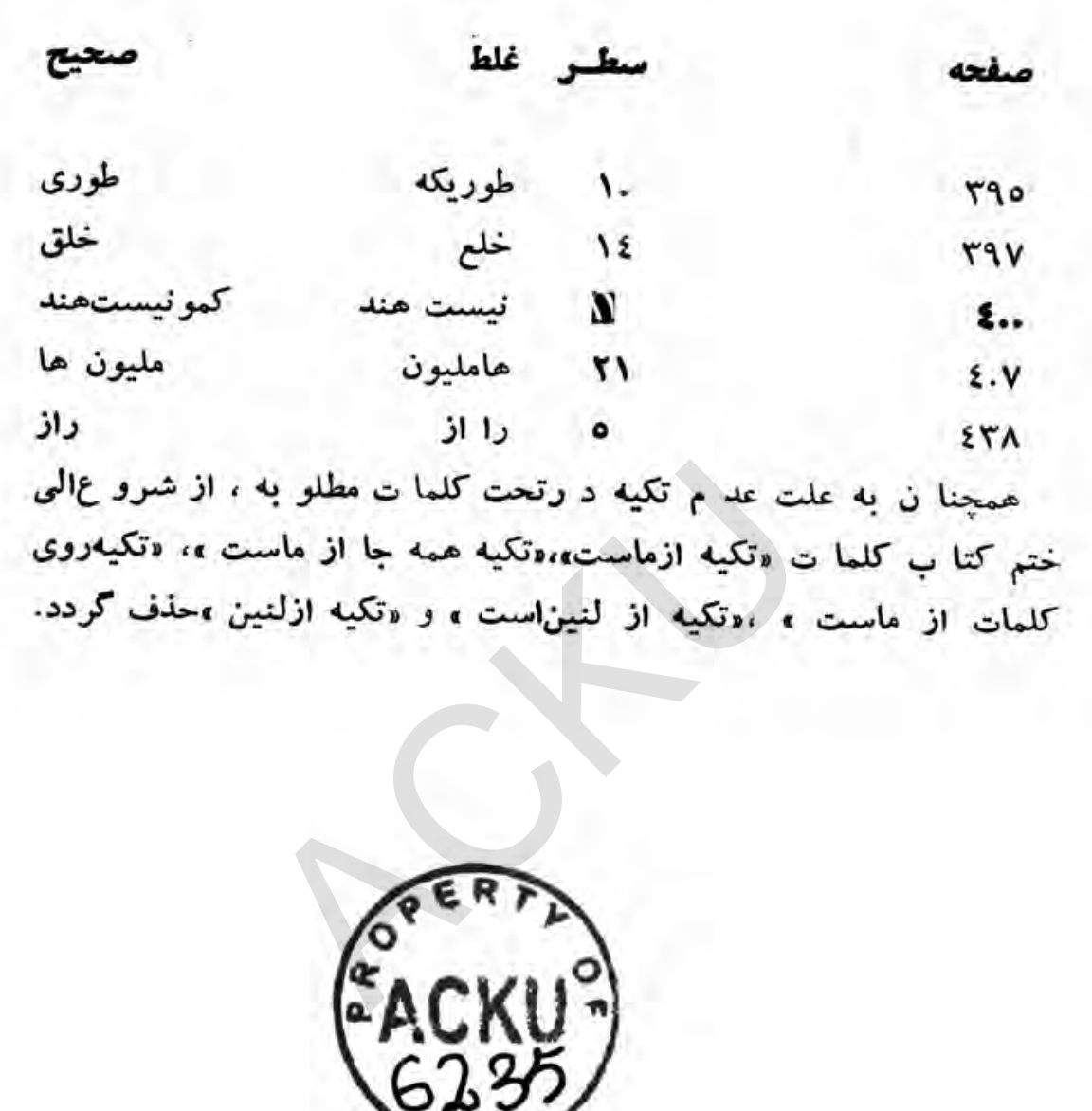

6235

446 
8

مط

$$
447
$$

